
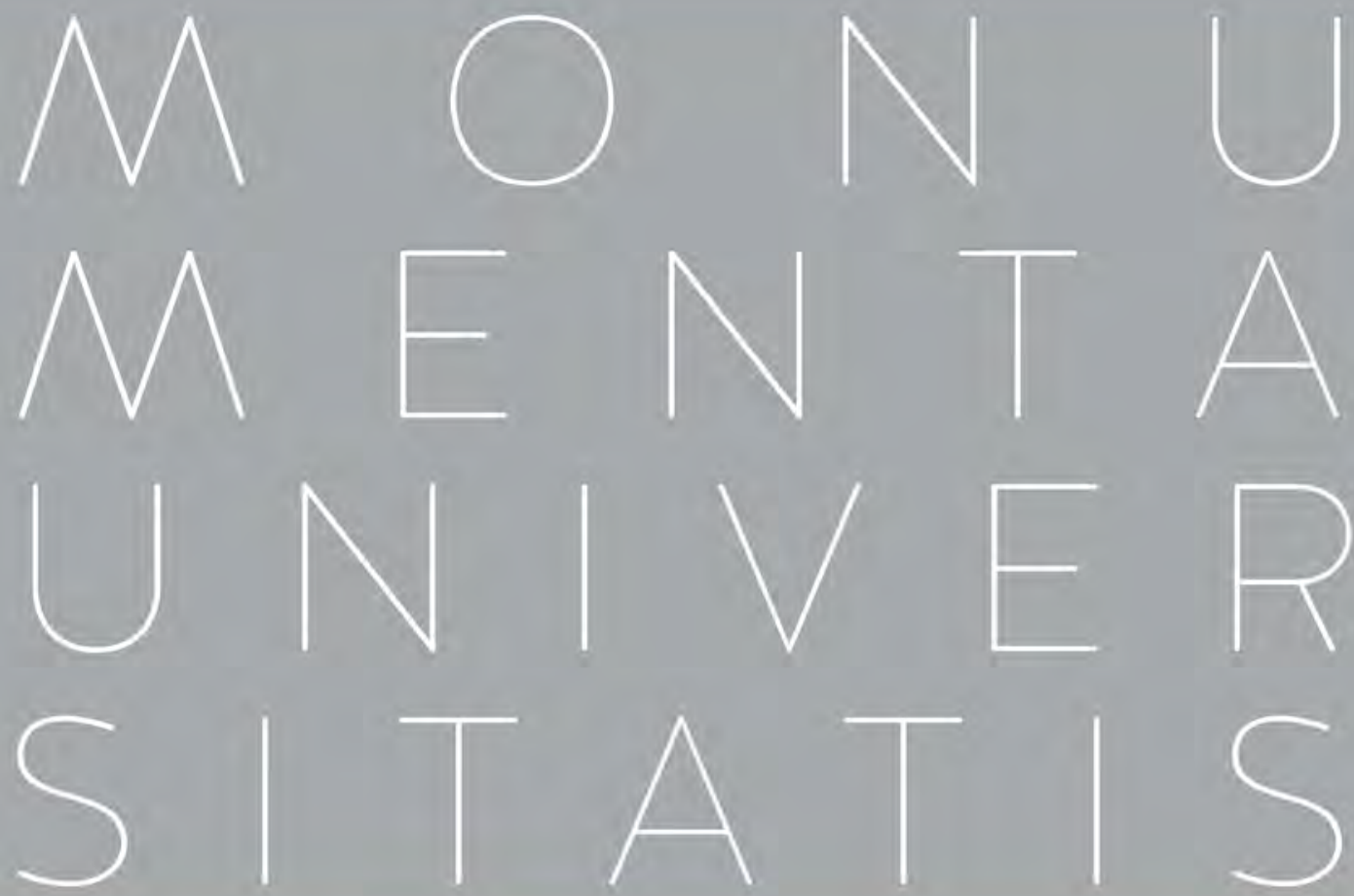

\title{
Dzieje
}

Uniwersytetu Warszawskiego

$$
1915-1945
$$
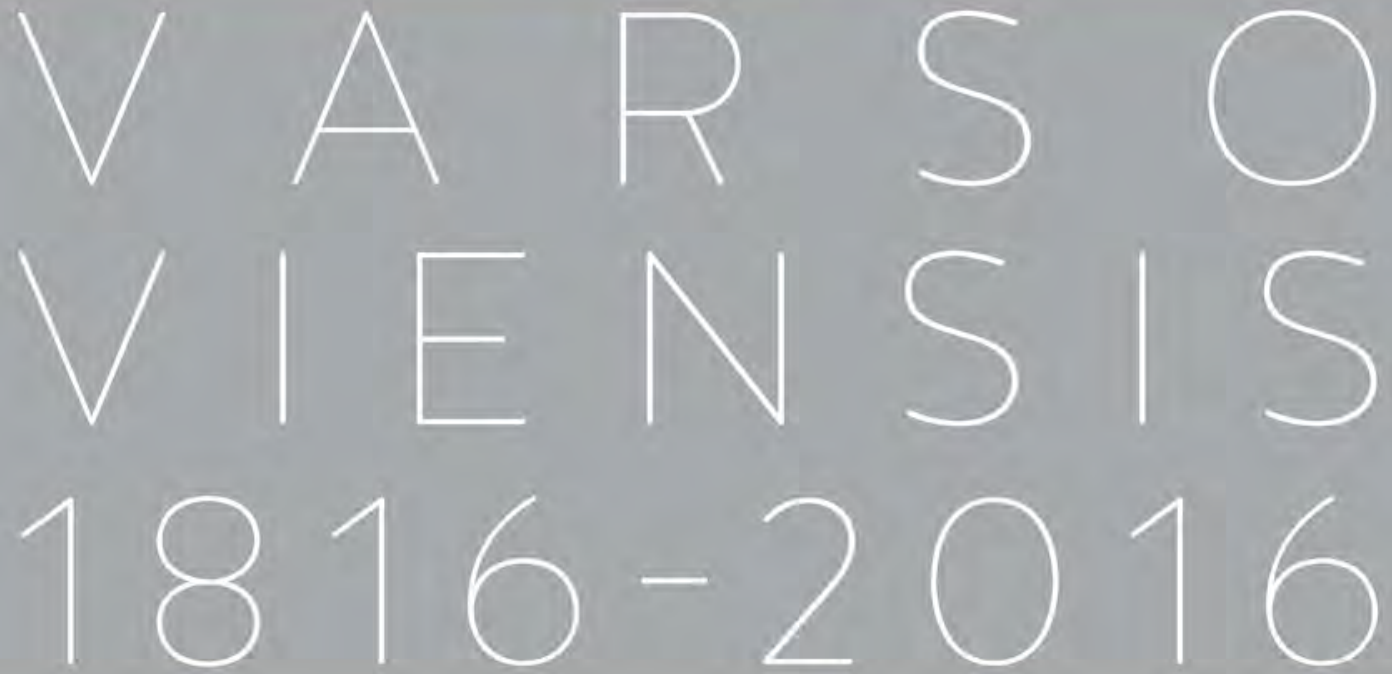


\section{e-MONUMENTA_WUW 2016}




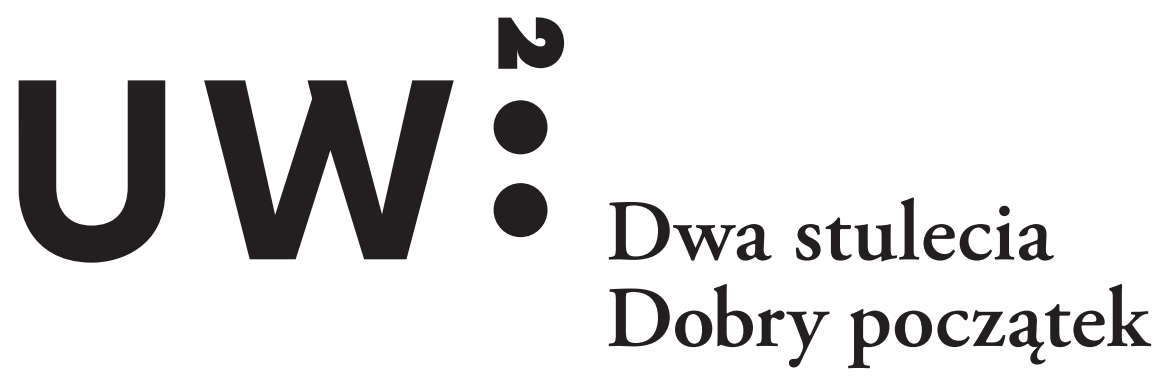




\section{Zespół Rektorski ds. Wydawnictw Jubileuszowych}

dr hab. Waldemar Baraniewski

Wydział Historyczny UW/

Wydział Zarządzania Kulturą Wizualną ASP

prof. dr hab. Tomasz Kizwalter

Wydział Historyczny UW

dr hab. Piotr M. Majewski

Wydział Historyczny UW

prof. dr hab. Piotr Salwa

Wydział "Artes Liberales” UW

prof. dr hab. Henryk Samsonowicz

Wydział Historyczny UW

prof. dr hab. Wojciech Tygielski - przewodniczący

Wydział Historyczny UW

prof. dr hab. Marek Wąsowicz

Wydział Prawa i Administracji UW

prof. dr hab. Andrzej Kajetan Wróblewski

Wydział Fizyki UW 


\section{Szanowni Państwo! Drodzy Czytelnicy!}

W 2016 roku będziemy obchodzić jubileusz dwóchsetlecia Uniwersytetu Warszawskiego. Nasz Uniwersytet nie jest jedynie wyższa szkoła, nie jest tylko pracownia uczonych - to środowisko, którego działania $w$ ciagu dwóch wieków polskiej historii stanowiły istotny wkład do wiedzy, kultury, myśli ludzkiej.

Z okazji jubileuszu powstaje seria wydawnicza Monumenta Universitatis Varsoviensis, w której opisujemy dzieje i dorobek naszej Uczelni oraz przypominamy sylwetki jej najwybitniejszych profesorów.

W syntetycznej formie przedstawiamy również losy oraz architekture budynków Uniwersytetu, a także zbiory $i$ kolekcje, które sa $w$ naszym posiadaniu oraz nad którymi przyszło nam sprawować pieczę. Nie zabraknie też dokumentów ilustrujących różne sfery społecznego oddziaływania Uczelni, a takíe świadectw życia codziennego naszej społeczności.

Kolejne tomy ukazywać się będa sukcesywnie, od roku 2016. Mamy nadzieję, że spotkają się z Państwa życzliwym przyjęciem $i$ wzbudza zainteresowanie.

Gaudeamus igitur!

Katarzyna Chałasińska-Macukow Rektor Uniwersytetu Warszawskiego w latach $2005^{-2012}$

Marcin Patys

Rektor Uniwersytetu Warszawskiego

Warszawa, 19 listopada 2012 r.

\section{e-MONUMENTA_WUW 2016}




\section{Monumenta Universitatis Varsoviensis $1816-2016$}

Dzieje Uniwersytetu

Warszawskiego 1816-1915

Dzieje Uniwersytetu

Warszawskiego 1915-1945

Dzieje Uniwersytetu

Warszawskiego po 1945

Nauki humanistyczne

na Uniwersytecie

Warszawskim

Nauki społeczne

na Uniwersytecie

Warszawskim

Nauki ścisłe i przyrodnicze na Uniwersytecie

Warszawskim
PORTRETY UCZONYCH Poczet Rektorów

Profesorowie Uniwersytetu Uniwersytetu Warszawskiego

Warszawskiego 1816-1915

PORTRETY UCZONYCH

Profesorowie Uniwersytetu

Warszawskiego 1915-1945

$(A-€)$

PORTRETY UCZONYCH

Profesorowie Uniwersytetu

Warszawskiego 1915-1945

$(M-\grave{Z})$

PORTRETY UCZONYCH

Profesorowie Uniwersytetu

Warszawskiego po 1945

(A-K)

PORTRETY UCZONYCH

Profesorowie Uniwersytetu

Warszawskiego po 1945

$(\mathrm{L}-\mathrm{R})$

PORTRETY UCZONYCH

Profesorowie Uniwersytetu

Warszawskiego po 1945

$(\mathrm{S}-\dot{\mathrm{Z}})$
Gmachy Uniwersytetu

Warszawskiego

Uniwersytet Warszawski

i fotografia 1839-1921

Ludzie, miejsca, wydarzenia 


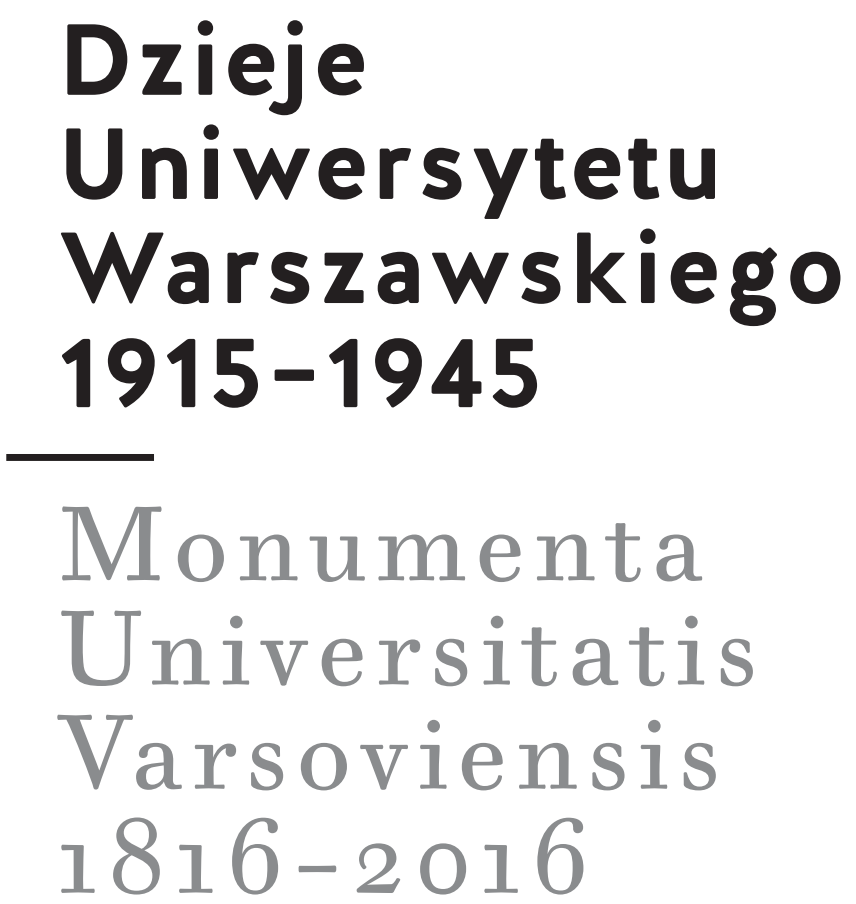

WARSZAWA 2016 


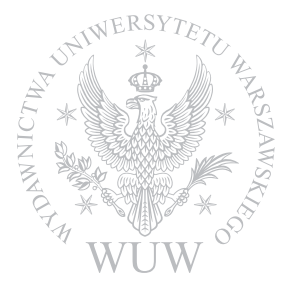

Redaktor naukowy

Piotr M. Majewski

Dyrektor WUW

Anna Szemberg

Redaktor Naczelny WUW

Anna Kędziorek

Redaktor prowadzący WUW

Beata Jankowiak-Konik

Redakcja

Bartosz Działoszyński

Korekta

Elżbieta Błuszkowska

Róża Paszkowska

Indeks

Bartosz Działoszyński

Projekt graficzny serii

M arcin Władyka / Studio Headme @

Konsultacja graficzna

Krzysztof Stefaniuk

Projekt stron tytułowych

Krzysztof Stefaniuk

Koordynator produkcji

Martyna Chołuj

Skład i łamanie

Marcin Szcześniak

ISBN 978-83-235-1791-7 (MUV)

ISBN 978-83-235-2166-2

C Copyright by Wydawnictwa

Uniwersytetu Warszawskiego

Warszawa 2016

Wydawnictwa Uniwersytetu

Warszawskiego

00-497 Warszawa

ul. Nowy świat 4

e-mail: wuw@uw.edu.pl

Księgarnia internetowa

www.wuw.pl

Wydanie 1

Druk i oprawa

POZKAL

N A R O D O W E

A R C H I W U M

C Y F R OW E

Wydawnictwa UW dziękują Narodowemu Archiwum Cyfrowemu za bezpłatne udostępnienie zdjęć 


\section{SPIS TREŚCI}

TOMASZ KIZWALTER, PIOTR M. MAJEWSKI

\section{PRZEDMOWA}

TOMASZ KIZWALTER

15 UNIWERSYTETY EUROPEJSKIE W XX WIEKU

PIOTR M. MAJEWSKI

51 SPOŁECZNOŚĆ AKADEMICKA 1915-1939

296 Załącznik 1: Władze akademickie Uniwersytetu Warszawskiego w latach 1915-1939

297 Załącznik 2: Topografia głównego kampusu UW, stan z 1938 r.

298 Załącznik 3: Lokalizacja budynków uniwersyteckich w Warszawie w latach 1915-1939

MAREK P. DESZCZYŃSKI

325 UNIWERSYTET WARSZAWSKI W II RZECZYPOSPOLITEJ

PIOTR MAJEWSKI

\section{UNIWERSYTET CZASU WOJNY}

510 Aneks 1: Kadra konspiracyjnego UW i jej straty

522 Aneks 2: Adresy lokali konspiracyjnych i ich gospodarze (wybór)

537 BIBLIOGRAFIA

547 NOTY O AUTORACH

549 INDEKS NAZWISK

563 SPIS ILUSTRACJI 


\section{TOMASZ KIZWALTER, Piotr M. MAJEWSKI}

\section{Przedmowa}

W latach 1907-1913 ukazały się w Warszawie 4 tomy Królewskiego Uniwersytetu Warszawskiego (1816-1831) autorstwa Józefa Bielińskiego; w latach 1981-1982 wydano dwutomowe Dzieje Uniwersytetu Warszawskiego: tom obejmujący lata $1807-1915$ redagował Stefan Kieniewicz, tom traktujący o okresie 1915-1939 - Andrzej Garlicki. To 2 dotychczasowe próby całościowego przedstawienia historii UW. Każda z nich należała do epoki, w której powstawała: była zależna od aktualnych tendencji historiograficznych, badawczego warsztatu autorów, oczekiwań potencjalnych czytelników, sytuacji politycznej. Wydaje się oczywiste, że po ponad zo latach od publikacji Dziejów pod redakcją Kieniewicza i Garlickiego warto wydać nową historię Uniwersytetu Warszawskiego. Jubileusz uczelni to dobra po temu okazja, jesteśmy jednak przekonani o potrzebie takiego wydawnictwa niezależnie od względów jubileuszowych. Po pierwsze dlatego, że narracja naszych poprzedników kończy się w 1939 r. - obecnie możemy rozszerzyć ten zakres o kolejne 3 etapy dziejów uczelni: okupację niemiecką, PRL i III Rzeczpospolitą. Po drugie, ponieważ - z całym uznaniem dla tego, co do tej pory dokonano i co w znacznej mierze zachowuje swą wartość - można dziś wyjść poza dotychczasowe ustalenia, przygotowując historię, która w większym stopniu odpowiadać będzie oczekiwaniom współczesnego czytelnika.

Powiedzmy rzecz całkiem banalną: w ciągu ostatnich zo lat znacznie zmienił się świat, Polska, badania historyczne, wiedza na temat przeszłości uniwersytetów, a także zainteresowania odbiorców prac z dziedziny historii. Biorąc to pod uwagę, zespól autorów przedstawianych teraz Państwu Dziejów Uniwersytetu Warszawskiego starał się położyć szczególny nacisk na 2 zespoły zagadnień. Podstawą każdej historii uniwersytetu muszą być jego dzieje jako instytucji. Nie zaniedbując tej problematyki, postanowiliśmy jednak możliwie szeroko 
potraktować historię ludzi - pracowników uczelni i studentów - oraz dzieje stosunków uczelni z władzami politycznymi.

W światowej historiografii mamy do czynienia z długą tradycją badań wielkich procesów i masowych zjawisk. Współcześnie chętnie nadaje się wszakże przeszłości bardziej ludzki wymiar, skupiając się na życiu jednostek i konkretnych zbiorowości. Tego rodzaju podejście ma wiele zalet, dlatego też sądzimy, że trudno pisać dziś historię uczelni, nie poświęcając odpowiednio dużo uwagi związanym z nią osobom, ich poglądom, mentalności, życiu codziennemu. O tyle, o ile to było tylko możliwe, autorzy Dziejów starali się zatem stworzyć plastyczne portrety społeczności pracowników i studentów UW. Ci ostatni zwłaszcza zasługują na to, aby znaleźć się na bardziej eksponowanym miejscu, niż to bywało w starszych pracach, w których na plan pierwszy wysuwały się instytucja, nauka i nauczanie oraz profesura, a o studentach pisano najczęściej wtedy, gdy stawali się wybitnymi absolwentami.

Funkcjonowanie każdej uczelni zależy w jakimś stopniu od sytuacji politycznej. W przypadku Uniwersytetu Warszawskiego aspekt ten jest szczególnie istotny, zważywszy na dramatyzm nowoczesnych dziejów Polski. Kataklizmy wojenne i okupacyjne przerywały tu niejeden raz ciągłość życia; społeczeństwo - a przynajmniej znaczna jego część znajdowało się często w ostrym konflikcie z władzą, obcą lub podległą obcemu mocarstwu. Rzutowało to w przemożny sposób na historię warszawskiego Uniwersytetu.

Jego początki sięgały Księstwa Warszawskiego, kiedy to powołano w Warszawie Szkołę Prawa i Nauk Administracyjnych oraz Szkołę Lekarską. Uniwersytet utworzono ostatecznie w $1816 \mathrm{r}$. i stał się on zwieńczeniem edukacyjnego systemu Królestwa Polskiego oraz ważnym ośrodkiem kształcenia polskiej inteligencji. Likwidacja Uniwersytetu po upadku powstania listopadowego - świadectwo przekonania władz Imperium Rosyjskiego, że istnienie uczelni szkodzi ich kontroli nad polskim terytorium - otwierała okres, w którym w Warszawie istniały tylko szkoły półwyższe. W latach 1862-1869 Szkoła Główna, produkt sprzyjającej koniunktury politycznej, choć nienazwana uniwersytetem, pełniła w istocie jego funkcję. Wśród jej studentów byli ludzie, którzy wkrótce mieli stać się czołowymi postaciami polskiego życia umysłowego. Rusyfikacyjne dążenia Petersburga po stłumieniu powstania styczniowego sprawiły, że Szkoła została przekształcona w rosyjskojęzyczny Cesarski Uniwersytet Warszawski. Bywał on często uznawany przez Polaków za ciało obce, nienależące do prawdziwej uniwersyteckiej tradycji Warszawy. Przygotowując naszą publikację, wychodziliśmy jednak z założenia, że błędem byłoby pomijanie lub marginalizowanie tej fazy 
dziejów UW. Po pierwsze, Cesarski Uniwersytet nie był zupełnie oddzielony od życia polskiego społeczeństwa: przez długi czas większość jego studentów stanowili Polacy, Polacy znajdowali się też - choć w tym przypadku ich udział systematycznie malał - wśród wykładowców. Po drugie, historia rosyjskojęzycznego UW to ważny fragment dziejów rosyjsko-polskich stosunków w tamtym okresie. Po trzecie, Cesarski Uniwersytet zasługuje na uwage jako jedna z uczelni Imperium - niezaliczająca się do czołówki, lecz mająca swoje osiągnięcia. Ewakuacja rosyjskiego uniwersytetu do Rostowa nad Donem, przeprowadzona w 1915 r., gdy Rosjanie opuszczali „Kraj Przywiślański”, i tamtejsza, blisko 2-letnia działalność pod szyldem „warszawskim” zamykają pierwszy tom Dziejów.

Również w XX stuleciu uczelnia dzieliła dramatyczne losy kraju i jego stolicy. Początek drugiego tomu Dziejów to wrzesień 1915 r., kiedy niemieckie władze okupacyjne reaktywowały Uniwersytet Warszawski z polskim jako językiem wykładowym. Po 3 latach pod rządami niemieckimi podczas I wojny światowej Uniwersytet płynnie wszedł w okres niepodległości i wkrótce stał się największą wyższą uczelnią II Rzeczypospolitej. Aż do wybuchu kolejnej wojny w 1939 r. skupiały się tu niczym w soczewce charakterystyczne dla młodej polskiej państwowości konflikty polityczne i narodowościowe, a także procesy modernizacyjne. Należy odnotować, iż w 1935 r. uczelnia została przemianowana ustawą sejmową na Uniwersytet Józefa Piłsudskiego; nazwy tej nigdy formalnie nie zmieniono, jednak po 1939 r. zaprzestano jej formalnie używać. II wojna światowa i niemiecka okupacja Warszawy przerwały funkcjonowanie uczelni, przynosząc jej ogromne straty ludzkie i materialne. Uznaliśmy, że również ten okres musi zostać omówiony w Dziejach, chociażby ze względu na fakt, iż Uniwersytet kontynuował swoją działalność dydaktyczną, a do pewnego stopnia także naukową, w podziemiu, w ramach tajnego nauczania.

Wreszcie trzeci tom Dziejów obejmuje okres od zakończenia wojny do współczesności. W latach 1945-1989, podobnie jak w 20-leciu międzywojennym, Uniwersytet Warszawski zajmował niezwykle ważne miejsce na mapie skomplikowanych relacji łączących środowiska naukowe, młodzież akademicką i władze państwowe - tym razem podporządkowane rządzącej partii komunistycznej. Rozgrywające się tu wydarzenia miały nierzadko bardzo istotne znaczenie dla sytuacji w całym kraju, by wymienić chociażby brutalnie stłumione studenckie protesty w marcu 1968 r. czy formowanie się opozycji demokratycznej. Oblicze uczelni zmieniało się tė̇, co staramy się ukazać, wraz z dokonującymi się przemianami społecznymi. Dzieje kończy rozdział poświęcony 
uniwersytetowi w okresie po upadku systemu komunistycznego w $1989 \mathrm{r}$. Mimo że lata te dzieli od współczesności stosunkowo niewielki dystans, zdecydowaliśmy się uwzględnić je, gdyż doszliśmy do wniosku, iż bez najważniejszych faktów na temat ostatniego ćwierćwiecza historii uczelni obraz jej dziejów byłby dalece niepełny.

$\mathrm{Na}$ koniec garść uwag dotyczących strony formalnej. Wszystkie tomy Dziejów Uniwersytetu Warszawskiego są dziełem zbiorowym, co oznacza również, że poszczególne rozdziały odzwierciedlają wyniki badań i przemyślenia ich autorów, książka nie aspiruje natomiast - poniekąd wbrew jubileuszowemu charakterowi serii wydawniczej do rangi „oficjalnej” monografii uczelni. W trosce o funkcjonalność publikacji poszczególne tomy Dziejów opatrzyliśmy selektywnymi bibliografiami oraz wykazami źródeł - wspólnymi dla całości danego tomu. Podstawowe informacje na temat wykorzystanych przez siebie materiałów $i$ istotniejsze uwagi o charakterze warsztatowym podaje na ogól każdy z autorów, ich powtarzanie nie miałoby więc tu większego sensu. Przypisy w tekście numerowane są w obrębie poszczególnych rozdziałów, które także pod względem merytorycznym stanowią osobne całości. Przytaczane w przypisach i bibliografiach publikacje w języku rosyjskim zapisane zostały zgodnie z zasadami transkrypcji, natomiast wszystkie cytaty w tekście głównym podajemy w przekładzie na polski. 

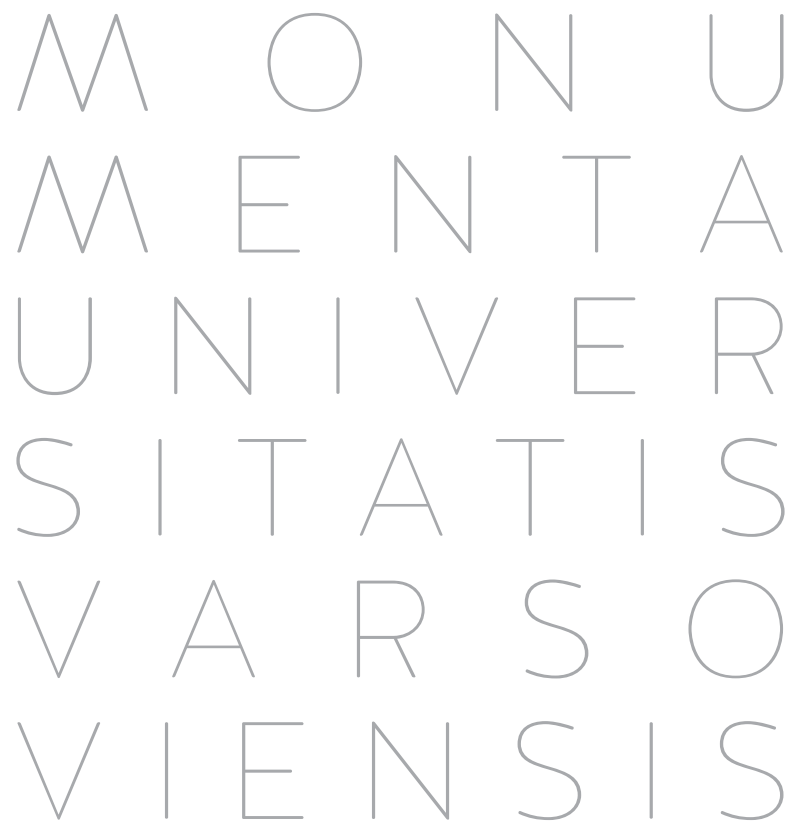

S

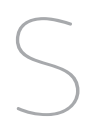




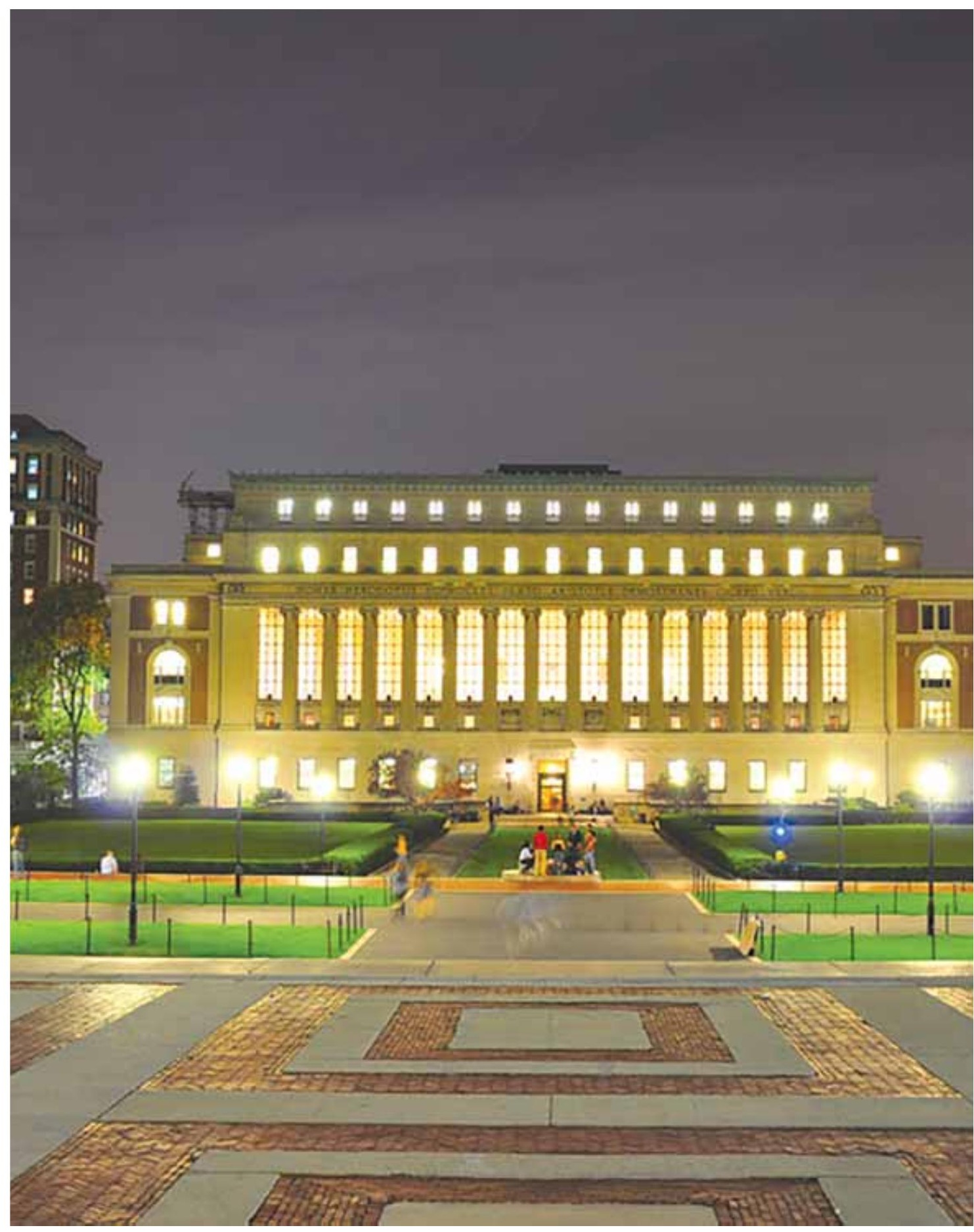

e-MONUMENTA_WUW 2016 


\section{UNIWERSYTETY EUROPEJSKIE W XX WIEKU}

W ubiegłym stuleciu historia europejskich uniwersytetów przyspieszyła w bezprecedensowy sposób ${ }^{1}$. To prawda, że już wcześniej następowały bardzo istotne zmiany. W XVIII w. rzecznicy Oświecenia podejmowali reformy tradycyjnych, wywodzących się ze średniowiecza struktur uniwersyteckich i wpływali na umysłowy klimat uczelni. Uniwersytety w XIX w. przekształcały się w nowoczesne instytucje, które próbowały sprostać podwójnemu wyzwaniu nowej epoki: uprawiać naukę, zachowując niezależność umysłu, a zarazem być praktycznie użytecznymi. Koncepcja wyższej szkoły zawodowej, ukształtowana w rewolucyjno-napoleońskiej Francji, oraz idea uniwersytetu badawczego, którą sformułował w Prusach Wilhelm von Humboldt, to dwa podstawowe wzorce wpływające na kierunek rozwoju europejskich uczelni. Dla wielu członków środowisk akademickich ideał Humboldtowski - wizja uniwersytetu prowadzącego niezależne, bezinteresowne badania i uczącego ich prowadzenia - stał się celem, do którego należy dążyć. Potrzeby praktyczne nie dawały jednak o sobie zapomnieć: wizja Humboldta musiała w znacznym stopniu rozmijać się z oczekiwaniami władz państwowych, kół gospodarczych, wreszcie studentów. Wypadkową tych rozbieżnych często dążeń stał się XIX-wieczny rozwój uniwersytetów. Pod koniec stulecia było ich więcej niż na początku, zatrudniały liczniejszą kadrę, miały większe znaczenie jako placówki badawcze; wzrosła też liczba studiującej w nich młodzieży.

Jedno wszakże nie ulegało istotnej zmianie: mimo wzrostu liczby studentów wykształcenie uniwersyteckie pozostawało dobrem elitarnym, domeną warstw wyższych i średnich. Zasadnicze rozszerzenie dostępu 
do studiów miała przynieść dopiero druga połowa XX w. To przede wszystkim pod tym względem historia uniwersytetów przyspieszyła wtedy biegu. W 1949 r. były w Europie 204, uczelnie uznawane za uniwersytety; w 1984, r. ich liczba wzrosła do 524 ; w 2005 r. przekroczyła już $1000^{2}$. W drugiej połowie ubiegłego stulecia liczba studiujących na uniwersytetach wzrosła pięciokrotnie ${ }^{3}$. W ostatnich kilku dziesięcioleciach studia nabrały zatem masowego charakteru, co z jednej strony było wielkim osiągnięciem, z drugiej - postawiło uczelnie wobec nowych problemów. Zanim jednak do tego doszło, Europa doświadczyć musiała wydarzeń, które przyniosła jej pierwsza połowa stulecia.

Dodajmy w tym miejscu krótkie wyjaśnienie. Dla historyka użyteczne jest uznawanie wieku za epokę o swoistych cechach, która nie musi być ściśle powiązana z podziałami kalendarzowymi. Wyznaczanie granic poszczególnych epok staje się z reguły okazją do sporów między badaczami. W przypadku XIX w. przyjmuje się najczęściej, że jego koniec wyznacza I wojna światowa - spierać się natomiast można, czy powinien to być wybuch, czy też wygaśnięcie działań wojennych. Musimy oczywiście zdawać sobie sprawę z umowności takich chronologicznych podziałów: istotne zmiany nie dokonują się przecież w jednej chwili, wymagają czasu. Niezależnie zatem od tego, czy wojnę światową zaliczymy do XIX, czy też XX w., należy traktować ją jako okres przejściowy. Kataklizm wojenny kończył jedną epokę i otwierał następną, kształtując warunki życia, klimat umysłowy i emocjonalny, struktury ustrojowe, granice państw. Pod tym potężnym wpływem znalazły się również środowiska uniwersyteckie.

\section{Wielka Wojna}

3 VIII 1914, r. Rzesza Niemiecka wypowiedziała wojnę Francji. Tego samego dnia Max Planck, rektor Friedrich-Wilhelms-Universität, współtwórca teorii kwantów i przyszły laureat Nagrody Nobla, wygłaszał uroczystą prelekcję z okazji 104. rocznicy założenia uczelni, którą kierował. W zatłoczonej auli Uniwersytetu Berlińskiego panowało ogólne podniecenie: zaczynała się wojna i niejeden ze studentów oraz wykładowców miał przed sobą wyjazd na front. Rektor początkowo trzymał się tematyki naukowej, ale w pewnym momencie przeszedł do sprawy najbardziej aktualnej, przemawiając - jak wspominali świadkowie zwięźle, ale z przejmującym patosem. Mówił, że Niemców oczekuje 


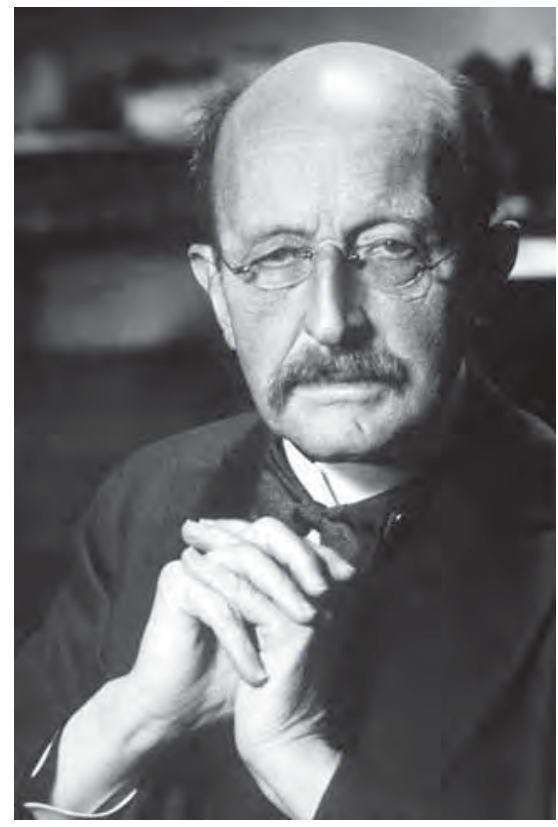

1. Max Planck walka o honor, a może nawet samą egzystencję narodu. Uroczystość kończyła się w podniosłym nastroju: pożegnano wyjeżdżających na wojnę, a następnie odśpiewano Deutschland, Deutschland über alles ${ }^{4}$.

Podobnie działo się na innych niemieckich uczelniach. Rektorzy i senaty uniwersytetów bawarskich wystosowali apel, który głosił, że „zamilkły muzy” i zaczyna się „święta wojna”. W Tybindze pierwszy semestr rozpoczynającego się roku akademickiego zakończono już 1 sierpnia. Studenci licznie zgłaszali się na ochotnika do wojska, ochotników nie brakowało też wśród profesorów, nie tylko najmłodszych wiekiem. Alfred Weber, ekonomista z Heidelbergu, wyjechał jako oficer na front w wieku 4,6 lat. W przypadku profesury zgłoszenie się do wojska nie musiało, rzecz jasna, oznaczać służby frontowej. Pięćdziesięcioletni Max, słynny brat Alfreda, od dawna w stanie spoczynku z powodów zdrowotnych, rozpoczął służbę oficerską w administracji wojskowych szpitali. Według relacji żony, pierwsze miesiące wojny uważał za „punkt szczytowy egzystencji”; wojna, podkreślał, mimo swych potworności jest czymś „wielkim i cudownym”. Kto nie znalazł się, w takiej czy innej roli, w wojsku, ten mógł wspierać wojenny wysiłek jako zaangażowany ideowo wykładowca. Wykłady dla wojskowych i dla cywilów, w głębi kraju i na froncie, ale z jednym celem - aby przyczynić się do zwycięstwa ${ }^{5}$.

Patriotyczny zapał Niemców nie był wyjątkowy, choć trochę wyróżniał się natężeniem i agresywnymi akcentami. W każdym z przystępujących do wojny państw powszechnie spodziewano się konfliktu krótkiego i oczywiście zwycięskiego. Zwycięstwo miało opromienić chwałą rodzimą armię i doprowadzić do realizacji celów, o których mówili politycy i propagandyści. Uniwersytety wchodziły w okres wojny jako część podporządkowanych państwu struktur opiniotwórczych, a środowiska akademickie na ogół dobrze wypełniały przypisane sobie zadanie: wykładowcy i studenci, umysłowa elita swych społeczeństw, świecili przykładem patriotycznego zaangażowania.

W Wielkiej Brytanii, gdzie silne były tendencje do izolowania się od spraw kontynentu, decyzja o przystąpieniu do wojny również nie wywołała silniejszego sprzeciwu - ani wśród ogółu mieszkańców, ani 
w kręgach uniwersyteckich. Wybitny angielski filozof i matematyk Bertrand Russell, wykładowca Cambridge, pacyfista, sprzeciwiał się udziałowi Wielkiej Brytanii w wojnie. Pod koniec lipca 1914, r. był na swym uniwersytecie. W Autobiografii pisał później tak: „Czułem, że Anglia powinna pozostać neutralna, i zbierałem podpisy wielu profesorów i fellowów pod oświadczeniem tej treści, które ukazało się w «Manchester Guardian». W dniu wypowiedzenia wojny prawie wszyscy z nich zmienili zdanie". 3 sierpnia, w przeddzień wypowiedzenia wojny Niemcom przez Wielką Brytanię, wierzący w siłę nastrojów antywojennych Russell pojechał do Londynu. „Wieczór spędziłem na włóczeniu się po ulicach, obserwowaniu pogodnego tłumu i wczuwaniu się w emocje przechodniów. W tym dniu i w następnych odkryłem ku swojemu zdziwieniu, że przeciętnych mężczyzn i kobiety cieszy perspektywa wojny". Podobnych obserwacji dokonywał także w swym własnym środowisku: „Pierwsze dni wojny zdumiewały mnie w najwyższym stopniu. Moi najlepsi przyjaciele, jak np. Whiteheadowie, byli nastawieni bardzo wojowniczo". Russell, który nie zmieniał swego nastawienia do wojny, popadał w środowiskową izolację („[...] zacząłem spostrzegać, że mnie unikają przy stole profesorów w sali jadalnej”") $)^{7}$ W 1916 r. uniwersytet pozbawił go stanowiska wykładowcy; w 1918 r. Russell trafił na pół roku do więzienia za prasowe wypowiedzi, które uznano za obrazę amerykańskiego sojusznika Wielkiej Brytanii ${ }^{8}$.

Wojna, która okazała się nieporównanie dłuższa i bardziej wyczerpująca, niż wcześniej przypuszczano, uwidoczniła, jak wielka może być praktyczna użyteczność odkryć naukowych i rozwoju techniki. Wielu wybitnych przedstawicieli nauk przyrodniczych odznaczyło się na tym polu, oferując nowe możliwości działania armiom swoich krajów, ale i narażając się na zarzut współodpowiedzialności za frontowe masakry. Chemik Fritz Haber, od 1911 r. dyrektor Kaiser-Wilhelm-Institut für physikalische Chemie und Elektrochemie, honorowy profesor zwyczajny chemii fizycznej na Uniwersytecie Berlińskim, znacznie wspomógł wojenną gospodarkę Niemiec, opracowując jeszcze przed wojną metodę syntezy amoniaku. Po wybuchu wojny podjął badania nad gazami bojowymi i stał się jednym z twórców nowej, budzącej powszechny lęk broni, którą Niemcy zastosowali po raz pierwszy w kwietniu 1915 r. Za syntezę amoniaku Haber otrzymał po zakończeniu działań wojennych Nagrodę Nobla z chemii za 1918 r.; jako twórca gazów bojowych był przez zwycięskich aliantów oskarżany o złamanie konwencji haskiej i uważany za przestępcę wojennego ${ }^{9}$.

Wojna sprawiła, że zacieśniły się więzi między światem polityki, gospodarką, wojskiem i nauką, a przynajmniej tymi jej dziedzinami, 
które mogły mieć bezpośrednie znaczenie militarne. Zjawiska te wywarły jednak stosunkowo niewielki wpływ na uniwersytety: prace na rzecz armii prowadzono głównie poza uczelniami, w specjalnych ośrodkach badawczych, przeważnie związanych z przemysłem i administracją państwową. Najlepszym tego przykładem była wojenna aktywność niemieckich Instytutów Cesarza Wilhelma (Kaiser-Wilhelm-Institute). Jeżeli wojna oddziaływała na uniwersytety, to przede wszystkim w sposób dezorganizujący. Było to oczywiste w przypadku terenów, na których toczyły się walki: Rosjanie, wycofując się przed naporem armii niemieckiej, ewakuowali w głąb Imperium pracowników oraz znaczną część studentów i majątku Cesarskiego Uniwersytetu Warszawskiego; ale i tam, gdzie nie dotarły działania wojenne, widać było wpływ wojny. Wykładowcy i studenci założyli mundury, tysiące z nich miało nie powrócić z frontu; uczelnie pracowały w trudnych warunkach, a w odczuciu władz i opinii publicznej kwestia ich potrzeb musiała schodzić na daleki plan ${ }^{10}$. A kiedy wojna dobiegła wreszcie końca, nie oznaczało to wcale zasadniczej poprawy położenia uniwersytetów.

\section{„Wiek skrajności”: nazizm}

Epoka, którą otwierała I wojna światowa, bywała później nazywana „wiekiem skrajności” i „wiekiem nienawiści”"1. Można te określenia uznać za trafne, można widzieć w nich przesadę - w końcu historia ludzkości nigdy nie była domeną szczęścia - ale nie sposób zaprzeczyć, że wraz z wybuchem Wielkiej Wojny Europa, po kilku dziesięcioleciach wyraźnej stabilizacji, zaczynała wchodzić w nowy, znacznie bardziej burzliwy okres swych dziejów. Traktaty pokojowe z lat 19191920 nie stworzyły - i zapewne nie mogły stworzyć - podstaw nowego ładu europejskiego. Trudności gospodarcze sprzyjały nasilaniu się napięć społecznych, radykalne ideologie uwodziły miliony obietnicą szybkiego rozwiązania narastających problemów, załamywała się wiara w demokrację parlamentarną.

Pamiętając, że niełatwo o wiarygodne uogólnienia w skali całego kontynentu, możemy powiedzieć, iż summa summarum nie był to dobry okres dla europejskich uniwersytetów. Nękająca Europę zła koniunktura gospodarcza - w tym zwłaszcza Wielki Kryzys przełomu lat dwudziestych i trzydziestych - sprawiała, że w obliczu różnych palących kwestii sprawy uniwersyteckie uznawano za mniej ważne ${ }^{12}$. 
Nawet w tych dość stabilnych politycznie państwach, które zachowywały ustrój parlamentarnej demokracji, jeszcze przed ogólnym załamaniem koniunktury uczelnie przeważnie słabo się rozwijały; w dobie kryzysu mamy do czynienia ze stagnacją albo regresem. Szans rozwoju nie dawały też pojawiające się wtedy tradycjonalistyczne na ogól, autorytarne dyktatury, które miały skłonność do narzucania uczelniom różnych ograniczeń natury politycznej. Zapowiedzią prawdziwej destrukcji życia uniwersyteckiego mogły być poczynania faszystowskiego reżimu we Włoszech, ale na wielką skalę doszło do niej w państwach mających totalitarne aspiracje: nazistowskich Niemczech i stalinowskim Związku Radzieckim.

Zarówno niemieckie cesarstwo, jak imperium carów były państwami, które upadły pod ciężarem wojennych niepowodzeń. Dla niemieckich środowisk akademickich przegrana wojna i upadek monarchii stanowiły bolesne doświadczenie. Nacjonalistyczny zapał, z jakim witano początek działań zbrojnych, przekształcił się w głęboką frustrację. Republika Weimarska, nowe państwo powstałe na gruzach cesarstwa, uważana była na ogół za narzuconą przez zewnętrznych i wewnętrznych wrogów narodu, obcą i szkodliwą strukturę - widziano w niej zerwanie ciągłości niemieckich dziejów. Spotykało się „republikanów z rozsądku”, którzy akceptowali istniejące państwo bez sympatii, z powodów pragmatycznych, ale i oni znajdowali się w mniejszości ${ }^{13}$. „Od 1919 roku niemieckie uniwersytety mogły się uważać za bastiony wrogów republiki”"14.

W przypadku uniwersytetów dobrze sprawdza się teza, że „,pod wieloma względami Hitler miał już przygotowany grunt, gdy doszedł do władzy"15. Profesura, w czasach cesarstwa ważny składnik państwowego establishmentu, miała w większości poglądy konserwatywne, na ogół o dość umiarkowanym odcieniu, chociaż wśród młodszego pokolenia pojawiali się radykałowie wzywający do „konserwatywnej rewolucji”. I umiarkowani, i rzecznicy nacjonalistyczno-konserwatywnego radykalizmu odrzucali zarówno zachodnioeuropejski liberalizm, jak marksizm i bolszewicki rewolucjonizm. Liberalny system wartości i demokrację parlamentarną uważano za świadectwa duchowego upadku, triumfu bezdusznego racjonalizmu i postępującej komercjalizacji; marksizm i bolszewizm postrzegano jako zjawiska z jednej strony wrogie liberalizmowi, z drugiej - wyrastające z tych samych co on, materialistycznych i antynarodowych podstaw. Amerykanizujący się Zachód i sowiecki Wschód miały stanowić podwójne zagrożenie dla niemieckiej tożsamości narodowej i niemieckiej kultury, będącej, jak podkreślano, skarbnicą najcenniejszych wartości. Uniwersyteccy konserwatyści mogli uznawać narodowy socjalizm Hitlera za prostacki i wulgarny, lecz 
w ich poglądach nie było przeważnie nic, co skłaniałoby do przeciwstawienia się mu. Przeciwnie, nazizm zaczął wydawać się niejednemu propozycją do przyjęcia, a w końcu nawet czymś atrakcyjnym - Hitler zapowiadał przecież narodowe odrodzenie Niemiec i marsz ku prawdziwej wielkości narodu ${ }^{16}$.

Atrakcyjność nazizmu mogła wzrastać w oczach wykładowców, którzy znajdowali się na niższych szczeblach akademickiej hierarchii - w tym zwłaszcza rosnącej liczebnie grupy „docentów prywatnych” (Privatdozenten), mających prawo wykładania, ale bez wynagrodzenia. Kryzys finansowy, w jakim znajdowały się uniwersytety w dobie Weimaru, bardzo ograniczał możliwości służbowego awansu. Niejeden sfrustrowany swym położeniem spodziewał się, że przewrót polityczny szerzej otworzy wrota do kariery ${ }^{17}$.

Jeszcze łatwiej przychodziło nazistom zdobywanie zwolenników wśród studentów. W okresie cesarstwa na uniwersytetach działały wprawdzie różnorodne organizacje studenckie, ale ton życiu uczelni nadawały przede wszystkim korporacje kultywujące idee nacjonalistyczne; ci, którym nie odpowiadały poglądy i obyczajowość dominujące w tych środowiskach, byli spychani na margines. Na takim podłożu, w atmosferze powojennej frustracji, wobec kryzysu gospodarczego i wielkich trudności ze znalezieniem pracy po studiach, młodzież chętnie zwracała się w stronę narodowego socjalizmu ${ }^{18}$.

Dojście Hitlera do władzy w zasadniczy sposób zmieniło warunki, $\mathrm{w}$ jakich pracowały niemieckie uniwersytety. Uczelnie, podobnie jak inne instytucje i organizacje, zostały poddane procedurom „ujednolicenia" (Gleichschaltung), czyli podporządkowania nowemu reżimowi. W kwietniu 1933 r. władze rozpoczęły czystkę personalną: wielu wykładowców, Żydów i krytyków nazizmu, zostało usuniętych z uniwersytetów. W latach 1933-1936 z uczelni zwolniono ogólem 16,3\% wykładowców; dla Berlina wskaźnik ten wynosił 32,4\%, Frankfurtu nad Menem - 32,3\%, Heidelbergu - 24,3\% ${ }^{19}$. Niektórzy ze zwolnionych mieli paść ofiarą nazistowskich prześladowań; większość, mniej więcej dwie trzecie, wyemigrowała, głównie do USA. Stopniowo usuwano też żydowskich studentów - do 1938 r. kiedy oficjalnie zabroniono Żydom studiowania, pozostała ich już tylko garstka, poddawana ciągłym szykanom. Autonomia uniwersytecka została zniesiona - rektorzy stali się „Führerami” swych uczelni, podległymi Ministerstwu Nauki, Wychowania i Kultury Narodowej Rzeszy; senatom i dziekanom odebrano wiele dotychczasowych uprawnien.

Poczynania nazistowskich władz nie spotkały się z poważniejszym oporem na uczelniach. Protesty były odosobnione, a znaczna część 
środowisk akademickich czynnie poparła nazistów. Wydarzeniem o symbolicznym charakterze stała się akcja publicznego palenia książek uznanych przez reżim za szkodliwe. $10 \mathrm{~V} 1933$ r. na berlińskim Opernplatz spłonęło 20 tysięcy tomów. Przemawiał wtedy, triumfując, minister propagandy Rzeszy Joseph Goebbels, lecz nie on był inicjatorem owego autodafe, przedsięwzięcia o ogólnokrajowym zasięgu, które objęło prawie wszystkie uniwersytety niemieckie. Zainicjowali je działacze Niemieckiego Związku Studentów, rywalizując w krzewieniu „nowego ducha" z Narodowosocjalistyczną Niemiecką Federacją Studentów. Do akcji przyłączyły się nacjonalistyczne organizacje studenckie. Kiedy uniwersyteckie biblioteki oczyszczano z potępionych przez nazistów książek, członkowie akademickich elit nie protestowali - przeciwnie, większość z nich stała przy ogniskach, manifestując poparcie dla walki z tym, co „nieniemieckie" ${ }^{20}$.

Po stronie narodowego socjalizmu ostentacyjnie opowiedzieli się niektórzy z najwybitniejszych uczonych. Dwie najbardziej znane z tych postaci to filozof Martin Heidegger i prawnik Carl Schmitt. Heidegger, profesor na uniwersytecie we Fryburgu Bryzgowijskim, został w kwietniu 1933 r. rektorem tej uczelni. 1 maja wstąpił do NSDAP, 27 maja wygłosił swój rektorski wykład inauguracyjny, w którym przewidywał, że w nowych warunkach politycznych nastąpi gruntowna odnowa uniwersytetów. Z jego inspiracji powstała deklaracja wierności niemieckiej profesury wobec Hitlera i nazistowskiego państwa ${ }^{21}$. Schmitt, który został członkiem NSDAP tego samego dnia co Heidegger, a jesienią 1933 r. objął katedrę na Uniwersytecie Berlińskim, jeszcze bardziej zaangażował się jako zwolennik nazizmu. Stał się ważnym uczestnikiem życia publicznego III Rzeszy i starał się wypracować możliwie przekonującą legitymację władzy narodowych socjalistów ${ }^{22}$.

Heideggera i Schmitta łączy to, że po pewnym czasie ich związki z nazistowskim reżimem rozluźniły się. Nie odeszli od nazizmu zupełnie, ale znaleźli się poza głównym nurtem państwowej aktywności Rzeszy, a ich działania ograniczyły się do sfery akademickiej. Miało to oczywiście różne indywidualne przyczyny, warto jednak przy tej okazji podkreślić, że narodowy socjalizm stworzył takie warunki uprawiania nauki, które okazywały się kłopotliwe nawet dla jego przekonanych zwolenników - o ile tylko wykazywali pewną dozę umysłowej niezależności. Jeśli wielu konserwatywnych naukowców, wrogo nastawionych do Republiki Weimarskiej, spodziewało się, że Hitler otworzy przed niemiecką nauką perspektywy jakiegoś odrodzenia, to przynajmniej niektórzy z nich mogli z czasem poczuć się rozczarowani. Nie miało to większego znaczenia praktycznego: zarówno nieludzki 
charakter systemu, jak jego intelektualny prymitywizm nie budziły szerszych sprzeciwów. Rzeczywiści i potencjalni krytycy wyemigrowali, zostali zmuszeni do milczenia lub nie żyli. Ci, którzy pozostali, kierowali się wiarą w Hitlera, koniunkturalizmem i konformizmem w różnych proporcjach.

Po latach w Republice Federalnej Niemiec toczyła się dyskusja na temat „nowoczesności” bądź też „nienowoczesności” nazizmu i III Rzeszy $^{23}$. Debata tego rodzaju nie mogła doprowadzić do żadnej ostatecznej konkluzji, ponieważ wnioski, do jakich dochodzono, zależały od sposobu pojmowania i oceniania „nowoczesności”, to zaś było, jest i z pewnością będzie przedmiotem niedających się rozstrzygnąć kontrowersji. Nie ulega w każdym razie wątpliwości, że pod rządami Hitlera niemiecka nauka znalazła się w stanie głębokiego upadku. Powód pierwszy to eliminacja wielu wybitnych uczonych; drugi, jeszcze ważniejszy - poddanie działalności naukowej państwowo-partyjnej presji, wynikającej z mieszaniny motywów ideologicznych i pragmatycznych.

Dyktatura o totalitarnych ambicjach, usiłująca wcielić w życie projekt rasistowskiego imperium, narzucała nauce ideologiczne, prostackie schematy, a z trzymania się ich czyniła kwestię lojalności wobec wodza, państwa i narodu. Rezultatem tego stała się destrukcja nauki rozumianej jako niezależna aktywność umysłowa. Nie może specjalnie dziwić ruina humanistyki i nauk społecznych, które, ilustrując nacjonalistyczno-rasistowskie tezy, zostały w istocie sprowadzone do roli propagandowego instrumentu nazistów ${ }^{24}$. Bardziej osobliwe były ideologiczne oddziaływania w dziedzinie nauk ścisłych: próby stworzenia „niemieckiej matematyki”, wolnej od „,̇ydowskiego formalizmu” i „abstrakcyjności”, czy też „niemieckiej fizyki”, odrzucającej teorię względności i mechanikę kwantową, również jako „żydowskie”. Nauki ścisłe i przyrodnicze trudniej ulegały nazistowskiej ideologizacji - tym bardziej że państwowo-partyjny nacisk miał dwoisty charakter, to zaś mogło prowadzić do wewnętrznych sprzeczności $\mathrm{w}$ owej polityce naukowej. Z jednej strony starano się bowiem kształtować naukę zgodnie z nacjonalistyczno-rasistowskimi wyobrażeniami, z drugiej - żądano praktycznej użyteczności prowadzonych badań. A kto tylko nie był całkiem zaślepionym fanatykiem, ten prędzej czy później mógł się zorientować, że ideologiczne drogowskazy nie prowadzą do zbyt użytecznych rezultatów. Niemniej trzeba podkreślić, że wśród konsekwentnych zwolenników „niemieckiej fizyki” znaleźli się Philipp Lenard, laureat Nagrody Nobla z 1905 r., i Johannes Stark, noblista z 1919 r. (o tym, że ich poczynania budziły środowiskowe sprzeciwy, może świadczyć uniemożliwienie przez innego 
noblistę, Maxa von Laue - nagroda w 1914 r. - przyjęcia Starka do Pruskiej Akademii Nauk) ${ }^{25}$.

Ideę „niemieckiej fizyki” można uznać za kuriozum niemające istotnych konsekwencji praktycznych - poza karierami, jakie w III Rzeszy robili rzecznicy takich pomysłów. Niemiecką naukę łączyły jednak z życiową praktyką związki jak najbardziej poważne, a często przerażające. Wytyczna praktycznej użyteczności miała od początku w znacznej mierze sens militarny, gdy zaś wybuchła wojna światowa, praca dla wojska stała się jednym z dwóch podstawowych zadań. Jednym z dwóch, ponieważ nauka stanowiła też ważny czynnik przy opracowywaniu i realizacji planów ideologicznie uzasadnianego ludobójstwa: szybka zagłada milionów byłaby niemożliwa bez gruntownej wiedzy z zakresu organizacji i zarządzania, zbrodnicze eksperymenty medyczne, które prowadzono po części z myślą o armii, miały też służyć skuteczniejszemu prowadzeniu rasistowskiej polityki.

Oprócz podporządkowania nazistowskiej ideologii i związanego z tym upadku nauki, okres III Rzeszy przyniósł niemieckim uniwersytetom głęboki regres z punktu widzenia rozwoju studiów wyższych, także w kategoriach ilościowych. Programy nauczania uległy ideologizacji, studentów starano się intensywnie indoktrynować, lecz Hitler tak czy owak odnosił się z niechęcią do wykształcenia uniwersyteckiego. Można to po części wywodzić z jego osobistych kompleksów, rzecz miała jednak głębsze podłoże ideologiczne, reżim nazistowski musiał bowiem - mimo skutecznego podporządkowywania sobie środowisk akademickich - widzieć w uniwersyteckiej tradycji czynnik zagrażający jego totalitarnym ambicjom. W III Rzeszy liczba studentów znacznie spadła. Ogółem w niemieckich szkołach wyższych studiowało: w roku akademickim 1931/1932 - 128 tys. osób, w roku 1937/1938 - 57,5 tys., w roku 1943/1944 (po powiększeniu obszaru Wielkich Niemiec) 85 tys. Jeszcze wyraźniej zaznaczał się ten spadek w przypadku uniwersytetów: 1931 r. - 100 tys. studentów, 1939 r. - 40 716, 1943/1944 r. - 54 085. Miał tu znaczenie niż demograficzny lat trzydziestych, ale ważne były przede wszystkim konsekwencje polityczno-ideologicznych decyzji władz, takich jak ogólne ograniczenie przyjęć na studia oraz wprowadzenie przepisu, że kobiety mogą stanowić co najwyżej 10\% ogółu studiujących ${ }^{26}$.

Wpływ, jaki nazizm wywarł na stan kadry akademickiej, nie wynikał jedynie z czystek personalnych. W nowej sytuacji politycznej możliwe stały się ruchy kadrowe wynikające z nowych, ściśle ideologicznych kryteriów oceny wykładowców. Narodowosocjalistyczna gorliwość stanowiła skuteczne narzędzie służbowego awansu dla ludzi, którzy nie zasługiwali 
na ten awans jako badacze i nauczyciele akademiccy ${ }^{27}$. Przyspieszała karierę ludzi zdolnych, lecz hołdujących nazistowskim wyobrażeniom i pozbawionych skrupułów. Nie zapominajmy też o obojętnych ideowo cynikach, sprawnie dostosowujących się do realiów III Rzeszy ${ }^{28}$.

\section{„Wiek skrajności”: stalinizm}

W jakiej mierze stalinowski Związek Radziecki był podobny do hitlerowskich Niemiec? Niekończące się dyskusje na ten temat mają charakter tyleż naukowy, co polityczny i światopoglądowy. Zwolennicy tezy o zasadniczym podobieństwie wskazują na totalitarną naturę obu systemów ustrojowych: i w jednym, i w drugim przypadku rządzący dążyli do pełnego podporządkowania sobie społeczeństwa, narzucenia mu radykalnej ideologii i wprzęgnięcia do realizacji utopijnych wizji - budowy światowego porządku komunistycznego lub rasistowskiego imperium. W obu przypadkach stosowano także podobne metody: masową indoktrynację i terror przeradzający się w ludobójstwo. Krytycy takiej koncepcji, której fundament stanowi pojęcie „totalitaryzmu”, podkreślają, że Związek Radziecki i III Rzeszę wiele różniło: poziom rozwoju cywilizacyjnego, tradycje rodzimej kultury, źródła panującej ideologii. Kwestionują również przydatność „totalitaryzmu” jako głównego narzędzia konceptualizacji dziejów dwóch dyktatur ${ }^{29}$.

Porównywanie sytuacji niemieckich i sowieckich uniwersytetów może dostarczyć argumentów zarówno rzecznikom koncepcji totalitarnego podobieństwa, jak i jej krytykom - obok podstawowych różnic widzimy tu uderzające podobieństwa. Odmienna była geneza każdego z systemów: Hitler stał na czele ruchu po części społecznie radykalnego, ale do rządów powołały go tradycyjne elity, establishment wywodzący się z czasów cesarstwa; Stalin doszedł do władzy w państwie będącym wytworem rewolucyjnego przewrotu, który obalił dotychczasowe hierarchie społeczne. Hitler, choć po uchwyceniu władzy szybko pokazał swym dotychczasowym protektorom, kto jest panem Niemiec, doszedł do porozumienia z niemieckimi warstwami wyższymi. Naziści zmuszali do emigracji, milczenia w kraju, zamykali do więzień lub zabijali tych członków niemieckich elit intelektualnych, którzy nie odpowiadali ich ideologicznym wyobrażeniom, lecz represjonowani stanowili wyraźną mniejszość. Bolszewicy, zniszczywszy dawne warstwy wyższe, rozbili 
też środowiska twórcze carskiego imperium. Część przedrewolucyjnej warstwy oświeconej przetrwała w Związku Radzieckim, sowiecka inteligencja była jednak w przeważającej mierze produktem nowej epoki.

„Wybitnego uczonego, czołowego specjalistę w tej czy innej dziedzinie trzeba oszczędzić, nawet jeśli ma reakcyjne poglądy" ${ }^{\prime 30}$. Lenin powtarzał to podobno wielokrotnie Anatolijowi Łunaczarskiemu, który po przewrocie bolszewickim jako ludowy komisarz oświaty miał zarządzać całością życia umysłowego kraju ${ }^{31}$. To zdanie, brzmiące przecież dość ponuro, sygnalizowało, że w kwestii „czołowych specjalistów” przywódca bolszewików skłonny był działać pragmatycznie (podobnie jak w dziedzinie polityki gospodarczej). Ci z przedstawicieli inteligencji, którzy nie padli ofiarą masowego terroru w okresie wojny domowej i nie wyemigrowali, nie znajdowali się zatem w sytuacji całkiem beznadziejnej. Jeśli ich kwalifikacje okazywały się użyteczne dla nowego reżimu, mogli liczyć - przynajmniej chwilowo - na przyzwoite traktowanie. Im silniejsza pozycja w świecie nauki, tym większe były szanse na życie w dobrych warunkach: światowej sławy fizjolog Iwan Pawłow, noblista z 1904, r., choć poglądy miał z punktu widzenia bolszewików bez wątpienia „reakcyjne”, był hołubiony przez sowieckie władze i dożył w dostatku późnego wieku ${ }^{32}$. Jednakże ani Lenin, ani inni liderzy bolszewiccy w żadnym razie nie wyrzekali się swych rewolucyjnych celów, to zaś niedobrze wróżyło ludziom uważanym za produkt obalonego systemu. Na korzyść przedrewolucyjnej inteligencji działała natomiast zarówno cywilizacyjna słabość kraju - tradycyjnie zapóźnionego, a wyniszczonego jeszcze przez wojnę - jak i względna słabość bolszewików, którzy potrafili uchwycić władzę, ale sami nie rozporządzali środkami pozwalającymi myśleć o realizacji bardzo ambitnych planów.

Ideolodzy bolszewiccy, myśląc o głębokiej przebudowie społeczeństwa i dojściu do komunizmu, widzieli bowiem w rewolucyjnych przemianach coś, co w bezprecedensowy sposób wyzwoli twórcze siły ludzkości. Przeświadczenie o cywilizacyjnym znaczeniu rewolucji było istotnym składnikiem poglądów Marksa, a w Rosji, wobec tutejszych problemów rozwojowych, miało szczególny ciężar gatunkowy. Trocki, który swe ideologiczne wizje konstruował ze szczególnym rozmachem, z pewnością nie może być uznany za postać reprezentatywną dla całej bolszewickiej elity, ale jego poglądy zasługują na uwagę. W tomie Literatura i rewolucja z 1924, r., pisząc o niezwykłym rozwoju, jaki stanie się możliwy w komunizmie, roztaczał przed czytelnikami oszałamiające perspektywy: „Człowiek, który nauczy się poruszać rzeki i góry, budować pałace na szczycie Mont Blanc i na dnie Atlantyku, zdolny będzie wyposażyć swe życie nie tylko w bogactwo, intensywność i blask, ale 
również w dynamizm najwyższej próby [...]. Człowiek postawi sobie za cel opanowanie własnych uczuć [...] i w ten sposób wzniesie się na nową płaszczyznę egzystencji, stworzy wyższy typ społeczno-biologiczny, czyli, jeśli można się tak wyrazić, przekształci się w nadczłowieka" ${ }^{\prime 33}$. Trocki wychodził tu znacznie poza horyzont wyobrażeń większości bolszewickich działaczy, lecz nie wydaje się, aby jego eugeniczne fantazje były sprzeczne z ich odczuciami. Idea postępu naukowo-technicznego, pojmowanego jako narzędzie przekształcania życia ludzkiego, była mocno zakorzeniona w leninowskiej mutacji marksizmu. Przed przywódcami nowego państwa stał jednak podstawowy dylemat: czy dążąc do rozwoju, trzymać się ideologii i posługiwać metodami nowymi, zgodnymi z radykalną doktryną, czy też raczej zachowywać się pragmatycznie, iść na kompromis z rzeczywistością i zachować przynajmniej część tego, co „stare"? Dylemat ten pozostawał aktualny aż do końca istnienia Związku Radzieckiego, wpływał także w decydujący sposób na relacje między władzami a uczelniami.

W okresie wojny domowej wśród uniwersyteckiej profesury przeważały nastroje wrogie bolszewikom. Już wkrótce po przewrocie, którego dokonali Lenin i Trocki, na uczelniach rozległy się oficjalne protesty; później większość profesorów liczyła na zwycięstwo przeciwników rewolucji, a gdy ci ponieśli klęskę, wykładowcy uczelni z terenów, które opuszczały wojska „białych”, często wyjeżdżali z kraju wraz z ewakuującymi się oddziałami (i tak większa część kadry dawnego Cesarskiego Uniwersytetu Warszawskiego, przeniesionego w 1915 r. do Rostowa nad Donem, popłynęła w 1920 r. do Konstantynopola) ${ }^{34}$. W atmosferze rewolucyjnej ekscytacji władze przystąpiły wkrótce do działań mających pozbawić uniwersytety samodzielności i uczynić je narzędziem nowej polityki edukacyjnej. Dekret z października 1918 r. znosił naukowe stopnie magistra i doktora, usuwał z uniwersytetów profesorów, którzy pracowali na tej samej uczelni co najmniej dziesięć lat lub co najmniej piętnaście lat piastowali stanowisko profesorskie, otwierał wreszcie możliwość ubiegania się o zwolnione stanowiska przed każdym, kto, jak pisano, wyrobił sobie reputację jako uczony lub nauczyciel ${ }^{35}$. Okazało się jednak szybko, że szkolnictwo wyższe niełatwo przekształcić w nowym duchu - „stara” profesura była stale niezbędna, bo wśród zwolenników bolszewizmu brakowało ludzi o odpowiednich kwalifikacjach.

Warunki pracy uniwersytetów miała uregulować ustawa z 2 IX 1921 r. Podporządkowywała ona uczelnie bezpośrednio Ludowemu Komisariatowi Oświaty, który m.in. mianował rektora i zatwierdzał nominacje na stanowiska profesorskie. Podległość LKO nie była wszakże jedynym zewnętrznym czynnikiem wpływającym na działalność uniwersytetów. 
W praktyce większe znaczenie miewała nierzadko presja lokalnej administracji państwowej - urzędnicy chętnie ingerowali w sprawy uczelni. Istniał wreszcie istotny czynnik wewnętrzny w osobach „rewolucyjnych" studentów. Młodym zapaleńcom wydawało się, że mogą kierować uniwersytetem, a głównym przeciwnikiem była dla nich oczywiście „reakcyjna” profesura (choć nie cieszyło ich także zacieśnianie państwowej kontroli nad uczelniami). Przedrewolucyjni profesorowie, poddawani wszystkim tym naciskom, przez pewien czas utrzymywali swe pozycje ${ }^{36}$. Zdarzały się sytuacje kryzysowe: jesienią $1922 \mathrm{r}$. bolszewicy deportowali z kraju pod zarzutem wrogiej aktywności stu kilkudziesięciu twórców i naukowców, w tym znaczną grupę nauczycieli akademickich $^{37}$. Ogólnie jednak biorąc, do 1928 r. w stosunkach między władzami państwowymi a profesurą panował względny spokój ${ }^{38}$.

Zmiana tej sytuacji wiązała się z przejmowaniem pełni władzy w Związku Radzieckim przez Stalina i wyraźnym przyspieszeniem działań mających na celu przebudowę całego kraju. Uzyskawszy pod koniec lat 20. kontrolę nad partią komunistyczną, Stalin uczynił z partyjnej biurokracji narzędzie panowania nad społeczeństwem, któremu narzucił ideologię marksistowską w niezbyt wyrafinowanej wersji Lenina, jeszcze przez siebie prostacko skodyfikowanej. Partyjna dyktatura, wspierająca się na wszechobecnej indoktrynacji i ludobójczym terrorze, umożliwiała taki model rozwoju, którego nie można było wprowadzić ani w demokracjach, ani w państwach autorytarnych: przymusową kolektywizację rolnictwa i forsowną industrializację. Koncepcja wspieranego przez państwo uprzemysłowienia zaczęła sobie zdobywać w tamtym czasie popularność w wielu krajach, Stalin nadał jej jednak charakter skrajny i realizował z niezwykłą bezwzględnością ${ }^{39}$.

Ideologiczna mobilizacja, która w intencji władz partyjno-państwowych miała objąć wszystkie dziedziny życia, i program przyspieszonej modernizacji musiały wywrzeć głęboki wpływ na stan nauki i sytuację uniwersytetów. We wcześniejszym okresie zbrodnicza brutalność bolszewików przeplatała się - z takich czy innych powodów - z pewną elastycznością działania, a totalitarna wizja porządku społecznego nabierała dopiero konkretnych kształtów. Dawało to naukowcom i uczelniom skromny, lecz ważny margines swobody. Pod rządami Stalina niezależna aktywność umysłowa stopniowo obumierała, aż po II wojnie światowej wzmożone naciski ze strony partii, poparte jak zwykle represjami, sprawiły, że w wielu dziedzinach właściwie zupełnie zani$\mathrm{k} ł a . Z$ punktu widzenia partyjnego kierownictwa nie ulegało wątpliwości, że niezależność intelektualna badaczy stanowi czynnik społecznie szkodliwy. Nauka, podobnie jak w III Rzeszy, miała przede wszystkim 


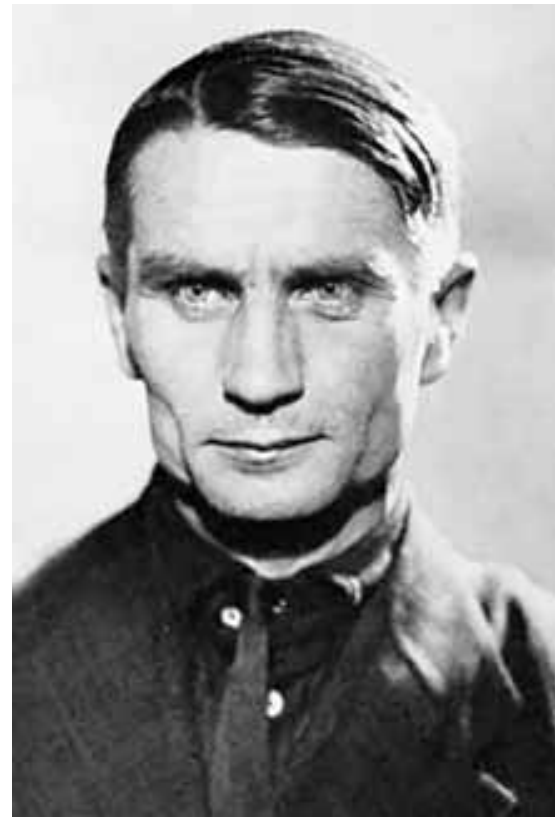

2. Trofim Łysenko

służyć praktyce - politycznej i techniczno-gospodarczej. Humanistyka musiała wspierać ideologię, czyli w istocie partyjną propagandę; nauki przyrodnicze - mieć wyniki użyteczne dla gospodarki i wojska ${ }^{40}$. I podobnie jak w III Rzeszy, owo ideologiczno-praktycystyczne skrępowanie dawało rezultaty dziwaczne, czasem całkiem kuriozalne, w ostatecznym rozrachunku nierzadko szkodliwe dla gospodarczych i militarnych możliwości Związku Radzieckiego.

Najbardziej chyba znanym przykładem owych zniekształceń pracy naukowej była osobliwa kariera Trofima Łysenki. W latach 3o. ten rzutki agronom zaczął popularyzować tezę, że organizmy żywe wykazują niemal nieograniczoną plastyczność pod wpływem zmian środowiskowych, a to, co twierdzi zachodnia genetyka, jest burżuazyjnym wymysłem. Poglądy Łysenki zyskały sobie uznanie sowieckiego kierownictwa i wróg genetyki stał się czołowym autorytetem nauk biologicznych w Związku Radzieckim. Piastował wysokie stanowiska, spłynęły nań różne zaszczyty (był członkiem Akademii Nauk ZSRR, przewodniczył Akademii Nauk Rolniczych). Jego pozycja nie załamała się po śmierci Stalina; dopiero po zgonie Nikity Chruszczowa władze zezwoliły na otwartą krytykę „łysenkizmu”.

Sprawa Łysenki pokazuje kilka interesujących aspektów sowieckiego życia naukowego. Po pierwsze, miała znaczenie ideologiczne: atak na zachodnią, „burżuazyjną” naukę był, z punktu widzenia Stalina i jego otoczenia, czymś użytecznym propagandowo, a idea plastyczności organizmów dobrze pasowała do komunistycznych marzeń o podboju przyrody ${ }^{41}$. Po drugie, pomysły Łysenki, ignoranta i szarlatana, trafiały do przekonania sowieckim decydentom, ponieważ obiecywał, że praktyczne zastosowanie jego koncepcji przyniesie ogromne korzyści rolnictwu (okazało się to zupełną iluzją). Kolektywizacja wywołała dramatyczny spadek produkcji rolnej - w tej sytuacji kariera pomysłowego agronoma była w znacznej mierze pochodną palącej potrzeby rozwiązania tego problemu. Po trzecie, Łysenko urodził się w rodzinie chłopskiej, co w latach 30. stanowiło cenny atut. Stalin chciał zniszczyć resztki dawnej inteligencji i „burżuazyjne” nawyki mentalne, stąd promowanie „chłopskich uczonych" ${ }^{{ }_{42}}$. 
Ideologizacja pracy naukowej, podporządkowanie badań praktycznym potrzebom państwa, inżynieria społeczna w sferze nauki i edukacji wszystkie te zjawiska były wyraźnie widoczne w życiu uniwersytetów. W dobie stalinizmu ideologiczne kanony narzucano wszystkim niemal dziedzinom nauki, choć, z dość oczywistych względów, w nierównym stopniu. Matematykę pozostawiono w spokoju, ingerencje pojawiły się natomiast w fizyce. Oficjalnie potępiono teorię względności i mechanikę kwantową - podobnie jak w III Rzeszy, ale z innych powodów, chodziło bowiem o ich niezgodność z filozoficznymi założeniami leninowskiego marksizmu. Jeszcze silniejsze były ideologiczne naciski w naukach biologicznych, a w tych warunkach otwierało się szerokie pole do rozmaitych urzędowo sankcjonowanych nadużyć. Przypadek Łysenki nie był bynajmniej czymś odosobnionym. Wystarczy wspomnieć o nie mniej spektakularnym casusie Olgi Lepieszynskiej, wpływowej partyjnie lekarki, która ogłosiła, że wytwarza żywe komórki z nieożywionej substancji organicznej, i zyskała oficjalny poklask (w 1950 r. została laureatką Nagrody Stalinowskiej). Obszarem najbardziej intensywnej ideologizacji stały się jednak - co nie powinno zbytnio dziwić - nauki humanistyczne i społeczne ${ }^{43}$.

Jeszcze w samych początkach władzy bolszewickiej Lenin zabiegał o to, aby na uniwersytetach zajmowano się w odpowiednio dużym wymiarze marksizmem. Przez kilka lat zamiar ten napotykał poważne trudności. „Stara” profesura odnosiła się na ogół niechętnie do nowej ideologii, marksistowskich wykładowców było niewielu, a ci, którzy pozostawali do dyspozycji, nie dawali wcale gwarancji lojalności wobec bolszewików. Marksizm, który przed rewolucją mógł być atrakcyjny jako krytyka istniejącego porządku, po rewolucji, stając się ideologią grupy rządzącej, tracił tę atrakcyjność. Kiedy po śmierci Lenina wprowadzono na uniwersytety jako przedmiot „leninizm”, rzecz zaczęła polegać na nużącym powtarzaniu frazesów ${ }^{44}$.

W 1928 r. Stalin rozpętał jednak kampanię wymierzoną w „burżuazyjnych specjalistów". Zapoczątkował ją proces kilkudziesięciu inżynierów i techników z kopalń w Szachtach w Zagłębiu Donieckim, fałszywie oskarżonych o antysowiecki spisek - zapadło wtedy 11 wyroków śmierci. Był to sygnał, że następuje zwrot w polityce wobec dawnych elit umysłowych, a także tradycyjnych instytucji - takich jak uniwersytety. Zaczynał się okres masowych czystek personalnych, pokazowych procesów, terroru na niespotykaną dotąd skalę i nasilenia totalitarnych ambicji władz. Dla uczelni oznaczało to przewrót kadrowy oraz jeszcze silniejsze podporządkowanie państwu i oficjalnej ideologii. Trzeba tu podkreślić, że działania, które podjął Stalin z myślą o umocnieniu 
swej pozycji, miały istotny kontekst społeczny. Represje wobec politycznych i intelektualnych elit - zarówno „burżuazyjnej” inteligencji, jak uformowanej po bolszewickim zwycięstwie warstwy kierowniczej ZSRR - otwierały drogę awansu „ludziom nowym”, wywodzącym się głównie spośród robotników i uboższego chłopstwa.

Wkrótce po zdobyciu władzy, wobec kłopotów z pełną kontrolą nad uniwersytetami, bolszewicy przystąpili do tworzenia własnych struktur edukacyjnych. Chodziło im, po pierwsze, o przygotowanie marksistowskich wykładowców i propagandystów oraz lojalnych kadr administracyjnych, po drugie, o umożliwienie pracownikom fizycznym przyspieszonego zdobycia średniego wykształcenia, tak aby mogli iść na studia. W 1918 r. powołano do życia Socjalistyczną Akademię Nauk Społecznych, w 1920 r. powstał Uniwersytet Komunistyczny im. Swierdłowa, a w 1921 r. - Instytut Czerwonej Profesury. System „komunistycznych uniwersytetów" i placówek o pokrewnym charakterze, rozwijający się w następnych latach, miał kompensować władzom niezadowalający, z ich punktu widzenia, stopień kontroli nad tradycyjnymi uczelniami. Jednocześnie starano się doprowadzić do zmiany społecznego składu zbiorowości studenckiej na tych uczelniach. Nie dało spodziewanych rezultatów rozwiązanie najprostsze i najbardziej radykalne, czyli dopuszczenie, na mocy dekretu z sierpnia 1918 r., do bezpłatnych studiów wyższych wszystkich, którzy ukończyli 16 lat. Profesura przyjęła to posunięcie z wielką niechęcią, młodzi proletariusze i chłopi garnęli się do studiowania mniej chętnie, niż przypuszczali bolszewiccy działacze, ci zaś, którzy zdecydowali się studiować, często zupełnie nieprzygotowani, słabo sobie radzili i nieraz rezygnowali. Uczelniom polecono więc otwierać „wydziały robotnicze” (raboczyje fakultiety, w skrócie rabfaki), mające zadbać o to, aby robotniczo-chłopscy kandydaci otrzymali w możliwie szybkim tempie wykształcenie na poziomie średnim. Rezultaty tych działań można oceniać z dużą dozą sceptycyzmu, ale tak czy owak na uniwersytetach rosła liczba studentów, których pochodzenie uważano za właściwe. To tym ludziom Stalin, niszcząc istniejące dotąd elity, umożliwiał awans; to oni tworzyli kadry stalinowskiej biurokracji, robili kariery i gotowi byli czcić przywódcę ZSRR jako postać najwybitniejszą w dziejach ${ }^{45}$.

Kiedy staramy się scharakteryzować sowiecki system kształcenia uniwersyteckiego, nie możemy pominąć czynnika niezmiernie ważnego, choć słabiej uchwytnego niż kwestie instytucjonalne, statystyki społeczne lub dane dotyczące prowadzonych na uczelniach badań. Leszek Kołakowski pisał po latach o „kulturze parweniuszy”, stalinowskich aparatczyków - pospiesznie awansowanych, niedokształconych, 
o wąskich horyzontach, nienawidzących tego, czego nie mogli zrozumieć $^{46}$. Kultura ta nadawała ton życiu pod rządami Stalina. Lata 20. były w ZSRR okresem kulturowego fermentu, eksperymentów czasem poronionych, czasem interesujących. W miarę utrwalania się władzy Stalina partia tłumiła tę aktywność, a sowiecka kultura - w oficjalnej retoryce „proletariacka” - nabierała coraz więcej cech konserwatywnych i drobnomieszczańskich. „Kultura parweniuszy” wycisnęła głębokie piętno na życiu sowieckich uczelni, które zachowały nazwę „uniwersytetów”, ale zatraciły to, co w europejskiej tradycji stanowiło o uniwersyteckim charakterze szkoły wyższej.

W 1916 r. w Imperium Rosyjskim było 10 uniwersytetów; w 1925 r. w Związku Radzieckim liczba ich wzrosła do 34. Liczba studentów zwiększyła się w tym czasie z prawie 39 tys. do 52 tys. ${ }^{47}$ Ten ilościowy wzrost łączył się ściśle z kampanią industrializacyjną i całym programem przekształcenia ZSRR w światową potęgę. Rozwojowe ambicje ekipy stalinowskiej w znacznej mierze określiły tė̇ kierunki zmian w sowieckim szkolnictwie wyższym.

Koncepcja uniwersytetu, jaką w początku XIX w. przedstawił Humboldt, była nie tyle pragmatycznym projektem, co odległym - być może w ogóle nieosiągalnym - ideałem. Dążenie do niego decydowało jednak o tożsamości europejskich uniwersytetów. Dla kierownictwa ZSRR ideał bezinteresownego poszukiwania prawdy był bezużyteczny, a pod pewnymi względami nawet wybitnie szkodliwy. Zasada podporządkowania nauki bezpośrednim potrzebom państwa sprawiła, że powstał scentralizowany i hierarchiczny aparat biurokratycznego zarządzania działalnością naukową ${ }^{48}$. Naukowcy, których pracę uznawano za przydatną dla państwa - w tym zwłaszcza, jak w przypadku fizyków, z militarnego punktu widzenia - zyskiwali wysoką pozycję społeczną (rzecz jasna pod warunkiem pełnej lojalności politycznej). Szkolnictwo wyższe, poddane ścisłej kontroli administracyjnej, rozbudowywano według kryterium praktycznej użyteczności. Na przełomie lat 20. i zo. dały się zresztą słyszeć głosy o bezużyteczności uniwersytetów, oderwanych od "prawdziwego" życia i jego potrzeb; na niektórych uczelniach zaczęto likwidować wydziały uznawane za niepotrzebne, czyli humanistyczne i społeczne ${ }^{49}$.

Ostatecznie uniwersytety przetrwały, stały się jednak dość skromną częścią potężnej struktury instytucjonalnej. W dziedzinie badań na plan pierwszy wysuwały się placówki Akademii Nauk ZSRR, która zgodnie ze statutem z 1935 r. była najwyższą instytucją naukową kraju; istniała też rozległa sieć instytutów podległych poszczególnym ministerstwom. W dziedzinie nauczania nacisk kładziono na szkolnictwo 
zawodowe: techniczne, medyczne, ekonomiczne, rolnicze. Pojawiła się też tendencja do przekształcania tych wydziałów uniwersyteckich, które uznawano za związane z techniką i gospodarką, w odrębne uczelnie. Stalinowska polityka wywarła głęboki i trwały wpływ na szkolnictwo wyższe: w 1960 r. było w ZSRR 4o uniwersytetów, a szkół wyższych ogółem - 739; na uniwersytetach studiowało 249 tys. osób, co stanowiło ok. 10\% ogółu studentów ${ }^{50}$.

Po II wojnie światowej sowiecki system organizacji nauki i wyższej edukacji narzucono krajom zajętym przez Armię Czerwoną. Przemiany, jakie nastąpiły w ZSRR po śmierci Stalina, nie wywołały dalej idących przekształceń tego systemu, choć nastąpiło wtedy pewne osłabienie ideologicznego nacisku na naukę.

\section{Wielka Wojna po raz drugi}

II wojna światowa przyniosła uniwersytetom europejskim bardzo zróżnicowane doświadczenia. Położenie uczelni w krajach opanowanych przez Niemcy było pochodną ogólnych zasad, jakie regulować miały politykę okupacyjną, te zaś różniły się od siebie znacznie w zależności od obszaru, którego dotyczyły. W Europie Zachodniej - pojawiały się tu oczywiście pewne lokalne odmienności - uniwersytety znalazły się pod ścisłym nadzorem policyjnym, obowiązywała restrykcyjna cenzura, a wszelkie przejawy oporu stawały się powodem represji. Z uczelni zostali usunięci Żydzi, którzy następnie w większości trafili do obozów zagłady.

W Europie Środkowo-Wschodniej i Wschodniej - gdzie niemiecka polityka również miała niejednakowy charakter - ogólny ton działaniom Niemiec nadawała idea utworzenia na tych terenach rasistowskiego imperium. Narzędziem nazistowskiej inżynierii społecznej stało się ludobójstwo i czystki etniczne. Zgodnie z zespołem dokumentów, który otrzymał nazwę Generalplan Ost, większość miejscowej ludności miała zostać fizycznie zlikwidowana lub wysiedlona na wschód od Uralu $^{51}$. Generalplan Ost opracowywano w pierwszych latach wojny, ale stanowił on rozwinięcie i konkretyzację planów wcześniejszych. Kiedy we wrześniu 1939 r. wojska niemieckie zajęły część terytorium Polski, rozpoczęły się masowe egzekucje Żydów i polskiej inteligencji. Jesienią 1939 i wiosną 1940 r. ofiarą akcji „Inteligencja” padło ponad 100 tys. osób ${ }^{52}$. 
Eksterminacja inteligencji stanowiła kluczowy składnik programu sprowadzenia społeczeństwa polskiego do poziomu niezdolnej do politycznej aktywności, niewykwalifikowanej siły roboczej. Z nazistowskiego punktu widzenia nie mogło zatem być mowy ani o polskich uniwersytetach, ani nawet szkołach średnich. Dla słowiańskich pracowników fizycznych odpowiednia miała być czteroklasowa szkoła powszechna. W memoriale przygotowanym wiosną 1940 r. przez Himmlera i zatwierdzonym przez Hitlera czytamy: „Celem tych szkół powszechnych jest jedynie nauczenie rachowania najwyżej do 500, pisowni nazwisk, nauka, która jest boskim przykazaniem bycia posłusznym Niemcom, a także uczciwym, pilnym oraz rzetelnym. Umiejętność czytania uważam za zbędną" ${ }^{93}$.

Symbolicznego znaczenia nabrało oficjalne poniekąd zetknięcie się polskiej profesury z niemieckim aparatem bezpieczeństwa. 3 XI 1939 r. rektor Uniwersytetu Jagiellońskiego Tadeusz Lehr-Spławiński otrzymał od oficera SS polecenie zebrania wykładowców na prelekcję o niemieckim stanowisku wobec uniwersytetów. Profesorowie i asystenci - w zdecydowanej większości pracownicy UJ, ale także przedstawiciele innych uczelni - zgromadzili się 6 XI 1939 r. w jednej z sal Collegium Novum. Przybył tam SS-Sturmbannführer Bruno Müller, prawnik z wykształcenia, jeden z dowódców działającej w Polsce „grupy operacyjnej” SS. Oświadczył, że uczelnia rozpoczęła rok akademicki bez zezwolenia władz, a jej wykładowcy są wrogo nastawieni do nauki niemieckiej. W związku z tym, zakończył, obecni na sali Polacy zostaną wysłani do obozu koncentracyjnego. Podczas akcji, którą nazywano później Sonderaktion Krakau, zatrzymano 183 osoby, w tym 14,2 wykładowców UJ. 11 aresztowanych wkrótce zwolniono, resztę przewieziono do obozu Sachsenhausen; część po pewnym czasie znalazła się w Dachau. Nacisk europejskiej opinii - w tym m.in. interwencja Mussoliniego sprawił, że władze niemieckie ostatecznie zdecydowały się uwolnić krakowskich naukowców, wielu z nich jednak zmarło w obozie lub wkrótce po jego opuszczeniu ${ }^{54}$. Mimo niezwykłej bezwzględności, z jaką Niemcy prowadzili swą politykę, nie udało im się sparaliżować polskiego życia umysłowego, w tym także działalności uniwersytetów. Pod okupacją, mimo terroru i bardzo trudnych warunków materialnych, rozwinęły się struktury tajnego szkolnictwa wyższego.

Poczynania nazistowskiego reżimu znajdowały silne wsparcie w niemieckich środowiskach akademickich. Theodor Schieder, młody wówczas historyk, który miał zrobić imponującą karierę uniwersytecką w Republice Federalnej Niemiec, w swoim opracowaniu z października 1939 r. zalecał czystki etniczne na wielką skalę w „odzyskanych 
prowincjach wschodnich", widząc w takich działaniach środek w pełni usprawiedliwiony interesami narodu niemieckiego; niepokoiła go także możliwość „wyłonienia się nowej polskiej warstwy przywódczej" Historycy przedstawiali argumenty mające ideowo podbudować ekspansję na wschód, co nasiliło się wraz z atakiem na ZSRR. Hermann Heimpel - po wojnie jedna z najbardziej prominentnych postaci życia akademickiego Republiki Federalnej Niemiec - w książce wydanej w 1941 r. podkreślał, że średniowieczne cesarstwo, którego spadkobiercami są Niemcy, miało „wewnętrzne uzasadnienie w misji miecza na Wschodzie". Reinhard Wittram widział w Niemcach tych, którzy tworzą podstawy europejskiej jedności ${ }^{56}$.

Heimpel, profesor we Fryburgu Bryzgowijskim i Lipsku, od 1941 r. pracował na Uniwersytecie Rzeszy w Strasburgu; Wittram otrzymał katedrę na Uniwersytecie Rzeszy w Poznaniu. Reichsuniversitäten to placówki będące szczególnie jaskrawym przejawem wprzęgnięcia instytucji uniwersytetu w poczynania państwowo-partyjnego aparatu III Rzeszy. Pod takim szyldem funkcjonował od 1939 r. niemiecki uniwersytet w Pradze; w 1941 r. powstały podobne uczelnie w Strasburgu i Poznaniu. Uniwersytety Rzeszy, utworzone na terenach świeżo opanowanych przez Niemcy, miały charakter ściśle związany z planami budowy nazistowskiego imperium i narzucenia Europie nowego porządku politycznego. Zakładano, że prowadzone w tych placówkach prace z zakresu gospodarki rolnej, etnografii i antropologii służyć będą rozwojowi niemieckiego osadnictwa, studia historyczne zaś dowodzić wyższości Niemców nad innymi narodami ${ }^{57}$. Zalążkiem niemieckiego uniwersytetu w Krakowie miał być Institut für Deutsche Ostarbeit, założony w $1940 \mathrm{r}^{58}$

Wskazując na zaangażowanie niemieckiej nauki w działania, które III Rzesza podejmowała podczas wojny, musimy pamiętać, że uczelnie nie odgrywały tu zbyt ważnej roli. Naukowcy z Uniwersytetu Berlińskiego uczestniczyli w przygotowywaniu Generalnego Planu Wschodniego, ale reżim wolał tworzyć osobne placówki do wykonywania praktycznych zadań; przedsięwzięcia o bezpośrednim znaczeniu militarnym były rzecz jasna utajnione, pracowały zaś nad nimi wyselekcjonowane zespoły badaczy, znajdujące się pod rygorystycznym nadzorem służb bezpieczeństwa. Zarówno w ZSRR, jak USA i Wielkiej Brytanii prace z dziedziny techniki wojskowej, wykorzystujące najnowsze osiągnięcia nauk ścisłych i przyrodniczych, także prowadzone były w specjalnych ośrodkach pod ścisłą kontrolą polityczną i policyjną.

II wojna światowa w jeszcze większym stopniu niż pierwsza uświadomiła europejskim politykom, elitom intelektualnym i gospodarczym, 
a także przynajmniej części opinii publicznej, jak ogromne są możliwości praktycznego wykorzystania osiągnięć naukowych. Symbolem najzupełniej wymiernej potęgi nauki stał się amerykański „Projekt Manhattan", którego produktem była bomba atomowa. Postępująca zmiana społecznego statusu nauki miała wpływać na sytuację uniwersytetów, lecz proces ten nie był ani szybki, ani jednoznaczny w swych konsekwencjach. Tymczasem Europa stanęła wobec ogromu zniszczeń, jakie pozostawiła po sobie wojna.

Problem odbudowy dotyczył równiė̇ uniwersytetów. Zniszczenia, o które w tym przypadku chodziło, miały różny zakres w różnych krajach, a ich charakter bywał tak materialny, jak intelektualny i moralny. $\mathrm{Na}$ Wschodzie odbudowie towarzyszyło narzucanie sowieckich rozwiązań ideowo-organizacyjnych w dziedzinie nauki i szkolnictwa - część ogólnego przewrotu ustrojowego. W Polsce w czasie wojny została wyniszczona większość inteligencji. Warstwa wykształcona padła tu z jednej strony ofiarą nazistów, z drugiej - terroru stalinowskiego, który dosięgnął tysiące Polaków po rozpoczętej 17 IX 1939 r. inwazji ZSRR na wschodnie ziemie Rzeczypospolitej; wielu inteligentów znalazło się na emigracji w Europie Zachodniej i pozostało tam po wojnie. W warunkach polskich trzeba było zatem nie tylko usuwać zniszczenia materialne, ale i odtwarzać warstwę inteligencką. Nauka polska miała wkrótce znaleźć się pod presją stalinizmu. Nie należy jednak zapominać, że nowy reżim podjął szeroko zakrojone działania na rzecz rozwoju uczelni i instytutów badawczych.

Niemcy były po wojnie zrujnowane materialnie, podstawowy problem stanowiła tu jednak spuścizna nazizmu, który w minionych latach znalazł tak wielu zwolenników na uniwersytetach. Kwestia wyższych uczelni wchodziła na gruncie niemieckim w zakres szerszych programów denazyfikacyjnych, z rozmaitą chęcią i umiarkowanym powodzeniem wprowadzanych w życie przez władze okupacyjne. W okupowanych podczas wojny przez Niemcy krajach Zachodu zaczęły się rozliczenia z tymi, którzy kolaborowali z III Rzeszą. Skompromitowani wykładowcy tracili uniwersyteckie stanowiska. We Francji, gdzie starano się uporać z dziedzictwem reżimu Vichy, najważniejsza decyzja dotyczyła sfery grande écoles, elitarnych uczelni usytuowanych poza podstawową siecią uniwersytetów. Wobec poparcia, jakie kolaboranckie władze zyskały w kręgach wyższych urzędników, postanowiono udoskonalić system kształcenia biurokratycznej elity. W październiku 1945 r. Rząd Tymczasowy Republiki utworzył École Nationale d'Administration, której zadaniem miało być odpowiednie przygotowywanie wyższych kadr urzędniczych ${ }^{59}$. 


\section{Masowość, rewolta, reformy}

Rok 1945 był ważną cezurą w dziejach europejskich uniwersytetów. Podstawowe znaczenie miała w tym przypadku stabilizacja polityczna w Europie: zakończył się okres wielkich wojen i gwałtownych wstrząsów wewnętrznych, a rywalizacja amerykańsko-sowiecka, choć kilkakrotnie groziła przekształceniem się w światowy konflikt zbrojny, ostatecznie nie wykroczyła poza formę ,zimnej wojny”. Wschodnia część kontynentu znalazła się pod kontrolą ZSRR, co przyniosło tym obszarom nieudane próby modernizacji, a w konsekwencji stagnację i kryzysy społeczno-gospodarcze. Część zachodnia, w której utrwalił się ustrój parlamentarnej demokracji, mogła natomiast wejść na drogę szybkiego wzrostu gospodarczego i głębokich przemian cywilizacyjnych. Umożliwiło to uniwersytetom zachodnioeuropejskim rozwój na niespotykaną dotąd skalę. Nie znaczy to jednak, że był to rozwój bezproblemowy i niewzbudzający kontrowersji, a jego obecne rezultaty mogą wszystkich zadowolić.

Walter Rüegg, próbując podsumować powojenne dzieje uniwersytetów w Europie, pisze o wielkim sukcesie, ale dodaje, że nastąpiła wówczas „prowincjonalizacja europejskich uniwersytetów” i „utrata przez nie światowej dominacji w dziedzinie badań i nauczania". O ile do II wojny światowej można było obserwować przyjmowanie europejskiego modelu uniwersytetu na innych kontynentach, o tyle po wojnie rolę wzorca do naśladowania przejęły uczelnie amerykańskie. Sama Europa Zachodnia znalazła się w tej dziedzinie pod rosnącym wpływem USA ${ }^{60}$.

W 1945 r. wielu ludzi podejmujących decyzje w sprawach zachodnioeuropejskiego szkolnictwa wyższego uważało, że zadanie, które stoi przed nimi, to przywrócenie uniwersytetów do stanu, w jakim znajdowały się przed wojną. Jednakże od pierwszych lat okresu powojennego pojawiała się też druga, nasilająca się z upływem czasu tendencja: jej rzecznicy sądzili, że uczelnie wymagają poważnych reform. Doświadczenia trzydziestolecia, które zamykał upadek III Rzeszy, skłaniały do szukania możliwie trwałych podstaw nowego, demokratycznego i liberalnego porządku. Uniwersytety, wskazywano, powinny być czynnikiem sprzyjającym korzystnym zmianom społecznym, lecz ich przedwojenny model budził z tego punktu widzenia zastrzeżenia. Padały zatem zarzuty elitarności i izolowania się od „realnego” życia. Uniwersytet jako „wieża z kości słoniowej”, siedlisko uprzywilejowanych i wywyższających 
się, nie mógł mieć szerszego oddziaływania społecznego, a jednocześnie wcale nie był odporny na zagrożenia, które czyniły iluzją jego intelektualną i moralną niezależność. Przypadek uniwersytetów niemieckich, przez długie lata świecących przykładem Europie i światu, był wystarczająco wymowny.

Reformatorskie postulaty z trudem trafiały do przekonania politykom. W dobie powojennej odbudowy i nasilającej się „zimnej wojny” uznawano na ogół, że jest wiele ważniejszych problemów niż kwestia szkolnictwa wyższego. Pierwsze rządowe decyzje w sprawie reform zaczęły zapadać w połowie lat 50. We Francji, Republice Federalnej Niemiec, później w Wielkiej Brytanii władze starały się wypracować coś, co do tej pory w Europie Zachodniej istniało w najlepszym razie w zalążku: sprecyzowany program działania państwa w dziedzinie wyższej edukacji. Postanawiano wzmacniać uczelnie pod względem materialnym, ulepszać programy studiów, wspierać rozwój badań. Dla rządów istotnym bodźcem stała się chęć skutecznego konkurowania z USA i ZSRR ${ }^{61}$. Okazało się jednak, że posunięcia te nie uchroniły uczelni przed poważnymi trudnościami. Na plan pierwszy wysunął się tu czynnik, który zmieniał oblicze powojennej Europy - wyż demograficzny.

Od 1950 do 1970 r. liczba ludności Wielkiej Brytanii wzrosła o 13\%, Włoch - 17\%, RFN - 28\%, Szwecji - 29\%, Holandii - 35\%; liczba ludności Francji zwiększyła się od 1946 r. do końca lat 6o. o blisko 30\%. Powojenna stabilizacja, poprawa warunków materialnych, w tym socjalna polityka państwa, łatwość znalezienia pracy - wszystko to złożyło się na baby boom, który miał bardzo istotne konsekwencje oświatowe ${ }^{62}$. Polityczne elity Zachodu, chcąc zbudować solidne fundamenty europejskiego ładu i uniknąć fatalnych zagrożeń, nękających nasz kontynent w pierwszej połowie stulecia, tworzyły instytucje państwa opiekuńczego. Miało ono zapewnić ogółowi swych obywateli świadczenia i usługi, których warstwy niższe były wcześniej pozbawione; dobra koniunktura gospodarcza sprzyjała realizacji tej strategii. Wśród najważniejszych elementów wcielanego wtedy w życie programu znajdowało się upowszechnienie edukacji na poziomie wyższym niż podstawowy. Szkoły średnie, w okresie międzywojennym trudno dostępne dla młodzieży z „ludu”, traciły swój elitarny charakter, a wraz z tym rosła liczba chętnych do studiów wyższych. W większości państw zachodnioeuropejskich absolwenci szkół średnich mieli wolny wstęp na wyższe uczelnie (pewnym wyjątkiem była pod tym względem Wielka Brytania, w której uniwersytetom przysługiwało prawo regulowania przyjęć).

W rezultacie lata 6o. stały się okresem boomu uniwersyteckiego - przynajmniej według kryteriów ilościowych. We Francji w 1950 r. 
na uniwersytetach studiowało 129 tys. osób, w 1960 r. - 24,0,7 tys., w 1970 r. - 694,8 tys.; odpowiednie dane dla Włoch: 18o,1 tys., 268 tys., 682 tys.; dla Holandii: 18,1 tys., 40,7 tys., 103,4 tys.; dla Wielkiej Brytanii: 81 tys., 129 tys., 258 tys. W RFN w 1960 r. liczba studentów na uniwersytetach wynosiła 247,2 tys., w 1970 r. - 4,12 tys.; w Hiszpanii odpowiednio 76,4 tys. i $23^{2}, 1$ tys. ${ }^{63}$ Wyzwaniu, jakie stanowił taki napływ studentów, starano się sprostać, zakładając nowe uczelnie. Wyglądało to rozmaicie w poszczególnych krajach. W Wielkiej Brytanii liczba uniwersytetów rosła od początku lat 50., z wyraźnym przyspieszeniem w latach 6o. Podobnie kształtowała się sytuacja w Republice Federalnej Niemiec, z tą istotną różnicą, że tu zakładanie uczelni nasiliło się w pierwszej połowie lat 70. W 1949 r. było w Wielkiej Brytanii 27 uniwersytetów, w 1984 r. - 48; w RFN nastąpił w tym czasie wzrost od 15 do 57. We Włoszech w 1949 r. istniały 24 uniwersytety, w 1984, r. - 49, a większość nowych uczelni utworzono w latach 70. i pierwszej połowie 8o. We Francji natomiast, gdzie w 1949 r. było 16 uniwersytetów, do 1968 r. powstały tylko dwie nowe uczelnie, w 1964 i 1965 r., ale w 1984 r. liczba uniwersytetów sięgnęła 81, przeważnie w wyniku podziału tych, które stały się już nadmiernie rozrośnięte ${ }^{64}$.

Im wolniej rozbudowywano sieć uniwersytecką, tym większe obciążenia spadały na istniejące uczelnie. Uniwersytety przyjmowały coraz więcej studentów, a niektóre z nich rozwijały się do rozmiarów, które jeszcze niedawno trudno było sobie wyobrazić. W połowie lat 8o. na monachijskim Ludwig-Maximilians-Universität, Freie Universität w Berlinie Zachodnim, czy tė̇ madryckim Universidad Complutense studiowało już ponad 60 tys. studentów, a rzymski uniwersytet Sapienza miał ich 120 tys. ${ }^{65}$ Rozrost ten wywoływał wiele problemów: ogromnymi uczelniami trudno było zarządzać, uczelniana infrastruktura stała się przeciążona, warunki studiowania pogarszały się („Wszędzie panował tłok - w bibliotekach, akademikach, salach wykładowych, stołówkach..."66).

Rewolta studencka z końca lat 6o. miała, jak każde tego rodzaju zjawisko, wiele przyczyn. W Europie Zachodniej jedną z najważniejszych wydaje się stan, w jakim znajdowały się tamtejsze uniwersytety, przy czym kwestie materialne i praktyczne łączyły się tu ściśle z kulturowo-ideowymi. W połowie lat 6o. młodzież studiująca na przepełnionych i często zaniedbanych uczelniach miała poczucie, że zarówno władze uniwersyteckie i większość profesury, jak państwowy establishment obojętnie albo nawet wrogo odnoszą się do jej problemów. Wyraźnie rysowały się kulturowe różnice między starszymi generacjami a częścią środowisk młodzieżowych: młodzi ubierali się w sposób, który dla starszych 


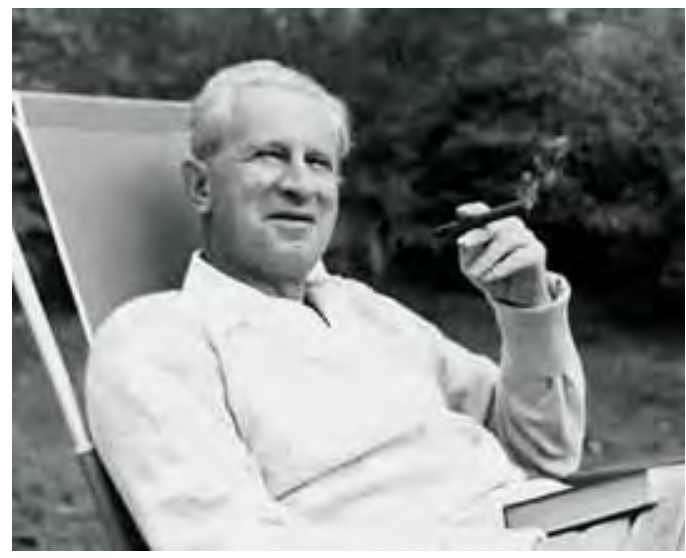

3. Herbert Marcuse w 1955 r. był ekscentryczny albo skandalicznie niedbały, słuchali muzyki będącej dla ich rodziców lub dziadków prymitywnym hałasem, czasem próbowali narkotyków, a obyczaje seksualne tego powojennego pokolenia stanowiły według „starych" świadectwo moralnego upadku.

W takiej atmosferze wśród studentów zyskiwały na popularności radykalne idee o dość eklektycznym rodowodzie: marksizm - zwłaszcza w wersji Trockiego - łączył się w nich z freudyzmem, inspirowano się też maoizmem i rozmaitymi „trzecioświatowymi” socjalizmami oraz tradycją anarchistyczną. Wśród ideologów, którzy stali się autorytetami młodych radykałów, na czoło wysuwał się Herbert Marcuse, niemłody już (rocznik 1898) filozof niemiecki, emigrant z 1933 r., następnie wykładowca renomowanych uniwersytetów amerykańskich, rzucający gromy na zmaterializowaną jego zdaniem i bezduszną cywilizację Zachodu.

Za oceanem od połowy lat 6o. nasilały się studenckie protesty przeciwko wojnie prowadzonej przez USA w Wietnamie. 2 VI 1967 r. niemieccy studenci demonstrowali w Berlinie Zachodnim przeciwko wizycie szacha Iranu - interweniowała policja, jeden z funkcjonariuszy zastrzelił Benno Ohnesorga, studenta filologii na Wolnym Uniwersytecie. Śmierć Ohnesorga wywołała falę masowych demonstracji w całej Republice Federalnej Niemiec. Wiosną następnego roku manifestacje nabrały gwałtownego charakteru, były kolejne ofiary śmiertelne i setki rannych. Gwałtowny przebieg miały też studenckie wystąpienia we Włoszech. We Francji od jesieni 1967 r. narastał konflikt między młodzieżą z niedawno powstałego kampusu w Nanterre - inwestycja na paryskim przedmieściu miała rozładować tłok na Sorbonie - a władzami uczelni. Od początku 1968 r. narastała tam fala niepokojów, aż w kwietniu kampus został zamknięty. Ruch studencki dał wtedy o sobie znać ze zdwojoną siłą w centrum Paryża. Sorbonę okupowano, a w maju na ulicach miasta pojawiły się barykady; dochodziło do brutalnych starć z policją.

"Paryski maj” 1968 r. stał się symbolem studenckiej rewolty. Jej bezpośrednie rezultaty trudno było uznać za imponujące. Radykalny ruch, przez pewien czas masowy, wygasł dość szybko; część ekstremistów sięgnęła po metody terrorystyczne, wydała wojnę państwu 
i prędzej czy później została przez nie zneutralizowana. Wydarzenia 1968 r., przez przeciwników „nowej lewicy” uważane często za erupcję bezsensownej przemocy i świadectwo zatrucia destrukcyjną ideologią, z pewnością nie były jednak polityczną efemerydą, która przeminęła bez trwałych śladów. Dziś można w nich widzieć przejaw głębokich zmian społeczno-kulturowych i jeden z punktów zwrotnych w dziejach europejskich uniwersytetów.

W krajach, które doświadczyły studenckiego radykalizmu, lata 70. to okres, w którym przyspieszono zakładanie nowych uniwersytetów. Inwestycje w tej dziedzinie miały poprawić materialną podstawę umasowionego kształcenia. Działaniom tego rodzaju zaczęły towarzyszyć reformy, które w znacznej mierze zmieniły obraz życia uniwersyteckiego w Europie Zachodniej. Uniwersytety demokratyzowały się, w przeszłość odchodził model uczelni zdominowanej przez profesurę. Przestało być rzeczą oczywistą, że interesy uczelnianego środowiska reprezentować mogą jedynie profesorowie. Prawo współdecydowania o sprawach uniwersytetu uzyskiwały teraz ciała złożone z przedstawicieli pracowników różnych kategorii i studentów. Jednocześnie rozrost poszczególnych uczelni i całych systemów kształcenia sprawiał, że biurokratyzowało się uniwersyteckie zarządzanie. Lawinowy przyrost przepisów i zarządzeń mógł budzić niechęć w środowiskach akademickich. Podstawowym problemem, przed którym stanęli teraz administrujący uniwersytetami, stawał się jednak wzrost kosztów funkcjonowania uczelni. Uniwersytecka ekspansja mocno obciążała państwowe budżety ${ }^{67}$.

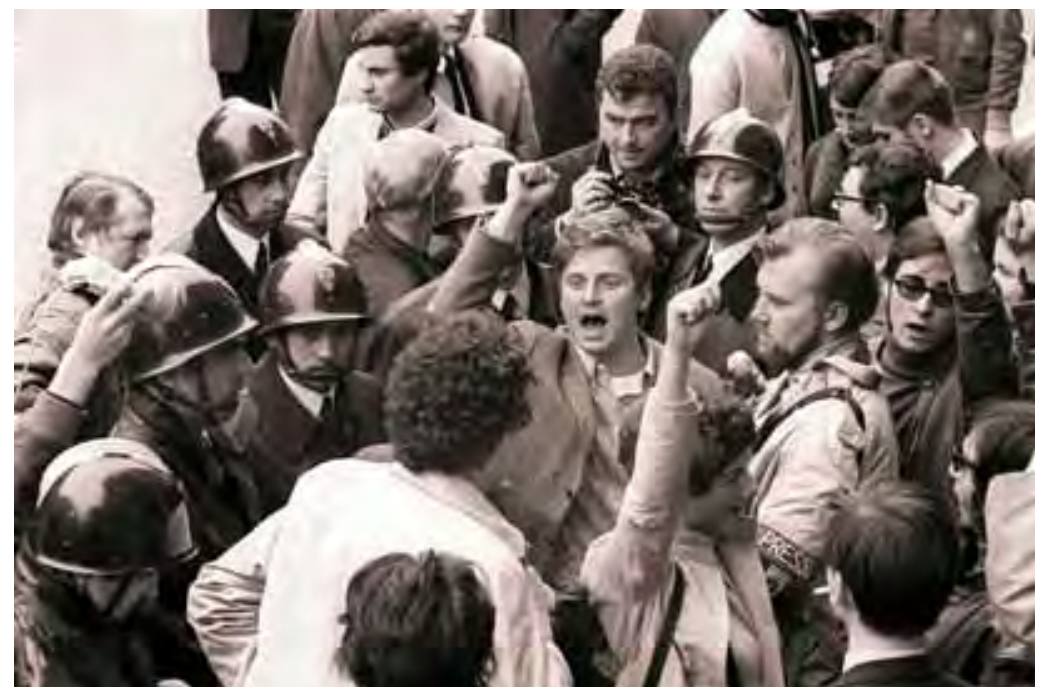

4. Demonstracje w Paryżu, maj 1968 r. Pośrodku jeden z przywódców studenckiej rewolty, Daniel Cohn-Bendit, śpiewający Międzynarodówke 
W Wielkiej Brytanii, której premierem w 1979 r. została Margaret Thatcher, dokonano w tej dziedzinie zwrotu budzącego do dziś wielkie kontrowersje. Zwycięstwo wyborcze Thatcher było przejawem ogólnej tendencji ujawniającej się wtedy w krajach Zachodu: zwątpienia w "państwo opiekuńcze" i zastępowania tej koncepcji ideą wolnorynkowego ładu. Postulaty, które przedstawiła konserwatywna ekipa Thatcher, wyróżniały się jednak radykalizmem ${ }^{68}$. Jeśli idzie o uniwersytety, to punktem wyjścia była tu teza, że znalazły się w kłopotach finansowych, ponieważ marnotrawią przyznawane im przez państwo pieniądze. To, co robią uczelnie, podkreślano, musi być ekonomicznie opłacalne i społecznie użyteczne. W sferze akademickiej powinny zatem obowiązywać zasady przedsiębiorczości: jeśli państwo łoży na szkolnictwo wyższe, to wydatki te należy ograniczać i racjonalizować. Uniwersytety miały odtąd zabiegać o środki - zarówno ze źródeł państwowych, jak prywatnych - a państwo miało kontrolować, czy pieniądze podatników są właściwie wydawane. Pierwszą istotną decyzją brytyjskiego rządu było wprowadzenie w 1981 r. opłat za studia dla cudzoziemców; podsumowanie rządowych działań stanowił Education Reform Act z 1988 r. (nie obejmował Szkocji, która miała odrębne instytucje oświatowe) ${ }^{69}$.

Uniwersyteckie posunięcia rządu Thatcher miały swych entuzjastów, ale wywołały też gwałtowną krytykę, płynącą z różnych kierunków. Nie może specjalnie dziwić, że krytykowali rząd ludzie związani z opozycyjną Partią Pracy. Zarzutów nie szczędzili jednak również konserwatyści, w tym także przekonani zwolennicy polityki, którą Thatcher prowadziła w innych dziedzinach. Krytyce przyświecało hasło „a university is not a business". Znany konserwatywny polityk Enoch Powell - który niegdyś został w wieku 25 lat profesorem classics w Sydney - ostrzegał, że zastosowanie wobec uniwersytetu zasady ekonomicznej użyteczności przyniesie jego nieuchronny upadek. Krytycy wskazywali, że nowe reguły finansowania pozornie tylko zbliżają uczelnie do wolnorynkowego ideału, a w istocie ściśle je podporządkowują państwowej biurokracji. Mnożyły się procedury kontrolne i ewaluacyjne. Wykładowcy skarżyli się, że muszą poświęcać coraz więcej czasu na pisanie planów i sprawozdań; protesty wywoływało wprowadzanie „bibliometrycznego profilowania", pozwalającego „oceniać profesorów bez czytania ich prac" (Shirley R. Letwin), na podstawie liczby cytowań. Co więcej, Education Reform Act znosił tenure, czyli gwarancję stałego zatrudnienia dla profesorów. Rząd przekonywał, że umożliwi to dopływ „świeżej krwi” na uniwersytety, lecz krytycy dowodzili, iż rządowa decyzja podkopuje intelektualną, polityczną i moralną niezależność profesury ${ }^{70}$. 
Ostateczny bilans zmian, jakie w okresie rządów Thatcher wprowadzono w szkolnictwie wyższym, może być przedmiotem sporów, nie ulega jednak wątpliwości, że tendencja do zaszczepiania na uczelniach zasad „przedsiębiorczości” okazała się w Europie silna i w znacznej mierze ukształtowała ten stan rzeczy, z jakim obecnie mamy do czynienia. W obliczu problemów związanych z wielkim rozrostem struktur edukacyjnych idea „biznesowego" zarządzania uniwersytetami ma wielu zwolenników we wpływowych środowiskach. Walter Rüegg, starając się ocenić stan europejskich uczelni w początku XXI w., podkreśla, że taki styl zarządzania nie jest wcale szkodliwy dla kształcenia, którego podstawę stanowią badania, i wskazuje na uniwersytety amerykańskie ${ }^{71}$.

\section{Wyzwanie amerykańskie, europeizacja, globalizacja}

W ${ }_{196} 6$ r. francuski polityk i publicysta Jean-Jacques Servan-Schreiber opublikował książkę zatytułowaną Le Défi américain. Przekonywał w niej, że Stany Zjednoczone zdecydowanie górują nad Europą pod względem możliwości rozwoju gospodarczego. Publikacja szybko stała się światowym bestsellerem, pobudzającym do dyskusji. Jej temat miał kluczowe znaczenie dla tych, którzy chcieli rywalizować z USA - sojusznikiem, ale i konkurentem. Szkolnictwo wyższe było jedną z dziedzin, w których „amerykańskie wyzwanie” rzucało się w oczy bardzo wyraźnie. Wzrost światowego znaczenia amerykańskich uniwersytetów stanowił oczywiście jeden z aspektów osiągania przez Stany Zjednoczone statusu supermocarstwa. Supermocarstwowość polityczno-militarna miała oparcie w potędze gospodarczej, potencjale naukowym i atrakcyjności wzorców kulturowych.

Uniwersytety amerykańskie, które wyrosły na gruncie zmodyfikowanej przez kolonistów tradycji angielskiej, w XIX w. zaczęły podlegać oddziaływaniu humboldtowskiego modelu uczelni. Założony w $1876 \mathrm{r}$. w Baltimore Johns Hopkins University był pierwszym w USA uniwersytetem o celach wyraźnie badawczych. W XX w. na gruncie amerykańskim ukształtował się zróżnicowany wewnętrznie system szkolnictwa wyższego, w którym uniwersytety badawcze tworzą czołówkę wyróżniającą się wysokim poziomem nauczania. The Servicemen's Readjustment Act (potocznie „G.I. Bill”) z 1944 r., na mocy którego państwo pokrywało koszty studiowania weteranom wojennym, otwierał epokę 
widocznej demokratyzacji studiów. Procesy demokratyzacyjne nabrały jeszcze tempa w latach 6o., wraz z nasileniem się kampanii o emancypację rasową i rozwojem ruchu feministycznego. „G.I. Bill” był czymś znamiennym dla epoki, w której państwo podejmowało coraz więcej zadań społecznych, lecz charakterystyczną cechą amerykańskiego systemu edukacji wyższej pozostało znaczenie, jakie dla jego funkcjonowania ma sektor pozarządowy. Elita uniwersytetów badawczych - Harvard University, Princeton University, Stanford University, University of Chicago, Yale University, Columbia University - to uczelnie prywatne. Zdecydowaną większość uczelni państwowych stanowią uniwersytety stanowe, w zasadzie finansowane przez państwo, ale intensywnie zabiegające o dodatkowe fundusze ze źródeł zarówno publicznych, jak prywatnych. „Menedżerski” sposób zarządzania uniwersytetami uważany jest w USA za rzecz oczywistą.

Po II wojnie światowej uczelnie amerykańskie stały się światowymi centrami badawczo-oświatowymi, a uniwersytety europejskie doświadczyły - jak ujął to Rüegg - „prowincjonalizacji”. Przestały być tym, czym były przez długi czas: wzorem dla reszty świata ${ }^{72}$. W popularnych rankingach wyższych uczelni (szanghajskim czy QS) prym wiodą uniwersytety amerykańskie, z którymi w pewnym stopniu konkurować mogą brytyjskie, w tym zwłaszcza Oksford i Cambridge. Rankingi uczelni bywają nie bez racji ostro krytykowane ${ }^{73}$, ale dominacja USA nie ulega wątpliwości.

W obliczu „amerykańskiego wyzwania” stanęły uniwersytety, których europejskość stopniowo nabierała pogłębionego znaczenia, coraz bardziej wykraczając poza ramy li tylko geograficznej charakterystyki. Trzeba jednak pamiętać, że szkolnictwo wyższe nie przodowało w dziedzinie integracji europejskiej. I choć procesy integracyjne - początkowo dotyczące przede wszystkim gospodarki - musiały wywrzeć wpływ na życie uczelni, to „europeizacja” europejskich uniwersytetów następowała dość powoli i nie bez przeszkód. Poczynania powstałej w 1949 r. Rady Europy miały pod tym względem bardzo ograniczone znaczenie. W traktatach rzymskich z 1957 r., powołujących do życia Europejską Wspólnotę Gospodarczą, sprawy kształcenia wyższego zajmowały odległe miejsce. Spory wokól jednej z kwestii poruszanych w traktatach zaczęły jednak skłaniać do starań o zacieśnienie współpracy w sferze akademickiej. Chodziło o wzajemne uznawanie przez członków EWG dyplomów wyższych uczelni. Trudności związane z ustalaniem kryteriów, jakie powinny w tej dziedzinie obowiązywać, znacznie przyczyniły się do zwołania w $1971 \mathrm{r}$. konferencji ministrów odpowiedzialnych za edukację i badania w sześciu państwach Wspólnoty. Konferencja 


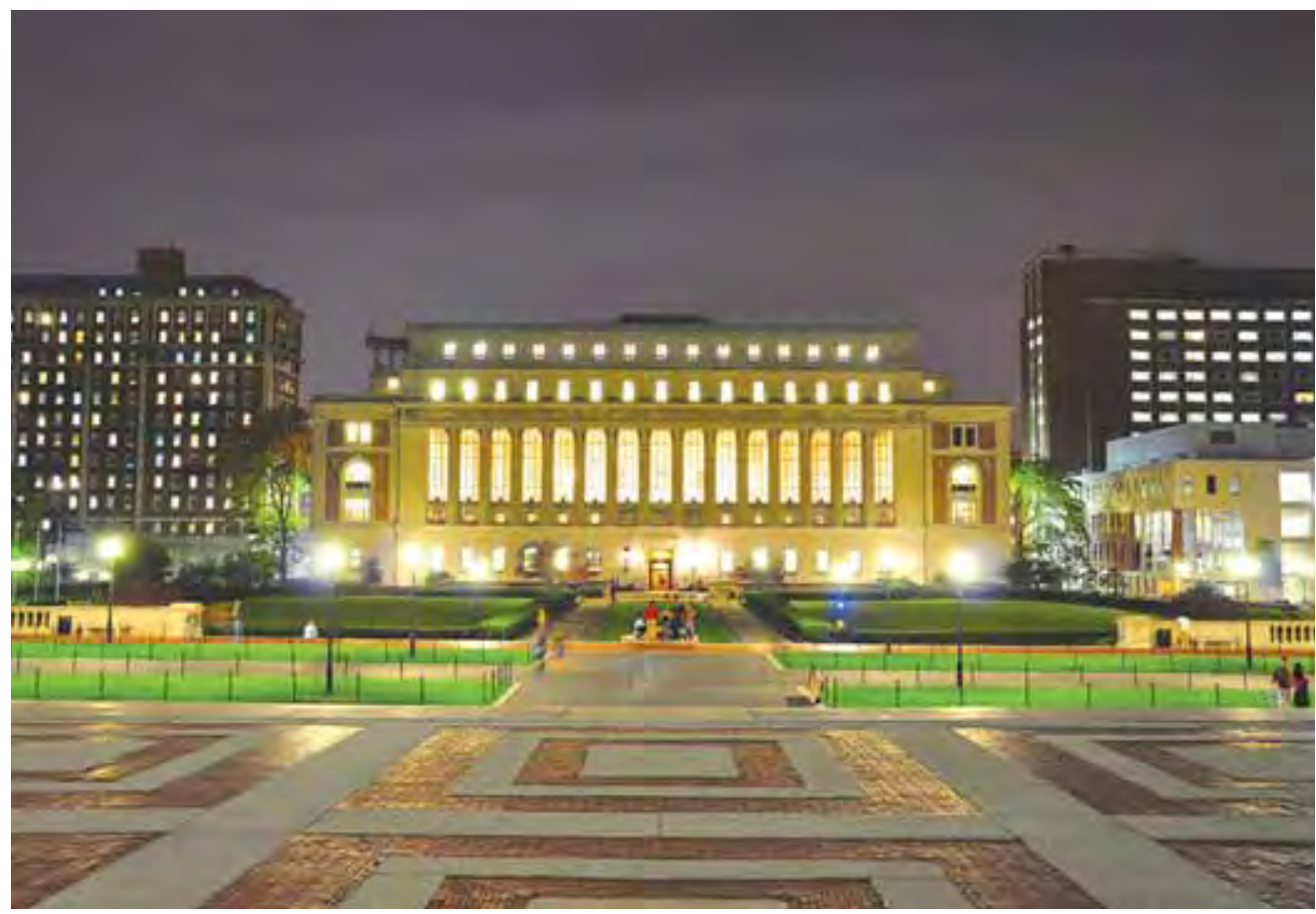

5. Uniwersytet Columbia, Butler Library

powołała komisję mającą zająć się możliwościami rozwoju akademickiej współpracy w ramach EWG. W 1973 r. został opublikowany raport tej komisji, w którym podkreślano, że bez naukowego i edukacyjnego współdziałania nie uda się osiągnąć podstawowego celu traktatów rzymskich, czyli przyspieszenia rozwoju gospodarczego ${ }^{74}$. Europejska integracja w dziedzinie szkolnictwa wyższego - wychodząca, o czym należy pamiętać, poza ramy EWG, a później Unii Europejskiej - nabrała tempa w latach 8o. Powstały wtedy programy mające ułatwić naukową i edukacyjną współpracę - takie jak Erasmus (European Action Scheme for the Mobility of University Students), zainaugurowany w 1987 r., stwarzający organizacyjne podstawy wymiany studentów między krajami Europy. W 1999 r. 29 państw podpisało Deklarację Bolońską. Wyrażano w niej zamiar utworzenia Europejskiego Obszaru Szkolnictwa Wyższego. Przyjęty wtedy program - znany jako Proces Boloński - zakładał ujednolicenie podstawowych zasad studiowania, co otwierało perspektywę prawdziwie intensywnej współpracy ${ }^{75}$.

Jakie będą europejskie uniwersytety w nadchodzących latach? Akademicka integracja Europy, której podstawą stał się Proces Boloński, 
posuwa się do przodu. Po upadku wschodnioeuropejskiego „realnego socjalizmu" procesami integracyjnymi zostały objęte państwa dawnego bloku sowieckiego. Jeśli jednak przyszłość uczelni na naszym kontynencie ma być w znacznej mierze przyszłością wspólną, to ku czemu właściwie zmierzamy? O zadania uniwersytetu pytano od wieków i będzie się pytać nadal. Pytania te są pochodną naszych podstawowych dylematów życiowych. Jaką wartość ma wiedza? Jak do niej dochodzić? Jeśli ma być użyteczna, to na czym ta użyteczność polega? Czy wiedza może być bezużyteczna i czy użyteczność może obniżyć rangę wiedzy? Szukając odpowiedzi, poddajemy weryfikacji ustalone wzorce kształcenia i wypracowujemy stopniowo nowe. I tylko to z pewnością się nie zmieni. 


\section{Przypisy}

1 Podstawowe kompendium wiedzy o europejskich uniwersytetach w XX w. to 2 tomy ukończonego przed kilku laty wydawnictwa: A History of the University in Europe, red. W. Rüegg, t. III: Universities in the Nineteenth and Early Twentieth Centuries (1800-1945), red. W. Rüegg, Cambridge 2004; t. IV: Universities since 1945, red. W. Rüegg, Cambridge 2011.

2 G. Neave, Patterns, [w:] A History of the University, t. IV, s. 51, 6o.

3 W. Rüegg, Themes, [w:] tamże, s. 3; dane dla poszczególnych krajów (lata 1970 i 1990): A.H. Halsey, Admission, [w:] tamże, s. 208.

4 S. Bruendel, Volksgemeinschaft oder Volksstaat. Die "Ideen von 1914" und die Neuordnung Deutschlands im Ersten Weltkrieg, Berlin 2003, s. 33 .

5 Tamże, s. 33-38; zob. M. Eksteins, Święto wiosny. Wielka wojna i narodziny nowego wieku, tłum. K. Rabińska, Warszawa 1996, s. $218-229$.

6 B. Russell, Autobiografia 1914-1944, tłum. A. Podzielna, Warszawa 1998, s. 9-11. A.N. Whitehead (1861-1947) był angielskim matematykiem i filozofem.

7 Tamże, s. 15 .

8 Tamże, s. 32-41.

9 M. Szöllösi-Janze, Fritz Haber 1868-1934. Eine Biographie, München 1998, s. 175-181, 263-480.

10 Zob. W. Rudy, Total War and TwentiethCentury Higher Learning: Universities of the Western World in the First and Second World Wars, Rutherford 1991, s. 15-64.

11 E.J. Hobsbawm, Wiek skrajności. Spojrzenie na Krótkie Dwudzieste Stulecie, tłum. J. Kalinowska-Król, M. Król, Warszawa 1999; N. Ferguson, The War of the World: History's Age of Hatred, London 2006.

12 N. Hammerstein, Epilogue: Universities and War in the Twentieth Century, [w:] A History of the University, t. III, s. 64,4.
13 A. Gallin, Midwives to Nazism: University Professors in Weimar Germany, 1925-1933, Macon, GA 1986, s. 9-14.

14 D.J.K. Peukert, Republika Weimarska. Lata kryzysu klasycznego modernizmu, tłum. B. Ostrowska, Warszawa 2005, s. 238 .

15 H.A. Winkler, Długa droga na Zachód. Dzieje Niemiec, t. I: 1806-1933, tłum. V. Grotowicz, M. Kopij, W. Kunicki, Wrocław 2007, s. 514.

16 Tamże, s. 430-437; zob. F.K. Ringer, Die Gelehrten. Der Niedergang der deutschen Mandarinen 1890-1933, Stuttgart 1983, s. $385-394$.

17 M. Grüttner, Die deutschen Universitäten unter dem Hakenkreuz, [w:] Zwischen Autonomie und Anpassung: Universitäten in den Diktaturen des 20. Jahrhunderts, wyd. J. Connelly, M. Grüttner, Paderborn 2003, s. 71-77.

18 D.J.K. Peukert, Republika Weimarska, s. 103-104; K. Jarausch, Deutsche Studenten 1800-1970, Frankfurt am Main 1984, s. $165^{-1} 7^{6}$.

19 M. Grüttner, Die deutschen Universitäten, s. 83 .

20 I. Kershaw, Hitler 1889-1936. Hybris, tłum. P. Bandel, wstęp M. Zmierczak, Poznań 2008 , s. 4,20 .

21 Tamże, s. 418

22 R. Mehring, Carl Schmitt: Aufstieg und Fall. Eine Biographie, München 20o9, s. $304,-436$.

23 Zob. Nazizm, Trzecia Rzesza a procesy modernizacji, wybór i oprac. H. Orłowski, tłum. M. Tomczak, Poznań 2000.

24 S. Tyrowicz, Światło wiedzy zdeprawowanej. Idee niemieckiej socjologii i filozofii (19331945), Kraków 2009 (wyd. I 1970).

25 M. Walker, Bomba atomowa Hitlera, tłum. M. Antosiewicz, Warszawa 1999, s. $14,-54,60-61$.

26 K.H. Jarausch, Deutsche Studenten, s. $176-179$. 
27 M. Grüttner, Die deutschen Universitäten, s. $85-87$.

28 W. Schulze, Die Bundesrepublik, die deutsche Nation und Europa, [w:] Nationale Geschichtskulturen - Bilanz, Ausstrahlung, Europabezogenheit. Beiträge des internationalen Symposions in der Akademie der Wissenschaften und der Literatur, Mainz, vom zo. September bis 2. Oktober 2004, wyd. H. Duchhardt, Stuttgart 2006, s. $285^{-2} 88$.

29 Zob. A. Gleason, Totalitarianism: The Inner History of The Cold War, New York 1995.

30 R. Pipes, Rosja bolszewików, tłum. W. Jeżewski, Warszawa 2005, s. 344.

31 Zob. S. Fitzpatrick, The Commisariat of Enlightenment: Soviet Organization of Education and the Arts under Lunacharsky, Cambridge 2002.

32 D.P. Todes, Ivan Pavlov: A Russian Life in Science, Oxford 2014.

33 Cyt. za: A. Walicki, Marksizm i skok do królestwa wolności. Dzieje komunistycznej utopii, Warszawa 1996, s. 368; zob. L. Trotsky, Literature and Revolution, tłum. R. Strunsky, red. W. Keach, Chicago 2005, s. 206-207.

34 S. Fitzpatrick, The Cultural Front: Power and Culture in Revolutionary Russia, Ithaca $199^{2}$, s. 37 .

35 R. Pipes, Rosja bolszewików, s. 345.

36 S. Fitzpatrick, The Cultural Front, s. 38-4,1.

37 Tamże, s. 51-52.

38 Zob. case study jednego ze środowisk naukowych: M. Robinson, Losy elity akademickiej. Rosyjska slawistyka od 1917 roku do poczatku lat 3o., tłum. M. Skarżyński, Warszawa 2014.

39 Zob. A. Leszczyński, Skok w nowoczesność. Polityka wzrostu $w$ krajach peryferyjnych, 1943-1980, Warszawa 2013

40 L. Kołakowski, Główne nurty marksizmu. Powstanie - rozwój - rozkład, Londyn 1988, s. $870-871$
41 Tamże, s. 871.

42 D. Joravsky, The Lysenko Affaire, Cambridge 1970.

43 L. Kołakowski, Główne nurty, s. 883-910.

44 S. Fitzpatrick, The Cultural Front, s. 41-50.

45 R. Pipes, Rosja bolszewików, s. 345-349;

E. Acton, Rosja. Dziedzictwo caratu i władzy radzieckiej, tłum. J. Stawiński, Warszawa 2013, s. 24,6-24,8.

46 L. Kołakowski, Główne nurty, s. 904-910.

47 R. Pipes, Rosja bolszewików, s. 346.

48 N. Krementsov, Stalinist Science, Princeton 1997.

49 M. David-Fox, Das seltsame Schicksal der russischen Universitäten vor und nach der Revolution von 1917, [w:] Zwischen Autonomie, s. 30-35.

50 G. Neave, Patterns, s. 36-37; zob. M. David-Fox, Das seltsame Schicksal, s. 36-37.

51 Zob. C. Madajczyk, Generalny Plan Wschodni. Zbiór dokumentów, Warszawa 1990.

52 M. Wardzyńska, Był rok 1939. Operacja niemieckiej policji bezpieczeństwa $w$ Polsce Intelligenzaktion, Warszawa 2009; zob. C. Madajczyk, Polityka III Rzeszy $w$ okupowanej Polsce, t. I-II, Warszawa 1970.

53 Cyt. za: H.A. Winkler, Długa droga, t. II: 1933-1990, s. 82 .

54 J. August, Sonderaktion Krakau. Die Verhaftung der Krakauer Wissenschaftler am 6. November 1939, Hamburg 1997.

55 H.A. Winkler, Długa droga, s. 81.

56 Tamże, s. 90 .

57 T. Wróblewska, Die Reichsuniversitäten Posen, Prag und Straßburg als Modelle nationalsozialistischer Hochschulen in den von Deutschland besetzten Gebieten, Toruń 2000.

58 M.G. Esch, Das Krakauer „Institut für Deutsche Ostarbeit": Aufgaben, Struktur, Arbeitsweise, Düsseldorf 1989 (kserokopia pracy magisterskiej, Biblioteka 
Niemieckiego Instytutu Historycznego w Warszawie); A. Rybicka, Instytut Niemieckiej Pracy Wschodniej=Institut für Deutsche Ostarbeit: Kraków 1940-1945, Warszawa 2002.

59 G. Neave, Patterns, s. 32-33.

60 W. Rüegg, Themes, [w:] A History of the University, t. IV, s. 3-4.

61 Tamże, s. 13-14.

62 T. Judt, Powojnie. Historia Europy od roku 1945, tłum. R. Bartołd, Poznań 2010, s. 390-392.

63 G. Neave, Patterns, s. 4,2.

64 Tamże, s. 4,6-52.

65 Tamże, s. 4.4.

66 T. Judt, Powojnie, s. 465-466.

67 W. Rüegg, Themes, s. 14 .

68 Zob. m.in. E.J. Evans, Thatcher and Thatcherism, wyd. 2, London-New York 2004; P. Pierson, Dismantling the Welfare
State? Reagan, Thatcher, and the Politics of Retrenchment, Cambridge 1994;

E.A. Reitan, The Thatcher Revolution: Margaret Thatcher, John Major, Tony Blair, and the Transformation of Modern Britain, 1979-2001, Lanham 2003.

69 S.R. Letwin, The Anatomy of Thatcherism, New Brunswick 1993, s. 264-269.

70 Tamże, s. $269-276$.

71 W. Rüegg, Themes, s. 14.

72 Tamże, s. 21-22.

73 Zob. A.K. Wróblewski, Pozycja nauki polskiej $w$ międzynarodowych rankingach, „Studia BAS" 2013, nr 3 (35), s. 89-106.

74 W. Rüegg, Themes, s. 25-26.

75 Reform of Higher Education in Europe, wyd. J. Enders, H.F. De Boer, D.F. Westerheijden, Rotterdam 2011; EU Higher Education Law. The Bologna Process and Harmonization by Stealth, Alphen aan den Rijn 2011. 


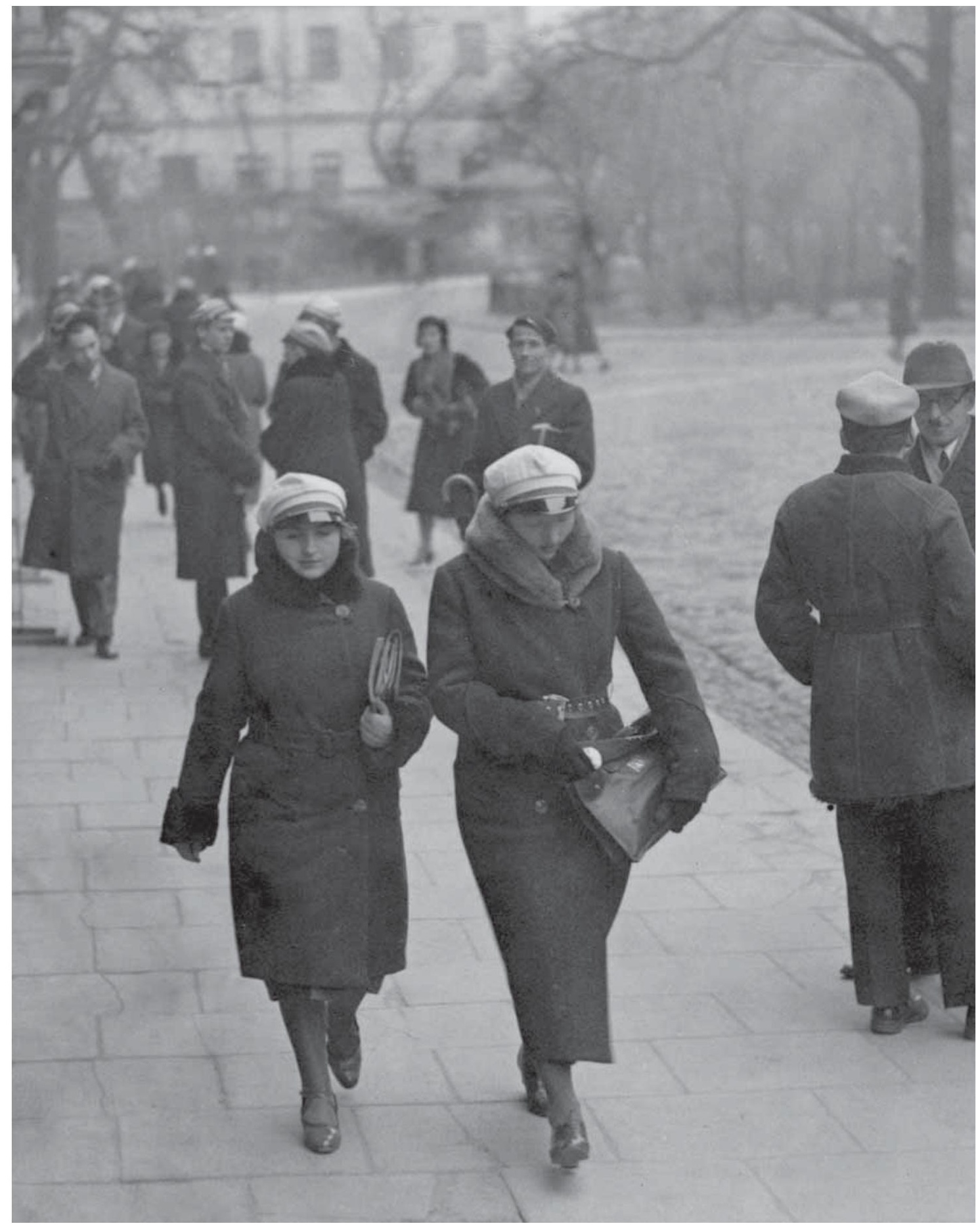

e-MONUMENTA_WUW 2016 


\section{SPOŁECZNOŚĆ AKADEMICKA 1915-1939}

Studium to poświęcone jest pracownikom i studentom Uniwersytetu Warszawskiego w okresie międzywojennym. Chcąc ukazać jak najpełniejszy obraz obu tych środowisk, zdecydowałem się sięgnąć po różne rodzaje źródeł począwszy od akt urzędowych, poprzez druki o charakterze sprawozdawczym wydawane w tamtych latach przez uczelnię, materiały statystyczne, prasę akademicką i ogólnopolską, aż po liczne pamiętniki i wspomnienia. Sądzę, że zestawione ze sobą pozwalają one dość wiernie odtworzyć najważniejsze fakty i zjawiska, nawet jeśli poszczególne z nich (mam tu na myśli przede wszystkim, choć nie tylko, źródła pamiętnikarskie) nieuchronnie naznaczone są piętnem subiektywizmu.

Wśród źródeł urzędowych szczególnie istotne dla mojej pracy okazały się teczki osobowe studentów, przechowywane w Archiwum Uniwersytetu Warszawskiego, które w przeciwieństwie do pozostałych, przeważnie zniszczonych akt kancelarii uniwersyteckiej z lat 1915-1939, przetrwały II wojnę światową stosunkowo kompletne. (Zachowało się ok. 80\% tego zasobu). Zapoznanie się ze stu kilkudziesięcioma z nich pozwoliło mi nie tylko lepiej zrozumieć przebieg studiów na różnych wydziałach, lecz także poznać problemy życiowe, z jakimi musiało borykać się wielu słuchaczy. Z tych samych względów niezwykle przydatne okazały się dla mnie wyrywkowo zachowane podania o stypendia, w których studenci szczegółowo opisywali swą sytuację rodzinną i materialną.

Podkreślam znaczenie źródeł o charakterze jednostkowym równiė ze względu na przyjęte przeze mnie założenia metodologiczne, w myśl których postanowiłem, w miarę możliwości, ilustrować charakterystykę 
statystyczną społeczności uniwersyteckiej przypadkami konkretnych, znanych z imienia i nazwiska wykładowców i studentów. Podejście takie odpowiada łączeniu analizy ilościowej i jakościowej, znanemu we współczesnych badaniach socjologicznych. Dość często starałem się przy tym oddawać głos świadkom opisywanych wydarzeń. Mam nadzieję, że autentyczność ich języka i odczuć zrekompensuje Czytelnikom trudy przedzierania się przez liczne i niekiedy długie cytaty. Zdaję sobie sprawę, iż relacje te, w większości spisywane wiele lat po II wojnie światowej, mogą być obarczone błędami wynikającymi z zawodności ludzkiej pamięci. Z tego względu traktowałem je z ograniczonym zaufaniem w kwestiach szczegółowych, uznałem natomiast, że wystarczająco wiernie oddają one atmosferę studiów na Uniwersytecie i indywidualne odczucia ich autorów.

W wybranych przypadkach, na ile było to możliwe, próbowałem zasygnalizować, jak potoczyły się późniejsze losy osób związanych z uczelnią w latach międzywojennych. W moim przekonaniu, zwłaszcza historie absolwentów Uniwersytetu stanowią fascynujący przyczynek do dziejów Polski w XX w., godny osobnego opracowania.

Wiele informacji statystycznych i wyliczeń, na które powołuję się $\mathrm{w}$ tej pracy, podaję na podstawie bazy danych studentów UW w systemie Uniwersyteckiego Systemu Obsługi Studentów (USOS), z której można skorzystać w Archiwum Uniwersytetu Warszawskiego. Obejmuje ona wszystkich słuchaczy, którzy immatrykulowali się na uczelni w latach 1915-1939 i dostarcza historykowi nieocenionego narzędzia do badań tej zbiorowości pod względem cech takich jak płeć, wiek, czas studiowania itp. Niekompletne pozostają na razie jedynie dane USOS na temat wyznania studentów, co stanowi jedyny właściwie poważny mankament tego źródła.

Mimo różnorodności źródeł do dziejów Uniwersytetu w latach międzywojennych nie zawsze pozwalają one w pełni prześledzić dynamikę badanych zjawisk społecznych w całym tym okresie, ponieważ dotyczą niekiedy tylko pewnego wycinka czasu. W niektórych przypadkach wnioskuję na ich podstawie na temat całej epoki 1915-1939, zakładając że tego rodzaju uproszczenie nie skrzywi w istotnym stopniu obrazu ówczesnej rzeczywistości.

$\mathrm{Na}$ koniec uwaga o charakterze redakcyjnym: chociaż Uniwersytet Warszawski od 1935 r. nosił nazwę Uniwersytetu Józefa Piłsudskiego i w ślad za tym aż do wybuchu II wojny światowej w różnego rodzaju dokumentach pojawiał się pod skrótem UJP, dla uproszczenia posługuję się jedynie jego pierwotną nazwą i wyprowadzonym od niej skrótem UW. Skrótu UJP używam jedynie w nazwach własnych i cytatach. 


\section{Przestrzeń i czas}

W dwudziestoleciu międzywojennym, podobnie jak dzisiaj, sercem Uniwersytetu Warszawskiego był kompleks zabytkowych gmachów przy Krakowskim Przedmieściu. Od wschodu dochodził on do skarpy wiślanej, zboczem której, ku ul. Browarnej, ciągnęły się w dół należące do uczelni ogrody. Od południa ograniczała go ul. Oboźna, zaś od północy klasztor sióstr Wizytek i znajdująca się na jego tyłach od strony Powiśla niewielka uliczka Gęsta, dziś już nieistniejąca. Granice ówczesnego kampusu (oczywiście nikt nie używał jeszcze wówczas tego określenia) nie w pełni pokrywały się ze współczesnymi. Do Uniwersytetu nie należały pałace Uruskich (Czetwertyńskich) i Tyszkiewiczów przy Krakowskim Przedmieściu, Szpital Św. Rocha wraz z tzw. małym dziedzińcem, ani budynek Domu Kupca przy ul. Oboźnej. Inne było również rozmieszczenie większości wydziałów i kierunków.

$\mathrm{Na}$ teren Uniwersytetu wchodziło się od Krakowskiego Przedmieścia przez neobarokową bramę, której zwieńczona orłem krata stanowiła już wówczas jeden z charakterystycznych znaków rozpoznawczych uczelni. Nie było natomiast ogólnodostępnych wejść na kampus

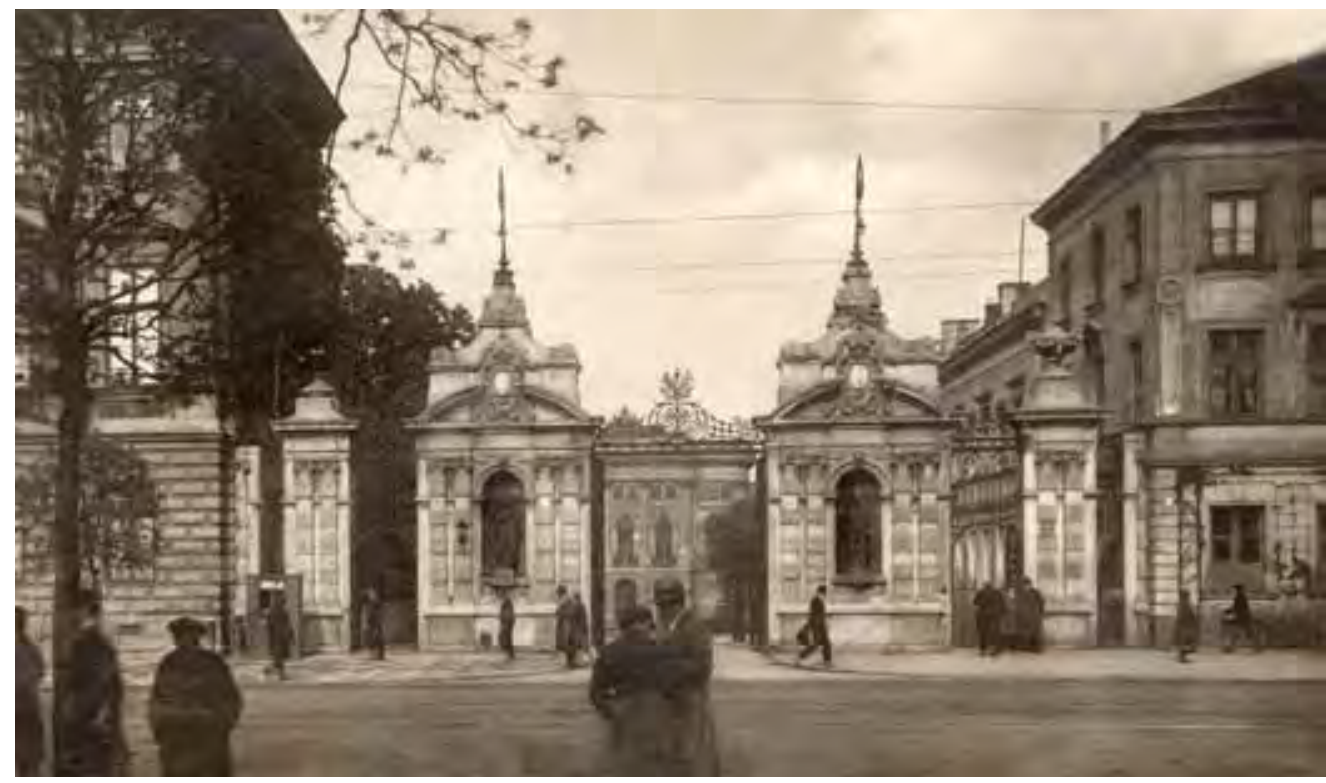

1. Brama Uniwersytetu od strony Krakowskiego Przedmieścia 


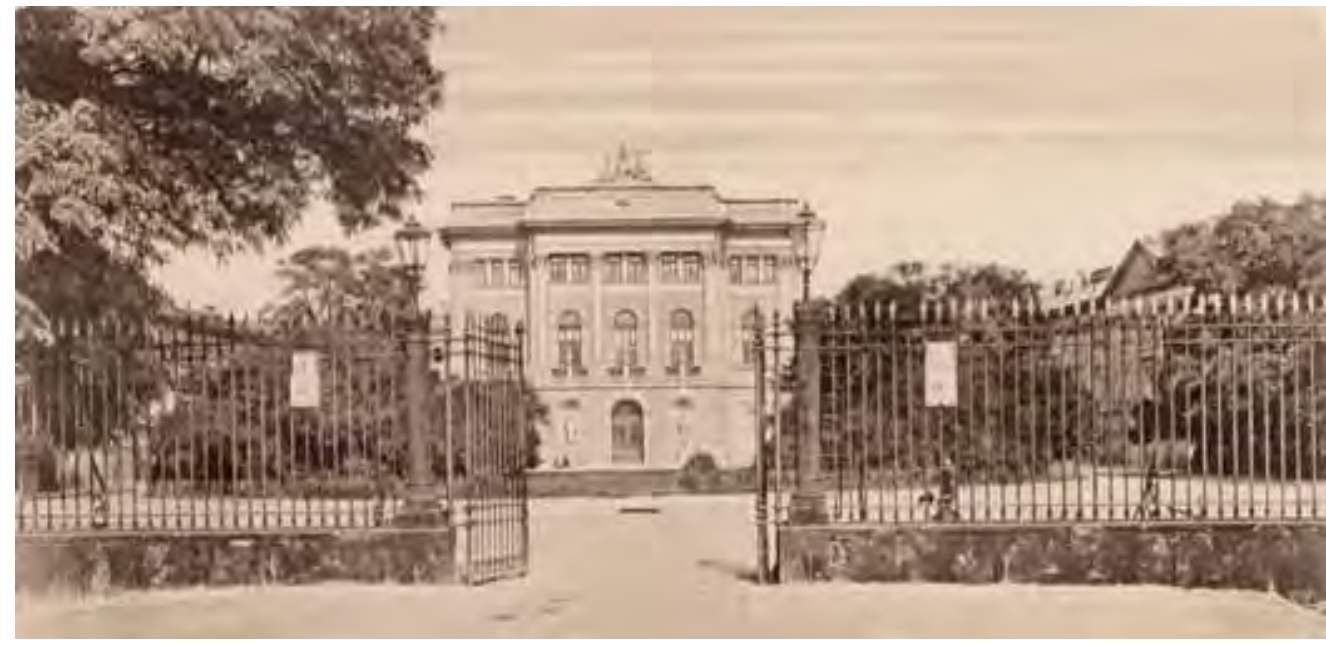

2. Gmach Biblioteki Uniwersyteckiej - na pierwszym planie krata oddzielająca główny dziedziniec od tzw. uliczki prowadzącej od strony Krakowskiego Przedmieścia

z pozostałych stron. (Furty od strony klasztoru sióstr Wizytek oraz od ul. Oboźnej pozostawały przeważnie zamknięte, mógł je otworzyć tylko woźny). Prowadząca od bramy uliczka wiodła na główny dziedziniec, nad którym dominował budynek biblioteki uniwersyteckiej. Kierując się w jego stronę, wchodzący na Uniwersytet po lewej stronie napotykali prostopadły Gmach Medycyny Teoretycznej, gdzie mieściły się niektóre pracownie wydziałów Lekarskiego i Filozoficznego, przejęte po podziale tego ostatniego przez Wydział Matematyczno-Przyrodniczy. Po przeciwnej stronie dziedzińca widzieli podobny budynek, w którym działało Muzeum Zoologiczne, i gdzie przechowywano wypchane lub zakonserwowane $\mathrm{w}$ słojach okazy zwierząt (dziś nazywany z tej racji Gmachem Pomuzealnym). Znajdowała się tam również reprezentacyjna Sala Kolumnowa ze zbiorem odlewów gipsowych słynnych rzeźb oraz pomieszczenia paru zakładów przyrodniczych. Po odbudowie tego gmachu, poważnie uszkodzonego jesienią 1935 r. na skutek pożaru, został on na kilka miesięcy przed wybuchem wojny przekazany w połowie Wydziałowi Humanistycznemu, stając się siedzibą Instytutu Historycznego oraz Zakładu Archeologii Klasycznej ${ }^{1}$.

Równolegle do biblioteki, po jej lewej stronie, usytuowany był tzw. Budynek Seminaryjny, który, zgodnie ze swą nazwą, stanowił siedzibę większości seminariów Wydziału Prawa i niektórych seminariów Wydziału Filozoficznego (a następnie Humanistycznego), w tym przede wszystkim pracowni historycznych, połączonych w 1927 r. w Instytut Historyczny. Mieściło się w nim również państwowe Archiwum 


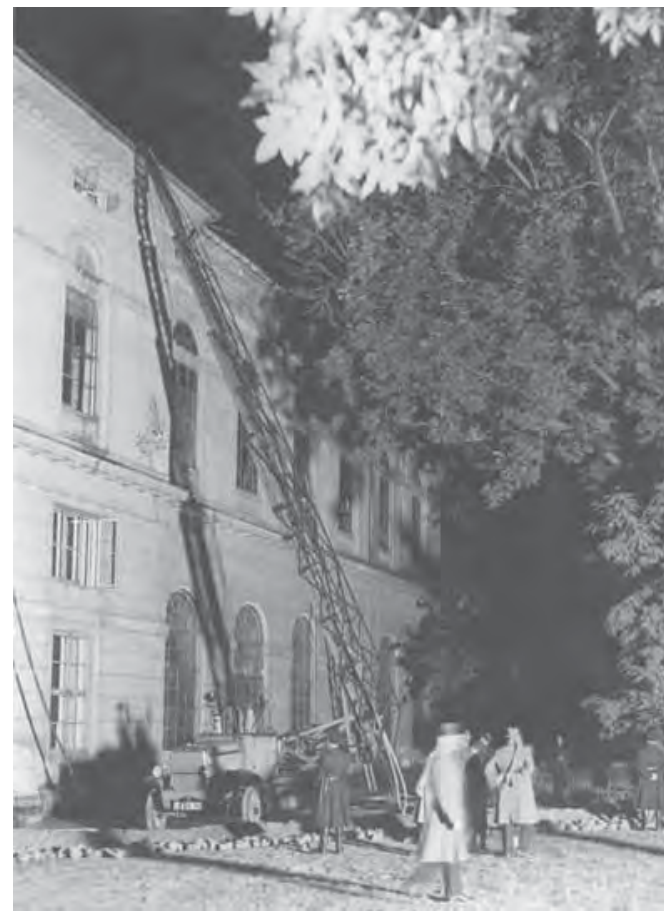

3. Pożar Budynku Pomuzealnego w październiku $1935 \mathrm{r}$.
Oświecenia Publicznego. Aż do połowy lat 30 . był on ostatnim większym gmachem uniwersyteckim z tej strony kampusu. Za Budynkiem Seminaryjnym, na granicy z posesją zakonu Wizytek znajdowały się już tylko oficyny, w których mieszkali niektórzy pracownicy uczelni. Przestrzeń pomiędzy tymi budynkami wypełniał akacjowy gaj, który później wycięto pod budowę Gmachu Audytoryjnego (Auditorium Maximum), oddanego do użytku w 1935 r. Jego główna aula mogąca pomieścić ponad 1000 słuchaczy i 4, mniejsze sale wykładowe służyły odtąd przede wszystkim potrzebom wydziałów Prawa i Humanistycznego.

Po prawej stronie biblioteki, w równoległym do niej, wydłużonym tzw. Budynku Porektorskim (określanym tak, ponieważ mieścił niegdyś mieszkanie rektora) tłoczyły się seminaria Wydziału Humanistycznego (filozoficzne, psychologiczne, filologii romańskiej i angielskiej oraz historii sztuki), a do początku lat 3o. także seminaria matematyczne Wydziału Matematyczno-Przyrodniczego. Jeszcze bardziej na prawo znajdowała się dawna Szkoła Główna, gdzie ulokowano pracownie botaniczne i zoologiczne tegoż wydziału. Dalsze jego zakłady - chemii organicznej i nieorganicznej, mineralogii, geologii i paleontologii - mieściły się w dużym budynku po południowej stronie Pałacu Kazimierzowskiego, dochodzącym swym bokiem do ul. Oboźnej. Nazywano go Gmachem Zakładów Wydziału Matematyczno-Przyrodniczego. Natomiast w budynku położonym po północnej stronie pałacu, który określano jako Gmach Pokuratorski, znajdowały się niektóre zakłady Wydziału Farmaceutycznego. Sam Pałac Kazimierzowski, zwany Gmachem Głównym, stanowił siedzibę władz rektorskich i kwestury oraz dziekanów poszczególnych wydziałów, mieściła się w nim również reprezentacyjna aula, do czasu oddania do użytku Auditorium Maximum będąca zarazem największą salą wykładową Uniwersytetu. W Gmachu Głównym prowadzono ponadto seminaria językoznawcze i polonistyczne $\mathrm{Wy}_{\mathrm{-}}$ działu Humanistycznego oraz zajęcia Studium Teologii Prawosławnej 


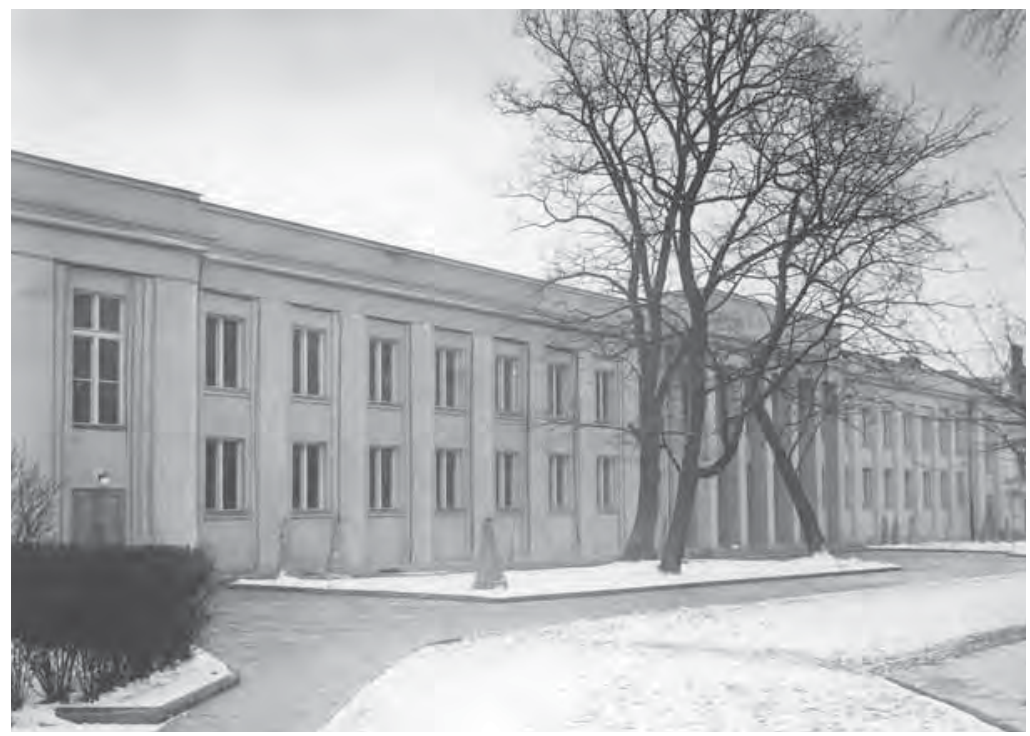

4. Nowy Gmach

Audytoryjny,

styczeń $1936 \mathrm{r}$.

i Wydziału Teologii Ewangelickiej do czasu przeprowadzki tego drugiego do Gmachu Porektorskiego².

Położony w centrum miasta, a zarazem stanowiący wydzieloną enklawę, ocieniony drzewami teren Uniwersytetu odznaczał się szczególnym genius loci, którym potrafił oczarować również przyjezdnych. Jeszcze przed odzyskaniem niepodległości zachwycał się nim m.in. profesor Uniwersytetu Jagiellońskiego Stanisław Kutrzeba: „Pozazdrościć może Warszawie uniwersyteckich gmachów niejedna europejska wszechnica bogato wyposażona. Bo doprawdy trudno o lepsze warunki, w których mógłby się uniwersytet pomieścić. Położony on w samem centrum Warszawy, boć wchodzi się do niego z Krakowskiego Przedmieścia więc głównej arteryi miejskiego ruchu, na wprost prawie kościoła św. Krzyża. A to centralne położenie w środku miasta nie niesie za sobą tych niedogodności, jakie mają inne uniwersytety, tak pomieszczone; - uniwersytet mimo to, że leży koło przewalającej się życiem i gwarem tego życia huczącej ulicy, ma jednak zapewnioną ciszę, niezbędną czy o wykład chodzi, czy o pracę w seminariach. Bo Uniwersytet Warszawski - to nie jeden gmach jakiś ogromny, na ulicę setkami okien patrzący; to szereg gmachów rozłożonych wygodnie na znacznym obszarze, «posesyę» tworzącym"3.

Niestety, ta często cytowana, pochlebna i zasadniczo aktualna do dziś charakterystyka nie oddawała całej prawdy o sytuacji Uniwersytetu w okresie międzywojennym. I to nie tylko dlatego, że, jak ubolewał 


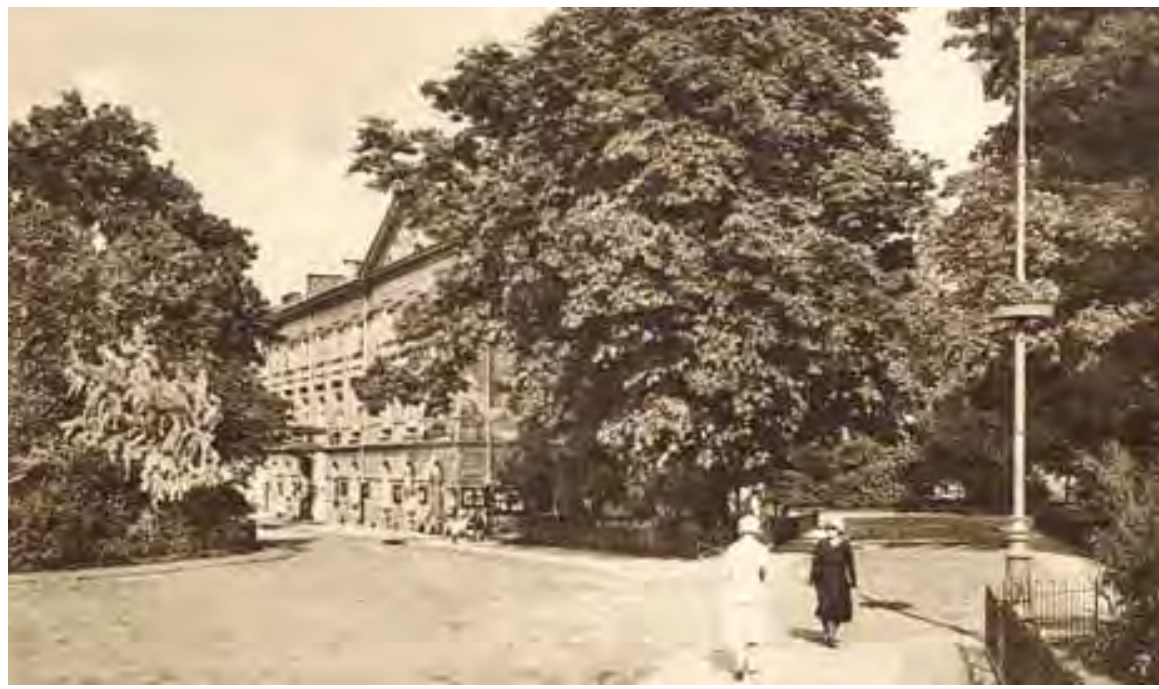

5. Fragment głównego kampusu w pobliżu Gmachu Porektorskiego

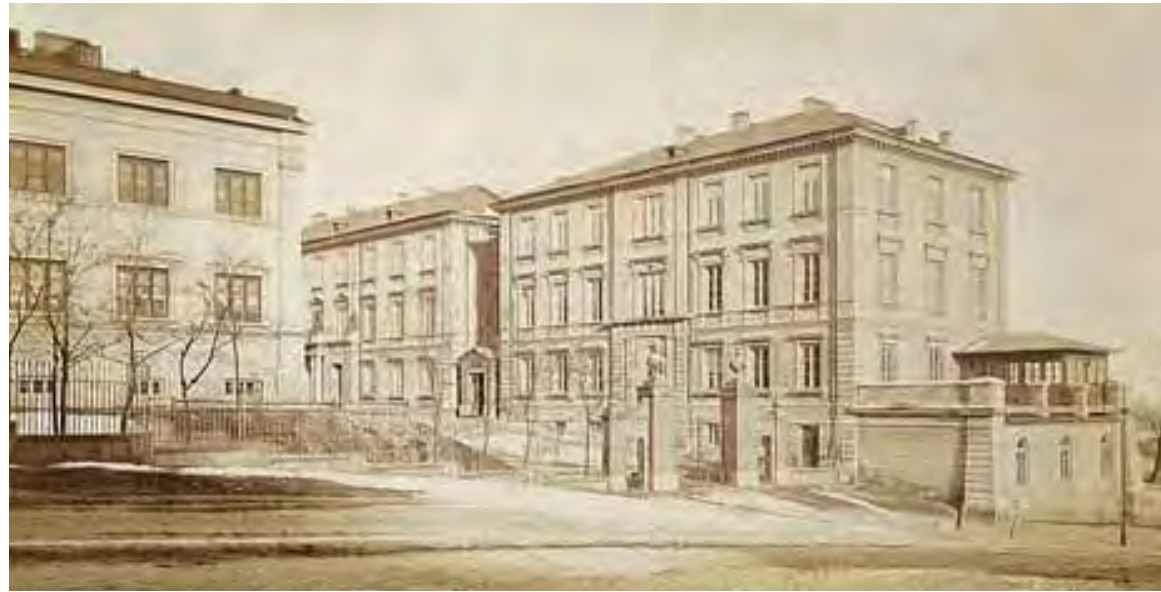

6. Gmach Zakładów Wydziału Matematyczno-Przyrodniczego od strony ul. Oboźnej

pod koniec lat 30. rektor Włodzimierz Antoniewicz, „aby mógł jednak być swoją istotną pięknością chlubą stolicy, [...] musi: zmienić szpetną i tandetną bramę rosyjską, posiąść porządne bruki, uformować i utrzymywać estetyczne zieleńce i ogrody, otoczyć je mocnymi i niebrzydkimi sztachetami, przebudować przestarzałą kanalizację i unowocześnić oświetlenie elektryczne. [...] A na razie wygląd ten nie wiele odbiega od małomiasteczkowych stosunków, czym też odbija niekorzystnie od wszystkich 


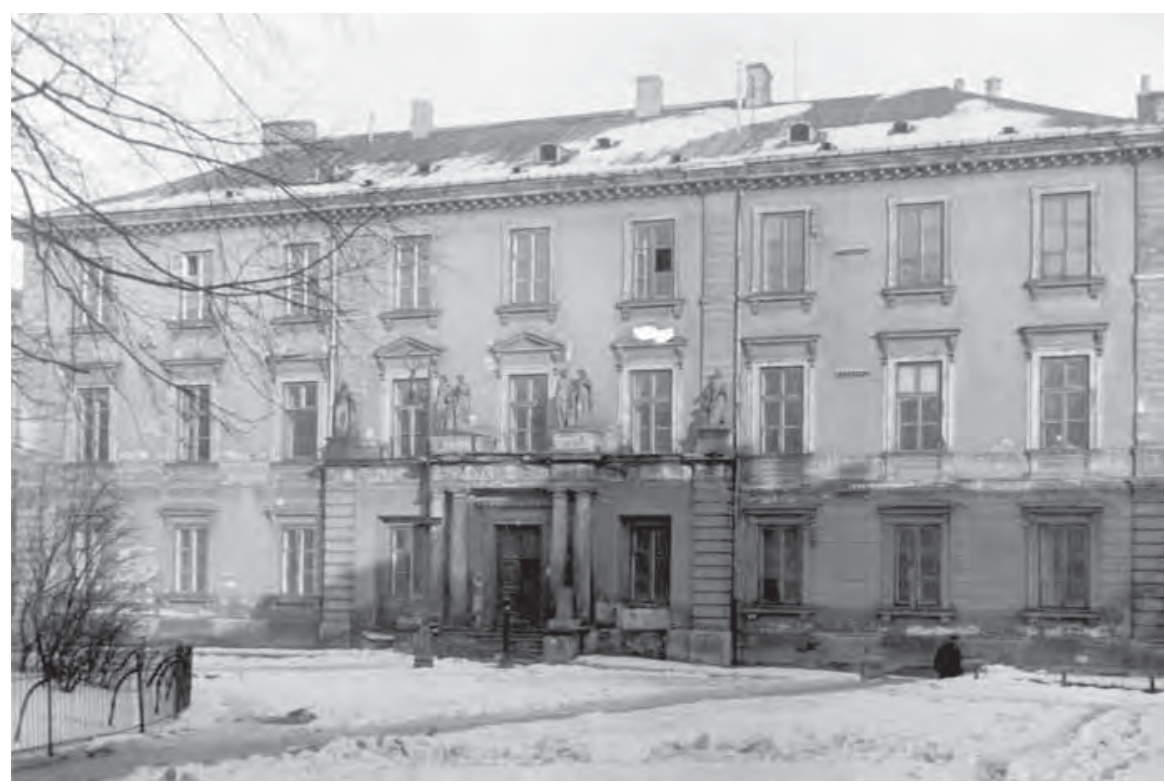

7. Gmach Pokuratorski w lutym 1928 r.

Uniwersytetów w Polsce"'. Znacznie poważniejszym mankamentem była ciasnota. Już w latach 20. kampus przy Krakowskim Przedmieściu nie mógł sprostać rosnącym potrzebom lokalowym uczelni. W Pałacu Kazimierzowskim „zajęcie miejsca na parapecie okna uważało się za wielkie szczęście, często słuchało się wykładów stojąc" Większość seminariów i pracowni gnieździła się w niewielkich pokoikach, a niektóre z nich nie miały w ogóle własnych siedzib i jedynie korzystały grzecznościowo z użyczonych im lokali. W opłakanym stanie technicznym znajdowały się budynki. Mimo pewnych inwestycji powyższy stan rzeczy nie zmienił się zasadniczo aż do II wojny światowej. Ostatnie z opublikowanych przed jej wybuchem sprawozdań rektorskich mówiło wręcz o „bezprzykładnym prymitywizmie zakładów naukowych” i „nędzy lokalowej”. Jeszcze inną bolączkę stanowił nieograniczony dostęp osób postronnych do pomieszczeń uniwersyteckich, czego efektem była plaga kradzieży okryć wierzchnich pozostawianych w szatniach przez słuchaczy ${ }^{7}$.

Ze względu na ograniczoną pojemność kampusu przy Krakowskim Przedmieściu sporą część placówek Uniwersytetu rozmieszczono w innych częściach miasta. Siedziby niektórych z nich należały do uczelni, inne były przez nią wynajmowane. Zdecydowanie najbliżej głównego kampusu, bo w przylegającym do kościoła Św. Krzyża gmachu seminarium duchownego na rogu Krakowskiego Przedmieścia i ul. Traugutta 
mieścił się Wydział Teologii Katolickiej, nazywany Collegium Theologicum. W równie nieodległym Pałacu Staszica przy Nowym Świecie 72 ulokowano Zakład Antropologii Wydziału Lekarskiego, Zakład Geograficzny Wydziału Matematyczno-Przyrodniczego oraz wchodzące w skład Wydziału Humanistycznego socjologię, etnografię, etnologię, części filozofii i archeologii. Podążając dalej Nowym Światem dochodziło się do położonych przy tej ulicy pod numerem 19 Zakładów Serologii i Mikrobiologii oraz Higieny Wydziału Lekarskiego, a także (pod numerem 9) do Zakładu Cytologii Wydziału Matematyczno-Przyrodniczego. Jeszcze dalej, przy placu Trzech Krzyży 8 znajdowało się Seminarium Pedagogiczne i Zakład Psychologii Wychowawczej Wydziału Humanistycznego. Do Uniwersytetu należał również Ogród Botaniczny przy Alejach Ujazdowskich wraz ze zlokalizowanym na jego terenie Obserwatorium Astronomicznym, skąd - co stanowi pewną ciekawostkę - podawany był sygnał czasu dla Polskiego Radia i instytucji państwowych. W drugiej połowie lat zo. jako jego filię wybudowano wysokogórskie Obserwatorium Meteorologiczno-Astronomiczne na szczycie Pop Iwana (2022 m n.p.m.) w Czarnohorze, które stało się tym samym najbardziej odległą i najwyżej położoną placówką Uniwersytetu Warszawskiego. Budowę obiektu i instalację sprzętu optycznego zakończono w październiku 1937 r., rok później został przekazany do użytku uczelni ${ }^{8}$.

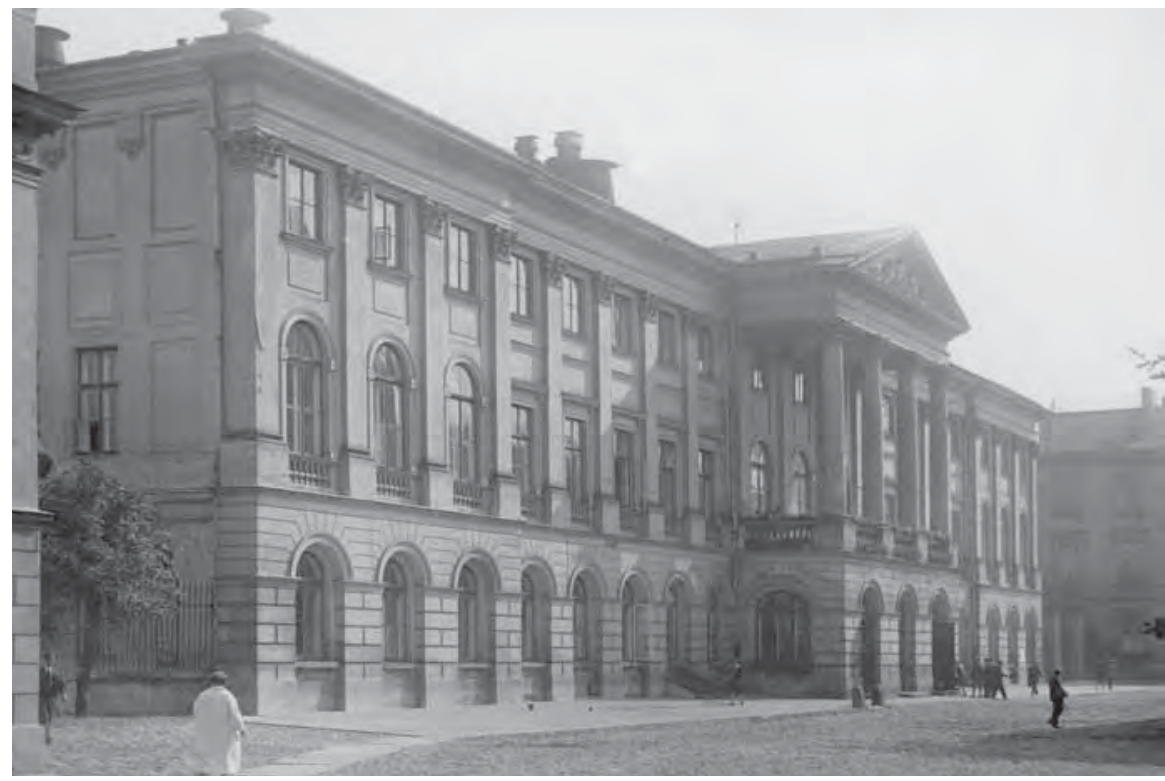

8. Pałac Kazimierzowski, wrzesień 1927 r. 


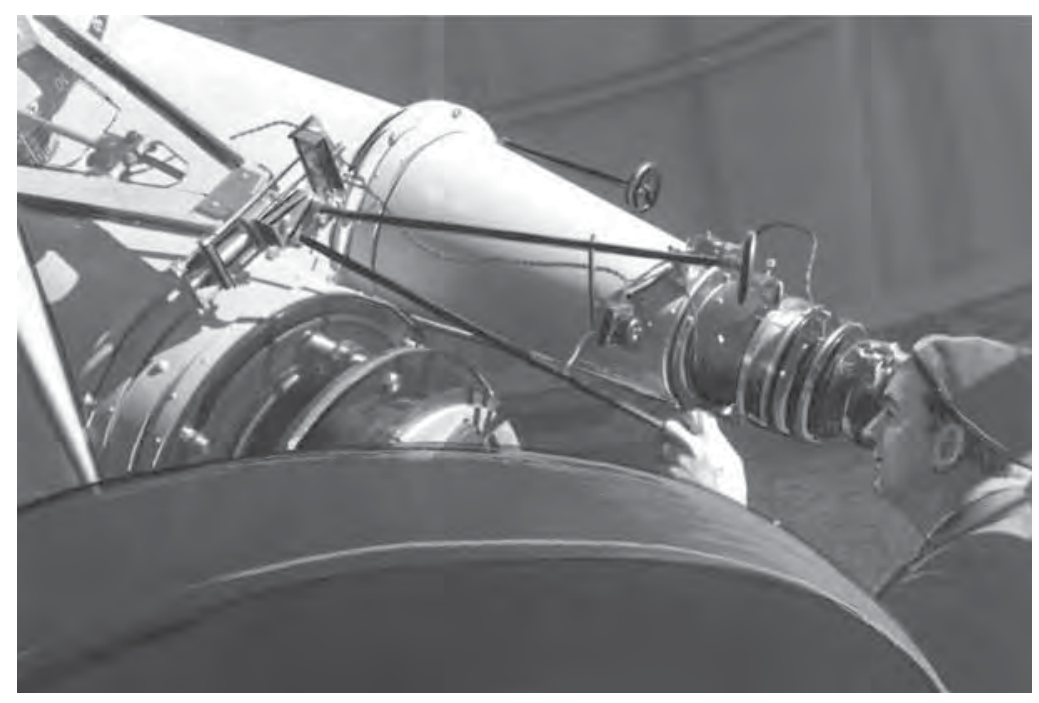

9. Luneta

Obserwatorium

Meteorologiczno-

-Astronomicznego UW na szczycie Pop Iwan, ok. $193^{8} \mathrm{r}$.

$\mathrm{Na}$ zachód od głównego kampusu, w nieistniejącej już dziś kamienicy przy ul. Królewskiej 10, usytuowanej vis-à-vis gmachu Zachęty, znajdował się należący do Wydziału Humanistycznego Instytut Orientalistyczny, który w $193^{2}$ r. połączył seminaria egiptologiczne, sinologiczne, indologiczne i turkologiczne oraz nowo utworzoną bibliotekę islamistyczną. Większość placówek Wydziału Lekarskiego położona była natomiast w południowo-zachodniej części Śródmieścia. Jego główny budynek, tzw. Collegium Anatomicum, znajdował się przy ul. Chałubińskiego 5. Tuż obok, przy ul. Oczki 1 wybudowano w latach 20. gmach Zakładu Medycyny Sądowej z salami prosektoryjnymi i ich zapleczem. Naprzeciwko niego, w kwartale wyznaczonym ulicami Chałubińskiego, Nowogrodzką, Lindleya i Oczki usytuowane były pawilony uniwersyteckiego Szpitala Dzieciątka Jezus. Wraz z gmachem Wydziału Farmaceutycznego, zorganizowanym w odrestaurowanych koszarach przy ul. Oczki 3, gdzie po nadbudowaniu dwóch dodatkowych pięter przeniesiono również Seminarium Matematyczne, Zakład Mechaniki Teoretycznej, a z czasem także Zakład Fizyki Teoretycznej Wydziału Matematyczno-Przyrodniczego, budynki te - choć niewyodrębnione z tkanki miasta - stanowiły przez swe skupienie w jednym miejscu rodzaj drugiego kampusu uniwersyteckiego.

Do Wydziału Lekarskiego należał także szpital Św. Ducha przy ul. Elektoralnej 12, klinika pediatryczna w narożniku ulic Litewskiej i Marszałkowskiej, położnicza przy ul. Starynkiewicza 3 i psychiatryczna na terenie Szpitala Św. Jana Bożego przy ul. Konwiktorskiej 7 . 


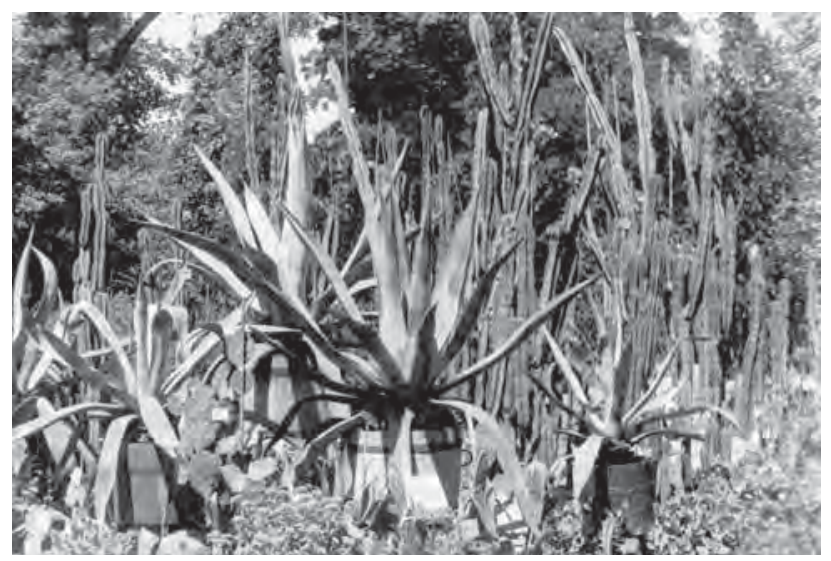

10. Kaktusy w Ogrodzie Botanicznym UW, 1937 r.

W sumie, pod koniec lat 20. zajęcia dydaktyczne prowadzono na medycynie aż w 23 miejscach, rozrzuconych po wszystkich dzielnicach ${ }^{9}$. Rozproszone były również obiekty Wydziału Matematyczno-Przyrodniczego. Do tych, o których była już mowa wcześniej, dodać należy otwarty w 1921 r. przy ul. Hożej 69 okazały Zakład Fizyki Doświadczalnej, jak również Zakład Fizjologii Zwierząt mieszczący się w Instytucie Radowym przy ul. Wawelskiej 15. Pod koniec lat 30. wzniesiono także nowoczesny, rozległy gmach chemii przy ul. Pasteura 1 na Ochocie, a także przeniesiono tam Zakład Chemii Nieorganicznej z Krakowskiego Przedmieścia. Uroczyste poświęcenie budynku z udziałem prezydenta Mościckiego - który sam był z wykształcenia profesorem chemii - odbyło się w czerwcu 1939 r., wybuch wojny uniemożliwił już jednak uruchomienie tam zajęć dydaktycznych. We względnie komfortowej sytuacji pod względem położenia znajdował się natomiast Wydział Farmaceutyczny, gdyż oprócz gmachu przy ul. Oczki i sal na terenie głównego kampusu przy Krakowskim Przedmieściu, od roku akademickiego 1927/1928 zajmował jeszcze budynek przy ul. Przemysłowej 25 na Solcu, niestety dość zaniedbany. Mieścił się w nim również Zakład Chemii Analitycznej należący do Wydziału Lekarskiego. Jedynym zupełnie nierozczłonkowanym lokalowo kierunkiem Uniwersytetu była weterynaria, której siedzibę stanowił kompleks powojskowych budynków przy ul. Grochowskiej 77 na Pradze.

Omawiając umiejscowienie Uniwersytetu na mapie ówczesnej Warszawy wspomnieć trzeba również o kinie Urania położonym w gmachu Muzeum Rolnictwa i Przemysłu przy Krakowskim Przedmieściu, pomiędzy kościołem Św. Anny a Resursą Obywatelską, wynajmowanym do czasu powstania Auditorium Maximum na wykłady dla szczególnie 


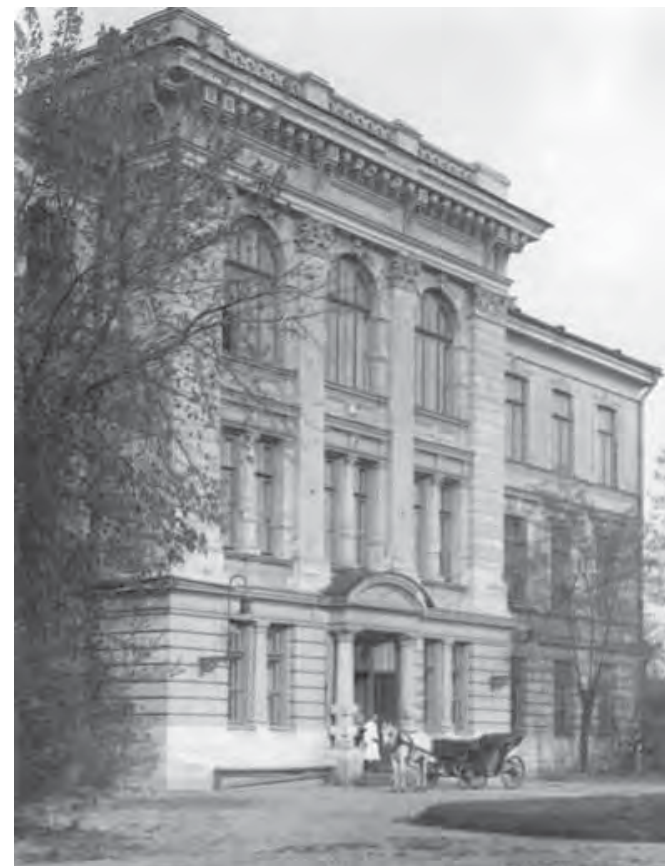

11. Budynek Wydziału Weterynaryjnego UW przy ul. Grochowskiej licznych pierwszych roczników prawa. I tam zresztą brakowało miejsc siedzących, przynajmniej na początku każdego roku akademickiego, gdy większości słuchaczy nie znudziło się jeszcze chodzenie na zajęcia. Co bardziej przedsiębiorczy studenci zaopatrywali się nawet w składane krzesełka rybackie, które za opłatą przechowywał im woźny ${ }^{10}$.

W sumie placówki Uniwersytetu rozrzucone były w ok. 40 budynkach położonych w kilkunastu miejscach stolicy. Zmuszało to studentów niektórych wydziałów do regularnego podróżowania po mieście pomiędzy zajęciami, co z pewnością było dla nich dość uciążliwe, nie mówiąc nawet o tym, iż nie zapewniało im ciszy i skupienia, czym tak zachwycał się przybysz z Krakowa. W najgorszej sytuacji pod tym względem znajdowali się medycy i adepci nauk matematyczno-przyrodniczych. Większość prawników i spora część humanistów mogła natomiast pobierać naukę na terenie głównego kampusu, co najwyżej z koniecznością niedługiego spaceru w stronę Starego Miasta, placu Trzech Krzyży lub placu Piłsudskiego. Na skutek rozproszenia zajęć po całym niemal mieście słuchacze Uniwersytetu, wyróżniający się białymi czapkami z amarantowym paskiem lub różnobarwnymi deklami korporacji stanowili za to stały element pejzażu ówczesnej Warszawy. Ich wzmożona ruchliwość na ulicach była zazwyczaj niezawodnym zwiastunem niepokojów politycznych. „Było rzeczą charakterystyczną w ówczesnej Warszawie, że gdy na Uniwersytecie «coś się działo» (wybuchały jakieś zamieszki, manifestacje itp., co bynajmniej nie należało do rzadkości), z gmachu Muzeum [Rolnictwa i Przemysłu] wylewała się kilkusetosobowa gromada studentów prawa i podążała hurmem na teren uczelni. Wszyscy przechodzący wiedzieli już w czym rzecz: «studenteria się burzy»" - relacjonował po latach jeden ze słuchaczy ${ }^{11}$.

Wspomniane czapki - przede wszystkim uniwersyteckie maciejówki - noszone były powszechnie przez studentów. Rzadziej wkładały je studentki, które chętniej używały własnych, indywidualnie dobranych 


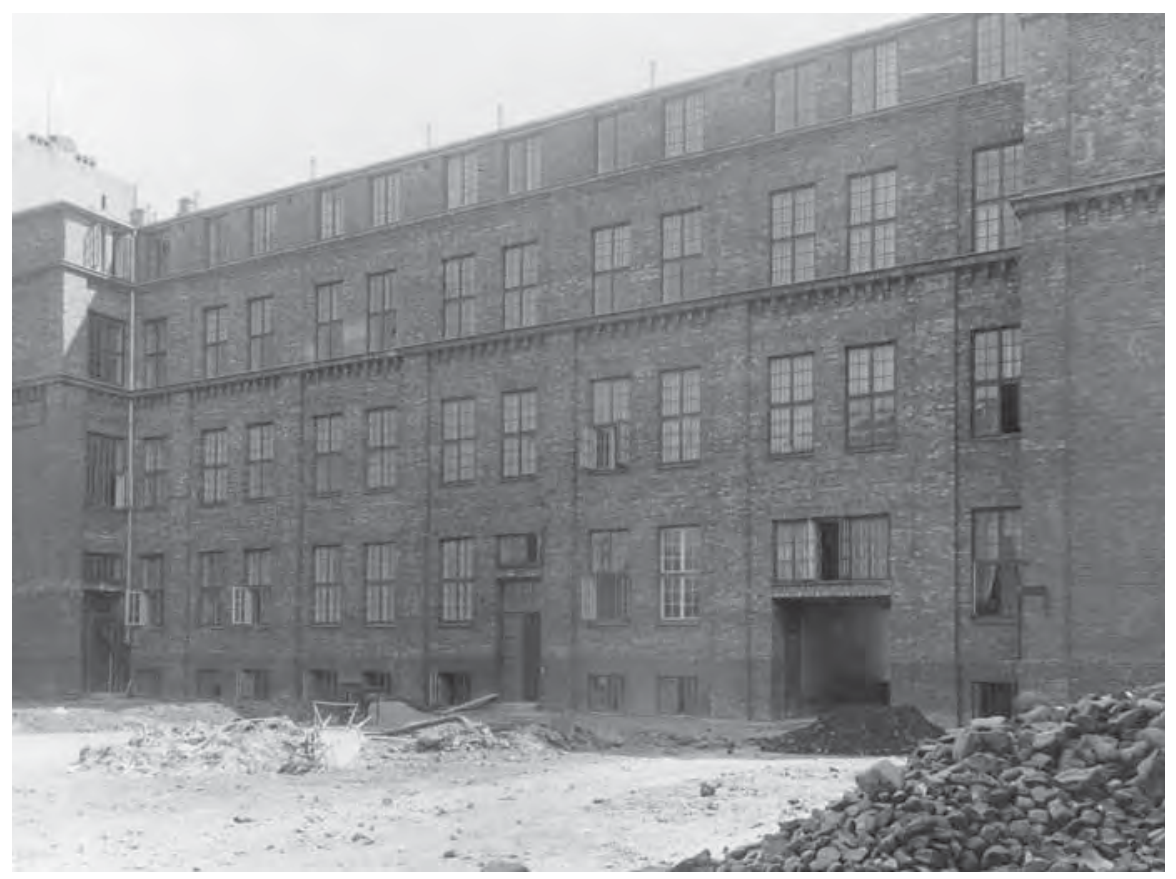

12. Budynek Wydziału Farmaceutycznego UW przy ul. Przemysłowej w 1928 r.

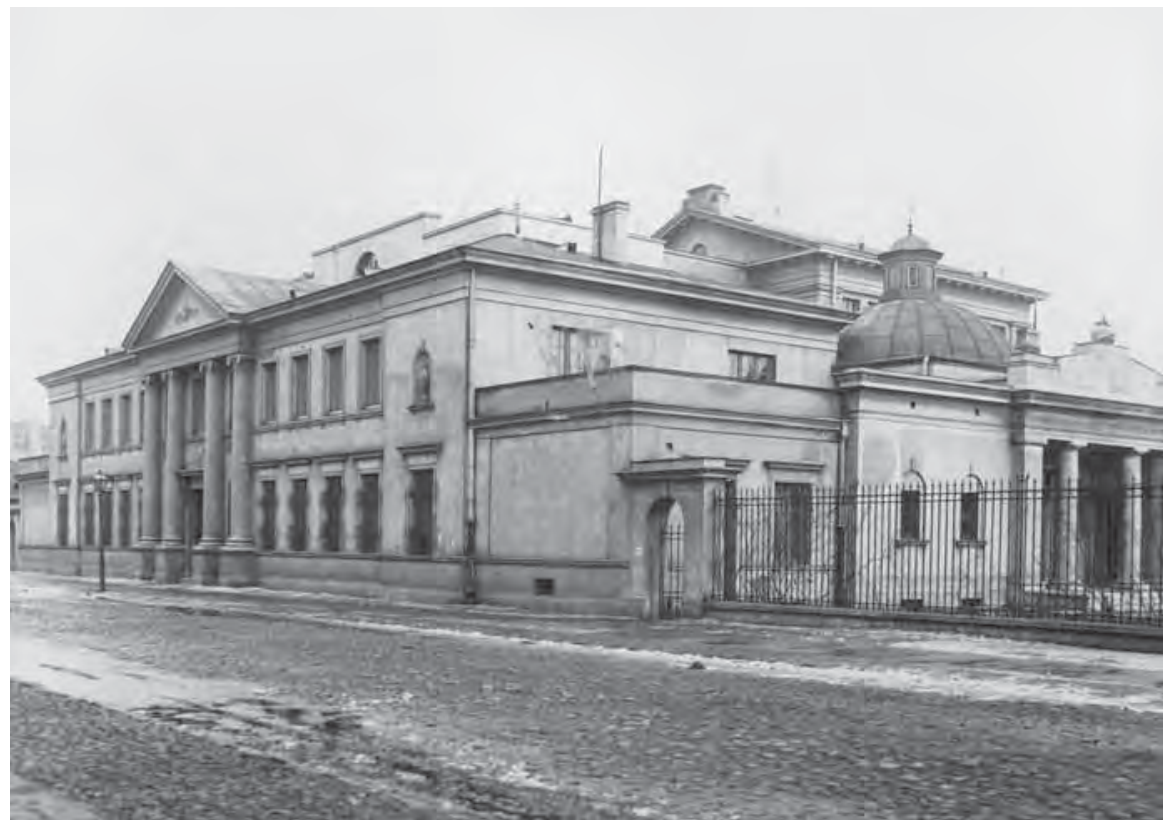

13. Budynek Zakładu Medycyny Sądowej przy ul. Oczki w latach międzywojennych 


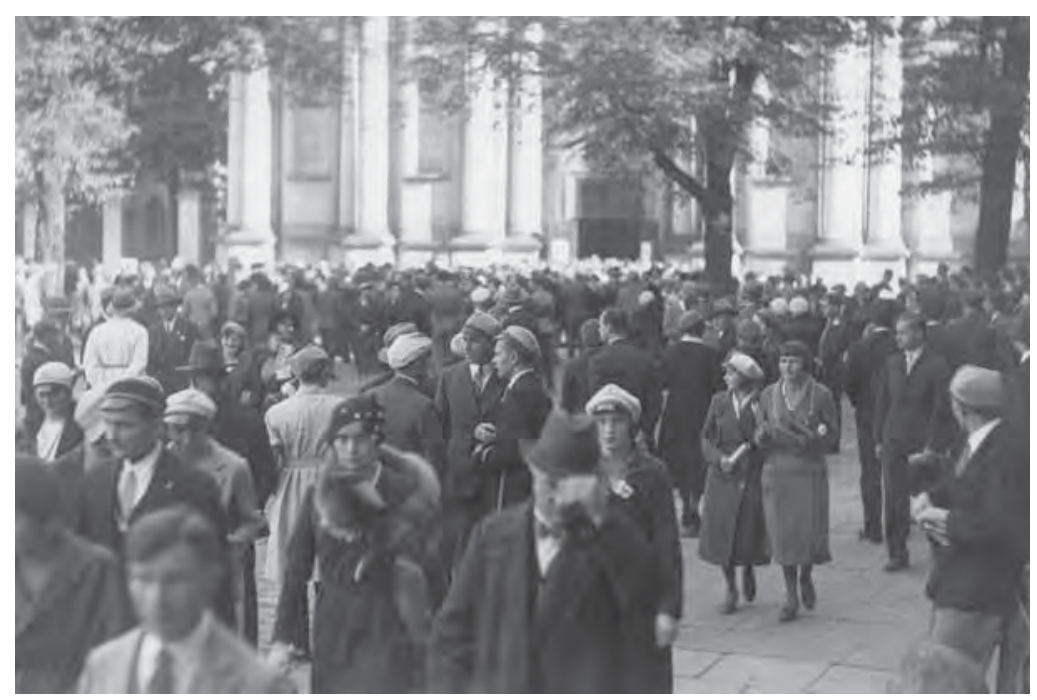

14. Młodziė̇

akademicka przed kościołem sióstr Wizytek po nabożeństwie z okazji inauguracji roku akademickiego $193^{2 / 1933}$

nakryć głowy, kierując się zapewne modą lub względami estetycznymi. Uniwersyteckie maciejówki stanowiły jedyny zewnętrzny wyróżnik przynależności do stanu akademickiego, gdyż w przeciwieństwie do czasów carskich ani studenci Uniwersytetu, ani tym bardziej jego pracownicy nie nosili już mundurów. Wyjątek pod tym względem stanowili jedynie woźni, których w 1937 r. wyposażono w uniformy i rogatywki zaprojektowane przez znawcę barwy i broni Bronisława Gębarzewskiego ${ }^{12}$. Togi i birety profesorowie wdziewali jedynie w sytuacjach uroczystych, takich jak inauguracja roku akademickiego, promocje doktorskie itp. Na co dzień na uczelni obowiązywał natomiast niepisany dress code, charakterystyczny dla ówczesnej warstwy inteligenckiej w przestrzeni publicznej. Fotografie z okresu międzywojennego pokazują studentów-mężczyzn w marynarkach i koszulach pod krawatem, a w chłodniejszej porze roku w ciemnych płaszczach. Niekiedy pojawiają się na nich mundury podchorążych z Centrum Wyszkolenia Sanitarnego, którzy pobierali naukę na Wydziale Lekarskim na mocy porozumienia uczelni z władzami wojskowymi, albo młodszych oficerów odkomenderowanych na UW z Wojskowego Instytutu Geograficznego. (Zgodnie z ówczesną normą nawet na co dzień występowali oni w uniformach, budząc swym szykiem zazdrość pozostałych słuchaczy i podziw słuchaczek ${ }^{13}$ ). Studentki, których stopniowo przybywa na fotografiach, noszą się zazwyczaj skromnie (marynarskie kołnierzyki sukienek niektórych z nich upodabniają je do pensjonarek), ale tu i ówdzie można dostrzec także elegantki w zarzuconych na ramiona futrzanych szalach i oryginalnych nakryciach głowy. 


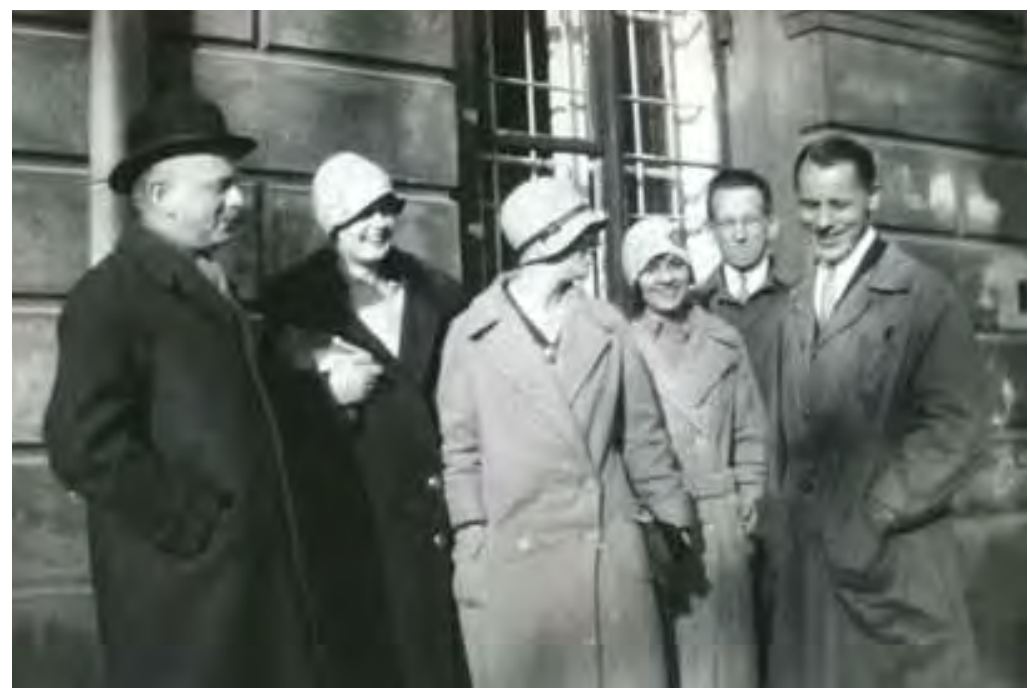

15. Uczestnicy

seminarium

historycznego

prof. Marcelego

Handelsmana

(pierwszy od lewej).

Pierwszy od prawej

doc. Tadeusz

Manteuffel,

lata $3^{0 .} \mathrm{XX}$ w.

Pracownicy naukowi Uniwersytetu, poza scenami z zajęć laboratoryjnych, nieodmiennie ubrani są w garnitury, zwykle trzyczęściowe, spod których dość często wystają jeszcze wysokie, dobrze znane z XIX w. kołnierzyki, plastycznie i nie bez powodu zwane Vatermörder - ewidentny przejaw tradycjonalizmu stroju. Do wyjątków należy zdjęcie jednego z profesorów z końca lat 20., przechodzącego Krakowskim Przedmieściem w pumpach, wełnianych podkolanówkach i marynarce, pod którą widoczny jest pulower i koszula z krawatem. Być może zrobiono je w sytuacji nieformalnej, poza czasem zajęć na Uniwersytecie, a być może i tam okazjonalnie pozwalano sobie już na takie ekstrawagancje. Zarówno profesor, jak i bardziej konwencjonalnie ubrany w płaszcz i garnitur, towarzyszący mu docent Wydziału Humanistycznego mają na głowach modne wówczas homburgi, miękkie filcowe kapelusze z lekko podwiniętym rondem i zagłębieniem pośrodku główki. To również dyskretny element wzorowanej na Anglikach sportowej elegancji, która zawitała już wówczas na uczelnię. $\mathrm{Na}$ innych fotografiach uchwycono jednak profesorów w czarnych melonikach, a w sytuacjach szczególnie uroczystych widzimy ich w cylindrach. Jak się wydaje, nowe trendy w zakresie ubioru stosunkowo powoli znajdowały uznanie wśród kadry naukowo-dydaktycznej uczelni, którą cechował pod tym względem zauważalny konserwatyzm.

Jest gorzką ironią losu, że cezury wyznaczające ramy czasowe dziejów Uniwersytetu Warszawskiego w omawianym okresie były skutkami 


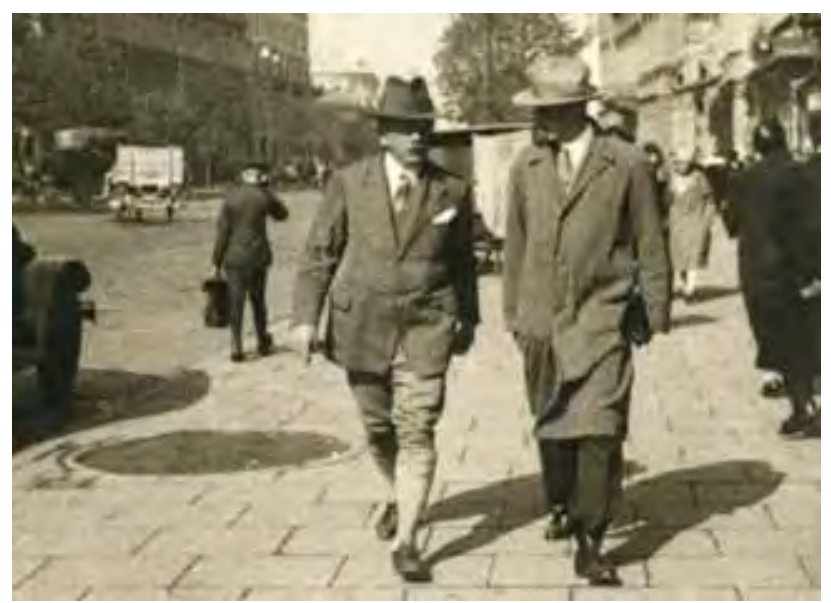

16. Profesor Marceli Handelsman

i docent Stanisław Arnold

na Krakowskim Przedmieściu

w pobliżu Uniwersytetu,

wrzesień $1929 \mathrm{r}$.

dwóch okupacji niemieckich podczas kolejnych wojen światowych. Uroczyste wznowienia działalności uczelni z udziałem generała-gubernatora Hansa von Beselera nastąpiło 15 XI 1915 r., przestała zaś ona de facto funkcjonować wraz z zajęciem przez Niemców stolicy pod koniec września 1939 r., na mocy decyzji generalnego gubernatora Hansa Franka, choć jeszcze w początkach niemieckich rządów prowadzono pewne czynności urzędowe, m.in. na niektórych wydziałach wydawano dyplomy osobom, które złożyły wszystkie egzaminy przed rozpoczęciem wojny $^{14}$. Życie uczelni pomiędzy tymi datami toczyło się w rytmie następujących po sobie kolejnych lat akademickich, jednak nie przez cały ten czas uczelnia pracowała normalnym trybem. Uniwersytet zawiesił w praktyce działalność dydaktyczną w roku akademickim 1918/1919, gdy odradzała się polska państwowość i toczyły się walki o granice. Zajęcia zawieszono po raz kolejny latem 1920 r., kiedy w obliczu zagrożenia Warszawy inwazją bolszewicką młodzież akademicka oddała się gremialnie do dyspozycji władz wojskowych; wznowiono je dopiero w styczniu następnego roku, co spowodowało, iż przepadło pełne półrocze zajęć ${ }^{15}$.

Początkowo poszczególne lata akademickie dzieliły się na semestry, a od jesieni 1920 r. na trymestry: jesienny, zimowy i wiosenny. Obejmowały one łącznie zo tygodni zajęć. Podobnie jak dzisiaj, inauguracja roku akademickiego miała zazwyczaj miejsce na początku października. Uświetniał ją uroczysty przemarsz władz Uniwersytetu w togach i biretach z Pałacu Kazimierzowskiego na mszę świętą w pobliskim kościele ss. Wizytek, który pełnił nieformalnie funkcję świątyni akademickiej. Pod koniec lat 3o. program ten rozszerzono o podniesienie flagi państwowej na budynku biblioteki uniwersyteckiej. Pozbawiony 


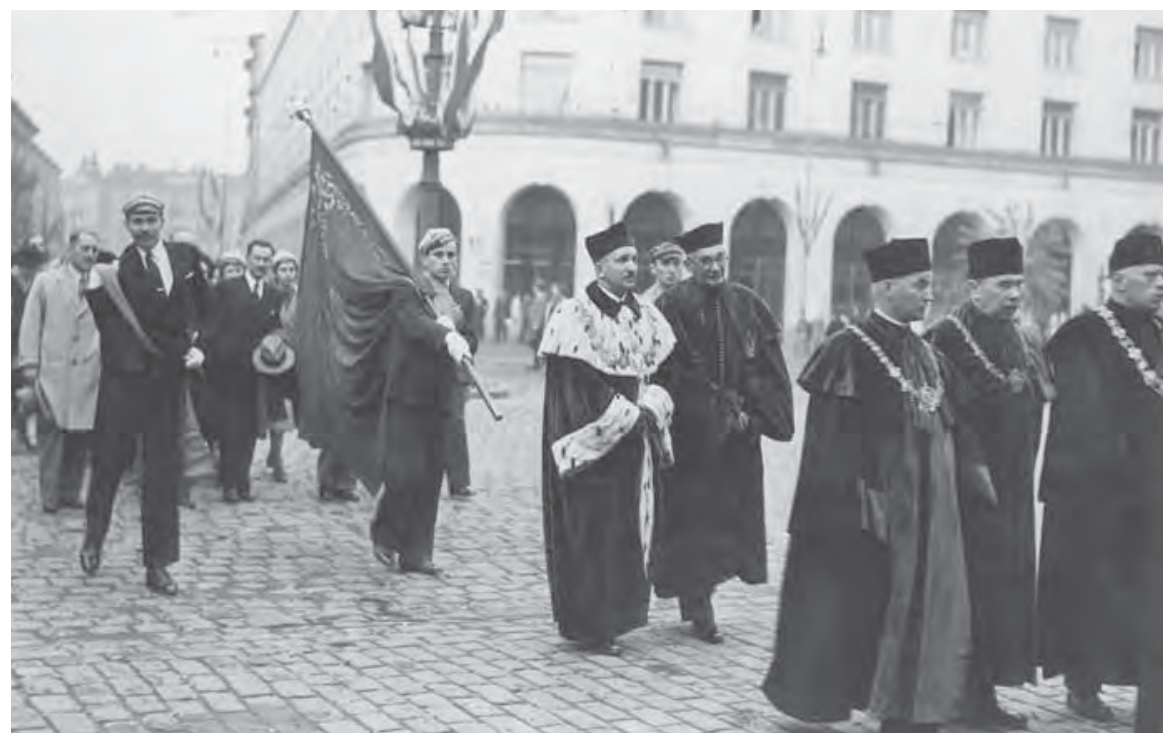

17. Inauguracja roku akademickiego 1938/1939. Senat, władze rektorskie i młodzież w drodze na mszę św. do kościoła sióstr Wizytek. Pośrodku, w pelerynie z gronostajów, rektor Włodzimierz Antoniewicz

pompy charakter miało natomiast rozpoczęcie roku dla nowo przyjętych studentów, którzy po prostu odbierali indeksy z sekretariatu. Podobnie nie organizowano té̇ uroczystych graduacji.

Inaugurowany na początku października trymestr jesienny kończył się już koło połowy grudnia, po czym następowała prawie miesięczna przerwa bożonarodzeniowa, ciągnąca się aż do pierwszej niedzieli po święcie Trzech Króli. W zaczynającym się następnie trymestrze zimowym uczono się nieprzerwanie mniej więcej do połowy marca. Ferie wiosenne, które po nim następowały, trwały z reguły ponad miesiąc, obejmując również święta Wielkanocy. Trymestr wiosenny zaczynał się w drugiej połowie kwietnia i trwał do końca czerwca. W czerwcu i lipcu odbywała się letnia sesja egzaminacyjna; studenci mogli jednak prosić o wyznaczenie daty egzaminu po wakacjach - odbywał się on wtedy w sesji jesiennej we wrześniu lub na początku października. W indywidualnych przypadkach, o ile zgodził się na to profesor, egzaminy mogły mieć miejsce równiė̇ w trakcie trymestrów.

Zajęcia na Uniwersytecie odbywały się przez 6 dni w tygodniu, od poniedziałku do soboty, od 8.0o do 20.00. Na różnych kierunkach prowadzono je w różnych porach - na naukach przyrodniczych, fizyce, chemii, medycynie, farmacji i weterynarii, gdzie konieczne były ćwiczenia laboratoryjne, przeważnie odbywały się do godziny 18.00; na prawie, 


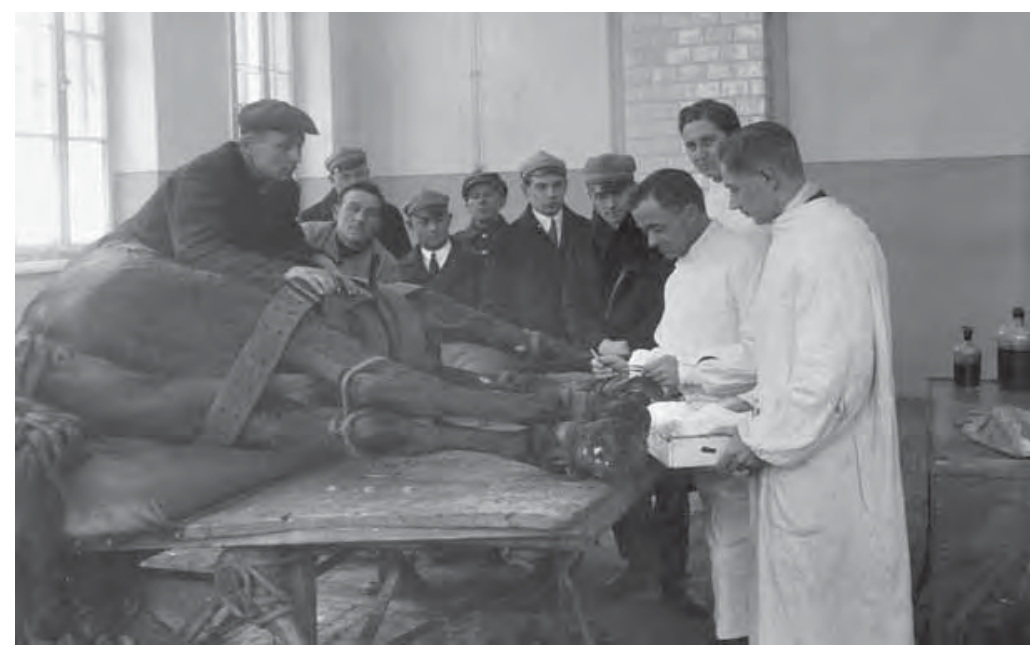

18. Operacja konia na Wydziale Weterynaryjnym luty $1928 \mathrm{r}$.

kierunkach humanistycznych i teologicznych - również w późnych godzinach popołudniowych i wieczornych. Od poniedziałku do piątku od 9.0o do 19.45 można było korzystać z czytelni publicznej, czasopism i profesorskiej w bibliotece uniwersyteckiej, w soboty kończyły one pracę o godzinę wcześniej. Wypożyczalnia działała w dni powszednie od 9.30 do $13.3^{0}$, a we wtorki i piątki dodatkowo również od 16.00 do $18.00^{16}$.

Większość wykładów i ćwiczeń dydaktycznych odbywała się na Uniwersytecie co 2 godziny zegarowe; nauka trwała najczęściej go minut, po czym następowała przerwa, umożliwiająca studentom dotarcie na kolejne zajęcia. W rejonie kampusu przy Krakowskim Przedmieściu, tak jak i dzisiaj, dzwon zegara na budynku biblioteki, odmierzający upływ kwadransów i pełnych godzin, ułatwiał społeczności akademickiej orientację w czasie.

\section{Kadra uniwersytecka. Przebieg kariery akademickiej}

Uruchomienie przez niemieckie władze okupacyjne Uniwersytetu Warszawskiego jesienią 1915 r. wymagało stworzenia od podstaw jego kadry naukowej. W pierwszym roku funkcjonowania uczelni liczyła 
ona zaledwie $3^{6}$ wykładających (była to funkcja tymczasowa, obejmująca zarówno profesorów, jak i docentów), 6 lektorów, 1 adiunktaprosektora, i 23 asystentów. Do wiosny 1919 r. liczba wykładających wzrosła do 72 , adiunktów do 6, a asystentów do 59. Ubyło natomiast lektorów, których pozostało jedynie $3^{17}$. Ogółem w latach 1915-1919, uwzględniając zmiany kadrowe, na stanowiskach wykładowców zatrudnionych zostało 87 osób, z których aż 48 (56\%) wywodziło się z szeroko rozumianego warszawskiego środowiska naukowego, obejmującego m.in. Towarzystwo Kursów Naukowych i Towarzystwo Naukowe Warszawskie, a także stołecznych lekarzy i nauczycieli szkół średnich. Pozostali wykładowcy oddelegowani zostali przeważnie z ośrodków akademickich Galicji (17 osób ze Lwowa i 11 z Krakowa - łącznie 32\%), po kilku pochodziło z uniwersytetów niemieckich, rosyjskich i austriackich ${ }^{18}$.

Przeprowadzona w ciągu kilku miesięcy po odzyskaniu niepodległości tzw. stabilizacja kadry naukowej Uniwersytetu przyniosła zniesienie stanowiska „wykładającego" i wprowadzenie systemu tytułów naukowych i funkcji, analogicznego jak na uczelniach galicyjskich. Po jej ukończeniu, w semestrze letnim roku akademickiego 1918/1919 liczba samodzielnych pracowników UW wzrosła do 86. Obok zo profesorów zwyczajnych i 19 nadzwyczajnych (nazywanych zbiorczo profesorami rzeczywistymi), znalazło się wśród nich 12 profesorów honorowych, przeważnie już w wieku emerytalnym, 9 zastępców profesorów i 16 docentów tymczasowych, z których większość musiała w ciągu następnych 2 lat poszukać sobie innych miejsc pracy. W nowym składzie osobowym dominowali uczeni zatrudnieni już wcześniej na Uniwersytecie, którzy w liczbie $5^{8}$ pomyślnie przeszli weryfikację. Pozostałych 28 osób powołano z innych ośrodków akademickich ${ }^{19}$. Ponadto na uczelni zatrudnionych było 109 niesamodzielnych pracowników naukowych w tym: 7 lektorów, 13 adiunktów (prosektorów) i 89 asystentów ${ }^{20}$.

Wprowadzony w ramach stabilizacji system tytułów naukowych i funkcji został zatwierdzony ustawą o szkołach akademickich uchwaloną w lipcu 1920 r. i obowiązywał do wybuchu II wojny światowej, z niewielkimi tylko zmianami wynikającymi z przyjętych później aktów prawnych.

$\mathrm{Na}$ szczycie uczelnianej hierarchii znajdowali się profesorowie zwyczajni. Ich nominacji dokonywała głowa państwa na wniosek rady wydziału, przyjęty przez senat akademicki i zatwierdzony przez ministra wyznań religijnych i oświecenia publicznego. Kandydata na wakującą katedrę rada wydziału wybierała po zasięgnięciu opinii wśród wszystkich profesorów danej dziedziny nauki w kraju. (Procedura ta nie była 


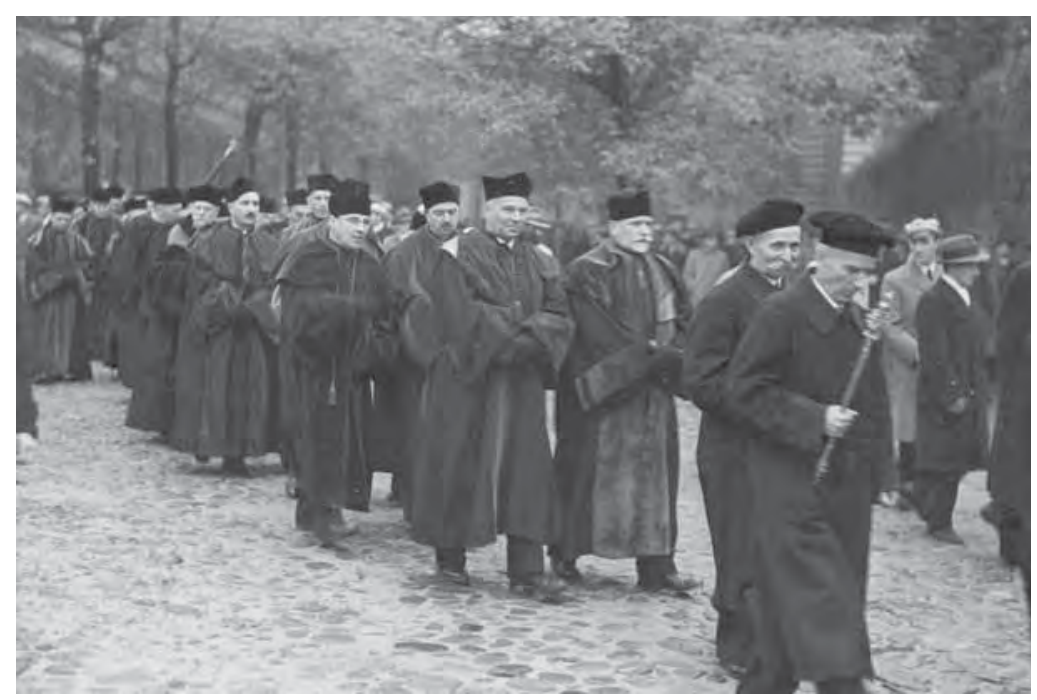

19. Senat

Uniwersytetu

Warszawskiego

podczas inauguracji

roku akademickiego

$1936 / 1937$

jednak konieczna w przypadku osób mających już tytuł profesorski). Tylko profesorowie zwyczajni mogli zostać wybrani na stanowiska rektorskie i dziekańskie, co obok wyższego uposażenia i prestiżu stanowiło właściwie jedyną różnicę w stosunku do położenia usytuowanych niżej w hierarchii profesorów nadzwyczajnych. Warunkiem awansu ze stopnia profesora nadzwyczajnego na zwyczajnego było udokumentowanie odpowiednio większego dorobku naukowego. Oba rodzaje etatów były przy tym niejako przypisane do konkretnych katedr: profesorem można było zostać mianowanym tylko wówczas, gdy jedna z nich zostawała zwolniona lub gdy tworzono nową; profesor zwyczajny nie mógł objąć katedry nadzwyczajnej, ani na odwrót. Profesor rzeczywisty był nieusuwalny. Władze państwowe nie mogły go odwołać inaczej niż na wniosek $2 / 3$ składu macierzystej rady wydziału lub senatu akademickiego, w przypadku, gdyby wszczęto przeciw niemu postępowanie dyscyplinarne lub honorowe. Przyjęta w 1933 r. ustawa zapewniła jednak ministrowi wyznań religijnych i oświecenia publicznego możliwość likwidowania katedr, w ten sposób mógł on zatem odwoływać również profesorów. Pensum profesorskie obejmowało 5 godzin wykładu i 2 godziny ćwiczeń lub seminarium tygodniowo. Profesor miał przechodzić na emeryturę po 35 latach pracy lub po ukończeniu 65 . roku życia, później wprowadzono jednak możliwość kontynuowania pracy naukowo-dydaktycznej również po przekroczeniu tej granicy wiekowej ${ }^{21}$.

Ze względu na niedostatek fachowców z tytułami profesorskimi, katedry powierzano niekiedy osobom o niższych kwalifikacjach formalnych, 
przyznając im stanowiska zastępców profesorów. Ciążyły na nich te same obowiązki dydaktyczne i organizacyjne jak na profesorach, nie przysługiwały im jednak analogiczne prawa. Otrzymywali té̇ niższe uposażenia. Zastępcy profesorów powoływani byli nie w drodze nominacji, lecz poprzez podpisanie z uczelnią umowy, która musiała zostać zatwierdzona przez ministra. Jeszcze mniejsze zobowiązania Uniwersytet podejmował wobec profesorów honorowych, którzy mieli prawo prowadzenia zajęć, lecz na ogół nie pobierali pensji. (W praktyce na stanowisko to przenoszono zwykle profesorów rzeczywistych, gdy osiągnęli wiek emerytalny, a chciano, aby nadal prowadzili wykłady) ${ }^{22}$. Istniała też kategoria profesorów kontraktowych, czyli takich, którzy nie zaliczali się, jakbyśmy dziś powiedzieli, do minimum kadrowego Uniwersytetu, a jedynie prowadzili tu wykłady na zasadzie umowy-zlecenia.

Bez jakiegokolwiek wynagrodzenia pracowali na uczelni docenci, przy czym docentura nie miała formalnie charakteru stopnia naukowego, lecz jedynie związana była z wykonywaniem veniam legendi, czyli - jak to wówczas dość pokrętnie ujmowano - „prawa do obowiązku bezpłatnego wykładania". Przyznawała ją rada wydziału po pomyślnym odbyciu procedury habilitacyjnej, na którą składały się: ocena dorobku naukowego kandydata ze szczególnym uwzględnieniem wydanej drukiem rozprawy, odbycie przez niego kolokwium egzaminacyjnego i wygłoszenie na forum rady wykładu na jeden z dwóch przedstawionych jej do wyboru tematów. Docentura była ograniczona do konkretnej uczelni, co oznaczało, że np. docent Uniwersytetu Jagiellońskiego, chcąc wykładać na Uniwersytecie Warszawskim, musiał przenieść tu swe uprawnienia, uzyskawszy zgodę odpowiedniej rady wydziału. Venia legendi wygasała, jeśli docent nie prowadził zajęć dłużej niż przez jeden rok akademicki ${ }^{23}$. W praktyce, jak wynika $\mathrm{z}$ uniwersyteckich statystyk i sprawozdań, docenci UW zatrudniani byli niekiedy jako zastępcy profesorów, zlecano im też odpłatne prowadzenie wykładów, co zapewniało im choćby tymczasowo środki do życia ${ }^{24}$.

Niższy szczebel hierarchii akademickiej tworzyli pracownicy pomocniczy, do których zaliczali się adiunkci (tj. głównie prosektorzy i demonstratorzy), lektorzy prowadzący zajęcia z języków nowożytnych, a także starsi i młodsi asystenci oraz zastępcy asystentów. Pierwsze dwie kategorie miały status urzędników państwowych i nie oczekiwano od nich kontynuowania kariery naukowej. Asystentura z założenia traktowana była natomiast jako okres przejściowy przed uzyskaniem habilitacji. W związku z tym zastępców asystentów zatrudniano nie dłużej niż na 2 lata, młodszych asystentów na 3 lata, a starszych na 6 , 
z możliwością przedłużenia angażu na kolejne 4 lata, o ile się do tego czasu habilitowali. Młodsi asystenci i zastępcy asystentów nie musieli legitymować się dyplomem ukończenia wyższej uczelni, co sprawiało, że na stanowiska te przyjmowano niekiedy wyróżniających się studentów ${ }^{25}$.

W praktyce postanowienia ustawy naginano niekiedy do bieżących potrzeb. Adiunktury i asystentury wykorzystywano do zatrudniania naukowców o kwalifikacjach znacznie wyższych od wymaganych, dla których chwilowo nie udało się znaleźć innych stanowisk, a chciano ich zatrzymać na uczelni. W połowie lat zo. można było spotkać docentów pracujących nie tylko jako adiunkci, ale nawet jako młodsi asystenci. $\mathrm{Z}$ kolei na stanowiskach starszych asystentów zdarzały się osoby bez dyplomu ukończenia wyższej uczelni ${ }^{26}$.

Po przeprowadzonej w 1919 r. stabilizacji liczba pracowników naukowych zatrudnionych na Uniwersytecie Warszawskim początkowo istotnie wzrosła, lecz już w połowie lat 20. trend ten uległ zahamowaniu. Rosnące potrzeby dydaktyczne, spowodowane m.in. powoływaniem nowych katedr i wydziałów, musiały zderzyć się z ograniczonymi możliwościami kadrowymi uczelni oraz polityką personalną Ministerstwa Wyznań Religijnych i Oświecenia Publicznego (MWRiOP), na którą wpływ miały z kolei głównie względy budżetowe. Nie wszystkie katedry pozostawały z tego powodu obsadzone, uczelnia nie mogła też zrealizować w pełni swych planów dydaktycznych i badawczych, na co regularnie narzekali rektorzy. $\mathrm{Na}$ przełomie lat 20. i zo. na Uniwersytecie Warszawskim pracowało 73 profesorów zwyczajnych, 32 nadzwyczajnych, 12 honorowych, 11 kontraktowych i 9 zastępców profesorów (w tym 6 docentów UW). Docentów było 87, lektorów 17, adiunktów-prosektorów 31, asystentów zaś 227. Wykłady zlecone prowadziło 117 osób, z których 44, były docentami $\mathrm{UW}^{27}$.

Mimo iż kolejna dekada rozpoczęła się w cieniu kryzysu gospodarczego, przyniosła ona zauważalną poprawę sytuacji kadrowej. W roku akademickim 1937/1938, według sprawozdania rektorskiego, na uczelni pracowało już 80 profesorów zwyczajnych, 45 nadzwyczajnych, 19 honorowych, 6 zastępców profesorów, 164, docentów, 24, lektorów, 56 adiunktów i 24,0 asystentów. (Skład osobowy Uniwersytetu na ten sam rok podaje nieco inne liczby). Wykładów i ćwiczeń zleconych prowadzono w sumie 174, powierzając je częściowo pracownikom naukowym UW, a zwłaszcza docentom. Zatrudniano w ten sposób 67 osób. (Jedna osoba prowadziła niekiedy kilka zajęć). Zanikła natomiast zupełnie funkcja profesora kontraktowego ${ }^{28}$. 
Tabela 1. Kadra naukowo-dydaktyczna UW 1915-1939

\begin{tabular}{|c|c|c|c|c|c|c|c|c|c|c|c|c|}
\hline 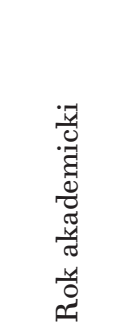 & 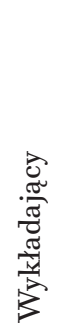 & $\begin{array}{l}5 \\
\vdots \\
0 \\
0 \\
0 \\
0 \\
0 \\
0 \\
0 \\
0 \\
0 \\
0 \\
0 \\
0 \\
0 \\
0 \\
0\end{array}$ & 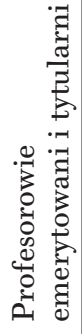 & 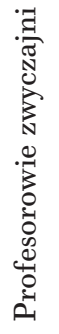 & 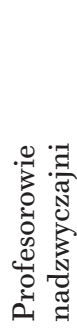 & 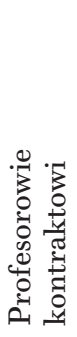 & 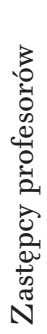 & 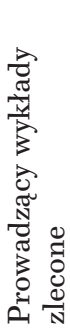 & 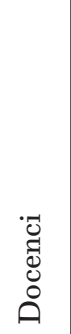 & 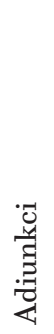 & 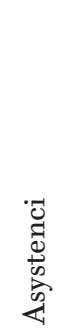 & 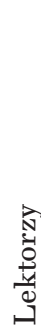 \\
\hline $1915 / 16$ & 36 & - & - & - & - & - & - & - & - & 1 & 23 & 6 \\
\hline 1916/17 & 50 & - & - & - & - & - & - & - & - & 2 & 41 & 4 \\
\hline $1917 / 18$ & 53 & - & - & - & - & - & - & - & - & 2 & 46 & 4 \\
\hline 1918/19 & 72 & - & - & - & - & - & - & - & - & 6 & 59 & 3 \\
\hline $1919 / 20$ & - & 11 & - & 43 & 19 & 8 & 8 & - & 18 & 13 & 89 & 7 \\
\hline $1920 / 21$ & - & 11 & - & 53 & 21 & - & 13 & 3 & 16 & 15 & 117 & 7 \\
\hline $1921 / 22$ & - & 10 & - & 61 & 17 & - & 13 & 16 & 8 & 20 & 150 & 6 \\
\hline $1922 / 23$ & - & 12 & - & 68 & 24 & 1 & 13 & 43 & 14 & 19 & 183 & 13 \\
\hline $1923 / 24$ & - & 13 & - & 69 & 28 & 1 & 9 & 49 & 30 & 22 & 193 & 11 \\
\hline $1924 / 25$ & - & 13 & - & 69 & 26 & 1 & 6 & 59 & 33 & 23 & 205 & 11 \\
\hline $1925 / 26$ & - & 12 & - & 70 & 26 & 2 & 8 & 59 & 36 & 26 & 212 & 14 \\
\hline $1926 / 27$ & - & 11 & - & 71 & 31 & 4 & 10 & 79 & 57 & 29 & 214 & 14 \\
\hline $1927 / 28$ & - & 12 & - & 70 & 33 & 5 & 9 & 85 & 70 & 26 & 214 & 16 \\
\hline $1928 / 29$ & - & 12 & - & 71 & 34 & 3 & 10 & 109 & 74 & 30 & 230 & 17 \\
\hline $1929 / 30$ & - & 12 & - & 73 & 32 & 11 & 9 & 117 & 87 & 31 & 227 & 17 \\
\hline $1930 / 31$ & - & 11 & - & 74 & 30 & 10 & 9 & 118 & 94 & 33 & 232 & 15 \\
\hline $1931 / 32$ & - & 10 & - & 73 & 32 & 10 & 9 & 112 & 103 & 35 & 220 & 16 \\
\hline $1932 / 33$ & - & 9 & - & 72 & 32 & 8 & 8 & 120 & 115 & 36 & 213 & 20 \\
\hline $1933 / 34$ & - & 7 & 6 & 68 & 29 & 9 & 9 & 121 & 123 & 39 & 218 & 22 \\
\hline $1934 / 35$ & - & 6 & 8 & 74 & 33 & 6 & 11 & 130 & 134 & 39 & 223 & 23 \\
\hline $1935 / 36$ & - & 11 & b.d. & 80 & 38 & b.d. & 9 & 172 & 148 & 55 & 235 & 23 \\
\hline $1936 / 37$ & - & 12 & 11 & 81 & 46 & b.d. & 7 & 128 & 147 & 55 & 238 & 22 \\
\hline $1937 / 38$ & - & 19 & 15 & 80 & 45 & b.d. & 6 & 174 & 164 & 56 & 240 & 24 \\
\hline
\end{tabular}

Źródło: T. Manteuffel, Uniwersytet Warszawski w latach 1915/16-1934/35. Kronika, Warszawa 1936; SUW 1934/1935 i 1935/1936, s. 45; SUW 1936/1937, s. 12-14; SUW 1937/1938, s. 12-14. 
Poza kadrą naukowo-dydaktyczną Uniwersytet zatrudniał również personel pomocniczy, na który składali się urzędnicy rektoratu, kwestury i poszczególnych wydziałów, pracownicy biblioteki, a także tzw. funkcjonariusze niżsi, czyli przede wszystkim pielęgniarki w szpitalach uniwersyteckich, laboranci oraz woźni. W początkach lat 20. na uczelni pracowało 37 urzędników, 17 bibliotekarzy i 4,02 funkcjonariuszy, co dawało łącznie 4,56 osób. Siły te uważano za niewystarczające w stosunku do rosnących potrzeb ${ }^{29}$. Do końca tej samej dekady sytuacja uległa pewnej poprawie, ponieważ stan personelu zwiększył się do 475 etatów. W biurach uniwersyteckich zatrudnionych było wówczas 4,2 urzędników, w bibliotece 25 urzędników i 13 funkcjonariuszy niższych, kolejnych 39 funkcjonariuszy niższych pracowało w administracji, $109 \mathrm{w}$ poszczególnych zakładach, a $247 \mathrm{w}$ klinikach ${ }^{30}$. Mimo że na rok przed wybuchem II wojny światowej Uniwersytet zatrudniał w sumie 504, urzędników i funkcjonariuszy niższych, w ocenie ówczesnego rektora była to nadal liczba zbyt mała. Uczelnia nieustannie zabiegała o dodatkowe etaty $\mathrm{w}$ ministerstwie ${ }^{31}$.

$\mathrm{W}$ połowie lat 30. Uniwersytet Warszawski ze 128 profesorami, 198 docentami i 286 pracownikami pomocniczymi stanowił pod względem liczebności kadry naukowej największą szkołę wyższą w Polsce. Pracowało tu 16\% ogółu wszystkich polskich profesorów, 14\% docentów i taki sam odsetek sił pomocniczych. Różnice w stosunku do pozostałych uczelni nie były jednak zawrotne, przynajmniej gdy idzie o profesurę. Drugi co do wielkości w kraju Uniwersytet Jagielloński liczył 113 profesorów, 109 docentów i 221 osób na etatach pomocniczych, Uniwersytet Poznański zatrudniał 99 profesorów, 136 docentów i 203 pracowników pomocniczych, Uniwersytet Jana Kazimierza we Lwowie odpowiednio 87,127 i 230, a Uniwersytet Stefana Batorego w Wilnie - 85, 88 i $203^{32}$.

Uniwersytet Warszawski charakteryzował się zarazem najmniej korzystnym współczynnikiem liczby słuchaczy przypadających na jednego profesora, który w roku akademickim 1934/1935 wynosił 73 osoby, podczas gdy na UJ było ich 59, na UJK 69 , na UP $5^{2}$, a na USB jedynie 4,2. (Średnia dla wszystkich szkól wyższych w kraju to 6o studentów). Sytuację stołecznej uczelni poprawiała do pewnego stopnia stosunkowo duża liczba docentów. Uwzględniając zarówno ich, jak i profesorów, na jednego wykładowcę przypadało tu 29 studentów, natomiast na uniwersytecie krakowskim współczynnik ten wynosił zo, na lwowskim 28 , na poznańskim 22, a na wileńskim 21. Powyższe wyliczenia dowodzą, iż kadra naukowa UW była relatywnie bardziej obciążona niż na innych uczelniach obowiązkami dydaktycznymi takimi, jak egzaminowanie, ocena prac seminaryjnych itp. 
Jak ustaliła Hanna Kolendo, w latach 1919-1929 (po stabilizacji) pracowało na Uniwersytecie Warszawskim ogółem $5^{8}$ profesorów zwyczajnych, 33 nadzwyczajnych, 14 honorowych i 24, zastępców profesorów. Największa grupa spośród nich rekrutowała się z dawnego zaboru austriackiego: 15 profesorów przybyło z Krakowa, a 12 ze Lwowa. Kolejnych 25 nominatów pochodziło formalnie z Warszawy, część z nich nie była jednak wcześniej trwale związana ze stolicą, lecz przeprowadziła się tu stosunkowo niedawno z innych ośrodków akademickich, m.in. z Rosji. (Pierwsze lata niepodległości charakteryzowały się w ogóle dużymi przepływami kadry naukowej pomiędzy różnymi ośrodkami akademickimi w Polsce, niektórzy wykładowcy zatrudnieni byli więc na Uniwersytecie tylko przejściowo). W latach 20. na uczelni pojawiło się także 7 pierwszych profesorów będących wcześniej jej docentami. (Pierwsza habilitacja odbyła się na UW w czerwcu 1920 r., veniam legendi z zoologii uzyskał wówczas dr Witold J. Stefański). Wśród zastępców profesorów większość stanowiły osoby pochodzące z Warszawy, $8 \mathrm{z}$ nich było docentami macierzystej uczelni ${ }^{33}$.

W ciągu kolejnego dziesięciolecia kadra naukowa Uniwersytetu powiększyła się o 15 profesorów zwyczajnych, 39 nadzwyczajnych, 6 honorowych i 6 zastępców profesorów. Aż połowę spośród 6o katedr objęli wówczas docenci UW, przy czym 6 z nich przeniosło tu habilitacje z innych uczelni, natomiast 7 było wcześniej studentami Uniwersytetu Warszawskiego i tutaj się doktoryzowało. Ten ostatni fakt świadczył o normalizacji funkcjonowania uczelni, która powoli była już w stanie od początku do końca samodzielnie wykształcić swą kadrę profesorską. Tych spośród profesorów zatrudnionych w latach zo., którzy nie pochodzili z Warszawy, przyciągał na Uniwersytet jego stołeczny charakter i lepsze perspektywy pracy naukowej. W sumie, w latach 1919-1939 nominacje profesorskie otrzymało na UW 195 osób, z czego zo jako zastępcy. Zdecydowana większość z nich pozostawała na katedrach do chwili osiągnięcia wieku emerytalnego lub, co zdarzyło się w kilkunastu przypadkach, wcześniejszej śmierci ${ }^{34}$.

W tym samym okresie na Uniwersytecie Warszawskim zatrudniono ogółem 270 docentów, z których 238 (tj. prawie 90\%) habilitowało się właśnie tutaj, a pozostali przenieśli się z innych ośrodków. Wśród habilitantów rodzimych 93 osoby pracowały wcześniej na uczelni na stanowiskach asystentów lub adiunktów-prosektorów. Około połowa docentów uzyskała wcześniej na Uniwersytecie doktorat, a niektórzy ukończyli również studia magisterskie ${ }^{35}$.

Nie dysponujemy niestety danymi na temat łącznej liczby pracowników pomocniczych, którzy zostali zatrudnieni na uczelni w latach 


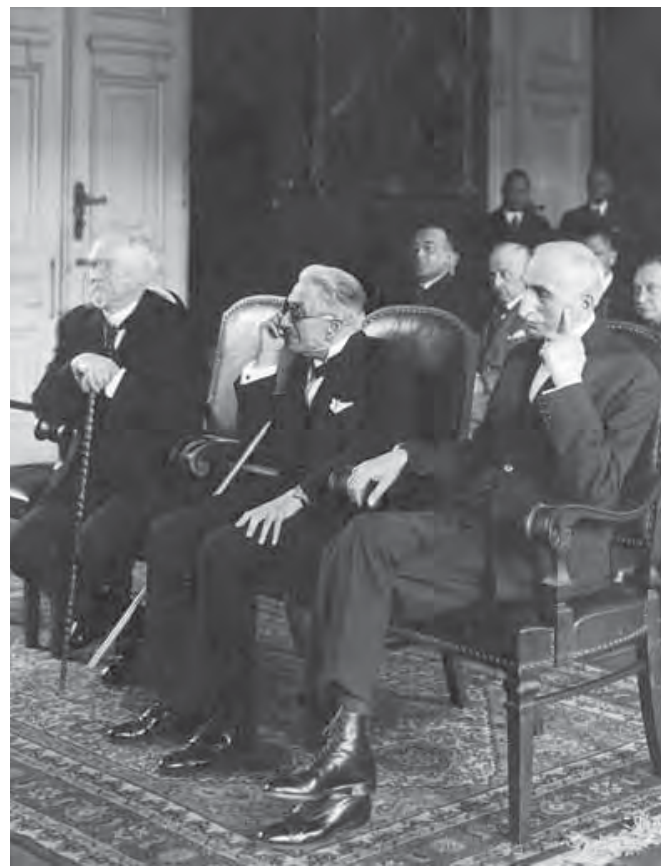

20. Profesor Ludwik Krzywicki (po lewej) i prof. Szymon Askenazy (po prawej) jako laureaci Nagrody Miasta Stołecznego Warszawy, zo V 1934 r.
1915-1939, lecz biorąc pod uwagę rotację spowodowaną przejściowym charakterem asystentury, należy przypuszczać, iż było ich około tysiąca.

Uwzględniając wykładających w latach 1915-1919, na Uniwersytecie Warszawskim do wybuchu II wojny światowej zatrudnionych zostało łącznie 499 samodzielnych pracowników naukowych. Była to grupa niejednorodna pod względem przebiegu wcześniejszej kariery zawodowej. Około 70\% z nich ukończyło studia przed rokiem 1918. Znajdowało się wśród nich aż 223 absolwentów uczelni rosyjskich, w tym 97 osób, które studiowały na Cesarskim Uniwersytecie w Warszawie. Zgodnie z przyjętym w tamtych czasach modelem, wiele z nich pobierało jednak naukę również na uniwersytetach w innych krajach. Absolwenci uczelni rosyjskich przeważali zwłaszcza wśród lekarzy i prawników, natomiast humaniści kształcili się wcześniej przede wszystkim na uczelniach galicyjskich z polskim językiem wykładowym, których absolwentami było ogółem 14,2 (29\%) późniejszych profesorów i docentów Uniwersytetu Warszawskiego. Ponadto 121 samodzielnych pracowników naukowych uczelni studiowało przed 1918 r. w Niemczech, 57 we Szwajcarii, 24 na uczelniach austro-węgierskich poza Galicją, a 25 we Francji. Absolwenci szkół wyższych z pozostałych państw występowali bardzo nielicznie. Pewną ciekawostkę stanowić może fakt, iż jeden z profesorów Uniwersytetu Warszawskiego, językoznawca Karol Appel w ogóle nie odbył żadnych studiów. Wśród zatrudnionych na UW 14,2 profesorów i docentów, którzy ukończyli szkoły wyższe już po odzyskaniu przez Polskę niepodległości, zdecydowana większość, bo aż 95, studiowała na uczelni macierzystej. Kolejne 33 osoby uczęszczały do szkół wyższych w Krakowie lub Lwowie, za granicą zaś kształciło się 26 osób ${ }^{36}$.

W momencie uruchomienia Uniwersytetu w 1915 r. jego kadra naukowa była stosunkowo młoda. Średnia wieku wykładających osiągała wówczas zaledwie 42 lata. Po przeprowadzonej w 1919 r. stabilizacji 
współczynnik ten wzrósł do 50 lat, przy czym przeciętny wiek profesorów zwyczajnych wynosił 49 lat, nadzwyczajnych 32 lata, zastępców profesorów 4,2 lata, a docentów tymczasowych 4,5 lat. Średnia wieku profesorów honorowych osiągnęła 74 lata. W ciągu kolejnych dwóch dekad każda z tych grup wyraźnie „postarzała się”. W 1929 r. przeciętny wiek profesorów zwyczajnych wzrósł do 55 lat, a przez kolejne dziesięciolecie osiągnął $5^{8}$ lat. W roku wybuchu II wojny światowej najliczniejszą grupą wśród nich (4.1\%) były osoby w wieku 61-65 lat, a więc formalnie zbliżające się już do emerytury. Wymogu przechodzenia na nią po ukończeniu 65. roku życia nie egzekwowano jednak zbyt rygorystycznie, bowiem 10 profesorów zwyczajnych pracowało nadal, mając ponad 66 lat. Średnia wieku profesorów nadzwyczajnych osiągnęła do 1929 r. 47 lat, a przez kolejną dekadę zmniejszyła się do 46 lat. Prawie połowę z nich stanowily w 1939 r. osoby w wieku 36-4.5 lat. Żaden profesor nadzwyczajny nie przekroczył wieku emerytalnego. Przeciętny wiek docentów wyniósł w 1929 r. 4,2 lata, a 10 lat później 44 lata; analogiczny współczynnik dla profesorów honorowych wzrósł w tym okresie do 77, a później obniżył się do 76 lat. Wydziały różniły się przy tym bardzo istotnie pod względem przeciętnego wieku pracowników, bowiem poszczególne gałęzie nauki charakteryzowały się, tak jak i dziś, zróżnicowaną dynamiką karier akademickich ${ }^{37}$. Pewne wyobrażenie na ten temat daje średnia wieku docentów wykładających na UW. Pod koniec 1937 r. wynosiła ona na Wydziale Prawa 36 lat, na Matematyczno-Przyrodniczym 39 lat, na wydziałach teologicznych 4,0 lat, na Humanistycznym 4,2 lata, na Weterynaryjnym 46 lat, a na Lekarskim i Farmaceutycznym po 4,8 lat $^{38}$.

Zjawisko starzenia się kadry naukowo-dydaktycznej wynikało z dwóch faktów. Po pierwsze, okrzepnięcie struktury organizacyjnej uczelni w latach 20. zakończyło okres bardzo szybkich awansów na stanowiska profesorskie, wymuszonych wcześniejszym brakiem kadr. Kariera akademicka nowo zatrudnianych na Uniwersytecie osób rozwijała się od tego czasu bardziej rutynowo i na ogół powolniej. Po drugie, profesorowie, którzy rozpoczęli pracę w pierwszych latach po uruchomieniu uczelni, przeważnie pozostawali na niej aż do osiągnięcia wieku emerytalnego (a często nawet dłużej), nowych katedr przybywało zaś bardzo niewiele. Konsekwencją tego była zmniejszająca się w latach 30. rotacja kadry i malejące szanse docentów na szybkie uzyskanie profesury na Uniwersytecie.

Ze względu na fakt, iż kadrę naukową uczelni rekrutowano po 1915 r. zupełnie od podstaw, trudno byłoby wskazać jeden dominujący tu w całym omawianym okresie model kariery akademickiej. W okresie 


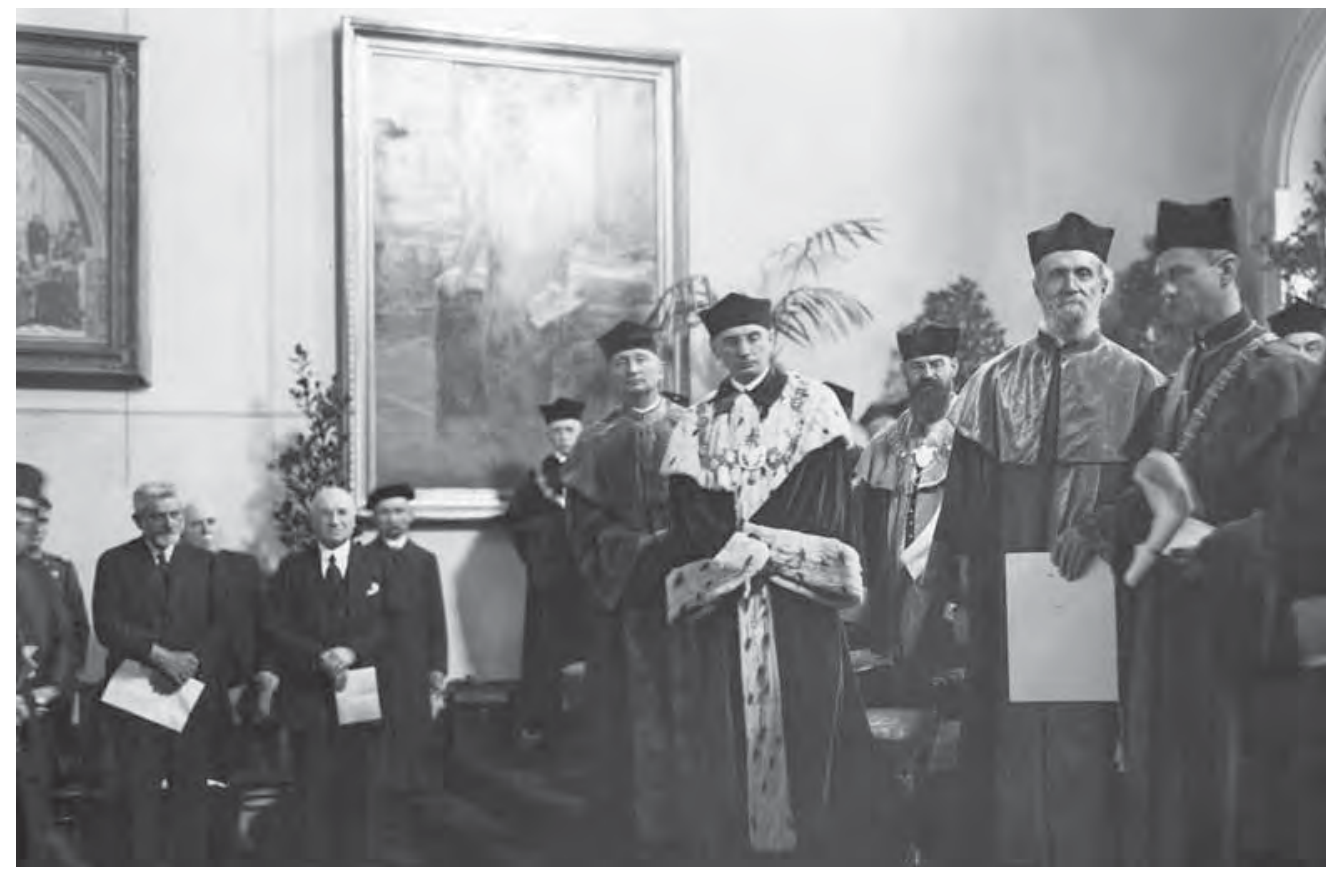

21. Jubileusz 50-lecia pracy naukowej prof. Tadeusza Zielińskiego. W pierwszym rzędzie stoją od prawej: prof. Tadeusz Kotarbiński, jubilat, rektor Tadeusz Brzeski, prof. Gustaw Przychocki

założycielskim na Uniwersytet napływali naukowcy o zróżnicowanych życiorysach, uczelnia zaś oferowała im wówczas możliwość szybkiego awansu profesorskiego. (Zaowocowało to notabene spektakularnymi sukcesami w dziedzinach takich, jak np. fizyka, matematyka, filozofia, językoznawstwo czy archeologia). Kilkudziesięciu profesorów, wśród nich postaci tej rangi co psycholog Stefan Baley, historyk Marceli Handelsman albo filozof Tadeusz Kotarbiński, nie uzyskało nigdy habilitacji, przeskakując niejako ten etap kariery akademickiej. Wraz z upływem lat okres poprzedzający otrzymanie własnej katedry stopniowo wydłużał się, coraz częstsze stawało się natomiast uzyskiwanie na Uniwersytecie Warszawskim kilku kolejnych stopni naukowych. Pewne prawidłowości dotyczące zawodowego curriculum vitae pracowników, które można zaobserwować, dopiero się kształtowały i nie musiały występować w każdym przypadku. Tym bardziej jak zostało już powiedziane, w niektórych dyscyplinach naukowych awansowano szybciej, a w innych wolniej ${ }^{39}$.

Szansą rozpoczęcia kariery naukowej była na ogół propozycja pozostania na uczelni w charakterze asystenta, którą profesor składał wyróżniającym się studentom. „Gdy widział, że ten czy ów zapowiadał 


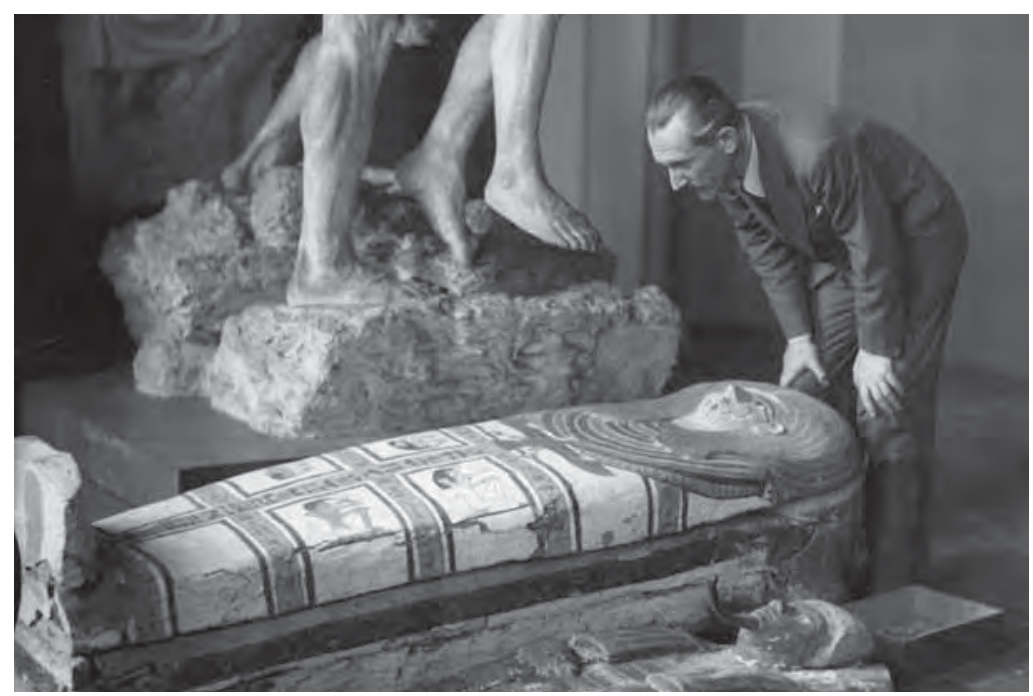

22. Profesor

Kazimierz

Michałowski

podczas oględzin

egipskiego sarkofagu,

1937 r.

się nieźle, to wtedy mówił - «No proszę Pana, to znaczy Pan...»" - tak zapamiętał początki swojej pracy naukowej pod kierunkiem Stefana Pieńkowskiego jego ówczesny asystent, fizyk Władysław Kapuściński ${ }^{40}$. Także na innych wydziałach i kierunkach wejście w świat akademicki następowało na mocy indywidualnej decyzji wykładowcy, nie istniały natomiast zinstytucjonalizowane formy naboru kandydatów w postaci egzaminów na studia doktoranckie. Przez pewną część okresu międzywojennego - przy tym różnie na różnych wydziałach (omawiam to dokładniej w rozdziale poświęconym przebiegowi studiów) - ukończenie Uniwersytetu Warszawskiego pozwalało zresztą uzyskać od razu tytuł doktorski, asystentura zaś służyła przygotowaniu rozprawy habilitacyjnej. Wraz ze stopniowym upowszechnieniem się magisterium kariera akademicka uległa natomiast automatycznemu wydłużeniu o etap studiów doktoranckich. Chcąc kontynuować pracę naukową nowo wypromowany doktor pozostawał wtedy na uczelni najczęściej aż do habilitacji na stanowisku starszego asystenta, rzadziej adiunkta.

Wśród docentów wykładających w 1937 r. na Uniwersytecie Warszawskim mediana wieku uzyskania habilitacji wynosiła $3^{8}$ lat. W przypadku osób, których kariera naukowa przebiegała już według nowego systemu (studia magisterskie plus doktoranckie), pomiędzy doktoratem a habilitacją upływało zatem przeciętnie około 10 lat. Niektóre jednostki odbiegały jednak bardzo wyraźnie od średniej - matematyk Alfred Tarski habilitował się w wieku zaledwie 24 lat, miało to jednak miejsce w czasach, gdy studia zapewniały jeszcze dyplom doktorski. O dwa lata 


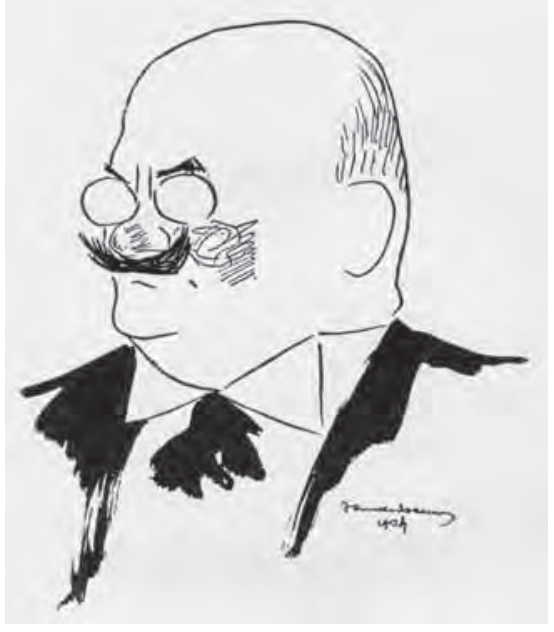

23. Karykatura prof. Mieczysława Michałowicza z Wydziału Lekarskiego starszy był w tym samym punkcie kariery akademickiej idący nowym trybem historyk Janusz Pajewski. Na drugim biegunie znajdowało się kilkunastu naukowców, którzy veniam legendi zdobyli już po pięćdziesiątce. Najstarszy z nich, historyk medycyny Ludwik Zembrzuski liczył sobie wtedy aż 59 lat. Wiek uzyskania habilitacji zależał niewątpliwie po części od czynników takich jak wcześniejsza droga zawodowa, sytuacja życiowa, motywacje itp., ale miał też wyraźny związek z uprawianą dziedziną nauk. Najszybciej habilitowano się bowiem na Wydziale Prawa (przeciętnie w wieku $3^{2}$ lat) i Matematyczno-Przyrodniczym (35 lat); dalsze w kolejności były wydziały teologiczne (37 lat), Humanistyczny (38 lat) i Lekarski (4,1,5 roku). Na samym końcu plasowały się wydziały Farmaceutyczny i Weterynaryjny, gdzie średnia wieku habilitantów wynosiła 4,2,5 roku ${ }^{41}$.

Kolokwium habilitacyjne, ze względu na towarzyszący mu stres, uchodziło za dość nieprzyjemne przeżycie. Nie wszyscy - nawet bardzo wybitni później naukowcy - wspominali po latach z zadowoleniem wykład wygłaszany później przez siebie przed radą wydziału ${ }^{42}$. Niektórzy z podchodzących do habilitacji dopatrywali się wręcz wymierzonych w siebie spisków, zorganizowanych przez swych wrogów osobistych bądź politycznych. Wśród zwolenników prawicy nie brakowało podejrzeń, iż za wszystkim stała masoneria. Za jej niedoszłą ofiarę uważał się np. jeden z docentów Wydziału Lekarskiego, Zdzisław A. Michalski: „Akcję utrącania mnie przy habilitacji rozpoczął, według mnie, członek Warszawskiej Loży Masońskiej, docent anatomii patologicznej, Wilhelm Czarnocki. [...] Na psa ujadającego wybrano również członka loży - pediatrę Michałowicza. Ten podobno miał prywatną urazę do mnie, gdyż jakoby powtórzono mu, że uważam go jako lekarza za skończonego durnia. Było to istotnie zgodne z moją opinią..." ${ }^{\prime 43}$. Spiskowa teoria dziejów z powodzeniem służyła, jak widać, za wygodne uzasadnienie prywatnych uprzedzeń i animozji, które niekiedy rzeczywiście nie pozostawały zapewne bez wpływu na przebieg głosowań habilitacyjnych. Zdarzało się przy tym, iż rady wydziałów odrzucały niektórych kandydatów ${ }^{44}$.

Uzyskanie veniam legendi otwierało drogę do profesury, ale względnie rzadko zdarzało się, by docent otrzymał własną katedrę bezpośrednio 
po habilitacji. W 1937 r. co piąty z wykładających na Uniwersytecie docentów czekał na nią już 10 lat lub więcej. (Na przykład w przypadku Tarskiego, o którym była mowa wcześniej, od habilitacji minęło wówczas 12 lat, a profesorem został on dopiero w Stanach Zjednoczonych w czasie II wojny światowej) ${ }^{45}$. W ciągu dwudziestolecia międzywojennego wyraźnie wydłużył się przeciętny czas oczekiwania na profesurę, zwłaszcza zwyczajną. Najczęściej wynosił on - jak się wydaje - kilkanaście lat, choć w latach zo. pojawiła się na Uniwersytecie także grupa trzydziestokilkuletnich profesorów nadzwyczajnych, świeżo po habilitacji ${ }^{46}$.

Uzyskanie profesury było trudne. Mogło nastąpić tylko albo w wyniku zwolnienia katedry przez jednego z dotychczasowych wykładowców, albo powołania nowej, co zwykle wymagało dodatkowych funduszy i długotrwałych zabiegów władz rektorskich w Ministerstwie. Biorąc pod uwagę, że na awans czekało zwykle wielu docentów, w obu przypadkach wymagało to posiadania przez osobę ubiegającą się o profesurę odpowiednio mocnej pozycji w środowisku uczelnianym. Poza względami merytorycznymi, takimi jak dorobek naukowy czy pożądana z punktu widzenia potrzeb Uniwersytetu specjalizacja, konieczni byli także sojusznicy w radzie wydziału gotowi zapewnić danej kandydaturze większość głosów. Następnie wniosek musiał zostać zatwierdzony przez Senat UW i dopiero stamtąd trafiał do Ministerstwa. O ile starający się o profesurę docent uzyskał wcześniej na Uniwersytecie stopień doktora, liczył - jak się wydaje - przede wszystkim na wsparcie swego dawnego promotora. Historyk Tadeusz Manteuffel wspomina np. o bezskutecznych próbach utworzenia dla niego na Wydziale Humanistycznym katedry historii Francji, podejmowanych w latach zo. przez Marcelego Handelsmana ${ }^{47}$.

Mechanizm podejmowania decyzji o obsadzie stanowisk profesorskich na Uniwersytecie ukazują dzienniki Wacława Borowego. Jego starania o katedrę historii literatury polskiej wiosną 1938 r. wspierane były przez profesorów Andrzeja Tretiaka i Jana Bystonia, podczas gdy prof. Julian Krzyżanowski proponował na to stanowisko doc. Zygmunta Szweykowskiego. W głosowaniu nad obiema kandydaturami zwyciężył Borowy wynikiem 21 do 5 głosów, o czym poinformowali go telefonicznie jego stronnicy, zanim jeszcze dziekan Wydziału Humanistycznego przesłał mu oficjalne pismo z propozycją podjęcia pracy. Wzmianki Borowego o jego „poważnym zmartwieniu” rezultatem głosowania i obawach Bystronia, by „nie zrobił zwolennikom «psikusa»”, świadczą, iż niejednomyślną decyzję uważano prawdopodobnie za pewną ujmę prestiżową. Z kolei telefon z gratulacjami od Krzyżanowskiego, 


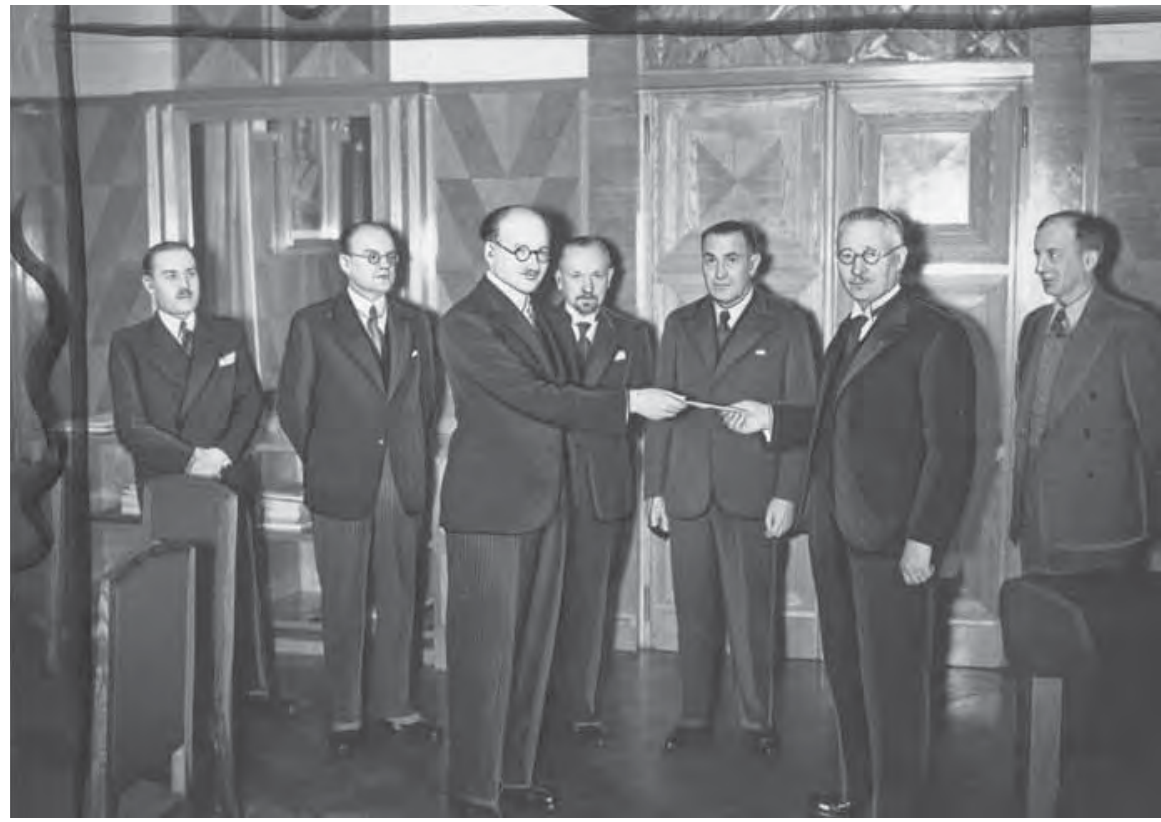

24. Docent Wacław Borowy odbiera państwową nagrodę literacką z rąk ministra Wojciecha Świętosławskiego, styczeń $1938 \mathrm{r}$.

który odnotowuje Borowy, dowodzi, że nawet w sytuacjach ewidentnego konfliktu interesów starano się zachowywać wobec siebie kurtuazję ${ }^{48}$.

Jak dowodzą niektóre przypadki, o otrzymaniu bądź nieotrzymaniu stanowiska profesora na Uniwersytecie nie zawsze jednak przesądzały wyłącznie względy merytoryczne. Docent Tadeusz Manteuffel miał nadzieję, iż w 1935 r. zostanie powołana dla niego katedra historii średniowiecza, ale jak zanotował po latach, przygotowując materiały do wspomnień z okresu międzywojennego: „Okazało się jednak, iż względy, jak myślę, natury kumoterskiej, spowodowały przyznanie jej bizantynistyce. [...] Rozżalony cierpko to wypominałem memu mistrzowi" ${ }^{\prime 49}$. Z kolei cytowany już przeze mnie doc. Michalski, jak zwykle węsząc wszędzie spiski wolnomularskie, utrzymuje, że na Wydziale Lekarskim „katedry były obsadzane [...] nie przez kandydatów najlepszych, lecz najbardziej odpowiednich, oczywiście dla masonerii [... ${ }^{350}$.

Fakt, że przy obsadzaniu stanowisk profesorskich na Uniwersytecie rzeczywiście odgrywały niekiedy względy polityczne i intrygi, choć wcale niekoniecznie masońskie, potwierdza casus Szymona Askenazego. Propozycję powołania tego uznanego historyka i dyplomaty na katedrę historii politycznej i dyplomatycznej Polski nowożytnej na Wydziale Prawa wysunął w 1919 r. prof. Leon Petrażycki, uważany za jednego 
z najwybitniejszych polskich uczonych tamtych czasów. Została ona jednomyślnie uchwalona przez Radę Wydziału i zatwierdzona przez Senat UW, wkrótce potem jednak prof. Karol Lutostański zażądał uchylenia tej decyzji pod pretekstem uchybień formalnych. (Chociaż sam zapewnił wcześniej ustnie Petrażyckiego, że popiera wniosek, teraz utrzymywał, że skierowanie sprawy do Senatu UW nastąpiło wbrew jego woli. Wskazywał też, że w porządku dziennym posiedzenia Rady Wydziału nie było punktu dotyczącego profesury dla Askenazego). Zarzuty zostały uwzględnione, co doprowadziło do unieważnienia decyzji Senatu i reasumpcji głosowania przez radę, która tym razem odrzuciła wniosek Petrażyckiego. Lutostański, będący inspiratorem i głównym realizatorem intrygi, występował przeciw kandydaturze Askenazego, obłudnie argumentując, iż broni nauki przed zakusami polityków, choć jego własne intencje były właśnie na wskroś polityczne. (Swoją rolę odegrało najprawdopodobniej zarówno żydowskie pochodzenie kandydata, jak i przypisywana mu przynależność do masonerii). Próba kompromisowego rozwiązania tej kompromitującej dla Uniwersytetu afery przez mianowanie Askenazego profesorem honorowym z pensja profesora zwyczajnego została zakulisowo utrącona przez ówczesnego dziekana Wydziału Prawa prof. Zygmunta Cybichowskiego, który celowo przewlekał sprawę i mnożył trudności formalne. Ostatecznie Askenazy dopiero w 1928 r., już za rządów piłsudczyków, został mianowany

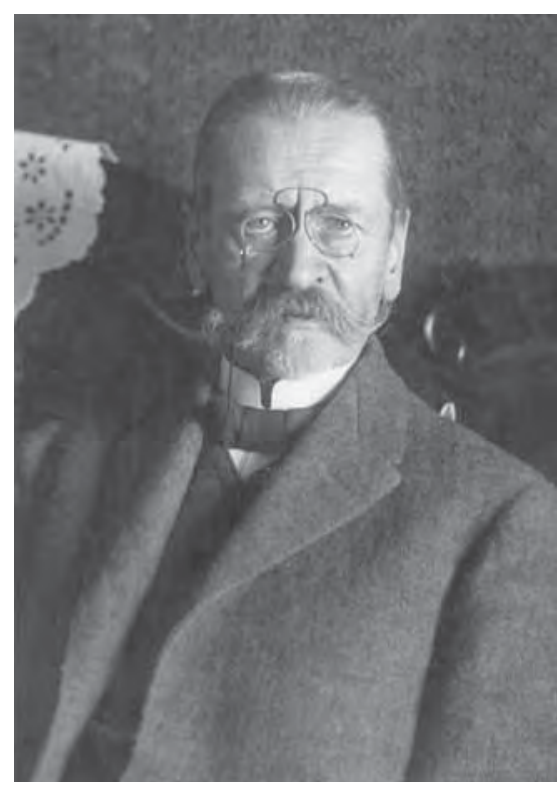

25. Profesor Leon Petrażycki, 1925 r. profesorem honorowym na nowo utworzonym wówczas Wydziale Humanistycznym. Petrażycki, w proteście przeciw postępowaniu swych kolegów prawników, podał się w 1920 r. do dymisji, której wprawdzie nie przyjęto, lecz na Wydziale Prawa aż do jego samobójczej śmierci w 1931 r. traktowano go jak ciało obce ${ }^{51}$.

Polityczne intrygi wokół obsady katedr prowadzono także na innych wydziałach. $\mathrm{Na}$ Humanistycznym zwolennicy Piłsudskiego po zamachu majowym starali się zablokować kandydaturę krakowskiego historyka Stanisława Kota, niewątpliwie ze względu na jego niechętny stosunek do Marszałka. $\mathrm{Na}$ posiedzeniach Rady Wydziału prof. Tadeusz Wałek-Czarnecki dyskredytował go, zarzucając, iż ,wykorzystując swe stosunki w poselstwie polskim w Paryżu [...] skorzystał 
z tej sposobności, ażeby przewieźć przez granicę polską w bagażu dyplomatycznym kosztowny dywan wschodni i uchylić się przez to od opłaty celnej", co nieszczególnie wiązało się wszakże z dorobkiem naukowym. W odróżnieniu od sprawy Askenazego, o profesurze Kota przesądziło jednak nie stanowisko gremiów akademickich, lecz veto Ministerstwa, nieżyczącego sobie przeciwnika piłsudczyków na $\mathrm{UW}^{52}$.

Tego rodzaju otwarte konfrontacje wokół nominacji profesorskich należały jednak na Uniwersytecie do wyjątków. Jeżeli nawet dochodziło do konfliktu interesów przy obsadzaniu poszczególnych katedr, jak miało to miejsce w przypadkach Borowego i Manteuffla, żadna ze stron nie dążyła do eskalacji i nagłośnienia sporu, zdając sobie sprawę, że niewiele da się w ten sposób osiągnąć. (Sprawa Askenazego była zresztą aż nadto dobitnym dowodem, że choćby najlepsza kandydatura nie miał szans powodzenia przy braku wystarczającego poparcia w radzie wydziału). Przegranym pozostawała więc gorycz porażki i nadzieje na lepszy obrót sprawy przy kolejnym wakacie na którejś z katedr.

Zwycięzca, o ile jego kandydaturę zatwierdziło MWRiOP, wchodził do uniwersyteckiej elity. Objęcie katedry miało charakter uroczysty. Panował zwyczaj, że po złożeniu przed rektorem stosownego ślubowania, nowo mianowany profesor wygłaszał wykład inauguracyjny, na który oprócz studentów przychodzili rektor, dziekan danego wydziału, liczni profesorowie i docenci, a także różni znajomi nominata (którym zdarzało się później niekiedy podrzemywać, co zauważali prelegenci). Uczonego oficjalnie przedstawiano i witano na Uniwersytecie. Jego pierwsze wystąpienie przed tak niecodzienną publicznością poprzedzone było zwykle starannymi przygotowaniami i próbami, mogło bowiem zaważyć - podobnie jak wcześniej wykład habilitacyjny - na reputacji dobrego lub złego wykładowcy ${ }^{53}$.

Ze względu na zróżnicowaną specyfikę poszczególnych kierunków uniwersyteckich nie istniał, jak się wydaje, jeden model pracy profesorów. Inaczej wyglądać musiała ona w przypadku chirurga, który zajęcia na UW łączył z operowaniem w klinice, inaczej duchownego wykładającego na którymś z 3 wydziałów teologicznych, a jeszcze inaczej humanisty czy prawnika. Niezależnie od tych różnic, każdy profesor zobowiązany był do prowadzenia zajęć dydaktycznych, egzaminowania i pracy naukowej, a także do uczestnictwa w posiedzeniach rady swego wydziału ${ }^{54}$. Jego kalendarz wypełniały też na ogół dość ciasno inne obowiązki zawodowe (zebrania różnych komisji i towarzystw naukowych) i towarzysko-reprezentacyjne. „Czasem zastanawiam się, jak i kiedy przy tym trybie życia mogłem przygotowywać wykłady i pisać książki" - zastanawiał się po latach Władysław Tatarkiewicz ${ }^{55}$. 


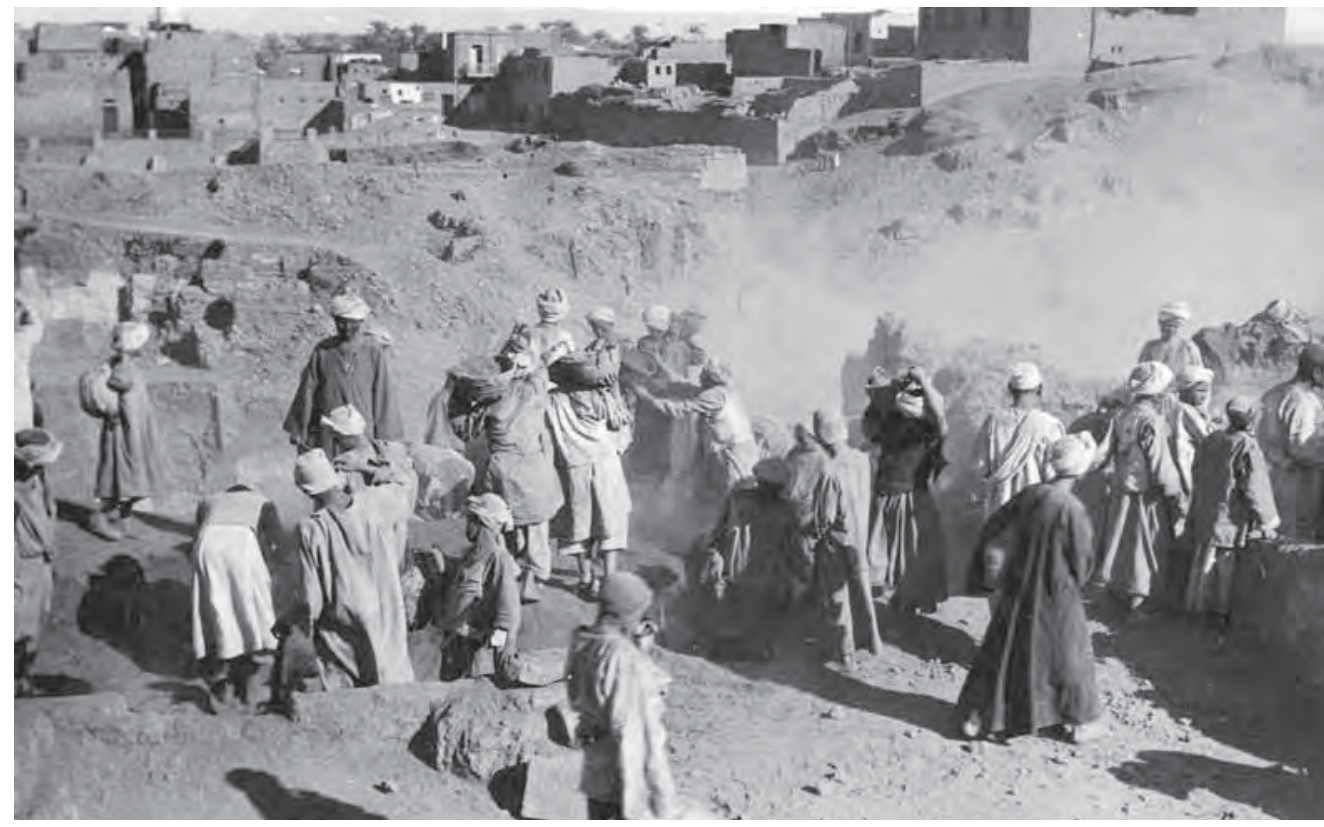

26. Wykopaliska w Edfu w Egipcie z udziałem Kazimierza Michałowskiego i Jerzego Manteuffla, 1938 r.

Mimo że profesorowie Uniwersytetu byli ludźmi zajętymi, niektórzy znajdowali czas na kultywowanie akademickiego esprit de corps, spotykając się w kawiarni Lourse'a w Hotelu Europejskim przy Krakowskim Przedmieściu, gdzie, jak wspomina Kazimierz Michałowski, „codziennie, z wyjątkiem niedzieli, przy tradycyjnej «półczarnej» tak żywo biło tętno intelektualne [...] warszawskiego życia uniwersyteckiego" ${ }^{156}$. Spotkania takie ułatwiały lepsze poznanie się osobom, które na co dzień wykładały na różnych wydziałach, służyły też zapewne uprawianiu uniwersyteckiej polityki. Przy stoliku gromadzili się przede wszystkim profesorowie humaniści o poglądach liberalnych - Stanisław Kętrzyński, Stanisław Wędkiewicz, Tadeusz Wałek-Czarnecki, Stefan Czarnowski czy Marceli Handelsman - ale przysiadali się też zwolennicy innych stronnictw politycznych, jak np. narodowy demokrata Roman Rybarski albo sam Michałowski (wówczas również sympatyzujący raczej z prawicą). Rytuał codziennej kawy u Lourse'a, poza wymiarem towarzyskim, potwierdzał także przynależność profesury do ówczesnej elity społecznej: w dwudziestoleciu międzywojennym w kawiarni tej bywali bowiem dziennikarze, artyści, literaci i właśnie ludzie nauki. Co charakterystyczne, sporadycznie tylko do profesorskiego stolika u Lourse'a zapraszano docentów - spotykali się oni popołudniami raczej we własnym gronie 
w kawiarni „Italia” przy Nowym Świecie, pomiędzy Alejami Jerozolimskimi a ul. Chmielną ${ }^{57}$.

Elitarność kawiarnianego kręgu, typowa zresztą dla międzywojennych obyczajów, kiedy kelnerowi zdarzało się bezceremonialnie wyprosić arywistów, usiłujących dosiąść się do stolika zajmowanego przez stałych bywalców, nie przeszkadzała, by w innych sytuacjach profesorowie i niżsi stopniem pracownicy naukowi stykali się na gruncie towarzyskim chętnie i bez poczucia przekraczania granic społecznych. Na długo przed objęciem katedry na UW Borowy blisko przyjaźnił się z Antoniewiczami, Manteuffel bywał regularnie na przyjęciach u Handelsmanów oraz u prof. Michałowicza, z którego młodą żoną zapoznał się na seminarium historycznym swego promotora. (Michałowicz leczył z kolei jako pediatra dzieci Handelsmana). Profesor Oskar Halecki gościł w domu swych wyróżniających się studentów i doktorantów ${ }^{58}$. Jak się wydaje, zwłaszcza w przypadku relacji mistrz-uczeń skracanie dystansu wobec młodych adeptów nauki poprzez przeniesienie relacji z nimi na grunt towarzyski należało wręcz do dobrego tonu, służyło wprowadzeniu ich na uniwersyteckie i stołeczne salony - zarówno zupełnie dosłownie, jak i w przenośni.

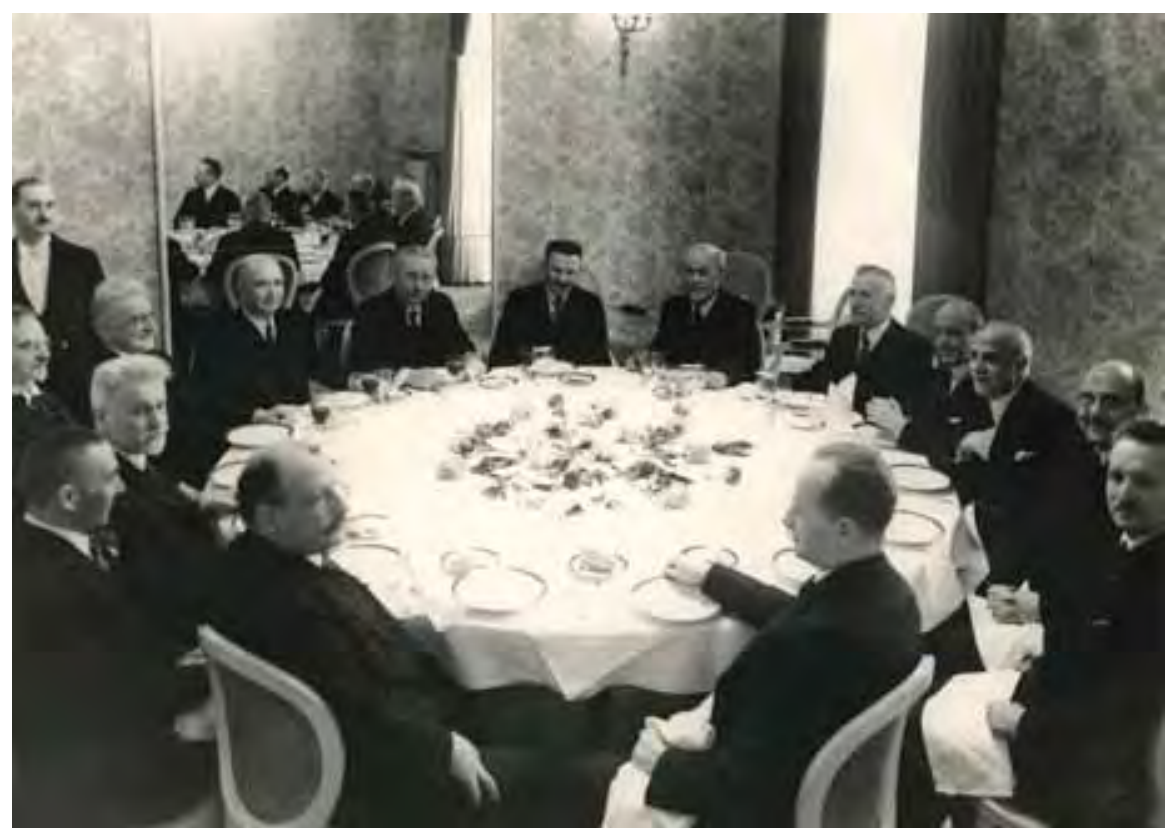

27. Spotkanie rektorów i dziekanów UW w Hotelu Europejskim, 9 VI 1939 r. 
Więzi środowiskowe umacniały także pobyty w domu pracy twórczej i odpoczynku w Mądralinie koło Otwocka, ufundowanym przez Stanisława Hiszpańskiego, właściciela renomowanej warszawskiej firmy szewskiej, a ponadto znanego społecznika. Korzystali z nich tak profesorowie, jak i niżsi stopniem pracownicy naukowi, ale wyłącznie płci męskiej, gdyż zgodnie ze swym regulaminem ośrodek był niedostępny dla kobiet (nie mogły one również odwiedzać gości). Jeden z ówczesnych docentów, historyk Janusz Pajewski, wspominając pobyt w Mądralinie w renomowanym profesorskim towarzystwie, składającym się z przedstawicieli różnych nauk, zauważa: „sympatyczny zwyczaj, że pracując i wypoczywając osobno, posiłki jadało się zawsze razem, sprzyjał życiu towarzyskiemu i był okazją do wielu interesujących pogawędek i rozmów przeciągających się nierzadko do późnych godzin nocnych"s9.

Czy na podstawie opisanych powyżej, dość przypadkowych mimo wszystko migawek z przedwojennego świata akademickiego, stwierdzić można istnienie na międzywojennym Uniwersytecie specyficznego „środowiska”, z określonym habitusem, poczuciem własnej odrębności i więzami towarzyskimi, odgrywającymi niekiedy kluczową rolę również na gruncie zawodowym? Zapewne tak, choć być może należałoby raczej mówić o luźnej konstelacji różnych środowisk, powiązanych w ten lub inny sposób z uczelnią, niekoniecznie zgodnych ze sobą w większości spraw, jednakowo przynależących do elit ówczesnej Warszawy. Inne było środowisko, w którym obracał się liberalny inteligent żydowskiego pochodzenia, piłsudczyk Handelsman, albo Michałowicz - też piłsudczyk, ale o rodowodzie pepeesowskim, podejrzewany o związki z masonerią, inne, w którym spotykali się endeccy profesorowie Rybarski czy Bohdan Wasiutyński, a jeszcze inne Antoniewicza i Borowego - zachowawcze, ale bez szczególnego zaangażowania politycznego. Mimo różnorodnych konfliktów interesów, napięć i animozji, jakie niewątpliwie występowały pomiędzy tymi środowiskami i należącymi do nich osobami, w pewnych sytuacjach były one w stanie występować zgodnie, stając się „środowiskiem” ponad wszystkimi podziałami. Konsens warszawskich elit był niezbędny do powołania Uniwersytetu w 1915 r., większość profesury solidarnie sprzeciwiała się w 1933 r. narzuconej przez władze państwowe nowej ustawie o szkolnictwie wyższym, a po 1939 r. środowiskowe więzi pozwoliły na utworzenie podziemnego Uniwersytetu i konspiracyjnych struktur Polskiego Państwa Podziemnego. 


\section{Obraz społeczny pracowników Uniwersytetu}

Nasza wiedza na temat pochodzenia społecznego kadry naukowo-dydaktycznej Uniwersytetu Warszawskiego ma charakter niepełny. Dane, których reprezentatywność trudno dziś ocenić, dotyczą nieco ponad połowy profesorów i docentów. Wskazywałyby one, iż grupa ta wywodziła się w ok. 2/3 ze środowiska inteligenckiego. Niewiele mówi to jednak o sytuacji majątkowej i pozycji społecznej, gdyż warstwa ta była bardzo zróżnicowana wewnętrznie. Obejmowała zarówno zamożnych lekarzy, prawników itp., jak i niższych rangą urzędników czy prowincjonalnych nauczycieli. Stosunkowo wielu samodzielnych pracowników naukowych wywodziło się ponadto z rodzin ziemiańskich $(13,5 \%)$. Rzadziej występowały natomiast osoby o rodowodzie chłopskim (9\%), a jeszcze mniej licznie potomkowie rodzin drobnomieszczańskich (3\%) i robotniczych $(3,5 \%)^{60}$. Brak jest jakichkolwiek zbiorczych danych o pochodzeniu społecznym adiunktów i asystentów, należy jednak przypuszczać, iż jego struktura nie odbiegała diametralnie od występującej wśród profesorów i docentów.

Kadrę naukowo-dydaktyczną Uniwersytetu tworzyli w ogromnej większości obywatele polscy. Cudzoziemców zatrudniano niemal wyłącznie jako wykładowców w Studium Teologii Prawosławnej oraz jako nauczycieli języków obcych. Pierwsza z tych grup liczyła w sumie 11 osób i dominowali w niej Ukraińcy spoza granic Rzeczpospolitej. Zaliczali się do nich m.in. kierownik Studium, zwierzchnik Polskiego Autokefalicznego Kościoła Prawosławnego biskup Dionizy Waledyński oraz Aleksander Łotocki - pełniący funkcję wicepremiera emigracyjnego rządu Ukraińskiej Republiki Ludowej ${ }^{61}$. W działalność niepodległościową zaangażowany był także inny Ukrainiec pracujący na Uniwersytecie, językoznawca prof. Roman Smal-Stocki. Zatrudnianie na uczelni osób tych narodowości stanowiło element, realizowanej ze zmienną konsekwencją przez władze II Rzeczypospolitej, polityki prometejskiej, a także - gdy mowa o Studium Teologii Prawosławnej - polityki wyznaniowej państwa, zmierzającej do ścisłego związania kościołów wschodnich z Polską. Wynikało również z braku odpowiednich kadr rodzimych.

W połowie lat 30. na stanowiskach lektorów języków nowożytnych pracowało 14, cudzoziemców. Kilku obcokrajowców prowadziło wówczas ponadto wykłady zlecone na Wydziale Humanistycznym (dr Pierre Francastel i Jean Fabre z Francji, dr Arturo Stanghellini i dr Italo Siciliano 


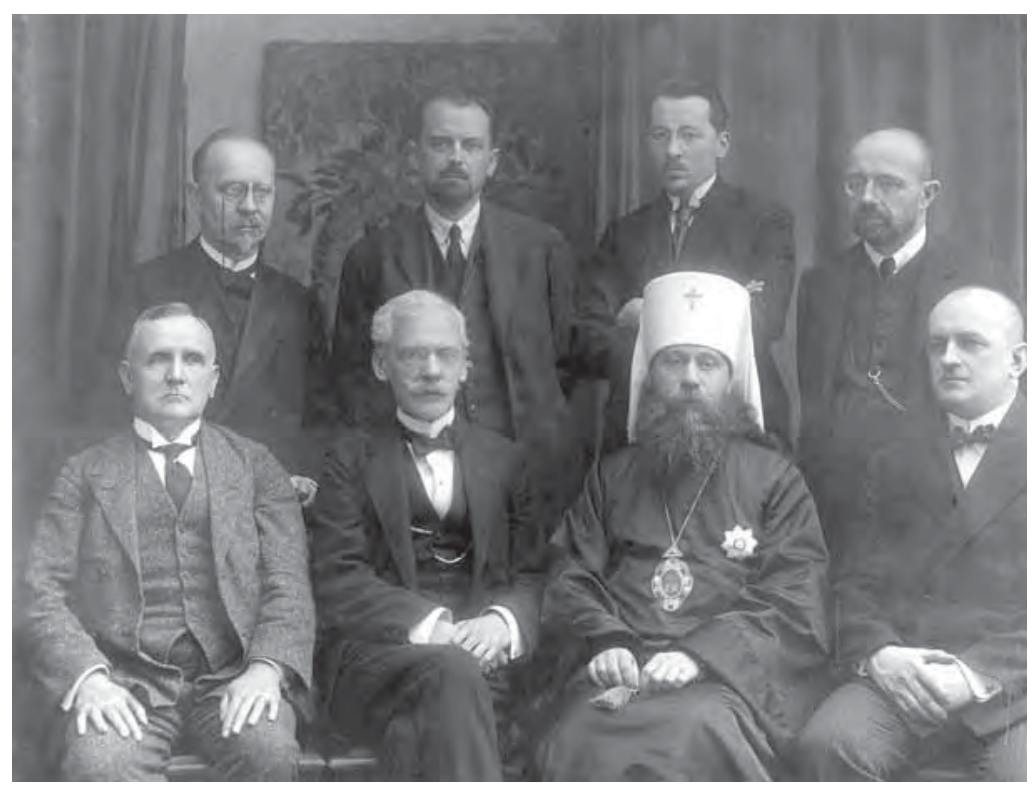

28. Komisja

Organizacyjna

Studium Teologii

Prawosławnej,

1924-1925. Siedzą

od lewej: prof. Ignacy

Koschembahr-

-Łyskowski, rektor

Uniwersytetu

Warszawskiego

prof. Franciszek

Krzyształowicz,

kościelny kurator

Studium Teologii

Prawosławnej

metropolita Kościoła

Prawosławnego

w Polsce Dionizy

Waledyński,

prof. Eugeniusz

Jarra. Stoją od

lewej: prof. Jan

Porzeziński, prof.

Wacław Makowski,

prof. Franciszek

Czubalski,

prof. Kazimierz

Nitsch

z Włoch oraz spolonizowany Węgier, doc. UW Andorján Divéky). Francuz, prof. Henri Mazeaud wykładał gościnnie na Wydziale Prawa ${ }^{62}$. Większość z nich, jak się wydaje, nie znała biegle polskiego, wykłady prowadzili więc w swych językach ojczystych.

Znacznie trudniej jest ustalić, jaki odsetek wśród kadry naukowo-dydaktycznej Uniwersytetu Warszawskiego stanowili przedstawiciele zamieszkujących II Rzeczpospolitą mniejszości narodowych. Problem polega nie tylko na braku odpowiednich danych, ale również na nieprecyzyjności kryteriów i niejednoznacznym charakterze świadomości narodowej. Wątpliwości wzbudzać musi zwłaszcza przypadek osób pochodzenia żydowskiego, całkowicie zasymilowanych do polskości, uważających się za Polaków w sensie kulturowym i państwowym. Klasyfikując je jako „Żydów”, co chętnie czyniła ówczesna prawica nacjonalistyczna, mimowolnie powielamy jej interpretację, wykluczającą te osoby z polskiej wspólnoty narodowej. Poprzestając na stwierdzeniu, że były one Polakami, pomijamy istotny - choć nie zawsze otwarcie ujawniany element ich tożsamości. Dylematu tego nie da się w sposób jednoznaczny rozstrzygnąć, najbezpieczniej będzie więc przyjąć, iż świadomość narodowa poszczególnych osób, rozpięta pomiędzy polskością a żydowskością, stanowiła w istocie kontinuum bardzo różnych wariantów.

Według paszkwilanckich i ze swej natury wątpliwych nie tylko moralnie wykazów, które rozpowszechniała prasa prawicowa, na stanowiskach 
naukowo-dydaktycznych zatrudnionych miało być na Uniwersytecie w 1937 r. ponad 6 o osób o żydowskich korzeniach, wymienionych z imienia, nazwiska i funkcji, co stanowiło zamierzony element antysemickiej nagonki. Liczba ta była niemal na pewno zawyżona, gdyż kilku wykładowców trafiło na listę ewidentnie z przyczyn politycznych, z dorobionym uzasadnieniem, iż pochodzą z rodzin frankistów, innych zaś wciągnięto na nią ze względu na „źle” brzmiące nazwiska, co później niekiedy prostowano, serdecznie przepraszając ,za mimowolnie wyrządzoną krzywdę"63. W pewnym uproszczeniu można jednak przyjąć, że była to górna granica liczby pracowników naukowych Uniwersytetu pochodzenia żydowskiego.

Nie da się zapewne precyzyjnie określić, na ile osoby te czuły się Polakami, a na ile Żydami. Rzadkością były jednak wśród pracowników Uniwersytetu osoby, które podkreślały swe żydowskie pochodzenie, traktując je jako integralny, a niekiedy wręcz dominujący, element własnej tożsamości. Zaliczali się do nich m.in. prof. Mojżesz Schorr, specjalizujący się w filologii semickiej i dziejach starożytnego Bliskiego Wschodu, doc. Majer Bałaban, zajmujący się dziejami Żydów polskich w epoce nowożytnej, czy też wybitny historyk czasów napoleońskich prof. Askenazy. Zabawną rozmowę z ostatnim z nich, dotyczącą stosunku do własnych korzeni, zapamiętał absolwent Wydziału Humanistycznego Janusz Pajewski: „- Panie, co mi tam Radziwiłł czy Lubomirski - podjął Askenazy z rozbawieniem. - Lubomirski może się wykazać genealogią sięgającą XIII wieku, Radziwiłł i to nie, a ja, panie, przodkami na tysiąc lat przed Chrystusem"64.

Jeszcze większą rzadkość stanowili wśród kadry naukowej Uniwersytetu Ukraińcy. Według ściśle poufnego wykazu, którego w maju 1934 r. zażądało od rektora MWRiOP, pracowało ich wówczas na uczelni 8, w tym 5 w Studium Teologii Prawosławnej, stanowiącym, jak zostało już powiedziane, osobny przypadek jako instrument polityki wschodniej II Rzeczypospolitej ${ }^{65}$. Uwzględniwszy Romana Smal-Stockiego, który również zaliczał się do środowiska emigracyjnego, nietrudno ustalić, iż na uczelni pracowało w istocie tylko 2 Ukraińców, będących obywatelami Polski; wszyscy pozostali pochodzili „zza kordonu”.

Zainteresowanie władz naukowcami pochodzenia ukraińskiego miało związek z narastającymi wśród tej mniejszości tendencjami antypaństwowymi (kilka tygodni później nacjonaliści ukraińscy zamordowali ministra Bronisława Pierackiego) i niewątpliwie nie ułatwiało życia nielicznym Ukraińcom zatrudnionym na Uniwersytecie. Już wcześniej traktowano ich zresztą najczęściej z nieufnością, co doskonale ilustruje argumentacja, jakiej musiał używać prof. Władysław Witwicki 


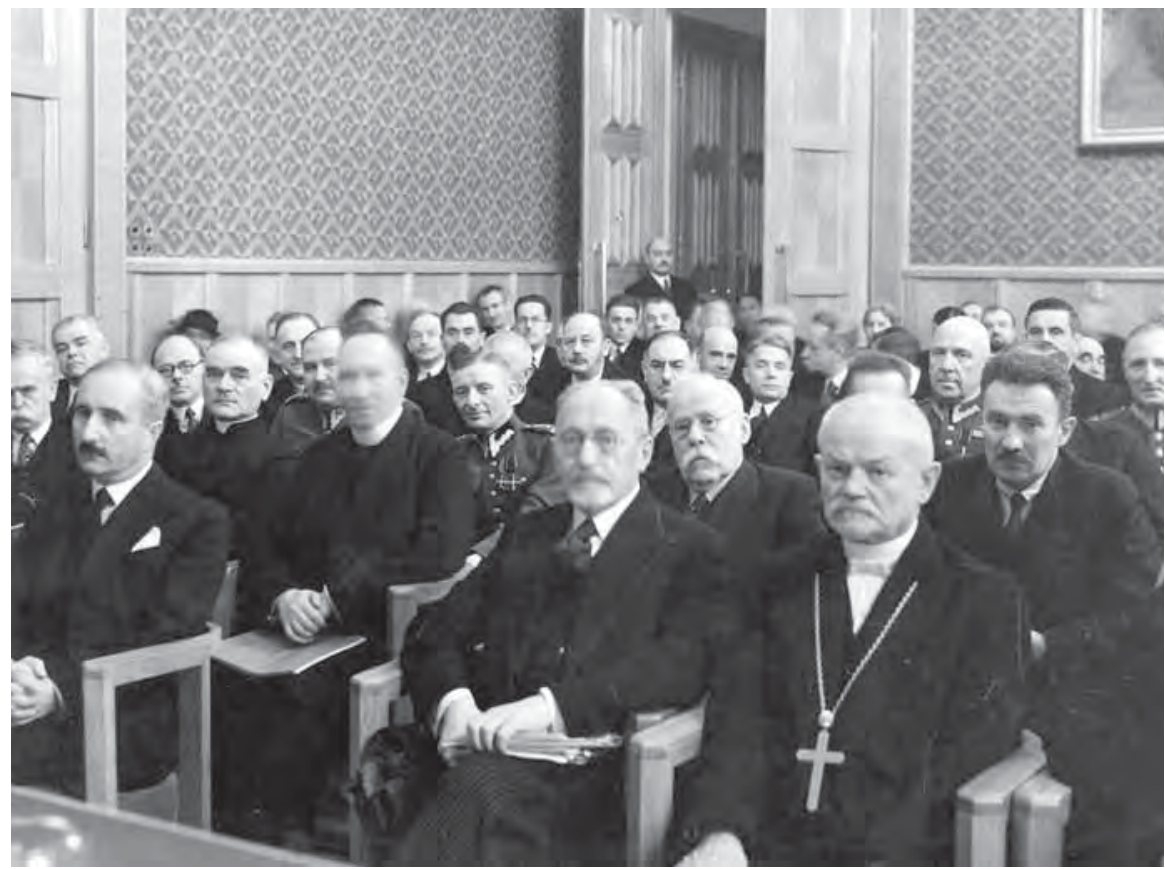

29. Członkowie Państwowej Rady Oświecenia Publicznego, listopad 1936 r. W pierwszym rzędzie pierwszy od lewej prof. Władysław Tatarkiewicz, pierwszy od prawej prof. Juliusz Bursche, prezes Konsystorza Kościoła Ewangelicko-Augsburskiego, w drugim rzędzie, drugi od prawej, prof. Mojżesz Schorr

rekomendując w 1926 r. Stefana Baleya na katedrę psychologii wychowawczej: „Przeciwko niemu mogłoby w czyichś oczach przemawiać pochodzenie z ojca Rusina. - On jest jednak równocześnie synem matki Polki, ochrzczono go po grecku i wychowano w szkołach średnich ruskich - jako uczony pracował nad podniesieniem kultury wśród Rusinów i pomnażał dorobek naukowy polski. Z najlepszymi z pośród Polaków we Lwowie łączą go węzły przyjaźni osobistej i współpracy naukowej. [...] $\mathrm{W}$ jego pracach widać serdeczne wczucie się i zrozumienie naszych poetów, z którymi zżył się od dziecka. Przeciwko polskości nie występował nigdy - zatem z tej strony wszelkie obawy uznać trzeba za płonne [...]"66.

Drugim z zatrudnionych na Uniwersytecie polskich Ukraińców był prof. Miron Korduba. Po bardzo długich wysiłkach zaangażowano go na Wydziale Humanistycznym jako specjalistę z zakresu historii Ukrainy. Przez cały czas znajdował się pod baczną obserwacją władz państwowych - w jego aktach osobowych zachował się donos, że „bynajmniej nie tai swej niechęci do Polski oraz w sposób nader obelżywy wyrażał się o rządzie" ${ }^{67}$. Jak pokazują przykłady obu naukowców, o ile na Uniwersytecie chętnie zatrudniano ukraińskich emigrantów z obszarów 


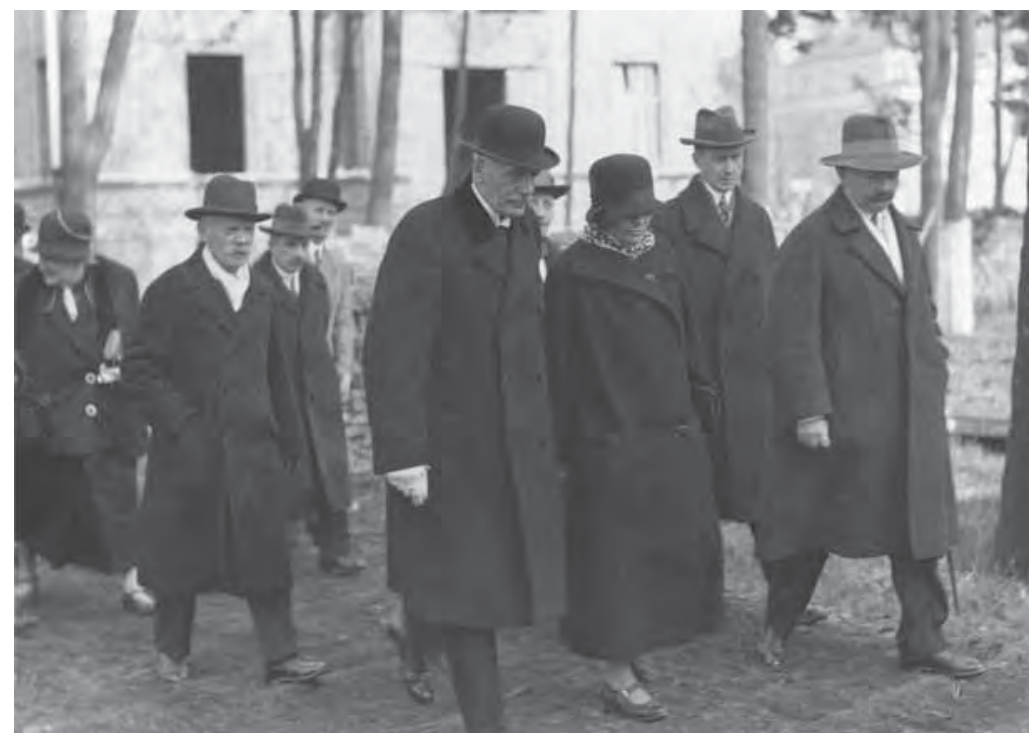

30. Maria

Skłodowska-Curie w towarzystwie prezydenta Ignacego Mościckiego

(czwarty od prawej) i prof. Stefana

Pieńkowskiego (pierwszy od prawej) podczas zwiedzania Instytutu Radowego w Warszawie, $193^{2} \mathrm{r}$

Związku Radzieckiego, o tyle bycie Ukraińcem polskim zdecydowanie nie ułatwiało kariery akademickiej.

Wśród pracowników uczelni znajdowały się także pojedyncze osoby o korzeniach niemieckich. Jak się jednak wydaje, albo identyfikowały się one w pełni z polskością, jak profesor Wydziału Teologii Ewangelickiej, pastor Edmund Bursche (za odrzucenie niemieckiej tożsamości zapłaci w czasie II wojny światowej śmiercią w obozie koncentracyjnym Mauthausen), albo - jak pastor prof. Rudolf Kesselring z tego samego wydziału - zachowując niemiecką świadomość narodową, wyraźnie czuły się związane z polskością w sensie państwowym i kulturowym ${ }^{68}$.

Ogólnie rzecz biorąc, w latach 3o. liczba pracowników naukowych UW wywodzących się z mniejszości narodowych nie przekraczała najpewniej kilkudziesięciu, przy czym przeważały wśród nich osoby w pełni zasymilowane do polskości. W zestawieniu z ponad 600 osobami zatrudnionym wówczas na uczelni pozwala to określić kadrę naukowo-dydaktyczną jako w ogromnej większości etnicznie polską.

Charakterystyka kadry naukowo-dydaktycznej Uniwersytetu Warszawskiego byłaby niepełna bez uwzględnienia struktury płci. Podobnie jak na wszystkich wyższych uczelniach w Polsce, tak i tu kobiety należały do rzadkości. W latach 1915-1939 jedynie 14 kobiet zostało zatrudnionych jako samodzielne pracownice naukowe UW, stanowiły zatem ok. 3\% ogółu tej grupy. Ponadto Marię Skłodowską-Curie mianowano profesorem honorowym, co miało jednak wymiar wyłącznie 
symboliczny, gdyż wielka Polka nie prowadziła tu żadnych badań ani wykładów. Tylko 2 spośród pracujących na Uniwersytecie kobiet uzyskały przed II wojną światową rzeczywiste stopnie profesorskie: Cezaria Jędrzejewiczowa, obejmując w 1934 r. katedrę etnografii polskiej na Wydziale Humanistycznym, i Irena Maternowska, która 3 lata później otrzymała na Wydziale Weterynaryjnym, nie bez sprzeciwów ze strony niektórych profesorów-mężczyzn, katedrę nauki o środkach spożywczych pochodzenia zwierzęcego. (Pierwsza z nich, niezależnie od swych kompetencji, stanowiła przy tym w gruncie rzeczy przypadek szczególny jako żona urzędującego wówczas ministra wyznań religijnych i oświecenia publicznego). Pozostałych 12 pań było docentkami, z czego 8 na Wydziale Humanistycznym, a 4 na Lekarskim. Taka właśnie "geografia" zatrudnienia kobiet na Uniwersytecie stanowiła wypadkową kilku czynników, na które składały się względna otwartość lub mizoginia poszczególnych rad wydziałowych, determinacja i kwalifikacje zawodowe konkretnych badaczek, a także specyfika różnych środowisk naukowych ${ }^{69}$.

Nieco lepiej przedstawiała się pozycja kobiet wśród niższych stopniem pracowników naukowych. Na podstawie Składu Uniwersytetu można ustalić, że pod koniec lat 30. pracowało tam 47 asystentek, co odpowiadało $20 \%$ ogółu osób tego stopnia. (Odsetek ten był więc wyraźnie wyższy niż w grupie docentów i profesorów.) Najwięcej asystentek, bo aż 24, zatrudniał Wydział Lekarski, dalszych 10 Matematyczno-Przyrodniczy, 9 Humanistyczny, 2 Weterynaryjny; po 1 pracowało na prawie i farmacji ${ }^{70}$. Kobiety umocniły zatem swą pozycję na wydziałach, na których były już wcześniej obecne jako studentki, a ponadto - by posłużyć się terminologią militarną - zdobyły przyczółki tam, gdzie wcześniej niepodzielnie panowali mężczyźni. „Niekiedy zastanawiałam się, jakimi oczyma On, przedstawiciel starszego pokolenia, patrzył na swoją asystentkę, młodą emancypantkę (zostałam asystentką mając zaledwie 21 lat)" - wspomina swego promotora Wacława Miszewskiego prawniczka, Zofia Gawrońska-Wasilkowska, pierwsza i jedyna przed II wojną światową kobieta wśród pracowników naukowych Wydziału Prawa, próbując zrozumieć motywy, jakimi kierował się proponując jej asystenturę. „Skoro jednak zaaprobował jako swoją współpracownicę kobietę, i to $\mathrm{w}$ zawodzie, w którym kobiety były jeszcze rara avis, to widocznie pozbawiony był w tym względzie oporów i przesądów, a może nawet z pewną ciekawością wychodził naprzeciw nowym czasom" Najwidoczniej nawet w środowiskach uniwersyteckich konserwatywnie usposobionych względem naukowej pracy kobiet dokonywały się już w latach 30. powolne zmiany. 


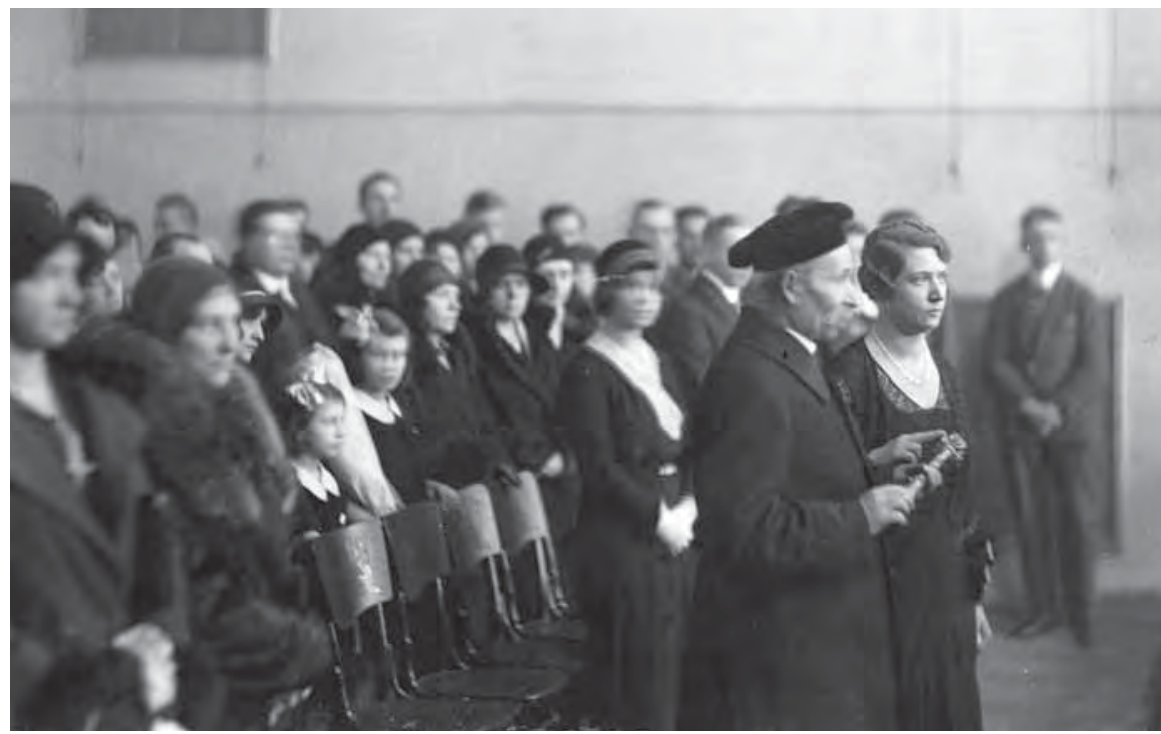

31. Promocja doktorska Flory Wandy Kluczyckiej (pierwsza z prawej) na Wydziale Farmaceutycznym, 6 II $1931 \mathrm{r}$.

Tam, gdzie już wcześniej nastąpiła wyraźna feminizacja studentów, jak na Wydziale Humanistycznym, pozycja kobiet wśród asystentek wyglądała, rzecz jasna, korzystniej, a ich obecność wydawała się już zupełnie oczywista ${ }^{72}$. (Dotyczyło to również lektorów języków obcych, wśród których było 6 pań). W ogólnym rozrachunku kadra naukowa Uniwersytetu aż do wybuchu II wojny światowej pozostawała jednak elitarnym klubem męskim, którego drzwi dopiero lekko uchylały się przed kobietami. Z tego względu do rzadkości należały również pracujące na uczelni małżeństwa. W roku akademickim 1937/1938 par takich naliczyć można było 7, głównie wśród docentów i asystentów tych samych wydziałów. W jednym tylko przypadku - Bolesława i Marii Gutowskich - było to małżeństwo profesorskie, w którym mąż wykładał na Wydziale Weterynaryjnym, a żona w SGGW, prowadząc jednocześnie na Uniwersytecie Warszawskim wykłady zlecone ${ }^{73}$.

Nie istniał wprawdzie żaden przepis ograniczający pracę naukową kobiet, na ich niekorzyść działały jednak stereotypy kulturowe i negatywne nastawienie do ich aktywności zawodowej w ogóle. W 1926 r. w województwie śląskim wprowadzona została tzw. ustawa celibatowa, pozwalająca zwalniać z pracy zamężne nauczycielki (uchylono ją dopiero w 1938 r.), a otrzymywane przez Uniwersytet Warszawski z MWRiOP polecenia, dotyczące sporządzania wykazów zatrudnionych mężatek, nie pozostawiały wątpliwości, że władze 
państwowe rozważały wprowadzenie podobnego rozwiązania również w oświacie wyższej ${ }^{74}$.

Pracę naukową kobiet utrudniała również konieczność godzenia jej z obowiązkami macierzyńskimi, a najczęściej również z dodatkowym zarobkowaniem, bowiem - o czym będzie jeszcze mowa dalej - zarobki asystentki lub docentki na Uniwersytecie z trudem wystarczyłyby na utrzymanie. Nic więc dziwnego, że podejmując decyzję o karierze na uczelni, niektóre kobiety świadomie rezygnowały z posiadania dzieci. Maria Ossowska, jedna z nielicznych przed wojną docentek UW, lojalnie zapowiedziała to swemu mężowi Stanisławowi jeszcze przed ślubem: „Tutaj sytuacje nasze nie są tak bardzo jednakowe. Niedosypianie w nocy, szycie kaftaniczka itp. itp. należą do kobiety. To nie są rzeczy ważne, ale tym gorzej, bo pochłaniają dużo energii i czasu. [...] Nie można pracować jak się źle spało, i ma się głowę ciężką i obolałą od bezsenności. Nie można także dniu przysporzyć godzin, a trudno zmieścić w ramach 24 godzin: pracę zawodową, zarobkową, pracę naukową, momenty wytchnienia. Wszystkie zajęcia kobiece mnożą się wtedy niesłychanie [...]"75.

Pracownicy Uniwersytetu Warszawskiego nie byli środowiskiem społecznie jednorodnym. Wynikało to nie tylko z ich zróżnicowanego

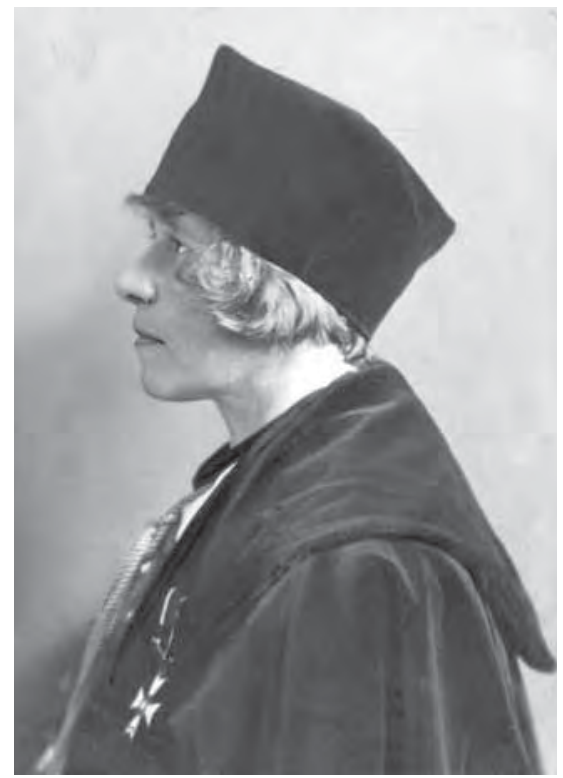

32. Cezaria Baudouin de Courtenay-Jędrzejewiczowa, jeszcze w todze profesorskiej Uniwersytetu Stefana Batorego. W 1934 r. objęła katedrę etnografii polskiej na Wydziale Humanistycznym UW pochodzenia, które zostało już scharakteryzowane wcześniej, ale również z pozycji zajmowanej trwale lub przejściowo w hierarchii akademickiej, która na ogół w dużym stopniu determinowała status materialny poszczególnych osób. Nakładały się na to podziały związane z rodzajem wykonywanej pracy.

Wyraźnie wyodrębnione grupy stanowili przede wszystkim zatrudnieni na uczelni urzędnicy i funkcjonariusze, którzy z natury rzeczy pełnili rolę usługową wobec studentów i pracowników naukowo-dydaktycznych. Kadra urzędnicza była stosunkowo silnie jak na ówczesne warunki sfeminizowana: w roku akademickim 1937/1938 wśród 95 urzędników uniwersyteckich wszystkich szczebli (uwzględniając pracowników BUW) znajdowało się aż $5^{1}$ kobiet (54\%). Wykonywały one głównie prace biurowe, podczas gdy wszystkie stanowiska kierownicze, takie jak kierownik sekretariatu, audytor, kwestor, kierownik rachuby, intendent, wszyscy referendarze 


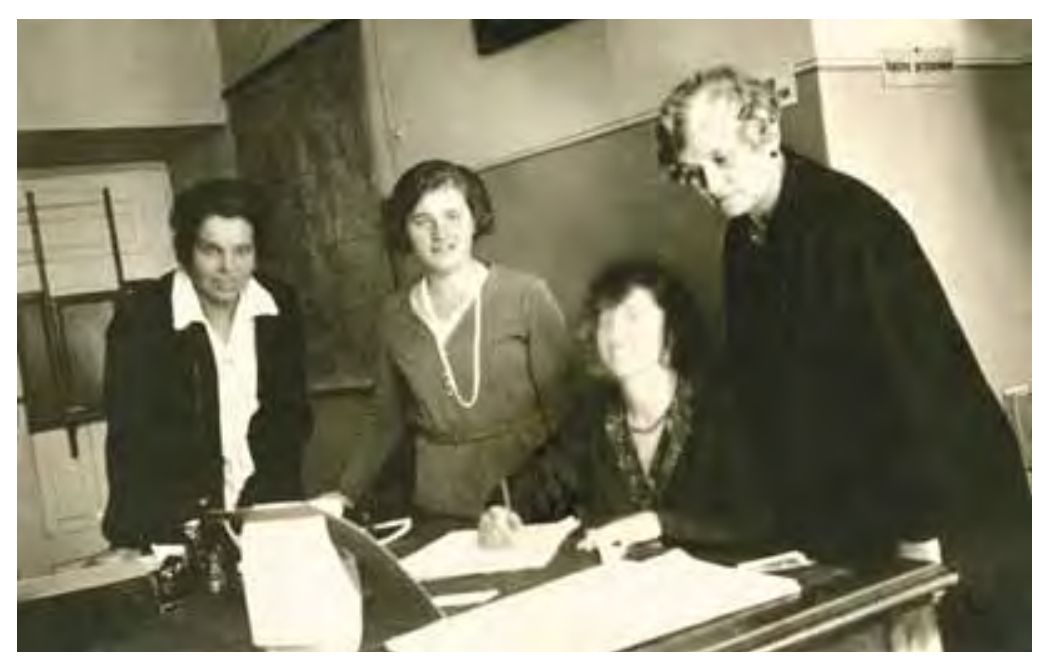

33. Urzędniczki

rektoratu, 1931-1939

i podreferendarze, zajmowali mężczyźni ${ }^{76}$. Pracownicy administracji uczelni skupieni w Kole Urzędników (wyraźnie wzorowanym na podobnych organizacjach studenckich) prowadzili we własnym gronie życie towarzyskie, organizując zabawy taneczne i herbatki, co niekiedy zamiast integracji prowadziło do konfliktów ${ }^{77}$. Mimo iż rektorzy przy okazji inauguracji kolejnych lat akademickich zawsze dziękowali wylewnie urzędnikom za ich pracę na rzecz uczelni ${ }^{78}$, ci czuli się chyba niedoceniani, skoro po ukazaniu się w 1936 r. kroniki Uniwersytetu opracowanej przez Tadeusza Manteuffla, sekretarz Władysław Wayda dość ostro skrytykował go za nieuwzględnienie w publikacji tej grupy i jej zasług ${ }^{79}$.

Bardziej krytycznie niż władze uczelni oceniało zatrudnionych na Uniwersytecie urzędników MWRiOP. W 1930 r. zwróciło ono uwage rektorowi, że tylko połowa $\mathrm{z}$ nich legitymowała się wykształceniem odpowiadającym zajmowanym stanowiskom, a jedynie zupełnie nieliczni złożyli wymagane egzaminy urzędnicze ${ }^{80}$. Nie wiadomo, czy w kolejnych latach problem ten w jakikolwiek sposób rozwiązano. Faktem jest, że na rok przed wybuchem II wojny światowej tylko 4, na 61 urzędników uniwersyteckich (nie licząc pracowników BUW) legitymowało się wykształceniem wyższym ${ }^{81}$.

Zarobki urzędników i funkcjonariuszy uniwersyteckich były regulowane przez państwo i cechowały się znaczną rozpiętością. Pod koniec lat 30. zasadnicze wynagrodzenie kierownika Biblioteki UW, który zajmował na uczelni najwyższą pozycję w urzędniczej hierarchii służbowej, stanowiło 70o zł, dwaj jego zastępcy (starsi bibliotekarze) zarabiali miesięcznie po 450 zł. Pensje kwestora i sekretarza Uniwersytetu 
wynosiły 335 zł. Szeregowi urzędnicy otrzymywali, w zależności od grupy uposażenia, od 130 do 210 zł, niżsi funkcjonariusze najczęściej 100-130 zł $\mathfrak{l}^{82}$. Túz przed wybuchem II wojny światowej pielęgniarka kierująca ambulatorium na Wydziale Lekarskim zarabiała $250 \mathrm{zl}$, sekretarka kliniki $200 \mathrm{zl}$, pielęgniarka instrumentariuszka i technik rentgenolog po 180 zł. Pensja woźnego wynosiła 150 zł, laboranta 8o-10o zł, a szatniarki 60 zł ${ }^{83}$. Najniższe z tych zarobków z wielkim trudem wystarczały na życie, przez co niektórzy z pracowników zmuszeni byli ratować się pożyczkami zaciąganymi u kadry naukowo-dydaktycznej, które później nie zawsze byli w stanie zwrócić. Zadłużenie musiało przybierać dość poważne rozmiary, skoro w 1933 r. rektor Ujejski uznał za stosowne wydać specjalny okólnik kategorycznie zakazujący urzędnikom i funkcjonariuszom zapożyczania się u profesorów, adiunktów i asystentów ${ }^{84}$.

Poza wysokością wynagrodzeń o środowisku urzędników i funkcjonariuszy wiemy dość niewiele, w dokumentach zachowanych w archiwum uniwersyteckim pojawia się ono głównie w kontekście różnych nadużyć i nieprawidłowości, jest to jednak siłą rzeczy obraz skrzywiony i niepełny ${ }^{85}$. Skądinąd wiadomo, że niższy personel uczelni aż do września 1937 r., kiedy MWRiOP wyegzekwowało przestrzeganie prawa pracy, był zmuszany do pracy nawet po kilkanaście godzin dziennie, bez jakichkolwiek dni wolnych ${ }^{86}$. Ze sporadycznych wzmianek w dziennikach Wacława Borowego, który pracował w BUW najpierw jako starszy bibliotekarz, a później jej kierownik, dowiadujemy się natomiast, iż niektórzy profesorowie traktowali personel pomocniczy z wyższością, awanturując się z woźnymi i „babami wypożyczalnianymi”, domagającymi się od nich wypełniania rewersów i oddawania książek w terminie ${ }^{87}$. Choć Borowy odnotowuje takie postawy z wyraźnym zażenowaniem, jego własne wyobcowanie ze świata personelu bibliotecznego i bardzo intensywne kontakty ze środowiskiem naukowym Uniwersytetu potwierdzają pośrednio, iż obie te grupy nie miały ze sobą zbyt wiele wspólnego.

Mimo że zasadnicza linia podziału przebiegała wśród pracowników Uniwersytetu pomiędzy personelem urzędniczym a kadrą naukowo-dydaktyczną, również ta ostatnia stanowiła grupę silnie zróżnicowaną wewnętrznie pod względem materialnym, a co za tym idzie społecznym. Czynnikami różnicującymi były zarówno wysokość zarobków, jak i stabilność zatrudnienia, którą osiągało się de facto dopiero w momencie awansu na stanowisko profesorskie, czyli - jak pamiętamy z poprzedniego rozdziału - najczęściej po 4,o. roku życia. O ile pracownik naukowy nie był niezależny materialnie np. dzięki zamożnej rodzinie, do chwili otrzymania własnej katedry jego kariera upływała pod znakiem 
niepewności, czy uda mu się zdobyć środki do życia. Dotyczyło to nie tylko rozpoczynających dopiero pracę naukową asystentów, ale także docentów, a więc osób posiadających już na ogół rodziny, zwykle w średnim wieku, których w ówczesnym systemie z założenia nie zatrudniano na uczelni na regularnych etatach. Uniwersytet, co także zostało już powiedziane, starał się w miarę możliwości pomagać obu tym grupom, angażując poszczególne osoby jako zastępców profesorów, na stanowiskach pomocniczych, bądź też zlecając im odpłatnie prowadzenie wykładów, ale ogólna kondycja środowiska asystentów i docentów pozostawała mizerna.

$\mathrm{Z}$ takiego stanu rzeczy i jego negatywnych konsekwencji dobrze zdawały sobie sprawę władze Uniwersytetu. Podsumowując rok akademicki 1937/1938 rektor Włodzimierz Antoniewicz mówił: „[...] Niezmiernie doniosłą sprawą jest fatalny przeważnie stan materialny docentów. Zamiast oddawać się pracom naukowym i być rzeczywistą pomocą w pracach pedagogicznych są nasi docenci zmuszeni do żmudnego zdobywania środków utrzymania w sądownictwie i adwokaturze, w wielugodzinnej praktyce lekarskiej, w nauczycielstwie i w robotach przemysłowych. [...] Nie ulega zaś kwestii, że jednym z powodów obecnego już braku docentów w pewnych dyscyplinach jest nędza tych śmiałków, którzy w obecnych ciężkich dla życia codziennego czasach przedkładają możność umiłowanej pracy naukowej nad ułatwione i pokaźne zarobki”. Podobny odpływ „na lepiej uposażone stanowiska państwowe i prywatne, zazwyczaj mające z pracą naukową mało wspólnego" dotykał, zdaniem Antoniewicza, asystentów ${ }^{88}$.

Pod koniec lat zo. młody człowiek podejmujący jako asystent pracę naukową na Uniwersytecie mógł liczyć na pensję rzędu 150 zł - czyli porównywalną z wynagrodzeniem robotnika niewykwalifikowanego. Gdy po kilku latach awansował na stanowisko starszego asystenta, jego uposażenie wzrastało do 210-26o zł, sporadycznie nawet do 300 zł. O ile nie zarobkował równolegle poza uczelnią, to takim poziomem dochodów musiał zadowolić się w większości przypadków co najmniej do habilitacji. Docentura, jak już zostało powiedziane, nie zapewniała sama w sobie stabilizacji materialnej. Nieliczni szczęśliwcy, których po zdobyciu veniam legendi zatrudniono na Uniwersytecie jako zastępców profesorów, otrzymywali uposażenie w wysokości 50\% pensji profesorskiej, czyli ok. 500 zł miesięcznie. Docenci pracujący jako adiunkci zarabiali od 335 do $450 \mathrm{zl}$. Ci, którzy po habilitacji pozostali na etatach asystenckich, uzyskiwali od 260 do $335 \mathrm{zl}$. W obu przypadkach stanowisko i uposażenie były zbyt niskie w stosunku do kwalifikacji, ale pozwalały przetrwać na uczelni do czasu uzyskania 
katedry ${ }^{89}$. Osoby, którym udało się utrzymać w ten sposób etat, mogły uważać się za uprzywilejowane. W połowie lat zo. stanowiły one jednak tylko 30\% środowiska docenckiego ${ }^{90}$.

Tylko część docentów mogła prowadzić na Uniwersytecie prace zlecone. W roku akademickim 1934/1935 szansę taką dostał co czwarty z nich ${ }^{11}$. W tym czasie, według stawek ustalonych przez ministerstwo, za prowadzenie wykładu w wymiarze 1 godziny tygodniowo docent otrzymywał 50 zł miesięcznie, a za 1 godzinę ćwiczeń 35 zł. Wypełniając w ten sposób pełne pensum dydaktyczne zarabiał $320 \mathrm{zl}$. Była to suma prawie czterokrotnie mniejsza niż uposażenie profesorskie i ok. 4.0\% niższa od wynagrodzenia docenta zatrudnionego jako zastępca profesora, choć na obu stanowiskach obowiązywało analogiczne pensum ${ }^{92}$. Nie było przy tym żadnej gwarancji, iż w następnym roku otrzyma się ponownie prowadzenie zajęć.

Największa grupa docentów (w 1935 r. było ich 59 pośród ogółem 161 pracowników tego stopnia) nie miała żadnej możliwości zarobkowania na Uniwersytecie ${ }^{93}$, ale chcąc zachować veniam legendi, musiała nieodpłatnie prowadzić tu wykłady. Było to możliwe dzięki znalezieniu gdzie indziej etatu, dającego się pogodzić z dydaktyką i pracą naukową. Możliwości takie istniały jednak jedynie w niektórych dziedzinach nauki i tylko w niektórych zawodach. Bez większego trudu na uczelni wykładać mógł bowiem duchowny, który miał zapewnione zakwaterowanie, wikt i opierunek w parafii bądź zgromadzeniu zakonnym, adwokat zatrudniony w prywatnej kancelarii, czy też lekarz prowadzący własną praktykę. Mógł sobie na to pozwolić również humanista pracujący w archiwum, bibliotece, szkole średniej lub w muzeum, ale już prawnik decydując się na posadę urzędniczą w administracji państwowej, albo chemik, który otrzymał angaż w przemyśle, mieli niewielkie szanse, aby pracować zarobkowo, a jednocześnie kontynuować wykłady na Uniwersytecie.

W każdym przypadku dodatkowe zajęcia pochłaniały czas i energię, kosztem rozwoju własnego i wypoczynku. Zatrudniony w Bibliotece Uniwersyteckiej i usiłujący godzić to z publicystyką i badaniami naukowymi Wacław Borowy zanotował pesymistycznie na początku 1925 r.: „Coraz dotkliwiej czuję, że przy zarobkowem zajęciu 6-godzinnem tylko jedno «zajęcie dodatkowe» mieć można (ja przynajmniej nigdy więcej nie potrafiłem: albom był dziennikarzem, albo naukowcem, albo redaktorem, albo się uczyłem). Przy mojej gimnastyce i przy lekcjach angielszczyzny - artykułopisarstwo cały już «czas» wypełnia i aż się za jego brzegi przelewa (...)"94. Podobne rozterki przeżywało zapewne wielu innych docentów i asystentów. 
Trudna sytuacja materialna wywoływała zrozumiałą frustrację środowiska docenckiego. $\mathrm{Z}$ jego grona wychodziły postulaty, aby każdy pracownik naukowy uczelni państwowej wraz ze zdobyciem habilitacji automatycznie uzyskiwał etat (4.50 zł) i wszystkie przywileje urzędnika państwowego. Inna propozycja przewidywała, iż docenci zatrudnieni w instytucjach publicznych mogliby korzystać tam ze zwolnienia z połowy obowiązków etatowych, celem prowadzenia wykładów na uczelniach. Niezależnie od tego docenci zabiegali o przyznanie im pierwszeństwa w konkursach na stanowiska państwowe, zniżek na bilety kolejowe, a także zwolnienia ich dzieci z czesnego w państwowych szkołach średnich i wyższych. Za szczególnie palący problem uznawali poprawę warunków mieszkaniowych „nieodpowiadających ani ich stanowisku, ani wymogom pracy badawczej, ani wreszcie warunkom materialnym". W tym celu domagali się prawa przynależności do spółdzielni profesorskich, lub budowy osobnych domów dla docentów, współfinansowanych z opłat studenckich ${ }^{95}$.

Rejestr tych postulatów dokumentuje najważniejsze bolączki, z jakimi musieli zmagać się na co dzień pracownicy naukowi Uniwersytetu Warszawskiego przed i po uzyskaniu habilitacji. Do wybuchu II wojny światowej ich sytuacja nie uległa istotniejszej poprawie. Należy przy tym podkreślić, że w drugiej połowie lat zo. i tak była ona wyraźnie lepsza niż wcześniej - w czasach powszechnej pauperyzacji po I wojnie światowej, a następnie w latach wielkiego kryzysu gospodarczego. Położenie docentów, a także asystentów UW w tamtym okresie charakteryzowano jako wprost opłakane ${ }^{96}$.

Przesadą byłoby jednak stwierdzenie, że wszystkim docentom powodziło się źle. Uznany warszawski lekarz Zdzisław A. Michalski (leczył m.in. prezydenta Mościckiego i jego żonę) żył po habilitacji na bardzo wysokiej stopie: obracał się w kręgach polityków i ziemian, uprawiał żeglarstwo, urządzał rajdy motocyklowe, był w stanie od ręki pożyczyć większą sumę pieniędzy działaczom ONR „Falanga” bez pewności, że ją kiedykolwiek odzyska. Mógł sobie oczywiście na to wszystko pozwolić nie z pensji uniwersyteckiej, ale dzięki prowadzonej równolegle praktyce prywatnej ${ }^{97}$. Wykładający na Wydziale Humanistycznym i zatrudniony na posadzie państwowej w Archiwum Oświecenia Publicznego doc. Tadeusz Manteuffel prowadził życie skromniejsze, ale stać go było na zakup w 1934, r. używanego samochodu chevrolet, podróże rekreacyjne po Polsce, a okazjonalnie nawet na wakacje w Szwajcarii. Jego sytuację materialną ustabilizowało jednak wydatnie małżeństwo z córką znanego warszawskiego architekta Jana Heuricha. Wniosła ona do wspólnego gospodarstwa nie tylko mieszkanie, ale także jedną 


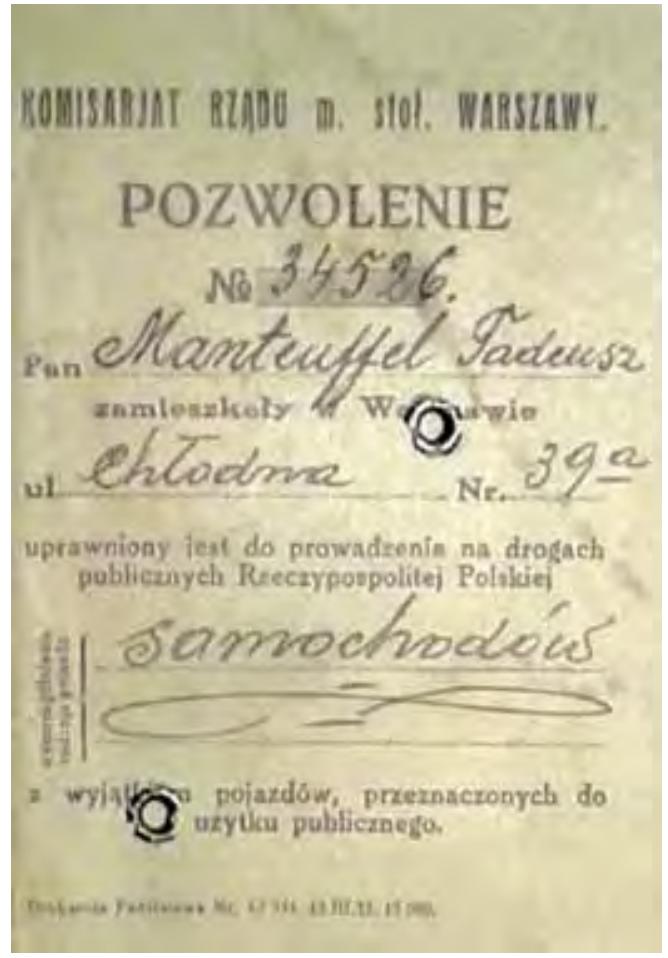

34. Prawo jazdy doc. Tadeusza Manteuffla czwartą czynszów z należącej do jej rodziny kamienicy przy ul. Chłodnej oraz odsetki od pokaźnych depozytów bankowych. W 1937 r. ze źródeł tych Manteufflowie uzyskali 11.04.0 zł, podczas gdy z honorariów autorskich i kursów pan domu zarobił $3286 \mathrm{z}$. Zachowane zeznanie podatkowe, z którego pochodzą powyższe dane, nie uwzględnia zarobków doc. Manteuffla w archiwum, ale z całą pewnością miesięczny budżet jego rodziny oscylował wokół 1000 zł, był więc, jak na ówczesne realia, wysoki ${ }^{98}$.

Tym uczonym, którzy nie mieli zaplecza w postaci bogatej rodziny, pełną stabilizację materialną zapewniała dopiero profesura, choć i to na dobre dopiero od połowy lat 20., gdy ustabilizowana została sytuacja gospodarcza państwa. W poprzedniej dekadzie pewna część profesorów z trudem wiązała ponoć koniec z końcem, na co wpływ miały drożyzna i pożerająca zarobki hiperinflacja. W szczególnie trudnym położeniu znajdowały się osoby zmuszone przeprowadzić się do Warszawy z innych miast, gdyż często nie było ich tu stać na zakup ani wynajem mieszkania. Przez cały właściwie okres międzywojenny sytuacja mieszkaniowa w stolicy była bowiem ciężka, a co istotniejsze, gorsza niż w pozostałych ośrodkach akademickich. Jeszcze w 1929 r. tytułem tzw. odstępnego za dwuizbowe mieszkanie na peryferiach stolicy trzeba było zapłacić 2 tys. zł, natomiast za lokal czteropokojowy w Śródmieściu niekiedy nawet 20 tys. zł. (Komorne w pierwszym przypadku wynosiło później 6o zł, w drugim zaś $150 \mathrm{z} 1)^{99}$. Wysokie ceny nieruchomości w stolicy skutecznie zniechęcały część ludzi nauki z innych miast do podejmowania pracy na Uniwersytecie Warszawskim. W roku akademickim 1923/1924, ok. $5^{\circ}$ profesorów czekało na mieszkanie, „przebywając na razie w ciasnych mieszkaniach prowizorycznych lub dojeżdżając do Warszawy", a niektóre katedry nie mogły zostać uruchomione właśnie z tego względu ${ }^{100}$.

Jeszcze na początku lat 30. rektor Mieczysław Michałowicz kreślił ponury obraz kondycji życiowej stanu profesorskiego: „Co to jest profesor? 
Jest to w obecnych warunkach polskich najczęściej ów niepraktyczny oryginał, który mniej więcej do 4.5 roku życia głodował nad książkami, zaś w 45 roku życia został profesorem, by głodować dalej. Taki profesor nie ma środków, by kupić sobie mieszkanie i jak dotychczas mieszkał $\mathrm{w}$ jednym pokoju umeblowanym z całą rodziną, w składziku przy gabinecie naukowym, w trupiarni, jak się dało"101. Przypadki takie zapewne rzeczywiście zdarzały się, uogólnienie było, jak się jednak wydaje, nazbyt pesymistyczne. Tylko nieliczni profesorowie musieli zmagać się z aż tak poważnymi problemami bytowymi, nietrudno jednak ze słów Michałowicza wywnioskować, że dla pomyślnego przebiegu kariery naukowej i ogólnej jakości życia - co najmniej do uzyskania katedry uniwersyteckiej - znaczenie miało posiadanie własnego mieszkania w Warszawie lub środków pozwalających na jego zakup.

Niezależnie od zróżnicowanej sytuacji materialnej poszczególnych osób, zarobki profesorskie, co najmniej od czasu reformy monetarnej Grabskiego, która położyła kres hiperinflacji, należały do najlepszych w sferze budżetowej. Profesor nadzwyczajny zaszeregowany był do V, zwyczajny zaś do VI grupy uposażenia urzędników państwowych. Pod koniec lat 30. pierwszy z nich otrzymywał $700 \mathrm{zl}$, a drugi $1000 \mathrm{zl}$ wynagrodzenia zasadniczego, czyli tyle samo co, odpowiednio, pułkownik i generał brygady Wojska Polskiego. Dodatek funkcyjny z tytułu pełnienia godności rektora wynosił 500 zł miesięcznie. Prorektorzy otrzymywali z racji swej funkcji po $300 \mathrm{z}$, a dziekani po $250 \mathrm{zl}$. Z przypadkowo zachowanego dokumentu dotyczącego jednego z profesorów zwyczajnych Wydziału Humanistycznego wynika, że w 1936 r. jego pensja łącznie z dodatkiem służbowym wynosiła $1210 \mathrm{z}$. Po odliczeniu 15 zł na obowiązkowo subskrybowaną przez wszystkich urzędników państwowych pożyczkę inwestycyjną i potrąceniu 205,70 zł podatku dochodowego otrzymywał on „na rękę" $989,30 \mathrm{zl}^{102}$.

Nie wszyscy profesorowie żyli przy tym wyłącznie z "gołej” pensji uniwersyteckiej. Choć ustawa zakazywała im zasadniczo wykonywania zajęcia ubocznego połączonego ze stałym wynagrodzeniem, czyli, jak byśmy dziś powiedzieli, zarobkowania na drugim etacie, minister wyznań religijnych i oświecenia publicznego w trybie indywidualnym, na wniosek rady wydziałowej zatwierdzony przez senat akademicki, mógł wyrazić na to zgodę w drodze wyjątku. Pozwolenie takie udzielane było na ściśle określony czas i wymagało każdorazowego odnawiania, choć niektórzy wykładowcy nie dopełniali tego obowiązku ${ }^{103}$. Z przywileju pracy dodatkowej korzystała część profesorów UW podejmując wykłady zlecone na innych uczelniach, np. w Szkole Głównej Handlowej lub w Wolnej Wszechnicy Polskiej ${ }^{104}$. Szczególny przypadek stanowili 
medycy, którzy mogli bez ograniczeń prowadzić prywatną praktykę, stanowiącą na ogół główne źródło ich dochodu. Znany profesor, cieszący się dobrą renomą i mający zamożną klientelę, zarabiał często miesięcznie nawet 2000 zł, a zdarzali się wybitni specjaliści, których dochody dochodziły do 10 tys. $\mathrm{z}^{105}$.

Pewne dochody przynosiła także praca naukowa i popularyzatorska, były one jednak siłą rzeczy mało regularne. Honorarium autorskie anglisty, prof. Andrzeja Tretiaka za biografię Byrona wydaną przez Państwowe Wydawnictwa Książek Szkolnych wyniosło w 1934 r. 1000 zł. Ten sam uczony za hasło „Wielka Brytania” do Encyklopedii Świat i Życie otrzymał 2 lata później 300 zł. Jego umowa na przetłumaczenie $\mathrm{z}$ angielskiego na polski książki poświęconej postaci Piusa XI wynosiła 4,4 zł za arkusz druku ${ }^{106}$. W porównaniu z dodatkowymi dochodami lekarza czy posiadającego kamienicę rentiera nie były to więc kokosy.

Dodatkowe zarobki zapewniały profesorom także różne dodatkowe czynności na Uniwersytecie. Egzaminatorzy pobierali część opłat wnoszonych przez studentów za egzaminy; odpowiednią gratyfikację wypłacano także członkom komisji kwalifikacyjnych na wydziałach, gdzie obowiązywały egzaminy wstępne. Przy dużej liczbie zdających dawało to całkiem pokaźne sumy. Przykładowo, podczas egzaminów wstępnych na Wydział Lekarski każdy z trzech egzaminatorów otrzymywał w 1927 r. po 5 zł od przepytywanego kandydata, co przy blisko 4,00 chętnych zapewniało wynagrodzenie w wysokości prawie $2000 \mathrm{z}^{107}$. Jeszcze wyższe kwoty wchodziły w grę w przypadku egzaminów w regularnym toku studiów na tych kierunkach, gdzie, jak na prawie, podchodziło do nich wielu studentów. W drugiej połowie lat 20. do kieszeni profesora wpływało tam 6 zł od każdego zdającego, co w zależności od roku studiów i charakteru egzaminu dawało mu łącznie od 24,00 do nawet 7000 zł. Podwójna opłata obowiązywała za poprawki ${ }^{108}$. Dziesięć lat później stawki za egzaminy, których wysokość uregulowało w międzyczasie MWRiOP, wahały się, w zależności od przedmiotu, od 4 do $9 \mathrm{z}^{109}$. System ten rodził nieco dwuznaczną sytuację, w której egzaminatorzy byli tym lepiej wynagradzani, im więcej „oblewali” studentów. Jak wspomina jeden z ówczesnych słuchaczy, „kursowała wśród studentów plotka, że gdy prof. Jarra jedzie na wakacje do Włoch, to «robi» 500 poprawek, a gdy do Jugosławii - to wystarcza mu tylko 4,00"110.

Z opłatami pobieranymi od studentów związana jest bodaj najgłośniejsza afera uniwersytecka okresu międzywojennego, prawdziwa cause célèbre uczelni, której warto poświęcić dłuższą dygresję, poniewȧ mówi ona sporo zarówno o stosunku profesury do spraw finansowych, 
jak i o relacjach panujących w jej gronie. Wywołało ją zorganizowanie przez prof. Zygmunta Cybichowskiego w maju 1933 r. dodatkowego, dobrowolnego kolokwium z wykładanych przez siebie na Wydziale Prawa przedmiotów, za udział w którym studenci musieli uiścić 10 zł „opłat seminaryjnych". Zgodnie z relacją jednego z nich, „chętnych było mnóstwo", czemu trudno się dziwić, gdyż kolokwium stanowiło w istocie dodatkowy „zerowy” termin egzaminu, a więc zwiększało szanse zaliczenia przedmiotu. Gdy już około połowa zainteresowanych skorzystała z oferty Cybichowskiego, kolokwium zostało decyzją władz wydziałowych wstrzymane, a przeciwko jego organizatorowi wszczęto postępowanie dyscyplinarne, pod zarzutem, że pobieranie od studentów dodatkowych opłat miało charakter bezprawny i mogło spowodować stronniczość egzaminatora. Przeciw Cybichowskiemu wystąpił uniwersytecki rzecznik dyscyplinarny, prof. Karol Lutostański, prywatnie jego kolega z wydziału ${ }^{111}$.

Cybichowski najpierw sam domagał się wytoczenia sobie postępowania dyscyplinarnego, później jednak zmienił zdanie i, wykorzystując swe doświadczenie prawnicze, odwoływał się od decyzji Rady Wydziału, a następnie senatu uniwersyteckiego, który zawiesił go w prawach profesora $^{112}$. W międzyczasie zwrócił studentom pobrane opłaty. Sprawa oparła się wkrótce o MWRiOP, które jej rozstrzygnięcie, dla zachowania bezstronności, przekazało Komisji Dyscyplinarnej dla Profesorów SGGW. Ciało to uznało wprawdzie, iż postępowanie Cybichowskiego uwłaczało godności profesora, lecz biorąc pod uwagę jego wcześniejszą pracę, w czerwcu 1935 r. rekomendowało ograniczenie się do udzielenia mu nagany ${ }^{113}$. Gdy Senat UW odrzucił tę sugestię i podtrzymał decyzję o zawieszeniu, Cybichowski zgłosił wobec niej sprzeciw, a jednocześnie w prywatnych listach poinformował o swej sprawie ministra, przypochlebnie powołując się na swą wierność zmarłemu właśnie wówczas marszałkowi Piłsudskiemu i inne zasługi dla obozu rządzącego ${ }^{114}$. W efekcie ministerstwo w kwietniu 1936 r. uchyliło uchwałę Senatu, Uniwersytet przewlekał jednak sprawę, oficjalnie informując o tej decyzji zainteresowanego dopiero rok później i to na wyraźne polecenie ministra ${ }^{115}$. Jednocześnie na uczelni wszczęto przeciw Cybichowskiemu nowe postępowanie dyscyplinarne, tym razem o oszczerstwa i obrazę, a MWRiOP - najwyraźniej chcąc zakończyć wielomiesięczny konflikt - przeniosło skłóconego z Uniwersytetem profesora w stan spoczynku, zwijając jego katedrę i powołując na jej miejsce inną. W myśl swej dotychczasowej strategii Cybichowski zaskarżył i tę decyzję, tym razem do Naczelnego Trybunału Administracyjnego, lecz choć przyznano mu tam rację, nie zdołał już powrócić do pracy akademickiej ${ }^{116}$. 
Wlokąca się przez z górą 4 lata sprawa Cybichowskiego ukazuje, że nawet stosunkowo błaha kwestia mogła urosnąć na Uniwersytecie do rangi wielkiej afery, gdy w grę wchodziły drażliwe sprawy finansowe. Miało to niewątpliwy związek z zakorzenioną w inteligenckim etosie etyką środowiskową, potępiającą czerpanie korzyści materialnych z nauczania i działalności naukowej. Praktyka niekoniecznie szła z nią jednak w parze, a pieniądze liczono niekiedy bardzo skrupulatnie, o czym świadczyć może nie tylko sam czyn Cybichowskiego, ale również jego późniejsze skargi do min. Wacława Jędrzejewicza. Zawieszony w prawach wykładowcy profesor utyskiwał w nich bowiem na dotkliwość kary, jaką stanowiła dla niego utrata ponad 8 tys. zł z tytułu opłat egzaminacyjnych w ciągu 17 miesięcy zawieszenia w prawach profesora, a swemu oskarżycielowi, prof. Lutostańskiemu, przypisywał przy tym - słusznie czy niesłusznie - zamiar przechwycenia tego dochodu ${ }^{117}$.

$\mathrm{Z}$ potępieniem ze strony środowiska spotkał się również profesor Wydziału Lekarskiego Edward Loth, który w 1934, r. rozesłał do lekarzy w Warszawie i Ciechocinku pismo zachęcające do przepisywania chorym wkładek ortopedycznych jednej z firm, obiecując po $3 \mathrm{zl}$ od każdego skierowanego do siebie pacjenta. Istotą zarzutów było w tym przypadku występowanie przez profesora w roli przedstawiciela handlowego prywatnego przedsiębiorstwa. Uniwersytecka Komisja Dyscyplinarna ukarała go wprawdzie tylko upomnieniem za to, że „wszedł w kolizję z obowiązującą w Polsce etyką lekarską, a przez to obniżył powagę swego stanowiska profesorskiego", lecz jak skomentował to je-

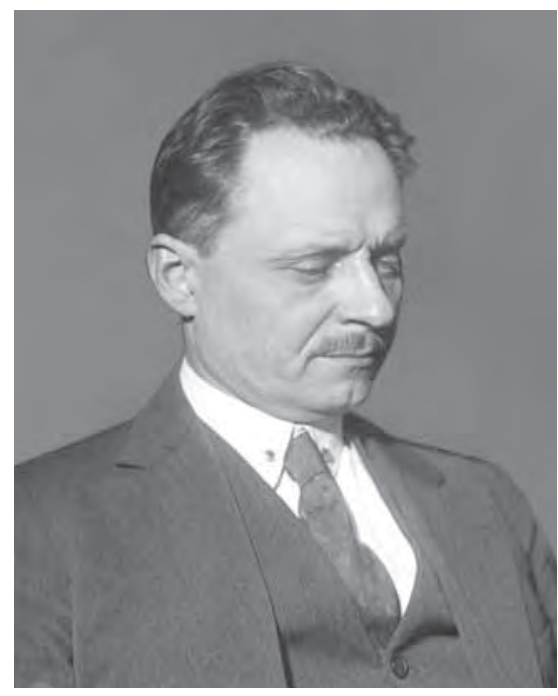

35. Profesor Edward Loth den z jego młodszych kolegów, incydent ten „pozbawił go zupełnie wpływów na wydziale"118. Sprawa Lotha dowodzi, że na Uniwersytecie za nieetyczne uważano podejmowanie przez profesorów prac mających wyraźnie komercyjny, interesowny charakter, a tym samym godzących w wizerunek uczelni jako świątyni nauki.

Zamykając nawias dygresji o sporadycznych, bądź co bądź, nieprawidłowościach związanych z dodatkowym zarobkowaniem, stwierdzić należy, iż niezwykle trudno byłoby dzisiaj oszacować przeciętny dochód uzyskiwany przez profesorów Uniwersytetu ze źródeł innych niż uposażenie zasadnicze. Niewątpliwie jednak już sam etat profesorski gwarantował w ówczesnych realiach 
stabilizację finansową i większości osób zapewniał pod względem materialnym awans do wyższej klasy średniej. Sytuacje, gdy pensja uniwersytecka nie wystarczała profesorowi na godziwe życie, dotyczyły, jak się wydaje, głównie osób, które nie dysponując własnym mieszkaniem musiały je wynajmować, a przy tym posiadały liczną rodzinę, albo spadały na nie dodatkowe wydatki. $\mathrm{Z}$ trudnościami takimi np. zmagał się prof. Korduba, który do Warszawy przeprowadził się ze Lwowa bez rodziny i musiał utrzymywać dwa domy. Najwyraźniej nie posiadając żadnych oszczędności, gdy jego córka wychodziła za mąż, zmuszony był zabiegać w ministerstwie o pożyczkę na posag dla niej ${ }^{119}$. Z kolei niektórzy renomowani lekarze czy prawnicy, osiągając wysokie dochody dodatkowe, zaliczali się niewątpliwie do elity finansowej ówczesnej Polski i, podobnie jak cytowany już przeze mnie doc. Michalski, utrzymywanie się wyłącznie z uposażenia profesorskiego uważali zapewne za „klepanie biedy”.

Dobra sytuacja materialna profesorów przekładała się, rzecz jasna, na poziom i styl ich życia, choć zapewne pomiędzy poszczególnymi osobami musiały występować spore różnice, wynikające z odmiennego pochodzenia społecznego, uwarunkowań rodzinnych czy cech charakteru. Ze wspomnień Władysława i Teresy Tatarkiewiczów np. wyłania się obraz życia charakterystycznego dla ówczesnej elity społecznej kraju: utrzymywali oni żywe kontakty towarzyskie z przedstawicielami korpusu dyplomatycznego, bywali na eleganckich balach i rautach, a także sami wydawali w swoim reprezentacyjnym mieszkaniu przyjęcia, na które niekiedy zapraszali nawet do 100 osób. Letnie miesiące spędzali w rodzinnym dworze na Podlasiu, często także wspólnie podróżowali po świecie przy okazji służbowych wyjazdów profesora. W wielu takich długich podróżach, m.in. po Włoszech, Ameryce Południowej czy Jugosławii byli gośćmi rezydujących tam, zaprzyjaźnionych polskich dyplomatów. Nie trzeba dodawać, że w prowadzeniu domu Teresie Tatarkiewiczowej na co dzień pomagała służąca, gdyż w tamtejszych realiach było to standardem właściwie we wszystkich rodzinach inteligenckich ${ }^{120}$. (Jako przykład ze środowiska uniwersyteckiego posłużyć mogą pod tym względem dość skromnie żyjący Ossowscy albo średnio zamożny Borowy) ${ }^{121}$.

Na stosunkowo wysokiej stopie żyło też wielu innych profesorów Uniwersytetu. Rektor Antoniewicz oprócz mieszkania w Warszawie posiadał dom letni w Milanówku, dysponował także prywatnym samochodem (swej pasji motoryzacyjnej o mało nie przypłacił życiem, powodując w 1938 r., w czasie jednej z podróży po Polsce, wypadek) ${ }^{122}$. Profesor Oskar Halecki spędzał rokrocznie wraz z żoną urlop we Szwajcarii, 
bo - jak pisze jego uczeń - „kraj ten oboje bardzo lubili”123. Z kolei Marceli Handelsman wyjeżdżał z rodziną na wakacje do Biarritz we Francji ${ }^{124}$. Mogli sobie na to pozwolić, mimo że podróże zagraniczne, zwłaszcza rodzinne, były wtedy relatywnie dużo kosztowniejsze niż obecnie, chociażby ze względów na wysokie opłaty paszportowe. (W 1938 r. dwutygodniowe wczasy w Bułgarii dla jednej osoby wraz z tygodniową podróżą w obie strony, zorganizowane przez „Rodzinę Urzędniczą”, a więc w standardzie „budżetowym”, kosztowały dyrektora BUW Wacława Borowego w sumie 573 zl) ${ }^{125}$.

Jak już zostało kilkakrotnie powiedziane, kondycja materialna pracowników uczelni miała ścisły związek z ich sytuacją mieszkaniową. $\mathrm{Na}$ krótko przed wybuchem II wojny światowej wynajęcie w dobrej części Śródmieścia 2 pokoi z kuchnią kosztowało ok. 100-120 zł miesięcznie. Na Mokotowie, Ochocie, Żoliborzu lub na bliskiej Pradze za 120-14,0 zł można już było wynająć trzypokojowe mieszkanie z kuchnią i łazienką. Za 4 pokoje, w zależności od dzielnicy, powierzchni i standardu, należało zapłacić ponad 200 zł. Dochodziło do tego komorne, które w lewobrzeżnej części miasta wynosiło średnio od 18 zł za mieszkanie jednoizbowe w starym budownictwie, po prawie $90 \mathrm{zl}$ za trzyizbowe w budynkach nowoczesnych. (Na Pradze opłaty te były proporcjonalnie niższe). Zakup własnego dwupokojowego mieszkania spółdzielczego na Żoliborzu stanowił wydatek rzędu 12 tys. zł. Za sześciopokojową willę w tej samej części miasta żądano 26 tys. zł gotówką ${ }^{126}$.

Chociaż w zestawieniu z uposażeniami profesorskimi przedwojenne ceny mieszkań mogą wydawać się relatywnie dużo korzystniejsze niż obecnie (zakup willi na Żoliborzu stanowił równowartość tylko 2 pensji rocznych!), dla niższych stopniem pracowników naukowych, którzy w ogromnej większości przypadków musieli utrzymywać rodzinę $\mathrm{z}$ jednej pensji, nie były one już tak przystępne. Za okazyjnie oferowane „dwuipółpokojowe” mieszkanie z kuchnią, łazienką i piwnicą w budynku Zakładu Ubezpieczeń Społecznych przy ul. Sułkowskiego na Żoliborzu matematyk doc. Alfred Tarski musiał wyłożyć od ręki 3500 zl, a resztę spłacać w długoterminowych ratach. Nie dysponował jednak żadnymi oszczędnościami i transakcję udało mu się sfinalizować jedynie dzięki prywatnej pożyczce ${ }^{127}$.

Należy przypuszczać, że w podobnej sytuacji znajdowało się również wielu innych uczonych, dlatego część z nich ubiegała się o mieszkanie w domach wybudowanych przez Stowarzyszenie Mieszkaniowe Spółdzielcze Profesorów Uniwersytetu Warszawskiego. Czynsze wahały się tam, w zależności od metrażu, od 57 do 225 zł; średnia opłata wynosiła 134 zł. Do spółdzielni tej mogli należeć jednak (przynajmniej w teorii) 


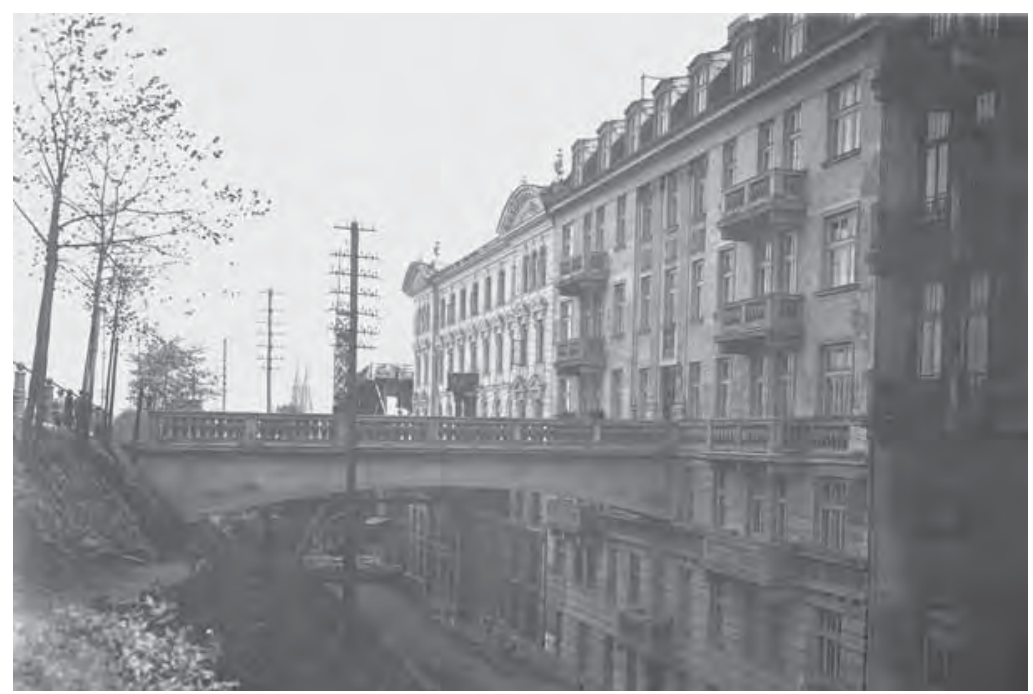

36. Nieistniejący już

dom profesorski

przy ul. Nowy Zjazd 5

wyłącznie profesorowie, a liczba lokali była ograniczona, więc niektórzy członkowie spółdzielni latami oczekiwali na przydział lokalu ${ }^{128}$. Powyższe realia rzutowały niewątpliwie na to, gdzie i jak mieszkano, z drugiej strony wybór miejsca zamieszkania świadczył zazwyczaj również o aspiracjach i statusie społecznym poszczególnych osób.

W roku akademickim 1937/1938 spośród 162 profesorów figurujących w Składzie Uniwersytetu aż 6o mieszkało w Śródmieściu, głównie w jego reprezentacyjnych rejonach. Popularnymi ulicami były zwłaszcza Koszykowa, Marszałkowska i Mokotowska. (Prestiżowymi adresami, takimi jak al. Róż, ul. Szopena czy Lekarska, szczyciło się zwłaszcza wielu medyków). Kolejnych 11 wykładowców zajmowało lokale w budynkach Uniwersytetu na głównym kampusie i w innych częściach miasta, a $50 \mathrm{w}$ domach spółdzielni profesorskiej przy ul. Brzozowej 10 i 12, Nowym Zjeździe 5 i Sewerynów 6 . Największy odsetek w obu tych grupach stanowili humaniści i przedstawiciele nauk matematyczno-przyrodniczych, co pośrednio wskazuje na ich relatywnie gorsze położenie materialne niż np. lekarzy, którzy najwyraźniej łatwiej mogli zakupić bądź wynająć odpowiednie mieszkanie na wolnym rynku. Zdecydowanie mniej profesorów UW mieszkało w dzielnicach sąsiadujących ze Śródmieściem: 7 na bliskim Mokotowie, 5 na Ochocie w okolicach pl. Narutowicza, 5 na Żoliborzu $\mathrm{w}$ rejonie pl. Wilsona oraz pl. Inwalidów i 8 na Pradze. Tylko pojedyncze osoby mieszkały w okolicach uważanych za gorsze ze względu na ich przekrój społeczny (Powiśle, Stare Miasto, Muranów) lub bardziej odległych od centrum miasta (Sadyba) ${ }^{129}$. 
Nie zawsze zapewne profesorowie mieszkali w dobrych warunkach, bo przecież także w świetnie położonych, reprezentacyjnych kamienicach mogły znajdować się mieszkania gorsze - małe i niedoświetlone, na wysokich kondygnacjach bez windy - czego w ogromnej większości przypadków nie sposób już dziś zweryfikować. Profesor Michałowicz malował tę rzeczywistość w 1931 r. w zdecydowanie czarnych barwach, twierdząc, iż „poza kilku szczęśliwcami, rozporządzającymi kilkoma pokojami - inni mieszczą się w dwóch ciemnych, wilgotnych pokoikach z żoną gruźliczką, inni śpią na kanapie, bo nie ma gdzie wstawić łóżka w owym domu profesorskim itd." ${ }^{130} \mathrm{Nie}$ był to jednak z pewnością reprezentatywny obraz sytuacji mieszkaniowej profesorów UW, o czym świadczyć może krańcowo odmienny standard domu przy ul. Prezydenckiej, do którego na krótko przed wybuchem II wojny światowej przeprowadził się wraz z rodziną Władysław Tatarkiewicz. Jego żona opisuje go następująco:

„Wnętrza willi, w której zamieszkaliśmy później, były nadzwyczaj starannie wykończone [...]. W każdym pokoju były szafy w ścianie: w sypialnym z siwego orzecha kaukaskiego, zajmujące całą ścianę, na podeście schodów były na pierwszym piętrze szafy na futra obite od wewnątrz blachą i kryte jesionowym fornirem. Obok pokój miał szafę, biurko i szafę na odzież - czeczotowe, a na drugim piętrze (gdzie była też druga łazienka), była cała ściana półek bibliotecznych fornirowanych mahoniem. Tam postawiliśmy trzy nasze szafy biblioteczne, też mahoniowe. Na podeście schodów też były półki na książki. Obok był pokój mansardowy Krzysia [syna - P.M.M.], jedyny bez szafy. Na parterze był salonik jadalny z wyjściem na taras i ogródek. Wszystko miało powierzchnię $100 \mathrm{~m}^{2}$. Na dole była też kuchnia i pokoik służbowy oraz trzecie w.c. Pod całą willą były piwnice, jedne ogrzewane, gdzie można by nawet mieszkać, a inne na warzywa i opał. Dom był idealnie wygodny $[. . .]^{\prime \prime 131}$. Na zakup willi Tatarkiewiczowie mogli sobie pozwolić, sprzedawszy niewielką kamienicę czynszową, która wcześniej stanowiła ich dodatkowe źródło dochodu. Oba przedstawione powyżej obrazy należy oczywiście traktować jako przeciwległe bieguny tej samej rzeczywistości społecznej; większość profesorów Uniwersytetu lokowała się pod względem komfortu mieszkania najprawdopodobniej gdzieś pomiędzy nimi.

Na podstawie Składu Uniwersytetu można również odtworzyć, gdzie mieszkali pracownicy naukowi niższych szczebli. Podstawową różnicę w stosunku do profesorów stanowiła w ich przypadku niemożność korzystania z domów spółdzielni przy ul. Brzozowej, Nowym Zjeździe i Sewerynów, choć od tej reguły zdarzały się pojedyncze wyjątki. 
Jeśli chodzi o docentów i zastępców profesorów, największą grupę wśród nich (aż $7^{2}$ osoby) stanowili mieszkańcy Śródmieścia. Relatywnie więcej docentów niż profesorów zamieszkiwało jednak w innych dzielnicach: 15 na Mokotowie, 14 na Żoliborzu, 10 na Ochocie, 6 na Powiślu, 4. w rejonie Starego Miasta, 2 na Muranowie i 1 na Pradze. Należy przypuszczać, że w pierwszych trzech osiedlali się przede wszystkim ci pracownicy uczelni, którym, mimo niepewnego finansowo statusu docenta, udało się jakoś ustabilizować materialnie. Wybór taki wpisywał się w zarysowujący się w latach 30 . trend stopniowego odpływu ludzi zamożniejszych ze Śródmieścia ku peryferiom. Z kolei Powiśle, Stare Miasto, Muranów i Praga, oferując wyraźnie niższe ceny najmu i komornego (przy wyraźnie gorszym na ogół standardzie mieszkania), przyciągały prawdopodobnie osoby gorzej sytuowane, które np. nie miały stałego zatrudnienia na Uniwersytecie i musiały utrzymać się z zajęć zleconych itp. Siedmiu docentów zakwaterowanych było ponadto w lokalach służbowych (przeważnie w budynkach uniwersyteckich), tylu samo w kościelnych, 1 dojeżdżał z okolic Warszawy, a 8 z innych miast ${ }^{132}$.

Wpływ sytuacji materialnej na miejsce zamieszkiwania wyraźnie widać również w grupie asystentów. Najpopularniejszą dzielnicą wśród nich pozostawało wprawdzie Śródmieście, gdzie zamieszkiwała prawie połowa z nich, lecz nie można wykluczyć, że część z osób, które pochodziły w Warszawy, wciąż jeszcze mieszkała tam przy rodzinach. Pozostali asystenci zauważalnie częściej niż docenci wybierali, czy też raczej zmuszeni byli wybierać, dzielnice dalsze lub uważane za gorsze. Na Mokotowie mieszkało 11 z nich, na Ochocie 10, na Żoliborzu 8, na Powiślu 16, na Pradze 17, 5 na Muranowie, 4, w rejonie Starego Miasta, a 1 na Woli. Z okolic podmiejskich dojeżdżało do pracy na uczelni 14, asystentów, a 23 kwaterowało w różnych lokalach służbowych, w warunkach najpewniej dalekich od komfortowych ${ }^{133}$. Jak widać, w grupie tej wyraźnie częściej niż wśród profesorów czy docentów występowały osoby zamieszkujące $\mathrm{w}$ tanich i niecieszących się dobrą opinią dzielnicach, albo w miejscowościach podwarszawskich, o czym zapewne również decydowały w głównej mierze względy finansowe.

Skład Uniwersytetu pozwala też ustalić miejsce zamieszkania pracowników administracji i Biblioteki UW. Kilkoro z nich zajmowało lokale należące do uczelni znajdujące się na terenie głównego kampusu lub mieszkania w domach profesorskich. Były to w większości osoby na stanowiskach kierowniczych, co wskazywałoby, że zakwaterowanie takie mogło stanowić formę bonusu, dostępnego dla tych, którzy znajdując się na co dzień blisko władz rektorskich, potrafili go sobie załatwić. Podobnie jak w przypadku pracowników naukowych, prawie 
Tabela 2. Pracownicy UW wg miejsca zamieszkania w roku akademickim 1937/1938

\begin{tabular}{|c|c|c|c|c|}
\hline $\begin{array}{c}\text { Miejsce } \\
\text { zamieszkania }\end{array}$ & Profesorowie & $\begin{array}{c}\text { Docenci } \\
\text { i zastępcy } \\
\text { profesorów }\end{array}$ & Asystenci & Urzędnicy \\
\hline $\begin{array}{l}\text { Mieszkania } \\
\text { służbowe UW i in. }\end{array}$ & 11 & 13 & 23 & 5 \\
\hline Budynki kościelne & 6 & 7 & 0 & 0 \\
\hline Domy profesorskie & 50 & 3 & 1 & 2 \\
\hline Śródmieście & 61 & 72 & 117 & 43 \\
\hline Mokotów & 7 & 15 & 11 & 0 \\
\hline Ochota & 5 & 10 & 10 & 1 \\
\hline Żoliborz & 5 & 14 & 8 & 3 \\
\hline Muranów & 3 & 2 & 5 & 3 \\
\hline Sadyba, Bielany & 2 & 0 & 0 & 1 \\
\hline Powiśle & 1 & 6 & 16 & 9 \\
\hline Stare Miasto & 0 & 4 & 4 & 8 \\
\hline Praga & 8 & 1 & 17 & 9 \\
\hline Wola & 0 & 0 & 1 & 0 \\
\hline Okolice Warszawy & 1 & 1 & 14 & 10 \\
\hline Inne miasta & 1 & 6 & 0 & 0 \\
\hline Brak danych & 1 & 6 & 10 & 0 \\
\hline Razem & 162 & 158 & 237 & 95 \\
\hline
\end{tabular}

Źródło: Opracowanie własne na podstawie: Skład Uniwersytetu na rok akademicki 1937/1938, Warszawa 1937.

połowa urzędników miała adresy śródmiejskie. Większość osób, jak się jednak wydaje, wybierała nieco mniej reprezentacyjne ulice, takie jak np. Złota czy Hoża. Rzuca się także w oczy, że relatywnie wielu szeregowych pracowników administracji uczelnianej mieszkało na ówczesnych peryferiach miasta i w tzw. gorszych okolicach (9 na Powiślu, 8 w rejonie Starego Miasta, 9 na Pradze), a 10 dojeżdżało do pracy z miejscowości podwarszawskich takich jak Włochy, a nawet Wołomin czy Grodzisk. Miało to niewątpliwy związek z ich nienajlepszą sytuacją materialną. Potwierdzają to także przypadki osób figurujących w Składzie Uniwersytetu pod takim samym adresem, które najpewniej wspólnie wynajmowały mieszkanie ${ }^{134}$.

Porównanie miejsc zamieszkania poszczególnych kategorii pracowników Uniwersytetu Warszawskiego pozwala zaobserwować zależność 
pomiędzy adresem a pozycją w hierarchii akademickiej, która w większości przypadków przekładała się również na zamożność konkretnych osób. O ile zatem profesorowie zamieszkiwali najczęściej w reprezentacyjnych częściach Śródmieścia, docenci wyraźnie częściej niż oni wybierali Mokotów, Ochotę i Żoliborz, natomiast asystenci i pracownicy administracyjni Powiśle, Pragę i okolice Warszawy. Nie była to jednak tendencja bardzo silna, a na decyzje mieszkaniowe dokonywane przez poszczególne osoby mogły mieć wpływ także inne czynniki, takie jak np. odległość od miejsca pracy (stąd np. relatywnie dużo osób zatrudnionych na Wydziale Weterynaryjnym mieszkało na Pradze, a kilku pracowników Wydziału Matematyczno-Przyrodniczego w budynku Obserwatorium Astronomicznego przy Ogrodzie Botanicznym), albo okoliczności pozauniwersyteckie, takie jak otrzymanie mieszkania od rodziny, w posagu lub dzięki pełnieniu funkcji duchownych.

$\mathrm{Na}$ marginesie zauważyć można, że adresy pracowników Uniwersytetu pozwalają zlokalizować rejony miasta szczególnie wśród nich popularne. Zaliczał się do nich przede wszystkim kwartał Śródmieścia od północy zamknięty Al. Jerozolimskimi, od wschodu Nowym Światem, Wiejską i Al. Ujazdowskimi, a od południa i zachodu Polami Mokotowskimi i stacją filtrów na granicy z Ochotą. Atrakcyjność tej okolicy podnosiło sąsiedztwo budynków uniwersyteckich należących do Wydziału Lekarskiego oraz Matematyczno-Przyrodniczego, które stanowiły miejsce pracy części kadry naukowo-dydaktycznej. Były to także tereny tradycyjnie zamieszkiwane przez zamożne warszawskie mieszczaństwo, z którego wywodziła się pewna część pracowników naukowych. W latach 30. nowa dzielnica akademicka wyrosła wokół pl. Narutowicza na Ochocie, gdzie z kolei znajdowały się Domy Studenckie. Młodą inteligencję przyciągał bliski Mokotów, a także domy Warszawskiej Spółdzielni Mieszkaniowej na Żoliborzu, gdzie zamieszkanie miało w wielu przypadkach wymiar ideowy, bowiem skupiały się tam osoby o poglądach lewicowych, np. Maria i Stanisław Ossowscy, Zofia Podkowińska czy Zdzisław Zmidrygier-Konopka. (Ceny mieszkań były tam przystępniejsze, a zapisanie się do spółdzielni wymagało przedstawienia rekomendacji dwóch jej członków, co właściwie wykluczało napływ osób przypadkowych) ${ }^{135}$. Uderzające, że zaledwie jeden pracownik Uniwersytetu mieszkał na robotniczej Woli, a tylko paru na Muranowie, gdzie tradycyjnie przeważała w latach międzywojennych społeczność żydowska. Istniały więc granice, zarówno w wymiarze przestrzennym, jak i społeczno-kulturowym, których wybierając miejsce zamieszkania starano się nie przekraczać, nawet pod presją braku pieniędzy. 


\section{Studenci - liczba i struktura wiekowa}

Uniwersytet Warszawski był największą szkołą wyższą II Rzeczpospolitej pod względem liczby słuchaczy. Po przywróceniu w 1921 r. zajęć, zawieszonych w czasie wojny bolszewickiej, uczyło się tu $75^{18}$ studentów. W kolejnych latach ich liczba wahała się od 814.5 w roku akademickim 1924/1925 do 9933 w roku 1932/1933, na ogół przekraczając 9 tysięcy. Oznacza to, iż studiował tu mniej więcej co piąty polski student. Dla porównania, druga co do wielkości uczelnia, jaką przez większość lat międzywojennych był Uniwersytet Jagielloński, liczyła w szczytowym okresie 7653 studentów, Uniwersytet Jana Kazimierza - 7358, Uniwersytet Poznański - 5334, zaś Uniwersytet Stefana Batorego - $3923^{136}$.

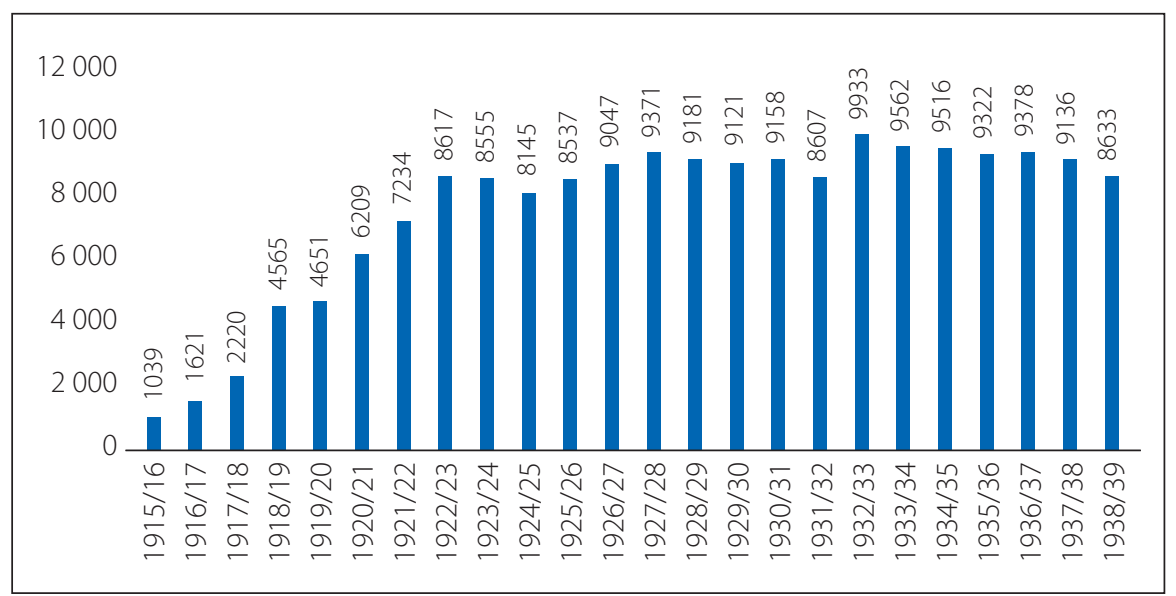

Wykres 1. Liczba studentów UW 1915-1939

Przytoczone powyżej dane, zaczerpnięte z publikacji poświęconej szkolnictwu wyższemu w ówczesnej Polsce, należy traktować jako przybliżone, gdyż liczba studentów zmieniała się w zależności od trymestru, nie wszyscy zapisujący się na Uniwersytet podejmowali też w ogóle studia. Ze sporządzonych na użytek wewnętrzny statystyk wynika, że np. w pierwszym półroczu roku akademickiego 1922/1923 immatrykulowanych zostało na Uniwersytecie Warszawskim $1015^{6}$ studentów, lecz aż $500 \mathrm{z}$ nich zostało niemal natychmiast skreślonych z powodu nieuiszczenia czesnego, a dalszych 496 zwróciło się w ciągu pierwszych 
kilku miesięcy o świadectwa wystąpienia. W efekcie, w drugim półroczu tego samego roku liczba studiujących spadła do 8380, chociaż w międzyczasie na Uniwersytet zapisały się nowe osoby ${ }^{137}$. Podobna płynność stanu osobowego występowała przez cały okres międzywojenny.

Ogółem w latach 1915-1939 na Uniwersytecie immatrykulowało się $5743^{6}$ osób, wśród których było 21379 kobiet (37\%) i 36057 mężczyzn (63\%). Jako pierwszy uczynił to 17 XI 1915 r. Romuald Kalinowski, urodzony w 1890 r. w Warszawie, absolwent tamtejszego IV Rosyjskiego Gimnazjum Rządowego, który wcześniej zdążył już ukończyć uniwersytet w Dorpacie. Tuż po nim zapisany został Józef Rubinraut, dziewiętnastolatek wyznania najprawdopodobniej mojżeszowego, mający za sobą naukę w VII Gimnazjum w Warszawie. Żaden z nich uczelni nie ukończył: pierwszy skreślony został z listy studentów w 1917 r., drugi przerwał studia 5 lat później ${ }^{138}$.

W sumie w pierwszym roku funkcjonowania uczelni zapisało się na nią 1110 studentów, w 2 kolejnych latach I wojny światowej liczba nowo wstępujących była jeszcze niższa i nie przekraczała tysiąca. Najmniej studentów, bo zaledwie 54,8, przybyło w 1920 r., kiedy Uniwersytet został faktycznie zamknięty ze względu na wojnę bolszewicką i związaną z nią mobilizację studentów oraz kadry naukowej. Za to w 1921 r. - w pierwszym prawdziwym roku pokoju - immatrykulowała się rekordowa liczba $433^{1}$ osób. W późniejszych latach przybywało co roku średnio ok. 2700 nowych studentów. W 1939 r. zdążyło jeszcze wstąpić na Uniwersytet $92^{139}$. Ostatnią osobą figurującą w matrykułach sprzed wybuchu II wojny światowej jest Maria Gumowska, absolwentka Państwowego Gimnazjum Żeńskiego im. ks. Adama Jerzego Czartoryskiego w Wilnie, wyznania rzymsko-katolickiego, urodzona w 1914 r. w Słonimiu, która po 1945 r. nie powróciła już na uczelnię $e^{140}$. Ze względu na płeć i wyznanie jej postać symbolizować może zmiany, jakie następowały wśród słuchaczy Uniwersytetu od jesieni 1915 r., gdy na uczelnię zapisali się 2 pierwsi studenci - mężczyźni, z których pierwszy był pochodzenia polskiego, a drugi żydowskiego.

Studenci rozpoczynający naukę na Uniwersytecie różnili się dość istotnie pod względem wieku. Najmłodsi mieli zaledwie ${ }_{15}$ lat, przypadki takie zdarzały się jednak coraz rzadziej w miarę krzepnięcia systemu oświatowego odradzającego się państwa polskiego. W $1915 \mathrm{r}$. na uczelnię zapisało się 4 piętnastolatków, w 1921 r. - 6, lecz w całych latach 30. było już ich łącznie tylko 4. Młodzież taka była najczęściej „produktem” eksternistycznej nauki w domu w początkowych latach edukacji, która pozwalała dostać się do gimnazjum od razu do klasy wyższej, a tym samym spędzić w jego murach mniej lat i wcześniej 
Tabela 3. Immatrykulacje na UW z podziałem według płci 1915-1939

\begin{tabular}{|c|c|c|c|c|c|}
\hline Rok & $\begin{array}{c}\text { Liczba } \\
\text { immatryku- } \\
\text { lowanych } \\
\text { kobiet }\end{array}$ & $\begin{array}{c}\text { Odsetek } \\
\text { kobiet wśród } \\
\text { immatrykulo- } \\
\text { wanych }\end{array}$ & $\begin{array}{c}\text { Liczba } \\
\text { immatryku- } \\
\text { lowanych } \\
\text { mężczyzn }\end{array}$ & $\begin{array}{l}\text { Odsetek męż- } \\
\text { czyzn wśród } \\
\text { immatrykulo- } \\
\text { wanych }\end{array}$ & $\begin{array}{l}\text { Liczba im- } \\
\text { matrykulacji } \\
\text { ogółem }\end{array}$ \\
\hline 1915 & 107 & $9,6 \%$ & 1003 & $90,4 \%$ & 1110 \\
\hline 1916 & 96 & $12,9 \%$ & 651 & $87,1 \%$ & 747 \\
\hline 1917 & 253 & $27,9 \%$ & 654 & $72,1 \%$ & 907 \\
\hline 1918 & 751 & $31 \%$ & 1668 & $69 \%$ & 2419 \\
\hline 1919 & 759 & $38,4 \%$ & 1219 & $61,6 \%$ & 1978 \\
\hline 1920 & 160 & $29,2 \%$ & 388 & $70,8 \%$ & 548 \\
\hline 1921 & 1611 & $37,2 \%$ & 2720 & $62,8 \%$ & 4331 \\
\hline 1922 & 1019 & $31,6 \%$ & 2202 & $68,4 \%$ & 3221 \\
\hline 1923 & 1042 & $35,3 \%$ & 1910 & $64,7 \%$ & 2952 \\
\hline 1924 & 998 & $37,9 \%$ & 1638 & $62,1 \%$ & 2636 \\
\hline 1925 & 998 & $37,5 \%$ & 1664 & $62,5 \%$ & 2662 \\
\hline 1926 & 1087 & $36 \%$ & 1937 & $64 \%$ & 3024 \\
\hline 1927 & 1135 & $37,6 \%$ & 1889 & $62,4 \%$ & 3024 \\
\hline 1928 & 1104 & $41 \%$ & 1586 & $59 \%$ & 2690 \\
\hline 1929 & 1186 & $41,8 \%$ & 1652 & $58,2 \%$ & 2838 \\
\hline 1930 & 1384 & $41,2 \%$ & 1972 & $58,8 \%$ & 3356 \\
\hline 1931 & 1374 & $43,3 \%$ & 1799 & $56,7 \%$ & 3173 \\
\hline 1932 & 1152 & $40,6 \%$ & 1687 & $59,4 \%$ & 2839 \\
\hline 1933 & 981 & $41,8 \%$ & 1365 & $58,2 \%$ & 2346 \\
\hline 1934 & 859 & $37,6 \%$ & 1429 & $62,4 \%$ & 2288 \\
\hline 1935 & 760 & $35,2 \%$ & 1397 & $64,8 \%$ & 2157 \\
\hline 1936 & 820 & $36,9 \%$ & 1404 & $63,1 \%$ & 2224 \\
\hline 1937 & 830 & $39,3 \%$ & 1282 & $60,7 \%$ & 2112 \\
\hline 1938 & 966 & $47,2 \%$ & 1082 & $52,8 \%$ & 2048 \\
\hline 1939 & 32 & $34,8 \%$ & 60 & $65,2 \%$ & 92 \\
\hline Ogółem & 21379 & $37,2 \%$ & 36057 & $62,8 \%$ & 57436 \\
\hline
\end{tabular}

Źródło: Opracowanie własne na podstawie danych USOS.

uzyskać świadectwo dojrzałości. Nie należy chyba z góry zakładać, że musiały to być zawsze jednostki wybitnie uzdolnione. Spośród 4 szesnastolatków, którzy, jak wówczas mówiono, wstąpili na Uniwersytet w 1915 r., ukończył go tylko 1 i to dopiero po 10 latach nauki ${ }^{141}$. 


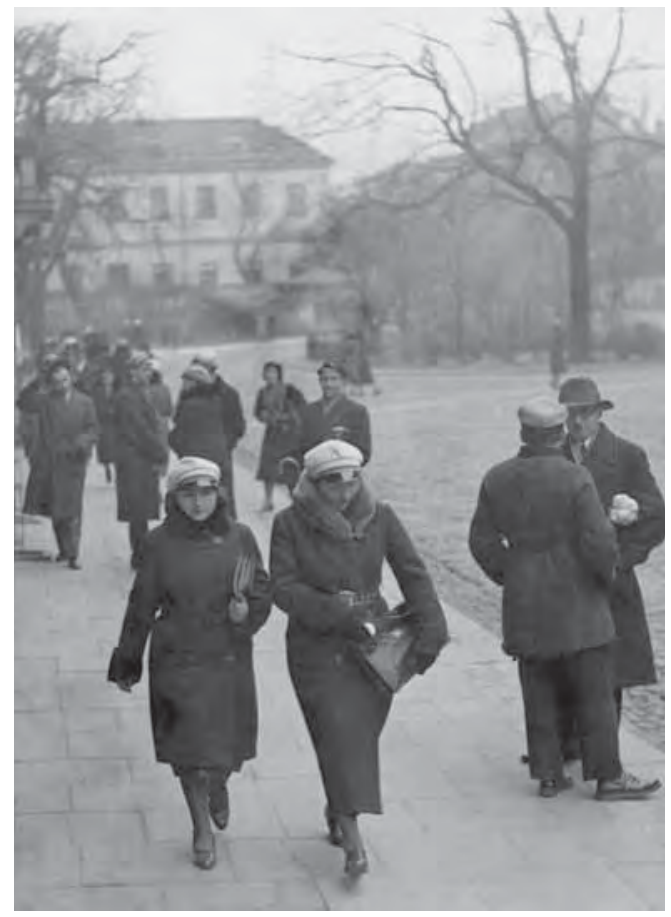

37. Studenci UW w drodze na wykłady, listopad $193^{1} \mathrm{r}$.
Siedemnastolatkowie zdarzali się wśród kandydatów na Uniwersytet częściej, stanowiąc do 5\% kolejnych roczników. Wśród rozpoczynających studia najliczniej jednak reprezentowana była młodzież w wieku od 18 do 21 lat, czyli taka, która zdawała właśnie w miarę normalnym trybem egzamin dojrzałości. W 1915 r. stanowiła ona blisko $55 \%$ immatrykulowanych, w $19^{21}$ r. -61\%, zaś w 1931 r. już prawie $76 \%$. Wzrost tego odsetka wskazuje na stopniowe normowanie się sytuacji w kraju po wojennych zawieruchach, dzięki czemu więcej młodzieży miało szansę kontynuować edukację, trafiając na uczelnię bezpośrednio ze szkół średnich ${ }^{142}$.

Część młodzieży nie mogła zapisać się na Uniwersytecie od razu po uzyskaniu matury, gdyż musiała wpierw zgromadzić odpowiednie środki na opłacenie czesnego, podejmując na pewien czas pracę zarobkową. „[...] Maturę zdałem z wynikiem dobrym w 1931 r. Rok szkolny 1931/1932 przesiedziałem w domu, pracując jak i ile można było, byle dostać się na uniwersytet" - opisywał jeden $\mathrm{z}$ kandydatów ${ }^{143}$. Powodowało to zwiększenie przeciętnego wieku osób rozpoczynających studia. W przypadku mężczyzn pewien wpływ na wiek kandydatów na Uniwersytet miało również - nawet już w czasach pokoju - wcześniejsze odbywanie przez część z nich zasadniczej służby wojskowej. W II Rzeczypospolitej obowiązkiem tym objęci byli wszyscy obywatele płci męskiej, którzy w danym roku kalendarzowym kończyli 21. rok życia. Fakt bycia studentem nie zapewniał automatycznego wyreklamowania z wojska, więc część poborowych decydowała się odsłużyć je bezpośrednio po uzyskaniu świadectwa dojrzałości, aby później nie przerywać nauki w szkole wyższej. Jako tzw. poborowi z cenzusem trafiali do koszar na 12 miesięcy, na uczelnię zaś zapisywali się już jako podchorążowie rezerwy, o rok starsi, niż gdyby uczynili to bezpośrednio po maturze. (Postąpił tak m.in. Władysław Jamontt, późniejszy działacz Ruchu Narodowo-Radykalnego „Falan-

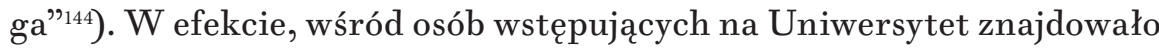


się proporcjonalnie więcej kobiet w wieku 18-19 lat niż ich rówieśników-mężczyzn. W 1931 r. w rocznikach tych stanowiły one 50-54\% immatrykulowanych. Świeżo upieczeni podchorążowie zasilali z kolei roczniki dwudziestodwu- i dwudziestoczterolatków, w których bardzo wyraźnie przeważali liczbowo nad kobietami ${ }^{145}$.

Część młodych mężczyzn uzyskiwała odroczenie powołania do wojska do momentu ukończenia 23. roku życia „z tytułu odbywania nauki w wyższych zakładach naukowych", które warunkowo mogło zostać przedłużone o kolejne 2 lata studentom niektórych kierunków politechnicznych oraz medycyny i weterynarii ${ }^{146}$. Pozwalało to ukończyć studia w normalnym trybie tylko w przypadku, gdy nauka odbywała się bez opóźnień. W innych sytuacjach studenci zmuszeni byli do jej zawieszenia na czas odbywania służby, co władze akademickie przyjmowały z zasady z wyrozumiałością, udzielając im stosownych urlopów, a także idąc na rękę w sprawie przełożenia terminów egzaminów itp. Dokumentują to liczne akta osobowe, w których część korespondencji z Uniwersytetem prowadzona jest już z jednostek wojskowych ${ }^{147}$. W każdym przypadku powszechny obowiązek obrony kraju traktowano niezwykle poważnie, o czym przekonał się na własnej skórze student Wydziału Humanistycznego Jan Radożycki, którego na skutek pomyłki w aktach policja - głucha na jakiekolwiek tłumaczenia - doprowadziła siłą z domu studenckiego na komisariat, gdzie dopiero zdołał wytłumaczyć nieporozumienie ${ }^{148}$.

Normalizacja systemu oświatowego w latach międzywojennych przejawiała się również poprzez spadek liczby studentów najstarszych. O ile w 1915 r. na Uniwersytet zapisało się ok. 5\% osób w wieku powyżej 30 lat, o tyle w $1921 \mathrm{r}$. było ich wśród nowo przyjętych 4,3\%, natomiast w 1931 r. - tylko $2,1 \%{ }^{149}$. Niektórzy z nich w momencie immatrykulacji byli już nobliwymi panami, a głównym motywem tak późnego podejmowania przez nich studiów bądź ich wznowienia była chęć podniesienia prestiżu społecznego lub kontynuacji kariery zawodowej. „Ze mną zaś zdawał jakiś pan, z wyglądu starszy od Profesora, i odpowiedzi nie bardzo mu wychodziły" - zapamiętał swój egzamin jeden z przyszłych prawników. „Profesor w pewnej chwili zapytał go, który raz u niego zdaje. Powiedział, że trzeci. Na to Namitkiewicz: «Toż od razu zauważyłem, twarz wybitnie znajoma, że student był dependentem u rejenta i miał możliwość zostania rejentem, ale na przeszkodzie stał brak dyplomu»"150.

Dwaj najbardziej wiekowi studenci spośród przyjętych w $1915 \mathrm{r}$. przyszli na świat na rok przed powstaniem styczniowym. Jak napisał w swoim curriculum vitae jeden $\mathrm{z}$ nich, zapisany na Wydział Prawa Henryk Makowski, jego celem było dokończenie studiów rozpoczętych 
w młodości na Uniwersytecie Cesarskim w Warszawie, po przerwaniu których w 1887 r. uczęszczał do seminarium duchowego w Kielcach oraz ukończył wyższą szkołę muzyki kościelnej w Ratyzbonie, aby następnie wykładać w kraju liturgikę, liturgię, harmonię i śpiew gregoriański. Celu swego nie zdołał niestety osiągnąć. W ciągu blisko 9 lat spędzonych na Uniwersytecie po 1915 r. udało mu się nie złożyć ani jednego egzaminu (za każdym razem przedkładał zwolnienia lekarskie bądź wnosił o urlop) i w 1924, r. został ostatecznie skreślony z listy studentów ${ }^{151}$. Rzeczywistość - jak to się często zdarza - nie pozwoliła zrealizować marzeń młodości.

Bywało też jednak inaczej, o czym świadczyć może przypadek Dominika Ruckiego, najstarszego studenta Uniwersytetu Warszawskiego w latach międzywojennych. W momencie immatrykulacji na Kursach Farmacji w 1926 r. liczył on sobie równo 7o lat, a za sobą miał ukończone w 1880 r. studia w Moskwie i bogate doświadczenie w kierowaniu aptekami i laboratoriami chemicznymi w Rosji, na Ukrainie, a od 1920 r. również w Polsce. Choć nie ma o tym mowy w jego życiorysie, należy przypuszczać, iż studia na Uniwersytecie Warszawskim traktował on w kategoriach dokształcania się, względnie nostryfikacji zdobytego w carskiej Rosji tytułu. Ukończył je we wzorowym tempie, uzyskując w ciągu 2 lat polski dyplom magistra farmacji ${ }^{152}$.

Nie wszyscy studenci kończyli jednak naukę w przewidzianym czasie, dużej części z nich nie udawało się to zresztą w ogóle. W latach zo. w składanych przez siebie sprawozdaniach rocznych kolejni rektorzy Uniwersytetu szacowali, iż dyplom zdobywało tylko 10-14\% słuchaczy. Wskaźnik ten wykazywał pewną tendencję rosnącą ${ }^{153}$. Wyliczano go porównując liczbę wydanych $\mathrm{w}$ danym roku dyplomów magisterskich i doktorskich z całkowitą liczbą studentów. Miał on więc charakter orientacyjny: ukazywał wprawdzie odsetek absolwentów w poszczególnych latach na tle ogółu słuchaczy, lecz nic nie mówił o tym, ilu konkretnych immatrykulowanych w rzeczywistości ukończyło studia.

Dzisiaj współczynnik taki można już precyzyjnie wyliczyć korzystając z uniwersyteckiej bazy danych, zawierającej informacje o przebiegu studiów wszystkich, którzy wstąpili na Uniwersytet Warszawski w latach 1915-1939. Jak się okazuje, sytuacja przedstawiała się en masse lepiej, niż wynikałoby to ze sprawozdań rektorskich. (Różnicę tę można wytłumaczyć faktem, iż wielu studentów kończyło studia ze sporym opóźnieniem, odsetek absolwentów kumulował się więc niejako dopiero w dalszych latach). Niemniej jednak w żadnym z roczników dyplomu nie udało się uzyskać więcej niż połowie osób rozpoczynających studia. Stosunkowo najlepiej pod tym względem sytuacja wyglądała wśród 
immatrykulowanych na Uniwersytecie jeszcze przed odzyskaniem przez Polskę niepodległości, gdyż uczelnię ukończyło 39-4,6\% tych roczników. Miały one najwięcej czasu na studiowanie, można też zakładać, że relatywnie częściej występowały w nich osoby szczególnie zmotywowane do zdobywania wiedzy. Ponadto w rocznikach tych dominowali mieszkańcy Warszawy (o czym będzie jeszcze mowa dalej), którym pod względem materialnym było łatwiej studiować niż przybyszom z prowincji, chociażby ze względu na możliwość mieszkania przy rodzinie ${ }^{154}$.

W efekcie napływu na Uniwersytet większej liczby kandydatów, jaki można obserwować po 1918 r., odsetek osób kończących studia wyraźnie natomiast spadł i utrzymywał się w granicach 28-39\%. Przeważnie występowała przy tym prawidłowość, że im liczniejszy był rocznik rozpoczynający naukę, tym mniejszy jego procent ją kończył. Dane te dotyczą osób, które immatrykulowały się do $193^{2}$ r. W kolejnych latach analogiczny wskaźnik gwałtownie się obniżył i wynosił: 23,5\% dla 1933 r., 17\% dla 1934, r. i 9,5\% dla 1935 r. (Spadek ów wynikał z przedłużania nauki przez część studentów, którzy nie zdążali potem obronić dyplomu w terminie, co również zostanie omówione dalej.) Osoby przyjęte na UW w późniejszych latach nie mogły ukończyć studiów w normalnym trybie przed wybuchem II wojny światowej, nie ma więc sensu uwzględniać ich w tym zestawieniu. Ogółem, spośród wszystkich 57436 słuchaczy Uniwersytetu, którzy zostali immatrykulowani w latach 1915-1939, dyplomy uzyskało 16307 osób, tzn. 28,4\%. Dalszych 1578 osób (2,7\%) ukończyło naukę już po 1945 r. Studia ukończył zatem przeciętnie mniej niż co trzeci z zapisanych na Uniwersytet. Średnio każdego roku mury uczelni opuszczało 678 osób legitymujących się dyplomem jej ukończenia ${ }^{155}$.

Największy odsetek studentów „wykruszał się" na Uniwersytecie po pierwszym roku nauki. Według obliczeń rektora Stefana Pieńkowskiego dotyczących połowy lat 3o., odpadał wówczas co drugi ze słuchaczy prawa, teologii i nauk humanistycznych, co trzeci na Wydziale Matematyczno-Przyrodniczym oraz co czwarty na wydziałach Farmaceutycznym, Lekarskim i Weterynaryjnym. Na drugim roku ubywało kolejnych 30\% studentów pierwszych z tych kierunków, 21\% drugich i $15 \%$ trzecich. Trzeci i czwarty rok charakteryzowały się już wyraźnie mniejszymi stratami: na teologii, prawie i humanistyce wynosiły one odpowiednio $15 \%$ i $7,5 \%$, na naukach matematyczno-przyrodniczych - 10,5\% i $6 \%$, a na farmacji, medycynie i weterynarii - 9\% i $4,5 \%{ }^{156}$.

Jak widać, najtrudniej było przetrwać studentom początkowe lata studiów. Wiązało się to zarówno z odsiewem jednostek niedających sobie rady z nauką, jak i „wykruszaniem się” tych, którzy nie byli 
w stanie podołać kontynuowaniu edukacji pod względem finansowym. (Wynikałoby z tego, że również w przypadku osób niezamożnych motywacja, aby utrzymać się na Uniwersytecie, rosła w miarę zbliżania się do dyplomu). Z przedstawionych przez Pieńkowskiego liczb płynie też wniosek, iż najwięcej studentów odpadało na kierunkach, na które dostać się mógł niemal każdy, kto posiadał świadectwo dojrzałości, natomiast najmniej tam, gdzie, jak na medycynie, farmacji i weterynarii, obowiązywały egzaminy wstępne. Najwyraźniej, ostra selekcja kandydatów skutecznie eliminowała pewną część osób przypadkowych, a ci, którzy przeszli przez jej sito, byli później lepiej zmotywowani do nauki niż przyjęci bez egzaminu. $\mathrm{Z}$ drugiej strony, na medycynę, prawo i farmację zapisywało się więcej osób wywodzących się z zamożnych rodzin, którym na ogół nie groziło ryzyko przerwania studiów z powodu braku funduszy. Jeszcze inne uwarunkowania występowały w przypadku słuchaczy kierunków teologicznych, z których wielu było duchownymi lub klerykami, podlegającymi dyscyplinującemu nadzorowi instytucji kościelnych, a ponadto mającymi zapewnione utrzymanie.

Znajduje to potwierdzenie $\mathrm{w}$ danych dotyczących całego okresu 1915-1939. Do wybuchu II wojny światowej Wydział Prawa ukończyło $33 \%$ wszystkich zapisanych tam słuchaczy. W przypadku Wydziału Humanistycznego współczynnik ten wynosił 19\%, Filozoficznego - 21\%, Lekarskiego - 55\%, Farmaceutycznego 49\%, a Weterynaryjnego - 39\%. Wydział Teologii Katolickiej do wybuchu II wojny światowej zdołało absolwować 4.1\%, Wydział Teologii Ewangelickiej - 4,2\%, a Studium Teologii Prawosławnej - 25\%. Dużo niższy niż wynikałoby to z szacunków Pieńkowskiego był natomiast ogólny odsetek absolwentów Wydziału Matematyczno-Przyrodniczego ( $9 \%$ ), na którym, poza chemią, również nie było zresztą egzaminów wstępnych ${ }^{157}$.

Z wysokim odsetkiem studentów, którzy nie kończyli studiów, wiązało się inne negatywne zjawisko w postaci notorycznego ich przedłużania. Fenomen ten miał długą tradycję, sięgającą czasów zaborów i występował wówczas we wszystkich polskich szkołach wyższych. „Opóźnienia w studiach są zjawiskiem powszechnym, występującym poza nielicznymi wyjątkami w znacznych przeważnie rozmiarach" - stwierdza autorka opublikowanego w 1937 r. Atlasu szkolnictwa wyższego, przytaczając na poparcie tej tezy dane dotyczące różnych kierunków ${ }^{158}$.

Nie inaczej sytuacja wyglądała na Uniwersytecie Warszawskim. Dla immatrykulowanych w 1915 r. mediana czasu nauki poprzedzającej uzyskanie dyplomu wynosiła 8 lat, co oznacza, że tylko nieco więcej niż połowa wszystkich absolwentów ukończyła studia po tylu właśnie latach. Był to jednak rocznik, którego edukację mogły przedłużyć 
Tabela 4. Immatrykulowani i absolwenci poszczególnych wydziałów UW 1915-1939

\begin{tabular}{|c|c|c|c|c|}
\hline & 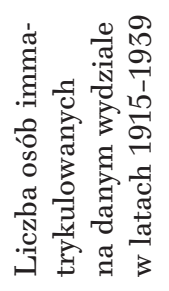 & 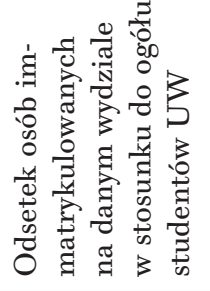 & 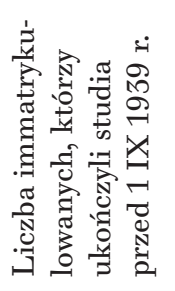 & 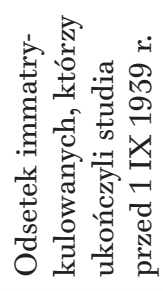 \\
\hline $\begin{array}{l}\text { Wydział Teologii } \\
\text { Katolickiej }\end{array}$ & 398 & $0,7 \%$ & 164 & $41,2 \%$ \\
\hline $\begin{array}{l}\text { Wydział Teologii } \\
\text { Protestanckiej }\end{array}$ & 334 & $0,6 \%$ & 142 & $42,5 \%$ \\
\hline $\begin{array}{l}\text { Studium Teologii } \\
\text { Prawosławnej }\end{array}$ & 589 & $1 \%$ & 147 & $25 \%$ \\
\hline Wydział Prawa & 19217 & $33,5 \%$ & 6359 & $33,1 \%$ \\
\hline Wydział Lekarski & 5590 & $9,7 \%$ & 3052 & $54,6 \%$ \\
\hline $\begin{array}{l}\text { Wydział } \\
\text { Filozoficzny }\end{array}$ & 12379 & $21,6 \%$ & 2627 & $21,2 \%$ \\
\hline $\begin{array}{l}\text { Wydział } \\
\text { Humanistyczny }\end{array}$ & 9802 & $17,1 \%$ & 1838 & $18,8 \%$ \\
\hline $\begin{array}{l}\text { Wydział } \\
\text { Matematyczno- } \\
\text {-Przyrodniczy }\end{array}$ & 6358 & $11,1 \%$ & 665 & $9,3 \%$ \\
\hline $\begin{array}{l}\text { Wydział } \\
\text { Farmaceutyczny }\end{array}$ & 1547 & $2,7 \%$ & 753 & $48,7 \%$ \\
\hline $\begin{array}{l}\text { Wydział } \\
\text { Weterynaryjny }\end{array}$ & 1432 & $2,5 \%$ & 560 & $39,1 \%$ \\
\hline Ogółem & 57646 & & 16307 & $28,3 \%$ \\
\hline
\end{tabular}

Źródło: Opracowanie własne na podstawie danych USOS.

Uwaga: Suma osób immatrykulowanych na poszczególnych wydziałach jest wyższa niż łączna liczba studiujących na UW, gdyż niektóre osoby immatrykulowały się na więcej niż jednym wydziale. Dane dla Wydziału Farmaceutycznego obejmują również wcześniejsze Kursy Farmacji.

najpierw I wojna światowa, a później wojna z bolszewikami. Ten sam parametr dla przyjętych na Uniwersytet w 1921 r. wynosił 6 lat, zaś dla rocznika, który rozpoczął naukę w $193^{1}$ r. - 5 lat. Przyjmując dla uproszczenia, że prawidłowy tok studiów wynosił od 4, do 5 lat (w zależności od wydziału), możemy obliczyć, iż w przepisowym terminie dyplom uzyskało tylko 4\% spośród immatrykulowanych w 1915 r., 33\% spośród przyjętych na studia w 1921 r. oraz 48\% spośród zapisanych dekadę później. W każdym z tych roczników występowało stosunkowo 
wielu słuchaczy, których śmiało określić można mianem „wiecznych studentów": aż 31,5\% z przyjętych na Uniwersytet w 1915 r. studiowało 10 lat i więcej, wśród tych z 1921 r. było ich 13,2\%. $Z$ rocznika immatrykulowanego w 1931 r., po 8 latach nauki, w roku wybuchu II wojny światowej, dyplomu broniło $7 \%$ osób ${ }^{159}$.

Poszczególne wydziały Uniwersytetu różniły się dość poważnie między sobą pod względem rzeczywistej długości studiów. Wśród absolwentów prawa z roku akademickiego 1933/1934 było tylko $28 \%$ osób, które ukończyły czteroletni kurs bez jakichkolwiek opóźnień, na medycynie trwającej nominalnie 5 lat i 1 trymestr współczynnik ten wynosił 19\%, zaś na kierunkach teologicznych - 17\%. W przypadku nauk humanistycznych dyplomy obroniło w terminie (tzn. po 4 latach), zaledwie 9,5\% słuchaczy. Jeszcze gorsza sytuacja panowała na farmacji (3 lata i 2 trymestry), gdzie uzyskało je w przepisowym czasie tylko $6 \%$ absolwentów, i na czteroletnich studiach matematyczno-przyrodniczych (2\%). Na Wydziale Weterynaryjnym żaden z 50 dyplomantów w roku akademickim 1933/1934 nie ukończył studiów, które trwałyby obowiązujące 4 lata i 2 trymestry ${ }^{160}$.

Mimo że w dwudziestoleciu międzywojennym zjawisko przedłużania studiów na Uniwersytecie Warszawskim stopniowo się zmniejszało, sytuacja była wciąż daleka od satysfakcjonującej. Należy przy tym pamiętać, że przedstawione powyżej wyliczenia dotyczą wyłącznie absolwentów, nie uwzględniają natomiast zupełnie słuchaczy, którzy przerwali naukę, spędziwszy wcześniej niekiedy wiele lat w murach uczelni. Zjawisko było więc de facto powszechniejsze, niż wynikałoby to ze statystyk, na co zwracał zresztą uwagę - w wymiarze ogólnopolskim - już w lutym 1939 r. senator Kazimierz Bartel, kilkukrotny premier i profesor Politechniki Lwowskiej, w polemice sejmowej z ministrem wyznań religijnych i oświecenia publicznego Wojciechem Świętosławskim ${ }^{161}$.

Niekwestionowanym rekordzistą Uniwersytetu, gdy chodzi o długie studiowanie, był urodzony w 1896 r. w Warszawie Izaak Ginzberg. Jego losy stanowią skondensowany obraz perypetii życiowych wielu studentów, warto więc prześledzić je w całości. Po uzyskaniu matury w 1914, r. Ginzberg wstąpił w grudniu 1915 r. do sekcji przygotowawczo-lekarskiej Wydziału Matematyczno-Przyrodniczego, naukę jednak z nieznanych dziś powodów przerwał, po czym w październiku $1917 \mathrm{r}$. wystąpił o ponowne przyjęcie na medycynę, otrzymując decyzję pozytywną. Nie jest jasne, co działo się z nim przez kolejne 5 lat. Załączony do akt studenckich indeks Ginzberga, wystawiony na rok akademicki 1919/1920 przez uniwersytet w Rostowie nad Donem, dokąd ewakuował się z Warszawy Uniwersytet Cesarski, wskazuje, iż jego 
posiadacz znalazł się pod koniec I wojny światowej w Rosji, próbując tam kontynuować edukację. Na Uniwersytecie Warszawskim pojawił się ponownie jesienią 1921 r., otrzymując dopuszczenie do dalszych studiów na Wydziale Lekarskim. W latach 1922-1924, złożył egzaminy wchodzące w skład tzw. pierwszego rigorosum, a w listopadzie $1927 \mathrm{r}$. uzyskał nawet absolutorium. W tym momencie Ginzberga opuściło jednak szczęście. Jak wyjaśniał w późniejszym podaniu do Rady Wydziału, negatywne oceny z kolejnego, drugiego rigorosum, do którego podszedł w 1926 r., były „pewnego rodzaju wstrząsem, który wytrącił mnie z prawidłowego biegu pracy. Na domiar nieszczęścia, w rodzinie mojej [...] zaszły okoliczności zmuszające mnie do natychmiastowej pracy zarobkowej. Praca ta, jak również zmartwienia z powodów rodzinnych i pewnego niepowodzenia w studiach, mocno nadszarpnęły moje zdrowie". W latach 1929-1930 Ginzberg próbował bez powodzenia zdawać kolejne egzaminy i tylko życzliwe stanowisko Rady Wydziału, do której się odwołał, uchroniło go w 1931 r. od skreślenia z listy studentów. Przez następnych pięć lat Ginzberg mozolnie poprawiał niezdane wcześniejsze egzaminy i stawiał czoła nowym (tylko 2 z 12 zdał bez poprawek, do niektórych podchodził aż trzykrotnie). Wbrew wszystkim tym przeciwnościom uzyskał w styczniu $193^{6}$ r. dyplom lekarski, mając lat 4,0, z których 21 spędził studiując na Uniwersytecie ${ }^{162}$. Nie wiadomo niestety, czy zdobyte z takim trudem wykształcenie pomogło mu uratować się w czasie Zagłady.

Trudno jest wskazać jedną przyczynę tak częstego „wykruszania się" studentów oraz przeciągania przez nich czasu spędzanego w murach uczelni; w grę wchodził raczej szereg różnych, nakładających się na siebie czynników. Często jednym z nich było ubóstwo, uniemożliwiające utrzymanie się w Warszawie, zmuszające do podejmowania pracy zarobkowej, przerywania nauki, a niekiedy prowadzące do porzucenia studiów. Wśród zachowanych podań o stypendia znaleźć można cały szereg przypadków osób, które ze względu na brak środków do życia musiały na jakiś czas zrezygnować z nauki, często opuszczając wówczas w ogóle stolicę ${ }^{163}$. Jak jednak zauważa jeden z ówczesnych słuchaczy, „pewna liczba studentów, szczególnie pochodzących z lepiej sytuowanych materialnie kół społeczeństwa, wstępowała na studia dlatego, że «tak wypadało». Ci studenci zwracali na siebie uwagę swobodnym stylem zachowania, szukaniem rozrywek i pewnej rangi społecznej, związanej ze studiowaniem na wyższej uczelni, lecz bardzo lekko rezygnowali ze studiów lub przeskakiwali z wydziału na wydział, w poszukiwaniu sposobów unikania wysiłków związanych ze studiami"164. Do Uniwersytetu Warszawskiego odnieść można wreszcie - jak sądzę 
- także spostrzeżenia, które przywoływany wcześniej Bartel poczynił na podstawie własnych obserwacji na Politechnice Lwowskiej: niedostateczne przygotowanie większości kandydatów, rozpolitykowanie słuchaczy skutecznie odciągające ich od nauki, a także „przeciążenie młodzieży akademickiej programem naukowym"165. Na ten ostatni czynnik zwracała uwagę również autorka Atlasu szkolnictwa wyższego Halina Wittlinowa ${ }^{166}$.

Mimo iż pomiędzy wznowieniem funkcjonowania uczelni w $1915 \mathrm{r}$. a wybuchem II wojny światowej upłynęło zaledwie niecałe ćwierćwiecze, studenci, którzy przewinęli się w tym okresie przez Uniwersytet, należeli do różnych generacji, ukształtowanych przez odmienne okoliczności historyczne. $\mathrm{Na}$ podstawie dostępnych źródeł trudno jest przedstawić ich pełną charakterystykę, każdy ich dokładniejszy opis siłą rzeczy prowadzić musiałby zresztą do pewnych uproszczeń. $Z$ pewnością da się jednak wskazać najważniejsze wyróżniające cechy. Pierwszą z generacji stanowili ci studenci, którzy sporą część dorosłego życia przeżyli jeszcze w epoce rozbiorów. Dominowali oni na Uniwersytecie mniej więcej do połowy lat 20 . Wielu z nich wzięło udział w walkach o granice powstającego państwa i wojnie z bolszewikami, które stanowiły dla ich pokolenia najważniejsze doświadczenie zbiorowe, niweczące zresztą niektórym bezpowrotnie szanse na dokończenie studiów. Cieszyła ich sama możliwość nauki w języku ojczystym na wyższej uczelni we własnym, niepodległym państwie ${ }^{167}$. Podziały polityczne $\mathrm{w}$ tej generacji, przynajmniej $\mathrm{w}$ środowisku etnicznie polskim, były wciąż jeszcze wyraźnie tonizowane przez integrujące doświadczenie zdobywania niepodległości ${ }^{168}$.

Grupa druga, która przeważała na Uniwersytecie w dekadzie 19251935, częściowo mogła jeszcze pamiętać schyłek rozbiorów i Wielką Wojnę, lecz naturalnym punktem odniesienia była już dla niej rzeczywistość pierwszych lat niepodległości. Jak się wydaje, i ona umiała docenić komfort studiowania w czasach pokoju, we względnej stabilizacji, pamiętając wszechobecną wcześniej biedę i niepewność. Grupa ta była początkowo stosunkowo spokojna, zaczęło się to jednak zmieniać pod wpływem wielkiego kryzysu gospodarczego i narastających napięć politycznych w kraju. Zapoczątkowana wówczas radykalizacja uwidoczniła się jednak w pełni dopiero w postawach kolejnej generacji, która przyszła na świat podczas I wojny światowej lub już w wolnej Polsce, i pojawiła się na Uniwersytecie około połowy lat zo. Stanowiła ona produkt postępującej w tym czasie modernizacji społecznej ze wszystkimi jej dobrymi i złymi skutkami: dynamizmem, otwarciem na nowoczesność, ale również sympatiami dla tendencji totalitarnych. 


\section{Pochodzenie geograficzne studentów}

Przez całe dwudziestolecie międzywojenne w statystykach sporządzanych przez Uniwersytet Warszawski, według wzoru wprowadzonego przez MWRiOP, studentów dzielono w zależności od miejsca urodzenia na pochodzących z Warszawy, Kongresówki, Wielkopolski, Małopolski, Kresów Wschodnich oraz z zagranicy. Nie jest w pełni jasne, jakie konkretnie obszary zaliczano do poszczególnych kategorii - tym bardziej że dokonywali tego sami studenci, wypełniając odpowiedni formularz. Formalnie rzecz biorąc, np. Białystok i Grodno znajdujące się w czasach carskich poza granicami Kongresówki powinny zostać uznane za „Kresy”, co jednak kłóciło się tak z potocznymi odczuciami, jak i podziałem administracyjnym kraju po odzyskaniu niepodległości. Nie wiadomo też, czy przez Kresy rozumiano tylko terytorium państwa polskiego, czy również tereny położone na wschód od granicy ryskiej, które należały do Rzeczpospolitej przed rozbiorami. Małopolska, utożsamiana z dawną Galicją, obejmowała z kolei również województwa lwowskie, tarnopolskie i stanisławowskie, zaś Wielkopolska, jak należy sądzić, także województwa pomorskie i śląskie.

Główne zaplecze rekrutacyjne Uniwersytetu stanowiła Warszawa, skąd wywodziło się $1663^{2}$ (29\%) słuchaczy immatrykulowanych w latach 1915-1939. Statystyki uniwersyteckie nie podają niestety, ilu studentów mieszkało w stolicy przed podjęciem studiów, lecz z pewnością było ich więcej niż urodzonych tam, chociażby ze względu na dość liczny napływ do miasta Polaków z Rosji i ziem wschodnich, które po $1921 \mathrm{r}$. znalazły się poza granicami Rzeczypospolitej. Osoby urodzone w Warszawie występowały szczególnie licznie wśród pierwszego rocznika przyjętego na uczelnię (blisko $5^{1} \%$ ), co stosunkowo łatwo wytłumaczyć trwającymi wtedy działaniami wojennymi, utrudniającymi kandydatom spoza stolicy podejmowanie studiów poza miejscem zamieszkania. Po odzyskaniu niepodległości i zakończeniu wojny bolszewickiej udział rozpoczynających studia, którzy urodzili się w Warszawie, wyraźnie spadł i oscylował między $25 \% \mathrm{w} 1935$ r. a 31\% w 1931 r. ${ }^{169}$ Wahania te miały niewątpliwie związek z aktualną sytuacją gospodarczą kraju: liczba studentów spoza stolicy malała w latach kryzysu, ponieważ ze względu na konieczność samodzielnego utrzymania się w wielkim mieście było im trudniej pozwolić sobie na studia niż warszawiakom mieszkającym przy rodzinach. 
W grupie studentów spoza Warszawy najliczniejsi byli urodzeni na terenach Kongresówki. W roku akademickim 1921/1922 stanowili oni 38\% ogółu słuchaczy, w późniejszych latach ich odsetek dochodził nawet do $47 \%$. Łącznie $\mathrm{z}$ osobami urodzonymi w stolicy, z byłego Królestwa Polskiego wywodziło się zatem w poszczególnych latach akademickich ogólem od $72 \%$ do $80 \%$ studentów ${ }^{170}$.

Wśród Kongresowiaków drugą pod względem liczebności grupą po warszawiakach byli w latach 1915-1939 słuchacze urodzeni w Łodzi; w liczbie 2932 stanowili oni 5,1\% ogólu immatrykulowanych. Po kilkuset studentów wywodziło się z innych większych miast dawnego Królestwa Polskiego: 774 z Lublina (1,4\%), 688 z Częstochowy (1,2\%), 617 z Radomia (1,1\%), 589 z Piotrkowa (1\%), 490 z Płocka (o,9\%), 388 z Kielc (o,7\%), 376 z Siedlec (o,7\%), 368 z Kalisza (o,7\%), 333 z Sosnowca (o,6\%), a 34,0 także z Białegostoku (o,6\%), który przed 1918 r. znajdował się na ziemiach wcielonych bezpośrednio do Cesarstwa Rosyjskiego. Mniej licznie reprezentowani byli wśród słuchaczy Uniwersytetu Warszawskiego mieszkańcy Włocławka (282), Łomży (262), Skierniewic (176), Zamościa (173), Mławy (168), Łowicza (164), Pułtuska (140), Pabianic (132), Chełma (121), Konina (120), Ciechanowa (118), Będzina (117), Kutna (114), Żyrardowa (114), Zawiercia (113), Suwałk (109) i Zgierza (106). Po kilkadziesiąt osób przybyło wreszcie na studia z pomniejszych miast i miasteczek Kongresówki, takich jak Łuków, Gostynin, Pruszków, Ostrowiec, Dąbrowa Górnicza, Sochaczew, Przasnysz i wiele innych ${ }^{171}$.

Tabela 5. Pochodzenie terytorialne studentów UW z uwzględnieniem płci w roku akademickim $1932 / 1933$

\begin{tabular}{|l|c|c|c|c|c|c|}
\hline & $\begin{array}{c}\text { Liczba } \\
\text { mężczyzn }\end{array}$ & $\begin{array}{c}\text { Odsetek } \\
\text { mężczyzn }\end{array}$ & $\begin{array}{c}\text { Liczba } \\
\text { kobiet }\end{array}$ & $\begin{array}{c}\text { Odsetek } \\
\text { kobiet }\end{array}$ & $\begin{array}{c}\text { Liczba } \\
\text { słuchaczy } \\
\text { ogółem }\end{array}$ & $\begin{array}{c}\text { Odsetek } \\
\text { słuchaczy } \\
\text { ogółem }\end{array}$ \\
\hline Warszawa & 1643 & $27,7 \%$ & 1449 & $36,5 \%$ & 3092 & $31,2 \%$ \\
\hline Kongresówka & 2588 & $43,6 \%$ & 1480 & $37,3 \%$ & 4068 & $41,1 \%$ \\
\hline Wielkopolska & 109 & $1,8 \%$ & 43 & $1,1 \%$ & 152 & $1,5 \%$ \\
\hline Małopolska & 514 & $8,7 \%$ & 249 & $6,3 \%$ & 763 & $7,7 \%$ \\
\hline $\begin{array}{l}\text { Kresy } \\
\text { Wschodnie }\end{array}$ & 519 & $8,7 \%$ & 298 & $7,5 \%$ & 817 & $8,2 \%$ \\
\hline Zagranica & 562 & $9,5 \%$ & 454 & $11,4 \%$ & 1016 & $10,3 \%$ \\
\hline Ogółem & 5935 & $100 \%$ & 3973 & $100 \%$ & 9908 & $100 \%$ \\
\hline
\end{tabular}

Źródło: AUW, AcUW/RP 65, wykaz studentów za rok 1932/1933. 
Po 1921 r. stosunkowo liczną grupą studentów, sięgającą 10\% ogółu immatrykulowanych, były osoby urodzone na Kresach Wschodnich ${ }^{172}$. Należy przypuszczać, że spora część z nich już przed podjęciem studiów mieszkała w Warszawie, dokąd trafiła - najczęściej mocno spauperyzowana - w następstwie I wojny światowej, rewolucji w Rosji i wojny bolszewickiej. Inni przeprowadzili się do Warszawy ze względu na kariery zawodowe rodziców. Tych, którzy nie tylko urodzili się na Kresach, ale również nadal tam zamieszkiwali, przyciągało prawdopodobnie na Uniwersytet Warszawski jego stołeczne usytuowanie, związany z nim prestiż i nadzieja lepszych perspektyw na pracę w przyszłości. Podobne mechanizmy występowały w przypadku studentów wywodzących się z Małopolski. Wskazuje na to wzrost ich odsetka z około 4\% na początku lat 20. do prawie $8 \%$ dekadę później ${ }^{173}$.

Warto zauważyć, iż zarówno w przypadku osób mieszkających na Kresach Wschodnich, jak i w Małopolsce, udanie się na studia do Warszawy było opcją trudniejszą i wymagającą większych nakładów finansowych niż wyjazd na bliżej położone uczelnie: Uniwersytet Stefana Batorego, Uniwersytet Jagielloński czy Uniwersytet Jana Kazimierza. Mimo to, w całym okresie 1915-1939 na Uniwersytet Warszawski zapisało się 263 studentów urodzonych w Wilnie, 431 we Lwowie, 327 w Krakowie, 143 w Grodnie, 140 w Pińsku, 101 w Stanisławowie, $5^{1} \mathrm{w}$ Tarnopolu i $41 \mathrm{w}$ Łucku, by wymienić tylko ważniejsze miasta Polski wschodniej i południowej ${ }^{174}$.

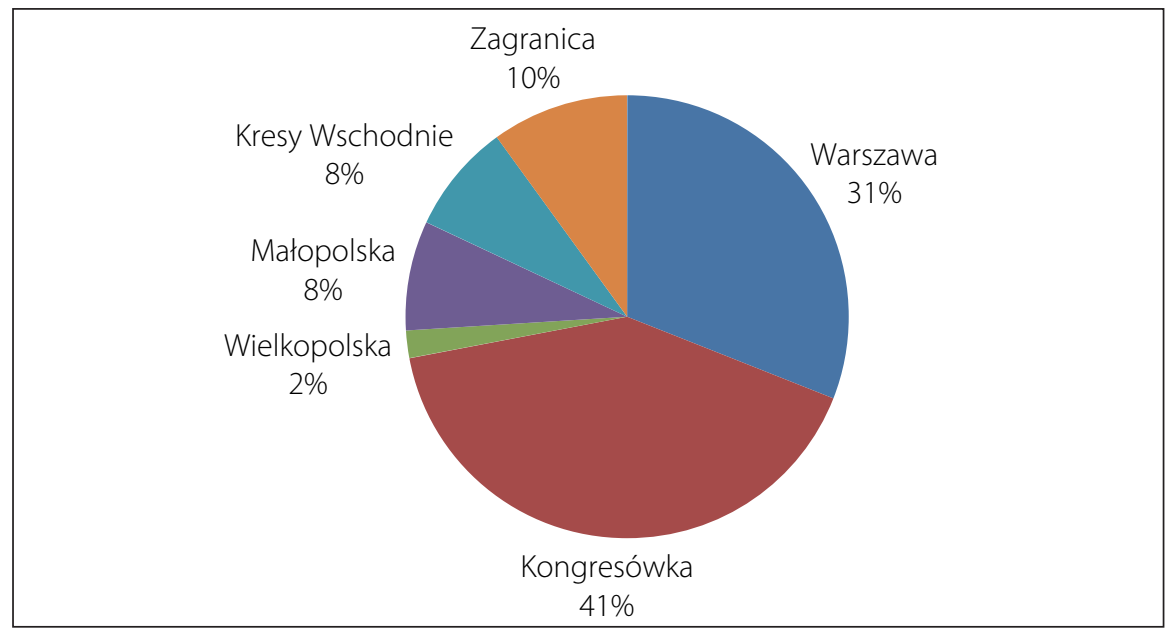

Wykres 2. Pochodzenie terytorialne studentów UW (rok akademicki 1932/1933) 
Co ciekawe, atrakcyjność stolicy niemal zupełnie nie działała natomiast na osoby pochodzące $\mathrm{z}$ dawnego zaboru pruskiego, jakkolwiek utworzony w 1919 r. Uniwersytet Poznański nie mógł się poszczycić takimi tradycjami jak uczelnie w Krakowie, Wilnie czy Lwowie. Według statystyk uniwersyteckich z Wielkopolski wywodziło się na początku lat 20. 2,3\% studentów, później odsetek ten spadł do $1,5 \%{ }^{175}$. W całym okresie 1915-1939 z Poznania pochodziło zaledwie 45 osób immatrykulowanych na Uniwersytecie Warszawskim, z Bydgoszczy 17, z Torunia - 14, z Grudziądza - 10, zaś z Katowic - 8. Z pomniejszych miast i miasteczek Wielkopolski i Pomorza na studia do Warszawy wyjechało dosłownie po parę osób ${ }^{176}$. Wskazuje to na bardzo silnie poczucie odrębności regionalnej wśród mieszkańców dawnego zaboru pruskiego, którzy ponadto prawdopodobnie niekiedy wciąż chętniej wybierali naukę w Berlinie, Wrocławiu lub innych niemieckich ośrodkach akademickich.

Zaskakująco wysoki wydaje się, na pierwszy rzut oka, odsetek studentów Uniwersytetu Warszawskiego urodzonych za granicą. Na początku lat 20. wynosił on blisko 8\%, a w ciągu 10 następnych lat wzrósł nawet do ponad $10 \%$. W sporym stopniu był on, jak należy przypuszczać, dziedzictwem rozbiorów, podczas których wielu Polaków los rozrzucił po licznych krajach, w tym zwłaszcza po państwach zaborczych, skąd różnymi drogami trafiali później do ojczyzny. Największą grupę wśród pochodzących z zagranicy słuchaczy Uniwersytetu Warszawskiego stanowiły osoby urodzone w Rosji (nie licząc Kongresówki i Kresów, o których była już mowa wcześniej). Z samych tylko większych miast imperium carskiego wywodziło się ponad $3 \%$ studentów, w tym $5^{28}$ z Kijowa, 306 z Petersburga i 293 z Moskwy ${ }^{177}$. Do rzadkości nie należeli jednak słuchacze, którzy przyszli na świat w miejscowościach dziś dla nas tak egzotycznych jak Charbin, Archangielsk, Tomsk czy Taszkient.

Obok potomków zesłańców, urzędników, albo wojskowych w służbie carskiej, pochodzenie z Rosji deklarowali także studenci z polskich rodzin osiadłych od wieków na wschodnich rubieżach dawnej Rzeczpospolitej. Przykładem może być Tadeusz Manteuffel, późniejszy wybitny historyk średniowiecza, profesor i kronikarz Uniwersytetu. Urodzony w 1902 r. w Rzeżycy w Inflantach Polskich (obecnie Rēzkene na Łotwie), już przed wybuchem I wojny światowej rozpoczął naukę w gimnazjum w Warszawie, skąd jednak przed zajęciem miasta przez wojska niemieckie latem 1915 r. ewakuował się wraz z rodziną do Petersburga. Do Polski wrócił dopiero jesienią 1918 r. i uzyskawszy rok później maturę, wstąpił na Wydział Filozoficzny UW' ${ }^{178}$. Młodszy od niego o 11 lat Józef Garliński - też znany historyk, specjalizujący się 
po latach w dziejach II wojny światowej - już po traktacie ryskim wraz z najbliższymi opuścił, nie bez przygód zresztą, spustoszony majątek w Garlinach na ziemi kijowskiej i przez zieloną granicę przedostał się do Polski ${ }^{179}$. Losy obu, podobnie jak wielu innych studentów Uniwersytetu Warszawskiego z „zagranicy”, stanowiły przeskok z zanikającego szlacheckiego świata I Rzeczypospolitej ku rodzącej się nowoczesności II Rzeczypospolitej.

Nie wszyscy studenci urodzeni za granicą byli oczywiście Polakami - znajdowali się wśród nich również obywatele innych państw. $\mathrm{Na}$ podstawie danych, jakimi dysponujemy dla początku lat 3o., możemy wyróżnić wśród nich 3 grupy, liczące wówczas w sumie 59 osób (0,7\% wszystkich słuchaczy). Pierwszą z nich, bardzo nieliczną (8 osób), stanowili studenci deklarujący przynależność państwową rosyjską lub ukraińską. Byli oni de facto bezpaństwowymi emigrantami, których rodziny znalazły w Polsce schronienie przed bolszewikami. Podejmowali naukę na Uniwersytecie na takich samych prawach jak Polacy, lecz stanowili wyraźnie odrębne środowisko. Wydawali nawet własne gazety.

Drugą grupę tworzyli studenci narodowości polskiej lub pochodzenia polskiego będący obywatelami innych państw, a także cudzoziemcy, których jeden z rodziców był Polakiem. W roku akademickim 1931/1932 było ich 26, w tym 12 z Łotwy, 5 z Litwy, 6 z Czechosłowacji, 2 z Rumunii i 1 ze Stanów Zjednoczonych ${ }^{180}$. Nietrudno zauważyć, że pochodzenie studentów o polskich korzeniach dość wiernie odzwierciedlało ówczesną geografię rozmieszczenia mniejszości polskich w krajach ościennych. Niektórzy z nich trafili do Warszawy w wyniku przeprowadzki rodziny, np. George Chitulescu, który z tego względu przeniósł się w 1929 r. z uniwersytetu w Bukareszcie na Wydział Lekarski UW ${ }^{181}$. Większość jednak zapisywała się na Uniwersytet Warszawski, chcąc uzyskać wyższe wykształcenie w języku ojczystym, co nie było możliwe w państwach, z których pochodzili. Przykładem może być urodzony w Trzyńcu na Śląsku Cieszyńskim Karol Klus, który w 1930 r. przyjechał studiować na Uniwersytecie Warszawskim teologię protestancką, najpewniej z zamiarem późniejszego powrotu do Czechosłowacji i podjęcia pracy jako pastor wśród tamtejszych Polaków ${ }^{182}$. W innych przypadkach podjęcie nauki wiązało się z decyzją o trwałej reemigracji do Polski. Znajdował się wśród nich m.in. obywatel brytyjski Ryszard Truszkowski, późniejszy docent na Wydziale Lekarskim. Zapisał się on na Uniwersytet Warszawski mając za sobą ukończone studia chemiczne na University College w Londynie. W 1925 r. podjął jako asystent pracę na Wydziale Weterynaryjnym UW, 2 lata później obronił doktorat na Wydziale Przyrodniczym, a w 1930 r. przeniósł się na Wydział Lekarski 
na stanowisko starszego asystenta, a równocześnie rozpoczął tam studia medyczne, które ukończył w 1935 r., zdobywając trzeci już z kolei dyplom doktorski ${ }^{183}$. Wiek XX pisał jednak swoje własne scenariusze na przekór ludzkim planom: Klus po 1945 r. trafił nie na Zaolzie, lecz do Kluczborka, na tzw. ziemie odzyskane, gdzie organizował parafię ewangelicką dla ludności autochtonicznej ${ }^{184}$, natomiast Truszkowski objął w czasie wojny odpowiedzialną funkcję dowódczą w brytyjskich służbach specjalnych, organizując m.in. w czerwcu 1940 r. ewakuację z Francji do Anglii polskiego premiera i naczelnego wodza, gen. Władysława Sikorskiego ${ }^{185}$.

Poniekąd najciekawszą, a jednocześnie najbardziej zróżnicowaną i barwną grupę stanowili studenci cudzoziemscy, niedeklarujący polskiego jako języka ojczystego, ani bliższych związków rodzinnych z Polską. Na początku lat 3o. było wśród nich 5 Anglosasów, 2 Bułgarów, 2 Francuzów, Estończyk, Grek, Ormianin, Rumun, Serb, Węgier, a nawet Chińczyk. Część z nich przybywała na Uniwersytet Warszawski jako stypendyści rządu polskiego, najczęściej aby kontynuować tu studia historyczne bądź polonistyczne. Zaliczali się do nich m.in. Francuzi Jacques Arnaudies i Solange Beaulieux z podyplomowej École Nationale des Langues Orientales Vivantes w Paryżu, których dziś uznalibyśmy raczej za doktorantów niż studentów (Arnaudies tytułował się nawet, zdecydowanie nieco na wyrost, profesorem $)^{186}$. Stypendystą władz RP był również najbardziej egzotyczny słuchacz UW w dwudziestoleciu międzywojennym, Yu Houo Joei. Po ukończeniu Uniwersytetu Francusko-Chińskiego w Pekinie podjął on studia doktoranckie w Lyonie, skąd przyjechał do Warszawy na rok akademicki 1931/1932. Na Wydziale Humanistycznym uczęszczał na wykłady z literatury polskiej. Później pracował na uczelni jako lektor języka chińskiego ${ }^{187}$. Z kolei Ernst Bahr, Niemiec z Wolnego Miasta Gdańska studiujący germanistykę, filozofię i historię na tamtejszej politechnice, zapisał się na własną rękę na Wydział Humanistyczny UW, uczęszczając w roku akademickim 1933/1934 m.in. na zajęcia z dziejów nowożytnych, etnografii i literatury staropolskiej, jak również na zajęcia z języka polskiego dla cudzoziemców. Najwyraźniej okazały się one przydatne, gdyż już po wojnie Bahr stał się dość znanym w Niemczech Zachodnich specjalistą od historii Polski, blisko powiązanym ze Związkiem Wypędzonych ${ }^{188}$.

Odrębną kategorią studentów cudzoziemskich byli słuchacze Studium Teologii Prawosławnej z Bałkanów i Europy Południowo-Wschodniej, przyciągnięci do Warszawy, jak należy przypuszczać, renomą tego wydziału. Podobnie jak w przypadku Ilie Băcioiu z Rumunii, stypendysty 


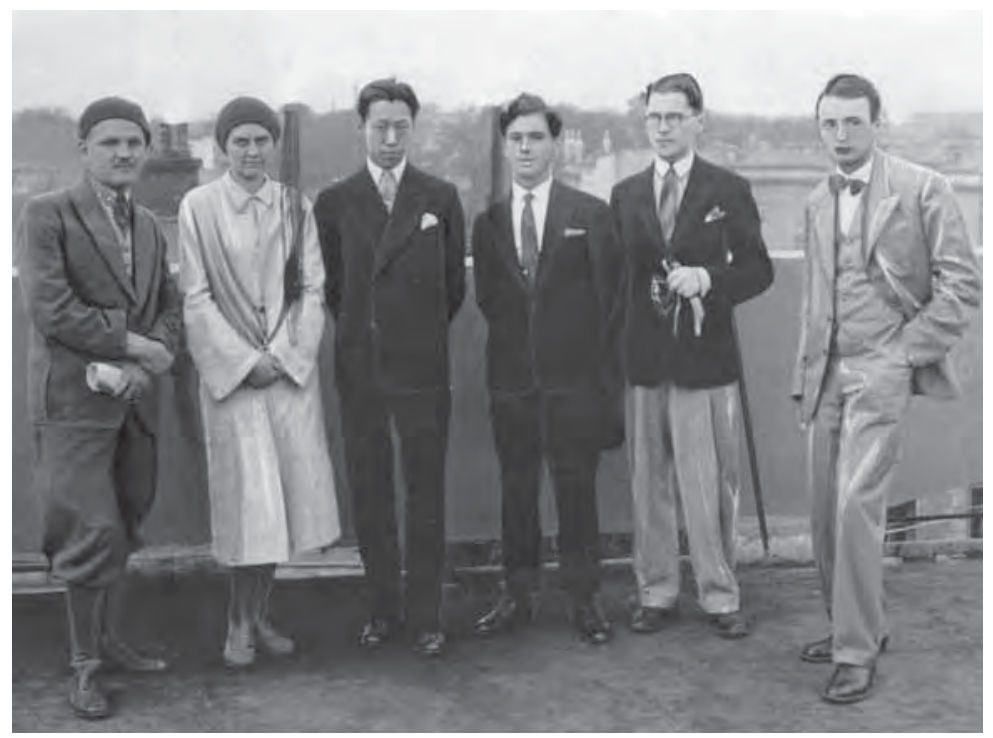

38. Chiński student UW Yu Houo Joei, późniejszy lektor języka chińskiego, na wycieczce w Krakowie, sierpień $1930 \mathrm{r}$.

tamtejszego patriarchy, studia na Uniwersytecie Warszawskim stanowiły dla nich ważny etap kariery duchownej ${ }^{189}$.

Wspomnieć trzeba wreszcie o obcokrajowcach, którzy wstąpili na uczelnię na skutek zbiegu okoliczności. Przykładem może być jeden ze studentów jugosłowiańskich, który przyjechał do Warszawy do brata, sekretarza tamtejszego poselstwa i w październiku 1934, r. zapisał się na Wydział Farmaceutyczny UW. Po przeniesieniu brata rok później do Belgradu znalazł się w trudnych warunkach materialnych, utrzymując się tłumaczeniami z greki, tureckiego, rumuńskiego i bułgarskiego, dopóki nie otrzymał stypendium Federacji Słowiańskich Farmaceutów w Warszawie. Najwyraźniej jednak jego sytuacja nie uległa trwałej poprawie, gdyż w czerwcu 1937 r. został zawieszony w prawach akademickich w wyniku oskarżenia o przywłaszczenie cudzego mienia. Wkrótce potem otrzymał świadectwo odejścia z Uniwersytetu i zapewne powrócił do swej ojczyzny ${ }^{190}$.

Podsumowując, można powiedzieć, iż w okresie międzywojennym Uniwersytet Warszawski był ośrodkiem akademickim o znaczeniu przede wszystkim regionalnym. Jego studenci rekrutowali się głównie z terenów dawnej Kongresówki oraz, w mniejszym stopniu, z ziem wschodnich II Rzeczpospolitej. Uczelnia przyciągała również polskich repatriantów z Rosji, a także Polaków pochodzących z innych państw. Gościła też niewielką liczbę studentów cudzoziemskich, przeważnie zainteresowanych kulturą i dziejami Polski. 


\section{Struktura płci studentów}

Międzywojenny Uniwersytet Warszawski był widownią postępującej emancypacji kobiet, które - w przeciwieństwie do czasów carskich - miały prawo się nań zapisywać już od momentu reaktywacji uczelni przez niemieckie władze okupacyjne w 1915 r. Wśród ogółu immatrykulowanych

Tabela 6. Liczba i odsetek kobiet wśród studentów UW 1915-1939

\begin{tabular}{|c|c|c|}
\hline Rok akademicki & Liczba kobiet & Odsetek kobiet \\
\hline $1915 / 16$ & 94 & $9,0 \%$ \\
\hline $1916 / 17$ & 180 & $11,1 \%$ \\
\hline $1917 / 18$ & 404 & $18,2 \%$ \\
\hline $1918 / 19$ & 1084 & $23,7 \%$ \\
\hline $1919 / 20$ & 1626 & $35,0 \%$ \\
\hline $1920 / 21$ & 2086 & $33,6 \%$ \\
\hline $1921 / 22$ & 2480 & $34,3 \%$ \\
\hline $1922 / 23$ & 2936 & $34,1 \%$ \\
\hline $1923 / 24$ & 2985 & $34,9 \%$ \\
\hline $1924 / 25$ & 2947 & $36,2 \%$ \\
\hline $1925 / 26$ & 3137 & $36,8 \%$ \\
\hline $1926 / 27$ & 3253 & $36,0 \%$ \\
\hline $1927 / 28$ & 3353 & $35,8 \%$ \\
\hline $1928 / 29$ & 3466 & $37,8 \%$ \\
\hline $1929 / 30$ & 3551 & $38,9 \%$ \\
\hline $1930 / 31$ & 3620 & $39,5 \%$ \\
\hline $1931 / 32$ & 3546 & $41,2 \%$ \\
\hline $1932 / 33$ & 3996 & $40,2 \%$ \\
\hline $1933 / 34$ & 3771 & $39,4 \%$ \\
\hline $1934 / 35$ & 3736 & $39,3 \%$ \\
\hline $1935 / 36$ & 3426 & $36,8 \%$ \\
\hline $1936 / 37$ & 3728 & $39,8 \%$ \\
\hline $1937 / 38$ & 3700 & $40,5 \%$ \\
\hline $1938 / 39$ & 3647 & $42,3 \%$ \\
\hline
\end{tabular}

Źródło: T. Manteuffel, Uniwersytet Warszawski w latach 1915/16-1934/35. Kronika, Warszawa 1936; AUW, AcUW RP/66; SUW 1934/1935 i 1935/1936, s. 45 .

Uwaga: zestawienie uwzględnia również tzw. wolnych słuchaczy. 
w latach 1915-1939 znalazło się ich 21 379, czyli 37\% ${ }^{191}$. W ogólnym rozrachunku kobiety stanowiły zatem wciąż jeszcze mniejszość, systematycznie wzrastał jednak, mimo pewnych wahań, ich odsetek wśród osób wstępujących na studia. W 1915 r. wynosił on $9,6 \%$, w 1921 r. 37\%, dekadę później - 43,3\%, a w 1938 r., po wcześniejszym wyrównaniu spadku, do jakiego doszło w połowie lat 30. - aż $47,2 \%{ }^{192}$.

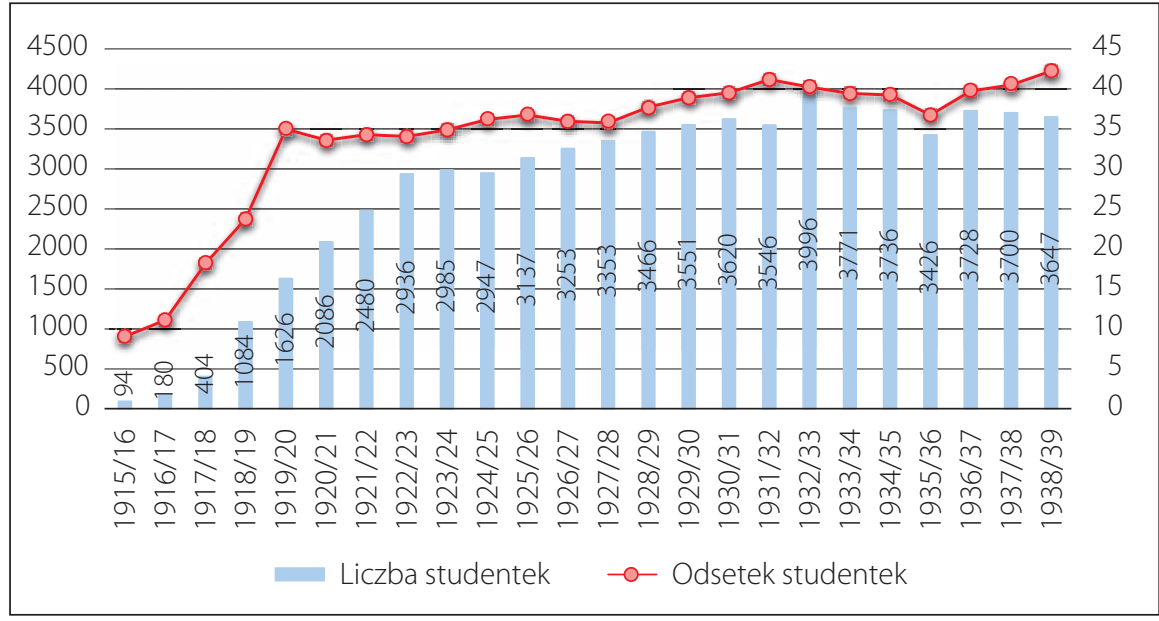

Wykres 3. Liczba i odsetek studentek UW 1915-1939

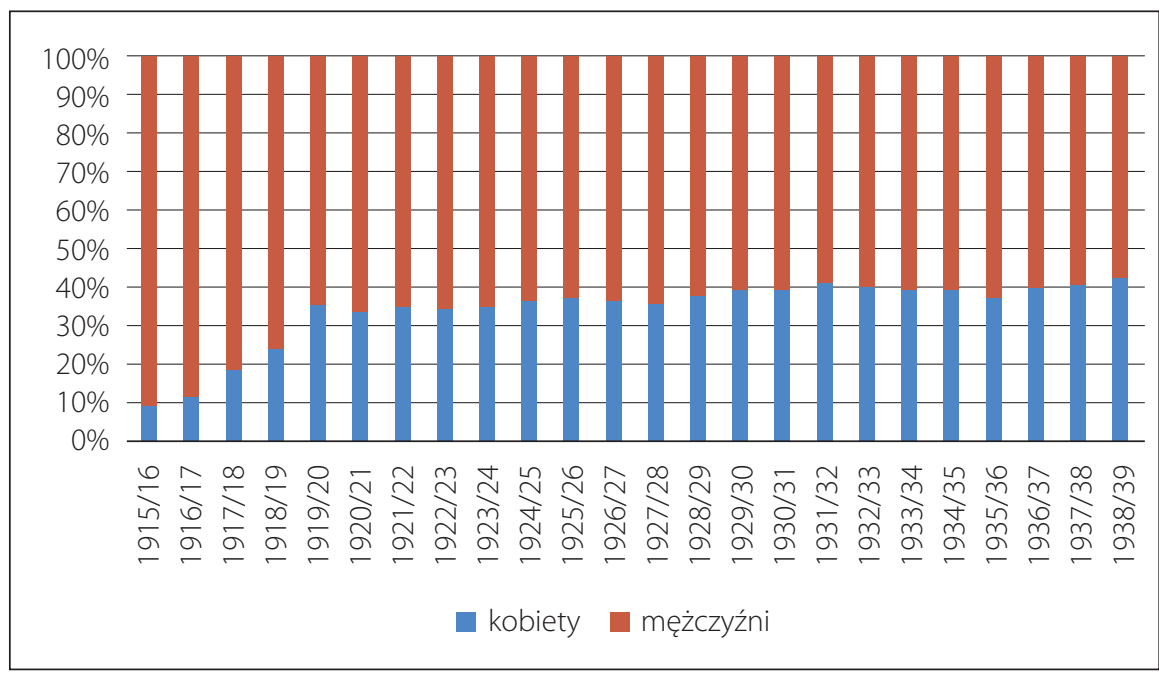

Wykres 4. Struktura płci słuchaczy UW 1915-1939 
Odpowiednio do tego wzrastał odsetek studentek w skali całej uczelni, który w roku akademickim 1920/1921 przekroczył 33\%, dekadę później $39 \%$, natomiast w ostatnim roku akademickim przed wybuchem II wojny światowej osiągnął $4,2,3 \%{ }^{193}$. Było to zgodne z trendem, który występował w całym kraju, choć Uniwersytet Warszawski wyraźnie wyprzedzał pod względem stopnia feminizacji wszystkie inne polskie uniwersytety, nie mówiąc nawet o politechnikach. W połowie lat zo. wśród państwowych szkół wyższych większym odsetkiem kobiet mogły wykazać się jedynie warszawska Akademia Szkół Pięknych oraz tamtejsza Akademia Stomatologiczna ${ }^{194}$.

$\mathrm{Na}$ Uniwersytecie Warszawskim, podobnie jak na innych uczelniach w II Rzeczypospolitej, kobiety wybierały na ogół inne kierunki studiów niż mężczyźni. Najrzadziej zapisywały się na fakultety teologiczne, co wynikało z faktu, iż kształciły one przede wszystkim przyszłych duchownych: w latach 1915-1939 jedynie 7 pań studiowało na Studium Teologii Prawosławnej, a 4, na Wydziale Teologii Ewangelickiej. Bardzo niewiele $\mathrm{z}$ nich, bo tylko $8 \% \mathrm{w}$ całym badanym okresie, wstąpiło również na weterynarię. Kobiety stanowiły $20 \%$ wszystkich immatrykulowanych na Wydziale Prawa (w pierwszym roku akademickim po otwarciu Uniwersytetu studiowały tam tylko 2 kobiety!) oraz $21 \%$ na Wydziale Lekarskim. Na Wydziale Matematyczno-Przyrodniczym panie stanowiły w okresie międzywojennym w sumie $38 \%$ słuchaczy, a na Wydziale Farmaceutycznym - 46\%. Najbardziej sfeminizowane były: Wydział Filozoficzny, gdzie w latach 1915-1927 odsetek studiujących kobiet osiągnął $52 \%$, oraz będący jego kontynuacją Wydział Humanistyczny, na którym analogiczny współczynnik dochodził do $71 \%{ }^{195}$.

Miało to wpływ na strukturę płci na poszczególnych kierunkach. $\mathrm{Na}$ Wydziale Prawa w pierwszych latach niepodległości odsetek pań wzrósł skokowo do $18 \%$, lecz już ok. 1922 r. zaczął spadać, aby dopiero na początku lat 30. ustabilizować się na poziomie ok. 20\%. Podobna tendencja występowała na Wydziale Lekarskim, gdzie ten sam wskaźnik zmniejszył się z 34\% do 19-22\%, a także na Wydziale Farmaceutycznym (wzrost do $65 \% \mathrm{w}$ połowie lat 20., a następnie stopniowy spadek do 4,0\%). Również na Wydziale Filozoficznym - choć już w roku akademickim 1917/1918 uczyło się tam nieco więcej kobiet niż mężczyzn - po gwałtownym wzroście odsetka studiujących płci pięknej do 66\% w roku akademickim 1920/1921, w kolejnych latach spadł on do 54\%. Dopiero w połowie lat zo., już po podziale Wydziału Filozoficznego na kierunki matematyczno-przyrodniczy i humanistyczny, współczynnik feminizacji umocnił się tam, dochodząc do $47 \%$ na pierwszym z nich i do $78 \%$ na drugim ${ }^{196}$. 
Tabela 7. Porównanie struktury płci na poszczególnych wydziałach UW w roku akademickim $1928 / 19^{29}$ i $1937 / 193^{8}$

\begin{tabular}{|c|c|c|c|c|c|c|c|c|}
\hline \multirow[b]{2}{*}{ Jednostka } & \multicolumn{2}{|c|}{$\begin{array}{l}\text { Liczba } \\
\text { mężczyzn }\end{array}$} & \multicolumn{2}{|c|}{$\begin{array}{l}\text { Odsetek } \\
\text { mężczyzn }\end{array}$} & \multicolumn{2}{|c|}{ Liczba kobiet } & \multicolumn{2}{|c|}{ Odsetek kobiet } \\
\hline & 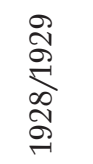 & 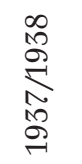 & 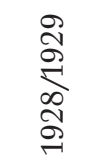 & 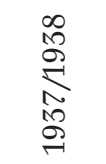 & 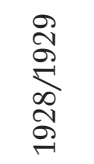 & 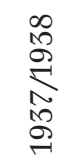 & 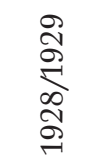 & 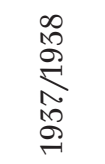 \\
\hline $\begin{array}{l}\text { Wydział Teologii } \\
\text { Katolickiej }\end{array}$ & 59 & 57 & $100 \%$ & $100 \%$ & 0 & 0 & $0 \%$ & $0 \%$ \\
\hline $\begin{array}{l}\text { Wydział Teologii } \\
\text { Ewangelickiej }\end{array}$ & 81 & 82 & $97,6 \%$ & $98,8 \%$ & 2 & 1 & $2,4 \%$ & $1,2 \%$ \\
\hline $\begin{array}{l}\text { Studium } \\
\text { Teologii } \\
\text { Prawosławnej }\end{array}$ & 174 & 123 & $100 \%$ & $98,4 \%$ & 1 & 2 & $0 \%$ & $1,6 \%$ \\
\hline Wydział Prawa & 2260 & 1795 & $85 \%$ & $78,9 \%$ & 399 & 480 & $15 \%$ & $21,1 \%$ \\
\hline $\begin{array}{l}\text { Wydział } \\
\text { Lekarski }\end{array}$ & 848 & 722 & $81,1 \%$ & $76,1 \%$ & 197 & 129 & $18,9 \%$ & $23,9 \%$ \\
\hline $\begin{array}{l}\text { Wydział } \\
\text { Humanistyczny }\end{array}$ & 928 & 928 & $30,5 \%$ & $33,5 \%$ & 2117 & 1839 & $69,5 \%$ & $66,5 \%$ \\
\hline $\begin{array}{l}\text { Wydział } \\
\text { Matematyczno- } \\
\text {-Przyrodniczy }\end{array}$ & 1014 & 755 & $63,7 \%$ & $49,8 \%$ & 577 & 760 & $26,3 \%$ & $50,2 \%$ \\
\hline $\begin{array}{l}\text { Wydział } \\
\text { Farmaceutyczny }\end{array}$ & 92 & 149 & $35,9 \%$ & $54,4 \%$ & 164 & 125 & $64,1 \%$ & $45,6 \%$ \\
\hline $\begin{array}{l}\text { Wydział } \\
\text { Weterynaryjny }\end{array}$ & 259 & 303 & $96,6 \%$ & $88,3 \%$ & 9 & 40 & $3,4 \%$ & $11,7 \%$ \\
\hline Ogółem & 5715 & 4914 & $62,2 \%$ & $59,3 \%$ & 3466 & 3376 & $37,8 \%$ & $40,7 \%$ \\
\hline
\end{tabular}

Źródło: Rocznik polityczny i gospodarczy 1939, Warszawa 1939, s. 513; Źródło: T. Manteuffel, Uniwersytet Warszawski w latach 1915/16-1934/35. Kronika, Warszawa 1936, s. 310.

Jak można zauważyć, w całym okresie 1915-1939 kobiety znacznie rzadziej niż mężczyźni dostawały się na Uniwersytecie Warszawskim na prawo, medycynę, farmację i weterynarię, znacznie częściej niż oni studiowały natomiast nauki humanistyczne. $Z$ danych, jakimi dysponujemy dla roku akademickiego 1934/1935, wynika, iż było to po części efektem dyskryminacji przy naborze na studia. (Kandydatów na studia medyczne, farmaceutyczne i weterynaryjne obowiązywał egzamin wstępny). Można to stwierdzić na podstawie dysproporcji pomiędzy odsetkiem kandydatów jednej i drugiej płci, którzy zostali przyjęci na poszczególne kierunki. $\mathrm{Na}$ farmację dostało się bowiem $62 \%$ zdających mężczyzn 
i tylko 27\% kobiet, zaś na medycynę odpowiednio 32\% i $26 \%$. Różnice te wydają się zbyt duże, aby można było uznać je za efekt przypadku, wszystko wskazuje na to, że na obu tych wydziałach stosowano po cichu rodzaj niepisanego numerus clausus dla płci pięknej. (Potwierdza to także przebieg egzaminów wstępnych na Wydział Lekarski w latach 20., który omawiam w rozdziale poświęconym charakterowi studiów). Dyskryminacja kobiet nie występowała natomiast przy przyjmowaniu na studia prawnicze. Podobnie zresztą działo się w skali całego kraju, przynajmniej w roku, którego dotyczą zachowane dane ${ }^{197}$.

O ile więc przewaga mężczyzn na medycynie i farmacji była w pewnym stopniu spowodowana zamierzoną polityką rekrutacyjną Uniwersytetu, o tyle na prawie musiała mieć źródło w zjawiskach szerszych, występujących również poza jego murami. Można przypuszczać, że najważniejszy z nich stanowiła męska dominacja w zawodach, do których drogę tradycyjnie otwierało ukończenie tego wydziału. W 1931 r. w całej służbie publicznej II Rzeczypospolitej zatrudnionych było jedynie około 300 kobiet $^{198}$, głównie na stanowiskach pomocniczych, jako sekretarki, biuralistki itp. Przez całe dwudziestolecie międzywojenne żadna z nich nie została ministrem (nikomu nie śniło się tym bardziej, aby mogła być „ministrą”), dyrektorem departamentu, wojewodą, ani nawet starostą powiatowym czy notariuszem. Tylko jedna kobieta została mianowana prokuratorem, kilka sędziami w sądach dla nieletnich $^{199}$. Kandydatki na studia wyższe musiały mieć świadomość tego stanu rzeczy, stąd rzadko wybierały prawo jako kierunek dający niewielkie szanse na znalezienie pracy. Podobny mechanizm działał zresztą niewątpliwie - niezależnie od dyskryminacyjnych praktyk przy naborze na studia - również w przypadku medycyny, ponieważ zawód lekarza także należał wówczas do silnie zmaskulinizowanych: w 1938 r. było w Polsce 2034 lekarek, stanowiły one 16\% czynnych zawodowo medyków ${ }^{200}$.

Mutatis mutandis, na tej samej zasadzie wytłumaczyć można, dlaczego kobiety tak często decydowały się na studiowanie na Uniwersytecie nauk humanistycznych i matematyczno-przyrodniczych - oba kierunki przygotowywały do pracy w oświacie, a zawód nauczyciela był w II Rzeczypospolitej bardzo silnie, jak na ówczesne warunki, sfeminizowany. W połowie lat 30. kobiety stanowiły prawie połowę kadry w szkołach powszechnych i 37,5\% w średnich ogólnokształcących ${ }^{201}$. W tym przypadku na rodzaj wybieranych przez kobiety studiów bardzo istotny wpływ miały zatem korzystne perspektywy późniejszego znalezienia pracy w zawodzie. Na rzecz takiego wyboru przemawiały również pozytywistyczne wzorce kulturowe, kształtujące aspiracje wielu 
kandydatek na studia na wzór Stasi Bozowskiej, bohaterki Siłaczki Żeromskiego. Ideały takie przyświecały np. Marii Eigerównie, która zdecydowała się porzucić przepych fabrykanckiego domu, aby po studiach przyrodniczych na Uniwersytecie szerzyć oświatę w żydowskim sztetlu w Drohiczynie, co jej samej wydało się później podróżą w czasie w mroki średniowiecza ${ }^{202}$. Nie bez znaczenia był także obowiązujący wówczas wzorzec aktywności zawodowej kobiet, kładący nacisk na pełnienie służby wobec społeczeństwa kosztem rezygnacji z ambicji osobistych $^{203}$. Nie ulega jednak wątpliwości, iż większość kobiet podchodziła do nauki na Uniwersytecie bardzo racjonalnie, widząc w niej przede wszystkim szansę zdobycia zawodu pozwalającego na podjęcie pracy zawodowej. Inną rzeczą pozostaje, że wiele z nich rezygnowało później ze swych planów, poświęcając się rodzinie, nie mogąc uzyskać etatu itp.

Nie udało mi się odnaleźć żadnych dokumentów, które stanowiłyby oficjalną podstawę prawną dyskryminacji kobiet podczas rekrutacji na kierunki takie jak medycyna i farmacja. Jak się wydaje, tego rodzaju praktyki miały raczej charakter odruchowy i nie musiały być odgórnie wprowadzane, gdyż wynikały z konsensu zasiadających w komisjach profesorów, którzy oceniali kandydatki na studia bardziej krytycznie niż kandydatów płci męskiej. Źródłem takiej postawy mogło być przekonanie, iż kierunki te, jako zbyt trudne lub odpowiedzialne, nie są przeznaczone dla kobiet, studiuje ich już tam zbyt wiele, albo że w ogóle nie powinny one podejmować nauki w szkołach wyższych. Uprzedzeniom takim dawano wyraz zupełnie otwarcie, na ogól jednak starając się je na różne sposoby zracjonalizować. Przykładem może być sprawozdanie rektora Franciszka Krzyształowicza, profesora Wydziału Lekarskiego UW, za rok akademicki 1924/1925, w którym następująco komentuje on wzrastający odsetek studentek: „Pragnę na chwilkę zatrzymać się na tym fakcie wzmagającej się frekwencji kobiet na Uniwersytecie, co można rozpatrywać z rozmaitych stron. W każdym razie objaw ten nie zdaje się być zdrowym, bo jest to dążność kobiet do pracy najczęściej nieproduktywnej z dużym nakładem pracy i wysiłków w kierunku umysłowym i ekonomicznym. Wysiłek ten dotyczy nie tylko oddzielnych osobników, ale i Państwa, bo studia uniwersyteckie kosztują Państwo b. dużo, muszą zatem dawać maximum wyników. Poddaję to pod rozwagę tych pań, które tą sprawą w szczególności się zajmują i potrafią ocenić, czy ten ruch usamodzielniania kobiet postępuje w odpowiednim kierunku i czy jest w swej większości produktywnym dla życia społecznego"204.

Podobnie uważał inny z rektorów, profesor filologii klasycznej Gustaw Przychocki, który z kolei utyskiwał, iż „kończące studia kobiety 
z tych czy innych powodów swych dyplomów nie wykorzystują" - a więc, w domyśle, ich kształcenie nie jest decyzją racjonalną ${ }^{205}$. Choć dziś poglądy takie uznane zostałyby za przejaw seksizmu, w tamtych czasach mieściły się w granicach poprawności politycznej, brak jest bowiem świadectw, by wywołały czyjekolwiek oburzenie. Przekładały się one, rzecz jasna, na traktowanie studentek podczas studiów, o czym będzie mowa w jednym z dalszych rozdziałów.

Struktura miejsca zamieszkania kobiet studiujących na Uniwersytecie Warszawskim była inna niż w przypadku mężczyzn. Przede wszystkim, znacznie większy był wśród nich odsetek osób pochodzących ze stolicy. W 1915 r. studentki urodzone w Warszawie stanowiły 57\% wszystkich immatrykulowanych wtedy pań, podczas gdy dla mężczyzn wskaźnik ten wynosił 50\%. W 1921 r. było to odpowiednio $36 \%$ i $25 \%$, w 1926 r. $-32 \%$ i $25,5 \%$, w 1931 r. - 38\% i $26 \%$, w 1935 r. - 30\% i $22 \%$, a w 1938 r. $-36 \%$ i $22 \%$. W całym okresie międzywojennym z Warszawy pochodziło bez mała 35\% słuchaczek oraz 25\% słuchaczy Uniwersyte$\mathrm{tu}^{206}$. Relatywnie mniej kobiet niż mężczyzn wywodziło się natomiast z dawnej Kongresówki, spoza stolicy. W połowie lat 20. osoby urodzone na tych terenach stanowiły $38 \%$ wszystkich studiujących na UW kobiet i aż 50\% mężczyzn. Odsetki studentów obojga płci z bardziej odległych części kraju były do siebie zbliżone i wynosiły wówczas nieco mniej niż 20\%. W ciągu kolejnych 8 lat sytuacja zmieniła się częściowo, do czego przyczynił się liczniejszy napływ słuchaczy spoza Kongresówki. Wciąż jednak z prowincji pochodziło relatywnie mniej kobiet niż mężczyzn, którzy uczyli się na Uniwersytecie ${ }^{207}$.

Fakty te mówią sporo o różnej mobilności społecznej obu płci i jej odmiennej dynamice. Nietrudno bowiem zauważyć, że od początku lat 3o. kobiety urodzone poza stolicą coraz rzadziej zapisywały się na uczelnię, podczas gdy odsetek wywodzących się stamtąd mężczyzn systematycznie rósł, mimo przejściowych wahań. Wynikało to z kilku przyczyn. W realiach międzywojennych, a zwłaszcza w czasach wielkiego kryzysu, który dotarł do Polski na początku lat 3o., młodym kobietom z prowincji trudniej było utrzymać się samodzielnie w Warszawie, gdyż - poza korepetycjami - większość prac dorywczych, jakie musieli podejmować studenci, była na ogół typowo męska. Po drugie, rodziny dysponujące ograniczonymi środkami materialnymi wolały inwestować w wykształcenie synów niż córek, wychodząc zapewne z założenia, iż mężczyzna będzie musiał utrzymać w przyszłości rodzinę, natomiast kobieta będzie żyć przy mężu. „Mój ojciec uważał, że kobieta nie potrzebuje kończyć nawet gimnazjum, bo i tak niedługo wyjdzie za mąż i urodzi dzieci" - relacjonuje jedna z ówczesnych studentek, która mogła podjąć 
naukę na UW wyłącznie dzięki uporowi matki ${ }^{208}$. Przeciwni studiom córki byli również rodzice Marii Niedźwieckiej (później Ossowskiej), w czym wybitna socjolożka upatrywała później przyczyny dręczącego ją długo kompleksu niższości wobec mężczyzn ${ }^{209}$. Wiązało się to z patriarchalnym modelem ról genderowych, który na prowincji był bardziej rozpowszechniony niż w stolicy, co uznać można za trzeci z powodów zmniejszania się napływu kandydatek na studia spoza Warszawy.

Studiujące na Uniwersytecie Warszawskim kobiety wyróżniały się na tle swych kolegów relatywnie większą zamożnością środowiska rodzinnego. $\mathrm{Na}$ fakt ów zwrócił uwagę pod koniec lat 20 . w swym sprawozdaniu rektor Przychocki ${ }^{210}$, lecz brak jest na ten temat precyzyjnych danych szczegółowych. Można jednak zakładać, że sytuacja na UW nie odbiegała pod tym względem od realiów panujących w całym szkolnictwie wyższym, gdzie aż 8o\% studentek pozostawało na utrzymaniu rodzin, podczas gdy komfort taki miało jedynie $65 \%$ studentów płci męskiej ${ }^{211}$. Z liczb tych wynika pośrednio, iż wysłanie na Uniwersytet córki było większym luksusem niż kształcenie syna, gdyż częściej wymagało utrzymywania jej aż do końca nauki. Mogły sobie na to pozwolić tylko niektóre rodziny, skutkiem czego na Uniwersytecie studiowało więcej zamożnych kobiet niż mężczyzn. Fakt ten wyjaśnia zarazem, dlaczego studentki UW, częściej niż ich koledzy, pochodziły z Warszawy: w stolicy znajdowało się największe skupisko ludzi na tyle dobrze sytuowanych, aby zapewnić wykształcenie wyższe swoim dzieciom, niezależnie od ich płci. Jednocześnie było to dla nich przedsięwzięcie mniej kosztowne niż w przypadku osób pochodzących z prowincji, gdyż nie wymagało ponoszenia wydatków związanych z zakwaterowaniem i wyżywieniem dziecka w obcym mieście.

Kobietom było trudniej ukończyć Uniwersytet niż mężczyznom. Znacznie częściej niż oni „wykruszały się” w trakcie nauki, co widać było już w pierwszych latach niepodległości, kiedy to na różnych wydziałach najpierw gwałtownie wzrósł, a potem równie szybko zmniejszył się odsetek słuchaczek. Tendencja ta utrzymała się do końca lat 30. W ostatniej dekadzie przed wybuchem wojny studia kończyło każdego roku od $8 \%$ do 10,4\% studentek, podczas gdy podobny wskaźnik dla mężczyzn wahał się od $9 \%$ do $16 \%{ }^{212}$. Potwierdzają to statystyki dostępne w uniwersyteckiej bazie danych: jedynie w roczniku rozpoczynającym naukę w 1916 r. zdarzyło się, że odsetek studentek, którym udało się dotrwać na uczelni do uzyskania dyplomu, był większy, niż miało to miejsce w przypadku ich kolegów. W późniejszych latach dysproporcja ta kształtowała się na niekorzyść płci pięknej i sięgała od kilku do kilkunastu punktów procentowych. W skali całego okresu 
Tabela 8. Absolwenci UW wg płci i roku immatrykulacji 1915-1939

\begin{tabular}{|c|c|c|c|c|}
\hline \multirow[t]{2}{*}{ Rok } & \multicolumn{2}{|c|}{$\begin{array}{l}\text { Liczba osób immatrykulowanych } \\
\text { w danym roku, które ukończyły } \\
\text { studia przed } 1 \text { IX } 1939 \text { r. }\end{array}$} & \multicolumn{2}{|c|}{$\begin{array}{c}\text { Odsetek osób immatrykulowanych } \\
\text { w danym roku, które ukończyły } \\
\text { studia przed } 1 \text { IX } 1939 \text { r. }\end{array}$} \\
\hline & kobiety & mężczyźni & kobiety & mężczyźni \\
\hline 1915 & 47 & 467 & $43,9 \%$ & $46,6 \%$ \\
\hline 1916 & 49 & 284 & $51,0 \%$ & $43,6 \%$ \\
\hline 1917 & 88 & 269 & $34,8 \%$ & $41,1 \%$ \\
\hline 1918 & 203 & 544 & $27,0 \%$ & $32,6 \%$ \\
\hline 1919 & 208 & 400 & $27,4 \%$ & $32,8 \%$ \\
\hline 1920 & 36 & 137 & $22,5 \%$ & $35,3 \%$ \\
\hline 1921 & 321 & 930 & $19,9 \%$ & $34,2 \%$ \\
\hline 1922 & 232 & 703 & $22,8 \%$ & $31,9 \%$ \\
\hline 1923 & 250 & 650 & $24,0 \%$ & $34,0 \%$ \\
\hline 1924 & 328 & 644 & $32,9 \%$ & $39,3 \%$ \\
\hline 1925 & 328 & 630 & $32,9 \%$ & $37,9 \%$ \\
\hline 1926 & 344 & 760 & $31,7 \%$ & $39,2 \%$ \\
\hline 1927 & 367 & 781 & $32,3 \%$ & $41,3 \%$ \\
\hline 1928 & 396 & 659 & $35,6 \%$ & $41,6 \%$ \\
\hline 1929 & 369 & 702 & $31,1 \%$ & $42,5 \%$ \\
\hline 1930 & 398 & 786 & $28,8 \%$ & $39,9 \%$ \\
\hline 1931 & 314 & 668 & $22,8 \%$ & $37,1 \%$ \\
\hline 1932 & 267 & 542 & $23,2 \%$ & $32,1 \%$ \\
\hline 1933 & 154 & 398 & $15,7 \%$ & $29,1 \%$ \\
\hline 1934 & 102 & 293 & $11,9 \%$ & $20,5 \%$ \\
\hline 1935 & 34 & 152 & $4,5 \%$ & $10,9 \%$ \\
\hline 1936 & 12 & 37 & $1,5 \%$ & $2,6 \%$ \\
\hline 1937 & 9 & 15 & $1,1 \%$ & $1,2 \%$ \\
\hline 1938 & 0 & 3 & $0,0 \%$ & $0,3 \%$ \\
\hline 1939 & 0 & 0 & $0,0 \%$ & $0,0 \%$ \\
\hline Ogółem & 4842 & 11435 & $22,7 \%$ & $31,7 \%$ \\
\hline
\end{tabular}

Źródło: Opracowane własne na podstawie danych USOS.

międzywojennego wynosiła ona 9\% - Uniwersytet ukończyło 11435 wszystkich immatrykulowanych w latach 1915-1939 mężczyzn i 484,2 kobiet, co stanowiło odpowiednio $31,7 \%$ oraz $22,7 \%{ }^{213}$.

Kobiety studiowały także przeciętnie dłużej niż mężczyźni, zwłaszcza w pierwszych latach po uruchomieniu Uniwersytetu Warszawskiego przez 
Niemców w 1915 r. Wśród słuchaczek immatrykulowanych w $1921 \mathrm{r}$. mediana czasu nauki poprzedzającej uzyskanie dyplomu wynosiła 7 lat i była o 2 lata wyższa niż w przypadku ich kolegów. W trakcie kolejnych 10 lat dysproporcja ta została wprawdzie niemal zupełnie zniwelowana, ale trzeba pamiętać, że część mężczyzn przerywała naukę ze względu na konieczność odbycia zasadniczej służby wojskowej, a zatem nawet kończąc Uniwersytet po tylu latach, co ich koleżanki, studiowali de facto krócej od nich o $\operatorname{rok}^{214}$.

Przyczyn opisanych powyżej zjawisk - większego „wykruszania się” kobiet w czasie studiów i ich dłuższego, niż w przypadku mężczyzn, studiowania - szukać należy w nierównym położeniu obu płci. Kobiety częściej przerywały naukę, gdy pogarszała się sytuacja materialna ich rodzin, ponieważ miały znacznie mniejsze szanse niż ich koledzy na znalezienie dorywczej pracy, pozwalającej samodzielnie sfinansować studia i utrzymać się w Warszawie. Inną przyczyną było zamąż́ójście, po którym nie zawsze mogły kontynuować naukę, chociażby ze względu na macierzyństwo. Nie każda studentka miała pod tym względem takie szczęście jak Irena Krzyżanowska, która po zawieszeniu w prawach studenckich na Wydziale Prawa już jako mężatka, Krzyżanowska-Sendlerowa, powróciła na Uniwersytet i w 1939 r. ukończyła Wydział Humanistyczny ${ }^{215}$.

Podsumowując, chociaż Uniwersytet Warszawski był najbardziej sfeminizowaną uczelnią wyższą przedwojennej Polski, a pod koniec lat 3o. studiowało na nim niemal tyle samo kobiet, co mężczyzn, sytuacja słuchaczek różniła się w zależności od wydziału. Na niektórych kierunkach stanowiły one większość, na innych wciąż pozostawały zaledwie tolerowaną mniejszością, której liczebność ograniczano poprzez dyskryminacyjne praktyki w trakcie naboru na studia. Przede wszystkim jednak na sytuację studentek Uniwersytetu negatywnie rzutowało ogólne położenie kobiet w ówczesnym społeczeństwie, które, jak trafnie ujmuje to tytuł poświęconej tej problematyce monografii, miały równe z mężczyznami prawa, lecz nierówne szanse.

\section{Struktura wyznaniowa i narodowościowa studentów}

Wielonarodowy i wielowyznaniowy charakter przedwojennej Polski przekładał się na strukturę narodowościową słuchaczy Uniwersytetu Warszawskiego. Obok Polaków, którzy od momentu odzyskania niepodległości 
stanowili zdecydowaną większość słuchaczy, studiowali tu przede wszystkim Żydzi, a ich obecność stanowiła od lat 20. powód coraz bardziej gwałtownych ataków ze strony prawicy. Odsetek pozostałych narodowości był natomiast bardzo niewielki i nie miał w praktyce wpływu na sytuację panującą na uczelni.

$\mathrm{Na}$ Uniwersytecie Warszawskim pochodzenie studentów określano na podstawie ich wyznania, uznając za Żydów wszystkich, którzy zadeklarowali religię mojżeszową w wypełnianych przez siebie ankietach personalnych. Formalnie rzecz biorąc, nie stawiano znaku równości pomiędzy wyznaniem a narodowością (w drugiej połowie lat 30 . rozróżniano je nawet wyraźnie w kwestionariuszach osobowych ${ }^{216}$ ), postępowano tak jednak w praktyce. Była to interpretacja szersza, niż gdyby za kryterium żydowskości przyjęto język lub subiektywną świadomość narodową, wykluczała bowiem z grona Polaków nawet całkowicie zasymilowane osoby wyznania mojżeszowego, o ile nie dokonały wcześniej konwersji na chrześcijaństwo. Wynikało to pozornie z przyczyn praktycznych (kryterium wyznaniowe uznać można w ówczesnych warunkach za najbardziej zobiektywizowane), wpisywało się też jednak w antysemickie tendencje, coraz wyraźniej widoczne w kraju już w latach 20. Władze Uniwersytetu Warszawskiego co najmniej od lat 30. w osobach wyznania mojżeszowego widziały raczej "Żydów" niż „żydów". Nie traktowały ich też jako takich samych obywateli Rzeczpospolitej jak studentów pozostałych wyznań, ale konsekwentnie wyszczególniały ich jako osobną kategorię w większości zestawień statystycznych. W pracy tej dla uproszczenia, w ślad za ówczesnym uzusem, posługuję się zamiennie pojęciami „osoby wyznania mojżeszowego" i „Żydzi”, choć nie każdy studiujący na Uniwersytecie Żyd musiał wyznawać religię mojżeszową, ani też nie każdy wyznawca tej religii musiał uważać się za Żyda w sensie etnicznym.

Od 30 IV 1923 r. wyznanie odnotowywano oficjalnie w matrykułach przy nazwisku każdego słuchacza. Władze Uniwersytetu dysponowały jednak odpowiednimi danymi również dla lat wcześniejszych, o czym świadczą częściowo zachowane zestawienia studiujących ${ }^{217}$ oraz statystyki zamieszczone w monografii uczelni przygotowanej w połowie lat 30. przez Tadeusza Manteuffla. Do tego czasu sprawa Żydów studiujących w szkołach wyższych stała się jednym z najgłośniejszych problemów polityki wewnętrznej II Rzeczypospolitej, znajdując przełożenie na obsesyjną wręcz (choć skądinąd przydatną dziś bardzo dla historyka) szczegółowość sprawozdań, obejmujących już nie tylko liczbę i odsetek Żydów w skali całego Uniwersytetu i poszczególnych jego wydziałów, ale także dane na temat uzyskanych przez nich dyplomów 
i przeprowadzonych nostryfikacji dyplomów ${ }^{218}$. Dane takie gromadzono też i publikowano dla całej oświaty wyższej w państwie. Przypominało to podszyte niepokojem mierzenie poziomu szkodliwej substancji w krwi chorego albo stopnia zanieczyszczenia środowiska naturalnego.

$\mathrm{Z}$ czysto statystycznego punktu widzenia można powiedzieć, że ponownie uruchomiony przez Niemców jesienią 1915 r. Uniwersytet Warszawski był uczelnią bardziej „żydowską" niż „polską" - zapisało się nań wówczas $5^{27}$ studentów wyznania mojżeszowego, którzy stanowili 50,8\% ogółu słuchaczy. Sytuację tę uznać należy jednak za wyjątkową. Jak już zostało powiedziane, nieco ponad połowa pierwszego rocznika studentów pochodziła z Warszawy, co - biorąc pod uwagę, iż w tym czasie odsetek żydowskiej ludności miasta wynosił około 4.0\% - musiało skutkować również pewną nadreprezentacją osób wyznania mojżeszowego wśród kandydatów na studia. Pogłębiał ją fakt, iż przed zajęciem Warszawy przez wojska niemieckie w 1915 r. tamtejsza żydowska młodzież męska w znacznie mniejszym stopniu niż polska zmobilizowana została do armii rosyjskiej, była więc liczniej obecna na miejscu w chwili uruchomienia uczelni. W pierwszych latach po otwarciu Uniwersytet przyciągał też prawdopodobnie Żydów relatywnie silniej niż Polaków, ponieważ wcześniej, w czasach carskich byli oni oficjalnie dyskryminowani przy przyjmowaniu na studia, a obecnie mogli „nadrabiać” lata upośledzenia. Należy wreszcie podkreślić, iż nadreprezentacja osób wyznania mojżeszowego występowała w okresie międzywojennym na niemal wszystkich polskich wyższych uczelniach, a zjawisko to miało szersze uwarunkowania kulturowe w postaci etosu nauki i szeroko rozpowszechnionych wśród Żydów strategii awansu społecznego poprzez edukację.

W pierwszych latach funkcjonowania Uniwersytetu Warszawskiego liczba słuchaczy wyznania mojżeszowego systematycznie rosła, dochodząc w roku akademickim 1919/1920 do 1337 osób. W tym samym czasie ich udział względny stopniał jednakże do $28,8 \%$, co było efektem coraz liczniejszego napływu na uczelnię studentów chrześcijańskich (polskich). Po zakończeniu wojny bolszewickiej, w roku akademickim 1920/1921, liczba żydowskich studentów wzrosła skokowo do 2417, czemu towarzyszyła zwyżka o 10 punktów procentowych. Później, mimo że bezwzględna liczba słuchaczy wyznania mojżeszowego zwiększała się aż do 2659 w roku 1922/1923, odpowiadające jej wartości względne spadały, osiągając poziom niecałych $31 \%$. W kolejnych latach, z wyjątkiem roku akademickiego 1932/1933, systematycznie zmniejszała się zarówno liczba żydowskich studentów, jak też ich odsetek w skali Uniwersytetu. W ostatnim roku przed wybuchem II wojny światowej było 
Tabela 9. Liczba i odsetek słuchaczy UW pochodzenia żydowskiego 1915-1939

\begin{tabular}{|c|c|c|}
\hline Rok akademicki & $\begin{array}{c}\text { Liczba studentów } \\
\text { pochodzenia żydowskiego }\end{array}$ & $\begin{array}{c}\text { Odsetek studentów } \\
\text { pochodzenia żydowskiego }\end{array}$ \\
\hline $1915 / 16$ & 527 & $50,7 \%$ \\
\hline $1916 / 17$ & 774 & $47,7 \%$ \\
\hline $1917 / 18$ & 1018 & $45,9 \%$ \\
\hline $1918 / 19$ & 1506 & $33,0 \%$ \\
\hline $1919 / 20$ & 1337 & $28,7 \%$ \\
\hline $1920 / 21$ & 2417 & $38,9 \%$ \\
\hline $1921 / 22$ & 2405 & $33,2 \%$ \\
\hline $1922 / 23$ & 2659 & $30,9 \%$ \\
\hline $1923 / 24$ & 2655 & $31,0 \%$ \\
\hline $1924 / 25$ & 2207 & $27,1 \%$ \\
\hline $1925 / 26$ & 2170 & $25,4 \%$ \\
\hline $1926 / 27$ & 2145 & $23,7 \%$ \\
\hline $1927 / 28$ & 2184 & $23,3 \%$ \\
\hline $1928 / 29$ & 2182 & $23,8 \%$ \\
\hline $1929 / 30$ & 2187 & $24,0 \%$ \\
\hline $1930 / 31$ & 2177 & $23,8 \%$ \\
\hline $1931 / 32$ & 1968 & $22,9 \%$ \\
\hline $1932 / 33$ & 2552 & $25,7 \%$ \\
\hline $1933 / 34$ & 2184 & $22,8 \%$ \\
\hline $1934 / 35$ & 2009 & $21,1 \%$ \\
\hline $1935 / 36$ & 1818 & $19,5 \%$ \\
\hline $1936 / 37$ & 1594 & $17,0 \%$ \\
\hline $1937 / 38$ & 1427 & $15,6 \%$ \\
\hline $1938 / 39$ & 1231 & $14,3 \%$ \\
\hline
\end{tabular}

Źródło: T. Manteuffel, Uniwersytet Warszawski w latach 1915/16-1934/35. Kronika, Warszawa 1936; AUW, AcUW RP/66; SUW 1934/1935 i 1935/1936, s. 45.

Uwaga: zestawienie uwzględnia również tzw. wolnych słuchaczy.

ich już tylko 1231, co odpowiadało 14,3\% ogółu słuchaczy ${ }^{219}$. Immatrykulowanych zostało wtedy na uczelni zaledwie 34,2 Żydów - stanowili oni 13,6\% wśród nowo przyjętych osób ${ }^{220}$.

Przedstawione powyżej zmiany wpisywały się w trendy charakterystyczne dla całej oświaty wyższej na ziemiach polskich, gdzie najpierw w latach 1910/1911-1921/1922 doszło do wzrostu odsetka Żydów na uczelniach z $18,2 \%$ do $24,6 \%$, a następnie do jego gwałtownego spadku 
do $13,2 \% \mathrm{w}$ roku akademickim 1935/1936. Nawet w połowie lat 30 . Uniwersytet Warszawski pozostawał jednak największym skupiskiem studentów wyznania mojżeszowego w całym kraju i drugą po wileńskim Uniwersytecie Stefana Batorego uczelnią państwową z ich największą liczbą względną, dystansując pod tym ostatnim względem Uniwersytet Jana Kazimierza we Lwowie oraz Uniwersytet Jagielloński ${ }^{221}$.

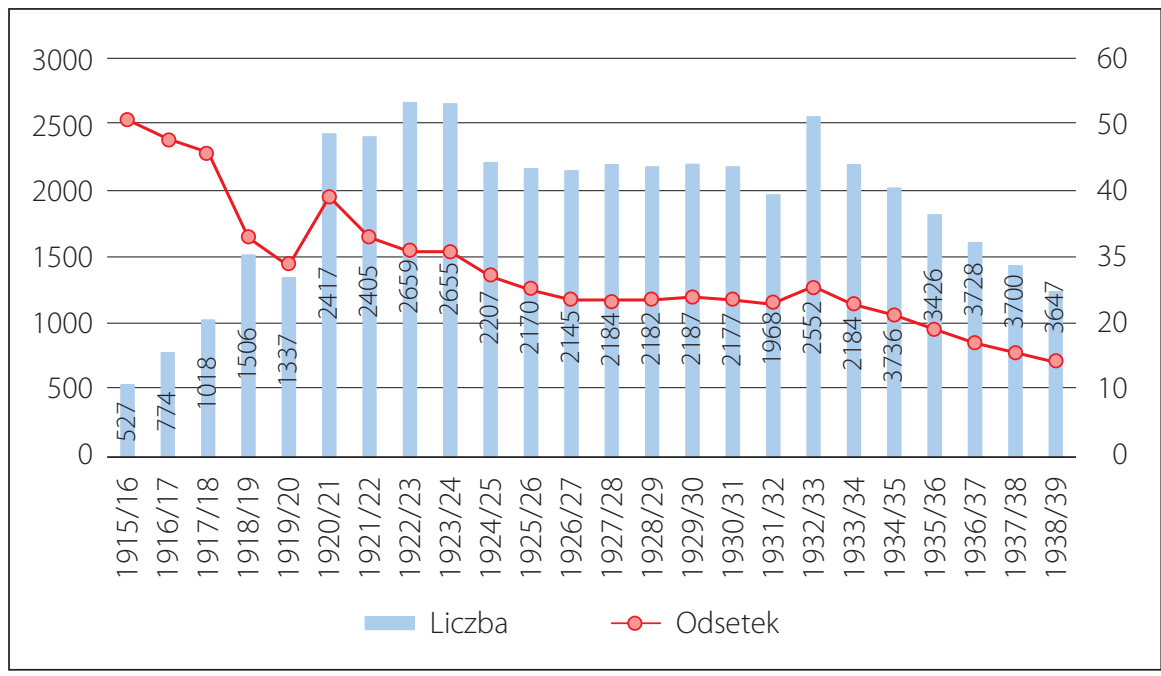

Wykres 5. Liczba i odsetek studentów UW pochodzenia żydowskiego 1915-1939

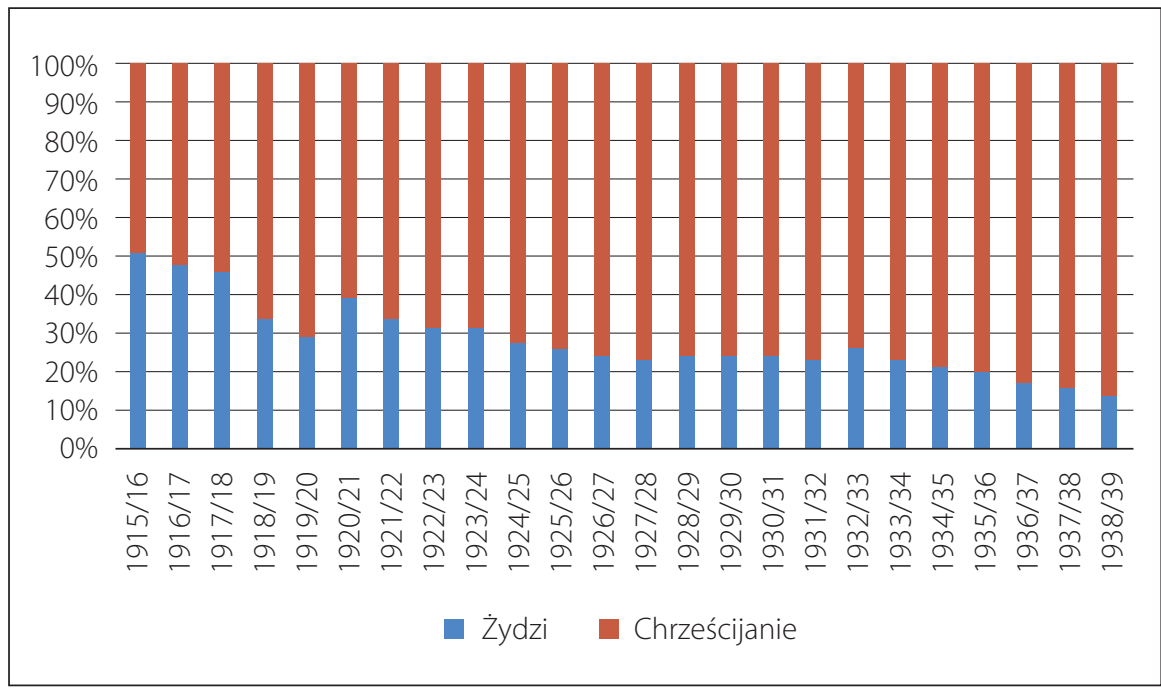

Wykres 6. Struktura wyznaniowa słuchaczy UW 1915-1939 
Niemniej jednak, pomiędzy 1915 a 1939 r. odsetek studentów wyznania mojżeszowego na Uniwersytecie Warszawskim zmniejszył się ponad trzykrotnie, a ich liczba w przededniu wybuchu II wojny światowej była ponad dwukrotnie niższa niż w pierwszej połowie lat 20. Żydzi, z pozycji równorzędnej Polakom grupy słuchaczy, zepchnięci zostali na uczelni do roli niezbyt pokaźnej mniejszości. Była ona wiąż relatywnie liczniejsza niż odsetek Żydów w skali całego państwa, który wynosił wówczas około 10\%, ale konfrontowanie obu tych współczynników, co chętnie czyniono, aby uzasadnić potrzebę odgórnego ograniczenia liczby Żydów na Uniwersytecie, wydaje się metodologicznie błędne. Jeżeli już, to odsetek osób wyznania mojżeszowego studiujących na UW należałoby porównywać raczej z liczebnością mniejszości żydowskiej w Warszawie (ok. 30\% w 1939 r.) i byłej Kongresówce, skąd, jak zostało wcześniej powiedziane, pochodziło w sumie około trzech czwartych wszystkich słuchaczy. Przyjmując taką perspektywę nietrudno zauważyć, że pod koniec lat 3o. Żydzi nie tylko nie byli na Uniwersytecie Warszawskim nadreprezentowani, ale wręcz studiowało ich tam wyraźnie mniej, niż wynikałoby z potencjału ludnościowego mniejszości żydowskiej na terenach będących głównym zapleczem rekrutacyjnym uczelni.

Powyższy stan rzeczy był pochodną całokształtu stosunków polsko-żydowskich w dwudziestoleciu międzywojennym, na który składały się również postawa władz Uniwersytetu Warszawskiego i polskiej większości jego studentów, włącznie z rozgrywającymi się na jego terenie antysemickimi ekscesami. O czynnikach tych będzie jeszcze mowa w dalszej części tego tekstu. W tym miejscu ograniczę się jedynie do omówienia kwestii, czy na uczelni ograniczano w sposób odgórny liczbę słuchaczy pochodzenia żydowskiego.

Żądania wprowadzenia takiej regulacji, zwanej potocznie numerus clausus, stanowiły przez cały okres międzywojenny bardzo ważny punkt programu zarówno polskiej prawicy narodowej, jak i powiązanych z nią, niezwykle prężnych i wpływowych organizacji studenckich, działających również na Uniwersytecie Warszawskim. Wiosną 1923 r. postulat stosownej nowelizacji ustawy o szkołach wyższych z 1920 r. trafil pod obrady Sejmu, gdzie został zaakceptowany przez parlamentarną Komisję Oświatową. Chociaż projekt nie został ostatecznie poddany pod głosowanie ze względu na protesty części środowiska naukowego, lewicy parlamentarnej i Ligi Narodów, ówczesny minister wyznań religijnych i oświecenia publicznego Stanisław Głąbiński wystosował do władz poszczególnych uczelni okólnik, w którym wyraził awansem zgodę na wprowadzanie numerus clausus na mocy decyzji rad wydziałowych. Zgodnie z przedstawioną przez niego wykładnią, ustanawianie 
takich limitów w pełni dopuszczała obowiązująca ustawa z 1920 r., co było jawną nadinterpretacją, gdyż w rzeczywistości mówiła ona jedynie o możliwości ograniczenia liczby studentów, ale bez stosowania klucza narodowościowego bądź wyznaniowego ${ }^{222}$.

Ankieta przeprowadzona wcześniej przez sejmową Komisję Oświatową wśród wszystkich szkół wyższych w kraju wykazała, iż zdecydowana większość wydziałów, bo ok. 3/4, rzeczywiście opowiadała się - bezwarunkowo lub warunkowo - za przyjęciem numerus clausus. Na Uniwersytecie Warszawskim rozkład sił był jednak inny, ponieważ regulację taką poparła w pełni jedynie rada Wydziału Teologii Katolickiej, zaś rada Wydziału Lekarskiego uznała, iż poszczególne wydziały mogą przyjmować limity wynikające z odsetka mniejszości żydowskiej w skali całego państwa, lecz nie muszą. Wydziały Teologii Ewangelickiej, Prawa oraz Filozoficzny sprzeciwiły się zasadzie numerus clausus ${ }^{223}$. Wprawdzie po zamachu majowym MWRiOP wydało w 1927 r. okólnik cofający radom wydziałów prawo ustanawiania takiej zasady ${ }^{224}$, temat pozostał jednak aktualny, gdyż od początku lat 30. prawica nacjonalistyczna prowadziła praktycznie nieustającą krucjatę w sprawie ograniczenia liczby Żydów na wyższych uczelniach, albo wręcz ich całkowitego stamtąd usunięcia (numerus nullus). Jakkolwiek wydawałoby się to nam dziś zaskakujące i moralnie naganne, przekonanie, iż na uniwersytetach studiuje zbyt wielu słuchaczy tej narodowości, było nieobce nawet ideowym przeciwnikom endecji. Piłsudczyk Bartel, potępiając antysemickie ekscesy jako barbarzyńskie, mówił w 1939 r. w Senacie RP o niezdrowym „przeroście ilościowym Żydów w handlu, przemyśle, rzemiośle i wolnych zawodach", sugerując, iż rozwiązanie tego problemu przyniosą odpowiednie ograniczenia na wyższych uczelniach ${ }^{225}$. Również prof. Ludwik Hirszfeld, wykładowca Uniwersytetu Warszawskiego, sam pochodzący ze zasymilowanej rodziny żydowskiej, wypowiadając się po wojnie na temat numerus clausus, wyrażał się z pewnym zrozumieniem o żądaniu jego wprowadzenia na wydziałach lekarskich ze względu na konieczność zapewnienia odpowiedniej liczby lekarzy dla wsi, gdzie rzekomo nie chcieli podejmować praktyki medycy pochodzenia żydowskiego ${ }^{226}$.

Nie są znane uchwały któregokolwiek z wydziałów Uniwersytetu Warszawskiego ani z lat 20., ani z zo., kiedy uczelnia dosłownie kipiała od antysemickich awantur, które formalnie wprowadzałyby numerus clausus dla osób wyznania mojżeszowego. Faktu takiego nie potwierdzają równiė̇ żadne inne dokumenty, publikacje prasowe ani wspomnienia. Wzmianki o numerus clausus pojawiają się wprawdzie w niektórych dokumentach, ale wszystko wskazuje na to, iż pojęcia 


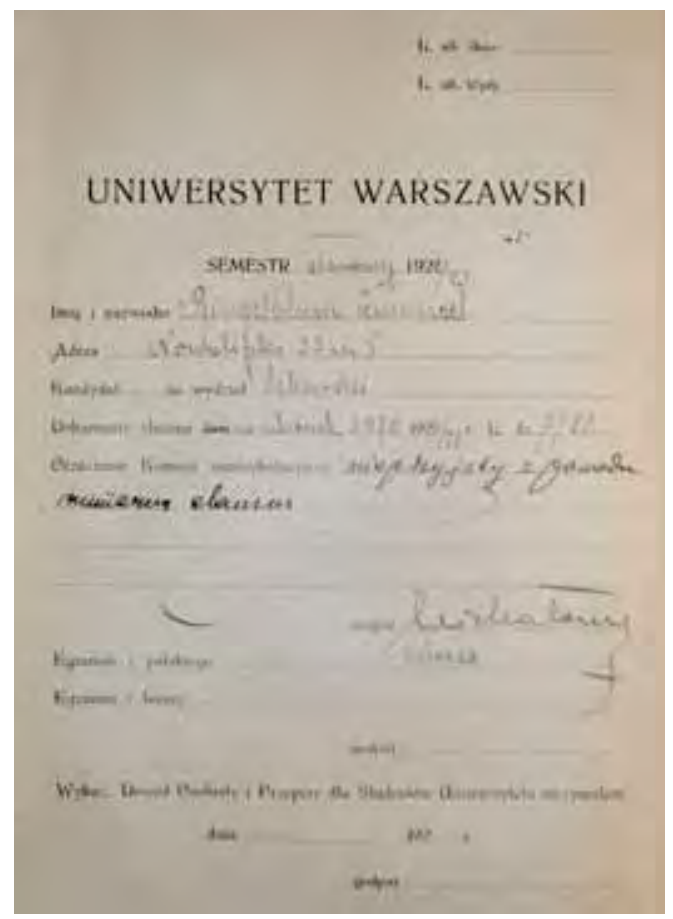

39. Teczka osobowa Emanuela Ringelbluma z adnotacje „nieprzyjęty z powodu numerus clausus” tego użyto w innym znaczeniu. Adnotacja „nieprzyjęty z powodu numerus clausus" znajduje się np. w aktach osobowych Emanuela Ringelbluma, który w 1920 r. bezskutecznie próbował zapisać się na Wydział Lekarski. (W efekcie późniejszy twórca podziemnego archiwum getta warszawskiego wstąpił w 1922 r. na Wydział Filozoficzny, który ukończył 5 lat później, zdobywając zawód historyka) ${ }^{227}$. Podobny passus pojawia się w sprawozdaniu rektora Antoniewicza za rok akademicki 1936/1937, w którym pisze on o „coraz częściej wprowadzanej selekcji konkursów i tzw. numerus clausus na niektórych wydziałach"228, a także w okolicznościowej publikacji Manteuffla z 1936 r. poświęconej historii Uniwersytetu ${ }^{229}$. Obowiązywanie takiej zasady na wydziałach: Lekarskim, Farmaceutycznym, Weterynaryjnym i Prawa potwierdzały też władze państwowe z zastrzeżeniem, iż nie jest ona wymierzona w studentów żadnego z wyznań. Istnieje wprawdzie hipoteza, że poufne postanowienie w sprawie ograniczenia liczby przyjmowanych na wyższe uczelnie $\dot{Z} y$ dów przyjęto $5 \mathrm{X} 1937$ r. na tej samej konferencji rektorów, na której zadecydowano o wprowadzeniu getta ławkowego, ale nie ma na to właściwie żadnych dowodów, a ponadto nic nie wskazuje, aby weszło ono w życie na Uniwersytecie Warszawskim ${ }^{230}$.

Za całkowicie pewne można więc uznać, że na żadnym z wydziałów UW nigdy nie uchwalono numerus clausus dla kandydatów wyznania mojżeszowego, co oczywiście nie wyklucza, że zasada taka funkcjonowała w stosunku do nich w sposób niepisany. Adnotacje i wzmianki o numerus clausus należy raczej interpretować jako synonim wprowadzenia limitu miejsc na niektórych kierunkach, stosowanego - przynajmniej w teorii - nie tylko wobec Żydów. W praktyce natomiast limity te uderzały przede wszystkim właśnie w nich, ponieważ na studia przyjmowano proporcjonalnie mniej osób wyznania mojżeszowego niż chrześcijan, co opisuje szczegółowo w rozdziale poświęconym przebiegowi studiów medycznych. 
Dla części okresu międzywojennego jesteśmy w stanie w pewnym przybliżeniu określić, jaką część studentów wyznania mojżeszowego stanowili Żydzi zasymilowani, statystyki uniwersyteckie uwzględniały bowiem również język ojczysty słuchaczy. Osoby tej religii deklarujące jako mowę ojczystą polski uznać można za spolonizowane, choć nie jest to wyróżnik pewny, gdyż jakaś część z nich mogła dorastać w polskim środowisku językowym, lecz nie uważać się za Polaków. W każdym razie była to jednak grupa najściślej związana z polskością. Co bardzo ciekawe, statystyki rozróżniały dalej hebrajski i „żargon żydowski”, jak określano jidysz, mimo że pierwszym z nich ówcześni Żydzi polscy na co dzień się w ogóle nie posługiwali. Wskazywanie tego języka przez część osób wyznania mojżeszowego miało więc niewątpliwie walor deklaracji, że czują się Żydami w sensie etnicznym oraz - co szło z tym najczęściej w parze - sympatyzują z syjonizmem. Postawy nacjonalistyczne występowały wśród studentów żydowskich już w czasie I wojny światowej i łączyły się z wyraźną niechęcią wobec Żydów zasymilowanych, uważanych za „odszczepieńców”. Były one równoznaczne ze świadomym dystansowaniem się wobec polskości ${ }^{231}$.

Przykłady pogłębiania się tego procesu widać w kolejnych latach. Od końca lat 20. do Żydowskiego Stowarzyszenia Medyków UW przyjmowano już tylko osoby deklarujące narodowość żydowską; studenci wyznania mojżeszowego narodowości polskiej - najwyraźniej uznawani za nie-Żydów - zostali z niego wykluczeni ${ }^{232}$. Ulotka Wzajemnej Pomocy Studentów Żydów z mniej więcej tego samego okresu potępia pozostawanie Żydów poza tą organizacją jako „piętno odstępstwa, odszczepienie od żydostwa, zdradę wobec społeczeństwa żydowskiego"2333. W skali całego Uniwersytetu liczebność Żydów świadomych narodowo wzrosła w latach 30. z $4 \%$ do $6,5 \%$ słuchaczy ${ }^{234}$, a więc więcej niż o połowę. Do jej przedstawicieli należał między innymi Icko Jezernicki, późniejszy premier Izraela - Icchak Szamir, który mając za sobą naukę w hebrajskiej szkole powszechnej i takim samym gimnazjum, zapisał się w 1933 r. na Wydział Prawa UW, lecz już 2 lata później zwrócił się o świadectwo wystąpienia i wyemigrował do Palestyny ${ }^{235}$.

W ciągu lat 20. trzykrotnie wzrósł, z 3\% do 9\%, również odsetek studentów UW deklarujących jako swój język ojczysty jidysz, których z kolei uznać można za osoby niezasymilowane narodowo w środowisku polskim. Znaczenie przedstawionych powyżej przemian widać w pełni dopiero na tle ogólnej dynamiki liczby słuchaczy żydowskich. Okazuje się bowiem, że w latach 1921-1933 dokonał się wśród nich prawdziwy przewrót tożsamościowy: o ile na początku tego okresu 3 na 4, słuchaczy wyznania mojżeszowego podawało polski jako swą mowę ojczystą, 

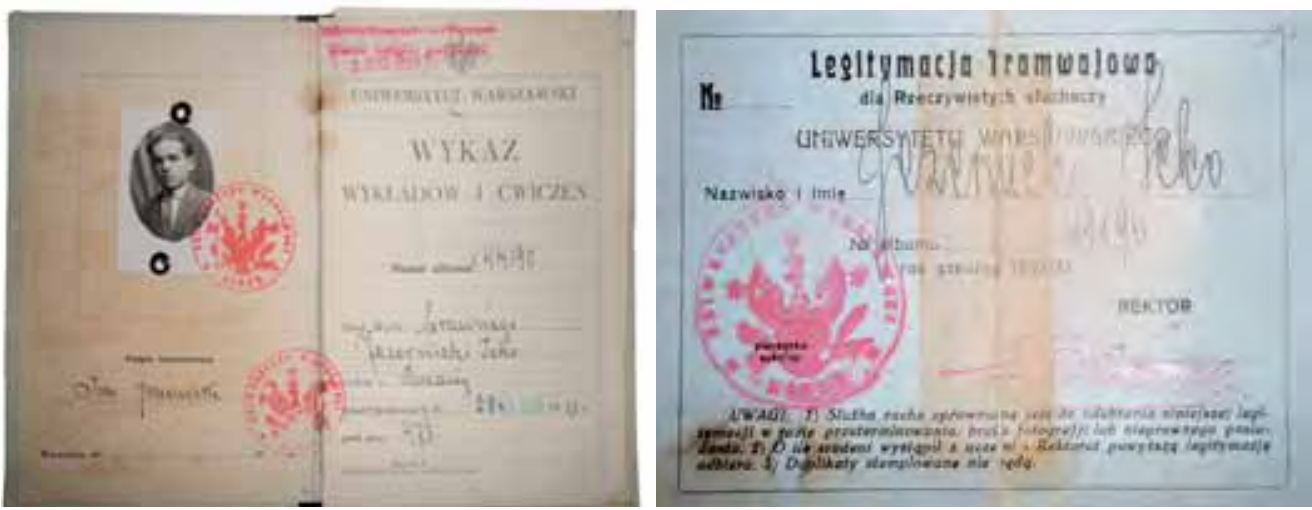

40 Indeks i studencka legitymacja tramwajowa Icko Jezernickiego - późniejszego premiera Izraela Icchaka Szamira

o tyle na koniec - już tylko 1 na 4 . W tym samym czasie liczba studentów, których językiem ojczystym był polski, spadła w skali całego Uniwersytetu z $89 \%$ do $77 \%{ }^{236}$.

Nie dysponujemy niestety równie szczegółowymi danymi dla lat późniejszych; ze składanych przez rektorów sprawozdań wiadomo jedynie, iż odsetek osób deklarujących polski jako język ojczysty zaczął wówczas stopniowo wzrastać i w roku akademickim 1938/1939 przekroczył $90 \%{ }^{237}$. Wydaje się jednak bardzo prawdopodobne, że wcześniejszy trend dysymilacyjny utrzymał się i także po 1933 r. wśród studentów wyznania mojżeszowego dominowała już na Uniwersytecie młodzież nieidentyfikująca się z polskością, często wręcz świadomie niechcąca się do niej asymilować ${ }^{238}$. Żydzi byli zatem spychani na Uniwersytecie coraz bardziej do roli mniejszości, ale ci, którzy mieli szansę studiować, coraz rzadziej czuli się częścią narodu polskiego.

Przyczyn opisanego powyżej zjawiska należy szukać tak w polityce państwa i zachowaniu społeczności polskiej względem mniejszości żydowskiej, jak i w postawach samej tej mniejszości, która w dużej części zachowywała odrębność kulturową i językową, żyjąc własnym życiem, często niemal bez kontaktów z Polakami. „Było sporo przemysłowców, lekarzy, adwokatów, dziennikarzy Żydów. Częściowo byli oni nosicielami kultury polskiej, częściowo była ona im obca lub obojętna" - pisał wkrótce po II wojnie światowej prof. Hirszfeld. „[...] Wielu Żydów nawet ze sfer inteligenckich, nie miało kontaktów ze sferami polskimi ani osobistych przyjaciół Polaków. Sfery niższe często nie umiały nawet mówić po polsku"239. Młodzież żydowska, która wybierała się na Uniwersytet, musiała wprawdzie władać językiem polskim w stopniu co najmniej dobrym, ale nie musiało to iść w parze 
z poczuciem związków z Polakami. Tym bardziej iż antysemickie ekscesy tu i na innych wyższych uczelniach dodatkowo zniechęcały do asymilacji. Trudno bowiem przypuszczać, aby coraz głośniejsze żądania ustanowienia numerus clausus, a później nawet numerus nullus, zaczepki, nagminnie okazywana pogarda, wreszcie wprowadzenie getta ławkowego i przemoc fizyczna ze strony prawicowych bojówek mogły mieć inny skutek. Polska większość zbyt dobitnie dawała Żydom do zrozumienia, że nie uważa ich za Polaków i nie życzy sobie, aby się nimi stali.

$\mathrm{Na}$ tle ogółu słuchaczy osoby wyznania mojżeszowego wyróżniały się wybieranymi przez siebie kierunkami studiów, co nie tylko wynikało z ich indywidualnych zainteresowań czy strategii edukacyjnych, ale odzwierciedlało również zmieniającą się topografię utrudnień i przeszkód stawianych im na poszczególnych wydziałach. W pierwszym roku akademickim nowo otwartego Uniwersytetu przytłaczająca większość Żydów, bo aż 70\%, zapisała się na medycynę, $16 \%$ na nauki matematyczno-przyrodnicze, prawie $11 \%$ na prawo, a zaledwie $2,6 \%$ na filozofię. W ciągu następnych 5 lat sytuacja zmieniła się jednak dość wyraźnie i w roku akademickim 1920/1921 największa część słuchaczy wyznania mojżeszowego studiowała już na Wydziale Prawa $(43,4 \%)$, kolejne 28,5\% na Filozoficznym, 26,8\% zaś na Lekarskim. Lata 20. przyniosły dalszy spadek odsetka Żydów, którzy byli słuchaczami medycyny - studiował tam tylko co dziesiąty z nich, a sytuacja taka utrzymała się aż do wybuchu II wojny światowej. Coraz mniej Żydów wybierało także prawo: w roku akademickim 1927/1928 studiował tam co trzeci słuchacz narodowości żydowskiej, zaś w roku 1938/1939 jedynie co siódmy. Coraz więcej studentów wyznania mojżeszowego wybierało natomiast Wydział Filozoficzny (55,5\% w roku akademickim 1926/1927), a po jego podziale w 1927 r. - sukcesyjne wydziały Matematyczno-Przyrodniczy i Humanistyczny. $\mathrm{Na}$ pierwszy z nich w inauguracyjnym roku akademickim 1927/1928 uczęszczało 18,3\% wszystkich żydowskich studentów UW, na drugim uczyło się 35,6\% z nich. Do 1939 r. współczynniki te wzrosły do odpowiednio $21,2 \%$ i $51,1 \%$.

Nauki matematyczno-przyrodnicze i humanistyczne były wybierane zdecydowanie częściej przez kobiety niż mężczyzn wyznania mojżeszowego. W roku akademickim 1933/1934 bez mała co druga ze wszystkich żydowskich słuchaczek Uniwersytetu studiowała na Wydziale Humanistycznym, a dalszych 18\% na Wydziale Matematyczno-Przyrodniczym. W tym czasie na oba te wydziały uczęszczało w sumie $21,5 \%$ żydowskich studentów płci męskiej, podczas gdy aż 61\% z nich uczyło się na Wydziale Prawa. Zauważalnie więcej żydowskich 
mężczyzn niż kobiet było tė̇ słuchaczami medycyny ${ }^{240}$. Brak jest niestety odpowiednich zestawień, aby zbadać rozwój sytuacji w drugiej połowie lat 3o., lecz wydaje się prawdopodobne, iż powyższe różnice miały charakter trwały ${ }^{241}$.

Przez całe dwudziestolecie międzywojenne bardzo niewielki odsetek Żydów, nieprzekraczający łącznie 2,5\%, był przyjmowany na weterynarię i farmację. Nie zapisywali się oni tė̇ w ogóle na żaden z 3 uniwersyteckich wydziałów teologicznych, gdyż miały one charakter wybitnie konfesyjny, przygotowując przyszłych duchownych katolickich, ewangelickich i prawosławnych ${ }^{242}$.

Tabela 10. Porównanie struktury wyznaniowej poszczególnych wydziałów UW w roku akademickim 1928/1929 i 1938/1939

\begin{tabular}{|c|c|c|c|c|c|c|c|c|}
\hline \multirow[b]{2}{*}{ Jednostka } & \multicolumn{2}{|c|}{$\begin{array}{c}\text { Liczba } \\
\text { studentów } \\
\text { chrześcijańskich }\end{array}$} & \multicolumn{2}{|c|}{$\begin{array}{c}\text { Odsetek } \\
\text { studentów } \\
\text { chrześcijańskich }\end{array}$} & \multicolumn{2}{|c|}{$\begin{array}{l}\text { Liczba } \\
\text { studentów } \\
\text { Żydów }\end{array}$} & \multicolumn{2}{|c|}{$\begin{array}{l}\text { Odsetek } \\
\text { studentów } \\
\text { Żydów }\end{array}$} \\
\hline & 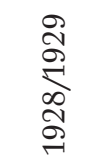 & 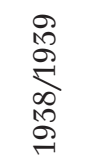 & 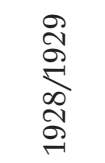 & 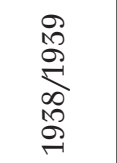 & 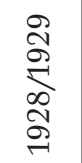 & 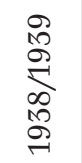 & 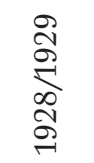 & 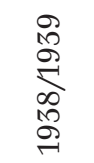 \\
\hline $\begin{array}{l}\text { Wydział Teologii } \\
\text { Katolickiej }\end{array}$ & 59 & 58 & $100 \%$ & $100 \%$ & 0 & 0 & $0 \%$ & $0 \%$ \\
\hline $\begin{array}{l}\text { Wydział Teologii } \\
\text { Ewangelickiej }\end{array}$ & 83 & 60 & $100 \%$ & $100 \%$ & 0 & 0 & $0 \%$ & $0 \%$ \\
\hline $\begin{array}{l}\text { Studium Teologii } \\
\text { Prawosławnej }\end{array}$ & 175 & 102 & $100 \%$ & $100 \%$ & 0 & 0 & $0 \%$ & $0 \%$ \\
\hline Wydział Prawa & 1850 & 2135 & $69,6 \%$ & $92 \%$ & 809 & 180 & $30,4 \%$ & $8 \%$ \\
\hline Wydział Lekarski & 818 & 899 & $78,3 \%$ & $87,5 \%$ & 227 & 129 & $21,7 \%$ & $12,5 \%$ \\
\hline $\begin{array}{l}\text { Wydział } \\
\text { Humanistyczny }\end{array}$ & 2308 & 2267 & $75,8 \%$ & $78 \%$ & 737 & 629 & $24,2 \%$ & $22 \%$ \\
\hline $\begin{array}{l}\text { Wydział } \\
\text { Matematyczno- } \\
\text {-Przyrodniczy }\end{array}$ & 1226 & 1252 & $77 \%$ & $82,5 \%$ & 365 & 261 & $23 \%$ & $17,5 \%$ \\
\hline $\begin{array}{l}\text { Wydział } \\
\text { Farmaceutyczny }\end{array}$ & 225 & 240 & $87,9 \%$ & $93 \%$ & 31 & 18 & $12,1 \%$ & $7 \%$ \\
\hline $\begin{array}{l}\text { Wydział } \\
\text { Weterynaryjny }\end{array}$ & 255 & 389 & $95,1 \%$ & $96,5 \%$ & 13 & 14 & $4,9 \%$ & $3,5 \%$ \\
\hline Ogółem & 6951 & 7402 & $76,1 \%$ & $85,25 \%$ & 2182 & 1231 & $23,9 \%$ & $14,5 \%$ \\
\hline
\end{tabular}

Źródło: T. Manteuffel, Uniwersytet Warszawski w latach 1915/16-1934/35. Kronika, Warszawa 1936, s. 310; AUW, AcUW RP/66.

Uwaga: zestawienie uwzględnia również tzw. wolnych słuchaczy. 
Gwałtownie rosnącą od końca lat 20. popularność wydziałów Matematyczno-Przyrodniczego i Humanistycznego wśród osób wyznania mojżeszowego tłumaczyć należy kilkoma zjawiskami. Po pierwsze, część osób wybierała je, aby z czasem przenieść się stamtąd na bardziej oblegane kierunki, w tym zwłaszcza medycynę. Po drugie, miały one najbardziej otwarty charakter wobec mniejszości narodowych. Po trzecie, panowało niepozbawione słuszności przekonanie, iż na medycynę, farmację czy prawo znacznie trudniej jest się Żydom dostać, a po ich ukończeniu znaleźć zatrudnienie. Pisała o tym (z pewną mimo wszystko przesadą) liberalna prasa żydowska, datując początki tej sytuacji już na lata 20.: „Praktyczne wydziały jak medycyna i farmacja już wtedy były zamknięte na siedem spustów, szło się więc z prądem na pseudo-praktyczny wydział prawa. Jednakże w ostatnich latach dokonała się ciekawa ewolucja. Młodzież wstępuje na wyższą uczelnię «tak sobie», «dla matrykuły»... [...] Na medycynę, farmację i chemię nikt nawet nie próbował się dostać" ${ }^{243}$. To ostatnie twierdzenie było akurat nieprawdziwe, gdyż w latach zo. Żydzi stanowili wciąż bardzo dużą grupę wśród kandydatów na Wydział Lekarski. Faktem jest natomiast, iż byli oni dyskryminowani przy rekrutacji na medycynę, co analizuję w jednym z kolejnych rozdziałów, poświęconym specyfice studiów na Uniwersytecie.

W tym kontekście interpretować należy również odmienne wybory kierunku studiów dokonywane przez kobiety i przez mężczyzn narodowości żydowskiej. Pierwsze z nich miały niewątpliwie świadomość, że obok pochodzenia na ich niekorzyść działa dodatkowo płeć, nie dająca większych perspektyw na znalezienie pracy po studiach medycznych lub prawniczych. Trudno jest natomiast stwierdzić, w jakim stopniu na wybór rodzaju studiów przez młodzież wyznania mojżeszowego miały wpływ antysemickie ekscesy do jakich dochodziło od końca lat 20. zwłaszcza na wydziałach Prawa i Lekarskim.

Wybory, jakich dokonywali lub do jakich zmuszeni byli kandydaci na studia narodowości żydowskiej, przekładały się bezpośrednio na strukturę etniczną poszczególnych wydziałów i jej dynamikę. I tak na Wydziale Prawa w pierwszym roku po otwarciu Uniwersytetu studiowało $26 \%$ studentów wyznania mojżeszowego, w roku akademickim 1920/1921 - 39\%, 10 lat później - 30\%, zaś w ostatnim roku przed wybuchem II wojny światowej - zaledwie $8 \%$. Na medycynie odsetek Żydów zmniejszał się z 69\% w roku akademickim 1915/1916, przez 45\% w 1920/1921, 23\% w 1930/1931 aż do 13\% w roku 1939. Na Wydziale Filozoficznym w roku inauguracji Uniwersytetu było $18 \%$ słuchaczy żydowskich. Do roku akademickiego 1926/1927 wskaźnik ten 
wzrósł wprawdzie do $25 \%$, jednak trend nie utrzymał się na żadnym z dwóch kierunków, które powstały po jego podziale w 1927 r. Pomiędzy tym rokiem a ostatnim rokiem pokoju odsetek studentów wyznania mojżeszowego na Wydziale Matematyczno-Przyrodniczym skurczył się z 24\% do 17\%, zaś na Wydziale Humanistycznym z 24\% do $21 \%$. Żydowskich studentów ubywało także na wydziałach Farmaceutycznym i Weterynaryjnym. W momencie powołania pierwszego z tych kierunków, w roku 1918/1919 Żydzi stanowili 16\% jego słuchaczy, 20 lat później - już tylko $\%$ \%. W przypadku drugiego odsetek ten zmniejszył się w podobnym okresie z 44\% do $3 \%$. Jak już zostało powiedziane, studentów narodowości żydowskiej nie odnotowywano przez całe dwudziestolecie międzywojenne na żadnym z 3 uniwersyteckich wydziałów teologicznych ${ }^{244}$.

Poza Żydami na Uniwersytecie studiowało bardzo niewielu przedstawicieli innych mniejszości narodowych zamieszkujących II Rzeczpospolitą. Najliczniejszą z nich, Ukraińców, reprezentowało w szczytowym momencie, na początku lat 3o., zaledwie go słuchaczy. Zapisywali się w większości na Studium Teologii Prawosławnej, z czego wnosić należy, iż pochodzili najczęściej z Wołynia i południowej Lubelszczyzny, gdzie narodowość ukraińska nie szła zazwyczaj w parze z wyznaniem grekokatolickim. Mniej więcej tyle samo było na uczelni polskich Niemców, z których około połowa studiowała z kolei na Wydziale Teologii Protestanckiej, a spora część germanistykę na Wydziale Filozoficznym (a później Humanistycznym). Jeszcze liczniej występowali studenci, którzy jako język ojczysty deklarowali rosyjski. Ich maksymalną liczbę (172 osoby) odnotowano w roku 1922/1923, później utrzymywała się ona najczęściej na poziomie 110-130 osób. Byli to głównie Rosjanie posiadający polskie obywatelstwo. Również wśród nich stosunkowo pokaźną grupę, w latach 30. sięgającą 30\% ogółu, stanowili studenci Studium Teologii Prawosławnej. Oprócz nich na początku tejże dekady na Uniwersytecie pojawiło się również nieco ponad 20 osób, które jako swój język ojczysty deklarowało białoruski.

W sumie, nie licząc obcokrajowców, o których była mowa we wcześniejszym podrozdziale, odsetek studentów narodowości innej niż polska i żydowska nie przekraczał na Uniwersytecie Warszawskim 4\%. Jak można zauważyć z przedstawionych powyżej liczb, uczelnia przyciągała spośród nich przede wszystkim osoby zainteresowane karierą duchowną ${ }^{245}$. 


\section{Struktura społeczna studentów}

Jak można się zorientować z przedstawionych wcześniej danych dotyczących pochodzenia geograficznego studentów, bardzo zróżnicowana była struktura ich miejsca zamieszkania. Uwzględniając Warszawę, z której wywodził się prawie co trzeci z nich, $4,2 \%$ wszystkich immatrykulowanych przyszło na świat w dużych miastach, liczących więcej niż 100 tys. mieszkańców. Dalszych 17\% urodziło się w miejscowościach jak na warunki II Rzeczpospolitej średnich, o wielkości od 10 tys. do 100 tys. osób. Kolejne 4,1\% stanowili studenci z małych miasteczek i ze wsi, przy czym odsetek tych ostatnich szacować można na kilkanaście procent ${ }^{246}$.

Biorąc pod uwagę niski stopień urbanizacji ówczesnej Polski, nietrudno zauważyć, iż na Uniwersytecie Warszawskim wyraźnie nadreprezentowana była młodzież miejska. Osoby urodzone w dużych miastach występowały wśród studentów czterokrotnie liczniej niż wynikałoby to ze struktury ludnościowej kraju. Nadreprezentacja tych, którzy pochodzili z miast średniej wielkości, była prawie dwukrotna. Natomiast mieszkańcy wsi i małych miasteczek zdarzali się wśród immatrykulowanych 2 razy rzadziej niż w całej populacji ${ }^{247}$. W pewnym uproszczeniu można na tej podstawie stwierdzić, że osoby mieszkające na wsi trafiały na Uniwersytet, statystycznie rzecz ujmując, ośmiokrotnie rzadziej niż mieszkańcy wielkich miast.

Powyższe obserwacje znajdują potwierdzenie $\mathrm{w}$ wycinkowych danych na temat pochodzenia społecznego studentów, które dotyczą roku akademickiego 1934/1935. Największą grupę stanowiły wówczas dzieci szeroko rozumianej inteligencji: pracowników umysłowych $(21,8 \%)$, urzędników administracji państwowej i samorządowej (12,7\%), profesorów i nauczycieli (4,4\%), duchownych (1\%), osób zatrudnionych w wolnych zawodach $(7,5 \%)$, a także oficerów $(1,1 \%)$. Stanowiły one w sumie niemal połowę wszystkich słuchaczy. Ojcami $6,9 \%$ studentów byli wielcy przedsiębiorcy, zaś 15,7\% drobni przedsiębiorcy, 2,3\% - właściciele ziemscy posiadający majątek większy niż 5o ha, 5,4\% - rolnicy gospodarujący na gruntach o powierzchni 5-5o ha, 3,7\% - małorolni i robotnicy rolni, zaś $6,7 \%$ osób pochodziło z rodzin robotniczych. Rodzicami prawie $9 \%$ słuchaczy byli ponadto emeryci, inwalidzi i renciści, jak można przypuszczać, najczęściej należący wcześniej do grupy pracowników państwowych ${ }^{248}$. 
Tabela 11. Studenci UW w roku akademickim 1934/1935 wg zawodu i stanowiska ojca

\begin{tabular}{|c|c|c|c|}
\hline & $\begin{array}{c}\text { Zawód } \\
\text { i stanowisko ojca }\end{array}$ & $\begin{array}{l}\text { Liczba } \\
\text { studentów }\end{array}$ & $\begin{array}{c}\text { Odsetek } \\
\text { studentów }\end{array}$ \\
\hline Rolnictwo & Powyżej 50 ha & 213 & $2,3 \%$ \\
\hline & $15-50$ ha & 184 & $2 \%$ \\
\hline & 5-15 ha & 319 & $3,4 \%$ \\
\hline & Mniej niż 5 ha & 287 & $3,1 \%$ \\
\hline & Pracownicy umysłowi & 192 & $2 \%$ \\
\hline & Robotnicy rolni & 60 & $0,6 \%$ \\
\hline Przemysł, & Przedsiębiorcy więksi & 644 & $6,9 \%$ \\
\hline handel, & Przedsiębiorcy mniejsi & 1472 & $15,7 \%$ \\
\hline & Pracownicy umysłowi & 1864 & $19,8 \%$ \\
\hline & Robotnicy & 628 & $6,7 \%$ \\
\hline Służba publiczna & Urzędnicy państwowi i samorządowi & 1198 & $12,7 \%$ \\
\hline i wolne zawody & $\begin{array}{l}\text { Profesorowie i nauczyciele szkół } \\
\text { publicznych }\end{array}$ & 331 & $3,5 \%$ \\
\hline & $\begin{array}{l}\text { Profesorowie i nauczyciele szkół } \\
\text { prywatnych }\end{array}$ & 80 & $0,9 \%$ \\
\hline & Duchowni & 99 & $1 \%$ \\
\hline & Wolne zawody & 703 & $7,5 \%$ \\
\hline & Oficerowie & 102 & $1,1 \%$ \\
\hline & $\begin{array}{l}\text { Niżsi funkcjonariusze i pracownicy } \\
\text { fizyczni administracji państwowej } \\
\text { i samorządowej }\end{array}$ & 125 & $1,3 \%$ \\
\hline & Podoficerowie & 47 & $0,5 \%$ \\
\hline Pozostałe & Służba domowa & 14 & $0,1 \%$ \\
\hline & Emeryci, inwalidzi, renciści & 840 & $8,9 \%$ \\
\hline Ogółem & & 9402 & $100 \%$ \\
\hline
\end{tabular}

Źródło: H. Wittlinowa, Atlas szkolnictwa wyższego, Warszawa 1937, s. $5^{2}$.

W oczywisty, choć bardziej skomplikowany niż wydawałoby się dziś sposób przekładało się to na zamożność i pozycję społeczną słuchaczy. Halina Wittlinowa, która dobrze znała ówczesne realia, ponieważ sama studiowała w latach 20. na Uniwersytecie Warszawskim, uzyskując tu tytuł doktorski, w swym opracowaniu na temat szkolnictwa wyższego, z którego zaczerpnięto przytaczane powyżej dane, dokonała stratyfikacji studentów, dzieląc ich, według zawodu i stanowiska ojca, na 4. podstawowe grupy. Podział ten wydaje się niezwykle przydatny dla zrozumienia stosunków panujących na Uniwersytecie, gdyż - niezależnie 
od wartości samych danych statystycznych - ukazuje, na jakie warstwy dzieliła się społeczność studencka w oczach sobie współczesnych.

$\mathrm{Na}$ szczycie ówczesnej hierarchii społecznej znajdowała się grupa określana jako „właściciele więksi”, którą dziś nazwać można by mianem ówczesnej klasy wyższej. Zaliczały się do niej dzieci ziemian i najzamożniejszych przedsiębiorców, stanowiące 10\% słuchaczy Uniwersytetu Warszawskiego. Była to warstwa najbardziej uprzywilejowana pod względem materialnym, co niewątpliwie przekładało się również na warunki studiowania, późniejsze perspektywy życiowe itp. Jednoznaczne ulokowanie na drabinie społecznej grupy kolejnej, „pracowników umysłowych" - których dzieci stanowiły aż 58\% słuchaczy - sprawia pewien problem, gdyż obejmowała ona zarówno osoby bardzo dobrze sytuowane, np. lekarzy, adwokatów i wyższych wojskowych, jak i mniej zamożnych urzędników (w tym emerytowanych) lub nauczycieli. Warstwę tę charakteryzował jednak stosunkowo wysoki prestiż, co pozwala usytuować ją jako całość na drugim miejscu hierarchii społecznej. Grupę trzecią, „właścicieli mniejszych”, stanowili „właściciele i dzierżawcy gospodarstw rolnych od 5 do 50 ha, mniejsi przedsiębiorcy w przemyśle, rzemieślnicy samodzielni, mniejsi przedsiębiorcy handlowi, samodzielni szoferzy, furmani", czyli niższa klasa średnia. Wywodziło się z niej $20 \%$ słuchaczy. Na ostatnim miejscu plasowało się $12 \%$ studentów z rodzin „robotników i małorolnych”, do których autorka zaliczyła także rzemieślników najemnych, niższych funkcjonariuszy administracji państwowej i samorządowej, służbę domową i wyrobników ${ }^{249}$.

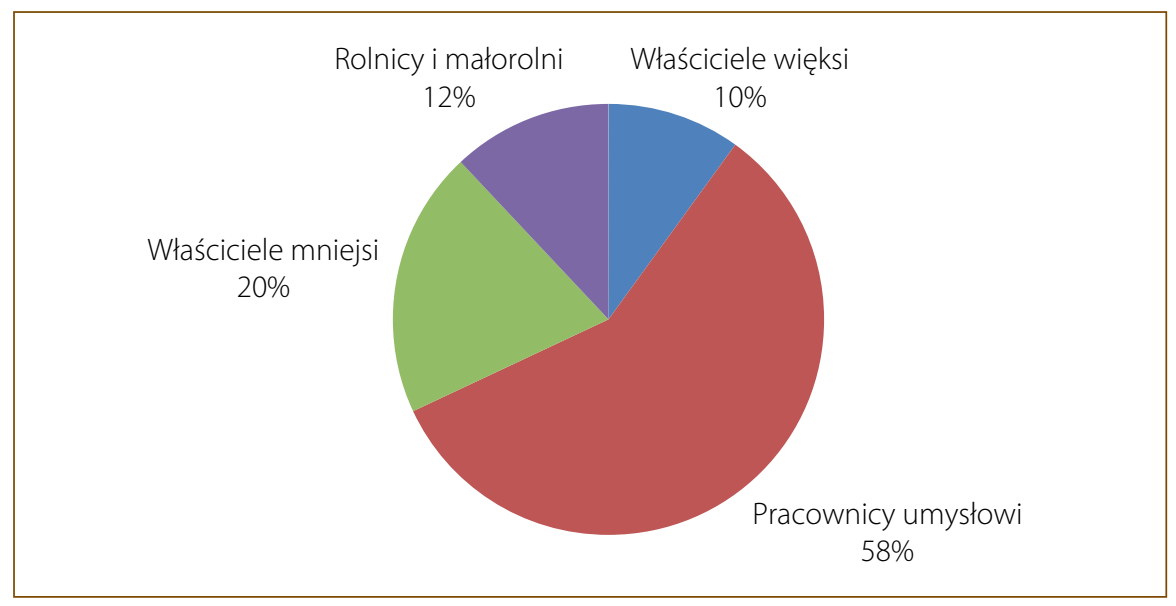

Wykres 7. Struktura społeczna studentów UW według zawodu ojca (1934/1935) 
Pochodzenie słuchaczy Uniwersytetu Warszawskiego odbiegało bardzo istotnie od struktury zawodowej ludności kraju, podobnie zresztą jak miało to miejsce na wszystkich innych wyższych uczelniach w ówczesnej Polsce. Świadczył o tym przede wszystkim niezwykle wysoki odsetek studentów z rodzin inteligenckich. W porównaniu do odsetka pracowników umysłowych wśród ogółu czynnych zawodowo obywateli, który wynosił na początku lat 30. mniej niż 5\%, nadreprezentacja tej grupy społecznej była na Uniwersytecie więcej niż dwunastokrotna. Słuchacze pochodzenia chłopskiego i robotniczego trafiali natomiast na studia dużo rzadziej niż wynikałoby to z liczebności tych warstw, co z jednej strony wynikało z ich niezamożności, z drugiej jednak było efektem braku odpowiednich wzorców i aspiracji ${ }^{250}$.

W porównaniu z innymi wyższymi uczelniami w Polsce na Uniwersytecie Warszawskim studiowało relatywnie nieco więcej osób wywodzących się z rodzin pracowników umysłowych, przedstawicieli wolnych zawodów, drobnych przedsiębiorców i robotników przemysłowych, zauważalnie mniej niż gdzie indziej było natomiast dzieci chłopów małorolnych. Różnice te stanowiły pochodną wielkomiejskiego charakteru Warszawy, gdzie liczniej niż gdzie indziej reprezentowane były niektóre grupy społeczne, a wysokie koszty utrzymania ograniczały napływ na studia najmniej zamożnych osób ze wsi ${ }^{251}$.

Pochodzenie społeczne determinowało w pewnym stopniu wybór kierunku studiów. Choć największy odsetek młodzieży chłopskiej studiował na prawie, o wiele częściej niż przedstawiciele innych grup społecznych zapisywała się ona na kierunki teologiczne, w tym zwłaszcza na $\mathrm{Wy}$ dział Teologii Katolickiej, gdzie w roku akademickim 1934/1935 stanowiła prawie połowę wszystkich słuchaczy. Nietrudno wywnioskować, że wiązało się to $\mathrm{z}$ charakterystyczną dla tej grupy społecznej strategią awansu społecznego, wyrażającą się ludowym przysłowiem, iż „kto ma księdza w rodzie, tego bieda nie ubodzie". Podobnie interpretować należy wysoki odsetek osób pochodzenia chłopskiego (w tym również z rodzin małorolnych) wśród studentów weterynarii - wykształcenie takie pozwalało bowiem znaleźć na wsi zatrudnienie młodym ludziom, którzy nie mogli liczyć na samodzielne gospodarstwo po rodzicach.

Odmienne w pewnej mierze strategie edukacyjne widać w przypadku młodzieży robotniczej i takiej, której ojcowie byli drobnymi przedsiębiorcami lub emerytami. Mniej więcej co trzeci student wywodzący się z tych warstw uczył się na Wydziale Humanistycznym, a co piąty na Matematyczno-Przyrodniczym. Zauważalnie mniej popularne były wśród nich natomiast studia prawnicze, a jeszcze mniej lekarskie. Powyższa tendencja wynikała najprawdopodobniej z faktu, że ukończenie 
kierunków humanistycznych lub matematyczno-przyrodniczych dawało stosunkowo duże szanse zdobycia posady nauczycielskiej, a zapisanie się na prawo lub medycynę wymagało zdania egzaminu wstępnego lub co najmniej udokumentowania znajomości łaciny, której często nie mieli absolwenci gorszych szkół średnich. Dwa ostatnie wydziały uchodziły ponadto za najbardziej kosztowne.

Najliczniej reprezentowana na Uniwersytecie Warszawskim młodzież z rodzin pracowników umysłowych wybierała najczęściej prawo lub studia humanistyczne, w dalszej kolejności nauki matematyczno-przyrodnicze i medycynę. Potomkowie „właścicieli większych” najchętniej studiowali z kolei prawo (niemal co drugi student z rodzin ziemiańskich i więcej niż co trzeci z rodzin przemysłowców). Na Wydziale Prawa uczyła się też $1 / 3$ osób, których ojcowie wykonywali wolne zawody, grupa ta zdecydowanie częściej niż pozostałe wybierała jednak studia medyczne i farmację. Należy przypuszczać, że byli to w dużej mierze potomkowie rodzin lekarskich i właścicieli aptek, którzy zamierzali kontynuować rodzinne tradycje ${ }^{252}$.

W pewnym uproszczeniu można powiedzieć, iż takie wydziały, jak medycyna, farmacja i prawo miały na Uniwersytecie charakter bardziej elitarny pod względem społecznym, podczas gdy kierunki teologiczne, humanistyczne, matematyczno-przyrodnicze i weterynaria były wybierane częściej przez osoby mniej zamożne, wywodzące się z warstw niższych. Przekładało się to rzecz jasna na strukturę społeczną poszczególnych wydziałów, którą obrazuje tabela 12.

Wypadkowa miejsca zamieszkania oraz pochodzenia społecznego decydowała oczywiście nie tylko o samym podjęciu nauki na Uniwersytecie na tym bądź innym wydziale, lecz także o późniejszym przebiegu studiów, warunkach życia w Warszawie, kręgu towarzyskim, w jakim dana osoba się obracała, jej aspiracjach i rozrywkach, a często również o szansach na ukończenie uczelni i perspektywach pracy zawodowej. Różnice społeczne nieuchronnie uwidaczniały się nie tylko w ubiorze, ale także w sposobie bycia i wysławiania się, w ogładzie towarzyskiej - krótko mówiąc, w wyniesionym z domu i własnego środowiska kapitale kulturowym. Jak to się zwykle dzieje, osobom niezamożnym obok pieniędzy często brakowało pewności siebie. Dało się to dostrzec już pierwszego dnia zajęć. „Był to tłum dość zróżnicowany” - wspominał słuchaczy pierwszego roku Wydziału Prawa Ryszard Matuszewski. „Składała się nań zarówno młodzież z gimnazjów warszawskich, swobodna i pewna siebie, jak nieco, zwłaszcza na początku, zagubieni przybysze ze szkół na prowincji; eleganckie panny i wymuskani młodzieńcy kwitli na tle rzeszy wyglądającej raczej szaro i ubogo"253. 
Tabela 12. Pochodzenie społeczne studentów poszczególnych wydziałów UW w roku akademickim 1934/1935 wg zawodu ojca

\begin{tabular}{|c|c|c|c|c|c|c|c|c|c|}
\hline & 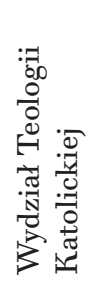 & 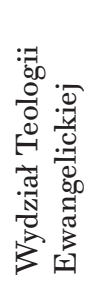 & 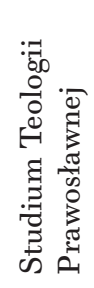 & 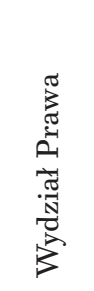 & 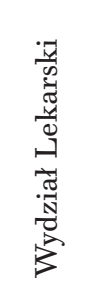 & 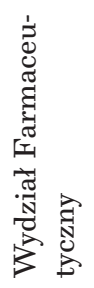 & 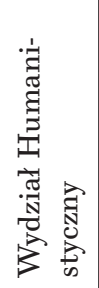 & 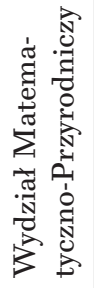 & 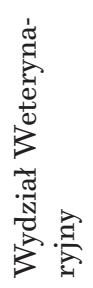 \\
\hline Chłopi & $49,2 \%$ & $25,7 \%$ & $22,9 \%$ & $7,7 \%$ & $6,3 \%$ & $8,4 \%$ & $7,7 \%$ & $6,4 \%$ & $16,9 \%$ \\
\hline $\begin{array}{l}\text { Robotnicy } \\
\text { rolni }\end{array}$ & - & - & $0,9 \%$ & $0,6 \%$ & $0,9 \%$ & - & $0,7 \%$ & $0,7 \%$ & $1,1 \%$ \\
\hline Ziemianie & $3,3 \%$ & $4 \%$ & - & $3,4 \%$ & $1,7 \%$ & $1,0 \%$ & $1,8 \%$ & $1,2 \%$ & $3,1 \%$ \\
\hline Robotnicy & $11,5 \%$ & $13,9 \%$ & $1,8 \%$ & $6,9 \%$ & $4,4 \%$ & $6,7 \%$ & $9,1 \%$ & $11,4 \%$ & $8,5 \%$ \\
\hline $\begin{array}{l}\text { Drobni } \\
\text { przedsiębiorcy }\end{array}$ & - & $9,9 \%$ & - & $16,6 \%$ & $12,3 \%$ & $17,8 \%$ & $15,6 \%$ & $18,8 \%$ & $13,1 \%$ \\
\hline $\begin{array}{l}\text { Pracownicy } \\
\text { umysłowi }\end{array}$ & $27,9 \%$ & $41,6 \%$ & $67,0 \%$ & $40,4 \%$ & $43,9 \%$ & $34,7 \%$ & $42,5 \%$ & $41,4 \%$ & $40,3 \%$ \\
\hline Wolne zawody & - & - & $3,7 \%$ & $8,2 \%$ & $13,7 \%$ & $15,5 \%$ & $5,7 \%$ & $5,4 \%$ & $4,0 \%$ \\
\hline Emeryci & $8,2 \%$ & $4,0 \%$ & $3,7 \%$ & $7,9 \%$ & $9,3 \%$ & $6,0 \%$ & $10,1 \%$ & $9,4 \%$ & $8,7 \%$ \\
\hline $\begin{array}{l}\text { Wielcy } \\
\text { przedsiębiorcy }\end{array}$ & - & $1,0 \%$ & - & $8,1 \%$ & $7,4 \%$ & $9,8 \%$ & $6,8 \%$ & $5,2 \%$ & $4,2 \%$ \\
\hline
\end{tabular}

Źródło: M. Pleskaczyńska, Struktura społeczna młodzieży UWw okresie międzywojennym (na podstawie danych z roku akademickiego 1934/1935), „Roczniki Uniwersytetu Warszawskiego” 2/1971, s. 48.

W tłumie studentów Uniwersytetu Warszawskiego wprawny obserwator dostrzec mógł przedstawicieli wszystkich warstw społecznych - choć nie w takich proporcjach, jak w skali całego kraju. Zdarzali się wśród nich ziemianie - potomkowie znanych rodów arystokratycznych, jak np. Szeptyccy, Sobańscy, czy Radziwiłłowie. W ich przypadku pochodzenie z prowincji nie wiązało się, rzecz jasna, z jakimkolwiek upośledzeniem społecznym. Nawet jeśli rodziny niektórych z nich utraciły już wówczas część swych majątków i osiadły w miastach, bez większego trudu były w stanie wykształcić dzieci na Uniwersytecie. Inną kwestią pozostaje, że dzieci te nie zawsze wykazywały wystarczającą determinację, aby studia ukończyć. Antoni Sobański, znany bon-vivant, a przy tym - jak pisał o nim Witold Gombrowicz - „wybitnie inteligentny, Europejczyk, duża kultura, doskonałe maniery, osobowość zwracająca na siebie uwagę" - pisujący później do „Wiadomości Literackich”254, porzucił naukę po 9 trymestrach na Wydziale Filozoficznym, co nie przeszkodziło mu 
jednak brylować na warszawskich salonach artystycznych i intelektualnych ${ }^{255}$. Jeszcze szybciej zrezygnował ze studiów późniejszy senator Krzysztof Radziwiłł, chociaż deklarował, iż zamierza „kształcić się w dziedzinie polonistyki celem poświęcenia się karierze naukowej”256. Niezależnie od indywidualnych przyczyn, jak np. konieczność objęcia odziedziczonego majątku, która, jak się wydaje, przeszkodziła w studiach Radziwiłłowi, arystokraci nie mieli aż takiej motywacji do nauki, ponieważ i bez ukończenia Uniwersytetu cieszyli się wystarczającym prestiżem i na ogól nie musieli podejmować pracy zarobkowej. Inaczej już jednak przedstawiała się sytuacja zbiedniałych potomków najlepszych nawet rodów. Przykładem może być Jerzy Giedroyc, który w czasie studiów na Wydziale Prawa musiał zarabiać nie tylko na potrzeby własne, ale również pomagać rodzicom w utrzymaniu domu ${ }^{257}$.

Studenci z rodzin arystokratycznych byli łatwo rozpoznawalni z racji swych nazwisk. Zapewne z reguły im to pomagało, niekiedy jednak mogło też nieco komplikować życie. Kiedy Andrzej Szeptycki próbował na przykład zdobyć zaliczenie wykładu, podsuwając profesorowi przez jednego z kolegów indeks do podpisu, został natychmiast zdemaskowany. „Nazwisko studenta było znane, arystokracja w najlepszym wydaniu, rodzony stryj - arcybiskup grecko-katolicki, metropolita, drugi stryj - zastępca naczelnego wodza w 1919 roku" - relacjonuje świadek tego zdarzenia. - „Student zainteresował profesora, który spojrzawszy na zgłaszającego się po indeks powiedział: «Coś się pan tak zmienił?» Przyłapany na mistyfikacji nielegalny zastępca podszedł przepraszając i tłumacząc, że trymestr się kończy, że właścicielowi coś niespodziewanie akurat wypadło, że bywa na wykładach i że nadal będzie na nie chodzić... Profesor odsunął jednak indeks i uśmiechnąwszy się z wyrozumiałą ironią powiedział: «Ale ja i po świętach podpiszę indeks panu Szeptyckiemu». A potem, rozejrzawszy się po sali, po której przeleciał szmer zainteresowania, powiedział pogodnie wśród ogólnej wesołości: «nie chciało się panu hrabiemu»"258. Uszczypliwość, na jaką pozwolił sobie wykładowca, nie służyła, rzecz jasna, zdyscyplinowaniu słuchaczy, ale wyłącznie zamanifestowaniu lekkiego dystansu wobec arystokratów, co zostało zresztą właściwie odczytane na sali. Dla Szeptyckiego, podobnie jak dla wielu innych ziemian, nieodległa przyszłość nie była już natomiast tak beztroska: jako oficer rezerwy Wojska Polskiego we wrześniu 1939 r. wyruszył na front, dostał się do niewoli radzieckiej i został zamordowany w Katyniu.

W uprzywilejowanej sytuacji znajdowali się również studenci wywodzący się z rodzin bogatych przemysłowców. Marię Eigerównę, której ojciec był znanym warszawskim fabrykantem i właścicielem kilku 
cementowni, rodzina wysłała na krótko przed wybuchem I wojny światowej na kilka miesięcy do prywatnego gimnazjum do Lozanny, celem uzyskania matury, skąd odebrała ją potem angielska miss, pełniąca rolę prywatnej guwernantki. Niezgoda na dobrobyt, jaki ją otaczał również podczas studiów na Uniwersytecie w latach 1917-1920, stała się w końcu dla Eigerówny prawdziwą obsesją. Jak sama wspomina: „Doszłam do wniosku, że skoro wciąż jeszcze pozostaję w domu i skoro do chwili zdobycia dyplomu będę nadal korzystać z dobrobytu opartego na krzywdzie i wyzysku, muszę przynajmniej w pewnej mierze upodobnić się do ludzi pracy. Robotnicy pracują osiem godzin, a więc i ja powinnam uczyć się osiem godzin dziennie. [...] $\mathrm{Z}$ zegarkiem w ręku przestrzegałam, bym mniej niż osiem godzin nie spędzała na wykładach i przy książce. Wszystkie pauzy i przerwy rzetelnie odliczałam, podobnie jak zwykł czynić to fabrykant w stosunku do robotników"259. Nie skończyło się, niestety, na tych nieszkodliwych dziwactwach i Eigerówna, mimo dalszych studiów w Berlinie, chętnie sfinansowanych przez papę zaniepokojonego jej radykalnymi sympatiami politycznymi, trafila ostatecznie do Komunistycznej Partii Polski, gdzie już pod nazwiskiem Maria Kamińska stała się zawodową funkcjonariuszką partyjną, za co przesiedziała nawet kilka lat w więzieniu. Był to przypadek zapewne najbardziej konsekwentnego odrzucenia „burżuazyjnego pochodzenia”, ale wcale nie odosobniony. W jednych ze wspomnień z połowy lat 30 . pojawia się opis demonstracji studenckiej, podczas której synowie ziemian i fabrykantów nieśli transparent „Pamiętaj, że wielki przemysł i ziemiaństwo to nasz wspólny wróg”" ${ }^{\prime 260}$. Gombrowicz, który sam również zmagał się z kompleksem dobrego urodzenia, tłumaczył go instynktownym, młodzieńczym buntem przeciw „nierzeczywitości” swego uprzywilejowania społecznego, zapewniającego ,życie ułatwione, nie znające istotnej walki ani o byt, ani o jego wartości"261.

Większość studentów wywodzących się z dobrze sytuowanych rodzin nie przeżywała jednak z tego powodu większych rozterek, lecz korzystała z dobrodziejstw zamożności. Tak teczki osobowe, jak i nieliczne wspomnienia niewiele mówią o ich sytuacji materialnej podczas studiów. Opłacane przez rodziców regularnie czesne i pieniądze przesyłane na utrzymanie się w Warszawie, bądź możliwość mieszkania przy rodzinie w przypadku osób pochodzących ze stolicy, pozwalały skupić się na nauce, zaangażować w działalność polityczną, albo prowadzić intensywne życie towarzyskie. Komfort taki miał na przykład studiujący na Wydziale Prawa Kazimierz Brandys, który wspominając lata studenckie, kwestie materialne kwituje jedynie wzmianką, iż ojciec pozwalał mu od czasu do czasu dorobić sobie w prowadzonej przez siebie 
firmie ${ }^{262}$. Jedyną niedogodnością mogła być w takich przypadkach co najwyżej całkowita zależność finansowa od rodziny i wynikająca z tego konieczność podporządkowania się jej decyzjom. „Zawaliłem egzaminy na drugi rok prawa - pisze Brandys - ojciec nie mógł mi tego wybaczyć, wysłał mnie na wakacje pod kuratelą Mariana. [...] Wróciłem po tych wakacjach z nadszarpniętą wiarą w siebie, z utraconą pewnością ruchów - jakbym wypadł z zawiasów - i w następnym roku przelazłem ciężko przez wiosenne egzaminy, zmordowany nocnym kuciem skryptów”263. Było to doświadczenie niewątpliwie „upupiające”, ale nie zagrażało podstawom egzystencji ani życiowym planom wchodzącego w dorosłość młodego człowieka.

Większych trosk materialnych nie mieli też słuchacze pochodzący z rodzin urzędniczych, jak np. przywódca „Falangi” Bolesław Piasecki, czy profesorskich, jak inny działacz radykalnej prawicy narodowej Wojciech Wasiutyński, albo córka wybitnego znawcy nowożytnych dziejów Polski i dyplomaty, Regina Askenazy. W aktach osobowych tych i wielu innych osób z tej grupy społecznej nie ma śladów problemów finansowych w postaci podań o zwolnienie z czesnego, przyznanie stypendium itp. ${ }^{264}$. Sprawy takie nie pojawiają się także ani w aktach, ani w lapidarnych zapiskach sporządzanych podczas studiów przez Witolda Gombrowicza, pochodzącego z rodziny ziemiańskiej, która na krótko przed I wojną światową przeprowadziła się do Warszawy, wtapiając się w środowisko zamożnego mieszczaństwa. Obok faktu odmrożenia nosa, nazwisk pojedynczych wykładowców Wydziału Prawa i dziewczyn, z którymi flirtował, późniejszy autor Ferdydurke odnotowywał w nich głównie wakacje spędzane w rodzinnym dworze w Małoszycach, majątkach prowadzonych przez swych braci lub w willi zaprzyjaźnionych fabrykantów w Sopocie. (Po latach przypomniał sobie jeszcze z czasu studiów tenisa, szachy, gawędy z przyjaciółmi i, przede wszystkim, błogie lenistwo ${ }^{265}$. Oczywiście również w obrębie grupy dobrze sytuowanych rodzin pracowników umysłowych, urzędników czy oficerów występowały różnice zamożności i nie zawsze studenci pochodzący z takich rodzin żyli na wysokiej stopie. Brak pieniędzy nie stanowił jednak w tej grupie istotnej przeszkody utrudniającej ukończenie Uniwersytetu.

Sytuacja komplikowała się natomiast, gdy nawet względnie zamożni rodzice wpadali w kłopoty finansowe, co przydarzało się ojcu Józefa Garlińskiego, który po 1920 r. otworzył praktykę adwokacką w Ostrowie Wielkopolskim. „Ojciec znów zaczął przesyłać pieniądze nieregularnie. Byłem w ciągłych trudnościach finansowych [...]" - wspomina Garliński i dodaje nieco dalej: „Tylko w Grudziądzu [tzn. w czasie służby wojskowej - P.M.M.] nie odczuwałem braku pieniędzy. W latach szkolnych było 


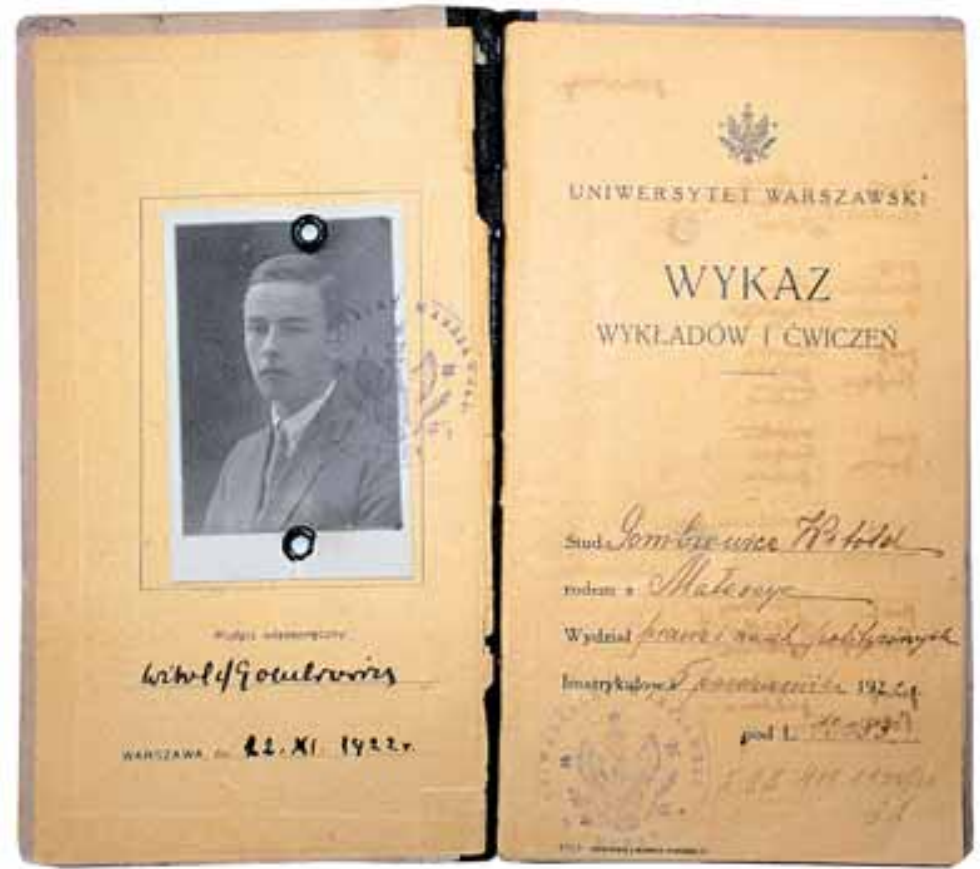

41. Indeks studenta

Wydziału Prawa

Witolda Gombrowicza

różnie, teraz w Warszawie, na studiach, bardzo podobnie. Musiałem płacić za uniwersytet, bo zwolnienie z opłat, nawet gdybym szedł na samym czele, nie mogło mnie objąć. Musiałem gdzieś mieszkać, jeść, ubierać się, jeździć tramwajami, a regularność nadchodzących od ojca przesyłek pieniężnych była bardzo wątpliwa" ${ }^{9266}$. Podobny problem dotknął późniejszego publicystę Karola Zbyszewskiego, gdy jego ojciec, urzędnik Ministerstwa Skarbu, stracił w 1928 r. posadę. Cała rodzina znalazła się wówczas na utrzymaniu jego starszego brata, dyplomaty przebywającego wówczas na placówce w Paryżu, a on sam, chcąc pozostać na Uniwersytecie, musiał ubiegać się o stypendia ${ }^{267}$.

Dla mniej zamożnej inteligencji, na przykład emerytowanych nauczycieli czy urzędników, wysłanie na Uniwersytet do stolicy choćby jednego dziecka okupione było często licznymi wyrzeczeniami, a i to nie zapewniało niekiedy środków wystarczających na opłacenie stancji i wyżywienia. Przykładem mogą być losy późniejszego poety i literata Jana Śpiewaka, którego rodzina, mimo prawniczego wykształcenia ojca, z trudem wiązała w Równem koniec z końcem. O swoich pierwszych miesiącach na Uniwersytecie Warszawskim pisał on: „Na razie żyję w warunkach luksusowych, jakich się nawet nie spodziewałem. Jestem dobrze, modnie ubrany. Matka pomyślała o wszystkim, wyprawiła do 
Warszawy jak panicza, kosztem domu i dużego wysiłku ojca. Skoro mam mieszkać razem z synem zamożnych ludzi, nie mogę gorzej od niego wyglądać. Muszę żyć oszczędnie i dlatego posyła mi paczki żywnościowe. Pieniądze mógłbym lekkomyślnie wydać, a tak jest pewność, że nie będę głodował"268.

Jeszcze cięższe było na ogół położenie studentów pochodzących z rodzin „właścicieli mniejszych” oraz „robotników i małorolnych”. Typową sytuację takich osób dobrze charakteryzuje jedno z zachowanych podań o stypendium: „Jestem synem oficjalisty rolnego. Ojciec mój zarabia około 120 złotych miesięcznie, a ta skromna pensja wystarcza zaledwie na skromne wyżywienie rodziny na wsi, wobec tego z domu nie otrzymuję żadnych zasiłków"269. Wśród 46 studentów Wydziału Weterynaryjnego, którzy w 1938 r. złożyli podania o pomoc materialną, dominowały dzieci chłopów i robotników, niekiedy bezrobotnych, kilka osób pochodziło z rodzin niższych urzędników i funkcjonariuszy państwowych (głównie pracowników PKP), 2 osoby miały ojców organistów, a jedna - kupca. W sumie aż $25 \mathrm{z}$ nich zaliczało się do grupy „robotników i małorolnych”, a 15 do „właścicieli mniejszych”. Pozostałych 6 osób miało pochodzenie inteligenckie, przy czym ojcowie aż $5 \mathrm{z}$ nich byli już emerytami ${ }^{270}$.

Poza niskimi dochodami na niekorzyść słuchaczy wywodzących się z niższych warstw społecznych działała często również wielodzietność ich rodzin. W opisywanej powyżej grupie 46 studentów weterynarii aż 19 osób miało troje rodzeństwa lub więcej. Tylko jedna z nich zaliczała się do inteligencji, wszyscy pozostali pochodzili z grup „właścicieli mniejszych” lub „robotników i małorolnych”271. W trudnym położeniu byli zwłaszcza ci studenci, którzy byli najstarszymi dziećmi w rodzinie, gdyż oczekiwano od nich, że jak najszybciej się usamodzielnią i odciążą domowy budżet. Jak wyjaśniał jeden z nich: „rodzice nie mogą mi dać żadnych zapomóg, ponieważ sami są niezamożni. Ojciec mój utrzymuje ze swego skromnego rzemiosła dziesięcioro dzieci, których pragnąłby wykształcić i zapewnić im przyszłość. Ja jestem w domu najstarszym, nie mogę żądać od ojca zapomóg, które odbiłyby się z konieczności na moim młodszym rodzeństwie" ${ }^{9272}$. Samodzielności oczekiwano zwłaszcza od młodych mężczyzn, co stanowiło odwrotną stronę ich uprzywilejowanej pozycji na rynku pracy: „W poprzednich latach otrzymywałem pomoc z domu nieznaczną, w tym roku jednakże zdany jestem wyłącznie na własne siły” - objaśniał swą sytuację student prawa. „Albowiem w tym roku siostra moja skończyła gimnazjum i wstąpiła na U.J.P. w Warszawie na wydział matematyczno-przyrodniczy. Otóż, o ile tylko matka będzie miała pieniądze, to będzie pomagała siostrze" ${ }^{973}$. 
Położenie studentów z warstw najuboższych pogarszało się dramatycznie, gdy rodzina traciła dotychczasowe źródła utrzymania na skutek śmierci jednego lub obojga rodziców, ich choroby, niedołężności lub utraty pracy. Obficie ilustrują to zachowane podania o zapomogi i zwolnienia z czesnego z Wydziału Weterynaryjnego z 1938 r., a także wnioski o stypendia Fundacji im. Młockich. „Jestem w b. ciężkich warunkach mat.[erialnych], gdyż ub. roku utraciłem ojca, a matka otrzymując 107 zł miesięcznie emerytury i mając 4 dzieci nie może mnie utrzymać" - pisał student z Mołodeczna. Ojciec innego słuchacza, według załączonego zaświadczenia, „[...] lat 73 mający, zamieszkały w Łasku [...], z zawodu dorożkarz, posiada oficynę drewnianą o 1 izbie, w której mieszka, oraz $\frac{1}{2} 2$ ha ziemi własnej i dorożkę jednokonną. Prócz tego uprawia 1 ha ziemi wydzierżawionej. Dochód z ziemi i dorożkarstwa wystarcza mu zaledwie na skromne utrzymanie, skutkiem czego [...] nie jest w stanie zapłacić czesnego za syna". W opłakanej sytuacji znajdowali się też niektórzy studenci mieszkający w Warszawie. „Mam ojca chorego (sparaliżowanego) od lat 17, który jest na utrzymaniu rodziny, matka zaś zarabia 20 zł miesięcznie pracując u swojej siostry, dlatego też nie mogę zupełnie liczyć na jakąkolwiek pomoc pieniężną ze strony rodziny. Nie mogę także zajmować się jakąkolwiek pracą zarobkową, gdyż studia na wydziale weterynaryjnym pochłaniają bardzo dużo czasu" - motywował swoją prośbę jeden ze słuchaczy, wyjaśniając dalej, iż poprzedni rok studiów ukończył tylko dzięki stypendium państwowemu, które pozwoliło mu zamieszkać w Domu Akademickim na Ochocie. Podobne dramaty osobiste znaleźć można również w wielu innych podaniach ${ }^{274}$.

W jaki sposób niezamożność rodziny przekładała się w praktyce na sytuację studiujących, ilustrują perypetie późniejszego premiera Izraela Menachema Begina, który studiował na Wydziale Prawa w latach 1931-1935. Kolejne lata nauki były dla niego ciągłą walką o przetrwanie, gdyż jego ojciec, były sekretarz gminy żydowskiej w Brześciu nad Bugiem pozostawał bez pracy i utrzymywał się wraz z całą rodziną, jak stwierdza załączone świadectwo niezamożności, „z dorywczych zasiłków". Jeszcze przed rozpoczęciem studiów Begin zwrócił się więc o odroczenie czesnego za pierwszy rok, lecz uwzględniono je tylko połowicznie. Podobnie stało się na drugim roku, co wobec nieuiszczenia w terminie reszty należności doprowadziło do skreślenia Begina z listy studentów. Ponownie wpisany na nią pod koniec 1933 r., także w kolejnych latach zmuszony był ubiegać się o odroczenia czesnego i zwolnienia z opłat egzaminacyjnych. Jego zobowiązania wobec skarbu państwa sięgnęły ostatecznie 284,20 zł, które zobowiązał się spłacać 
do $3^{1}$ VIII 1944 r. Kiedy pod koniec 1937 r. Beginowi - wówczas już absolwentowi UW - zdarzyło się nie wnieść jednej z rat, kwestura uniwersytecka zagroziła skierowaniem sprawy na drogę sądową. Później zgodziła się jednak życzliwie rozłożyć zaległą kwotę na niewielkie raty pięciozłotowe, wychodząc najwyraźniej z założenia, że lepszy wróbel w garści niż kanarek na dachu, a ostatecznie prolongowała również spłatę kolejnej transzy należności ${ }^{275}$. Ze względu na wybuch wojny Begin - jak bardzo wielu innych słuchaczy - nie zdążył już uregulować swych zobowiązań wobec uczelni.

Jak widać, nawet ukończenie Uniwersytetu nie zawsze uwalniało od problemów finansowych związanych ze studiowaniem. Niekiedy zdarzało się wręcz, że zaciągnięte podczas studiów długi wpychały młodych ludzi w nędzę. Pod koniec lat 3o. rozgoryczona absolwentka Wydziału Humanistycznego pisała z żalem pod adresem władz uczelni, iż nie przestrzegły studentów przed ,zaciąganiem pożyczek na studia, które nie mogą zapewnić im nawet najskromniejszego bytowania w przyszłości, jeśli nie mają własnych kapitałów, kamienic, silnych i bezczelnych łokci". Jej zadłużenie wobec skarbu państwa z tytułu zaległego czesnego wynosiło w tym czasie 4 ,170 zł, po kilku latach bezrobocia została eksmitowana z mieszkania wraz z niedołężną matką, a uzyskany w końcu etat w bibliotece (16o zł) z trudem pozwalał jej utrzymać się przy życiu. Spłata astronomicznie wysokiego, z jej punktu widzenia, długu znajdowała się zupełnie poza zasięgiem jej możliwości ${ }^{276}$.

Mimo iż przedstawione powyżej przypadki dokumentują, jak trudno było utrzymać się na uczelni studentom niezamożnym, ukazują one również inną, poniekąd paradoksalną prawdę na temat ówczesnej rzeczywistości społecznej: nawet ubogie osoby pochodzące z prowincji mogły wstąpić na Uniwersytet i przeżyć w Warszawie, o ile tylko były odpowiednio zdolne lub zdeterminowane, aby się uczyć. Doskonałym tego przykładem może być biografia Stefana Wesołowskiego, wybitnego później chirurga urologa. Pochodził on z północnego Mazowsza, z ubogiej rodziny chłopskiej. Jego ojciec, nie będąc w stanie opłacić edukacji syna w gimnazjum państwowym w Płońsku, zmuszony został przenieść go do przyklasztornej szkoły z internatem w odległym Dubnie na Wołyniu, gdzie koszty utrzymania były dużo niższe. Stamtąd z bardzo dobrym wynikiem Wesołowski dostał się w 1927 r. na Wydział Lekarski UW, na którym mógł studiować dzięki stypendium lokalnego sejmiku powiatowego (6oo zł rocznie), pożyczkom zaciąganym w różnych instytucjach i niewielkiej pomocy ze strony rodziny. Wkrótce stał się jednym z najbardziej aktywnych działaczy Koła Medyków, a także współautorem i współorganizatorem słynnych wówczas 


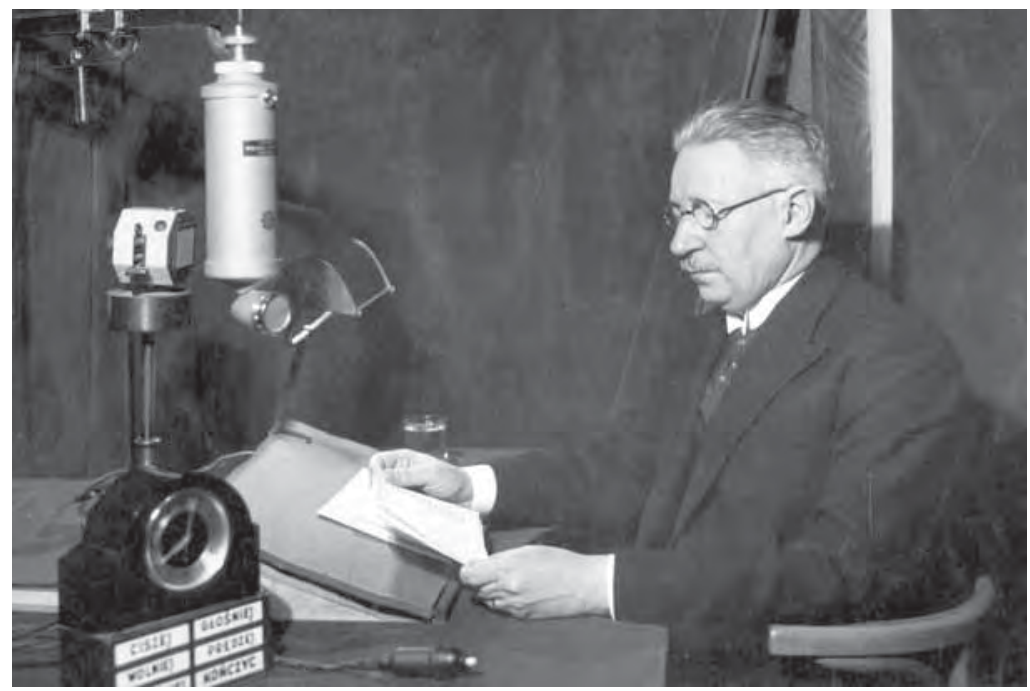

42. Minister wyznań religijnych i oświecenia publicznego prof. Wojciech Świętosławski podczas odczytu radiowego „O pomoc społeczną dla młodzieży akademickiej", 30 I $1936 \mathrm{r}$.

na całą Warszawę zabaw taneczno-satyrycznych ${ }^{277}$. Podobnie jak Begin, Wesołowski ukończył studia z pokaźnymi długami, a ponieważ dopiero 3 lata później otrzymał pierwszą płatną posadę, miał kłopoty z ich spłatą. W podaniu o rozłożeniu na mniejsze raty odroczonych opłat akademickich wyliczał, iż oprócz Uniwersytetu musi stopniowo regulować zobowiązania wobec Koła Medyków, Bratniej Pomocy i Towarzystwa Lekarskiego ${ }^{278}$.

Bieda nie przeszkodziła również w uzyskaniu dyplomu ani Beginowi, ani Śpiewakowi, o których była mowa wcześniej, choć nie ma wątpliwości, iż znacznie więcej studentów biednych niż bogatych nie kończyło studiów. Studiowanie na przekór biedzie wymagało z pewnością bardzo wielu wyrzeczeń, sporej obrotności i pewnej dozy życiowego szczęścia. Zmuszało również najczęściej do podejmowania równoległej ze studiami pracy zarobkowej, a niekiedy wręcz wiązało się z niedojadaniem i upokarzającą koniecznością ciągłego zabiegania o pomoc materialną, zwolnienia z opłat, doraźne pożyczki itp. Z drugiej strony, znacznie mniejsza niż dzisiaj ogólna zamożność przedwojennego społeczeństwa sprawiała, że bieda nie stygmatyzowała studentów i nie wypychała ich poza nawias społeczności akademickiej.

Przeciwnie, zauważyć można dość powszechne zrozumienie i życzliwość, z jakimi, nie tylko na Uniwersytecie, podchodzono do mizernej kondycji finansowej wielu słuchaczy. Tym, którzy nie wykazywali odpowiedniej empatii, studenci potrafili zresztą dać się solidnie we znaki. Jeden z pamiętnikarzy opisuje, że gdy bogaty właściciel jednej 
z najlepszych kawiarni odmówił wsparcia organizacji akademickich, „o godzinie otwarcia zakładu zjawiła się grupa studentów i zajęła miejsca przy wszystkich stolikach. [...] Każdy ze studentów zamówił szklankę wody sodowej i przez trzy godziny siedział przy tej wodzie, potem zaś pojawiła się zmiana. Po dwóch dniach takiej legalnej okupacji - policja nie miała nic do powiedzenia, jako że prawa nie naruszano, a wodę sodową pić wolno - właściciel lokalu «pękł» i klnąc zapłacił żądaną przez organizację studencką sumę, którą uważał za haracz"279. Historia ta wydarzyła się wprawdzie w Krakowie, ale musiała mieć szeroki rezonans również w stolicy, skoro ówczesny słuchacz Uniwersytetu Warszawskiego przytoczył ją, naturalnie z pełną aprobatą, po kilkudziesięciu latach. Jak widać, w fakcie, że student jest biedny, nie widziano niczego wyjątkowego, ani nie traktowano tego w kategoriach ujmy na jego honorze.

\section{Studenci: źródła utrzymania, czesne, wydatki, zdrowie}

Informacje na temat źródeł utrzymania słuchaczy Uniwersytetu Warszawskiego są w pewnej mierze sprzeczne. Według danych z roku akademickiego 1934/1935, które przytacza Atlas szkolnictwa wyższego, większość studentów utrzymywała się głównie ze środków otrzymywanych od rodzin. W sytuacji takiej znajdowało się aż 6o\% z nich. Uniwersytet zajmował pierwsze miejsce w kraju pod względem odsetka słuchaczy utrzymujących się na własną rękę, który osiągał tu $32 \%$, podczas gdy średnia krajowa wynosiła $26 \%$. Jak uważa autorka Atlasu Halina Wittlinowa, miało to związek ze stosunkowo największymi możliwościami zarobkowania, jakie oferowała stolica. Ponadto 8\% studentów UW korzystało z różnego rodzaju stypendiów, co również stanowiło wyróżnik na tle ogółu oświaty wyższej. (W skali całej Polski otrzymywało je wówczas 5,5\% słuchaczy). Pozycję tę Uniwersytet zawdzięczał przede wszystkim bardzo dużej liczbie stypendiów dla studentów medycyny przyznawanych przez różnego rodzaju instytucje samopomocowe - korzystał z nich niemal co trzeci słuchacz Wydziału Lekarskiego, podczas gdy na innych uniwersytetach odsetek stypendystów nie przekraczał 10\% ${ }^{280}$.

Odmienny obraz wyłania się z publikacji z drugiej połowy lat 20., według której aż 73\% studentów wszystkich szkół wyższych zmuszonych 
było utrzymywać się samodzielnie, $25 \%$ otrzymywało jakąkolwiek pomoc z domu (z czego mniej więcej połowie nie wystarczała ona na życie), a tylko $2 \%$ korzystało ze stypendiów ${ }^{281}$. Ponieważ trudno jest zakładać, że sytuacja panująca na Uniwersytecie Warszawskim była całkowitą odwrotnością realiów ogólnokrajowych, jak również że w ciągu kilku zaledwie lat, przypadających na czasy wielkiego kryzysu gospodarczego, nastąpiła tak diametralna poprawa warunków studiowania, wydaje się pewne, iż któreś z tych źródeł (albo w jakimś stopniu oba) podają dane nieprawdziwe. Mogło to wynikać z deklaratywnego charakteru informacji na temat źródeł utrzymania, które pochodziły z ankiet przeprowadzanych wśród studentów, zaniżających prawdopodobnie wielkość pomocy otrzymywanej od rodziny.

W przeciwieństwie do autorów wcześniejszej monografii dziejów Uniwersytetu Warszawskiego w dwudziestoleciu międzywojennym, którzy podzielali pogląd o konieczności samodzielnego utrzymywania się przez większość studentów ${ }^{282}$, uważam za bliższy prawdy wniosek Wittlinowej, że podstawowe źródło utrzymania słuchaczy stanowiła pomoc ze strony rodziny. Świadczą o tym np. dane z roku akademickiego 1931/1932, opublikowane przez Bratnią Pomoc. Wynika z nich, iż wsparcie materialne z domu otrzymywało $56 \%$ studentek i $40 \%$ studentów, przy czym kobiety dostawały najczęściej więcej pieniędzy niż mężczyźni ${ }^{283}$. (Potwierdza to obserwację, że wykształcenie córki było droższe niż syna, o czym pisałem w rozdziale poświęconym strukturze płci). Liczby te odnoszą się wprawdzie wyłącznie do studentów chrześcijańskich, nie ma jednak powodów, aby sądzić, że sytuacja słuchaczy wyznania mojżeszowego była diametralnie inna. Do podobnych wniosków prowadzą informacje, które znaleźć można w kwestionariuszach wypełnianych przez najuboższych studentów Wydziału Weterynaryjnego, ubiegających się o zwolnienie $\mathrm{z}$ czesnego lub stypendia socjalne. Na ogólną liczbę 46 takich osób, tylko 14, nie przysyłano z domu jakichkolwiek pieniędzy, jeden student otrzymywał pomoc w postaci paczek żywnościowych, a 9 mieszkających w Warszawie lub mających tu krewnych mogło nieodpłatnie korzystać z mieszkania i (niekiedy) z wyżywienia. Pozostałe 23 osoby dostawały co miesiąc od rodziny średnio około $30 \mathrm{z}^{284}$.

Należy przypuszczać, że skoro nawet około 2/3 najuboższych otrzymywało pewną pomoc od rodziny, w tym połowa z nich w postaci gotówki, tym bardziej wśród zamożniejszych studentów przeważać musieli ci, których utrzymywali rodzice lub krewni. Zarówno przykład słuchaczy weterynarii, jak i dane zebrane przez Bratnią Pomoc, pokazują zarazem, że często łączono ze sobą różne źródła utrzymania. Duża część 
studentów musiała zarobkować, ponieważ środki otrzymywane od rodziny były niewystarczające, aby przeżyć w stolicy. Inni, choć utrzymywali ich rodzice, dorabiali, aby zdobyć pieniądze na własne wydatki, a tym samym odciążyć domowy budżet. Jeszcze inni uzupełniali częściowo swe dochody różnymi pożyczkami lub zapomogami, o których będzie mowa dalej.

Warto podkreślić, iż w sytuacji śmierci rodziców lub ich niedołężności wsparcia materialnego często udzielało studiującym starsze rodzeństwo, a niekiedy również dalsi krewni. Naukę Jana Radożyckiego na Uniwersytecie finansował na przykład jego wuj, ksiądz Jan Stawarczyk, który pracował tu naukowo na Wydziale Teologii Katolickieje28. W takich sytuacjach sponsorzy rościli sobie zwykle prawo do kontrolowania postępów w nauce, albo nawet prowadzenia się swoich podopiecznych. Radożycki pilnie studiował, aby nie zawieść wuja dobrodzieja, ale prowadzący życie artysty poeta Artur Rzeczyca po jakimś czasie zraził sobie i rodziców, i resztę krewnych, którzy przestali przesyłać pieniądze ${ }^{286}$. Solidarność rodzinna działała oczywiście w obie strony i do rzadkości nie należały również sytuacje, gdy po śmierci jednego lub obojga rodziców to student Uniwersytetu zmuszony był przejąć rolę głównego żywiciela rodziny, utrzymując młodsze rodzeństwo ${ }^{287}$.

Z informacji zebranych przez Bratnią Pomoc wynika, iż na początku lat 30. zarobkowało $59 \%$ studentek i $53 \%$ studentów chrześcijańskich. Mniej więcej co czwarta z kobiet zarabiała miesięcznie nie więcej niż $50 \mathrm{zl}, 28 \%$ od 50 do $100 \mathrm{zl}$, kolejne $30 \%$ od 100 do $200 \mathrm{zl}$, natomiast $15 \%$ ponad 200 zł. Struktura zarobków mężczyzn wyglądała inaczej: dochód poniżej 50 zł deklarowało tylko 5\% z nich, 23\% uzyskiwało od 50 do $100 \mathrm{zl}, 44 \%$ od 100 do $200 \mathrm{zl}, 20 \%$ od 200 do $250 \mathrm{zl}$, a $8 \%$ powyżej $250 \mathrm{z}{ }^{288}$. (Dla porównania, pensja robotnika niewykwalifikowanego wynosiła wówczas ok. 100-200 zł, starszy asystent zarabiał na Uniwersytecie 250 zł). Jak widać, rozpiętość dochodów była bardzo duża. Studentki podejmowały nieco częściej pracę niż studenci, ale zarabiały od nich zdecydowanie gorzej, w znacznie większym stopniu zależały więc od pomocy finansowej ze strony rodziny.

Najczęstszą formą zarobkowania studentów były korepetycje. Z informacji zamieszczanych we wnioskach o pomoc wynika, iż pod koniec lat 3o. wynagrodzenie za godzinę zajęć wynosiło ok. 1 zł, a jedna osoba mogła w ten sposób zarobić miesięcznie najczęściej 30-40 z ${ }^{289}$. Pojawiająca się regularnie $\mathrm{w}$ ofertach pracy informacja o wyznaniu korepetytora („Student-chrześcijanin...”) wskazuje, że rodziny chrześcijańskie niechętnie zatrudniały w takim charakterze żydowskich słuchaczy Uniwersytetu, a reguła ta działała prawdopodobnie także 
vice versa. Zdarzało się, że korepetycji udzielano w zamian za stancję, a nawet za obiady ${ }^{290}$.

Prosty rachunek wykazuje, że osoba wynajmująca w Warszawie mieszkanie, bez żadnego wsparcia ze strony rodziny, miała wielkie trudności, aby utrzymać się z korepetycji. Chcąc zarobić $4.0 \mathrm{zl}, \mathrm{mu}-$ siała udzielać 10 lekcji tygodniowo (co wymagało przecież dodatkowo pewnego przygotowania się i dojazdu do klienta), a kwota ta z trudem wystarczała nawet na bardzo nędzną wegetację. W dużo lepszej sytuacji znajdowali się studenci mieszkający w Warszawie przy rodzinach, którzy dzięki zarobkom z korepetycji mogli dokładać się do domowych wydatków. Jak wyjaśniała jedna ze studentek weterynarii: „Mieszkam przy rodzicach i mam od nich życie, ale gdy zarabiam korepetycjami, wówczas daję im około 30 zł miesięcznie ${ }^{\$ 291}$. W przypadku osób lepiej sytuowanych dawanie lekcji mogło stanowić natomiast źródło dochodów, niezależne od rodzicielskiego kieszonkowego. „Zostawszy studentem, chciałem uniezależnić się od pomocy Rodziców przynajmniej w zakresie wydatków osobistych" - wspomina z kolei Tadeusz Manteuffel, który w czasie studiów udzielał tygodniowo do 10 godzin korepetycji ${ }^{292}$.

Ciężko było jednak pogodzić z nauką dużą liczbę korepetycji, a tylko taka mogła zapewnić zarobek pozwalający myśleć o samodzielnym utrzymaniu się. „Mieszkając poza miastem i daleko od stacji [...] i mając dużą ilość godzin pracy na Uniwersytecie, nie mogę wziąć ponad jedną korepetycję (30 zł miesięcznie)" - pisała studentka sekcji przyrodniczej Wydziału Filozoficznego w podaniu o stypendium ${ }^{293}$. Podobne problemy miało wielu innych słuchaczy, którzy występując o stypendia próbowali uciec z zaklętego kręgu pracy zarobkowej przeszkadzającej w nauce.

Specyficzną formę korepetycji stanowiły tzw. kondycje, czyli pomoc $\mathrm{w}$ nauce dzieciom na prowincji. Wiązały się one z koniecznością opuszczenia Warszawy, niektórzy studenci decydowali się jednak na nie, ponieważ rodziny oferowały preceptorom swych latorośli, oprócz wynagrodzenia, zazwyczaj wyżywienie i zakwaterowanie - niekiedy w komfortowych warunkach, np. we dworze ziemiańskim. Dla wielu osób były więc kondycje okazją do podreperowania zdrowia i odzyskania sił. „Wskutek wyczerpania fizycznego w roku 1923/1924 przerwałam studia na Uniwersytecie, uzyskałam urlop i wyjechałam na wieś na kondycje" - informowała Fundację im. Młockich studentka Wydziału Filozoficznego ${ }^{294}$. Co ciekawe, w przypadku niektórych kierunków (głównie prawa) możliwe było pogodzenie takiej posady z formalnym kontynuowaniem nauki na Uniwersytecie. „W zeszłym roku nie mogłem spełnić mojej potrzeby kształcenia się, bo haniebne warunki mieszkaniowe (mieszkałem w suterenie) i materialne wygnały mnie na wieś 
na kondycję. Tam oczywiście uczyłem się ze skryptów i podręczników i egzamin złożyłem. Ale nauka ograniczona do tego, aby tylko zdać egzamin, mnie nie zadowala" - opisywał swe położenie pewien student Wydziału Prawa ${ }^{295}$.

Mimo że korepetycji udzielało bardzo wielu słuchaczy Uniwersytetu (a może właśnie dlatego), zdobycie posady korepetytora nie było wcale łatwe, szczególnie dla osób pochodzących spoza Warszawy, które nie dysponowały tu odpowiednią siecią kontaktów towarzyskich, znajomości szkolnych i rodzinnych. Aplikując o stypendium inny student prawa, weteran walk o niepodległość i powstań śląskich, wyznawał: „przed paru jednak dniami utraciłem dwie korepetycje, nie znam tutejszych stosunków, nie posiadam znajomych, niedawno bowiem przyjechałem do Warszawy, co nie pozwala mi przypuszczać, abym wkrótce zdobył nowe środki utrzymania"296. Minusem korepetycji był również ich sezonowy charakter: w większości przypadków zarobki kończyły się wraz z początkiem wakacji, choć sporadycznie zdarzały się przypadki, że zamożne rodziny angażowały studentów jako preceptorów dla dzieci również w miesiącach letnich, zabierając ich nawet ze sobą na wypoczynek. Ofertę taką otrzymał np. jeden z niemieckich studentów, uczący swego języka ojczystego synów przemysłowca i wielokrotnego ministra Czesława Klarnera ${ }^{297}$.

Nie zawsze też korepetycje były miłym doświadczeniem. „Powodziło mi się coraz gorzej. Z domu otrzymywałem grosze, musiałem zarabiać korepetycjami” - wspomina Jan Śpiewak. „Te «korki» były obrzydliwe, poniżające, a przy tym trudne do zdobycia, trzeba było szukać protekcji, aby móc zarobić parę złotych. Ubrylantynowane mamy patrzyły na mnie podejrzliwie, nieraz siedziały na lekcjach, kontrolowały, jak uczę i czego uczę. Tłuste łapska błyszczały od złota. Uparcie wbijałem bęcwałom do głowy zasady gramatyki, wyjaśniałem, tłumaczyłem literaturę polską. Mamy dopiekały, jak mogły. Pokojówki patrzyły z politowaniem na korepetytora, który ze spoconym łbem, zadyszany wpadał, aby się nie spóźnić i gnał dalej na drugi koniec miasta. Wykłady uniwersyteckie, «korki», nieustanny pośpiech, przeskakiwanie z tramwaju do tramwaju męczyło, wracałem do pokoju, aby trochę odpocząć" ${ }^{298}$.

W znacznie lepszej sytuacji znajdowali się ci, którym udało się zdobyć pracę stałą, choć ta z kolei jeszcze trudniej dawała się zazwyczaj pogodzić z nauką. Przyznawał to z perspektywy lat Giedroyc: „Zresztą w pierwszym okresie studiów mało chodziłem na Uniwersytet, gdyż musiałem pracować zarobkowo. Pracowałem w biurze ogłoszeń PAT na Krakowskim Przedmieściu, gdzie wypisywałem ogłoszenia komorników i inne nudziarstwa. Zarabiałem za to zupełnie nieźle; starczało i na 
moje wydatki, i na pomoc dla domu"299. Funkcjonować tak można było jednak na Wydziale Prawa, gdzie na ogół nie egzekwowano obecności studentów na zajęciach; na Wydziale Lekarskim albo na weterynarii byłoby to już niemożliwe. Jak pisał jeden z niedoszłych medyków, tłumacząc, dlaczego przeniósł się na Wydział Prawa: „Skazany [po śmierci ojca - P.M.M.] na wiele godzin codziennej pracy zarobkowej, nie mógłbym dalej kontynuować mych kosztownych studiów medycznych, absorbujących cały dzień ze względu na obowiązkowe laborki i kliniki”300.

Studenci chwytali się różnych zajęć, znajdując zatrudnienie jako biuraliści, urzędnicy, magazynierzy, egzekutorzy, taksatorzy, kelnerzy lub bufetowe ${ }^{301}$. Jeden z prawników najpierw pracował na 3 zmiany jako robotnik sezonowy w fabryce konserw i przetworów owocowych, a następnie na wyścigach konnych jako „blokier, goniec i kontroler stajenny" ${ }^{\prime 302}$. Część osób próbowała godzić studia na Uniwersytecie z pracą nauczyciela; była to, oprócz korepetycji i kondycji, jedna z niewielu posad, na których kobiety mogły dorabiać na równi z mężczyznami ${ }^{303}$. Medycy wyjeżdżali w wakacje do uzdrowisk i sanatoriów, gdzie do ich formalnych obowiązków należała nie tylko rehabilitacja, lecz również obtańcowywanie kuracjuszek ${ }^{304}$. Niektórzy z przyszłych prawników relacjonowali dla prasy procesy sądowe ${ }^{305}$. Jako korektor w „Gazecie Warszawskiej", i to już od pierwszego roku studiów, dorabiał sobie Wojciech Wasiutyński, chociaż jako syn profesora Uniwersytetu nie musiał martwić się o utrzymanie. (Być może zatem głównym motywem zatrudnienia się była w jego przypadku chęć wejścia w dorosły świat polityki?) ${ }^{306}$. Późniejszy poeta i tłumacz Seweryn Pollak został zaangażowany jako sekretarz literacki przez spadkobiercę wielkiej fortuny przemysłowej Marka Eigera (prywatnie brata komunistki Marii Kamińskiej), pisującego pod pseudonimem Stefan Napierski ${ }^{307}$. Najbardziej bodaj oryginalny sposób dorabiania znalazł sobie Stefan Otwinowski, przyszły dramatopisarz i publicysta, który „bardzo lubił tańczyć, tańczył znakomicie, a nawet w początkach [...] studiów wykorzystywał tę umiejętność w celach zarobkowych, angażując się w warszawskich lokalach jako fordanser"308. O żadnym z tych zajęć nie wiemy niestety, na ile było dochodowe i czy nie powodowało kolizji z nauką. Przeważnie były to jednak prace „dorywcze, mało opłacalne, a co najgorsze - niestałe”, jak charakteryzował je jeden z ówczesnych studentów ${ }^{309}$.

Niełatwo też było zdobyć zatrudnienie. Pośrednictwem w poszukiwaniu pracy zajmowała się, bardzo zresztą profesjonalnie, Bratnia Pomoc, ale na początku lat 30. popyt na rynku pracy tak dalece przewyższał podaż, iż zainteresowani ustawiali się w kolejce na 20 godzin przed otwarciem biura. W tym czasie organizacja dysponowała rocznie 
1455 ofertami; w każdym trymestrze na listę oczekujących zapisywało się ok. 300 studentów ${ }^{310}$. Jeszcze trudniejsze było poszukiwanie pracy na własną rękę, co opisywał w podaniu o stypendium inny ze słuchaczy: „Obszedłem już wszystkie biura, ogłaszałem się trzykrotnie w «Kurierze Warszawskim», reflektowałem już nawet na posadę stróża nocnego, wszystko jednak bez skutku, pracy w porze wiecz[ornej] lub nocnej otrzymać nie mogłem"si1.

Skoro już mowa o pracy nocnej, o ile wierzyć historii przytaczanej przez wiceministra wyznań religijnych i oświecenia publicznego księdza Bronisława Żongołłowicza, zdarzało się ponoć, iż studentki Uniwersytetu Warszawskiego dorabiały sobie w charakterze luksusowych prostytutek, obsługujących najwyższych dygnitarzy państwowych. Jedna z nich, wyjątkowo piękna słuchaczka farmacji miała jednorazowo zarobić, jak dosadnie ujął to pamiętnikarz, „pod Beckiem”, ówczesnym szefem polskiej dyplomacji, aż 100 zł, które zresztą zaraz szlachetnie podarowała pewnemu niezamożnemu koledze ${ }^{312}$. Jeśli i historia, i stawka były prawdziwe, oznaczałoby to, że dochody przyszłej farmaceutki przewyższały prawdopodobnie zarobki wielu profesorów. Nie był to jednak, pod żadnym chyba względem, przypadek reprezentatywny dla ówczesnej społeczności akademickiej.

Jedna tylko w pełni wiarygodna relacja dokumentuje fakt zarobienia przez studenta Uniwersytetu większej sumy pieniędzy. Udało się to Józefowi Garlińskiemu, który podjąwszy się zredagowania dla wojska okolicznościowej publikacji, otrzymał nie tylko 150 zł tytułem korekty technicznej, ale również $25 \%$ zysków od wpływów z pozyskanych przez siebie ogłoszeń. W ten sposób, korzystając po części z renomy, jaką cieszyła się armia, zarobił w krótkim czasie ponad $1000 \mathrm{zl}$ - kwotę dla niego wówczas zupełnie astronomiczną ${ }^{313}$. Był to jednakże dochód jednorazowy, gdyż podobna okazja zarobku już się nie powtórzyła.

Trudno jest precyzyjnie ustalić, jakie wydatki pociągały za sobą studia na Uniwersytecie Warszawskim, ponieważ ich wielkość i struktura zależały w dużej mierze od warstwy społecznej, z której wywodził się dany student, i miejsca jego zamieszkania. Większość relacji pochodzących od lepiej sytuowanych słuchaczy Uniwersytetu milczy na temat spraw finansowych, z czego wywnioskować można, iż koszty związane ze studiowaniem nie stanowiły problemu absorbującego ich uwagę, w każdym razie nie na tyle, aby wspominać je po latach. W przypadku studentów (nie tylko tych zamożnych), zamieszkałych w stolicy przy rodzinie, wydatki na zakwaterowanie i wyżywienie były proporcjonalne do statusu materialnego ich domów, ale ich precyzyjne wyliczenie przekraczałoby zakres tej pracy. Całkiem sporo można 
natomiast powiedzieć o wydatkach słuchaczy najbiedniejszych, zwłaszcza pochodzących spoza Warszawy, i na tej podstawie oszacować, ile wynosiło minimum egzystencjalne niezbędne, aby utrzymać się podczas studiów na Uniwersytecie.

Mimo iż Uniwersytet Warszawski był uczelnią państwową, nauka na nim miała charakter płatny. Wszyscy studenci, oprócz wpisowego i czesnego, musieli wnosić opłaty za korzystanie z pracowni i biblioteki, za udział w seminariach, a także za egzaminy. Wysokość tych stawek ustalało początkowo corocznie dla wszystkich państwowych szkół wyższych w kraju MWRiOP. Wnoszone przez słuchaczy opłaty odnotowywano w indeksach i na specjalnych formularzach prowadzonych przez kwesturę. Nieuiszczenie ich na czas skutkowało skreśleniem z listy studentów. Wysokość czesnego rosła systematycznie od początku lat 20., co częściowo było skutkiem panującej wówczas hiperinflacji: w roku akademickim 1920/1921 opłata ta wynosiła $45^{0}$ marek polskich, podczas gdy 2 lata później już 10 ooo marek. Towarzyszył temu równie skokowy wzrost pozostałych należności. Wraz z reformą skarbową i wprowadzeniem złotego w 1924, r. nastąpiła ukryta podwyżka. Wysokość czesnego ustalono wówczas na 50 zł rocznie, łączna suma opłat wahała się jednak - w zależności od liczby seminariów, zajęć w pracowniach, egzaminów, a tym samym wydziału i roku studiów - od 90 do $150 \mathrm{zl}^{314}$.

Opłaty akademickie uiszczano w 2 ratach półrocznych. Najtańsze były studia prawnicze i humanistyczne, najdroższe zaś medyczne. Przykładowo, Józef Goldberg, w latach stalinowskich okryty ponurą sławą dyrektor Departamentu Śledczego Ministerstwa Bezpieczeństwa Publicznego, znany później lepiej pod przybranym nazwiskiem jako Jacek Różański, który studiował na Wydziale Prawa w latach 1925-1929, za 2 pierwsze lata nauki zapłacić musiał po 91 zł, za trzeci rok 102 zł, zaś za czwarty 104, zł. Ponadto 21,20 zł kosztowała go poprawka z prawa rzymskiego na pierwszym roku, zaś 14,4,0 zł poprawka z prawa narodów na roku drugim, które niestety, nie wyrobiły w nim przywiązania do praworządności ${ }^{315}$. Studiujący nieco później na Uniwersytecie inny student wyznania mojżeszowego, Dawid Berencwajg, który w 1940 r. został zamordowany przez NKWD w Charkowie jako lekarz podporucznik rezerwy Wojska Polskiego, musiał corocznie uiszczać za naukę na Wydziale Lekarskim 149-151 zł ${ }^{316}$.

W lipcu $193^{2}$ r. MWRiOP wprowadziło radykalną podwyżkę czesnego i całkowicie zmieniło system jego obliczania. Słuchaczy wszystkich wydziałów obowiązywały odtąd jednakowe opłaty roczne, różniły się one natomiast w zależności od roku studiów. Najwyższą stawkę, 
w wysokości $270 \mathrm{z}$, ustalono dla studentów pierwszego roku; na drugim roku wynosiła ona $250 \mathrm{zl}$, na trzecim $220 \mathrm{zl}$, zaś na czwartym i dalszych - 200 zł. Podobnie jak we wcześniejszych latach, czesne regulowano najczęściej w 2 ratach. Słuchaczom przysługiwało prawo wystąpienia o zmniejszenie tych opłat, przy czym i pod tym względem system świadomie faworyzował studentów lat wyższych, gdyż ewentualna ulga miała charakter progresywny, wynosząc 5\% ogółu opłat na pierwszym roku i rosnąc o 5\% każdego kolejnego roku nauki (aż do czwartego włącznie). Kolejna reforma nastąpiła w 1936 r. Zrównała ona opłatę roczną dla wszystkich lat studiów, ustalając jej wysokość na wszystkich uniwersytetach na 200 zł. Za egzaminy płaciło się od 4 do 9 zł, ponadto 15 zł kosztował egzamin magisterski. Przy ubieganiu się o przyjęcie na Uniwersytet należało uiścić opłatę manipulacyjną w wysokości $10 \mathrm{zł}$, a także $10 \mathrm{zł}$ za egzamin wstępny z każdego przedmiotu, po przyjęciu zaś zo zł wpisowego. Najlepsi studenci mieli prawo ubiegać się o zwolnienie z połowy opłat. Osoby niezamożne mogły też wystąpić o odroczenie całości lub części opłat akademickich na okres nie dłuższy niż 10 lat od momentu zakończenia nauki ${ }^{317}$. W takim przypadku podpisywali umowę ze skarbem państwa, reprezentowanym przez władze Uniwersytetu, zobowiązując się do zwrotu odroczonych płatności w określonym terminie.

$\mathrm{Z}$ przywileju odroczenia opłat akademickich w połowie lat 30. korzystało 4,286 osób, czyli prawie co drugi studiujący na UW. (Do wybuchu wojny liczba ta zmniejszyła się niemal dwukrotnie i wynosiła 2234 osoby, równocześnie jednak, o czym będzie jeszcze mowa dalej, istotnie wzrosła grupa słuchaczy pobierających stypendia) ${ }^{318}$. Jednym z beneficjantów odroczenia opłat był studiujący na Wydziale Prawa w latach 1932-1936 Jan Kott, późniejszy krytyk literacki i teatralny, tłumacz i eseista, po wojnie najpierw gorliwy marksista, a później dysydent, profesor Uniwersytetu w latach 1952-1969. W ciągu 3 kolejnych lat nauki, począwszy od drugiego roku studiów, uzyskiwał on odroczenia płatności połowy czesnego, w czym nie przeszkodziło mu zatrzymanie przez policję podczas rozdawania komunistycznych ulotek na manifestacji pierwszomajowej i związane z tym postępowanie dyscyplinarne na uczelni. Jego dług wobec Skarbu Państwa sięgnął ostatecznie 335 zł, którą to kwotę Kott miał spłacić do $3^{1}$ VIII 1945 r. (Niezależnie od odroczenia czesnego otrzymał on równiė̇ w roku akademickim 1935/1936 stypendium państwowe w wysokości 6oo zł rocznie, co pokazuje notabene, jak łagodny wobec swych przeciwników był przedwojenny polski autorytaryzm, w każdym razie na gruncie uniwersyteckim) $)^{319}$. 
Nie ulega wątpliwości, że czesne i inne opłaty były bardzo poważnym obciążeniem dla studentów niezamożnych, a zwłaszcza dla wywodzących się ze wsi, gdzie na skutek wielkiego kryzysu gospodarczego i tzw. nożyc cenowych wiele rodzin nie było w stanie zgromadzić wystarczającej ilości gotówki, aby opłacić dziecku choćby tylko pierwszą ratę. Być może właśnie ze względu na podwyżkę liczba studentów Uniwersytetu w roku akademickim 1933/1934, spadła o blisko 400 w stosunku do roku poprzedniego i już do wybuchu wojny nie wróciła do wcześniejszego poziomu ${ }^{320}$. Z drugiej strony, z ówczesnych wyliczeń wynika, iż nawet po podwyżce opłat akademickich w $193^{2}$ r. ani Uniwersytet, ani skarb państwa na oświacie wyższej nie zarabiały; przeciwnie, do nauki każdego studenta budżet musiał dopłacić co roku ok. 1000 zł $^{321}$. Skoro zresztą po podwyżce uczelnia nie miała problemu z naborem kandydatów, a na niektórych kierunkach musiała wręcz organizować egzaminy wstępne, zdrowy rozsądek wskazuje, iż opłaty nie przekraczały en masse możliwości finansowych ówczesnego społeczeństwa. Dla porównania, w dobrej warszawskiej szkole średniej, jaką było gimnazjum im. Jana Zamoyskiego, czesne na początku lat 30. wynosiło 1000 zł rocznie ${ }^{322}$. W renomowanym Zakładzie Jezuitów w Chyrowie rok nauki (wraz z internatem) w drugiej połowie lat 20. kosztował 1500 zl. Nawet za podrzędne gimnazjum prowadzone na Podkarpaciu przez ojców Saletynów trzeba było zapłacić rocznie 300 zł, kwota ta obejmowała jednak wyżywienie i internat ${ }^{323}$.

Bardzo poważny wydatek związany ze studiami stanowiło zakwaterowanie. Musiała go ponosić zdecydowana większość osób przybyłych z prowincji, którzy stanowili mniej więcej 2/3 ogółu studentów. Tylko nieliczni z nich mogli bowiem liczyć na gościnę u krewnych. Niemal wszyscy słuchacze Uniwersytetu pochodzący z Warszawy mieszkali natomiast przy swych rodzinach. Jedyny przypadek wyprowadzki z domu rodzinnego w stolicy do domu akademickiego, o jakim wspomina znany mi materiał źródłowy, spowodowany był nadzwyczajną biedą ${ }^{324}$. Również niektóre osoby zamieszkałe w okolicach Warszawy pozostawały w domach rodzinnych, dojeżdżając stamtąd na zajęcia. Było to jednak czasochłonne i uciążliwe. Studentowi mieszkającemu w Skierniewicach codzienna podróż na Uniwersytet i z powrotem zajmowała około 5 godzin. Inny, dojeżdżający z Brwinowa, skarżył się, iż „,chciałby się przenieść do Warszawy, bo z Brwinowa na Grochów [gdzie mieścił się Wydział Weterynaryjny - P.M.M.] jest b. daleko i zła komunikacja, nadto bilet kosztuje drogo i duża strata czasu" ${ }^{325}$.

Studenci wynajmowali przeważnie pokoje na mieście, gdyż miejsc w akademikach i tzw. ogniskach było przez większą część dwudziestolecia 


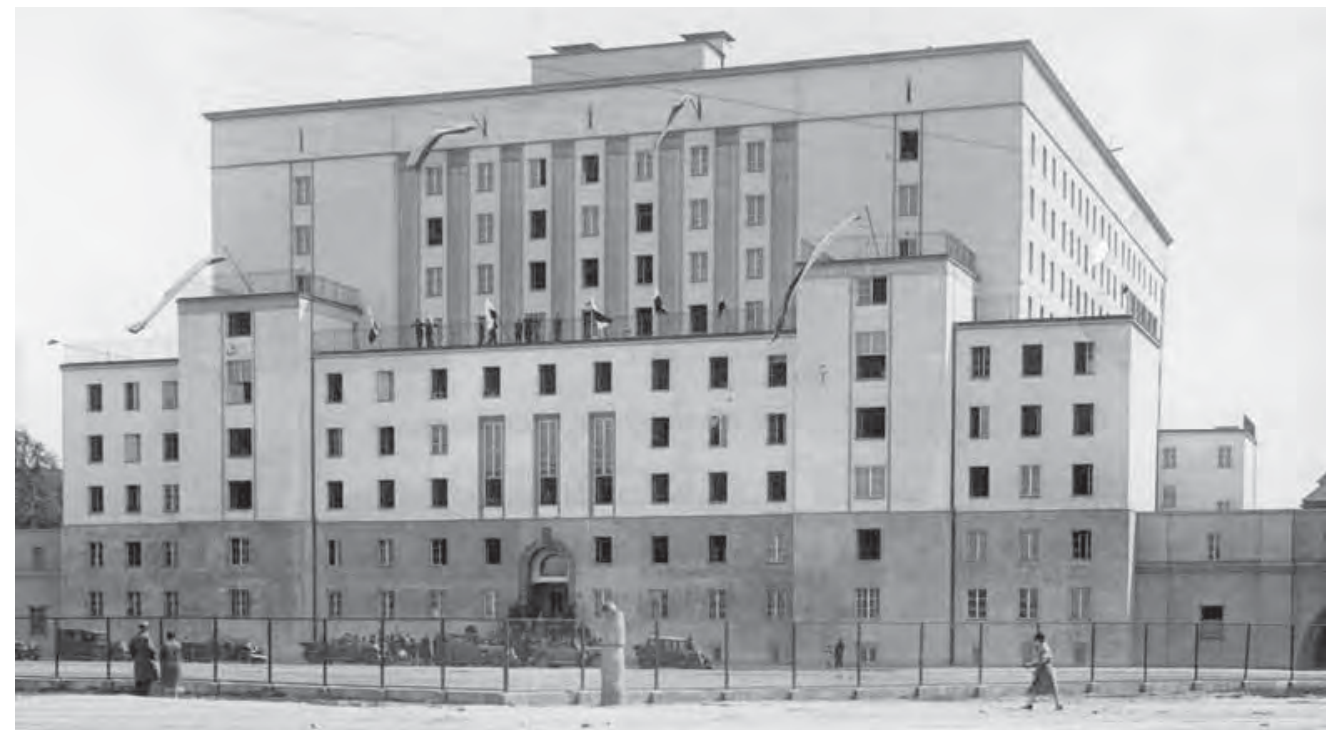

43. Dom Akademicki przy ul. Grójeckiej w dniu oddania do użytku, 1930 r.

międzywojennego zdecydowanie zbyt mało. W 1927 r. do dyspozycji słuchaczy wszystkich szkół wyższych w całej stolicy było zaledwie 800 łóżek. Uniwersytet wykorzystywał ok. $450 \mathrm{z}$ nich. Sytuacja poprawiła się wyraźnie dopiero na początku lat 3o., gdy na Ochocie ukończono budowę głównego gmachu Kolonii Akademickiej im. Bolesława Chrobrego, mogącego pomieścić 1650 osób w 759 pokojach. Jak utrzymywała zarządzająca nimi początkowo Bratnia Pomoc, zapotrzebowanie na mieszkania ze strony słuchaczy UW zostało wówczas całkowicie pokryte, co dotyczyło jednakże wyłącznie osób wyznania chrześcijańskiego ${ }^{326}$.

W listopadzie 1933 r. władze państwowe przejęły Kolonię z rąk Bratniej Pomocy, ustanawiając tam zarząd komisaryczny, a następnie przekazały ją specjalnie powołanej Fundacji Domy Akademickie w Warszawie. Przeprowadzona wtedy kontrola wykazała, iż w kompleksie na Ochocie 200-300 miejsc noclegowych stało pustych, a kilkuset lokatorów kwalifikowało się do eksmisji. Po likwidacji tych i innych patologii, o których będzie jeszcze mowa dalej, budynek był w pełni obłożony. W roku akademickim 1937/1938 musiano nawet odrzucić z braku miejsc aż zoo podań studenckich. W latach 1936-1937 Fundacja przejęła akademiki przy ul. Polnej 5o, dom Auxilium Academicum przy Tamce 4 i 2 domki dotychczasowego półsanatorium przy ul. Lipińskiej na Bielanach, zyskując łącznie 4,09 nowych miejsc ${ }^{327}$. Według sprawozdania rektorskiego, w przedostatnim roku akademickim 


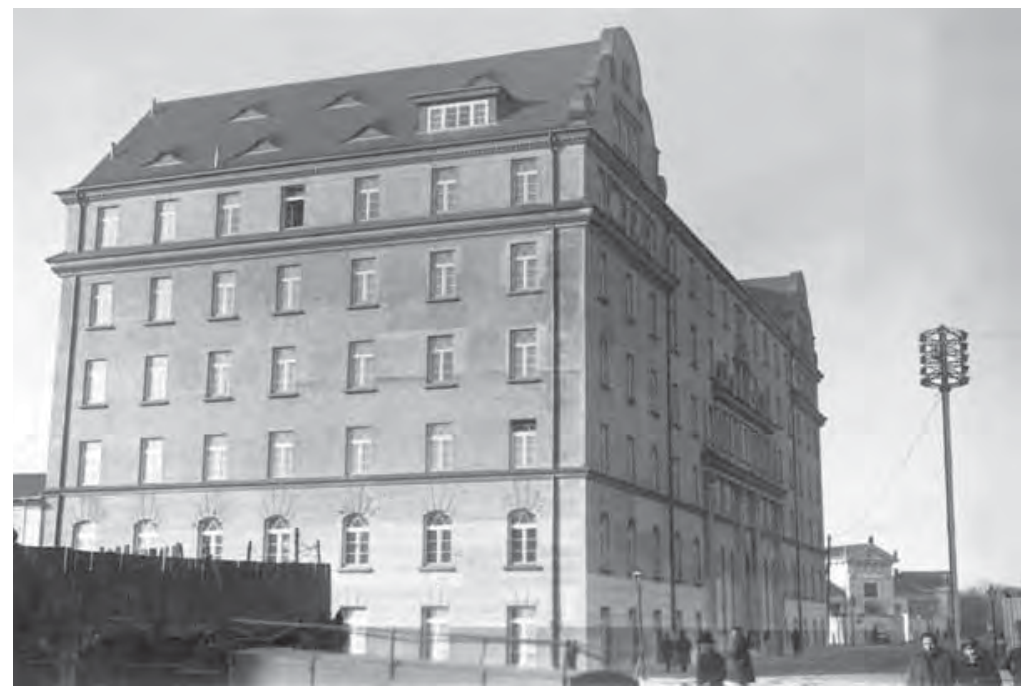

44. Dom akademicki

dla młodzieży

żydowskiej przy

ul. Namiestnikowskiej na Pradze, $193^{2}$ r.

przed wybuchem wojny w domach akademickich mieszkało w sumie 765 chrześcijańskich studentów Uniwersytetu, z tego 498 mężczyzn w Kolonii na Ochocie, 40 przy ul. Polnej i 25 na Bielanach. Kobiety w liczbie 202 zajmowały budynek przy Tamce ${ }^{328}$. Ponadto ok. zoo słuchaczy wyznania mojżeszowego, których zupełnie pominięto w powyższym zestawieniu, mieszkało w Domu Akademickim Studentów Żydów na rogu ulic Namiestnikowskiej i Brukowej (dziś Sierakowskiego i Okrzei) na Pradze 229 .

Dla przybyszy z prowincji poszukiwanie zakwaterowania było najczęściej pierwszym zderzeniem z wielkomiejskim światem stolicy, a zarazem testem życiowej zaradności. „Pierwsze kłopoty, jakie pojawiły się po przyjeździe do Warszawy, to była sprawa mieszkania" - wspomina Stefan Wesołowski. „Należało znaleźć je wcześniej. Zacząłem uciążliwe poszukiwania - bez skutku. Pamiętam, jak na Wspólnej zaproponowano mi wspaniały pokój za zawrotną dla mojej kieszeni sumę siedemdziesięciu złotych. Znużony całodziennym poszukiwaniem trafiłem wreszcie na ulicę Brzeską na Pradze, w okolicy Dworca Wschodniego, do pani, której mąż był maszynistą kolejowym". Mieszkający tam już sublokator zaproponował mu podział komornego, dzięki czemu mieszkanie kosztowało go ostatecznie $30 \mathrm{zł}$ miesięcznie ${ }^{330}$.

Stawka taka należała do przeciętnych. Jak wynika z informacji podawanych przez studentów w podaniach o zapomogi, pod koniec lat 30. minimalny koszt stancji wynosił około $15^{-25}$ zł miesięcznie, przy czym za cenę tę oferowano noclegi w gorszych, peryferyjnych 


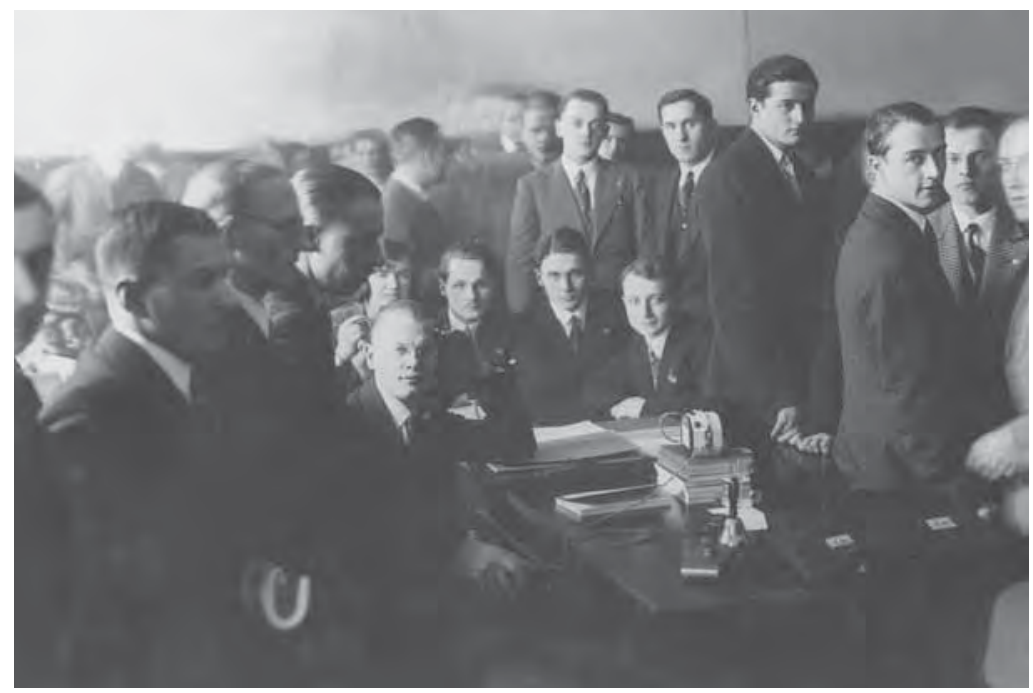

45. Walne zebranie

Bratniej Pomocy Studentów UW, luty $193^{2} \mathrm{r}$.

dzielnicach, najczęściej w kilkuosobowych izbach ${ }^{331}$. „Studenci znajdujący się w szczególnie trudnej sytuacji materialnej gnieździli się w wieloosobowych pokojach, tak zastawionych łóżkami, że pozostawało wolne jedynie bardzo wąskie przejście. Właściwie były to prywatne domy noclegowe" - wspomina jeden ze ówczesnych słuchaczy ${ }^{332}$. Z publikacji poświęconej zwalczaniu gruźlicy dowiadujemy się natomiast, „że studenci mieszkają grupami w pokojach ciemnych, pozbawionych wody, z ustępami w podwórzu, że pranie bielizny jest luksusem, że mieszkają kątem i często razem z chorymi" ${ }^{\prime 333}$.

W lepszych częściach miasta i w bardziej komfortowych warunkach ceny musiały być odpowiednio wyższe. Na tym tle zdecydowanie konkurencyjnie wypadało zakwaterowanie w domach studenckich. Za pokój jednoosobowy w Kolonii Akademickiej na Ochocie trzeba było zapłacić na początku lat 30. $60 \mathrm{zl}$, za miejsce w dwuosobowym $30-35$ zł, w trójce - 25 zł, zaś w pokojach sześcio- i siedmioosobowych - 12,50 zł. Ceny w pozostałych akademikach były na ogół zbliżone ${ }^{334}$. W drugiej połowie lat 3o., po przejęciu Kolonii przez Fundację, opłaty dość istotnie obniżono i wynosiły: 38 zł za pokój jednoosobowy, 26 zł za miejsce w dwuosobowym, $22 \mathrm{zl}-\mathrm{w}$ trzyosobowym, $15 \mathrm{zl}$ - w czteroosobowym i $10 \mathrm{zł}$ w salach wieloosobowych ${ }^{335}$.

Domy studenckie miały na dodatek wyższy standard niż większość sublokatorskich pokojów wynajmowanych prywatnie. „W Kolonii czynna jest stołownia, sklepy żywnościowe, ambulatorium, basen pływacki w sezonie zimowym prowadzony pod kierunkiem AZS, boisko do 


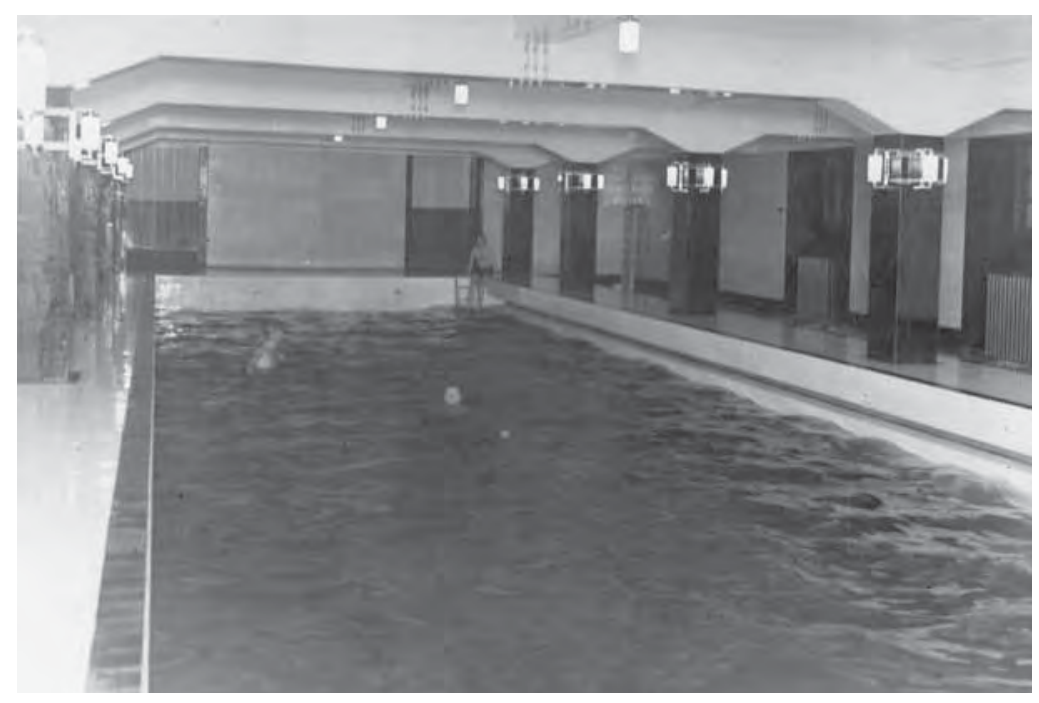

46. Pływalnia w Domu Akademickim przy ul. Grójeckiej, 1931 r.

gier sportowych, korty tenisowe, sala gimnastyczna, czytelnia pism, biblioteka, pralnia, zakład szewski i krawiecki, zakład fryzjerski" zachwalał informator dla studentów. Warunkiem otrzymania miejsca w akademiku było jednak uzyskanie tzw. kwalifikacji mieszkaniowej ze strony Bratniej Pomocy ${ }^{336}$. W atmosferze panującego na Uniwersytecie rozpolitykowania i przy całkowitym zdominowaniu Bratniaka przez prawicę narodową oznaczało to, że o zakwaterowaniu tam nie mógł nawet marzyć student wyznania mojżeszowego, a często również Polak o „niewłaściwych” przekonaniach politycznych, tzn. należący do konkurencyjnej organizacji samopomocowej ${ }^{337}$. Członkowie Bratniej Pomocy mogli natomiast ubiegać się również o tzw. stypendium mieszkaniowe, czyli dofinansowanie zakwaterowania w domach studenckich. W roku akademickim 1931/1932 przyznano je 119 osobom. Wysokość dopłat wahała się od 10 do $30 \mathrm{zł}$, najczęściej było to 10-15 zł338.

Po przejęciu domów studenckich przez Fundację to ona decydowała o przyznawaniu miejsc noclegowych, co uwolniło tę procedurę od wpływów polityki. (Żydzi nadal nie mieli jednak prawa korzystać z akademików). Jednocześnie wprowadzony został system stypendiów mieszkaniowych, pozwalających osobom niezamożnym sfinansować w całości lub częściowo zakwaterowanie w Kolonii Akademickiej. Ich liczba z $5^{113}$ w roku 1933/1934, wzrosła do $105^{0} \mathrm{w}$ ostatnim roku przed wybuchem wojny. Dla studentów pierwszego roku powołano też specjalną bursę, do której nabór prowadzono za pośrednictwem szkól średnich na prowincji, wyławiając uzdolnioną, lecz szczególnie ubogą 


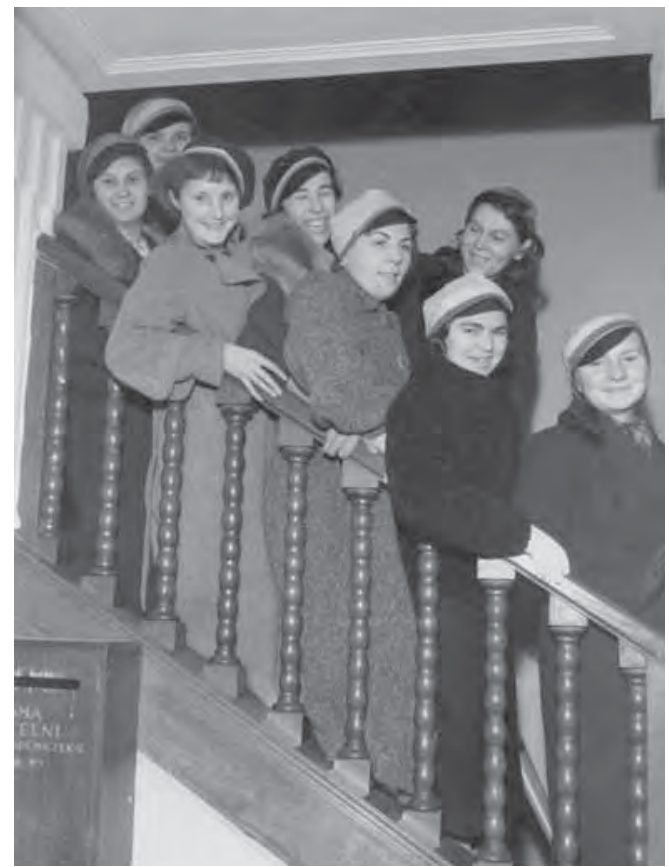

47. Mieszkanki Domu Akademiczek przy ul. Górnośląskiej 14, 1936 r. młodzież. Kilkudziesięciu zakwalifikowanym do takiego stypendium osobom każdego roku Fundacja finansowała zakwaterowanie w domu studenckim, wikt i opierunek, a ponadto wypłacała co miesiąc $20 \mathrm{zł}$ na własne wydatki ${ }^{339}$.

$\mathrm{Na}$ marginesie spraw noclegowych warto nadmienić, iż domy akademickie pod rządami Bratniej Pomocy tworzyły specyficzny półświatek, co było efektem przebywania pod jednym dachem wielu młodych ludzi, często po raz pierwszy w życiu uwolnionych spod ciężaru rodzicielskiej kurateli. Kwitł znany również z późniejszych czasów proceder nocowania kolegów, którzy „nie mieli gdzie się zatrzymać z braku pieniędzy i często gościli nielegalnie («na waleta», czyli nie płacąc za pokój) w domu akademickim, m.in. i u mnie" - wspomina Jan Radożycki. „Działo się tak mimo zakazu ze strony policji, gdyż oczywiście nie byli zameldowani. Policja od czasu do czasu organizowała na nich «obławy» w domu akademickim i ci, co wpadli w jej ręce, byli karani" ${ }^{\prime 340}$. Fakt ten potwierdza Władysław Siła-Nowicki, zwracając jednak uwagę również na inny aspekt zjawiska: „W akademikach panowały dość swobodne stosunki obyczajowe, ale osoby płci odmiennej, przychodzące $\mathrm{z}$ reguły w niedwuznacznych celach, można było wprowadzać tylko do pewnej godziny. [...] Kiedy jednak odwiedzałem kolegów, zawsze widywałem sporo damskich główek, wychylających się przez okna i niewątpliwie przebywających tam od dnia poprzedniego" ${ }^{\prime 34}$. O ekscesach mających miejsce w Kolonii na Ochocie krążyły wręcz w Warszawie legendy: „Za rządów «Bratniaka» na korytarzach odbywały się zawody motocyklowe, w pokojach pozostawały na noc wesołe panienki, budżet był stale deficytowy, bo wielu mieszkańców nie płaciło, obiady wydawano o dziwacznych godzinach"342. Specjalna komisja powołana przez władze uniwersyteckie stwierdziła później, iż Kolonia była terenem nieustającej agitacji politycznej, zamieszkiwało w niej ponad 100 osób nieuprawnionych, wśród nich „męty społeczne, poszukiwane niejednokrotnie przez policję kryminalną; kobiety miały nieograniczone prawo wstępu na teren 


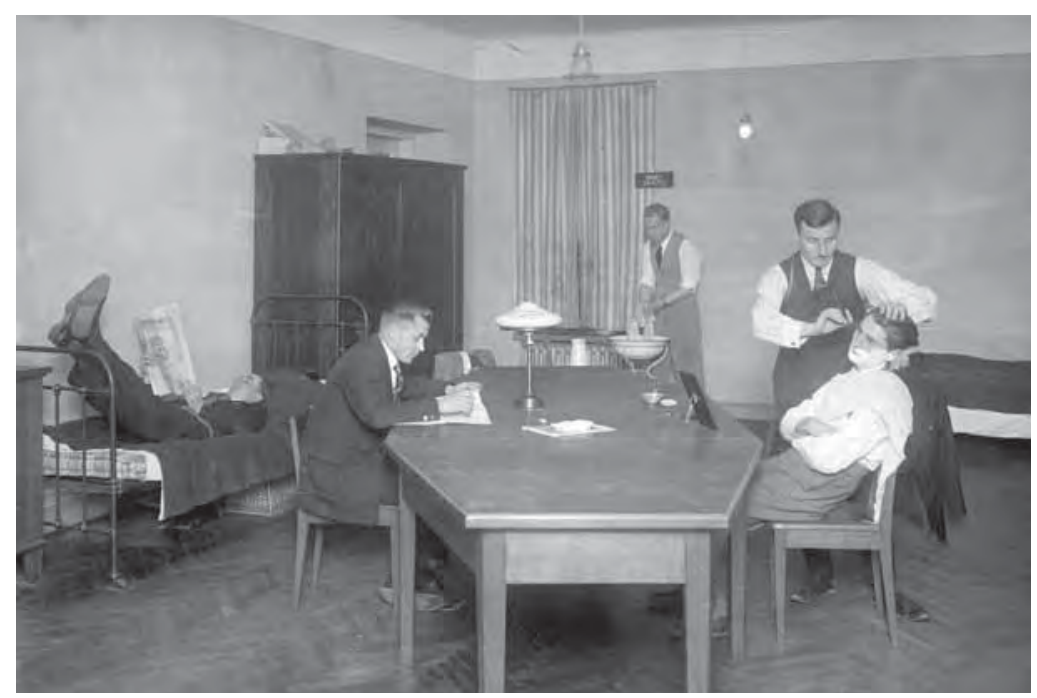

48. Studenci w jednym z pokojów w Domu Akademickim przy ul. Grójeckiej, lata $30 . \mathrm{XX}$ w.

i chętnie widziane przez mieszkańców swobodnie plądrowały po całym gmachu, brały udział w urządzanych libacjach, pozostawały na noc, a nawet mieszkały przez czas dłuższy, wędrując od pokoju do pokoju; stąd skandale towarzyskie zakończone niejedną tragedią, częste awantury prostytutek i szerzenie się chorób wenerycznych"343.

Porządki panujące w akademikach nie podobały się - choć z różnych względów - zarówno Kościołowi katolickiemu, jak i władzom sanacyjnym. Kardynał Hlond narzekał, że „domy akademickie stały się «burdelami» - dosłownie, że o tym wie od zakonnic, komunikujących mu o studentkach, zarażonych syfilisem, a zamieszkałych w domach akademickich"344. Czynniki państwowe były z kolei zaniepokojone brakiem kontroli nad akademikami, w których „źle się administruje, przyjmuje studentów agitatorów, nierobów, uniezależnia się od władzy szkolnej, w wypadku ekscesów nie dopuszcza do domu władzy bezpieczeństwa" ${ }^{345}$. Przesądziło to ostatecznie o odebraniu Kolonii Bratniej Pomocy. (Przy okazji przemianowano ją na Domy Studenckie im. Prezydenta Narutowicza, co stanowiło dodatkowe upokorzenie dla nacjonalistycznej prawicy, jak wiadomo, nienawidzącej tego patrona).

Źle prowadzić mogli się oczywiście również studenci mieszkający na stancjach, ale prywatni właściciele mieszkań na ogół skuteczniej czuwali nad przestrzeganiem porządku i moralności niż administratorzy domów akademickich. Jan Śpiewak wspomina konsekwencje, jakie również on musiał ponosić na skutek swawoli swego sublokatora: „Wspólnie z nim wynajmowałem pokoje jeszcze ze dwa lata. Długo nie zagrzewaliśmy 
miejsca. Dwa, trzy miesiące i... dalej. Pędził nas z miejsca na miejsce niepokój, pędziła burzliwa natura kolegi, uwikłany w miłostki narażał się wszystkim gospodyniom, które często zazdrosnym okiem patrzyły na jego erotyczne wyczyny"346. Studenci urządzali także niekiedy na stancjach różnego rodzaju facecje, np. wzorem swych XIX-wiecznych poprzedników, opisanych w Lalce przez Bolesława Prusa, strasząc pozostałych lokatorów ludzkimi szkieletami. Sprawy takie mogły jednak łatwo znaleźć finał w sądzie, zwłaszcza gdy dowcipnisie zalegali z czynszem ${ }^{347}$. Jak widać, nawet w materii tak delikatnej jak moralność niewidzialna ręka rynku działała sprawniej od najbardziej restrykcyjnych regulacji administracyjnych.

Drugim kluczowym wydatkiem związanym ze studiowaniem w Warszawie było wyżywienie. Większość słuchaczy Uniwersytetu pochodzących z prowincji, którzy w przeciwieństwie do swych kolegów ze stolicy nie mogli liczyć na posiłki w domu, stołowała się w jadłodajniach prowadzonych przez organizacje samopomocowe lub dotowanych z myślą o studentach. Informator z początku lat 30. wydany przez Centralę Bratnich Pomocy wymienia 7 takich lokali, w większości umiejscowionych w domach akademickich. Jeden z nich znajdował się również na terenie głównego kampusu, w Gmachu Pomuzealnym. Ceny obiadów wahały się w nich od 65 groszy do $1,50 \mathrm{zl}$, serwowano także śniadania i kolacje ${ }^{348}$. Niezamożni studenci mogli ubiegać się przy tym o specjalne bony, uprawniające do otrzymywania obiadów bezpłatnie lub za połowę ceny. $\mathrm{Na}$ początku lat 30. z pierwszych z nich korzystało codziennie 244, z drugich zaś 116 słuchaczy ${ }^{349}$. Później, gdy Fundacja Domy Akademickie przejęła zarząd nad Kolonią na Ochocie, rozwinięto tam również na szeroką skalę pomoc żywieniową, wydając każdego dnia około 1800 posiłków. Dzięki ich dotowaniu kolacja i śniadanie mogły kosztować 4,o groszy, zupa 20 groszy, a drugie danie 50 groszy. Najubożsi studenci mogli otrzymać bony na darmowe posiłki. Liczba osób otrzymujących je wzrosła z 83 w roku 1933/1934 do 570 w ostatnim roku akademickim przed wybuchem II wojny światowej ${ }^{350}$.

Miejsc, gdzie mogli się żywić studenci, było jednak znacznie więcej. Obok lepszych jadłodajni, np. prowadzonej przez Siostry Służebniczki na Sewerynowie, gdzie obiad kosztował średnio 1,80-2 zł i dokąd zachodziła równiė̇ profesura ${ }^{351}$, istniał cały szereg tanich garkuchni, zorientowanych na uboższych studentów. Jedną z nich wspomina Śpiewak: „[...] Dostaję ulgowe kartki na obiad, biegam co dzień na drugi kraniec miasta, aż na Leszno. Mała knajpka nosi, nie wiadomo czemu, nazwę «Cyganeria». Właściciele, Ignac i ruda Ignacowa, są poczciwi, traktują nas, studentów, familiarnie. Obiadki są nędzne, 
ale kosztują pięćdziesiąt groszy. Za złotówkę można zjeść wszędzie normalny, dobry obiad $\mathrm{z}$ trzech dań. $\mathrm{Na}$ to nie mam pieniędzy"352. Studenckie garkuchnie nie były z pewnością wzorem zdrowego żywienia, na co zwracali uwagę ówcześni lekarze, ubolewając: „Wiemy o tym, że znaczna część młodzieży akademickiej odżywia się byle czym i że to, nawet najskromniejsze pożywienie jest przyrządzane w sposób nieliczący się z wymaganiami higieny: wiemy, że jarzyny są w przedziwnej pogardzie u pań, wydających «obiady domowe» na «prawdziwym maśle» [...]"353.

Na podstawie przytaczanych powyżej cen można wyliczyć, że średni koszt pełnego wyżywienia, obejmującego 3 posiłki dziennie, nie przekraczał miesięcznie 50 zł. W rzeczywistości wielu studentów oszczędzało jednak na jedzeniu jeszcze bardziej niż czynił to Jan Śpiewak. W wielokrotnie przywoływanych już przeze mnie kwestionariuszach, słuchacze weterynarii, o ile w ogóle wyszczególniali taką pozycję, szacowali swoje wydatki na jedzenie na 20-4.5 zł. Spora część z nich korzystała z bonów na ulgowe lub darmowe obiady (10-15 w miesiącu) przyznawanych przez Bratnią Pomoc, bądź otrzymywała niewielkie paczki żywnościowe z domu. Większość wiodła jednak, jak eufemistycznie określił to jeden z nich, „życie dostosowane do zarobków”354. Jak mogło ono wyglądać w praktyce, ilustruje podanie studenta Wydziału Humanistycznego do Fundacji im. Młockich: „Żyję z drobnych pożyczek zaciąganych u kolegów, żyję, to znaczy, że zjadam 2 lub w najlepszym razie 3 obiady w tygodniu i pewną ilość śniadań i kolacji złożonych z herbaty i chleba". Jego kolega kilka lat wcześniej informował pod koniec listopada, iż od początku roku akademickiego żywi się wyłącznie chlebem i wodą ${ }^{355}$.

Należy przypuszczać, że niewiele tylko lepszy był jadłospis wszystkich tych osób, które na wyżywienie mogły przeznaczyć ok. 15-20 zł miesięcznie, a nie miały prawa korzystania z kuchni. Samodzielnie przygotowując posiłki można było skromnie wyżywić się nawet za tak niewielką kwotę. (W 1938 r. kilogram chleba kosztował w Warszawie średnio $3^{1}$ groszy, litr mleka - 26 groszy, kilogram mięsa wieprzowego - 1,47 zł, kilogram masła 3,54, $\mathbf{z}^{359}$ ). Radzili sobie tak na przykład niektórzy niezamożni studenci w Kolonii Akademickiej na Ochocie. „W korytarzowej kuchence gotowali rano zupę, kupowali chleb i sami organizowali trzy dzienne posiłki" ${ }^{357}$. Inni, jak Jan Radożycki, przygotowywali wspólnie tylko śniadania: „Śniadanie jadałem wspólnie z kolegą [...], który mieszkał w wieloosobowej sali i rano szedł po mleko, ser i masło i przygotowywał stół, a ja pokrywałem koszty za nas obu. Był to pewien sposób pomocy biedniejszemu 
koledze, który nie przyjąłby jej w innej formie" ${ }^{3_{358}}$. Niezależnie od tego, jak dzielono koszty zakupu produktów spożywczych, wspólne przyrządzanie posiłków stanowiło formę oszczędniejszego żywienia się niż gotowanie samodzielne.

O ile jednak samodzielne gotowanie było możliwe w niektórych domach akademickich, o tyle dość rzadko zdarzało się na stancjach. Gospodynie niechętnym okiem patrzyły na kręcących się przy garnkach studentów, nawet jeśli lokal wynajmowano formalnie z prawem używalności kuchni. Ich opory umacniała nienajlepsza reputacja studenterii, rozpowszechniana po mieście stugębną plotką: „Pani Halasińska kochana, pani pozwala temu sublikatorowi w swojem naczyniu parkotać? A czy pani wie, co on tam paprze? Taki, któren na doktora terminuje, różne świństwa potrafi pitrasić. Skąd pani, nieszczęśliwa kobito wisz, że on tam trupa nie gotuje, żeby się potem na niem kształcić?". Tak się zresztą istotnie zdarzało; bohater felietonu Wiecha, skąd zaczerpnięty został powyższy cytat, trafił przed sąd, gdyż preparował w kuchni ludzką czaszkę ${ }^{359}$.

Oprócz opłat akademickich, zakwaterowania i wyżywienia studia na Uniwersytecie wiązały się z szeregiem pomniejszych wydatków.

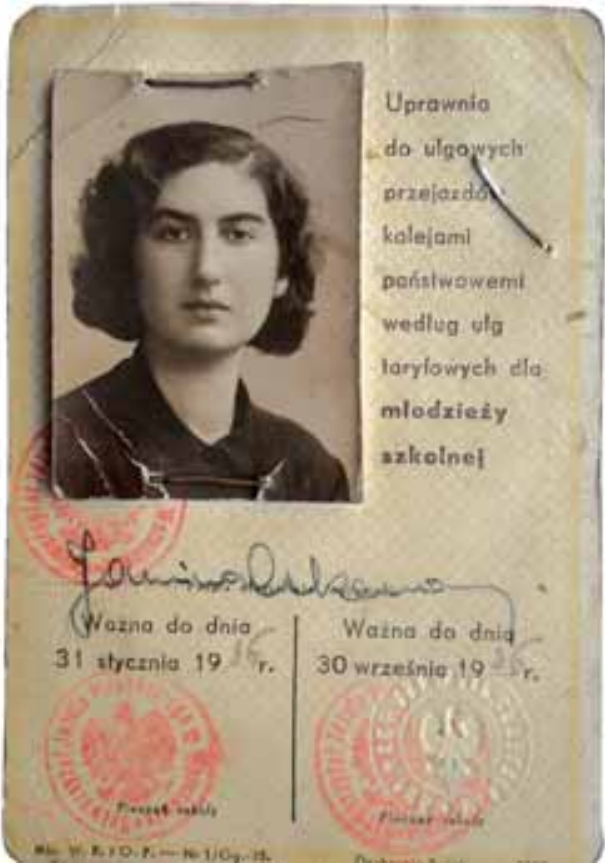

49. Studencka legitymacja kolejowa Reginy Askenazy

Większość studentów musiała korzystać z komunikacji miejskiej, której bilet miesięczny kosztował w Warszawie pod koniec lat 30. od 10 do kilkunastu złotych $^{360}$. Relatywnie drogie były również bilety kolejowe, a uzyskanie zniżki studenckiej wymagało każdorazowego wystąpienia o nią z podaniem do rektora. (Większość studentów z prowincji wyjeżdżała z tych względów do domów rodzinnych rzadko, na ogół tylko na ferie bożonarodzeniowe, wielkanocne i na wakacje letnie). Pewne nakłady finansowe konieczne były wreszcie na uzupełnienie i wymianę garderoby, zakup książek i pomocy naukowych itp. $\mathrm{Z}$ bardzo wyrywkowych danych na ten temat wynika, że mniej zamożni studenci przeznaczali na oba powyższe cele nie więcej niż 10-20 $\mathrm{zt}^{361}$.

Jaką więc minimalną kwotą trzeba było dysponować, aby studiować na 
Uniwersytecie Warszawskim? Na przełomie lat 20. i zo. Bratnia Pomoc obliczała ją na 210 zł miesięcznie, na co składały się następujące wydatki: mieszkanie (30 zł), wyżywienie (100 zł), podręczniki i nauka (25 zł), ubranie (4,0 zł) oraz inne ( $15 \mathrm{zl})^{362}$. Kwoty te, podawane w oskarżycielskim kontekście niedostatecznej troski państwa o studentów, wydają się jednak mocno zawyżone i mówią nie tyle o minimum egzystencjalnym, ile o życiu na całkiem dobrym poziomie. W każdym razie studenci Uniwersytetu ubiegający się w 1938 r. o pomoc materialną określali swe wydatki miesięczne na 50 do $120 \mathrm{z}$. Średnio wynosiły one $78 \mathrm{zk}^{363}$. Duża rozpiętość danych wynikała nie tylko ze zróżnicowanych możliwości i potrzeb, jakie występowały nawet wśród osób najuboższych, ale prawdopodobnie także $\mathrm{z}$ nieuwzględnienia $\mathrm{w}$ bilansie wydatków przez część petentów opłat akademickich, których dokonywano w trybie półrocznym. Przyjmując, że te ostatnie wynosiły wówczas około $250 \mathrm{zl}$ rocznie, czyli $25 \mathrm{zl}$ w przeliczeniu na każdy miesiąc nauki, zakwaterowanie kosztowało średnio $30 \mathrm{zl}$, wyżywienie $45 \mathrm{zl}$, bilet miesięczny $10 \mathrm{zl}$, a pozostałe wydatki kolejne $10 \mathrm{zl}$, otrzymujemy sumę $120 \mathrm{z}^{364}$. Kwota taka pozwalała przeżyć w stolicy na dość skromnym, lecz godnym poziomie. Podobnie wyliczyć można, że dla rodziny mieszkającej w Warszawie wysłanie dziecka na Uniwersytet wiązało się z dodatkowym miesięcznym wydatkiem rzędu $4.5 \mathrm{zl}$ miesięcznie, do którego dochodziły, rzecz jasna, koszty jego wyżywienia i mieszkania w ramach wspólnego gospodarstwa domowego.

Zestawienie wyliczonych powyżej minimalnych wydatków związanych z nauką na Uniwersytecie $(120 \mathrm{zl}) \mathrm{z}$ dochodami z korepetycji (średnio $30 \mathrm{zl}$ ) i przeciętnym wsparciem finansowym, które najubożsi słuchacze otrzymywali od swoich rodzin (również ok. 30 zł), wskazuje na istnienie poważnej dziury w wielu studenckich budżetach. W jej łataniu pomagały różnego rodzaju pożyczki, w tym przede wszystkim tzw. honorówki (przyznawane przez organizacje samopomocowe na słowo honoru, bez poręczenia, które należało spłacić w ciągu trzech tygodni). Ich popularność była ogromna, zwłaszcza w latach kryzysu. W roku akademickim 1931/1932 Bratnia Pomoc udzieliła pożyczek ponad 2100 studentom, co oznacza, że korzystał z nich mniej więcej co trzeci chrześcijański słuchacz uczelni. (Brak jest danych o sytuacji studentów żydowskich, ale mało prawdopodobne wydaje się, by była ona wyraźnie lepsza) ${ }^{365}$.

Podobną rolę spełniały różnego rodzaju zwrotne lub bezzwrotne zapomogi, zasiłki rektorskie, stypendia państwowe, samorządowe i przyznawane przez prywatne fundacje. W przedostatnim roku akademickim przed wybuchem wojny korzystało z nich łącznie 2978 
studentów UW. Najkorzystniejsze z nich były Państwowe Stypendia Akademickie wynoszące 6 oo zł rocznie, przyznano ich jednak tylko 456 . $\mathrm{Na}$ pozostałą liczbę składały się zasiłki i pożyczki z funduszu rektorskiego o przeciętnej wysokości $50 \mathrm{zl}$, jednorazowe pożyczki państwowe, których wartość wahała się od 40 do 75 zł, 37 stypendiów pochodzących z fundacji działających przy Uniwersytecie (średnio $5^{17} \mathrm{zl}$ ), a także $15^{2}$ stypendia ufundowane przez inne organizacje i instytucje ${ }^{366}$. Gdy i te świadczenia nie pokrywały różnicy pomiędzy kosztami studiów w Warszawie a dochodami studentów, jedynym sposobem utrzymania się na Uniwersytecie pozostawało ograniczanie przez nich wydatków na stancję, jedzenie i ubranie, czyli w praktyce - biedowanie.

Ciężkie warunki materialne, z którymi musiało zmagać się wielu studentów - często jeszcze przed podjęciem nauki na Uniwersytecie nie pozostawały bez wpływu na ich stan zdrowia. Wyniki obowiązkowych badań kandydatów na studia z roku akademickiego 1936/1937 wskazują, że w pełni zdrowych było jedynie $68 \%$ z nich. Najlepiej pod tym względem sytuacja przedstawiała się wśród osób wybierających wydziały teologii prawosławnej (100\% zdrowych) i katolickiej (83\%), najgorzej wśród zdających na Wydział Humanistyczny (56\%) i Matematyczno-Przyrodniczy (66\%). Powyższe zróżnicowanie odzwierciedlało niewątpliwie niejednakową kondycję kandydatów na poszczególne kierunki studiów i miało przede wszystkim związek z płcią i pochodzeniem społecznym, a w mniejszym stopniu także z narodowością badanych. Najzdrowszą kategorią kandydatów byli mężczyźni chrześcijanie (78\% całkowicie zdrowych), za nimi plasowali się mężczyźni wyznania mojżeszowego (75\%), jeszcze dalej kobiety chrześcijanki (55\%), na samym zaś końcu kobiety wyznania mojżeszowego (50\%). Przeciętny stan zdrowia był więc wyraźnie gorszy na tych wydziałach, które chętnie wybierały kobiety, lepszy natomiast na zmaskulinizowanych. Mógł on być także skutkiem uwarunkowań społecznych, gdyż - jak pamiętamy - na wydziały Matematyczno-Przyrodniczy i Humanistyczny zapisywała się częściej niż np. na prawo lub medycynę młodzież niezamożna. Dochodziły do tego specyficzne uwarunkowania dotyczące tylko niektórych kategorii kandydatów: na teologię prawosławną wstępowali np. zazwyczaj synowie popów, dobrze odżywieni dzięki uprzywilejowanej pozycji społecznej swych ojców; kandydaci na teologię katolicką uczęszczali zaś zwykle wcześniej do seminariów duchownych, gdzie mieli możliwość podreperować stan zdrowia ${ }^{367}$.

Najpoważniejszy problem zdrowotny wśród studentów Uniwersytetu stanowiła gruźlica, będąca wówczas główną przyczyną zgonów w Polsce. 
(Umierał na nią co piąty obywatel, 90\% populacji miało kontakt z jej prątkami) ${ }^{368}$. W formie czynnej, wymagającej leczenia lub obserwacji, występowała ona u blisko $2 \%$ kandydatów na studia w roku akademickim 1937/1938, jednak zmiany gruźlicze w płucach wykryto wówczas w sumie aż u $18 \%$ osób $^{369}$. Okres studiów, kiedy wielu słuchaczy żyło $\mathrm{w}$ fatalnych warunkach materialnych, nie poprawiał tej statystyki. Pod koniec lat 20. gruźlicę zaobserwowano u co trzeciego lokatora warszawskich domów studenckich. W kolejnych kilku latach odsetek ten wprawdzie radykalnie się zmniejszył, ale stało się tak przede wszystkim na skutek planowego ograniczania liczby chorych w akademikach. Przez 8 miesięcy 1935 r. w Warszawie zarejestrowano łącznie 808 studentów szkół wyższych cierpiących na gruźlicę lub nią zagrożonych, z których $3^{2} 7$ wymagało hospitalizacji. W okresie tym 36 osób ukończyło naukę, 79 trafiło do sanatoriów, 73 umieszczono w prewentorium na Bielanach, 10 zaś zmarło. Jednocześnie każdego roku wykrywano wśród studentów od kilku do kilkunastu przypadków gruźlicy prątkującej, grożącej zakażeniem. Wywiady środowiskowe przeprowadzone wśród chorych dokumentowały, iż zdecydowana większość z nich mieszkała w niezadowalających warunkach ${ }^{370}$.

Oprócz gruźlicy kandydaci na Uniwersytet cierpieli stosunkowo często na dolegliwości serca i układu krążenia (15\%), schorzenia zębów i jamy ustnej (30\%), wady wzroku (18\%), choroby skóry (9\%), wykazywali wątłą budowę ciała i wady postawy (14\%). Ponadto u $13 \% \mathrm{z}$ nich, przeważnie u kobiet, wykryto zaburzenia hormonalne. Choć nawet sprawozdanie rektorskie, skąd pochodzą powyższe dane, stanowczo wyklucza, by „stan zdrowia nowo wstępujących polepszał się na dalszych latach studiów", należy odnotować, iż studenci Uniwersytetu mieli do dyspozycji profesjonalną i, co zapewne ważniejsze, dofinansowywaną przez państwo opiekę medyczną. Koncentrowała się ona wprawdzie przede wszystkim na zwalczaniu gruźlicy i chorób wenerycznych, ale zapewniała też dostęp do lekarzy pierwszego kontaktu i specjalistów. $\mathrm{Za}$ umówioną wizytę u lekarza $\mathrm{w}$ przychodni student musiał wnieść opłatę w wysokości o,50 zł, za wizytę u dentysty 1 zl, za konsultacje u specjalisty 1,50 zł. Wezwanie lekarza do domu kosztowało 2 zł, dzień pobytu w szpitalu wyceniono na 1 zł, w sanatorium zaś na 3 zł. Całkowicie bezpłatne były wizyty w poradni przeciwgruźliczej, w przeciwwenerycznej opłata wynosiła o,50 zł. Słuchacz pokrywał ponadto tylko połowę kosztów lekarstw, zdjęć rentgenowskich, analiz, okularów itp. - resztę dopłacało państwo. Był to więc system, jak na ówczesne warunki, bardzo opiekuńczy ${ }^{371}$. 


\section{Specyfika studiów na Uniwersytecie Warszawskim}

W chwili otwarcia Uniwersytetu Warszawskiego przez władze niemieckie w 1915 r. składał się on z zaledwie 3 wydziałów: Prawa i Nauk Państwowych, Filozoficznego oraz Matematyczno-Przyrodniczego z wyodrębnionym oddziałem przygotowawczo-lekarskim. Do wybuchu II wojny światowej poprzez tworzenie nowych struktur organizacyjnych i podział istniejących uczelnia rozrosła się do 9 jednostek, wśród których znajdowały się: Wydział Teologii Katolickiej, Wydział Teologii Ewangelickiej, Studium Teologii Prawosławnej, Wydział Prawa, Lekarski, Humanistyczny, Matematyczno-Przyrodniczy, Farmaceutyczny i Weterynaryj$n^{372}$. Poszczególne wydziały miały, co zrozumiałe, zróżnicowane programy nauczania, różniły się też bardzo istotnie pod względem wielkości, co było wypadkową polityki władz państwowych, możliwości i potrzeb Uniwersytetu oraz zainteresowań i strategii edukacyjnych osób zainteresowanych pobieraniem nauki. W rozdziale tym przedstawione zostaną zasady, na jakich prowadzona była działalność dydaktyczna na największych wydziałach: Prawa, Lekarskim oraz Filozoficznym, a po podziale tego ostatniego - na Humanistycznym i Matematyczno-Przyrodniczym.

W pierwszych latach funkcjonowania uczelni obowiązywał system nauczania wzorowany na austriackim. Oznaczało to, że mógł na nią wstąpić każdy kandydat legitymujący się egzaminem dojrzałości, przy czym przez pewien czas istniała pod tym względem luka pozwalająca przyjmować na Wydział Teologii Katolickiej również osoby duchowne bez matury ${ }^{373}$. Podczas studiów nie weryfikowano corocznie wiedzy słuchaczy według odgórnie przyjętego programu, lecz pozostawiano im pełną swobodę wyboru rodzaju wykładów, ćwiczeń i egzaminów. Jedyny wymóg formalny stanowiła konieczność zaliczenia 12 godzin lekcyjnych zajęć tygodniowo, którego wypełnienie potwierdzać miały w indeksie podpisy wykładowców, uzyskiwane najpierw w chwili zapisywania się na dany przedmiot, a następnie na zakończenie semestru. Nie kontrolowano natomiast na ogół frekwencji w trakcie poszczególnych zajęć, z czego skwapliwie korzystało wielu słuchaczy, programowo nie chodząc na wykłady. (Powyższy system rozliczania zajęć utrzymał się na niektórych wydziałach, z całym dobrodziejstwem inwentarza, aż do 1939 r., 


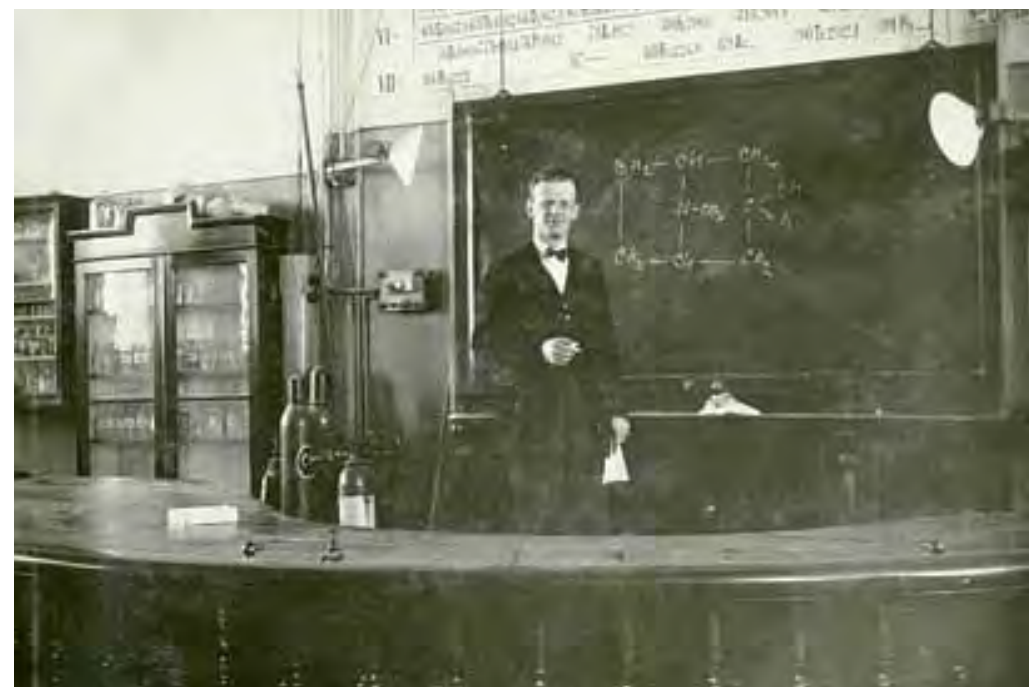

50. Sala wykładowa Wydziału

Farmaceutycznego, lata $30 . \mathrm{XX}$ w.

co z nostalgią bądź dezaprobatą wspominają zgodnie niemal wszyscy pamiętnikarze). Kończąc naukę na Uniwersytecie każdy jego absolwent uzyskiwał absolutorium, po czym mógł ubiegać się o tytuł doktora lub, w przypadku niektórych kierunków, o dyplom nauczycielski ${ }^{374}$.

Po odzyskaniu przez Polskę niepodległości zasady studiowania uległy wyraźnemu zaostrzeniu. Przede wszystkim, na poszczególnych wydziałach w latach 20. stopniowo wprowadzano obowiązkowe egzaminy po każdym roku nauki, od zdania których zależało przejście na rok następny. Po drugie, już w 1920 r. ustanowiono dla osób kończących studia stopień magistra. W ciągu 4 lat reformą tą objęto kolejne wydziały UW - każdy jednak w innym czasie, co powodowało spore zamieszanie. Ponadto kilkakrotnie przedłużano okres przejściowy, pozwalając absolwować wyższe uczelnie z tytułem doktora osobom, które rozpoczęły studia przed wejściem w życie ustawy. Ostatni taki termin wyznaczono na koniec 1933 r. dla słuchaczy medycyny, później było to już możliwe wyłącznie za indywidualną zgodą MWRiOP. Studenci, którzy zapisali się na Uniwersytet Warszawski po reformie, celem uzyskania stopnia doktorskiego musieli natomiast najpierw ukończyć studia magisterskie, a następnie przez co najmniej 2 kolejne lata kontynuować naukę i dopiero wtedy przedstawić rozprawę doktorską ${ }^{375}$. Było to dla nich mniej korzystne również z przyczyn finansowych. „Warunki materialne lekarzy wówczas się zmieniły" - wspomina jeden z absolwentów Wydziału Lekarskiego - „Gdy na medycynę wstępowałem, kończący studia otrzymywał tytuł «Dr med.» i zaraz mógł nieźle zarabiać. 
Tabela 13. Liczba studentów na poszczególnych wydziałach UW 1915-1939

\begin{tabular}{|c|c|c|c|c|c|c|c|c|c|c|}
\hline \multirow[b]{2}{*}{ 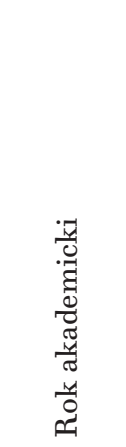 } & \multirow{2}{*}{ 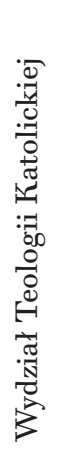 } & \multirow{2}{*}{ 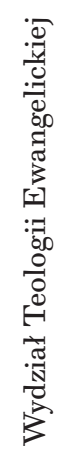 } & \multirow{2}{*}{ 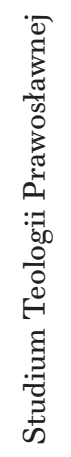 } & \multirow[b]{2}{*}{ 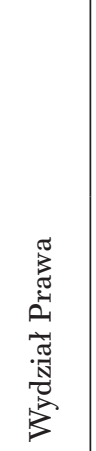 } & \multirow[b]{2}{*}{ 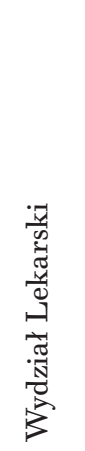 } & \multicolumn{2}{|c|}{ 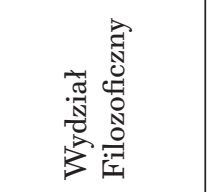 } & \multirow{2}{*}{ 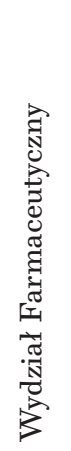 } & \multirow{2}{*}{ 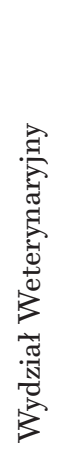 } & \multirow[b]{2}{*}{ 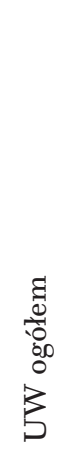 } \\
\hline & & & & & & 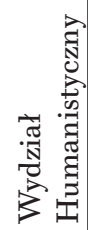 & 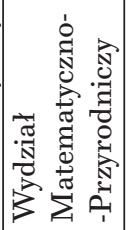 & & & \\
\hline $1915 / 16$ & - & - & - & 216 & 538 & 77 & 208 & - & - & 1039 \\
\hline $1916 / 17$ & - & - & - & 543 & 771 & \multicolumn{2}{|c|}{307} & - & - & 1621 \\
\hline 1917/18 & - & - & - & 867 & 941 & \multicolumn{2}{|c|}{412} & - & - & 2220 \\
\hline $1918 / 19$ & 39 & - & - & 1755 & 1422 & \multicolumn{2}{|c|}{1096} & 253 & - & 4565 \\
\hline $1919 / 20$ & 38 & - & - & 1697 & 1168 & \multicolumn{2}{|c|}{1361} & 291 & 34 & 4651 \\
\hline $1920 / 21$ & 22 & 2 & - & 2668 & 1454 & \multicolumn{2}{|c|}{1826} & 204 & 23 & 6209 \\
\hline $1921 / 22$ & 49 & 30 & - & 2418 & 1710 & \multicolumn{2}{|c|}{2781} & 175 & 71 & 7234 \\
\hline $1922 / 23$ & 67 & 42 & - & 3049 & 1692 & \multicolumn{2}{|c|}{3478} & 184 & 104 & 8617 \\
\hline $1923 / 24$ & 68 & 36 & - & 3080 & 1522 & \multicolumn{2}{|c|}{3557} & 195 & 96 & 8555 \\
\hline $1924 / 25$ & 68 & 35 & - & 2592 & 1381 & \multicolumn{2}{|c|}{3704} & 212 & 153 & 8145 \\
\hline $1925 / 26$ & 68 & 46 & 66 & 2465 & 1236 & \multicolumn{2}{|c|}{4232} & 240 & 184 & 8537 \\
\hline $1926 / 27$ & 55 & 58 & 127 & 2467 & 1113 & \multicolumn{2}{|c|}{4715} & 279 & 233 & 9047 \\
\hline $1927 / 28$ & 62 & 76 & 177 & 2589 & 1076 & 3179 & 1697 & 254 & 261 & 9371 \\
\hline $1928 / 29$ & 59 & 83 & 175 & 2659 & 1045 & 3045 & 1591 & 256 & 268 & 9181 \\
\hline $1929 / 30$ & 63 & 87 & 139 & 2875 & 1039 & 2917 & 1431 & 243 & 327 & 9121 \\
\hline $1930 / 31$ & 49 & 92 & 126 & 3147 & 969 & 2835 & 1359 & 241 & 340 & 9158 \\
\hline $1931 / 32$ & 43 & 82 & 83 & 2844 & 941 & 2752 & 1306 & 236 & 320 & 8607 \\
\hline $1932 / 33$ & 55 & 95 & 96 & 3501 & 1087 & 3026 & 1484 & 245 & 344 & 9933 \\
\hline $1933 / 34$ & 53 & 98 & 105 & 3166 & 1098 & 2875 & 1432 & 288 & 447 & 9562 \\
\hline $1934 / 35$ & 61 & 101 & 109 & 2984 & 1129 & 2856 & 1530 & 297 & 449 & 9516 \\
\hline $1935 / 36$ & 64 & 102 & 123 & 3075 & 1138 & 2481 & 1563 & 294 & 482 & 9322 \\
\hline $1936 / 37$ & 59 & 88 & 115 & 2860 & 1081 & 2818 & 1674 & 259 & 424 & 9378 \\
\hline $1937 / 38$ & 55 & 82 & 112 & 2646 & 1003 & 2883 & 1620 & 276 & 459 & 9136 \\
\hline $1938 / 39$ & 58 & 60 & 102 & 2315 & 1028 & 2896 & 1513 & 258 & 403 & 8633 \\
\hline
\end{tabular}

Źródło: T. Manteuffel, Uniwersytet Warszawski w latach 1915/16-1934/35. Kronika, Warszawa 1936; AUW, AcUW RP/66; SUW 1934/1935 i 1935/1936, s. 45.

Uwaga: Zestawienie uwzględnia również tzw. wolnych słuchaczy. Dane dotyczące Wydziału

Farmaceutycznego obejmują także Kursy Farmacji. 


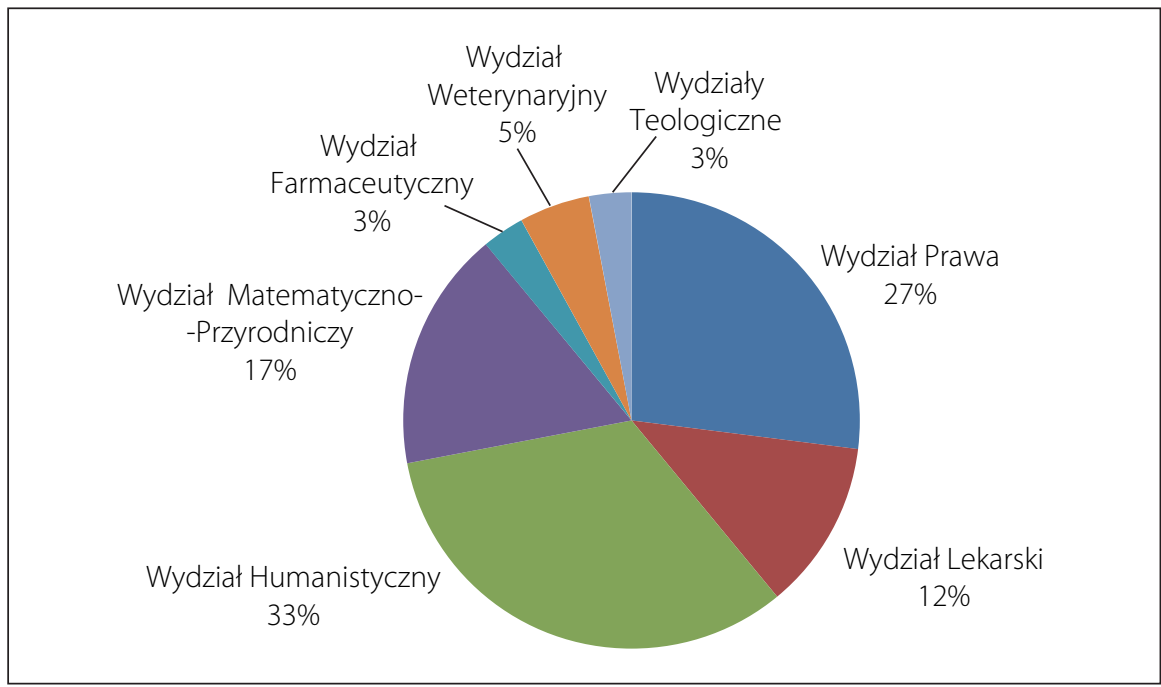

Wykres 8. Struktura wielkości wydziałów UW (rok akademicki 1937/1938)

Tymczasem, gdy ja zbliżałem się do końca, miałem otrzymać tytuł lekarza, po czym obowiązywał rok praktyki w szpitalu nie mniejszym niż 100 łóżek. A koniunktura gospodarcza była wówczas pod psem" ${ }^{\prime 376}$. Od nowych zasad uczyniono jednak istotny wyjątek, pozwalając uzyskać tytuł doktora wszech nauk lekarskich osobom studiującym nowym trybem medycynę, o ile złożą odpowiednie egzaminy do 31 XII $19^{2} 7$ r. $^{377}$ Biorąc pod uwagę nagminne przeciąganie przez studentów nauki ponad przepisowe terminy, przez sporą cześć okresu międzywojennego na Uniwersytecie studiowały więc obok siebie osoby kończące studia z tytułem magistra i takie, które po takim samym lub zbliżonym toku studiów zostawały doktorami.

Zmiany przepisów znajdowały odzwierciedlenie w statystyce wydawanych przez Uniwersytet dyplomów magisterskich i doktorskich. W pierwszej połowie lat 20. liczba jednych i drugich była mniej więcej zbliżona i wynosiła każdego roku akademickiego ok. 300-4,00. Wraz $\mathrm{z}$ upowszechnianiem się nowego systemu studiów liczba absolwentów z tytułem magistra zaczęła gwałtownie rosnąć, by od roku akademickiego 1932/1933 utrzymywać się powyżej 1100. (Wyjątek stanowił ostatni rok przed wybuchem wojny, kiedy mury Uniwersytetu opuściło 1065 magistrów). W tym samym okresie liczba promocji doktorskich spadła do kilkudziesięciu rocznie ${ }^{378}$.

Przyczyniło się to, rzecz jasna, do umocnienia prestiżu doktoratu. Już wcześniej, gdy był on pierwszym tytułem akademickim, Stanisław Ossowski, dyskutując na temat konieczności jego uzyskania ze swą 
przyszłą żoną Marią, choć nieco przewrotnie kontestował wówczas potrzebę doktoryzowania się, przyznawał, że sens słów zależy dla słuchacza „nie tylko od ich brzmienia, ale od tego, kto je wypowiada" ${ }^{379}$. Głos doktora miał w społeczeństwie inną wagę niż osoby bez tego tytułu, zwłaszcza gdy dyskusja miała charakter intelektualny. Kilkanaście lat później znany już wówczas publicysta Karol Zbyszewski, którego rozprawa Niemcewicz od przodu $i$ tyłu została odrzucona przez $\mathrm{Wy}_{\mathrm{y}}$ dział Humanistyczny UW, wykpiwał we wstępie do jej książkowego wydania niedoszłe benefity: „Nie będę figurował w książce telefonicznej jako «dr Zbyszewski» i fryzjer z przeciwka nie będzie mi mówił «Szanowanie panu doktorowi!». To są te przywileje stanu doktorskiego, o których mamrocze po łacinie Jego Magnificencja rektor przy promocji' ${ }^{380}$. Było to jednak robienie dobrej miny do złej gry, bo gdyby Zbyszewskiemu rzeczywiście obojętne było posiadanie tytułu doktorskiego, w ogóle nie próbowałby go uzyskać, a książkę opublikowałby bez ambicji naukowych.

Przez większość okresu międzywojennego największą jednostką organizacyjną UW był Wydział Prawa. Jego studenci stanowili w kolejnych latach od 21\% do 43\% ogółu słuchaczy, przy czym najczęściej odsetek ten wahał się w granicach 29-36\%. W niektórych latach ich liczba przekraczała $3000^{381}$. W latach $1915^{-1939}$ na prawie immatrykulowało się łącznie 19217 studentów, czyli mniej więcej co trzeci ze wszystkich zapisanych na Uniwersytet Warszawski zamierzał zostać prawnikiem ${ }^{382}$. Tendencja taka nie była specyfiką wyłącznie warszawską, lecz występowała również w skali całego państwa. (W roku akademickim 1934/1935 przyszli prawnicy stanowili 30\% ogółu słuchaczy wszystkich szkół wyższych w Polsce) ${ }^{383}$.

Popularność studiów prawniczych wynikała, jak można sądzić, przede wszystkim z przekonania, iż zapewnią one w przyszłości dobrą pozycję na rynku pracy, otwierając drogę do stanowisk nie tylko w adwokaturze i wymiarze sprawiedliwości, ale także w administracji państwowej i samorządowej. Jakaś część młodych ludzi wybierała przy tym prawo z braku konkretnie sprecyzowanych zainteresowań. Jerzy Giedroyc, który ukończył ten kierunek na Uniwersytecie Warszawskim, napisał o sobie po latach: „Ponieważ do końca nie byłem zdecydowany, co ze sobą zrobić po maturze, jak to się zwykle dzieje w takich przypadkach, zapisałem się na prawo"384. Podobne sytuacje musiały zdarzać się często, skoro oficjalne sprawozdanie dziekana Wydziała Prawa za rok akademicki 1927/1928 stwierdzało: „[...] O ile na kursach II, III i IV ilość studentów wynosi stale 4.00 do 500, na kursie I przewyższa ona 1200, a więc jest trzykroć wyższa. Fakt ten ma przyczyny oczywiste: tłumaczy 
go [...] nieoględny pęd młodzieży na Wydział Prawa, pęd nie liczący się zupełnie z powołaniem kandydatów do tej dziedziny wiedzy [...]"385.

$\mathrm{Z}$ powodu dużej liczby chętnych prawo było jednym z tych kierunków, na które (począwszy od roku akademickiego 1932/1933) dokonywano odsiewu kandydatów ${ }^{386}$. Jeden $\mathrm{z}$ nich, kiedy przyszedł złożyć dokumenty w dziekanacie, usłyszał od progu: „To jest nasz najpopularniejszy wydział. Kto nie wie, co studiować, zgłasza się na prawo. Mamy rocznie około dwóch tysięcy zgłoszeń, a możemy przyjąć tylko tysiąc. Dlatego obowiązuje ostry konkurs matur" ${ }^{\prime 387}$. Było w tym sporo przesady, ponieważ z danych, jakimi dysponujemy dla roku akademickiego 1934/1935, wynika, iż przyjęto wówczas 799 spośród 925 kandydatów, tzn. aż 86\%. Była to liczba o prawie 10 punktów procentowych wyższa niż średnia dla całego Uniwersytetu i 2,5 razy większa niż analogiczny współczynnik dla Wydziału Lekarskiego ${ }^{388}$. Nie ma dowodów, by w innych latach obowiązywały kryteria ostrzejsze.

W praktyce selekcji kandydatów dokonywano sprawdzając, czy spełniają wymogi formalne, i odrzucano przede wszystkim tych, którzy nie mogli udokumentować znajomości łaciny, czyli absolwentów niektórych gimnazjów realnych, liceów matematyczno-przyrodniczych i szkół handlowych. Poza tymi wyjątkami nie słyszało się, „aby czyjaś zdana matura została odrzucona, a delikwent nie został przyjęty"389. Często przymykano oko również na brak zaliczonej łaciny, dając kandydatowi szansę na uzupełnienie tego przedmiotu w trakcie pierwszego roku studiów, co musiał potwierdzić egzaminem złożonym przed kuratorium okręgu szkolnego ${ }^{390}$.

Program studiów prawniczych został stopniowo uregulowany rozporządzeniami MWRiOP w latach 1918-1921. Wprowadzono nimi system egzaminów rocznych, od których zależała promocja na kolejny rok. Przepisowa nauka na Wydziale Prawa miała odtąd trwać 4 lata ${ }^{391}$. Przez niemal wszystkie relacje ówczesnych studentów tego wydziału narzekania na morderczy charakter tych egzaminów przeplatają się ze wspomnieniami powszechnej absencji na zajęciach w trakcie roku akademickiego. $\mathrm{Z}$ upływem czasu niektórzy słuchacze krytykowali ten system jako nieefektywny. Do wniosków takich doszedł m.in. Wojciech Wasiutyński, skądinąd syn wykładowcy Wydziału Prawa: „Profesorowie wydziału prawa reprezentowali wysoki poziom naukowy, ale system nauki był zły. Ze szkoły średniej z jej rygorami i stałym kontaktem z uczącymi, przechodziło się nagle do wielkiej sali z kilkuset studentami i zmieniającymi się na katedrze wykładowcami. Wystarczyło przyjść dwa razy - na początku i na końcu trymestru - żeby wziąć podpis profesora; poza tym można go było nawet nie słuchać. 
Wykłady wydawane były przez Bratniak w formie powielanych skryptów. Obowiązkowych seminariów nie było. Wyłącznie ustny egzamin z całego roku, ze wszystkich przedmiotów, zdawało się jednego dnia. Wynik zależał nie tylko od stanu wiedzy zdającego, ale od wielu innych okoliczności. Znałem ludzi inteligentnych i pilnych, którzy «oblewali» egzaminy z powodu zdenerwowania, i innych, którzy się prawie nie uczyli («kasztany kwitną, trzeba się zabrać do egzaminów» - mawiał jeden z nich), a zdawali”392. Jerzy Giedroyc wspomina natomiast: „Dwa miesiące przed każdą sesją egzaminacyjną brałem urlop, trochę udawałem, że choruję, i kułem do egzaminów, a że miałem szczęście, jakoś zdawałem je na tróje" ${ }^{\text {393 }}$.

Nie bez racji jeszcze inny ówczesny student określił istniejący wówczas system jako „iście diaboliczny”, wspominając stres towarzyszący zaliczeniu roku: „[...] Po kilkumiesięcznym wkuwaniu tekstów, komentarzy, kodeksów przychodziło się na godzinę, powiedzmy dziesiątą, i proszę bardzo: tu prawo międzynarodowe, a tam, naprzeciwko, prawo administracyjne. Tu statystyka, a w tamtym pokoju procedura karna. Jeszcze w innym pokoju elegancki, z bródką, prof. Wacław Makowski, współautor wchodzącego właśnie w życie nowego kodeksu karnego [...]. Gdy więc zdałeś już prawo karne i wypadałeś nieco zziajany na korytarz, z miejsca otaczał cię tłum rozgorączkowanych, zaczerwienionych, nieco nieprzytomnych kolegów i koleżanek, by zarzucić cię pytaniami: «Jak?», «Co pytał?», «W jakim humorze?», «Ciężko było?», «Co dostałeś?», «Jakie było pierwsze pytanie?», «Stary, żyjesz?». Ledwie zaspokoiłeś ich ciekawość, już cię czekały następne drzwi i następny egzamin, powiedzmy, z historii ustroju dawnej Polski. Ale idąc tam wiedziałeś - o, nieszczęsny, że to przecież jeszcze nie koniec! [...] Nic dziwnego, że po czterech, pięciu czy sześciu godzinach takiego magla wychodziłeś z uniwerku na wyraźnie chwiejnych nogach i... z kompletną pustką w głowie"394.

Niska frekwencja na zajęciach i charakter egzaminów na Wydziale Prawa były w istocie zjawiskami współzależnymi: studenci nie chodzili na wykłady, mając świadomość, iż nie dowiedzą się z nich na ogół niczego, co nie zostałoby napisane przez wykładowców w podręcznikach lub w skryptach opracowanych przez starszych kolegów. Normę tę utrwalali profesorowie, tolerując opuszczanie zajęć przez studentów. (Jeden z nielicznych wyjątków stanowił prof. Józef Rafacz, który dzięki dobrej pamięci wzrokowej potrafił wyłuskać na egzaminie osoby, które nie pojawiały się na jego zajęciach ${ }^{395}$ ). Wykładowcy domagali się za to często powtarzania później na egzaminach słowo w słowo treści swoich publikacji. Szczególnie znany pod tym względem był prof. Eugeniusz Jarra, 


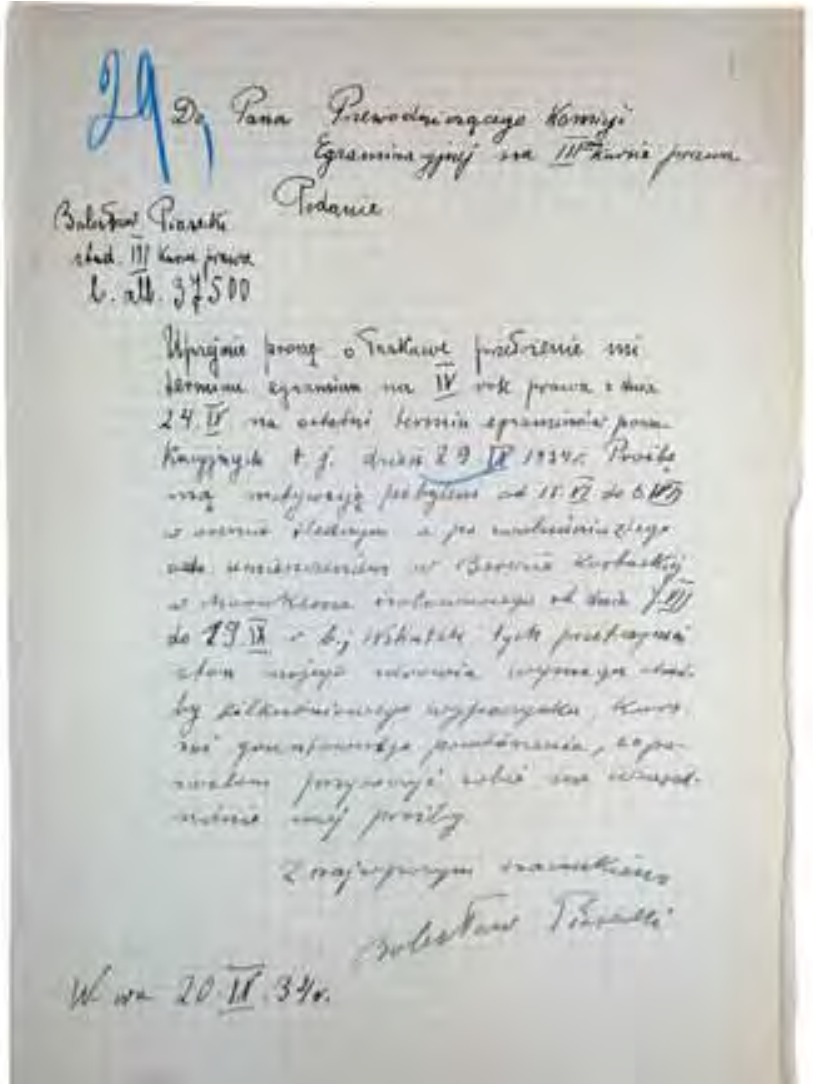

51. Podanie Bolesława Piaseckiego o przełożenie terminu egzaminów z powodu pobytu w areszcie śledczym i osadzenia w obozie odosobnienia w Berezie Kartuskiej

który organizował nawet dla chętnych specyficzne egzaminy zerowe, polegające na recytowaniu z pamięci całych partii swego podręcznika przed audytorium pełnym studentów. Obraz taki mocno utkwił w pamięci jednemu z ówczesnych słuchaczy: „Kiedy padło z katedry jedno z tych sakramentalnych pytań, na które jedynie ścisła i właściwa odpowiedź zawarta była w podręcznikowych formułkach, Jurek, a po nim Janek [koledzy autora - P.M.M.] w nagle zaległej ciszy zaczęli, zdanie po zdaniu, stronica po stronicy, recytować wykuty na pamięć tekst. Trudno zapomnieć ten moment: Jurek recytuje śmiało i pewnie, a twarz Jarry rozjaśnia się i rozpływa w błogim uśmiechu. Mija minuta, druga, trzecia. I nagle wśród skupionej ciszy zaczynają szeleścić kartki. Wszyscy szukają właściwej stronicy, by sprawdzić, czy ścisłość recytowanego z podręcznika tekstu jest zupełna. Po kwadransie bezbłędnej recytacji profesor łaskawie przerywa, by stwierdzić, że tak oto wygląda odpowiedź wzorowa" ${ }^{9396}$. 


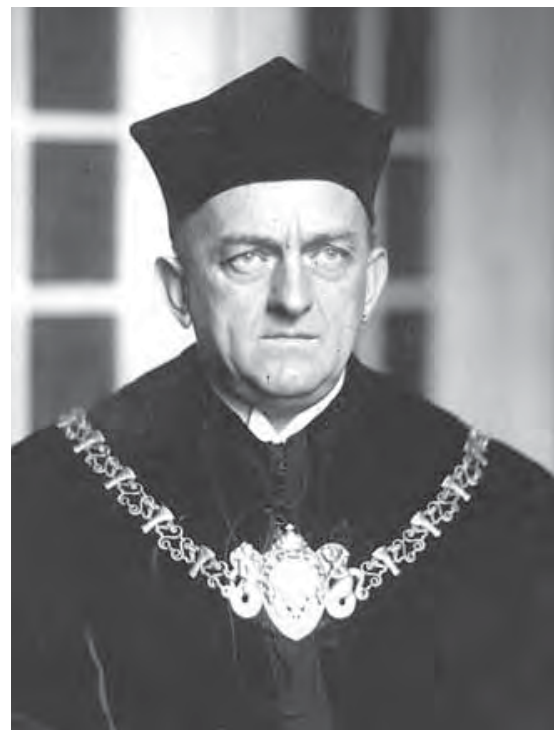

52. Profesor Eugeniusz Jarra, 1928 r.
Seminaria miały na Wydziale Prawa charakter nieobowiązkowy, więc uczęszczali na nie tylko nieliczni studenci autentycznie zainteresowani nauką. W zgodnej opinii wielu osób wspominających lata swych studiów, to właśnie ten rodzaj zajęć był najbardziej rozwijający intelektualnie. Omawiano tam referaty i przygotowywane przez seminarzystów prace doktorskie. Niektórzy profesorowie analizowali ze studentami rzeczywiste bądź hipotetyczne casusy prawne. Wacław Makowski wraz ze swym asystentem Stanisławem Batawią pewnego razu zainscenizowali nawet $\mathrm{w}$ tym celu między sobą szarpaninę zakończoną spoliczkowaniem, z której następnie kazali pisać zszokowanym studentom, będącym jej świadkami, zeznania. (Okazały się one, czego dowieść miał eksperyment, całkowicie sprzeczne ${ }^{397}$. Na 2 lata przed wybuchem II wojny światowej program studiów prawnych częściowo zreformowano, wprowadzając obowiązkowe seminaria i ćwiczenia, które, jak oczekiwał rektor, „niewątpliwie pogłębią wśród młodych prawników metody pracy naukowej i dadzą im możność zetknięcia się z praktycznymi zajęciami w różnych specjalnościach ich przyszłej kariery prawniczej”398. Praktycznych skutków tej zmiany nie zdążono już jednak zaobserwować.

Student prawa nie zaliczał roku, jeśli otrzymał ocenę niedostateczną z więcej niż jednego przedmiotu. W przypadku, gdy trafiła mu się tylko jedna dwójka, uzyskiwał zaliczenie warunkowe, co oznaczało, iż musiał zdać egzamin w uzgodnionym z profesorem terminie poprawkowym. Konieczność zdawania wszystkich egzaminów jednego dnia i ich pamięciowy charakter powodowały, że pewna część studentów w ogóle do nich nie podchodziła. Według danych z połowy lat 20., postępowało tak aż ok. 4,0\% słuchaczy pierwszego i zbliżony odsetek ostatniego roku studiów. Na drugim i trzecim roku zdarzało się to maksymalnie kilkunastu procentom studentów. Wśród tych, którzy do egzaminów podeszli, oblewała je na pierwszym roku niemal połowa, a na kolejnych latach od kilku do ponad $20 \%{ }^{399}$. Na tym tle zupełnie ulgowo przedstawiała się kwestia ukończenia studiów, ponieważ tytuł magistra otrzymywało się na Wydziale Prawa bez konieczności zdawania jakichkolwiek dodatkowych egzaminów, wyłącznie na podstawie absolutorium, potwierdzającego zaliczenie 4 , lat nauki ${ }^{400}$. 
Drugim, poniekąd klasycznym kierunkiem uniwersyteckim była medycyna. W latach 1915-1939 na Wydziale Lekarskim UW immatrykulowanych zostało łącznie 559 o osób, co stanowiło niemalże 10\% wszystkich przyjętych w tym okresie na studia ${ }^{401}$. Przez pierwsze 3 lata po wznowieniu działalności przez Uniwersytet była to jego najliczniejsza jednostka organizacyjna; studiowało tu 4,2-52\% ogółu studentów. Później odsetek ten zaczął gwałtownie spadać, aby począwszy od roku akademickiego 1926/1927 ustabilizować się na poziomie 11-12\% ${ }^{402}$. Regres ów wymuszony został głównie przez brak środków materialnych, pozwalających zapewnić odpowiednią infrastrukturę dydaktyczną. W sprawozdaniu za rok 1925/1926 dziekan Wydziału Lekarskiego informował o chronicznym niedofinansowaniu ze strony władz państwowych, warunkach pracy i nauki znacznie gorszych niż za czasów państw zaborczych i wynikającym z tego ograniczeniu liczby przyjmowanych studentów, ,jakie okazało się konieczne już od kilku lat ze względu na niemożność pomieszczenia liczby ich większej w naszych pracowniach szczupłych i nie mających widoków na rozszerzenie"403.

W tych okolicznościach, wobec dużej liczby osób chcących studiować medycynę na UW, Wydział Lekarski wprowadził w 1925 r. konkurs matur. Oprócz wymaganej znajomości łaciny, „dla lepszego poznania kandydata, oraz dla wyrobienia sobie właściwego sądu o jego wartości i jego zdolnościach uwzględniano także stopnie maturalne z poszczególnych przedmiotów, jak nauk przyrodniczych, języków obcych itd." Metodą tą z 4,00 kandydatów przyjęto 117, w tym $100 \mathrm{w}$ pierwszej turze, pozostałych zaś decyzją Rady Wydziału, po uwzględnieniu odwołań, uzupełnieniu brakujących dokumentów itp. Jak można obliczyć, naukę mógł zatem podjąć tylko mniej więcej co trzeci ubiegający się o miejsce na Wydziale Lekarskim. (Poza powyższą procedurą kwalifikacyjną, jak co roku, na mocy specjalnego porozumienia z Ministerstwem Spraw Wojskowych, przyjęto zo elewów Wojskowej Służby Sanitarnej). „W praktyce z tym wszystkim przecież duże bywały trudności" - czytamy na temat konkursu matur w sprawozdaniu dziekańskim - w związku z czym począwszy od roku akademickiego 1926/1927, za zgodą MWRiOP, wprowadzono regularne egzaminy wstępne, mające na celu „wykazanie stopnia wykształcenia ogólnego przy pomocy testów, na wzór amerykański"404. Warto poświęcić im nieco więcej uwagi, gdyż ich przebieg ukazuje bardzo istotne zjawiska występujące wówczas na Uniwersytecie.

W ramach egzaminów wstępnych kandydaci na Wydział Lekarski musieli przygotować streszczenie wysłuchanego wykładu oraz napisać tzw. pracę dowolną na jeden z dwóch danych do wyboru tematów. 


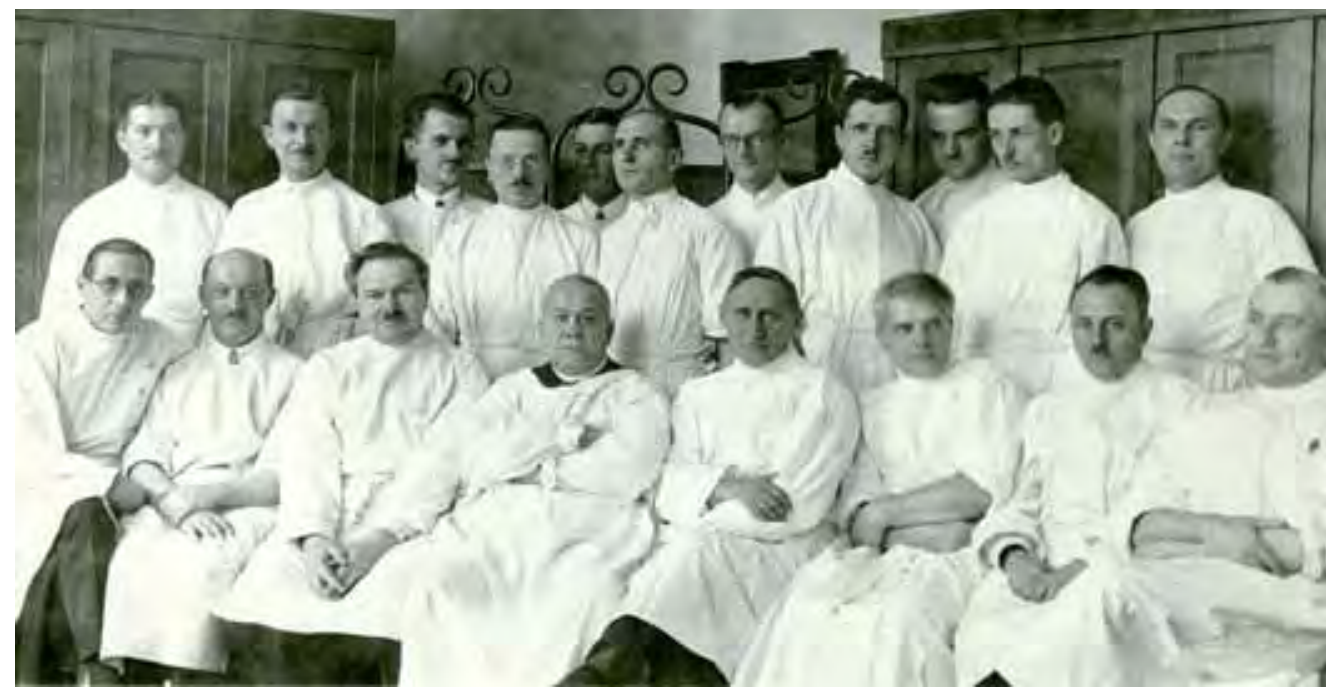

53. Profesorowie kliniki chirurgicznej UW, 1919-1936

W $193^{1}$ r. wykład dotyczył np. „Roli filtracji przy wydzielaniu moczu”, a praca pisemna mogła dotyczyć zagadnień tak od siebie odległych, jak „Wpływ alkoholu na człowieka” i „Książka”. Oprócz tego brano pod uwagę średnią ocen ze świadectwa maturalnego, początkowo uwzględniając wszystkie przedmioty (łącznie z gimnastyką i śpiewem), a dopiero od pewnego czasu wiodące (matematykę, język polski i obcy, przyrodę, historię i geografię). Pod koniec lat zo. zrezygnowano z rozprawek na tematy „dowolne”, zastępując je testem, w którym kandydaci musieli odpowiedzieć na szereg „pytań natury ogólnej”, a także przetłumaczyć na polski krótkie wypowiedzi pisemne z języków obcych. Jako odrębne zadanie dodano także omówienie na piśmie filmu naukowego o tematyce medycznej ${ }^{405}$. Za przystąpienie do egzaminu każdy z kandydatów musiał uiścić opłatę w wysokości 20 zł (dane z 1927 r.), z której pokrywano koszty sekretariatu i opłacano honoraria trzech egzaminatorów ${ }^{406}$.

W 1931 r. podania o przyjęcie na Wydział Lekarski złożyło 545 osób, zaś do egzaminów wstępnych przystąpiło ich 537. Przyjęto 120 osób, czyli mniej więcej co piątego kandydata. Podobnie jak w latach poprzednich, dodatkowych 6o studentów stanowili podchorążowie Wojskowej Służby Sanitarnej, których nabór przeprowadzała we własnym zakresie armia. Zbliżone realia - od 3 do 5 kandydatów na jedno miejsce - występowały podczas egzaminów wstępnych w całym okresie 19261939. Wielu z kandydatów, którym nie udało się dostać na medycynę, próbowało szczęścia za rok, a niekiedy nawet przez kilka kolejnych 
lat z rzędu. Przy tak dużej liczbie kandydatów rekrutacji towarzyszyły różne negatywne zjawiska, jak podrzucanie wypracowań napisanych przez osoby trzecie, czy organizowanie „nielegalnych”, tzn. nieautoryzowanych przez Uniwersytet kursów przygotowawczych, które miały zapewnić przyjęcie na studia ${ }^{407}$. Zdarzały się też afery kryminalne, na przykład wyłudzanie pieniędzy na rzekome przekupienie egzaminatorów. (Fakt, iż znajdowali się chętni, aby zapłacić za to kilka tysięcy złotych, świadczy nota bene o wysokiej wartości rynkowej studiów medycznych na UW) ${ }^{408}$.

Niezależnie od tego profesorowie, a zwłaszcza dziekani Wydziału Lekarskiego byli przedmiotem zmasowanych zabiegów o protekcję, co opisał jeden z nich, nieprzypadkowo chyba posługując się terminologią militarną: „Dziekan był oblegany w Uniwersytecie, w domu i na ulicy przez procesje wstawiających się za kandydatami, był zasypywany listami i musiał chcąc nie chcąc stawić wszystkiemu czoło - sytuacja niezwykle trudna psychologicznie, bo w tej nawale atakujących prośbami byli przyjaciele i krewni, wojsko i cywile, czcigodni starcy, rozmaite panie i podlotki. Taka ofensywa trwająca kilka tygodni mogła zmusić do poddania się na słabszych odcinkach frontu nawet najmężniejszego dziekana" ${ }^{909}$.

Czy system egzaminów wstępnych był sprawiedliwy? Przede wszystkim nie służyły one sprawdzeniu wiedzy z zakresu nauk przyrodniczych niezbędnej, aby studiować medycynę, lecz zbadaniu ogólnej inteligencji kandydatów i ich umiejętności poprawnego formułowania wypowiedzi na piśmie. Jak stwierdzały same władze Wydziału Lekarskiego w piśmie do MWRiOP, miały one na celu „bardziej zapoznanie się z właściwościami danego umysłu i stopniem inteligencji, niż sprawdzenie określonej sumy mniej lub bardziej specjalnych wiadomości”"110. Charakter zadań egzaminacyjnych wyraźnie faworyzował kandydatów o predyspozycjach lub dobrym wykształceniu humanistycznym, wysławiających się bezbłędnie po polsku, co obniżało szanse tych, którym brakowało takich kompetencji, nawet jeśli wyróżnialiby się wyjątkowymi zdolnościami w zakresie nauk przyrodniczych.

Funkcjonowanie tak pomyślanego systemu rekrutacyjnego można przeanalizować na przykładzie lat, dla których dysponujemy odpowiednio szczegółowymi danymi. Wyjątkowo ciekawy jest pod tym względem zwłaszcza 1927 r., gdyż z przeprowadzonego wtedy naboru zachowały się arkusze z indywidualną punktacją poszczególnych kandydatów. Podania o przyjęcie na medycynę złożyło wówczas 381 osób, wśród których było 302 mężczyzn (81\%) i 79 kobiet (19\%). Kandydaci wyznań chrześcijańskich stanowili 51\%, zaś Żydzi 49\%. Na studia zakwalifikowanych 
zostało łącznie 115 osób, w tym kilka po złożeniu odwołań do rady wydziału. Znalazło się między nimi 94 mężczyzn (82\%) i 21 kobiet (18\%); 83 osoby były Polakami (72\%), a $3^{2}$ Żydami (28\%). Dodatkowo przyjęto zo podchorążych - wyłącznie mężczyzn narodowości polskiej - co zmieniało oczywiście proporcje płci i wyznania wśród przyjętych na studia; grupa ta, jako rekrutowana poza Uniwersytetem, została jednak przeze mnie pominięta w dalszej analizie.

Łatwo zauważyć, że Żydów było prawie dwukrotnie mniej wśród przyjętych na Wydział Lekarski niż wśród kandydatów. Dysproporcja ta staje się jeszcze bardziej wyrazista, gdy obliczymy, jakie szanse zakwalifikowania na medycynę mieli kandydaci obu narodowości. Okazuje się otóż, że o ile dla Polaków szanse wynosiły $4,2 \%$, o tyle dla Żydów dwuipółkrotnie mniej - bo jedynie 17\%. Taki sam wskaźnik pozwala ustalić, iż podczas rekrutacji dyskryminowano równiė̇ kobiety: przyjęto na studia $26 \% \mathrm{z}$ nich, podczas gdy mężczyzn dostało się 31\%. Jak to się często zdarza, efekty obu dyskryminacji sumowały się, czego skutkiem była następująca hierarchia szans powodzenia podczas egzaminów: mężczyzna narodowości polskiej - 43\%, kobieta narodowości polskiej - 40\%, mężczyzna narodowości żydowskiej - 19\%, kobieta narodowości żydowskiej - 11\%. Ujmując to nieco inaczej, Polakom płci męskiej było 2 razy łatwiej dostać się na Wydział Lekarski Uniwersytetu Warszawskiego niż Żydom i 4 razy łatwiej niż Żydówkom, które stanowiły tym samym najbardziej upośledzoną kategorię kandydatów. Polki miały natomiast tylko nieznacznie mniejsze szanse przyjęcia niż ich rodacy płci męskiej j11. Prowadzi to do wniosku, że na medycynę starano się przede wszystkim nie dopuścić zbyt wielu Żydów (niezależnie od płci), uprzedzenia wobec kobiet odgrywały natomiast mniejszą rolę i ujawniały się głównie wobec kandydatek wyznania mojżeszowego.

Nieproporcjonalnie dużego odsiewu osób narodowości żydowskiej na egzaminach wstępnych nie da się wytłumaczyć ich gorszym przygotowaniem merytorycznym. Wskazują na to wyniki ze świadectwa maturalnego, które wpisywano w arkuszach przy nazwisku każdego z kandydatów. Po przeliczeniu wynika z nich, że ubiegający się o przyjęcie na medycynę Żydzi legitymowali się statystycznie wyższą średnią punktów $(3,73)$ niż Polacy $(3,68)$. Podobnie zresztą rzecz się miała z kobietami $(3,84)$, które jeszcze wyraźniej wyprzedzały mężczyzn $(3,67)$. Zdecydowanie najwyższą średnią punktów ze świadectwa wykazywały się przy tym kandydatki narodowości żydowskiej $(3,84)$, nieco niższą Polki (3,83), jeszcze niższą mężczyźni - Żydzi (3,7), zaś najsłabszą mężczyźni - Polacy $(3,0)$, którzy, jak na ironię, byli przyjmowani na studia najliczniej ${ }^{412}$. Z rozbieżności pomiędzy ocenami maturalnymi 
a wynikami egzaminów zdawano sobie sprawę na Wydziale Lekarskim, tłumaczono ją jednak nierównym poziomem szkół średnich i „bałamutnym" charakterem ocen wystawianych przez niektóre z nich ${ }^{413}$.

Nie sposób dziś dokładnie odtworzyć, jak w praktyce odbywało się faworyzowanie Polaków i dyskryminowanie Żydów. Należy jednak przypuszczać, że miało ono w dużej mierze charakter systemowy, opierając się przede wszystkim na trybie egzaminów wstępnych, które - jak już zostało powiedziane - obok ogólnej inteligencji sprawdzały przede wszystkim biegłość posługiwania się poprawną polszczyzną. Przy tak dużej liczbie kandydatów umożliwiały one odsiew osób popełniających nawet drobne błędy językowe. W cytowanym już piśmie do MWRiOP władze Wydziału Lekarskiego przedstawiały cały ich katalog, donosząc, iż „obok fatalnej częstokroć budowy zdań i używania germanizmów czy rusycyzmów uderzają przede wszystkim karygodne błędy ortograficzne" ${ }^{\text {"14 }}$. Sprawdzian był więc de facto zakamuflowanym egzaminem z języka państwowego. Uderzało to zwłaszcza, choć nie tylko, w Żydów. Osoby słabo zasymilowane do polskości nie miały właściwie żadnych szans, aby przejść przez sito tak prowadzonej rekrutacji. Oprócz tego podpisane imieniem i nazwiskiem sprawdziany pozwalały bez trudu ustalić, kto jest ich autorem. Otwierało to pole do subiektywnych decyzji oceniających prace, którzy mogli kierować się własnymi uprzedzeniami i preferencjami, podzielanymi zapewne przez większość kolegów. (Inaczej trudno jest wytłumaczyć, dlaczego np. kandydatki pochodzenia żydowskiego osiągały dużo gorsze wyniki niż mężczyźni tej samej narodowości).

Dane z kolejnych lat są wprawdzie zbyt mało dokładne, aby zbadać przebieg rekrutacji równie wnikliwie jak dla 1927 r., lecz nie pozostawiają żadnych wątpliwości, iż dyskryminacja kandydatów pochodzenia żydowskiego przy naborze na medycynę miała nadal miejsce. W okresie 1929-1934, odsetek Żydów wśród przyjętych na ten kierunek był zawsze co najmniej dwukrotnie niższy niż wśród przystępujących do egzaminów wstępnych ${ }^{415}$. Prowadzi to do wniosku, że co najmniej od 1927 r. na Wydziale Lekarskim obowiązywał w praktyce niepisany numerus clausus dla osób pochodzenia żydowskiego, którego skwapliwie przestrzegały kolejne władze dziekańskie.

Jak już zostało powiedziane w jednym z poprzednich rozdziałów, kandydaci, którzy nie zakwalifikowali się na medycynę, zapisywali się niekiedy na inne wydziały Uniwersytetu, albo nawet na inną z uczelni krajowych bądź zagranicznych. Część z nich chciała zapewne uniknąć w ten sposób zmarnowania roku, inni planowali przenieść się później na Wydział Lekarski. Do liczby tej należy doliczyć osoby, które nie 
podchodziły nawet do egzaminów wstępnych na UW, udając się od razu na studia za granicę, z zamiarem przeniesienia się za jakiś czas do Warszawy, a także studentów innych uczelni, zmuszonych do przeprowadzki do stolicy przez różne okoliczności życiowe.

Gdy chodzi o osoby pochodzenia żydowskiego, na podstawie uniwersyteckiej bazy danych możemy ustalić, iż mniej więcej $\mathrm{l} / 4$, z kandydatów, których nie przyjęto na medycynę, jeszcze w tym samym roku wstąpiła na UW na inne kierunki. Dwóm z nich, którzy uzyskali wyjątkowo wysokie oceny z egzaminu wstępnego, a nie legitymowali się znajomością łaciny, pozwolono studiować na Wydziale Lekarskim pod warunkiem uzupełnienia tego przedmiotu. Najwięcej, bo aż 24 osoby, trafiły na Wydział Prawa, 3 na Matematyczno-Przyrodniczy i dalsze 3 na Filozoficzny. Kolejnych 13 kandydatów z 1927 r. zapisało się na Uniwersytet Warszawski w następnych latach, z czego 5 udało się dostać na Wydział Lekarski (jednemu z nich dopiero po 7 latach!). Tylko jedna z osób przyjętych na inne kierunki przeniosła się natomiast z czasem na medycynę, co podważa obiegową opinię o powszechności takich praktyk ${ }^{416}$.

$\mathrm{Z}$ informacji, jakie w niektórych latach podawano, dowiadujemy się, iż ogólna liczba przyjmowanych na wyższe lata medycyny wahała się od kilkunastu do ponad 40 osób, przenoszących się głównie z innych uniwersytetów krajowych, co stanowiło bardzo poważne obciążenie dla pękającego już i tak w szwach Wydziału Lekarskiego. „Choć bardzo wielu petentom musi się odmówić, to przecież corocznie Dziekan jest zmuszony przyjąć pewną ich liczbę, w efekcie czego wyższe lata mają zbyt wielu studentów [...]" - czytamy w sprawozdaniu za rok akademicki $1936 / 1937^{417}$.

Również w tym przypadku dysponujemy tylko fragmentarycznymi danymi na temat mechanizmów podejmowania decyzji. W 1930 r. podania o przyjęcie bez egzaminów na wyższe lata medycyny Uniwersytetu Warszawskiego złożyło 47 osób, z których 21 studiowało na innych uczelniach w Polsce, 23 za granicą (co charakterystyczne, znajdowali się wśród nich wyłącznie Żydzi), 2 osoby były absolwentami innych wydziałów UW, a jedna próbowała dostać się na pierwszy rok, nie będąc słuchaczką żadnego uniwersytetu. W grupie tej było w sumie $3^{1} \dot{\mathrm{Z} y}$ dów, tzn. około 2/3. Zakwalifikowano 19 osób, w tym 7 warunkowo, uzależniając ostateczną decyzję od przedstawienia przez nich ocen z dotychczasowych studiów, bądź od konsultacji z wybranymi profesorami wydziału. Wśród przyjętych było 6 Polaków i tylu samo Żydów, wśród przyjętych warunkowo - kolejnych 6 Polaków i 1 Żyd ${ }^{418}$.

Trzy lata później złożono 66 podań. O przyjęcie na wyższe lata medycyny ubiegało się 20 studentów uczelni polskich (dwoje Żydów), 
33 zagranicznych (3o Żydów), a także 13 słuchaczy (3 Żydów) innych wydziałów UW lub Państwowego Instytutu Dentystycznego w Warszawie. Pozytywnie rozpatrzono 11 wniosków, z których 3 zostały złożone przez osoby wyznania mojżeszowego ${ }^{419}$. Zarówno w 1930, jak i 1933 r. Polacy mieli znacznie większe szanse niż Żydzi, aby przenieść się na medycynę. Uderzające jest również, iż konsekwentnie odrzucono przytłaczającą większość podań osób studiujących na uczelniach zagranicznych, co nosiło znamiona niepisanej zasady i uderzało przede wszystkim właśnie w Żydów. Interesujące wydaje się także, że chętniej przyjmowano na medycynę osoby przenoszące się z innych uczelni polskich niż z innych wydziałów rodzimego Uniwersytetu. Wśród tych ostatnich dominowali absolwenci Wydziału Weterynaryjnego, dużo rzadziej zdarzali się studenci innych kierunków.

W sytuacji, gdy pochodzenie stało się poważną przeszkodą, aby zostać przyjętym na Wydział Lekarski, część Żydów próbowała obejść istniejące restrykcje, zdobywając wykształcenie medyczne za granicą, a następnie nostryfikując uzyskany dyplom na Uniwersytecie Warszawskim. Liczba ubiegających się o to zaczęła wyraźnie wzrastać od początku lat 30., co wiązało się zapewne ze stopniowym powrotem do kraju osób, które wyjechały kilka lat wcześniej studiować medycynę w innych państwach. W roku akademickim 1925/1926 na Wydziale Lekarskim przeprowadzono 18 nostryfikacji, 4 lata później 20, a w roku 1932/1933 w toku znajdowało się już 411 spraw, z których 9 sfinalizowano. W ostatnim roku akademickim przed wybuchem wojny dyplomy lekarskie nostryfikowało 25 osób. We wszystkich tych latach przytłaczająca większość wniosków została złożona przez osoby pochodzenia żydowskiego ${ }^{420}$.

Już w latach 20. władze Wydziału Lekarskiego UW doskonale zdawały sobie sprawę, jakie były przyczyny popularności nostryfikacji wśród Żydów i zabiegały o odgórne ich zakazanie przez władze państwowe. W tym też celu Rada Wydziału przyjęła specjalną uchwałę, którą 23 IX 1925 r. przekazała MWRiOP, wydziałom lekarskim pozostałych uniwersytetów w kraju, a także opublikowała w prasie. Głosiła ona:

„Sprawa nostryfikacji dyplomów zagranicznych na Wydziałach Lekarskich staje się ważnym zagadnieniem społecznym, wobec ilości zgłoszeń i przynależności ich do elementów nie zawsze pożądanych dla społeczeństwa. [...] Wydziały Lekarskie naszych uczelni, wprowadzając «numerus clausus», powodowały się w swych decyzjach nie tylko pojemnością swoich zakładów, lecz i nie w mniejszej mierze pojemnością terenu przyszłej pracy swych wychowańców. Znaczne liczby nostryfikantów, otrzymując prawo praktyki w Kraju, niweczą wyliczenia, 
na których oparte są kalkulacje «numerus clausus» na Wydziałach Lekarskich i mogą spowodować w przyszłości obniżenie niezbędnego poziomu dobrobytu lekarzy, zamieniając ich w najniebezpieczniejszy pod względem społecznym proletariat inteligentów. [...] Wydział Lekarski Uniwersytetu Warszawskiego uznaje, że w danym momencie zapotrzebowanie lekarzy w kraju jest w całości pokryte, pomimo ich mniejszego odsetka w stosunku do liczby ludności w porównaniu z krajami zachodnimi o wyższej kulturze, co jednak objaśnia się małym stanem dobrobytu i niedostatecznym uświadomieniem potrzeb sanitarnych u nas [...]. Wydział Lekarski uznając, że liczba lekarzy kończących obecnie i mogących kończyć w przyszłości corocznie Wydziały Lekarskie polskich uniwersytetów może w zupełności sprostać zapotrzebowaniu lekarzy w Kraju, uważa za niezbędne w obawie nadprodukcji fachowców w tej gałęzi pracy, zaprzestać przyjmowania do nostryfikacji dyplomów uczelni zagranicznych, ograniczając je tylko do tych wyjątkowych przypadków, w których znaczne zasługi naukowe kandydata zagranicznego mogą zapewnić Krajowi realne korzyści" ${ }^{\prime 21}$.

Powyższego stanowiska, w pełni podtrzymanego później przez Radę Wydziału Lekarskiego w dyskusji, jaka się wywiązała z innymi ośrodkami akademickimi ${ }^{422}$, nie należy z pewnością oceniać w oderwaniu od ówczesnych realiów społecznych i politycznych. Nawet jeżeli sformułowania "numerus clausus" profesorowie używali formalnie w sensie ograniczenia liczebności nostryfikantów niezależnie od ich wyznania, obostrzenie takie w praktyce uderzało przede wszystkim w Żydów, którzy stanowili w tej grupie większość. Trudno w tej sytuacji przypuszczać, by autorzy uchwały nie podzielali poglądu o nadmiernej liczbie osób pochodzenia żydowskiego w środowisku lekarskim i nie dążyli do ograniczenia ich dalszego napływu na rynek usług medycznych, odbywającego się z pominięciem studiów w kraju. Uchwała ukazuje ponadto, że interes narodowy utożsamiano w praktyce z własnym interesem zawodowym, obawiając się pogorszenia sytuacji materialnej lekarzy polskich w następstwie umocnienia się konkurencji ze strony żydowskich kolegów po fachu. Autorów uchwały niezbyt interesowała natomiast społeczna ani etyczna strona problemu: kraj był, według nich, zacofany pod względem dostępności służby zdrowia i należało się z tym pogodzić. Chociaż Wydziałowi Lekarskiemu nie udało się doprowadzić do formalnego zakazania nostryfikacji dyplomów zagranicznych, nie ma wątpliwości, że nastawienie do Żydów nie zmieniło się wśród tamtejszej profesury na lepsze ${ }^{423}$. $\mathrm{Na}$ rok przed wybuchem II wojny światowej Rada Wydziału Lekarskiego uchwaliła zresztą wstrzymanie nostryfikacji aż do $194,2 r^{424}$ 


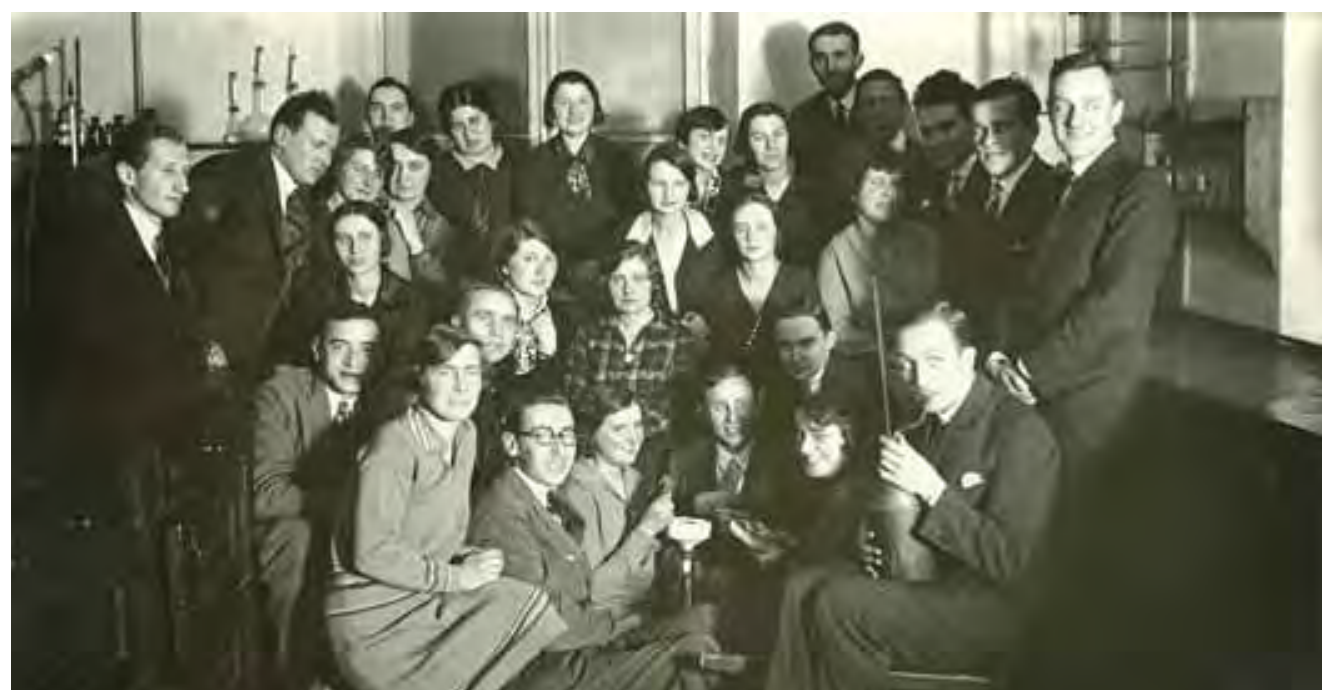

54. Studenci w laboratorium Zakładu Chemii Organicznej, lata zo. XX w.

Studia na Wydziale Lekarskim należały z pewnością do najtrudniejszych na Uniwersytecie. Po unormowaniu ich trybu przez MWRiOP w latach 1918-1920 miały trwać przepisowo 5 lat i 1 trymestr. Początkowo dzieliły się na dwie części - ogólną i specjalistyczną - z których każda kończyła się grupą egzaminów, zwaną odpowiednio pierwszym lub drugim rigorosum. Do pierwszej z nich można było podejść po ukończeniu pierwszych 2 lat studiów i należało zdać wchodzące w jej skład egzaminy w ciągu roku. Uczęszczanie na wykłady z części specjalistycznej było możliwe dopiero po zaliczeniu pierwszego rigorosum. Drugie rigorosum miało już w dużej części charakter praktyczny. Od jesieni $1920 \mathrm{r}$. wprowadzono egzaminy po każdym z 4 pierwszych lat studiów, od których wyniku zależała możliwość kontynuowania nauki. Powtarzanie roku więcej niż 2 razy powodowało skreślenie z listy słuchaczy. W 1928 r. weszła w życie kolejna reforma studiów lekarskich, która ustaliła ich ścisły program, a egzaminy podzieliła na 7 grup. Trzy pierwsze z nich należało złożyć przed uzyskaniem absolutorium. Po zdaniu kolejnych 4 grup student otrzymywał dyplom lekarski i mógł kontynuować naukę celem uzyskania stopnia doktora medycyny ${ }^{425}$.

Egzaminy medyczne były bardzo trudne. Poszczególnych grup przedmiotów nie zdawało od $15 \%$ do $29 \%$ studentów. W roku akademickim 1936/1937 ocenę niedostateczną otrzymał w sumie niemal co czwarty podchodzący do egzaminu. Zdecydowana większość z nich miała prawo 
do poprawki, ale dla 81 osób (6,5\% spośród tych, którzy nie zaliczyli) oznaczało to wykreślenie $z$ listy studentó ${ }^{426}$.

Szczególną trudność psychologiczną stanowił na studiach medycznych publiczny charakter niektórych egzaminów. „[...] Profesor zasiadał z asystentami, a dookoła na krzesłach kilku egzaminowanych, za nimi zaś cała masa kolegów, a nawet ukończonych lekarzy, którzy przychodzili specjalnie na egzamin, gdyż był on jakby przeglądem wykładów profesora, wnosząc zawsze coś nowego i ciekawego" ${ }^{\text {"427. }}$. Nowinki te zwykle nie wychodziły na dobre studentom, którzy przygotowując się do egzaminów, usiłowali przewidzieć, o co zostaną zapytani. Jeden z nich skrupulatnie zbierał nawet przez wiele lat pytania zadawane przez poszczególnych profesorów wraz z prawidłowymi odpowiedziami, a następnie wydał je ponoć w formie skryptu zatytułowanego Katechizm ${ }^{428}$.

Jak chyba w każdych czasach i na każdej uczelni, tak i na Wydziale Lekarskim UW o sukcesie na egzaminie niejednokrotnie decydowała nie tylko wiedza, ale i łut szczęścia. Jednemu z adeptów medycyny udało się np. zręcznie zmienić kierunek rozmowy z egzaminującym go z fizyki prof. Pieńkowskim z praw Newtona na teorię Einsteina, o której przeczytał popularyzatorski artykułu w „Wiadomościach Literackich", dzięki czemu otrzymał czwórkę ${ }^{429}$. Ten sam

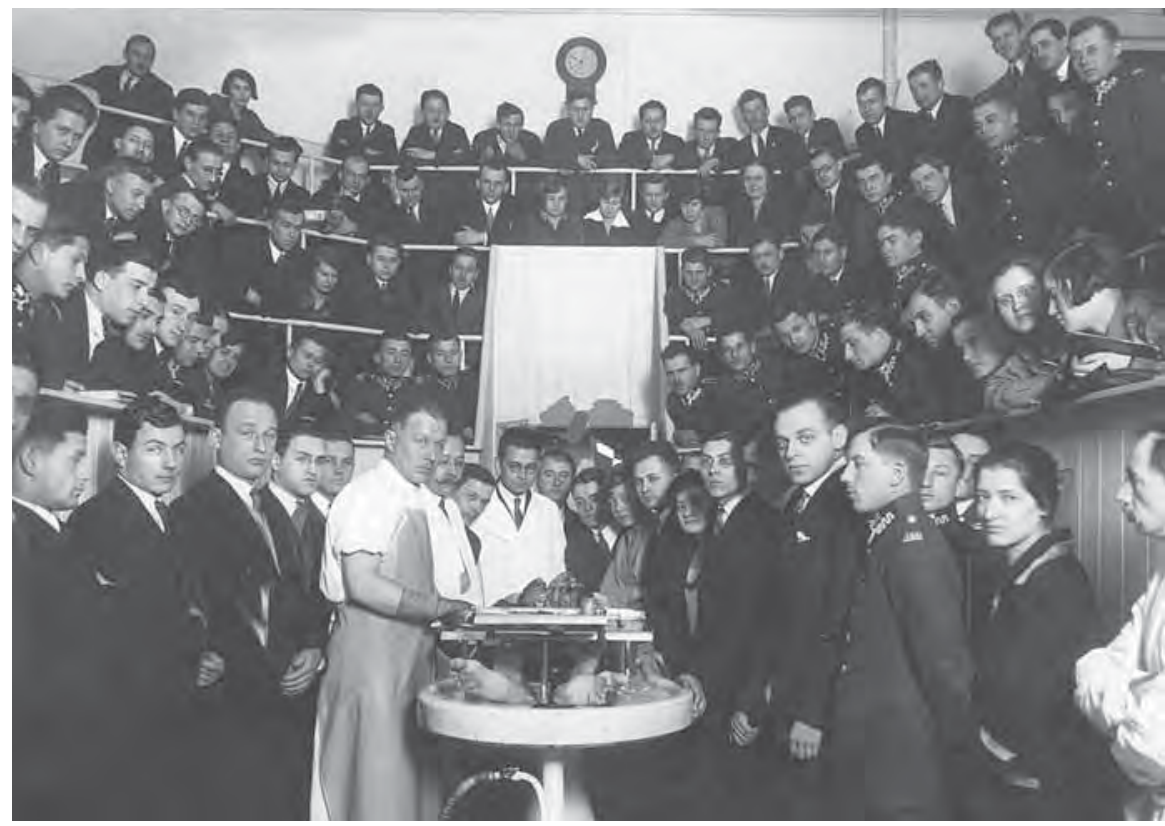

55. Sekcja zwłok podczas zajęć prof. Ludwika Paszkiewicza, luty 1928 r. 
student, mimo iż uczył się, jak twierdzi, bardzo systematycznie, musiał natomiast podchodzić aż trzykrotnie do egzaminu z chorób wewnętrznych u prof. Michałowicza, ponieważ został przez niego przyuważony podczas sesji egzaminacyjnej z kajakiem: „Przyjrzał mi się uważnie. Przyzwyczajony do zmęczonych nauką, bladych studentów w przedegzaminacyjnej tremie niezbyt przyjaźnie spojrzał na mnie. Wyczułem, że nie jest zachwycony widokiem opalonego, rześkiego studenta w mundurze, który przed egzaminem myśli o kajaku"\$30.

W przeciwieństwie do Wydziału Prawa, na medycynie dużo poważniej podchodzono do regularnego uczęszczania przez studentów na zajęcia. Zwłaszcza na ćwiczeniach o charakterze praktycznym regularnie kontrolowano obecność, która w efekcie przekraczała zazwyczaj 90\%. Na wykładach frekwencja przedstawiała się zauważalnie gorzej, wahając się od zo do $70 \%{ }^{431}$. Jak należy przypuszczać, wiele zależało pod tym względem zarówno od rygoryzmu danego wykładowcy, jak i atrakcyjności prowadzonych przez niego zajęć. Z relacji ówczesnych studentów wynika, iż do najbardziej lubianych należały wykłady prof. Edwarda Lotha, charakteryzowanego po latach jako „wspaniały wykładowca, pełen humoru, ilustrujący wykłady kolorowymi rycinami, które powstawały spod jego cudownych palców za pomocą kredek. A wszystko to okraszone frywolnymi dowcipami". Na ostatni wykład w roku Loth miał zwyczaj zapraszać nagie modelki, aby w ten sposób zapoznawać słuchaczy z anatomią ludzkiego ciała. W tym przypadku frekwencja przekraczała 100\%, ponieważ tłumnie pojawiali się na sali również studenci innych wydziałów ${ }^{432}$. Na przyszłych medykach wrażenie robiły wykłady z fizyki prowadzone gościnnie na ich wydziale przez prof. Pieńkowskiego „[...] Cieszyły się ogromną popularnością, gdyż wszystko się działo jak w latarni czarodziejskiej. Profesor prowadził wykład, a zgodnie z treścią jego słów zapalały się cudowne ogniki, gasło światło, pojawiały się na tablicy wzory itd. ${ }^{\prime 333}$. Tak samo zresztą wykłady Pieńkowskiego na fizyce - równie doskonale wyreżyserowane i połączone z demonstracjami odpowiednich doświadczeń - uważane były za jedne z najlepszych na całym Uniwersytecie. Obok studentów nauk matematyczno-przyrodniczych, którzy przychodzili na nie często po kilka razy z rzędu, przyciągały tłumnie słuchaczy również innych wydziałów ${ }^{434}$.

Trzecim z filarów Uniwersytetu Warszawskiego był Wydział Filozoficzny. Łączył on szereg różnych kierunków: od matematyki, fizyki i chemii po psychologię, historię, archeologię, etnografię, filologie i, oczywiście, samą filozofię. Między innymi ze względu na swą heterogeniczność I IX 1927 r. został podzielony na Wydziały Humanistyczny i Matematyczno-Przyrodniczy, które odpowiednio do swych 


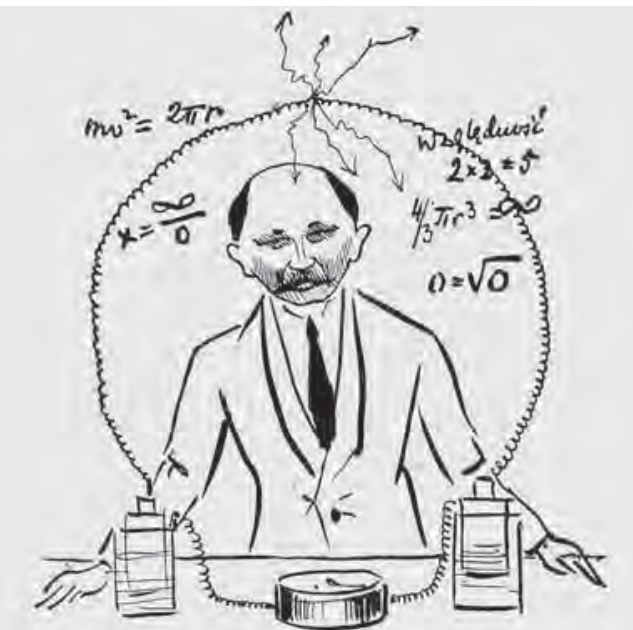

56. Profesor Stefan Pieńkowski w karykaturze profili przejęły poszczególne zakłady i seminaria. W latach 1915-1939 na wszystkich tych 3 wydziałach immatrykulowało się łącznie 28539 osób, co odpowiadało bez mała połowie wszystkich słuchaczy UW. Z liczby tej na Wydział Filozoficzny w całym tym okresie przypadało 12379 studentów (21,6\%), na Wydział Humanistyczny 9802 (17,1\%), zaś na Matematyczno-Przyrodniczy $6358(11,1 \%)^{435}$.

$\mathrm{Na}$ Wydział Filozoficzny, a później na Humanistyczny przyjmowano każdego, kto mógł się wylegitymować świadectwem dojrzałości. $\mathrm{Na}$ Wydziale Matematyczno-Przyrodniczym było nieco inaczej, gdyż w sekcji przyrodniczej początkowo stosowano konkurs matur, począwszy zaś od roku akademickiego 1936/1937 wprowadzono dodatkowo egzamin wstępny na chemię ${ }^{436}$.

W pierwszych latach funkcjonowania uczelni Wydział Filozoficzny ustępował wielkością wydziałom Prawa i Lekarskiemu, ale już w roku akademickim 1921/1922 przewyższył je pod względem liczby studentów, stając się największą jednostką Uniwersytetu. W ostatnim roku przed podziałem było na niego zapisanych ponad 4700 osób, tzn. co drugi ze wszystkich słuchaczy UW. Większość z nich przejął następnie Wydział Humanistyczny, na którym w poszczególnych latach uczyło się ok. 2500-300o osób, co odpowiadało 27-34\% ogółu studentów. Był on zatem tylko nieznacznie mniejszy niż Wydział Prawa, stanowiący wówczas najpopularniejszy kierunek studiów. Liczba słuchaczy Wydziału Matematyczno-Przyrodniczego nie przekroczyła natomiast nigdy 1700; oznacza to, iż uczęszczało tam 15-18\% wszystkich studentów Uniwersytetu Warszawskiego ${ }^{437}$.

Podobnie jak na innych wydziałach, na Wydziale Filozoficznym początkowo obowiązywał austriacki regulamin studiów. Ustawa o szkołach akademickich z lipca 1920 r. nie przyniosła pod tym względem żadnej zmiany, ponieważ przez kilka lat brakowało do niej rozporządzeń wykonawczych. Oznaczało to, iż samo studium zachowało tu w dużej mierze charakter wolny, zaś momentem zasadniczej weryfikacji wiedzy słuchaczy był dopiero egzamin doktorski. Jak wspomina Tadeusz Manteuffel, ówczesny „doktorat polegał na przedstawieniu rozprawy, ocenianej przez promotora i koreferenta oraz złożeniu dwóch rigorosów. 


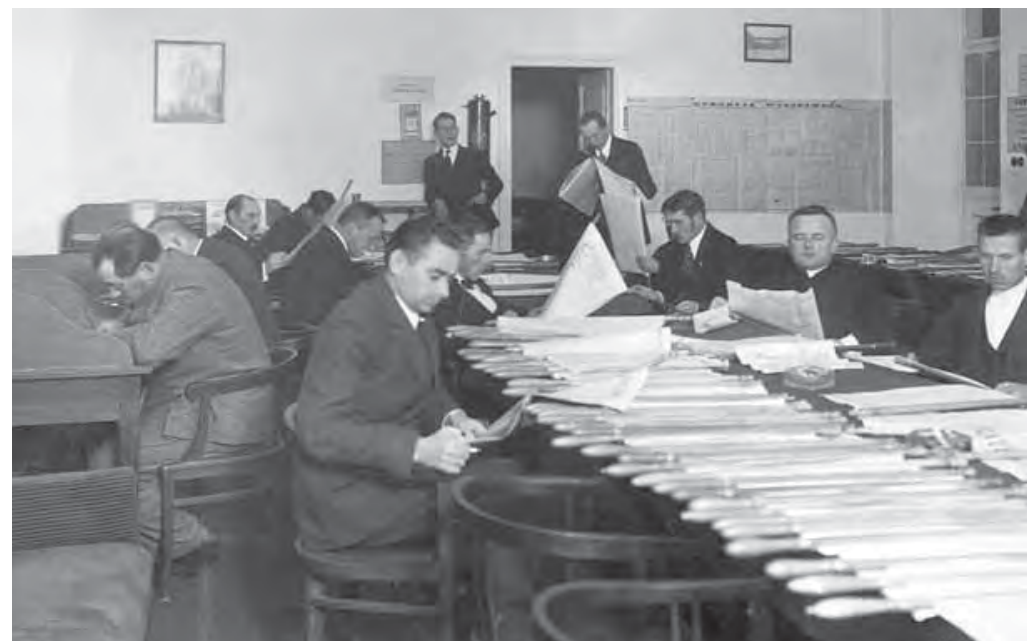

57. Czytelnia

Biblioteki

Uniwersyteckiej,

$1935 \mathrm{r}$.

Tak zwane duże, dwugodzinne, odbywało się wobec promotora, koreferenta pracy oraz przedstawicieli przedmiotu pobocznego. Małe, jednogodzinne, było poświęcone dwóm gałęziom filozofii, wybranym przez zdającego spośród trzech możliwych, a więc historii filozofii, logiki i psychologii”"338.

Już w 1920 r. wydane zostało natomiast rozporządzenie ministra wyznań religijnych i oświecenia publicznego, drobiazgowo określające przebieg egzaminów państwowych na nauczyciela szkół średnich, które dotyczyło studentów Wydziału Filozoficznego zainteresowanych pracą w oświacie. Egzaminy te miały się składać z części naukowej oraz pedagogicznej. Do pierwszej z nich można było przystąpić po ukończeniu w przepisowym trybie 3 lat studiów. Obejmowała ona wypracowanie domowe na zadany temat (często będące pracą seminaryjną lub laboratoryjną), wypracowanie klauzurowe, pisane z pamięci w ciągu 5 godzin, oraz egzamin ustny z jednego z 12 przedmiotów głównych oraz łaciny lub jednego z 6 przedmiotów dodatkowych. Warunkiem dopuszczenia do części pedagogicznej było zaliczenie egzaminu naukowego, a także ukończenie studium pedagogicznego lub odbycie dwuletniej praktyki w szkole. W ramach części pedagogicznej należało złożyć egzaminy z języka polskiego, filozofii, pedagogiki oraz dydaktyki przedmiotów głównego i dodatkowego, a także poprowadzić lekcję próbną przed komisją ${ }^{439}$.

Studia magisterskie uruchomiono dopiero pod koniec istnienia $\mathrm{Wy}_{\mathrm{y}}$ działu Filozoficznego (pierwsze egzaminy tego stopnia przeprowadzono na jesieni 1926 r.), a upowszechniły się one już na jego wydziałach sukcesyjnych, które powołały do ich koordynacji wspólną komisję $e^{440}$. Egzaminy magisterskie należało składać w toku ostatnich lat studiów, 
a nie jak obecnie, w ramach obrony pracy dyplomowej. Służyły więc one przede wszystkim sprawdzeniu wiedzy z przedmiotów wiodących danego kierunku studiów i odpowiadały dzisiejszym egzaminom semestralnym lub rocznym. Przykładowo, Henryk Jabłoński, po wojnie prominentny działacz PZPR i wieloletni przewodniczący Rady Państwa, który studiował historię na Wydziale Humanistycznym w latach 1927-1931, zanim pod koniec czerwca 1931 r. przedstawił pracę dyplomową poświęconą postaci Aleksandra Waszkowskiego, ostatniego naczelnika Warszawy w powstaniu styczniowym, już 2 lata wcześniej zdał egzaminy z głównych zasad nauk filozoficznych oraz dziejów średniowiecza polskich i powszechnych, następnie w 1930 r. egzamin z metodologii badań historycznych i nauk pomocniczych historii Polski, w ostatnich zaś miesiącach studiów - egzaminy z dziejów starożytnych oraz dziejów nowożytnych i nowoczesnych polskich i powszechnych. W dniu obrony pracy dyplomowej musiał jeszcze zdać u swego promotora prof. Wacława Tokarza egzamin końcowy z „pogłębionej znajomości dziejów politycznych Polski ze szczególnym uwzględnieniem epoki powstania styczniowego" ${ }^{441}$.

Reforma była początkowo mocno krytykowana przez część profesury. Germanista Zygmunt Łempicki punktował: „Egzaminy magisterskie w podwójnym sensie zagrażają bytowi obecnej nauki uniwersyteckiej. Dla uczniów stają się jedynym celem ich studiów uniwersyteckich. Całkowicie paraliżują pracę naukową, a nie dają wyników, zamieniając się w mechaniczne «wkuwanie się» z najgorszych podręczników. Nie są świadectwem kontroli wiedzy i nie przyczyniają się do większego nabycia wiedzy pozytywnej przez uczniów. Są czysto pamięciowym sposobem ogłuszania się uczniów przed egzaminami i prowadzą wyłącznie do ubiegania się o świadectwa. Natomiast niszczą dotychczasowy system, w którym przewagę dawano przygotowaniu do badań naukowych i wykształceniu pogłębionemu umysłów młodzieży"442. Tego rodzaju głosy, przypominające nieco dzisiejszą krytykę licencjatu, nie przekonały jednak władz państwowych do przywrócenia dawnego trybu studiów.

Egzaminy magisterskie nie były czystą formalnością. W roku akademickim 1927/1928 nie zdał ich na Wydziale Humanistycznym co piąty z przystępujących. Najgorzej wypadły egzaminy z filologii niemieckiej i orientalistyki, gdyż nie przeszła ich ponad połowa studentów; ponad 30\% uzyskało negatywną ocenę z pedagogiki i historii sztuki. Na tym tle za stosunkowo liberalne kierunki mogły uchodzić filologie angielska, słowiańskie i klasyczna, z których egzamin magisterski oblało tylko ok. $10 \%$ zdających $^{443}$.

Taki system studiów był daleki od doskonałości, już chociażby ze względu na swój pogmatwany charakter. Został on ujednolicony dopiero 
na początku lat 3o. Uprawnienia pedagogiczne można było odtąd uzyskać po ukończeniu osobnego, jednorocznego studium i złożeniu odpowiedniego egzaminu państwowego ${ }^{444}$. Prawdziwy był do pewnego stopnia pogląd wyrażony przez Łempickiego, iż studia magisterskie, skoncentrowane na ogół na uzyskaniu uprawnień nauczycielskich, pozostawiały zbyt mało miejsca na swobodny rozwój intelektualny i poznanie warsztatu danej dziedziny nauki. Z drugiej strony, ich program odpowiadał realnemu zapotrzebowaniu na wykwalifikowanych nauczycieli szkól średnich i tym samym zapewniał pracę absolwentom. $\mathrm{Z}$ pewnością nie każdy adept chemii, geografii, czy historii zdradzał poza tym ambicje i miał odpowiednie kwalifikacje, aby samodzielnie prowadzić prace badawcze z prawdziwego zdarzenia. Po kilku latach nawet dawny krytyk reformy przyznawał: „System magisterski [...] raczej zwycięsko przeszedł próbę życia. Do jego zalet nade wszystko zaliczam oddzielenie grupy ludzi idących dalej w nauce, od tych, którzy przez fakt uzyskania doktoratu rzekomo weszli na drogę naukową. Doktoraty nowego typu okazały się doskonałą szkołą dla młodych uczonych, a znaczna ich liczba świadczy bezsprzecznie o dużym, rosnącym bezinteresownym zajmowaniu się nauką" ${ }^{\prime 45}$.

Tak więc wraz z wprowadzeniem studiów magisterskich doktorat stał się przepustką do dalszej kariery akademickiej. Był on sprawą kosztowną. Absolwent Uniwersytetu, który zamierzał się o niego ubiegać, musiał złożyć podanie o przyjęcie na studia doktoranckie, a następnie opłacać w czasie ich trwania (przepisowo nie mniej niż przez 2 lata) czesne równe stawce obowiązującej na czwartym roku studiów magisterskich. Dodatkowy ciężar stanowiły koszty związane $\mathrm{z}$ otwarciem przewodu, recenzjami rozprawy i dopuszczeniem do egzaminów. „Największym wydatkiem była jednak konieczność przedstawienia uczelni 100 egzemplarzy drukowanej rozprawy - co stanowiło warunek konieczny dopuszczenia do promocji [...]" - relacjonuje jeden z ówczesnych doktorantów Wydziału Prawa. „Ostatnią, wcale nie najmniejszą grupę wydatków stanowiły koszty promocji, w które wchodziły opłacenie sali, jej oświetlenia, woźnych uniwersyteckich («za berła i sztandar»). Koszty te można było zmniejszyć, organizując promocję zbiorową, co pozwalało na sfinansowanie niektórych wydatków metodą składkową. Natomiast w całkowicie indywidualnych rejonach pozostawały koszty grupy ostatniej: ubioru delikwenta. Należało wystąpić we fraku z wszystkimi akcesoriami lub w długiej sukni typu wizytowego, również z wszelkimi dodatkami. Mężczyźni uciekali się przy tym zwykle do pomocy wypożyczalni strojów, które w owych latach korzystały nieraz z garderób teatralnych. Końcowy rachunek przeciętnie wyrażał się sumą około 
2000 zł, czyli mniej więcej równowartości średniego dziesięciomiesięcznego wynagrodzenia młodego człowieka"446. Nic więc dziwnego, że nie wszyscy chętni byli w stanie udźwignąć koszty doktoryzowania się i wykruszali się wkrótce po zapisaniu na studia doktoranckie.

Doktorat traktowano bardzo formalistycznie, o czym przekonał się wzmiankowany już przeze mnie Karol Zbyszewski, kiedy w $193^{8}$ r. Rada Wydziału Humanistycznego odrzuciła jego pracę poświęconą Niemcewiczowi. Została ona uznana za niespełniającą wymogi dysertacji naukowej, gdyż autor zamieścił w niej np. fikcyjne dialogi, a język rozprawy - choć niezwykle żywy i barwny - daleki był od standardów panujących w świecie nauki. (Próbkę jego dosadności stanowić może charakterystyka Szczęsnego Potockiego: „gustował tylko w prostytutkach; poślubił kolejno Józefinę z Mniszchów i Greczynkę Wittową - obie puszczały się z każdym, kto miał na nie ochotę") $)^{447}$. Niedoszły doktor odpłacił się Uniwersytetowi, zamieszczając, we wstępie do wydanej rok później drukiem pracy, jadowitą krytykę poziomu literackiego powstających tam publikacji naukowych. „Skromnie twierdzę, że mam dość wiadomości na napisanie pół tuzina rozpraw doktorskich” - pisał. „Nasłuchałem się ich dużo, wiem, jak powinny wyglądać: meeeee - meeee - muuuu... coś pośredniego między sprostowaniem urzędowym a obwieszczeniem o licytacji. Pedantyczna dokładność, rozwlekłość, oschłość, zagmatwany styl, zupełne lekceważenie czytelnika - oto zasadnicze cechy. W rezultacie najgorliwsza narzeczona zasypia nad dziełem ukochanego doktusia"448.

Jak się wydaje, Wydział Filozoficzny, a następnie wydziały Humanistyczny i Matematyczno-Przyrodniczy na tle pozostałych kierunków uniwersyteckich oferowały swym studentom - również na poziomie magisterskim - największe możliwości indywidualnego rozwoju. Ze wspomnień Kazimierza Kuratowskiego wyłania się obraz seminarium matematycznego, na którym wybitni przedstawiciele tej nauki: Stefan Mazurkiewicz, Zygmunt Janiszewski czy Wacław Sierpiński, traktowali studentów bardziej jako partnerów do dyskusji niż uczniów. Ostatni z nich miał nawet zwyczaj odczytywać im na zajęciach swą korespondencję fachową $\mathrm{z}$ najwybitniejszymi matematykami tamtych czasów $^{49}$. Mazurkiewicz z kolei w dużej mierze improwizował swe wykłady, w najlepszym tego słowa znaczeniu: „rozpoczynał dowód i gdzieś tam w jakimś momencie zwracał uwagę na to, że to nie tak - «a to proszę państwa, to ja to przemyślę» - bez żadnego wstydu, bez żadnych zahamowań - «ja to przemyślę, dowód podam na następny raz»"450.

Indywidualnemu rozwojowi sprzyjała także atmosfera Zakładu Fizyki Doświadczalnej, który powstał w dużej mierze dzięki determinacji prof. Pieńkowskiego, a następnie został przez niego ukształtowany 


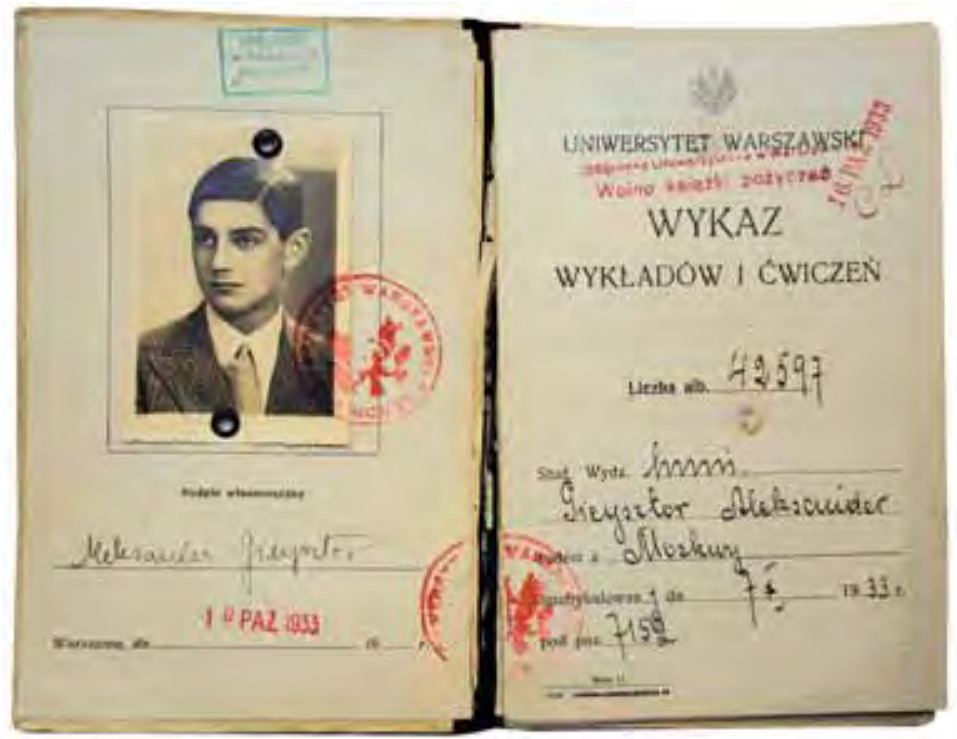

58. Indeks studenta

Wydziału Humanistycznego

Aleksandra Gieysztora; nad zdjęciem widoczny stempel „miejsce w ławkach parzystych"

jako elitarne środowisko naukowe. „Seminarium Pieńkowskiego było niesłychanie fascynujące. To seminarium było dla nas szkołą nauki" wspomina jeden z jego uczniów. „[...] Referowało się tylko prace oryginalne. Dla Pieńkowskiego nie istniała sprawa języków. Mówił np. «Pan zreferuje sprawę czasu życia wzbudzonych atomów». Literaturę trzeba było sobie szukać w «Physical Review», «Physikalische Zeitschrift», «Journal de Physique». Referowało się prace oryginalne i od razu na seminarium była dyskusja jak pomiędzy ludźmi, którzy rzeczywiście sami to robią"451. Żona profesora relacjonowała natomiast po latach, że ,znał [on] każdego ze swych uczniów, wiedział o warunkach prywatnych swych pupilów, starał się zawsze znaleźć sposób przyjścia im z pomocą"452. Obejmowała ona nie tylko sferę rozwoju zawodowego, jak np. organizowanie, dzięki osobistym kontaktom, niezwykle rzadkich wówczas zagranicznych staży naukowych, ale niekiedy również wsparcie materialne: dyskretne przekazywanie niezamożnym uczniom własnej odzieży, czy zatrudnianie ich na etatach palaczy w gmachu fizyki na Hożej, aby zapewnić im w ten sposób dach nad głową i źródło utrzymania ${ }^{453}$. Zaangażowanie Pieńkowskiego przynosiło wymierne efekty. Praktycznie każda praca dyplomowa powstająca w Zakładzie Fizyki Doświadczalnej była publikowana w prestiżowych czasopismach krajowych lub zagranicznych ${ }^{454}$.

Wysoki poziom miały również studia historyczne, nieodbiegające zbytnio pod względem charakteru od współczesnych. Reprezentatywnym 
przykładem ich nowoczesności mogą być ćwiczenia z historii średniowiecza prowadzone przez dr Wandę Moszczeńską. Pod ich sylabusem podpisałaby się zapewne większość współczesnych mediewistów: „W związku z badanymi tekstami zapoznali się słuchacze z 1) zasadami krytyki zewnętrznej: autorstwo, czas i miejsce powstania, ustalanie tekstu, stąd umiejętność wydania i korzystania z wydawnictw źródłowych, 2) wymaganiami hermeneutyki: dobre zrozumienie przekazu, wiarogodność, sprawdzanie i ustalanie wiadomości przez analizę wewnętrzną i porównanie z innymi źródłami; 3) z naukami pomocniczymi: szczegółowiej chronologia (zasady datowania, technika rozwiązywania dat); filologia (właściwości łaciny średniowiecznej). Ponieważ chodziło o uzyskanie maximum aktywności ze strony słuchaczy, wykonali oni szereg prac, z których sprawozdania bądź składali na posiedzeniach, bądź przedstawiali do przejrzenia" ${ }^{355}$. Młody asystent Witold Kula, po zajęciach z ekonomii prowadzonych przez siebie pod koniec lat zo., organizował wśród słuchaczy anonimową ankietę, w której mogli oceniać go jako wykładowcę ${ }^{456}$.

Tak jak wykłady prof. Lotha na medycynie czy Pieńkowskiego na fizyce, tak na Wydziale Humanistycznym tłumy słuchaczy, również z innych kierunków, przyciągały wykłady Władysława Tatarkiewicza i Tadeusza Kotarbińskiego z filozofii oraz Władysława Witwickiego z psychologii. „[...] Cieszyły się nieprawdopodobną frekwencją studentów, którzy przychodzili zainteresowani tematem i urzeczeni pięknem jego przedstawiania"457. Tego rodzaju interdyscyplinarna wymiana poszerzała niewątpliwie horyzonty intelektualne słuchaczy i dawała im poczucie studiowania na Uniwersytecie jako całości, a nie tylko na jego poszczególnych wydziałach.

Zarówno na Wydziale Humanistycznym, jak i Matematyczno-Przyrodniczym nauka opierała się przynajmniej w niektórych przypadkach na relacji uczeń-mistrz. Miało to miejsce zwłaszcza, gdy student wyróżniał się pod względem intelektualnym, a profesor widział w nim materiał na przyszłego naukowca ${ }^{458}$. Osobista relacja, zwłaszcza w humanistyce, nie pozostawała niekiedy bez wpływu na światopogląd ucznia. Tadeusz Manteuffel wspomina swego promotora: „Z prof. Handelsmanem stykałem się również na gruncie prywatnym, zapraszał mnie bowiem często do domu i inicjował długie rozmowy na przeróżne tematy. Stosunek ten nabrał charakteru kontaktów przyjacielskich. Nie ukrywam, że wpływ prof. Handelsmana zaważył nie tylko na moim rozwoju naukowym, ale również na ewolucji, jakiej uległ w tym czasie mój światopogląd”459.

Podobną drogę przebył inny wybitny historyk Stefan Kieniewicz, który po paru dekadach „mówił o sobie jako o apolitycznym inteligencie, liberalnym demokracie. Wspomniał, że liberalizmu nauczył 


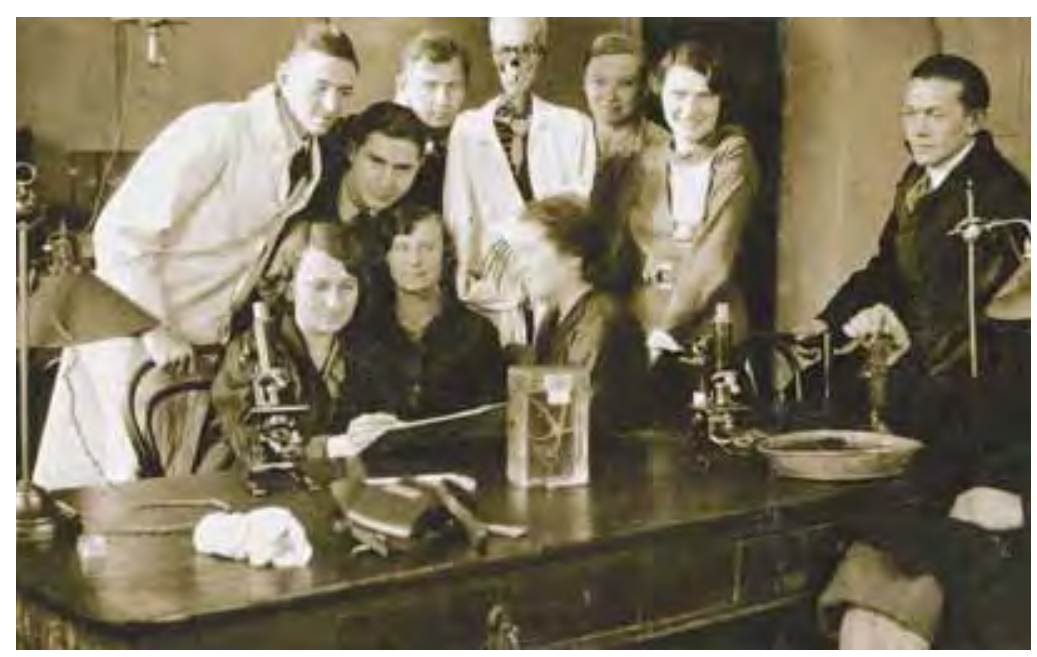

59. Studenci

w pracowni

biologicznej Wydziału

Matematyczno-

-Przyrodniczego

w budynku Szkoły

Głównej, 1935 r.

go profesor Handelsman. Był uczestnikiem jego seminarium. Wśród uczniów profesora Handelsmana znajdowali się młodzi naukowcy o sympatiach zarówno profaszystowskich, jak prokomunistycznych; profesor najmniejszym odcieniem nie dawał odczuć różnicy w swoim stosunku do jednych i drugich"460. Ten ostatni passus wskazuje, że etos nauki stojącej ponad podziałami politycznymi nakazywał przynajmniej niektórym profesorom zachowywać neutralność i kurtuazję wobec wszystkich swych studentów, niezależnie od wyznawanych przez nich poglądów. Ulubionym uczniem Tatarkiewicza, który skądinąd nie pochwalał antysemityzmu i ekscesów radykalnej prawicy na Uniwersytecie, był na przykład Jan Mosdorf - prezes Młodzieży Wszechpolskiej i jeden z przywódców ONR; napisał pod jego kierunkiem pracę magisterską poświęconą poglądom etycznym Zygmunta Balickiego ${ }^{461}$. Na tej samej zasadzie pod kierunkiem sympatyzującego z prawicą Wacława Tokarza prace pisali studenci komuniści i socjaliści, jak np. Rafał Gerber czy Henryk Jabłoński ${ }^{462}$. Po partnersku traktował swoich studentów także inny historyk, Oskar Halecki, „bez odcienia wyższości, zawsze mentorskiej, pełen zrozumienia dla odmiennych poglądów, nieraz przecież niedowarzonych i naiwnych"463.

Jak się wydaje, relacje mistrz-uczeń nie występowały natomiast zbyt powszechnie na innych wydziałach, na przykład na prawie. $\mathrm{Wy}$ nikało to zapewne w głównej mierze z odmiennego, bardziej masowego charakteru studiów, jak i innego modelu nauczania. Wśród bardzo licznych relacji na ich temat udało mi się znaleźć tylko jedną, która ukazuje profesora w roli tutora, traktującego studentów w sposób 
partnerski i zindywidualizowany. Pochodzi ona od Jerzego Giedroycia, który wspominał po latach: „Wśród profesorów Wydziału Prawa był wtedy Petrażycki, moja miłość, tym większa, że zwalczano go bardzo na Uniwersytecie; jego konkurentem był Jarra, potworny profesor, którego podręczniki trzeba było wykuwać na pamięć. Petrażycki za to był znakomity. [...] Prac Petrażyckiego nie znałem; zetknąłem się z nimi znacznie później. Ale byłem z nim w stosunkach osobistych: przychodziłem do jego mieszkania na rozmowy i asystowałem przy dyskusjach, które się u niego odbywały; mogłem siedzieć w kącie i słuchać. Był to jedyny profesor prawa, z którym miałem bezpośredni kontakt. Pozostałych spotykałem tylko na egzaminach"464. Inni wykładowcy dostrzegali z wysokości swych katedr co najwyżej wyróżniających się studenckich przywódców politycznych, o ile, jak należy przypuszczać, reprezentowali oni odpowiadający im światopogląd. Wspominany przez Giedroycia z taką niechęcią Jarra wyróżniał na przykład Bolesława Piaseckiego, któremu pozwalał nawet odprowadzać się z Uniwersytetu do domu ${ }^{465}$. Trudno jednak w tym przypadku mówić o relacji uczeń-mistrz, była to raczej wzajemna fascynacja polityczna.

Byli także profesorowie manifestujący swą wyższość wobec studentów, a nawet młodszych pracowników naukowych. Zapamiętani tak zostali prawnicy Ignacy Koschembahr-Łyskowski oraz Józef Rafacz. Pierwszy

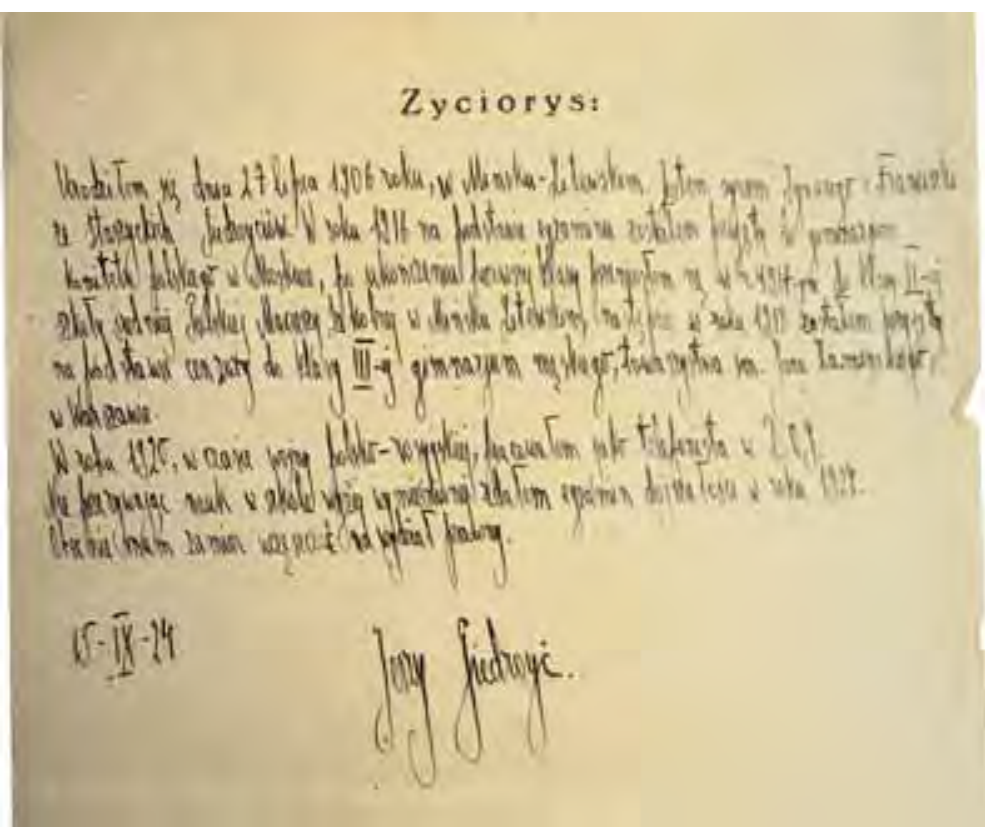

6o. Odręczny życiorys Jerzego Giedroycia z 1924 r. w aktach studenckich 
z nich "miał wygląd dostojnego starca, jakby senatora rzymskiego", ale „w czasie egzaminów potrafil traktować studentów w sposób ordynarny, wręcz karczemny"; drugi wprowadził na swym seminarium sztywny ceremoniał i narzucał swym uczniom dziwaczne ograniczenia dotyczące pracy naukowej i publikowania dorobku badawczego ${ }^{466}$. Były to jednak, jak pokazuje wiele innych relacji, wyjątki. Nawet jeśli stosunkowo niewielu wykładowców traktowało studentów po partnersku, jednych i drugich z pewnością nie dzieliła przepaść, ani w wymiarze społecznym, ani psychologicznym. Słuchaczce archeologii Janinie Rosenównie zdarzyło się nawet w złości tupnąć nogą na swego promotora, profesora Antoniewicza, kiedy ten odmówił zabrania na objazd naukowy jej najlepszej koleżanki. „- Nikt nigdy na mnie nie tupał powiedział z godnością Profesor i trzasnął trzymaną książką o pulpit. - A na mnie też nikt nie trzaskał książkami" - odcięła się studentka. Antoniewicz nie żywił jednak do niej za to urazy ${ }^{467}$. Stosunek większości profesury do studentów przybierał niekiedy nieco patriarchalny odcień, ale w gruncie rzeczy cechowała go życzliwość i wyrozumiałość - pod pewnymi względami wręcz przesadna, o czym będę jeszcze pisał w rozdziale poświęconym kulturze politycznej Uniwersytetu.

Niektórzy profesorowie traktowali studentów jak uczniaków, ale na ich usprawiedliwienie trzeba dodać, że i ci ostatni zachowywali się często tak, jakby wciąż jeszcze znajdowali się w gimnazjum. Była już mowa o nagminnym opuszczaniu wykładów, na których duża część słuchaczy pojawiała się jedynie na początku i na końcu trymestru, aby otrzymać odpowiednie wpisy w indeksie. Dochodziło do tego ściąganie, a ściślej rzecz biorąc, korzystanie z podpowiedzi, w których udzielaniu wyspecjalizowali się woźni, przysłuchujący się od lat egzaminom na prawie i ćwiczeniom laboratoryjnym na medycynie ${ }^{468}$. Jeden z prawników wspomina: „Byłem świadkiem, jak podczas przerwy w egzaminie, otoczony przez studentów [woźny - P.M.M.], prowadził dla nich prawdziwy kurs przygotowawczy według schematu: «Jak on pana zapyta... to pan jemu odpowie...»". Woźny ów, chodząca encyklopedia prawa, popadł ponoć później niestety w alkoholizm, przepijając napiwki, chętnie dawane przez studentów za pomoc w egzaminach ${ }^{469}$. Skala procederu pozwala skądinąd sądzić, że młodzież akademicka nie traktowała w czasach międzywojennych ściągania jako czynności szczególnie nagannej moralnie. Sztubacka solidarność brała też najwyraźniej górę nad kalkulacjami natury pragmatycznej (kolega, który nieuczciwie uzyskuje lepszą ocenę, pośrednio pogarsza moje własne notowania), które znamy dziś z krajów anglosaskich.

Niezależnie od wybranego kierunku studiów większość słuchaczy Uniwersytetu Warszawskiego wierzyła zapewne, że jego ukończenie 
pozwoli im znaleźć dobrą posadę, co nierzadko miało przypieczętować okupiony wielkim nakładem sił i licznymi wyrzeczeniami awans społeczny. $\mathrm{Na}$ absolwentów wyższych uczelni nie zawsze czekały jednak etaty w wyuczonym zawodzie. Przestrzegali przed tym niektórzy wykładowcy, wywołując niedowierzanie i szok u swych słuchaczy ${ }^{470}$. W latach 30. w zwiększenie konkurencyjności absolwentów na rynku pracy zaangażowało się państwo, organizując praktyki zawodowe dla studentów. Odbywały się one w ministerstwach lub podległych im instytucjach, takich jak np. urzędy, szkoły czy szpitale. Ich oferta była jednak stosunkowo wąska. W roku akademickim 1932/1933 uczącym się na Uniwersytecie Warszawskim prawnikom przyznano jedynie 5 praktyk wakacyjnych, medykom i farmaceutom - 95, weterynarzom zaś - 13. W kolejnych latach liczba miejsc wzrosła: w roku akademickim 1937/1938 studentom prawa przydzielono 39 praktyk, przyszłym lekarzom i farmaceutom - 94, weterynarzom - 76 , a słuchaczom kierunków przyrodniczych i humanistycznych - 94. Wiele złożonych podań zostało jednak rozpatrzonych negatywnie, a z drugiej strony - czego przyczynę trudno dziś ustalić - osoby, które zakwalifikowały się na praktykę, dość często jej później nie podejmowały ${ }^{471}$.

Studenci UW mogli ubiegać się ponadto o wakacyjne praktyki zagraniczne. W roku akademickim 1937/1938 przyznano ich 51, z czego najwięcej, bo aż ı6, pochodziło z Węgier ${ }^{472}$. Można powątpiewać, jaka była w tym wypadku ich użyteczność, biorąc pod uwagę barierę językową, której nie próbowano nawet niwelować jakimikolwiek kursami. Jak się wydaje, wymiana międzynarodowa prowadzona była zresztą w sposób nie zawsze przemyślany. Ryszard Matuszewski, który jako student prawa pojechał na Węgry na taką praktykę, trafił do wielkiej stadniny koni w prowincjonalnym Mezőhegyes, gdyż Węgrzy potrzebowali akurat weterynarzy. Zupełnie bezużyteczny, nudził się tam setnie przez miesiąc, po czym urządził sobie kilkutygodniowy wypad do jugosłowiańskiego Dubrownika (wspominał go później jako najwspanialszą podróż swego życia), a jego nieobecność nie została nawet zauważona przez gospodarzy ${ }^{473}$. Zdarzały się też jednak praktyki zagraniczne, które przynosiły wymierne korzyści zawodowe, gdy np. student medycyny trafiał do pracy w szpitalu w kraju, gdzie był w stanie porozumieć się przynajmniej w podstawowym zakresie ${ }^{474}$.

W ogólnym rozrachunku, duża część absolwentów UW w dwudziestoleciu międzywojennym (zwłaszcza w dobie wielkiego kryzysu) wchodziła na rynek pracy bez pewności, czy znajdzie zatrudnienie. Brak jest wprawdzie danych, które pozwalałyby zbadać poziom bezrobocia w tej konkretnie grupie, ale w skali całego kraju w 1931 r. bez pracy 


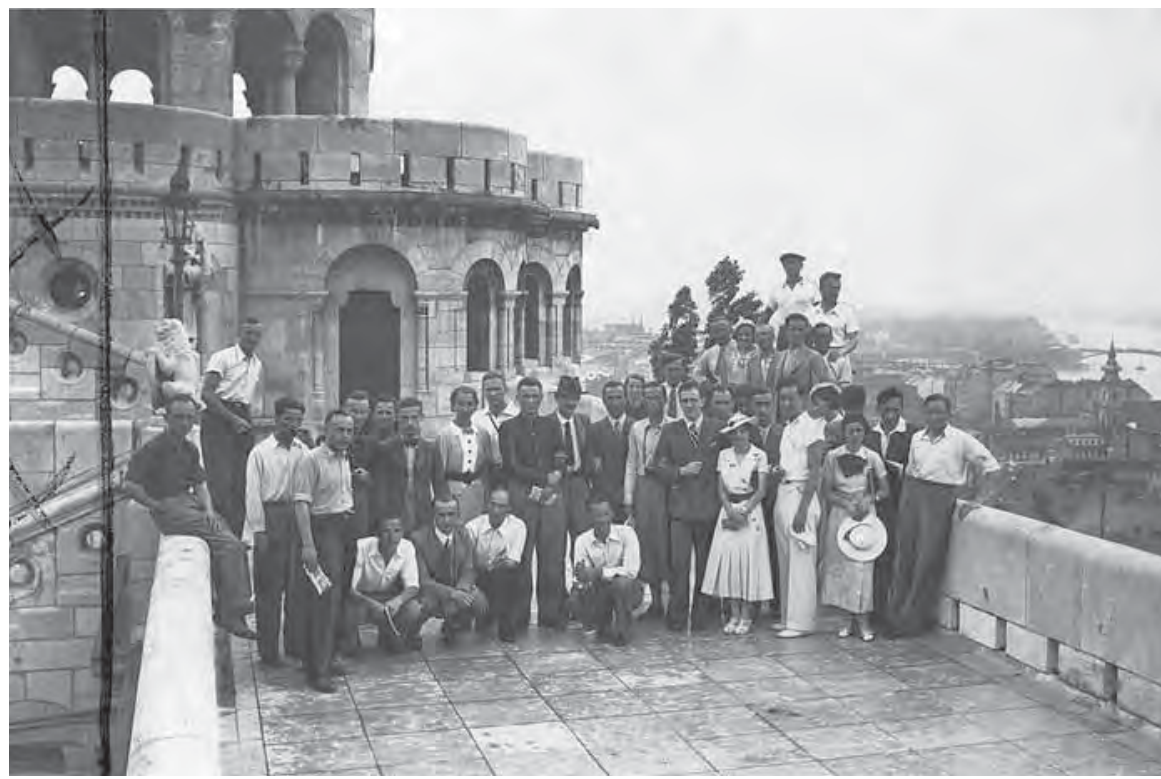

61. Polscy studenci zwiedzają Budapeszt w ramach praktyk wakacyjnych na Węgrzech, lipiec $1936 \mathrm{r}$.

pozostawało 12\% (78 tys.) pracowników umysłowych, przy czym w samej Warszawie, stanowiącej dla uczelni naturalne zaplecze pracodawcze, współczynnik ten był wyższy i wynosił ponad 16\% (16,4 tys.) ${ }^{475}$. Nawet jeśli druga połowa lat 30. przyniosła pewną poprawę, słabe perspektywy pracy dla absolwentów przyjmowano z wyraźnym niepokojem, wskazując na niebezpieczeństwo radykalizacji pauperyzujących się rzesz młodych inteligentów. Nie było to, jak się wydaje, przekonanie pozbawione podstaw, biorąc pod uwagę, że lata wielkiego kryzysu przyniosły na uczelni natychmiastową erupcję zamieszek o podłożu antysemickim: najwyraźniej, mając świadomość pogarszania się koniunktury gospodarczej, polscy studenci zwrócili się przeciwko swym żydowskim kolegom, widząc w nich niebezpieczną konkurencję na rynku pracy.

Omawiając charakter studiów na Uniwersytecie Warszawskim w dwudziestoleciu międzywojennym wspomnieć należy na koniec również o kilku istotnych różnicach w stosunku do modelu edukacji istniejącego obecnie. Pierwszą z nich był brak obowiązkowej dla wszystkich studentów nauki języków nowożytnych. Na Wydziale Humanistycznym funkcjonowały wprawdzie już na przełomie lat 20. i zo. lektoraty 15 języków obcych (później przybyło jeszcze kolejnych 10), uczęszczali 
na nie jednak obligatoryjnie tylko studenci kierunków filologicznych, a inni rzadko korzystali z takiej możliwości ${ }^{476}$. Od słuchaczy oczekiwano znajomości języków obcych wyniesionej ze szkoły średniej, o czym świadczy chociażby sprawdzanie jej na egzaminach wstępnych na medycynę, Uniwersytet nie rozwijał jednak tej wiedzy, ani jej nie utrwalał. W pierwszych latach niepodległości większość studentów musiała jeszcze znać rosyjski lub niemiecki jako języki urzędowe państw zaborczych, ale później, gdy na uczelnię przychodziły kolejne roczniki kształcące się już w wolnej Polsce, wszystko zależało od domu i poziomu gimnazjum. System taki stawiał w uprzywilejowanym położeniu słuchaczy wywodzących się z rodzin zamożniejszych lub inteligenckich, gdzie naukę języków obcych traktowano jako część należytego wychowania. Wśród ogółu studentów przeciętna znajomość języków nowożytnych pozostawiała natomiast, jak zauważali oni sami, bardzo wiele do życzenia ${ }^{477}$.

Kto studiując na Uniwersytecie chciał uczyć się języków nowożytnych, zdany był zatem przede wszystkim na własne siły. Niektórzy zapisywali się w tym celu do Instytutu Francuskiego, który mieścił się wówczas w Pałacu Staszica. Oferował on raczej możliwość pogłębienia znajomości języka niż jego nauki od podstaw i był placówką jak na ówczesne standardy bardzo nowoczesną. „Biblioteka Instytutu Francuskiego była wspaniała i bardzo łatwo dostępna. Nie było tam wypisywania żadnych kart zamówień: brało się samemu książki z półek, potem oddawało je bibliotekarce, której obowiązkiem było włożenie książki z powrotem na odpowiednie miejsce. [...] Wykłady z francuskiej literatury, historii, historii sztuki oraz francuskiego prawa prowadzili znakomici specjaliści [...]". Francuski i niemiecki były wówczas uważane za najważniejsze języki obce, ich też najczęściej uczono w szkołach średnich. „Ale - wspomina ten sam pamiętnikarz - świadomość, że angielski staje się językiem najbardziej uniwersalnym, zaczynała powoli do nas przenikać. Łatwym i niedrogim sposobem nauki angielskiego były w Warszawie - tak jak i dziś - kursy u Metodystów na placu Zbawiciela"478. Już na początku lat 20. studenci Uniwersytetu uczyli się tego języka także na zajęciach prowadzonych przez YMCA ${ }^{479}$. Mniej popularna była nauka włoskiego, którą oferował Instytut Kultury Włoskiej. Naukę języków organizowały także niektóre stowarzyszenia studenckie, np. Żydowskie Stowarzyszenie Medyków. Najbardziej rozpowszechnioną formę uzupełniania czy też pogłębiania znajomości języków obcych stanowiły jednak prywatne lekcje u mieszkających w Warszawie cudzoziemców ${ }^{480}$.

Do specyfiki studiów w okresie międzywojennym, nie tylko zresztą na Uniwersytecie Warszawskim, należał również brak obowiązkowych zajęć wychowania fizycznego dla ogółu studentów, co wpisywało się 
w ogólnie niski poziom kultury fizycznej w ówczesnej Polsce. Konsekwencją tego była nienajlepsza kondycja zdrowotna słuchaczy, która zaniepokoiła władze wojskowe, usiłujące poprawić pod koniec lat zo. stan obronności kraju. Postulowały one wprowadzenie tygodniowo co najmniej 2 godziny ćwiczeń, początkowo przynajmniej na pierwszym roku studiów, czego nie zdążono już jednak zrealizować przed wybuchem wojny ${ }^{481}$. Pod koniec lat 30 . obowiązkowe zajęcia $\mathrm{z}$ wychowania fizycznego, najpierw w wymiarze 1, a później 2 godzin tygodniowo na ostatnim roku studiów wprowadzono jedynie dla słuchaczy przygotowujących się do egzaminów nauczycielskich. W roku akademickim 1937/1938 uczestniczyły w nich 373 osoby. Trenowano gimnastykę, lekkoatletykę, gry zespołowe, boks i pływanie. Ćwiczenia odbywały się w Centrum Wyszkolenia Sanitarnego, w salach Domu Medyków i budynku YMCA, a także w pływalni Oficerskiego Yacht-Klubu i innych obiektach wojskowych, ponieważ Uniwersytet nie posiadał własnej infrastruktury sportowej ${ }^{482}$.

Zainteresowanie Ministerstwa Spraw Wojskowych stanem zdrowia studentów miało ścisły związek z reaktywowaniem Legii Akademickiej, istniejącej w latach 1918-1919 jako formacja ochotnicza, w ramach której zamierzano prowadzić szkolenie wojskowe na wyższych uczelniach. Zgodnie z wytycznymi wydanymi w styczniu 1938 r. przez ministra Tadeusza Kasprzyckiego oraz ustawą o powszechnym obowiązku służby wojskowej z kwietnia tego samego roku, do Legii mieli należeć docelowo wszyscy słuchacze obojga płci. Na początek obowiązkowym przysposobieniem wojskowym objęto jednak tylko 876 studentów pierwszych dwóch lat, którzy nie odbyli jeszcze zasadniczej służby wojskowej, a także wybranych rezerwistów spośród studentów lat starszych. W ramach Legii Akademickiej na uczelniach prowadzone miały być zajęcia, kursy i obozy. W roku akademickim 1937/1938 na trzytygodniowe przeszkolenie w Centralnym Obozie Wyszkoleniowym w Lidzbarku powołano 24,1 słuchaczy Uniwersytetu, którzy byli tam przygotowywani do roli oficerów rezerwy. Dalszych 21 trafiło do tzw. obozów społecznych, gdzie zapoznawali się przede wszystkim z zasadami ratownictwa, a także obrony przeciwlotniczej i przeciwgazowej. (Ćwiczenia z tej ostatniej były od kwietnia 1938 r. na Uniwersytecie obowiązkowe dla wszystkich słuchaczy pod rygorem niewydania dyplomu) ${ }^{483}$.

Wkrótce potem armia zwróciła się do rektorów wyższych uczelni o zapewnienie w programie zajęć w okresie wiosenno-letnim odpowiedniej liczby dni na potrzeby przysposobienia wojskowego; na Uniwersytecie Warszawskim miały się one odbywać w soboty i dni przedświąteczne, tak aby każdy student mógł co drugi tydzień uczestniczyć w szkoleniach. 


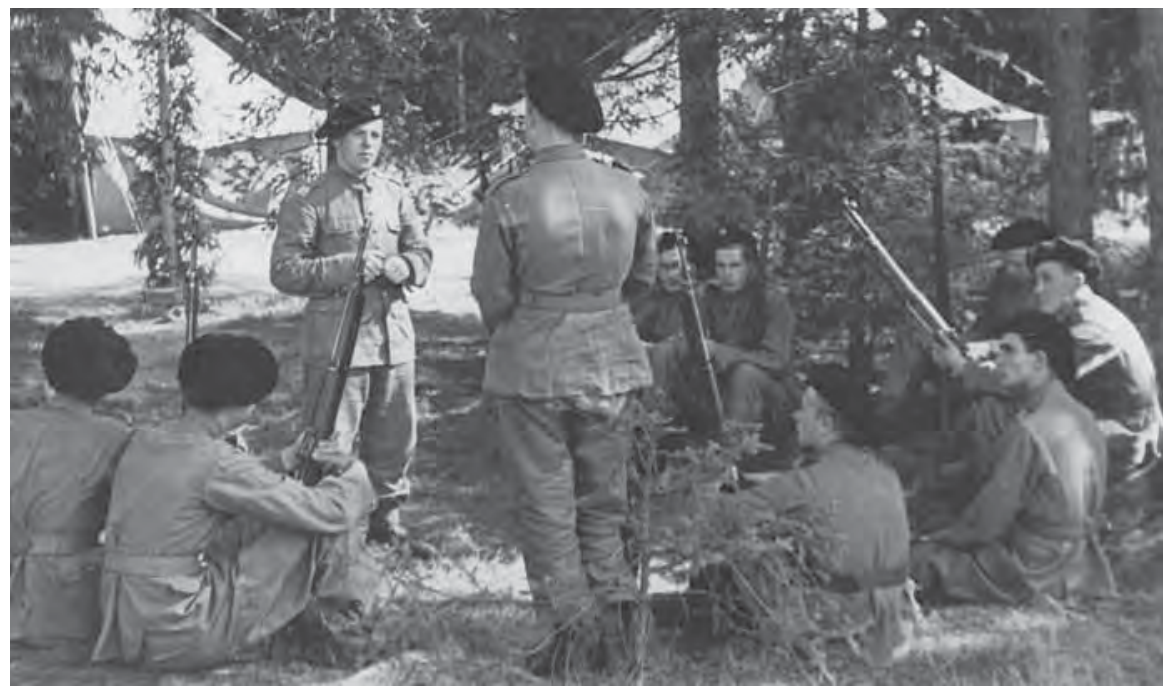

62. Centralny obóz wyszkolenia Legii Akademickiej w Lidzbarku, sierpień 1938 r.

Ostatecznie w roku akademickim 1937/1938 przeprowadzono jednak tylko 4, zajęcia (1-3 V i 4, VI) i, „mimo że młodzież na ogół odnosiła się do Legii Akademickiej, poza nielicznymi jednostkami, z zapałem, a nawet entuzjazmem, obowiązkowość w przychodzeniu na zbiórki stała na stopniu niezadawalającym, a już obowiązku usprawiedliwienia swych nieobecności nie bardzo respektowano". (Absencja rosła z ćwiczeń na ćwiczenia z $17 \%$ do $58 \%)^{484}$. W praktyce, w przeciwieństwie do zajęć przysposobienia wojskowego w okresie PRL, Legia Akademicka nie zdążyła trwalej wpisać się w życie Uniwersytetu Warszawskiego, ponieważ działała zbyt krótko.

Jak widać z przedstawionych powyżej przypadków wydziałów Prawa, Lekarskiego, Humanistycznego i Matematyczno-Przyrodniczego, warunki studiowania na Uniwersytecie Warszawskim były w okresie międzywojennym bardzo zróżnicowane. W zależności od wydziału, kierunku, a także czasu i konkretnych wykładowców studia mogły być mniej lub bardziej rozwijające intelektualnie, mieć charakter pamięciowy bądź ukierunkowany na samodzielne myślenie, masowy albo zindywidualizowany. Słuchaczy w jednym przypadku traktowano po partnersku i z wyszukaną uprzejmością, a w innym odpytywano i besztano jak uczniaków. W tej sytuacji trudno jest właściwie mówić o jednolitej dla całej uczelni specyfice studiów, co najwyżej da się wskazać pewne tendencje przeważające na Uniwersytecie lub charakterystyczne dla jego ówczesnej atmosfery. 


\section{Życie społeczne i towarzyskie studentów, obyczajowość, rozrywki}

W środowisku studenckim, tak jak w każdej większej zbiorowości, występowały rozmaite zależności i linie podziałów, wyznaczające skomplikowaną mapę relacji społecznych. Co za tym idzie, dzieliło się ono według szeregu różnych kryteriów na wiele mniejszych i większych grup i grupek. Najsilniejsze i najbardziej rzucające się w oczy były na Uniwersytecie Warszawskim podziały narodowościowe. Przejawiały się one przede wszystkim bardzo wyraźnym separowaniem się studentów chrześcijan od słuchaczy pochodzenia żydowskiego, co konsekwentnie propagowała prawica nacjonalistyczna. „Odcięliśmy się od Żydów, stworzyliśmy czysto aryjską «rzeczpospolitą akademicką»" - wspominał z dumą po latach jeden z liderów narodowej demokracji Tadeusz Bielecki, studiujący na UW w latach 1927-1929 ${ }^{485}$. Uwieńczeniem tych dążeń, wspieranych od początku lat zo. gwałtownymi rozruchami, było formalne wprowadzenie $5 \mathrm{X} 1937 \mathrm{r}$. tzw. getta ławkowego, czyli obowiązkowego podziału miejsc w salach wykładowych na parzyste, przeznaczone dla studentów chrześcijańskich, nieparzyste - dla studentów wyznania mojżeszowego oraz nienumerowane, w których można było zasiadać dowolnie ${ }^{486}$. Fakt ten, jak również inne przykłady dyskryminacji Żydów, omawiam szerzej w rozdziale poświęconym kulturze politycznej uczelni, tu chciałbym jedynie zaznaczyć, iż segregacja wyznaniowa, nawet przed wprowadzeniem getta ławkowego, miała na Uniwersytecie charakter powszechny i zinstytucjonalizowany.

Żydów z założenia nie przyjmowano do większości organizacji studenckich, czego formalną podstawę stanowił obowiązujący w nich tzw. paragraf aryjski. Dotyczyło to w pierwszym rzędzie Bratniej Pomocy - największej z działających na Uniwersytecie organizacji, skupiającej niemal wszystkich słuchaczy chrześcijańskich, której regulamin wykluczał nie tylko członkostwo osób wyznania mojżeszowego, ale także tych, którzy je porzucili, oraz innych bezwyznaniowców ${ }^{487}$. „Byłam Żydówką, więc nie miałam prawa należeć do Bratniaka" - relacjonowała po latach Irena Krzywicka. „Odzwyczaiwszy się w szkole od antysemityzmu, nie mogłam z początku pojąć, dlaczego moi koledzy, z którymi co dzień spędzałam po kilka godzin na wykładach i seminariach, poza zajęciami odpowiadali mi pólgębkiem, rozmawiali ze sobą ponad moją 


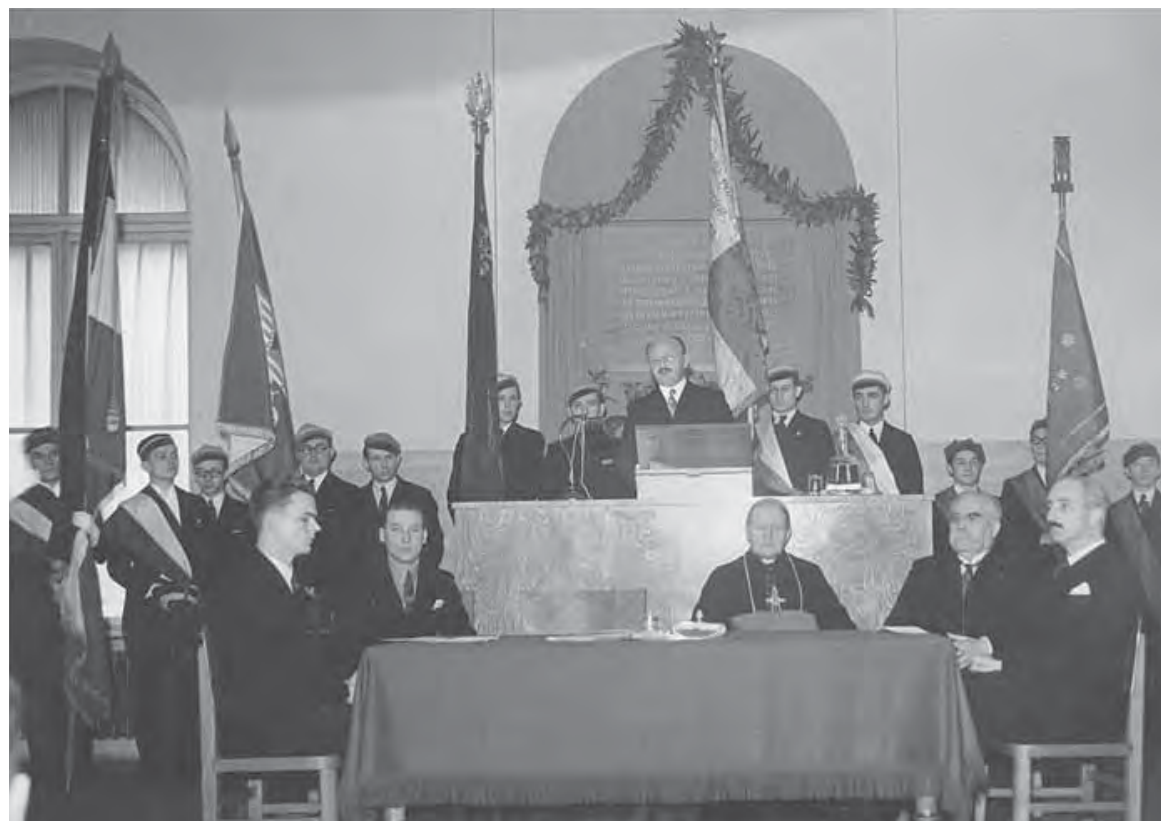

63. Obchody 20. rocznicy powstania Towarzystwa Bratniej Pomocy Studentów Uniwersytetu Warszawskiego, styczeń 1936 r. Przemawia rektor Stefan Pieńkowski, za stołem prezydialnym od prawej profesorowie UW: Władysław Tatarkiewicz, Bronisław Koskowski i ks. Antoni Szlagowski

głową. Do Koła Polonistów nie chciano mnie przyjąć"488. Paragraf aryjski miał bardzo poważne konsekwencje praktyczne: nie mogąc należeć do Bratniej Pomocy, Żydzi tracili prawo zakwaterowania w prowadzonych przez nią domach akademickich, korzystania z darmowych lub dotowanych posiłków, które rozdzielała, nie mogli też uczestniczyć w głównym nurcie studenckiego życia kulturalnego, imprezach sportowych itp., ani nawet nosić czapek, będących zewnętrznym wyróżnikiem słuchaczy UW. Dyskryminowano ich bez skrupułów przy wymaganym przez MWRiOP opiniowaniu przez Bratnią Pomoc podań o odroczenie czesnego i stypendia państwowe. W roku akademickim 1931/1932 organizacja ta rekomendowała odrzucenie $4,2 \%$ spośród 701 wniosków złożonych przez Polaków i 4,2\% spośród 4,4,2 wniosków żydowskich. (Wzajemna proporcja 1:10 obu tych wskaźników nakazuje sądzić, iż przyjęto ją a priori $)^{489}$. Bratnia Pomoc wraz ze swymi rozległymi agendami była więc de facto narzędziem polskiego egoizmu narodowego i antysemityzmu, o czym zresztą jej kierownictwo mówiło z prawdziwą dumą, nazywając Żydów „olbrzymim, ropiejącym wrzodem”"490.

Żydzi nie mogli ubiegać się ponadto o niektóre stypendia prywatne, gdyż część fundacji, np. im. Młockich, na mocy swych statutów udzielała 


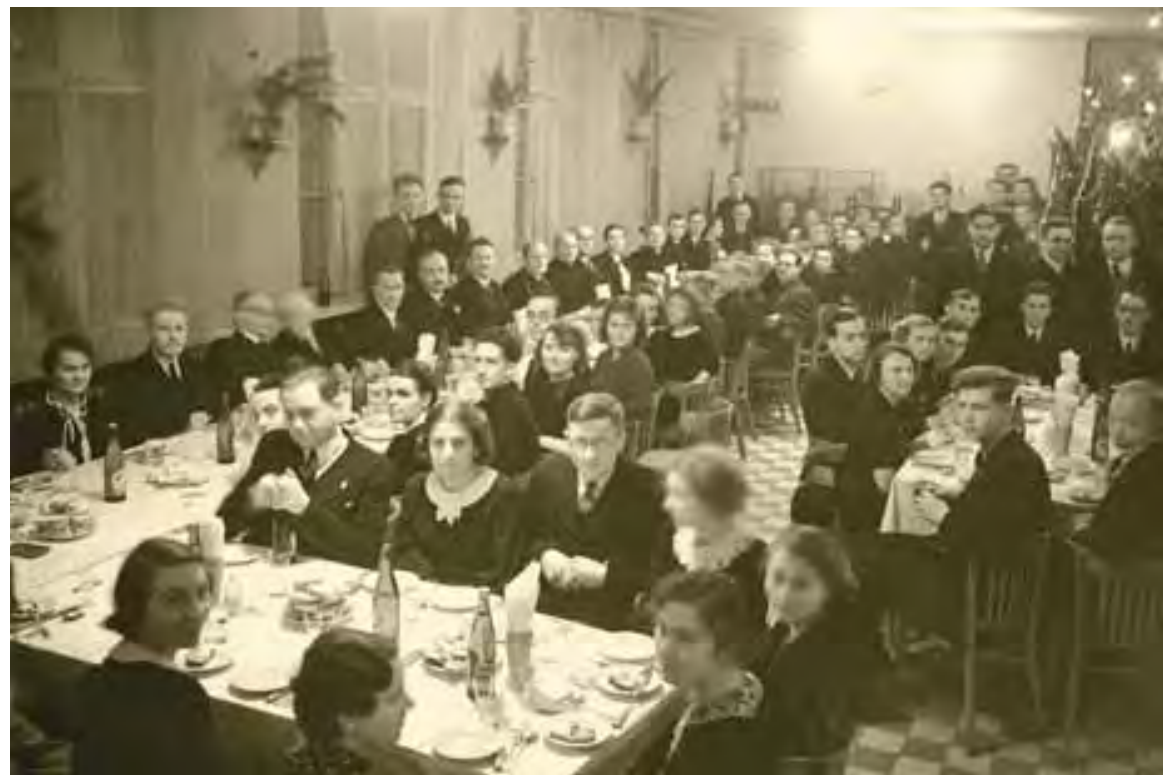

64. Wieczerza wigilijna w Bratniej Pomocy, 24, XII 1936 r., fot. K. Jankowski

wsparcia wyłącznie studentom chrześcijańskim. Nie przyjmowano ich także do wszystkich tych organizacji quasi-politycznych i ideowych, które znajdowały się pod wpływem prawicy, czyli np. do zdecydowanej większości działających na Uniwersytecie korporacji studenckich. Już w 1923 r. wprowadziły one w stosunku do Żydów „domniemanie niehonorowości”, wyłączając ich tym samym symbolicznie ze społeczności akademickiej. (Wniosek w tej sprawie złożył na ogólnopolskim zjeździe korporantów student Wydziału Prawa UW, znany później adwokat i poseł na Sejm Stronnictwa Narodowego Zbigniew Stypułkowski) ${ }^{491}$. Żaden będący przy zdrowych zmysłach $\dot{Z} y d$ nie wstąpiłby zapewne do prawicowych organizacji politycznych takich jak Obóz Wielkiej Polski czy ONR ze względu na ich wojujący antysemityzm, jednak i tam obowiązywał paragraf aryjski. Z czasem analogiczny zapis wprowadzono również w większości kół naukowych, o czym tryumfalnie informowała prasa akademicka. (W Kole Prawników paragraf aryjski ustanowiono już na początku lat 20.) ${ }^{492}$. W ostatnim roku akademickim przed wybuchem wojny osób pochodzenia żydowskiego postanowiono nie przyjmować do Sodalicji Mariańskiej Akademików, natomiast w Bratniej Pomocy i niektórych kołach naukowych uchwalono wymóg udowodnienia przez kandydatów aryjskiego pochodzenia do trzeciego pokoleń wstecz. Jednocześnie wykluczono z nich osoby „obcujące i przyjaźniące się z Żydami”"493. 
Już wcześniej zresztą w środowisku studentów chrześcijańskich podejrzliwość budziło nawet publiczne pokazanie się w towarzystwie Żydów. Jan Radożycki, który, mimo endeckich poglądów, mieszkając w domu akademickim na Ochocie przyjął wizytę syna cadyka ze swej rodzinnej miejscowości, musiał się z tego gęsto tłumaczyć przed kolegami: „«To ty utrzymujesz przyjacielskie stosunki z Żydami?»” pytali go z wyraźnym wyrzutem ${ }^{494}$. Pod koniec lat 30 ., gdy antysemickie nastroje sięgały zenitu, radykalna prawica rozprowadzała na Uniwersytecie ulotki, piętnujące $z$ imienia i nazwiska polskie studentki, które wyszły za Żydów, i inne osoby utrzymujące z nimi kontakty towarzyskie ${ }^{495}$. Nic więc dziwnego, że we wspomnieniach zdecydowanej większości ówczesnych studentów, którzy sami nie byli pochodzenia żydowskiego, brak jest jakichkolwiek wzmianek o kolegach wyznania mojżeszowego. Żydzi pojawiają się na ich kartach na ogół jako odległa część uniwersyteckiego świata lub jako bezimienne ofiary rozruchów.

Separatyzm - choć pozbawiony tak agresywnego charakteru jak polski - występował zresztą również wśród Żydów. O ile nie wywodzili się oni z w pełni zasymilowanych rodzin, które całkowicie zerwały z religią mojżeszową, dokonując już we wcześniejszych pokoleniach konwersji na chrześcijaństwo (jak np. Brandysowie), to trzymali się na ogół we własnym środowisku i nie wchodzili z Polakami w jakiekolwiek kontakty. W przeanalizowanej przez Marcina Kulę korespondencji prowadzonej przez pewną warszawską rodzinę żydowską, której jeden z synów studiował na Uniwersytecie, a drugi na Politechnice, nie pojawiają się żadne wzmianki o relacjach ze studentami chrześcijańskimi. Przez kilkanaście lat cała ta rodzina funkcjonowała w świecie zupełnie odrębnym od polskiego, prowadząc życie towarzyskie, zawodowe itp. wyłącznie wśród swoich współwyznawców ${ }^{496}$.

Zarówno wykluczanie Żydów z większości sfer życia akademickiego, jak również zamykanie się przez nich we własnym środowisku spowodowało, iż rozwinęli oni na Uniwersytecie równolegle do Polaków szereg zupełnie odrębnych aktywności. Powołali Wzajemną Pomoc Studentów Żydów UW, dysponowali własnymi jadłodajniami i domem studenckim, tworzyli swoje organizacje ideowe i polityczne, korporacje oraz koła naukowe ${ }^{497}$. Inicjatywy te, choć całkowicie zrozumiałe, gdyż pozbawione w praktyce jakiejkolwiek alternatywy, utrwalały na terenie uczelni segregację rasową, jaka istniała poza jej murami, i którą starała się umocnić polska prawica nacjonalistyczna. Polscy i żydowscy studenci uczęszczali na ten sam Uniwersytet, słuchali tych samych wykładów, lecz funkcjonowali w dwóch różnych, coraz bardziej wzajemnie zamykających się na siebie światach. Niewielkimi enklawami 
ponadnarodowych kontaktów pozostały jedynie organizacje lewicowe (w tym przede wszystkim komunistyczne), sympatyzujące z nimi często środowiska artystyczne, a także niektóre kręgi naukowe.

Podziały dotyczyły zresztą nie tylko Żydów i Polaków. Także o wiele mniej liczni na Uniwersytecie Ukraińcy tworzyli hermetyczne środowisko, dysponujące własną organizacją samopomocową Ukraińska Studencka Hromada, a także korporacją Zaporoża, powiązaną nota bene, o czym wówczas jednak nie wiedziano, z polskim wywiadem wojskowym $^{498}$. Na ogół nie wchodzili w bliższe relacje z Polakami, oczywiście ze wzajemnością. Doświadczył tego Giedroyc, gdy zaczął uczęszczać na jedno z seminariów na Wydziale Humanistycznym: „[...] Zacząłem wtedy studiować historię ukraińską u prof. Korduby, co było dla mnie wielkim przeżyciem, bo poza mną byli tam sami Ukraińcy, którzy patrzyli na mnie ze zdumieniem, jak gdybym był żelaznym wilkiem"499.

W dużej mierze odrębne od reszty słuchaczy życie towarzyskie i społeczne prowadzili także studiujący na Uniwersytecie Warszawskim Niemcy, chociaż z pojedynczych dostępnych relacji pamiętnikarskich wynika, iż polska większość słuchaczy oraz wykładowcy odnosili się do nich z życzliwością i kurtuazją ${ }^{500}$. (Stosunek do nich różnił się zatem wyraźnie od podejścia Polaków do Żydów, a prawdopodobnie także do Ukraińców). Od 1926 r. niemieccy studenci UW skupieni byli w korporacji o nazwie Verein Deutscher Hochschüler in Warschau. Stawiała sobie ona za cel zapobieżenie polonizacji swych członków, a po 1933 r. coraz wyraźniej propagowała wśród nich światopogląd nazistowski. Nie bez sukcesów: jeden z jej członków, germanista Karl Grundmann, który pod koniec lat 3o. objął stanowisko asystenta na Wydziale Humanistycznym, w czasie wojny został radcą urzędu propagandy we władzach Generalnego Gubernatorstwa, zajmując się udowadnianiem niemieckości Warszawy ${ }^{501}$. Inny Niemiec, absolwent Wydziału Matematyczno-Przyrodniczego UW Alexander Mann, jako porucznik Wojska Polskiego trafił w 1939 r. do niewoli radzieckiej i został zamordowany w Katyniu ${ }^{502}$.

Nieco trudniej jest dziś odtworzyć pozostałe linie podziałów występujące wśród studentów i ustalić ich hierarchię. Bardzo mało wiadomo o słuchaczach wyznania mojżeszowego; w świetle panujących w ówczesnej Polsce konfliktów i separatyzmów narodowych, o których była mowa powyżej, naturalne wydaje się jednak, iż przyjaźnie i znajomości były zawiązywane przede wszystkim we własnym środowisku etnicznym - Polacy trzymali się z Polakami, Żydzi z Żydami, Ukraińcy zaś z Ukraińcami. Druga, dość oczywista uwaga dotyczy związków pomiędzy zamożnością, a zaangażowaniem w życie społeczne: aby udzielać 
się organizacyjnie lub towarzysko potrzebne były odpowiednie nadwyżki sił i czasu, a tymi nie zawsze dysponowali słuchacze, zmuszeni utrzymywać się podczas studiów z własnej pracy zarobkowej. Trudno się dziwić, że młody człowiek, z trudem łączący studia z trzyzmianową pracą w fabryce, nie należał do żadnych organizacji studenckich ${ }^{503}$. Tego rodzaju przypadków było z pewnością więcej, choć da się również wskazać słuchaczy, którzy - jak wspominani już przeze mnie Wesołowski czy Śpiewak - mimo braku pieniędzy prowadzili intensywne życie towarzyskie.

Bardzo istotną rolę w życiu towarzyskim odgrywało miejsce pochodzenia, a zwłaszcza to, czy dany student wywodził się ze stolicy, czy spoza niej. Fakt ten w oczywisty sposób rzutował na sytuację w czasie studiów na Uniwersytecie: w przeciwieństwie do warszawiaków przybysze z prowincji musieli odnaleźć się w nieznanym sobie na ogół nowym otoczeniu i zazwyczaj od podstaw wybudować sieć kontaktów społecznych. Jej zalążkiem często stawały się znajomości nawiązane przy okazji poszukiwania zakwaterowania i później podczas wspólnego wynajmowania stancji bądź mieszkania w domach studenckich. Przeradzały się one niekiedy w wieloletnie przyjaźnie ${ }^{504}$.

Zarówno warszawiacy, jak i studenci z prowincji dość często pozostawali podczas studiów w kręgu znajomości nawiązanych jeszcze w gimnazjum, rozszerzanych ewentualnie stopniowo o dalsze osoby. Grupę taką tworzyli na przykład absolwenci stołecznego gimnazjum im. Jana Zamoyskiego o radykalnie prawicowych sympatiach, skupieni wokół przywódcy ONR „Falanga” Bolesława Piaseckiego ${ }^{505}$. Jeden z nich, Jerzy Tymiński, wspomina wsparcie, jakiego udzielali sobie nawzajem podczas studiów na Wydziale Prawa: „Ja np. odziedziczyłem wszystkie skrypty po Wojtku Kwasieborskim, moim starszym koledze z gimnazjum, on otrzymał je od Bolesława Niklewicza, ja z kolei przekazałem te zasłużone pomoce naukowe Andrzejowi Niklewiczowi. [...] Pokreślone, z różnymi glosami na marginesach, pomięte wyglądały jak obraz nędzy i rozpaczy. A przecież takie właśnie cenione były bardziej niż skrypty nowe, chociażby dlatego, że na zasadzie podkreśleń, wykrzykników i uwag poprzednich użytkowników od razu było wiadomo, co trzeba uważnie czytać - a co tylko pobieżnie przerzucić" ${ }^{\prime 506}$. Zbliżone, choć zdecydowanie luźniejsze relacje łączyły absolwentów gimnazjum im. Adama Mickiewicza, przy czym ich środowisko miało z kolei pierwotnie orientację piłsudczykowską, a z czasem coraz wyraźniej lewicową $a^{507}$.

Tego rodzaju nieformalne grupki tworzyli też studenci pochodzący z gimnazjów pozawarszawskich, np. z Kalisza, Torunia czy nawet 
odległego Łucka ${ }^{508}$. Istniały również koła prowincjonalne o charakterze sformalizowanym, tworzące wspólnie ogólnopolskie zrzeszenie i stawiające sobie za cel „kontynuowanie przyjaźni z ławy szkolnej, niesienie wzajemnej pomocy materialnej i naukowej, utrzymywanie bliskiego kontaktu z macierzystymi regionami"509. Jak pisze Wojciech Wasiutyński (skądinąd sam pochodzący z Warszawy): „Koła prowincjonalne grupowały studentów wedle miejsca pochodzenia albo ściślej wedle gimnazjum, jakie kończyli na prowincji. W latach dwudziestych były one bazą ludowców i lewicy sanacyjnej, tzw. «niezamożnej młodzieży akademickiej», potem przeszły pod kierownictwo Młodzieży Wszechpolskiej"510. Inny pamiętnikarz charakteryzuje je jako „milczącą większość", skoncentrowaną na prowadzeniu samopomocy we własnym gronie, niechętną radykalnym rozwiązaniom, lecz mogącą przesądzić swymi głosami o układzie sił w Bratniaku, a przez to atrakcyjną dla różnych działających na Uniwersytecie organizacji ${ }^{511}$.

Uderzające jest, że ilekroć we wspomnieniach na temat przedwojennych studiów na Uniwersytecie mowa jest o przyjaźniach i życiu towarzyskim, bardzo często okazuje się, iż miały one - w mniejszym lub większym stopniu - zabarwienie polityczne. Wynikało to z niebywałego upolitycznienia życia uczelni. Organizacje, takie jak Obóz Wielkiej Polski i Młodzież Wszechpolska, piłsudczykowski Legion Młodych, liberalny Związek Polskiej Młodzieży Demokratycznej, lewicowy Związek Niezależnej Młodzieży Socjalistycznej czy jego komunistyczny odłam Związek Niezależnej Młodziė̇y Socjalistycznej „Życie" zapewniały studentom nie tylko możliwość ekspresji politycznej, ale stanowiły dla nich również atrakcyjną płaszczyznę kontaktów towarzyskich. W ich kręgach bawiono się na „herbatkach tańcujących", zawierano przyjaźnie, podkochiwano się w sobie, a niekiedy nawet zawierano małżeństwa ${ }^{512}$. Ponieważ zaś organizacje te, a przede wszystkim prawica narodowa, kontrolowały zdecydowaną większość pozostałych sfer życia społecznego na Uniwersytecie Warszawskim - Bratnią Pomoc, korporacje, koła naukowe - polityka wpływała na relacje o charakterze prywatnym, stając się drugim, obok narodowości, najważniejszym kryterium podziałów wśród studentów. „Miałam bardzo dużo przyjaciół na studiach. Była to młodzież w większości lewicowa" - relacjonuje studentka psychologii, sama związana z komunistycznym „Życiem”513. Z pewnością zdecydowanie częstszym zjawiskiem była przyjaźń łącząca osoby pochodzące z nawet bardzo odległych od siebie miejscowości niż nawet powierzchowna znajomość pomiędzy obwiepolakiem, jak potocznie nazywano członków OWP, a lewicującym aktywistą ZPMD. 
Omawiając różne płaszczyzny życia społecznego na Uniwersytecie nie można pominąć wspomnianych powyżej korporacji studenckich i kół naukowych. Pierwszych z nich na początku lat zo. działało w Warszawie aż $27, w$ tym 13 na $U^{5} W^{514}$. W środowisku polskim miały one przeważnie profil konserwatywnie lub radykalnie prawicowy i skupiały wyłącznie mężczyzn. (Kobiet z zasady do nich nie przyjmowano, istniały natomiast nieliczne odrębne korporacje żeńskie). Osobne korporacje, o czym była już mowa, grupowały słuchaczy mniejszości narodowych.

Korporacje w największym bodaj stopniu spośród wszystkich działających na uczelni organizacji dawały swym członkom poczucie przynależności do elitarnego kręgu towarzyskiego, odgrodzonego od zewnętrznego świata murem własnych rytuałów i zasad. Świadomie dążyły do wytworzenia w swych szeregach esprit de corps, czemu służyć miał przede wszystkim rozbudowany kodeks honorowy, spisany i wydany drukiem w połowie lat zo. z inicjatywy tego środowiska ${ }^{515}$. W korporacjach pielęgnowano też więzi koleżeńskie, starając się, by nie zanikały wraz z ukończeniem Uniwersytetu. W tym celu podtrzymywano kontakty z korporantami, którzy opuścili już mury uczelni ${ }^{516}$. W ramach korporacji prowadzono działalność samokształceniową i niekończące się debaty polityczne, ale także chętnie bawiono się. „Korporacja dawała okazję do picia, «dziewczynek» i arogancji, ale ujmowała je w pewne karby. Kto się publicznie upił lub zrobił awanturę, musiał się wyrzec picia na semestr lub nawet rok. Uczono też punktualności, grzeczności, szacunku dla starszych kolegów i «filistrów». Nieprzyjemną stroną korporacji był snobizm" - charakteryzował ją po latach Wojciech Wasiutyński ${ }^{517}$. Na zewnątrz korporanci wyróżniali się, nosząc zamiast białych czapek z amarantowym otokiem Bratniej Pomocy kolorowe nakrycia głowy, zwane deklami.

Życie towarzyskie, które prowadzono w ramach korporacji, było bardzo intensywne. Każdego tygodnia 2 lub 3 wieczory spędzano w gronie kompanów na tzw. kwaterze. Nic więc dziwnego, że niektórzy studenci z braku czasu rezygnowali z przynależności do takich organizacji ${ }^{518}$. Kolidowała ona nie tylko z nauką, ale - co było w wielu przypadkach jeszcze istotniejsze - z pracą zarobkową, którą musiało podejmować wielu słuchaczy. $Z$ tego też względu na działalność w korporacjach mogła pozwolić sobie najczęściej tylko młodzież odpowiednio zamożna, niemusząca walczyć o utrzymanie się w Warszawie.

Korporacje akademickie, jak wszystkie organizacje aspirujące do miana elitarnych, były z założenia nieliczne. Należało do nich około $5 \%$ studentów ${ }^{519}$. Przez największą z nich, Aquilonię, w latach 1915-1939 przewinęło się łącznie 175 osób. Przeciętnie liczyła ona $5^{0}$ członków ${ }^{520}$. 


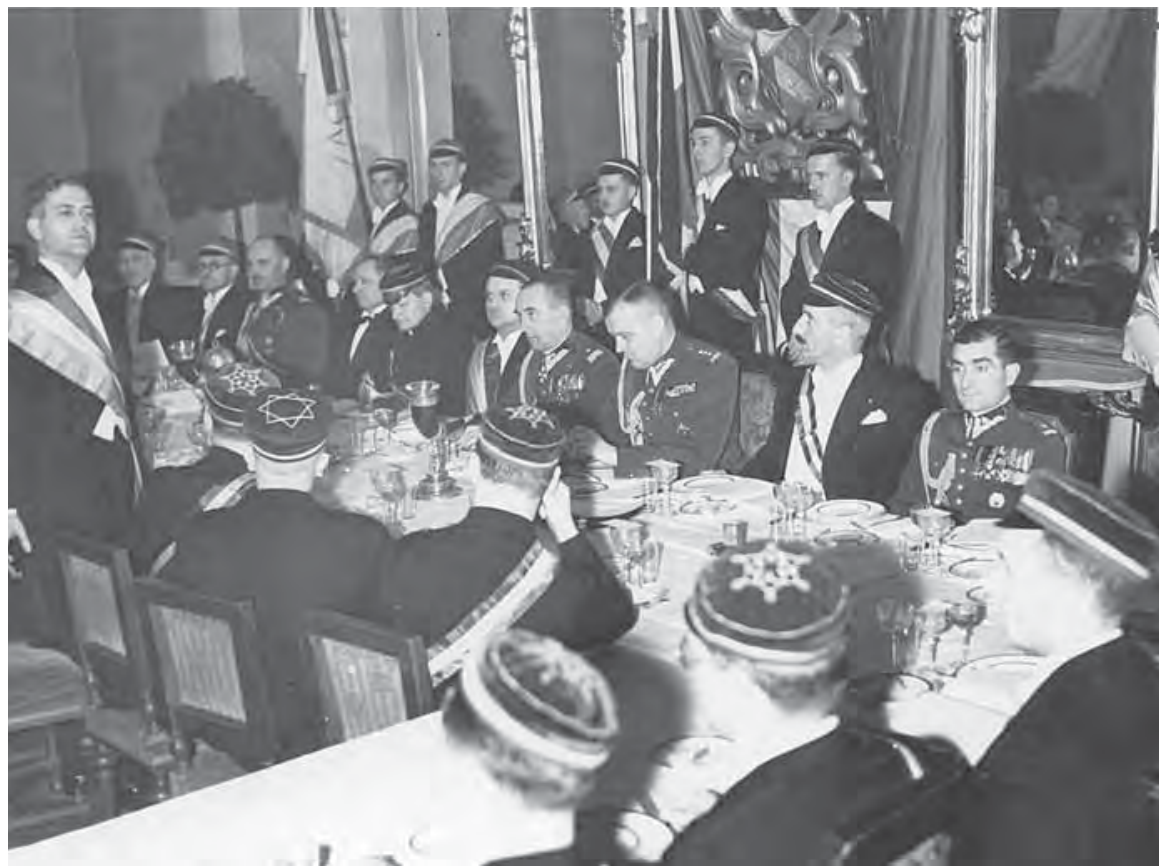

65. Doroczny komers korporacji „Aquillonia” w Warszawie, listopad 1938 r. Wśród siedzących trzeci od lewej gen. Władysław Anders, dalej, ku prawej: prof. Edward Loth, ks. prof. Antoni Szlagowski, prezes korporacji G. Gaczeński, gen. Władysław Bortnowski, płk Leon Strzelecki i prof. Władysław Tatarkiewicz

Nowych adeptów przyjmowano do nich na ogół z rekomendacji już wypróbowanych działaczy; propozycję wstąpienia składano osobom, o których wiedziano, iż mają zbliżone sympatie polityczne, zapewne kierując się także takimi kryteriami, jak aktywność organizacyjna, inteligencja czy dobre pochodzenie. Nie bez znaczenia był także status społeczny, ponieważ w korporacjach dominowała młodzież zamożniejsza, podkreślająca swą wyższość wobec reszty studenckiej braci ${ }^{521}$. Ciekawe świadectwo na temat okoliczności przystąpienia do korporacji pozostawił Jerzy Giedroyc: „Podział na endeków i nieendeków, choć bardzo ważny, nie wykluczał jednak stosunków towarzyskich czy koleżeńskich. Toteż na pierwszym roku studiów, zresztą zupełnie przypadkowo, dzięki kilku kolegom szkolnym, wstąpiłem do korporacji «Patria», która była całkiem endecka: jej pierwszym prezesem czy założycielem był Janusz Rabski. Nie tylko mi to nie przeszkadzało, ale stosunkowo szybko zostałem «barwiarzem», a nawet prezesem korporacji"522. Giedroyc, mający wówczas poglądy konserwatywno-piłsudczykowskie, wystąpił jednak z Patrii, gdy przyjęła deklarację programową Młodzieży Wszechpolskiej, później zaś jako redaktor „Buntu Młodych” znalazł się w ostrym 
konflikcie z prawicą narodową, a nawet przegrał wytoczony mu przez nią proces. W ogólnym rozrachunku to ona sprawowała bowiem rząd dusz w działających na Uniwersytecie korporacjach akademickich ${ }^{523}$.

Zupełnie inny charakter niż korporacje miały koła naukowe, których na rok przed wybuchem wojny działało na Uniwersytecie aż $32^{524}$. „Działalność kół idzie w dwóch kierunkach: ściśle naukowym oraz naukowo-wychowawczym. Koła organizują z jednej strony dyskusje, konferencje i wycieczki naukowe, zakładają biblioteki i sale czytelniane, wydają skrypty i książki, ogłaszają konkursy na prace naukowe, udzielają praktyk itp. Z drugiej koła stawiają sobie za cel wszczepić w swych członków umiłowanie nauki, jak i sztukę zorganizowanego i wydajnego działania" - objaśniał informator dla studentów z $193^{2}$ r. ${ }^{525}$

Do zdecydowanej większości kół naukowych - poza Polonistami, Historykami, Historykami Sztuki oraz Kołem Socjologii Pozytywnej - od przełomu lat 20. i zo. nie przyjmowano Żydów, w związku z czym zmuszeni byli tworzyć swe własne: np. Stowarzyszenie Medyków Żydów czy Koło Prawników Żydów. W sumie w 1938 r. działało 5 żydowskich kół naukowych. Nie wiadomo, jak rzecz miała się w praktyce w przypadku Ukraińców, żadnych przeszkód nie stwarzano natomiast nigdzie Niemcom; jeden z nich, Oskar Kossmann był nawet przez pewien czas przewodniczącym Koła Geografów. Poza tym koła naukowe były przynajmniej w teorii apolityczne, a zatem otwarte dla wszystkich studiujących. Niektóre z nich, jak na przykład koła Etnografów czy Geografów, były niewielkie i stanowiły zarazem dość zwarte grupy towarzyskie ${ }^{526}$. Inne miały charakter masowy, dzieliły się na szereg mniejszych środowisk, a ich działalność obejmowała również sfery samopomocy, wypoczynku itp. Do Koła Medyków, które miało taki właśnie charakter, w roku akademickim 1934/1935 należało 826 osób, co stanowiło $97 \%$ wszystkich studentów Wydziału Lekarskiego wyznań chrześcijańskich $^{527}$. Choć siłą rzeczy w poszczególnych kołach dominowali słuchacze kierunków odpowiadających ich profilowi, zapisywali się do nich niekiedy także studenci innych wydziałów. W ten właśnie sposób z Kołem Polonistów związali się uczęszczający na prawo Ryszard Matuszewski i Jan Kott. Relacja pierwszego z nich ukazuje, że zaważyły o tym nie tylko zainteresowania naukowe: „Któregoś dnia [Kott - P.M.M.] zaproponował mi, abyśmy się zapisali do uniwersyteckiego Koła Polonistów, ponieważ - jak podkreślił - jest to najbardziej lewicowe koło na uniwersytecie. Zgodziłem się od razu, ale na pewno nie tylko dlatego, że nęciła mnie owa «lewicowość». Wyrażała się w tym, zresztą i u Janka chyba też, tęsknota do środowiska, gdzie zajmowano się sprawami, które nas w istocie znacznie bardziej interesowały niż 
wiedza prawnicza". Bezkrytyczny zachwyt większości członków Koła Polonistów nad ZSRR i ich wrogość wobec Polski zniechęciły Matuszewskiego do tego środowiska, Kott natomiast uległ fascynacji komunizmem, która przetrwała powojenne lata stalinizmu i zakończyła się u niego dopiero wraz z fiaskiem popaździernikowej Odwilży w 1956 r. ${ }^{528}$

Podczas gdy Koło Polonistów miało charakter zdecydowanie lewicowy, za bastion prawicy nacjonalistycznej uważane było Koło Prawników $^{529}$. Jak oznajmiał informator dla studentów, pod jej wpływem znajdowała się również zdecydowana większość pozostałych kół, przy czym od połowy lat 30. w co najmniej 5 rządzili oenerowcy ${ }^{530}$. W praktyce zatem zapisana w statutach apolityczność akademickich organizacji naukowych była w dużej mierze fikcją. Nie musiało to koniecznie oznaczać, że należeli do nich wyłącznie zwolennicy dominującej w danym środowisku ideologii. Tak jak wśród Polonistów trafiali się odosobnieni zwolennicy prawicy, tak też na przykład do Koła Prawników mógł należeć słuchacz o poglądach liberalnych lub lewicowych, o ile nie był Żydem lub bezwyznaniowcem i nie karano go sądownie za działalność komunistyczną, gdyż te przypadki wykluczał statut. Nie mógł też, co oczywiste, przyznawać się zbyt głośno do swoich poglądów, gdyż groziłby mu za to ostracyzm towarzyski, podobny do tego, jaki spotkał w Kole Polonistów Alfreda Łaszowskiego, gdy zaczął nagle głosić hasła antysemickie ${ }^{531}$.

Życie towarzyskie studentów nie ograniczało się oczywiście wyłącznie do politykowania, bardzo istotną rolę odgrywały w nim również rozrywki. $\mathrm{Z}$ perspektywy ówczesnego starszego pokolenia bywały one krytykowane jako bezwartościowe, a samą młodzież przedstawiano w związku z tym jako pozbawioną w większości jakichkolwiek ambicji intelektualnych. Ubolewał nad tym w 1939 r. w przemówieniu senackim Kazimierz Bartel i choć opierał się na swych doświadczeniach z Politechniki Lwowskiej, jego zarzuty odnosiły się do całej społeczności studenckiej: „Co się tyczy młodzieży i jej środowisk, to zainteresowania 80\% młodzieży bez względu na płeć idą prawie wyłącznie w kierunku sportu, a następnie aktorek, względnie aktorów filmowych i ich przeżyć. (Wesołość). Znam cały szereg dziewcząt, a także chłopców, których głównym zajęciem intelektualnym jest zbieranie fotosów artystów i artystek, które można nabyć, kupując wyroby czekoladowe pewnych firm w odpowiednich opakowaniach. Na dalszym miejscu idzie zainteresowanie zabawami, w pierwszym rzędzie tanecznymi, lekką literaturą itp. Zainteresowania intelektualne wśród młodzieży są dziś rzadkością i spotkać je można przede wszystkim u Żydów, albo u fizycznie ułomnych, którzy nie mogą uprawiać sportów. (Wesołość)" ${ }^{\prime 532}$. 


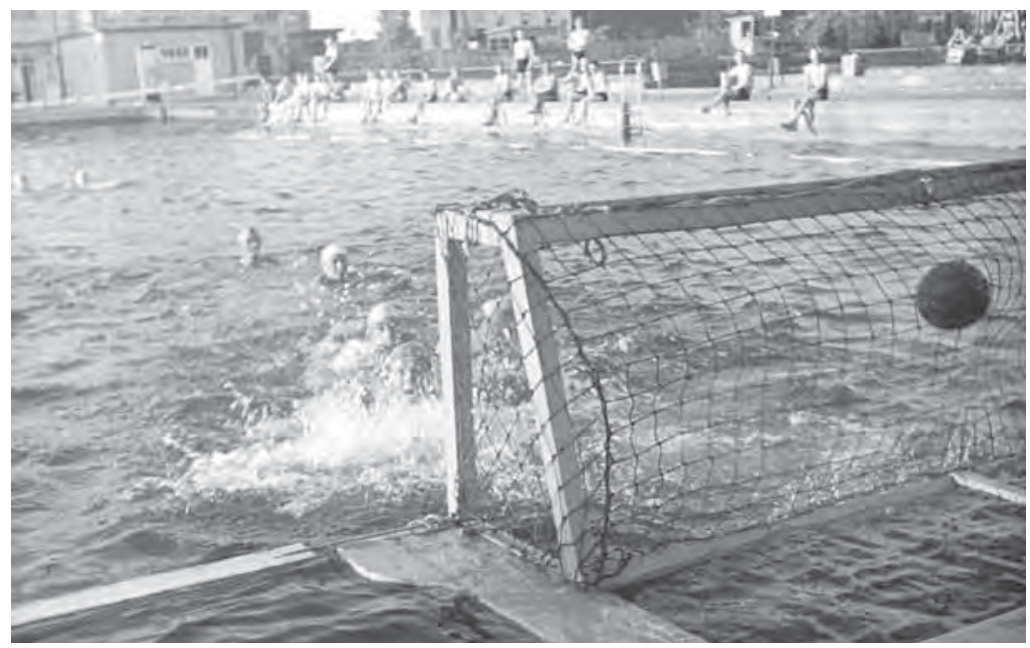

66. Mecz piłki wodnej z udziałem drużyn Akademickiego Związku Sportowego w Warszawie i Klubu Wojskowego Legia, Stadion Wojska Polskiego im. marszałka Józefa Piłsudskiego w Warszawie, 7 VI 1938 r.

W opiniach Bartla było sporo przesady wynikającej z ponadczasowego przekonania osób starszych o mierności młodszych generacji, jednak wspomnienia ówczesnych studentów i inne źródła potwierdzają, iż młodzież rzeczywiście poszukiwała rozrywek uważanych w tamtych czasach za mało rozwijające intelektualnie. Nie natrafiłem wprawdzie na żadną wzmiankę o zbieraniu fotosów aktorek i aktorów, ale biorąc pod uwagę ogromną wówczas popularność filmu (w $193^{8}$ r. w liczącej niecałe 1,2 mln mieszkańców Warszawie sprzedano 14,9 mln biletów kinowych!), można być pewnym, że i wśród studentów cieszył się on dużym zainteresowaniem. Tym bardziej iż przeciętna cena biletu wynosiła około 1 zł, była to więc rozrywka dostępna również dla mniej zamożnych słuchaczy ${ }^{533}$. Dla uczciwości należy dodać, że bardziej wyrobieni kulturalnie studenci chodzili także do teatrów, wybierając zresztą często repertuar ambitny. „Byłem w ciągłych trudnościach finansowych, ale na teatr zawsze wygrzebywałem kilka złotych" - wspomina jeden z nich ${ }^{534}$. Bratnia Pomoc rozprowadzała zresztą wśród słuchaczy UW bezpłatne i ulgowe (w cenie od 50 groszy do 3 zl) bilety teatralne, których w roku akademickim 1931/1932 wydano odpowiednio 2440 i 5861, co stanowić może pewien miernik popularności tej formy rozrywki ${ }^{535}$.

Jest również prawdą, że studenci interesowali się sportem, choć w sposób czynny uprawiało go wciąż bardzo niewielu z nich. Grywano w tenisa, hokeja, a także piłkę nożną, siatkówkę i koszykówkę, uprawiano lekkoatletykę, boks, pływanie, strzelectwo, szermierkę, łyżwiarstwo. Latem organizowano spływy kajakowe, zimą wyjazdy narciarskie i górskie wędrówki po Tatrach i Karpatach Wschodnich. Kulturę fizyczną 


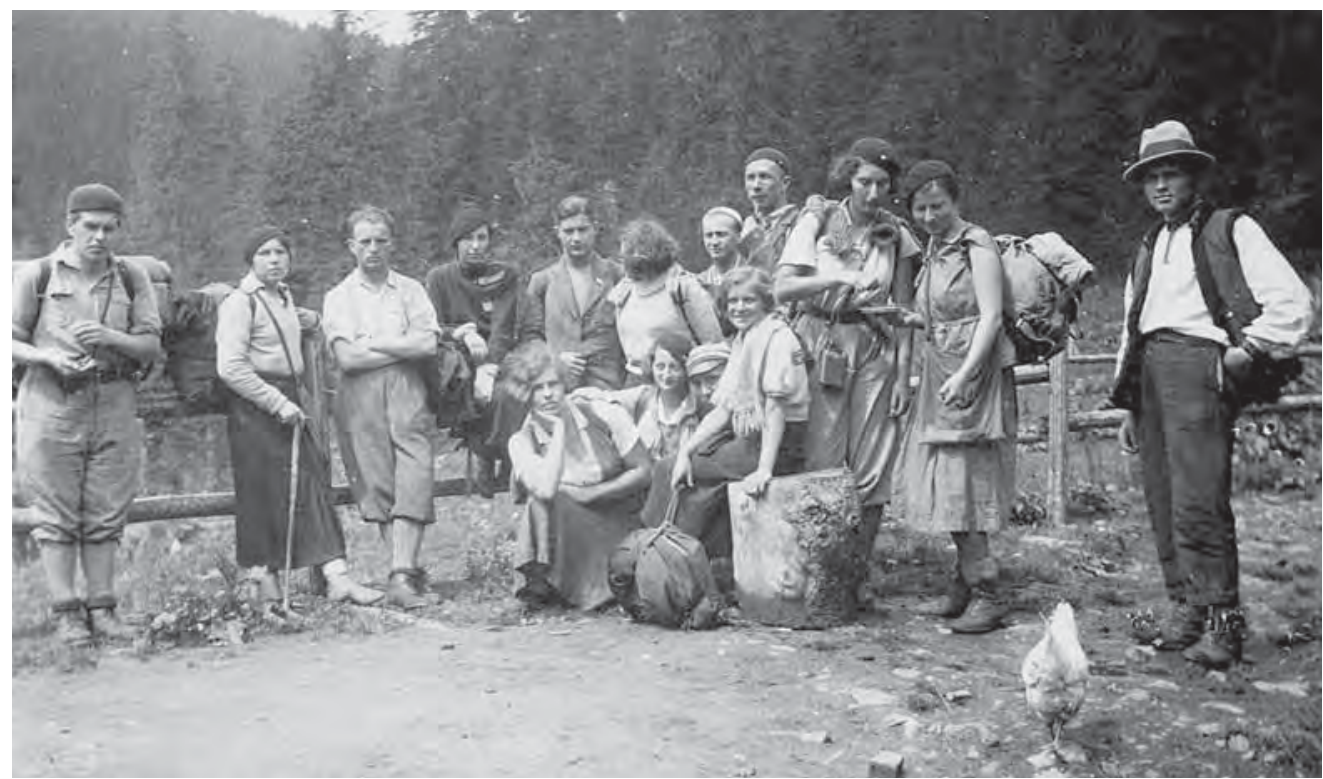

67. Wycieczka Koła Przyrodników UW do Czarnohory i w Gorgany. Przed schroniskiem pod Doboszanką - T. Wiśniewski, W. Sommer, H. Sawicka-Krasnodębska, H. Sandner, P. Meinhardt, 9 VI 1934, r.

propagował Akademicki Związek Sportowy, w ramach którego trenowano większość wymienionych powyżej dyscyplin - na stosunkowo niewielką skalę, za to z myślą o medalach. Sport zawodniczy pozostawał jednak rozrywką elitarną. AZS prowadził wprawdzie także kursy nauki pływania (w roku akademickim 1932/1933 wzięło w nich udział 140 studentów), ale w zestawieniu z blisko 10 tys. słuchaczy Uniwersytetu była to wciąż garstka zapaleńców ${ }^{536}$.

Popularyzacją sportu amatorskiego jako formy aktywnego wypoczynku zajmowały się również organizacje studenckie, takie jak Sekcja Wychowania Fizycznego przy Kole Medyków. W połowie lat zo. na organizowane przez nią nadmorskie obozy wypoczynkowo-sportowe w Cetniewie wyjeżdżało latem blisko 500 osób, na letnich obozach w podzakopiańskim Kościelisku wypoczywało 173 studentów, zimą w kursach narciarskich w Tatrach i Bieszczadach uczestniczyło ich w sumie 327; frekwencja na warszawskich kortach tenisowych Koła w latach $19^{2} 5^{-193^{2}}$ wahała się od 9oo do 14,20 osób rocznie ${ }^{537}$. Nie były to liczby małe, biorąc pod uwagę, że w tym czasie na medycynie studiowało nieco ponad 1100 osób.

Trzecia z wymienionych wcześniej rozrywek - szeroko rozumiane życie towarzyskie - w relacjach pamiętnikarskich jawi się jako rozrywka 
wśród studentów najpopularniejsza. Bawiono się na różne sposoby i w różnym gronie. Słuchacze Uniwersytetu chętnie przesiadywali w kawiarniach, tocząc tam dyskusje o polityce, sztuce i zapewne wielu innych sprawach, których po latach, gdy spisywali wspomnienia, już nie potrafili sobie przypomnieć. Z czasów swoich studiów na Uniwersytecie, które przypadły na lata I wojny światowej, późniejszy polityk sanacyjny Tadeusz Katelbach zapamiętał: „Około 11 w nocy szło się do Udziałowej na pół czarnej lub rzadziej do sąsiadującego z Udziałową Cristalu, aby wymienić sobie wojenno-polityczne ploteczki dnia i posłuchać muzyczki, która wygrywała repertuar pieśni legionowych i popularnych operetek, zwłaszcza modną w tym czasie «Czardaszkę»"538. Podobnie było w czasach pokoju, co z kolei odnotował Jan Śpiewak, wspominając spotkania w gronie literacko-artystycznej bohemy, w kręgu której się obracał: „Można było nie dojadać, ale wieczorem - musieliśmy być w «Ziemiańskiej». Ciągnęła nas tam atmosfera towarzyskich dyskusji, nieraz ostrych sprzeczek, a przeważnie szermierki słownej"539.

Z pewnością nie stroniono od alkoholu. „Abstynentów nie znałem” wspomina jeden ze studentów prawa, dodając do razu - ,Z tym jednak zastrzeżeniem, że upijanie się po prostu i natychmiast eliminowało studenta z pewnych kręgów towarzyskich, koleżeńskich, organizacyjnych. W każdym razie litrówkami się wódki nie piło" ${ }^{540}$. Zwłaszcza w męskim gronie, charakterystycznym przede wszystkim dla korporacji, za kołnierz wszakże nie wylewano. Jerzy Giedroyc, porównując studentów

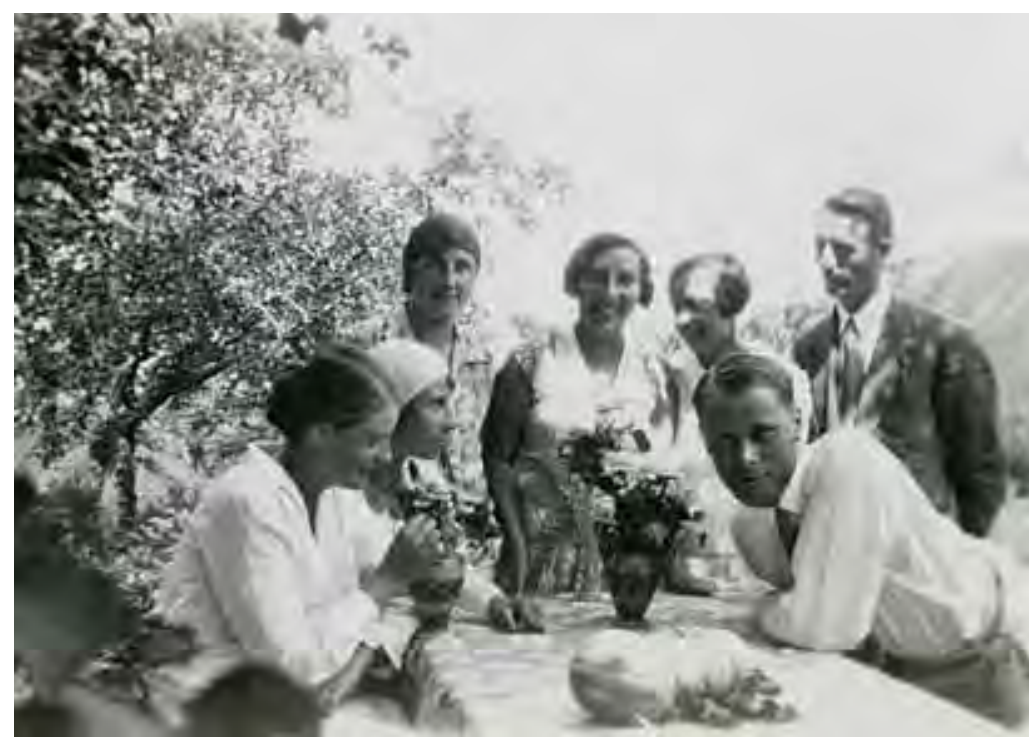

68. Uczestnicy seminarium historycznego prof. Marcelego Handelsmana podczas pobytu wakacyjnego w Zaleszczykach. Po prawej, oparty o stół, doc. Tadeusz Manteuffel, 1929 r. 
polskich z łotewskimi, których kiedyś spotkał, doszedł wprawdzie do wniosku, że „w życiu korporacyjnym [na Uniwersytecie - P.M.M.] nie konsumowano dużo alkoholu", ale ocena ta była prawdopodobnie dość względna. Wojciech Wasiutyński był bardziej samokrytyczny: „W pierwszych latach studiów, zanim wchłonęła mnie bez reszty polityka, piłem za dużo. Spotykaliśmy się prawie co dzień w południe przed Bratniakiem na uniwersytecie i szli prawie zawsze do baru. Każdego tygodnia była albo kwatera piwna albo czyjeś imieniny. $\mathrm{Na}$ imieninach grało się w karty (niewysoko). Ja wolałem pokera od brydża" ${ }^{341}$. Niektóre wydarzenia, jak na przykład świętowanie ukończenia studiów, stawały się okazją do ostrych libacji. Ich obraz dają barwne wpisy studentów do albumu Koła Medyków, które in extenso zamieścił w swych wspomnieniach Stefan Wesołowski: „[...] Muszę stwierdzić, że to setne kompany: szpagatówkę chleją jak wodę, serdele wcinają aż miło, aż za serce chwyta. [...] Ojej! Pijatyka ku czci magistra prawa Świecińskiego dnia 7/XII 32 , jeszcze nie czułem się taki wlany, jak dziś. Holender jasny, ledwo trzymam się na nogach! [...] Wlani wszyscy jak «najęci»: Kol. Świeciński z majestatycznym uśmiechem opowiada kawały z dziedziny prawa. Stefan z rozwichrzoną czupryną zalany od stóp do głowy z wykrzywioną pod wpływem alkoholu gębą recytuje i wygłasza tzw. dobre mowy alkoholowe. [...] Kazik obejmuje i wtula się w piersi przybyłego Teodora w przekonaniu, że to ciocia jego «żony»" ${ }^{\text {"542 }}$. Upić się do nieprzytomności i dosłownie leżeć w rynsztoku zdarzało się nawet studentom wybitnie uzdolnionym, pochodzącym z dobrych, mieszczańskich domów ${ }^{543}$.

Charakterystycznym rysem ówczesnego życia studenckiego były jednak przede wszystkim różnego rodzaju imprezy zorganizowane. Koło Prawników prowadziło co wtorek spotkania towarzyskie, ,gdzie przy muzyce, za niewielką opłatą można było potańczyć, zagrać w brydża, zjeść kanapkę lub ciastko, wypić kawę lub herbatę". W okresie karnawału w oficerskim kasynie garnizonowym przy al. Szucha odbywał się natomiast bal młodych prawników, na który zapraszano profesorów wraz z małżonkami ${ }^{544}$. Potańcówki organizowali także Poloniści, wynajmując w tym celu lokal - stosownie do swego profilu ideowego - w bardziej proletariackim otoczeniu, zapewnianym przez budynek Związku Kolejarzy przy ul. Czerwonego Krzyża na Powiślu. Jak wspomina Matuszewski, czołowi intelektualiści, tacy jak np. Stefan Żółkiewski, „przychodzili wprawdzie na owe niepoważne harce, ale woleli czas ich wykorzystać na kontynuowanie debat [...], jako że na reformowanie świata czy też tylko nauk humanistycznych czasu nigdy nie było dość. Nie wszyscy jednak polonistyczni głowacze byli tak 
jednostronni. Byli tacy, co czasem ochoczo puszczali się w tany, jak Sewer Pollak, którego wprawdzie kontrolowała z loży, wodząc za nim surowym wzrokiem, jego chuda czarna żona Wanda Grodzieńska, ale widać było, że tego raczej łagodnego intelektualistę wyraźnie znosi w stronę co ładniejszych koleżanek" ${ }^{\prime 45}$.

Prawdziwym przedsiębiorstwem rozrywkowym była Sekcja Towarzyska Koła Medyków, do której pod koniec lat 20. należało 55 osób. Podobnie jak prawnicy prowadziła ona raz w tygodniu, w niedziele w godzinach od 16 do 22, świetlicę, w której spotykano się, aby pograć w szachy lub warcaby, potańczyć lub po prostu porozmawiać. Na przełomie lat 20. i zo. korzystało z niej od kilkudziesięciu do nawet zoo studentów, co świadczy o dużej intensywności toczącego się w jej ścianach życia towarzyskiego. Przede wszystkim jednak Koło Medyków słynęło z organizowanego w karnawale balu, który należał do największych imprez towarzyskich stolicy. Ogromną popularnością cieszyły się także Szopki Medyków, wzorowane na występach warszawskich kabaretów Morskie Oko i Qui Pro Quo. Za pomocą kukiełek parodiowano w nich profesorów Uniwersytetu oraz znane osobistości z życia publicznego kraju, czemu towarzyszyły humorystyczne kuplety. Zachęceni popularnością szopek studenci Wydziału Lekarskiego poszerzyli z czasem swą ofertę o kolejne imprezy, takie jak Śledź Medyków, opłatek i choinka, fuksówka, święcone, Józefinki i Rewia Medyczna ${ }^{546}$.

Program artystyczny tych imprez nie był chyba zbyt wysokich lotów. Wacław Borowy skomentował jedną z nich w swym dzienniku: „Widowisko nędzne nad wyraz. Lichy jeden wyjec przyśpiewuje banalnym laleczkom mizerne piosenki, przeplatając je grobowo smętnem w niedowcipności gadaniem"547. Podobały się jednak studenterii i nadawały jej życiu towarzyskiemu szczególny koloryt. Oddaje go wpis z ówczesnej kroniki na temat balu kostiumowego z okazji Choinki w 1933 r., który przytacza Stefan Wesołowski, główny animator Sekcji Towarzyskiej Koła Medyków: „Zjawiła się na sali cała galeria cudacznie wystrojonych «typów» $\mathrm{i}$ «typków», które chlubnie wystawiały na pokaz stroje z «Polskiego» i z różnych innych instytucji [...]. Zjawił się więc cały korowód odalisek, heter, gejsz, paziów, Żydów, szlachciców, Rzymian itp., którzy budzili szczery zachwyt i odurzenie wśród białogłów i czerni (czytaj krepa fraków i smokingów). Niemałą atrakcję stanowiły następujące postaci: Żyd, Neron i Frankenstein. [...] Żyda «odstawiał» [...] p. S. WES [Wesołowski - P.M.M.]. Figura to niezbyt imponująca pod względem wyglądu zewnętrznego, tym niemniej imponowała wszystkim robieniem niesłychanego rumoru i ilością wypitego miodu. [...] Neron, prócz $200 \mathrm{~kg}$ żywej wagi, miał jeszcze tę zaletę, że absolutnie nie posługiwał 
się łaciną [...]". Repertuar musiał nosić pewne podteksty antysemickie, skoro Wesołowski odnotował aplauz prasy prawicowej i niesmak żydowskiego „Naszego Przeglądu” („Szowinistyczne zapędy młodych żydożerców...”), uczestnikom zabawy to jednak najwyraźniej nie przeszkadzało ${ }^{548}$.

Przygotowane przez siebie przedstawienia medycy wystawiali również gościnnie w zaprzyjaźnionych instytucjach stołecznych, takich jak Towarzystwo Higieniczne czy Centralny Instytut Wychowania Fizycznego, a także jeździli z nimi w po kraju, występując w szpitalach, sanatoriach, domach zdrojowych itp. Ponieważ wstęp na imprezy był płatny, tak intensywna działalność rozrywkowa zapewniała regularne, choć bardzo nierówne dochody. Tournée po Polsce w lipcu 1933 r. przyniosło $234,0 \mathrm{z}$, dochody z Balu Medyków w latach 1925-1931 wahały się od 2800 do blisko 9000 zł (w zależności od aktualnej koniunktury gospodarczej); w roku akademickim 1929/1930 czysty zysk Sekcji Towarzyskiej zamknął się niebagatelną kwotą 6070 zl. Środki te gromadzono przede wszystkim z przeznaczeniem na budowany wówczas Dom Medyka, który został oddany do użytku w 1936 r. Częściowo służyły też one prawdopodobnie dofinansowaniu wyjazdów turystycznych i wycieczek naukowych koła ${ }^{549}$.

Zarówno przytaczane powyżej relacje, jak i innych świadectwa dokumentują, iż jedną z najbardziej lubianych rozrywek studenckich były w latach międzywojennych imprezy taneczne. „Eleganckie bale korporacyjne miały bardzo starannie przygotowywanego mazura, naturalnie tańczono też kujawiaka i oczywiście inne tańce współczesne, trochę polki i oberka, no i walca figurowego, z wodzirejem" - wspomina z wyraźną nostalgią jeden z ówczesnych słuchaczy Uniwersytetu. „Szczególną reputacją cieszyły się bale korporacji Arkonia, najstarszej w Warszawie, w Resursie Obywatelskiej, korporacji Jagiellonia w Resursie Kupieckiej, bal towarzystwa Latarni (opieki nad niewidomymi), gdzie «cała Warszawa» spotykała się w Hotelu Europejskim" ${ }^{550}$. W stwierdzeniu „cała Warszawa” nie ma wiele przesady. $\mathrm{Na}$ jednym z takich balów studiującemu wówczas historię Januszowi Pajewskiemu zdarzyło się, iż jego partnerkę poprosił do tańca były prezydent Stanisław Wojciechowski ${ }^{551}$. Niektórzy studenci oddawali się balowaniu z taką intensywnością, że zwłaszcza w okresie karnawału nie pozostawało im już zbyt wiele siły na naukę. Jedna ze studentek wspomina, iż opuszczała tyle zajęć, że któregoś razu asystentka profesora przysłała po nią rano do domu kolegę z ostrzeżeniem przed kolejną nieobecnością, która poskutkuje brakiem zaliczenia; w efekcie na wykład musiała popędzić w sukni balowej i pantofelkach, maskując swój nietypowy strój starym fartuchem ${ }^{552}$. 
Jak już zostało wspomniane, na bale zapraszano profesorów. Niektórzy z nich chętnie przyjmowali zaproszenia, gdyż odpowiadała im taka forma rozrywki. „Już gdy wchodziłem, otaczała mnie młodzież. [...] Wiedzieli, że lubię tańczyć, i dbali o to, bym nigdy nie był sam" - zapamiętał Ludwik Hirszfeld ${ }^{553}$. Inni, jeśli nawet uważali udział w balach za jeszcze jeden obowiązek reprezentacyjny, nie uchylali się od niego. „W uroczystym polonezie otwierał bal, w pierwszej parze, Magnificencja Rektor Uniwersytetu z panią generałową, żoną Komendanta Centrum Wyszkolenia Sanitarnego. W drugiej parze gen. bryg. dr med. Jan Kołłątaj-Srzednicki z panią rektorową, a za nimi inni dostojni goście z żonami - profesorowie, generałowie i wyżsi oficerowie $[\ldots]^{\prime \prime 554}$.

Bawiono się nie tylko na balach. W latach 3o. popularne stały się wśród studentów potańcówki w prywatnych mieszkaniach, głównie w środowisku zamożniejszej, inteligenckiej młodzieży pochodzącej z Warszawy. (Lokatorom stancji trudno byłoby urządzić tańce w wynajmowanym pokoju, podobnie jak studentowi z rodziny robotniczej, zamieszkującemu z bliskimi w wieloosobowej izbie, często bez elementarnych wygód). Wieczory taneczne organizowali zwykle rodzice dorastających i dorosłych panien, w czym nietrudno dopatrzyć się lepiej lub gorzej skrywanych intencji matrymonialnych. $\mathrm{Z}$ tego też względu dbano, aby młodzieży męskiej było więcej niż dziewcząt ${ }^{555}$. Na prywatnych potańcówkach, nie nazywanych jeszcze wówczas prywatkami, obowiązywał znacznie lżejszy i bardziej nowoczesny repertuar niż na balach. Przy dźwiękach gramofonu tańczono fokstrota, slow-foksa, charlestona, walce angielskie i tanga. Zabawa odbywała się zazwyczaj pod czujnym okiem rodziców, brały w niej wszak udział „dobrze ułożone panienki z dobrych domów", jak określił to Ryszard Matuszewski, jeden z uczestników takich spotkańn ${ }^{556}$. W małych środowiskach, jakie stanowili np. archeolodzy lub geografowie, również na takie imprezy zapraszano niekiedy wykładowców ${ }^{557}$.

Nie zawsze zapewne owe potańcówki miały grzeczny charakter, zwłaszcza jeśli „element rodzicielski, ciotczny itd. w ogóle był wyeliminowany". Na krótko przed wojną mogło się już tak zdarzyć nawet w wyższych klasach gimnazjalnych, a więc z pewnością również wśród studentów. Gombrowicz, który brał udział w jednej z takich imprez, z rozbawieniem opisuje jej przebieg:

„Z początku było nudnawo, nieśmiaławo, jakieś tam pogaduszki, rzadkie śmiechy, już kombinowałem jak by tu prysnąć... gdy wtem otworzyły się drzwi do sąsiedniego pokoju w którym bufet był i wszyscy powoli skupili się wokół stołu, na którym stały alkohole. Z tego 
co nastąpiło pozostało mi wrażenie ostrego crescenda, gwałtownie wzrastającego brzęczenia... do rozmiarów szumu... ta młodzież rzuciła się na wódkę, w ciągu pięciu minut byliśmy pod gazem, nigdy nie widziałem żeby tyle osób upiło się razem, od razu, jakby na komendę... ja oczywiście też, i potem już dobrze nie pamiętam co się działo, zdaje mi się że jeździłem na motocyklu i wyłaziłem na drzewo" "558.

Studenci wybierali się również na dancingi do nocnych lokali, czego barwny obraz utrwalił Matuszewski: „Ciągnęło nas bowiem oczywiście nocne życie stolicy, choć nie bardzo było nas na nie stać; nocne warszawskie dancingi były drogie. Ale mieliśmy na to typowe, studenckie sposoby. Pamiętam kilka wypraw do modnej «Adrii» przy ul. Moniuszki. Wstęp do tego lokalu, gdzie bywali na ogół ludzie dobrze nadziani forsą, a także ówcześni dygnitarze, był bezpłatny. Płaciło się słono za konsumpcję. [...] Ale któżby studentowi takiemu jak ja, który przychodził do «Adrii» z panienką, żeby pokręcić się po parkiecie w takt dobrej muzyki jazzowej, kazał zajmować miejsce przy stoliku lub cisnąć się do baru? Oddawało się palta do szatni i szło się tańczyć, a kiedy orkiestra robiła przerwę, był w sąsiedniej salce drugi, mniejszy parkiet. W ten sposób udawało nam się, jeżeli mieliliśmy na to ochotę, przetańczyć w eleganckim lokalu nawet kilka godzin. Przytuleni do siebie, rozmarzeni muzyką, wirowaliśmy wśród wyfraczonych gorsów i pań w wytwornych toaletach, by nad ranem wymknąć się z lokalu nie wydawszy nic poza drobnymi na szatnię" 559 .

Popularność wśród studentów tańca jako rozrywki towarzyskiej w niepośledniej mierze wynikała z faktu, iż bale, potańcówki czy wyjścia do lokali rozrywkowych stanowiły najbardziej naturalną i akceptowaną społecznie sposobność nawiązania bliższych kontaktów z płcią odmienną - przynajmniej w środowisku inteligenckim, które nadawało ton na Uniwersytecie. Relacje te, wpisujące się ściśle w panoramę ówczesnego życia społecznego, towarzyskiego i obyczajowego, wymagają nieco bliższego omówienia.

Jakkolwiek stosunki damsko-męskie są przedstawiane we wspomnieniach ówczesnych słuchaczy Uniwersytetu na ogół dość dyskretnie, nie oznacza to, iż zajmowały one $\mathrm{w}$ ich życiu miejsce nieistotne. Studia, w trakcie których mężczyźni i kobiety spędzali ze sobą stosunkowo dużo czasu, sprzyjały nawiązywaniu znajomości, także tych bliższych, intymnych. „Tak systematycznie uczęszczaliśmy na te wykłady, siadając zawsze na tej samej ławce, że w końcu zaczęliśmy traktować się jak starzy znajomi" - pisze Władysław Broniewski o jednej z poznanych na Uniwersytecie koleżanek. - „Jakiś maleńki rodzaj flirtu, nie traktowany jednak jako taki ani przeze mnie, ani przez nią?500. 
Choć niewielu ówczesnych studentów przyznaje to wprost, w cenie u obojga płci była atrakcyjność fizyczna. Studiująca w drugiej połowie lat 20. na Wydziale Humanistycznym Janina Rosenówna z właściwą wielu kobietom złośliwością tak opisywała swe otoczenie: ,[...] Rodzaj męski na archeologii przedstawiał się rozpaczliwie. Nic tylko siąść i płakać - «Tylko na Politechnice są chłopcy do rzeczy» - wzdychałam smętnie - ale na Politechnice jest mnóstwo matematyki, więc to nie dla mnie i tak daleko do niej. Lecz sprawiedliwie trzeba przyznać, że i uczęszczające [na archeologię - P.M.M.] dziewczęta i te zamężne też urodą nie grzeszyły. Może studia ówczesne stanowiły rekompensatę za te braki" ${ }^{561}$. Z kilku innych równie szczerych pod tym względem wspomnień wynika, iż studenci jednej i drugiej płci chętnie wchodzili w mniej lub bardziej trwałe relacje o charakterze uczuciowym.

„Muszę sobie znaleźć towarzyszkę. Ona mi uprzyjemni trochę życie. Chociażby się mi podobała tylko tydzień, to i to warto. Znajdę potem drugą, o ile mi się tamta sprzykrzy" - zapisał w swym dzienniku z rozbrajającą szczerością student medycyny Pesach Rajman, pomiędzy marzeniami o żydowskim państwie w Palestynie a rozważaniami o sytuacji na frontach trwającej już wówczas piąty rok Wielkiej Wojny. Zamiar ten udało mu się urzeczywistnić kilka tygodni później, kiedy zapoznał się z niejaką panną Bronką, niebędącą raczej słuchaczką UW. Chociaż podczas spaceru nad Wisłą niemiłosiernie zanudzał swą wybrankę opowieściami o okrętach podwodnych, zdołał ją nawet, jak skrupulatnie odnotował, dwa razy pocałować, nie bez pewnych oporów z jej strony, ponieważ, „jak koza uciekała mu spod rąk”. Dalsze perspektywy tej obiecującej znajomości były jednak wątpliwe, gdyż mało praktyczny Rajman na następną randkę umówił się dopiero na 1 maja, tzn. za przeszło 8 miesięcy, „w dniu miłości, w dniu święta międzynarodowego, gdy wszyscy proletariusze świata marzą o zbawieniu narodów"562.

Mniej więcej w tym samym czasie, na początku lat 20., o względy studiującej na Wydziale Filozoficznym Ireny Goldberżanki (później Krzywickiej) niestrudzenie zabiegało aż 3 kolegów, spośród których dopiero po dłuższym czasie wybrała późniejszego męża, jak sama przyznaje, bez wielkiej miłości ze swej strony. Do tego dochodziło kilku odleglejszych lub bardziej przelotnych adoratorów, z których jeden, student prawa, zostałby dziś niewątpliwie uznany za prześladującego swą ofiarę stalkera. „Chodził za mną jak cień na uniwersytet, z uniwersytetu po sprawunki, raz nawet polazł za mną na jakiś pogrzeb. Nigdy nie podszedł ani nie powiedział słowa" - pisze Krzywicka. Drugi adorator zachowywał się podobnie, trzeci zaproponował jej małżeństwo już po pierwszym walcu przetańczonym na jednej z „herbatek” i nie chciał 


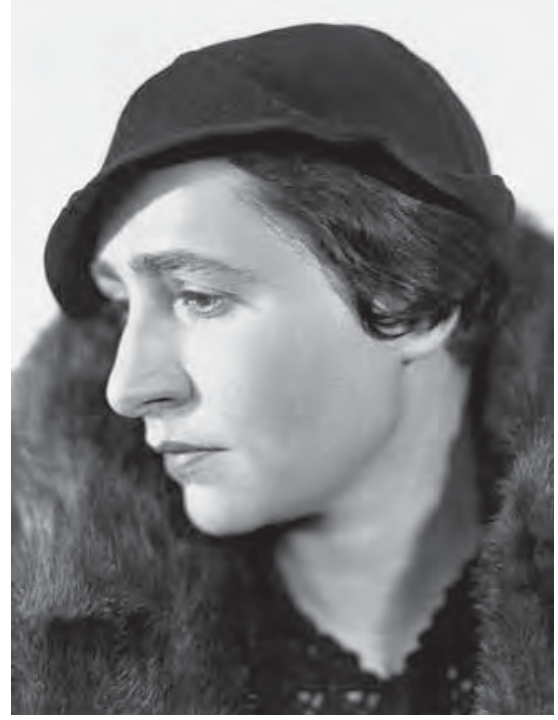

69. Irena Krzywicka, lata 20. XX w. pogodzić się z odmową; czwarty uczynił ten sam krok, a gdy dziewczyna oświadczyła mu, iż jest Żydówką, wykrzyknął: „To niemożliwe, niemożliwe" i uciek ${ }^{563}$.

Typ cichego, choć natrętnego wielbiciela musiał występować dość często wśród studentów, przynajmniej w pierwszych latach po reaktywacji Uniwersytetu, ponieważ także studiująca wtedy Maria Eigerówna wspomina chłopaka, który długo się kręcił wokół niej, a gdy zaczęła go wreszcie unikać, zasypywał ją tasiemcowymi listami ${ }^{564}$. Nawet Broniewski, skądinąd bardzo daleki od hołdowania miłości platonicznej, wkrótce po zapisaniu się na uczelnię jesienią 1918 r. zakochał się w zupełnie nieznanej sobie dziewczynie, co opisywał nader samokrytycznie w pamiętniku: „Jakże ja sam sobie wydaję się śmiesznym, gdy łażąc bez celu, bezwiednie skręcam tam, gdzie ona mieszka. [...] Kocham kobietę, której nie znam i nie wiem nawet, jak się nazywa, którą zaledwie kilka razy widziałem przelotnie na ulicy. Kiedyś wiosną śledziłem ją spotkawszy wieczorem na Daniłłowiczowskiej; szła z bratem do teatru. Poszedłem za nimi. Wyśledziłem, gdzie siedzi, i wszystkie antrakty spędziłem na niemym wpatrywaniu się na nią. [...] Po przedstawieniu tropiłem ją aż do jej mieszkania na Hożej 66"565.

Zachowania takie miały zapewne różne źródła. Jedni studenci, tak jak Broniewski, tworzyli w ten sposób na własny użytek mit miłości romantycznej, fizycznej zaś szukali w innych miejscach; inni po prostu nie potrafili przezwyciężyć wrodzonej nieśmiałości. W przypadku jeszcze innych młodych ludzi wynikały one - tak samo chyba zresztą jak oświadczyny po pierwszym tańcu czy niezgrabne zaloty Rajmana - z braku odpowiedniego obycia w kontaktach towarzyskich z płcią przeciwną, który doskwierał wielu absolwentom męskich szkół średnich. Jak się jednak wydaje, wraz z przemianami obyczajowymi i rozpowszechnianiem się w międzywojennej Polsce szkół koedukacyjnych zahamowania tego rodzaju stawały się zjawiskiem rzadszym, a relacje pomiędzy młodymi mężczyznami a kobietami wyzwolone zostały z nienaturalnych konwenansów, „odpadły całe tony afektacji, przesad, zmanierowania, tej jakiejś konwulsyjności, jaka cechowała starsze pokolenie" ${ }^{566}$. I w latach 30. zdarzały się jednak wśród studentów Uniwersytetu samobójstwa i zabójstwa z miłości, o czym jak zawsze chętnie informowała prasa ${ }^{567}$. 
Wspomnienia studentów płci męskiej z lat zo. ukazują już nieco bardziej bezpośredni model relacji damsko-męskich, choć też daleki jeszcze od standardów współczesnych. Matuszewski, który jako jeden z nielicznych porusza tę kwestię w miarę otwarcie, pisze: „Interesowały mnie już oczywiście dziewczyny i tajemniczy świat seksu, choć słowo to nie było jeszcze wtedy w użyciu i w ogóle sprawa granicy pomiędzy strefą miłosnych uczuć a strefą zmysłów nie przedstawiała się jasno, budziła pewien niepokój i rodziła problemy, których nie dawało się rozstrzygnąć ani przy pomocy wskazań kościoła czy rad matczynych, ani przy pomocy literatury, ani nawet drogą własnego doświadczenia, które było jednak tylko splotem przypadków. Były to więc niekiedy przyjaźnie z domieszką flirtu czy erotycznych zbliżeń, ale nie mniej często sprowadzające się do zwykłego koleżeństwa, miłych kontaktów towarzyskich, uczestnictwa w studenckich zebraniach czy potańcówkach". Dalej następuje charakterystyka 3 dziewczyn, z którymi autor spotykał się w czasie studiów. Z jego niedopowiedzeń i zawoalowanych sugestii wynikać może, iż żadna z tych znajomości nie przerodziła się $\mathrm{w}$ relację erotyczną, gdyż wszystkie trzy panienki, pochodzące $\mathrm{z}$ tzw. dobrych domów, bacznie pilnowały się, aby nie naruszyć obowiązujących wówczas zasad ${ }^{568}$.

Normy obyczajowe były zaś bardzo restrykcyjne, przynajmniej w środowiskach mieszczańskich i inteligenckich, z których wywodzili się w zdecydowanej większości autorzy dostępnych nam relacji. Młodzi ludzie, nawet od dawna sobie znajomi, zwracali się do siebie na ogól per „pani”, „pan”. (Maria Niedźwiecka i Stanisław Ossowski form tych używali wobec siebie po kilku latach wspólnie spędzonych studiów. $\mathrm{Na}$ „ty" przechodzili bardzo powoli i nieśmiało dopiero w intymnej korespondencji, gdy byli już właściwie parą) ${ }^{569}$. Na początku lat 20. nie uchodziło, aby panna odwiedzała mężczyznę spoza swej rodziny w jego domu. Dekadę później student mógł już zabrać swoją dziewczynę na wspólny wyjazd na kajaki lub w Tatry, ale w charakterze przyzwoitek musieli im towarzyszyć koledzy lub koleżanki. Nie mogło być przy tym oczywiście mowy o spaniu razem w namiocie czy jednym pokoju, mimo iż obydwoje zainteresowani byli już pełnoletni ${ }^{570}$. Brak odpowiednich źródeł nie pozwala niestety powiedzieć, czy podobne zasady obowiązywały wśród studentów wywodzących się z niższych warstw społecznych, ale wydaje się to prawdopodobne, ponieważ wstępując na uczelnię ich przedstawiciele przejmowali na ogól wzorce obowiązujące wśród inteligencji.

Rygorystyczne normy obyczajowe nie oznaczały bynajmniej, iż w każdym wypadku ich przestrzegano. $Z$ przytaczanych już przeze mnie 


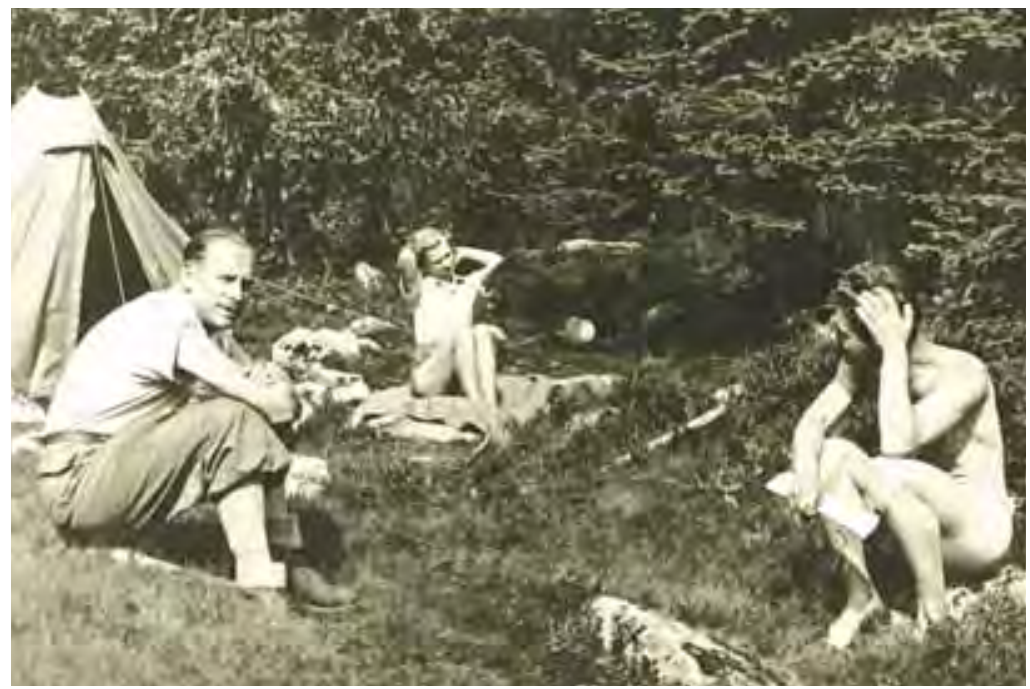

70. Młodzi

pracownicy

naukowi Wydziału

Matematyczno-

-Przyrodniczego

na biwaku na Hali

Gąsienicowej

w Tatrach.

Od lewej: H. Sandner,

T. Sandner,

M. Gieysztor,

lipiec $1937 \mathrm{r}$.

wcześniej w innym kontekście relacji pamiętamy, że w domach akademickich, mimo surowych zakazów, nagminnie nocowały osoby płci przeciwnej, jedną z rozrywek korporantów były wypady na „dziewczynki", mieszkanki żeńskich akademików chorowały podobno na syfilis, a jedna ze studentek dorabiała sobie jako luksusowa prostytutka. O podejmowaniu przez młodzież współ̇̇ycia seksualnego świadczą także wyniki obowiązkowych badań lekarskich słuchaczy Uniwersytetu z końca lat 3o. O ile w 1937 r. chorobę weneryczną wykryto tylko u jednego kandydata na studia, o tyle wśród osób już immatrykulowanych wstydliwe przypadłości były na tyle częste, że zwalczanie ich uznano za drugi, po walce z gruźlicą, zasadniczy kierunek działań przychodni akademickiej ${ }^{571}$. Według danych wcześniejszych o kilka lat (z jesieni 1929 r.), wykryto je lub podejrzewano u około $3 \%$ wszystkich mieszkańców domów studenckich. Wskaźnik ten jest zaskakująco niski, być może dlatego, iż nie wszyscy lokatorzy poddali się badaniom $^{572}$. Jak można sądzić, zapadanie na choroby weneryczne wynikało przede wszystkim z korzystania przez studentów z usług prostytutek (tak zapewne należy rozumieć owe „dziewczynki”).

Wzmianki o przykładnym prowadzeniu się „dobrze ułożonych panienek z dobrych domów" każą natomiast przypuszczać, że studentki na ogół znacznie ostrożniej niż ich koledzy decydowały się na kontakty seksualne. Regułę tę potwierdzają pojedyncze wyjątki, znane ze wspomnień. Jednym z nich była Irena Goldberżanka, która zaplanowała sobie, iż dziewictwo utraci ze spotkanym w Zakopanem profesorem 


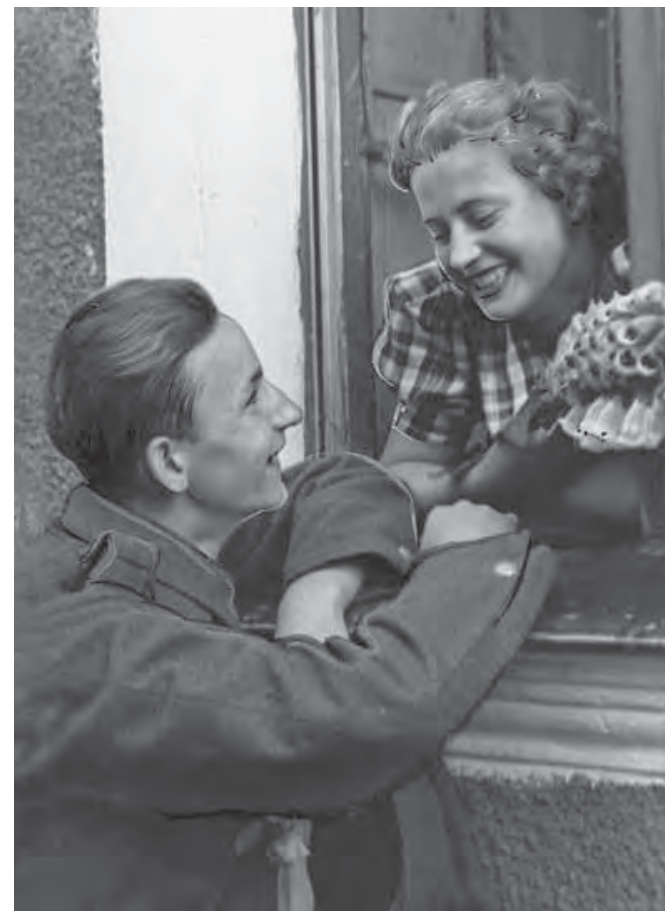

71. Student Legii Akademickiej z dziewczyną, sierpień $1938 \mathrm{r}$.
Gustawem Przychockim (urzekł ją klasyczny kształt jego czaszki), było w tym jednak chyba więcej młodzieńczych fantazji erotycznych niż autentycznej swobody seksualnej. Plan spalił zresztą na panewce, ponieważ wybranek, nie mając najmniejszego pojęcia o jej zamiarach, nie wykazał się odpowiednią inicjatywą. Spotkanie w kawiarni z obcym, starszym mężczyzną wystarczyło jednak, aby zaczęto plotkować o niej i o Przychockim, iż są kochankami ${ }^{573}$. Za to studiująca na Wydziale Lekarskim Irena Grasberżanka, wedle własnych, nieco ekshibicjonistycznych wspomnień, swój „pierwszy raz” rzeczywiście przeżyła w Tatrach, z kolegą ze studiów (późniejszym mężem), ukrywając wspólny wyjazd w góry przed rodziną. Wyjście romansu na jaw naraziło ją na pretensje ze strony ojca, który zapowiedział: „Nie pozwolę, aby Irka zachowywała się jak ladacznica"574. Oba te przykłady pokazują, iż studentki decydujące się na współżycie ryzykowały nie tylko zajście w niechcianą ciążę, która mogła przekreślić ich plany życiowe, ale także konflikt z rodziną i utratę reputacji - równie groźną, zwłaszcza gdyby kochanek nie kwapił się do małżeństwa. „[...] W tamtych czasach szanujące się kobiety nie żyły z mężczyznami bez ślubu" - podsumowuje swe perypetie Grasberżanka $^{575}$.

Tymczasem studenckie małżeństwa stanowiły wówczas rzadkość. Na podstawie zmian nazwiska w matrykułach można np. wyliczyć, że spośród 1186 kobiet immatrykulowanych na uczelni w 1929 r. w latach studiów na zamążpójście zdecydowało się zaledwie $3^{1}$ słuchaczek, czyli mniej niż $3 \%$ ogółu ${ }^{576}$. Brak jest niestety analogicznych danych na temat studentów, należy jednak sądzić, że było ich jeszcze mniej. Dla wielu mężczyzn studia były czasem, kiedy mogli się wyszaleć, wyżyć w działalności organizacyjnej i politycznej (a niekiedy również w ulicznych burdach), zanim życie zmusiło ich do ustatkowania się. „Dwa różne życia, dwa rodzaje obowiązków, w korporacji akademickiej i w związku małżeńskim, stanowiły nadmierny ciężar dla młodych barków. Student 
żonaty tracił zazwyczaj swą młodzieńczą niefrasobliwość, swe przemiłe, beztroskie szaławilstwo; tracił niewątpliwie swój «fason»" - podsumował z wyraźną aprobatą dla kawalerskiego stanu jeden z profesorów prawa, dodając dalej, że małżeństwo nie sprzyjało również nauce ${ }^{577}$.

Przede wszystkim jednak, od mężczyzn, którzy decydowali się założyć rodzinę, oczekiwano samodzielności finansowej, a o tę było trudno w trakcie nauki. Gdy studiujący na trzecim roku prawa Jan Garliński, zakochany w przebywającej w Polsce Angielce, napisał do jej ojca list, w którym prosił o rękę córki, otrzymał grzeczną, lecz stanowczą odpowiedź, iż gentelman nie powinien składać kobiecie propozycji matrymonialnych, dopóki nie jest w stanie zapewnić swej narzeczonej utrzymania. Odmowę przyjął z pokorą: „Pełnoletniość dawała nam formalne prawo decydowania o naszym losie, lecz nasza młodość nie była na tyle arogancka, by zlekceważyć oczywiste realia. Miałem przed sobą studia, materialnie zależałem od ojca, nie mogłem od razu zapewnić przyszłej żonie jakiegokolwiek normalnego życia [...]". Ze ślubem musiał się wstrzymać do ukończenia studiów ${ }^{578}$. Podobnie uważały, rzecz jasna, kobiety, nawet jeśli skrycie marzyły o miłości romantycznej. Studentka prawa Teodora Żukowska kilka razy odrzucała oświadczyny swego kolegi, bowiem „zawrzeć małżeństwo i założyć dom można było dopiero wtedy, gdy miało się ukończone studia i zapewnioną pozycję życiową" ${ }^{\text {"579. }}$ Mając niewątpliwie świadomość takiego stanu rzeczy, Ryszard Matuszewski i Eugeniusz Łazowski, z których wspomnień czerpałem już wcześniej informacje o studenckim życiu i obyczajach, wstrzymywali się z oświadczynami do zakończenia nauki i znalezienia pracy.

$\mathrm{Na}$ ożenek w czasie studiów mogli sobie pozwolić jedynie ci młodzi mężczyźni, których rodziny mogły, a ponadto miały ochotę pomagać im materialnie na nowej drodze życia. Zdarzało się tak jednak raczej rzadko. Niezwykle zamożni rodzice Hilarego Koprowskiego, późniejszego twórcy szczepionki przeciw polio, który pod koniec lat 3o. ożenił się w tajemnicy przed nimi, będąc na trzecim roku medycyny, przyjęli wprawdzie ten fakt do wiadomości, ale nie pomogli nowożeńcom usamodzielnić się pod względem mieszkaniowym, w związku z czym każde z nich mieszkało po ślubie osobno, w swoim dotychczasowym domu rodzinnym. Podobnie zresztą bywało i po ukończeniu studiów, czego dowodem może być przypadek Ireny Goldberżanki i Jerzego Krzywickiego, którzy przez pierwsze 3 lata po ślubie zamieszkiwali osobno, gdyż nie mieli pieniędzy na własne lokum, a dobrze sytuowany ojciec pana młodego, skądinąd wybitny socjolog i wykładowca uniwersytecki, nie widział powodu, aby zapewnić im własny dach nad głową ${ }^{580}$. Trudno się dziwić, że w takich realiach studenci rzadko zawierali związki 
małżeńskie. Jeśli mimo to ich koleżanki wychodziły za mąż, to wybierały najczęściej mężczyzn od siebie starszych, zdolnych utrzymać rodzinę. Już na studiach mężatkami zostały np. Irena Krzyżanowska-Sendlerowa oraz wybitna później znawczyni kultury Celtów Janina Rosen-Przeworska, która - co stanowiło bardzo rzadki wyjątek - kontynuowała naukę również po urodzeniu dziecka. Jej dwie koleżanki z zakładu archeologii przedhistorycznej, mimo posiadania absolutorium, po ślubie nie powróciły na uczelnię ${ }^{581}$. Pozwala to przypuszczać, że dla części ówczesnych kobiet małżeństwo było wciąż ważniejszą zdobyczą życiową niż dyplom Uniwersytetu Warszawskiego.

\section{Kultura polityczna Uniwersytetu Warszawskiego}

Obraz społeczności akademickiej Uniwersytetu lat 1915-1939 byłby niepełny bez uwzględnienia postaw, wartości i wzorów zachowań, które określa się na ogół zbiorczo mianem kultury politycznej. Omówienie zacząć należy od jej najbardziej zewnętrznego komponentu, czyli obowiązujących na uczelni norm zachowania, potocznie nazywanych wówczas po prostu „kulturą". Jak to się jednak często zdarza w przypadku zjawisk oczywistych dla ich uczestników, niełatwo jest znaleźć odpowiednie źródła do ich szczegółowej analizy. Polscy studenci i wykładowcy Uniwersytetu, którzy pozostawili po sobie wspomnienia, pomijaja na ogół ten aspekt życia akademickiego, zapewne właśnie dlatego, iż był dla nich zupełnie oczywisty. Dopiero ze wspomnień niemieckiego słuchacza UW, pochodzącego z Łodzi Oskara Kossmanna możemy się dowiedzieć, jaka była specyfika obyczajów warszawskiego środowiska inteligenckiego, z którym zapoznał się właśnie na uczelni:

„[...] Warszawiakowi zależy w szczególnym stopniu na szlachetności swego towarzystwa, na formach grzecznościowych, na demonstrowaniu możliwie najwyższego statusu społecznego w swoim codziennym otoczeniu. Nie jest przypadkiem, że warszawiak przez «kulturę» rozumie w pierwszej kolejności doskonałe pod względem formy dżentelmeńskie zachowanie (das formvollendete Kavaliersverhalten) i określa jako «kulturalnego» tego, kto wie, jak zrobić wrażenie przyjmując gości i żegnając się z nimi, kto potrafi okazać należny szacunek starszym, zachowuje się dwornie wobec dam, co jednakże nie wiąże się z żadnym wysiłkiem duchowym, gdyż dotyczy jedynie błyszczącej, zewnętrznej 
powłoki. Wewnętrzna postawa pozostaje od tego niezależna. Obecnie przybiera to w Warszawie formę salonu towarzyskiego, który nieprzypadkowo stanowi promieniejące centrum każdego lepszego mieszkania"582.

Powierzchowność dobrego wychowania nie była zapewne specyfiką wyłącznie warszawską, ani nawet polską, choć być może w Warszawie bardziej niż gdzie indziej rzucał się w oczy kontrast między ogromną kurtuazją a faktycznymi postawami. Nietrudno przy tym zauważyć, że oba zjawiska zaobserwowane przez Kossmanna na uczelni - przywiązanie do form grzecznościowych i potrzeba podkreślania własnej pozycji społecznej - stanowiły dziedzictwo kultury szlacheckiej i ziemiańskiej, która w II Rzeczpospolitej została w dużej mierze przejęta przez inteligencję. Uniwersytet Warszawski stanowił z natury rzeczy ważny element transmisji wzorów kulturowych w tej warstwie społecznej, przyczyniając się, jak można zakładać, do ich przejmowania również przez tych studentów, którzy sami wywodzili się np. z rodzin drobnomieszczańskich, chłopskich bądź robotniczych.

Dla zrozumienia kultury politycznej Uniwersytetu Warszawskiego w okresie międzywojennym ważniejsze niż „kultura” w sensie, w jakim wzmiankowana została ona powyżej, wydaje się jednak słowo „polityka”. O jej znaczeniu decydowała przede wszystkim niezwykła bujność życia publicznego uczelni. Rozumieć należy przez nią nie tylko czynną rolę, jaką wielu profesorów i studentów odgrywało w polityce na poziomie ogólnopaństwowym - by wymienić chociażby prominentnych działaczy Stronnictwa Narodowego takich jak Tadeusz Bielecki, Roman Rybarski czy Bohdan Wasiutyński, polityków BBWR jak Wacław Makowski i Jan Kochanowski, czy też przywódców radykalnej prawicy na czele z Jerzym Kurcyuszem, Janem Mosdorfem i Bolesławem Piaseckim - ale przede wszystkim mnogość różnego rodzaju organizacji, które działały wśród studentów ${ }^{583}$.

Według danych rektorskich, I IX 1938 r. zarejestrowanych było przy Uniwersytecie 69 stowarzyszeń, w tym 32 naukowe, 6 samopomocowych, 19 kulturalno-towarzyskich (głównie kół regionalnych), 8 ideowo-wychowawczych (tzn. korporacji), 2 sportowe i 2 przyjaciól narodów $^{584}$. Zgodnie z ustawą o szkolnictwie wyższym organizacje stricte polityczne nie mogły działać na uczelniach, ale zakaz ten pozostawał martwą literą. Jak już zostało powiedziane w poprzednim rozdziale, upolityczniony charakter miały w większości zarówno korporacje, jak i koła naukowe, a stowarzyszenia samopomocowe stanowiły wręcz ekspozytury ugrupowań politycznych - co dotyczyło przede wszystkim największego z nich, Bratniej Pomocy, przekształconej przez prawicę nacjonalistyczną we własny systemem klientalny. Dodać należy, 


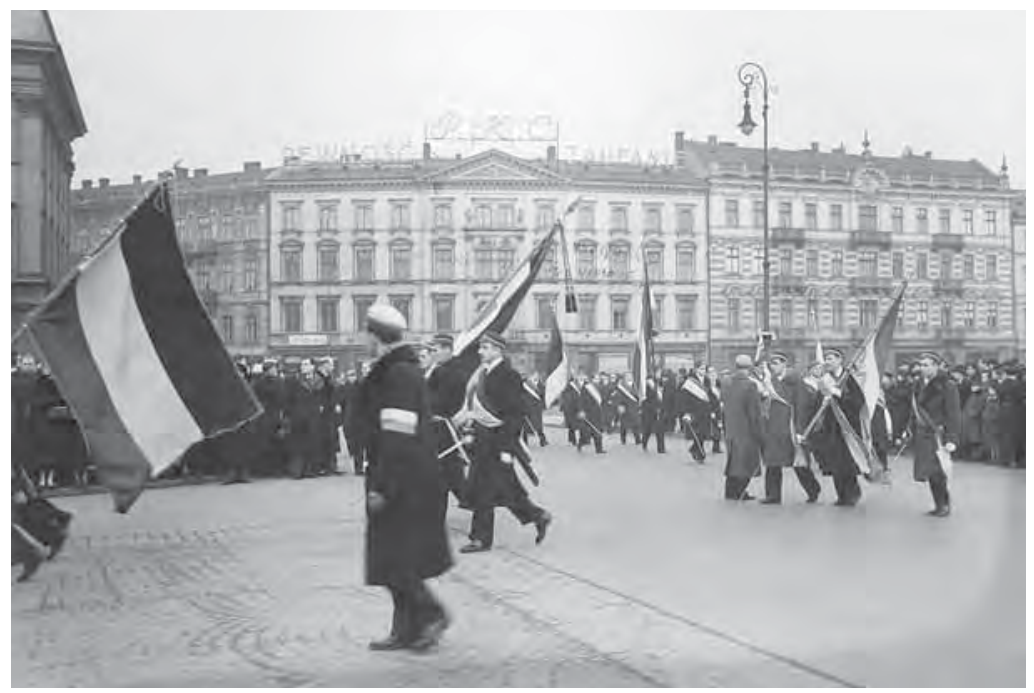

72. Poczty sztandarowe organizacji studenckich w drodze do Grobu Nieznanego Żołnierza podczas obchodów 20 rocznicy powstania Towarzystwa Bratniej Pomocy Studentów Uniwersytetu Warszawskiego, styczeń $1936 \mathrm{r}$.

że Uniwersytet Warszawski był jednym z głównych bastionów Obozu Wielkiej Polski, a następnie matecznikiem Obozu Narodowo-Radykalnego; swoje przyczółki próbowali tu zająć i utrzymać także piłsudczycy, ludowcy i komuniści ${ }^{585}$.

Nie będzie więc z pewnością nadużyciem stwierdzenie, iż charakterystycznym rysem życia Uniwersytetu Warszawskiego w okresie 19151939 było rozpolitykowanie. Stanowiło ono w pewnej mierze naturalną reakcję na odzyskanie niepodległości i powstałą wówczas możliwość nieskrępowanej działalności politycznej. Nawet po zamachu majowym Uniwersytet zapewniał bardzo duży zakres swobody, przypominając wentyl bezpieczeństwa, którym uchodziły gromadzące się wśród młodzieży niezadowolenie i frustracja. Jedną z przyczyn rozpolitykowania, być może najważniejszą, było ponadto przekonanie wielu studentów o swym wyjątkowym posłannictwie społecznym. Uważał tak na przykład Tadeusz Katelbach, który opisał to następująco we swych wspomnieniach: „Trudno to wyrazić, by nie wpaść w tani patos lub przesadę, ale dla nas uniwersytet w czasach 1915-1918 nie był tylko sobie zwykłą uczelnią. Studia i życie organizacyjne, zagadnienia czysto intelektualne i polityczne, wszystko to razem zlewało się w jakąś jedną całość. Skutek był taki, że w murach odrodzonej Alma Mater Varsoviensis czuliśmy się jak w szkole, przygotowującej nas przede wszystkim do przyszłej służby publicznej”586. Również w latach późniejszych, aż do wybuchu II wojny światowej wielu słuchaczy traktowało Uniwersytet jako naturalną odskocznię do dalszej działalności politycznej, a siebie 


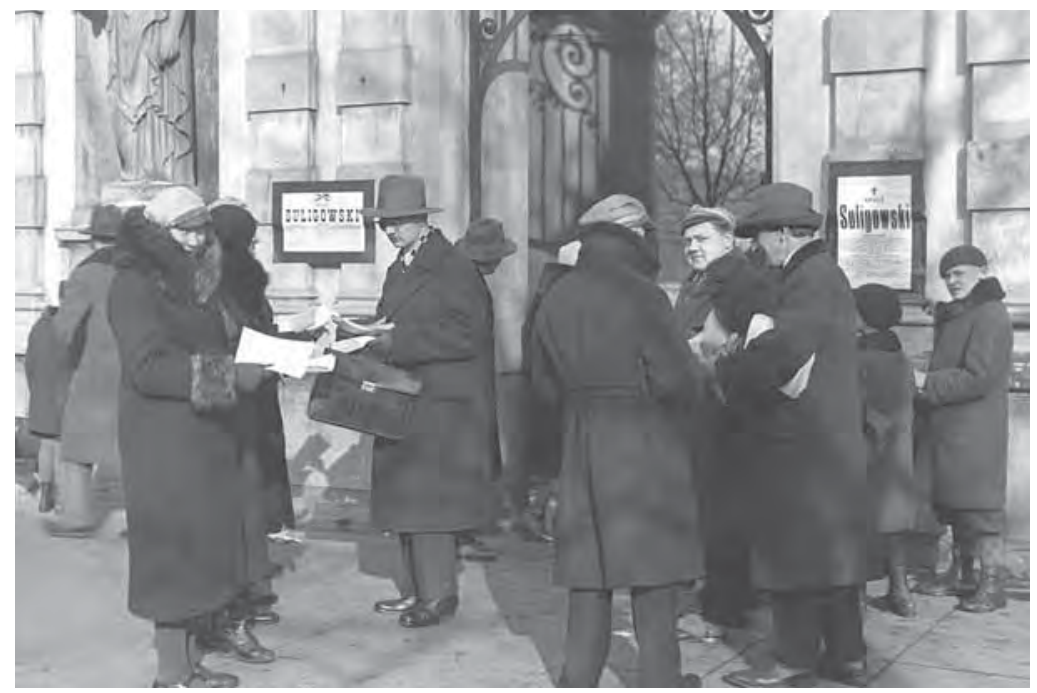

73. Studenci rozdający ulotki przed bramą Uniwersytetu, luty $193^{2} \mathrm{r}$.

samych uważało za awangardę narodu. Utwierdzały ich w tym partie, przedstawiając studentów jako przyszłych przywódców mas ${ }^{587}$.

Utożsamianie studentów z elitą polityczną narodu (i ich utożsamianie się z nią przez nich samych) wynikało w dużej mierze ze strukturalnej słabości międzywojennej Polski. Zauważył to po latach nie kto inny, jak Wojciech Wasiutyński, który jako student UW na przełomie lat 20. i zo. sam bardzo aktywnie uczestniczył w uniwersyteckim życiu politycznym: „W krajach nieuprzemysłowionych, a w okresie międzywojennym Polska wciąż jeszcze do nich należała, studenci - z braku rozwiniętej klasy średniej - grają wielką rolę polityczną". Zaraz dodaje on jednak, iż „młodzież polska nie była jednak podobna do dzisiejszej młodzieży studenckiej z krajów Trzeciego Świata. Nie była masą buzującą, którą co pewien czas organizacje rewolucyjne podrywają do demonstracji" ${ }^{588}$. Z zastrzeżeniem tym trudno się zgodzić. Mimo iż Wasiutyński się od tego odżegnywał, studenci UW, w tym także on sam, niezwykle chętnie wylegali na ulice, aby uprawiać tam politykę. Określenie „masa buzująca” wydaje się w stosunku do nich nad wyraz trafne. Jedyną różnicą w tej mierze w stosunku do krajów rozwijających się, gdzie studenckie rozruchy miały w XX w. charakter na ogół lewicowy, była w przedwojennej Polsce ich przeważnie prawicowa orientacja.

Przejawem rozpolitykowania studentów było przy tym nie tylko samo angażowanie się w działalność polityczną, lecz również jej formy, przypominające niekiedy te znane ze szlacheckich sejmików. Warto przytoczyć w tym kontekście inną obserwację Wasiutyńskiego: „Nad 


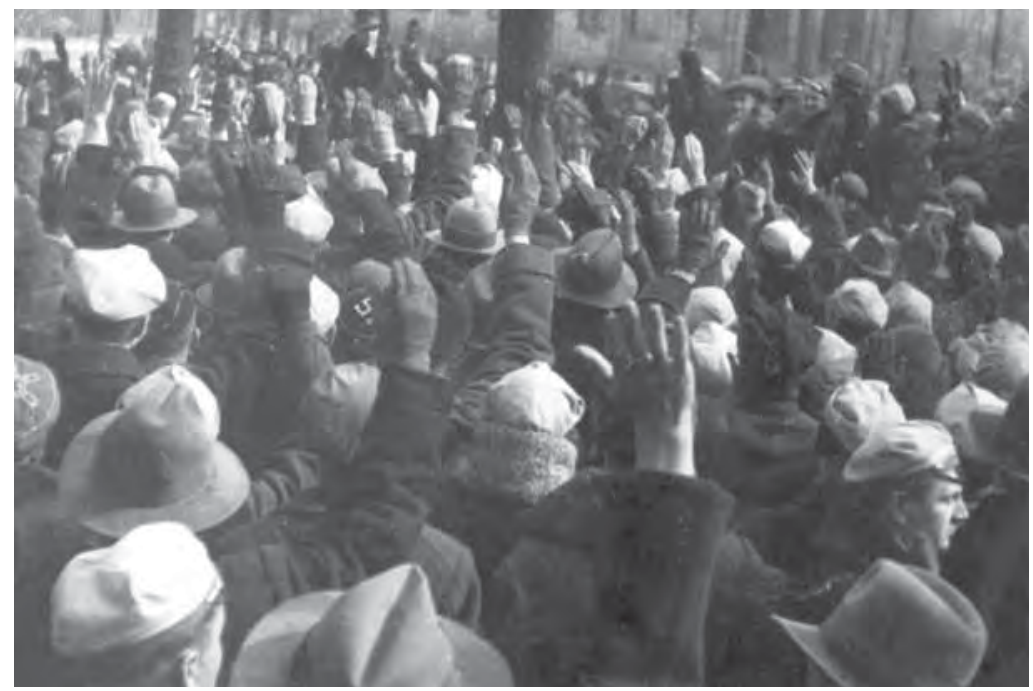

74. Wiec studencki na terenie Uniwersytetu, marzec $1931 \mathrm{r}$.

życiem wewnętrznym korporacji akademickich ciążyło właściwe Polakom gadulstwo. Studenci, którzy nie mogli liczyć na dopuszczenie do mównicy na wielkim zebraniu, wyżywali swoją chęć gadania na posiedzeniach koła korporacyjnego. Im błahsza sprawa, tym więcej i tym dłużej o niej mówiono, bo każdy miał swoje zdanie"589. Opinia ta w mniejszym lub większym stopniu odzwierciedla realia panujące we wszystkich organizacjach działających jawnie na terenie Uniwersytetu, w których bez końca debatowano, głosowano, powoływano komisje, zwoływano walne zebrania, uchwalano rezolucje, wykluczano się nawzajem, oskarżano i broniono się przed sądami koleżeńskimi. Niekiedy oczywiście dyskusje dotyczyły spraw ważnych dla społeczności studenckiej, jak chociażby wyboru władz Bratniej Pomocy, ale przeważnie większość pary szła w gwizdek.

Podobnie jak niegdyś brać szlachecka, studenci byli również niezwykle przeczuleni na punkcie swego honoru. Gdy jeden z profesorów Wydziału Prawa zwrócił podczas wykładu uwagę chłopakowi, by przestał nieustannie spoglądać na zegarek, poczuli się tym urażeni wszyscy słuchacze. $\mathrm{Na}$ zwołanym naprędce wiecu uchwalona została rezolucja o wysłaniu do wykładowcy deputacji z żądaniem przeprosin. Inny student, wyproszony z sali wykładowej przez profesora za gadanie, następnego dnia przysłał mu sekundantów. W obu przypadkach skończyło się na polubownym załatwieniu sprawy, ale w innych sytuacjach dochodziło w takich okolicznościach do eskalacji konfliktu ${ }^{590}$. Asystent Wydziału Filozoficznego, który ośmielił się upomnieć studentkę, iż nie 
wolno wprowadzać osób postronnych do pracowni botanicznej, został za tę obrazę wyzwany na pojedynek przez towarzyszącego jej kolegę; tym samym zagroził mu ojciec dziewczyny, pułkownik Wojska Polskiego. Kiedy pracownik naukowy odmówił udzielenia satysfakcji studentowi, ów zapowiedział, iż nie pozostaje mu nic innego, jak przy pierwszej okazji spoliczkować go publicznie. Nie wiadomo, czy do tego ostatecznie doszło, znamienne jest natomiast, że profesor, któremu polecono zbadać sprawę, uznał, iż studentka miała prawo poczuć się obrażona zwróceniem jej uwagi przez asystenta, a jej towarzysz - dochodzić satysfakcji honorowej ${ }^{591}$.

W sposób szczególny kultywowano zasady „postępowania honorowego" w korporacjach. Wydany z ich inicjatywy przez Juliusza Sas-Wisłockiego kodeks absolutyzował zasadę obrony czci własnej, obligując, pod sankcją utraty praw honorowych, każdego korporanta (a postulatywnie także każdego męskiego członka społeczności akademickiej „pochodzenia niewątpliwie aryjskiego") do domagania się „zadośćuczynienia honorowego" w przypadku, gdyby poczuł się obrażony. Choć pozwalał on uniknąć walki osobom, które nie chciały występować przeciw prawu lub nauce Kościoła katolickiego, dopuszczał też możliwość pojedynku na broń białą lub pistolety „aż do zupełnej niezdolności pojedynkowej jednego z walczących"592. Nie ma powodu, aby wątpić w prawdziwość ironicznej relacji Witolda Gombrowicza, który wspominał, przytaczając zresztą przykład własnego brata Jerzego, że na Uniwersytecie manii pojedynków ,oddawało się spore grono studentów, należycie w niej wyspecjalizowanych i obznajomionych gruntownie z kodeksem honorowym Boziewicza, dzięki czemu żaden zatarg nie mógł się obyć bez ich współudziału w charakterze sekundantów, arbitrów lub ekspertów"5993.

Czemu się zresztą dziwić? Również wśród profesorów UW wciąż jeszcze zdarzało się, że zatargi próbowano rozstrzygać na drodze pojedynku. W 1923 r. historyk Wacław Tokarz (pułkownik Wojska Polskiego) przysłał sekundantów matematykowi Wacławowi Sierpińskiemu za to, że ten skrytykował opublikowanie w kierowanym przez niego Wojskowym Instytucie Naukowo-Wydawniczym, słabej, zdaniem Sierpińskiego, pracy pod tytułem Analiza Matematyczna ${ }^{594}$. Zatarg honorowy miał też 4, lata później prof. Antoniewicz z dyrektorem Państwowego Muzeum Archeologicznego Romanem Jakimowiczem ${ }^{595}$. W obu przypadkach przelewano na szczęście jedynie atrament, oponenci uniknęli natomiast stanięcia na ubitej ziemi. Rację ma zapewne Gombrowicz, pisząc (zarówno w kontekście obyczajów panujących na Uniwersytecie, jak i poza jego murami), że "te honorowe zabiegi coraz bardziej groteskowe przybierały kształty” i pełniły funkcje „sportu dla amatorów”, 
specyficznej zabawy towarzyskiej, w której nie chodziło już o fizyczne pomszczenie doznanej zniewagi, lecz o archaiczny rytuał, pielęgnowany przez część społeczeństwa ${ }^{596}$. Niewątpliwie bowiem fakt wyzywania adwersarza na pojedynek był wyraźną pozostałością po kulturze szlacheckiej, o której trwaniu na uczelni pisałem na początku tego rozdziału.

Panujące na Uniwersytecie przewrażliwienie na punkcie honoru umacniało wśród działaczy studenckich postawy nieprzejednane i konfrontacyjne. Zarówno wobec władz uczelni, jak i państwowych zachowywali się oni butnie i arogancko. Kiedy w listopadzie 1931 r. zajścia antysemickie wywołane na Uniwersytecie przez prawicę nacjonalistyczną rozprzestrzeniły się na część Śródmieścia, ówczesny prezes Młodzieży Wszechpolskiej i równocześnie prezes zarządu Bratniej Pomocy Jerzy Kurcyusz trzykrotnie proponował rektorowi Janowi Łukasiewiczowi, że rozruchy może uspokoić, lecz jednocześnie cynicznie żądał w zamian zgody na demonstrację polityczną na dziedzińcu Uniwersytetu, co prowadziłoby do oczywistej eskalacji kryzysu. Kilka miesięcy wcześniej inny prominentny działacz Bratniaka Michał Słomiński pozwolił sobie zagrozić Bronisławowi Żongołłowiczowi, sekretarzowi stanu w MWRiOP, iż ewentualne zamknięcie Uniwersytetu w wypadku zamieszek studenckich może pociągnąć za sobą, „zamachy na osoby wysoko postawione". Żongołłowicz nie bez racji referował więc ministrowi Januszowi Jędrzejowiczowi pesymistyczny obraz sytuacji na uczelni: „[...] Masa studencka coraz bardziej staje się ciemna, hałaśliwa, brutalna i hultajska. [...] Masa studencka i jej związki, stowarzyszenia, korporacje, wyrosły spontanicznie, niewspółmiernie do sił kształtujących. Pojęcie związków legalnych i nielegalnych nie istnieje w tej masie. Ogromna większość studentów nie uczy się. Poziom straszliwy. «Autonomia»nieróbstwa, burd, zaburzeń. Dalej będzie gorzej"597. Ta ostatnia diagnoza, której nie można oczywiście rozciągać na słuchaczy pozostających poza wpływami radykalnej prawicy, okazała się, niestety, prorocza.

Większość studentów Uniwersytetu, których miał na myśli Żongołłowicz, poczułaby się niewątpliwie oburzona jego opinią, przede wszystkim dlatego, iż w ich własnym mniemaniu wszystko, co czynili, służyć miało ojczyźnie. „Dla nas Polska jest rzeczą świętą. Zmiażdżymy wszystkich, którzy stoją nam na przeszkodzie" - zapowiadało wydawane przez wszechpolaków z Bratniej Pomocy czasopismo „Alma Mater", uzasadniając, dlaczego należy walczyć o całkowite usunięcie Żydów z wyższych uczelni ${ }^{598}$. „Świadomi dziejowej odpowiedzialności - my młode pokolenie polskie [...] - przystępujemy do codziennego trudu pomnażania sił Polski, by była gotowa na czas, przystępujemy do pracy i walki o wielkość swego narodu i państwa" - wtórował mu 
w czerwcu 1938 r. „Akademik”, organ Związku Młodej Polski, młodzieżowej przybudówki Obozu Zjednoczenia Narodowego ${ }^{599}$. Nie ma powodu, aby wątpić w szczerość tych i podobnych deklaracji, ani by kwestionować patriotyzm środowiska akademickiego. Nawet ideowy przeciwnik prawicy, jakim był Ludwik Krzywicki, przyznawał: „A tłum zwyczajny młodzieży endeckiej, ciemny jak tłumy szlachty przybywające na pole elekcyjne na Woli, tym bardziej był przeświadczony o swej prawości. Rdzeń ten młodej endecji [...] był zbiorem ciasnych, wąskich, brutalnych, ale bądź co bądź szczerych ideowców"600.

Patriotyzm był więc z pewnością ważnym elementem kultury politycznej Uniwersytetu Warszawskiego, a wielu pracowników naukowych uczelni i jej studentów dowiodło go czynem, walcząc na ochotnika w wojnach o niepodległość i granice w latach 1918-1920, nie uchylając się od służby wojskowej w czasie pokoju, czy też biorąc później udział w II wojnie światowej. „Nie miałem wątpliwości, że powinienem to uczynić" - po latach skomentował krótko swoją decyzję o wstąpieniu do wojska w 1920 r. student Tadeusz Manteuffel, sympatyzujący wówczas z obozem narodowym. (Udział w wojnie bolszewickiej kosztował go utratę prawej ręki) ${ }^{601}$. Podobnie odczuwała zapewne większość słuchaczy i kadry naukowo-dydaktycznej, niezależnie od dzielących ich poglądów politycznych. Nieliczni, którzy jak Gombrowicz (wtedy jeszcze szesnastolatek) nie zgłosili się do wojska ze strachu lub pod wpływem obaw rodziców, doświadczali wstydu publicznych upokorzeń (panienki pytające na ulicach „Dlaczego kawaler nie w mundurze?”) i goryczy wewnętrznej alienacji („Miałem uczucie, że jestem sam, sam przeciwko wszystkim, że trzeba się zamknąć w sobie i nikomu nie dawać dostępu") ${ }^{602}$.

Od patriotyzmu dystansowali się jedynie komuniści, choć i ich postawy były w tej mierze do pewnego stopnia niekonsekwentne, albo zmieniały się zależnie od okoliczności. Przykładem może być Władysław Broniewski, który mając za sobą służbę w Legionach, w październiku 1918 r. zapisał się na Wydział Filozoficzny UW, niedługo potem znów przywdział mundur, aby walczyć z bolszewikami i na uczelnię powrócił dopiero 3 lata później, po zakończeniu wojny, też zresztą na krótko, gdyż zaraz pochłonęła go działalność rewolucyjna ${ }^{603}$. Część studentów-komunistów maskowała się natomiast, udając jedynie patriotyczne zaangażowanie. Opisuje to Maria Kamińska, wspominając wznowienie nauki na Uniwersytecie w 1921 r.: „Bratniak żądał od każdego zaświadczenia: gdzieś był, coś robił w dniach trwogi. Bez tego nie było możliwości kontynuowania studiów. [...] Większość jednakże kolegów i koleżanek spośród naszego lewicowego grona zaopatrzyła się 
już uprzednio w różne papierki stwierdzające - wbrew prawdzie - ich współdziałanie z organizacjami pomocy frontowi"'604. Niezależnie od specyficznej, komunistycznej optyki, relacja ta ukazuje, że patriotyzm był na tyle ważnym elementem uniwersyteckiego esprit de corps, iż nawet komuniści nie odważali się go otwarcie zakwestionować. Próba rozbicia przez lewicę antykomunistycznego wiecu studenckiego zorganizowanego w kwietniu 1926 r. w budynku filharmonii przy ul. Jasnej zakończyła się wielką bijatyką, której rezultaty całkowicie potwierdziły dominację prawicy w środowisku uniwersyteckim ${ }^{605}$.

Komuniści działali oczywiście na Uniwersytecie Warszawskim również w latach późniejszych, i to nie tylko wśród studentów, ale także w szeregach kadry naukowej. (Archeolog doc. Ludwik Sawicki był nawet, jak się wydaje, funkcjonariuszem Komunistycznej Partii Polski aktywnie zaangażowanym w działalność antypaństwową ${ }^{60}$ ). Przezornie jednak nie obnosili się publicznie z takimi elementami swojego programu, jak np. utworzenie polskiej republiki radzieckiej, dyskutując o tym jedynie - jak wspomina cytowany już przeze mnie w jednym z wcześniejszych rozdziałów Matuszewski - wyłącznie we własnym gronie. Otwarte wystąpienie z takimi tezami naraziłoby ich niewątpliwie na wykluczenie społeczne, razy ze strony radykalnej prawicy, a także represje władz uniwersyteckich i państwowych. „Identyfikacja komunizmu z ZSRR była jednak czynnikiem powstrzymującym jego oddziaływanie. W ogromnej większości młodzież uniwersytecką w Warszawie cechował patriotyzm i niechęć do obcych agentur. W stolicy nadal żywa była pamięć walk o niepodległość i bitwy, jaką stoczyła armia polska w sierpniu 1920 r. na przedmieściach miasta" - podkreśla jeden z ówczesnych studentów ${ }^{607}$.

Żarliwy patriotyzm prawicowego mainstreamu na Uniwersytecie miał charakter jednoznacznie nacjonalistyczny - rząd dusz sprawowała tu niemal niepodzielnie endecja i wyrosłe z jej pnia organizacje takie jak Obóz Wielkiej Polski, Młodzież Wszechpolska czy później ONR (niekiedy wzajemnie ostro skonfliktowane). Sympatyzowała z nimi większość kadry naukowo-dydaktycznej uczelni, przede wszystkim lokując swe sympatie po stronie bardziej zachowawczych „starych"608. Ugrupowania narodowe obejmowały swoimi wpływami, jak obliczano, około 7o-9o\% społeczności studenckiej w Polsce i niezależnie od pojawiających się pomiędzy nimi gwałtownych sporów, nadawały oblicze ideowe całemu Uniwersytetowi ${ }^{609}$. Jak głosiła jedna z ulotek Stronnictwa Narodowego skierowanych do studentów: ,[...] wchodzicie w życie dojrzałe jako mniej lub więcej zdeklarowani narodowcy. Jedni z Was mieli już okazję zetknięcia się osobistego z naszą organizacją, inni podlegali (czasem 


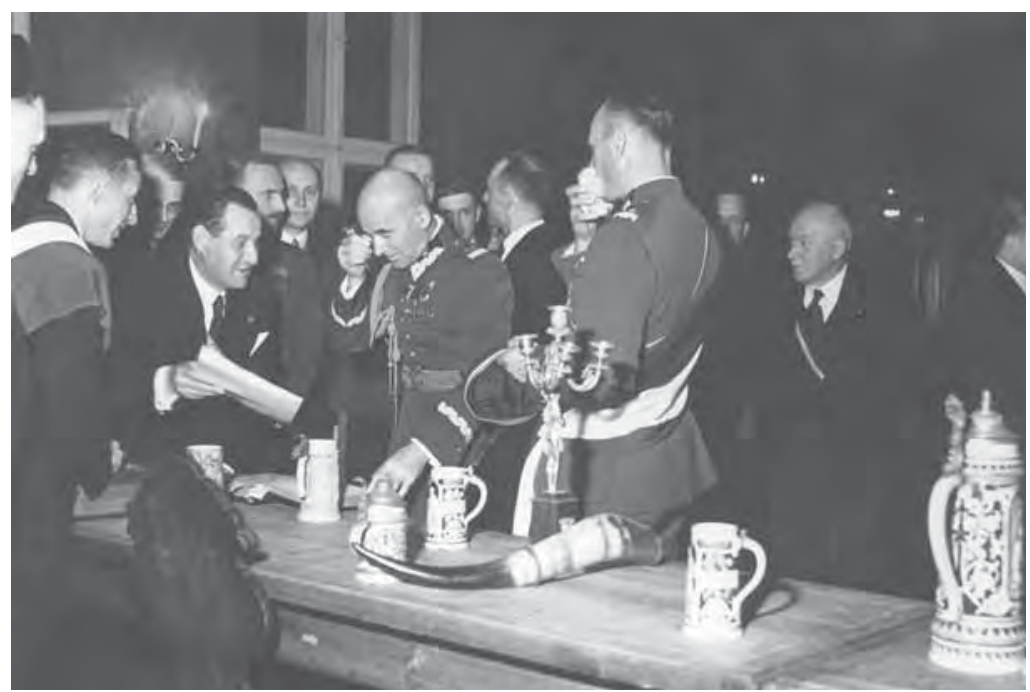

75. Komers korporacji akademickiej "Arkonia" z udziałem marszałka Edwarda Śmigłego-Rydza, będący wyrazem zbliżenia między obozem sanacyjnym a radykalną prawicą, $18 \mathrm{~V} 1937 \mathrm{r}$.

nawet nieświadomie) wpływom naszej akcji”"610. Nawet jeśli było w tym trochę przesady, piłsudczycy, ludowcy, demokraci, socjaliści i komuniści znajdowali się na uczelni w zdecydowanej mniejszości, mimo iż pierwsi z nich po 1926 r. korzystali z wydatnego wsparcia władz państwowych. Co więcej, w drugiej połowie lat zo. część piłsudczyków w dużej mierze przejęła nacjonalistyczny program swych dotychczasowych przeciwników politycznych, zasilając młodzieżową przybudówkę Obozu Zjednoczenia Narodowego, w której kluczowe stanowiska zajęli na Uniwersytecie Warszawskim oenerowcy. Symbolicznym wyrazem zbliżenia pomiędzy nimi a radykalną prawicą narodową stał się na gruncie akademickim udział marszałka Śmigłego-Rydza w komersie korporacji Arkonia $18 \mathrm{~V} 1937$ r. $^{611}$

Ostrze panującego na Uniwersytecie nacjonalizmu zwracało się przede wszystkim przeciwko Żydom, czego zarówno źródłem, jak i efektem był panujący w polskiej społeczności akademickiej antysemityzm. Miał on swe źródło w procesach i zjawiskach występujących również poza murami uczelni, tu jednak przybierał formy szczególnie drastyczne, stanowiąc z pewnością istotny i mało chlubny element kultury politycznej przedwojennego Uniwersytetu. O niektórych przejawach antysemityzmu wspominałem już we wcześniejszych rozdziałach tej pracy, w tym miejscu chciałbym pokusić się natomiast o kilka obserwacji pozwalających dookreślić charakter i skalę tego zjawiska.

Zacząć trzeba od tego, że na Uniwersytecie Warszawskim, podobnie zresztą jak w całym ówczesnym społeczeństwie, ludzi dzielono na 
Żydów i nie-Żydów tak samo naturalnie i odruchowo, jak na mężczyzn i kobiety. Co charakterystyczne, pochodzenia innego niż żydowskie nie dociekano i nie ekscytowano się nim. Gdy w czasie dyskusji o wprowadzeniu paragrafu aryjskiego w Kole Medyków jego przewodniczący Wiktor Szyryński złożył dymisję z uzasadnieniem, że jako polski Tatar także nie jest Aryjczykiem, wywołało to powszechną konsternację ${ }^{612}$.

Żydów identyfikowano tym łatwiej, iż wielu studentów wyznania mojżeszowego, oprócz wyznawania tej religii, wyróżniało się obyczajami, charakterystycznymi imionami i nazwiskami, czasami rysami twarzy, językiem lub specyficzną wymową w języku polskim. Podział na Żydów i Polaków sam w sobie nie byłby jeszcze niczym nadzwyczajnym (wielu Żydów miało przecież poczucie własnej odrębności), gdyby osób tej narodowości nie uważano jednocześnie za gorszych od Polaków, a żydowskiego pochodzenia za kompromitujące. Kwintesencję takich przekonań w skondensowanej formie stanowić może karykatura opublikowana w $193^{1} \mathrm{r}$. w jednym z prawicowych pisemek akademickich, zatytułowana „Paso-żyd”, przedstawiająca rozgniatanego pod butem Żyda-insekta ${ }^{613}$. Pomijając jej radykalne, eliminacyjne wręcz przesłanie, ujawnia ona przede wszystkim bezmiar pogardy dla osób wyznania mojżeszowego, manifestowanej przez polskie środowiska studenckie,

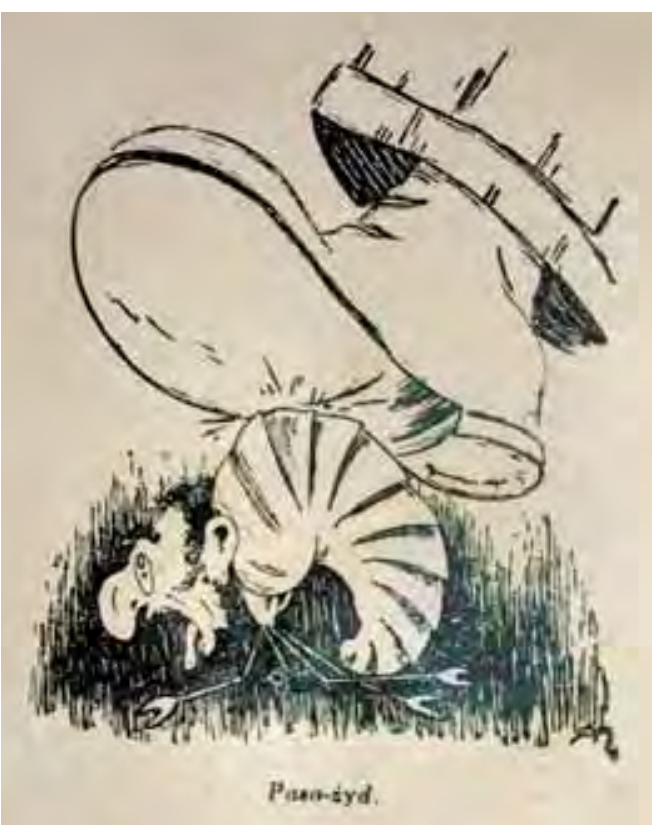

76. Antysemicka karykatura z gazetki studenckiej "Głos Akademicki", $193_{1}$ r. w których rząd dusz sprawowała prawica nacjonalistyczna. Zresztą nie tylko ona dawała temu wyraz. Kazimierz Brandys wspomina, że na zebraniach piłsudczykowskiego Legionu Młodych, do którego wówczas należał, „przemówienia często nie różniły się treścią od haseł oenerowskiej «Falangi». Kiedy pewien mówca, występując przeciw antysemickim nastrojom $\mathrm{w}$ organizacji, powiedział: «Moja matka jest z pochodzenia Żydówką» - rozległ się szyderczy śmiech"614.

Jak już zostało powiedziane wcześniej, na Uniwersytecie Warszawskim przez całe dwudziestolecie międzywojenne za kryterium, według którego definiowano żydowskie pochodzenie studentów, formalnie uznawano wyznanie mojżeszowe, ale jednocześnie coraz wyraźniej traktowano Żydów 
jako mniejszość narodową, a nie religijną. (Podobna tendencja występowała zresztą także wśród samych Żydów). Polska prawica nacjonalistyczna szła często jeszcze dalej, postrzegając Żydów jako wrogą rasę, przedstawiającą stałe zagrożenie dla polskości. Próbkę takiego podejścia stanowić może publikacja z marca 1923 r. domagająca się wprowadzenia dla Żydów numerus clausus, zamieszczona w ogólnopolskim czasopiśmie "Akademik", a więc pochodząca ze środowiska uniwersyteckiego i dotycząca jego problemów: „Pośród wrogów naszego narodu niewątpliwie najgroźniejszym jest - żyd. Od wieków osiadły na naszej ziemi, stał się pijawką, zarazą, rakiem, który toczy nasze polityczne ciało. [...] Żmije, ścigane po całym świecie, mordowane w średniowieczu przez wszystkie ludy, do naszego kraju się zbiegły i tu znalazły «kraj mlekiem i miodem płynący». [...] Kwestia żydowska nie zawsze występuje z całą jaskrawością i żydzi są mistrzami w wszelkiej symulacji. [...] Żydzi zasymilowani są dla społeczeństwa trucizną deprawacji, są szermierzami rozpusty, zohydzają literaturę, zaogniają kwestię społeczną z jednej strony jako kapitaliści - wyzyskiwacze, z drugiej jako czerwoni obrońcy ludu. Żydzi zasymilowani są szpiegami, którzy wciskają się do wszelkich naczelnych stanowisk, aby tam pracować «pro Judea»"615.

Tego rodzaju publikacja, która nota bene mogłaby z powodzeniem ukazać się w Niemczech na łamach nazistowskiego „Der Stürmer”, stanowiła zwiastun poglądów, jakie na dobre rozpowszechniły się na polskiej prawicy - w tym również na Uniwersytecie Warszawskim w drugiej połowie lat 30. W przeciwieństwie do III Rzeszy nie stworzyła ona wprawdzie wewnętrznie spójnej ideologii rasistowskiej, ale definiowała żydowskość w kategoriach nie tylko religii, lecz także, z czasem coraz wyraźniej, krwi. Autor cytowanego już przeze mnie wcześniej Akademickiego kodeksu honorowego (1934) stwierdzał w komentarzu do jednego z jego paragrafów: „Akademickie prawo zwyczajowe już dawno wykluczyło żydów ze społeczności honorowej. Kryterjum rasowe niniejszego kodeksu, choć nieznane dotychczasowym polskim kodeksom honorowym nie jest zatem czemś nowem. [...] Zakaz powyższy nie obejmował bezwyznaniowych, oficerów Wojsk Polskich i kawalerów orderów Rz.P. Praktyka poszła jednak znacznie dalej, przenosząc pojęcie żyda z płaszczyzny wyznaniowej na płaszczyznę narodową, a raczej rasową i czyniąc wyjątek jedynie dla oficerów Wojsk Polskich oraz wyjątki indywidualne" ${ }^{\prime 616}$.

Było to zgodne z kierunkiem ewolucji ówczesnego polskiego nacjonalizmu, którego mainstream w praktyce coraz wyraźniej wzorował się pod tym względem na hitleryzmie, nawet jeśli w teorii się od niego 
odżegnywał, przede wszystkim ze względu na niechętną rasizmowi postawę Kościoła katolickiego ${ }^{617}$. Jedną z konsekwencji takiego właśnie podejścia było doszukiwanie się żydowskich przodków u przeciwników politycznych, do czego chętnie uciekano się również w ramach walk frakcyjnych w obozie narodowym. Posiadanie żydowskiej babki zarzucano m.in. Wojciechowi Wasiutyńskiemu, który procesował się nawet w tej sprawie z kilkoma redakcjami, w tym m.in. z „Wiadomościami Literackimi”, ochoczo wykorzystującymi ów temat dla ośmieszania prawicowych antysemitów. Prawica traktowała jednak kwestię pochodzenia śmiertelnie poważnie ${ }^{618}$.

Dociekaniom na temat autentycznych bądź urojonych żydowskich przodków innych osób z upodobaniem oddawano się na Uniwersytecie także w relacjach prywatnych bądź służbowych. Wykładowca Wydziału Lekarskiego, a prywatnie zdeklarowany sympatyk endecji, doc. Michalski w spisanych po wojnie wspomnieniach chętnie informuje czytelników o pochodzeniu opisywanych przez siebie kolegów i ich rodzin („Handelsman - spolszczony Żyd”, „klinika Rzętkowskiego była nieprawdopodobnie zażydzona”, „zdolny Żyd Marceli Landsberg” itp.) ${ }^{619}$. Tego rodzaju znaną i dziś obsesję przejawiał również studiujący w drugiej połowie lat 20. na Wydziale Filozoficznym UW Alfred Łaszowski, skądinąd obiecujący, początkujący poeta i krytyk literacki, który uległ odurzeniu antysemityzmem, a swoich dotychczasowych przyjaciół, Irenę Skwarównę i Jana Kotta, zaczął nazywać „Chają Skwarą” i „Jojne Kottem" ${ }^{\prime 20}$. (Zasłynął później szerzej żądaniem kary śmierci dla Tadeusza Boya-Żeleńskiego, Ireny Krzywickiej i Antoniego Słonimskiego, za co wyrzucono go z PEN-Clubu). Antysemityzm nie tylko antagonizował więc na Uniwersytecie stosunki pomiędzy Polakami a Żydami, lecz także zatruwał relacje $\mathrm{w}$ środowisku etnicznie polskim.

Mimo że tendencje antysemickie nasiliły się na Uniwersytecie wraz z początkiem lat 3o., błędem byłoby przypuszczać, iż wcześniej stosunek Polaków do Żydów był poprawny albo przynajmniej obojętny. Antyżydowskie nastroje występowały na uczelni jeszcze przed odzyskaniem przez Polskę niepodległości, co dokumentują zapiski żydowskiego studenta Pesacha Rajmana z 1917 r. Opisuje on reakcję Polaków na protesty słuchaczy wyznania mojżeszowego, spowodowane niedopuszczeniem ich do udziału w konferencji stowarzyszeń akademickich, nie ukrywa przy tym własnej wściekłości: „Powstał taki hałas po tych słowach, że to było coś strasznego. Polacy krzyczeli «Precz!», «Wyrzucić ich!» Żydzi oklaskiwali swego mówcę, któremu okropny szum podobny do rozszalałej burzy przerywał słowa. Jak jeden mój kolega określił trafnie, był to ryk pijanych chłopów. Wiele Polaków gwizdało, inni krzyczeli 
«Do Palestyny!», słowem było coś strasznego, nie do opisania. [...] Zauważyłem, że nie było ani jednego Polaka, który byłby łagodnie względem Żydów usposobiony. [...] Jedno mnie dziwi, jak wobec takich gwałtów polskich można dalej twierdzić, że «Jestem Polakiem». Człowiek z godnością osobistą, z rozumem powinien by był się wstydzić nazwać się Polakiem, tj. chamem brutalnym. Jak jeszcze można znosić tę chamówkę wobec takich zajść na Politechnice, gdzie, podobno, Polacy mówili, że jesteśmy nieproszonymi gośćmi" ${ }^{\text {"221. }}$.

Ponad rok później (6 XI 1918 r.) studiujący wówczas na Uniwersytecie Władysław Broniewski zanotował w swoim Pamiętniku po podobnym wiecu: „Co za bydło! Hurrapatriotyzm połączony ze zwierzęcym antysemityzmem - oto treść uczuć nurtujących przeciętnego obywatela akademickiego" ${ }^{\prime 622}$. Kolejna erupcja nienawiści do Żydów nastąpiła na uczelni w 1922 r., na fali histerii środowisk nacjonalistycznych, wywołanej wyborem Gabriela Narutowicza na prezydenta państwa. (Za jego kandydaturą głosowali m.in. parlamentarzyści mniejszości żydowskiej). Studiująca na Wydziale Filozoficznym Maria Niedźwiecka, która w tym czasie powróciła do kraju z dłuższego pobytu we Francji, opisywała w listach do narzeczonego, Stanisława Ossowskiego, który wciąż jeszcze przebywał za granicą, przeszkadzające jej normalnie pracować na Uniwersytecie „zaognienie polityczne [...], ten nastrój i ograniczenie wszelkich zainteresowań do spraw politycznych i sprawy żydowskiej [...]. Sprawa żydowska postawiona na ostrzu noża i biedny Łukasiewicz ma ciężki rektorat wobec ciągłych manifestacji uniwersyteckich przeciwko Żydom i wobec żądań studentów, by ograniczyć ich dostęp do uniwersytetu do 11\%"623. Antysemityzm, który nasilił się na uczelni w latach zo., nie stanowił więc w istocie żadnego novum, nabrał jedynie nowego rozmachu.

Antysemityzm przybierał na Uniwersytecie zróżnicowane formy. Najłagodniejszą i najpowszechniejszą z nich były uprzedzenia wyniesione z domów rodzinnych i środowisk socjalizacji, za którymi nie szedł jednak w parze czynny udział w rozruchach i innych wystąpieniach. Osoby im ulegające postrzegały żydowskich kolegów jako obcych, często zapewne również jako niebezpieczną konkurencję na uczelni, a w przyszłości na rynku pracy, ale nie angażowały się w politykę, albo przynajmniej, z przyczyn takich jak strach, wrodzona bierność, skrupuły moralne, brak czasu itp., nie uczestniczyły czynnie w ekscesach organizowanych przez radykalną prawicę. Można je porównać, oczywiście toutes proportions gardées, do świadków (bystanders), o których mówimy w kontekście Zagłady Żydów podczas II wojny światowej. Ich postawy przybierały szereg różnych odcieni: od odruchów współczucia dla prześladowanych 
Żydów, przez obojętność wobec ich losu, aż po skrywane lub uzewnętrzniane zadowolenie. Zawsze jednak były równoznaczne $\mathrm{z}$ faktycznym przyzwoleniem na antysemickie awantury prawicy.

Maria Rutkowska, mimo iż na studiach była ściśle związana z OWP, a następnie z ONR, a więc niewątpliwie akceptowała antysemicki program tych organizacji, była poruszona brutalnymi napaściami na żydowskich studentów, a po latach umiała zdobyć się na krytyczną autorefleksję: „walka tocząca się wokół sprawy «numerus clausus» [...] miała akcenty dla mnie bardzo przykre. Widziałam raz jeden w gmachu Wydziału Medycznego przy ulicy Oczki bójkę na schodach: tędzy bojówkarze spychali stopień po stopniu broniących się przeciwko temu czarnowłosych żydowskich studentów. Pamiętam, że wyszłam stamtąd oburzona. Tłumaczono mi potem, że bójki wynikają z gorącości młodych temperamentów i że przecież do bójek nikt nikogo nie zachęca" ${ }^{\prime \prime 24}$.

W przeciwieństwie do niej, większość przedwojennych studentów albo w ogóle nie wspomina antysemickich ekscesów, albo czyni to zdawkowo i bez emocji, podkreślając swój dystans wobec opisywanych wydarzeń. „Utarczki czynne na terenie Uniwersytetu zastały mnie właściwie «zdziwionego» tym, co się dzieje" - wzmiankuje jeden z prawników $^{625}$. Z kolei jego kolega trzymał się od nich z daleka, ponieważ doradzono mu, „aby izolować się od wszystkich ruchów politycznych"626. Nie była to przestroga pozbawiona sensu, wziąwszy pod uwagę, iż prawicowe bojówki bez skrupułów nie tylko atakowały na uczelni Żydów, lecz także terroryzowały Polaków. Studentka, która po wprowadzeniu getta ławkowego (przypadkowo zresztą) usiadła po stronie wyznaczonej dla Żydów, usłyszała od jednego ze swoich kolegów: „Koleżanka ma piękny nosek [...]. Szkoda byłaby, gdyby uległ zmasakrowaniu...”627.

Jeszcze inni studenci UW, nawet z perspektywy kilku dziesięcioleci, wykazują wciąż pewne zrozumienie dla antysemickich rozruchów. „Dla mnie osobiście antyżydowskie ekscesy na wyższych uczelniach były zawsze odrażające. Nie brałem nigdy w nich udziału" - zapewnia Władysław Siła-Nowicki. Wcześniej racjonalizuje jednak panujące na Uniwersytecie nastroje, powołując się na nadreprezentację Żydów wśród wykształconych warstw społeczeństwa: „Oczywiście rozróżnianie uprawnień do wstępu do szkół średnich, a szczególnie do wyższych, dla różnych ze względu na narodowość grup ludności godziło w zasadniczy sposób w demokrację. Ale... ale życie ma swoje prawa. [...] Nie powiem więc, że słuszne, ale zrozumiałe były w tej sytuacji żądania wprowadzenia numerus clausus". Nieco dalej określa on przemoc wobec Żydów mianem „dziecinnej zabawy” w porównaniu z tym, co przynieść im miała okupacja niemiecka. Swoje słowa ubarwia anegdotą 


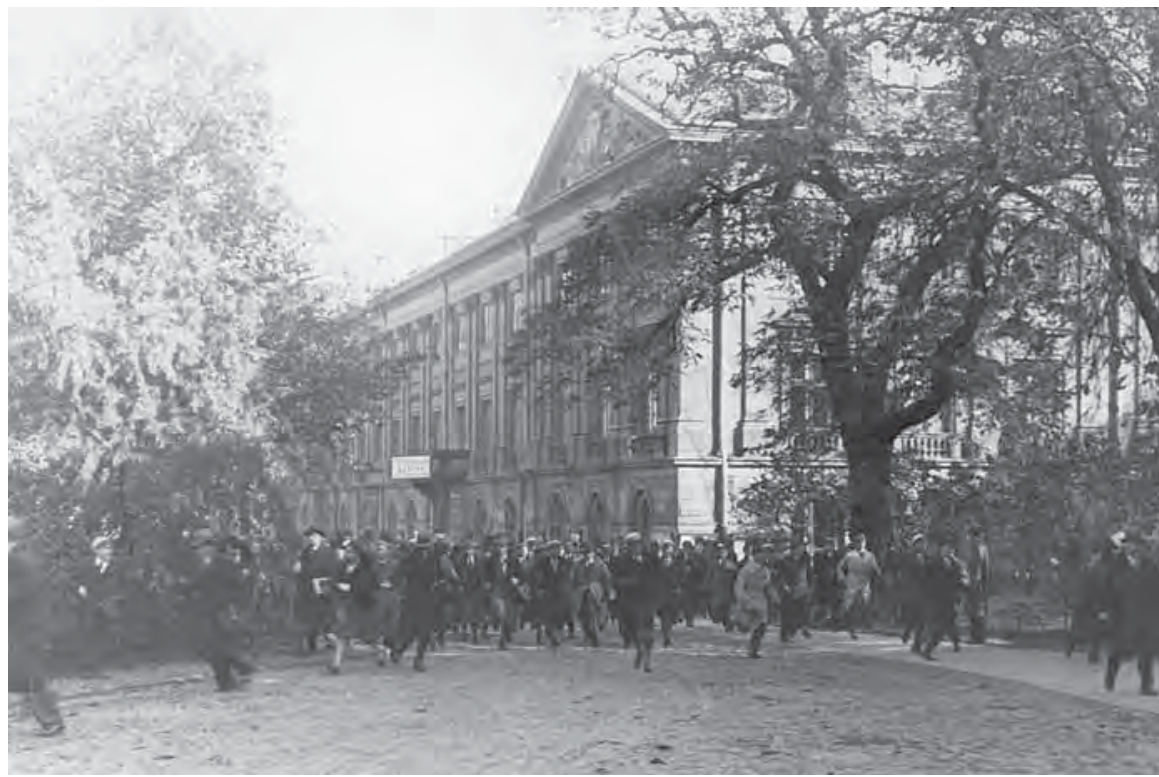

77. Zamieszki na terenie Uniwersytetu, październik 1933 r.

o Żydzie, któremu w czasie wojny śni się piękny sen, „co nas polskie studenty biły....", bagatelizując w ten sposób wagę całego problemu ${ }^{628}$. Jak wykazała ankieta przeprowadzona wśród studentów przez „Gazetę Polską" w kwietniu 1937 r., polscy studenci, podobnie jak Siła-Nowicki, najczęściej nie pochwalali antyżydowskich burd radykalnej prawicy, ale podzielali pogląd o nadmiarze Żydów na wyższych uczelniach $^{629}$. Zastrzeżenia nie dotyczyły więc celu, jakim było pozbycie się z Uniwersytetu osób pochodzenia żydowskiego, a jedynie sposobu jego osiągnięcia. W praktyce przeciw pałkarskim metodom protestowano jednak niezwykle rzadko, co pozwala sądzić, że milcząco akceptowano je jako nieuchronne.

Skądinąd nawet studenci, o których aktywnym udziale w antyżydowskich rozruchach wiemy z innych źródeł, po latach woleli przemilczeć ten fakt. Jan Barański, relegowany z Uniwersytetu za przewodzenie okupacji Auditorium Maximum w 1937 r., w napisanych po wojnie wspomnieniach odżegnuje się od rasizmu i nienawiści do Żydów, zapewniając, iż „żądania studenckie oparte były [...] nie na żadnych, ani rasistowskich, ani też antyżydowskich zasadach, ale na celach ekonomicznych dla zachowania równowagi etnicznej w Polskim życiu narodowym, zgodnym z tradycjami polskiego liberalizmu i tolerancji”630. Nie powinien nas jednak zmylić brak relacji pamiętnikarskich, których 
autorzy jednoznacznie przyznawaliby się do antysemickich poglądów. Większość uczestników ówczesnych ekscesów na Uniwersytecie, spisując po wojnie swe wspomnienia, musiała doskonale zdawać sobie sprawę, iż po Zagładzie publiczne deklarowanie antysemityzmu stało się moralnie naganne, a tym samym kompromitujące. Stąd też występowania postaw takich możemy się tylko domyślać po przemilczaniu stosunku do Żydów, pomniejszaniu znaczenia rozruchów, albo uzasadnianiu ich, jak w przypadku Barańskiego i Siły-Nowickiego. Wnikliwsi obserwatorzy tamtych wydarzeń nie mieli jednak wątpliwości, że antyżydowskie rozruchy milcząco popierała nie tylko większość studentów, ale także duża część kadry naukowej i personelu uniwersyteckiego. Ludwik Krzywicki, obserwujący ówczesne wydarzenia nieco z boku jako kontraktowy wykładowca UW, zauważa: „Profesorowie, którzy mieli odwagę wystąpić publicznie w prasie lub podczas wykładów, mogli być pewni, że w razie napaści ze strony młodzieży nie zawsze znajdą sympatyczne poparcie ze strony pozostałych kolegów - jedni z nich sympatyzowali z awanturującą się młodzieżą, [drudzy - P.M.M.] woleli zachować się

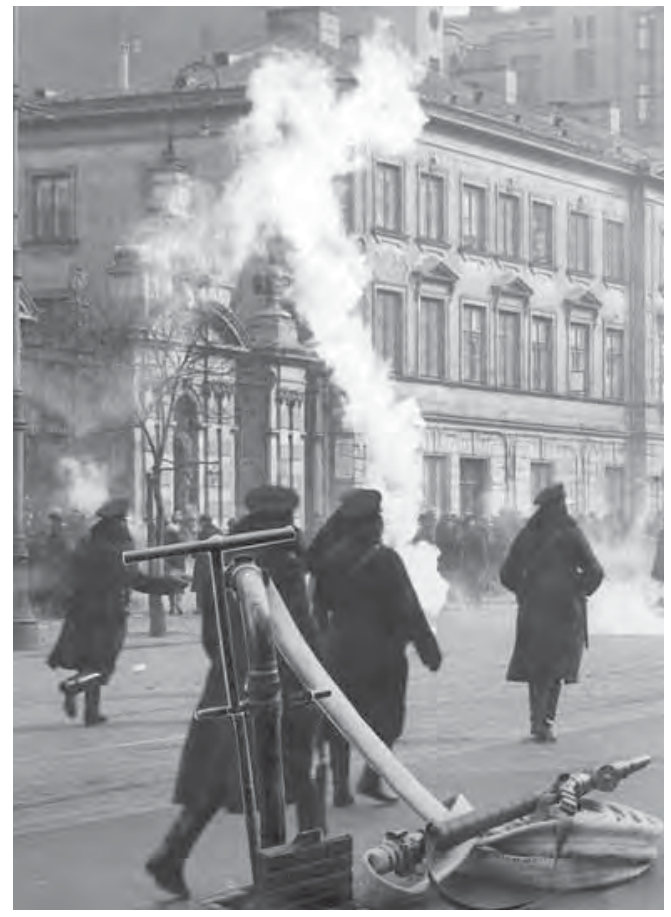

78. Policja rozpędza zamieszki studenckie na Krakowskim Przedmieściu za pomocą gazu łzawiącego i wody z motopompy, marzec $1931 \mathrm{r}$. biernie, gdyż po co im... wtykać palce pomiędzy drzwi. A w końcu część służby w zakładach uniwersyteckich i prawie cały ogół urzędników raczej współczuł z młodzieżą, zwłaszcza tam, gdzie przeważały kobiety, a szczególnie panienki jako sekretarki, urzędniczki itd. ${ }^{631}$ " Podobnego zdania na temat postawy większości swych kolegów byli profesorowie Czarnowski, Kotarbiński i Szymanowski ${ }^{632}$.

Także wiele innych faktów potwierdza, że kadra naukowo-dydaktyczna Uniwersytetu Warszawskiego - z pewnymi wyjątkami, o których będzie mowa dalej - zachowywała obojętność wobec losu Żydów i, nazywając rzeczy po imieniu, wyznawała w sporej części poglądy antysemickie, nawet jeśli w większości nie akceptowała brutalnych metod radykalnej prawicy. Przede wszystkim niekonsekwentnie i nieudolnie, a czasami nawet przyzwalająco zachowywały się 
względem rozruchów władze uczelni. Gdy w listopadzie $193^{1}$ r. narodowcy wywołali antyżydowskie zamieszki na Uniwersytecie i przyległych ulicach, zmartwieniem rektora Łukasiewicza, który sam nie zdołał opanować sytuacji na terenie głównego kampusu, było, aby „policja na ulicach używała wody oraz innych łagodnych środków podczas wyprawianych przez studentów ulicznych ekscesów"1633. Kilka lat później, po najgwałtowniejszych w dwudziestoleciu międzywojennym zamieszkach na Uniwersytecie, które zakończyły się 25 XI 1937 r. odbiciem przez policję gmachu Auditorium Maximum z rąk okupujących go prawicowych bojówek, rektor Antoniewicz napisał w swym sprawozdaniu, iż brutalne zachowanie młodzieży akademickiej „powinno ustać raz na zawsze, gdyż walkę o słuszne postulaty można prowadzić tylko słusznymi i nienagannymi środkami". Przytaczane przez niego w tym samym dokumencie dane pokazują, że sprawców przemocy potraktowano nad wyraz pobłażliwie. Wprawdzie aż $25^{2}$ najbardziej aktywnych bojówkarzy stanęło przed specjalną komisją dyscyplinarną powołaną przez MWRiOP, ale wydawane przez nią wyroki były bardzo niskie; z Uniwersytetu trwale relegowano tylko nielicznych prowodyrów. Jeszcze łagodniej postąpiły władze uczelni: spośród 94 sprawców, którzy trafili przed sędziów uniwersyteckich ukarano tylko 22, kolejnym 18 zaś udzielono upomnień rektorskich. Antoniewicz nie omieszkał jednocześnie zaznaczyć, że w poprzednich latach wśród uczestników antypaństwowych wystąpień studenckich było aż $94 \%$ Żydów, czym mimochodem pośrednio uzasadniał prawicowe ekscesy zagrożeniem ze strony „żydokomuny”634. Z pełnym zrozumieniem „do poczynań na rzecz utrzymania narodowego stanu posiadania w stosunku do etnicznie obcej mniejszości narodowej - w państwie polskim w ogóle, a na uczelni w szczególności" podchodził również audytor, odpowiedzialny za przestrzeganie prawa na terenie Uniwersytetu, zachęcając jedynie młodzież do większej „przezorności w wyborze środków działania”635.

$\mathrm{Z}$ innych zachowanych świadectw wynika, że także inne postępowania w sprawie ekscesów antysemickich prowadzone były przez władze uniwersyteckie niemrawo lub stronniczo. (Podobnie zresztą nie spieszyły się z ich rozpatrywaniem sądy powszechne, przed którymi latem 1939 r. toczyło się wciąż 50 spraw studentów UW, w tym najstarsza sprzed 5 lat) ${ }^{636}$. Polska studentka Wydziału Matematyczno-Przyrodniczego zeznająca przeciwko jednemu z prawicowych słuchaczy, Edmundowi Zadzierskiemu, który przemocą wyrzucił jej koleżankę-Żydówkę z audytorium, została potraktowana przez sędziego prof. pastora Karola Michejdę jak osoba niepoważna i niewiarygodna; audytor kilkakrotnie podnosił na nią głos, zarzucał kłamstwa, a jej zachowanie uznał za 


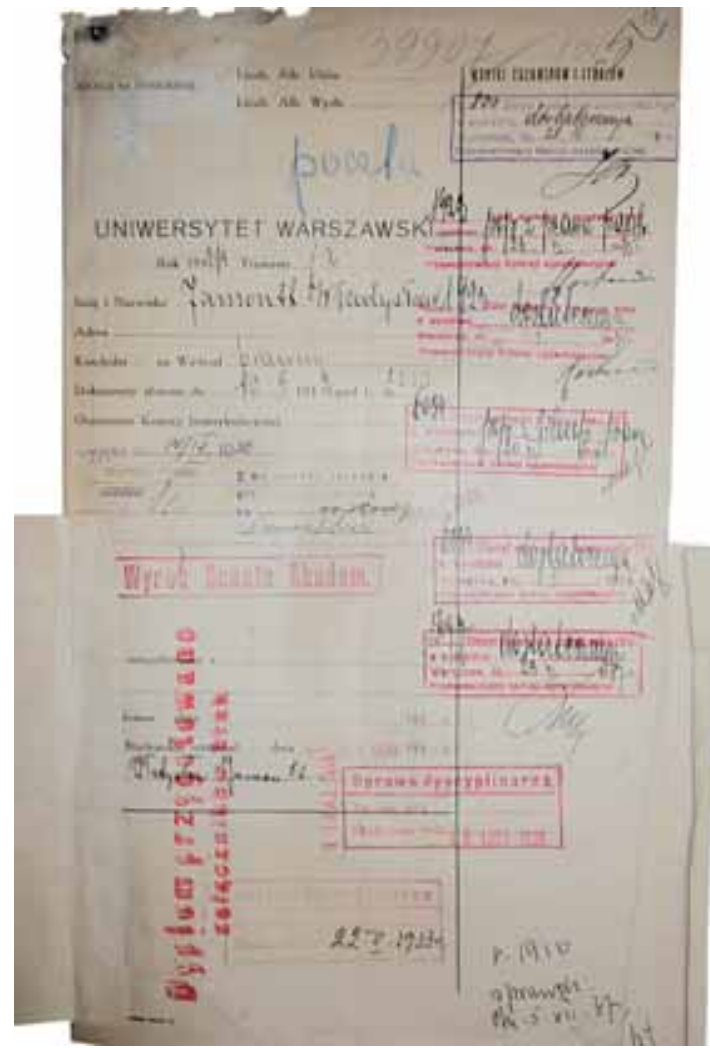

79. Studenckie akta osobowe Władysława Jamontta zaangażowanego w działalność radykalnej prawicy, $\mathrm{z}$ adnotacjami o prowadzonych przeciw niemu postępowaniach dyscyplinarnych wyzywające. Do sprawcy zajścia odnosił się natomiast $\mathrm{z}$ kurtuazją, pozwalając mu np. bezkarnie insynuować, iż świadek jest komunistką̨ ${ }^{637}$.

Przede wszystkim jednak ogromnej większości przypadków napaści na żydowskich studentów w ogóle na Uniwersytecie Warszawskim nie ścigano, mimo że były to często brutalne pobicia z użyciem kastetów, pałek i żyletek, kończące się hospitalizacją ofiar. Śledztw jednak nie podejmowano, zadawalając się zrzuceniem winy na „nieznanych sprawców”. Nie wdrożono też jakichkolwiek procedur, które zapewniłyby bezpieczeństwo potencjalnym ofiarom, jak chociażby wprowadzenie na teren kampusu posterunku policyjnego, co bezskutecznie postulował prof. Kotarbiński ${ }^{638}$. Rozwiązanie takie uznano za naruszające autonomię Uniwersytetu, ale było w tym wiele hipokryzji. „Nie lubiłem tego wyrazu «autonomia» - napisał później prof. Hirszfeld. „Kryła się za nim obłuda, zacofanie lub niedołęstwo. Autonomia powinna chronić indywidualność naukową badacza, a nie wybryki. Studenci biją na śmierć swoich kolegów, profesorowie demokraci są zmuszeni uciekać przez okno, ażeby ich rozwydrzona smarkateria nie pobiła, a rektorzy rozpływają się w przemówieniach swych nad kochaną młodzieżą i nie wpuszczają policji, która zrobiłaby porządek" ${ }^{039}$.

Pobłażanie wybrykom radykalnej prawicy jaskrawo kontrastowało ze stanowczością, z jaką na Uniwersytecie Warszawskim ścigano wykroczenia spowodowane przez Żydów. Przekonała się o tym studentka Wydziału Prawa Cywja Asterblum, która w 1936 r. miała nazwać prawicowych bojówkarzy „polskim bydłem”. (Według jej własnej wersji, wyraziła się "Co za bydło", a sama została pobita przez polskie koleżanki). Została za to natychmiast zawieszona przez rektora w prawach studenta, a następnie oskarżona przed sądem powszechnym 


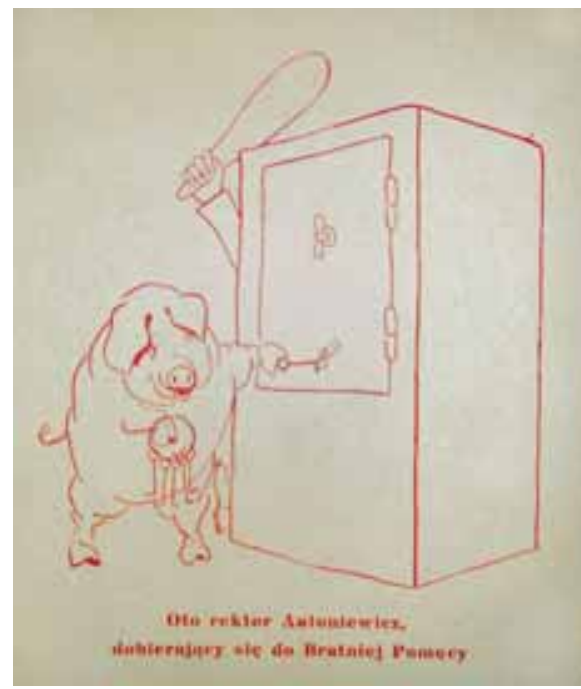

8o. Karykatura wymierzona w rektora Włodzimierza Antoniewicza, rozpowszechniana na Uniwersytecie przez prawicę o lżenie narodu polskiego i, po wydaniu prawomocnego wyroku (2 miesiące więzienia), pozbawiona przez uniwersytecką komisję dyscyplinarną prawa studiowania w jakiejkolwiek szkole wyższej ${ }^{640}$. Krytyków takiej polityki skutecznie kneblowano. Kiedy w październiku 1936 r. docent Wydziału Matematyczno-Przyrodniczego Aleksander Rajchman opublikował w prasie list otwarty zarzucający władzom UW świadome tolerowanie przemocy ze strony prawicy, został natychmiast zawieszony przez Senat Akademicki jako pracownik naukowy pod zarzutem, iż „wystąpieniem swym naraził powagę i dobro Uniwersytetu". Wdrożono przeciw niemu postępowanie dyscyplinarne, a rektor Antoniewicz przesłuchiwał go niczym pospolitego przestępcę ${ }^{641}$.

W kontekście postawy władz Uniwersytetu Warszawskiego względem zajść antysemickich nie sposób też pominąć wprowadzenia na uczelni 5 X 1937 r. getta ławkowego. Słuchacze wyznania mojżeszowego mieli odtąd zasiadać w ławach nieparzystych, chrześcijanie - w parzystych. Zarządzenie nakazywało informowanie władz uczelni o przypadkach niestosowania się do obowiązującej odtąd na uczelni segregacji, a opornym groziło karami dyscyplinarnymi ${ }^{642}$. Decyzję o wprowadzeniu getta ławkowego podjął rektor Antoniewicz, działając w porozumieniu z władzami innych szkół wyższych i za przyzwoleniem MWRiOP. Uzasadniał ją koniecznością uspokojenia w ten sposób wrzenia panującego wśród studentów, a także „powszechnym pragnieniem studentów Polaków do siedzenia oddzielnie od studentów Żydów, którzy dobrowolnie na to nie chcieli się zgodzić" ${ }^{643}$.

Wprowadzenie getta ławkowego stanowiło w istocie definitywną kapitulację władz akademickich przed coraz radykalniejszymi i coraz bardziej pewnymi siebie organizacjami prawicy nacjonalistycznej, które już wcześniej próbowały przemocą zmusić studentów wyznania mojżeszowego do zasiadania w oddzielnych ławach ${ }^{644}$. Niezależnie od deklarowanych przez rektora intencji było ono równoznaczne $\mathrm{z}$ formalnym uznaniem przez Uniwersytet Warszawski antysemityzmu jako zasady obowiązującej w życiu społeczności akademickiej. Zarządzenie sankcjonowało prawnie segregację rasową, co stało w sprzeczności z konstytucją państwa. W wymiarze praktycznym pogarszało diametralnie 


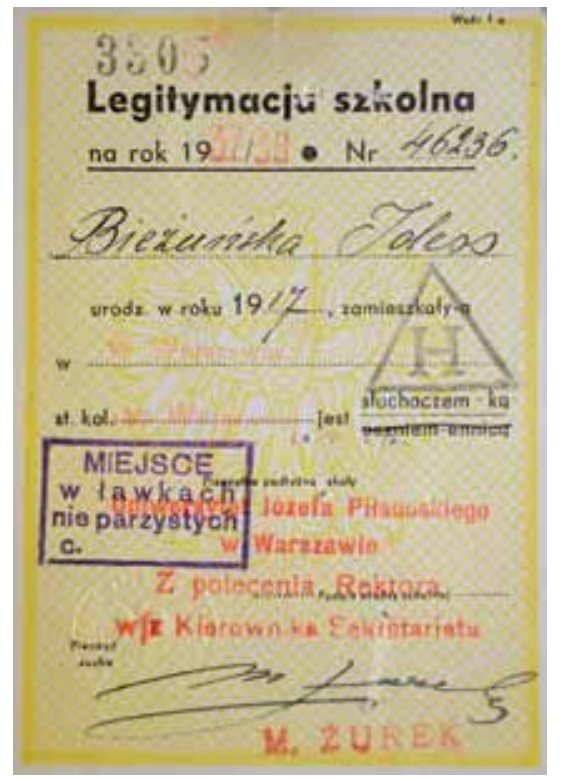

81. Legitymacja studencka Idess (Izabeli) Bieżuńskiej na rok akademicki 1937/1938 z pieczątką "miejsce w ławkach nieparzystych" położenie studentów pochodzenia mojżeszowego, których łatwo było zidentyfikować na podstawie wbijanych $w$ indeksach stempli z napisem „Miejsce w ławkach nieparzystych”. Bojówkarze zajmujący się pilnowaniem „prawidłowego" zasiadania w salach mogli odtąd w majestacie prawa brutalnie wyrzucać z ławek słuchaczy o semickich rysach. Od jesieni 1938 r. również władze uczelni zaczęły zresztą egzekwować przestrzeganie podziału na ławki parzyste i nieparzyste, m.in. zawieszając w prawach studenckich Żydów odmawiających zasiadania na wyznaczonych im miejscach ${ }^{645}$.

O ile pobłażliwą postawę władz uniwersyteckich wobec awanturujących się studentów tłumaczyć można by jeszcze nieudolnością, zamiarem wyciszenia rozruchów za wszelką cenę albo fałszywie pojmowaną troską o dobre imię uczelni, o tyle względy takie nie krępowały poszczególnych wykładowców, którzy mogli na różne sposoby przeciwstawiać się antysemityzmowi. Zdarzało się to dość rzadko, bywało jednak skuteczne. Profesor Hirszfeld wspomina na przykład, iż odmówił podporządkowaniu się zarządzeniu o wprowadzenia getta ławkowego. „Pamiętam, jak przyszedł do mnie starosta farmaceutów i zapytał, czy będą wprowadzone oddzielne ławki dla Żydów. Odpowiedziałem, że nie, że nie zastosuję się do zarządzenia rektora i że wysunięcie tej sprawy zrobiłoby mi przykrość. «Rozumiem, panie profesorze, za chwilę to załatwię». I więcej nie było o tym mowy"646. Brak jest także jakichkolwiek świadectw, aby do antyżydowskich awantur dochodziło w Zakładzie Fizyki Doświadczalnej, kierowanym przez prof. Pieńkowskiego. "Postawa ludzi nadających ton Hożej po prostu je odrzucała” - podsumował krótko jeden z ówczesnych studentów ${ }^{647}$.

Przeciwko gettu ławkowemu najbardziej stanowczo występowano na Wydziale Humanistycznym. Jego wprowadzeniu sprzeciwiali się publicznie m.in. profesorowie Kotarbiński, Czarnowski, Stanisław Arnold, Handelsman i doc. Maria Ossowska, a Rada Wydziału zwróciła się do rektora Antoniewicza z rezolucją potępiającą dyskryminację Żydów jako niemoralną i sprzeczną z konstytucją ${ }^{648}$. Wzbierającej fali szowinizmu oparło się środowisko Instytutu Historycznego ${ }^{649}$. Również psycholog Stefan Baley oświadczył studentowi, który domagał się, by 


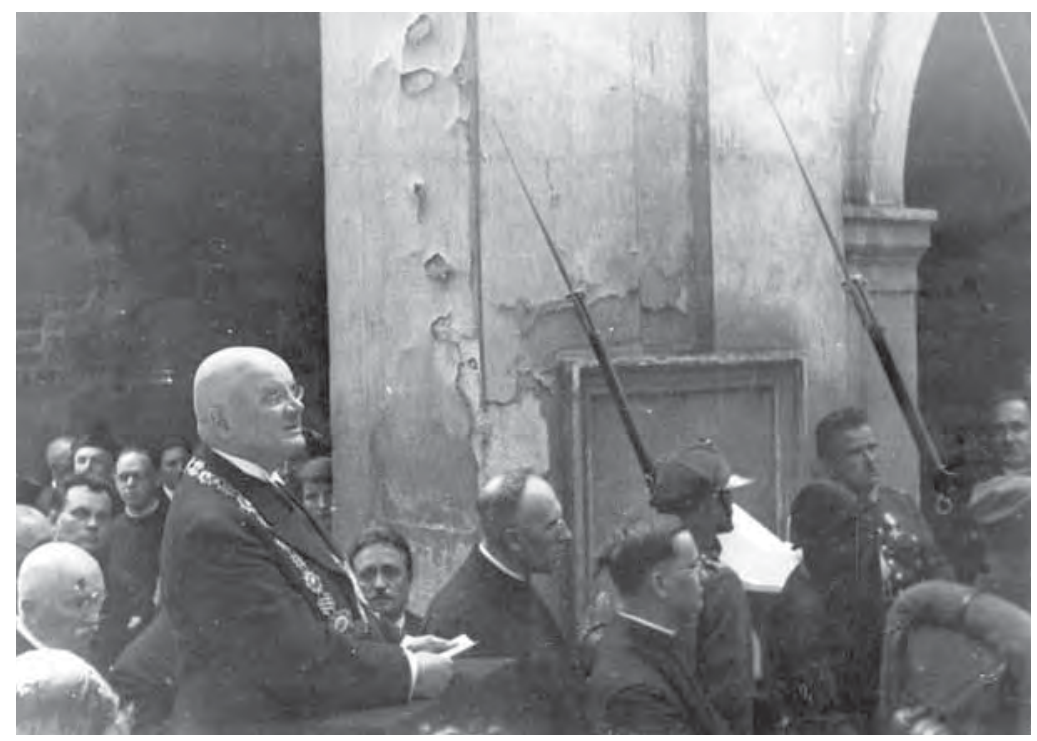

82. Rektor

Mieczysław Michałowicz przemawia podczas pogrzebu ministra wyznań religijnych i oświecenia publicznego Sławomira Czerwińskiego, 7 VIII $1931 \mathrm{r}$.

Żydzi siedzieli osobno, „bo to jest gorsza rasa”: „Proszę pana, niech pan opuści salę. Uprzedzam, że u mnie pan magisterium nie zrobi, niech się pan gdzie indziej zapisze" ${ }^{650}$. Wszystkie powyższe przypadki nie oznaczały rzecz jasna pełnej jednomyślności Wydziału Humanistycznego wobec antysemityzmu. W grudniu 1938 r. jego rada z trudem i dopiero po długiej debacie przyjęła rezolucję potępiającą kolejną falę antyżydowskich ekscesów na uczelni. Jeden z dyskutantów sprzeciwiał się np. określeniu ich epitetem „opłakane”, retorycznie dociekając: „Czy kto nad nimi płakał?"'651.

$\mathrm{Na}$ Wydziale Lekarskim stanowczo protestował przeciw gettu ławkowemu prof. Mieczysław Michałowicz, zabierając w tej sprawie głos również jako senator Rzeczpospolitej. Solidaryzowali się z nim profesorowie Szymanowski i Franciszek Venulet ${ }^{652}$. W grudniu 1937 r. pod listem otwartym przeciwko wprowadzenia getta podpisało się 20 profesorów i 6 docentów Uniwersytetu Warszawskiego ${ }^{653}$. Biorąc pod uwagę, iż w tym czasie na uczelni pracowało 312 samodzielnych pracowników naukowych, była to jednak zdecydowana mniejszość.

Wykładowców, którzy zdecydowali się w tej sprawie zabrać głos publicznie, regularnie napadała prawicowa prasa studencka, wymyślając im od masonów i szabesgojów ${ }^{654}$. Pod ich adresem, a także ku przestrodze tym, którzy zechcieliby się do nich przyłączyć, formułowano niedwuznaczne pogróżki: „Wyraźnie trzeba stwierdzić, że podobne wystąpienia [...] nie mogą się powtórzyć. Albo ci panowie będą 
profesorami, będą służyć nauce polskiej, albo niech już dziś zrezygnują i inaczej zabezpieczą swój byt materialny, np. przez wyjazd do czerwonej Hiszpanii lub Tel Avivu, gdzie chętnie przez Żydów zostaną przyjęci". Tej i podobnym jej publikacjom towarzyszyły listy pracowników naukowych UW, których żydowskie korzenie ujawniano bądź insynuowano. (W ich układaniu pomagali ponoć niektórzy profesorowie-Polacy) ${ }^{655}$.

Żadne przykrości nie spotykały natomiast tych wykładowców, którzy nie kryli swej niechęci do Żydów, ani poparcia dla ich dyskryminacji. Po wprowadzeniu na Uniwersytecie w październiku 1937 r. getta ławkowego szerokim echem odbiła się zwłaszcza postawa ówczesnego dziekana Wydziału Prawa, znanego polityka narodowej demokracji Romana Rybarskiego, który odmówił zaliczenia swego wykładu żydowskim studentom, słuchającym go na stojąco w proteście przeciw decyzji rektora. Sprawa oparła się o Ministerstwo, które nakazało wszczęcie przeciw profesorowi postępowania dyscyplinarnego. Rybarski wytłumaczył się jednak, iż protestujący nie uczęszczali wystarczająco regularnie na jego wykład i w geście dobrej woli zaproponował udzielenie im zaliczenia po przedłożeniu dodatkowego referatu, co rektor Antoniewicz uznał za w pełni satysfakcjonujące ${ }^{656}$. Zadowolenia z wprowadzenia getta nie ukrywali też inni wykładowcy ${ }^{657}$. Jeden z nich umówił się ponoć nawet z oenerowcami, iż spóźni się na wykład o 15 minut, aby mogli oni w tym czasie oczyścić salę z Żydów ${ }^{658}$. Sam rektor Antoniewicz nie zaliczał się bynajmniej do zwolenników endecji, a jedynie był zręcznym konformistą, płynącym z głównym nurtem polityki. Wręczając tego samego roku doktoraty honoris causa ministrowi Beckowi i marszałkowi Śmigłemu-Rydzowi, będące wyrazem uznania za ich rolę w odebraniu Czechosłowacji Zaolzia, zakończył przemówienie nie tylko gromkim „Maszerować!", ale również apelem do polskiej młodzieży, „by pracowała pilniej, albowiem na uniwersytet wstępuje dziesięć procent Żydów, a kończy go dwadzieścia pięć procent". Zostało to nie bez słuszności odebrane przez część słuchaczy jako wypowiedź o wyraźnym podtekście antysemickim ${ }^{659}$.

Obok niezaliczenia wykładu przez prof. Rybarskiego przeciwnikom getta ławkowego najgłośniejszym przypadkiem dyskryminacji słuchaczy wyznania mojżeszowego na Uniwersytecie Warszawskim była tzw. sprawa zwłok żydowskich. Spowodowało ją niewywiązywanie się przez kahały z obowiązku dostarczania odpowiedniej liczby trupów do zajęć prosektoryjnych na Wydziale Lekarskim, w efekcie czego w listopadzie 1926 r. kierownik Zakładu Anatomii Prawidłowej prof. Edward Loth odmówił udostępnienia preparatów studentom pierwszego roku wyznania mojżeszowego. (Wychodził z kuriozalnego dziś założenia, usankcjonowanego wkrótce potem decyzją Senatu UW, że studenci 


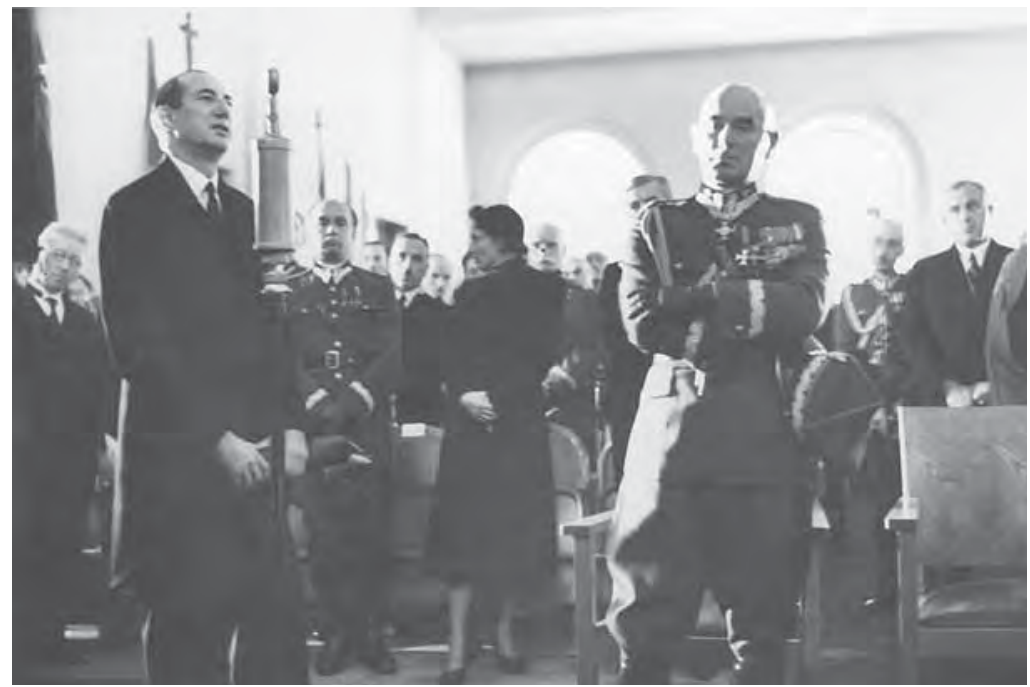

83. Uroczystość nadania doktoratów honoris causa marsz. Edwardowi Śmigłemu-Rydzowi (po prawej) i ministrowi Józefowi Beckowi podczas inauguracji roku akademickiego $1938 / 1939$.

Żydzi mogą ćwiczyć wyłącznie na zwłokach osób własnej narodowości, których pozyskiwanie napotykało jednak, z przyczyn religijnych, na poważne przeszkody). Skarga Żydowskiego Stowarzyszenia Medyków na postępowanie wykładowcy została uznana przez niego za kłamliwą, czego nie potwierdziło jednak postępowanie wyjaśniające, prowadzone przez specjalnie powołaną komisję Rady Wydziału. Loth uparcie nie przyjmował do wiadomości jej kolejnych uchwał, w których komisja żądała natychmiastowego umożliwienia pracy w prosektorium studentom obu wyznań. Domagał się natomiast wytoczenia skarżącym go Żydom spraw dyscyplinarnych. Zatarg trwał przez kilka tygodni i został zażegnany dopiero dzięki pojednawczej postawie dziekana Jerzego Modrakowskiego i innych członków komisji. Awantura zakrawała na czarną komedię, w której z dokładnością do 1/4 części ludzkiego ciała przeliczano korpusy, głowy, kończyny oraz zwłoki noworodków, ale jej istota dotyczyła bardzo poważnej, choć niewyartykułowanej na razie otwarcie przez żadną ze stron kwestii, czy studentom żydowskim przysługują takie same prawa jak chrześcijańskim ${ }^{660}$.

Zwycięstwo przeciwników jawnej dyskryminacji w tej konkretnej sprawie nie przesądzało niestety ani późniejszej postawy innych wykładowców, ani polityki całego Wydziału Lekarskiego. Awantury w prosektoriach powtarzały się w następnych latach, a ich polityczny charakter stał się aż nadto oczywisty. Pojawiające się przy takich okazjach ulotki przedstawiały sprawę zwłok żydowskich jako „zniewage wszystkich akademików Polaków” i zapowiadały „nasze z Żydami porachunki”661. 


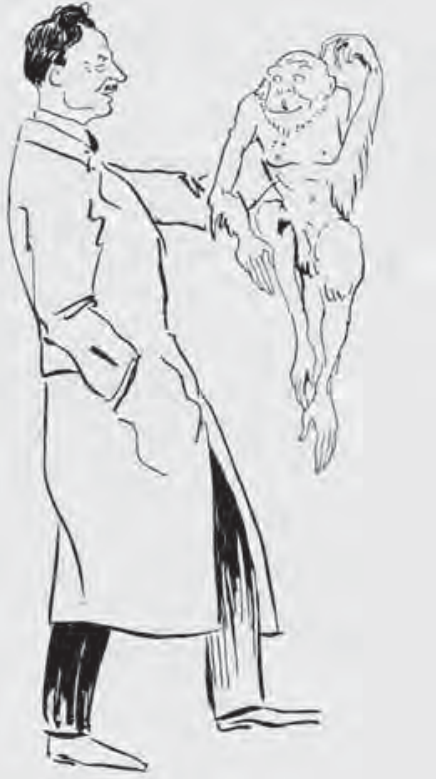

84. Profesor Edward Loth z Wydziału Lekarskiego w karykaturze

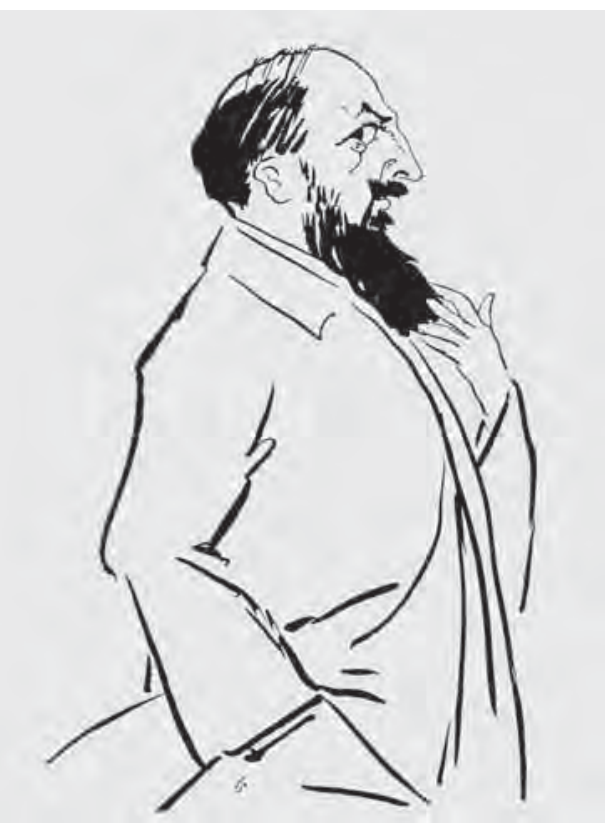

85. Karykatura profesora Jerzego Modrakowskiego z Wydziału Lekarskiego

W tych okolicznościach w listopadzie 1931 r. ówczesny dziekan wydziału prof. Ludwik Paszkiewicz uległ żądaniom prawicy, nakazując, aby żydowskim studentom udostępniać tylko zwłoki ich współwyznawców ${ }^{662}$.

Profesor Loth jesienią $193^{2}$ r., celowo zignorował polecenie dziekana, aby nie wpuszczać na teren swego zakładu podejrzanych osobników niebędących studentami medycyny, czym wydatnie ułatwił prawicowym bojówkarzom wszczęcie rozruchów w gmachu Collegium Anatomicum $^{663}$. Ów wybitny chirurg, ulubieniec polskich studentów, szczery patriota, oficer II Brygady Legionów, bohater wojny polsko-bolszewickiej, a później także Polski podziemnej, odznaczony krzyżem Virtuti Militari i czterokrotnie Krzyżem Walecznych, nie zaliczał się wcale do zwolenników radykalnej prawicy. Jego antysemityzm miał, można by rzec, charakter autonomiczny i wynikał zapewne z rasistowskiego światopoglądu - Loth był jednym z czołowych propagatorów eugeniki w ówczesnej Polsce ${ }^{664}$.

Co charakterystyczne, większość profesorów unikała jednak otwartego wyrażania poparcia dla getta ławkowego i publicznego atakowania Żydów ${ }^{665}$. Antysemityzm wśród kadry naukowej Uniwersytetu był przeważnie maskowany hipokryzją, jak to bywa pomiędzy ludźmi kulturalnymi. Jeden z krytyków getta ławkowego, prof. Manfred Kridl 
z Uniwersytetu Stefana Batorego (wcześniej pracujący na UW), nazwał go antysemityzmem „etycznym”: „Antysemita «etyczny» sam nie bije Żydów, ani nie rozbija sklepów żydowskich, ale rzadko kiedy zdobędzie się na potępienie takich czynów, boi się opinii kumoszek i pałkarzy, więc zawsze stara się znaleźć jakieś okoliczności łagodzące, jakieś usprawiedliwienie, boleje, roztkliwia się, może nawet prawić morały, ale w rezultacie rozkłada ręce i biernie przygląda się widowisku. Umie w przedziwny sposób łączyć kulturę osobistą i humanitaryzm w ogóle z pogardą dla Żydów [...]" ${ }^{\text {"666 }}$.

Antysemityzm był więc wśród kadry naukowej UW z jednej strony zjawiskiem dość częstym, z drugiej - nie tak powszechnym, ostentacyjnym i agresywnym, jak w przypadku studentów. Niektórzy naukowcy nie obnosili się w ogóle ze swoimi poglądami, jak wyrafinowany intelektualista Wacław Borowy, któremu dopiero w dziennikach zdarza się tu i ówdzie ujawnić antysemickie uprzedzenia („spacer po zażydzonych ulicach tej uroczo położonej miejscowości”, „Prawie same Żydy. Z rzadka zobaczysz twarz polską. [...] Wśród kup śmieci - cheder: grzeczne małe Żydki...”, „,...wstępujemy na obiad do fantastycznego «Zawiercia», wspaniale urządzonego i zaludnionego obskurnymi Żydami"). Ten sam Borowy daje jednak w innym miejscu wyraz swemu niesmakowi, komentując antyżydowskie ekscesy przechodniów po rozruchach studenckich na Uniwersytecie w listopadzie 1938 r.: „Wyszedłszy wieczorem na przechadzkę, widzę na Marszałkowskiej coś, czego mi się jeszcze widzieć nie zdarzyło. Idzie jakiś jegomość przyzwoicie (choć trochę dziwacznie) ubrany i pluje przed każdym spotkanym Żydem, a do tych, którzy go mijają, przegaduje najgorszymi wyzwiskami. Strasznieśmy zdziczeli"'667. Najwyraźniej nawet osobom niewolnym od antysemickich uprzedzeń pewne zachowania nie mieściły się jednak w głowie. Niewykluczone przy tym, że ta sama „potęga smaku”, która nie pozwalała zaakceptować brutalnych form antysemityzmu, powodowała lepiej lub gorzej skrywaną niechęć do Żydów - zwłaszcza tych słabo zasymilowanych, drażniących akademicką elitę ostentacyjną innością, niepoprawną polszczyzną, hałaśliwym zachowaniem, zacofaniem itp. Czy postawę taką można nazwać antysemityzmem? Małgorzata Szpakowska w pracy poświęconej „Wiadomościom Literackim” zwraca uwagę, że podzielała ją często również zasymilowana inteligencja pochodzenia żydowskiego, np. Antoni Słonimski, który potrafił pisać o „chałaciarskim smrodzie” i brutalnie wykpiwać żydowski przesąd i obskurantyzm. „Z dzisiejszej perspektywy nie brzmi to dobrze" - podsumowuje badaczka, podkreślając jednocześnie, iż po Zagładzie stosunek do szeroko rozumianej kultury żydowskiej zmienił się diametralnie, ulegając daleko idącej 
idealizacji i sentymentalizacji ${ }^{668}$. Także tę okoliczność należy, jak sądzę, uwzględnić analizując postawy pracowników naukowych Uniwersytetu, które bywały niekiedy złożone i niejednoznaczne: niechętne Żydom, a zarazem odległe od wojującego antysemityzmu.

Bardzo trudno jest orzec, czy poza sytuacjami kryzysowymi, do jakich niewątpliwie zaliczały się awantury w prosektoriach i dotyczące ustanowienia getta ławkowego, antysemityzm wykładowców przejawiał się na co dzień wyraźnie niesprawiedliwym ocenianiem studentów wyznania mojżeszowego, otwartym szykanowaniem ich albo utrudnianiem im nauki w inny sposób. $Z$ pojedynczych wspomnień polskich możemy się dowiedzieć, iż nawet profesorowie znani z niechęci do Żydów starali się obiektywnie egzekwować ich wiedzę. Przykładem miał być Rybarski, który według relacji jednego z prawników oblał zarówno dwóch chaotycznie odpowiadających Żydów, jak i członków ONR, którzy „licząc na prawicowe nastawienie Profesora, żywili nadzieję, że znaczki organizacji (mieczyki Chrobrego) skompensują niedostatek wiadomości" ${ }^{669}$. Trudno to potwierdzić, gdyż nie dysponujemy wynikami z egzaminów, uwzględniającymi wyznanie zdających, ale wydaje się, że etos nauczyciela akademickiego mógł brać w niektórych przypadkach górę nad antysemityzmem. Z drugiej strony, nieobecność wzmianek o dyskryminacji studentów żydowskich nie przesądza sprawy i może wynikać z niepełnego charakteru materiału źródłowego, który w przypadku słuchaczy wyznania mojżeszowego niemal nie istnieje.

Brak jest także relacji dokumentujących, aby antysemityzm był przyczyną otwartych konfliktów w łonie kadry naukowej Uniwersytetu Warszawskiego. Być może, mimo powszechności uprzedzeń wobec Żydów, obowiązujące na uczelni normy środowiskowe nie pozwalały, aby dawać temu otwarcie wyraz w stosunkach służbowych i towarzyskich. Jak dowodzą cytowane już przeze mnie wcześniej wspomnienia doc. Michalskiego, z pewnością interesowano się, kto ma żydowskie pochodzenie, lecz nie natrafiłem na relacje, aby kogoś z tego powodu obrażano lub dyskryminowano. Napaść studentów na prof. Handelsmana, niezależnie od przeważających wśród profesury sympatii narodowych, spotkała się z niemal jednomyślnym potępieniem, co pozwala sądzić, iż solidarność zawodowa była silniejsza niż niechęć wobec kolegów pochodzenia żydowskiego.

Inną sprawą pozostaje, czy Żydzi mieli takie same szanse jak Polacy, by w ogóle rozpocząć pracę na Uniwersytecie. Jak już zostało powiedziane w rozdziale poświęconym kadrze naukowo-dydaktycznej, według rozpowszechnianych przez radykalną prawicę materiałów, pod koniec lat 3o. miało pracować na uczelni ok. 60 osób pochodzenia żydowskiego. 
Liczba ta była niemal na pewno zawyżona. Przyjmując jednak nawet, iż byłyby to dane wiarygodne, oznaczałyby one, że osoby pochodzenia żydowskiego stanowiły na Uniwersytecie Warszawskim ok. 10\% pracowników naukowych, czyli mniej więcej tyle, ile wynosił odsetek Żydów w skali państwa i znacznie mniej niż ich odsetek wśród ogółu inteligencji kraju. Innymi słowy, wbrew temu, co uparcie powtarzała propaganda endecka, pisząca o „zażydzeniu” uczelni, osoby pochodzenia żydowskiego były na Uniwersytecie angażowane rzadziej niż wynikałoby to z potencjału intelektualnego tej grupy ludności. Aleksander Hertz wspomina w tym kontekście bezskuteczne próby zatrudnienia się na uczelni w latach 30. przez Rafała Blütha, katolickiego publicysty, konwertyty z judaizmu. „Nazwisko Rafała, jego pochodzenie i wygląd w żadnym wypadku nie były w Polsce okolicznościami ułatwiającymi karierę naukową" - twierdzi ${ }^{670}$.

Diagnozę tę potwierdza opisana w jednym z wcześniejszych rozdziałów próba przyznania w 1919 r. katedry Szymonowi Askenazemu na Wydziale Prawa, którą zablokowali przeważający wśród tamtejszej profesury sympatycy prawicy nacjonalistycznej. U podłoża ich postawy leżało niewątpliwie pochodzenie Askenazego, choć w tym przypadku najprawdopodobniej nałożyło się na nią rozpowszechnione przekonanie o jego związkach z masonerią, które próbował, z odwrotnym oczywiście efektem, dementować. Endecki publicysta Adolf Nowaczyński ukuł mu nawet przezwisko „Aszkemason Szymonazy"671.

Ocena polityki zatrudnienia wobec Żydów wykracza oczywiście poza problematykę stricte uniwersytecką i wymaga dopiero szczegółowego zbadania, gdyż wpływ na decyzje uczelni miało także MWRiOP. W każdym razie, wraz z nasilaniem się antysemickich ekscesów w drugiej połowie lat 30. również wśród pracowników naukowych UW pochodzenia żydowskiego narastały obawy o własną przyszłość. „Zobaczymy zapewne i «oczyszczanie» ciała profesorskiego" - ostrzegał w liście do „Naszego Przeglądu” w listopadzie 1937 r. doc. Rajchman ${ }^{672}$. Nie były one bezpodstawne. Żądanie usunięcia z uczelni wykładowców pochodzenia żydowskiego stopniowo przesączało się z pisemek radykalnej prawicy do programów innych grup interesów. W lutym 1939 r. paragraf aryjski uchwaliło Zrzeszenie Asystentów UJP, zwracając się jednocześnie do rektora „o nieprzyjmowanie na stanowiska profesorów, docentów, adiunktów i asystentów osób pochodzenia żydowskiego" ${ }^{\prime 673}$.

Chociaż antysemityzm kadry naukowej UW nie przybierał form bardzo drastycznych, nie należy lekceważyć jego negatywnego wpływu na kulturę polityczną uczelni. Tolerowanie przez władze rektorskie i sporą część profesury ekscesów antyżydowskich, a także odnoszenie 
się ze zrozumieniem do „słusznych postulatów” polskiej młodzieży, umacniało radykalną prawicę $\mathrm{w}$ przekonaniu, iż racja znajduje się po jej stronie, a przede wszystkim zapewniało jej niemal całkowitą bezkarność. Efektem była postępująca radykalizacja tendencji antysemickich na Uniwersytecie, którą trafnie przewidział na początku lat 30 . Żongołłowicz. Nieliczne kontrprzykłady dowodzą, że mogło stać się inaczej, gdyby profesorowie częściej potępiali antysemityzm i próbowali zaszczepić wśród polskich studentów tolerancję i „parę nadrzędnych wartości humanizmu", które, jak wspominał po latach Aleksander Gieysztor, w dużym stopniu uodporniły środowisko historyczne na tę dolegliwośćc74. Jego nieco starszy kolega z seminarium Handelsmana, Tadeusz Manteuffel opisuje na przykładzie własnej ewolucji poglądów, jak wielką pozytywną rolę w kształtowaniu studenckich postaw mogli odegrać wykładowcy: „,[...] Ulegałem wpływom nacjonalizmu. Te zręby światopoglądowe pod wpływem przeżywanej rzeczywistości zaczynały się jednak kruszyć. [...] Wpłynęły na to zarówno kontakty z kolegami pochodzenia semickiego, jak z prof. Handelsmanem"675.

Antysemityzm dużej części kadry naukowej i większości polskich słuchaczy Uniwersytetu Warszawskiego tworzył sprzyjający klimat dla antyżydowskich ekscesów, które wszczynała na uczelni prawica nacjonalistyczna. Sami sprawcy, jak dostrzegali niektórzy obserwatorzy, po prostu wykorzystywali tę okoliczność, dążąc przy okazji rozprawy z Żydami do destabilizacji sytuacji w kraju. „Endecja zrozumiała, że hasła antysemickie nadawały się w roli środka do opanowania tłumów i rozkołysania namiętności, młodzież zaś akademicka miała spełnić rolę przedniego zastępu w tym uderzeniu na rząd hasłami przeciw Żydom" - uważał Ludwik Krzywicki ${ }^{676}$. Nie oznacza to oczywiście, iż działająca na Uniwersytecie prawica nie była antysemicka, a jedynie wyczulona na problemy wynikające z dużego odsetka Żydów w państwie, jak sugerują dziś niektórzy jej apologeci ${ }^{677}$. Niewątpliwie podzielała ona antyżydowskie uprzedzenia, którym hołdowała większość studentów, a niektórzy jej przedstawiciele owładnięci byli wręcz obsesyjną nienawiścią do Żydów (casus Alfreda Łaszowskiego). Decyzje podejmowane przez jej przywódców miały jednak charakter przemyślanej strategii, której ostatecznym celem było przejęcie władzy w Polsce i urzeczywistnienie własnych koncepcji politycznych i ustrojowych. Żydzi padliby z pewnością w pierwszej kolejności ich ofiarą, ale pogromy nie stanowiły dla nacjonalistycznej prawicy celu samego w sobie. Według relacji Władysława Jana Grabskiego, związanego w latach zo. z ONR, nawet przywódca „Falangi” Bolesław Piasecki traktował hasła antysemickie czysto instrumentalnie, „miał opinię człowieka pozbawionego zupełnie 


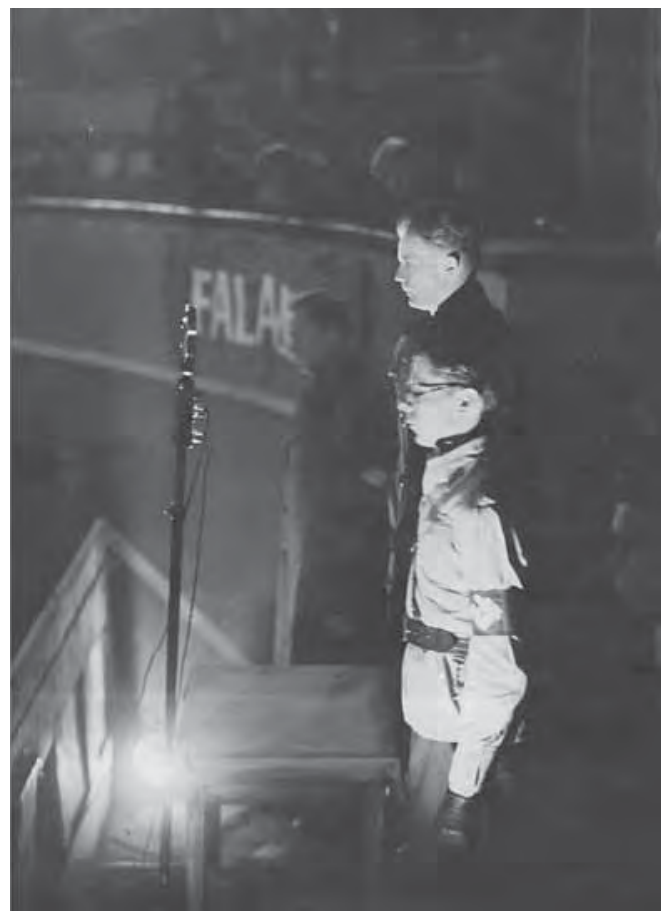

86. Bolesław Piasecki (w tle) przemawia na zebraniu Ruchu Narodowo-Radykalnego „Falanga”, Warszawa 28 XI $1937 \mathrm{r}$. emocji w tym kierunku". Jan Józef Lipski, który zasłyszał tę wypowiedź i przeanalizował publicystykę ONR, stawia w związku z tym diagnozę, iż antysemityzm był „świadomie, z premedytacją - zarówno poglądem, programem jak i socjotechniką, połączoną z programowym stosowaniem obfitego repertuaru brutalnych metod"678. Pogląd ten można, jak przypuszczam, rozciągnąć na zdecydowaną większość działających na uczelni ugrupowań nacjonalistycznych.

Uniwersytet Warszawski, gdzie podobnie zresztą jak na innych wyższych uczelniach panował antysemityzm, miał przy tym jeszcze inne zalety z punktu widzenia tej cynicznej strategii. Żydzi znajdowali się w mniejszości, byli przeciwnikiem łatwo rozpoznawalnym i niemal zupełnie bezbronnym, a konieczność respektowania przez policję państwową eksterytorialności uczelni zapewniała na ogół sprawcom całkowitą bezkarność. Jak zauważa jeden z historyków przedwojennej społeczności żydowskiej, „napadano więc na Bogu ducha winnych Żydów, zahukanych i najsłabszych. Natomiast bano się zaczepiać silnych tragarzy i bojówkarzy żydowskich organizacji socjalistycznych"679.

Nie ulega wątpliwości, że antysemityzm był bardzo skutecznym instrumentem eskalowania napięć na Uniwersytecie Warszawskim i w innych szkołach wyższych. Świadczy o tym chociażby porównanie liczebności działających na terenie uczelni prawicowych ugrupowań radykalnych, która w latach 30. nie przekraczała 2\% ogółu słuchaczy, z rozmiarami rozruchów, przyciągających setki, jeśli nie tysiące studentów $^{680}$. Z pewnością nie wszyscy ich uczestnicy brali czynny udział w napaściach na żydowskich kolegów, ale tłum zapewniał wsparcie moralne i poczucie przewagi liczebnej tym, którzy dopuszczali się bezpośrednich aktów przemocy. Jak się wydaje, granica między sprawcą a bystanderem była zresztą bardzo często płynna: skandowanie antysemickich haseł, kolportowanie wydawnictw, okazywanie Żydom pogardy, a nawet sama obecność na nielegalnych manifestacjach stanowiły 
formę współuczestnictwa w ekscesach i łatwo mogły przerodzić się w bardziej aktywny współudział w postaci blokowania bramy Uniwersytetu, osaczania żydowskich studentów itp.

Było znanym faktem, że przywódcy prawicy nacjonalistycznej unikali stawania w pierwszym szeregu demonstrantów, obawiając się zapewne ewentualnych represji ze strony władz państwowych. „[...] Prowodyrzy, jak Słomiński, Kurcjusz na ulice nie wychodzą, lecz kierują ruchawką z domów u telefonów, zaś sztab główny - Dmowski, Stroński, Rybarski itd. nie dają się ująć" - zanotował w $193^{2}$ r. Żongołłowicz ${ }^{681}$. Rolę oddziałów uderzeniowych pełniły natomiast podczas ekscesów dobrze zorganizowane i zaprawione w ulicznych starciach bojówki, składające się częściowo ze studentów UW, a częściowo rekrutowane za pieniądze poza uczelnią z różnorakich mętów społecznych. Ich członkowie stanowili, według relacji Wasiutyńskiego, „element odważny, nic nie mający do stracenia i mało zainteresowany ideologią, poza tym, że nie lubił $\dot{Z} y-$ dów i policji” ${ }^{\prime 62}$. Antysemickie zamieszki zapewniały im sposobność, aby rozrabiać na ulicach, podobnie jak dzisiaj czynią to pseudokibice i inni „zadymiarze” przy okazji imprez sportowych i uroczystości publicznych.

Rekrutów dostarczały bojówkom młode roczniki studentów, wyjątkowo liczne zwłaszcza na Wydziale Prawa ${ }^{683}$. Chociaż w ówczesnej prasie lewicowej pojawiały się głosy, iż zamieszki antyżydowskie były dziełem „paniczyków” - młodzieży z zamożnych domów, która szukała w ten sposób rozrywki, albo celowo wręcz odwracała uwagę klas upośledzonych od prawdziwych problemów społecznych ${ }^{684}$, sytuacja była najpewniej bardziej złożona. Uprawniona wydaje się hipoteza, iż wśród demonstrujących znajdowało się sporo studentów wywodzących się ze zubożałej inteligencji i „właścicieli mniejszych”, często z prowincji, którzy Żydów uważali za groźną konkurencję i przyczynę pauperyzacji swych rodzin, szczególnie w dobie wielkiego kryzysu gospodarczego. Niektórzy z nich już podczas nauki w gimnazjach znaleźli się w kręgu oddziaływania ideologii endeckiej. Przykładem może być wspominany już wcześniej przeze mnie Jan Barański, wywodzący się z niezbyt zamożnej chłopskiej rodziny spod Częstochowy, który wyróżniał się podczas studiów aktywnością $\mathrm{w}$ organizowaniu antyżydowskich ekscesów $^{685}$. Niezależnie od motywacji społecznych i światopoglądowych, rozruchy stanowiły dla młodych ludzi, na ogół niemających wcześniej żadnej styczności z wielkim światem, niewątpliwą atrakcję: znajdowali się nagle w centrum ogólnokrajowych wydarzeń politycznych, walcząc, jak wierzyli, po słusznej stronie w obronie polskości.

Analizując przyczyny panujących na uczelni nastrojów antysemickich należy zwrócić uwagę również na bardzo silnie rozpowszechniony 
wśród studentów Uniwersytetu mit „żydokomuny”. Był on propagowany m.in. przez działaczy Bratniej Pomocy, którzy przedstawiali żydowskich słuchaczy uczelni jako wrogów niepodległości i zwolenników utworzenia polskiej republiki rad, strasząc „olbrzymim niebezpieczeństwem grożącym ze strony żydowstwa Polsce” w postaci „dążeń żydów do zrealizowania idei swego państwa na terytorjum pasa idącego od morza Bałtyckiego po Czarne, obejmującego Polskę i Ukrainę, (bez Poznańskiego i Pomorza)”. Jednocześnie Żydzi stanowić mieli „czynnik niesłychanego rozkładu kultury, etyki i moralności życia polskiego, w sposób coraz bardziej arogancki - dążąc do opanowania całkowicie tego życia" ${ }^{\prime 686}$. Nawet po wojnie, gdy jawne manifestowanie antysemityzmu stało się niepoprawne politycznie, niektórzy uczestnicy antyżydowskich zamieszek pisali wciąż bez skrępowania o działającej w latach 3o. na Uniwersytecie „żydokomunie”, na potwierdzenie słuszności swych postaw przytaczając nowe argumenty w postaci „Światły, Borejszy, Minca, Bermana, Modzelewskiego i wielu innych", którzy „prześladowali Naród Polski, nie wyłączając rasistowskich mordów, w stylu Hitlera" ${ }^{\prime 687}$.

Utożsamianie Żydów z bolszewizmem - na Uniwersytecie podobnie jak w całym społeczeństwie - miało źródło w nadreprezentacji osób tej narodowości w ruchu komunistycznym. Była ona faktem także w działającym w warszawskim środowisku akademickim ZNMS „Życie”, w którym młodzież pochodzenia żydowskiego stanowiła ok. $75 \%$ członków. Wśród ówczesnych studentów UW znajdowali się m.in. przyszli prominentni działacze komunistyczni tej narodowości Jakub Berman i Jacek Różański czy stalinowska prokurator Helena Wolińska, których postaci do dziś przywoływane są na potwierdzenie tezy o istnieniu „żydokomuny". (W aktach uniwersyteckich brak jest nota bene śladów, by $\mathrm{w}$ czasie studiów otwarcie manifestowali swe poglądy) ${ }^{688}$. Wbrew temu, co insynuowała prawica, nie oznaczało to jednakże, iż wszyscy studenci-Żydzi sympatyzowali z komunizmem. Według szacunków z końca lat 30., w ruchu komunistycznym działało ok. 400 słuchaczy wszystkich wyższych uczelni w stolicy, w tym najwięcej właśnie na Uniwersytecie $^{689}$. Komunistów żydowskiego pochodzenia mogło zatem studiować na UW nie więcej niż 150-200, co odpowiadało 10-15\% ogółu żydowskich studentów w tamtym czasie. Pozostali byli w większości zwolennikami syjonizmu, wobec którego komuniści zachowywali wrogośćc ${ }^{60}$. Nie każdy Żyd był więc komunistą, ani nie każdy komunista Żydem. Tych, którzy byli i jednymi, i drugimi, można było jednak spotkać na uczelni wystarczająco często, aby zapewnić propagandzie antysemickiej pretekst do piętnowania ogólu Żydów jako bolszewików 
i wrogów niepodległości. Stereotyp taki miał wielką siłę oddziaływania ze względu na patriotyczne nastroje większości studentów.

Od początku lat 30 . aż do wybuchu wojny, poza rokiem akademickim 1934/1935, który wyjątkowo upłynął niemal bez zakłóceń porządku, zamieszki na Uniwersytecie Warszawskim miały najczęściej bardzo podobny scenariusz. Do największych dochodziło na jesieni, a istotną rolę w ich eskalowaniu odgrywały celebrowane przez narodowców uroczystości ku pamięci studenta Stanisława Wacławskiego, który zginął 10 XI $193^{1}$ r. w Wilnie, obrzucając się kamieniami ze studentami żydowskimi. (Rok później panteon prawicy akademickiej powiększył się o studenta Grotowskiego ze Lwowa, był on jednak nieco gorszym kandydatem na męczennika ruchu studenckiego, gdyż został zabity przez żydowskiego sutenera w domu publicznym, w efekcie kłótni o prostytutkę) ${ }^{691}$.

Rozruchy wybuchały na ogół albo bezpośrednio po mszy świętej w intencji Wacławskiego odprawianej w kościele św. Anny przy Krakowskim Przedmieściu, albo po wykładach dla pierwszego i drugiego roku prawa prowadzonych w sali pobliskiego kina Urania przez prof. Jarrę, nazywanego ponoć z racji takiej prawidłowości „katalizatorem", mimo iż odżegnywał się od antysemickich intencji ${ }^{692}$. Miejsce i czas rozpoczęcia ekscesów nie były przypadkowe. Początek roku akademickiego gwarantował wysoką frekwencję uczestników (później, jak pamiętamy, studenci masowo opuszczali wykłady), a msza lub popularny wykład ułatwiały zgromadzenie dużej liczby słuchaczy w centralnej części miasta. Wkrótce potem tłum studentów ruszał w kierunku głównego kampusu, gdzie pod hasłami walki o polskość Uniwersytetu, z okrzykami „Bić Żydów!”, zrywano wykłady i rozpoczynano polowanie na osoby o semickich rysach twarzy, demokratów i komunistów, bijąc i wyrzucając złapanych z terenu uczelni. Zamieszki rozprzestrzeniały się niekiedy również na okolice UW i na jego budynki położone w innych częściach Warszawy, np. Collegium Anatomicum, jak również na domy studenckie i Politechnikę. Trwały zazwyczaj nie dłużej niż dzień lub dwa, gdyż władze rektorskie lub państwowe szybko zawieszały aż do odwołania zajęcia dydaktyczne. W roku akademickim 1936/1937 spowodowane w ten sposób przerwy w nauce trwały a $\dot{z} 4$ tygodnie ${ }^{693}$.

Oprócz tych ponurych rokrocznych juwenaliów, na Uniwersytecie Warszawskim w latach 30. dochodziło również do ekscesów mających inne przyczyny bezpośrednie niż walka z Żydami. W listopadzie 1936 r. zostały one wywołane konfliktem wewnętrznym w szeregach prawicy na tle rysującego się zbliżenia z rządzącą sanacją i przerodziły się, o czym już pisałem wcześniej, w kilkudniową okupację kampusu, zakończoną 


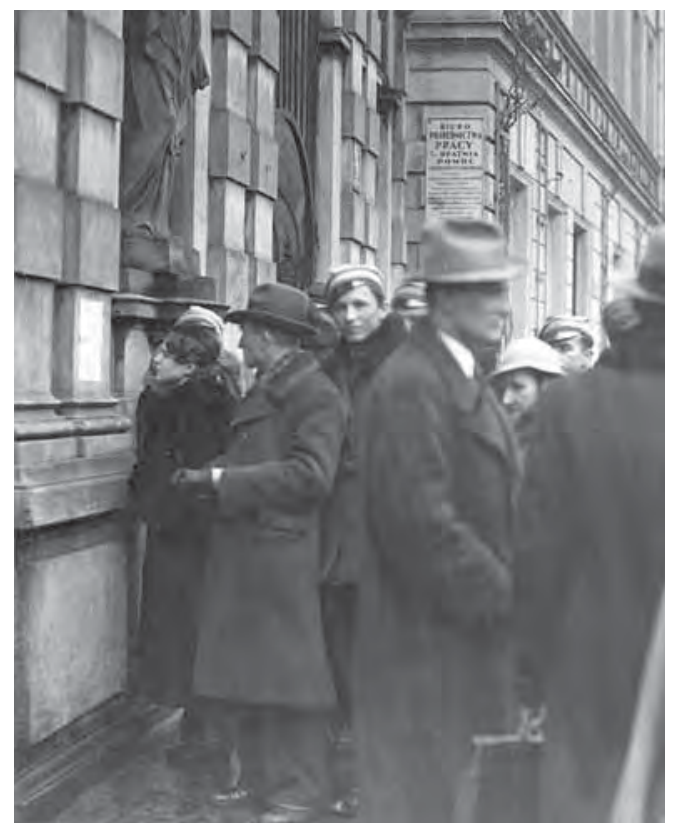

87. Studenci UW czytający przy bramie głównej ogłoszenie o zamknięciu uczelni w związku z rozruchami antysemickimi, marzec 1934, r. dopiero szturmem wezwanej przez rektora policji na budynek Auditorium Maximum $^{694}$. W jej trakcie prawicowi studenci zabarykadowali się na pierwszym piętrze tego gmachu, uprzednio zamykając w piwnicy kobiety i mniej pewnych uczestników blokady; siły porządkowe zmuszone były użyć armatek wodnych. Z kolei w roku akademickim 1932/1933 prawica akademicka organizowała demonstracje przeciwko przygotowywanej przez MWRiOP nowej ustawie o szkolnictwie wyższym (tzw. reformie jędrzejowiczowskiej) i związanym z nią podwyżkom czesnego. Nieodmiennie jednak rozruchom towarzyszyły hasła antysemickie i akty przemocy wobec studentów wyznania mojżeszowego. Od jesieni $193^{6}$ r. do napaści na Ż̀dów dochodziło zresztą właściwie przez cały rok akademicki, bez specjalnych okazji ${ }^{695}$.

Z przedstawionych powyżej faktów wynika dość oczywista konkluzja, iż obok antysemityzmu bardzo istotny rys kultury politycznej Uniwersytetu Warszawskiego stanowiła skłonność do przemocy lub - w przypadku władz rektorskich, kadry naukowo-dydaktycznej i biernej części studentów - do tolerowania przemocy. Mowa jest nie o nagminnej skądinąd przemocy werbalnej czy sztubackich przepychankach, lecz o bardzo brutalnych pobiciach, do których dochodziło w biały dzień, w gmachach uczelni lub na jej głównym kampusie. Jak zostało wspomniane, prawicowe bojówki posługiwały się kamieniami, kastetami, nożami i osadzonymi na kijach żyletkami, a wspomagający je studenci laskami, które z tej racji nazywano „wiecówkami”. (Pojawienie się sprzedawców lasek w pobliżu Uniwersytetu zapowiadało nieuchronne nadejście antyżydowskich ekscesów) ${ }^{696}$. Schwytanych Żydów i przeciwników politycznych oenerowcy przepuszczali niekiedy przez szpaler uzbrojonych w pałki oprawców, czym antycypowali słynne później w czasach komunistycznych „ścieżki zdrowia"697. Jesienią ${ }^{1938}$ r. w gmachu chemii zrzucono człowieka ze schodów łamiąc mu nogę. (Polscy studenci będący świadkami, gdy wynoszono go jęczącego, śmiali się) ${ }^{698}$. Kazimierz Brandys, który podczas studiów działał w lewicowym 


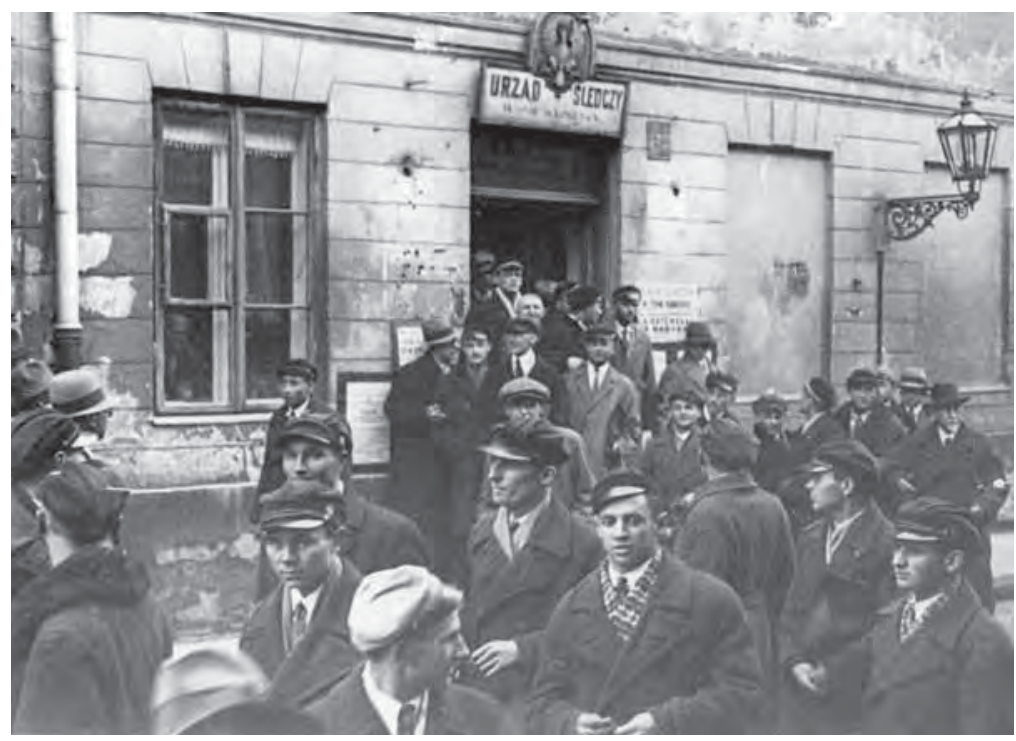

88. Grupa studentów $\mathrm{UW}$, aresztowanych tymczasowo za udział w zamieszkach antyżydowskich, opuszcza Urząd Śledczy przy ul. Daniłłowiczowskiej, listopad $1931 \mathrm{r}$.

Związku Niezależnej Młodzieży Socjalistycznej, wspomina: „Uczestniczyłem w różnych akcjach. Rozkładaliśmy ulotki przed bramą uniwersytetu, na wykładach staliśmy pod ścianą, protestując przeciwko gettu ławkowemu, tworzyliśmy straż porządkową w czasie pochodów i wieców, kolportowaliśmy wieczorami pisma antyfaszystowskie na ulicach Śródmieścia. Zawsze w mniejszości, za każdym razem napadani przez bojówki. Bywało, że z wieczornego kolportażu ten i ów wracał pokrwawiony. Nosiłem przy sobie rewolwer-straszak, który podarował mi Marian, i gumową oponę od wózka dziecinnego. Bojówkarze używali kastetów i linek z żelaznymi kulkami" ${ }^{\text {699 }}$.

O brutalnych metodach prowadzonej przez siebie walki politycznej uniwersytecka prawica mówiła otwarcie, z nieukrywaną wręcz dumą. Działo się tak już w latach 20., kiedy nie doszło jeszcze do gwałtownej eskalacji przemocy na uczelni. Ulotka Młodzieży Wszechpolskiej z maja 1926 r. zachęcała do głosowania na kandydatów tej organizacji do zarządu Bratniej Pomocy, powołując się na ich wyczyny we wcześniejszej bijatyce ze zwolennikami lewicy w budynku filharmonii przy ul. Jasnej: „Czy pamiętacie, jak w spontanicznym wzlocie ducha narodowego licho uzbrojona garstka bohaterów narodowych (kilku zaledwie miało browningi i kastety, reszta musiała sobie radzić laskami i krzesłami), śpiewając pobiła na głowę i resztę zwartą masę uzbrojonych przez Moskwę zamaskowanych krasnoarmiejców. Nie mogąc zamknąć ich w kryminale, uwięźliśmy ich w szpitalach"700. 
U członków działających na Uniwersytecie prawicowych bojówek kilkakrotnie znajdywano broń palną ${ }^{701}$. Na terenie uczelni nie padły wprawdzie od kul żadne ofiary, ale studenci UW posługiwali się nią podczas rozruchów poza murami kampusu. Podczas ataku na legalny pochód Bundu 1 V 1937 r. członek ONR Olejniczak śmiertelnie postrzelił pięcioletniego żydowskiego chłopca i poważnie ranił kilka innych osób, które przypatrywały się manifestacji. Podczas procesu przysłuchujący się rozprawom jego koledzy reagowali śmiechem na zeznania świadków i rodziny ofiary ${ }^{702}$. Inny członek tego samego ugrupowania Władysław Jamontt w maju 1934, r. został aresztowany pod zarzutem udziału w strzelaninie w siedzibie ONR przy ul. Wolskiej. Ponieważ śledztwo przeciw niemu zostało ostatecznie umorzone przez prokuraturę w lutym 1936 r., Sąd Akademicki również zamknął wytoczoną mu sprawę dyscyplinarną ${ }^{703}$. (Gotowość do posługiwania się przemocą pchnęła później Jamontta, już jako oficera podziemia, do zaplanowania i przeprowadzenia w czerwcu 1944 r. mordu politycznego na oficerach Biura Informacji i Propagandy AK Ludwiku Widerszalu i Tadeuszu Makowieckim w 1944, r. - skądinąd pracownikach naukowych Uniwersytetu Warszawskiego $\left.{ }^{704}\right)$.

Radykalna prawica odrzucała jakiekolwiek ograniczenia moralne w posługiwaniu się przemocą. Nie cofała się przed fizyczną napaścią na profesorów, uznawanych przez siebie za wrogów politycznych. Jej bojówki 6 II 1933 r. poturbowały Tadeusza Wałka-Czarneckiego, a w nocy z 14, na 15 III 1934, r. pobiły na terenie UW Marcelego Handelsmana ${ }^{705}$. Profesora Kotarbińskiego, który próbował wylegitymować podczas swego wykładu jednego z prowodyrów zamieszek, „zepchnięto do wolnej przestrzeni w audytorium i przerzucano niby piłkę ${ }^{M 706}$. W listopadzie 1931 r. rozgrzani ekscesami na Uniwersytecie polscy studenci rozpoczęli polowanie na Żydów również poza jego granicami, biorąc na cel żydowskie dzieci w Ogrodzie Saskim, które wyrzucali z wózków ${ }^{707}$. Bez skrupułów, brutalnie bito na uczelni kobiety. Wystarczającym powodem bywał „nieodpowiedni” wygląd, co wywoływało niepokój polskich studentów o niektóre chrześcijańskie koleżanki. „Niepokoiłem się o Murkę. Brunetka z prostym nosem, mogła być łatwo wzięta za Żydówkę. Wiedziałem, że ostentacyjnie siada po stronie lewej. Na szczęście nikt jej nie zaczepił. Widziała jednak na własne oczy, jak bojówkarze bili kolegów i koleżanki do krwi za to, że byli Żydami. Widziała, jak na sali wykładowej zakładu fizyki ściągnęli jej koleżankę-Żydówkę po schodach za włosy" - zapamiętał jeden ze studentów medycyny ${ }^{708}$. Dostępne są również relacje dokumentujące przemoc prawicowych bojówek wobec studentek-Polek, o ile stawały 
one w obronie swych żydowskich koleżanek, nie chciały przestrzegać getta ławkowego itp. ${ }^{709}$

Chociaż akty przemocy były na Uniwersytecie głównie dziełem radykalnej prawicy, posługiwali się nią również jej przeciwnicy polityczni, w tym przede wszystkim lewica. Ich działania miały przeważnie charakter defensywny, lecz i oni niekiedy świadomie prowokowali oenerowców i wszczynali z nimi awantury. Jeden z ówczesnych działaczy ZNMS chełpił się po latach akcją zorganizowaną w odwecie za napad na pochód pierwszomajowy w $193^{6}$ r.: „Młodzież turowska zainicjowała akcję tępienia mieczyków (znaczek w klapie - miecz opleciony wstęgą - «wąż na krzyżu» - jak określaliśmy je szyderczo). Napotkani «narodowcy» zostali pozbawieni noszonych pyszałkowato dekli korporanckich oraz swego godła, znaczka organizacyjnego; a że przy tym ucierpiały nieco (bo zostały poobdzierane) klapy marynarek, to już trudno"710. W tym samym roku, podczas listopadowej blokady Uniwersytetu prowadzonej przez prawicę na teren głównego kampusu wdarła się od strony ul. Oboźnej lewicowa bojówka, która „poturbowała przy odpowiednich okrzykach młodzież endecką i wydostawszy się bramą na Krakowskie Przedmieście zmieszała się z tłumem"711. W obronie własnej siły używali też sporadycznie Żydzi. Jeśli wierzyć relacjom „obwiepolskiej" Bratniej Pomocy, w 1931 r. studentów wyznania mojżeszowego usiłujących sforsować blokadę Uniwersytetu prowadzoną przez prawicowe bojówki wspierali sportowcy z klubu Makabi oraz występujący w cyrkach bokserzy. Również oni mieli używać „wiecówek”712.

Łatwość, z jaką na Uniwersytecie Warszawskim posługiwano się przemocą, miała z pewnością swoje szersze uwarunkowania, wynikające z tendencji występujących wtedy w całym kraju, gdzie konflikty polityczne zbyt często rozwiązywano za pomocą pięści, pałki i karabinu. Prawdą jest, że posługiwała się nią chętnie nie tylko prawica narodowa, ale również rządzący piłsudczycy, nie mówiąc nawet o komunistach ${ }^{713}$. Brak jest na ten temat wiarygodnych danych liczbowych, wszystkie dostępne relacje dokumentują jednak, że na Uniwersytecie zdecydowanie dominowała przemoc prawicowa. Radykalna prawica o coraz bardziej wyraźnych dyspozycjach totalitarnych, dla której, mimo deklarowanego przez nią przywiązania do chrześcijaństwa, cel uświęcał każde środki, nadawała pod tym względem ton kulturze politycznej uczelni. „Na uniwersytecie szefem bojówek «Falangi» był wysoki blady fanatyk, Andrzej Świetlicki [...]. Nie zapomnę jego twarzy o zapadniętych policzkach i pociemniałych oczach, kiedy podnosił z chodnika na lasce moją studencką czapkę, którą zrzucili mi w bójce" - wspomina Kazimierz Brandys, a nieco dalej dodaje: „Znałem oenerowców i komunistów 


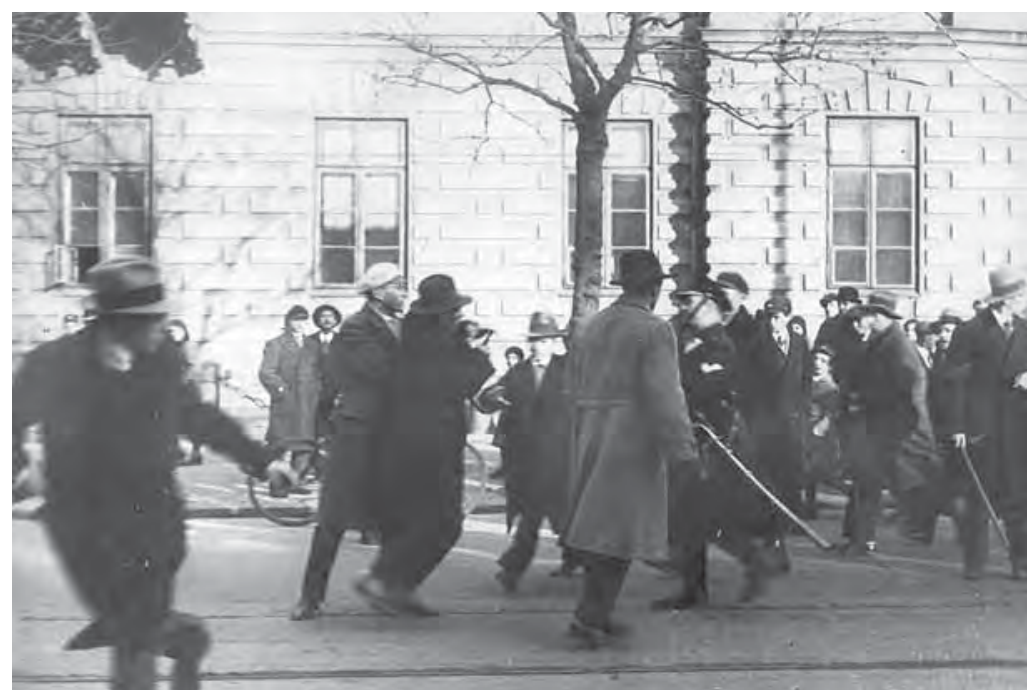

89. Zamieszki przed

Uniwersytetem, listopad $193^{1} \mathrm{r}$.

o twarzach marzycieli. Totalizmy mają swoje słowo pisane oraz siłę działania, tworzące romantyczną sugestię pchnięcia naprzód historii. Jest pewien typ człowieka, który przychodzi na świat z pojęciem historii jako Boga w czasie; w ruchu dziejów widzi cel etyczny, drogę do ideałów. Tacy ludzie często ulegają promieniowaniu totalizmów" "714.

Dodajmy, że ludzi tych zarówno po prawej, jak i lewej stronie sceny politycznej kształtowała w dużej mierze właśnie kultura polityczna Uniwersytetu Warszawskiego. Nadmiernym uproszczeniem byłoby wprawdzie obarczać uczelnię wyłączną odpowiedzialnością za wyhodowanie oenerowskich pałkarzy, z których część, jak zabójcy Ludwika Widerszala i Tadeusza Makowieckiego, nie wahała się w czasie wojny popełniać bratobójczych mordów, ale można z pewnością zastanawiać się, w jakim stopniu panujący na Uniwersytecie klimat polityczny i intelektualny przyczyniał się do rozprzestrzeniania się takich postaw. Niepozbawione sensu wydaje się w tym kontekście również pytanie o wpływ, jaki doświadczenie przemocy i upokorzenia w czasach studiów miało na komunistów żydowskiego pochodzenia takich jak Jacek Różański czy Helena Wolińska, którzy w stalinowskim aparacie represji dopuszczali się później tortur, zbrodni albo mordów sądowych na prawdziwych bądź rzekomych przeciwnikach politycznych. Trudno wreszcie uniknąć refleksji, iż bierność, z jaką większość polskiej społeczności akademickiej obserwowała antyżydowskie ekscesy radykalnej prawicy, przygotowała w pewnym stopniu grunt pod późniejszą obojętność wobec Zagłady. Słowa, które napisano w czasopiśmie Bratniej 
Pomocy jesienią 1937 r. po wprowadzeniu getta ławkowego, okazały się pod tym względem boleśnie prorocze: „Dla Żydów nie ma miejsca w naszym środowisku, oddziela ich od nas drut kolczasty, przez który nikomu nie wolno przechodzić" ${ }^{\prime 15}$.

Agresywny nacjonalizm, antysemityzm i skłonność do przemocy, cechujące kulturę polityczną Uniwersytetu Warszawskiego, niezależnie od istnienia enklaw, w których do końca pielęgnowano wartości humanistyczne, były dotkliwą porażką uczelni jako instytucji powołanej do tego, by krzewić otwartość, tolerancję dla innych poglądów, obiektywizm i dążenie do prawdy. Młodzież przychodząca na Uniwersytet w dwudziestoleciu międzywojennym była już wprawdzie często negatywnie nastawiona do tych wartości, odrzucała „liberalizm, pacyfizm, humanitaryzm, ckliwy patriotyzm, socjalizm i inne wytwory ubiegłego stulecia" "716, ale lata studiów na ogół ją w tej postawie umacniały. Efektem takiej edukacji byli wykształceni barbarzyńcy, których sposób widzenia świata, nieodbiegający wiele od nazistowskiego, dobrze oddaje artykuł w piśmie „Akademik”, opublikowany w odpowiedzi na protest Oskara Langego przeciw w prowadzeniu getta ławkowego: „Jest niepomierną perfidią twierdzenie p. Langego, że ghetto lawkowe... zepchnie do ghetta kulturę polską. Może zepchnie, ale w oczach pp. Einsteinów, Ludwigów, Mannów, Blumów, Zweigów itp. Ale o to nie dbamy" ${ }^{\text {"17 }}$.

Ostatnim elementem kultury politycznej Uniwersytetu Warszawskiego, który wymaga omówienia, jest pozycja kobiet w społeczności akademickiej. Ich coraz liczniejszy napływ na uczelnię, jaki nastąpił w latach 1915-1939, musiał spowodować zmiany również w sferze wyobrażeń na temat roli obu płci, zderzając się z panującymi wówczas stereotypami i normami społecznymi. Biorąc pod uwagę już choćby fakt, że w okresie tym odsetek studiujących na Uniwersytecie pań wzrósł z 10 do $4,2 \%$, zakładać należy przy tym, iż ich sytuacja miała charakter dynamiczny, zmieniając się wraz z postępami emancypacji w całej II Rzeczypospolitej.

W pierwszych latach po uruchomieniu Uniwersytetu uczących się tam kobiet nie traktowano, jak się wydaje, zbyt poważnie, a one same czuły się jeszcze bardzo niepewnie w nowej dla siebie roli akademiczek, zwłaszcza w sytuacjach publicznych. Doskonale pokazuje to relacja Marii Eigerówny, która opisuje reakcje na zgłoszony przez siebie postulat, aby w zarządzie Bratniej Pomocy nie zasiadali wyłącznie mężczyźni: „Z drżeniem serca podałam do prezydium mą karteczkę z prośbą o głos. Gdy po jakimś czasie usłyszałam swoje nazwisko, szłam na mównicę, a podłoga kołysała się pode mną. Miałam wrażenie, że ani jedno słowo nie przejdzie mi przez gardło. Wzięłam się w garść. I oto wszystkie 
oczy skierowały się ku mnie. Nagle szalony wybuch śmiechu zawtórował mym słowom. Studenci zaczęli rzucać głośne uwagi, wykpiwające mój wniosek. Mimo to kończyłam przemówienie, nie bacząc na docinki. A potem jeden mówca po drugim wchodził na mównicę i tak czy owak wyszydzał mój pomysł. Bo i cóż - kobieta do kierownictwa Bratniaka? Studenci też potrafią zadbać o potrzeby koleżanek" ${ }^{\prime 718}$.

Dążenia emancypacyjne musiały jednak nieubłaganie narastać, bowiem w roku akademickim 1931/1932 zarząd Bratniej Pomocy postanowił wprowadzić w swym gronie parytet kobiet, odpowiadający ich liczbie w szeregach tej organizacji. (Było ich wówczas 2586 wśród ogółem 8121 członków). Kobiety zajęły w efekcie 7 spośród 31 stanowisk we władzach Bratniaka, w tym funkcje sekretarza generalnego i jednego z sekretarzy, dwóch spośród czterech członków Sekcji Kwalifikacyjnej, zajmującej się rozdziałem miejsc w domach studenckich, dwóch skarbników i kierownika Sekcji Gospodarczej ${ }^{719}$. Było to wprawdzie wyraźnie mniej niż deklarowany parytet, ale powierzone paniom zdania wskazywały, iż nie potraktowano ich w sposób czysto dekoracyjny.

Pod koniec lat 30 . kobiety zajmowały już w życiu studenckim mocną pozycję, udzielały się w kołach naukowych i organizacjach politycznych, dotrzymywały mężczyznom kroku na wyjazdach naukowych i imponowały błyskotliwością jak prawniczka Irena Szmakfeferówna, „legendarna, jak ją określała Szopka Akademicka «Madame Bufeterfly», z powodu częstego przebywania w bufecie studenckim w gmachu głównym, jedna z najinteligentniejszych koleżanek, jakie spotkaliśmy na studiach, pełna uroku i fantazji, znana nie tylko ze swego dowcipu, ale i wszechstronnego humanistycznego wykształcenia". Stosownie do tych przemian zmieniło się zachowanie mężczyzn, którzy nie mogli traktować już koleżanek z protekcjonalną wyższością lub wyłącznie jako obiektów westchnień. Na niektórych kierunkach, jak np. archeologia czy etnografia, feminizacja postępowała zresztą tak szybko, że to oni znaleźli się w mniejszości ${ }^{720}$. Jak wspomina studiująca wówczas na medycynie Irena Koprowska: „Podczas zajęć mężczyźni traktowali nas po partnersku, ale poza uniwersytetem zachowywali się jak inni młodzi mężczyźni w Polsce - szarmancko i z kurtuazją. Ustępowali nam miejsca w tramwaju, otwierali przed nami drzwi, podawali płaszcz, a zimą nawet pomagali założyć botki" ${ }^{\text {"721 }}$.

Inna sprawa, że nawet pod koniec lat 30. stereotypy kulturowe dotyczące kompetencji i ról społecznych obu płci wciąż jeszcze były w Polsce niezwykle głęboko zakorzenione i w dużej mierze akceptowane przez same kobiety. Jedna ze słuchaczek Wydziału Prawa, Wanda Iwanowska, pochodząca skądinąd z wpływowej warszawskiej rodziny 
(jej ojciec był senatorem RP), podsumowała ówczesne relacje następująco: „do rozumu i uczciwości «chłopców» my, dziewczęta miałyśmy [...] bezgraniczne zaufanie". Dalej, charakteryzując swoją codzienną działalność w Legionie Młodzieży Polskiej, kontynuuje: „Praca czasem długo w noc. Bo «chłopcy» byli niemożliwie zalatani i zdenerwowani. Całą «czarną» robotę jak zawsze zwalali na nas, tylko, że wówczas częściej niż normalnie byli niezadowoleni" ${ }^{\prime 722}$. Mimo przebijającej w tych słowach dyskretnej ironii, zapewne będącej już efektem późniejszych doświadczeń życiowych autorki, nietrudno zauważyć, że nawet w środowiskach postępowych panował model, w którym odpowiedzialne zadania rezerwowali sobie mężczyźni, a kobiety, choć traktowane zazwyczaj z zachowaniem odpowiednich form grzecznościowych, wykonywały bez szemrania niewdzięczne czynności pomocnicze. Kurtuazja wobec płci pięknej nie była zresztą powszechna i bezwarunkowa, zważywszy, iż w tym samym czasie na Uniwersytecie żydowskie studentki bito pięściami po twarzach lub ciągnięto za włosy po schodach.

Wiele wskazuje na to, że znacznie gorzej niż studenci radzili sobie z obecnością kobiet na uczelni niektórzy profesorowie. We wcześniejszych rozdziałach zostało już powiedziane, iż kadra naukowo-dydaktyczna Uniwersytetu była bardzo silnie zmaskulinizowana, a nawet w oficjalnych wystąpieniach rektorskich poddawano jeszcze w wątpliwość sens studiowania przez kobiety, przynajmniej na pewnych wydziałach. Dość rozpowszechnione musiało być również przekonanie, że „panny idą do Uniwersytetu dla złapania męża", skoro po latach prof. Jarra w niewielkich objętościowo i, niestety, mocno ulukrowanych wspomnieniach, poświęcił wiele miejsca polemizowaniu z tą teorią ${ }^{723}$. Myśleli tak jednak z pewnością także niektórzy ówcześni studenci, czego dowodem są wzmianki w ich wspomnieniach o „rozpieszczonych pannicach”, które na Uniwersytet uczęszczały tylko po to, „aby miło spędzać czas, no i może przy okazji złapać kandydata na męża"724. Przypadki opuszczenia uczelni przez słuchaczki wychodzące za mąż utwierdzały oczywiście taki stereotyp.

Zdarzały się sytuacje okazywania przez profesorów antyfeministycznych uprzedzeń, także wobec kobiet zatrudnionych na Uniwersytecie. W $193^{6}$ r., gdy na Wydziale Weterynaryjnym głosowano nad przyznaniem profesury nadzwyczajnej Irenie Maternowskiej, kandydatura ta była kontestowana przez część rady, a dwóch jej członków zgłosiło wręcz wobec niej swe votum separatum ${ }^{725}$. Kilka lat wcześniej Maria Ossowska, będąca wówczas starszą asystentką na Wydziale Humanistycznym, usłyszała w prywatnej rozmowie od prof. Kazimierza Ajdukiewicza: „kobiety nie nadają się właściwie prawie do niczego. 
Są złymi nauczycielkami itd., itd.”. Z jej gorzkiego komentarza, iż „prof. Ajdukiewicz jest w tej sprawie bardziej jeszcze ciasny niż Kotarbiński", wnosić należy, że także ów drugi wybitny humanista o wyraźnie postępowych poglądach nie był wolny od mizoginicznych przesądów ${ }^{726}$.

We wspomnieniach wielu prawników pojawiają się z kolei anegdoty na temat Ignacego Koschembahra-Łyskowskiego, mentalnie należącego wciąż do świata XIX w. (urodził się w 1864, r.), który „obecność pań wśród studiujących uważał wyraźnie za dopust boży", zwracał się do swych słuchaczy wyłącznie per „proszę panów”, a zapytany o przyczyny ignorowania kobiet oznajmiał z irytacją, iż w myśl prawa rzymskiego „panowie obejmują panie”. Według innej opowieści, ten sam wykładowca, najwyraźniej chcąc publicznie zawstydzić jedną ze studentek, miał zadać jej pytanie: „Czy Pani mogłaby w starożytnym Rzymie prowadzić dom publiczny?” W odpowiedzi usłyszał ponoć: „Ja nie, bo jestem niezamężna, ale jeśli chodzi o małżonkę Pana Profesora, to nie byłoby przeszkód". Anegdotka ta, jeśli nawet nieprawdziwa, to na pewno zgrabnie wymyślona, pokazuje nota bene, że nie wszystkie kobiety w latach 30. dawały się już tak łatwo skonfundować mężczyznom ${ }^{727}$.

$\mathrm{Z}$ perspektywy lat tego typu historie wspominane są przez mężczyzn z uśmiechem jako element ówczesnego kolorytu, ale dla kobiet niekoniecznie musiały być one przyjemne. Koschembahr-Łyskowski był bowiem na egzaminach postrachem studentek, które z obawy przed jego mizoginizmem starały się wyglądać jak najmniej kobieco, przebierając się „,w jakąś najlichszą sukienczynę, [...] by jako przepracowana bidula, skromnie ubrana, z widocznym wysiłkiem odpowiadająca na przemyśl-

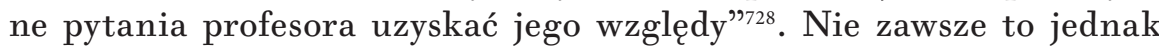
pomagało. Koschembahr-Łyskowski „zirytowany ignorancją zdającej potrafil grzmieć: «Pani powinna garnki szorować, dzieci rodzić, a nie prawo rzymskie studiować»". Inna rzecz, że i do mężczyzn zdarzało mu się powiedzieć, że powinni sprzedawać gazety „a nie wycierać ławek spodniami na Uniwersytecie"

Tego rodzaju seksistowskie zachowania należały wprawdzie do wyjątków, chociaż także wielu innych profesorów traktowało studentki w sposób nieco nienaturalny, najwyraźniej czując się niezręcznie w kontaktach z młodymi kobietami. Jedna z prawniczek wspomina w tym kontekście swego promotora, prof. Wacława Miszewskiego, który „odnosił się do studentek nawet z pewną galanterią, którą dziś nazwano by staroświecką, lecz zawsze z pewnym dystansem"730. Z kolei archeolog, prof. Antoniewicz czuwał nad morale swych uczennic, robiąc im wymówki o makijaż, brak pończoch czy nie dość skromną, w jego przekonaniu, sukienkę $e^{731}$. Powodem takich uwag były zapewne obawy, 


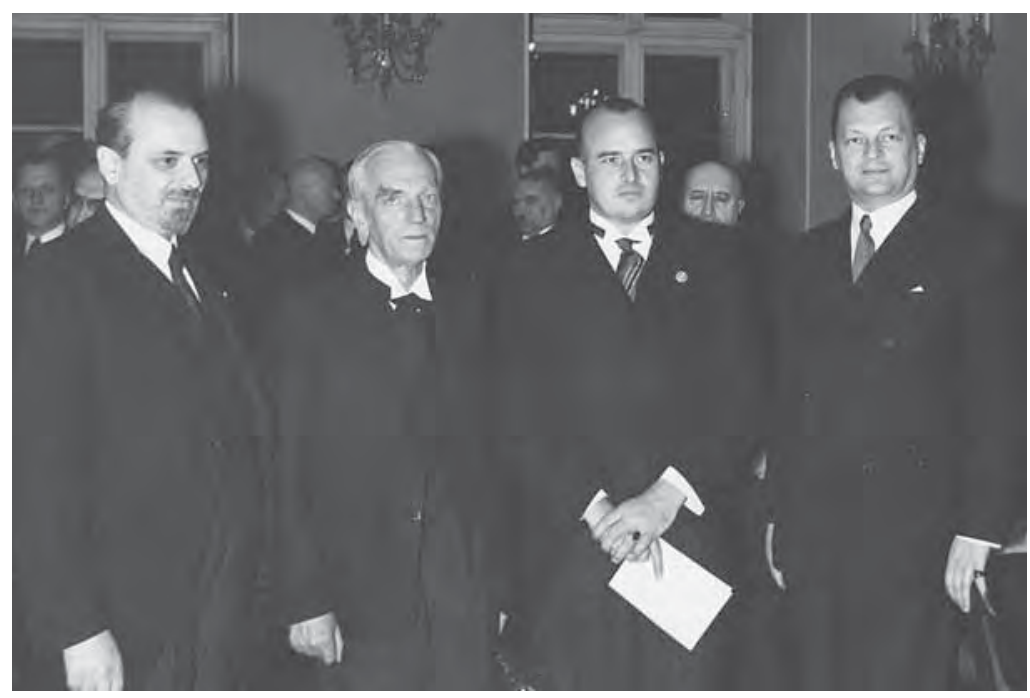

9o. Profesor Wacław Makowski jako wicemarszałek Senatu RP w Pałacu Staszica podczas spotkania prawników polskich i niemieckich ${ }_{15}$ XII $193^{8}$ r.; drugi z prawej minister sprawiedliwości Rzeszy Hans Frank - już niebawem generalny gubernator okupowanych ziem polskich

aby przebywanie w towarzystwie zbyt modnie ubranej i swobodnie zachowującej się młodej kobiety nie zostało uznane przez otoczenie za sytuację dwuznaczną, a być może Antoniewicz w ten pokrętny sposób walczył również z własnymi pokusami.

W stosunku wykładających na Uniwersytecie mężczyzn do studiujących tam młodych kobiet pojawiał się bowiem niekiedy element zainteresowania atrakcyjnością fizyczną. Jak wspomina jeden ze studentów prawa, prof. Namitkiewicz ,dziewczyny pytał łagodnie, nieraz z półuśmiechem, jakby dając tym do zrozumienia, że nie bierze zbyt poważnie i na serio powołania prawniczego swojej rozmówczyni. Wszystkie one miały u niego zapewnione trójki. Ładniejsze nawet i czwórki"732. Słabość części profesorów do płci pięknej studenci nie tylko doskonale zauważali, ale i bez skrupułów wykorzystywali. U prof. Makowskiego, mającego opinię „konesera życia i kobiet”, na którego egzaminy wchodzono kilkuosobowymi grupami, mężczyźni wypychali do przodu pięknonogie koleżanki, „sadowiąc dziewczyny z wyciągniętymi jak się dało nogami", aby w ten sposób przychylnie usposobić profesora do wszystkich zdających ${ }^{733}$. W tym akurat przypadku zainteresowanie było zresztą obustronne, gdyż Makowski, otoczony splendorem władzy jako parokrotny minister sprawiedliwości, „wysoki barczysty, o żywych czarnych oczach i szpakowatej krótkiej brodzie, zawsze nienagannie ubrany, budził westchnienia niektórych koleżanek" ${ }^{9734}$.

W zdecydowanej większości przypadków wzajemne zainteresowanie atrakcyjnością fizyczną nie przekraczało, jak się wydaje, obowiązujących 
w tamtych czasach norm obyczajowych, choć należy odnotować, że na Uniwersytecie zdarzały się również romanse pomiędzy profesorami a studentkami, o czym wspomina np. w swych plotkarskich wspomnieniach doc. Michalski z Wydziału Lekarskiego ${ }^{735}$. Zapewne z tego powodu małżonki niektórych profesorów niechętnie odnosiły się do pojawiających się w ich otoczeniu słuchaczek, a zdarzało się nawet, iż prewencyjnie towarzyszyły swym mężom w objazdach naukowych oraz na posiedzeniach zakładów ${ }^{736}$.

Biorąc pod uwagę przedstawione powyżej fakty, stwierdzić należy, że społeczność akademicka Uniwersytetu Warszawskiego, mimo wyraźnej dominacji mężczyzn wśród kadry naukowo-dydaktycznej, pogodziła się z pojawieniem się kobiet w murach uczelni, stopniowo uznając ich obecność - z mniejszymi lub większymi oporami - za naturalną, a pod pewnymi względami wręcz atrakcyjną. Trudno oprzeć się wrażeniu, iż nieliczni przeciwnicy emancypacji kobiet z biegiem czasu coraz bardziej zaczynali uchodzić za niegroźnych dziwaków. Pod koniec lat 30. kultura polityczna Uniwersytetu pozostawała wciąż jeszcze nieco patriarchalna, ale nie była już w ogólnym rozrachunku mizoginiczna.

Względna łatwość, z jaką przyjęto pojawienie się kobiet na Uniwersytecie Warszawskim, wyraźnie kontrastowała z postępującym wykluczaniem ze społeczności akademickiej osób pochodzenia żydowskiego. Jest znamienne, że w ciągu ćwierćwiecza, które upłynęło od uruchomienia uczelni w 1915 r. do przerwania przez nią działalności po wybuchu II wojny światowej, odsetek studiujących na niej Żydów zmniejszył się z 51\% do 14\%, podczas gdy odsetek kobiet wzrósł z 10 do 4,2\%. Nie oznacza to oczywiście, iż kobiety wypierały z Uniwersytetu Żydów. Oba przeciwbieżne zjawiska były natomiast skutkami modernizacji społecznej, dokonującej się wówczas w Polsce w przyspieszonym tempie. Jakkolwiek w potocznym rozumieniu nacjonalizm, którego jednym z przejawów był antysemityzm, wydawać może się daleki od nowoczesności, stanowił on w istocie, jak uważa teoretyk tego zagadnienia Ernst Gellner, jej kluczowy komponent, integrujący rodzące się społeczeństwo przemysłowe i zastępujący słabnące więzy lokalne, rodzinne, religijne i stanowe ${ }^{737}$. Niezależenie od moralnej oceny jego skutków, panujący na Uniwersytecie nacjonalizm, podobnie jak awans kobiet, był więc wyrazem modernizacyjnych aspiracji kształcących się tu przyszłych elit polskiego społeczeństwa.

Gellner podkreśla tė̇ kluczową rolę wyższych uczelni w procesie kształtowania się nowoczesności opartej na nacjonalizmie, co z powodzeniem można odnieść również do Uniwersytetu Warszawskiego: „Fundamentem obecnego porządku społecznego nie są już oprawcy, 
lecz profesorowie. Głównym narzędziem i symbolem władzy nie jest już gilotyna, lecz uroczyście nadany doctorat d'état. [...] Źródłem nacjonalizmu są szczególne wymogi strukturalne społeczeństwa przemysłowego. Ruch ten nie jest owocem ideologicznej aberracji ani nadmiaru uczuć. Choć ci, którzy w nim uczestniczą, prawie bez wyjątku nie wiedzą, co czynią, ich działalność stanowi tylko zewnętrzny przejaw czegoś znacznie głębszego: nieuchronnego procesu wzajemnego dopasowywania się państwa i kultury"738. Tak też należy interpretować kulturę polityczną Uniwersytetu w okresie międzywojennym. 


\section{Załącznik 1}

\section{Władze akademickie Uniwersytetu Warszawskiego w latach 1915-1939}

\begin{tabular}{|c|c|c|}
\hline Rok akademicki & Rektor & Prorektor \\
\hline $1915 / 16$ & Józef Brudziński & Józef Wierusz Kowalski \\
\hline $1916 / 17$ & Józef Brudziński & Józef Wierusz Kowalski \\
\hline $1917 / 18$ & Antoni Kostanecki & $\begin{array}{l}\text { Józef Brudziński } \\
\text { Jan Łukasiewicz }\end{array}$ \\
\hline 1918/19 & Antoni Kostanecki & Stanisław Józef Thugutt \\
\hline $1919 / 20$ & Stanisław Józef Thugutt & Antoni Kostanecki \\
\hline $1920 / 21$ & Jan K. Kochanowski & Stanisław Józef Thugutt \\
\hline $1921 / 22$ & Jan Mazurkiewicz & Jan K. Kochanowski \\
\hline $1922 / 23$ & Jan Łukasiewicz & Jan Mazurkiewicz \\
\hline $1923 / 24$ & Ignacy Koschembahr-Łyskowski & $\begin{array}{l}\text { Jan Łukasiewicz } \\
\text { Wiktor Porzeziński }\end{array}$ \\
\hline $1924 / 25$ & Franciszek Krzyształowicz & Ignacy Koschembahr-Łyskowski \\
\hline $1925 / 26$ & Stefan Pieńkowski & Franciszek Krzyształowicz \\
\hline $1926 / 27$ & Bolesław Hryniewiecki & Stefan Pieńkowski \\
\hline $1927 / 28$ & Antoni Szlagowski & Bolesław Hryniewiecki \\
\hline $1928 / 29$ & Gustaw Przychocki & Antoni Szlagowski \\
\hline $1929 / 30$ & Tadeusz Brzeski & Gustaw Przychocki \\
\hline $1930 / 31$ & Mieczysław Michałowicz & Tadeusz Brzeski \\
\hline $1931 / 32$ & Jan Łukasiewicz & Mieczysław Michałowicz \\
\hline $1932 / 33$ & Józef Ujejski & Jan Łukasiewicz \\
\hline $1933 / 34$ & Stefan Pieńkowski & Tadeusz Brzeski \\
\hline $1934 / 35$ & Stefan Pieńkowski & Franciszek Czubalski \\
\hline $1935 / 36$ & Stefan Pieńkowski & Franciszek Czubalski \\
\hline $1936 / 37$ & Włodzimierz Antoniewicz & Franciszek Czubalski \\
\hline $1937 / 38$ & Włodzimierz Antoniewicz & Franciszek Czubalski \\
\hline $1938 / 39$ & Włodzimierz Antoniewicz & Stefan Mazurkiewicz \\
\hline
\end{tabular}




\section{Załącznik 2}

Topografia głównego kampusu UW, stan z $193^{8}$ r.

1. Brama główna

2. Gmach Medycyny Teoretycznej

3. Gmach Pomuzealny

4. Budynek Seminaryjny

5. Auditorium Maximum

6. Biblioteka Uniwersytetu Warszawskiego

7. Budynek Porektorski

8. Gmach Szkoły Głównej

9. Gmach Zakładów Wydziału Matematyczno-Przyrodniczego

10. Ogrody uniwersyteckie

11. Pałac Kazimierzowski

12. Gmach Pokuratorski

13. Oficyny

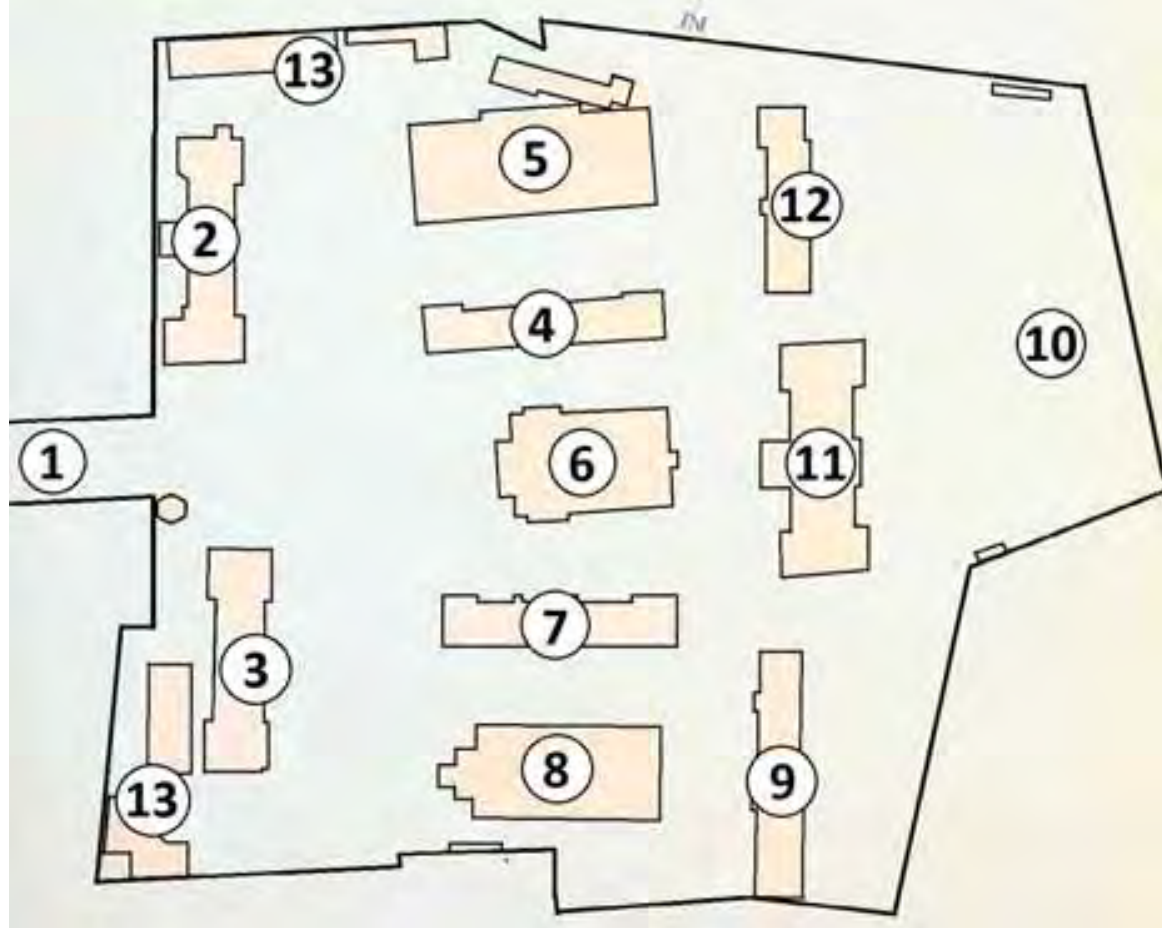




\section{Załącznik 3}

\section{Lokalizacja budynków uniwersyteckich w Warszawie w latach $1915^{-1939}$}

1. Główny kampus, ul. Krakowskie Przedmieście 26/28

2. Budynek Wydziału Teologii Katolickiej, ul. Traugutta 1

3. Zakład Geograficzny Wydziału Matematyczno-Przyrodniczego, Zakład Etnografii Polskiej, Zakład Etnologii i Etnografii Ogólnej, Zakład Socjologii i Historii Kultury oraz Seminarium Filozoficzne Wydziału Humanistycznego, Zakład Antropologii Wydziału Lekarskiego, Pałac Staszica, ul. Nowy Świat 72

4. Zakład Serologii i Mikrobiologii oraz Zakład Higieny Wydziału Lekarskiego, ul. Nowy Świat 19

5. Zakład Cytologii Wydziału Matematyczno-Przyrodniczego, ul. Nowy Świat 9

6. Seminarium Pedagogiczne i Zakład Psychologii Wychowania Wydziału Humanistycznego, plac Trzech Krzyży 8

7. Ogród Botaniczny i Obserwatorium Astronomiczne Wydziału Matematyczno-Przyrodniczego, Aleje Ujazdowskie 6/8

8. Budynek Wydziału Farmaceutycznego, Zakład Chemii Analitycznej Wydziału Lekarskiego, ul. Przemysłowa 25

9. Szpital Dzieciątka Jezus, ul. Nowogrodzka 59

10. Collegium Anatomicum Wydziału Lekarskiego, ul. Chałubińskiego 5

11. Klinika położniczo-ginekologiczna, ul. Starynkiewicza 3

12. Zakład Medycyny Sądowej Wydziału Lekarskiego, ul. Oczki 1

13. Zakład Mechaniki Teoretycznej, Zakład Fizyki Teoretycznej i seminaria matematyczne Wydziału Matematyczno-Przyrodniczego, ul. Oczki 3

14. Gmach fizyki Wydziału Matematyczno-Przyrodniczego, ul. Hoża 69

15. Klinika dermatologiczna, ul. Koszykowa 82a

16. Klinika pediatryczna w Instytucie Higieny Dziecięcej, ul. Litewska 16

17. Klinika psychiatryczna, Szpital Św. Jana Bożego, ul. Konwiktorska 7

18. Zakład Fizjologii Zwierząt Wydziału Matematyczno-Przyrodniczego, Instytut Radowy, ul. Wawelska 15

19. Gmach chemii Wydziału Matematyczno-Przyrodniczego, ul. Pasteura 1

20. Gmachy Wydziału Weterynaryjnego, ul. Grochowska 77

21. Instytut Orientalistyczny Wydziału Humanistycznego, ul. Królewska 10

22. Sala wykładowa w gmachu Muzeum Rolnictwa i Przemysłu, ul. Krakowskie Przedmieście 66

23. Szpital Św. Ducha, ul. Elektoralna 12
A. Dom profesorski, ul. Brzozowa 10
B. Dom profesorski, ul. Brzozowa 12
C. Dom profesorski, ul. Nowy Zjazd 5
D. Dom profesorski, ul. Sewerynów 7
E. Kolonia Akademicka im. Gabriela Narutowicza, ul. Akademicka 5
F. Dom akademicki, ul. Polna $5^{\circ}$
G. Dom akademicki Auxilium Academicum, ul. Tamka 4
H. Dom Akademicki Studentów Żydów, ul. Namiestnikowska 7 


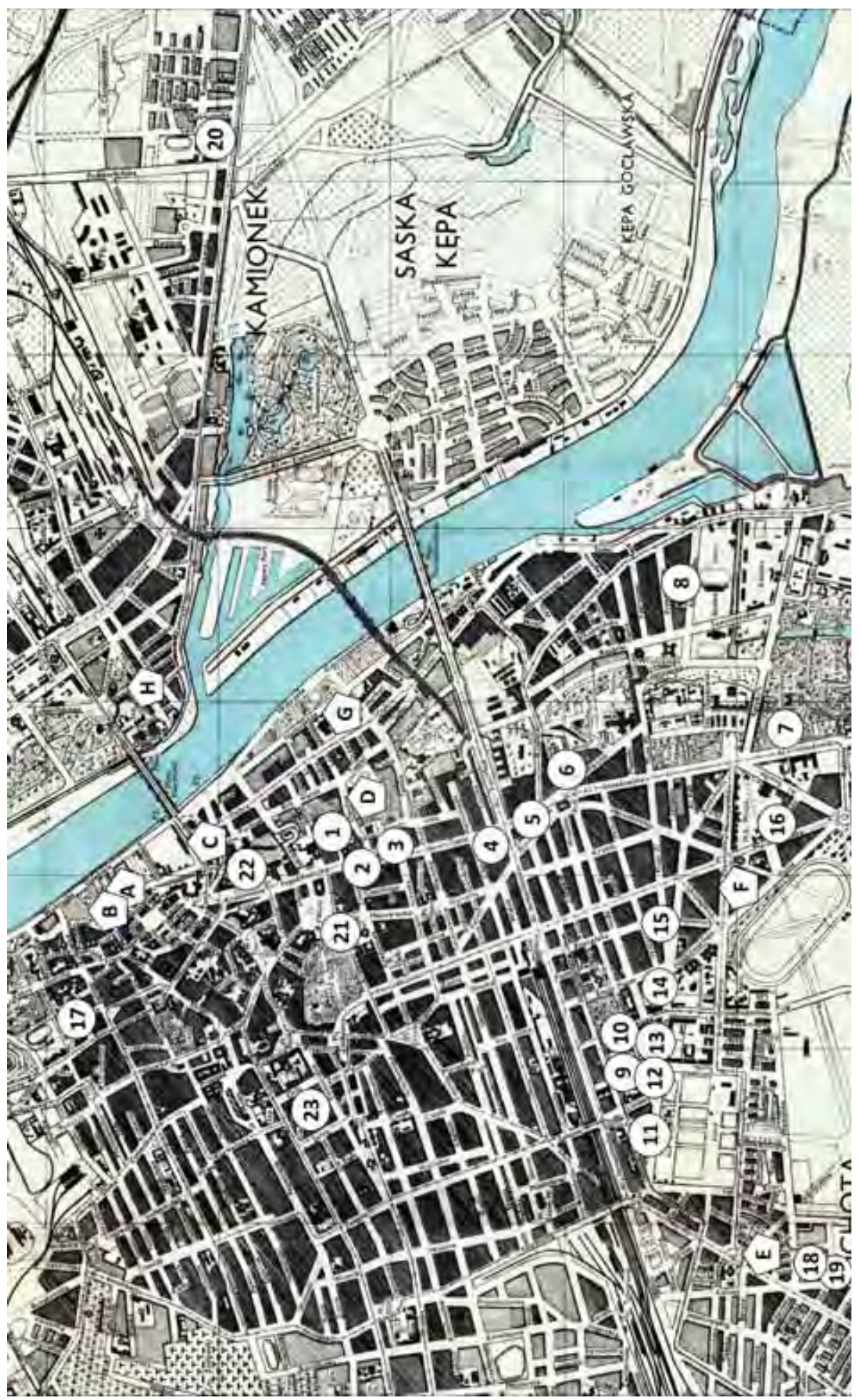




\section{Przypisy}

1 Topografię ówczesnego Uniwersytetu rekonstruuję na podstawie sprawozdań rektorskich z poszczególnych lat, a także kolejnych wydań Składu Uniwersytetu i Spisu wykładów. Pełna lista tych publikacji wraz z opisem bibliograficznym znajduje się w bibliografii. Tam również podane zostały rozwinięcia skrótów, w formie których przywoływane są w przypisach sprawozdania rektorskie i dziekańskie.

2 T. Manteuffel, Uniwersytet Warszawski w latach 1915/16-1934/35. Kronika, Warszawa $193^{6}$, s. 6o-263.

3 S. Kutrzeba, Królestwo i Galicya. Uwagi z czasów wojny, Warszawa-Kraków 1917, s. $5^{0-} 5^{1}$.

4 SUW 1936/1937, s. 4,2-43.

5 Fragmenty rozmowy $z$ Włodzimierzem Ścisłowskim, [w:] Fizycy wspominają. Zbiór 25 rozmów $i$ wspomnień fizyków polskich opublikowanych pierwotnie w „Postepach Fizyki” i w Kwartalniku Historii Nauki $i$ Techniki”, red. A.M. Kobos, Kraków 2014, s. 4.87 .

6 SUW 1937/1938, s. 37 .

7 Archiwum Uniwersytetu Warszawskiego (dalej jako AUW), AcUW RP/23, okólnik rektora S. Pieńkowskiego z 23 II 1935 r.

8 J. Gadomski, Budowa pierwszego w Polsce wysokogórskiego Obserwatorium im. Marszałka J. Piłsudskiego w Czarnohorze, „Urania” 1/1938, s. 1-4; Obserwatorium na Popie Iwanie było wówczas drugim w Europie pod względem wysokości położenia, po francuskim ośrodku na Pic du Midi de Bigorre (2877 m n.p.m.), znajdującym się zresztą wtedy od kilkunastu lat $\mathrm{w}$ remoncie.

9 SWL 1928/1929, s. 14,-15.

10 Wydział Prawa $w$ relacjach $i$ wspomnieniach pracowników naukowych $i$ studentów (1918-1950), [= „Studia Iuridica” t. 17], Warszawa 1990, relacja L. Kos-Rabcewicza-Zubkowskiego (1932-1936), s. 109. Daty po nazwisku oznaczają lata studiów na UW.
11 Wydział Prawa w relacjach

i wspomnieniach, relacja Z. Kolankowskiego (1931-1939), s. $7^{\text {o. }}$

12 SUW 1936/1937, s. 42.

13 O. Kossmann, Es begann in Polen. Erinnerungen eines Diplomaten und Ostforschers, Marburg 1995, s. 82-85.

14 Zob. np. AUW, RP/WP 93, pismo prof. C. Berezowskiego z 20 X 1939 r.; I. Koprowska, O moim życiu i medycynie. Wspomnienia, Poznań 1998, s. 98; Dzieje warszawskiego Wydziału Farmaceutycznego, red. J. Pachecka, J. Kowalski, P. Tomaszewski, Warszawa 2001, s. 82-83.

15 T. Manteuffel, Uniwersytet Warszawski w latach $1915 / 16-1934 / 35$, s. 23-35.

16 Spis wykładów na rok akademicki 1937-1938, Warszawa 1937, s. 53; T. Jabłoński, Młodość mego pokolenia, Warszawa 1977, s. 292.

17 T. Manteuffel, Uniwersytet Warszawski w latach $1915 / 16-1934 / 35$, s. 273, 279.

18 H. Kolendo, Kadra naukowa Uniwersytetu Warszawskiego w latach 1915-1939. Praca doktorska napisana pod kierunkiem prof. dr hab. Ireny Pietrzak-Pawłowskiej, Warszawa 1979 , s. 27-33.

19 Tamże, s. 43-51.

20 T. Manteuffel, Uniwersytet Warszawski w latach $1915 / 16-1934 / 35$, s. 281.

21 Ustawa z 13 VII 1920 r. o szkołach akademickich, „Dziennik Ustaw Rzeczpospolitej Polskiej" nr 72 rok 1920, art. 41-49, s. 12-15. Por.: Dzieje Uniwersytetu Warszawskiego 1915-1939, red. A. Garlicki, Warszawa 1982, s. 114,-122.

22 Ustawa z 13 VII 1920 r., art. 45, 49, s. 13-15.

23 Tamże, art. 50-59, s. 15-17. Por. AUW, RP/WL 11, rozporządzenie MWRiOP z 21 IV 1936 r. o sposobie postępowania habilitacyjnego, s. 86-87.

24 Zob. np.: SUW 1937/1938, s. 13.

25 Ustawa z 13 VII 1920 r., art. 62-66, s. 17-18.

26 Zob. np. SUW 1934/1935 i 1935/1936, s. 10-11. 
27 T. Manteuffel, Uniwersytet Warszawski w latach 1915/16-1934/35, s. 313. Zestawienie dla tego samego roku akademickiego 1929/1930, sporządzone na UW na użytek wewnętrzny podaje inne liczby: 102 profesorów zwyczajnych, 46 profesorów nadzwyczajnych, 4,2 adiunktów i 24,9 asystentów. Zob. AUW, AcUW RP/67, wykaz etatów na rok 1929/1930. Trudno dziś wytłumaczyć przyczynę powyższych rozbieżności. Posługuję się danymi oficjalnie opublikowanymi przez uczelnię, zakładając, że zostały one zweryfikowane i zatwierdzone przez jej władze.

28 Nieco więcej o prowadzących wykłady i ćwiczenia zlecone można powiedzieć na podstawie danych $\mathrm{z}$ roku akademickiego 1934/1935, kiedy spośród 201 zajęć powierzono: 20 profesorom UW, 41 docentom $\mathrm{UW}, 3^{1}$ adiunktom $\mathrm{i}$ asystentom $\mathrm{UW}$, 8 profesorom i docentom innych uczelni oraz 101 innym osobom. SUW 1934/1935 i 1935/1936, s. 11; SUW 1937/1938, s. 13; Sklad Uniwersytetu na rok akademicki 1937/1938, Warszawa 1937, s. 3-48.

29 SUW 1922/1923, s. 8-9, 16.

30 SUW 1929/1930, s. 6.

31 SUW 1937/1938, s. 89 .

32 H. Wittlinowa, Atlas szkolnictwa wyższego, Warszawa 1937, s. 4,1-4,2.

33 H. Kolendo, Kadra naukowa Uniwersytetu Warszawskiego w latach 1915-1939, s. 67-75; T. Manteuffel, Uniwersytet Warszawski w latach 1915/16-1934/35, s. 40.

34 H. Kolendo, Kadra naukowa Uniwersytetu Warszawskiego w latach 1915-1939, s. 65, $7^{6-8 o}$.

35 Tamże, s. 82-88.

36 Tamże, s. 103-109.

37 Tamże, s. 205-207.

38 Obliczenia własne na podstawie: Wykaz imienny docentów według stanu z dnia 31 grudnia 1937 r., Warszawa 1938, s. 13-18. Dziękuję prof. Andrzejowi Kajetanowi Wróblewskiemu za udostępnienie mi tego źródła.
39 H. Kolendo, Kadra naukowa Uniwersytetu Warszawskiego w latach 1915-1939, s. $116-126$.

40 Fragmenty rozmowy $z$ Władysławem Kapuścińskim, [w:] Fizycy wspominaja, s. 207 .

41 Obliczenia własne na podstawie: Wykaz imienny docentów, s. 13-18.

42 J. Pajewski, Przeszłość z bliska, Wspomnienia, Warszawa 1983 , s. 51-52; T. Manteuffel, Materiały do wspomnień 1918-1939, APAN, Materiały Tadeusza Manteuffla III/192, t. 119, s. 41-4,2.

43 Z.A. Michalski, Przez okopy, alkowy... do medycyny. Pamiętniki, t. II, Warszawa 1992, s. 340, 346.

44 Zob. np. W. Borowy, Dzienniki, Gabinet Rękopisów BUW, wpis z 23 II 1938 r.

45 Obliczenia własne na podstawie: Wykaz imienny docentów, s. 13-18.

46 H. Kolendo, Kadra naukowa Uniwersytetu Warszawskiego w latach 1915-1939, s. $195^{-197}$.

47 T. Manteuffel, Materiały do wspomnień $1918-1939$, s. 4,2 .

48 W. Borowy, Dzienniki, wpisy z 15-17 III $193^{8} \mathrm{r}$.

49 T. Manteuffel, Materiały do wspomnień $1918-1939$, s. 45 .

50 Z.A. Michalski, Przez okopy, t. I, s. 214.

51 A. Kojder, Gorzkie lata Leona Petrażyckiego w UW, [w:] Wydziat Prawa $w$ relacjach i wspomnieniach..., s. 178-189.

52 Cyt. za: T.P. Rutkowski, Stanisław Kot 1885-1975. Biografia polityczna, Warszawa 2000, s. 75- 76.

53 W. Borowy, Dzienniki, wpis z 21 XI $193^{8}$ r.; J. Pajewski, Przeszłość z bliska, Warszawa 1983, s. 45 .

54 Rozporządzenie prezydenta RP z 24, II 1928 r. o stosunku służbowym profesorów państwowych szkół akademickich i pomocniczych sił naukowych tych szkół, „Dziennik Urzędowy MWRiOP” Nr 16 z 12 XII 1933 r., s. 693. 
55 T. Tatarkiewiczowa, W. Tatarkiewicz, Wspomnienia - Zapiski do autobiografii, Poznań 2011, s. 204.

56 K. Michałowski, Wspomnienia, Warszawa 1986, s. 102-103.

57 A. Gieysztor, Środowisko historyczne Warszawy $w$ okresie międzywojennym, [w:] Nauka i szkolnictwo wyższe $w$ Warszawie, red. J. Kazimierski i in., Warszawa 1987 , s. 98; B. Meller, U Lourse'a, „Almanach Muzealny" 1/1997, s. 82-83;

58 J. Pajewski, Przeszłość z bliska, s. 70-74; APAN, Materiały Tadeusza Manteuffla III/192, Dopływ 2014, Wspomnienie o Mieczysławie Michałowiczu, b.d.

59 J. Pajewski, Przeszłość z bliska, s. 113-115.

60 H. Kolendo, Kadra naukowa Uniwersytetu Warszawskiego w latach 1915-1939, s. $192-195,203$.

61 T. Manteuffel, Uniwersytet Warszawski w latach $1915 / 16-1934 / 35$, s. 87-88.

62 SUW 1934/1935 i 1935/1936, s. 33; SWHUM 1934/1935, s. 10-11; SWHUM 1935/1936, s. 11-14; T. Manteuffel, Uniwersytet Warszawski w latach 1915/16-1934/35, s. 96. Nt. Divéky'ego por.: J. Pajewski, Przeszłość z bliska, s. 153-154.

63 W walce o polskość uczelni, „Alma Mater” z 18-31 X, 15-30 XI i 1-15 XII 1937 r. Według innego prawicowego czasopisma, "Akademika Polskiego" pod koniec 1934 r. na Wydziałach Lekarskim, Humanistycznym i Matematyczno-Przyrodniczym zatrudnionych było 31 osób pochodzenia żydowskiego, żadna z nich nie pracowała natomiast na Wydziale Prawa; M. Natkowska, Numerus clausus, getto ławkowe, numerus nullus, „paragraf aryjski”. Antysemityzm na Uniwersytecie Warszawskim 1931-1939, Warszawa 1999, s. 69 .

64 J. Pajewski, Przeszłość z bliska, s. 91.

65 AUW, AcUW/RP 70, pismo rektora S. Pieńkowskiego z 5 V 1934, r.

66 Archiwum Akt Nowych (dalej AAN), MWRiOP, mf. B-10598, akta osobowe S. Baleya, opinia W. Witwickiego z 3 XII 1926 r., s. 30.
67 AAN, MWRiOP, mf. B-12481, akta osobowe M. Korduby, niedatowany donos, s. 89 .

68 T. Manteuffel, Uniwersytet Warszawski w latach 1915/16-1934/35, s. 79-80.

Nt. R. Kesselringa zob.: http://www.galiziendeutsche.de/news/19/99/Prof-Dr-Dr-RudolfKesselring.htm; dostęp: 14, V 2014.

69 H. Kolendo, Kadra naukowa Uniwersytetu Warszawskiego w latach 1915-1939, s. 197-198.

70 Skład Uniwersytetu na rok akademicki $1937 / 1938$, s. $4-48$.

71 Wydział Prawa w relacjach i wspomnieniach..., relacja Z. Gawrońskiej-Wasilkowskiej (1930-1939), s. 6 o.

72 J. Rosen-Przeworska, Moje uniwerki, czyli o archeologii z epoki przedhistorycznej, [w:] Dzieje archeologii na Uniwersytecie Warszawskim, red. S.K. Kozłowski, J. Kolendo, Warszawa 1993, s. 138-139.

73 Skład Uniwersytetu na rok akademicki 1937/1938, s. 3-53.

$74 \mathrm{AUW}, \mathrm{AcUW} / \mathrm{RP}$ 70, pismo MWRiOP z 23 XII 1935 r.

75 Intymny portret uczonych. Korespondencja Marii i Stanisława Ossowskich, wyd. E. Neyman, Warszawa 2002, list z 23 I 1924, r., s. 237-238.

76 Skład Uniwersytetu na rok akademicki 1937/1938, s. 48-53.

77 AUW, AcUW/RP 76, odpis listu Jana Zawiszy do Komitetu Organizacyjnego zabawy tanecznej i herbatki Koła Urzędników z 8 II 1937 r. oraz odpowiedzi Ścisłego Komitetu Organizacyjnego i plenum Komitetu Organizacyjnego z 9 i 13 II 1937 r. Pracownik ten czuł się zmuszany do udziału w składkowej imprezie towarzyskiej. Gdy ją zbojkotował, organizatorzy przesłali mu paczkę z nieskonsumowanymi przez niego produktami, co z kolei uznał za obrazę. Pompatyczne nazwy gremiów przygotowujących imprezę są świadectwem naśladowania środowisk naukowych i studenckich.

78 Zob. np.: SUW 1936/1937, s. 4,1-4,2. 
79 T. Manteuffel, Materiały do wspomnień $1918-1939$, s. 45 .

80 AUW, AcUW/RP 22, pismo dyrektora departamentu W. Suchodolskiego z 28 IV $1930 \mathrm{r}$.

81 Skład Uniwersytetu na rok akademicki 1937/1938, s. 48-53.

82 Wykaz urzędników z podziałem na grupy uposażenia zob.: SUW 1936/1937, s. 41. Wysokość zarobków dla poszczególnych grup podaję na podstawie: Mały rocznik statystyczny 1939, Warszawa 1939, s. 278.

83 AUW, AcUW/RP 83, wnioski o zatrudnienie pracowników z maja-czerwca $1939 \mathrm{r}$.

84 AUW, AcUW/RP 23, okólnik J. Ujejskiego z 13 II 1933 r.

85 AUW, AcUW/RP 76, passim.

86 AUW, AcUW/RP 22, pismo dyr. Biura Personalnego w MWRiOP J.T. Lipki z 27 XII 1934, r.; SUW 1937/1938, s. $3^{6}$.

87 W. Borowy, Dzienniki, wpisy z 31 X i 12 XI 1924, r.

88 SUW 1937/1938, s. 13, 15.

89 AUW, AcUW/RP 83, wnioski o zatrudnienie pracowników z maja-czerwca 1939 r. Wykaz pomocniczych sił naukowych z podziałem na grupy uposażenia zob.: SUW 1937/1938, s. 14. Wysokość zarobków dla poszczególnych grup podaję na podstawie: Mały rocznik statystyczny 1939, s. 278 . Informacje o zarobkach zastępców profesorów zob.: H. Kolendo, Kadra naukowa Uniwersytetu Warszawskiego w latach 1915-1939, s. 57 .

90 SUW 1934/1935 i 1935/1936, s. 9.

91 Tamże.

92 APAN, Materiały Tadeusza Manteuffla III/192, t. 64, odpowiedź na ankietę komisji Zebrania Docentów z 20 XII 1934 r.

93 SUW 1934/1935 i 1935/1936, s. 9.

94 W. Borowy, Dzienniki, wpis z 27 I 1925 r.

95 APAN, Materiały Tadeusza Manteuffla III/192, t. 64 , niedatowany program
Zjazdu Docentów Państwowych Szkól Akademickich RP wraz z załączonymi postulatami, s. 97-91, 139 .

96 SUW 1922/1923, s. 8; SUW 1930/1931, s. 30.

97 Z.A. Michalski, Przez okopy, t. I, s. 262, t. II, s. $35^{6-368,} 37^{2-375}$.

98 T. Manteuffel, Materiały do wspomnień 1918-1939, s. 41, 46-47; APAN, Materiały Tadeusza Manteuffla III/192, t. „Dokumenty osobiste T. Manteuffla", Zeznanie o dochodzie z 26 II $1938 \mathrm{r}$.

99 J. Cegielski, Stosunki mieszkaniowe $w$ Warszawie $w$ latach $1864-1964$, Warszawa 1968, s. 186, 270.

100 SUW 1923/1924, s. 18. Por. Dzieje Uniwersytetu Warszawskiego 1915-1939, s. $120-125$.

101 Cyt. za: Dzieje Uniwersytetu Warszawskiego 1915-1939, s. 121.

102 AUW, AcUW/RP 75, pismo rektora S. Pieńkowskiego do prezesa Sądu Okręgowego we Lwowie z 13 I 1936 r. Wysokość zarobków na podstawie: Maty rocznik statystyczny 1939, s. 278; Por.: Dzieje Uniwersytetu Warszawskiego 1915-1939, s. $255^{-2} 5^{6}$.

103 AUW, AcUW/RP/22, okólnik MWRiOP z 2 III 1931 r. ws. zajęć ubocznych profesorów.

104 Zob. np. AAN, MWRiOP, mf. B-12056, akta osobowe E. Jarry, zgoda min. W. Świętochowskiego na prowadzenie wykładów zleconych w SGH z 11 VII 1937 r.

105 B. Poznańska, Środowisko lekarskie II Rzeczpospolitej, [w:] Inteligencja polska XIX $i$ XX wieku. Studia 6 , red. R. Czepulis-Rastenis, Warszawa 1991, s. $237-238$.

106 Gabinet Rękopisów BUW, nr inw. 294, t. 6, umowy A. Tretiaka z 6 IV 1934, r., 25 III 1936 r. i 25 I 1939 r.

107 AUW, RP/WL 2, wnioski z wstępnych egzaminów kwalifikacyjnych, notatka dziekana J. Mazurkiewicza z 1 VII 1927 r.

108 Gabinet Rękopisów BUW, nr inw. 16o, t. 33, notatka pt. Wysokość opłat egzaminacyjnych z 2 IV $1927 \mathrm{r}$. 
109 AAN, MWRiOP, mf. B-9252, okólnik z 1 VIII 1938 r. Por.: AUW, RP/WW, protokół posiedzenia Rady Wydziału Weterynaryjnego z 11 I 1937 r. z załączonym wykazem opłat.

110 Wydziat Prawa $w$ relacjach i wspomnieniach..., relacja Z. Zdrójkowskiego (1935-1942), s. 138 .

111 Tamże, relacja Z. Kolankowskiego (1931-1939), s. 77-8o; AUW, AcUW RP/77, pismo rektora J. Ujejskiego do MWRiOP z 13 VII 1933 r.

112 AUW, AcUW RP/77, pismo rektora J. Ujejskiego do Z. Cybichowskiego z 19 IX 1933 r.

113 AAN, MWRiOP, mf. B-11o61, akta osobowe Z. Cybichowskiego, orzeczenie Komisji Dyscyplinarnej z 21 VI 1935 r., s. $84,-86$.

114 AAN, MWRiOP, mf. B-11061, akta osobowe Z. Cybichowskiego, pismo rektora S. Pieńkowskiego z 9 IX 1935 r., s. 134; pismo Z. Cybichowskiego do rektora S. Pieńkowskiego z 11 IX 1935 r. i jego listy do W. Jędrzejewicza z 5 VII i 9 IX 1935 r., s. $105,123-124,162$.

115 AUW, AcUW RP/77, pisma min. W. Świętochowskiego do rektora S. Pieńkowskiego z 24, III 1936 r. i do rektora W. Antoniewicza z 31 III 1937 r.; pisma rektora W. Antoniewicza do B. Nawroczyńskiego z 3 XII 1936 r. i do Z. Cybichowskiego z 5 IV $1937 \mathrm{r}$.

116 AUW, AcUW RP/77, pismo min. W. Świętochowskiego do rektora W. Antoniewicza z 29 V 1937 r. wraz z załączonym odpisem wyroku NTA z $15 \mathrm{~V} 1937 \mathrm{r}$.

117 AAN, MWRiOP, mf. B-11061, akta osobowe Z. Cybichowskiego, listy do min. W. Jędrzejewicza z 30 XI 1934 r. i 9 IX 1935 r., s. 123, 356.

118 AUW, AcUW RP/77, orzeczenie Komisji Dyscyplinarnej ws. E. Lotha z $10 \mathrm{~V} 1935$ r.; Z.A. Michalski, Przez okopy, t. I, s. 215 .

119 AAN, MWRiOP, mf. B-124,81, akta osobowe M. Korduby, podania z 1 III i $22 \mathrm{~V}$ $193^{2}$ r., s. 53, 61.
120 T. Tatarkiewiczowa, W. Tatarkiewicz, Wspomnienia, s. 105-107, 149-151, 201-209.

121 Intymny portret uczonych, list z 21 VIII $193^{2}$ r., s. 295; W. Borowy, Dzienniki, wpis z 6 II 1924, r.

122 Tamże, wpis z 26 VII 1938 r.

123 J. Pajewski, Przeszłość z bliska, s. 71.

124 T. Manteuffel, Materiały do wspomnień $1918-1939$, s. 27

125 W. Borowy, Dzienniki, wpisy z 20 VI 1927 r. i 1 VIII 1938 r.

$126 \mathrm{Na}$ podstawie ogłoszeń w „Kurierze Warszawskim" z 2 X $193^{8}$ r., s. 57-61, 5 X 1938 r., s. 45. Por.: J. Cegielski, Stosunki mieszkaniowe $w$ Warszawie, s. 310.

127 AAN, MWRiOP, mf. B-15209, akta osobowe A. Tarskiego, podanie o pożyczkę z 25 XI 1935 r. wraz z zaświadczeniem ZUS r., s. 21-24.

128 Archiwum Spółdzielni Mieszkaniowej Profesorów Uniwersytetu Warszawskiego, zestawienie kwitów za komorne za lipiec 1939 r.

129 Skład Uniwersytetu na rok akademicki 1937/1938, s. 4-48.

130 Cyt. za: Dzieje Uniwersytetu Warszawskiego 1915-1939, s. 121-122.

131 T. Tatarkiewiczowa, W. Tatarkiewicz, Wspomnienia, s. 104.

132 Skład Uniwersytetu na rok akademicki 1937/1938, s. 4-48. Nt. zróżnicowania poszczególnych dzielnic Warszawy pod względem warunków mieszkaniowych zob.: J. Cegielski, Stosunki mieszkaniowe $w$ Warszawie, s. 300-302.

133 Skład Uniwersytetu na rok akademicki 1937/1938, s. 4-48.

134 Skład Uniwersytetu na rok akademicki 1937/1938, s. 48-53.

135 Z. Podkowińska, Moje wspomnienia o Ludwiku Sawickim i środowisku archeologów warszawskich okresu międzywojennego, Warszawa 1973, APAN, Materiały Zofii Podkowińskiej III/276, t. 60, s. 37 . 
136 H. Wittlinowa, Atlas szkolnictwa wyższego, s. $4,6-47$.

137 Szczegółowe dane statystyczne na temat studentów UW, zarówno w skali całej uczelni, jak i z uwzględnieniem poszczególnych wydziałów, zachowały się dla lat 1921/1922 - 1932/1933 oraz, mniej dokładne, dla roku 1938/1939 w: AUW, AcUW/RP 56-66. Informacje o charakterze liczbowym zawierają też sprawozdania kolejnych rektorów, które oznaczono w przypisach skrótami. (Ich pełne dane bibliograficzne podano w bibliografii): SUW 1922/1923, s. 9-10; SUW 1923/1924, s. 13; SUW 1924/1925, s. 8-10; SUW 1925/1926, s. 9-10; SUW 1927/1928, s. 15; SUW 1928/1929, s. 28 ; SUW 1929/1930, s. 29-31; SUW 1930/1931, s. 32-34; SUW 1931/1932, s. 22-23; SUW 1932/1933, s. 19-20; SUW 1933/1934, s. 16-18; SUW 1934/1935 - 1935/1936, s. 20-21, 45-46; SUW $1936 / 1937$, s. $28-29$; SUW 1937/1938, s. 54-56. Niektóre dane przytacza również T. Manteuffel, Uniwersytet Warszawski w latach 1915/16-1934/35, s. 273-334.

138 AUW, AcUW/RP 95, wpis z 17 XI 1915 r.

$139 \mathrm{Na}$ podstawie danych USOS.

140 AUW, AcUW/RP 106, wpis z 24, VI 1939 r.

$141 \mathrm{Na}$ podstawie danych USOS.

$142 \mathrm{Na}$ podstawie danych USOS.

143 AUW, AcUW/RP 88, t. 2, podanie J. Samsonowicza z 22 XII 1933 r.; podobnie podanie T. Szweykowskiego z 17 I 1924, r.

144 AUW, Jamontt Władysław, 39907/S, życiorys z 9 IX $193^{2} \mathrm{r}$.

$145 \mathrm{Na}$ podstawie danych USOS.

146 Organizacja życia akademickiego. Informator. Rok akademicki 1932/33, red. J. Paprocki, Warszawa 1933, s. 107-112.

147 Zob. np.: AUW, Moczarski Kazimierz, RP 23456/S, zaświadczenie dowódcy 1 kompanii 7 Baonu Podchorążych Rezerwy Piechoty z 31 III 1930 r. Por.: Wydziat Prawa $w$ relacjach $i$ wspomnieniach..., relacja Z. Kolankowskiego (1931-1939), s. 82 .
148 J. Radożycki, Aby o nich nie zapomniano. Wspomnienia, Szczecin 2007, s. 83-84.

$149 \mathrm{Na}$ podstawie danych USOS.

150 Wydział Prawa $w$ relacjach i wspomnieniach..., relacja Z. Brudnickiego (1934-1938), s. 118 .

151 AUW, Makowski Henryk, RP 347/S.

152 AUW, Rucki Dominik, KFARM, 832/S.

153 Zob. przypis 137.

$154 \mathrm{Na}$ podstawie danych USOS.

$155 \mathrm{Na}$ podstawie danych USOS.

156 Gabinet Rękopisów BUW, nr inw. 2585, niedatowane notatki odręczne S. Pieńkowskiego.

157 Na podstawie danych USOS. Obraz sytuacji komplikuje do pewnego stopnia fakt, iż do 1927 r. Wydział Filozoficzny obejmował sekcje humanistyczną i matematyczno-przyrodniczą, które później zastąpiły go, przekształcając się w odrębne wydziały: Humanistyczny i Matematyczno-Przyrodniczy.

158 H. Wittlinowa, Atlas szkolnictwa wyższego, s. $3^{6 .}$

$159 \mathrm{Na}$ podstawie danych USOS.

160 H. Wittlinowa, Atlas szkolnictwa wyższego, s. $5^{6-57}$.

161 K. Bartel, Przemówienie w Senacie przy budzecie Ministerstwa Wyznań Religijnych i Oświecenia Publicznego $w$ dniu 13 marca 1939 r., Warszawa 1939, s. 3-4.

162 AUW, Ginzberg Izaak, WL 892/S.

163 AUW, AcUW/RP-88, t. 1, zob. np. podania L. Korusiewicza z 2 V $1929 \mathrm{r}$. i H. Chutkiewicza z 13 VI 1927 r.

164 Wydział Prawa $w$ relacjach i wspomnieniach..., relacja S. Kotowskiego (1932-1939), s. 99 .

165 K. Bartel, Przemówienie w Senacie, s. 5-13.

166 H. Wittlinowa, Atlas szkolnictwa wyższego, s. 38 .

167 Wydziat Prawa $w$ relacjach i wspomnieniach..., relacja W. Szyszkowskiego (1924-1927), s. 4,o. 
168 J. Rakowski, ZET akademicki w latach 1918-1927, [w:] ZET w walce o niepodległość i budowe państwa. Szkice i wspomnienia, Warszawa 1996, s. 349 .

$169 \mathrm{Na}$ podstawie danych USOS

170 Zob. przypis 137 .

$171 \mathrm{Na}$ podstawie danych USOS.

172 Zob. przypis 137 .

173 Zob. przypis 137.

$174 \mathrm{Na}$ podstawie danych USOS.

175 Tamże.

176 Tamże.

177 Tamże.

178 AUW, Manteuffel Tadeusz, RP 5115/S, podanie o przyjęcie na studia z 19 IX $1919 \mathrm{r}$. z załączonym życiorysem.

179 J. Garliński, Świat mojej pamięci, Warszawa 1998, s. 9-4,1.

180 AUW, AcUW/RP 64, tabele 13 i 15, dane za rok akademicki 1931/1932. Wyszczególniają one osobno obywateli państw obcych oraz osoby według ich języka ojczystego. Nakładając na siebie obie te kategorie można domniemywać, że studenci, którzy nie deklarowali języka swego państwa (np. łotewskiego w przypadku obywateli Łotwy) byli narodowości polskiej.

181 AUW, Chitulescu Jerzy, WL 33064/S, podanie z 4 X $1929 \mathrm{r}$.

182 AUW, Klus Karol, RP 3364,8/S, podanie do rektora z załączonym życiorysem z 8 IX $1930 \mathrm{r}$.

183 AUW, Truszkowski Ryszard, WL 1674 / / S, karta osobowa z załączonym życiorysem, ankieta osobowa z 16 XI 1934, r.

184 http://www.lasowice.eu/readarticle. php?article_id $=48$; dostęp: 25 III 2013.

185 Jeffrey Bines, The Polish Country Section of the Special Operations Executive 19401946: A British Perspective, praca doktorska złożona na University of Stirling, 2004, s. 15 i n. https://dspace. stir.ac.uk/bitstream/1893/929/1/z\%2o Thesis.pdf; dostęp: 25 III 2013.
186 AUW, Arnaudies Jakub, RP 33012/S, niedatowany życiorys; Beaulieux Solange, RP 35091/S, życiorys z 1 X 1930 r.

187 AUW, Yu Houo Joei, RP 39213/S, podanie z 6 XI 1931 r. z załączonym życiorysem, pismo MWRiOP z 6 VII 1931 r., formularz wykładów dla kwestury z roku 1931/1932. Por. Skład Uniwersytetu na rok akademicki $1937 / 1938$, s. $3^{2}$

188 AUW, Bahr Ernst, RP 44333/S, karta osobowa z załączonym życiorysem, wykaz wykładów i ćwiczeń.

189 AUW, Bacioiu Ilie, RP $3635^{6 / S}$, karta osobowa z załączonym życiorysem.

190 AUW, Balabanović Dimitrije, WFARM 44989/S, karta osobowa, podanie o przyjęcie na studia z 3 IX 1934 r., podanie do rektora z 27 VI 1935 r. o zgodę na kontynuację studiów, pismo o zawieszeniu w prawach akademickich z 1 VI 1937 r.

$191 \mathrm{Na}$ podstawie danych USOS.

$192 \mathrm{Na}$ podstawie danych USOS.

193 Zob. przypis 137 .

194 W roku akademickim 1934/1935 na Uniwersytecie Poznańskim, Uniwersytecie Jagiellońskim i Uniwersytecie Jana Kazimierza studiowało ok. $28 \%$ kobiet, na Uniwersytecie Stefana Batorego - 32\%, na Politechnice Warszawskiej - 6\%, na Politechnice Lwowskiej - 5\%, na Akademii Górniczej w Krakowie - 1\%, na ASP w Warszawie - $47,5 \%$, zaś na Akademii Stomatologicznej - 72,5\%. Zob. H. Wittlinowa, Atlas szkolnictwa wyższego, s. 7-9, 50-51.

$195 \mathrm{Na}$ podstawie danych USOS.

196 Zob. przypis 137 .

197 W skali całego państwa na kierunki medyczne nie dostało się łącznie 70\% kandydatek i 52\% kandydatów, natomiast w przypadku prawa odrzucono niemal taki sam odsetek obu płci (17\%). Zob.: H. Wittlinowa, Atlas szkolnictwa wyższego, s. 34,-35, 54,-55.

198 Maly rocznik statystyczny 1939, s. 26 o. 
199 J. Żarnowski, Praca zawodowa kobiet $w$ Polsce międzywojennej, [w:] Kobieta i praca. Wiek XIX $i$ XX. Zbiór studiów, red. A. Żarnowska, A. Szwarc,

Warszawa 2000, s. 129-132.

200 Maly rocznik statystyczny 1939, s. 295.

201 Tamże, s. 317.

202 M. Kamińska, Ścieżkami wspomnień, Warszawa 196o, s. 165-174.

203 D. Kałwa, Model kobiety aktywnej zawodowo $w$ Polsce międzywojennej, [w:] Kobieta i praca, s. 321-323.

204 SUW 1924/1925, s. 10.

205 SUW 1928/1929, s. 29.

$206 \mathrm{Na}$ podstawie danych USOS.

207 Zob. przypis 137 .

208 A. Grupińska, 12 opowieści żydowskich, Wołowiec 2013, relacja Anny Lamoty, s. $5^{8 .}$

209 M. Grochowska, Wytraceni z milczenia, Warszawa 2005, s. 59 .

210 SUW 1928/1929, s. 28.

211 H. Wittlinowa, Atlas szkolnictwa wyższego, s. $3^{2}$.

212 Zob. przypis 137.

$213 \mathrm{Na}$ podstawie danych USOS.

$214 \mathrm{Na}$ podstawie danych USOS.

215 AUW, Sendlerowa Irena, KEM 2754, podanie o dopuszczenie do egzaminu dyplomowego i karta osobowa z 9 V 1939 r.

216 Zob. np. AUW, Danielak Fajga $5^{2625 / S}$, kwestionariusz dla kandydatów na UW z 3 IX $1938 \mathrm{r}$.

217 AUW, AcUW/RP 56, tabl. I-XIV.

218 Zob. np. SUW 1937/1938, s. 55-56.

219 Zob. przypis 137. Nie da się natomiast obecnie określić, ile osób wyznania mojżeszowego zostało immatrykulowanych na UW w całym okresie 1915-1939, gdy ż w bazie danych USOS informacje na temat wyznania studentów mają charakter fragmentaryczny. Do czasu, aż zostaną one uzupełnione, niemożliwe jest też zbadanie populacji żydowskich słuchaczy pod kątem miejsca urodzenia, wieku, długości studiów itp.

220 AAN, MWRiOP, mf. B-9247, s. 85, kandydaci przyjęci na I rok studiów w roku 1938/1939, s. 1 .

221 Pomiędzy rokiem 1932/1933 a 1934/1935 odsetek studentów żydowskich na Uniwersytecie Jana Kazimierza spadł z 31,8\% do 20,4\%, na Uniwersytecie Stefana Batorego z 29,7\% do 23,7\%, zaś na Uniwersytecie Jagiellońskim z 25,9\% do $16,6 \%$. Na podstawie: H. Wittlinowa, Atlas szkolnictwa wyższego, s. 10-11, 50-51; Organizacja życia akademickiego. Informator, s. 22-24.

222 Sejm RP, druk nr 770, Wniosek posłów z Koła Żydowskiego w sprawie okólnika wydanego przez Pana Ministra Wyznan Religijnych i Oświecenia Publicznego odnośnie do wprowadzenia „numerus clausus" w Uczelniach Wyższych z 9 X 1923 r. Por.: D. Mycielska, Postawy polityczne profesorów wyższych uczelni $w$ dwudziestoleciu międzywojennym, [w:] Inteligencja polska $w$ XIX $i$ XX wieku. Studia, t. IV, red. R. Czepulis-Rastenis, Warszawa 1985 , s. 320-323.

223 Numerus clausus, „Akademik” z 25 V 1923 r., s. 114.

224 A. Pilch, „Rzeczpospolita akademicka”. Studenci i polityka 1918-1933, Kraków 1997, s. 262.

225 K. Bartel, Przemówienie w Senacie, s. 19.

226 L. Hirszfeld, Historia jednego życia, Kraków 2011, s. 522.

227 AUW, Ringelblum Emanuel, RP 9070/S, karta osobowa z roku akademickiego 1922/1923, podanie o przyjęcie na Wydział Filozoficzny z 23 IV 1921 r.

228 SUW 1936/1937, s. 19.

229 Pisząc o trudnościach lokalowych w drugiej połowie lat 20. stwierdza on: „W tych warunkach praca wydziałów, które nie zastosowały u siebie numerus clausus, stawała się zupełnie niemożliwa"; T. Manteuffel, Uniwersytet Warszawski w latach $1915 / 16-1934 / 35$, s. 46 . 
230 M. Natkowska, Numerus clausus, s. 19,165 .

231 Centralna Biblioteka Wojskowa w Warszawie (dalej jako CBW), rękopis nr 138, Pamiętnik studenta medycyny Uniwersytetu Warszawskiego Pesacha Rajmana, wpis z 15 VI 1917 r., s. 13.

232 SWL 1929/1930, s. 103.

233 BUW, Gabinet Dokumentów Życia Społecznego, DU XVII P. 28 [3045], niedatowana ulotka Wzajemnej Pomocy Studentów Żydów.

234 Zob. przypis 137.

235 AUW, Jezernicki Icko, RP 4,119o/S, życiorys załączony do podania o przyjęcie na Wydział Prawa UW.

236 Zob. przypis 137 .

237 Zob. przypis 137 .

238 Dane dla roku akademickiego 1934/1935 zamieszczone w Atlasie szkolnictwa wyższego wskazują na słabszą niż dwa lata wcześniej, choć wciąż przeważającą na Uniwersytecie pozycję Żydów niezasymilowanych $\left(5_{1}^{1}, 5 \%\right)$. H. Wittlinowa, Atlas szkolnictwa wyższego, s. 50-51.

239 L. Hirszfeld, Historia jednego życia, s. $5^{20}$.

240 Zob. przypis 137.

241 Przemawia za tym fakt, iż podobne różnice w wyborach kierunku studiów występowały pomiędzy mężczyznami i kobietami wyznania mojżeszowego również w latach 20.

242 Zob. przypis 137.

243 S. Szwerdszarf, Ani „alma” ani „mater”. Reportaż o studentach-Żydach, „Nasz Przegląd" z 20 X 1936 r.

244 Zob. przypis 137.

245 Zob. przypis 137. Podstawowe statystyki uniwersyteckie nie uwzględniały narodowości ukraińskiej i białoruskiej, ani takich języków. Studentów deklarujących je w ankietach klasyfikowano jako ,innych”. Dla początku lat 30. zachowały się jednak szczegółowe zestawienia „innych”, gdzie m.in. zapisano liczby osób mówiących po ukraińsku i białorusku. Nt. studentów UW wywodzących się z mniejszości niemieckiej zob.: A. Heise, Der VDH Warschau 1926-1939, [w:] Die Vereine Deutscher Hochschüler in Polen 1922-1939, red. T. Bierschenk, Hannover 1988 , s. $113-121$.

246 Wyliczenia własne na podstawie danych USOS. Liczba miast i ich wielkość wg stanu z 1931 r. Odsetek studentów urodzonych na wsi w roku 1934/1935 wynosił 15\%. Podobnie kształtował się zapewne w całym omawianym okresie. Zob.: H. Wittlinowa, Atlas szkolnictwa wyższego, s. 30 .

247 W 1931 r. w miastach powyżej 100 tys. mieszkańców żyło 10,5\% ogółu obywateli Polski, w miastach o wielkości od 10 tys. do 100 tys. mieszkańców - 9,9\%, zaś pozostałych $79,6 \%$ - zamieszkiwało w małych miasteczkach i na wsiach. Ogólny współczynnik urbanizacji kraju wynosił wtedy 27,2\%. Maty rocznik statystyczny 1939 , s. 34 .

248 H. Wittlinowa, Atlas szkolnictwa wyższego, s. 28, 52-53. Por.: M. Pleskaczyńska, Struktura społeczna młodzieży $U W$ $w$ okresie międzywojennym (na podstawie danych z roku akademickiego 1934/1935), "Roczniki Uniwersytetu Warszawskiego" 2/1971, s. 46-47.

249 H. Wittlinowa, Atlas szkolnictwa wyższego, s. $24,-25$.

250 Maty rocznik statystyczny 1939, s. $3^{1}$.

251 H. Wittlinowa, Atlas szkolnictwa wyższego, s. 28, 52-53. Por.: M. Pleskaczyńska, Struktura społeczna młodzieży $U W$, s. $46-47$.

252 Wyliczenia na podstawie danych przytaczanych przez M. Pleskaczyńską, Struktura społeczna młodzieży $U W$, s. $48-5^{1}$.

253 R. Matuszewski, Chmury na pogodnym niebie, Warszawa 1998, s. 5

254 W. Gombrowicz, Wspomnienia polskie. Wędrówki po Argentynie, Kraków 1996, s. $15^{2}$. 
255 AUW, Sobański Antoni, RP 12661/S, karta archiwalna z 14, X 1925 r. Por. wstęp Tomasza Szaroty do: A. Sobański, Cywil $w$ Berlinie, Warszawa 20o6, s. 6-12.

256 AUW, Radziwiłł Krzysztof, RP 8676/S, życiorys dołączony do podania o przyjęcie na studia $\mathrm{z} 5$ IV $1921 \mathrm{r}$.

257 J. Giedroyc, Autobiografia na cztery ręce, Warszawa 1999, s. 23.

258 W. Siła-Nowicki, Wspomnienia $i$ dokumenty, t. 1, Wrocław 2002, s. 79.

259 M. Kamińska, Ścieżkami wspomnień, s. 96, 118-119 (cytat).

260 B. Wierzbiański, Wspomnienia warszawskie, [w:] ZET w walce o niepodległość $i$ budowe państwa, s. 435 .

261 W. Gombrowicz, Wspomnienia polskie, s. 12-13.

262 K. Brandys, Miesiace $197^{8-1981, ~ W a r s z a w a ~}$ 1997, s. 224.

263 Tamże, s. 14,2.

264 AUW, Askenazy Regina RP 33374/S, Piasecki Bolesław RP 37500/S, Wasiutyński Wojciech RP $28598 / \mathrm{S}$.

265 AUW, Gombrowicz Witold RP 12083/S; W. Gombrowicz, Kronos, Kraków 2013 , s. 23-26; tegoż, Wspomnienia polskie, s. $43-4,4$.

266 J. Garliński, Świat mojej pamięci, s. 208 , 231.

267 AUW, AcUW/RP 88, t. 2, podanie K. Zbyszewskiego z 1 III 1928 r.

268 J. Śpiewak, Przyjaźnie i animozje, Warszawa 1965 , s. 222.

269 AUW, AcUW/RP 88, t. 1, podanie Z. Kownackiego z 16 II 1928 r.

270 AUW, RP/WW 7l, obliczenia własne na podstawie ogółu podań.

271 Tamże.

272 AUW, AcUW/RP 88, t. 1, podanie W. Chojnowskiego z 20 XI 1924, r. Podobnie zob. podania H. Chutkiewicza z 13 VI 1927 r. i H. Biernackiego z 6 XI 1924, r.
273 AUW, AcUW/RP 88, t. 2, podanie A. Mackiewicza z 27 XI 1937 r.

274 AUW, RP/WW 71, cytaty z podań J. Krompiewskiego, Z. Chudobińskiego i S. Tarczyńskiego; AcUW/RP 88, t. 1, zob. np. podania J. Krasuskiego z 12 XI 1919 r., R. Boszko z 12 XI 1924, r., H. Chodakow z 11 XII 1933 r.

275 AUW, Begin Menachem, RP/Z 38382/S, podania Begina do władz UW z 15 VIII 1931 r., 14, X 1932 r., 10 II, 22 IV i 28 XI 1933 r., 15 IV 1935 r., 14, II, 23 VI i 31 VIII 1938 r., zobowiązanie spłaty pożyczki z 19 II 1936 r., pisma rektora UW do Begina z 28 I i 8 VII 1938 r.

276 AAN, MWRiOP, mf. B-9254, pismo M. Kamińskiej do rektora UW z 5 XII $193^{8}$ r., s. 56-61, pismo rektora Antoniewicza do Urzędu Skarbowego ws. zadłużenia M. Kamińskiej z 12 XI 1938 r., s. 66.

277 AUW, Wesołowski Stefan, WL 25269/S, podanie o przyjęcie na studia z załączonym życiorysem, kwestionariusz osobowy z 11 I 1933 r. Por.: S. Wesołowski, Od kabaretu do skalpela i lazaretu, Warszawa 2006, s. 14-15.

278 AUW, Wesołowski Stefan, WL $25^{269} / \mathrm{S}$, podanie z 1 XII $193^{6} \mathrm{r}$.

279 W. Siła-Nowicki, Wspomnienia i dokumenty, t. 1, s. 8 o.

280 H. Wittlinowa, Atlas szkolnictwa wyższego, s. $3^{1-33}$.

281 Organizacja życia akademickiego. Przewodnik, Warszawa 1927, s. 12.

282 Dzieje Uniwersytetu Warszawskiego 1915-1939, s. 140-141.

283 J. Kurcyusz, Sprawozdanie za rok 1931/1932. Towarzystwo "Bratnia Pomoc” Studentów Uniwersytetu Warszawskiego, Warszawa 1932, s. 214. Wśród studentek korzystających z pomocy finansowej rodzin $19 \%$ otrzymywało do $50 \mathrm{zl}, 4,4 \%$ 50-100 zł, 27\% 100-150 zł i 10\% powyżej 150 zł. Analogiczne dane dla mężczyzn wynosiły: $4,2,5 \%$ do $50 \mathrm{zl}, 17,5 \% 50-100 \mathrm{zl}, 27 \%$ 100-150 zł, powyżej 150 zł 10,5\%. 
284 AUW, RP/WW 71, wyliczenia własne na podstawie ogółu podań.

285 J. Radożycki, Aby o nich nie zapomniano, s. $57-59$.

286 J. Śpiewak, Przyjaźnie i animozje, s. 324.

287 AUW, AcUW/RP 88, t. 1, podanie S. Juszczaka z listopada $1930 \mathrm{r}$.

288 J. Kurcyusz, Sprawozdanie za rok 1931/1932, s. 214 .

289 AUW, RP/WW 71, podanie S. Karwasa.

290 Zob. np. ogłoszenia w „Kurierze Warszawskim” z 8 IX 1922 r. „Student wyższego kursu uniwersytetu, chrześcijanin, udzieli korepetycji za mieszkanie" i z 2 X 1938 r., a także w „Naszym Przeglądzie” z 5 XI 1933 r. "Za obiady przyjmie lekcje student". Por.: A. Grupińska, 12 opowieści żydowskich, relacja A. Lamoty, s. 59 .

291 AUW, RP/WW 71, podanie

I. Kwiatkowskiej.

292 T. Manteuffel, Materiały do wspomnień 1918-1939, s. 8.

293 AUW, AcUW/RP 88, t. 1, podanie I. Kozakiewiczówny z 14, XI 1924, r.

294 AUW, AcUW/RP 88, t. 2, podanie studentki, brak danych osobowych i daty.

295 AUW, AcUW/RP 88, t. 1, podanie W. Chojnowskiego z 20 XI 1924, r.

296 AUW, AcUW/RP 88, t. 1, podanie

K. Galińskiego z 15 IX 1922 r.

297 O. Kossmann, Es begann in Polen, s. 81.

298 J. Śpiewak, Przyjaźnie i animozje, s. $253-254$.

299 J. Giedroyc, Autobiografia, s. 23.

300 AUW, AcUW/RP 88, t. 2, podanie W. Warkałły z 8 X $1930 \mathrm{r}$.

301 AUW, AcUW/RP 88, t. 1, podania A. Dobrzańskiego z 9 XII 1928 r., J. Hewelke z 24, XI 1930 r.; tamże, t. 2, podanie Bolesława Tomaszewskiego z 30 XI 1938 r.; Organizacja życia akademickiego. Przewodnik, s. 12.
302 Wydział Prawa $w$ relacjach i wspomnieniach..., relacja S. Kotowskiego (1932-1937), s. 97-98.

303 AUW, AcUW/RP 88, t. 2, podania

H. Rychlewskiej z 20 XI 1924, r., M. Skolimowskiej z 25 X $1930 \mathrm{r}$.

304 S. Wesołowski, Od kabaretu, s. 37-38; Dzieje Uniwersytetu Warszawskiego 1915-1939, s. 137 .

305 Wydziat Prawa $w$ relacjach $i$ wspomnieniach ..., relacja H. Nowogródzkiego (1924,-1929), s. 48.

306 W. Wasiutyński, Prawa strona labiryntu, s. 8 o.

307 R. Matuszewski, Chmury na pogodnym niebie, s. 34 .

308 Tamże, s. $3^{8}$.

309 AUW, AcUW/RP 88, t. 1, podanie A. Bronikowskiego z 4, V $1929 \mathrm{r}$.

310 J. Kurcyusz, Sprawozdanie za rok 1931/1932, s. 170-171.

311 AUW, AcUW/RP 88, t. 1, podanie S. Kotowicza z 14, XI 1924, r.

312 B. Żongołłowicz, Dzienniki 1930-1936, Warszawa 2004, s. 380-381.

313 J. Garliński, Świat mojej pamięci, s. 229-231.

314 Dzieje Uniwersytetu Warszawskiego 1915-1939, s. 134-136.

315 AUW, Goldberg Józef, 20834/S, formularz opłat studenckich.

316 AUW, Berencwajg Dawid, WL 27323/S, formularz opłat studenckich.

317 Rozporządzenie MWRiOP z 25 IX 1933 r. o opłatach w państwowych szkołach akademickich, „Dziennik Urzędowy MWRiOP" Nr 16 z 12 XII 1933 r., s. 678-68o; AAN, MWRiOP, mf. B-9252, rozporządzenie z 6 VII 1936 r. o opłatach w państwowych szkołach akademickich, s. 74-75. Por. Dzieje Uniwersytetu Warszawskiego 1915-1939, s. 136, 262.

318 SUW 1934/1935 - 1935/1936, s. 47; SUW 1937/1938, s. 62. 
319 AUW, Kott Jan, RP 4.0509/S, zobowiązanie spłaty z 12 II 1937 r.; pismo rektora J. Ujejskiego w sprawie umorzenia postępowania z 17 II 1933 r. Nt. jego aresztowania zob. też: R. Matuszewski, Chmury na pogodnym niebie, s. 33-34.

320 Zob. przypis 137 .

321 Zob. np.: Gabinet Rękopisów BUW, nr inw. 2585 , niedatowane notatki odręczne S. Pieńkowskiego.

322 J. Tymiński, Pisane o zmierzchu. Wspomnienia z lat 1924-1985, Warszawa 1988 , s. 8.

323 J. Radożycki, Aby o nich nie zapomniano, s. 54 .

324 AUW, RP/WW 71, podania E. Grodzkiego i S. Tarczyńskiego; W. Siła-Nowicki, Wspomnienia i dokumenty, t. 1, s. 74; A. Grupińska, 12 opowieści żydowskich, relacja A. Lamoty, s. 59 .

325 AUW, RP/WW 71, podania

K. Markiewicza, E. Grodzkiego.

326 Organizacja życia akademickiego. Informator, s. 85-86; J. Kurcyusz, Sprawozdanie za rok 1931/1932, s. 176-177; Dzieje Uniwersytetu Warszawskiego 1915-1939, s. 146-151.

327 APAN, Materiały Franciszka Czubalskiego III/144, t. 11, niedatowany raport o sytuacji w FDA, s. 3-7.

328 SUW 1937/1938, s. 66.

329 http://www.warszawskapraga.pl/object_ route.php?object_id=155; dostęp: 6 XII 2013 .

330 S. Wesołowski, Od kabaretu, s. 27-28.

331 AUW, RP/WW 71, podania

S. Stępkowskiego, Z. Nędzusiaka,

J. Krompiewskiego, J. Latały.

332 Wydziat Prawa $w$ relacjach i wspomnieniach..., relacja C. Kunderewicza (1932-1939), s. 104.

333 M. Skokowska-Rudolfowa, Odpowiedzialność i partnerstwo, [w:] XX lat pracy Koła Medyków S.S.S.M.U.J.P. $w$ Warszawie 1915-1935, red. M. Pertkiewicz, Warszawa 2011, s. 216.
334 Organizacja życia akademickiego. Informator, s. 116-117; J. Kurcyusz, Sprawozdanie za rok 1931/1932, s. 178-179.

335 APAN, Materiały Franciszka Czubalskiego III/14, t. t. 11, niedatowany raport o sytuacji w FDA, s. 5-6.

336 Organizacja życia akademickiego. Informator, s. 88.

337 J.B. Saloni, Wspomnienie o ZNMS i o Leszku Raabe, [w:] Leszek Raabe we wspomnieniach przyjaciót, Warszawa 1963 , s. 135 .

338 J. Kurcyusz, Sprawozdanie za rok 1931/1932, s. 181-182.

339 APAN, Materiały Franciszka Czubalskiego III/144, t. 11, niedatowany raport o sytuacji w FDA, s. 9-14.

340 J. Radożycki, Aby o nich nie zapomniano, s. 59 .

341 W. Siła-Nowicki, Wspomnienia $i$ dokumenty, t. 1, s. 79-81.

342 J. Garliński, Świat mojej pamięci, s. 227.

343 APAN, Materiały Franciszka Czubalskiego III/14,4, t. 11, niedatowany raport o sytuacji w FDA, s. 3 .

344 B. Żongołłowicz, Dzienniki, s. 454.

345 Tamże, s. 661.

346 J. Śpiewak, Przyjaźnie i animozje, s. 247.

347 S. Wiechecki, Czaszka w rondlu, czyli opowiadania sq̨dowe, Kraków 2007, s. $145^{-14} 6$.

348 Organizacja życia akademickiego. Informator, s. 116 . Por. „Alma Mater” z 1-15 X 1937 r.

349 J. Kurcyusz, Sprawozdanie za rok 1931/1932, s. 180.

350 APAN, Materiały Franciszka Czubalskiego III/144, t. 11, niedatowany raport o sytuacji w FDA, s. 13-14.

351 J. Radożycki, Aby o nich nie zapomniano, s. $57-59$.

352 J. Śpiewak, Przyjaźnie i animozje, s. 222.

353 M. Skokowska-Rudolfowa, Odpowiedzialność i partnerstwo, s. 216. 
354 AUW, RP/WW 71, podania

Z. Chudobińskiego, M. Miklasa,

J. Krompiewskiego, T. Paciorkowskiego,

S. Tarczyńskiego, K. Zabolickiego,

S. Kowalczyka, J. Latały (cytat),

M. Szkudlińskiego, O. Turka,

J. Bakunińskiego, J. Maciejewskiego,

Z. Nędzusiaka.

355 AUW, AcUW/RP 88, t. 2, podanie

M. Witkowskiego z 10 III 1928 r.; t. 1, podanie W. Kelasza z 19 XI 1924, r.

356 Maty rocznik statystyczny 1939, s. 254.

357 J. Garliński, Świat mojej pamięci, s. 226.

358 AUW, RP/WW 71, podania

S. Tarczyńskiego i R. Lipnera; J. Radożycki, Aby o nich nie zapomniano, s. 59 .

359 S. Wiechecki, Czaszka $w$ rondlu, s. 30-31.

360 J. Garliński, Świat mojej pamięci, s. 226.

361 AUW, RP/WW 71, podania

S. Tarczyńskiego i R. Lipnera.

362 M. Prószyński, Sprawozdanie z działalności T-wa Bratnia Pomoc Studentów Uniwersytetu Warszawskiego. Złożyt za okres 25 II 1929 - 1 II 1930 Mieczysław Prószyński, Warszawa 1930, s. 15

363 AUW, RP/WW 71, wyliczenia własne na podstawie ogółu podań. Kwotę 120 zł podaje również: AUW, AcUW/RP 88, t. 2, podanie W. Łukaszewicza z 12 XII 1933 r.

364 Informator dla studentów z 1927 r. podawał zbliżone sumy: mieszkanie $20 \mathrm{zl}$, wyżywienie $50 \mathrm{zl}$, podręczniki i nauka $15 \mathrm{zl}$, ubranie $15 \mathrm{zl}$, komunikacja i inne $15 \mathrm{zl}$ - razem $115 \mathrm{zl}$ bez uwzględnienia opłat akademickich; Organizacja życia akademickiego. Przewodnik, s. 14.

365 J. Kurcyusz, Sprawozdanie za rok 1931/1932, s. 180, 219-220;

E. Kądziałkiewicz, Praca samopomocowa, [w:] XX lat pracy Koła Medyków, s. 53-56.

366 SUW 1937/1938, s. 62-66.

367 SUW 1936/1937, s. 34-37.

368 S. Jasiński, Kilka uwag o gruźlicy $i$ jej zwalczaniu wśród młodzieży akademickiej $w$ Polsce, [w:] XX lat pracy Koła Medyków, s. 204 .
369 SUW 1937/1938, s. 72.

370 M. Skokowska-Rudolfowa, Odpowiedzialność i pionierstwo, [w:] XX lat pracy Koła Medyków, s. 214-216.

371 SUW 1937/1938, s. 72-75.

372 T. Manteuffel, Uniwersytet Warszawski w latach 1915/16-1934/35, s. 7-49.

373 B. Żongołłowicz, Dzienniki, s. 668.

374 Statut tymczasowy Uniwersytetu Warszawskiego, Warszawa 1917 , s. 3; Przepisy dla studentów Uniwersytetu Warszawskiego, Warszawa [1917], s. 1-18.

375 K. Jaszczuk, Zmiany form studiowania w UW w okresie międzywojennym, opracowanie z 1990 r. w zbiorach AUW, s. 1-4.

376 S. Wesołowski, Od kabaretu, s. $9^{8}$.

377 T. Manteuffel, Uniwersytet Warszawski w latach 1915/16 - 1934/35, s. 115

378 Zob. przypis 137 .

379 Intymny portret uczonych, wpis z 2 II 1923 r., s. 182.

380 K. Zbyszewski, Niemcewicz od przodu i tyłu, Warszawa 1999, s. 14.

381 Wyliczenia na podstawie: T. Manteuffel, Uniwersytet Warszawski w latach 1915/16 - 1934/35, s. 273-334; SUW 1934/1935 1935/1936, s. 20-21; SUW 1936/1937, s. 28 ; SUW 1937/1938, s. 54-55.

$382 \mathrm{Na}$ podstawie danych USOS.

383 H. Wittlinowa, Atlas szkolnictwa wyższego, s. $2-3$.

384 J. Giedroyc, Autobiografia, s. 23.

385 SWP 1927/1928, s. 31 .

386 T. Manteuffel, Uniwersytet Warszawski w latach 1915/16-1934/35, s. 95-96. Por. np.: Spis wykładów na rok akademicki 1938-1939, Warszawa 1938, s. 6.

387 J. Garliński, Świat mojej pamięci, s. 204.

388 H. Wittlinowa, Atlas szkolnictwa wyższego, s. $2-3$. 
389 J. Tymiński, Pisane o zmierzchu, s. zo.

390 Wydział Prawa

$w$ relacjach $i$ wspomnieniach..., relacje

W. Szyszkowskiego (1924,-1927),

H. Nowogródzkiego (1924-1929),

C. Kunderewicza (1932-1939),

s. $16,43-44,103$.

391 T. Manteuffel, Uniwersytet Warszawski w latach 1915/16-1934/35, s. 89-93.

392 W. Wasiutyński, Prawa strona labiryntu, Gdańsk 1996, s. 8o.

393 J. Giedroyc, Autobiografia, s. 23-24.

394 J. Tymiński, Pisane o zmierzchu, s. $3^{2-33}$.

395 Tamże, s. 33-34.

396 R. Matuszewski, Chmury na pogodnym niebie, s. 7 .

397 Wydziat Prawa $w$ relacjach $i$ wspomnieniach..., relacje H. Nowogródzkiego (1924-1929), K. Brzoski (1925-1929), Z. Gawrońskiej-Wasilkowskiej (1930-1939), s. $46,54,58$.

398 SUW 1937/1938, s. 17 .

399 SWP 1927/1928, s. 32-34.

400 K. Jaszczuk, Zmiany form studiowania w UW, s. 2.

$401 \mathrm{Na}$ podstawie danych USOS.

402 Zob. przypis 137 .

403 AUW, RP/WL 1, Sprawozdanie dziekana Wydziału Lekarskiego UW za rok akademicki 1925/1926, maszynopis, s. 1,13 (cytat).

404 Tamże, s. 13-14.

405 AUW, RP/WL 2, Sprawozdanie dziekana Wydziału Lekarskiego UW za rok akademicki 1926/1927, maszynopis, s. 13-14; SWL 1928/1929, s. 18-19; SWL 1929/1930, s. 51; SWL 1930/1931, s. 58; SWL 1931/1932, s. 45; SWL 1932/1933, s. 34; SWL 1933/1934, s. 58 ; SWL $1934 / 1935$, s. $64-65$; SWL 1935/1936, s. 86; SWL 1936/1937, s. 11; SWL 1937/1938, s. 94-95.
406 AUW, RP/WL 2, wnioski z wstępnych egzaminów kwalifikacyjnych, notatka dziekana J. Mazurkiewicza z I VII 1927 r.

407 SWL 1929/1930, s. $5^{1 .}$

408 Powołując się na znajomości na Wydziale Lekarskim oszuści proponowali za kilka tysięcy złotych „załatwienie” egzaminu, a następnie nic w tym kierunku nie robili. Gdy student został przypadkowo przyjęty, „mówili, że to na skutek ich starań, gdy zaś kandydat nie był przyjęty, oświadczali, że sprawy nie udało się załatwić, a pieniądze zwracali zatrzymując drobną część, rzekomo wydaną na bezskuteczne starania". Afera z przyjmowaniem studentów na wydziat lekarski, „Nasz Przegląd” z 19 X 1933 r. Śledztwo w tej sprawie prowadziła na Wydziale Lekarskim prokuratura. Zob. AUW RP/WL 26, pisma wiceprokuratora Sądu Okręgowego w Warszawie J. Firstenberga do władz UW z 1 IX i 31 XII 1932 r. oraz 5 X 1933 r.

409 SWL 1929/1930, s. $5^{2}$.

410 AUW, RP/WL 2, pismo dziekana Konopackiego do MWRiOP z 17 X 1927 r.

411 AUW, RP/WL 2, lista kandydatów do egzaminu wstępnego kwalifikacyjnego na Wydziale Lekarskim Uniwersytetu Warszawskiego 1927/1928 i lista kandydatów przyjętych na I rok medycyny $1927 / 1928$.

412 Tamże.

413 AUW, RP/WL 2, Sprawozdanie dziekana Wydziału Lekarskiego UW za rok akademicki 1926/1927, maszynopis, s. 14; SWL 1929/1930, s. $5^{1 .}$

414 AUW, RP/WL 2, pismo dziekana Konopackiego do MWRiOP z 17 X 1927 r.

415 Zob. przypis 4.05.

$416 \mathrm{Na}$ podstawie danych USOS.

417 AUW, RP/WL 1, sprawozdanie dziekana Wydziału Lekarskiego Uniwersytetu Warszawskiego za rok akademicki 1925/1926, s. 13; AUW, RP/WL 2, Sprawozdanie dziekana Wydziału Lekarskiego UW za rok akademicki 1926/1927, maszynopis, s. 14; SWL 1936/1937, s. 12. 
418 AUW, RP/WL 4, lista podań o przyjęcie na Wydział Lekarski z 8 X 1930 r.

419 AUW, RP/WL 6, listy podań o przyjęcie na Wydział Lekarski z 30 IX 1933 r.

420 AUW, AcUW/RP 66, wykaz dyplomów nostryfikowanych na UW w roku akademickim 1938/1939; AUW, RP/WL 1, sprawozdanie dziekana Wydziału Lekarskiego Uniwersytetu Warszawskiego za rok akademicki 1925/1926, s. 10; RP/WL/2, protokoły z posiedzeń Komisji Nostryfikacyjnej WL z 24, II, 24, VI i 3 XI 1927 r.; SWL 1928/1929, s. 19; SWL 1929/1930, s. 48-49; SWL 1932/1933, s. 34 .

421 AUW, RP/WL 3, pismo dziekana Wydziału Lekarskiego z 23 IX 1925 r.

422 AUW, RP/WL 3, pismo dziekana Wydziału Lekarskiego do MWRiOP z 19 II 1926 r.

423 Podobne poglądy pojawiały się w całym ówczesnym środowisku medycznym. Zob.: B. Poznańska, Środowisko lekarskie II Rzeczpospolitej, s. 236-237.

424 AUW, RP/WL 8, protokół posiedzenia Rady Wydziału Lekarskiego z 28 VI 1938 r.

425 AUW, RP/WL 11, rozporządzenie MWRiOP z 16 III 1928 r. ws. organizacji studiów lekarskich, s. 1-9.

426 SWL 1929/1930, s. 49-50; SWL 1936/1937, s. $9^{2-93}$.

427 Łowicki Judym. Pamiętniki doktora Stanisława Rotstada oraz wspomnienia przyjaciół, red. H. Dusińska i J. Kapuścik, Warszawa 1998, s. 31 .

428 Tamże, s. 30.

429 E.S. Łazowski, Prywatna wojna.

Wspomnienia lekarza-żołnierza 1933-1944, Warszawa 1993, s. 23-24.

430 Tamże, s. 68-69.

431 SWL 1932/1933, s. 27; SWL 1935/1936, s. $36-4,1$

432 S. Wesołowski, Od kabaretu, s. 28. Podobnie: E.S. Łazowski, Prywatna wojna, s. 30; I. Koprowska, O moim życiu $i$ medycynie, s. 64 .
433 E.S. Łazowski, Prywatna wojna, s. zo.

434 Rozmowa z Ignacym Adamczewskim, [w:] Fizycy wspominaja, s. 13; Rozmowa z Tadeuszem Skalińskim, tamże, s. $384,-385$.

$435 \mathrm{Na}$ podstawie danych USOS.

436 Spis wykładów na rok akademicki

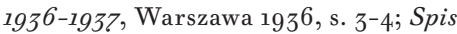
wykładów na rok akademicki 1937-1938, Warszawa 1937 , s. 5-6.

437 Zob. przypis 137.

438 T. Manteuffel, Materiały do wspomnień $1918-1939$, s. 8-9

439 T. Manteuffel, Uniwersytet Warszawski w latach $1915 / 16-1934 / 35$, s. 161-163.

440 SWHUM 1927/1928, s. 8o-81.

441 AUW, Jabłoński Henryk, KEM 2081, protokoły egzaminów z 10 I i 20 VI 1929 r., 11 I 1930 r., 11 i 16 I oraz 26 VI 1931 r., dyplom magistra filozofii z 30 VI $1931 \mathrm{r}$.

442 SWHUM 1927/1928, s. 10.

443 Tamże, s. 81.

444 Tamże, s. 178. Por.: A. Gieysztor, Środowisko historyczne Warszawy w okresie międzywojennym, s. 95 .

445 SWHUM 1933/1934, s. 9.

446 Wydziat Prawa $w$ relacjach $i$ wspomnieniach..., relacja Z. Kolankowskiego (1931-1939), s. 86.

447 K. Zbyszewski, Niemcewicz od przodu ityłu, s. 59 .

448 Tamże, s. 13.

449 K. Kuratowski, Notatki do autobiografii, Warszawa 1981, s. 6o-67.

450 Rozmowa z Tadeuszem Skalińskim, [w:] Fizycy wspominaja, s. 386.

451 Rozmowa z Leonardem Sosnowskim, [w:] Fizycy wspominaja, s. 4117.

452 Gabinet Rękopisów BUW, nr inw. 2604, t. 3, niedatowane wspomnienia Marii Pieńkowskiej, spisane po śmierci męża w 1953 r., s. 6-7. 
453 Tamże, s. 8-13. Podobnie zob.: Fragmenty rozmowy z Władysławem Kapuścińskim, [w:] Fizycy wspominaja, s. 211; Rozmowy z Arkadiuszem Piekara, tamże, s. 346 .

454 A.K. Wróblewski, Zarys dziejów uniwersyteckiego ośrodka fizyki na Hożej, [w:] 75 lat fizyki na Hożej, red. M. Kicińska-Habior, A.K. Wróblewski, Warszawa 1996, s. 10-13.

455 SWHUM 1927/1928, s. $5^{1 .}$

456 Gabinet Rękopisów BUW, nr inw. 4.281, ankiety z zajęć W. Kuli z listopada $1937 \mathrm{r}$.

457 A. Gieysztor, Środowisko historyczne Warszawy, s. 99; Rozmowa z Tadeuszem Skalińskim, [w:] Fizycy wspominaja, s. 389 .

458 Zob. np. Fragmenty rozmowy

z Władysławem Kapuścińskim, [w:] Fizycy wspominaja, s. 207.

459 T. Manteuffel, Materiały do wspomnień 1918-1939, s. 23 .

460 K. Brandys, Miesiace 1978-1981, s. $3^{2}$.

461 SWHUM 1927/1928, s. 31.

462 A. Gieysztor, Środowisko historyczne Warszawy, s. 100.

463 J. Pajewski, Przeszłość z bliska, s. 69.

464 J. Giedroyc, Autobiografia, s. 23.

465 J. Tymiński, Pisane o zmierzchu, s. 37;

E. Jarra, Wspomnienia o Uniwersytecie Warszawskim 1915-1939, Londyn 1972, s. $28-29$.

466 Wydział Prawa w relacjach i wspomnieniach..., relacje $\mathrm{K}$. Brzoski (1925-1929), Z. Kolankowskiego (1931-1939), s. 53 (cytat), 84-85.

467 J. Rosen-Przeworska, Moje uniwerki, s. 143.

468 E.S. Łazowski, Prywatna wojna, s. $3^{1 .}$

469 Wydziat Prawa

$w$ relacjach $i$ wspomnieniach..., relacja

C. Kunderewicza (1932-1939), s. 105 .

470 Tamże, relacja W. Rostockiego (19371939), s. 148.

471 AAN, MWRiOP, mf. B-9261, zestawienia praktyk studenckich w latach 1932/1933-
1937/1938 i praktyk niewykorzystanych w roku 1936/1937 i 1937/1938, s. 18, 35-38.

472 AAN, MWRiOP, mf. B-9261, zestawienie zagranicznych praktyk studenckich $\mathrm{w}$ roku 1937/1938, s. 46-47.

473 R. Matuszewski, Chmury na pogodnym niebie, s. 74-85.

474 S. Wesołowski, Od kabaretu, s. 114-121.

475 Maly rocznik statystyczny 1939, s. 258-259.

476 SWHUM 1929/1930, s. 13-14; SWHUM 1931/1932, s. 17; SWHUM 1932/1933, s. 13 , SWHUM 1933/1934, s. 16; SWHUM 1934/1935, s. 12; SWHUM 1935/1936, s. 13-14. Był to lektoraty z języków: norweskiego, szwedzkiego, duńskiego, rumuńskiego, włoskiego, greki, rosyjskiego, węgierskiego, bułgarskiego, angielskiego, hiszpańskiego, łaciny, francuskiego, niemieckiego i czeskiego. Później uruchomiono również zajęcia z estońskiego, serbsko-chorwackiego, serbsko-łużyckiego, litewskiego, arabskiego, ormiańskiego, japońskiego oraz języków nowoindyjskich.

477 Gabinet Rękopisów BUW, nr inw. 294 , t. 5, notatka z I Ogólnopolskiego Zjazdu Kół Neofilologicznych w Warszawie 7-8 XII $1930 \mathrm{r}$.

478 R. Matuszewski, Chmury na pogodnym niebie, s. 72-73.

479 Gabinet Rękopisów BUW, nr inw. 3810, Wojciech Stopczyk, Uniwersytet Warszawski i Legia Akademicka. Wspomnienia, s. 25 .

480 R. Matuszewski, Chmury na pogodnym niebie, s. 73-74; I. Koprowska, $O$ moim życiu i medycynie, s. 69-70; AUW, AcUW/RP 88, t. 1, podanie

S. Brzezińskiego z 16 X 1935 r.

481 AAN, MWRiOP, mf. B-9257, s. 85, pismo naczelnika Legii Akademickich płk Tomaszewskiego z $10 \mathrm{~V} 1938 \mathrm{r}$. wraz $\mathrm{z}$ załączonym referatem.

482 SUW 1937/1938, s. 79-8o.

483 AAN, MWRiOP, mf. B-9257, s. 2-24, wytyczne ministra spraw wojskowych 
z 15 I 1938 r. Por.: AUW, RP/WHum 155, pismo kierownika przeszkolenia OPLG do dziekana Wydziału Humanistycznego z 15 VII 1938 r.; SUW 1937/1938, s. 76-77.

484 AAN, MWRiOP, mf. B-9257, s. 54, pismo delegata ministra spraw wojskowych przy MWRiOP płk. Różyckiego z 26 I 1938 r.; SUW 1937/1938, s. 76 .

485 T. Bielecki, W szkole Dmowskiego, Gdańsk 2000, s. $25^{8}$.

486 AUW, AcUW RP/23, zarządzenie rektora W. Antoniewicza z 5 X 1937 r.

487 Organizacja życia akademickiego. Informator, s. 90.

488 I. Krzywicka, Wyznania gorszycielki, Warszawa 1995, s. 81-82.

489 J. Kurcyusz, Sprawozdanie za rok 1931/1932, s. 182-183.

490 Tamże, s. 21-25.

491 J. Sas-Wisłocki, Akademicki kodeks honorowy, Warszawa 1934, s. 17.

492 K. Brandys, Miesiace 1978-1981, s. 219; W. Bayer, Koło Prawników studentów Uniwersytetu Warszawskiego 1916 1939, [w:] Wydział Prawa w relacjach i wspomnieniach..., s. 192.

493 M. Natkowska, Numerus clausus, s. $155^{-1} 5^{6}$.

494 J. Radożycki, Aby o nich nie zapomniano, s. $16-17$.

495 APAN, Materiały Franciszka Czubalskiego III.14,4, t. 55, niedatowana ulotka ONR, s. 11.

496 M. Kula, Autoportret rodziny X. Fragment żydowskiej Warszawy lat międzywojennych, Warszawa 2007, s. 4,19-4,22.

497 Dzieje Uniwersytetu Warszawskiego 19151939, s. 173, 197-199. Por.: P. Tomaszewski, Polskie korporacje akademickie w latach 1918-1939. Struktura, myśl polityczna, działalność, Toruń 2011, s. 4445-451.

498 P. Tomaszewski, Polskie korporacje akademickie, s. 454-4,55.

499 J. Giedroyc, Autobiografia, s. 24.
500 O. Kossmann, Es begann in Polen, s. 73, 86.

501 T. Żukowska, Na skraju dwóch światów... Wspomnienia 1939-1953, Warszawa 2000, s. $76-77$.

502 P. Tomaszewski, Polskie korporacje akademickie, s. 462-463; A. Heise, Der VDH Warschau 1926-1939, s. 114-120.

503 Wydział Prawa $w$ relacjach i wspomnieniach..., relacja S. Kotowskiego (1932-1937), s. 98. Podobnie: Cz. Bobrowski, Wspomnienia ze stulecia, Lublin 1985 , s. 34 .

504 Zob. np. S. Wesołowski, Od kabaretu, s. 28-29; J. Śpiewak, Przyjaźnie i animozje, s. 306,324 .

505 W.J. Muszyński, Duch młodych. Organizacja Polska i Obóz Narodowo-Radykalny w latach 1934-1944. Od studenckiej rewolty do konspiracji niepodległościowej, Warszawa 2011, s. 21.

506 J. Tymiński, Pisane o zmierzchu, s. 34 .

507 R. Matuszewski, Chmury na pogodnym niebie, s. 14-17; E.S. Łazowski, Prywatna wojna, s. 22 .

508 R. Matuszewski, Chmury na pogodnym niebie, s. 38; Wydział Prawa $w$ relacjach $i$ wspomnieniach..., relacje Z. Zdrójkowskiego (1935-1942), W. Rostockiego (1937-1939), s. 135, 151.

509 Organizacja życia akademickiego. Informator, s. 72-73. Por. Dzieje Uniwersytetu Warszawskiego 1915-1939, s. 16o-161; J. Rakowski, ZET akademicki w latach 1918-1927, s. $35^{2}$.

510 W. Wasiutyński, Prawa strona labiryntu, s. 84 .

511 Wydziat Prawa $w$ relacjach $i$ wspomnieniach..., relacja W. Szyszkowskiego (1924-1927), s. $3^{2}$.

512 Zob. np. W. Leopold, Wspomnienia, maszynopis w posiadaniu autora, s. 11-12. Dziękuję dr. Januszowi Marszalcowi i Waldemarowi Stopczyńskiemu za jego udostępnienie.

513 A. Grupińska, 12 opowieści żydowskich, relacja Anny Lamoty, s. 59 . 
514 Organizacja życia akademickiego. Informator, s. 95-96; Dzieje Uniwersytetu Warszawskiego, s. 169-173.

515 J. Sas-Wisłocki, Akademicki kodeks honorowy, s. 10-14, 19-20.

516 P. Tomaszewski, Polskie korporacje akademickie, s. 50-62.

517 W. Wasiutyński, Prawa strona labiryntu, s. $84,-85$.

518 Wydział Prawa $w$ relacjach i wspomnieniach..., relacja

L. Kos-Rabcewicza-Zubkowskiego

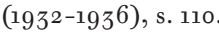

519 Dzieje Uniwersytetu Warszawskiego, s. $17^{2}$.

520 http://aquilonia.pl/index.php/o-nas/ historia.html; dostęp: $25 \mathrm{X} 2013$.

521 L. Krzywicki, Wspomnienia, t. III, Warszawa 1959, s. 298-zoo.

522 J. Giedroyc, Autobiografia, s. 24.

523 W.J. Muszyński, Duch młodych, s. 25-29.

524 SUW 1937/1938, s. 59, 81. Zaliczały się do nich: Koło Medyków, Prawników, Medyków Weterynaryjnych, Chemików, Farmaceutów, Historyków, Przyrodników, Klasyków, Polonistów, Historyków Sztuki Archeologów Klasycznych, Prehistoryków, Geografów, Etnografów, Socjologii Pozytywnej, Językoznawcze, Slawistów, Anglistów, Pedagogiczne, Romanistów, Teologiczne (katolickie), Teologów Ewangelików, Teologów Prawosławnych, Orientalistów, Prawników Żydów, Przyrodników Żydów, Chemików Żydów, Farmaceutów Żydów, Stowarzyszenie Medyków Żydów oraz Akademickie Koło Krajoznawcze.

525 Organizacja życia akademickiego. Informator, s. 70-71, 94-95.

526 Dzieje Uniwersytetu Warszawskiego, s. 194-195; J. Rosen-Przeworska, Moje uniwerki, s. 140-141; O. Kossmann, Es begann in Polen, s. 83; Próba ustanowienia paragrafu aryjskiego w Kole Historyków została z trudem udaremniona w 1934 r. Zob.: T. Jabłoński, Młodość mego pokolenia, s. 305-3o6.
527 W. Szczuciński, Członkowie Koła Medyków w ubiegtym dwudziestoleciu, [w:] XX lat pracy Koła Medyków, s. 4,1-4,2.

528 R. Matuszewski, Chmury na pogodnym niebie, s. 29-34 (cytat s. 29).

529 W. Wasiutyński, Prawa strona labiryntu, s. 84 .

530 Organizacja życia akademickiego. Informator, s. 79. Por.: M. Natkowska, Numerus clausus, s. 69 .

531 R. Matuszewski, Chmury na pogodnym niebie, s. 35, 102. Por. Statut Koła Prawników UW z 1924, r.; W. Bayer, Koło Prawników, s. 192.

532 K. Bartel, Przemówienie w Senacie, s. 7.

533 Maty rocznik statystyczny 1939, s. 348.

534 J. Garliński, Świat mojej pamięci, s. 208. Por. też: R. Matuszewski, Chmury na pogodnym niebie, s. 25-26.

535 J. Kurcyusz, Sprawozdanie za rok 1931/32, s. $172-173$.

536 "Akademicki Przegląd Sportowy" z 1 V 1933 r., s. 2; 15 VI 1933 r., s. 3. Por.: J. Garliński, Świat mojej pamięci, s. 207-208; R. Matuszewski, Chmury na pogodnym niebie, s. 59, 105-106; E.S. Łazowski, Prywatna wojna, s. 38-40, $5^{2-54}, 62 ; \mathrm{S}$. Wesołowski, Od kabaretu, s. $62-63,103$.

537 M. Pertkiewicz, Od Sekcji W.F. do Referatu Obozów $i$ W.F., [w:] XX lat pracy Koła Medyków, s. 65 .

538 T. Katelbach, Spowiedź pokolenia, Gdańsk 2001, s. 64.

539 J. Śpiewak, Przyjaźnie i animozje, s. 307.

540 J. Tymiński, Pisane o zmierzchu, s. 43.

541 W. Wasiutyński, Prawa stronq labiryntu, s. 8 o.

542 S. Wesołowski, Od kabaretu, s. 24,-25.

543 I. Krzywicka, Wyznania gorszycielki, s. $9^{6-97}$.

544 Wydział Prawa $w$ relacjach i wspomnieniach..., relacja J. Krośnickiego (1935-1939), s. 133. 
545 R. Matuszewski, Chmury na pogodnym niebie, s. $3^{6 .}$

546 S. Wesołowski, Życie towarzyskie na medycynie, [w:] XX lat pracy Koła Medyków, s. 66-72; tegoż, Od kabaretu, s. $29,49,252$; E.S. Łazowski, Prywatna wojna, s. 4,2 .

547 W. Borowy, Dzienniki, wpis z 28 I 1924, r.

548 S. Wesołowski, Od kabaretu, s. 4.4.

549 Tamże, s. 49-59, 62-63, 252-259; tegó், Życie towarzyskie, s. 66-72.

550 Wydziat Prawa $w$ relacjach i wspomnieniach..., relacja L. Kos-Rabcewicza-Zubkowskiego (1932-1936) s. 110-111.

551 J. Pajewski, Przeszłość z bliska, s. 101-102.

552 J. Rosen-Przeworska, Moje uniwerki, s. $137^{-1} 3^{8}$.

553 L. Hirszfeld, Historia jednego życia, s. 156.

554 E.S. Łazowski, Prywatna wojna, s. 25.

555 J. Pajewski, Przeszłość z bliska, s. 62-63.

556 E.S. Łazowski, Prywatna wojna, s. 41; R. Matuszewski, Chmury na pogodnym niebie, s. 11.

557 J. Rosen-Przeworska, Moje uniwerki, s. 14,0-14,1; O. Kossmann, Es begann in Polen, s. 83

558 W. Gombrowicz, Wspomnienia polskie, s. 14,4 .

559 R. Matuszewski, Chmury na pogodnym niebie, s. 12.

560 W. Broniewski, Pamiętnik 1918-1922, Warszawa 1987 , wpis z 4 XII $1921 \mathrm{r}$., s. 272 .

561 J. Rosen-Przeworska, Moje uniwerki, s. $14,0$.

562 CBW, rękopis nr 138, Pamiętnik studenta medycyny..., wpisy z 17 VII i 16 VIII 1918 r., s. $158,183-184$.

563 I. Krzywicka, Wyznania gorszycielki, s. 85-90, 102-104 (cytat), 131-132.

564 M. Kamińska, Ścieżkami wspomnień, s. 134 .
565 W. Broniewski, Pamiętnik, wpis z 13 II 1919 r., s. 76.

566 W. Gombrowicz, Wspomnienia polskie, s. 142 .

567 Zob. np. „Nasz Przegląd” z 17 III 1933 r.; Tajemnica pokoju Nr. 402 w Domu Akademickim, „Nasz Przegląd” z 31 VIII $1931 \mathrm{r}$.

568 R. Matuszewski, Chmury na pogodnym niebie, s. 10-12.

569 Intymny portret uczonych, list z 24, VI 1922 r., s. 106.

570 I. Krzywicka, Wyznania gorszycielki, s. 133 ; E.S. Łazowski, Prywatna wojna, s. 57-62. Podobnie zob.: R. Matuszewski, Chmury na pogodnym niebie, s. 104,-105.

571 SUW 1937/1938, s. 69-73.

572 „Biuletyn” [Centrali Akademickich Bratnich Pomocy] z maja 1930 r., s. 2.

573 I. Krzywicka, Wyznania gorszycielki, s. 104-105.

574 I. Koprowska, O moim życiu i medycynie, s. $74-79$.

575 Tamże, s. 81.

576 AUW, AcUW/RP 101, matrykuła za lata 1929-1930.

577 E. Jarra, Wspomnienia, s. 30-31.

578 J. Garliński, Świat mojej pamięci, s. $219-220$.

579 T. Żukowska, Na skraju dwóch światów, s. 21.

580 I. Koprowska, O moim życiu i medycynie, s. 79-85; I. Krzywicka, Wyznania gorszycielki, s. 143-14.4.

581 J. Rosen-Przeworska, Moje uniwerki, s. 147;

Z. Podkowińska, Fragmenty pamiętnika, [w:] Dzieje archeologii na Uniwersytecie Warszawskim, s. 121. Por. np.: Wydziat Prawa $w$ relacjach $i$ wspomnieniach..., relacja Z. Zdrójkowskiego (1935-19422), s. 139 .

582 O. Kossmann, Es begann in Polen, s. 72-73. 
583 D. Mycielska, Postawy polityczne profesorów, s. 297-302; Dzieje Uniwersytetu Warszawskiego, s. 127.

584 SUW 1937/1938, s. 81.

585 Dzieje Uniwersytetu Warszawskiego, s. 186-192. Działalność poszczególnych ugrupowań na terenie szkół wyższych omawia szczegółowo A. Pilch, „Rzeczpospolita akademicka".

586 T. Katelbach, Spowiedź pokolenia, s. 65.

587 APAN, Materiały Franciszka Czubalskiego III.144, t. 55, niedatowana ulotka Sekcji Akademickiej Stronnictwa Narodowego, s. 91 .

588 W. Wasiutyński, Prawa strona labiryntu, s. 82 .

589 Tamże, s. 88.

590 Wydziat Prawa $w$ relacjach $i$ wspomnieniach..., relacja W. Szyszkowskiego (1924-1927), s. 26 ; E. Jarra, Wspomnienia, s. 21-22.

591 APAN, Materiały Kazimierza Bassalika III.75, t. 6, list S. Krupko do K. Bassalika z 9 VI 1924, $\mathrm{r}$.

592 J. Sas-Wisłocki, Akademicki kodeks honorowy, s. 13, 67-76.

593 W. Gombrowicz, Wspomnienia polskie, s. 159 .

594 APAN, Materiały Tadeusza Manteuffla III.192, t. 136, uchwała Sądu Honorowego Oficerów Sztabowych przy Ministerstwie Spraw Wojskowych z 22 II 1924, r. wraz z załączonymi materiałami.

595 W. Borowy, Dzienniki, wpisy z 23-24 III i 3 VII $1927 \mathrm{r}$.

596 W. Gombrowicz, Wspomnienia polskie, s. 160 .

597 B. Żongołłowicz, Dzienniki, s. 122-123, $24,4-245$.

598 St. P., U źródeł ekscesów i zajść, „Alma Mater" z 18-31 X 1937 r.

599 Wo wierzymy i o co walczymy, "Akademik" z 1-15 VI 1938 r.

600 L. Krzywicki, Wspomnienia, t. III, s. 290.
601 T. Manteuffel, Materiały do wspomnień 1918-1939, s. 14.

602 W. Gombrowicz, Wspomnienia polskie, s. $22-24$.

603 AUW, Broniewski Władysław, RP/4366/S, karta osobowa z zo X 1918 r. wraz z życiorysem i podaniem o wznowienie z 9 X $1921 \mathrm{r}$.

604 M. Kamińska, Ścieżkami wspomnień, s. $217-218$.

605 T. Jabłoński, Młodość mego pokolenia, s. 315-319. Por.: A. Chojnowski, Wptywy komunistyczne na Uniwersytecie Warszawskim w latach 1918-1939, [w:] Komuniści w międzywojennej Warszawie, red. E. Kowalczyk, Warszawa 2014, s. 219-221.

606 Z. Podkowińska, Moje wspomnienia o Ludwiku Sawickim, s. 38-4,0, 4,4-50.

607 B. Wierzbiański, Wspomnienia warszawskie, s. 434

608 D. Mycielska, Postawy polityczne profesorów, s. 296-297.

609 Organizacja życia akademickiego. Informator, s. 79. Por. L. Krzywicki, Wspomnienia, t. III, s. 288.

610 APAN, Materiały Franciszka Czubalskiego III.144, t. 55, niedatowana ulotka Sekcji Akademickiej Stronnictwa Narodowego, s. 91 .

611 P. Tomaszewski, Polskie korporacje akademickie, s. $37^{8-38} 3$.

612 E.S. Łazowski, Prywatna wojna, s. $5^{6}$.

613 „Głos akademicki” z 25 XI 1931 r.

614 K. Brandys, Miesiace $1978-1981$, s. 217.

615 Ant. Sem., Zaraza, „Akademik” z 5 III 1923 r., s. 1.

616 J. Sas-Wisłocki, Akademicki kodeks honorowy, s. 17-18.

617 S. Rudnicki, Obóz Narodowo Radykalny. Geneza i działalność, Warszawa 1985, s. 308. Przeciwnego zdania jest W.J. Muszyński, który utrzymuje: "Antyżydowskość narodowców nie 
wynikała z pogardy rasistowskiej i ślepej nienawiści, lecz jej źródłem były kwestie ekonomiczne, społeczne i polityczne.

Prowadzący politykę antyżydowską ONR konsekwentnie stał na straży wartości chrześcijańskich, odcinał się od jakichkolwiek związków z ideologią rasistowską, traktującą Żydów jako rasę niższą"; W.J. Muszyński, Duch młodych, s. 197 .

618 M. Szpakowska, „Wiadomości Literackie” prawie dla wszystkich, Warszawa 2012 , s. $238-241$.

619 Z.A. Michalski, Przez okopy, t. I, s. 216, $219,254,257^{-25} 8$.

620 R. Matuszewski, Chmury na pogodnym niebie, s. 35, 102

621 CBW, rękopis nr 138, Pamiętnik studenta medycyny Uniwersytetu Warszawskiego Pesacha Rajmana, wpis z 22 V 1917 r., s. $4,-6$.

622 W. Broniewski, Pamiętnik, s. 41.

623 Intymny portret uczonych, list z 19 XII 1922 r., s. 157-158.

624 M. Rutkowska-Kurcyuszowa, Kamyki Dawida. Wspomnienia, Katowice 2005, s. $4,4-45$.

625 Wydziat Prawa $w$ relacjach i wspomnieniach..., relacja H. Pielińskiego (1934-1938), s. 121

626 Tamże, relacja Z. Zdrójkowskiego $\left(1935^{-1942)}\right.$, s. 140

627 L. Krzywicki, Wspomnienia, t. III, s. 318.

628 W. Siła-Nowicki, Wspomnienia i dokumenty, t. I, s. 69 .

629 M. Natkowska, Numerus clausus, s. $130-131$.

630 J. Barański, Lata młodości i walki, London [1983], s. $55^{-5} 5^{6}$.

631 L. Krzywicki, Wspomnienia, t. III, s. 310.

632 M. Natkowska, Numerus clausus, s. 79-82, 102 .

633 B. Żongołłowicz, Dzienniki, s. 245, $25^{2}$.

634 SUW 1936/1937, s. 39-40.
635 AUW, AcUW/RP 19, notatka audytora D. Teleżyńskiego z 8 VIII 1939 r., s. 4.

636 AUW, AcUW/RP 112, sprawozdanie audytora D. Teleżyńskiego z 4, VIII 1939 r.

637 M. Kula, Sprawa docenta Rajchmana, dok. V, list studentki B. Tokarskiej do A. Rajchmana z 4, XI 1936 r., [w:] Rozdział wspólnej historii. Studia z dziejów Żydów w Polsce ofiarowane profesorowi Jerzemu Tomaszewskiemu $w$ siedemdziesiata rocznice urodzin, Warszawa 2001, s. 233-236.

638 Tamże, dok. VI, list T. Kotarbińskiego do A. Rajchmana z 7 XI 1936 r., s. 236-238.

639 L. Hirszfeld, Historia jednego życia, s. 253.

640 AUW, Asterblum Cywja, RP 48277/S, odpisy decyzji rektora S. Pieńkowskiego z 8 II 1936 r. o zawieszeniu w prawach studenta i orzeczenia Komisji Dyscyplinarnej dla Studentów UJP z 28 IV 1939 r. Por. Studentka prawa oskarżona o zelżenie narodu polskiego, „Nasz Przegląd" z 17 X 1936 r.

641 M. Kula, Sprawa docenta Rajchmana, dok. I, pismo rektora W. Antoniewicza do A. Rajchmana z 5 XI 1936 r.; dok. II, pismo A. Rajmana do L. Berensona z 15 XI 1936 r., s. 226-231.

642 AUW, AcUW RP/23, zarządzenie rektora W. Antoniewicza z 5 X 1937 r.

643 SUW 1937/1938, s. 8.

644 Zob. np. AUW, AcUW RP/69, list otwarty prof. T. Kotarbińskiego, Z. Szymanowskiego i S. Czarnowskiego z 30 I 1936 r.

645 M. Natkowska, Numerus clausus, s. 167.

646 L. Hirszfeld, Historia jednego życia, s. $25^{2}$.

647 Rozmowa z Tadeuszem Skalińskim, [w:] Fizycy wspominaja, s. 391.

648 M. Natkowska, Numerus clausus, s. $147^{-1} 49$

649 A. Gieysztor, Środowisko historyczne Warszawy, s. 101.

650 A. Grupińska, 12 opowieści żydowskich, relacja A. Lamoty, s. 59 . 
651 W. Borowy, Dzienniki, wpis z 6 XII $193^{8}$ r.

652 Na froncie akademickim. Prof. Kotarbiński wykłada stojąc, „Nasz Przegląd” z 29 X 1937 r.; Zajścia antyżydowskie na Uniwersytecie J. P. $w$ Warszawie, „Nasz Przegląd” z 6 XI 1937 r.; Wczorajsze zajścia na Uniwersytecie J.P. w Warszawie, „Nasz Przegląd” z 19 XI 1937 r.; Prof. Michałowicz obywatel na posterunku, „Nasz Przegląd” z 24, XI 1937 r. Por. M. Natkowska, Numerus clausus, s. 14,8-149.

653 D. Mycielska, Postawy polityczne profesorów, s. $3^{28-329}$

654 Z. Dymecki, Wieczny wstyd prof. Michałowicza, „Alma Mater” z 1-15 XI 1937 r.

655 S. Boczyński, Panom Profesorom ku rozwadze, „Alma Mater” z 1-15 XII 1937 r.

656 AUW, AcUW/RP 77, pismo R. Rybarskiego do rektora W. Antoniewicza z 4 III 1938 r. wraz z odpowiedzią z 10 III $1938 \mathrm{r}$.

657 M. Natkowska, Numerus clausus, s. $15^{0-1} 5^{1 .}$

658 S. Rudnicki, Obóz Narodowo Radykalny, s. 305 .

659 SUW 1937/1938, s. 102; L. Hirszfeld, Historia jednego życia, s. 253-254.

660 AUW, RP/WL 2, Odpis pisma Żydowskiego Stowarzyszenia Medyków UW do Rady Wydziału Lekarskiego z 4 II 1927 r., protokoły posiedzeń komisji Rady Wydziału z 5, 8, 11 i 17 II 1927 r. wraz z załączonymi odpisami listów E. Lotha do J. Modrakowskiego z 10 i 11 II 1927 r. oraz jego niedatowanym oświadczeniem.

661 BUW, Gabinet Dokumentów Życia Społecznego, nr inw. 5/1228, niepodpisana ulotka z $30 \mathrm{X} 1931 \mathrm{r}$.

662 Tamże, nr inw. 5/1227, niepodpisana ulotka z 3 XI 1931 r.

663 APAN, Materiały Franciszka Czubalskiego III/144, t. 18, protokół zebrania Zakładu Medycyny Sądowej z 19 I 1933 r. wraz z załącznikami, s. 16-19.
664 A. Śródka, Odrodzony Uniwersytet Warszawski, [w:] Dzieje nauczania medycyny i farmacji $w$ Warszawie (17891950), red. M. Łyskanowski, A. Stapiński, A. Śródka, Warszawa 199o, s. 269-271. Biogram Lotha na stronie internetowej poświęconej lekarzom Powstania Warszawskiego zawiera kuriozalne zdanie: „Jesienią 1938 r. kierował wyprawą naukową do Ugandy, skąd przywiózł bogatą kolekcję małp i czaszek Murzynów"; http://lekarzepowstania.pl/tajne-studiamedyczne/wykladowcy/profesor-edwardloth-1884-1944/; dostęp: 18 IV 2014.

665 D. Mycielska, Postawy polityczne profesorów, s. 329 .

666 M. Kridl, Przypomnienie starych i prostych prawd, „Wiadomości Literackie” $\mathrm{nr} 4.5$ z 31 X 1937 r.

667 W. Borowy, Dzienniki, wpisy z 20 VI 1925 r., 17 VI 1926 r., $22 \mathrm{Vi} 3 \mathrm{XII} 1938 \mathrm{r}$.

668 M. Szpakowska, „Wiadomości Literackie” prawie dla wszystkich, s. 85-86.

669 Wydziat Prawa $w$ relacjach i wspomnieniach..., relacja A. Stelmacha (1931-1935), s. 67 .

670 A. Hertz, Wyznania starego człowieka, Warszawa 1991, s. 357.

671 J. Pajewski, Przeszłość z bliska, s. 84-85. Sparodiował to później Julian Tuwim w wierszu przewrotnie wyśmiewającym wiarę we wszechpotężne wpływy wolnomularzy, który opowiada, jak Askenazy nocą przybywa do Piłsudskiego, aby wydać mu rozkazy: „Widno jeszcze w Belwederze. / Stary marzy przy herbacie, / Demon wchodzi bez pukania. / «No, Piłsudski, jak się macie?» / - Rad staratsia! rżnie Marszałek / I pod daszkiem rękę trzyma. / «Co z Hubisztą? » Przeniesiony. / «Gdzie Hallery?» Już ich nima”.

672 A. Rajchman, Głos Aleksandra Rajchmana, „Nasz Dziennik” z 19 XI 1937 r.

673 M. Natkowska, Numerus clausus, s. 169.

674 A. Gieysztor, Środowisko historyczne Warszawy, s. 100-101.

675 T. Manteuffel, Materiały do wspomnień $1918-1939$, s. $23-24$. 
676 L. Krzywicki, Wspomnienia, t. III, s. 292.

677 Zob. np. W.J. Muszyński, Duch młodych, s. 4,2 .

678 J.J. Lipski, Antysemityzm ONR-Falangi, [Warszawa 1985], s. 7, 76-77. Przekonanie to podziela w gruncie rzeczy sympatyzujący z ówczesną prawicą W.J. Muszyński, Duch młodych, s. 98 .

679 M. Fuks, Żydzi w Warszawie. Życie codzienne. Wydarzenia. Ludzie, PoznańDaszewice 1992, s. 357 .

680 L. Krzywicki, Wspomnienia, t. III, s. 320.

681 B. Żongołłowicz, Dzienniki, s. 253.

682 W. Wasiutyński, Prawą strona labiryntu, s. 102. Por.: Z. Przetakiewicz, Od ONR-u do PAX-u. (Wspomnienia), Warszawa 1994, s. 18.

683 „Śmiecie padały nie na zwłoki Żyda”, „Nasz Przegląd” z 26 XI 1937 r. Por.: M. Natkowska, Numerus clausus, s. 9 .

684 M. Natkowska, Numerus clausus, s. 123.

685 J. Barański, Lata młodości i walki, s. 10-12, $3^{6-49}$

686 J. Kurcyusz, Sprawozdanie za rok 1931/1932, s. 19-22.

687 J. Barański, Lata młodości i walki, s. $5^{8}$.

688 AUW, Berman Jakub, RP 9247/S;

Goldberg Józef, RP 20834/S; Danielak

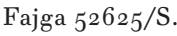

689 M. Natkowska, Numerus clausus, s. 123-124.

690 A. Pilch, „Rzeczpospolita akademicka”, s. 26o-261; A. Chojnowski, Wpływy komunistyczne na Uniwersytecie Warszawskim, s. 218-219.

691 B. Żongołłowicz, Dzienniki, s. 430.

692 L. Krzywicki, Wspomnienia, t. III, s. 314.

693 SUW 1936/1937, s. 11.

694 AUW, AcUW RP/69, sprawozdanie z nadzwyczajnego walnego zebrania Towarzystwa Bratnia Pomoc z 23 XI 1936 r. oraz relacje rektora W. Antoniewicza, prorektora F. Czubalskiego i kwestora
A. Lachowicza nt. przebiegu blokady z 30 XI 1936 r.

695 Kolejne odsłony antysemickich awantur szczegółowo omawia M. Natkowska, Numerus clausus, passim.

696 Wydział Prawa $w$ relacjach $i$ wspomnieniach ..., relacja C. Kunderewicza (1932-1939), s. 106.

697 M. Natkowska, Numerus clausus, s. 78.

698 W. Borowy, Dzienniki, wpis z 6 XII 1938 r.

699 K. Brandys, Miesiace 1978-1981, s. 224. Por.: B. Wierzbiański, Wspomnienia warszawskie, s. 4.25 .

700 Gabinet Dokumentów Życia Społecznego BUW, DU XVII.P2 8 (3053), ulotka z $7 \mathrm{~V} 1926 \mathrm{r}$.

701 L. Krzywicki, Wspomnienia, t. III, s. 34.1.

702 Student Olejniczak - działacz z pod znaku ONR'u, pod zarzutem zamachu na pochód „Bundu” w dniu 1-go maja, „Nasz Przegląd" z 28 XI 1937 r. Świadomie mija się z prawdą dowodzący bojówką ONR Zygmunt Przetakiewicz, który twierdzi, że nic nie było mu wiadomo o ofiarach tego napadu i pogłoski takie pojawiły się dopiero po wojnie. Zob.: Z. Przetakiewicz, Od ONR-u do PAX-u, s. 24.

703 AUW, Jamontt Władysław, RP 39907/S, karta osobowa z 10 IX $193^{2}$ r. z adnotacją o rozpoczęciu i zakończeniu postępowania dyscyplinarnego, pismo komisarza Policji Państwowej T. Banko do dziekana Wydziału Prawa z 4, X 1934, r., pismo rektora F. Czubalskiego do dziekana Wydziału Prawa z 18 II 1936 r.

704 J. Marszalec, Morderstwo na Makowieckich $i$ Widerszalu. Stara sprawa, nowe pytania, nowe wątpliwości, „Zagłada Żydów.

Studia i Materiały" nr 2, Warszawa 2006 , s. $3^{2-5^{2}}$.

705 M. Natkowska, Numerus clausus, s. 5o, 6o-62. O okolicznościach napadu na Handelsmana zob.: T. Jabłoński, Młodość mego pokolenia, s. 305-306.

706 L. Krzywicki, Wspomnienia, t. III, s. 309.

707 B. Żongołłowicz, Dzienniki, s. 244.

708 E.S. Łazowski, Prywatna wojna, s. $5^{6}$ 
709 W. Leopold, Wspomnienia, s. 2.

710 J. B. Saloni, Wspomnienie o ZNMS, s. 142.

711 L. Krzywicki, Wspomnienia, t. III, s. 338.

712 J. Kurcyusz, Sprawozdanie za rok 1931/1932, s. 19-20.

713 Trudno zgodzić się natomiast z tezą, iż odpowiedzialność za ów stan rzeczy spada na piłsudczyków ze względu na dokonany przez nich zamach stanu, albo tłumaczyć go znużeniem młodzieży nieskutecznością parlamentaryzmu, co czyni W.J. Muszyński, Duch młodych, s. $39,81-86$.

714 K. Brandys, Miesiace $197^{8-1981, ~ s . ~} 224$ 227.

715 S. Boczyński, O numerus nullus, „Alma Mater" z 1-15 X 1937 r.

716 T. Bielecki, W szkole Dmowskiego, s. 257.

717 J. Grabowski, Megafony warcza!', "Akademik" z 14, XII 1937 r.

718 M. Kamińska, Ścieżkami wspomnień, s. 130.

719 J. Kurcyusz, Sprawozdanie za rok 1931/1932, s. 5-6, 80-82.

720 Wydziat Prawa $w$ relacjach $i$ wspomnieniach..., relacja W. Szyszkowskiego (1924-1927), s. $3^{1}$ (cytat); J. Rosen-Przeworska, Moje uniwerki, s. 139-14,6; Z. Podkowińska, Fragmenty pamiętnika, s. 122-131.

721 I. Koprowska, O moim życiu i medycynie, s. $64-65$.

722 W. Leopold, Wspomnienia, s. 10-11.
723 E. Jarra, Wspomnienia, s. 30-31.

724 J. Tymiński, Pisane o zmierzchu, s. 35 .

725 H. Kolendo, Kadra naukowa Uniwersytetu Warszawskiego w latach 1915-1939, s. 202.

726 Intymny portret uczonych, list z 27 VII 1927 r., s. 255.

727 Wydzial Prawa $w$ relacjach $i$ wspomnieniach..., relacje W. Szyszkowskiego (1924,-1927), Z. Kolankowskiego (1931-1939), s. 22, 73 .

728 J. Tymiński, Pisane o zmierzchu, s. $35^{-36}$.

729 Wydzial Prawa $w$ relacjach i wspomnieniach..., relacje A. Stelmacha (1931-1935), J. Krośnickiego (1935-1939), Z. Zdrójkowskiego (1935-1942), s. $66,128,137$.

730 Tamże, relacja Z. Gawrońskiej-Wasilkowskiej (1930-1939), s. 6 o.

731 J. Rosen-Przeworska, Moje uniwerki, s. $143^{-144}$.

732 J. Tymiński, Pisane o zmierzchu, s. 36 .

733 Wydział Prawa w relacjach i wspomnieniach..., relacja H. Pielińskiego (1934-1938), s. 120

734 Tamże, relacja J. Krośnickiego, s. 131 (1935-1939).

735 Z.A. Michalski, Przez okopy, t. I, s. 219.

736 J. Rosen-Przeworska, Moje uniwerki, s. $14,2-143,149$

737 E. Gellner, Narody i nacjonalizm, Warszawa 1991, s. 81-85, 134-136.

738 Tamże, s. 48. 


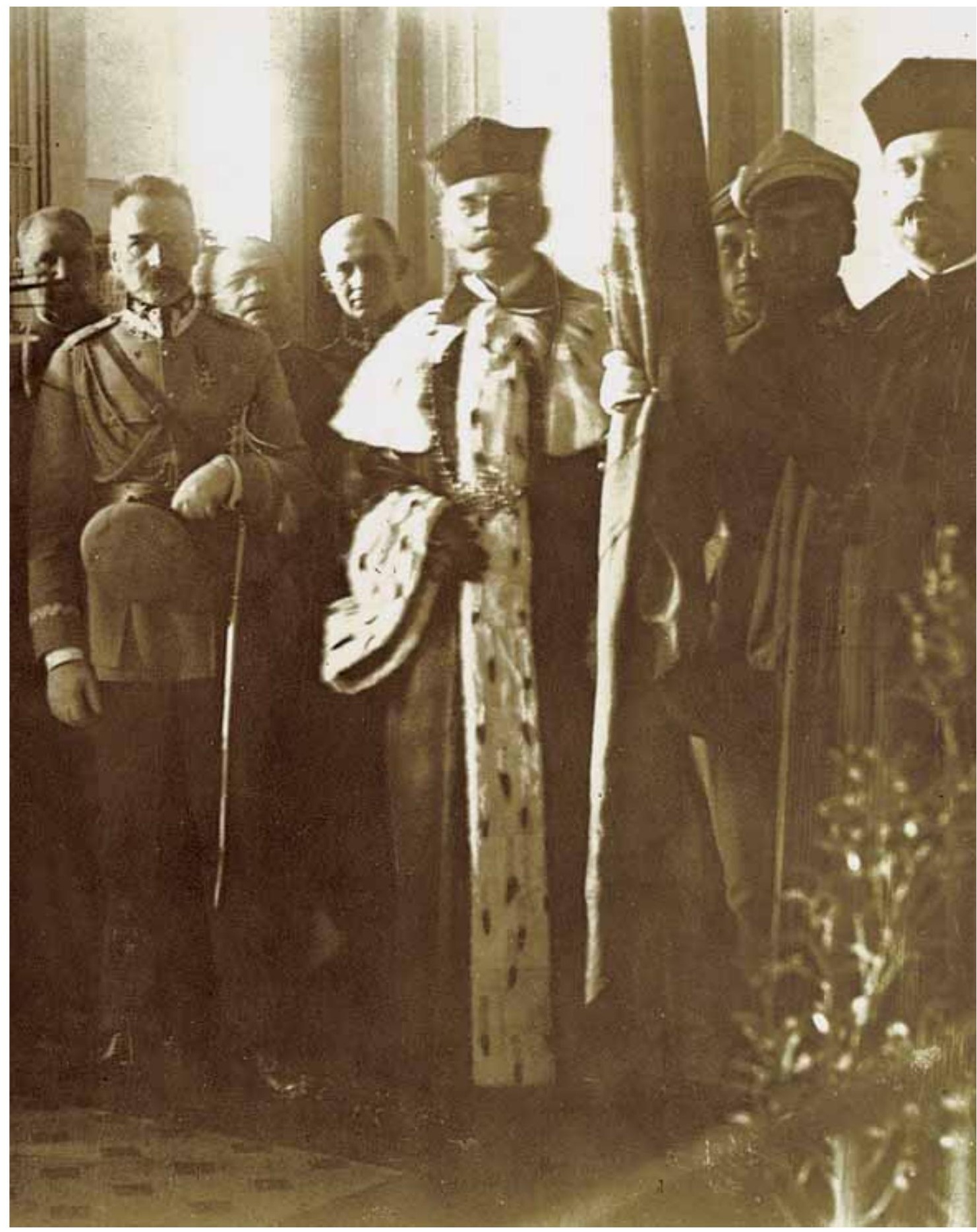

e-MONUMENTA_WUW 2016 


\section{UNIWERSYTET WARSZAWSKI W II RZECZY- POSPOLITEJ \\ Odrodzenie i działalność w okresie okupacji niemieckiej oraz wojen o granice i utrwalenie niepodległości (1915-1920)}

Drugi rok I wojny światowej przyniósł znaczące zmiany w dziejach narodu polskiego. W wyniku przełomu na froncie wschodnim, wywołanego zwycięstwem armii niemieckiej i austro-węgierskiej w bitwie pod Gorlicami (2 V 1915 r.), Rosja została zepchnięta do defensywy i zmuszona do stopniowego opuszczenia ziem Królestwa Kongresowego. Wkrótce zaborca rosyjski, zagrożony ofensywą z Prus Wschodnich oraz Galicji Środkowej i Wschodniej na Podlasie, Lubelszczyznę i Wołyń, nie był już w stanie utrzymać linii Wisły. W tej sytuacji w Piotrogrodzie zapadła decyzja o oddaniu Warszawy wojskom Państw Centralnych ${ }^{1}$.

Nadchodzące siły niemieckie podjęły walki o forty dawnej twierdzy, bronione przejściowo przez Rosjan. O północy 4/5 VIII lewobrzeżną część miasta opuścił ostatni pododdział kozaków. Władzę nad nią objął działający od roku Komitet Obywatelski miasta Warszawy, kierowany 
przez ks. Zdzisława Lubomirskiego. Spokoju pilnowała nieuzbrojona Straż Obywatelska. Jednocześnie ujawniły się podlegające Józefowi Piłsudskiemu warszawskie struktury Polskiej Organizacji Wojskowej. W Pałacu Namiestnikowskim ulokował się na pewien czas mobilizowany batalion warszawski Legionów Polskich. Rano 5 VIII eksplozje ładunków wybuchowych zniszczyły wszystkie mosty przez Wisłę. Wkrótce potem na rogatkach jerozolimskich, przy dzisiejszym pl. Artura Zawiszy, pojawiły się pierwsze pododdziały niemieckie. Podjęły one marsz ku centrum, zajmując zdewastowane koszary, cytadelę, forty, instalacje łączności i transportu, biorąc pod ochronę Zamek Królewski i archiwa. Warszawiacy - Polacy, jak i Żydzi - przyglądali się akcji z ciekawością, lecz umiarkowaną sympatią. Wraz z zajęciem reszty ziem Królestwa Polskiego, co nastąpiło w ciągu kolejnych tygodni, inicjatywa w tzw. sprawie polskiej przechodziła w ręce Państw Centralnych. Sama zaś „sprawa” - siłą rzeczy - europeizowała się.

Opanowany przez Niemcy i Austro-Węgry rdzeń terytorialny Polski został podzielony zasadniczo na dwie tzw. okupacje. Stolicą większej, niemieckiej była Warszawa; mniejszej, austro-węgierskiej - Lublin² ${ }^{2}$. Nowe, od końca sierpnia stałe już władze powołanego w uzgodnieniu z partnerami austro-węgierskimi Generalnego Gubernatorstwa Warszawa (Generalgouvernement Warschau - GGW), tworzyli: generalny gubernator gen. Hans von Beseler, szef zarządu cywilnego dr Wolfgang von Kries i gubernator wojskowy Warszawy gen. Ulrich von Etzdorf. Specyficzną rolę, jak bywa w przypadku szarej eminencji, odgrywał emisariusz polityczny cesarza Wilhelma II Hohenzollerna i kanclerza Rzeszy Theobalda von Bethmanna-Hollwega, zniemczony arystokrata ppłk hr. Bogdan Hutten-Czapski. Oni i podlegli im urzędnicy przystąpili do urzeczywistnienia planu budowy na opanowanym obszarze nowej struktury prawno-państwowej - ściśle powiązanego z Rzeszą Niemiecką „nowego” Królestwa Polskiego. Plan ten stanowił element koncepcji szerszej, obejmującej całą strefę, jaką w miarę odnoszonych sukcesów spodziewano się zdobyć na Rosji w pasie od Morza Bałtyckiego po Morze Czarne. Skonkretyzowany zasadniczo latem $1915 \mathrm{r}$. zamysł nosił miano „Mitteleuropy”3.

Dążąc do pozyskania mieszkańców zajętych ziem zaboru rosyjskiego władze Niemiec i Austro-Węgier szybko przyznały im swobody, jakich Rosja do końca faktycznie odmawiała. Należały do nich również koncesje w dziedzinie edukacyjnej wszystkich szczebli, którym wychodziły naprzeciw tradycje samoorganizacji społecznej sprzed sierpnia $1915 \mathrm{r}$. Od razu też pojawił się problem możliwości kształcenia na poziomie wyższym. W końcu lata w samym GGW dotyczył on grupy paru tysięcy 
młodych ludzi, z różnych powodów niezmobilizowanych, którzy z racji utrudnień wywołanych wojną, takich jak odcięcie od popularnych wśród młodzieży Królestwa uczelni Cesarstwa Wszechrosji w Rydze, Dorpacie, Sankt Petersburgu/Piotrogrodzie, Moskwie i Kijowie, ograniczenie ruchu osobowego (w tym zakordonowego), a także istnienia barier materialnych i językowych, nie mogli wyjechać na studia do Krakowa, odbitego Rosjanom Lwowa, Pragi lub Wiednia, nie mówiąc o Wrocławiu, Berlinie, Gdańsku, Królewcu albo neutralnej Szwajcarii. Chcąc zmniejszyć ubytek wśród osób wykształconych oraz studentów, którym wojna przerwała naukę, licznie ginących w okopach lub umierających w szpitalach, elity umysłowe nie mogły dopuścić do powstania luki w nauczaniu na poziomie akademickim. Stopniowo też pojawiały się projekty związane z odbudową państwowości i potrzebą posiadania odpowiednio przygotowanych pracowników. Pozostawało więc liczyć na odtworzenie szkół wyższych na miejscu, w Warszawie, w obiektach ewakuowanych w głąb Rosji: Cesarskiego Uniwersytetu Warszawskiego i Instytutu Politechnicznego Cesarza Mikołaja II ${ }^{4}$.

Szansę na to dała akcja władz Generalnego Gubernatorstwa obliczona na pozyskanie jego mieszkańców dla idei współpracy z Rzeszą Niemiecką. Wznowienie działalności uczelni wyższych miało stać się jednym z pierwszych, a zarazem najważniejszych kroków w tej mierze. Tym bardziej że miały one stać się dość szybko polskie, przez okupanta jedynie nadzorowane.

Do zagospodarowania schedy po Uniwersytecie Cesarskim przystąpiła grupa naukowców polskich, w części związanych z powołanym w 1905 r. Towarzystwem Kursów Naukowych, usiłująca od wybuchu wojny - lecz bezowocnie - otrzymać od władz rosyjskich zgodę na częściową polonizację uczelni lub powołanie odrębnej placówki. Specjalnie stworzonej w tym celu Komisji Szkół Wyższych TKN nie udało się uzyskać prawie nic, choć podejmowane działania spowodowały ukonstytuowanie się środowisk przyszłych twórców Uniwersytetu Warszawskiego, Politechniki Warszawskiej oraz innych zakładów naukowych, a ponadto pozwoliły opracować stosowne plany ${ }^{5}$. Doraźnie zaś w sierpniu 1915 r. organizatorzy szkolnictwa musieli stawić czoła spustoszeniom, jakie przyniosła pośpieszna ewakuacja, albowiem odezwa Komitetu Obywatelskiego miasta Warszawy, wydana zaraz po wkroczeniu do miasta oddziałów niemieckich, natychmiastowo oddała do dyspozycji Komisji Szkół Wyższych kampusy obu uczelni „w celu rozpoczęcia normalnych wykładów" . Sama komisja została włączona w strukturę powołanego niemal równocześnie Wydziału Oświecenia Komitetu Obywatelskiego i przekształcona w Sekcję Szkół Wyższych (SSW), 
kierowaną przez prof. Józefa Mikulowskiego-Pomorskiego, byłego dyrektora Akademii Rolniczej w Dublanach koło Lwowa, a ówcześnie szefa Kursów Przemysłowo-Rolniczych przy warszawskim Muzeum Przemysłu i Rolnictwa. Składała się ona z Komisji Uniwersyteckiej i Komisji Politechnicznej. Przewodnictwo pierwszej objął cechujący się dynamizmem działania lekarz pediatra, znany społecznik, choć bez doświadczenia pracy akademickiej, dr Józef Brudziński; drugiej - mechanik prof. inż. Henryk Czopowski. Komisja Uniwersytecka składała się z czterech podkomisji, odpowiadających projektowanym wydziałom - lekarskiej (referent: dr Brudziński) ${ }^{7}$, prawniczej (referent: prof. Walenty Miklaszewski) ${ }^{8}$, historyczno-filologiczno-filozoficznej (referent: prof. Władysław Smoleński) ${ }^{9}$ oraz przyrodniczej (referent: dr Tadeusz Miłobędzki) ${ }^{10}$. Wypracowane przez nią wytyczne zaakceptowała SSW Komitetu Obywatelskiego, preliminując kwotę 14,8 tys. rubli w swym budżecie. Wytyczne głosiły, że 1) nie należy „uruchamiać całego Uniwersytetu i całej Politechniki", ale wobec niedoboru kadry nauczającej i środków materialnych winno się „ograniczyć na przedmiotach, wykładanych zwykle na dwóch pierwszych semestrach"; 2) wskutek trudności w „pozyskiwaniu odpowiednich sił nauczycielskich” organizację uczelni należy rozwiązać prowizorycznie - wykładowcom nie nadawać tytułów profesorskich, powołując ich tylko na jeden rok; 3) zapewnić sobie pomoc uczelni krakowskiej i obu lwowskich w postaci „wytrawnych sił profesorskich"

Strona niemiecka miała jednak inne poglądy. Rozbieżności dotyczyły czterech zazębiających się zagadnień: tymczasowości lub stałości otwieranych uczelni, ich finansowania, uzyskania pomocy kadrowej spoza Kongresówki oraz autonomii wewnętrznej (opracowanie statutu, wybór wykładowców, mianowanie rektora, prawo SSW do modyfikacji ich struktur). Dodatkowo pojawił się problem języka niemieckiego, którego okupanci wymagali w stosunkach ze swoimi przedstawicielami.

W tle zabiegów o otwarcie uczelni dokonywało się przejęcie substancji byłego Uniwersytetu Cesarskiego. Wskutek zarządzeń władz rosyjskich składała się ona z budynków, niepełnych zasobów bibliotecznych, resztek innych zbiorów oraz mniej wartościowych elementów wyposażenia. Szczęśliwie, nie doszło do walk, silnego ostrzału ani plądrowania, co sprawiło, że gmachy nie doznały większych dewastacji. Ocalały ściany, dachy i instalacje. Uszkodzenia okien, drzwi, tynków i posadzek, do jakich dochodziło m.in. podczas załadunku wywożonego mienia, dały się szybko naprawić. Nie było jednak personelu, co stwarzało sytuację nieomal dramatyczną z punktu widzenia organizacji dydaktyki, ale też unikalną szansę natychmiastowej polonizacji. 


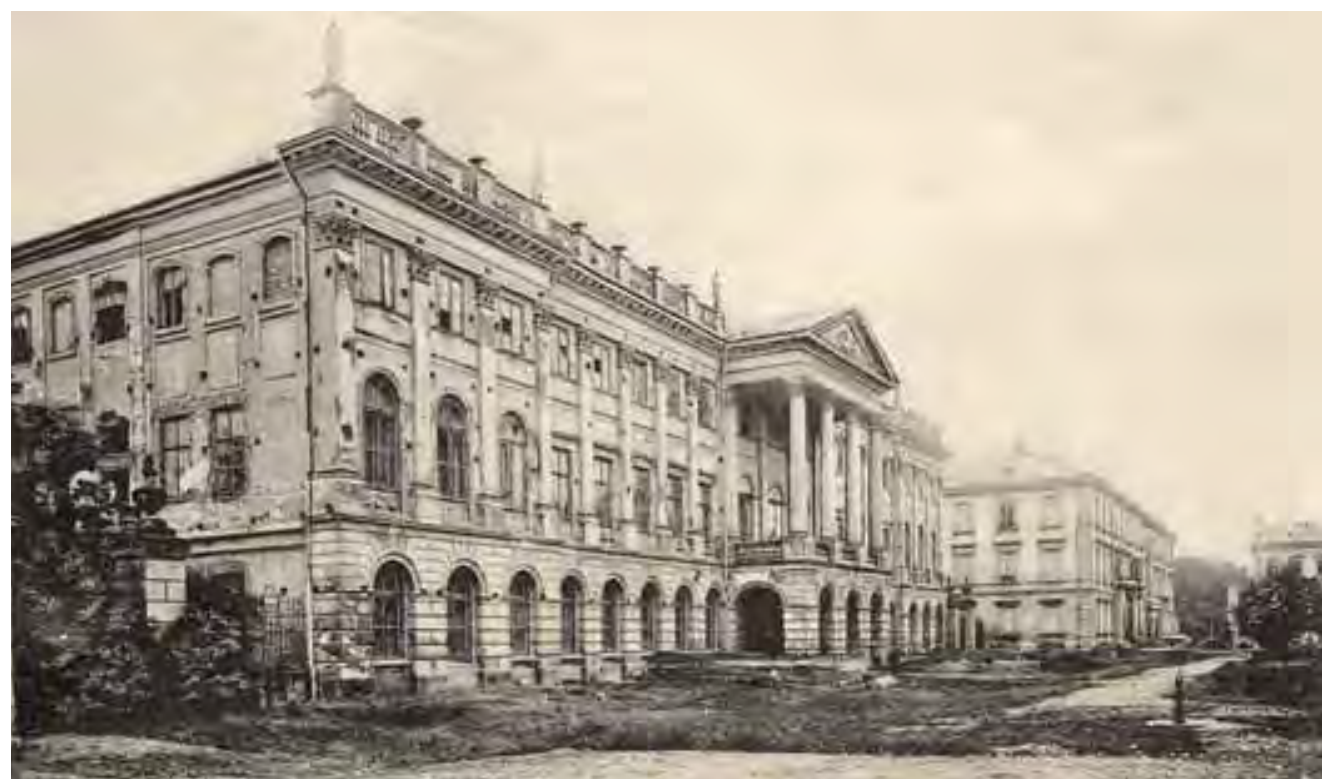

1. Pałac Kazimierzowski, prawdopodobnie ok. 1914 r.

Stan bibliotek przedstawiał się zadowalająco, jeśli chodzi o liczby. Książnica główna, która otrzymała nazwę Biblioteki Uniwersyteckiej w Warszawie, doliczyła się w zaokrągleniu 610 tys. woluminów. Gorsza była jakość księgozbioru. Jako że miał on służyć rusyfikacji, poddano go w XIX w. licznym konfiskatom (np. Gabinet Rycin wywieziony jeszcze po powstaniu listopadowym). W lwiej części składał się z literatury rosyjskiej uznanej przez władze za bezpieczną. Podobnie prace zagraniczne mogły trafić do zasobu tylko, gdy przeszły przez sita cenzorskie różnych poziomów. Zresztą nawet druków obcych a błagonadiożnych było zbyt mało jak na potrzeby uczelni europejskiej. Brakło też podstawowych edycji polskich (np. klasyków porozbiorowej literatury pięknej), wydawanych w autonomicznej Galicji, na Zachodzie, a także w konspiracji. Działy humanistyczne wypadało w zasadzie stworzyć od nowa. Na tym tle straty związane z wywozem do Rosji wszystkich rękopisów i inkunabułów oraz inwentarzy i archiwum biblioteki miały znaczenie duże, ale doraźnie nie najistotniejsze. Przed pierwszym dyrektorem BUW etnologiem dr. Stanisławem Poniatowskim i podległym mu personelem stanęło nie lada zadanie szybkiego udostępnienia zbiorów największej książnicy w Generalnym Gubernatorstwie Warszawa, a nade wszystko uzupełnienia luk w księgozbiorze. Stąd poniekąd wynikała akcja pisania przez znamienitych często naukowców 
i edycji przez różne wydawnictwa (warszawskie, krakowskie, lwowskie), na skalę dotąd niespotykaną, szeregu broszur popularyzujących stan wiedzy na tematy związane z szeroko pojętymi naukami społecznymi, w tym zwłaszcza dziejami myśli, literatury, historii i sztuki polskiej ${ }^{12}$. $\mathrm{Na}$ szczęście spory i stosunkowo nowoczesny gmach (dziś tzw. stary BUW, oddany do użytku w 1894, r.) nie przysparzał jeszcze poważniejszych problemów lokalowych ${ }^{13}$.

Znacznie trudniej było z innymi pomocami potrzebnymi w dydaktyce. Tu, choć stosowne kroki zaradcze podjęto bardzo szybko, problemy wywołane ewakuacją Uniwersytetu Cesarskiego jawiły się bardzo poważnie. Warunki działania właściwe dla lat 1915 r. ilustruje przykładowe sprawozdanie, złożone przez kuratora jednej z komórek przyszłego Wydziału Filozoficznego, dr. Kazimierza Stołyhwo:

Ostatnio, z chwilą wybuchu wojny [...], podczas nieobecności [dyrektora] prof. [Teodora] Wierzbowskiego, rosyjskie władze uniwersyteckie wywiozły do Moskwy cały szereg innych przedmiotów, a przede wszystkim prawie cały zbiór numizmatyczny. Pozostały zaledwie te nieliczne numizmaty, które znajdowały się w dolnych szufladach witryn, a których widocznie nie zauważono. [...] Po ewakuacji [...] Komisja Szkół Wyższych przy Tow[arzystwie] Kursów Naukowych, na skutek odezwy Komitetu Obywatelskiego stoł[ecznego] m. Warszawy z d[n.] 6 sierpnia 1915 r., objęła w posiadanie gmachy i ruchomości uniwersyteckie. Ponieważ zaś prof. T. Wierzbowski zrzekł się dalszej opieki nad zdewastowanym Gabinetem [...], przeto Komisja [...] zawezwała mnie [...] do objęcia [go]. [...] Gdy zaś następnie [...] mianowany zostałem przez Komitet Obywatelski [...] kuratorem Gabinetu [...], przystąpiłem niezwłocznie do pracy, przy czym najpierwszym zadaniem było doprowadzenie do porządku lokalu [...], który znajdował się w stanie wprost opłakanym. Ściana bowiem jego zewnętrzna, wewnątrz której przechodziła rura od motoru miejscowego oświetlenia elektrycznego, była uszkodzona, toteż swąd i kurz przedostawały się do wnętrza sali w takiej ilości, iż pobyt w nim był niemożliwy, a zbiory narażone na zniszczenie. Zwróciłem się więc przede wszystkim do Wydziału Budowlanego Komitetu [...], u którego wyjednałem naprawę uszkodzonej ściany. Gdy zaś to zostało uskutecznione, przystąpiliśmy wspólnie z p. Romanem Jakimowiczem, asystentem Pracowni Archeologicznej T[owarzystwa] N[aukowego] W[arszawskiego], do uporządkowania zbiorów Gabinetu [...].

Zbiory te, zawierające zarówno przedmioty z archeologii prehistorycznej i klasycznej, jak i okazy etnograficzne oraz różne przedmioty posiadające wartość historyczną, szczególnie dla nas, zastaliśmy w nadzwyczajnym nieładzie. Po oczyszczeniu ocalałych przed ewakuacją [...] zbiorów z grubej warstwy kurzu rozmieściliśmy je w szafach i witrynach. Ponieważ zaś nie znaleźliśmy 
w Gabinecie ani katalogu, ani inwentarza, które prawdopodobnie wywiezione zostały [...] podczas ewakuacji wraz ze zbiorami, przeto p. R. Jakimowicz przystąpił do inwentaryzowania ich ${ }^{14}$.

Nie było rady: tablice poglądowe, fotokopie, mapy, modele, zbiory okazów, preparaty, odczynniki czy aparatura musiały zostać wykonane lub zakupione na nowo. Zrazu pozostawały: głos, kreda, tablica, a nade wszystko - wyobraźnia wykładowców i słuchaczy, zdolna do wykreowania i odbioru eksperymentów myślowych. Podobnie jak w przypadku książek, można też było liczyć na dary osób fizycznych lub instytucji.

Kadra nauczająca stanowiła, jak zawsze w przypadku instytucji akademickiej, zagadnienie kluczowe. Trzeba ją było w znacznej mierze zaimprowizować. Do dyspozycji oddali się przede wszystkim działacze naukowi z Warszawy i obszaru Generalnego Gubernatorstwa - w znacznej mierze praktycy, niemający doświadczenia dydaktycznego. Pomocy w „siłach nauczających” mogły udzielić placówki akademickie z Galicji - uniwersytety Jagielloński i Lwowski. Tu jednak ograniczenia nałożyły władze niemieckie: nie chciały stworzyć w Warszawie „klona” szkół austro-polskich, przeciwnie - chodziło im raczej o powielenie modelu typowego dla Rzeszy. Dlatego z obu uczelni galicyjskich przybyło do stolicy okupowanego Królestwa zaledwie kilku wykładowców i profesorów. Niejako w zamian delegowano do Warszawy poddanych pruskich: germanistę i filozofa Wilhelma Paszkowskiego z Uniwersytetu Fryderyka Wilhelma w Berlinie, chemika Juliusa von Brauna ze Śląskiego Uniwersytetu Fryderyka Wilhelma we Wrocławiu oraz germanistę i filologa klasycznego Ryszarda Gansińca z berlińskiego Museum für Völkerkunde. Oprócz nich pomiędzy dydaktykami zatrudnionymi w pierwszym roku akademickim 7 pochodziło z Uniwersytetu Lwowskiego, jeden przyjechał ze Szwajcarii (fizyk Józef Wierusz-Kowalski z Uniwersytetu we Fryburgu). Przybysze zostali jednak zdominowani przez grupę 25 warszawian, stanowiącą ok. 70\% kadry ${ }^{15}$.

Proces podejmowania decyzji o polonizacji obu uczelni wyższych ilustruje relacja osoby miarodajnej, a mianowicie wspomnianego już rzecznika pojednania niemiecko-polskiego hr. Hutten-Czapskiego. Rzuca ona światło na pobudki, jakimi kierowały się władze Generalnego Gubernatorstwa Warszawa:

25 IX 1915 [r.] odbywała się u [von] Beselera konferencja [...] w sprawach zarządu cywilnego (Zivilvortrag). [Jego szef von] Kries wyłuszczył w dłuższym przemówieniu, że konieczne jest, aby ewakuowane przez Rosjan uniwersytet i politechnika otwarte zostały na nowo, ale z polskim językiem wykładowym. Trzeba 
umożliwić młodzieży normalne kształcenie i zapobiec, by wskutek przymusowej bezczynności nie stała się ofiarą niepożądanej agitacji i politycznych niepokojów. Wpływowe koła polskie poczyniły już kroki u władz okupacyjnych, w celu otrzymania pozwolenia na otwarcie obu uczelni. W spełnieniu tego życzenia widział Kries wielką myśl polityczną. Niespełnionym obietnicom Rosji przeciwstawiono by przychylność niemiecką. Niemcy nie mają zamiaru zatrzymać kraju tego na zawsze, pragną jednak związać go z sobą trwale. Musi on być dobrze rządzony, posiadać dobrych urzędników, prawników, lekarzy, inżynierów, budowniczych, techników, ba, nawet filozofów. Byłoby rzeczą ważną, żeby Polacy z chwilą, gdy niegdyś obejmą administrację kraju, mieli potrzebnych specjalistów. Nie należałoby jednak opierać wyższych uczelni - jak tego chcą Polacy - na funduszach miejskich lub prywatnych, a przeciwnie, muszą one być otwarte jako instytucje państwowe i utrzymywane z funduszów administracji okupacyjnej. Dałoby to jej do ręki atut moralny i polityczny, a uczelniom zapewniłoby pod względem organizacyjnym powodzenie, oparte na kilkusetletnich doświadczeniach nauki niemieckiej. Komitet Obywatelski [m.st. Warszawy] nie byłby w stanie przeprowadzić tego dzieła z powodu braku kompetencji wykonawczych. [...] Beseler zapytał mnie o zdanie. Odpowiedziałem w gorących słowach, że uważam utworzenie czysto polskich wyższych uczelni w Warszawie za najlepszą oznakę, iż Niemcy nie tylko nie mają zamiaru wynaradawiania Polaków, lecz przeciwnie, przygotowują polską administrację kraju. Również i Beseler zrozumiał ważność i doniosłość tego projektu i jako syn profesora uniwersytetu [Georga] rad był, że zostanie założycielem wielkich instytucji naukowych. $\mathrm{Z}$ wyjątkowym zadowoleniem dał swe zezwolenie ${ }^{16}$.

Jak widać, okupant udzielił nie tylko zgody, ale nawet błogosławieństwa. W działaniach Niemców znać było ducha jeszcze XIX-wiecznego: przekonania o potędze edukacji, także humanistycznej, oraz sile, jaką daje myśl ujęta w karby dyscypliny naukowej. Obie uczelnie odtwarzane w Warszawie stać się miały kotwicami zachodniej ekspansji intelektualnej zarzuconymi w zatoce, jakie stanowiły zalane od $1812 \mathrm{r}$. „morzem rosyjskim” ziemie Królestwa Polskiego. Wedle tej wizji nad środkową Wisłą miał się dokonać zwrot cywilizacyjny - od euroazjatyckiego półabsolutyzmu ku właściwemu dla Europy Zachodniej modelowi konserwatywno-liberalnego państwa prawnego, z monarchiczno-parlamentarną formą rządów. Opiekunami procesu jego inkubacji mieli stać się oświeceni generałowie i urzędnicy pruscy.

W tej sytuacji, pod naciskiem władz niemieckich zgodzono się na narzucony 25 X 1915 r. statut tymczasowy. Pierwszy z jego 48 paragrafów głosił, iż UW „ma za zadanie bezstronne i niezależne nauczanie w zakresie powierzonych jego pieczy gałęzi wiedzy, oraz rozwój ich 
przez prowadzenie samodzielnych prac i badań naukowych. Uniwersytet ma kierować w sposób celowy wykształceniem ogólnym i specjalnym młodzieży, oraz przysposabiać ją do zawodów, w których wyższe wykształcenie naukowe jest niezbędne bądź pożądane. [...]”. Dalej statut przewidywał zwierzchnictwo nad uczelnią szefa Zarządu Cywilnego Generalnego Gubernatorstwa, mającego prawo powoływania wykładowców i sędziego uniwersyteckiego, pozostawiał mianowanie rektora i I prorektora w gestii gubernatora generalnego, a nade wszystko redukował liczbę wydziałów do trzech (prawa i nauk państwowych, filozoficznego i matematyczno-przyrodniczego, ten ostatni z oddziałem przygotowawczo-lekarskim). Finansowanie uczelni zostało zastrzeżone dla administracji okupacyjnej ${ }^{17}$.

Strona niemiecka wezwała organizatorów Uniwersytetu i Politechniki do obioru kandydatów na rektorów i dziekanów. Doszło do tego jeszcze $12 \mathrm{X}$, na połączonym posiedzeniu wszystkich podkomisji. Kierowanie UW miał objąć dr Brudziński; pierwszym kandydatem na rektora był prof. Władysław Smoleński, który jednak nie przyjął jednogłośnego wyboru, dokonanego przez wszystkich wykładowców otwieranej uczelni ${ }^{18}$. Na dziekanów przewidziano: prof. Leona Kryńskiego (Wydział Lekarski), dr. Jana Lewińskiego (Wydział Przyrodniczy), dr. Jana K. Kochanowskiego (Wydział Historyczno-Filologiczny; po jego rezygnacji - prof. Adama Kryńskiego), dr. Alfonsa Parczewskiego (Wydział Prawa) ${ }^{19}$. Po akceptacji kandydatur przez Wydział Oświecenia Komitetu Obywatelskiego m.st. Warszawy 2 XI władze okupacyjne zatwierdziły statut tymczasowy uczelni i dr. Brudzińskiego jako rektora, choć nie obyło się po stronie niemieckiej bez intryg mających na celu utrącenie jego kandydatury; równocześnie w prasie rosyjskiej pojawiły się groźby wobec „zdrajców” przejmujących uniwersytet z rąk „wrogich Słowiańszczyźnie”. Kuratorem Uniwersytetu i Politechniki mianowano hr. Hutten-Czapskiego ${ }^{20}$. Jak głosił artykuł okolicznościowy, opublikowany krótko przed inauguracją uczelni:

Polski Uniwersytet w Warszawie powstaje w warunkach zgoła osobliwych i ciężkich, w roku klęsk i niepewności, w tempie przyspieszonym, a więc bez możności należytego porozumienia się z innymi dzielnicami naszej ojczyzny. Witamy go jednak z najgłębszym wzruszeniem, chcemy wierzyć w jego trwałość i rozwój pomyślny. Tak dawno byliśmy spragnieni zdobycia uczelni wyższej, narodowej z ducha i języka, tu - w sercu Polski - w Warszawie! [...] Młodzieży naszej los szczęśliwy otwiera zamknięte blisko od pół wieku podwoje świątyni nauki polskiej w stolicy kraju. Skończy się wreszcie jej tułaczka, zapłonie dla niej Znicz nauki rodzimej. [... $]^{21}$ 


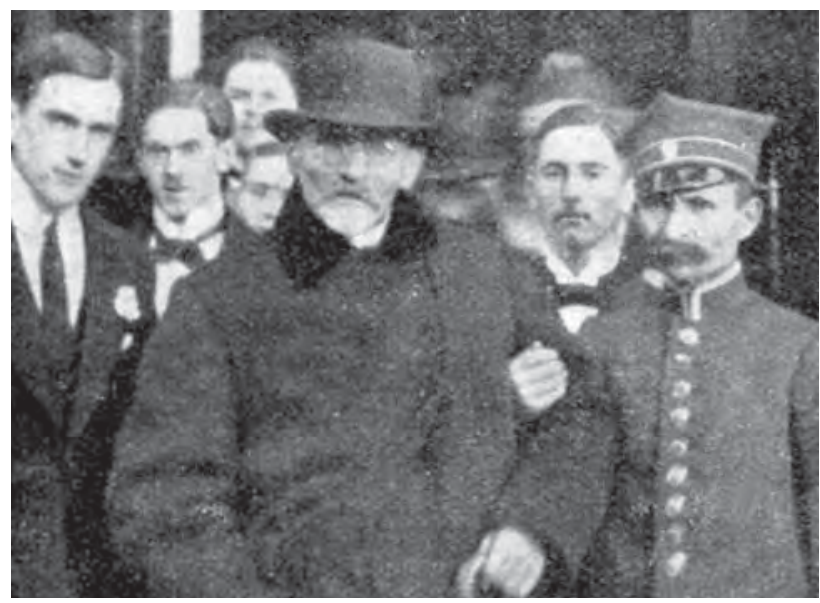

2. Uczestnicy uroczystej inauguracji wznowienia Uniwersytetu w $1915 \mathrm{r}$.

Obie uczelnie akademickie otwarto uroczyście 15 XI 1915 r. W ten sposób, po 46 latach przerwy, odrodził się pierwszy uniwersytet polski położony poza zaborem austriackim; powstała też druga po działającej od 1844 r. we Lwowie politechniczna szkoła wyższa. Obchód poprzedziła msza święta w archikatedrze św. Jana, celebrowana przez samego abp. warszawskiego Aleksandra Kakowskiego ${ }^{22}$. W jej trakcie w podniosły sposób przemówił wybitny kaznodzieja, ks. dr Antoni Szlagowski:

Zmartwychwstał Chrystus, gdy wzeszło słońce, zmartwychwstanie Polska, gdy jasna światłość oświaty i wiedzy w[z]ejdzie nad krajem i urośnie aż do dnia doskonałego. Noc przeminęła, dzień się przybliżył, jutrzenka już nam świta w onym prawie o powszechnym nauczaniu, co zbliża nas i wiąże z Komisją Edukacyjną, pierwszym w Europie wydziałem oświecenia. I brzask tego dnia upragnionego widzę, [...] w dwóch wyższych uczelniach, które roztwierają dziś narozcież podwoje swe w stołecznym mieście: Wszechnica, co dawno przestała być naszą i Politechnika, co naszą od początku nie była. Dziś wracamy do swego. Dziś w salach, gdzie mowa polska milczała, myśl polska odezwie się po raz pierwszy po latach wielu melodią polskiego słowa. [...]

A Wszechnicy naszej mówimy: Żyj! Niech cię żadne zmiennych losów zrządzenia losów nie pozbawią. Żyj! Krzew ducha narodowego, rozbudzaj zapał do wiedzy, twórz liczne zastępy światłych pracowników. Żyj! Niech o tobie kraj mówi, niech cię ceni, niech się tobą chlubi, niech cię kocha, jako matkę, Alma Mater. Żyj na wieki, a Bóg niechaj będzie z tobą.

Jednym z najważniejszych momentów inauguracji było wystąpienie rektora Brudzińskiego w odświętnie udekorowanym Pałacu Kazimierzowskim. Już na początku pięknie skomponowanej mowy zwrócił on 
uwage na elementy tradycji, nadziei i przyszłości oraz przynależności Polski do zachodniego kręgu cywilizacyjnego:

Witam wszystkich słowy, które oby już nigdy nie uległy zmianie: Mamy nareszcie w Warszawie Wszechnicę, w której salach rozbrzmiewać będą dźwięki naszej ukochanej a pięknej mowy ojczystej. Niechaj słowa te lecą jak dobra wieść na kraj cały, tak ciężko w dobie obecnej doświadczany, niech wleją otuchę w serca i dodadzą sił do wytrwania.

„W częstej kolei upadków i dźwigań naszego narodu odnowieniu życia towarzyszyło zawsze odnowienie nauk, i rozwój Szkoły Głównej poprzedzał, przygotowywał nieraz rozwój Państwa”.

Te słowa [Józefa] Mianowskiego niech nas natchną wiarą, że po raz trzeci wskrzeszona Wszechnica nasza żyć już będzie nieprzerwanym pasmem dni pożytecznej pracy, bo tym razem wskrzeszenie jej przeszło z Zachodu, ze źródeł „tej dawnej oświaty, którą Polska długo jaśniała, tej wielkiej zachodniej cywilizacji, którąśmy niegdyś z taką chwałą pielęgnowali u siebie, z taką zasługą krzewili wśród dalszych krajów i plemion”. (Mianowski) „Gdzie ustaje łacina, tam ustaje Europa” - tu nie ustaje Europa, bo łaciną, to jest „tą wielką puścizną starożytnego świata, która chrześcijańskim ożywiona duchem, stała się najwyższym moralnym i intelektualnym skarbem Zachodu" - żyła Polska wspólnie z Zachodem ${ }^{23}$.

Dalej, w odwołaniu do początków uczelni, zabrzmiał i inny ton, odnoszący się do szczególnie delikatnego w ówczesnej sytuacji zagadnienia autonomii:

Statut nie był podany do zatwierdzenia przez władzę najwyższą. Komisja kierowała się myślą, że pożyteczniej będzie, gdy statut zachowa charakter tymczasowości, aby po zyskanym doświadczeniu można było poczynić zmiany i dodatki. Do zepsucia dobrej atmosfery, jaka panowała w Uniwersytecie, wzięli się jednak energicznie komisarz cesarski [Nikołaj] Nowosilcow i radca [Jan Kalasanty] Szaniawski. Największe ciosy w postaci przepisów ograniczających spadły na młodzież. Społeczeństwo polskie i jego organa oficjalne, komisje sejmowe, potępiły ostro w osobnej uchwale tę działalność dozorczą w Uniwersytecie. Tak myśleli światli Polacy w roku 1825, a co powiedzieć moglibyśmy o tym my w tej sali zebrani, cośmy przeszli czasy [Aleksandra] Apuchtina i jego następców. Cudem zaiste ocaleliśmy, głównie dlatego, że tak obce były sobie te dwie dusze: nasza - zachodnia, ich - wschodnia, że odbijały się te wpływy i prześladowania jak o pancerz ${ }^{24}$.

Wspomniawszy luminarzy uczelni i polskiego życia umysłowego z jej pierwszego i drugiego wcielenia - tak spośród wykładowców, jak 
i studentów - Brudziński oddał hołd obecnym na uroczystości trzem profesorom Szkoły Głównej: lekarzowi Ignacemu Baranowskiemu oraz prawnikom Władysławowi Holewińskiemu i Walentemu Miklaszewskiemu. Następnie zwrócił się do najważniejszego w istocie gościa, gubernatora von Beselera:

Gdy od przeszłości powrócimy do chwili obecnej, jakże prawdziwe wydadzą się nam słowa [Zygmunta] Krasińskiego, bo oto mamy szlachetne wspomnienia, a więc wolno nam mieć i szlachetne nadzieje. Że nam je mieć wolno, zawdzięczamy to i Tobie, dostojny Panie, któryś się nie zawahał nawet wśród pożogi wojennej uczynić zadość najżywotniejszej potrzebie kulturalnej naszego narodu, dałeś swą sankcję na otwarcie i nadałeś Statuty naszym Szkołom Wyższym. Społeczeństwo nasze [...] odpowie na ten czyn troskliwą opieką, jaką na pewno obie Szkoły Wyższe otoczy, a Uniwersytet zachowa we wdzięcznej pamięci Tego, który mu nadał Statut taki, jakim się cieszą Wszechnice zachodnioeuropejskie z ustrojem autonomicznym wydziałów, z Senatem Akademickim na czele, a nade wszystko w językiem wykładowymi i urzędowym polskim ${ }^{25}$.

Pod koniec zaś dodał po niemiecku:

Uniwersytet Warszawski uświadamia sobie, że zawdzięcza swoje wskrzeszenie Waszej Ekscelencji. Jako syn wielkiego prawnika uznałeś, że jedynie nauka wskazuje właściwe drogi młodzieży w życiu. Ta nowa placówka nauki - w której oby wiele pokoleń wychowało się na dzielnych ludzi i pożytecznych obywateli - składa Panu, Ekscelencjo, wyrazy dziękczynne ${ }^{26}$.

W odpowiedzi na niemiecki passus przemowy rektora, „złożył Uniwersytetowi życzenia von Beseler głosem gardłowym, urywanym, skandującym według pruskiej maniery wojskowej”27. W ten sposób uczelnia została formalnie otwarta, rozpoczynając zupełnie nowy rozdział swej historii.

Wznowienie Uniwersytetu w Warszawie spotkało się z przyjaznym przyjęciem w innych polskich ośrodkach akademickich. Najlepiej odda ten nastrój dłuższy cytat, zaczerpnięty z wykładu okolicznościowego, wygłoszonego na jagiellońskiej Alma Mater przez wybitnego historyka prof. Stanisława Kutrzebę. Nosił on znamienny tytuł: „To światło kraju być powinno - i będzie" i obrazował punkt widzenia charakterystyczny dla działającej w zaborze austriackim generacji odbudowującej Polskę niepodległą, jej świadomość historyczną i państwową oraz nadzieje pokładane w rozgrywających się wydarzeniach. Cofając się aż do czasów Komisji Edukacji Narodowej, Kutrzeba omówił koleje losu 
warszawskiej uczelni, począwszy od jej założenia przez cara Aleksandra I aż po likwidację Szkoły Głównej, kończąc swą przemowę życzeniem:

Jeżeli też dziś tam, w Warszawie, ku której kierujemy myśl naszą, w tej chwili na nowo zawiązuje się nić wyższej nauki polskiej na polskim jej Uniwersytecie, to Rector Magnificus tej nowej Wszechnicy bezpośrednim swoim poprzednikiem Mianowskiego tam pewnie nazywa, chwyta w swoje dłonie te iskry nauki, które po tamtych dwóch Uniwersytetach tliły bez przerwy w popiele naniesionych wschodnim wiatrem żużli. Niechże je rozdmucha, by płomieniami wystrzeliły do końca wiedzy, by to słońce polska myśl rozżarzyć jeszcze potrafiła! Gdy dziś nasz Rektor tu, z Krakowa, z auli pierwszej polskiej Wszechnicy, śle serdeczne życzenia: „quod felix, faustum, fortunatumque sit” do tej z[e] snu zbudzonej siostrzycy, która ma wiedzą leczyć schorzałą naszą społeczność, możemy z wiarą w siły narodu i siły tych, co dziś ten Uniwersytet tworzą, powtórzyć słowa, które o Szkole głównej powiedział ówczesny dyrektor Komisji wyznań i oświecenia [Kazimierz] Krzywicki, gdy powstać miała: „to światło kraju być powinno - i będzie” [... $]^{28}$.

Trzeba w tym miejscu zaznaczyć, iż stanowisko działaczy i naukowców odtwarzających uczelnię warszawską, przyjmujących, że jej początek wyznacza dyplom władcy Królestwa Polskiego Aleksandra I Romanowa z 19 XI 1816 r., wzbudziło polemikę uczonych z Krakowa i Lwowa. Wykazując błędność takiego poglądu sugerowali oni, że Uniwersytet winien odwołać się do wcześniejszego o lat kilka - jeszcze w Księstwie Warszawskim - otwarcia szkół wyższych, a to Szkoły Prawa w 1808 r. i Szkoły Administracji w 1809 r. na mocy dekretów ks. Fryderyka Augusta Wettina ${ }^{29}$.

Odnowiona uczelnia miała tym razem dogodne warunki rozwoju: po pierwsze, utrzymywała się pomyślna koniunktura polityczna, mimo pogarszających się z biegiem wojny materialnych warunków bytowania jej studentów i pracowników; po drugie, już w początkowym okresie życia Uniwersytetu na jego czele stały dwie wybitne osobowości - rektor Brudziński i kurator Hutten-Czapski. O pierwszym z nich historyk Marceli Handelsman pisał:

On skupiał wszystko w swoim ręku, dawał pęd pomysłom, kierował ciałem nauczycielskim i młodzieżą, do niego zwracała się ona ze wszelkimi troskami swymi, wątpliwościami naukowymi, wahaniami politycznymi, kłopotami życiowymi, nawet - zawodami sercowymi. W tym bezruchym roku stopniowego zamierania życia w kraju, rektor był prawdziwym słońcem, ogrzewającym młodziė̇, a przez młodzież szeroko zataczającym kręgi swego autorytetu i swego oddziaływania na kraj okupowany ${ }^{30}$. 


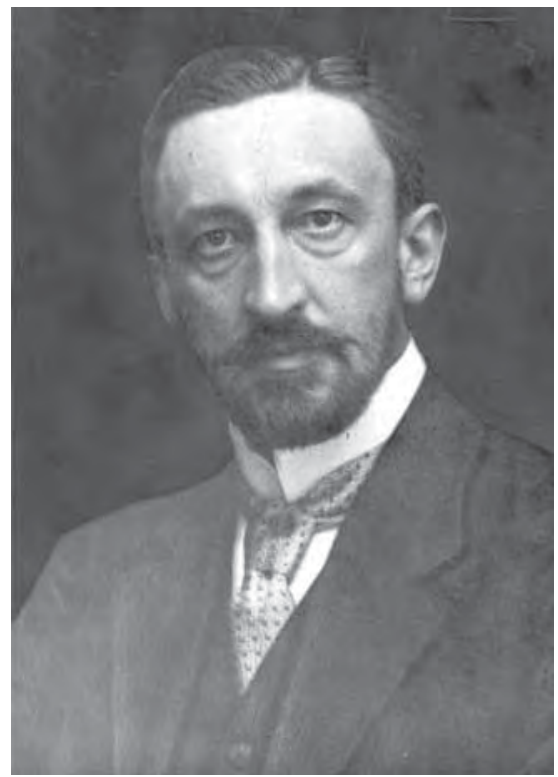

3. Lekarz pediatra, dr Józef Brudziński, pierwszy rektor UW po reaktywacji uczelni przez niemieckie władze okupacyjne w $1915 \mathrm{r}$.
Należy przypomnieć o zaangażowaniu pozauniwersyteckim Brudzińskiego. Stojąc na czele uczelni stał się rozpoznawalny i popularny - zwłaszcza po wielkiej manifestacji narodowej w 125. rocznicę uchwalenia Konstytucji 3 Maja. W lipcu został pierwszym prezesem Rady Miejskiej Warszawy. Jako czołowa osobistość życia publicznego Królestwa, mimo wahań, zdecydował się przyjąć niełatwe zadanie udania się w październiku tegoż roku do Berlina i Wiednia, gdzie odbył rozmowy z przedstawicielami rządów obu mocarstw na temat sprawy polskiej. Dla rektora krok ten oznaczał wejście (na krótko, bo jego życie miało dobiec niebawem kresu) na arenę polityczną. Będąc bezpartyjnym aktywistą, de facto stawiał Niemcom warunki i nie godził się na uprzedmiotowienie Królestwa zgodne z planem „podboju moralnego". W przygotowanym na przełomie lat 1916/1917 memoriale wysuwał wprost postulaty nierozłącznego traktowania kwestii niepodległości oraz zjednoczenia ziem polskich „na gruncie frontu antyrosyjskiego" ${ }_{31}$.

Rozwój wydarzeń politycznych i narastanie w Warszawie nastrojów antyniemieckich pogarszały jednak położenie rektora. Krytyczny skądinąd wobec jego postawy politycznej prawnik Eugeniusz Jarra napisał:

Wśród młodzieży umiał zdobyć sobie wiele sympatii i zaufania. Na nieszczęście wszedł do polityki, angażując się po stronie państw centralnych, podczas gdy studenci w olbrzymiej większości, z nieomylnym u młodzieży instynktem, mieli orientację aliancką. Stosunki zaczęły się psuć coraz bardziej, co Rektor brał głęboko do serca. Wpadł w końcu w chorobę na tle starej wady nerek $[\ldots]^{32}$.

Podnieść należy też niemałe zasługi położone na rzecz UW przez hr. Hutten-Czapskiego - osobę dziś niemal zapomnianą. Ten sam pamiętnikarz odmalował go następująco:

Hrabia [...] Bohdan Hutten-Czapski, słusznego wzrostu, chudy, wyprostowany, o bladoniebieskich oczach i siwej, wyszczotkowanej czuprynie, opięty w mundur [...] gwardii cesarskiej z rapierem na długich rapciach i w butach kawaleryjskich - zewnętrznie nie różnił się niczym od pruskiego oficera, bo nawet akcent 
jego mowy polskiej był obcy. Uniwersytet traktował jak koszary, zaglądając wszędzie, odwiedzając wykłady, rządząc się. [...] Poza tymi jednak starokawalerskimi dziwactwami, kurator [...] oddał wielkie usługi Uniwersytetowi, do którego przywiązał się szczerze. Co najważniejsze, powściągał różne na niego zakusy niemieckiej administracji cywilnej, grożąc natychmiastowym odwołaniem się do Wilhelma II, do którego miał dostęp bezpośredni. Po zdarciu przez młodzież z bramy uniwersyteckiej dwugłowego orła rosyjskiego, ufundował natychmiast pięknie wykutego w srebrze białego orła polskiego, który odtąd królował nad wejściem [...]. Ofiarował również srebrne, w ogniu złocone berło rektorskie [...]. Wreszcie, za polskich już czasów, zapisał Uniwersytetowi wraz z Politechniką wielkie swe dobra $[\ldots]^{33}$.

Hutten-Czapski był człowiekiem amortyzującym napięcia pomiędzy sferą nauki a polityki, jakie miały przenieść nadchodzące lata. Jego obecność u boku gubernatora von Beselera trudno przecenić. Mieli tego świadomość senatorowie obu uczelni warszawskich, nagradzając kilkanaście lat później sędziwego eks-kuratora doktoratami honoris causa ${ }^{34}$.

Uniwersytet rozpoczął pierwszy po odnowieniu rok akademicki 1915/1916 (dwudziesty drugi w swej historii) w listopadzie, jako uczelnia trzywydziałowa, z zawiązkiem wydziału czwartego (lekarskiego).

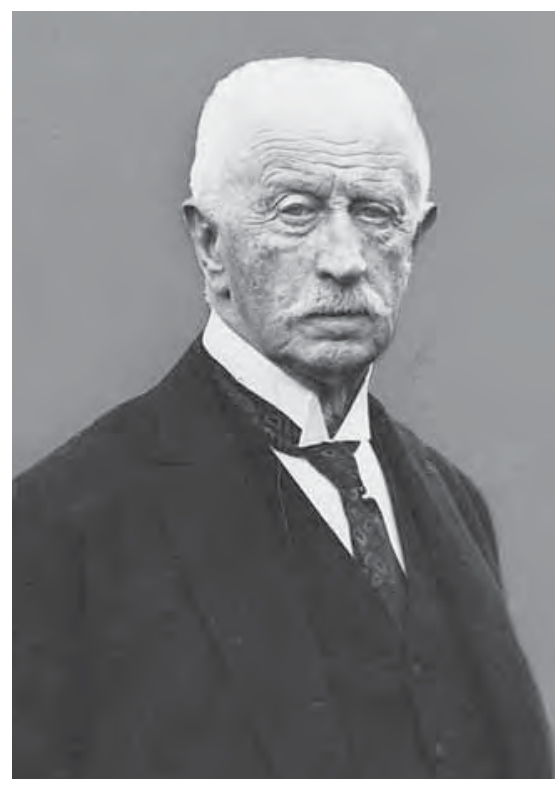

4. Hrabia Bogdan Hutten-Czapski, podczas I wojny światowej kurator Uniwersytetu Warszawskiego z ramienia niemieckich władz okupacyjnych (zdjęcie późniejsze)
W zawieszeniu pozostawała sprawa utworzenia wydziału piątego - teologicznego. Kwestii tej poświęcił sporo miejsca podczas mszy poprzedzającej inaugurację ks. dr Szlagowski. Nawiązując do nastawienia fides et ratio stwierdził m.in.: „W naszym więc wszech nauk przybytku prawda nadprzyrodzona i prawda przyrodzona w siostrzanym zespole wzajem się wspierać i wzajem się wyjaśniać będą. Teologia, ta wiedza najczcigodniejsza, wszech nauk królowa, wszystkim dziedzinom wiedzy ludzkiej podaje zasady, wskazuje podstawy; w zamian zaś odnajduje w nich sprawdziany i dowody niewzruszonych, niezmiennych, bo objawionych prawd swoich". Rzecz wymagała jednak skomplikowanych negocjacji w trójkącie Warszawa-BerlinWatykan, które zajęły z górą półtora roku, a przyspieszenia nabrały dopiero po całkowitym spolszczeniu szkolnictwa w Generalnym Gubernatorstwie Warszawa ${ }^{35}$. 
Pierwszy wykaz zajęć dydaktycznych zawierał 88 pozycji ${ }^{36}$. W semestrze zimowym immatrykulowano 1039 studentów, z czego aż 52\% na Oddziale Przygotowawczo-Lekarskim, 21\% na Wydziale Prawa i Nauk Państwowych, 20\% na Wydziale Matematyczno-Przyrodniczym, a tylko ok. 7\% wybrało Wydział Filozoficzny. Prócz 36 wykładowców zatrudniono 1 adiunkta, 23 asystentów oraz 6 lektorów, czyli 66 osób ${ }^{37}$. Pierwszych studentów wpisano do albumu $17 \mathrm{XI}^{38}$.

By oddać klimat ówczesnych zajęć, można posłużyć się skryptem jednego z pierwszych wykładów, jakie odbyły się na przyszłym $\mathrm{Wy}_{\mathrm{y}}$ dziale Lekarskim. W jego trakcie rektor Brudziński mówił głównie nie o zagadnieniach fachowych, lecz o tradycjach nauczania medycyny na stołecznej uczelni i jej perspektywach, przechodząc następnie do wyzwań stojących przed przyszłymi lekarzami:

Przyświecać nam tu będzie myśl, iż przyszły lekarz urabiać się powinien już podczas studiów na Uniwersytecie, nie tylko pod względem umysłowym, ale i moralnym, w związku z tym pomówimy o życiu młodzieży akademickiej w ogóle, a młodzieży lekarskiej w szczególności, przytaczając wzory swoje i obce. $\mathrm{Na}$ koniec przejdziemy do sprawy ściślejszej - kształcenia się lekarskiego, przy czym uwzględnimy i przygotowanie ogólnokształcące do studiów lekarskich, jak również konieczność przygotowania gruntownego przyrodniczego. [...] Jak widzicie, Panie i Panowie, tematu do naszych wspólnych rozważań nie zbraknie nam - zrozumiecie i uświadomicie sobie stopniowo, jakie zadania Was czekają i jak najlepiej ku nim zmierzać. Może niejeden z Was zawróci z drogi, albo zmieni swój sposób myślenia i życia, wzniesie się na duchu ku oczekującym go zadaniom. [...]

Wlać macie soki odżywcze młodości w zakłady lekarskie, w ludzi, w tych starszych kolegów Waszych, którzy tyle lat tęsknili do tego, aby mogli swoją wiedzę i doświadczenie nie tylko słowem pisanym, ale i żywym przy łóżku chorego przelewać w umysły i serca młodzieży lekarskiej - nie ukradkiem i dorywczo, jako coś zabronionego, jak było dawniej, ale w związku z wydziałem lekarskim $[\ldots]^{39}$.

Reaktywowany Uniwersytet zajmował miejsce najpocześniejsze pośród sześciu uczelni dawnej Kongresówki, z których wszystkie miały siedzibę w stolicy. Poza Politechniką należały do tego grona powstałe także w pierwszych miesiącach okupacji, jako pierwsze nowe zakłady prywatne: jednowydziałowa Wyższa Szkoła Handlowa w Warszawie, przekształcona w październiku 1915 r. z Wyższych Kursów Handlowych Augusta Zielińskiego ${ }^{40}$, a w grudniu Szkoła Nauk Społecznych i Handlowych (późniejsza Szkoła Nauk Politycznych w Warszawie), wywodząca się z reaktywowanego jeszcze przed wojną Towarzystwa 
Kursów Naukowych. W roku następnym, w podobnym do WSH trybie, Kursy Przemysłowo-Rolnicze stały się dwuwydziałową Wyższą Szkołą Rolniczą w Warszawie, którą we wrześniu 1918 r. przemianowano na Szkołę Główną Gospodarstwa Wiejskiego ${ }^{41}$. Wreszcie w 1917 r. zorganizowała się nawiązująca do tradycji kursów zapoczątkowanych już w 1895 r. Wyższa Szkoła Dziennikarska, afiliowana początkowo jako zakład Wydziału Humanistycznego UW. Prócz tego działała jednowydziałowa Warszawska Szkoła Sztuk Pięknych (zał. w 1816 r., odnowiona w 184, r. i 1904, r.) $)^{42}$ oraz Wyższe Kursy Naukowe, stanowiące pozostałość TKN, z których w 1919 r. powstała Wolna Wszechnica Polska ${ }^{43}$. Dominację Uniwersytetu dawało się dostrzec choćby w strukturze populacji akademickiej miasta. Wedle danych z roku akademickiego 1917/1918 na poszczególnych uczelniach studiowało: UW - 2220 (4,0,0\%), Politechnika Warszawska - 1185 (21,3\%), Wyższa Szkoła Handlowa - 182 (3,3\%), Wyższa Szkoła Rolnicza - 212 (3,8\%), Warszawska Szkoła Sztuk Pięknych - przypuszczalnie 110 (1,9\%), Wyższe Kursy Naukowe - 1647 (29,7\%) ${ }^{44}$. W przypadku kadry dydaktycznej odsetek ten mógł być nawet wyższy, ze względu na podejmowanie przez wykładowców pracy na więcej niż jednej uczelni. Stan ten wynikał z niedoboru personelu, a zarazem z niewysokich wynagrodzeń ${ }^{45}$.

Pierwszy po odnowieniu rok pracy przyniósł kilka incydentów w relacjach społeczności uniwersyteckiej z przedstawicielami aparatu okupacyjnego. W rocznice wybuchu powstań narodowych (29 XI 1915 i 22 I 1916 r.) dochodziło do zatargów studentów z policją, a w drugim przypadku także z żołnierzami armii niemieckiej. Nacisk na naukę języka niemieckiego wywierał skutek odwrotny od zamierzonego przez patronów uczelni - zaczynał kojarzyć się z czasami rosyjskimi ${ }^{46}$.

Podczas przygotowań do drugiego roku akademickiego (1916/1917) kurator Hutten-Czapski wystąpił z inicjatywą nadania Uniwersytetowi nowego, zliberalizowanego statutu. Choć zaproponowane przez niego zwierzchności niemieckiej zmiany zostały przyjęte tylko częściowo, można mówić o dostrzegalnym zwiększeniu autonomii uczelni. Regulacja weszła w życie 1 X 1916 r. i przewidywała wolny wybór dziekanów wydziałów. Zakładała powołanie Wydziału Medycznego, lecz zarazem fuzję wydziałów Filozoficznego i Matematyczno-Przyrodniczego pod nazwą Wydziału Filozofii. Precyzowała tė̇ rolę kuratora, czyniąc z niego pośrednika w relacjach między UW a Zarządem Cywilnym Generalnego Gubernatorstwa. Funkcję rektora, na drugą roczną kadencję, przyjął Brudziński.

Nowy statut liczył 4,4 paragrafy, a pierwszy z nich stwierdzał, że zadaniem uczelni jest „niezależne od wpływów partyjnych nauczanie 
w zakresie powierzonych jego pieczy gałęzi wiedzy, oraz rozwój ich przez prowadzenie samodzielnych prac i badań naukowych. Uniwersytet ma rozwijać dalej w sposób celowy wykształcenie ogólne i specjalne uczącej się młodzieży, oraz przysposabiać ją do zawodów, w których wyższe wykształcenie naukowe jest niezbędne bądź pożyteczne. [...]". Co ważniejsze, w odróżnieniu od wersji poprzedniej, poprzedzonej jedynie krótką preambułą, dokument rozpoczynała odezwa gubernatora v. Beselera z 24, VIII 1916 r., sformułowana w tonie życzliwym:

Uniwersytet Warszawski w pierwszym roku akademickim, ziszczając moje oczekiwania, rozwijał się pomyślnie i stał się przybytkiem pracy umysłowej, do którego młodzież polska pilnie i chętnie uczęszczała, wobec tego nadaję mu niniejszym nowy statut, który ma na celu przyczynić się do dalszego swobodnego rozwoju pracy naukowej uczelni i usamodzielnienia jej Zarządu. Warunki obecne nie pozwoliły wprawdzie jeszcze na nadanie [...] ostatecznego [...] ustroju, utworzenie jednak samodzielnego wydziału lekarskiego, połączenie wydziału matematyczno-przyrodniczego z filozoficznym w jedną całość, przyznanie zupełniej autonomii wszystkim wydziałom - stanowią wiele obiecujący postęp [...]. Dalsza organizacja Wszechnicy będzie przedmiotem mojej szczególnej troskliwości. Utworzenie wydziału teologicznego jest przygotowane. Prawo promocji i habilitacji, które zamierzam przyznać [...], jak również wskazówki co do studiów [...] wraz z przepisami egzaminacyjnymi [...] będą wkrótce rozważane [...]. Mam więc niepłonną nadzieję, że Wszechnica Warszawska stanie wkrótce całkowicie na równi ze swymi siostrzycami zachodnio-europejskimi, jako przybytek krzewienia nauki i pielęgnowania życia umysłowego. Oczekuję od akademickiego ciała nauczycielskiego, które - przyznaję to chętnie - wśród nader trudnych warunków poświęcało się z zaparciem swemu idealnemu zadaniu, że wespół z młodzieżą akademicką nadal dążyć będzie niestrudzenie do tego, aby na gruncie narodowego języka i narodowej kultury pielęgnować czystą wiedzę, ten łącznik narodów ${ }^{47}$.

Na nowy rok wpisano łącznie 1621 osób. Liczba studentów zwiększyła się więc o nieco ponad połowę ${ }^{48}$. Podobnie wzrosła wielkość „grona nauczycielskiego i pomocniczych sił naukowych"49. Jednak nie sprawy dydaktyczno-naukowe, którym poświęcano skądinąd wiele uwagi, publikując rozmaite pomoce ${ }^{50}$, miały zdominować życie Uniwersytetu. Jesienią doszło bowiem do wysokiego przebicia w grze międzynarodowej, w której kartą zyskującą znaczenie stawała się Polska. Na tym tle coraz większą rolę odgrywały zagadnienia polityczne i określona nimi postawa młodzieży ${ }^{51}$. Sprzyjała temu liberalizacja przepisów obowiązujących studentów ${ }^{52}$. 
Po powołaniu przez Niemcy i Austro-Węgry, mocą aktu z 5 XI 1916 r., związanego z nimi Królestwa Polskiego można mówić o tworzeniu się fundamentu odbudowującej się Rzeczypospolitej. Do instytucji już działających dochodziły nowe - tak na poziomie administracji centralnej, jak i samorządu. Najpierw powstała Tymczasowa Rada Stanu, czyli ciało opiniodawcze, mające współdziałać „przy tworzeniu dalszych urządzeń państwowych", istniejąca od stycznia do sierpnia $1917 \mathrm{r} .{ }^{53} \mathrm{Na}$ obszarze Generalnego Gubernatorstwa Warszawa ważnym krokiem stała się likwidacja prowizorium walutowego i wprowadzenie przez Niemców nowego pieniądza: marki polskiej, emitowanej od kwietnia tegoż roku przez pierwszy od kilkudziesięciu lat polski bank centralny - Polską Krajową Kasę Pożyczkową ${ }^{54}$. W oparciu o wydany 12 IX 1917 r. patent gubernatorów generalnych - w Warszawie von Beselera i w Lublinie gen. Stanisława Szeptyckiego - utworzono w końcu organy najwyższe: ${ }_{15} \mathrm{X}$ Radę Regencyjną, tj. przejściowe kolektywne szefostwo państwa ${ }^{55}$, a 7 XII pierwszy rząd, zwany czasem „królewsko-polskim”. Jako główną strukturę władzy ustawodawczej 4 II 1918 r. powołano Radę Stanu Królestwa Polskiego. Sądownictwo zostało spolszczone wcześniej. W ten sposób można mówić o odrodzeniu się państwa polskiego jeszcze przed likwidacją obu okupacji.

$\mathrm{Na}$ Uniwersytecie panował do czasu spokój, znaczony drobnym ustępstwem Niemców (29 XI) w postaci zniesienia wymogu prowadzenia korespondencji z kuratorem uczelni po niemiecku. $\mathrm{Z}$ początkiem semestru letniego sytuacja zaogniła się jednak pod wpływem niezadowalającego tempa procesu emancypacji państwowej i pogarszającej się dramatycznie sytuacji bytowej (nasilające się niedobory żywności i towarów konsumpcyjnych wywołane rabunkową gospodarką niemiecką i austro-węgierską). Incydenty z udziałem studentów i policji zaczęły przybierać na sile, a od marca 1917 r. pojawił się nowy czynnik - wskutek rewolucji w Rosji nastąpiła radykalizacja nastrojów ${ }^{56}$. Dlatego też w związku z uroczystościami z okazji 1 i $3 \mathrm{~V}$ doszło do zamieszek antyniemieckich, w których wzięli udział studenci Uniwersytetu, Politechniki i TKN. Policja okupacyjna interweniowała jak na ówczesne stosunki brutalnie, bijąc odróżniających się ubiorem akademików, a paru zatrzymując w areszcie, co było sprzeczne z przyjętymi zasadami postępowania przy likwidacji zatargów. Miały też miejsce dalsze zatrzymania. Władze okupacyjne wszczęły kroki, które groziły obwinionym sądem polowym.

Stało się to powodem do zwołania 4, V 1917 r. wiecu na Politechnice, a nazajutrz na Uniwersytecie ${ }^{57}$. Na drugim zgromadzeniu zebrani uchwalili protest wobec działań policji, żądali satysfakcji i uwolnienia 
aresztowanych. Ogłoszono też jednodniowe strajki. Ze stanowiskiem studentów UW wyrażonym w rezolucji solidaryzowały się wszystkie uczelnie stolicy. Powstała międzyuczelniana organizacja protestacyjna (Konfederacja Ogólnoakademicka), która wezwała do wstrzymania wpłat czesnego i bojkotu zajęć przybyłego z Prus germanisty prof. Paszkowskiego. Co istotne, młodzież wsparł rektor Brudziński, w toku burzliwych negocjacji z urzędnikami niemieckimi składając dymisję, która nie została przyjęta. Także sędzia UW prof. Ignacy Koschembahr-Łyskowski twardo domagał się poskromienia działań odwetowych, wykazując współwinę sił porządkowych, które nie przekazały sprawy do rozpatrzenia organom akademickim. Senat Uniwersytetu $6 \mathrm{~V}$ udzielił poparcia rektorowi i studentom, proponując rozwiązanie niekonfrontacyjne.

Konflikt eskalował jednak w kierunku politycznym, bowiem następnego dnia Senat Politechniki przyjął uchwałę wskazującą, iż tylko „oddanie w najkrótszym czasie zarządu szkolnictwa w ręce władz polskich" sprawi, że na Politechnice zapanuje spokój. $10 \mathrm{~V}$ odbyły się na uczelniach wiece, które zaaprobowały to żądanie i proklamowały wspólny strajk, który trwał dwa tygodnie. Za cenę przerwania protestu władze okupacyjne poszły na ustępstwa - aresztowanych zwolniono, zapowiedziano spolszczenie szkolnictwa, a władze szkół wyższych (w tym UW), wezwano do przygotowania projektu stosownych zmian w regulujących ich życie przepisach. Ale po polskiej stronie barykady pojawił się rozdźwięk: studenci nie chcieli zrezygnować z bojkotu Niemców na uczelniach oraz ich kwestury, profesura zaś miała zamiar negocjować dalej, by uzyskać nowe koncesje i dlatego potrzebowała ustępstwa młodzieży. Powstał zatem impas, w którym okupanci postanowili sięgnąć po groźby, choć narażali w ten sposób na krach cały plan pojednania z Polakami. Mówił o tym von Beseler w trakcie spotkania z rektorami uczelni $25 \mathrm{~V}$, konkludując: ,jeżeli mimo wszystkich [...] napomnień dadzą się zauważyć najmniejsze objawy niekarności, albo też działalność polityczna, wtedy semestr bieżący na wyższych uczelniach przepadnie, a co potem z tego wyniknie, zależeć będzie całkowicie od zachowania się studentów". Oznaczało to perspektywę zawieszenia lub nawet zamknięcia szkół wyższych.

Ponieważ studenci nie chcieli ustąpić i kontynuowali bojkot kuratora, profesorów z Prus i kwestury, 22 VI gubernator generalny zawiesił działanie UW. W odpowiedzi Senat wskazał - zgodnie z postulatami popieranymi przez młodzież - iż do kryzysu nie doszłoby, gdyby przeprowadzono całkowitą polonizację szkolnictwa. Władze niemieckie postanowiły ukarać zalegających z wpłatami czesnego skreśleniem z listy studentów i dać do zrozumienia personelowi dydaktycznemu, 
iż prolongata udzielonych mu zleceń stoi pod znakiem zapytania. Zarazem jednak, wobec braku innych pozytywnych możliwości rozwiązania narosłego zatargu, von Beseler i szef Zarządu Cywilnego von Kries pogodzili się z koniecznością spolszczenia administracji szkolnej. 20 IX 1917 r. w „Dzienniku Rozporządzeń dla Generał-gubernatorstwa warszawskiego" opublikowano stosowny dokument. Strajk studencki przyniósł znaczące zwycięstwo. Zarazem jednak zmianie ulegały relacje między niemieckimi patronami a polską społecznością akademicką. Nadzieje na jej pozyskanie zastąpiła podejrzliwość, wyrosła na podłożu rezygnacji z hołubionych, lecz jednak mało realnych zamysłów.

W czasie zawieszenia uczelni nastąpiło przygotowanie nowej podstawy prawnej jej działania. Departament Wyznań Religijnych i Oświecenia Publicznego Komisji Przejściowej przygotował statut. Ten trzeci z kolei, ale pierwszy polski akt miał charakter prowizoryczny ${ }^{58}$, lecz wprowadzał bardzo ważne zmiany w życiu Uniwersytetu. Do najistotniejszych należało oddzielenie uczelni od administracji okupacyjnej (m.in. za sprawą zniesienia funkcji kuratora), poddanie go zwierzchnictwu dyrektora DWRiOP, coroczny wybór rektora w drodze głosowania przez „ciało nauczycielskie", przyznanie funkcji prorektora każdorazowo ustępującemu rektorowi. Liczba wydziałów nie uległa zmianie. W zawieszeniu pozostała natomiast sprawa uzyskiwania stopni naukowych ${ }^{59}$.

Władze UW utrzymały w mocy przeprowadzone przez Niemców skreślenia z albumu, domagając się ponownej immatrykulacji od tych, którzy chcieli wznowić studia. Jednocześnie uznano, że skrócony strajkiem i pozbawiony sesji, wskutek zawieszenia uczelni, semestr letni zostaje zaliczony.

Zajęcia Uniwersytetu i Politechniki wznowiono 7 XI. Wspólnemu otwarciu roku akademickiego 1917/1918 „pod władzą Państwa Polskiego" przewodniczył prof. Józef Mikułowski-Pomorski, dyrektor Departamentu Wyznań Religijnych i Oświecenia Publicznego. Uroczystości odbyły się w kościele s.s. Wizytek i gmachu głównym Politechniki. W poczet uniwersytetu weszło 2220 studentów oraz 105 dydaktyków ${ }^{60}$.

Tabela 1. Rektorzy Uniwersytetu Warszawskiego (listopad 1915 - listopad 1918)

\begin{tabular}{|l|l|}
\hline $1915-1917$ & prof. dr Józef Brudziński (lekarz-pediatra) \\
\hline $1916-1917$ & prof. dr Józef Brudziński (lekarz-pediatra, po raz drugi) \\
\hline $1917-1918$ & prof. dr Antoni Kostanecki (ekonomista) \\
\hline $1918-1919$ & prof. dr Antoni Kostanecki (ekonomista, po raz drugi) \\
\hline
\end{tabular}

Źródło: Zestawienie na podstawie: Dzieje Uniwersytetu Warszawskiego 1915-1939, red. Andrzej Garlicki, PWN, Warszawa 1982, s. 312 n., uzupełnione przez autora. 
13 XI odbyły się pierwsze wybory rektora. Zwyciężył w nich prof. Brudziński, ale z powodu postępującej choroby wyboru nie przyjął, zostając tylko z urzędu prorektorem ${ }^{61}$. W drugim głosowaniu wyłoniono znanego ekonomistę, dr. Antoniego Kostaneckiego ${ }^{62}$, który objął funkcję.

Przyszło mu kierować uczelnią we względnym spokoju i stawić czoła niezbędnym pracom organizacyjnym. Za jego kadencji weszły w życie nowe przepisy, opracowane przez Departament, a następnie Ministerstwo Wyznań Religijnych i Oświecenia Publicznego w porozumieniu lub na wniosek Senatu ${ }^{63}$. Najważniejszą zmianą okazało się powołanie z początkiem semestru letniego Wydziału Teologicznego ${ }^{64}$. Prawnik Eugeniusz Jarra, nieco upraszczając sprawę, wspominał:

\begin{abstract}
Wydział teologiczny, uzupełniający tradycyjny system quattuor facultates, nie znajdował na razie [tj. w 1915 r.] rzeczników w kierowniczych sferach duchownych, mimo dobrej pamięci, jaką zapisał się w uniwersytecie Królestwa Kongresowego [...]; popierały one raczej wznowienie odrębnej Akademii Duchownej [...]. Niechęć do uniwersyteckiego wydziału teologicznego pokonał powoli ks. prałat Antoni Szlagowski, profesor Warszawskiego Seminarium Duchownego, człowiek wysokiej kultury i zacności, znany też ze sztuki kaznodziejskiej. On to dzięki pozyskaniu poparcia ówczesnego arcybiskupa warszawskiego ks. Al. Kakowskiego doprowadził po dwóch latach do powstania Wydziału Teologii, którego został pierwszym dziekanem ${ }^{65}$.
\end{abstract}

Tak jak w latach ubiegłych trwało uzupełnianie księgozbiorów i pomocy dydaktycznych ${ }^{66}$. Wydarzenia polityczne dawały jednak znać o sobie, angażując studentów i pracowników. Stało się tak przy okazji starań na rzecz zwolnienia byłych legionistów z obozów internowania (przełom listopada i grudnia 1917 r.), w których znaleźli się po tzw. kryzysie przysięgowym z lata tegoż roku, a następnie podczas protestu przeciw stanowiącym de facto kolejny rozbiór Polski postanowieniom pokoju podpisanego przez Państwa Centralne z Ukrainą w Brześciu nad Bugiem (9 II 1918 r.), czemu towarzyszyła trzydniowa żałoba ogłoszona przez Senat ${ }^{67}$.

W ostatnich miesiącach Wielkiej Wojny wraz z przygotowaniami do kolejnego roku akademickiego stopniowo kontraktowano nowych wykładowców z uczelni Krakowa i Lwowa ${ }^{68}$. Powstał też projekt nowego, stałego już statutu „Królewsko-Polskiego Uniwersytetu w Warszawie” oraz podręczny zbiór przepisów dla studentów ${ }^{69}$. Ofertę dydaktyczną poszerzało w pewnym stopniu otwarcie odrębnego od Uniwersytetu Instytutu Pedagogicznego, na którym - po spełnieniu ustalonych 
warunków - mogli uczyć się studenci UW, a także prowizorycznego Studium Weterynarii przy Wydziale Lekarskim ${ }^{70}$.

Rok akademicki 1918/1919, w którym uczelnią kierował ponownie wybrany na urząd rektora prof. Kostanecki ${ }^{71}$, okazał się mieć jednak przebieg zupełnie inny od spodziewanego. Pamiętający tamten czas historyk Tadeusz Manteuffel pisał:

$[\ldots]$ jesienią $[\ldots]$ atmosfera polityczna Warszawy przesycona była do najwyższego stopnia niepokojem. Prace akademickie rozpoczęły się mimo to normalnie przy wzmożonym napływie nowozapisanych studentów, których liczba w porównaniu z rokiem ubiegłym prawie że się podwoiła. Młodzież, wśród której dużo było powracających z Rosji wychodźców, z zapałem zabierała się do pracy ${ }^{72}$.

Dzieje mocno przyspieszały biegu. Okupanci na frontach byli już u kresu sił. Nie mogli więc przeciwstawić się emancypacji zależnych nominalnie od siebie struktur stworzonych w Królestwie Polskim. 7 X Rada Regencyjna wydała orędzie do narodu zapowiadające utworzenie „niepodległego państwa polskiego, obejmującego wszystkie ziemie polskie z dostępem do morza, z polityczną i gospodarczą niezawisłością, jako też z terytorialną nienaruszalnością". Rozwiązawszy Radę Stanu, zapowiadała utworzenie nowego gabinetu o jak najszerszej podstawie politycznej i przygotowanie przezeń w ciągu miesiąca „ustawy wyborczej do sejmu polskiego", by „niezwłocznie potem zwołać” sejm i „poddać jego postanowieniu dalsze urządzenie Władzy zwierzchniej państwowej, w której ręce Rada Regencyjna [...] władzę swoją ma złożyć" ${ }^{\prime 73}$. W ten sposób ukonstytuował się pierwszy na obszarze Kongresówki ośrodek władzy niepodległej. Oczekując zwolnienia Piłsudskiego z internowania i powrotu do Warszawy, w związku z zarekomendowaniem go na stanowisko ministra spraw wojskowych w gabinecie Józefa Świeżyńskiego, do wystąpienia przygotowywały się ogniwa liczącej kilkadziesiąt tysięcy członków POW, kierowanej przez płk. Edwarda Rydza ps. Śmigły. W gotowości stanęła podlegająca Radzie Regencyjnej resztka Legionów - umundurowana i uzbrojona Polska Siła Zbrojna (Polnische Wehrmacht). $19 \mathrm{X}$ powstała Rada Narodowa Księstwa Cieszyńskiego - pierwszy terytorialny ośrodek władzy. 31 X utworzono Polską Komisję Likwidacyjną, mającą charakter rządu tymczasowego dla Galicji. Równocześnie zaczęło się rozbrajanie stacjonujących w Krakowie oddziałów austro-węgierskich. Jednocześnie ı XI nad ranem wybuchło powstanie ukraińskie we Lwowie i we wschodniej części zaboru austriackiego. Jak zapisał w 1935 r. Tadeusz Manteuffel, znacząco przechodząc w narracji na czas teraźniejszy: 
Podniecenie ogarnia Warszawę. Udziela się ono młodzieży. Konferencja Ogólno-Akademicka zbiera się i postanawia w poczuciu ważności chwili zwołać we wszystkich wyższych uczelniach w dniu 6 listopada wiece dla zabrania stanowiska w wytwarzającej się sytuacji politycznej. Na odbytym wiecu uniwersyteckim uchwalono następującą rezolucję: 1. Rada Regencyjna winna natychmiast ustąpić, przelewając swą władzę w ręce Narodowego Rządu Ludowego. 2. Cała młodzież akademicka winna natychmiast wstąpić do armii polskiej. 3. Działalność Uniwersytetu winna ulec zawieszeniu. 4. W celu ułatwienia praktycznego wykonania uchwał wiecu, a w szczególności porozumienia się z Senatem Akademickim, utworzyć Komitet Wykonawczy o charakterze informacyjnym. Po wiecu młodzież demonstrowała przed Zamkiem, domagając się ustąpienia Rady Regencyjnej.

Tego samego dnia zebrał się Senat Akademicki Uniwersytetu, uchwalając ogłosić wspólnie z Senatem Akademickim Politechniki następującą odezwę: „W zgodnym postanowieniu młodzieży akademickiej, aby wstąpić do wojska celem zdobycia i wywalczenia niezależnego bytu państwowego Ojczyźnie, Senaty Akademickie witają doniosły czyn patriotyczny, z którym się w całości solidaryzują. W przeświadczeniu, że młodzież akademicka wstępując do wojska, stać będzie na straży jedności narodowej i służyć obronie zagrożonych granic Polski, Senaty Akademickie wyrażają zgodność uczuć swych z uczuciami młodzieży i postanawiają zawiesić wykłady i zajęcia" ${ }^{\text {"74 }}$.

Tak dla odnowionego Uniwersytetu Warszawskiego kończyła się I wojna światowa, a zarazem otwierała epoka nazwana później II Rzecząpospolitą. Jej początek wymagał ofiary, jaką stanowiła przerwa w działalności dydaktycznej. Niebawem uzupełniły ją kolejne, złożone przez poległych i rannych studentów oraz pracowników uczelni w mundurach Wojska Polskiego, podczas zmagań o granice i przetrwanie odrodzonego państwa.

Zawieszenie wykładów i zajęć w związku z wydarzeniami w kraju i za granicą otworzyło trwający blisko dziewięć kwartałów specyficzny okres pracy w rzeczywistych warunkach ${ }^{75}$. Charakteryzowała go nieobecność większości studentów w murach uczelni, uczestniczących w odbudowie państwowości, a także w konfliktach na rubieżach odrodzonej Rzeczypospolitej. Rola sprawcza w tych wielkich dniach ludzi młodych i wykształconych (tzn. posiadających przynajmniej maturę znaczącą wszak wtedy nieporównanie więcej niż dziś) nie dawała się przecenić. To przecież od działań „akademików”, z których wielu należało do POW, zaczęło się w Warszawie rozbrajanie zdemoralizowanych przegraną wojną pojedynczych żołnierzy i całych pododdziałów niemieckich. Oni też witali Józefa Piłsudskiego, który 10 XI powrócił 
z internowania w Niemczech. Przede wszystkim zaś zgłaszali się ochotniczo do odradzającej się armii.

Ukonstytuowany na uczelni Akademicki Komitet Wykonawczy, gdzie dominujący wpływ miała POW, nazajutrz po przyjeździe eks-brygadiera Legionów Polskich wezwał studentów do wstępowania do formacji, której nadano nazwę Legii Akademickiej. Zarejestrowani ochotnicy ze wszystkich szkół wyższych stolicy, częściowo uzbrojeni, ujęci w ramy tworzonych ad hoc pododdziałów, od godzin nocnych 10/11 XI wyruszali z terenu UW, aby obezwładniać straże niemieckie i przejmować - na ogół bez użycia siły - najważniejsze obiekty w mieście ${ }^{76}$.

Sprawne sformowanie i działanie Legii, co w sporej mierze było zasługą jej pierwszego dowódcy por. Kazimierza Sawickiego, wywarło pozytywne wrażenie na Piłsudskim, wówczas już głównodowodzącym Wojska Polskiego, a od 14, XI tymczasowym naczelniku państwa. Zapadła decyzja o utworzeniu z LA osobnego oddziału - pułku piechoty, jako że liczba ochotników szła w tysiące. Otrzymał on numer $3^{6}$ i 13 XII złożył przysięgę. Po przyspieszonym przeszkoleniu, pod dowództwem mjr. Zygmunta Bobrowskiego, pułk wyruszył 4 I 1919 r. koleją na front wojny polsko-ukraińskiej, na obszar byłej już Galicji Wschodniej. W upamiętnieniu bohaterskich bojów pod Żółkwią, Lwowem, Rohatynem, Brzeżanami, Czortkowem, a następnie Połockiem, Głębokiem, Duniłowiczami, Lidą, Białymstokiem, Małkinią, Ossowem, Wyszkowem i Ostrołęką, znaczonych liczbą ponad 600 poległych, 36. pułk piechoty otrzymał w 1929 r. oficjalnie miano „Legii Akademickiej". Udział UW w walkach o granice toczonych z Ukraińcami, a następnie w wojnie o przetrwanie z Rosją bolszewicką, nie ograniczał się tylko do szeregów tego pułku. Liczni studenci, a także pracownicy służyli w innych oddziałach liniowych, sztabach, służbach i jednostkach zaplecza ${ }^{77}$.

Zajęcia na UW były przerwane zrazu do października $1919 \mathrm{r}$. W tym czasie pomiędzy Ministerstwem Wyznań Religijnych i Oświecenia Publicznego, Senatem Akademickim i władzami wojskowymi trwała korespondencja w sprawie wznowienia wykładów i ćwiczeń. Wskutek decyzji Ministerstwa Spraw Wojskowych jesienią wróciła na uczelnię urlopowana na 12 tygodni pierwsza z trzech tur studentów-żołnierzy. Mieli oni w ciągu tego czasu zaliczyć materiał z połowy roku. Wraz z nimi mogli wznowić lub podjąć naukę - w normalnym trybie - niezdolni do służby i nieobjęci obowiązkiem wojskowym. Wkrótce urlopowanym lat najstarszych, z wyjątkiem przyszłych lekarzy, odroczono termin powrotu do oddziałów aż do 1 X 1920 r., by mogli ukończyć naukę ${ }^{78}$. 
Pierwszy rok akademicki w Polsce niepodległej znamionowały warunki niezwyczajne - duża część słuchaczy nosiła mundury, niektórzy też odznaczenia i widoczne ślady zranień; dał o sobie znać tłok $\mathrm{w}$ audytoriach i salach. Ten wywołany potrzebą wojenną chaos silnie utrudniał naukę i pracę, a przecież toczyło się jeszcze życie społeczne. Bardzo żywe formy przybierała często aktywność polityczna - po raz pierwszy co najmniej od powstania $183_{1} \mathrm{r}$. rozwijająca się $\mathrm{w}$ naprawdę wolnym mieście i kraju. Wypadki rozgrywające się na froncie wojny z bolszewikami miały jednak zaburzyć ten nadzwyczajny rok na uniwersytecie jeszcze silniej.

Kryzys wywołany majową ofensywą Armii Czerwonej na Białorusi sprawił, że los Polski i narodów ją zamieszkujących zależał od wyniku starcia, jakie miało rozegrać się późnym latem na wielkim obszarze od Torunia po Lwów i Grodno. Nadzwyczajny organ władzy - Rada Obrony Państwa z Piłsudskim na czele - wezwała 3 VII wszystkich obywateli do wstępowania do wojska w obronie ojczyzny. Trzy dni później, podczas wiecu studenckiego, który proklamował zgłoszenie się in corpore do służby w Armii Ochotniczej, ogólne zebranie profesorów UW przyjęło rezolucję:

W poczuciu, że na odezwę Naczelnego Wodza Wojska i Narodu odpowiedzieć powinni wszyscy - w przekonaniu, że ani wiek, ani stan, ani rodzaj zajęcia dla nikogo nie powinny stanowić wymówki - grona nauczycielskie najwyższych uczelni warszawskich powzięły [...] następującą jednomyślną uchwałę - wszyscy bez wyjątku oddajemy się do rozporządzenia władz wojskowych ${ }^{79}$.

W drugim zaciągu wojennym wzięli udział niemal wszyscy urlopowani z jednostek oraz duża część studentów nieobjętych dotąd służbą $\mathrm{w}$ armii. W celu ułatwienia rekrutacji utworzono Ligę Akademicką Obrony Państwa, która wysyłała wystawione pododdziały do obozu ćwiczeń w Rembertowie. Do szeregów Wojska Polskiego zgłosiła się też grupa pracowników uczelni, a ponad dwudziestu profesorów znalazło się w charakterze specjalistów cywilnych w strukturach służb wojskowych (medycznej, łączności itd.). Na uczelni podjęto równocześnie przygotowania do częściowej ewakuacji zbiorów, ochrony budynków od ognia, a także do opieki nad obiektami na wypadek wejścia nieprzyjaciela do stolicy. Późną jesienią, po zawarciu zawieszenia broni i wszczęciu rokowań pokojowych, rozpoczęła się demobilizacja akademików. Tak zakończyła się swoista wojenna „sesja egzaminacyjna” Uniwersytetu. 
Dopiero więc 10 I 1921 r., a zatem z ponad kwartalnym opóźnieniem, mógł rozpocząć się pierwszy pokojowy rok pracy uczelni. Nie od rzeczy będzie przytoczyć w zamknięciu tej części wywodów fragment wygłoszonej wówczas z tej okazji mowy rektora, prof. Jana K. Kochanowskiego:

Obchodzimy tu dzisiaj uroczystość niezapomnianą - święto najwyższego triumfu moralnego, jaki odnieść mogą wierni synowie Narodu. Oto umiłowana młodzież nasza, skupiająca się w tych murach dla czerpania wiedzy, porwawszy za oręż, stanęła jak jeden mąż w zwycięskiej obronie Ojczyzny. A zagrażał jej wróg najstraszliwszy - wróg, niosący zagładę nie tylko ciałom, ale i duszom ludzkim, któremu ulec, znaczyło dla Polski paść i pogrzebać wraz z sobą świat cywilizowany; zwyciężyć - to ocalić i siebie, i innych. Trudno o grozę większą i o hasło szczytniejsze na kartach dziejów [...]. Zasiadają między nami wiekopomni bohaterowie Narodu - hufiec uskrzydlonych ideałem najwyższym rycerzy cywilizacji.

Cześć im i hołd.

Witamy Cię [...], ukochana młodzieży nasza, sercem do głębi wzruszonym, z uczuciem wdzięczności i chluby. Oddani Ci, jako żywemu wcieleniu naszych ideałów, pragniemy służyć Ci tak, jak na to zasługujesz, a z Ciebie - z bohaterstwa Twego i wartości moralnych, czerpać możemy zaprawdę siły uskrzydlające w pochodzie ad astra! ${ }^{80}$

\section{Uniwersytet Warszawski i Uniwersytet Józefa Piłsudskiego w Warszawie w systemie polskiego szkolnictwa wyższego 1918-1939}

Z chwilą powołania pierwszych rządów odrodzonej Rzeczypospolitej w postaci gabinetów pod przewodnictwem Władysława Wróblewskiego w Warszawie i Ignacego Daszyńskiego w Lublinie, których zaplecze polityczne stanowiły odpowiednio: prawica i sfery konserwatywne oraz lewica i centrolewica, zagadnienia szkolnictwa wyższego od razu znalazły odbicie w programie nowych władz, w pełni wreszcie niezależnych 
od okupantów i zaborców. Na polu życia akademickiego odbudowa państwa postawiła przed administracją, istniejącą już w postaci powstałego w 1917 r. Ministerstwa Wyznań Religijnych i Oświecenia Publicznego Królestwa Polskiego, zadania dokończenia polonizacji szkół na powiększającym się w toku walk o granice obszarze całego państwa, rozbudowy sieci uczelni oraz stworzenia podstaw prawnych ich działalności, również pod kątem ujednolicenia obowiązujących przepisów. Przyczyniły się do tego zarówno inicjatywy oddolne, jak i polityka państwa ${ }^{81}$, prowadzona w następnych latach przez struktury MWRiOP, tj. przede wszystkim przez Departament (IV) Nauki i Szkół Wyższych $^{82}$, ale té̇ podsekretarzy stanu, Departament (I) Ogólny ${ }^{83}$, Biuro Personalne czy organa kolegialne, np. opiniodawczą Państwową Radę Oświecenia Publicznego, działającą od listopada $193^{2}$ r., a kierowaną przez ministra.

Tabela 2. Ministrowie wyznań religijnych i oświecenia publicznego RP

(listopad 1918 - wrzesień 1939)

\begin{tabular}{|c|c|c|}
\hline Minister & Okres urzędowania & Gabinet \\
\hline Bronisław Dembiński* & 5-17 XI 1918 & Rząd Władysława Wróblewskiego \\
\hline Gabriel Dubiel ${ }^{* *}$ & 7-17 XI 1918 & Rząd Ignacego Daszyńskiego \\
\hline Ksawery Prauss & 18 XI 1918 - 16 I 1919 & Rząd Jędrzeja Moraczewskiego \\
\hline dr Jan Łukasiewicz & 16 I - 9 XII 1919 & Rząd Ignacego Paderewskiego \\
\hline Tadeusz Łopuszański & $\begin{array}{l}13 \text { XII } 1919 \text { - } 9 \text { VI } 1920 \\
23 \text { VI - 24. VII } 1920\end{array}$ & $\begin{array}{l}\text { Rząd Leopolda Skulskiego } \\
\text { I rząd dr. Władysława Grabskiego }\end{array}$ \\
\hline Maciej Rataj & 24. VII 1920 - 13 IX 1921 & I rząd Wincentego Witosa \\
\hline dr Antoni Ponikowski & $\begin{array}{l}19 \text { IX } 1921 \text { - } 5 \text { III } 1922 \\
10 \text { III - } 6 \text { VI } 1922\end{array}$ & $\begin{array}{l}\text { I rząd dr. Antoniego Ponikowskiego } \\
\text { II rząd dr. Antoniego Ponikowskiego }\end{array}$ \\
\hline [Wakat] & 28 VI - 7 VII 1922 & Rząd Artura Śliwińskiego \\
\hline prof. Julian Nowak & 31 VII - 21 VIII 1922 & Rząd prof. Juliana Nowaka \\
\hline $\begin{array}{l}\text { prof. Kazimierz } \\
\text { Kumaniecki }\end{array}$ & 21 VIII - 14 XII 1922 & Rząd prof. Juliana Nowaka \\
\hline $\begin{array}{l}\text { prof. Józef Mikułowski- } \\
\text {-Pomorski* }\end{array}$ & 16 XII - 26 V 1923 & Rząd gen. Władysława Sikorskiego \\
\hline
\end{tabular}




\begin{tabular}{|c|c|c|}
\hline dr Stanisław Głąbiński & $8 \mathrm{~V}-27 \mathrm{X} 1923$ & II rząd Wincentego Witosa \\
\hline dr Stanisław Grabski & 27 X - 14. XII 1923 & II rząd Wincentego Witosa \\
\hline dr Bolesław Miklaszewski & 19 XII 1923 - 11 XII 1924 & II rząd Władysława Grabskiego \\
\hline prof. Jan Zawidzki* & 11 XII 1924 - 25 III 1925 & II rząd Władysława Grabskiego \\
\hline prof. Stanisław Grabski & $\begin{array}{l}25 \text { III - 14 XI } 1925 \\
20 \text { XI } 1925-5 \text { V } 1926 \\
10 \text { V - } 15 \text { V } 1926\end{array}$ & $\begin{array}{l}\text { II rząd Władysława Grabskiego } \\
\text { Rząd Aleksandra Skrzyńskiego } \\
\text { III rząd Wincentego Witosa }\end{array}$ \\
\hline $\begin{array}{l}\text { prof. Józef Mikułowski- } \\
\text {-Pomorski* }\end{array}$ & $\begin{array}{l}15 \mathrm{~V}-4 \mathrm{VI} 1926 \\
8 \mathrm{VI}-7 \mathrm{VII} 1926\end{array}$ & $\begin{array}{l}\text { I rząd prof. Kazimierza Bartla } \\
\text { II rząd prof. Kazimierza Bartla }\end{array}$ \\
\hline Antoni Sujkowski & $\begin{array}{l}7 \mathrm{VII}-24 \mathrm{IX} 1926 \\
27-30 \text { IX } 1926\end{array}$ & $\begin{array}{l}\text { II rząd prof. Kazimierza Bartla } \\
\text { III rząd prof. Kazimierza Bartla }\end{array}$ \\
\hline prof. Kazimierz Bartel ${ }^{*}$ & 2 X 1926 - 9 I 1927 & I rząd marsz. Józefa Piłsudskiego \\
\hline dr Gustaw Dobrucki & 9 I 1927 - 27 VI 1928 & I rząd marsz. Józefa Piłsudskiego \\
\hline dr Kazimierz Świtalski & 27 VI 1928 - 13 IV 1929 & IV rząd prof. Kazimierza Bartla \\
\hline dr Sławomir Czerwiński*** & $\begin{array}{l}14 \text { IV - } 7 \text { XII } 1929 \\
25 \text { XII } 1929-17 \text { III } 1930 \\
29 \text { III - } 23 \text { VIII } 1930 \\
25 \text { VIII - 4 XII } 1930 \\
4 \text { XII } 1930-26 \text { V } 1931 \\
27 \text { V - 4 VIII } 1931\end{array}$ & $\begin{array}{l}\text { Rząd dr. Kazimierza Świtalskiego } \\
\text { V rząd prof. Kazimierza Bartla } \\
\text { I rząd Walerego Sławka } \\
\text { II rząd marsz. Józefa Piłsudskiego } \\
\text { II rząd Walerego Sławka } \\
\text { Rząd Aleksandra Prystora }\end{array}$ \\
\hline Janusz Jędrzejewicz & $\begin{array}{l}12 \text { VIII } 1931 \text { - } 9 \text { V } 1933 \\
10 \text { V } 1933 \text { - } 22 \text { II } 1934\end{array}$ & $\begin{array}{l}\text { Rząd Aleksandra Prystora } \\
\text { Rząd Janusza Jędrzejewicza }\end{array}$ \\
\hline Wacław Jędrzejewicz & $\begin{array}{l}22 \text { II } 1934-13 \text { V } 1934 \\
15 \text { V } 1934-28 \text { III } 1935 \\
28 \text { III - } 12 \text { X } 1935\end{array}$ & $\begin{array}{l}\text { Rząd Janusza Jędrzejewicza } \\
\text { Rząd prof. Leona Kozłowskiego } \\
\text { III rząd Walerego Sławka }\end{array}$ \\
\hline $\begin{array}{l}\text { prof. Wojciech } \\
\text { Świętosławski }\end{array}$ & $\begin{array}{l}13 \text { X } 1935 \text { - } 15 \text { V } 1936 \\
15 \text { V } 1936 \text { - } 30 \text { IX } 1939\end{array}$ & $\begin{array}{l}\text { Rząd Mariana Zyndrama- } \\
\text {-Kościałkowskiego } \\
\text { Rząd gen. dr. Sławoja Składkowskiego }\end{array}$ \\
\hline \multicolumn{3}{|c|}{$\begin{array}{l}\text { * Jako kierownik resortu } \\
\text { ** Jako minister oświaty } \\
\text { *** Zmarł jako urzędujący minister } \\
\text { Źródło: Zestawienie na podstawie: Rocznik Polityczny i Gospodarczy", VIII (1939), reprint: Warszawa } 2003 \text {, } \\
\text { s. 89-99, uzupełnione przez autora. }\end{array}$} \\
\hline
\end{tabular}


Już w grudniu 1918 r. powstał Katolicki Uniwersytet Lubelski, założony jako spadkobierca tradycji Akademii Duchownej, działającej dotąd w Sankt Petersburgu/Piotrogrodzie. W następnym roku utworzono cztery dalsze szkoły wyższe. W zimie Warszawskie Towarzystwo Kursów Naukowych przeorganizowało się w Wolną Wszechnicę Polską, która kierowała swą ofertę do szerokich kręgów społecznych; ucząc adeptów w duchu liberalno-lewicowym, kładła nacisk na praktyczne zastosowanie wiedzy. W maju staraniem Poznańskiego Towarzystwa Przyjaciół Nauk utworzono pierwszą uczelnię polską na obszarze dawnego zaboru pruskiego - Uniwersytet Poznański. W październiku reaktywowano uczelnię akademicką w Wilnie, zniesioną przez Rosjan w $183^{2}$ r., która otrzymała nazwę Uniwersytetu Stefana Batorego, oraz powołano Akademię Górniczą w Krakowie.

U progu lat 20. sieć polskich szkół wyższych uzupełniały działające bez przerwy na obszarze dawnej Galicji: Uniwersytet Jagielloński (zał. 1364), Uniwersytet Jana Kazimierza (dawny Lwowski im. cesarza Franciszka I, założony w 1661 r. jako akademia jezuicka, w 1784, r. przekształcona na uniwersytet przez cesarza Austrii Józefa II), Szkoła Politechniczna we Lwowie (zał. w 184, r., przemianowana w 1920 r. na Politechnikę Lwowską), do której przyłączono jako osobny wydział Akademię Rolniczą w pobliskich Dublanach (1856) wraz ze lwowską Wyższą Szkołą Lasową (1874), a wreszcie Akademia Weterynarii we Lwowie (zał. 1881, przemianowana w 1922 r. na Akademię Medycyny Weterynaryjnej). Wraz ze Szkołą Sztuk Pięknych w Krakowie (1818) ${ }^{84}$, pierwszą uczelnią wojskową, tj. Wojenną Szkołą Sztabu Generalnego (1919), przemianowaną dwa lata później na Wyższą Szkołę Wojenną w Warszawie ${ }^{85}$ oraz z Państwowym Instytutem Dentystycznym (1920) dawało to łącznie 19 czynnych szkół akademickich (w tym 5 prywatnych: Wyższa Szkoła Handlowa, Szkoła Nauk Politycznych, Wyższa Szkoła Dziennikarska, Katolicki Uniwersytet Lubelski i Wolna Wszechnica Polska), skupiających ok. 20 tys. studentów ${ }^{86}$ i zatrudniających ok. 2 tys. naukowców (zob. tabela 3). Prócz tego w Wolnym Mieście Gdańsku, pozostającym w bliskim związku z RP, istniała politechnika niemiecka (Technische Hochschule) założona w 1904, r. Władze Rzeczypospolitej nie podjęły działań na rzecz jej polonizacji, choć bywały lata, gdy odsetek Polaków wśród jej studentów sięgał 1/3. W istotnej części byli oni stypendystami rządu polskiego lub instytucji publicznych $^{87}$. Szkoły muzyczne ${ }^{88}$, jak również seminaria duchowne wyznań chrześcijańskich $^{89}$ nie zaliczały się wtedy, wedle oficjalnych statystyk, do szkół wyższych. Poza tą kategorią znajdowały się też instytucje kształcące nauczycieli ${ }^{90}$. 


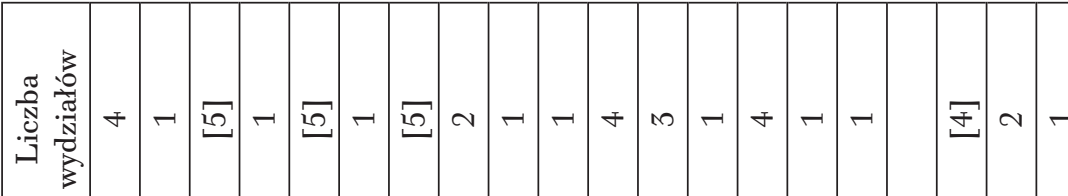

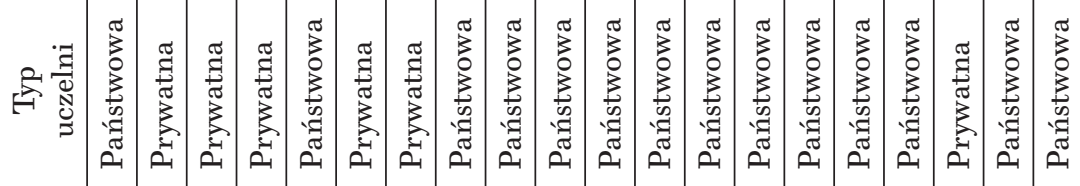

:

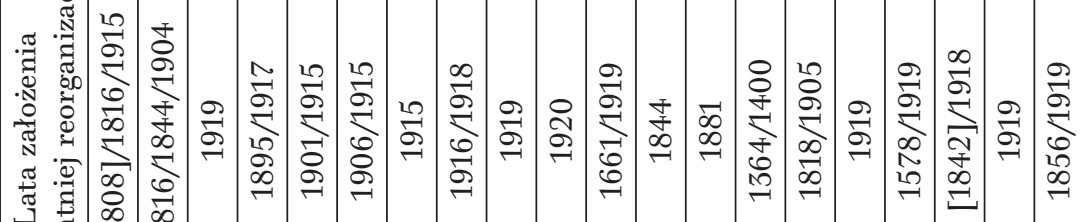

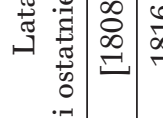

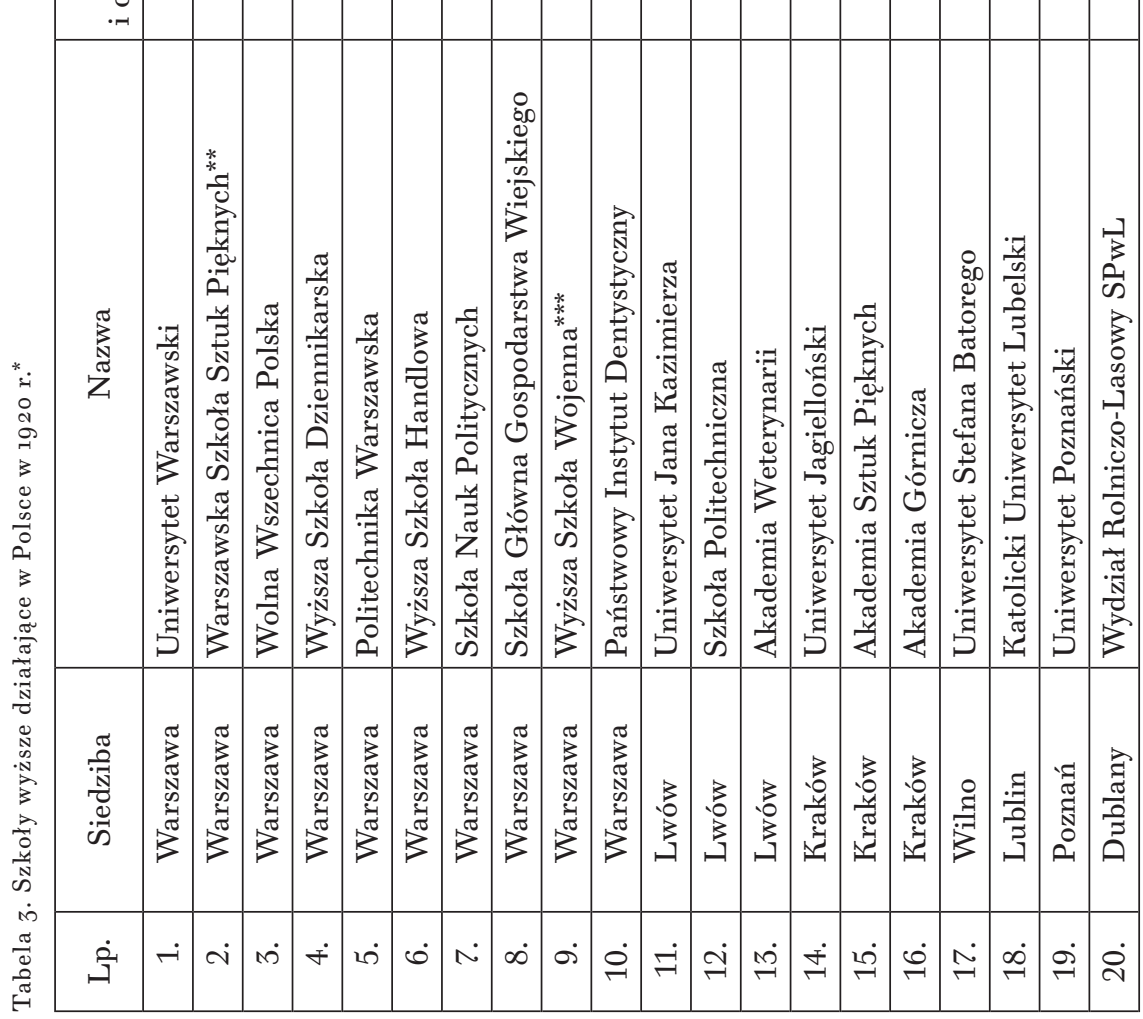

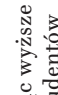

$: \frac{\pi}{\pi} \cdot \frac{\pi}{3}$

댕

胥 $\frac{\mathrm{s}}{\mathrm{m}}$

总

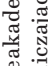

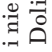

동

뭉

可

>

잉

क ल

需产

造

घี ฐู

눙

党

年

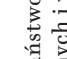

:

㺃

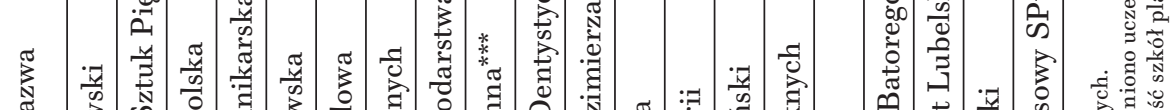

.

为

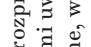

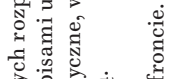

ส్

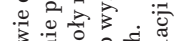

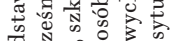

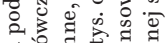

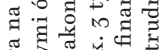

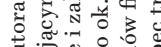

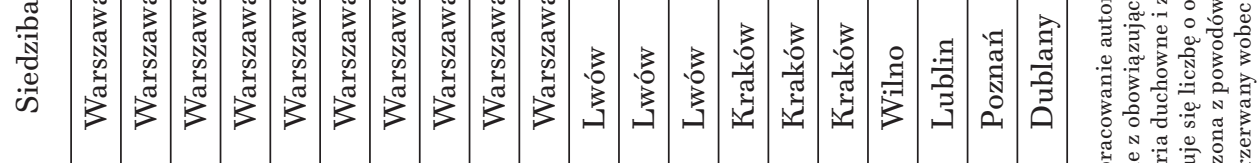

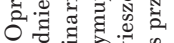

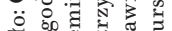

莒* 
Szkoły wyższe nie były jedynymi ośrodkami rozwoju nauki. Obok nich rolę bardzo istotną odgrywały organizacje niezajmujące się kształceniem młodzieży, ale przede wszystkim badaniami, upowszechnianiem ich wyników, doskonaleniem kadry i współpracą z zagranicą. Szczególne miejsce zajmowały: Polska Akademia Umiejętności z siedzibą w Krakowie (zał. 1872), Kasa im. Józefa Mianowskiego, Instytut Popierania Nauki w Warszawie (1881) oraz Komitet Porozumiewawczy i Rada Nauk Ścisłych i Stosowanych (1936, Warszawa-Kraków-Lwów). Oprócz nich istniały m.in.: Poznańskie Towarzystwo Przyjaciół Nauk (1857), Towarzystwo Naukowe w Toruniu (1875), Towarzystwo Przyjaciół Nauk na Śląsku (1892, przekształcone w 1920 r.; najpierw w Bytomiu, od 1922 r. w Katowicach), Towarzystwo Naukowe we Lwowie (1901), Towarzystwo Przyjaciół Nauk w Wilnie (19o6), Towarzystwo Naukowe Warszawskie (1907), Towarzystwo Naukowe w Płocku (1907), Towarzystwo Przyjaciół Nauk w Przemyślu (19o9), Towarzystwo Przyjaciół Nauki i Sztuki w Gdańsku (1922), Towarzystwo Przyjaciół Nauk w Lublinie (1927?), Towarzystwo Przyjaciół Nauk w Tarnowie (1929), Wołyńskie Towarzystwo Przyjaciół Nauk w Łucku (1935), Podolskie Towarzystwo Przyjaciól Nauk w Tarnopolu (1938?) ${ }^{91}$.

W tworzeniu instytucji zajmujących się nauką już w pierwszych latach niepodległości zaznaczył się duży udział inicjatywy władz centralnych oraz osobistości zbliżonych do tych kręgów. Spośród zakładów powołanych w takim trybie wymienić trzeba: Państwowy Instytut Naukowy Gospodarstwa Wiejskiego w Puławach (1918, od 1921 r. oddział w Bydgoszczy), Główny Urząd Statystyczny (1918), Państwowy Instytut Geologiczny w Warszawie (1919), Państwowy Centralny Zakład Epidemiologii w Warszawie (1919; w 1923 r. przekształcony w Państwowy Zakład Higieny), Akademię Nauk Technicznych w Warszawie (1920), Instytut Gospodarstwa Społecznego w Warszawie (1920), Instytut Badań Spraw Narodowościowych w Warszawie (1921), Morskie Laboratorium Rybackie w Helu (1921, od 1928 r. pod nazwą Stacja Morska, przeniesiona w 1938 r. do Gdyni), Państwowy Instytut Meteorologiczny w Warszawie z filią w Gdańsku-Nowym Porcie (1922, filię przeniesiono w 1927 r. do Gdyni), Instytut Badania Najnowszej Historii Polski w Warszawie (1923; w 1936 r. przekształcony w Instytut Józefa Piłsudskiego Poświęcony Badaniom Najnowszej Historii Polski), Instytut Bałtycki (1925, najpierw w Toruniu, od 1931 r. także w Gdyni, od 1937 r. wyłącznie tam), Państwowy Instytut Eksportowy w Warszawie (1927), Instytut Badania Koniunktur Gospodarczych i Cen w Warszawie (1928), Instytut Hydrograficzny (1928), Instytut Naukowo-Badawczy Europy Wschodniej w Wilnie (1930), Instytut Spraw Społecznych 
w Warszawie (1931), Instytut Radowy im. Marii Skłodowskiej-Curie w Warszawie (1932), Państwowy Instytut Telekomunikacyjny (1934), Instytut Śląski w Katowicach (1934), Państwowy Instytut Kultury Wsi w Warszawie (1936), Polskie Towarzystwo Wypraw Badawczych (1937) i Wołyński Instytut Naukowy przy Liceum Krzemienieckim w Krzemieńcu (1938). Poza tym działały wojskowe placówki badawcze (m.in. zał. w 1918 r. Wojskowy Instytut Naukowo-Oświatowy, w latach 1921-1935 pod nazwą Wojskowy Instytut Naukowo-Wydawniczy, zał. w 1919 r. Wojskowy Instytut Geograficzny itd. - wszystkie w Warszawie), a także liczne stowarzyszenia specjalistyczne, zrzeszenia branżowe oraz instytucje utworzone przez mniejszości narodowe: Ukraińców, Żydów, Białorusinów, Litwinów i Niemców (Warszawa, Lwów, Wilno, Poznań, Bydgoszcz, Toruń). Ośrodkami rozwoju nauki były też liczne biblioteki, archiwa i muzea - państwowe, samorządowe, fundacyjne, instytucji społecznych, kościelne oraz prywatne ${ }^{92}$.

Pierwszą ogólnopolską regulacją prawną położenia szkół wyższych była licząca 114, artykułów Ustawa o szkołach akademickich, uchwalona na wniosek pierwszego gabinetu Wincentego Witosa (tzw. rządu obrony narodowej) przez Sejm Ustawodawczy już 13 VII 1920 r. ${ }^{93}$ Obowiązywała ona prawie 12 lat i okazała się być najtrwalszym aktem normatywnym w tej dziedzinie. Jej mocą uczelnie zostały poddane władzy zwierzchniej MWRiOP, otrzymały ujednoliconą strukturę, charakteryzującą się przewagą organów kolegialnych (senatów i rad rozmaitych szczebli) nad władzą jednostek (rektorów, dziekanów, dyrektorów, kierowników). Profesorom ustawa zapewniała silną pozycję, w tym swobodę „podawania i oświetlania z katedry” - rzecz jasna wedle przekonań naukowych i tymże sposobem - „wszelkich zagadnień wchodzących w zakres ich specjalizacji”, co stwarzało rzeczywiste warunki wolności rozwoju badań i nauczania. Gwarantował je również art. 117 Konstytucji z 17 III 1921 r., obowiązujący także po wejściu w życie nowej ustawy zasadniczej z 23 IV 1935 r., który głosił:

Badania naukowe i ogłaszanie ich wyników są wolne. Każdy obywatel ma prawo nauczać, założyć szkołę lub zakład wychowawczy i kierować nimi, skoro uczyni zadość warunkom, w ustawie przepisanym, w zakresie kwalifikacji nauczycieli, bezpieczeństwa powierzonych mu dzieci i lojalnego stosunku do Państwa. Wszystkie szkoły i zakłady wychowawcze, zarówno publiczne jak i prywatne, podlegają nadzorowi władz państwowych w zakresie przez ustawy określonym ${ }^{94}$.

Szkoły wyższe utrzymały prawo nadawania stopni i tytułów naukowych: niższych - zawodowych (np. inżynierskich) i magisterskich oraz 
wyższych - doktorskich i habilitacji. Na wniosek ówczesnego ministra wyznań religijnych i oświecenia publicznego Macieja Rataja skreślono natomiast art. $5^{2}$ projektu ustawy, mówiący o tajnym głosowaniu rad wydziałów nad „odpowiednimi osobistymi kwalifikacjami kandydata" przed dopuszczeniem do habilitacji, zastępując go w artykule poprzednim zapisem o głosowaniu jawnym ${ }^{95}$.

Utrzymany został podział na szkoły państwowe i prywatne, w czym ujawniały się rozbieżności z Konstytucją, usunięte dopiero w dodatku do tekstu ustawy zasadniczej z 1935 r. Art. 119 Konstytucji z 1921 r. głosił bowiem: „Nauka w szkołach państwowych i samorządowych jest bezpłatna. Państwo zapewni uczniom, wyjątkowo zdolnym a niezamożnym, stypendia na utrzymanie w zakładach średnich i wyższych". Przejście uczelni do kategorii pierwszej, a więc finansowanej głównie przez rząd, zależało od wykonywania tzw. praw akademickich. Chodziło tu o odpowiednie wyposażenie w literaturę i pomoce naukowe, rekrutowanie kandydatów spośród osób legitymujących się świadectwem ukończenia ogólnokształcącej szkoły średniej (państwowej lub prywatnej, ale z uprawnieniami państwowymi) i złożeniem egzaminu dojrzałości, następnie odpowiednim pod względem kompetencji doborem kadry naukowej, czy też zgodności planu studiów z wymaganiami państwowych szkół akademickich.

Studia, mimo zastrzeżeń zgłaszanych w toku debat przez przedstawicieli lewicy, były więc płatne. Od osób przyjętych na I rok wymagano wpisowego, a ponadto corocznie czesnego, opłat za ćwiczenia odbywające się w pracowniach, za udział w seminariach i za składanie egzaminów. Młodziė̇ „niezamożna a pilna” mogła ubiegać się o odroczenie płatności. Studenci uzyskali możliwość zakładania w każdej szkole swoich stowarzyszeń (w tym korporacji), ale z zastrzeżeniem ich niepolityczności.

$\mathrm{Z}$ perspektywy blisko stulecia wolno uznać, że liberalna ustawa z 1920 r. zasadniczo sprawdziła się w praktyce. Praca uczelni wyższych wszystkich trzech kategorii (państwowych, prywatnych akademickich i prywatnych nieakademickich) przebiegała bez większych zakłóceń, jeśli nie liczyć burzliwego nieraz życia politycznego. Co znamienne, zamierzeniem szkół prywatnych stało się w większości wypadków (np. poza WSH) nabycie praw państwowych, co wymagało szeregu lat starań i dużych nakładów materialnych ${ }^{96}$.

W latach 20. stopniowo otwierano nowe placówki dydaktyczno-naukowe: jedną akademicką, tj. oddział Wolnej Wszechnicy Polskiej w Łodzi (1927) oraz dziewięć nieakademickich - Wyższą Szkołę Handlu Zagranicznego we Lwowie (1922), Wyższe Studium Handlowe w Krakowie (1925), Instytut Nauk Judaistycznych w Warszawie (1925, nabór 
od 1928; był to jedyny zakład stworzony przez mniejszość narodową), Wyższą Szkołę Handlową w Poznaniu (1926) ${ }^{97}$, Wyższą Szkołę Instytutu Naukowo-Badawczego Instytutu Europy Wschodniej w Wilnie (1930; od 1933 r. pod nazwą Szkoła Nauk Politycznych) ${ }^{98}$, następnie Państwową Wyższą Szkołę Budowy Maszyn i Elektrotechniki im. Hipolita Wawelberga i Stanisława Rotwanda w Warszawie (zał. 1895), która po upaństwowieniu i dwóch reorganizacjach stała się w 1929 r., a więc po dziesięcioletnich staraniach, uczelnią swego rodzaju honoris causa ${ }^{99}$, wreszcie podległe resortowi spraw wojskowych i również zlokalizowane w stolicy: Wyższą Szkołę Intendentury (1921-1932, a od $193^{6}$ r. istniała jako samodzielny wydział Wyższej Szkoły Wojennej) ${ }^{100}$, Centrum Wyższych Studiów Wojskowych w Warszawie (19231933; rozwiązane) ${ }^{101}$ oraz Centralny Instytut Wychowania Fizycznego im. Pierwszego Marszałka Polski Józefa Piłsudskiego (1930) ${ }^{102}$. Jak widać, nowe zakłady powstawały przede wszystkim w dawnych ośrodkach. Prócz tego, w 1923 r. upaństwowiono Wyższą Szkołę Sztuk Pięknych, zmieniając jej nazwę na Szkołę Sztuk Pięknych w Warszawie ${ }^{103}$.

Nastawienie władz państwowych wobec rozbudowy oświaty wyższej ilustruje wypowiedź ministra dr. Sławomira Czerwińskiego podczas inauguracji oddziału WWP w Łodzi 28 X 1928 r. Związany z obozem sanacyjnym dostojnik stwierdził wtedy, nawiązując do żywego w kręgach pomajowej elity władzy zamysłu przeprowadzenia zmian w systemie edukacji, w tym i w szkolnictwie wyższym:

Wołanie o reformę wychowania jest na ustach wszystkich i to nie tylko w Polsce, ale na całym kulturalnym świecie. [...] Prąd reformy dotychczas prawie nie dotknął szkolnictwa wyższego, są już jednak znaki na niebie i ziemi, że nie zatrzyma się on u starych murów europejskich wszechnic. Potrzeby życia współczesnego wołać będą [...], aby z lekkim sercem można było przejść nad nimi do porządku dziennego. Ale jeśli stwierdzamy, że niełatwą i nawet pewne przesilenie chorobowe wywołującą jest reforma szkoły średniej, to o ileż trudniejsze i o ile więcej oględności wymagające jest przeprowadzenie potrzebnych zmian na terenie szkolnictwa wyższego, tj. tego szkolnictwa, które w znacznej mierze bezpośrednio decyduje o twórczości duchowej narodu.

Dalej minister Czerwiński wyraźnie dawał do zrozumienia, że nie widzi obecnie możliwości poważniejszej zmiany istniejącego stanu rzeczy:

Łódź to ludne miasto, które za czasów zaborczych pod względem kulturalnym było traktowane gorzej, niż gdzie indziej traktuje się jakąś eksploatowaną kolonię zamorską, miasto, z którego chciano wszystko wycisnąć, by nic mu nie 
dać w zamian. [...] Zaprawdę przyznać trzeba, że kulturze tego miasta należałoby poświęcić więcej uwagi [...]. Ale nawet tak myśląc, musimy się zgodzić, że kreowanie uniwersytetu państwowego w Łodzi w chwili obecnej nie byłoby ani możliwe, ani wskazane. Pod względem liczby wyższych uczelni państwowych doszliśmy, zdaje się, do ostatecznej granicy możności ich tworzenia bez równoczesnej konieczności niebezpiecznego obniżenia ich poziomu naukowego. [...] Ale jeżeli tak jest, to tym żywsze uznanie należy wyrazić pod adresem kierowników Wolnej Wszechnicy za ich szczęśliwą inicjatywę ogarnięcia Łodzi pracą tej uczelni. Niechże więc ta praca rozwija się tu jak najpomyślniej [... $]^{104}$.

Niezależnie od stanowiska władz wielki kryzys gospodarczy, którego nasilenie przypadło w Polsce na lata 1931-1933, zahamował tempo przyrostu nowych uczelni, wobec trudności materialnych trapiących obywateli, stowarzyszenia i władze państwowe. Jedyną nową placówką była Szkoła Wschodoznawcza Instytutu Wschodniego w Warszawie (zał. 1931) ${ }^{105}$. Doszło do paru reorganizacji - w ten sposób powstał Państwowy Instytut Sztuki Teatralnej w Warszawie (zał. 1932), przekształcony ze Szkoły Dramatycznej działającej przy stołecznym Państwowym Kon-

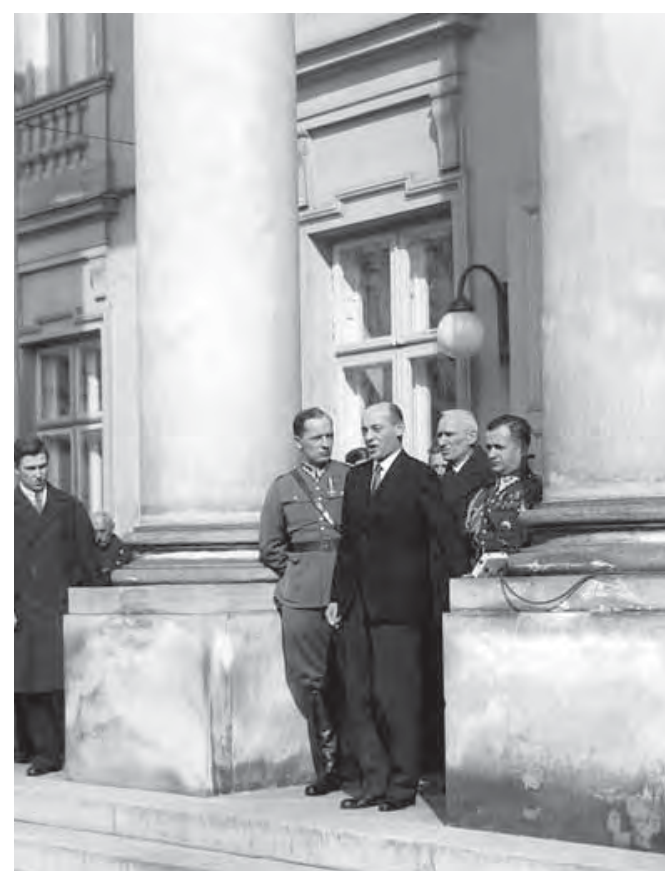

5. Minister wyznań religijnych i oświecenia publicznego Janusz Jędrzejewicz przemawia do delegacji szkół z okazji imienin marszałka Józefa Piłsudskiego, 18 III 1933 r. serwatorium Muzycznym ${ }^{106}$. W tym samym roku Szkoła Sztuk Pięknych w Warszawie stała się, także z nazwy, akademią. Z kolei w 1933 r. dotychczasowy Państwowy Instytut Dentystyczny, funkcjonujący od 13 lat pod opieką Wydziału Lekarskiego UW, usamodzielnił się jako Akademia Stomatologiczna w Warszawie ${ }^{107}$. Natomiast prywatna i akademicka WSH zmieniła w tymże roku swą nazwę na "Szkoła Główna Handlowa w Warszawie", co wymusiły wchodzące w życie nowe przepisy $^{108}$. Dwa i pół roku później nazwę zmienił Uniwersytet Warszawski, o czym będzie mowa poniżej ${ }^{109}$.

Zastój w powstawaniu nowych placówek wiązał się poniekąd ze zmianą sytuacji szkolnictwa wyższego, jaką stworzyło uchwalenie 15 III 1933 r. przez Sejm III kadencji, a następnie przyjęcie przez Senat, nowej Ustawy o szkołach akademickich. Była ona 
dziełem Janusza Jędrzejewicza, który w sierpniu $193^{1}$ r., po nagłej śmierci ministra Czerwińskiego, objął w rządzie Aleksandra Prystora kierownictwo MWRiOP. Miała ona wieńczyć dzieło reformy edukacji, przygotowywanej już od drugiej połowy lat $20 .{ }^{110}$

Jej inicjator był oddanym piłsudczykiem, z zawodu nauczycielem matematyki i działaczem oświatowym, oficerem rezerwy, publicystą, a od 1930 r. wiceprezesem organizacji tworzącej zaplecze polityczne sanacji, tj. Bezpartyjnego Bloku Współpracy z Rządem. W krótkim referacie dla marszałka Piłsudskiego tak określił on cele podejmowanych reform:

W skomplikowanym splocie problematyki wychowania młodzieży wszystkich poziomów na plan pierwszy pragnąłem wysunąć stosunek do państwa w sensie świadomości, jakie z tytułu przynależności państwowej spadają na każdego obywatela. Drugim ważnym momentem miała być próba odpolitycznienia szkoły, przez co rozumiałem zmniejszenie wpływów partii politycznych na młodzież. Punkt trzeci [...] dotyczył specjalnie stosunku kleru do państwa i odwrotnie [...] $]^{111}$.

W sprawie reformy minister współpracował ściśle z podsekretarzami stanu - ks. prof. Bronisławem Żongołłowiczem i Kazimierzem Pierackim. Istotę wprowadzonych zmian wyłożył lapidarnie następca Janusza Jędrzejewicza - jego brat Wacław, kierujący resortem do późnej jesieni 1935 r. Wedle niego reforma oświaty z 11 III $193^{2}$ r.:

[...] uporządkowała i postawiła na nowym miejscu szkolnictwo powszechne, które uprzednio było w wielkim zaniedbaniu. Według nowego programu szkoła powszechna zaczynała się od 7 roku życia i miała trwać 6 lat (poprzedzona ewentualnie przedszkolem), potem młodzież mogła wstąpić do czteroletniego gimnazjum ogólnokształcącego lub zawodowego. Po ukończeniu ogółem 10 lat nauki, uczeń otrzymywał tzw. małą maturę albo wstępował do liceum (dwuletniego ogólnokształcącego lub dwu- albo trzyletniego zawodowego). $\mathrm{Na}$ tym kończyło się pełne średnie wykształcenie (matura). Posiadając maturę uczeń mógł wstąpić do szkoły wyższej (uniwersytet, politechnika lub inne szkoły o poziomie akademickim).

Istotną stroną reformy była jej giętkość i możność przystosowania rodzaju szkoły do zainteresowań uczniów. I tak po szkole powszechnej, gdy uczeń miał 13 lat, mógł wybrać gimnazjum ogólnokształcące lub zawodowe. Gdy okazało się, że zmienił swoje upodobania, mógł z jednego rodzaju gimnazjum przejść do innego, np. z ogólnokształcącego do zawodowego. Ta giętkość sięgała dalej: po ukończeniu gimnazjum ogólnokształcącego mógł on wstąpić do liceum zawodowego [...] i tam uzyskać maturę. Potem czekała kandydata decyzja co do rodzaju studiów akademickich ${ }^{112}$. 


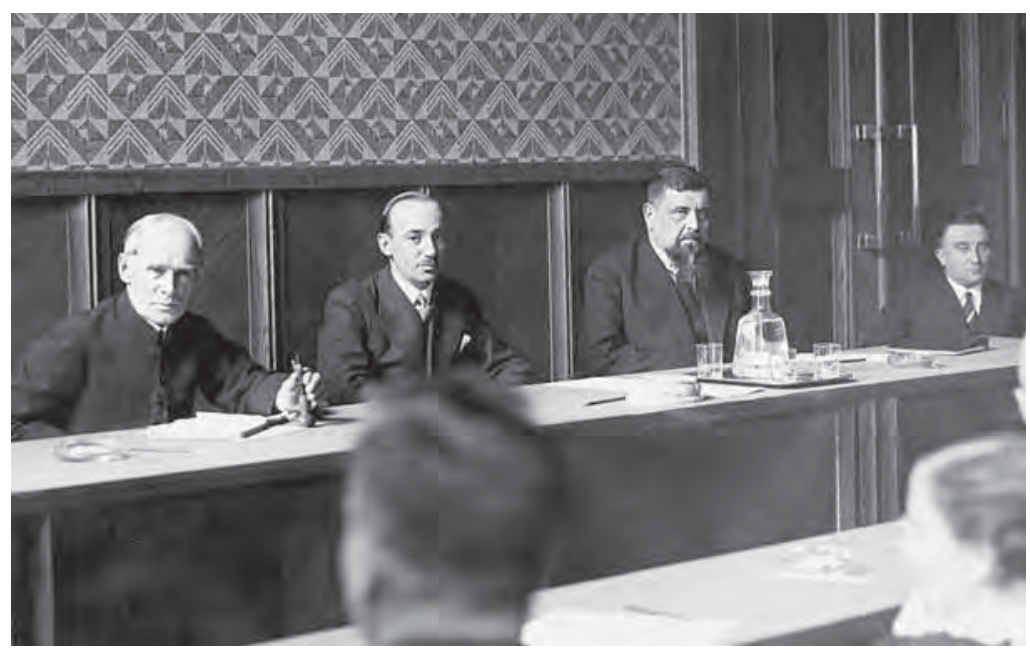

6. Posiedzenie

Państwowej

Rady Oświecenia

Publicznego

w Warszawie,

29 XI 1934 r.

Od lewej:

podsekretarz stanu

w Ministerstwie

Wyznań Religijnych

i Oświecenia

Publicznego

ks. Bronisław

Żongołłowicz, minister Wacław

Jędrzejewicz

i II podsekretarz

stanu Konstanty

Chyliński

Dopełniająca reformy systemu oświatowego nowa ustawa o szkolnictwie wyższym wprowadzała poważne zmiany w życiu akademickim. Liczący 62 artykuły akt wzmacniał nadzór administracyjny nad uczelniami, posunięty aż do możliwości kasowania wakujących katedr i znoszenia oraz tworzenia wydziałów na mocy rozporządzenia szefa rządu. Wzmacniał tė̇ pozycję rektorów kosztem organów kolegialnych, takich jak zebranie ogólne profesorów i senat akademicki, m.in. przez wydłużenie kadencji rektorskiej do 3 lat, lecz z drugiej strony elekt rekomendowany przez ministra musiał być zatwierdzony przez prezydenta RP. Jednocześnie ustawa dawała władzom resortu narzędzie pozwalające ewentualnie pacyfikować kręgi akademickie, znane z postawy niechętnej wobec obozu sanacyjnego ${ }^{113}$. Dotyczyło to tak wykładowców (m.in. poprzez utratę nieusuwalności), jak i urządzających burzliwe wystąpienia polityczne, a nieraz i awantury antyżydowskie studentów sympatyzujących z prawicą (np. przez ułatwienie interwencji służb bezpieczeństwa na terenie uczelni). Mimo uregulowania części problemów istotnie utrudniających funkcjonowanie placówek (m.in. kwestii katedr faktycznie wakujących) nowelizacja prawa spotkała się z ożywionymi protestami części środowisk akademickich, podnoszących m.in. zarzut naruszenia autonomii szkół wyższych ${ }^{114}$. Przeciw projektowi rządowemu wystąpili nie tylko ludzie nauki o poglądach antysanacyjnych, ale także wielu profesorów identyfikujących się wcześniej z obozem piłsudczykowskim.

Siłą rzeczy, inicjatywa zmian w sferze szkolnictwa i wychowania, w atmosferze konfliktu politycznego z opozycją, zaostrzonego przez 


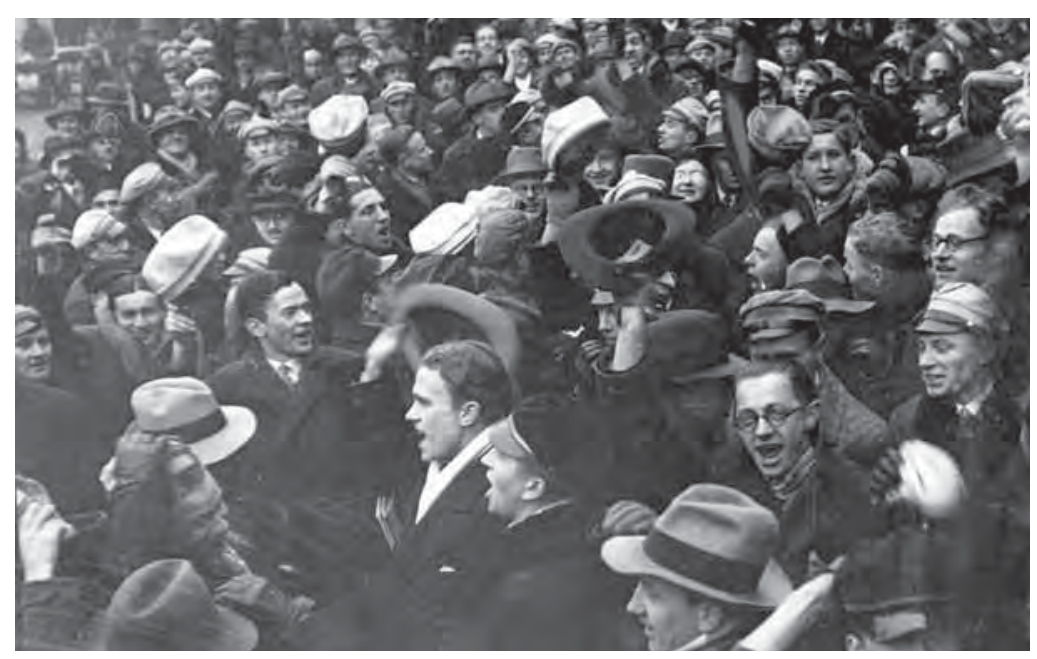

7. Studenci UW protestujący przeciwko procesowi brzeskiemu, styczeń $193^{1}$ r.

uchwały tzw. kongresu krakowskiego oraz przeciwakcję marszałka Piłsudskiego w postaci „sprawy brzeskiej”, musiała wywołać opór prawicy i lewicy parlamentarnej. Działo się tak m.in. dlatego, że niektórzy działacze opozycyjni pracowali na uczelniach wyższych i byli żywo zainteresowani w utrzymaniu status quo, a w każdym razie nie chcieli poddać się regulacjom formującym życie szkolne i akademickie na modłę rządową.

Protesty w „sprawie brzeskiej” miały miejsce również na Uniwersytecie Warszawskim. Jesienią 1930 r. 44 pracowników uczelni sygnowało list z apelem do profesorów będących posłami i senatorami o „przeciwdziałanie na terenie parlamentarnym poniewieraniu godnością ludzką i upadkowi moralnemu", a 14 profesorów (m.in. Marceli Handelsman, Władysław Mazurkiewicz, Mieczysław Michałowicz, Józef Ujejski) podpisało się pod listem wzywającym do natychmiastowego zbadania sprawy. Doszło też do incydentu na V Powszechnym Zjeździe Historyków Polskich w Warszawie, gdy profesorowie Szymon Askenazy i Wacław Tokarz wycofali przygotowane referaty w sprzeciwie wobec propozycji, by patronat zjazdu objął Piłsudski ${ }^{115}$.

Głos w debacie o reformie, o której pogłoski rozchodziły się od końca $193^{1}$ r., zabierali też naturalnie profesorowie związani z Uniwersytetem Warszawskim ${ }^{116}$. Choć wcześniej wysuwali projekty nowelizacji ustawy z 1920 r., to w większości byli przeciwni projektowi rządowemu. Oponowali m.in. rektorzy, których urzędowanie przypadło na okres krytyczny (profesorowie: lekarz Mieczysław Michałowicz, filozof Jan Łukasiewicz, a zwłaszcza filolog Józef Ujejski), uczestnicząc w zjazdach 


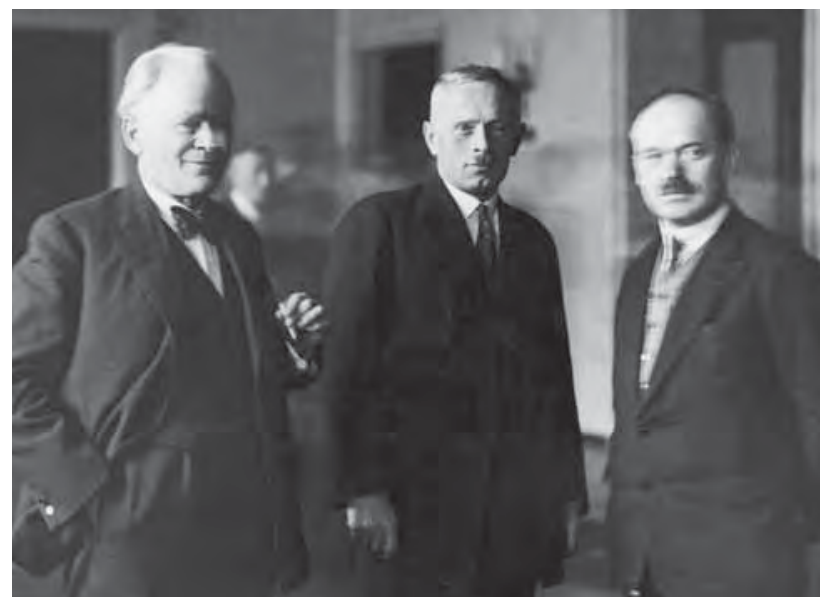

8. Prawnik i ekonomista z UW prof. Roman Rybarski (pośrodku) jako świadek w procesie brzeskim w towarzystwie oskarżonych Józefa

Putka (po prawej)

i Hermana Liebermana, październik $1931 \mathrm{r}$.

rektorskich. Także Senat Akademicki 20 XI $193^{2}$ r. „uznał zmianę ustawy [...] w punktach zasadniczych za niepożądaną", wskazując konkretne zapisy potencjalnie niekorzystne dla rozwoju szkolnictwa wyższego. Jego sprzeciw dotyczył pięciu spraw: braku kategorii samorządu akademickiego, zdegradowaniu roli Senatu do roli pomocniczo-doradczej, osłabienia pozycji rektora, możliwości szerokiej ingerencji MWRiOP $\mathrm{w}$ strukturę uczelni, a wreszcie nieokreślenia zasad działania organizacji młodzieżowych, które to reguły w myśl ustawy miały ustalać wyłącznie szkoły ${ }^{117}$.

Gdy nieznacznie zmieniony projekt znalazł się w Sejmie, Komisja Oświatowa konsultowała się z przedstawicielami kręgów naukowych. Sprzeciw swój wyraził wtedy m.in. rektor Ujejski, natomiast zamysły rządowe wsparł pracownik Wydziału Humanistycznego, historyk prof. Tadeusz Wałek-Czarnecki, który z tego powodu został nawet pobity na terenie UW przez studentów związanych z radykalną prawicą. Dalsze spory towarzyszące na uczelni planom wprowadzenia ustawy Tadeusz Manteuffel opisuje następująco:

Z chwilą, gdy okazało się, że uchwalenie nowej ustawy o szkołach akademickich jest rzeczą przesądzoną, Rektor J. Ujejski na nadzwyczajnym posiedzeniu Senatu Akademickiego w dn. 6 marca [1933 r.] złożył swój urząd, motywując ten krok wątpliwościami, czy jako rektor uczynił wszystko, aby zapobiec ograniczeniu samorządu akademickiego. Senat nie przyjmując rezygnacji tej do wiadomości, prosił rektora o cofnięcie swej decyzji. Solidaryzując się całkowicie ze stanowiskiem, zajętym przez rektora [...], Senat zakończył swoją uchwałę w tej sprawie [...] zdaniem: „Gdy się projekt stanie prawem odtąd naszym wspólnym 
zadaniem będzie, by to, co w tym nowym ustroju mamy za złe, nie przyniosło szkody Nauce Polskiej i Rzeczypospolitej”. Przychylając się do życzeń Senatu, rektor J. Ujejski rezygnację swoją cofną $\mathfrak{1}^{118}$.

Zamysł reformy krytykował też prof. Wojciech Świętosławski, chemik, były wykładowca UW i późniejszy minister wyznań religijnych i oświecenia publicznego. Stwierdzał on:

Projekt nowej ustawy [...] oparty został na powziętej z góry teorii, że ciało zbiorowe nie jest zdolne do płodnej i pożytecznej akcji i dlatego należy dać pełnię władzy osobie stojącej na czele Ministerstwa Oświaty. Przyjęty punkt widzenia sprawił, że niepodobna znaleźć [...] paragrafu, którego wykonanie nie mogłoby być sparaliżowane przez odpowiednie rozporządzenie Ministra [...]. W tym znaczeniu Ustawę poza kilku paragrafami [...] można by zastąpić krótko ujętym paragrafem, stwierdzającym, że Minister zostaje upoważniony do wydawania wszelkich zarządzeń, regulujących życie Szkół Akademickich [...]. Przytoczone [...] motywy sprawiają, że olbrzymia większość profesorów ustosunkowała się nieprzychylnie do projektu [...]. Profesorowie ci są przy tym przeświadczeni, że gdyby nawet Ustawa ta weszła w życie, faktycznie wykonywana prawie nigdy nie będzie. Ministrowie [...] sami dochodzić będą do wniosku, że z uprawnień im nadanych korzystać nie należy i milcząco lub jawnie przelewać będą swe uprawnienia na tych, którzy uprawnienia te ustawowo posiadać powinni. Jeżeli więc ogół profesorów jest nieprzychylnie usposobiony [...], dyktowane to jest przez uczucie niepokoju, że mogą się zdarzyć przypadki, gdy uprawnienia w pełni lub w części wyzyskane przez czynniki polityczne, spowodują niepowetowane szkody szkolnictwu wyższemu, a tym samym całemu krajowi ${ }^{119}$.

Tego rodzaju zarzuty nie były całkowicie bezpodstawne, choć trzeba pamiętać, że znacznie poważniejsze ograniczenie autonomii szkól wyższych nastąpiło już kilka lat wcześniej, praktycznie bez większych protestów ze strony opozycji i kręgów uniwersyteckich, mocą rozporządzenia prezydenta RP z 1928 r., które wprowadziło możliwość regulacji warunków zatrudnienia pracowników naukowych $\mathrm{w}$ teoretycznie autonomicznych wobec państwa szkołach wyższych ${ }^{120}$. Reforma ,jędrzejewiczowska" (bo taka przylgnęła do niej nazwa) była więc krytykowana i zwalczana tak intensywnie nie tyle ze względu na swój charakter merytoryczny, ile wskutek tego, iż jej uchwalenie przypadło na okres gwałtownie zaostrzającego się konfliktu pomiędzy obozem rządowym a opozycją.

Wedle słów samego Wacława Jędrzejewicza, poprzedzających wspomnienia brata z okresu premierostwa, nowa ustawa: 


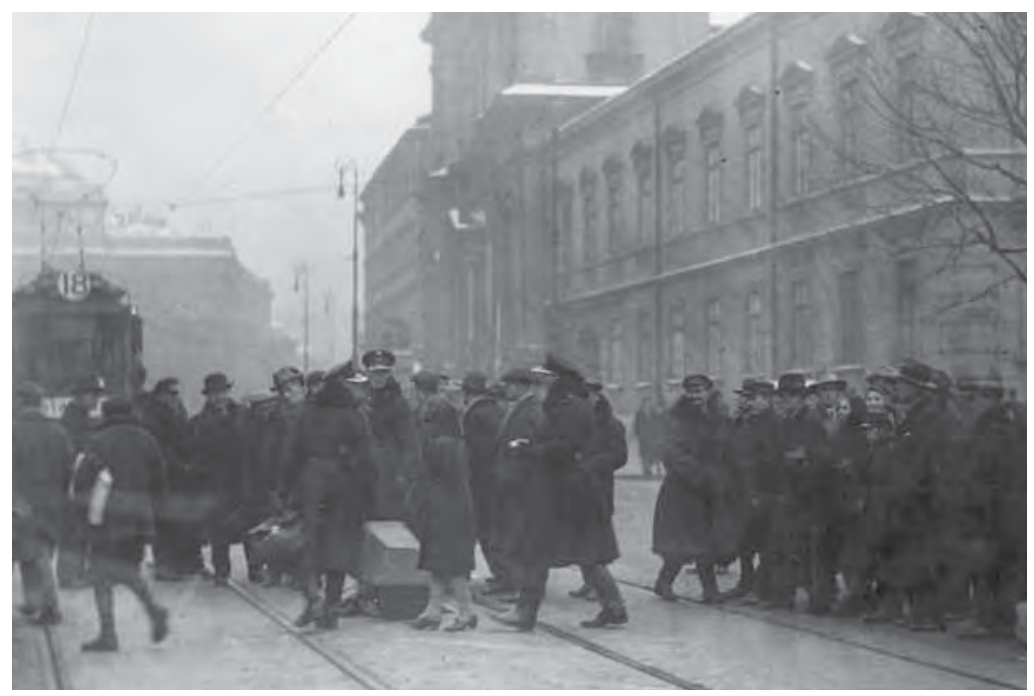

9. Trumna

umieszczona przez studentów na torach tramwajowych przed Uniwersytetem w ramach protestów przeciw nowej ustawie o szkolnictwie wyższym, marzec $1933 \mathrm{r}$.

[...] wywołała wiele komentarzy, najczęściej fałszywych. W istocie swej przewidywała wzmocnienie władzy rektora uniwersytetu. Dotychczasowy stan rzeczy, gdy kierownictwo spoczywało raczej w rękach wieloosobowego senatu akademickiego, dawał rezultaty ujemne dla uczelni zarówno pod względem administracyjnym, jak i organizacyjnym. Nowa ustawa, utrzymując autonomię uniwersytecką, obdarzała rektora, jako kierownika uczelni, znacznie większą władzą wykonawczą. Wychodząc z założenia, że państwowe szkoły akademickie są utrzymywane przez skarb państwa, że profesorowie, podobnie jak urzędnicy, opłacani są przez państwo, ustawa dała również większe prawa Ministerstwu [...], kierującemu zagadnieniami oświaty w państwie. Na tym tle swego czasu głośną była sprawa likwidacji przez Ministerstwo $5^{2}$ katedr uniwersyteckich. Potocznie mówiono o zwolnieniu $5^{2}$ profesorów, kierowników tych katedr. To nie odpowiadało rzeczywistości, bowiem ogromna większość tych katedr nie była obsadzona, często od szeregu lat, a warunki budżetowe wymagały redukcji wydatków. Zaledwie około dziesięciu profesorów istotnie zostało przeniesionych w stan nieczynny. Byli to profesorowie którzy, w opinii ministerstwa, więcej się zajmowali polityką wśród młodzieży akademickiej, niż pracą naukową $[\ldots]^{121}$.

Ofiarami tej ograniczonej czystki padli m.in. Stanisław Kot oraz Ludwik Jaxa Bykowski, Edward Dubanowicz i Adam Heydel. Na Uniwersytecie Warszawskim do cięć jednak nie doszło - przeciwnie, w roku akademickim 1933/1934, utworzono dziewięć nowych katedr ${ }^{122}$. Wskazuje to na stosunkowo zgodną współpracę uczelni z resortem, także w trudnych latach wielkiego kryzysu, znaczonych burzliwymi wystąpieniami 
studentów ${ }^{123}$. Warto dodać, że w niektórych przypadkach zwalniani profesorowie zdołali zatrudnić się na innych uczelniach, m.in. na UW. W ten sposób trafili na UW: matematyk Kazimierz Kuratowski, usunięty z Politechniki Lwowskiej, i biolog Jan Wilczyński, który musiał opuścić Uniwersytet Stefana Batorego ${ }^{124}$.

$\mathrm{Na}$ Uniwersytecie Warszawskim reforma jędrzejewiczowska spowodowała też inne zmiany organizacyjno-personalne. $\mathrm{Na}$ mocy nowych przepisów, w połowie 1933 r. na wydziałach wybrano elektorów, a ci dokonali wyboru rektora na pierwszą kadencję trzyletnią. Został nim fizyk prof. Stefan Pieńkowski, uchodzący za osobę koncyliacyjną ${ }^{125}$. Prawnik Eugeniusz Jarra wystawił mu w swych wspomnieniach bardzo pozytywną opinię:

Rektorem najbardziej dla Uniwersytetu zasłużonym był bezsprzecznie prof. Stefan Pieńkowski [...]. Jowialnym usposobieniem umiał działać nader uspokajająco na przebieg obrad. [...] Kiedy z ustawą r[oku] 1933 nastały trudne dla Uniwersytetu terminy, wybrano [go] ponownie rektorem [...], ufając jego zdolnościom dyplomatycznym. Jakoż w ciągu trzyletniej [...] kadencji umiał utrzymać względny spokój wśród młodzieży, coraz bardziej burzącej się przeciwko ówczesnemu kursowi rządowemu; umiał też dawać sobie doskonale radę z obydwu ministrami Jędrzejewiczami, a młodszego nazywał nawet do nas dobrotliwie „Wacuchną” [... $]^{126}$.

Niezależnie od dyplomatycznej zręczności prof. Pieńkowskiego, skutkiem wprowadzenia nowej ustawy było także powstanie ostrego podziału w środowisku akademickim i zantagonizowanie jego sporej części wobec obozu rządzącego. W wyniku dyskusji w łonie Państwowej Rady Oświecenia Publicznego na posiedzeniu 9-10 XI $193^{2}$ r. za projektem rządu opowiedziała się większość jej członków - 37 osób (w tym profesorowie: Zygmunt Czerny, Stefan Ehrenkreutz, Antoni Jakubski, Bolesław Miklaszewski, Józef Mikułowski-Pomorski, Mojżesz Schorr, Tadeusz Wałek-Czarnecki, Stanisław Zakrzewski), przeciw było dziewięć (m.in. profesorowie: Ignacy Chrzanowski, Stanisław Estreicher, Stanisław Kutrzeba, Stanisław Pawłowski), a jedna wstrzymała się. Podsekretarz stanu ks. Żongołłowicz, nota bene jedyny akademik w gronie twórców ustawy, uważał jednak ten wynik za pyrrusowe zwycięstwo:

Moim zdaniem przewaga merytoryczna była po stronie przeciw, zaś większością Rady, złożonej z urzędników Ministerstwa, nauczycieli szkół średnich i niższych, powołanych przez Ministra, Minister nie osiągnął celu, gdyż przykrycie, jakie sobie stworzył wnioskiem przez Radę przyjętym, nie daje należytej 


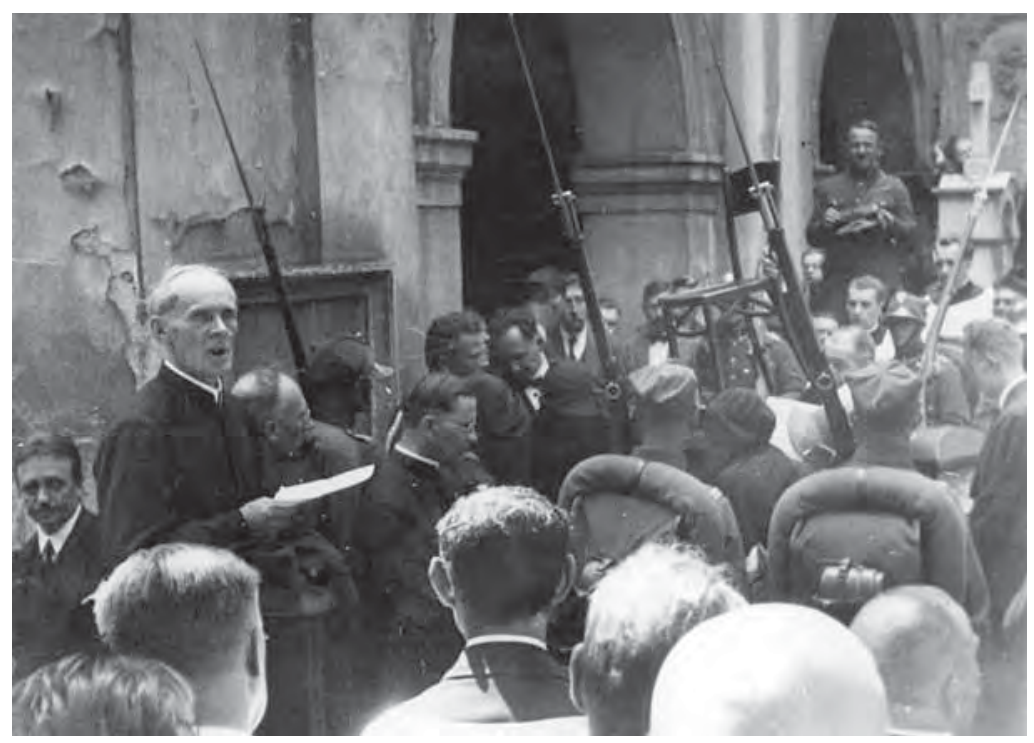

10. Uroczystości pogrzebowe ministra wyznań religijnych i oświecenia publicznego dr. Sławomira Czerwińskiego; przemawia podsekretarz stanu w tym resorcie, ks. Bronisław Żongołłowicz, 7 VIII $1931 \mathrm{r}$.

powagi i autorytetu projektowi, osobę samego Jędrzejewicza pomniejsza ten nieszczęsny manewr. Oba skrzydła profesorskie wykazały znaczne roznamiętnienie, brak umiaru i taktu. Jedni bowiem bronili całego projektu do najdrobniejszych szczegółów, drudzy uważali cały projekt za bezcelowy i bezwartościowy ${ }^{127}$.

Próbując podsumować w dużym uproszczeniu całościowy charakter reformy jędrzejewiczowskiej w aspekcie szkolnictwa wyższego można powiedzieć, że choć pełniła ona (i pełnić miała) w pewnej mierze rolę straszaka wobec opozycyjnie nastawionej części profesury, to jednocześnie jej głównym celem pozostawało uporządkowanie sytuacji panującej na wyższych uczelniach poprzez zwiększenie uprawnień władzy wykonawczej - tak rektorskiej, jak i ministerialnej. Wpisywało się to w powszechną w ówczesnej Polsce tendencję wzmacniania państwa, nie było natomiast - jak często mylnie się sądzi - zamachem na wolność badań naukowych czy niezależność środowisk akademickich jako takich. Apogeum tych dążeń do wzmocnienia roli państwa w systemie szkolnictwa wyższego i nauki przypadło już na okres po śmierci marszałka Piłsudskiego, kiedy w obozie władzy wyklarował się nowy układ sił. Przejawem takich tendencji było m.in. utworzenie Komitetu Porozumiewawczego czterech czołowych instytucji badawczych: Polskiej Akademii Umiejętności, Akademii Nauk Technicznych, Towarzystwa Naukowego Warszawskiego, Towarzystwa Nauk we Lwowie, a także Rady Nauk Ścisłych i Stosowanych. Dokumenty oficjalne mówiły 
wprost, że jednym z głównych powodów próby integracji kręgów naukowych była kwestia wzmożenia wysiłków na rzecz obrony kraju. Pierwsze kroki w tej materii można datować wszakże na sam początek dekady. Już w 1933 r. powstał Tymczasowy Komitet Doradczo-Naukowy przy II wiceministrze spraw wojskowych i szefie Administracji Armii gen. dr. Sławoju Składkowskim, którego wiosną $193^{6}$ r. zastąpił gen. inż. Aleksander Litwinowicz. Gremium tym kierował, co nie jest bez znaczenia, przyszły minister wyznań religijnych i oświecenia publicznego prof. Wojciech Świętosławski. Celem Komitetu Porozumiewawczego miało być „wspólne popieranie i obrona interesów nauki polskiej, a w szczególności: porozumienie się co do podziału pracy; wykonywania wspólnych przedsięwzięć naukowych; reprezentacji nauki polskiej za granicą; wydawnictw naukowych przeznaczonych dla zagranicy; ustalania stosunku do naukowych instytucji i form ich popierania". Natomiast do zadań Rady Nauk Ścisłych i Stosowanych należało: „śledzenie za rozwojem wszystkich dziedzin wiedzy; szybkie informowanie świata naukowego o dorobku nauki polskiej w zakresie wiedzy czystej i stosowanej, wydawanie opinii we wszystkich sprawach związanych z rozwojem nauk ścisłych i ich zastosowań; służenie Rządowi RP pomocą fachową we wszystkich zagadnieniach zawiązanych z potrzebami Państwa; uzgadnianie wniosków przedstawianych przez poszczególne komitety naukowe". Powołano 15 komitetów (antropologiczny, astronomiczny, biologiczny, chemiczny, fizyczny, geodezyjno-geofizyczny, geograficzny, górniczo-hutniczy, inżyniersko-architektoniczny, leśny, matematyczny, mechaniczno-elektrotechniczny, medyczny, mineralogiczno-geologiczny i rolniczy) ${ }^{128}$.

Na pierwszym posiedzeniu Rady Nauk Ścisłych i Stosowanych, które miało miejsce w Warszawie 29 XI $193^{6}$ r., padły znamienne słowa urzędującego ministra, prof. Świętosławskiego:

Jesteśmy świadkami gorączkowych zbrojeń wszystkich państw [...]. W tych warunkach społeczeństwo polskie musi się prędko otrząsnąć z nastrojów pacyfistycznych, zakorzenionych w nas głębiej niż gdzie indziej. Walki zaborczej prowadzić nie będziemy nigdy, ale musimy powiedzieć to śmiało i otwarcie, że od naszego obecnego wysiłku, od wysiłku dorastającej dziś młodzieży, od powszechnego uświadomienia najważniejszych zagadnień polskiej racji stanu zależy nasz byt, nasza przyszłość, moc i potęga naszego narodu i całość granic Rzeczypospolitej. [...]

Pogotowie obronne kraju jest w sposób najściślejszy związane z rozwojem kultury, zasobnością, samowystarczalnością, wreszcie siłą moralną i duchową postawą całego społeczeństwa. Każdy więc, kto przez swą pracę przyczyni się 


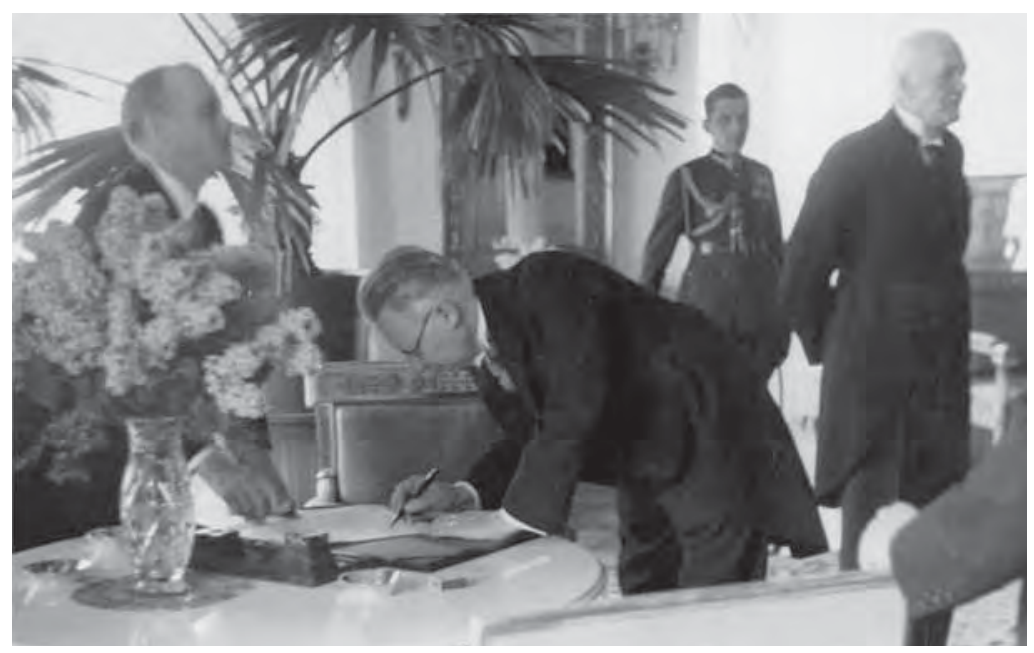

11. Minister wyznań religijnych i oświecenia publicznego Wojciech Świętosławski podczas podpisywania aktu zaprzysiężenia w obecności prezydenta RP prof. Ignacego Mościckiego, $16 \mathrm{~V} 1936 \mathrm{r}$.

na jakimkolwiek odcinku do wzbogacenia kultury duchowej i materialnej, ten potencjalnie staje się obrońcą ojczyzny, i to wtedy właśnie, gdy się szczęk oręża jeszcze nie rozlega. $[\ldots]^{129}$.

Minister Świętosławski nie był militarystą - przeciwnie, zaliczano go do liberalnego skrzydła w składzie ostatniego gabinetu II Rzeczypospolitej, kierowanego przez gen. Składkowskiego. Taki był po prostu duch czasu, a szef resortu wyznań religijnych i oświecenia publicznego, wraz z wicepremierem i ministrem skarbu inż. Eugeniuszem Kwiatkowskim, należał do tzw. grupy Zamku, protegowanej przez prezydenta prof. Ignacego Mościckiego. Ci trzej chemicy rozumieli się dobrze; zdawali sobie sprawę z faktu, że rozpoczynający się proces konsolidacji narodowej w przygotowaniu do nieodległej wojny może przynieść poważne napięcia polityczno-społeczne, na co niebagatelny wpływ miały stosunki ludnościowe ${ }^{130}$. Pożądane były więc mechanizmy luzujące, które mogły złagodzić oczekiwane konflikty. Jednym z nich stało się porozumienie z kręgami akademickimi, niezadowolonymi ze sztywności nadzoru ministerstwa, wynikającej z ustawy jędrzejewiczowskiej. Wskutek tego w połowie $1937 \mathrm{r}$. doszło do modyfikacji regulacji sprzed czterech lat.

Nowy akt prawny przewidywał m.in., że tworzenie i zamykanie nowych wydziałów następować będzie na mocy ustaw, a nie rozporządzeń ministra. Katedry obsadzone mogły być likwidowane tylko na wniosek rady danego wydziału. Rektorom państwowych szkół akademickich przydano prawo wydawania zarządzeń porządkowych, zaś rady 
wydziałowe obarczono obowiązkiem czuwania „nad rozwojem reprezentowanych przez nią nauk i nad ciągłością pracy w zakresie każdej z nich na wydziale”, czyniąc je odpowiedzialnymi „za poziom naukowy pracy i za poziom nauczania”, za „dobór odpowiednich sił naukowych oraz o odpowiednie warunki twórczości naukowej i działalności pedagogicznej”, a także za „racjonalny układ programu wykładów i ćwiczeń oraz czuwanie nad jego należytym wykonaniem". Inne zapisy precyzowały na nowo kompetencje dziekanów i kierowników, skład grona nauczycielskiego, tryb uzyskiwania docentury. Profesorom ustępującym z katedry dodano prawo dalszego wykładania. MWRiOP miało odtąd otrzymywać programy wykładów i ćwiczeń tylko do wiadomości. W miejsce uogólnionej kategorii słuchaczy wyodrębniono kategorie studentów i wolnych słuchaczy. W sposób zwarty określono tryb rekrutacji kandydatów, którzy mieli być „przyjmowani zależnie od postanowień regulaminu danego wydziału przez dziekana lub komisję, wybraną $\mathrm{w}$ tym celu przez radę wydziałową. W razie odmownego załatwienia podania o przyjęcie kandydaci mają prawo odwołać się do senatu, który orzeka ostatecznie". Uściślone zostały też zapisy dotyczące kwestii dyscyplinarnych, gdzie nieco zredukowano kompetencje karne sądów powszechnych ${ }^{131}$. Taki ład prawny życia akademickiego obowiązywał do wybuchu II wojny światowej, a częściowo aż do wydania nowych regulacji przez władze tzw. Polski Ludowej.

W okresie ożywienia koniunktury gospodarczej, trwającym mniej więcej od połowy 1935 r., który przyniósł pewną poprawę sytuacji materialnej mieszkańców kraju, a także finansów państwa, zdołano utworzyć, często w drodze reorganizacji, jeszcze kilka nowych uczelni, w istotnej części wojskowych. I tak, już w 1936 r. powstały w stolicy: Wyższa Szkoła Lotnicza oraz Wyższa Szkoła Inżynierii ${ }^{132}$. Rok później w Poznaniu zaczęła działać Państwowa Wyższa Szkoła Budowy Maszyn i Elektrotechniki ${ }^{133}$, a także Wyższe Katolickie Studium Społeczne, w Katowicach - Wyższe Studium Nauk Społecznych i Gospodarczych, we Lwowie - Główna Szkoła Gospodarstwa Domowego. W 1938 r., również we Lwowie, uruchomiono Wyższe Kursy Ziemiańskie im. Jerzego Turnaua ${ }^{134}$, warszawski Centralny Instytut Wychowania Fizycznego został przekształcony w Akademię Wychowania Fizycznego Józefa Piłsudskiego w Warszawie ${ }^{135}$, w Cieszynie natomiast podjęła pracę zreformowana Państwowa Wyższa Szkoła Gospodarstwa Wiejskiego ${ }^{136}$. Wtedy też doszło do likwidacji jednej uczelni - jesienią zamknięto warszawską Szkołę Wyższą Instytutu Wschodniego; część jej zadań przejęła powołana równocześnie Wyższa Szkoła Żywych Języków Wschodnich w Warszawie, powiązana z Instytutem Orientalistycznym UW ${ }^{137}$. 


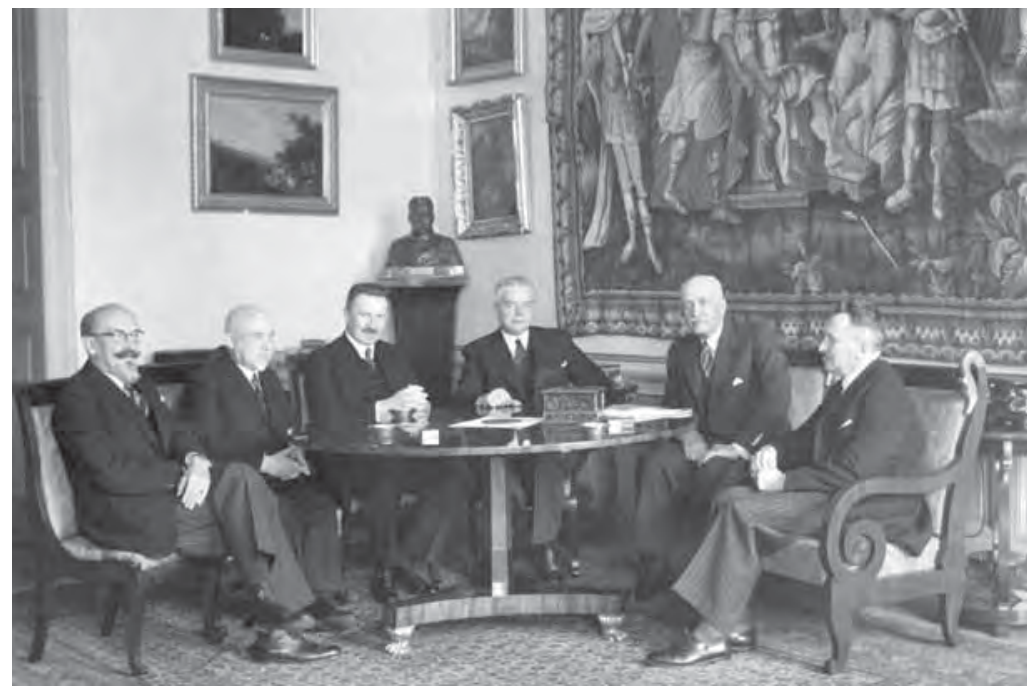

12. Rektorzy szkół wyższych u prezydenta, pierwszy z lewej prof. Jerzy

Modrakowski

kierujący wówczas

Akademią

Stomatologiczna

w Warszawie, pierwszy z prawej rektor UW prof. Włodzimierz Antoniewicz, październik $1938 \mathrm{r}$.

Wspomniane zakłady nie miały, poza AWFJP, charakteru akademickiego. Poza tym w 1937 r. nastąpiła nazewnicza akademizacja uczelni handlowych w Krakowie, Lwowie i Poznaniu ${ }^{138}$, co stanowiło przystanek na drodze do „wykonywania praw państwowych”. W kwietniu 1939 r. akademią sensu largo stała się też warszawska Szkoła Nauk Politycznych ${ }^{139}$.

Jeśli idzie o projekty niezrealizowane ze względu na wybuch II wojny światowej, to wspomnieć trzeba, że trwały przygotowania do utworzenia większej uczelni w stolicy województwa śląskiego, czego można było się spodziewać na początku lat 40. Przyczyniały się do tego nie tylko rzeczywiste potrzeby regionu i ambicje wojewody dr. Michała Grażyńskiego, ale przede wszystkim pokryzysowy wzrost zamożności tego najbogatszego województwa. Przyczółki już istniały, w przypadku uniwersytetu były to: Instytut Śląski, Towarzystwo Popierania Nauk na Śląsku oraz Instytut Pedagogiczny w Katowicach (zał. 1928; po wprowadzeniu w 1937 r. reformy stał się dwuletnim pedagogium policealnym), natomiast w przypadku politechniki trzyletnie Wyższe Studium Nauk Stosowanych i Górniczych ${ }^{140}$. W nieco dalszej perspektywie przewidywano otwarcie szkoły wyższej w Gdyni, bez wątpienia w oparciu o Instytut Bałtycki, a być może też Państwową Szkołę Morską i inne placówki ${ }^{141}$. Wiadomo, że zamierzony na kolejną dekadę program modernizacji kraju obejmował wzmocnienie uczelni już istniejących, a także rozwój wyższego szkolnictwa zawodowego, z naciskiem na dyscypliny mające bliski związek z życiem gospodarczym (nauki techniczne, rolne itd.) ${ }^{142}$. 
Resort wyznań religijnych i oświecenia publicznego nie zamierzał bowiem bezwarunkowo ulegać ogólnemu, cywilizacyjnemu trendowi do podnoszenia odsetka osób, które podjęły studia wyższe. Wbrew potocznemu mniemaniu, liczba studentów w II Rzeczypospolitej nie była bowiem mała. Dla okresu 1933-1937 średnia arytmetyczna wynosiła 1437 studentów na milion mieszkańców, co dawało wynik lepszy niż w Niemczech czy Wielkiej Brytanii, choć gorszy niż we Francji czy Szwecji ${ }^{143}$. Jak trafnie zauważył minister Świętosławski w złożonym na posiedzeniu Komisji Budżetowej Sejmu ostatnim wystąpieniu sprawozdawczo-programowym, z którego warto przytoczyć obszerniejszy fragment:

[‥] niepodobna nie zwrócić uwagi na niebezpieczeństwo bezrobocia wśród pracowników z akademickim wykształceniem, w których tkwi potencjonalnie[!] duży zasób środków włożonych w ich wykształcenie przez społeczeństwo i państwo. Bezrobocie takich pracowników bywa oceniane jako dotkliwa klęska społeczna. [...] Mimo to jednak należy zagadnienie powiększenia lub zmniejszenia dopływu słuchaczy do szkół akademickich traktować bardzo oględnie, nie ulegając sugestiom chwilowej koniunktury [...]. Często też okazuje się, że poprawa sytuacji gospodarczej zmienia w krótkim czasie stosunki na rynku pracy i w parę lat po okresie bezrobocia inteligencji może się okazać dotkliwy jej brak i odwrotnie. Podobną fazę przechodziła Polska w okresie kryzysu [gospodarczego] i przechodzi obecnie w chwili jego likwidowania. [...] Przyjmowanie [...] kandydatów ograniczane [dziś] bywa jedynie z braku wolnych miejsc w pracowniach, laboratoriach lub salach rysunkowych. Wiele danych wskazuje, że i nadal zajmować będziemy miejsce pośrednie pomiędzy państwami o względnie małej i znacznej liczbie studentów, zwłaszcza że warunki ogólne przemawiają raczej za powiększeniem liczby przyjmowanej młodzieży [...]. Nie bez znaczenia [...] jest pod tym względem okoliczność, że procentowo w odniesieniu do miliona mieszkańców posiadamy znacznie więcej młodzieży w ogóle, a wiejskiej w szczególności, aniżeli większość krajów Europy Zachodniej. Jeżeli więc doszlibyśmy do przekonania, że należy powiększać liczbę studentów, to powstaje zagadnienie, czy mamy to uczynić w ramach istniejących szkół akademickich, czy też tworzyć nowe szkoły tego typu. [...] Powstanie każdej nowej szkoły akademickiej związane jest z wielkimi kosztami, wynoszącymi kilkanaście milionów złotych. Poza tym utrzymanie jej wymaga stałego i znacznego powiększenia dotacji ze Skarbu Państwa. Ponieważ równocześnie z tymi potrzebami występuje olbrzymia liczba innych, Ministerstwo Oświaty widzieć będzie możność poważnego traktowania zagadnienia tworzenia nowych szkół akademickich dopiero wówczas, gdy Skarb zapewni odpowiednie dotacje na uczelnie już istniejące. [...] Mając na uwadze wszystkie względy powyższe, zdaje sobie Ministerstwo całkowicie sprawę, że boleśnie odczuwany brak 
wykwalifikowanych sił domaga się rozwiązania przez powiększenie pojemności uczelni już istniejących, a jeśli ten środek nie wystarczy, przez utworzenie szkół nowych ${ }^{144}$.

Jak widać, władze Rzeczypospolitej na przełomie czwartej i piątej dekady stulecia nie planowały stymulowania wzrostu liczby studiujących oraz zakładów. Zadaniem na najbliższe dziesięciolecie było raczej upowszechnienie wykształcenia gimnazjalnego, a potem licealnego, przede wszystkim o profilu zawodowym. Zwracał na to uwage znający od podszewki życie akademickie były premier oraz minister wyznań religijnych i oświecenia publicznego prof. Kazimierz Bartel, rozważając zbyt rozrywkowy i długi jego zdaniem tryb studiów na Politechnice Lwowskiej: „młodzieniec, kończący szkołę techniczną, czy jak to będzie miało wkrótce miejsce liceum techniczne, zdystansuje utytułowanego wprawdzie, ale znudzonego pseudo-studiami inżyniera. Nim ten ostatni dojdzie do dyplomu, technik nabędzie [...] kilkuletniej praktyki [...] i podciągnie się też z łatwością i teoretycznie często ponad poziom wymęczonego absolwenta Politechniki. [...] One [tj. szkoły zawodowe], nie zaś politechniki dostarczać będą młodych, energicznych, zdyscyplinowanych sił technicznych. Takich bowiem potrzeba krajowi" ${ }^{145}$. Liczba studentów szkół wyższych miała powiększać się samoczynnie, zwłaszcza na kierunkach dających łatwo możliwość znalezienia stałej i dobrej pracy, a więc ściśle powiązanych z programem rozwoju gospodarczego kraju, kładącym nacisk na inwestycje w przemysł, budownictwo, transport i łącznośćc ${ }^{146}$.

Stosownie do powyższych przekonań rozdzielane były środki finansowe. W drugiej połowie lat zo. budżet MWRiOP oscylował pomiędzy 15-16\% wydatków państwowych. Po istotnej obniżce w roku budżetowym 1934/1935 do 34,0,7 mln zł, w następnych czterech latach wzrósł on o 9,4\% (do 376,1 mln). Na rok budżetowy 1939/194,o preliminowano dalszy wzrost, o 5,8\% (do 399,4 mln zł). Z tych kwot gros pochłaniały nakłady na szkolnictwo powszechne i średnie (w tym zawodowe), a w puli przypadającej na naukę i szkoły wyższe (np. w roku budżetowym 1938/1939 było to $28,7 \mathrm{mln}$, tj. 9,2\% kredytów ministerstwa) dominowały wydatki płacowe, związane też z awansami i wzrostem liczby etatów. W latach 1936-1938 na budowę nowych lokali dla szkół akademickich wydano niecałe 11,5 mln zł, tj. przeciętnie po ok. $1 \%$ budżetu ministerstwa. Tymczasem, by zaspokoić najpilniejsze potrzeby szkolnictwa średniego, zawodowego i wyższego w tej dziedzinie niezbędna byłaby dotacja 27,5 mln zł przez cztery lata z rzędu, zatem kilkukrotnie większa od rzeczywistej. Dla pełni obrazu dodajmy, że 
inne resorty oraz skarb województwa śląskiego równiė̇ partycypowały w nakładach na oświatę, naukę i sztukę (w roku budżetowym 1938/1939 na sumę 54,7 $\mathrm{mln}$, co dawało dodatkowe 17,6\%). Z kolei dział zasadniczy zawierał też pozycje pozafiskalne, tj. tzw. taksę administracyjną i dochody z funduszu opłat studenckich ${ }^{147}$.

Uzupełnieniem możliwości zdobywania wykształcenia wyższego były studia obywateli RP za granicą. Odbywały się one głównie sumptem prywatnym. W końcu lat 3o. tylko w przypadku Wolnego Miasta Gdańska resort wyznań religijnych i oświecenia publicznego udzielał stypendiów studentom polskim uczącym się w Wyższej Szkole Technicznej ${ }^{148}$. Możliwe było oczywiście składanie aplikacji indywidualnych, bezpośrednio w uczelniach zagranicznych lub w instytucjach pośredniczących w rodzaju British Council. W jego przypadku ofertę kierowano do kawalerów w wieku 20-27 lat, posiadających dyplom ,jednej z uznanych wyższych uczelni w kraju", wykazujących się znajomością angielskiego „do słuchania wykładów i prowadzenia studiów w języku angielskim" (co weryfikował konsul brytyjski), mogących dowieść, że „posiadają dostateczne kwalifikacje dla prowadzenia samodzielnych prac badawczych na fakultecie przez nich obranym". Aplikant mógł wybierać spośród wielu kierunków: architektury, budownictwa okrętów i inżynierii morskiej, dziennikarstwa, ekonomii i socjologii, filologii i literatury angielskiej, górnictwa, handlu, historii, języków wschodnich, lotnictwa, medycyny dziecięcej, profilaktycznej lub tropikalnej (wraz z higieną), metalurgii, ogrodnictwa, prawa, rolnictwa, stosunków międzynarodowych, włókiennictwa, zdrowia publicznego oraz technologii: chemii, olejów mineralnych lub szkła ${ }^{149}$.

W wymiarze instytucjonalnym cywilne szkoły wyższe rozwijały stosunki z placówkami naukowo-dydaktycznymi i naukowymi w wielu krajach europejskich ${ }^{150}$, zawierając m.in. umowy o wizytach profesorów, wymianach stażystów, wycieczkach studentów ${ }^{151}$. Pojawiły się również inicjatywy stypendialne ${ }^{152}$. Z kolei uczelnie wojskowe, w tym szczególnie Wyższa Szkoła Wojenna, utrzymywały dość bliskie kontakty ze swymi odpowiednikami we Francji ${ }^{153}$.

Współpracę z zagranicą prowadził, rzecz jasna, również Uniwersytet Warszawski. Prócz utrzymywania kontaktu korespondencyjnego ${ }^{154}$, ogłaszania publikacji autorów cudzoziemskich i własnych w pismach obcych, członkostwa pracowników w organizacjach zagranicznych i międzynarodowych oraz zatrudniania obcokrajowców (np. jako lektorów języków) ${ }^{155}$ wymienić należy przede wszystkim pobyty badawcze - jak kwerendy biblioteczne, archiwalne i muzealne, pomiary i obserwacje, wykopaliska (np. w Edfu w Egipcie Górnym) ${ }^{156}$, dalej zjazdy i konferencje, 
wycieczki studenckie, wizyty delegacji oficjalnych, wyjazdy stypendialne ${ }^{157}$, a także wymiany profesorów. Jak wspominał prof. Eugeniusz Jarra, współpraca polegała na tym, że:

jakiś uniwersytet zagraniczny, np. paryski, wysyłał jednego roku swego profesora na zaproszenie Uniwersytetu Warszawskiego do niego na wykłady; w następnych latach na podobne zaproszenie Paryża jechał profesor warszawski. Ponieważ pary te dobierano według wydziałów, więc z tego samego uniwersytetu mogło przyjechać w jednym roku paru profesorów, wykładających na różnych wydziałach; mogli też przyjechać profesorowie z różnych uniwersytetów. Krajami wymiany była głównie Francja, Czechosłowacja, Włochy, Węgry; językiem wykładowym zazwyczaj język francuski. Wymiana profesorów, zbliżając uczonych różnych odległych środowisk, powodując wymianę myśli i informacji, miała dla życia naukowego bardzo poważne znaczenie; studenci natomiast mogli z niej odnosić korzyści tylko w ograniczonym kole tych, którzy znali dostatecznie język francuski. Bardzo rzadko zdarzały się wypadki, że obcy profesor władał językiem polskim w stopniu wystarczającym do wykładania. Miało to np. miejsce z profesorem prawa czeskiego w Pradze, [Karelem] Kadlecem, znawcą historii prawodawstw słowiańskich, który wygłosił [...] w roku 1925 pięć wykładów na warszawskim Wydziale Prawa ku prawdziwemu pożytkowi licznych słuchaczy, profesorów i studentów. Gościom dziękował zazwyczaj dziekan wydziału lub profesor ich specjalności. Jeżeli wobec cudzoziemców występował Uniwersytet jako całość, to korzystał zwykle z usług krasomówczych profesora [Oskara] Haleckiego, posiadającego fenomenalną zdolność przemawiania z jednakową swadą we wszystkich językach europejskich ${ }^{158}$.

Uniwersytet nawiązał i utrzymywał kontakty z uczonymi oraz placówkami (uniwersytety, instytucje, stacje, stowarzyszenia, fundacje, struktury Ligi Narodów) z co najmniej 33 krajów leżących na pięciu kontynentach (poza Australią), naturalnie z wielką przewagą Europy ${ }^{159}$. Ze względu na szczupłość funduszy opierały się one jednak często na możliwościach własnych poszczególnych pracowników, bowiem instytucjonalizacja współpracy naukowej Polski z państwami obcymi dopiero nabierała biegu. W kraju pomocy finansowej udzielało MWRiOP, Ministerstwo Spraw Zagranicznych, a także fundacje wspierające Uniwersytet i życie naukowe.

Wśród partnerów krajowych, z którymi uczelnia utrzymywała współpracę, wymienić trzeba zwłaszcza wojsko. Wisząca nad II Rzecząpospolitą zmora wznowienia napaści ze strony Rosji Sowieckiej (potem ZSRS), a także złe, od 1934 r. tylko czasowo uspokojone, stosunki z Niemcami sprawiały, że w życiu odbudowywanego państwa czynnik 
militarny odgrywał przez cały okres międzywojenny bardzo ważną rolę. Sytuacja ta rzutowała również na oczekiwania państwa wobec szkół wyższych. Nie chodziło tu tylko o służbę części adeptów czy też absolwentów - przyszłych podchorążych i oficerów rezerwy różnych broni odbywaną najczęściej w szkołach wojskowych, a od późnej jesieni 1937 r. także w obrębie Legii Akademickiej Uniwersytetu Józefa Piłsudskiego (UJP). Istotniejsze było kształcenie specjalistów, tak potrzebnych armii rozwiniętej podczas mobilizacji i spodziewanej wojny - lekarzy, weterynarzy, farmaceutów, geografów, prawników, duchownych itd. ${ }^{160}$ Jeszcze inną formę wypełniania powinności obronnych stanowiła kooperacja w dziele edukacji wybitnych oficerów, którzy podejmowali studia cywilne, albo też zostając słuchaczami Wyższej Szkoły Wojennej mogli zetknąć się z wykładowcami z Uniwersytetu ${ }^{161}$.

Miała też miejsce współpraca instytucjonalna. Rozwijała się stopniowo, z początku nieoficjalnie. Obejmowała rozmaite zagadnienia, interesujące np. wywiad (nauka języków, wiedza o krajach - potencjalnych przeciwnikach, geopolityka, wreszcie poszukiwanie kandydatów na pracowników), ale też struktury zajmujące się zagadnieniami technicznymi, ekonomicznymi i społecznymi. Od połowy lat 30., wraz z nasileniem się dążeń ekspansywnych Niemiec i Związku Sowieckiego, a tym samym wzmożeniem przygotowań państwa do obrony, kooperacja ta nasiliła się, nabierając charakteru półjawnego. Przykładem może być powołanie Instytutu Prawa Lotniczego i Zagadnień Gospodarczych Lotnictwa, o której to placówce ówczesny rektor UJP prof. Włodzimierz Antoniewicz stwierdził z okazji jej otwarcia:

Inicjatywa ta została podjęta z całą skwapliwością przez Uniwersytet Józefa Piłsudskiego. Wszak przecie organizacja badań w dziedzinie lotnictwa, które ma tak olbrzymią doniosłość w życiu narodu i państwa, spotka się z naszej strony z największą gotowością. Cieszymy się zaś zawsze, gdy możemy czynnie współpracować z czynnikami pozauniwersyteckimi, które reprezentują tak ważne funkcje państwowe. [...] Uniwersytet pragnie w swym skromnym zakresie służyć polskiemu lotnictwu przez prace naukowe, aby w ten sposób dorzucić wysiłek, na który go stać, do sukcesów wojskowych naszego lotnictwa i jego zdobyczy technicznych ${ }^{162}$.

Narastające napięcie w stosunkach międzynarodowych dało się odczuć na Uniwersytecie już w początku lat 30. Z tego okresu datują się bowiem pierwsze działania na rzecz stworzenia elementów systemu obrony przeciwlotniczej i przeciwchemicznej ${ }^{163}$. Proces ten został nasilony od września $193^{8}$ r., gdy wraz z kulminacją kryzysu czechosłowackiego 
i groźbą wybuchu wojny w Europie Środkowej, w Warszawie i innych miastach Polski doszło do częściowego rozwinięcia tzw. opl-pgaz (obrony przeciwlotniczej i przeciwgazowej) biernej. Z chwilą ujawnienia się konfliktu między RP a Rzeszą Niemiecką w końcu marca 1939 r. prace na tym polu znacznie przyspieszyły. Z postulowanych już wcześniej zamysłów budowlanych (m.in. wzmocnienie odporności gmachu Biblioteki Uniwersyteckiej na pożar) z braku kredytów rządowych nie udało się wykonać prawie nic. Jednak przeszkolenie personelu, wyznaczenie kierownictwa, sformowanie służb ochronnych i zaopatrzenie ich w sprzęt, określenie zadań i procedur na wypadek mobilizacji oraz wojny, przygotowanie instalacji alarmowych, zaciemnienia obiektów, ukryć prowizorycznych (rowy przeciwlotnicze kopane w ostatnich dniach sierpnia) oraz punktów pomocy medycznej należy uznać za czynności w zasadzie wystarczające w istniejących warunkach organizacyjno-finansowych. Gorzej wyglądało zaopatrzenie pracowników, którzy nie podlegali mobilizacji, w indywidualne środki ochrony. Musieli oni radzić sobie sami ${ }^{164}$. Nie rozwiązano natomiast kwestii ewakuacji najcenniejszych zbiorów i urządzeń, co dotyczyło zresztą niemal całego kraju. Pracownicy i studenci uczelni zaangażowali się też w zbiórkę pieniędzy i darów na Fundusz Obrony Narodowej i Pożyczkę Obrony Przeciwlotniczej ${ }^{165}$. Od wiosny, a głównie od połowy sierpnia, byli też powoływani do mobilizującej się stopniowo armii ${ }^{166}$.

U progu II wojny światowej istniało na obszarze Rzeczypospolitej licząc zgodnie z ówczesnymi, restrykcyjnymi zasadami - już 39 uczelni, przede wszystkim państwowych, skupionych w dziesięciu ośrodkach, z których sześć było miastami uniwersyteckimi sensu stricto (Warszawa, Lwów, Kraków, Poznań, Wilno, Lublin). Kształciło się na nich ok. $5^{6}$ tys. studentów ${ }^{167}$, a zatrudniały one ponad 3,3 tys. pracowników naukowych ${ }^{168}$ (zob. tabela 4).

Dwadzieścia jeden lat, jakie dzieliły odzyskanie niepodległości od okupowania Rzeczypospolitej przez Rzeszę Niemiecką i Związek Sowiecki, pozwoliło stworzyć stosunkowo nowoczesny system szkolnictwa wyższego, obejmujący cały kraj. Miał on charakter pluralistyczny (w aspekcie własnościowym i prawnym), a cechowały go typowe dla Polski międzywojennej dysproporcje. Obok wskazanych skupisk życia akademickiego istniały spore miasta i województwa pozbawione uczelni (np. Kielce i Częstochowa w kieleckim, Białystok i Grodno w białostockim, Łuck w wołyńskim). Niektóre obszary charakteryzowały się względnie dużym odsetkiem studentów (województwo warszawskie 


\begin{tabular}{|c|c|c|c|c|c|c|c|c|c|c|c|c|c|c|c|c|c|c|c|c|c|c|c|c|c|}
\hline 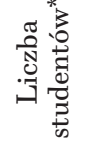 & $\begin{array}{l}\infty \\
\infty \\
\infty \\
\infty\end{array}$ & ल) & 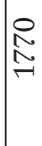 & 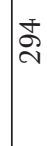 & 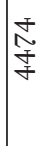 & కా & 5 & 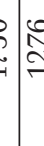 & 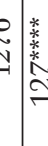 & 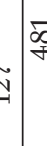 & 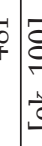 & $\vec{a}$ & : $\begin{array}{c}\infty \\
\infty \\
m\end{array}$ & 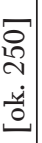 & $\mid \begin{array}{l}\overline{8} \\
0 \\
\dot{4} \\
\dot{0} \\
\end{array}$ & 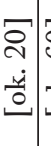 & $\begin{array}{l}8 \\
8 \\
\dot{4} \\
\end{array}$ & $\mathscr{\sigma}$ & 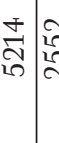 & $\begin{array}{l}\text { Nै } \\
\text { } \\
\text { Nै }\end{array}$ & $\stackrel{i}{\infty}$ & $\stackrel{ }{=}$ & & 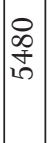 & $\stackrel{\sim}{\sim}$ \\
\hline
\end{tabular}

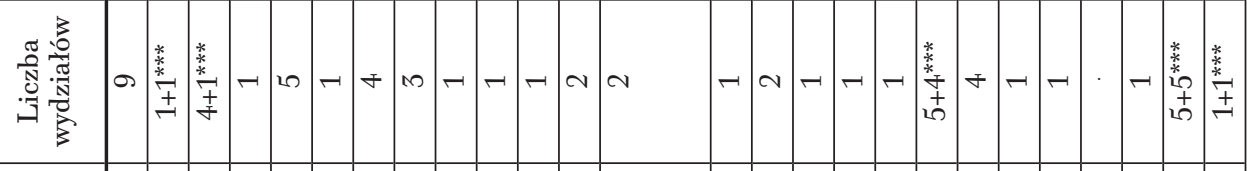
奈竞

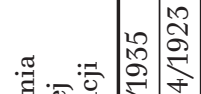

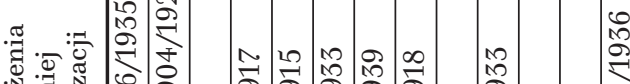
芯芯芯

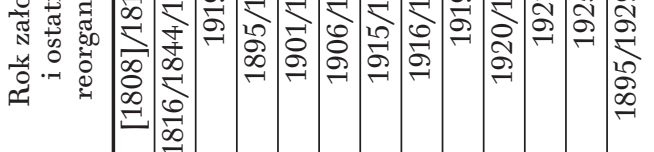

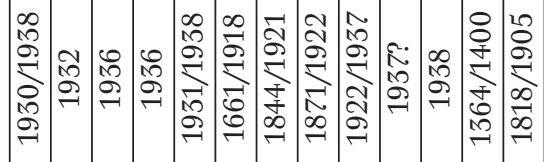

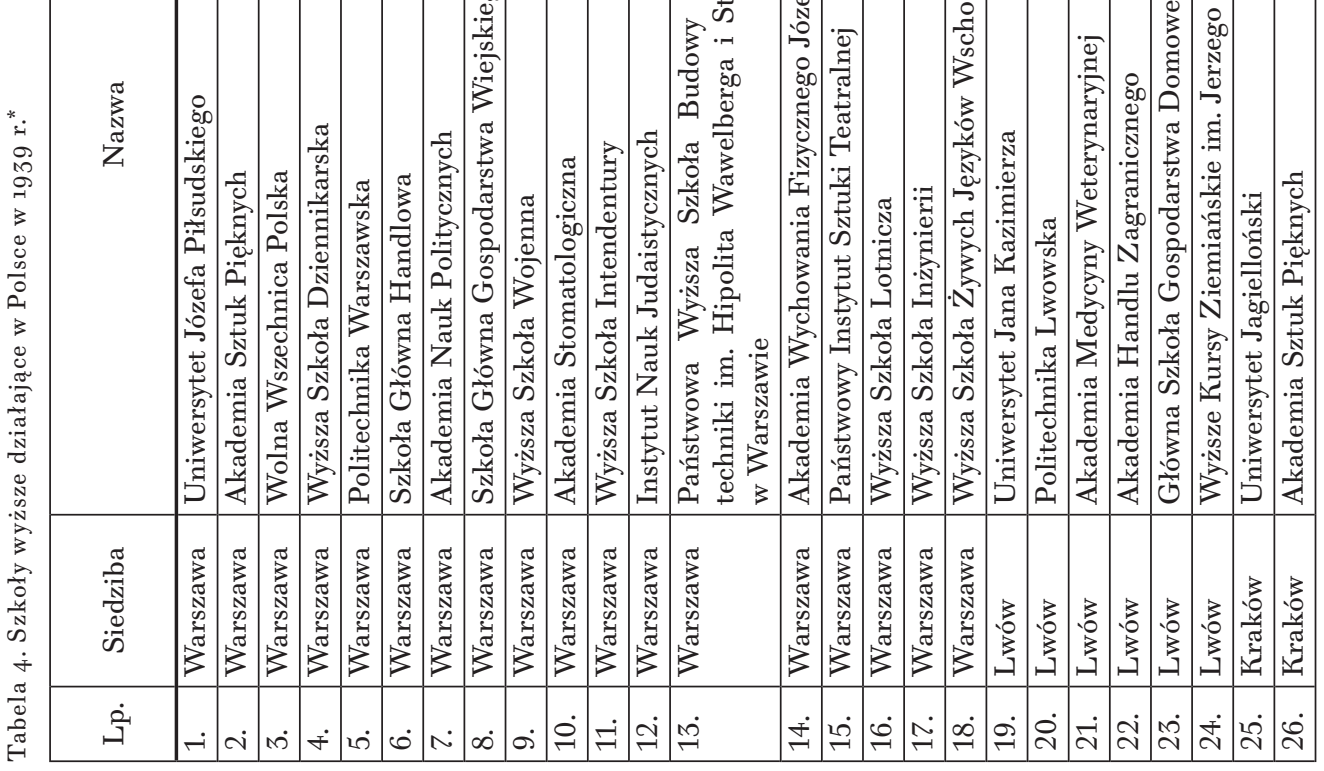




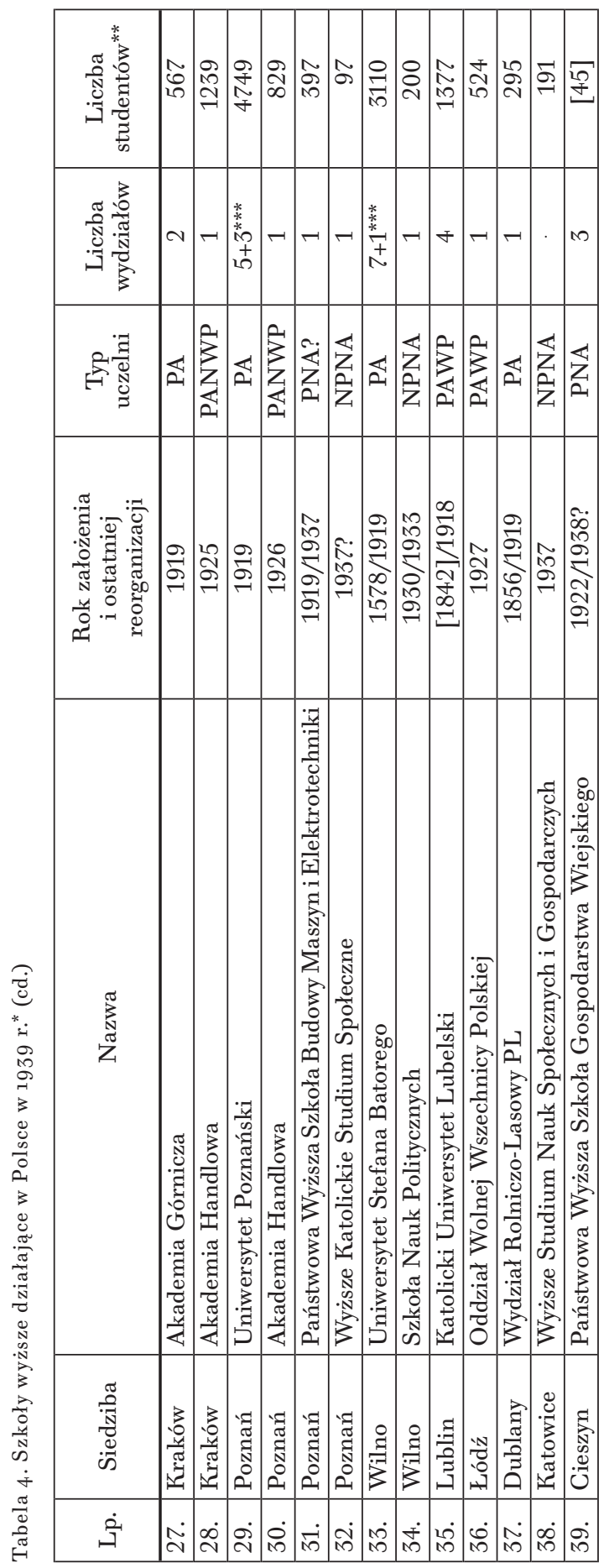

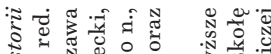

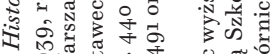

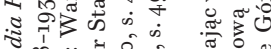

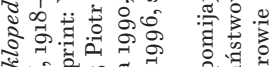

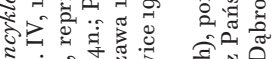

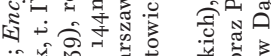

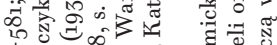

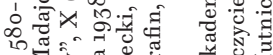

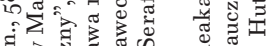

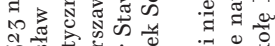

슬

讨

a 0 की

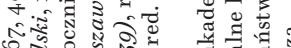

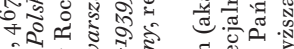

की.

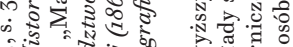

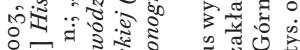

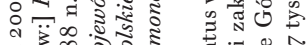

का

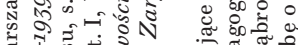

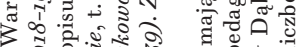

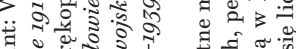

然.

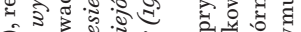

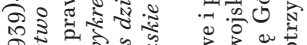

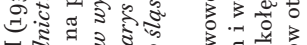

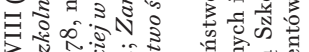

-

जิ 0 :

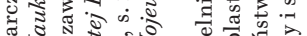

Z क्षे

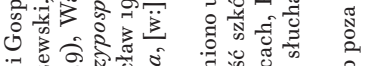

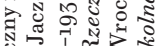

टี

造造产:

bo

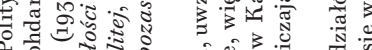

ติร

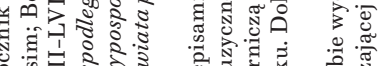

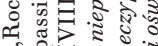

केख

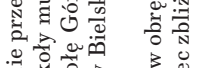

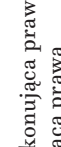

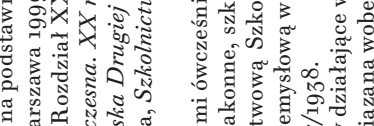

要

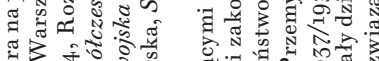

政

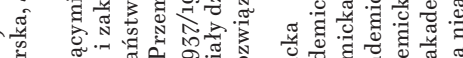

可

\%

ส

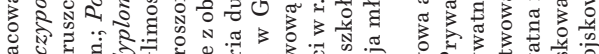

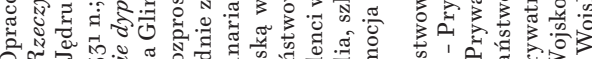

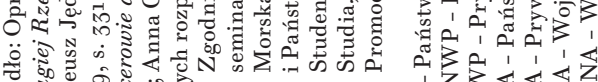

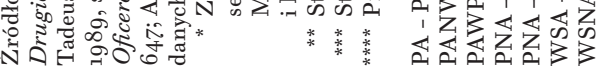


oraz krakowskie, lwowskie, poznańskie i wileńskie), a inne nad wyraz małym (poleskie, wołyńskie, nowogródzkie). Liczba szkół podwoiła się. Dominowały wśród nich uczelnie państwowe; było ich najwięcej i kształciły przeważającą większość (ok. 80\%) młodzieży. Liczba słuchaczy stopniowo rosła, choć studia pozostawały odpłatne. Obowiązywał system ulg, ale mimo to ukończenie nauki stanowiło poważne wyzwanie dla mniej więcej $1 / 3$ immatrykulowanych, zwłaszcza w okresach dekoniunktury gospodarczej. Trwały dorobek, obok dużych osiągnięć w poszczególnych dyscyplinach, stanowiło nadanie prawie 3 tys. stopni doktora i ok. 83 tys. niższych stopni naukowych ${ }^{169}$. Ogólny poziom nauczania jest trudny do oceny, ze względu na brak mierników pozwalających czynić porównania z innymi krajami. Kariery zagraniczne polskich uczonych, zapoczątkowane jeszcze przed 1939 r., świadczą jednak wybitnie na jego korzyść. Jeden z najlepszych przykładów stanowi droga zawodowa Michała Kaleckiego - posiadacza „zaledwie” tzw. półdyplomu Politechniki Warszawskiej, który musiał przerwać studia politechniczne zaczęte w Warszawie a kontynuowane w Gdańsku. Podjął pracę w Instytucie Badania Koniunktur Gospodarczych i Cen w Warszawie, by wkrótce wyjechać na stypendium do Wielkiej Brytanii, gdzie jego publikacje na temat teorii cyklu koniunkturalnego zrobiły prawdziwą furorę $e^{170}$.

Bariery rozwojowe oświaty wyższej wynikały z niedoboru kapitałów, odziedziczonego zacofania, konieczności nadrabiania straconego wieku porozbiorowego, co niosło za sobą np. koszt rozwoju administracji publicznej, a wreszcie ze względu na narastające zagrożenie wojenne i konieczność przeznaczania gros nakładów budżetowych na obronę. Z drugiej strony, te ostatnie stawały się kołem zamachowym dla industrializacji i inwestycji infrastrukturalnych, a tym samym sprzyjały rozbudowie wyższego szkolnictwa technicznego.

Uniwersytet Warszawski przez cały okres międzywojenny odgrywał w kraju rolę pierwszoplanową. Po upływie niemal dwóch dekad uczelnia skupiała przynajmniej ok. 16\% słuchaczy wszystkich wyższych zakładów naukowo-dydaktycznych w kraju, a w samej Warszawie udział ten można szacować na ok. 4,0\%. Jej siła wynikała też z liczebności i kwalifikacji pracowników ${ }^{171}$. Nie dysponujemy danymi, które pozwoliłyby wszechstronnie i bezspornie porównać wielkość oraz znaczenie dorobku UW z dokonaniami innych uniwersytetów. Jest to zresztą zagadnienie wykraczające poza ramy niniejszego rozdziału. Nie będzie jednak przesadą twierdzenie, że punkty odniesienia mogły dlań stanowić jedynie krakowska i - z racji dłuższej tradycji oraz uznania za granicą, choć mniejsza liczebnie - lwowska Almae Matres ${ }^{172}$. 


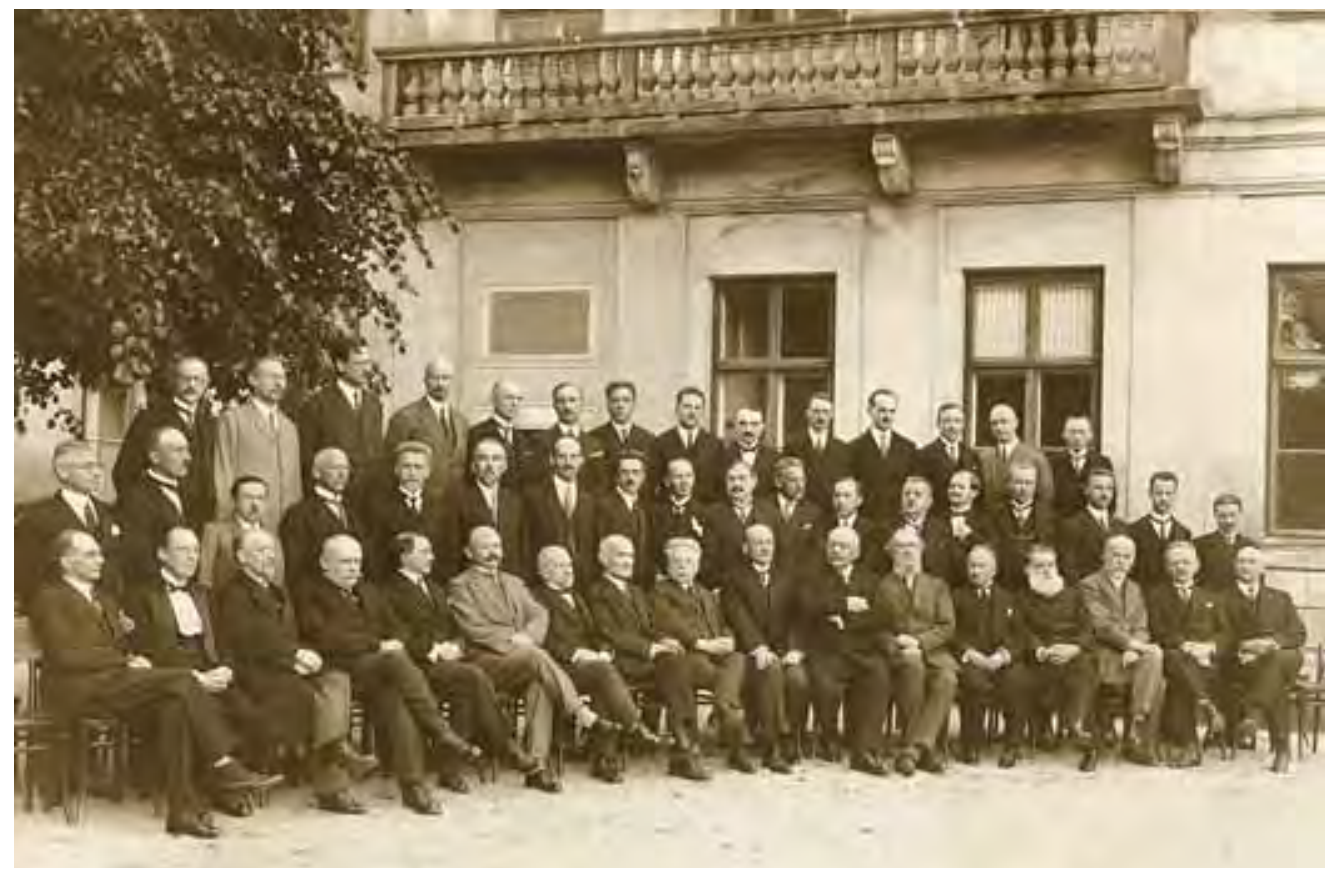

13. Profesorowie i docenci Wydziału Filozoficznego UW podczas ostatniego posiedzenia przed jego podziałem na wydziały Humanistyczny i Matematyczno-Przyrodniczy w 1927 r. W pierwszym rzędzie od lewej siedzą: Stefan Mazurkiewicz, Wacław Sierpiński, Wiktor Porzeziński, Kazimierz Żurawski, Stefan Pieńkowski, Adam Kryński, Jan Baudouin de Courtenay, Samuel Dickstein, Bolesław Hryniewiecki, Jan Karol Kochanowski, Tadeusz Zieliński, Antoni Przeborski, Karol Appel, Kazimierz Jabłczyński, Marceli Handelsman, Gustaw Przychocki; drugi rząd od lewej: Stanisław Słoński, Stanisław Lencewicz, Jan Lewiński, Stanisław Thugutt, Wiktor Lampe, Józef Ujejski, Oskar Halecki, Andrzej Tretiak, Michał Kamieński, Wacław Baehr, Kazimierz Bassalik, Kazimierz Białaszewicz, Bronisław Gubrynowicz, Konstanty Janicki, Jan Tur, Adam Krokiewicz, Tadeusz Kotarbiński, Stanisław Szober; trzeci rząd od lewej: Zygmunt Batowski, Wojciech Świetosławski, Kazimierz Ajdukiewicz, Bogdan Nawroczyński, Czesław Białobrzeski, Władysław Tatarkiewicz, Stanisław Leśniewski, Włodzimierz Antoniewicz, Tadeusz Wałek-Czarnecki, Stanisław Arnold, Wacław Roszkowski, Jan Samsonowicz, Witold Stefański, Henryk Mościcki

W okresie międzywojennym Uniwersytet Warszawski rozrósł się znacząco w sensie strukturalnym: z uczelni czterowydziałowej stał się zakładem liczącym osiem wydziałów i jedno studium. $\mathrm{Z}$ początkiem 1921 r. otwarto Studium Teologii Ewangelickiej, które 27 IX 1922 r. przekształciło się w Wydział Teologii Ewangelickiej. Równocześnie dotychczasowy Wydział Teologiczny zmienił nazwę na Wydział Teologii Katolickiej. 8 II 1925 r. podjął działalność Wydział Teologii Prawosławnej. W roku akademickim 1925/1926 nastąpiły dwie zmiany z jego początkiem dotychczasowy Wydział Prawa i Nauk Politycznych zmienił nazwę na Wydział Prawa, natomiast 29 I 1926 r. Oddział Farmaceutyczny Wydziału Lekarskiego stał się wydziałem samodzielnym. 
Początek kolejnego roku akademickiego 1927/1928 zaznaczył się zniesieniem Wydziału Filozoficznego, z jednoczesnym utworzeniem dwóch jednostek bardziej wyspecjalizowanych: Wydziału Humanistycznego oraz Wydziału Matematyczno-Przyrodniczego. Przemian dopełniło uruchomienie w tym samym czasie Wydziału Weterynaryjnego. W latach późniejszych następowały tylko drobniejsze zmiany, zachodzące w obrębie wydziałów ${ }^{173}$.

Podstawę prawną funkcjonowania uczelni, oprócz ustawy z 1920 r., aktów korekcyjnych oraz rozporządzeń MWRiOP (m.in. w sprawie nostryfikacji dyplomów, trybu uzyskiwania doktoratów), tworzyły: regulamin Senatu Akademickiego, regulaminy wydziałowe (ogólne i szczegółowe, np. dotyczące egzaminów, planów studiów) ${ }^{174}$, a wreszcie przyjęty 25 VI 1925 r. statut Uniwersytetu Warszawskiego. Po zatwierdzeniu przez rektora prof. Franciszka Krzyształowicza, a następnie przez Ministerstwo Wyznań Religijnych i Oświecenia Publicznego, zaczął obowiązywać od początku roku akademickiego 1925/1926.

Dokument ów liczył 163 artykuły ujęte w siedmiu rozdziałach. Stwierdzał na wstępie (art. 1.), że:

Zadaniem Uniwersytetu jest służyć nauce i Ojczyźnie, a przez to przyczyniać się do moralnego i umysłowego doskonalenia się rodzaju ludzkiego. W tym celu ma on poszukiwać i dochodzić prawdy naukowej, przewodniczyć w jej poznawaniu, rozpowszechniać ją przez swych uczniów. Zarazem też [...] ma sposobić młodzież do zawodów praktycznych, wymagających przygotowania naukowego.

Zasadę wolności badań rozwijał następnie art. 2:

Uniwersytet ma prawo wolności nauki i nauczania; każdy profesor i docent może oświetlać z katedry, według swego naukowego przekonania, wszelkie zagadnienia, wchodzące w zakres gałęzi wiedzy, których jest przedstawicielem, swobodnie obierać naukowy sposób ujęcia przedmiotu oraz metodę wykładów i ćwiczeń.

Uczelni zastrzegano status instytucji samorządnej (art. 3) oraz osobowość prawną, wraz z prawem posiadania majątku i zarządzania nim samodzielnie, a także podległości MWRiOP w zakresie kontroli samorządności finansowej (art. 3) ${ }^{175}$.

Dość szybko okazało się jednak, że ustalony stan prawny w niedalekiej przyszłości ulegnie modyfikacji. Jedną z przyczyn była zmiana wywołana zamachem stanu z maja $1926 \mathrm{r}$. i w następstwie przejęciem władzy przez obóz sanacyjny. Utworzona w końcu tegoż roku przez ministra Bartla komisja przygotowała projekt nowej ustawy o szkolnictwie, 


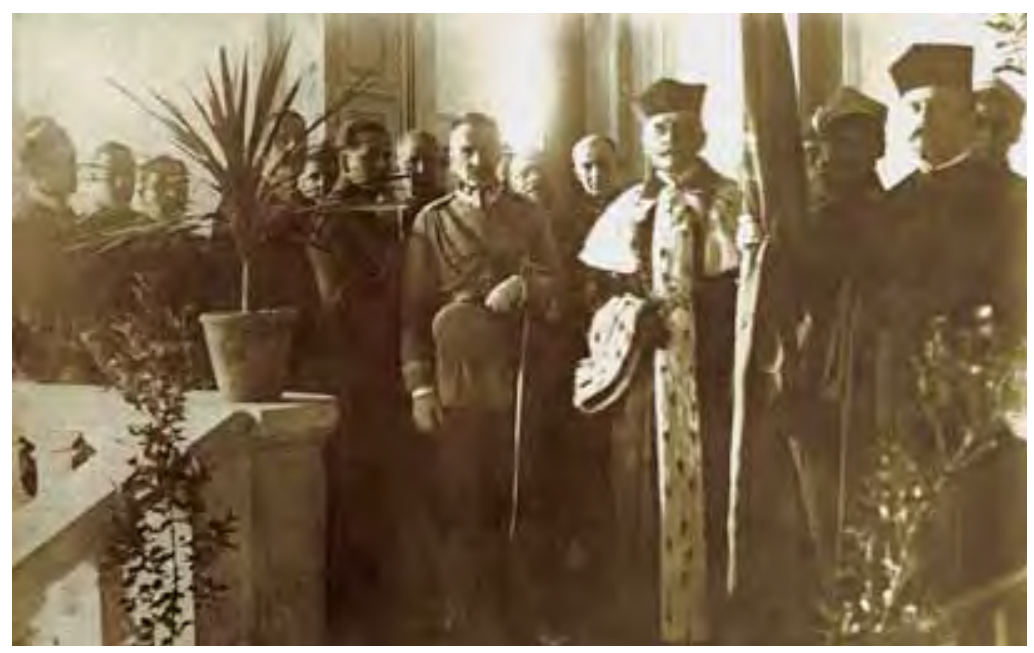

14. Wręczenie Uniwersytetowi Warszawskiemu insygniów przez marszałka Piłsudskiego, 2 V $1921 \mathrm{r}$.

który rozesłano do konsultacji „czynnikom powołanym”, m.in. władzom Uniwersytetu Warszawskiego. Wypowiedział się w tej materii Wydział Humanistyczny, który „ze względu na doniosłość podejmowanej reformy i troskę o wysoki poziom, jaki panować winien w całym szkolnictwie, na potrzeby kultury narodowej, na której straży stać musi szkoła wyższa i na obowiązek ujawnienia własnej opinii”, wydał memoriał w tej sprawie drukiem. Komisją wydziałową kierował dziekan, historyk prof. Marceli Handelsman. Dokument wykazywał zalety, jak też wady przygotowywanej nowej regulacji zagadnień oświatowych, odwołując się do doświadczeń z trzech zaborów, praktyki po 1915 r., a także rozwiązań zagranicznych. W konkluzji sprzeciwiał się likwidacji gimnazjów niższych, zalecał zwiększenie liczby 8-letnich gimnazjów klasycznych (zwłaszcza w regionach, gdzie ich brakowało), przywrócenie wysokiego pułapu egzaminów dojrzałości poprzez podniesienie poziomu szkół średnich oraz wymagań (względnie odstąpienie od przydania maturom prawa wstępu do szkół akademickich) oraz zawierał postulat, by uczelnie otrzymywały „młodzież tak przygotowaną, aby nie były zmuszone sprawdzać i uzupełniać jej wykształcenia w zakresie szkół średnich"176. Sugestie te nie zostały jednak przyjęte przez władze państwowe, a reforma jędrzejewiczowska, jak już zostało powiedziane, narzucała Uniwersytetowi i innym szkołom wyższym system, który spora część środowiska akademickiego stanowczo krytykowała.

Jak bodaj w każdej szkole wyższej, polityka Uniwersytetu Warszawskiego jako instytucji stanowiła wypadkową interesów różnych dziedzin nauki, a także wpływów i pozycji poszczególnych wydziałów, instytutów, 
Tabela 5. Rektorzy Uniwersytetu Warszawskiego/Uniwersytetu Józefa Piłsudskiego w Warszawie (listopad 1918 - sierpień 1939)

\begin{tabular}{|c|c|}
\hline 19 & $\begin{array}{l}\text { prof. dr Antoni Kostanecki (Wydział Prawa i Nauk Państwowych, } \\
\text { ekonomista, po raz drugi) }\end{array}$ \\
\hline $919-1920$ & f. dr Stanisław Józef Thugutt (Wydział Filozoficzny, mineralog) \\
\hline & f. dr Jan Karol Kochanowski (Wydział Filozoficzny, historyk) \\
\hline 1921-1922 & prof. dr Jan Mazurkiewicz (Wydział Lekarski, psychiatra) \\
\hline $922-1923$ & of. dr Jan Łukasiewicz (Wydział Filozoficzny, filozof-logik) \\
\hline $923-1924$ & $\begin{array}{l}\text { prof. dr Ignacy Koschembahr-Łyskowski (Wydział Prawa i Nauk } \\
\text { Politycznych, prawnik) }\end{array}$ \\
\hline 92 & $\begin{array}{l}\text { prof. dr Franciszek Krzyształowicz (Wydział Lekarski, } \\
\text { dermatolog-wenerolog) }\end{array}$ \\
\hline 26 & prof. dr Stefan Pieńkowski (Wydział Filozoficzny, fizyk) \\
\hline 27 & ział Filozoficzny, botanik) \\
\hline 192 & $\begin{array}{l}\text { ks. prof. dr Antoni Szlagowski (Wydział Teologii Katolickiej, } \\
\text { teolog-homiletyk) }\end{array}$ \\
\hline 192 & $\begin{array}{l}\text { prof. dr Gustaw Przychocki (Wydział Humanistyczny, filolog } \\
\text { klasyczny) }\end{array}$ \\
\hline 0 & Tadeusz Brzeski (Wydział Prawa, ekonomista) \\
\hline 193 & of. dr Mieczysław Michałowicz (Wydział Lekarski, pediatra) \\
\hline 193 & $\begin{array}{l}\text { f. dr Jan Łukasiewicz (Wydział Humanistyczny, filozof- } \\
\text { ik, po raz drugi) }\end{array}$ \\
\hline 0 & prof. dr Józef Ujejski (Wydział Humanistyczny, historyk literatury) \\
\hline 193 & $\begin{array}{l}\text { f. dr Stefan Pieńkowski (Wydział Matematyczno-Przyrodni- } \\
\text {, fizyk, po raz drugi)* }\end{array}$ \\
\hline & prof. dr Stefan Pieńkowski (jak wyżej)* \\
\hline & yżej)* \\
\hline 1936 & $\begin{array}{l}\text { prof. dr Włodzimierz Antoniewicz (Wydział Humanistyczny, ar- } \\
\text { cheolog pradziejowy)* }\end{array}$ \\
\hline 193 & prof. dr Włodzimierz Antoniewicz (jak wyżej)* \\
\hline 193 & f. dr Włodzimierz Antoniewicz (jak wyżej)* \\
\hline 1939 & $\begin{array}{l}\text { prof. dr Jerzy Modrakowski (Wydział Lekarski, farmakolog, fak- } \\
\text { tycznie nie sprawował urzędu)* }\end{array}$ \\
\hline
\end{tabular}

Źródło: Zestawienie na podstawie: Dzieje Uniwersytetu Warszawskiego 1915-1939, red. Andrzej Garlicki,

Warszawa 1982, s. 312 n., uzupełnione przez autora.

* Od roku akademickiego 1933/34, obowiązywała kadencja trzyletnia.

a często zapewne i konkretnych osób. Interesująca pod tym względem może być analiza grupy rektorów (zob. tabela 5). Jak widać, uczelnią kierował najdłużej fizyk, obrany dwukrotnie przed wojną prof. Stefan Pieńkowski. Podwójny rektorat zaliczyli też: ekonomista prof. Antoni Kostanecki (pierwszy raz jeszcze podczas I wojny światowej) oraz filozof prof. Jan Łukasiewicz. Jeden raz, lecz podczas trzyletniej, wydłużonej ustawą z 1933 r. kadencji, rządził archeolog prof. Włodzimierz Antoniewicz. Ci czterej ludzie wywarli na uczelnię doby Międzywojnia 
wpływ stosunkowo największy. Patrząc pod kątem dyscyplin, podgrupę rektorów dwukadencyjnych tworzyli: fizyk, ekonomiści, historycy i przyrodnicy (w obu dziedzinach sensu largo). Silniejszą pozycję wydawali się mieć jednak lekarze, wybierani aż trzykrotnie. Gdyby tą analizą objąć okres od 1915 r., to wraz z rektoratem Józefa Brudzińskiego dystansowaliby zresztą pozostałe dyscypliny pod względem liczby kadencji. Po jednym razie funkcję rektora pełnili: filolog, prawnik oraz teolog katolicki. Jeszcze inaczej rysują się proporcje międzywydziałowe. Można uznać, że na pierwszym miejscu plasowały się wspólnie: $\mathrm{Wy}$ dział Filozoficzny (pięciu rektorów i pięć lat rządów) i Wydział Humanistyczny (odpowiednio: czterech rektorów i sześć lat), na drugim - Wydział Lekarski (czterech rektorów i cztery lata), na trzecim znów wspólnie - Wydział Filozoficzny i Wydział Prawa (po trzech rektorów i po trzy lata), na czwartym - Wydział Matematyczno-Przyrodniczy (jedna kadencja trzyletnia); na piątym - Wydział Teologii Katolickiej (jedna kadencja roczna). Nigdy nie zostali natomiast wybrani przedstawiciele wydziałów: Teologii Ewangelickiej, Teologii Prawosławnej, Farmaceutycznego i Weterynaryjnego. Pamiętając jednak, że Wydział Humanistyczny i Wydział Matematyczno-Przyrodniczy stanowiły do 1927 r. jedność, największy wpływ wypadnie przypisać właśnie im (w sumie 10 rektorów i 14 , lat rządów).

Jak się wydaje, niezależnie od reprezentowanej przez siebie dziedziny nauki, kolejni rektorzy Uniwersytetu Warszawskiego byli nastawieni bardzo patriotycznie i propaństwowo. Pewne wyobrażenie o tym dają ich mowy, wygłaszane podczas inauguracji roku akademickiego. Niektóre z nich, jak wystąpienie prof. Jana Mazurkiewicza w 1921 r. albo prof. Józefa Ujejskiego 11 lat później, starały się przede wszystkim kształtować postawy obywatelskie, wzywając młodzież do rzetelnej nauki i „pracy pokojowej nad budową państwowości polskiej”, a także przestrzegając ją „przed przedwczesnym rzucaniem się w wir walk partyjnych, których nadmierna zawziętość, nie hamowana cnotą tolerancji braterskiej, na naszych oczach doprowadza do ruiny i chaosu, które widzimy w Rosji, albo do masowych skrytobójczych mordów, wynikających z różnicy zapatrywań politycznych, które widzimy w Niemczech, i które stoją na tym samym poziomie moralnym, co i mordy bolszewickie, tak samo należą do kategorii patologii społecznej"177.

Natomiast w drugiej połowie lat 30., a więc w warunkach zmienionych w sensie prawnym (nowa ustawa i konstytucja), rektor Antoniewicz podkreślał „twarde obowiązki kształtowania dusz, serc i charakterów wciąż nowych zastępów obywateli, wchodzących w szranki pracy Narodu 
i Państwa", nie unikając dyscyplinującego napomnienia, iż lata studiów „to niedługi okres, w którym umiejętnie należy wyzyskać ekonomię czasu [...]”. Obszernie nawiązywał do „wartości kultury Zachodu, do tych odwiecznych dla nas i niewyczerpanych źródeł twórczości narodów romańskich, opartej na tendencjach filozofii idealistycznej i na zasadach etyki chrześcijańskiej", ale nie ukrywał również, że wychowanie akademickie służyć musi przede wszystkim rozwojowi obronności państwa i budowaniu jego pozycji mocarstwowej:

Na czoło zasad wychowawczych, urabiających mocne charaktery młodych pokoleń, winno się wysunąć wzmożenie podstaw obronności Państwa. Nie chodzi zaś tu tylko o przysposobienie się do walki orężnej, ale w dużej mierze również o wyrabianie powszechnej gotowości do obrony Polski przed wciąż nadciągającymi siłami wrogimi pod względem moralnym i materialnym. Chodzi tu o zespalanie Narodu Polskiego pod sztandarem idei wielkiej i potężnej Polski, o wpajanie poczucia odpowiedzialności Polaków za losy Państwa Polskiego, o zrozumienie konieczności ekspansji polskiej w miarę przerastania naszych wewnętrznych sił i wartości. Należy konsekwentnie wpajać w krew i w serca nasze, że musimy podporządkowywać dobru Narodu i Państwa w razie potrzeby nasze dobro osobiste, oraz że przez wzmocnienie i uszlachetnienie życia rodzinnego i poszczególnych grup społecznych wzmagamy odporność na czynniki niwelujące siły narodowe. Musi nastąpić konsolidacja młodzieży patriotycznej na wspólnym froncie narodowym przeciwko złu, skądkolwiek ono nam grozi, ale przy pełni zrozumienia i szacunku dla przekonań indywidualnych, nie stojących w sprzeczności z pojęciem dobra Narodu i Państwa. [...] Wytężmy przeto wspólne starania, aby skonsolidować opinię zdecydowanej większości młodzieży akademickiej $[\ldots]^{178}$.

Nietrudno zauważyć, że w przytoczonych powyżej mowach rektorskich odbijała się niczym w zwierciadle ewolucja wzorców patriotyzmu, począwszy od etosu obywatelskiego, kształtowanego w dużej mierze przez wiarę w demokrację parlamentarną, aż ku modelowi charakterystycznemu dla okresu poprzedzającego wybuch II wojny światowej, gdy na pierwszy plan wysuwały się już hasła wzmocnienia państwa, oczekującego od obywateli przede wszystkim wypełnienia ich obowiązków. Uniwersytet pełnił przy tym nie tyle rolę biernego przekaźnika dyrektyw formułowanych przez władze, ale także stanowił jeden z podmiotów współkształtujących szeroko pojmowane postawy społeczne pokoleń wchodzących w dorosłość. Jego kolejne ekipy rektorskie, jak pozwalają sądzić liczne przykłady zgodnej współpracy uczelni i instytucji państwowych, o których była już kilkakrotnie mowa zwłaszcza 


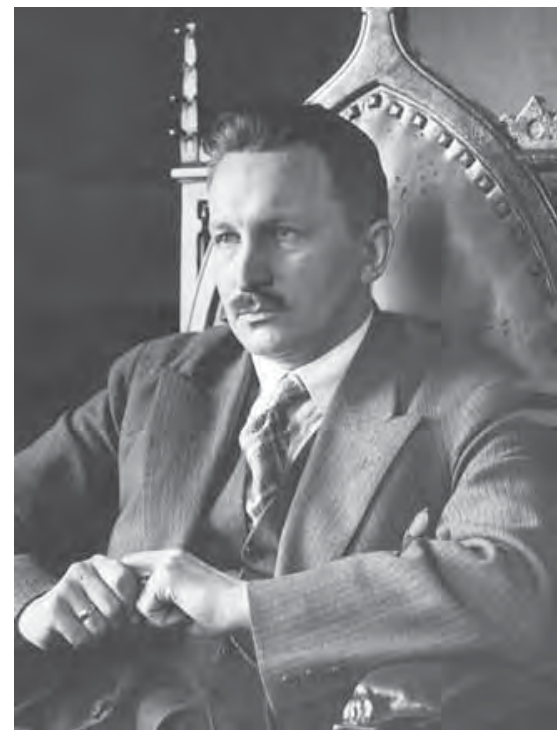

15. Archeolog prof. Włodzimierz Antoniewicz, rektor UW w latach 1936-1939 w kontekście lat zo., dość wyraźnie identyfikowały się z polityką obozu sanacyjnego.

Wyrazem tego była również zmiana nazwy uczelni, do jakiej doszło w 1935 r., po śmierci marszałka Piłsudskiego. Choć wskutek uchwalenia ustawy z 1933 r., a wcześniej w związku ze „sprawą brzeską" w warszawskich kręgach uniwersyteckich panował rozdźwięk co do sposobów prowadzenia polityki przez ludzi marszałka, to osobę przywódcy Rzeczypospolitej, a zarazem doktora honoris causa UW, jego władze otaczały demonstracyjnym szacunkiem. Przejawem tego stało się uroczyste odsłonięcie $28 \mathrm{X}$ 1934, r. jego portretu namalowanego przez Tadeusza Pruszkowskiego, który zawieszono w auli uczelni, upamiętniając ten fakt nawet drukiem broszury okolicznościowej ${ }^{179}$. Dla przedstawienia dalszych wydarzeń warto przytoczyć fragment z zakończenia sprawozdania złożonego przez ówczesnego rektora prof. Pieńkowskiego podczas inauguracji roku akademickiego 1935/1936:

Gdy po śmierci Marszałka Józefa Piłsudskiego Naród cały w głębokiej żałobie skupił swe myśli i uczucia na potężnej postaci duchowej Wielkiego Polaka, w gronie profesorskim naszej uczelni powstała myśl związania Uniwersytetu z Jego Imieniem.

Na podstawie opinii wszystkich wydziałów Senat Akademicki na specjalnym posiedzeniu w dniu 16 maja 1935 r. powziął jednomyślną uchwałę, którą [...] in corpore przedstawił $\mathrm{p}$ [anu] Ministrowi Wyznań Religijnych i Oświecenia Publicznego, a to w formie następującej:

„Na porozbiorowych zwaliskach Rzeczypospolitej powstał Uniwersytet w Warszawie. [...]

Świadom jest tego, że swój byt wolny wywodzi z dzieła Wskrzesiciela Polski - Józefa Piłsudskiego.

I jego ma za swego Założyciela.

Tedy blaskiem Jego Imienia pragnie zdobić imię swoje, aby odtąd na zawsze tego Uniwersytetu nauczyciele oraz uczniowie szli wzorem Józefa Piłsudskiego w oddaniu Ojczyźnie bezgranicznym, w umiłowaniu nauki głębokim, w osiąganiu celu niezłomnym.

Dając wyraz tej woli Uniwersytetu Senat Akademicki, uchwałą powziętą jednomyślnie w dniu wielkiej żałoby narodowej po zgonie Józefa Piłsudskiego, postanowił nadać naszemu Uniwersytetowi nazwę 


\section{UNIWERSYTETU JÓZEFA PIŁSUDSKIEGO}

i prosi Pana Ministra Wyznań Religijnych i Oświecenia Publicznego o wyjednanie dla tej uchwały sankcji ustawodawczej"180.

W następstwie, obecny na uroczystości prezydent RP Ignacy Mościcki, powołując się na własny dekret z 26 VIII 1935 r., wygłosił formułę nadania nowej nazwy. Od tej pory oficjalnie uczelnia nosiła miano „Uniwersytet Józefa Piłsudskiego w Warszawie”181. Zwieńczenie procesu intronizacji patrona stanowiło odsłonięcie 7 XI 1937 r. jego marmurowego popiersia dłuta Zofii Trzcińskiej-Kamińskiej, które ustawiono w auli Auditorium Maximum ${ }^{182}$.

Trend dobrowolnego zbliżania się Uniwersytetu Warszawskiego do obozu władzy nasilił się za kadencji rektora Antoniewicza, przypadającej na lata 1936-1939. Przejawiał się on również włączeniem się uczelni w zainicjowany przez generalnego inspektora sił zbrojnych marszałka Edwarda Śmigłego-Rydza proces konsolidacji społecznej, czego przykładem był adres złożony 3 III 1937 r. przez Antoniewicza i rektorów dwóch pozostałych szkół akademickich stolicy na ręce szefa Obozu Zjednoczenia Narodowego płk. dypl. Adama Koca ${ }^{183}$. Innym tego przejawem stało się nadawanie doktoratów honoris causa dygnitarzom państwowym, po raz pierwszy od 1931 r., gdy zaszczyt ten przypadł

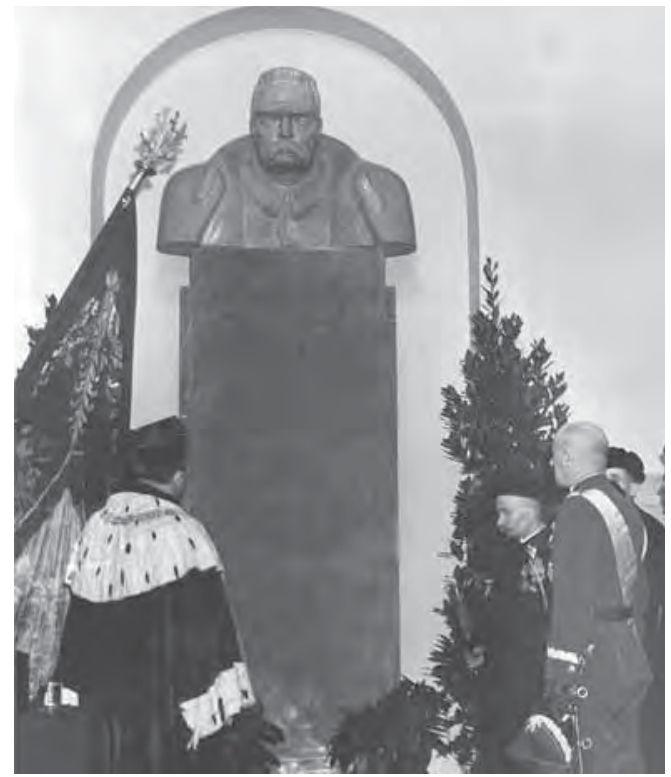

16. Rektor Antoniewicz i marszałek Śmigły-Rydz dokonują odsłonięcia popiersia marszałka Józefa Piłsudskiego w Pałacu Kazimierzowskim, listopad $1937 \mathrm{r}$.
Ignacemu J. Paderewskiemu - nie tylko wirtuozowi fortepianu, ale i politykowi. W maju $193^{6}$ r. Wydział Matematyczno-Przyrodniczy nadał doktorat honorowy z chemii prezydentowi Mościckiemu ${ }^{184}$, a następnie - już za rektoratu prof. Antoniewicza - w listopadzie 1938 r. dwóm najbardziej po szefie państwa wpływowym osobistościom, tj. marszałkowi Śmigłemu-Rydzowi (Wydział Lekarski - medycyna) oraz ministrowi spraw zagranicznych Józefowi Beckowi (Wydział Humanistyczny - filozofia). Szczególnie drugiej uroczystości, mającej miejsce niedługo po inkorporacji Śląska Zaolziańskiego, nadano bujną oprawę. W wystąpieniu do młodzieży rektor, wpisując się w ówczesną retorykę, posunął się aż do trawestacji zakończenia znanego rozkazu głównodowodzącego sił 


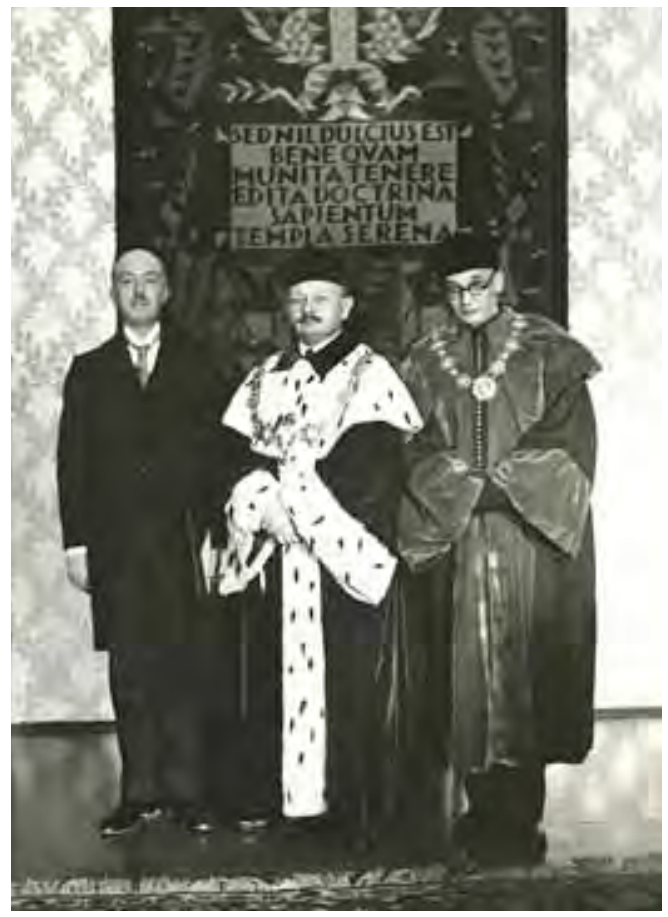

17. Uroczystość nadania doktoratu honoris causa ks. prof. Louisowi de Brogliemu. Pośrodku rektor Stefan Pieńkowski, 1935 r. zbrojnych z 2 X 1938 r., skierowanego do żołnierzy Wojska Polskiego wkraczających na Zaolzie: „W tym pochodzie Wy, Młodzi, musicie być w pierwszej czwórce i do Was też odnosi się rozkaz naszego Wodza Naczelnego Maszerować!"185.

W tym miejscu warto przyjrzeć się kryteriom nadawania przez Uniwersytet Warszawski doktoratów honorowych. Jeśli chodzi o Polaków, grono wyróżnionych ograniczało się nie tylko do polityków. Otrzymywali je - rzecz jasna, obok naukowców - także hierarchowie Kościoła katolickiego (np. prymas Edmund Dalbor, arcybiskupi: lwowski Józef Bilczewski i warszawski Aleksander Kakowski) oraz wybitni twórcy (Ignacy Paderewski, Jan Kasprowicz, Leopold Staff). W przypadku cudzoziemców (ok. 1/3 nadań) również występowali wojskowi, politycy i duchowni (były głównodowodzący wojsk Ententy marszałek Ferdinand Foch, prezydent Stanów Zjednoczonych Ameryki Thomas Woodrow Wilson, naczelnik Estonii Otto Strandman, car Bułgarii Borys III Koburg, nuncjusz papieski Achille Ratti - przyszły papiez Pius XI), a także działacze społeczni (szef zasłużonej także dla odbudowy Polski American Relief Association Herbert Hoover - przyszły prezydent USA). Jak wskazuje tabela 6, pośród wyróżnionych przeważali Francuzi, choć licznie reprezentowani byli też przedstawiciele państw Europy Środkowej. Najczęściej nadawały doktoraty honorowe Wydziały: Filozoficzny (potem Humanistyczny i Matematyczno-Przyrodniczy) oraz Prawa i Nauk Politycznych (potem Prawa) ${ }^{186}$.

Manifestowanie przez uczelnię lojalności wobec marszałka Śmigłego-Rydza i ministra Becka wiązało się nie tylko z obchodzoną jesienią $193^{8}$ r. 20. rocznicą odzyskania niepodległości, ale też z umacnianiem się pozycji obu dostojników na scenie politycznej, z których pierwszy miał wkrótce zostać następcą urzędującego prezydenta. Uhonorowanie go było więc z punktu widzenia interesów UJP rodzajem inwestycji $\mathrm{w}$ dobre relacje $\mathrm{z}$ politykiem kreowanym przez obóz sanacyjny 
Tabela 6. Doktoraty honoris causa nadane przez Uniwersytet Warszawski/Uniwersytet Józefa Piłsudskiego w Warszawie w latach 1915-1939

\begin{tabular}{|c|c|}
\hline Rok & Osoby \\
\hline 1915 & - \\
\hline 1916 & - \\
\hline 1917 & - \\
\hline 1918 & - \\
\hline 1919 & - \\
\hline 1920 & - \\
\hline 1921 & $\begin{array}{l}\text { Oswald Balzer, Jan Baudouin de Courtenay, abp Józef Bilczewski, Edmund Dalbor, } \\
\text { Samuel Dickstein, Benedykt Dybowski, marsz. Ferdinand Foch (Francja), Emil } \\
\text { Godlewski, Herbert Hoover (Stany Zjednoczone Ameryki), abp Aleksander Kakowski, } \\
\text { Jan Kasprowicz, Adam Kryński, marsz. Józef Piłsudski, abp Achille Ratti (Stolica } \\
\text { Apostolska), Władysław Stankiewicz, bp Władysław Szcześniak, Thomas Woodrow } \\
\text { Wilson (Stany Zjednoczone Ameryki) }\end{array}$ \\
\hline 1922 & - \\
\hline 1923 & Stanisław Michalski \\
\hline 1924 & Tadeusz Browicz, Jan Łukasiewicz \\
\hline 1925 & - \\
\hline 1926 & - \\
\hline 1927 & - \\
\hline 1928 & Jan Nepomucen Łoś, Jan Michał Rozwadowski \\
\hline 1929 & $\begin{array}{l}\text { Tadeusz Banachiewicz, Henri Berthélemy (Francja), Pietro Bonfante (Włochy), } \\
\text { Émile Bourgeois (Francja), Aleksander Brückner, Henri Capitant (Francja), Raffaelle } \\
\text { Garofalo (Włochy), François Gény (Francja), lord Hanworth of Hanworth (Wielka } \\
\text { Brytania), Scott Jacob Brown (Wielka Brytania), Kazimierz Twardowski }\end{array}$ \\
\hline 1930 & $\begin{array}{l}\text { Émile Borel (Francja), pastor Juliusz Bursche, Otto Strandman (Estonia), Tadeusz } \\
\text { Zieliński }\end{array}$ \\
\hline 1931 & $\begin{array}{l}\text { Bogdan Hutten-Czapski, Antoni Julian Nowowiejski, Ignacy Paderewski, Aleksander } \\
\text { Schoeneich, }\end{array}$ \\
\hline 1932 & - \\
\hline 1933 & Sébastien Charléty (Francja), Bronisław Dembiński \\
\hline 1934 & $\begin{array}{l}\text { Jan Kráčala (Czechosłowacja), Bolesław Limanowski, Dimitrie Pompeiu (Rumunia), } \\
\text { Gheorghe Țițeica (Rumunia) }\end{array}$ \\
\hline 1935 & $\begin{array}{l}\text { Louis de Broglie (Francja), Bálint Hóman (Węgry), Paul Montel (Francja), Eberhard } \\
\text { Vischer (Szwajcaria) }\end{array}$ \\
\hline 1936 & Arnaud Denjoy (Francja), Ignacy Mościcki \\
\hline 1937 & Constantin Angelescu (Rumunia) \\
\hline 1938 & Józef Beck, marsz. Edward Śmigły-Rydz \\
\hline 1939 & Borys III Koburg (Bułgaria), Leopold Staff \\
\hline
\end{tabular}

Źródło: Zestawienie na podstawie: Doktoraty honorowe - http://www.edu.pl/uniwersytet/historia (odczyt z 10 III 2015 r.) skorygowane przez autora. 


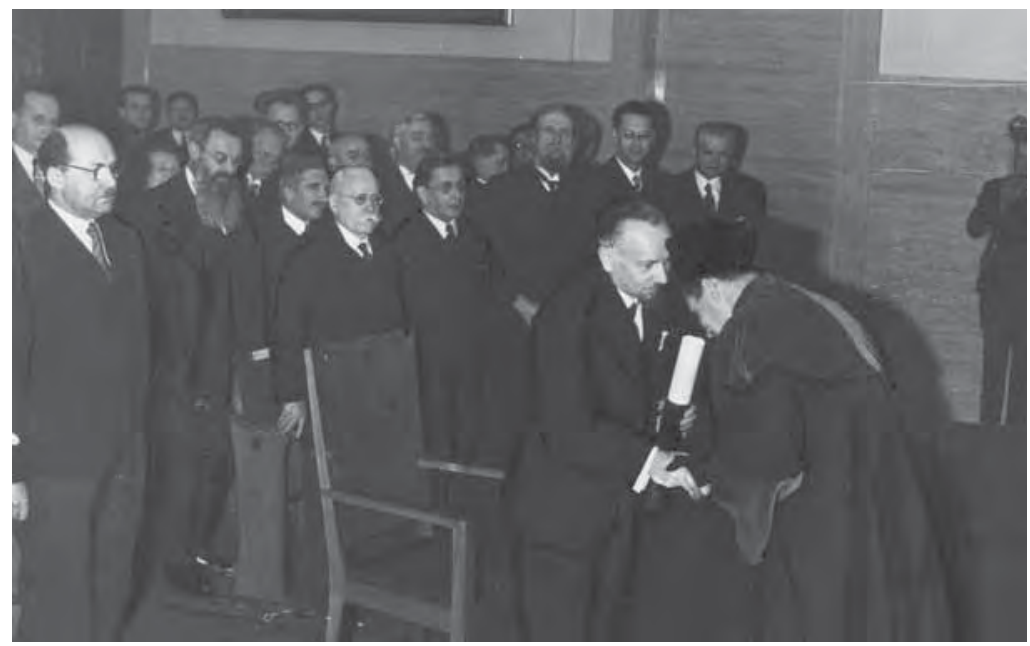

18. Uroczystość nadania doktoratu honoris causa Leopoldowi Staffowi, 1939 r. Dyplom wręcza prof. Julian Krzyżanowski, pierwszy z lewej prof. Wacław Borowy

na przywódcę państwa. Korzyści tych nie udało się już uczelni zdyskontować. Niemalże symboliczną wymowę pod tym względem ma fakt, iż kadencja ówczesnych władz rektorskich z prof. Antoniewiczem na czele upłynęła 31 VIII 1939 r. W dniu następnym, który okazał się początkiem II wojny światowej, pieczę nad Uniwersytetem przejęła ekipa farmakologa prof. Jerzego Modrakowskiego ${ }^{187}$. Jego krótka, parotygodniowa kadencja okazała się być ostatnią w okresie II Rzeczypospolitej.

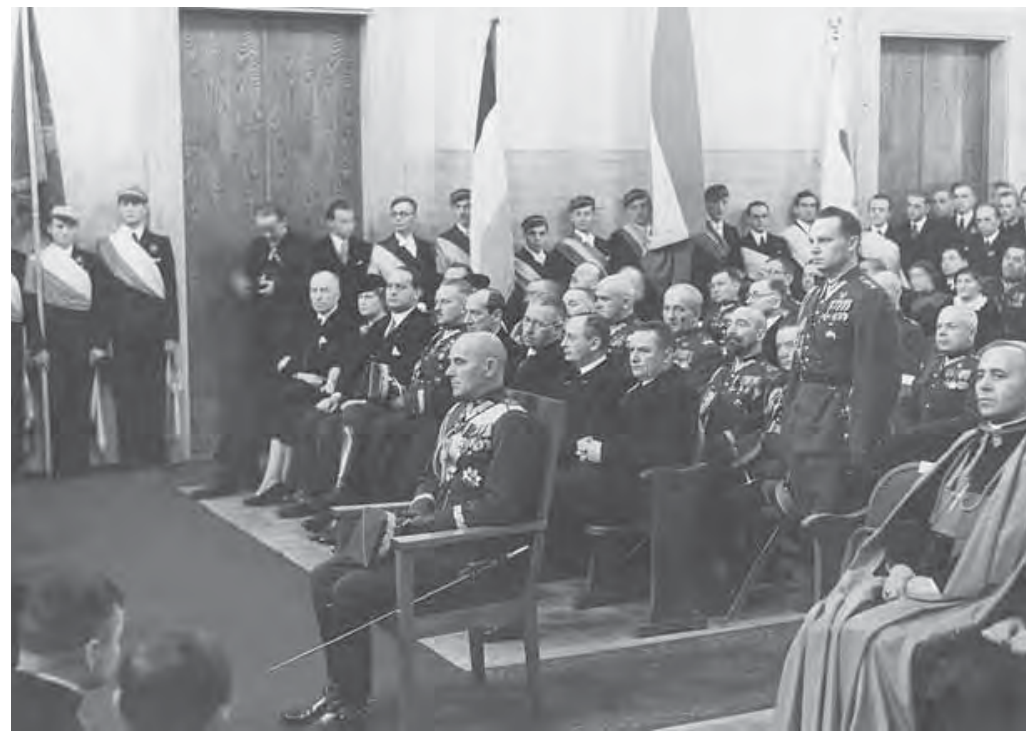

19. Inauguracja roku akademickiego 1937/1938.

$\mathrm{Na}$ honorowym miejscu pośrodku marszałek Śmigły-

-Rydz, pierwszy od prawej biskup polowy Józef Gawlina, w pierwszym rzędzie, trzeci od prawej, minister wyznań religijnych i oświecenia publicznego prof. Wojciech Świętosławski, na lewo od niego minister spraw zagranicznych Józef Beck. 


\section{Rozwój infrastruktury}

Wiosną 1927 r., a więc w dziewiątym roku niepodległości i dwunastym po odnowieniu Uniwersytetu Warszawskiego, na zarządzenie Ministerstwa Wyznań Religijnych i Oświecenia Publicznego, w wykonaniu decyzji Ministerstwa Skarbu, przeprowadzono w Polsce spis majątku należącego do uczelni państwowych. $27 \mathrm{~V}$ tegoż roku, pismem L.O.Prez.2645/27 resort wezwał władze Uniwersytetu Warszawskiego do przedstawienia stosownego wykazu ${ }^{188}$. Nietrudno odgadnąć, że wydane 14 VI, a więc u progu wakacji, polecenie rektora ks. prof. Antoniego Szlagowskiego nie wzbudziło entuzjazmu kierowników jednostek uczelni ${ }^{189}$. W terminie zgodnym z przepisami służbowymi udało się rektoratowi przygotować dwa zestawienia. Pierwszym był nader ogólny wykaz ruchomości pozostających w dyspozycji uczelni, ułożony w porządku alfabetycznym. Wobec unikalnego charakteru tego dokumentu warto przytoczyć jego treść w całości, także jako świadectwo przyrodzonej ówczesnemu szkolnictwu wyższemu niepodatności na żądania biurokracji:

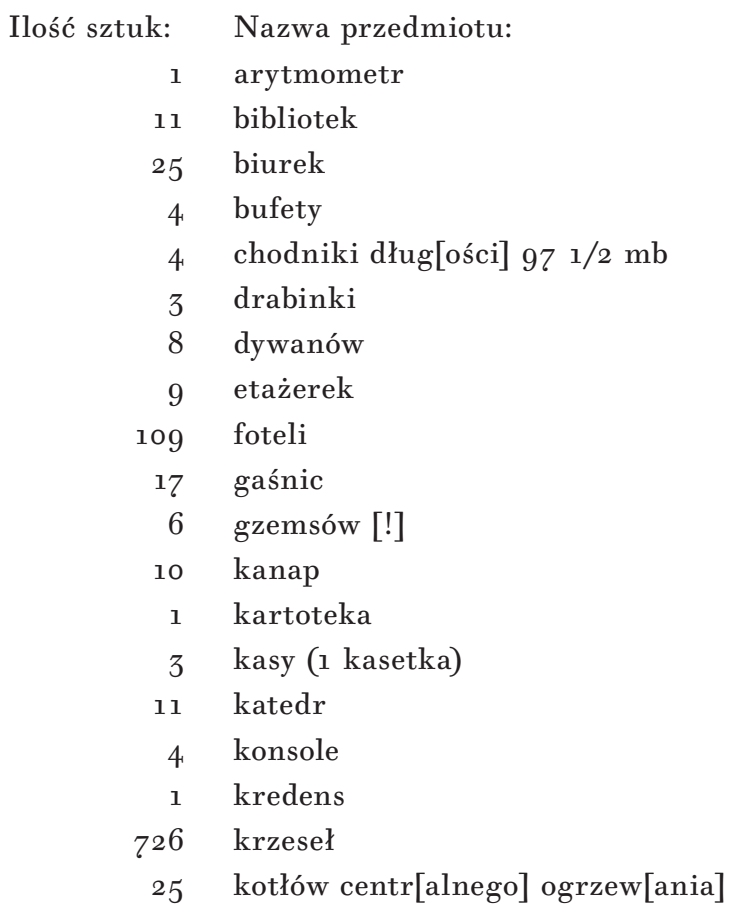


[Ilość sztuk: Nazwa przedmiotu:]

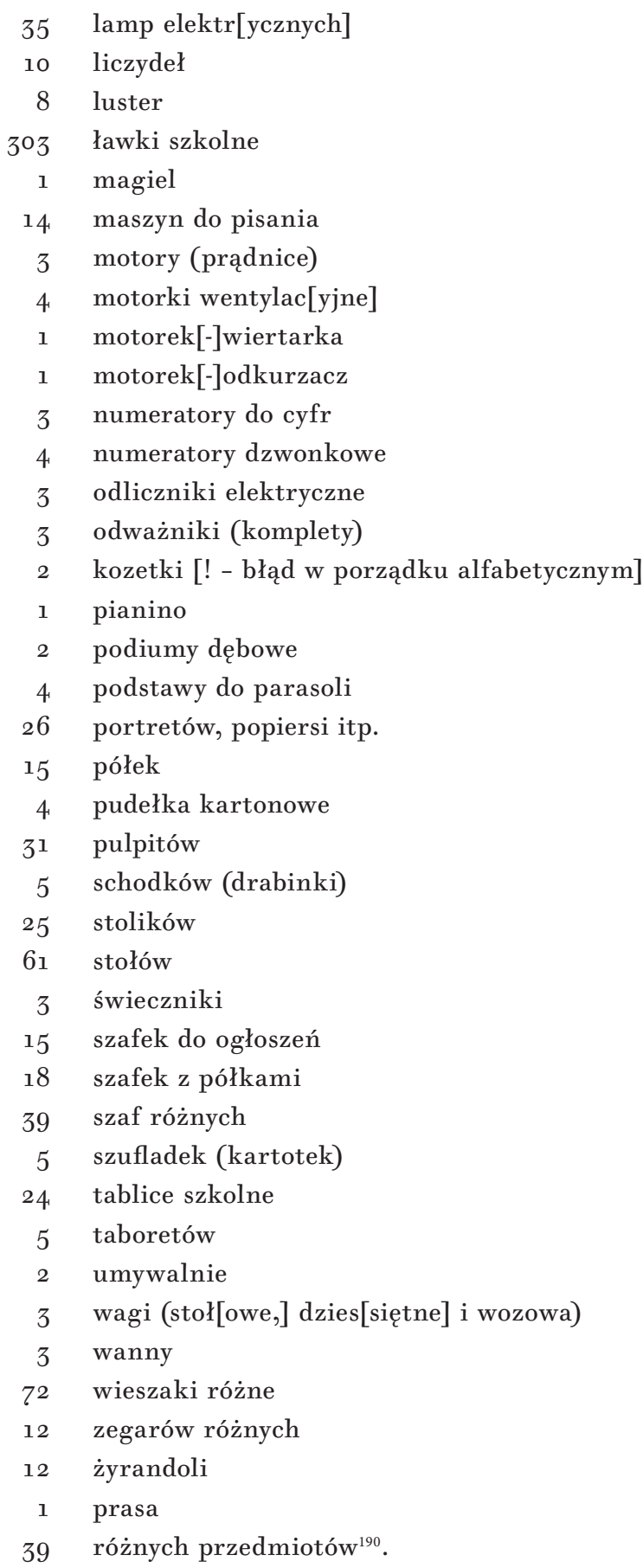




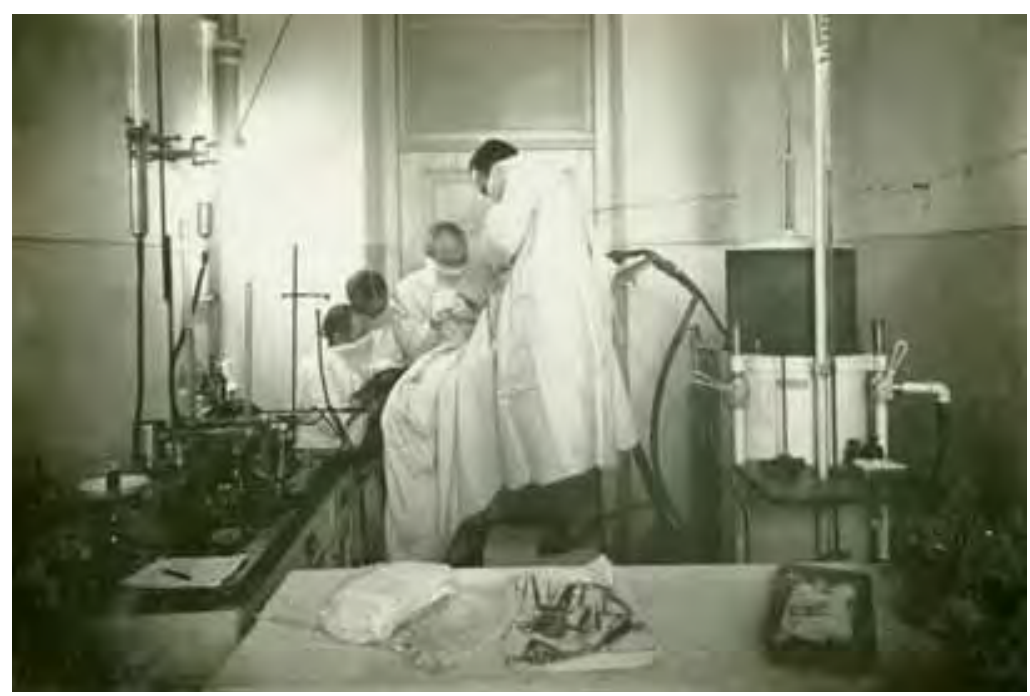

20. Badania naukowe w Oddziale Przemiany Materii Wydziału Lekarskiego, ok. $1933 \mathrm{r}$.

Nawet dla uczelni na dorobku nie było tego wiele - tak w sensie rzeczywistym, jak i pragmatyczno-biurowym. Wrażenie to rozwiewał drugi dokument, gdzie obok 10954,2 zł 50 gr, na jaką to kwotę oszacowano wymienione „urządzenie wewnętrzne”, wykazano dodatkowo nieruchomości posiadane przez Uniwersytet (33 budynki w stolicy ${ }^{191}$, z czego jeden w budowie ${ }^{192}$ ), ale bez określenia ich wartości ${ }^{193}$. Ponieważ rubryki „Pomoce naukowe” i „Zbiory biblioteki” pozostały w zestawieniu puste, władze rektorskie nie poprzestały na tym. Było to, jak zobaczymy, zgodne z jednym ze znanych dziś praw Cyrille’a Northcote'a Parkinsona.

Inwentaryzacja nabrała tempa dopiero jesienią, o czym przypominały ponaglenia rektoratu wysyłane już od października. Wskutek niekiedy mozolnych, a niekiedy powierzchownych prac inwentaryzacyjno-szacunkowych, pod koniec roku zaczęły stopniowo wyłaniać się rzeczywiste zarysy stanu majątkowego Uniwersytetu. Znamienny był tu raport dyrektora Biblioteki Uniwersyteckiej w Warszawie dr. Zygmunta Batowskiego, który stwierdzał, że choć „dokładne oszacowanie mienia bibliotecznego nie jest możliwe bez długich przygotowawczych studiów - zarówno ze względu na rozmaitość przedmiotów [...] i trudność określenia ceny niektórych z nich”, to dla „obecnych więc celów” majątek BUW składał się w przybliżeniu: ze zbioru książek (ok. 731 tys. tomów o wartości ok. 4,o mln zł), Gabinetu Rycin (ok. 100 tys. pozycji w cenie ok. 3,2 mln zł), nowych zbiorów graficznych (1269 rycin, rysunków itd. oraz 207 fotografii szacowanych na ok. 5 tys. zł), 
rękopisów rewindykowanych z Petersburga (ówcześnie już Leningradu - 9958 pozycji o wartości ok. 4,5 mln zł), rękopisów rewindykowanych z Rostowa nad Donem (1180 pozycji plus 1682 rękopisy ulotne i 6 nabytków nowych w cenie ok. 120 tys. zł), dalej zaś „sprzęty” o wartości ok. 110 tys. zł i obraz Henryka Siemiradzkiego Apoteoza Kopernika wyceniony na 20 tys. zł. Razem czyniło to 11870 ooo zł, nie licząc wartości gmachu biblioteki ${ }^{194}$.

Trudniej szły inwentaryzacje mienia wydziałów, instytutów, zakładów i seminariów. Ponieważ przedstawiane przez nie sprawozdania nie nadawały się, wskutek różnego stopnia szczegółowości, do prostego zsumowania, władze UW najwyraźniej poleciły w pewnym momencie przesyłać wykazy bezpośrednio do ministerstwa. Przeważały zestawienia jednostronicowe, obejmujące umeblowanie, aparaturę i pomoce naukowe oraz księgozbiory i kolekcje - jak np.: „Dział inwentarza I Zbiory: ca 25 ooo okazów ogólnej wartości ca 100000 zł. Dział inwentarza II - Biblioteka: 2633 n[umery] inwentarza ogólnej wartości 21 o64, zł. Dział inwentarza III - Pomoce naukowe: 1258 n[umerów] inwentarza ogólnej wartości 8000 zł. Dział inwentarza IV - Przyrządy: 206 n[umerów] inwentarza ogólnej wartości 10497 zł. Dział inwentarza V - Meble: 346 n[umerów] inwentarza ogólnej wartości 22025 zł"195. Na żądania uszczegółowienia odpowiadano zazwyczaj odmownie. Dyrektor Obserwatorium Astronomicznego UW, prof. Michał Kamiński pisał do rektora ks. prof. Szlagowskiego:

Do powyższego [wygotowanego 5 VII t.r.] mego pisma, niestety, nic więcej dodać nie mogę, gdyż około 7o-80\% majątku ruchomego Obserwatorium pochodzi z czasów przedwojennych; odnośne inwentarze, według wiadomości jakie posiadam zostały wywiezione do Rosji - jest więc rzeczą niemożliwą podać chociażby w przybliżeniu wartość narzędzi nabytych przed kilkudziesięciu laty. Co się zaś tyczy książek, większa ich część składa się z darów różnych obserwatoriów, a więc eo ipso ceny nie posiada. Pierwsze inwentarze majątku Obserwatorium zostały sporządzone przez P[ana] Dr. J. Krassowskiego w r[oku] 1916 i cen także nie zawierają [...]. Obecnie, [w związku] z wprowadzeniem nowych inwentarzy w r[oku] 1925, ceny wszystkich nabywanych przedmiotów są wpisywane do inwentarzy. Oszacowanie majątku ruchomego Obserwatorium mogłoby być dokonane jedynie przez ekspertów, z udziałem całego personelu [...] - co [...] zajęłoby wiele miesięcy czasu, przy zatrzymaniu wszystkich prac zakładowych ${ }^{196}$.

Jeszcze dobitniej brzmiała odpowiedź prof. Jana Baudoina de Courtenay'a (nota bene kandydata na prezydenta RP w wyborach z 1922 r.) do rektoratu UW z 1 VII 1927 r.: 


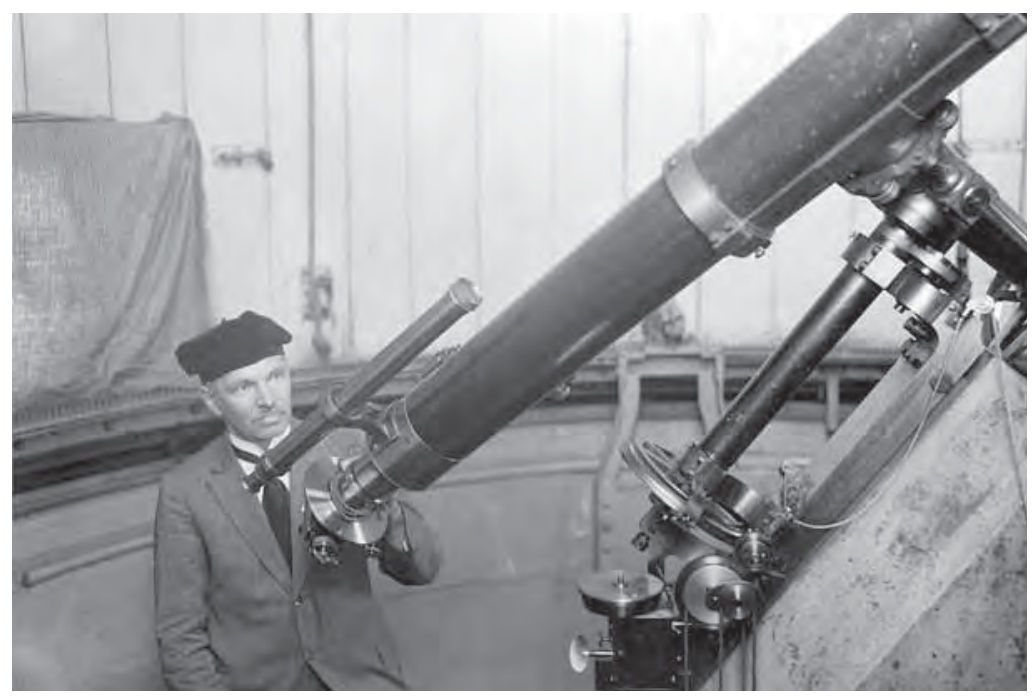

21. Dyrektor

Obserwatorium Astronomicznego UW prof. Michał Kamieński przy teleskopie, czerwiec $1925 \mathrm{r}$.

Seminarium Lingwistyczne nie posiada żadnego majątku nieruchomego. Posiada tylko meble, przyrządy piśmienne i bibliotekę. Wartość mebli można ocenić w przybliżeniu na 5000 zł, wartość zaś biblioteki (przeszło $55^{\circ}$ n[ume]rów w inwentarzu) na 10 ooo-15 ooo zł. O dokładnej ocenie mowy być nie może, ponieważ objąwszy kierownictwo Seminarium tylko przy niektórych przedmiotach znalazłem ocenę, prawie wszystko zaś było bez oceny. Dopiero ja zacząłem do każdego numeru inwentarza dopisywać także cenę kupna. Trudno wymagać ode mnie, ażebym oglądał teraz każdy przedmiot i każdą książkę osobno i robił poszukiwania dla określenia ich wartości. Zajęłoby mi to kilka tygodni czasu. Do takiej katorżnej roboty nie jestem obowiązany, a nie mam żadnego pomocnika. Moim obowiązkiem jest praca naukowa oraz [! - powinno być: «a nie»] inwentaryzowanie mienia i katalogowanie biblioteki ${ }^{197}$.

Z drugiej strony nadchodziły tė̇ czasem wykazy stosunkowo pełne. Inwentarz majątku ruchomego Seminarium Historycznego z 5 VII 1927 r. sygnowany przez prof. Marcelego Handelsmana zawierał nie tylko liczbę poszczególnych przedmiotów (4 biurka, 6 stołów, 57 krzeseł, 19 szaf, 2 etażerki, 2 fotele, 3 kosze wiklinowe, 4, spluwaczki, 4 lampy, 1 podstawka do map, 6 wieszaków, 2 popielniczki, 2 wiadra, miednica z podstawką i dzbanek, 6 pudełek katalogowych, 1 korytko na obrazki, 1 tablica czarna stojąca, młotek i dłuto, 9 kałamarzy, 15 suszek, 33 mapy oraz biblioteka o wartości 10 tys. zł), ale równiė̇ miejsce ich stałego użytkowania oraz ceny ${ }^{198}$. 


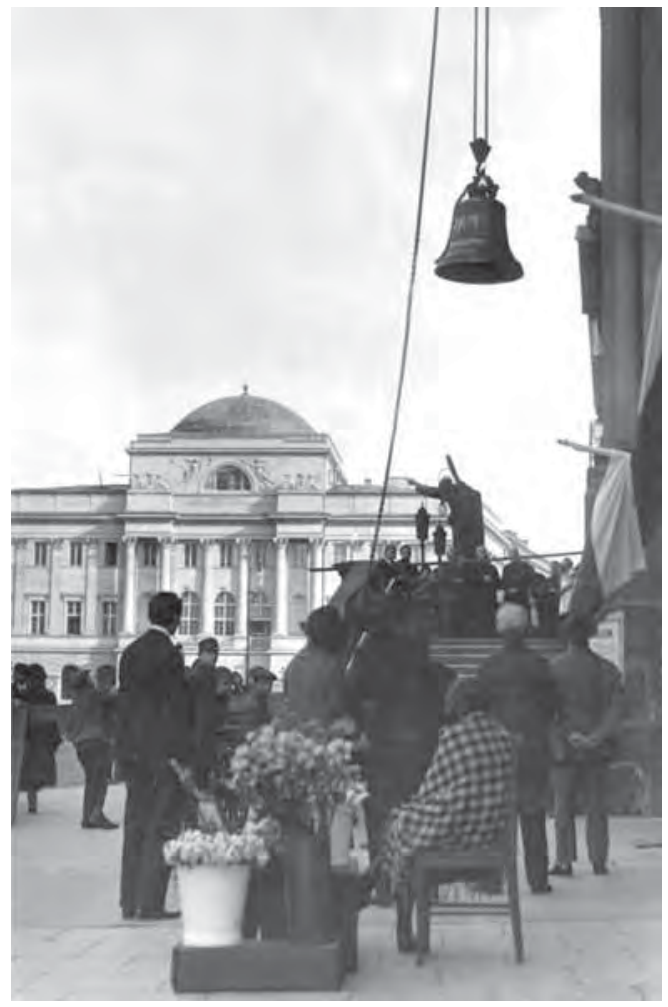

22. Zawieszenie dzwonu w kościele Św. Krzyża przy Krakowskim Przedmieściu, w tle Pałac Staszica (po rewaloryzacji przywracającej wygląd z początku XIX w.), mieszczący liczne instytucje uniwersyteckie, $1926 \mathrm{r}$.
Obok materiałów z 1927 r., dotyczących wyposażenia UW w majątek ruchomy, dysponujemy zestawieniami zebranymi przez Tadeusza Manteuffla w połowie lat $30 .{ }^{199}$ Pozwalają one stwierdzić istotny przyrost ruchomości w ciągu ośmiu lat po pierwszym spisie. Najważniejszy obiekt, serce każdej z uczelni - jej biblioteka główna (w tym przypadku dodatkowo największa w kraju), powiększyła swój zasób za kierownictwa dr. Batowskiego (do połowy 1929 r.), a następnie dyrekcji dr. Stefana Rygla, do $8135^{26}$ woluminów. Dawało to z górą 10 tys. pozycji rocznie, pochodzących z darów i wymiany oraz z tzw. egzemplarza obowiązkowego ${ }^{200}$. Jego użyteczność zwiększało wybitnie założenie najlepszego w Warszawie, aż do czasu powstania internetowych baz danych, katalogu przedmiotowego, oddanego do użytku w roku akademickim 1926/1927. W 1939 r., po Stefanie Ryglu i latach dyrekcji Wacława Borowego, BUW znajdujący się już w pieczy doc. dr. Adama Lewaka posiadał 824 , tys. druków, prawie 104, tys. rycin i $4113^{2}$ rękopisy $^{201}$. Zatem w ciągu omawianych 24, lat jej księgozbiór rozrósł się o 35\%. W ówczesnych trudnych warunkach finansowych było to osiągnięcie znaczące.

Jeśli chodzi o wyposażenie naukowo-dydaktyczne poszczególnych placówek, to za reprezentatywne uznać można sprawozdanie złożone przez Zakład Geograficzny UW w 1924, r., a opracowane pod kierunkiem prof. Stanisława Lencewicza. Zorganizowany na początku 1918 r., Zakład ten odziedziczył po rosyjskim gabinecie geografii fizycznej „nieco mebli, bibliotekę złożoną z czasopism i broszur treści geofizycznej [...], globus, teodolit oraz 3 magnetometry". Mieszczący się ówcześnie w Pałacu Staszica i dysponujący jeszcze tarasem obserwacyjnym na dachu dawnego pawilonu fizyki, nie otrzymał żadnej „fundacji inwestycyjnej" i opierał swój byt wyłącznie z dotacji na wydatki bieżące. W pierwszym roku działania, gdy „dotacja była większa, zakupiono 
szereg instrumentów, komplety czasopism niemieckich i kilkadziesiąt podręczników. Zwiększająca się wciąż dewaluacja marki [polskiej] doprowadziła do takiego stanu, że nie tylko zaprzestano nabywania instrumentów, ale nawet przerwano prenumeratę kilku czasopism [...]". Z pomocy naukowych Zakład posiadał przyrządy meteorologiczne (barograf, termograf, trzy anemometry, dwa psychometry, klatkę termometryczną, pluwiometr), topograficzne (teodolit, dwa aneroidy, dwa spadkomierze, taśmy, łaty i tyki miernicze, krokomierz, dwie busole), kartograficzne (planimetr i pantograf Coradiego, camera lucida, dwa kurwimetry, cyrkiel drążkowy, redukcyjny, komplet cyrkli i inne drobne przybory rysownicze) oraz hydrograficzne (m.in. dwa termometry). Miał zbiór map (topograficznych, geologicznych, gospodarczych, ściennych, plastycznych itd.) w liczbie $13^{2}$ pozycji inwentarzowych i 2615 arkuszy, nadto kolekcję fotografii i bibliotekę (2003 woluminy). Kierownik zdeponował przy tym swój zbiór map i odbitek ${ }^{202}$. Ten niewielki zasób, w połączeniu z pomiarami dokonywanymi na terenie kraju i wyjazdami zagranicznymi, pozwolił jednak rozwinąć dostrzegalną aktywność naukową w postaci publikacji polskich i obcojęzycznych (artykuły, monografie, podręczniki, mapy), a także wykształcić pierwszych specjalistów ${ }^{203}$.

W latach następnych postępował proces powolnego uzupełniania księgozbiorów ${ }^{204}$ oraz wyposażania zakładów w różnoraki sprzęt i pomoce, czego jednym z etapów było przejęcie zbiorów rewindykowanych z ZSRS na mocy traktatu ryskiego. Osiągnięty do 1939 r. poziom był zróżnicowany - wyższy w przypadku dyscyplin stosowanych, niższy w naukach społecznych ${ }^{205}$; w każdym razie wystarczał do kształcenia studentów. Zagadnienie wyposażenia schodziło jednak na plan dalszy wobec dramatycznej wręcz sytuacji lokalowej.

Już w 1920 r. ustępujący rektor prof. Stanisław Thugutt zauważył, iż Uniwersytet „Przystosowany do liczby 1500 studentów, ma ich przygarnąć sześć tysięcy. Toteż o każden przypadkowo zwolniony kącik zainteresowani staczają homeryczne walki [...]"206. Wystąpienia okolicznościowe rektorów UW z lat następnych niemal zawsze zawierały ten wątek. Kwestia budowlana nie zależała bowiem od stanu majątku uczelni, składającego się - oprócz wskazanych już elementów - także z paru nieruchomości w stolicy i poza nią (np. posiadłość Kujawy ${ }^{207}$, czy też słynne obserwatorium astronomiczne na Popie Iwanie w Czarnohorze, wybudowane w 1938 r. ze składek Ligi Obrony Powietrznej i Przeciwgazowej i przekazane w części UW), dalej inwentarza żywego, roślin, gotówki, wkładów na rachunkach bankowych, papierów wartościowych, dzieł sztuki, samochodu ciężarowego oraz zapisów i donacji ${ }^{208}$. Nie od 


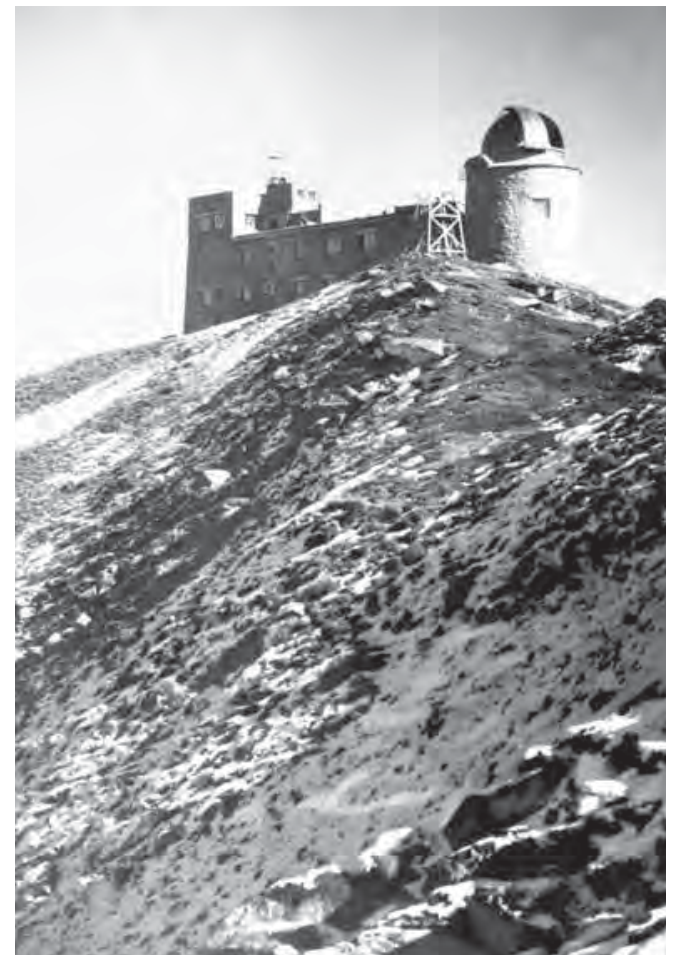

23. Obserwatorium Meteorologiczno-Astronomiczne UW na szczycie Pop Iwan w Czarnohorze, prawdopodobnie $193^{8} \mathrm{r}$.

rzeczy będzie tu przypomnieć, że najbardziej znaną fundację uniwersytecką założył niegdysiejszy kurator uczelni z ramienia Cesarstwa Niemieckiego hr. Bogdan Hutten-Czapski. Położony w Wielkopolsce północnej Smogulec był majątkiem ziemskim należącym do bezdzietnego arystokraty, z którego dochody netto zostały zapisane po połowie Uniwersytetowi i Politechnice Warszawskiej jako dodatkowe źródło „środków na popieranie nauki polskiej, a mianowicie na nagrody dla obywateli polskich i zapomogi na prace naukowe, wynalazki oraz odkrycia przez nich dokonane a także na wydawnictwa w języku polskim". Fundacja ta w końcu lat 3o. miała zacząć dawać przewidziany dochód ${ }^{209}$.

O ile więc Uniwersytet dysponował summa summarum całkiem sporym majątkiem, o tyle zasób ten tylko w małej części mógł podlegać obrotowi, choć i tak przynosił pewne zyski. Kondycja finansowa uczelni - jeśli pominąć tzw. dochody własne, uzyskiwane przede wszystkim przez Wydział Lekarski z tytułu opłat za leczenie - zależała od dotacji MWRiOP, a przede wszystkim od stworzonego w $193^{2}$ r. Funduszu Opłat Studenckich. Coroczne przychody Uniwersytetu były więc w ogólności wykładnikiem sytuacji materialnej studiujących i zasobności budżetu państwa, warunkowanych z kolei koniunkturą panującą w gospodarce, a zwłaszcza cechującymi ją ówcześnie zawirowaniami.

Przykładowo, z kopii „Ogólnego zestawienia planów finansowo-gospodarczych zakładów na rok akademicki 1939/4,0" wynika, że pośród wpływów w wysokości $1917308 \mathrm{zl}$ dochody własne (754. 380 zł) stanowiły $39,3 \%$, a dotacje (1 134, 013 zl) 59,1\%. Sam udział FOS wynosił aż $48,3 \%$ strony dochodowej. Zasadami wydatkowania wpływów rządziły odrębne przepisy, stopniowo się zmieniające. Największe grupy ekspensów stanowiły cele naukowe i osobowe (po ok. 25-30\% każdy), z rosnącym udziałem drugiej grupy. $\mathrm{Na}$ trzecim miejscu znajdowały się wydatki specjalne ${ }^{210}$. 


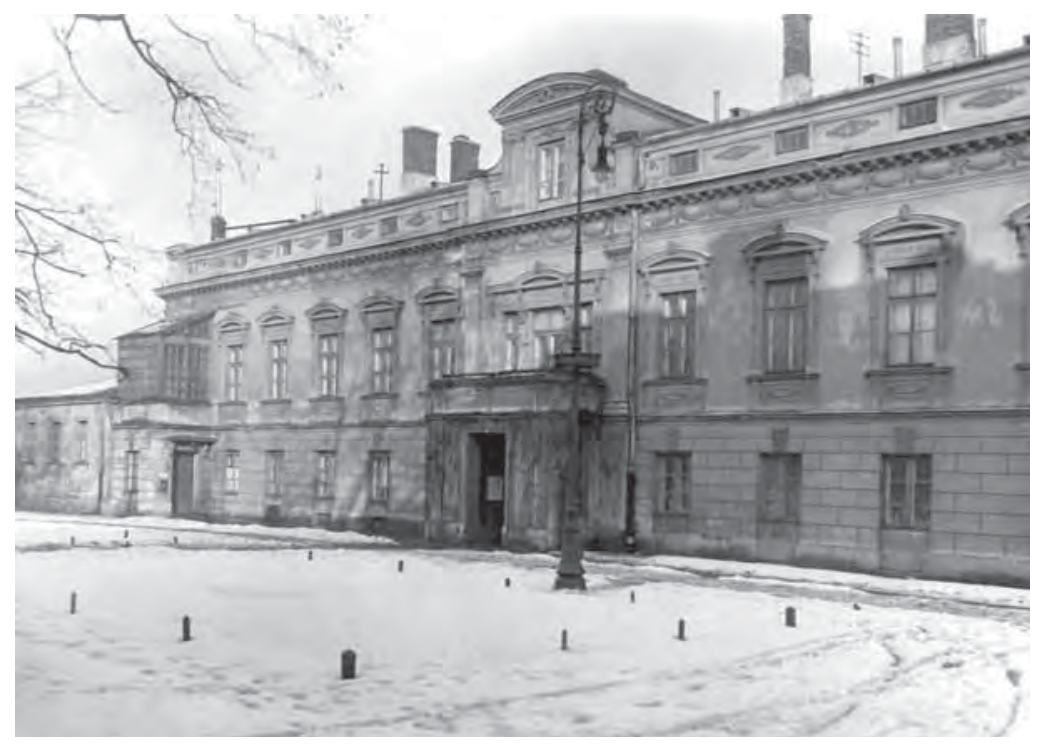

24. Gmach

Zakładów Wydziału

Matematyczno-

-Przyrodniczego,

luty $1928 \mathrm{r}$.

Dziewiętnaście lat, jakie upłynęły od stwierdzenia przez rektora Thugutta stanu krytycznego sytuacji lokalowej, miało przynieść tylko częściową poprawę. Jeszcze w listopadzie 1921 r. Senat Akademicki przyjął 10-letnią perspektywę dla doprowadzenia UW „pod względem budynków do poziomu stołecznych uniwersytetów"211. $\mathrm{Z}$ racji dopiero co zakończonej wojny z Rosją bolszewicką, która wyczerpała finanse kraju, ruch budowlany - wymagający nie tylko czasochłonnych prac projektowo-przygotowawczych, ale przede wszystkim dużych funduszy - mógł się jednak ożywić dopiero w roku następnym. Wobec niewykorzystania przez administrację rządową półtorarocza inflacji galopującej (1922 - maj 1923 r.), także okres hiperinflacyjny (maj 1923 - początek 1924, r.), paraliżujący gospodarkę kraju, nie mógł zostać spożytkowany na działania inwestycyjne. Następnie przyszedł kryzys postabilizacyjny (wiosna 1924, - połowa 1926 r., co zbiegło się z zamachem majowym), kiedy to z jednej strony gabinet Władysława Grabskiego zaplanował uruchomienie budowy nowego kampusu na Ochocie ${ }^{212}$, lecz z drugiej - w obliczu niebezpieczeństwa krachu dopiero co przeprowadzonej reformy walutowej - musiał skreślić dotacje budżetowe na ten cel. Od tej pory uczelnia, w swych skromnych zamysłach inwestycyjnych ${ }^{213}$, opierała się na kombinacji środków własnych, prywatnych (np. darowizny Ireny Warden, Fundacji Rockefellera) i społecznych (m.in. stowarzyszeń zawodowych), uzupełnianych jedynie w okresach korzystniejszej koniunktury przez państwo. Do końca lat 20. nie przyniosło to praktycznie 
żadnej poprawy sytuacji. W 1929 r. rektor prof. Gustaw Przychocki tak opisywał narastające problemy w tej dziedzinie:

\begin{abstract}
Zastraszająca ciasnota lokalów, a nawet po prostu brak najprymitywniejszych pomieszczeń, to główna bolączka wszystkich bez wyjątku Wydziałów i Zakładów, to główna przeszkoda w rozwoju stołecznego, największego w Polsce uniwersytetu. Nie pomogą tu żadne paliatywy, jak ograniczenie liczby przyjęć [...] czy dublowanie wykładów i ćwiczeń, lub nawet wynajmowanie [...] pojedynczych sal [...], gdyż oczywistą jest rzeczą, że lokale [...] obliczane pierwotnie na najwyżej 1000 studentów, nie mogą pomieścić dzisiejszej ich liczby, dochodzącej do 10 ooo. [...] Nieodzowną koniecznością jest zakreślona na wielką miarę rozbudowa Uniwersytetu, lub przynajmniej natychmiastowa budowa kilku najpotrzebniejszych zakładów, tudzież [...] gmachu dla celów administracji i reprezentacji oraz potrzeb Wydziału Humanistycznego ${ }^{214}$.
\end{abstract}

Kolejny wstrząs, jakim był paroksyzm wielkiego kryzysu gospodarczego, szczególnie dotkliwy w latach 1931-1933, musiał odbić się ujemnie na realizacji niezbędnych inwestycji ${ }^{215}$, a nawet wpłynął na zaniechanie remontów obiektów pełniących też rolę reprezentacyjną. Sytuację tę charakteryzował w gorzkich słowach w swym sprawozdaniu rektor Ujejski:

Obdrapany front historycznego pałacu Kazimierzowskiego [...] jest wiernym symbolem żałosnego warszawskiej almae matris ubóstwa. Przyjmujemy w nim każdego roku niemałą liczbę cudzoziemców, przywykłych do innego wyglądu świątyni nauk. Wewnątrz - dzięki Rektorowi [Mieczysławowi] Michałowiczowi - bez zażenowania już wprowadzamy ich do auli. Ale przykro nam, gdy wchodzą do sali posiedzeń senatu, której nazwa brzmi bardzo okazale, ale której krzesła jakże nieznośnie rażą swoją tanią brzydotą ${ }^{216}$.

Dopiero więc w nieco lepszym dla gospodarki i skarbu roku budżetowym 1934/1935 gabinet Janusza Jędrzejewicza (byłego szefa MWRiOP) znalazł kredyt na budowę nowego gmachu audytoryjnego. Także w ostatnich latach przed wybuchem II wojny światowej udział resortu w finansowaniu prac remontowo-budowlanych Uniwersytetu byl zdecydowanie żywszy niż w latach 20., na co pozwoliła m.in. pożyczka inwestycyjna, rozpisana przez rząd w maju $1935 \mathrm{rr}^{217}$

Nakłady na budynki obejmowały przede wszystkim remonty częściowe oraz przeróbki i rozbudowy obiektów już istniejących, wyraźnie rzadziej natomiast wznoszenie nowych gmachów. W pierwszej grupie działań, na których szersze przytoczenie nie ma tu miejsca, trudne położenie 


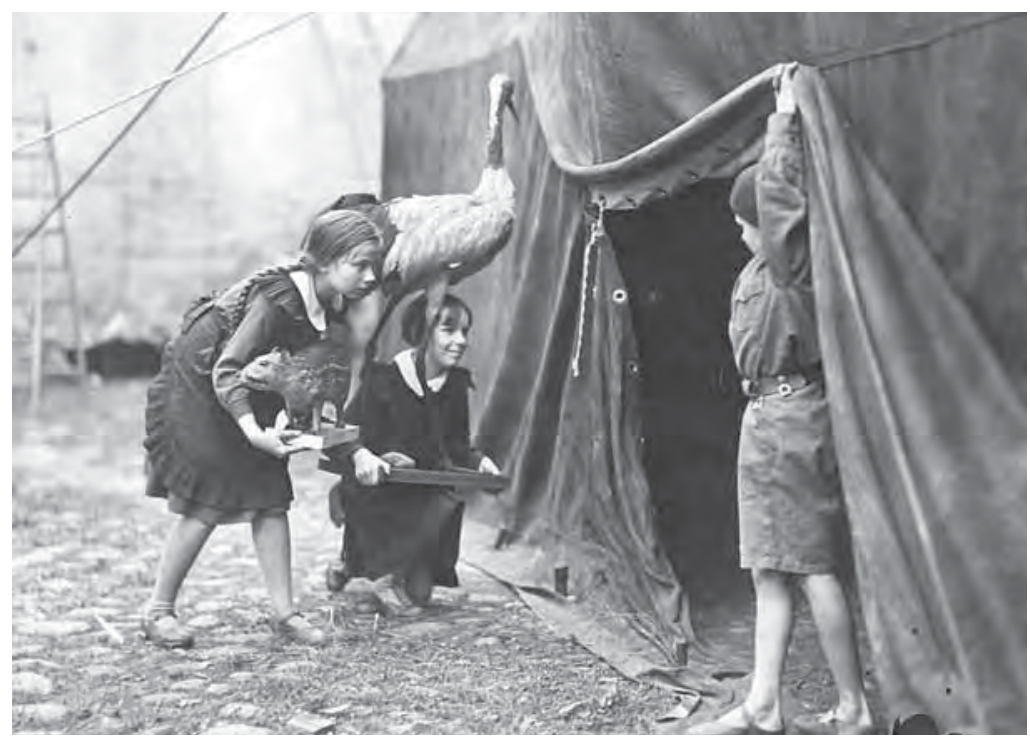

25. Zabezpieczanie ocalałych zbiorów zoologicznych po pożarze Budynku Pomuzealnego w październiku $1935 \mathrm{r}$.

wystarczająco charakteryzuje fakt, że remont generalny UW mógł się rozpocząć dopiero w roku budżetowym 1938/1939 ${ }^{218}$, a lista obiektów wymagających jak najszybszego rozpoczęcia prac liczyła kilkanaście pozycji ${ }^{219}$. W grupie drugiej natomiast na wymienienie zasługują: dokończenie budowy Instytutu Fizyki przy ul. Hożej 69 w 1921 r. (rozbudowanego następnie w roku 1932) ${ }^{220}$, wzniesienie nowego budynku Wydziału Prawa (Auditorium Maximum na terenie głównym, wedle projektu Aleksandra Bojemskiego, ukończone w 1935 r.) ${ }^{221}$, dalej zakup i przebudowa gmachu Wydziału Farmaceutycznego (ul. Przemysłowa 25, ukończona w $193^{2}$ r.) ${ }^{222}$, budowa Instytutu Chemii (ul. Wawelska 17, także wedle projektu A. Bojemskiego, ukończona w 1939 r.) ${ }^{223}$, trwająca wiele lat rozbudowa kompleksu budynków Wydziału Lekarskiego (Klinika Dermatologiczna przy ul. Koszykowej 82a, Pawilon Medycyny Sądowej przy ul. Oczki 1, Klinika Pediatrii przy ul. Marszałkowskiej 24 i Ambulatorium przy ul. Oczki 5/7) 224 , a w mniejszym stopniu także Wydziału Weterynaryjnego (ul. Grochowska $27^{2}$ - m.in. budynek mieszkalno-gospodarczy) 225 . Dochodziła do tego budowa w latach 20. domów z mieszkaniami dla profesorów (ul. Brzozowa 10 i 12, Nowy Zjazd 5, Sewerynów 10) 226 oraz, od połowy tej dekady, domów studenckich (dla mężczyzn - kompleks tzw. Kolonii Akademickiej przy pl. Narutowicza i ulicach przyległych oraz Auxilium Academicum przy Tamce 4, dla kobiet przy ul. Górnośląskiej 14 oraz ul. Dobrej 59 i Domu Akademickiego Studentów Żydów przy ul. Sierakowskiego 7), czy wreszcie 


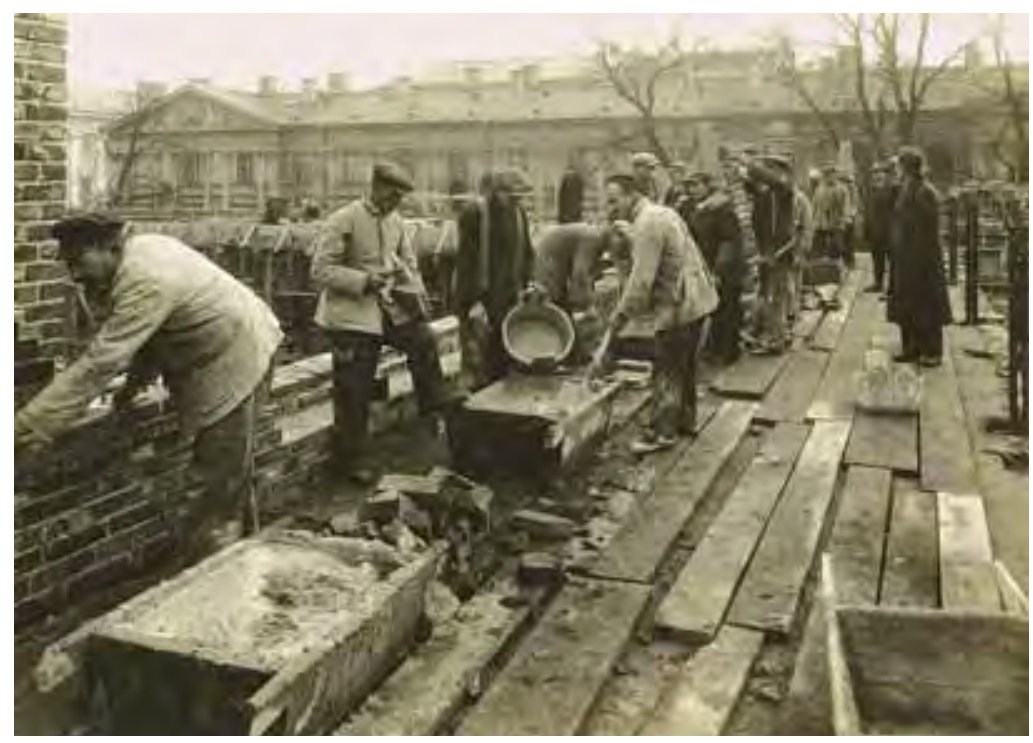

26. Budowa gmachu Auditorium Maximum, 21 XI 1934, r., fot. J. Raczyński

budynków należących do stowarzyszeń (np. dom Stowarzyszenia Filistrów Welecja przy ul. Chocimskiej 4) ${ }^{227}$. Większe przedsięwzięcia były możliwe dzięki stopniowemu uzyskiwaniu od władz państwowych i miejskich działek budowlanych (dawne rosyjskie obiekty wojskowe w rejonie Filtrów, Ochota) ${ }^{228}$.

Do zakończenia niezbędnych prac inwestycyjnych było jeszcze wszakże daleko. W uzasadnieniu wysokiego (30o tys. zł) ryczałtu remontowego na rok budżetowy 1939/1940 stwierdzono, co godzi się przytoczyć in extenso:

Uniwersytet Józefa Piłsudskiego znajduje się w opłakanych warunkach lokalowych, w gorszych niż jakakolwiek Uczelnia Wyższa w Polsce. Odziedziczył on stare budynki po Uniwersytecie rosyjskim, dostosowane do małej ilości studentów nie przekraczającej 200o. Budynki te są w bardzo złym stanie i nie były one od początku solidnie zbudowane, a w ciągu długiego okresu wojennego i trudności finansowych pierwszych lat powojennych uległy w bardzo wysokim stopniu zniszczeniu. Tymczasem potrzeby i obowiązki [...] wzrosły niepomiernie; liczy on prawie 10 ooo studentów obsługując stolicę, która z natury rzeczy daje największy procent studiujących w Polsce i wielkie obszary ciążące naturalnie do środka Państwa. Następnie na Uniwersytecie [...] z konieczności ciążą obowiązki reprezentacyjne wobec kraju i zagranicy, i zaniedbanie Uniwersytetu stołecznego rzuca smutne światło na warunki pracy naukowej w Polsce. Od czasu powstania Uniwersytetu uczyniono bardzo niewiele dla poprawienia tego 


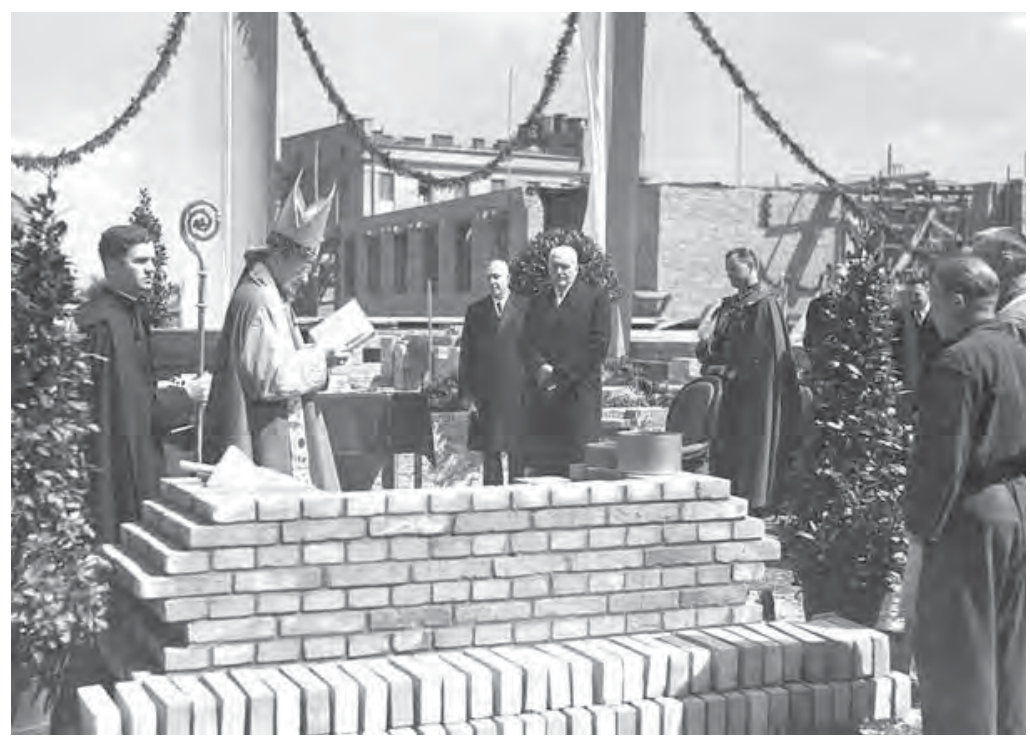

27. Uroczystość poświęcenia kamienia węgielnego pod budowę gmachu Instytutu Chemii przy ul. Pasteura. Drugi od lewej biskup pomocniczy archidiecezji warszawskiej ks. prof. Antoni Szlagowski, czwarty - prezydent Mościcki, wiosna $193^{8} \mathrm{r}$.

rozpaczliwego stanu, nadal na niektórych wydziałach uczęszczanie studentów na wykłady jest uwarunkowane ich zaletami sportowymi, wyprzedzaniem kolegów w zajęciu miejsca w audytorium, nadal studenci mdleją w duszącej atmosferze gazów pracowni chemicznych, prawie trzykrotnie przeciążonych, nadal kliniki uniwersyteckie są rozrzucone po całym mieście, pozbawione audytoriów, tak iż wykłady mogą się odbywać perypatetycznie w salach chorych, nadal Uniwersytet wynajmuje sale prywatne na pomieszczenie wykładów, nadal dla obcych gości Uniwersytetu trzeba szukać sal poza jego obrębem, gdyż niepodobna ich zapraszać do brudnych i odrapanych sal Uniwersytetu. Senat [...] w poczuciu ciążącej na nim odpowiedzialności, zwraca się do Ministerstwa [...] z prośbą o głębsze przychylne wniknięcie w potrzeby Uniwersytetu i o przedsięwzięcie celowej i planowej akcji, skierowanej ku naprawie istniejącego, wręcz rozpaczliwego stanu. Senat [...] zdaje sobie sprawę [...], że zapewnienie Uniwersytetowi pomieszczeń, któreby odpowiadały jego potrzebom i obowiązkom, jest sprawą bardzo kosztowną i musi być rozłożone na długie lata, mniema wszakże, że niezwłoczne rozpoczęcie akcji budowlanej jest niezbędne, tak aby w ciągu kilku lat [...] można było zaspokoić najpilniejsze potrzeby i przystąpić do planowej akcji ostatecznej rozbudowy [...].

Akcja budowlana [...] powinna być zwrócona w dwóch kierunkach: należy dążyć do stopniowego skupienia wszystkich klinik uniwersyteckich w szpitalu Dz[ieciątka] Jezus i zapewniania im wystarczających warunków egzystencji. Byłoby to pierwszymi krokami do objęcia całego szpitala [...] pod zarząd Uniwersytetu [...], ku czemu Zarząd Miejski m.st. Warszawy okazuje się być skłonny. 


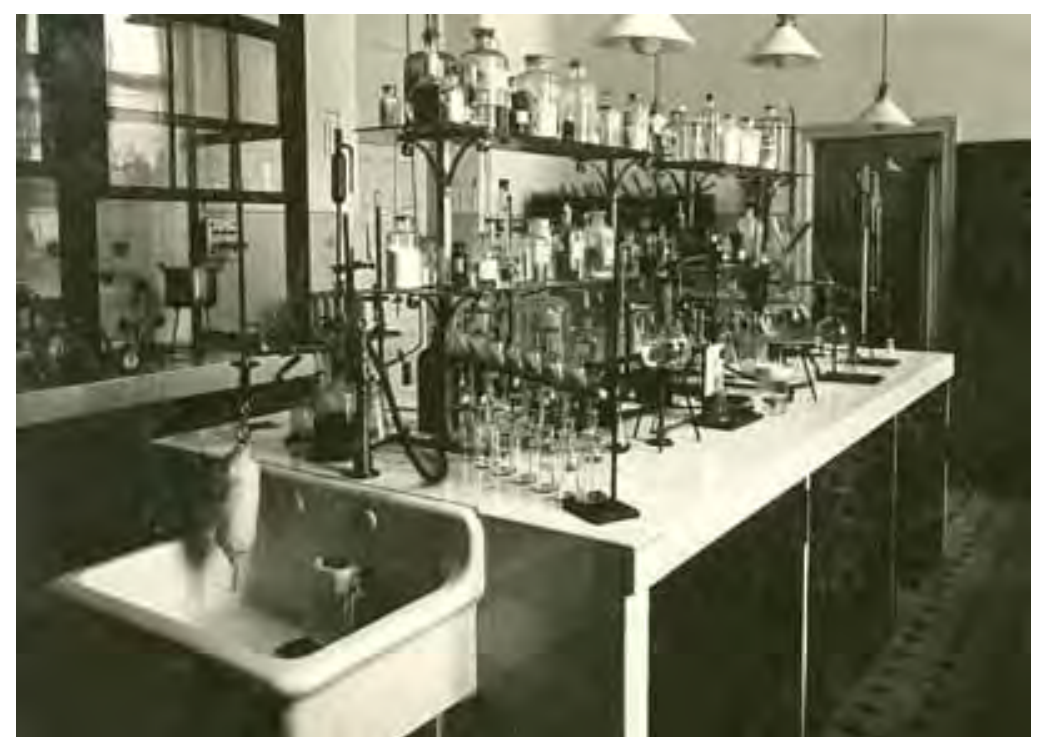

28. Jedno

z laboratoriów na

Wydziale Lekarskim, ok. 1933

Równolegle należy kontynuować dalszą rozbudowę Uniwersytetu na przyznanych od dawna gruntach w Rakowcu, gdzie w pierwszym rzędzie, po wybudowaniu Gmachu Chemii, winny być wzniesione budynki Ogrodu Botanicznego oraz pawilon Obserwatorium Astronomicznego. Poza tą akcją budowlaną potrzeba niestety znacznych sum na remont starych gmachów [... $]^{229}$.

Nawet jeśli ten wywód nie zawierał zbyt wiele barw ciemnych, to i tak obejmował postulaty, których spełnienie wymagało bardzo wysokich nakładów. Kilka miesięcy później, tuż przed napaścią Niemiec na Polskę, w wystąpieniu do ministra wyznań religijnych i oświecenia publicznego prof. Świętosławskiego (nota bene dawnego wykładowcy UW), rektor prof. Antoniewicz werbalizował najważniejsze potrzeby uniwersytetu następująco:

Sprawy budowlane i większego remontu nie wymagają obecnie większego uzasadnienia, gdyż są one od lat wysuwanym postulatem, a kolejność ich powoli się skraca w miarę wykonywanych robót. Na pierwszym miejscu stoi dalsza budowa Gmachu Chemii [...]. Następnie koniecznością dla normalnej i porządnej pracy Wydziału Lekarskiego jest budowa gmachów medycyny teoretycznejeje, tudzież przebudowa na potrzeby klinik budynków Szpitala Dzieciątka Jezus. Do nader pilnych należy również kapitalny remont zarysowanego w wielu miejscach gmachu b[yłej] Szkoły Głównej i dotychczasowego gmachu chemii [tj. zakładów przyrodniczych] przy ul. Krakowskie Przedmieście. Dalej idą postulaty 
REKTOR UNIWFRSYTERU IOZEKA FILSUDSKIEGO

I DZEKAN WYOZIALU MATEMATRCZWOIRZYHOONICZEGO

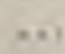

$\mathrm{NA}$

GMACHU CHI WIIIHWWERSYTETU

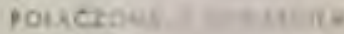

ZAKLADU CHEMII FIEORGANICZNEJ

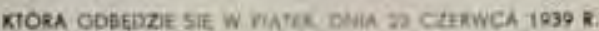

O GOOZ. 9 MIN 45 W NOWYM OUNCHIJ RZZY UL. FASTEURA. ROO WAWELSEIE!
29. Zaproszenie na

uroczystość poświęcenia

Gmachu Chemii,

czerwiec $1939 \mathrm{r}$.

Wydziału Weterynarii. Poza zaś normalną kolejnością potrzeb budowlanych i remontowych wysuwam niezmiernie pilne i doniosłe braki Biblioteki Uniwersyteckiej, która wymaga radykalnej pomocy ${ }^{231}$.

Tymczasem plany przygotowane na lata 40. przewidywały w obrębie projektowanej przez władze RP i miasta Dzielnicy Reprezentacyjnej Marszałka Józefa Piłsudskiego budowę obiektów mających stworzyć zaplecze sportowe dla studentów Uniwersytetu i Politechniki Warszawskiej ${ }^{232}$. Przede wszystkim jednak w przyznanym pierwszej z tych uczelni kompleksie gruntów o powierzchni 94 ha, obejmującym teren pomiędzy ulicami: Grójecką, Wawelską, Żwirki i Wigury a dawnym fortem rosyjskim Щ-M („Rakowiec”), przy dzisiejszej ul. H. Korotyńskiego, powstać miała cała „dzielnica intelektualna”. Jak wynika z dokumentacji UJP zamierzano wznieść tam w kolejności: zabudowania Wydziału Lekarskiego, Wydziału Matematyczno-Przyrodniczego, Ogrodu Botanicznego i Obserwatorium Astronomicznego, wydziałów teologicznych ${ }^{233}$, Wydziału Prawa i Wydziału Humanistycznego, a także Gmach Główny (z siedzibą Rektoratu, dziekanatów i biur), „Klub Intelektualistów” (Profesorów), gmach stowarzyszeń studenckich („Bratniej Pomocy”), Gmach Wychowania Fizycznego (dwie sale gimnastyczne, dwa baseny pływackie, hala gier i zabaw, gabinety lekarskie) wraz ze stadionem o częściowo krytych trybunach, a przede wszystkim nową siedzibę BUW ${ }^{234}$. Przebieg kampanii polskiej 1939 r. przekreślił ten śmiały i wcale realny zamysł. W postaci zmienionej i okrojonej powrócono do niego za czasów PRL, wznosząc budynek Wydziału Geologii, osiedle domów akademickich, a następnie 
kompleks oderwanej od UW Akademii Medycznej (dziś Warszawski Uniwersytet Medyczny).

Porównując wysiłek inwestycyjny Uniwersytetu Warszawskiego z inwestycjami podejmowanymi przez inne uczelnie warszawskie, jak Wyższa Szkoła Handlowa/Szkoła Główna Handlowa, Szkoła Główna Gospodarstwa Wiejskiego, Centralny Instytut Wychowania Fizycznego/Akademia Wychowania Fizycznego im. Marszałka, czy też Politechnika Warszawska, dochodzimy do wniosku, że Uniwersytet był placówką wypadającą pod tym kątem niekorzystnie. Wynikało to ze splotu kilku czynników: po pierwsze, z faktu przejęcia, z dobrodziejstwem inwentarza, schedy po prowincjonalnym uniwersytecie rosyjskim, dysponującym starymi na ogół budynkami i pozbawionym wszak większości wyposażenia; po drugie, ze stosunkowo skromnej w porównaniu z uczelniami technicznymi przydatności dyscyplin uniwersyteckich dla najważniejszego zadania Polski odrodzonej, tj. stałej rozbudowy potencjału obronnego; po trzecie, po $19^{2} 6$ r. UW stał się ostoją wpływów opozycyjnej wobec obozu rządzącego endecji i przez korzystny gospodarczo koniec lat 20. nie mógł liczyć na większą przychylność MWRiOP i innych resortów ${ }^{235}$; po czwarte, miał siedzibę w jednym z najdroższych rejonów stolicy ${ }^{236}$, co z kolei poważnie redukowało możliwości powiększania kampusu głównego; po piąte wreszcie, często ujawniał się czynnik skali - całkowity koszt nowego uniwersyteckiego gmachu wydziałowego mógł być zbliżony do ceny całej siedziby nowej, a zatem znacznie mniejszej uczelni. Zważywszy to wszystko, nie powinien dziwić powolny i w odniesieniu do substancji lokalowej niewystarczający proces rozwoju infrastruktury uniwersyteckiej w okresie międzywojennym, który jednak, w części zrealizowanej, zdołał odcisnąć ślad w krajobrazie Warszawy. Projekty zaś, którym przyszło pozostać jedynie na papierze, należy przywrócić pamięci. 


\section{Przypisy}

1 Zob. J. Pajewski, Pierwsza wojna światowa 1914-1918, Warszawa 1991, s. 286-29o.

2 Prócz tego istniały dwa inne obszary podlegające zarządowi niemieckiemu, w postaci etapów dowództwa frontu wschodniego (tzw. Ober-Ost): dawna gubernia suwalska (ok. 12,5 tys. $\mathrm{km}^{2}$ i ok. 124, tys. mieszkańców) oraz północna część oderwanej w 1912 r. guberni chełmskiej (ok. 6,4 tys. km² i ok. 320 tys. osób). Łącznie pod panowaniem Rzeszy znalazło się 2/3 obszaru i mniej więcej połowa ludności Kongresówki, w granicach z 1910 r. por. A. Stempin, Próba "moralnego podboju” Polski przez Cesarstwo Niemieckie w latach I wojny światowej, Warszawa 2013, s. 105-109; A. Wrzyszcz, Gubernia chełmska. Zarys ustrojowy, Lublin 1997, s. 53 n., 188 oraz Historia Polski $w$ liczbach, red. F. Kubiczek, A. Jezierski, A. Wyczański, t. I, Państwo i społeczeństwo, Warszawa 2003, s. 171. $\mathrm{O}$ austro-węgierskim gubernatorstwie generalnym Lublin - J. Lewandowski, Królestwo Polskie pod okupacja austriacka 1914-1918, Warszawa 1980, s. 38-154.

$3 \mathrm{~W}$ następnych kwartałach i latach projekt „Mitteleuropy” ewoluował. Jego szczytowa formę stanowił plan nowej organizacji tej części kontynentu sformułowany w marcu 1918 r. w związku z rokowaniami pokojowymi z Rosją Sowiecką w Brześciu nad Bugiem. Docelowo obejmował on strefę bałkańską oraz obszar od Łotwy i Litwy, przez Białoruś po całą Ukrainę. Miejsce Polski ulegało w nim fluktuacji: od jednego z filarów po element niepewny, wymagający szachowania przez sąsiadów, także zależnych od Niemiec por. J. Pajewski, Pierwsza wojna światowa..., s. 85-86, 9o-91, 3o6, 668; tegoż, Odbudowa państwa polskiego 1914-1918, Warszawa 1985, wyd. III, passim. Nowe, szerokie ujęcie tego kompleksu spraw daje A. Stempin, Próba „moralnego podboju”..., passim.

4 Nt. ewakuacji Uniwersytetu do Rostowa nad Donem zob. J. Schiller-Walicka, Uniwersytet Cesarski. Między edukacja a polityka 1869-1917, [w:] Dzieje Uniwersytetu Warszawskiego $w X I X w$., red. T.
Kizwalter, Warszawa 2016, s. 670-671. W nowym miejscu podjął on działalność jako czterowydziałowy Impieratorskij Warszawskij uniwiersitiet w g[orodie] Rostowie-na-Donu. W 1917 r. zakład przemianowano na Uniwersytet Doński, któremu rok później nadano imię działacza kozackiego, historyka i pedagoga Mitrofana Bogajewskogo. W latach 1925-1934, uczelnia nosiła nazwę Północnokaukaskiego Uniwersytetu Państwowego, potem krótko Rostowsko-nad-Dońskiego Uniwersytetu Państwowego, by w 1935 r. otrzymać imię ówczesnego premiera ZSRS Wiaczesława Mołotowa. Po oficjalnym potępieniu patrona, w latach 1957-1982 funkcjonował pod nazwą Rostowskiego Uniwersytetu Państwowego, by następnie (do 1991 r.) nosić miano innego dygnitarza sowieckiego Michaiła Susłowa. Od 2006 r. jest to Południowy Uniwersytet Federalny (JuFU) - zob. m.in. Obszczaja informacija, http://sfedu.ru/www/stat_ pages22.show?p=INF/abo (dostęp: 2 XI 2014, kopia w posiadaniu autora).

5 Komisją kierował prawnik, prof. Walenty Miklaszewski, a jej Sekcją Uniwersytecką filozof, prof. Adam A. Kryński - [W sprawie Uniwersytetu], b.m. i r.w., b.w., nadb. z: „Gazeta Lekarska” 1915, nr 46, s. 1-2; E. Jarra, Wspomnienia o Uniwersytecie Warszawskim 1915-1939, Londyn 1972, s. 5-6; M.M. Drozdowski, Warszawa w latach 1914-1939, Warszawa 1991, s. 117. Ze spuścizny projektowej tego czasu por. J. Brudziński, W sprawie organizacji ogólnej Uniwersytetu, a Wydziału Lekarskiego w szczególności, Warszawa 1915; S. Orłowski, W sprawie Instytutów Wydziału Lekarskiego Uniwersytetu Warszawskiego. Uwagi i dezyderaty, Warszawa-Lublin-Łódź 1915, nadb. z: „Medycyna i Kronika Lekarska” 1915, nr 28, s. 179-182; nr 29, s. 190-193; nr 30, s. 194-204.

6 [W sprawie Uniwersytetu], s. 2.

7 Członkowie: prof. Leon Kryński, dr Stanisław Orłowski, lek. Jan Pawiński, lek. Adam Puławski, dr Kazimierz Rzętkowski, lek. Alfred Sokołowski.

8 Członkowie: dr Dominik Anc, dr Stanisław Bukowiecki, dr Władysław Holewiński, dr Eugeniusz Jarra, dr Stanisław Kacperski, dr Franciszek Ochimowski, dr Alfons Parczewski. 
9 Członkowie: prof. A.A. Kryński, dr Gabriel Korbut, dr Jan Karol Kochanowski, dr Tadeusz Kochanowski, dr Józef Siemieński, dr Władysław Weryha. W. Smoleński ustąpił ze stanowiska nie godząc się na uzależnienie finansowe uczelni od okupanta.

10 Członkowie: dr Jan Krassowski, dr Jan Lewiński, dr Stefan Mazurkiewicz, dr Jan Sosnowski, dr Ludwik Szperl, dr Zygmunt Wóycicki.

11 K. Konarski, Dzieje szkolnictwa $w$ b[ytym] Królestwie Kongresowym 1915-1918, Kraków-Warszawa 1923, s. 123 n.

12 Dowodzi tego każda niemal kwerenda prowadzona w oparciu o ocalały na szczęście z pożóg wojennych katalog kartkowy BUW. Począwszy od 1915 r. widać znaczący przyrost publikacji tego typu: parę arkuszy druku, struktura podręcznikowa, bibliografia (w niej zaś prace polskie oraz niemieckie, austriackie, francuskie).

13 W. Stummer, Biblioteka Uniwersytecka $w$ Warszawie, [w:] Uniwersytet Warszawski 1808-1818-1958. Universitas Varsoviensis $1808-1818-1958$, red. A. Gieysztor, M. Strzemieński, Warszawa 1958, s. 24, 36 .

14 K. Stołyhwo, I. „Muzeum Antropologiczne” $w$ Warszawie. II. Sprawozdanie ze stanu Gabinetu Archeologicznego Uniwersytetu Warszawskiego w r [oku] 1915, Warszawa 1917, nadb. z: „Pamiętnik Fizjograficzny”, t. XXIV (1917), s. 4-5.

15 A. Stempin, Próba „moralnego podboju”...., s. $194-196$.

16 B. Hutten-Czapski, Sześćdziesiąt lat życia politycznego i towarzyskiego, Warszawa $193^{6}$, t. II, s. 297-298 (uzup. M.P.D.).

17 Statut tymczasowy Uniwersytetu Warszawskiego i ustawy tymczasowe wydziałów, Warszawa 1915. Postępowanie młodzieży miały regulować sygnowane przez W. von Kriesa Przepisy dla studentów Uniwersytetu Warszawskiego, [Warszawa 1915].

18 E. Jarra, Wspomnienia o Uniwersytecie Warszawskim..., s. 11.

19 W skład Senatu akademickiego weszli ponadto: dr Józef Wierusz-Kowalski (prorektor), dr Ignacy Koschembar-Łyskowski (sędzia), dr Antoni Kostanecki (przedstawiciel Wydziału Prawa i Nauk Państwowych), dr Józef Kallenbach i dr Jan Łukasiewicz (przedstawiciele Wydziału Filozoficznego) oraz dr Zygmunt Wóycicki i dr Edward Loth (przedstawiciele Wydziału Matematyczno-Przyrodniczego)

- Spis wykładów w semestrze zimowym 1915/1916 r. i w semestrze letnim 1916 r., Warszawa 1916, [s. 3]. Nazwy wydziałów zostały ustalone dopiero w listopadzie.

20 [W sprawie Uniwersytetu], s. 2-3; T. Manteuffel, Uniwersytet Warszawski w latach 1915/16-1934/35. Kronika, Warszawa 1936, s. 8. Przeciw

Brudzińskiemu występował Zygmunt Dziembowski-Pomian, ziemianin z Poznańskiego i były poseł do Reichstagu, współpracownik administracji okupacyjnej - M. Handelsman, $Z$ papierów rektora Brudzińskiego, [Warszawa 1928], s. 3-4, nadb. z: „Przegląd Historyczny” 1928, z. 2, s. 187-188; A. Stempin, Próba „moralnego podboju", s. 14,2, 189 .

21 [W sprawie Uniwersytetu], s. 3.

22 Przebieg uroczystości np. w: T. Manteuffel, Uniwersytet Warszawski w latach 1915/16 -1934/35, s. 8-10; B. Hutten-Czapski, Sześćdziesiąt lat życia..., t. II, s. 301-302; E. Jarra, Wspomnienia o Uniwersytecie Warszawskim..., s. 11-12. Brała w niej udział trzyosobowa delegacja Komendy Legionów Polskich. Teksty oficjalne - Otwarcie Uniwersytetu i Politechniki w Warszawie[:] 1915, [Warszawa-Warschau 1915]; Ks. A. Szlagowski, Mowa wypowiedziana podczas uroczystego nabożeństwa w Królewskiej Katedrze Metropolitalnej z powodu otwarcia Uniwersytetu i Politechniki Warszawskiej dnia 15 listopada 1915 r., Warszawa 1915.

23 J. Brudziński, Otwarcie Uniwersytetu Warszawskiego. Dnia 15 listopada 1915 roku. Mowa Rektora doktora medycyny..., [Warszawa] 1916, s. 1-3 (uzup. M.P.D.).

24 Tamże, s. 9-10 (uzup. M.P.D.).

25 Tamże, s. 21-22 (uzup. M.P.D.).

26 Tamże, s. 22-23 (uzup. M.P.D.). 
27 E. Jarra, Wspomnienia o Uniwersytecie Warszawskim..., s. 12.

28 S. Kutrzeba, Uniwersytety warszawskie. Odczyt wygłoszony na uroczystym zebraniu profesorów Uniwersytetu Jagiellońskiego $w$ auli Collegii Novi 15 listopada 1915 roku jako $w$ dniu ponownego otwarcia Uniwersytetu $w$ Warszawie, Kraków 1915, s. 3-16.

29 Por. S. Starzyński, Przyczynek do polskiej kroniki uniwersyteckiej, Kraków 1916, s. 9-13. Do 1808 r. jako daty inicjującej $\mathrm{w}$ istocie powstanie UW odwołuje się współcześnie, zgodnie z twierdzeniami niektórych badaczy, Wydział Prawa i Administracji - zob. O Wydziale, http:// wpia.uw.edu.pl/wydzial/o-wydziale (dostęp: 10 IX 2015, kopia w posiadaniu autora).

30 M. Handelsman, $Z$ papierów..., s. 5-6. Por. też: M. Handelsman, Brudziński Polikarp Józef, PSB, t. III, (Brożek Jan - Chwalczewski Franciszek), Kraków 1937, s. 12; J. Piłsudski, List do rektora Uniwersytetu Warszawskiego Józefa Brudzińskiego, [w:] tegoż, Pisma zbiorowe. Wydanie prac dotychczas drukiem ogłoszonych, t. IV, oprac. W. Lipiński, Warszawa 1937, s. 88-89; B. Hutten-Czapski, Sześćdziesiąt lat życia..., t. II, s. 355 n.

31 M. Handelsman, $Z$ papierów..., s. 8-22.

32 E. Jarra, Wspomnienia o Uniwersytecie Warszawskim..., s. 17. Dodać tu wypada, że ten wybitnie zasłużony dla stolicy lekarz, uczony i pedagog nie doczekał się do dziś upamiętnienia w przestrzeni publicznej miasta, jeśli nie liczyć niewielkiej sali w Pałacu Kazimierzowskim i kamienia w Ogrodzie Botanicznym.

33 Tamże, s. 10-11.

34 Tamże, s. 622-623. W przypadku UW nastąpiło to 13 V 1931. Doktorat przyznał Wydział Lekarski.

35 Ks. A. Szlagowski, Mowa wypowiedziana..., s. 8-11; T. Manteuffel, Uniwersytet Warszawski w latach 1915/16 - 1934/35, s. 10-15; ks. Z. Obertyński, Wskrzeszenie Warszawskiego Wydziału Teologicznego. (Na podstawie kroniki Uniwersytetu i materiałów archiwalnych), Warszawa 1938, s. 3-21, nadb. z: „Wiadomości Archidiecezjalne Warszawskie" 1938, nr 4, s. 190-214; A. Stempin, Próba „moralnego podboju"..., s. 398-4,10. W związku z tą sprawą wysuwano m.in. postulat powołania zamiast Wydziału Teologicznego na UW odrębnej uczelni katolickiej, w nieokreślonej faktycznie przyszłości - zob. J. Poray, Kilka uwag w sprawie Wydziału Teologicznego na Uniwersytecie Warszawskim, Warszawa 1915 , na prawach rękopisu, s. 3 .

36 Spis wykładów w semestrze zimowym 1915/1916 r..., s. 7-17.

37 T. Manteuffel, Uniwersytet Warszawski w latach $1915 / 16-1934 / 35$, s. 273.

38 Archiwum Uniwersytetu Warszawskiego (dalej AUW), AcUW/RP 95, Album Uniwersytetu, t. I, k..

39 J. Brudziński, Wykłady propedeutyki lekarskiej w Uniwersytecie Warszawskim $w$ przeszłości $i$ zadanie ich $w$ chwili obecnej. Wykład wstepny z propedeutyki lekarskiej $w$ dn. 1 kwietnia 1916 r., Warszawa 1916, nadb. z: „Gazeta Lekarska” 1916, nr 16, s. 3, 5-6, 8, 11-12. Inny przykład - W. Tatarkiewicz, $Z$ dziejów filozofii na Wszechnicy warszawskiej (Pierwszy wykład na Uniwersytecie warszawskim 18 listopada 1915 roku), Warszawa 1916, nadb. z: „Przegląd Filozoficzny” 1915, z. III-IV, s. 197-207.

40 A. Jarosz-Nojszewska, Wyższa Szkoła Handlowa 1915-1933, [w:] Historia Szkoty Głównej Handlowej w Warszawie 19o62006, red. W. Morawski, Warszawa 20o6, s. 43-44. Uchwały Wydziału Oświecenia KO m. Warszawy z 21 i 28 X $1915 \mathrm{r}$. potwierdziły, iż kursy są uczelniami wyższymi. Jej studenci otrzymali - z wzajemnością - prawo uczestnictwa w wykładach UW i PW.

41 K. Dunin-Wąsowicz, Warszawa 1914-1918, Warszawa 1989, wyd. II, s. 163; M.M. Drozdowski, Warszawa w latach 1914-1939, s. 119; S. Mauersberg, Szkolnictwo, [w:] Encyklopedia Historii Drugiej Rzeczypospolitej, Warszawa 1999, s. 439 .

42 Academy of Fine Arts in Warsaw, [Warszawa] b.m.w., s. [7] - http://www.asp. waw.pl/V_FIFD/OTHER/kalendarium.pdf (plik PDF w posiadaniu autora). 
43 Należy też dla porządku wymienić osiem zakładów prywatnych o charakterze półwyższym: Wyższe Handlowe Kursy Żeńskie, Wyższe Kursy Pedagogiczne dla Kobiet, Wyższe Kursy Pedagogiczne Żeńskie Katolickiego Związku Kobiet, Konserwatorium Muzyczne, Szkoła Muzyczna Warszawskiego Towarzystwa Muzycznego, Szkoła Mechaniczno-Techniczna im. Hipolita Wawelberga i Stanisława Rotwanda, Warszawska Szkoła Dramatyczna, Szkoła Dziennikarska przy Towarzystwie Literatów i Dziennikarzy - K. Dunin-Wąsowicz, Warszawa 1914-1918, s. 163 .

44 Obliczenie autora na podstawie: tamże; M.M. Drozdowski, Warszawa w latach 1914-1939, s. 119 .

45 Tamże, s. 118-119.

46 T. Manteuffel, Uniwersytet Warszawski w latach $1915 / 16-1934 / 35$, s. 15-16.

47 Statut Uniwersytetu Warszawskiego i ustawy wydziałów, Warszawa 1916, s. 5 n.

48 T. Manteuffel, Uniwersytet Warszawski w latach $1915 / 16-1934 / 35$, s. 275 .

49 Tamże, s. 275. Wykładowców było już 50, adiunktów 2, asystentów 41, lektorów 4 .

50 Wskazówki dotyczące studiów na wydziale prawa i nauk państwowych, [Warszawa 1917]. Na tym polu przejawiała się też działalność finansowa - zob. AUW, AcUW/RP 88, relikty dokumentacji Fundacji Stypendialnej im. Włodzimierza Młockiego z 1917 r. Przykłady zachowanej spuścizny naukowej tego czasu znajdują się w aktach ogólnych poszczególnych wydziałów (AUW, RP/WMP 150, dr S. Lencewicz, „Ogólne zagadnienia oświatowo-wychowawcze", 27 XII 1916, rękopis; SN 2, k. 1-43, księga protokołów Koła Polonistów Studentów Uniwersytetu Warszawskiego za okres 29 II 1916-17 II 1918).

51 Ilustruje to m.in. opublikowana korespondencja - [I. Moszczeńska], Przyczynek do dziejów odrodzenia Uniwersytetu Warszawskiego w latach 19151918 (odbicie w listach...), oprac. J. Rzepecki, „Roczniki Uniwersytetu Warszawskiego”, VIII (1968-1969), s. 72-75. Zob. też J. Rabski, Na drodze walki o dusze mtodego pokolenia. Stenogram odczytu uzupełniony aneksem $z$ dokumentami, Warszawa $193^{6}$, s. 3-4. Autor ten wskazuje, że jeszcze w 1915 r. powstało na UW zorientowane antyniemiecko Koło im. Maurycego Mochnackiego, grupujące zresztą nieliczną mniejszość spośród deklarujących poglądy polityczne młodych akademików. 4. XI 1916 r. zaledwie 18 osób opowiedziało się przeciw udziałowi w uroczystości zapowiedzianej na dzień następny.

52 Możliwe stało się zakładanie stowarzyszeń innych niż naukowe i samopomocowe, jak np. działającej w oparciu o obowiązującą od 8 VI 1916 r. regulację prowizoryczną Studenckiej Kasy Chorych UW - por. Statut tymczasowy Studenckiej Kasy chorych Uniwersytetu Warszawskiego, [Warszawa 1916]. Dopuszczalne było też odbywanie zebrań poza UW - T. Manteuffel, Uniwersytet Warszawski w latach 1915/16 1934/35, s. 17. Zob. tė̇ Ogólne przepisy dla stowarzyszeń studenckich na Uniwersytecie $i$ Politechnice $w$ Warszawie, Warszawa 1916. Z materiałów dotyczących aktywności korporacji - AUW, SS 2, „Lista Weletów Warszawskich w latach 1916-1939" (załącznik 2 do opracowania Tadeusza Kokeliego „Szkic historyczny korporacji «Welecja»", maszynopis z 1978 r.).

53 Por. W. Suleja, Tymczasowa Rada Stanu, Warszawa 1998, s. 198-199. Następczynią TRS była Komisja Przejściowa, urzędująca do 18 I $1918 \mathrm{r}$.

54 A. Jezierski, C. Leszczyńska, Historia gospodarcza Polski, Warszawa 1999, wyd. II, s. 225. W ten sposób stworzono możliwość inflacyjnego finansowania wydatków odbudowującego się państwa, co pozwalało m.in. na rozbudowę szkolnictwa.

55 Zob. Z.J. Winnicki, Rada Regencyjna Królestwa Polskiego i jej organy (1917-1918), Wrocław 1991, s. 29-69.

56 T. Manteuffel, Uniwersytet Warszawski w latach $1915 / 16-1934 / 35$, s. 17-18.

57 O przebiegu i skutkach protestu - tamże, s. 18-22; K. Dunin-Wąsowicz, Warszawa 1914-1918, s. 164; A. Stempin, Próba „moralnego podboju”..., s. 209-216; T. Katelbach, Strajk akademicki $w$ Warszawie 1917, Warszawa 1938, passim; B. Hutten-Czapski, Sześćdziesiąt lat życia..., t. II, s. 4,20-4,28. 
58 Statut tymczasowy Uniwersytetu Warszawskiego, Warszawa 1917, nadb. z: „Dziennik Urzędowy [Departamentu] Wyznań Religijnych i Oświecenia Publicznego" 1917, nr 2. Głównym autorem dokumentu był prawnik i historyk dr J. Kucharzewski. Projekt przedłożono do akceptacji von Beselerowi - T. Manteuffel, Uniwersytet Warszawski w latach 1915/16-1934/35, s. 22-23. Uzupełniały go Przepisy dla studentów Uniwersytetu Warszawskiego, [Warszawa 1917], oraz Ogólne przepisy dla stowarzyszeń studenckich na Uniwersytecie Warszawskim, [Warszawa 1917].

59 Statut liczył 4,4 paragrafy i nie miał preambuły. Paragraf 1 głosił, że UW „ma za zadanie krzewić nauki i umiejętności, doskonalić je i do użytku społeczności zastosowywać. Do tego celu [...] przede wszystkim dąży, dając młodzieży bezstronne i niezależne wykształcenie wyższe, mające przysparzać ojczyźnie światłych i użytecznych obywateli i ukształconych do właściwych zawodów pracowników oraz przysposabiać uczonych we wszystkich gałęziach wiedzy [...]”.

60 T. Manteuffel, Uniwersytet Warszawski w latach 1915/16-1934/35, s. 23-24, 277. Pomiędzy nimi byli i tacy, którzy mieli możność studiować na innych uczelniach, np. rosyjskich - por. AUW, RP/WP 113, akta osobowe studentów Wydziału Prawa, legitymacja studencka Stanisława Frejlicha, studenta Cesarskiego Uniwersytetu Moskiewskiego, datowana 17 IX 1916 r. Studentów uczyło: 53 wykładowców, 2 adiunktów, 46 asystentów i 4 lektorów. Ich liczba wzrosła więc tylko nieznacznie.

$61 \mathrm{Z}$ racji zgonu (18 XII) pierwszego rektora odnowionej uczelni, 12 I 1918 r. urząd prorektora przejął dr J. Łukasiewicz - T. Manteuffel, Uniwersytet Warszawski w latach $1915 / 16-1934 / 35$, s. 276 .

62 B. Kłapkowski, Kostanecki Antoni, [w:] PSB, t. XIV, Kopernicki Izydor - Kozłowska Maria, Wrocław-Warszawa-Kraków 19681969 , s. 328-33o.

63 Por. m.in. Rozporzadzenie wykonawcze co do przyjmowania słuchaczów nadzwyczajnych do Uniwersytetu Warszawskiego, jako uzupełnienie paragr[afu] 36 Statutu Tymczasowego Uniwersytetu Warszawskiego, [Warszawa 1918] z 23 I 1918 r., oraz: Przepisy ogólne o egzaminach na Wydziale Lekarskim Uniwersytetu Warszawskiego, [Warszawa 1918] z 19 I 1918 r.; Regulamin egzaminu prawno-historycznego na Wydziale prawa i nauk politycznych Uniwersytetu Warszawskiego, [Warszawa 1918] z 26 II 1918 r.; Regulamin końcowego egzaminu państwowego na Wydziale prawa i nauk politycznych Uniwersytetu Warszawskiego dla absolwentów nauk prawnych innych uniwersytetów, [Warszawa 1918] z 29 IV 1918 r.; Przepisy ogólne o egzaminach farmaceutycznych na Wydziale Lekarskim Uniwersytetu Warszawskiego, [Warszawa 1918] z 10 V 1918 r.

64 Ks. Z. Obertyński, Wskrzeszenie Warszawskiego Wydziału Teologicznego, s. 21-26. Zob. też Ustawa tymczasowa wydziału teologicznego Uniwersytetu Warszawskiego, [Warszawa] 1918, nadb. z: „Dziennik Urzędowy Ministerstwa Wyznań Religijnych i Oświecenia Publicznego" 1918, nr 4; Przepisy dodatkowe dla studentów Wydziału Teologicznego [Uniwersytetu Warszawskiego],

[Warszawa 1918] z 28 II 1918 r.

65 E. Jarra, Wspomnienia o Uniwersytecie Warszawskim..., s. 6.

66 AUW, RP/WMP 135, książka inwentarza ruchomego Seminarium Prawa Cywilnego, k. 1-17 (zapisy z 1918 r.).

67 T. Manteuffel, Uniwersytet Warszawski w latach 1915/16 - 1934/35, s. 24; K. Dunin-Wąsowicz, Warszawa 1914-1918, s. 6 o n. Szersze tło: W. Pobóg-Malinowski, Najnowsza historia polityczna Polski, t. 2, 1914-1939, wyd. III, Opole 1990, s. 112-129; J. Pajewski, Odbudowa..., s. 233-239;

A. Chwalba, Historia Polski 1795-1918, Kraków 2001, s. 588-589.

68 Spis wykładów i wykładajacych w semestrze zimowym 1918/1919 r., Warszawa 1918, zawierał 16 przedmiotów na Wydziale Teologicznym, 34, na Wydziale Prawa 
i Nauk Politycznych, 35 na Wydziale Lekarskim (i Studium Weterynarii), 25 na Studium Farmaceutycznym tegoż Wydziału i 123 na Wydziale Filozoficznym (z czego 55 w Sekcji Humanistycznej i 68 w Sekcji Matematyczno-Przyrodniczej).

69 T. Manteuffel, Uniwersytet Warszawski w latach 1915/16 - 1934/35, s. 25; Projekt statutu dla Uniwersytetu Warszawskiego. Opracowany przez Komisje ministerialna w r [oku] 1918, [Warszawa] 1918;

[Wyciag ze Statutu tymczasowego

Uniwersytetu Warszawskiego...],

[Warszawa 1918].

70 Tamże, s. 6; T. Manteuffel, Uniwersytet Warszawski w latach 1915/16 - 1934/35, s. 25

71 Tamże, s. 278. Prorektorem został mineralog, prof. Stanisław J. Thugutt.

72 Tamże, s. 26.

73 Powstanie II Rzeczypospolitej. Wybór dokumentów 1866-1925, red. H. Janowska, T. Jędruszczak, Warszawa 1984 , wyd. II, s. $4115 \mathrm{n}$.

74 T. Manteuffel, Uniwersytet Warszawski w latach $1915 / 16-1934 / 35$, s. 26 n.

75 Tamże, s. 26-27.

76 Tamże, s. 27; R. Gawkowski, Studencki pulk. 36 pułk piechoty Legii Akademickiej - jego powstanie i walki o niepodległość, [Warszawa 1998], s. 5-13.

77 Tamże, s. 13-24.

78 T. Manteuffel, Uniwersytet Warszawski w latach $1915 / 16-1934 / 35$, s. 28-33.

79 Tamże, s. 33-34. Autor cytowanego opracowania, jako 22-letni student I roku historii, spełnił obowiązek obywatelski w szeregach 210. pułku artylerii polowej, tracąc w wypadku podczas służby prawą rękę. Należał do grona najwybitniejszych mediewistów polskich i wychowawców młodzieży akademickiej.

80 Tamże, s. $35^{-3} 6$.

81 Poświęcona jest temu praca B. Jaczewskiego, Polityka naukowa państwa polskiego w latach 1918-1939, Wrocław 1978.
82 Po ostatniej reorganizacji składał się on z czterech komórek: Wydziału Nauki (od $193^{2}$ r. naczelnik Bolesław Kielski), Referatu Ustrojowo-Programowego (od 1926 r. kierownik dr Zygmunt Zagórowski), Referatu Administracyjnego (od 1936 r. kierownik Czesław Lubicz-Łapiński) i Referatu ds. Młodzieży Szkół Wyższych (od 1931 r. kierownik mgr Stanisław Kulesiński), a p.o. dyrektora był od 1936 r. prof. Józef Patkowski (przedtem, od 1934 r. prof. Jan S. Bystroń). Departament załatwiał ,w zakresie nauki sprawy związane $\mathrm{z}$ organizacją nauki i popieraniem polskiej twórczości naukowej w kraju i za granicą, sprawy ochrony przyrody i opieki nad zabytkami bibliotecznymi, przedhistorycznymi i paleontologicznymi, w zakresie szkolnictwa wyższego - sprawy ustawodawstwa, organizacji oraz nadzoru nad wykonywaniem ustaw i przepisów oraz opieki nad młodzieżą akademicką - „Rocznik Polityczny i Gospodarczy” (dalej: RPiG), s. 226 . Zob. też [ks.] B. Żongołłowicz, Dzienniki 1930-1936, oprac. D. Zamojska, Warszawa 2004 , passim.

83 Zajmował się sprawami: nadzoru nad pracami ustawodawczymi ministerstwa, jednolitej wykładni przepisów, budżetowymi, fundacyjnymi, budownictwa szkolnego, statystycznymi, zarządu wydawnictwami oraz obsługą kancelaryjno-administracyjno-gospodarczą.

84 Nie licząc jednak zawieszonej w latach 1918-1922 Warszawskiej Szkoły Sztuk Pięknych oraz Wydziału Sztuk Pięknych USB - W. Baraniewski, Szkolnictwo artystyczne, [w:] Encyklopedia Historii Drugiej Rzeczypospolitej, Warszawa 1999, s. 4.43; Academy of Fine Arts..., s. [10].

85 Szkoły wojskowe przeważnie dwuletnie, kształcące oficerów służby stałej (zawodowych), przemianowane w $1928 \mathrm{r}$. na szkoły podchorążych, wymagały od kandydatów matur, ale nie miały charakteru wyższych uczelni. W podchorążówkach inżynierii (zał. 1923 w Warszawie) i marynarki wojennej (zał. 1922, najpierw w Toruniu, od 1938 r. w Bydgoszczy) nauka trwała trzy lata, a w stołecznej Oficerskiej Szkole Sanitarnej (potem Szkole 
Podchorążych Sanitarnych) pięć lat - por. m.in. Zarys dziejów wojskowości polskiej (1864-1939), red. P. Stawecki, Warszawa 1990, s. 439-441, 534-535 (to samo dotyczyło szkół oficerów zawodowych innych służb mundurowych). Świadectwa dojrzałości wymagała też z-letnia Szkoła Handlu Morskiego i Techniki Portowej w Gdyni, istniejąca w latach 1929-1933 - zob. A. Tarkowska, Gdynia między wojnami. Opowieść o narodzinach $i$ życiu miasta 1918-1939, Łódź [2009], s. 70; S. Kitowski, Gdynia. Miasto z morza i marzen. Illustrated Tale of Gdynia. Gdynia. A city born from Sea and Dreams, Gdynia 2005, wyd. IV, s. 152-153. Natomiast utworzona w 1920 r. Państwowa Szkoła Morska w Tczewie (od 1931 r. w Gdyni), cztero- lub trzyipółletnia, kształcąca pracowników żeglugi morskiej i zawodów pokrewnych, miała status „zakładu naukowo-wychowawczego typu licealnego" - RPiG, s. 25o. Również Państwowa Szkoła Górnicza i Państwowa Szkoła Hutnicza (obie w Dąbrowie Górniczej), Państwowa Szkoła Przemysłowa w Bielsku i Państwowa Szkoła Górnicza w Katowicach zaliczały się do zakładów szczebla średniego tamże, s. 467. Ponadto w Wolnym Mieście Gdańsku działała Wyższa Szkoła Handlowa, utrzymywana przez Macierz Szkolną tamże, s. 4,28.

86 Wielkość szacunkowa. Brak ścisłych danych na ten temat w literaturze.

87 Por. M. Andrzejewski, Kultura, oświata (1920-1945), [w:] Historia Gdańska, red. E. Cieślak, t. IV/2, 1920-1945, red. tegoż, Sopot b.r.w., s. 273-274; E. Kołodziej, Dzieje Polonii w zarysie 1918-1939, Warszawa 1991, s. 128.

88 W końcu lat zo. konserwatoria i szkoły muzyczne szczebla wyższego działały w Bydgoszczy (2), Katowicach (państwowe), Kołomyi (filia), Krakowie, Lwowie (2), Łodzi, Poznaniu (państwowe), Przemyślu (filia), Radomiu (filia), Stanisławowie (2, w tym filia), Stryju (2 filie), Śniatyniu (filia), Tarnopolu (filia), Toruniu, Warszawie (państwowe i 4 filie), Wilnie, Złoczowie (filia) oraz Wolnym Mieście Gdańsku - RPiG, s. 574- 576 .
89 W końcu lat 3o. katolickie seminaria wyższe istniały w następujących miejscowościach: Kraków (4 arcybiskupie, 8 zakonnych dominikańskie i jezuickie o uprawnieniach fakultetów papieskich, z prawem nadawania stopni naukowych), Lublin (biskupie i 2 zakonne), Przemyśl (2 biskupie, w tym greckokatolickie), Dobromil (biskupie i zakonne greckokatolickie), Dubno (zakonne obrządku wschodnio-bizantyńskiego), Gniezno (arcybiskupie), Janów Podlaski (biskupie), Kielce (biskupie), Kruszewo (zakonne), Krystynopol (zakonne greckokatolickie), Lwów (arcybiskupie), Łomża (biskupie), Łódź (biskupie), Osieczno (zakonne), Pelplin (biskupie), Płock (biskupie), Poznań (biskupie), Potulice (zakonne), Sandomierz (biskupie), Suchary (zakonne), Tarnów (biskupie), Warszawa (arcybiskupie), Wilno (arcybiskupie), Włocławek (biskupie), Wronki (zakonne). Absolwenci większości z nich mogli, wedle regulacji z 1931 r., ubiegać się o magisterium wydziałów teologicznych uniwersytetów. Liczbę alumnów można szacować na ok. 2,5 tys. łącznie. Duchowni prawosławni i ewangeliccy studiowali na UW, natomiast żydowscy w seminarium Tachkemoni w Warszawie - tamże, s. 4,4,1-4,4,2; „Mały Rocznik Statystyczny", X (1939), reprint: Warszawa 1989 , s. 354; Seminaria duchowne, [w:] Encyklopedia Historii..., s. 4,02. Ponadto w roku akademickim 1938/1939 działało w stolicach archidiecezji i diecezji 13 (Warszawa, Tarnów, Płock, Wilno, Lwów, Łuck, Włocławek, Pińsk, Kraków, Siedlce, Kielce, Łódź, Radom; dalsze w organizacji) trzyletnich Instytutów Wyższej Kultury Religijnej, afiliowanych przy Instytutach Akcji Katolickiej, a zatrudniających profesorów wydziałów teologicznych i wyższych seminariów duchownych - RPiG, s. 436-437.

90 Wedle zreformowanego w latach 30. programu poza liceami pedagogicznymi, seminariami dla nauczycieli przedszkolnych i rzemiosł, zaliczały się do nich wymagające matur pedagogia (11) z 1138 słuchaczy oraz 4. zakłady specjalne - RPiG, s. 463-4,64.

91 Tamże, s. 527-529, 538-539. Jako przykład aktywności może posłużyć tarnowskie 
TPN - T. Opas, B. Jaśkiewicz, Towarzystwo Przyjaciół Nauk w Tarnowie. Historia powstania i działalności, „Nauka Polska”, 1979 , nr 11, s. 101-110.

92 RPiG, s. 531-532, 536-566; Polska współczesna. XX rok niepodległości Rzeczypospolitej Polskiej w wykresie i słowie, t. I, Województwo warszawskie, Warszawa 1938, s. 143-145; Encyklopedia Historii..., passim.

93 Ustawa $z$ dnia 13 lipca 1920 r. o szkołach akademickich, „Dziennik Ustaw Rzeczypospolitej Polskiej" (dalej DURP), 1920, nr 72, poz. 494

94 Prawo polityczne Rzeczypospolitej Polskiej 1918-1939. Wybór źródel, oprac. W. Sudnik, Warszawa 2002, s. 71 .

95 Minister chciał w ten sposób „nie dawać takim potworzonym i tworzącym się w uniwersytetach mafiom broni w rękę do utrącania ludzi" - M. Rataj, Wskazania obywatelskie i polityczne. Wybór pism i przemówień z lat 1919-1938, oprac. S. Lato, Warszawa 1987 , s. 111-112.

96 Ustawa $z$ dnia 13 lipca 1920 r. o szkołach akademickich, DURP, 1920, nr 72, poz. 494. Omówienie w: S. Mauersberg, Szkolnictwo, s. 439-4,40.

97 R. Jakubów, Akademia Handlowa $w$ Krakowie, Akademia Handlowa $w$ Poznaniu i Akademia Handlu Zagranicznego we Lwowie, [w:] Encyklopedia Historii..., s. 13-14; M. Czajka, Instytut Nauk Judaistycznych $w$ Warszawie, [w:] Encyklopedia Historii..., s. 133.

98 W. Sienkiewicz, Instytut Naukowo-Badawczy Europy Wschodniej, [w:] Encyklopedia Historii..., s. 133.

99 Prawda o Szkole Wawelberga, oprac. Z. Reicug, W. Sikorski, Warszawa $193^{8}$, s. 3-5; R. Jakubów, Państwowa Szkoła Budowy Maszyn i Elektrotechniki im. H. Wawelberga i S. Rotwanda, [w:] Encyklopedia Historii..., s. 280. Wskutek przewlekłych zabiegów, od jesieni 1937 r. "wawelberczycy" mogli pro foro interno uznawać się za studentów lub pracowników szkoły wyższej nieakademickiej, lecz w zestawieniach oficjalnych szkół wyższych z 1939 r. zakład nadal nie występował RPiG, s. 250, 508, 514.

100 Zarys dziejów wojskowości..., s. 4,41.

101 Centrum Wyższych Studiów Wojskowych miało przygotowywać generałów i pułkowników wszystkich rodzajów broni, będących zarazem absolwentami Wyższej Szkoły Wojennej lub jej odpowiedników za granicą, „do roli wyższych d[owódców] drogą pogłębiania i uzupełniania wiadomości [...] i rozszerzania ich wiedzy ogólnej do ram niezbędnych do roli kierowniczej w wojnie współczesnej”. Kurs trwał zrazu 10 miesięcy, a w 1926 r. został zintensyfikowany i skrócony do 6-8 miesięcy. Program uzupełniono o zagadnienia związane z pracą pokojową, adresując go przede wszystkim do dowódców związków taktycznych i kandydatów na te stanowiska - Zarys dziejów wojskowości..., s. 4,41-4,4,2, 534; Centrum Wyższych Studiów Wojskowych, [w:] Encyklopedia wojskowa, red. O. Laskowski, t. I, A - Custozza, Warszawa 1931, reprint: Warszawa 1996 , s. $607-608$.

102 Centralny Instytut Wychowania Fizycznego, [w:] Encyklopedia wojskowa, s. 598. CIWF powstał „z potrzeby kształcenia nauczycieli i instruktorów dla szkół wszelkiego typu". Zob. też: P. Rozwadowski, Państwowy Urzad Wychowania Fizycznego i Przysposobienia Wojskowego 1927-1939, Warszawa 2000.

103 Academy of Fine Arts..., s. [12].

104 S. Czerwiński, Przemówienie na otwarciu Oddziału Wolnej Wszechnicy Polskiej $w$ Łodzi $w$ dn. 28 października 1928 r., [w:] tegoż, O nowy ideat wychowawczy, Warszawa 1934, wyd. II, s. 105-108. W podobnym duchu, zwracając uwage na podejmowanie zadań naukowych „nie przez organa władzy państwowej, ale przez placówkę społeczną", szef resortu wypowiedział się półtora roku później uznając, że inicjatywa wileńskich kręgów naukowych stanowi dowód „istnienia w naszym społeczeństwie zdrowych i silnych państwowotwórczych pierwiastków". - Przemówienie na uroczystości otwarcia Instytutu Badań 
Naukowych Europy Wschodniej $w$ Wilnie $w$ dn. 23 lutego 1930 r. (tamże, s. 144,-145). O źródłach projektów reformatorskich zob. Konstytucja a wychowanie publiczne. Odczyt wygłoszony $w$ Wilnie $w$ dn. 28 listopada 1929 r. (tamże, s. 40-55).

105 I.P. Maj, Działalność Instytutu Wschodniego w Warszawie 1926-1939, Warszawa [2007], s. 90-92.

106 RPiG, s. 580-581; M. Ślusarska, Teatr, [w:] Encyklopedia Historii..., s. 456.

107 RPiG, s. 508, 514.

108 A. Podolska-Meducka, Szkoła Główna Handlowa. 1933-1939, [w:] Historia Szkoły Głównej Handlowej w Warszawie 1906-2006, red. W. Morawski, Warszawa 2006, s. $65-67$.

109 RPiG, s. 48o-482, 527-529; Polska współczesna..., s. 143-14.4.

110 Pierwsze projekty w tej materii narodziły się w latach 1923-1925, za rządów tzw. większości narodowej: w drugim gabinecie Wincentego Witosa i drugim gabinecie Władysława Grabskiego zob. S. Głąbiński, Wspomnienia polityczne, cz. I-III, Pelplin 1939, s. 534; S. Grabski, Pamiętniki, oprac. W. Stankiewicz, Warszawa 1989 , t. 2, s. 24,2-243.

111 J. Jędrzejewicz, W służbie idei. Fragmenty pamiętnika i pism, Londyn 1972, s. 123-163. Por. [ks.] B. Żongołłowicz, Dzienniki $1930-1936$, s. $209 \mathrm{n}$.

112 W. Jędrzejewicz, Wspomnienia, oprac. J. Cisek, Wrocław 1993, s. 216-217. Należy pamiętać, że pełny kurs w nowym systemie (i to tylko w zakresie gimnazjum i liceum ogólnokształcącego) odbył przed wybuchem II wojny światowej jedynie rocznik 1920, składający maturę na kwartał przed napaścią Niemiec na Polskę. Poza tym zmiany programowe dokonane przez prof. W. Świętosławskiego, następcę W. Jędrzejewicza, wypaczyły istotę liceum jako szkoły przygotowującej do studiów na uczelniach - tamże, s. 233 .

113 Pierwsze przejawy sprzeciwu miały miejsce podczas akcji protestacyjnej przeciw uwięzieniu byłych posłów w więzieniu w Brześciu nad Bugiem, w postaci listu otwartego, który podpisało łącznie 320 profesorów (głównie z UJ, PW, UP, PW i SGGW) - zob. D. Mycielska, Postawy polityczne profesorów wyższych uczelni $w$ dwudziestoleciu międzywojennym, [w:] Inteligencja polska $w X I X i X X$ wieku. Studia 4, red. R. Czepulis-Rastenis, Warszawa 1985 , s. 304-312.

114 Ustawa z dnia 15 marca 1933 r. o szkołach akademickich, DURP, 1933, nr 29, poz. 247. Krótka analiza - S. Mauersberg, Szkolnictwo, s. 4,40-4,4.1.

115 D. Mycielska, Postawy polityczne profesorów..., s. zo6, 310.

116 Por. T. Manteuffel, Uniwersytet Warszawski w latach 1915/16 - 1934/35, s. 5o; W. Świętosławski, Uwagi o projekcie nowej ustawy o szkołach akademickich, Warszawa 1932, na prawach rękopisu, s. 7 (interpunkcja zmieniona).

117 T. Manteuffel, Uniwersytet Warszawski w latach $1915 / 16-1934 / 35$, s. 51-54.

118 Tamże, s. 57-58. Por. też SUW 1932/1933, s. $23-24$.

119 W. Świętosławski, Uwagi o projekcie..., s. 3-10.

120 Rozporzqdzenie Prezydenta Rzeczypospolitej $z 24$ lutego 1928 o stosunku służbowym profesorów państwowych szkót akademickich i pomocniczych sit naukowych tych szkót, DURP, 1928, nr 24, poz. 204, znowelizowane $27 \mathrm{X} 193^{2}$ (DURP, $193^{2}$ r., nr 94, poz. 819).

121 J. Jędrzejewicz, W stużbie idei..., s. 167 .

122 SUW 1933/1934, s. 7. W tym momencie UW miał 22 katedry nieobsadzone, a 4, unieruchomione. O nominacji przyszłej żony ministra, Cezarii Baudouin de Courtenay, $I^{\circ}$ voto Vasmer, $2^{\circ}$ voto Ehrenkreutz, na katedrę etnologii i etnografii Polski mocno krytycznie pisze ks. Żongołłowicz (Dzienniki $1930-1936$, s. 543).

123 O stosunkach między kolejnymi rektorami a MWRiOP zob. tamże, np. s. 66, 163 , 381, 477. 
124 D. Mycielska, Postawy polityczne profesorów..., s. 317-320.

125 T. Manteuffel, Uniwersytet Warszawski w latach $1915 / 16-1934 / 35$, s. 58 .

126 E. Jarra, Wspomnienia o Uniwersytecie Warszawskim..., s. 19

127 [Ks.] B. Żongołłowicz, Dzienniki 1930-1936, s. 422. Tam również obszernie o przebiegu prac nad ustawą i toczących się wokół niej sporach (s. 381, 4113-4.72).

128 RPiG, s. 534. Szerzej o współpracy sił zbrojnych ze światem nauki - M. Jabłonowski, Wobec zagrożenia wojna. Wojsko a gospodarka Drugiej Rzeczypospolitej w latach 1935-1939, Warszawa 2001, s. 248-264.

129 W. Świętosławski, Przemówienie na I. posiedzeniu Rady Nauk Ścistych $i$ Stosowanych 29 listopada ${ }_{193} 6 \mathrm{r}$, Kraków 1936, s. [5-6].

130 Por. m.in. W. Świętosławski, Przyrost ludności w Polsce i jego konsekwencje, Warszawa 1937, nadb. z: „Oświata i Wychowanie" (dalej: OiW), 1937, z. 7, s. 11-16. Z rozważań ministra wynikało, że skutkiem wyżu demograficznego liczebność roczników młodzieży (19-22 lata) wchodzących na rynek pracy w 1945 r. będzie o $87 \%$ wyższa niż w roku sporządzenia analizy. Oznaczało to, że przełom dekad przyniesie wielki wzrost liczby uczniów w szkołach średnich, zawodowych i wyższych.

131 Ustawa z dnia 2 lipca 1937 r. o zmianie ustawy $z$ dnia 15 marca 1933 r. o szkołach akademickich, DURP, 1937, $\mathrm{nr} 5^{2}$, poz. 4,06. Obowiązywała ona w praktyce od roku akademickiego 1937/1938.

132 Zarys dziejów wojskowości.., s. 647.

133 Por. RPiG, s. 467; Prawda o Szkole Wawelberga, s. 36 . Była to dawna szkoła zawodowa, wyróżniona, podobnie jak „Wawelberg i Rotwand”, przymiotnikiem honorowym w nazwie. S. Mauersberg (Szkolnictwo, s. 440) zalicza PWSBMiE do grupy szkół wyższych.

134 Szkoły te funkcjonowały już w roku akademickim 1937/38 - zob. RPiG, s. 516, z powołaniem się na "dane tymczasowe" MWRiOP. Placówek tych nie wykazano jednak we wcześniejszym zestawieniu opisowym (s. $5^{12}$ ), choć o pierwszej wspomniano w rozdziale Miasta (s. 385 ), a o ostatniej pośród wymienionych rozporządzeń (s. 450). Główna Szkoła Gospodarstwa Domowego we Lwowie była przypuszczalnie zreformowanym Prywatnym Żeńskim Instytutem Gospodarczego Kształcenia Kobiet w Snopkowie k. Lwowa - por. przyp. 14,2.

135 RPiG, s. 450, 523-524; T. Wawrzyński, Centralny Instytut Wychowania Fizycznego, [w:] Encyklopedia Historii..., s. $55^{-} 5^{6}$.

136 A. Glimos-Nadgórska, Szkolnictwo i oświata pozaszkolna, [w:] Województwo śląskie (1922-1939). Zarys monograficzny, red. F. Serafin, Katowice 1996, s. 491. Tak jak warszawska i poznańska PWSBMiE, była ona dawną szkołą zawodową, wyróżnioną nazewniczo z racji osiągniętego poziomu (zał. 1922).

137 I.P. Maj, Działalność Instytutu Wschodniego..., s. 14,2 n. Powodem głównym były trudności finansowe, lecz poważną rolę odegrały narastające różnice zdań pomiędzy dawnymi protektorami uczelni i związanymi z nią osobistościami a instancjami państwowymi, które od 1936 r. stopniowo usztywniały kurs w dziedzinie polityki narodowościowej. Wszystko to przyniosło gruntowną reorganizację Instytutu Wschodniego, rezygnację z działalności dydaktycznej, poddanie placówki ściślejszemu nadzorowi ze strony Ministerstwa Spraw Zagranicznych i Oddziału II Sztabu Głównego WP, a w rezultacie zmiany personalne.

$138 \mathrm{~W}$ wydawnictwie przygotowanym do druku w 1937 r. (Polska współczesna..., s. 145), wymienione są jako „wyższe szkoły”; w wydanym w 1939 r. RPiG (s. 512) figurują jako akademie, lecz nadal w kategorii „nie wykonujące praw”.

139 R. Jakubów, Akademia Nauk Politycznych $w$ Warszawie, [w:] Encyklopedia Historii..., s. 14 . 
140 Por. A. Glimos-Nadgórska, Szkolnictwo $i$ oświata pozaszkolna, s. 4.91, 495, 502. Poza Katowicami pedagogia (zob. przyp. 9o) istniały w Kielcach, Krakowie, Krzemieńcu, Lublinie, Lwowie, Poznaniu, Toruniu, Wilnie i Warszawie. Zajęcia w nich rozpoczęły się jesienią 1937 r. Polska współczesna..., s. 127. Po 1945 r. w oparciu o część z nich (np. Kielce, Kraków) utworzono wyższe szkoły pedagogiczne, przekształcone w ostatnich dziesięcioleciach w uniwersytety.

141 Zob. A. Tarkowska, Gdynia między wojnami..., s. $7^{2}$ n. Niewykluczone, że zostałby wykorzystany projekt całego kompleksu Szkoły Handlu Morskiego i Techniki Portowej, opracowany w końcu lat 20., a zrealizowany tylko fragmentarycznie - M. Sołtysik, Gdynia. Miasto dwudziestolecia międzywojennego. Urbanistyka i architektura, Warszawa 1993, s. 165-167.

142 Zob. materiał propagandowy z epoki: Polska współczesna..., s. 199 n. Jednymi z pierwszych miały być, znajdujące się od $193^{8}$ r. w stadium reorganizacji zakłady typu wyższego, Państwowa Wyższa Szkoła Gospodarstwa Wiejskiego w Cieszynie i Prywatny Żeński Instytut Gospodarczego Kształcenia Kobiet w Snopkowie k. Lwowa (tamże, s. 134; RPiG, s. 472).

143 [W. Świętosławski], Przemówienie P[ana] Ministra Wyznań Religijnych i Oświecenia Publicznego oraz referaty wygłoszone na posiedzeniu Państwowej Rady Oświecenia Publicznego $w$ dniu zo listopada 1938 r., Warszawa 1939, nadb. z: OiW, 1938, z. 10, s. 11.

144 [W. Świętosławski], Przemówienie P[ana] Ministra Wyznań Religijnych i Oświecenia Publicznego wygłoszone na posiedzeniu Komisji Budżetowej Sejmu w dniu 26 stycznia 1939 roku, Warszawa 1939, nadb. z: OiW, 1939 , z. 2, s. 28-29 (uzup. M.P.D.).

145 K. Bartel, Przemówienie w Senacie przy budzecie Ministerstwa Wyznań Religijnych i Ó́wiecenia Publicznego $w$ dniu 13 marca 1939 r., Warszawa 1939, s. 5 (uzup. M.P.D.).

146 Szerzej: Polska współczesna..., s. 199-221. Przykład tzw. Centralnego Okręgu
Przemysłowego: J. Ostrowski, Widly Wisty i Sanu, Warszawa 1938, s. 7-49, 111-132, 135-233; M.P. Deszczyński, Rzeszów na mapie gospodarczej II Rzeczypospolitej, [w:] Rzeszów dawny i współczesny. Gospodarka, red. K. Kaszuba, A. Szromnik, Rzeszów 2005, s. 105-111.

147 [W. Świętosławski], Przemówienie P[ana] Ministra W[yznań] R[eligijnych] i O[świecenia] P[ublicznego] prof. $d r$. ... na Komisji Budżetowej Sejmu $w$ dniu 3 lutego 1938 roku, Warszawa 1938, nadb. z: OiW, 1938, z. 2, s. 7, 11; RPiG, s. $45^{1-4} 5^{2}$.

148 W roku akademickim 1937/1938 MWRiOP przyznało stypendia po 1200 zł 20 aplikantom, zaś piętnaście innych instytucji udzieliło wsparcia, w przeciętnej wysokości 4,15 zł, dalszym 94 osobom - RPiG, s. 518-520. Kwoty te można szacować na 20-60\% kosztów utrzymania studenta w Wolnym Mieście Gdańsku (nie licząc czesnego). Projektowi stypendialnemu towarzyszyła akcja propagandowa "Studiuj w Gdańsku” - E. Kołodziej, Dzieje Polonii w zarysie..., s. 128-129.

149 Por. np. informator Stypendia na dalsze wyższe studia $w$ Anglii dla absolwentów z Polski na rok 1938-1939, [Warszawa 1937].

150 Np. zajmujący się teorią ekonomii systemów totalitarnych, a zatrudniony na Uniwersytecie Stefana Batorego i kierujący działem studiów gospodarczych Instytutu Europy Wschodniej prof. Stanisław Swianiewicz współpracował z Osteuropa Institut we Wrocławiu i Institut für Osteuropeische Wirtschaft Uniwersytetu w Królewcu. Przebywał też w Berlinie, Kilonii i Hamburgu - S. Swianiewicz, W cieniu Katynia, Warszawa 1990, s. 15-26. Nb. do współpracy o charakterze analitycznym usiłował pozyskać kierowaną przez niego placówkę attachat wojskowy Cesarstwa Japonii w Warszawie. Po konsultacjach z rektorem prof. Stefanem Ehrenkreutzem, MSZ i Oddziałem II SG WP ,jeden ze stypendystów instytutu [...] zgodził się [...] robić dla attachatu 
japońskiego opracowania sowieckiej sytuacji gospodarczej na zasadzie swojej prywatnej umowy z czynnikami japońskimi” (tamże, s. 155-157).

151 Przykładowo w czerwcu 1935 r. przebywał w Polsce minister oświaty Szwecji Arthur Engberg. W trakcie pobytu podpisano protokół w sprawie współpracy kulturalnej między Polską a Szwecją, mocą którego powołano w obu krajach specjalne komitety koordynujące zaplanowane działania, także na polu nauki. W roku następnym rewizytował gościa prof. Świętosławski, a z wykładami pojechali tam wkrótce filolog klasyczny prof. Tadeusz Zieliński i historyk prof. Oskar Halecki P. Jaworski, Polska niepodległa wobec Skandynawii 1918-1939, Wrocław 2001, s. 205-206. Należy tu podkreślić rolę, jaką w procesie zbliżenia odgrywały stowarzyszenia społeczne i inicjatywy osobiste naukowców - vide przykłady z Bułgarii i Włoch: Dokumenty $i$ materiały do historii stosunków polsko-bułgarskich, red. W. Balcerak, t. I, 1918-1944, Wrocław 1982; Documenti per la storia delle relazioni italo-polacche (1918-1940). Dokumenty dotyczqce historii stosunków polsko-włoskich (1918-1940 r.), a c.d./oprac. M. di Simone, N. Eramo, A. Fiori, J. Stoch, [Roma] 1998, t. I-II.

152 Kierowane np. do przyszłych współpracowników politycznych „ruchu prometejskiego" - por. I.P. Maj, Działalność Instytutu Wschodniego..., s. 45 .

153 Zob. P. Stawecki, Oficerowie dyplomowani wojska Drugiej Rzeczypospolitej,

Wrocław 1997, s. 13-20, 22-29, 33. W przypadku Wyższej Szkoły Wojennej była to współpraca z École Supérieure de Guerre, wynikająca m.in. z obsadzenia do 1928 r. kluczowych stanowisk w uczelni warszawskiej przez oficerów francuskich.

154 Przykłady - AUW, AcUW/RP 118, minuta pisma rektora [prof. I. Koschembahra-Łyskowskiego] i Senatu UW do zarządu Instytutu Franklina w Filadelfii z 3 [VII] 1924, r. oraz adres jubileuszowy To The University College London, [Warszawa 1927].
155 Warunki pracy takiej osoby przedstawił Hiranmoy Ghosal, pracownik Instytutu Orientalistycznego UW, jedyny Hindus, który w okresie międzywojennym przebywał dłuższy czas w Polsce - H. Ghosal, Ksiega Walhalli, Warszawa 1971, s. 54, 63-64, 77-78.

156 Zob. skrypt wykładu prof. Kazimierza Michałowskiego Wykopaliska polskie w Egipcie - SUW 1937/1938, s. 106-108.

157 Por. AUW, AcUW/RP 119, kopia pisma kierownika Instytutu Orientalistyki UJP prof. Ananiasza Zajączkowskiego do rektora Antoniewicza z 21 IV 1937 r. Przykładowy wykaz jednorazowych stypendiów - SUW 1930/1931, s. 16.

158 E. Jarra, Wspomnienia o Uniwersytecie Warszawskim..., s. 23-24 (uzup. M.P.D.; pisownia poprawiona).

159 Były to: Austria, Belgia, Brazylia, Bułgaria, Czechosłowacja, Dania, Egipt, Estonia, Finlandia, Francja, Grecja, Hiszpania, Holandia, Japonia, Jugosławia, Indie, Kanada, Litwa, Łotwa, Niemcy, Norwegia, Palestyna, Portugalia, Rumunia, Stany Zjednoczone Ameryki, Syria, Szwajcaria, Szwecja, Turcja, Wielka Brytania, Włochy, Związek Południowej Afryki, Związek Sowiecki.

160 Por. Zarys dziejów wojskowości..., s. 485486, 489-49o, 492-496; SUW 1937/1938, s. $75-77$. 30 IV 1938 Legia Akademicka UJP liczyła 876 studentów I i II roku.

161 Wiązał się z tym udział pracowników uczelni w kształceniu młodych dyplomatów, pełniących służbę na pierwszej linii obrony interesów państwa na płaszczyźnie międzynarodowej.

162 Sprawozdanie z inauguracji prac Instytutu [Prawa Lotniczego i Zagadnień Gospodarczych Lotnictwa przy Wydziale Prawa Uniwersytetu Warszawskiego] z dnia 20 października 1938 r., Warszawa 1938, s. 4-5. Goście, m.in. minister komunikacji płk dypl. w st. sp. Juliusz Ulrych oraz dowódca lotnictwa gen. pil. inż. Ludomił Rayski, mogli z tej okazji wysłuchać erudycyjnego wykładu kierownika instytutu, nb. związanego z endecją, prof. Romana Rybarskiego „Lotnictwo w życiu krajów zamorskich”. 
163 Obszerna dokumentacja w: AUW, AcUW/RP 81, t. 1-2. Najstarszy dokument to ściśle tajne pismo okólne szefa Biura Personalnego MWRiOP dr. Antoniego Owsionki z 20 IX $193^{2}$ r. (k. 2). Na cele opl-pgaz., nie licząc wydatków osobowych i biurowych, preliminowano w roku akademickim 1939/1940 niemałą sumę $1624,25 \mathrm{zl}$.

164 Por. H. Ghosal, Ksiega Walhalli, s. 63 n.

165 Tylko w ciągu 4, tygodni (31 III-2 8 IV 1939) 1207 pracowników zadeklarowało 190500 zł na POP oraz 27350 zł na FON. Przeciętna preliminowana darowizna wyniosła więc ok. 180 zł - AUW, AcUW/RP 81, t. 2, k. 213, notatka kwestora UJP wz. kierownika Rachuby Wacława Łapińskiego z 29 IV 1939 r. Zob. też AUW, RP/WP 104.

166 Szczątek dokumentacji dotyczącej spraw mobilizacji osobowej - AUW, AcUW/RP 114 .

167 Dane za: S. Mauersberg, Szkolnictwo, s. 443, skorygowane przez autora. Wedle "danych tymczasowych MWRiOP" zawartych w RPiG (s. 451) było to 4,8,2 tys. osób w roku akademickim 1937/1938. Różnica wynika z doliczenia słuchaczy wyższych szkół wojskowych, duchownych i muzycznych.

168 Dane dla roku akademickiego 1936/1937 za: Z. Zaniewicki, L'organisation de l'enseignement supérieur en Pologne, Paris [1938], nadb. z: L'organisation de l'enseignement supérieur, Paris $193^{8}$, s. 16 .

169 Nowsze konkluzje - S. Mauersberg, Szkolnictwo, s. 4,43.

170 Z. Landau, Michał Kalecki, [w:] Encyklopedia Historii..., s. 145; K. Leowski, Michał Kalecki (1899-1970), [w:] Poczet wybitnych profesorów SGHSGPiS 1906-1986, red. A. Minkiewicz, Warszawa 1986, s. 61-102.

171 M.M. Drozdowski, Warszawa w latach 1914-1939, s. 378-379, 381-388; R. Mączewski, Warszawa między wojnami. Opowieść o życiu Stolicy 1918-1939, Łódź-Warszawa 2009, s. 127-129.
172 Uniwersytet Jagielloński dysponował nawet większą liczbą wydziałów i jednostek afiliowanych, ale za to mniejszą liczbą katedr (123 wobec 148 w UJP). Młodemu i dość dużemu Uniwersytetowi Poznańskiemu (107 katedr) brakowało wydziałów teologicznych, farmaceutycznego i weterynaryjnego, natomiast Uniwersytet Stefana Batorego miał za sobą dłuższy niż UW/UJP okres bezwzględnej przerwy w działalności (1832-1919) i rozwijał się mniej dynamicznie niż UP (95 katedr). UJK liczył 96 katedr - AUW, AcUW/RP 5o, k. 1, kopia elaboratu „Dane do ustalenia klucza podziału kredytów par. 16", maszynopis b.d. [1938].

173 Zob. T. Manteuffel, Uniwersytet Warszawski w latach 1915/16 - 1934/35, s. 49; RPiG, s. 491-4.96 (skład na rok akademicki 1937/1938); Dzieje Uniwersytetu Warszawskiego 1915-1939, red. A. Garlicki, Warszawa 1982, s. 312-315 (obejmuje téz wykaz dziekanów) oraz ks. E. Bursche, Wydziat Teologii Ewangelickiej, [Warszawa 1925]; Uroczystość otwarcia Studium Teologii Prawosławnej Uniwersytetu Warszawskiego dnia 8 lutego 1925 roku, Warszawa 1926.

174 Por. T. Manteuffel, Uniwersytet Warszawski w latach 1915/16-1934/35, s. 39-4,0; Uniwersytet Warszawski. Ustawy i rozporzadzenia M[inisterstwa] W[yznań] R[eligijnych] i Ośw[iecenia] Publ[icznego], dotyczace szkól akademickich (ze szczególnym uwzględnieniem Wydziału Lekarskiego, Oddziału Farmaceutycznego i Studium Weterynarii), oraz Statut Uniwersytetu Warszawskiego, Regulamin Senatu Akademickiego $i$ Wydziału Lekarskiego Uniwersytetu Warszawskiego, Warszawa 1925 .

175 Statut Uniwersytetu Warszawskiego, Regulamin Senatu Akademickiego i Wydziału Lekarskiego..., s. 265-311. Zachowane szczątki dokumentacji dotyczącej relacji z władzami zob.: AUW, AcUW/RP 22 oraz zespół akt MWRiOP w zasobie Archiwum Akt Nowych w Warszawie.

176 Memorial $w$ sprawie projektu ustawy o ustroju szkolnictwa, Warszawa 1928, s. 11. 
177 J. Mazurkiewicz, Mowa J[ego] M[agnificencji] Rektora Uniwersytetu Warszawskiego prof. dr. ... wygłoszona $w$ dniu otwarcia roku szkolnego 1921/22 $w$ Auli Uniwersytetu Warszawskiego, [Warszawa] b.r.w., s. 5; J. Ujejski, I. Myśl polska sto lat temu. Wykład wygłoszony podczas uroczystej inauguracji roku akademickiego 1932-33 $w$ dniu 23 października 1932. II. Przemówienie do młodzieży przed aktem immatrykulacji, Warszawa 1933 (podkr. oryg.).

178 W. Antoniewicz, Przemówienie wygłoszone podczas uroczystej inauguracji roku akademickiego $1936-37 \mathrm{w}$ dniu 18 października ${ }_{193} 6$, Warszawa 1936 , s. 8-10 (interpunkcja zmieniona).

179 Por. S. K[onopka], Odsłonięcie portretu Marszałka Józefa Piłsudskiego w auli Uniwersytetu Warszawskiego, Warszawa 1934, nadb. z: „Lekarz Wojskowy” 1934, nr 10, s. 5-27. W trakcie uroczystości przemawiał rektor Pieńkowski, dziekan Wydziału Lekarskiego prof. Franciszek Czubalski oraz komendant Centrum Wyszkolenia Sanitarnego gen. dr Jan Kołłątaj-Srzednicki.

180 SUW 1934/1935 - 1935/1936, s. 25-28. Por. też. T. Manteuffel, Uniwersytet Warszawski w latach 1915/16 - 1934/35, s. 58-59 (interpunkcja zmieniona).

181 Por. AUW, AcUW/RP 18, k. 1, „Statut Uniwersytetu Józefa Piłsudskiego w Warszawie", [Warszawa 1938]; SUW 1937/1938, s. 16. Co interesujące, najprawdopodobniej nigdy nie nastąpił formalny powrót do nazwy „Uniwersytet Warszawski" mocą ustawy lub dekretu. Rezygnacja z Piłsudskiego jako patrona nastąpiła de facto już w latach II wojny światowej, gdy działająca w konspiracji uczelnia przestała posługiwać się nazwą przyjętą w $1935 \mathrm{r}$. Zachowana dokumentacja z lata 1945 r. (AUW, BR/S-1) wskazuje, iż powrotu do niej nie brano również pod uwagę po zakończeniu wojny, co nie wydaje się zresztą szczególnie zaskakujące. W latach 8 o. do miana "Uniwersytet Józefa Piłsudskiego" odwoływało się chętnie Niezależne Zrzeszenie Studentów, lecz po 1989 r. władze uczelni uznały, iż zmiana nazwy dokonała się w sposób wiążący w okresie 1939-1944.

182 Uroczystego aktu dopełnił marszałek E. Śmigły-Rydz - SUW 1936/1937, s. 8.

183 Tamże, s. 18.

184 SUW 1934/1935 - 1935/1936, s. 30.

185 SUW 1937/1938, s. 91-102. (podkr. oryg.). Tamże wystąpienia obu doktorów honoris causa.

186 Zob. zestawienie Doktoraty honorowe - http://www.uw.edu.pl/uniwersytet/ historia (odczyt z 10 III 2015 r.) oraz sprawozdania rektorów z poszczególnych lat. Kopie niektórych dyplomów - AUW, AcUW/RP 115. E. Jarra (Wspomnienia o Uniwersytecie Warszawskim..., s. 16) tak zapamiętał uroczystość z udziałem F. Focha z 1923 r.: „Wysokie sfery ministerialne słuchać nawet nie chciały o jego wizycie w Uniwersytecie, podając wśród licznych powodów odmowy również... rzekome cierpienia pęcherzowe Marszałka. Wówczas Senat Akademicki udał się wprost do Ambasadora Francji [Hector André de Panafieu] i ku swej wielkiej satysfakcji otrzymał odpowiedź, że Foch zażądał stanowczo wstawienia do programu półgodzinnej wizyty w Uniwersytecie. Nieczęsto bywał on tak zapchany młodzieżą, jak dnia owego i nieczęsto ręce jej tak gorąco składały się do oklasku, jak na widok krępej, wąsatej postaci nowoczesnego pogromcy Hunów. Witający go imieniem młodzieży student, mimo otrzaskania z podobnymi występami, nie mógł z wrażenia dokończyć mowy. Odpowiadając prostymi słowami Marszałek położył główny nacisk na to, że po wywalczeniu niepodległości, najważniejszym zadaniem będzie obrona jej przed wrogami" (interpunkcja zmieniona).

187 T. Manteuffel, Uniwersytet Warszawski $w$ latach wojny $i$ okupacji. Kronika 1939/40 - 1944/45, Warszawa 1948, nadb. z: Straty Kulturalne Warszawy, red. W. Tomkiewicz, Warszawa 1948, s. 9 .

188 Dokumentacja w tej sprawie zob.: AUW, AcUW/RP 94 . 
189 Tamże, bpg (po k. 57),

list prof. W. Sierpińskiego

i prof. S. Mazurkiewicza z Gabinetu

i Seminarium Matematycznego

do rektora UW ks. prof. A. Szlagowskiego z 1 VII $1927 \mathrm{r}$

190 Tamże, k. 102, „Spis przedmiotów inwentarza ruchomego, zapisanego w księdze inwentarzowej Zarządu Gmachów Uniwersytetu Warszawskiego, ks[ięga] inwen[tarzowa] A" z 4, VII 1927 r., maszynopis, załącznik do pisma Zarządu Gmachów Uniwersytetu Warszawskiego do rektoratu UW.

191 Trzynaście na terenie głównym (nr hipoteki 394), jedenaście w Ogrodzie Botanicznym oraz gmachy: Obserwatorium Astronomicznego (Al. Ujazdowskie 6/8), Anatomicum (ul. T. Chałubińskiego 5), dawny Medycyny Sądowej (ul. W. Oczki 2), obecny Medycyny Sądowej (ul. W. Oczki 1), Apteki Wzorcowej (ul. W. Oczki 3), Kliniki Dermatologicznej (ul. Koszykowa 82a), Kliniki Psychiatrycznej (ul. Konwiktorska 7) i Instytutu Fizyki (ul. Hoża 69).

192 Gmach Kliniki Pediatrycznej przy ul. Marszałkowskiej 24.

193 Tamże, k. 101, „Wykaz objektów majątku państwowego, zapisanych w księgach inwentarzowych A Zarządu Gmachów Uniwersytetu Warszawskiego" z 4, VII 1927 r., maszynopis, załącznik do pisma Zarządu Gmachów UW do rektoratu.

194 Tamże, k. 99-100, pismo kierownika BUW dr. Z. Batowskiego do rektora ks. prof. A. Szlagowskiego z 14, XI 1927 r. Płótno H. Siemiradzkiego, też rewindykowane z ZSRS, zaginęło podczas II wojny światowej - J. Miziołek, Uniwersytet Warszawski. Dzieje i tradycja, Warszawa 2005, s. 188-189. O Gabinecie Rycin obszernie - Z. Batowski, Zbiór graficzny $w$ Uniwersytecie Warszawskim. $Z_{49}$ ilustracjami, Warszawa 1928. Autor zapisał: „Po 91 latach bezprawie zostało naprawione. Na zasadzie Traktatu ryskiego wróciło od razu wszystko, nie bez pewnych jednak braków, których widocznie nie dało się zrewindykować. [...] Wiadomo, że przezwyciężyć trzeba było wiele trudności, czynionych ze strony rosyjskiej Delegacji naszej przy odbiorze należności, mimo że obiekt wydania był niesporny i dokładnie określony, a akcja rewindykacyjna umiejętnie przeprowadzona" (s. 8-9).

195 Por. np. AUW, AcUW/RP 94, oszacowanie mienia Zakładu Geologicznego UW z 9 XI 1927 r., sygnowane przez kierownika ZG UW prof. Jana Lewińskiego. Majątek wyceniono na $162186 \mathrm{zł}$.

196 AUW, AcUW/RP 94, k. 6o, pismo bardzo pilne dyrektora Obserwatorium Astronomicznego prof. M. Kamieńskiego do rektora ks. prof. A. Szlagowskiego z 13 X 1927 r.

197 AUW, AcUW/RP 94, k. 43, pismo prof. Jana Baudoina de Courtenay'a do rektoratu UW z 1 VII 1927 r.

198 AUW, AcUW/RP 94, k. 39. Podobnie zob. k. 48-5o, kopia pisma kierownika Seminarium Filologii Germańskiej prof. Zygmunta Łempickiego do Ministerstwa Wyznań Religijnych i Oświecenia Publicznego z 5 XI 1927 r. wraz z załącznikiem.

199 T. Manteuffel, Uniwersytet Warszawski w latach $1915 / 16-1934 / 35$, m.in. s. 67 , 86-87, 96-98, 121-137, 181-199, 216-228, 247-251, 260-263 (omówienia zakładów poszczególnych wydziałów).

200 Tamże, s. 270-271. Autor ten pisał: „Biblioteka [...] została uznana za bibliotekę okręgową warszawską (województwa: warszawskie, łódzkie i lubelskie). Charakter biblioteki okręgowej ma jednak szereg niewygód, zmusza bowiem [...] książnicę o charakterze przede wszystkim naukowym, do przechowywania całej produkcji drukowanej okręgu warszawskiego". To, co było wtedy niedogodnością, po zniszczeniach lat 1939-1945 stało się błogosławieństwem dla badaczy zajmujących się okresem międzywojennym.

201 W. Stummer, Biblioteka Uniwersytecka $w$ Warszawie, [w:] Uniwersytet Warszawski 1808-1818-1958..., s. 38; SUW 1925/1926, s. 13. Większość rękopisów rewindykowanych z ZSRS przekazano powstającej Bibliotece 
Narodowej Józefa Piłsudskiego T. Manteuffel, Uniwersytet Warszawski w latach $1915 / 16-1934 / 35$, s. 271 .

202 Sprawozdanie Zakładu Geograficznego Uniwersytetu Warszawskiego. Compterendu de l'Institut de Géographie de l'Universite de Varsovie, Warszawa 1924, s. 3-6.

203 Nawet takich jak przyszły wybitny oficer dyplomowany por./kpt. Roman Umiastowski, który usiłował sfinalizować na UW studia przerwane służbą na froncie i wznawiane na Uniwersytecie Poznańskim. W 1924, r. opublikował on znakomitą Geografie wojenna Rzeczypospolitej Polskiej i ziem ościennych - P.M. Żukowski, Roman Umiastowski. Szkic biograficzny, [w:] R. Umiastowski, Dziennik wojenny 18 IX 1939 - 19 IX 1945 , oprac. P.M. Żukowski, Warszawa 2009 , s. $29-35$.

204 W tym przypadku, w kolejności znaczenia, drogą darów, wymiany i zakupów. Przykłady przyrostów: SWHUM 1927/1928, s. 30, 32-33, 37-38, 53, 57-6o, 65, 67, 72-74, 77, 79; SWL 1928/1929, s. 8-9; SWP 1929/1930, s. 36-41, 46-47, 58; SWTE 1931/1932 s. 25-29; SWTK 1934/1935, s. 17-18; SWM-P 1937/1938, s. 20, 22-23, 27-28, 31, 34-35, 40-41, 43, 46-49, 55-56, 59; Sprawozdanie z działalności Wydziału Farmaceutycznego Uniwersytetu Józefa Piłsudskiego $w$ Warszawie za rok akademicki 1937/38, [Warszawa 1938], maszynopis powielony w zbiorach AUW, s. 11-14.

$205 \mathrm{Na}$ temat stopniowego polepszania się warunków pracy innych jednostek UW zob. serie sprawozdań wydziałowych przechowywane w AUW oraz: W. Grzywo-Dąbrowski, Zakład Medycyny Sadowej Uniwersytetu Warszawskiego, [w:] Sprawozdanie z czynności Zakładu Medycyny Sadowej Uniwersytetu Warszawskiego za 1o-lecie 1921-1930 $r$. Compte rendu de l'Institut Médico-Légal a Varsovie pendant la période de 10 ans 1921-1930, Warszawa 1932, s. 3-7; T. Janiszewski, Sprawozdanie z działalności Zakładu Higieny
[Uniwersytetu Warszawskiego

i Uniwersytetu Józefa Piłsudskiego] za czas od lutego 1930 do września 1937 r., Warszawa 1938, nadb. z: „Lekarz Polski” 1938, nr 1, s. 2-5, 15-19; Dziesięciolecie Zakładu Psychologii Wychowawczej Uniwersytetu Józefa Piłsudskiego [w Warszawie] 1928-1938. Sprawozdanie opracowane przez Konwersatorium przy Zakładzie Psychologii Wychowawczej, red. M. Żebrowska, J. Kunicka, Warszawa 1938, s. 11 n. Źródłem aktowym ilustrującym stan wyposażenia pracowni chemicznych UW jest spuścizna inwentaryzacji dokonana na przełomie lat 1938/1939 w związku z przygotowaniami do biernej obrony przeciwlotniczej - AUW, AcUW/RP 81, k. 9on. Trzeba tu dodać, że z racji niedorozwoju wytwórczości krajowej urządzenia precyzyjne potrzebne w badaniach i dydaktyce można było początkowo zakupić jedynie za granicą, co wobec dążenia do ograniczenia przywozu i odpływu walut obcych przysparzało dodatkowych trudności. W latach 30. nastąpiła na tym polu poprawa, związana z rozwojem przemysłu w kraju, a tym samym obniżenia cen takiego sprzętu.

206 T. Manteuffel, Uniwersytet Warszawski w latach 1915/16-1934/35, s. 44 .

207 Majątek w pow. łukowskim, należący do Fundacji Stypendialnej im. Włodzimierza Młockiego założonej jeszcze w 1861 r., mającej na celu pomoc wybijającej się na polu naukowym młodzieży akademickiej. W 1933 r. został on oddany w dzierżawę "obywatelowi ziemskiemu" Zygmuntowi Strzeszewskiemu - por. np. AUW, AcUW/RP 87 i 88; SWP 1928/1929, s. 27.

208 Por. liczący 34, pozycje wykaz zapisów, funduszy stypendialnych i fundacji uniwersyteckich: SUW 1937/1938, s. 6o-61. Największy składnik spośród 357,7 tys. zł sumy (bez nieruchomości) stanowił zapis M. Górnickiego, opiewający na 120,1 tys. zł w papierach wartościowych, który w roku akademickim 1937/38 dał 5506,12 zł dochodu. W listopadzie 1938 r. powstała Fundacja Naukowa im. płk. Józefa Becka (tamże, s. 9-10), dysponująca 7o tys. zł ze składek pracowników służb zagranicznych 
na stypendia dla osób „specjalnie poświęcających się historii dyplomacji polskiej".

209 T. Manteuffel, Uniwersytet Warszawski w latach $1915 / 16$ - 1934/35, s. 48; Zarządzenie Ministra Wyznań Religijnych i Oświecenia Publicznego z dn. 14 lipca 1931 r. w sprawie zatwierdzenia statutu fundacji Smoguleckiej imienia Bogdana Hutten-Czapskiego, „Monitor Polski” 1931, poz. 284 . Jak z prostotą zapisał dawny kurator we wspomnieniach: „Od czasu mej młodości wiedziałem, że - głównie w Stanach Zjednoczonych Ameryki - ludzie zamożni, nie mający bliższych krewnych, znaczną część swego majątku przeznaczają na cele społeczne. Uznałem celowość takiej dobrowolnej ofiary [...] i postanowiłem również ze swej strony przyczynić się do poparcia celów kulturalnych. Podczas wojny doszedłem do przekonania, że w kierowaniu tą fundacją powinny mieć udział warszawskie uczelnie wyższe, u których kolebki stałem". B. Hutten-Czapski, Sześćdziesiąt lat życia..., t. II, s. 621-624. Donator uzyskał w dowód wdzięczności doktoraty honoris causa PW (nauki techniczne) oraz UW (medycyna). Otrzymał też Order Odrodzenia Polski I klasy.

210 Por. np. dokumentację planu finansowo-gospodarczego na rok akademicki 1939/1940 - AUW, AcUW/RP 54, k. 11. O utworzeniu Funduszu w 1932 r. - B. Jaczewski, Polityka naukowa państwa polskiego..., s. 149-150. Dane na temat ostatnich budżetów wykonanych SUW 1937/1938, s. 30-35.

211 T. Manteuffel, Uniwersytet Warszawski w latach $1915 / 16-1934 / 35$, s. 45 .

212 „Co do innych potrzeb Uniwersytetu, to potrzeba przede wszystkim budować" - I. Koschembahr-Łyskowski w SUW $1924 / 1925$, s. 18. Już wtedy dostrzeżono konieczność wzniesienia nowego gmachu BUW.

213 O tej sprawie nieco obszerniej: SUW $1926 / 1927$, s. 8-9.

214 SUW 1928/1929, s. 16-17 (podkr. oryg.).

215 SUW 1929/1930, s. 26-27; SUW 1930/1931, s. $3^{1-3^{2}}$.
216 SUW 1933/1934, s. 12-13. Można dodać, że pożar, który w październiku $1935 \mathrm{r}$. strawił poddasze Gmachu Pomuzealnego, był swoistym "dzwonem na trwogę" - zob. dokumentację fotograficzną w zbiorach Narodowego Archiwum Cyfrowego w Warszawie, sygn. 1-N-2392-1 do 6 oraz 1-N-2393-1 do 3 .

217 T. Manteuffel, Uniwersytet Warszawski w latach $1915 / 16$ - 1934/35, s. 45-46; SUW 1933/1934, s. 15; SUW 1934/1935 1935/1936, s. 19-20, 42-43.

218 Zasadnicze materiały w tej sprawie: AUW, AcUW/RP 5o, k. 14 n., „Preliminarz budżetowy remontu kapitalnego 1938/39"; AcUW/RP 52, k. 49 n. „Preliminarz budżetowy remontu kapitalnego 1939/40"; AcUW/RP 55, k. 25 n. „Preliminarz budżetowy remontu kapitalnego 194,0/4,1".

219 Tamże, sygn. AcUW/RP 52, k. 39 n., kopia „Wykazu niezbędnych remontów, które winny być wykonane w roku 1939/40 z planu finansowo-gospodarczego grupa II - Administracja - Rektor" z 14, VI 1939 r., sygnowanego przez intendenta

A. Zielińskiego. Do najważniejszych czynności zaliczono w tym dokumencie: remonty Zakładu Anatomii Patologicznej, Zakładu Farmacji Stosowanej,

Obserwatorium Astronomicznego,

Seminarium Filologii Klasycznej, wymianę ogrodzenia Ogrodu Botanicznego, modernizację sieci wodociągowej na terenie głównym (wraz z zainstalowaniem hydrantów przeciwpożarowych i budową studni artezyjskiej) oraz budowę składnicy sprzętu przeciwpożarowego, przeciwchemicznego i sanitarnego. Z kolei z zestawienia (k. 61) „Preliminarza budżetowego remontu kapitalnego na rok 1939/40" wynika, że główne pozycje w podgrupie „remontów gruntownych" stanowiła była Szkoła Główna (4,00 tys. zł) i Pałac Kazimierzowski (10o tys. zł), a w kategorii „Przebudowy i nadbudowy” przestrzeń między gmachami na terenie głównym ( 85 tys. zł) oraz Klinika Psychiatryczna (75 tys. zł) i BUW (5o tys. zł).

220 A.K. Wróblewski, 75 lat fizyki na Hożej, „Wiedza i Życie” 1996, nr 1, s. 36-37. 
221 B. Kaczorowski, T. Lis, Uniwersytet Warszawski. Przewodnik historyczny, Warszawa 1983, powiel., s. 17; J. Miziołek, Uniwersytet Warszawski..., s. 206.

222 Szeroko: Własnymi siłami. 9 czerwca 1928 r., Warszawa 1928; Komitet budowy gmachu dla Wydziału Farmaceutycznego Uniwersytetu Warszawskiego 1925-1932, Warszawa $193^{2}$

223 Z. Wielogórski, Historia Wydziału Chemii [Uniwersytetu Warszawskiego] - http://www.chem.uw.edu.pl/historia. php?group=fchem\&head=Historia (odczyt z 3 III 2015 r., kopia w posiadaniu autora).

224 O warunkach lokalowych Wydziału Lekarskiego por. m.in. S. Orłowski, W sprawie Instytutów Wydziału Lekarskiego Uniwersytetu Warszawskiego..., passim; A. Cyzewicz [właśc.: Czyżewicz], Rzut oka na dzieje i zadania kliniki położniczo-ginekologicznej Uniwersytetu Warszawskiego. Przemówienie wstępne przy otwarciu tej kliniki $w$ dniu 14 stycznia 1921 r., [Warszawa] 1921, s. 10; W obronie szkół akademickich. Odezwa Senatu Akademickiego Uniwersytetu Warszawskiego w sprawie gmachów Wydziału Lekarskiego oraz Studium Weterynarii w Grochowie, [Warszawa 1925], passim; Z. Michalski, Sprawozdanie z działalności kliniki wewnętrznej Uniwersytetu Warszawskiego w szpitalu św. Ducha za siedmiolecie 1918-1925 oraz rys historyczny tej kliniki, [Warszawa 1926], nadb. z: „Polskie Archiwum Medycyny Wewnętrznej", t. III, z. 2, s. 212 n.; SWL 1928/1929, s. 3-8; W. Grzywo-Dąbrowski, Zakład Medycyny Sadowej, passim; H. Bukowiecki, O funkcji społecznej uniwersytetów i osiagnięciach organizacyjnych Wydziału Farmaceutycznego Uniwersytetu Warszawskiego, [Warszawa 1948], nadb. z: „Farmacja Polska” 1948, nr 2, 3 i 4, passim.

225 Por. [J. Gordziałkowski], Uczelnia Weterynaryjna $w$ Warszawie, jej przeszłość, stan obecny i dalsze losy, Warszawa [1924], nadb. z: „Wiadomości Weterynaryjne", nr 45 (1924), s. 2-5; Wobronie..., passim; K. Millak, Walka o Wydział Weterynaryjny Uniwersytetu Warszawskiego i jej tło 1918-1927 (La lutte pour la création de la Faculté Vetérinaire de l'Université à Varsovie et son fond 1918-1927), Warszawa 1948, s. 11-12.

226 Zob. W. Pietrusiewicz, Stowarzyszenie Mieszkaniowe Spółdzielcze Profesorów Uniwersytetu Warszawskiego, [Warszawa] 2009 -http://sewerynow.waw.pl/index. php?option=com_content\&view= category\&layout=blog\&id=3\&Itemid $=3$ (odczyt z 3 III 2015 r., kopia w posiadaniu autora).

227 O wymienionych obiektach w ujęciu retrospektywnym - M. Leśniakowska, Architektura w Warszawie. Lata 1918-1939, Warszawa 2002, wyd. II, s. 29, 46, 62, 112113, 115, 123, 183; J. Zieliński, Atlas dawnej architektury ulic i placów Warszawy. Śródmieście historyczne, t. 1-15, Warszawa 1995-2011, passim, oraz portal internetowy Warszawa1939pl.

$228 \mathrm{~W}$ pierwszym przypadku, nastąpiło to już w roku akademickim 1918/1919, dzięki, jak stwierdził pamiętający te czasy autor, „osobistemu poparciu Naczelnika Państwa, Józefa Piłsudskiego" - T. Manteuffel, Uniwersytet Warszawski w latach 1915/16 1934/35, s. 45. Por. też: Wobronie..., s. 1-2. Wedle drugiego źródła Wojsko Polskie ostatecznie ustąpiło obszar na północ od ul. Koszykowej znacznie później, żywiąc przy tym nadzieję na przejęcie od UW terenów na Grochowie, gdzie zamierzano umieścić Szkołę Gazową.

229 AUW, AcUW/RP 52, k. 79-8o, kopia „Preliminarza budżetowego Uniwersytetu Józefa Piłsudskiego w Warszawie na rok 1939-40", s. 34-36. Korespondowała z tym, nie stroniąc jednak od podkreślenia dokonań uczelni na polu remontowo-budowlanym, wypowiedź rektora uczyniona w obecności generalnego inspektora sił zbrojnych marszałka E. Śmigłego-Rydza - SUW 1936/1937, s. 19-22; SUW 1937/1938, s. 37, 4,0-48.

230 Chodziło o budynek przy ul. Wawelskiej, mający pomieścić Zakład Chemii Fizjologicznej, Zakład Fizjologiczny, Zakład Farmakologii i Zakład Patologii Ogólnej. 
231 Tamże, k. 10, kopia pisma L. K.94,8o/39 rektora prof. W. Antoniewicza do ministra prof. W. Świętosławskiego z 30 VIII 1939 r., s. 3. W zestawieniu do „Preliminarza budżetowego remontu kapitalnego na rok 1939/40" (k. 61) w podgrupie „Nowe budowle” figurują, obok nowego Gmachu Chemii ( 2 mln zł), także kosztowne pozycje: Klinika Chorób Nerwowych (450 tys. zł), Gmach Farmaceutów (255 tys. zł), budowa psiarni (117 tys. zł). Wyczerpującą listę dezyderatów BUW zawiera kopia pisma jej dyrektora W. Borowego do rektora prof. W. Antoniewicza z $9 \mathrm{~V} 1938 \mathrm{r}$. (AUW, AcUW/RP 79, s. 19-26), którego znamienne pierwsze zdanie brzmi: „Biblioteka Uniwersytecka w obecnej sytuacji lokalowej nie może istnieć nadal". Niezależnie od widma zamknięcia z braku miejsca magazynu już w 1940 r. (m.in. wobec problemów z pomieszczeniem prasy i czasopism wielkoformatowych oraz dubletów), dyrektor postulował jak najszybsze podjęcie decyzji o lokalizacji nowego gmachu, a także przeprowadzenie prac zwiększających bezpieczeństwo przeciwpożarowe i przeciwlotnicze, np. w drodze wykonania stropu żelbetowego oraz schronów dla najcenniejszych zbiorów, kartotek i katalogów.

232 Zob. dyskusyjną próbę ujęcia tej problematyki: J. Trybuś, Warszawa niezaistniała. Niezrealizowane projekty urbanistyczne $i$ architektoniczne Warszawy dwudziestolecia międzywojennego, Warszawa 2012.
$233 \mathrm{Nb}$. był to projekt światopoglądowo pluralistyczny, bowiem przy ówczesnej ul. Opaczewskiej stał już gmach Wolnej Wszechnicy Polskiej.

234 AUW, AcUW/RP 79, s. 27-31, kopia niedatowanej [1939 r.] i niesygnowanej notatki „Ogólnouniwersyteckie potrzeby budowlane". Zob. też SUW 1937/1938, s. $4,8-49$.

235 Warto zwrócić uwagę, że fundusze na Gmach Chemii znalazły się, być może wskutek zbiegu okoliczności, w okresie skumulowania się wpływów wspomnianej grupy chemików (por. s. 378), rozpoczętym w grudniu 1935 r. objęciem przez prof. W. Świętosławskiego teki w gabinecie Mariana Zyndrama-Kościałkowskiego.

236 Por. ceny gruntów, wynoszące w 1939 r. w okolicy terenu głównego UW od $25^{\circ}$ do $500 \mathrm{zł}$ za $1 \mathrm{~m}^{2}$. Dla porównania, na Bielanach, gdzie rozbudowywała się AWF, koszt $1 \mathrm{~m}^{2}$ wynosił 15-20 zł Żoliborz. Obrazy z dziejów. Dzielnica Żoliborz na dawnych mapach, planach $i$ zdjeciach $w$ zbiorach Archiwum Państwowego m.st. Warszawy, oprac. P.E. Weszpiński, Warszawa 1998, s. 5o. W ręku władz miejskich znajdowało się w 1929 r. zaledwie 20\% gruntów (przy czym 11 lat wcześniej odsetek ten był niższy aż 10-krotnie), z czego lwia część właśnie w dzielnicach nowych - E. Szwankowski, Warszawa. Rozwój urbanistyczny $i$ architektoniczny, Warszawa 1952, s. 281; M.M. Drozdowski, Warszawa w latach 1914-1939, s. 79-8o. 


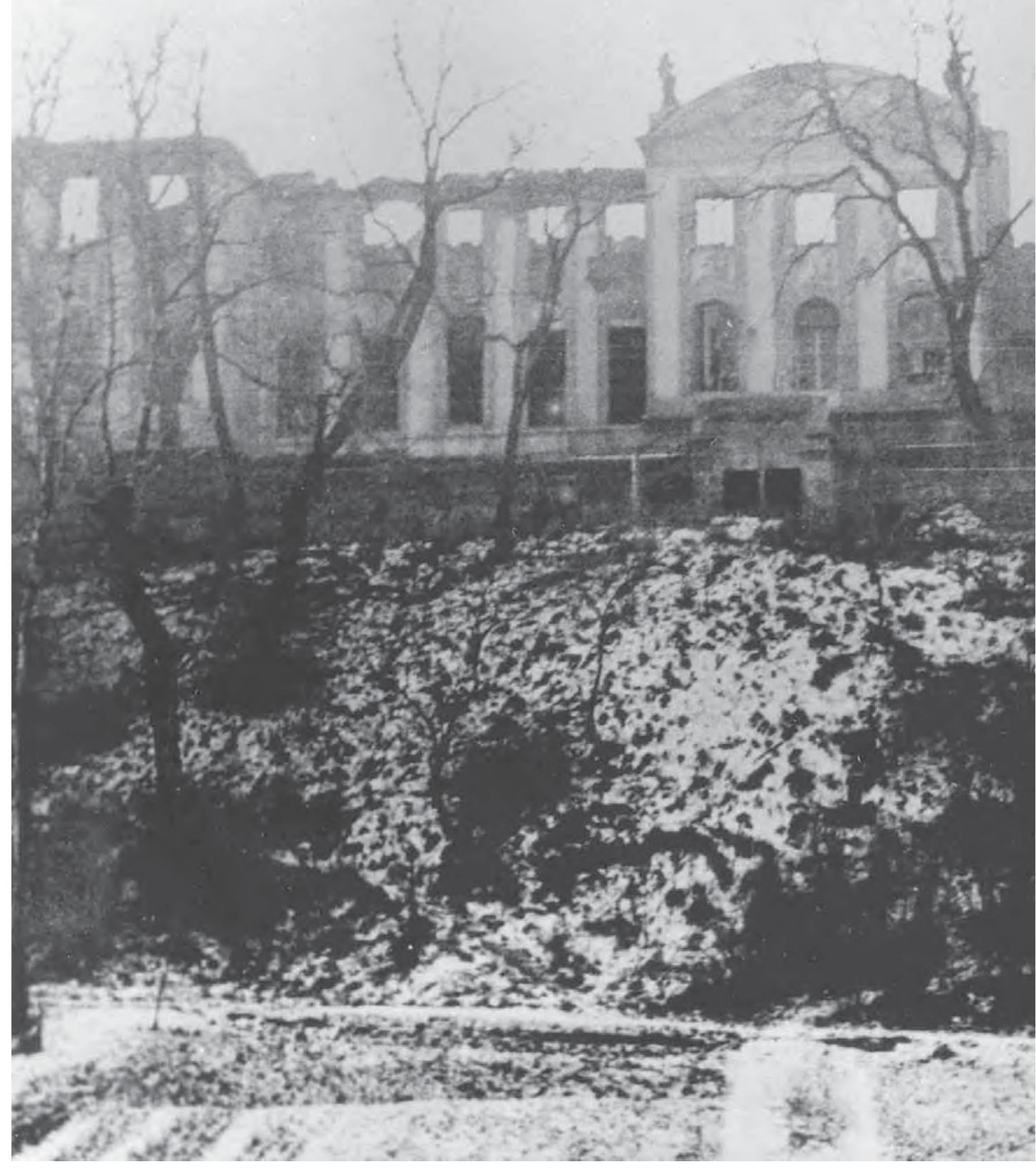




\title{
UNIWERSYTET CZASU WOJNY
}

\author{
To soli kulki z nieba? \\ Czy łzy w krzemień twarzy tak wrosły? \\ Czy ziemia tak bólem dojrzewa, jakeśmy w czasie dorośli?
}

Krzysztof Kamil Baczyński, fragment wiersza Pokolenie (listopad 194,1)

\section{Wprowadzenie}

Jedną z cech odróżniających czas wojny od czasu pokoju jest zamrożenie konfliktów, stanowiących treść życia publicznego w czasach pokoju. W sytuacji biologicznego i kulturowego zagrożenia zbiorowości spory ideologiczne, polityczne, konflikty narodowościowe i uprzedzenia natury religijnej nie tracą zwykle swych społecznych postaw, ale przybierają formy ekspresji właściwe czasom, w których na plan pierwszy wysuwają się zachowania mierzone wyobrażeniami o indywidualnym i zbiorowym heroizmie, postawy wspólnotowe: na miarę środowisk, społeczeństw, narodów.

Sposób prowadzenia wojny oraz sprawowania okupacji określały w 1939 r. standardy prawa międzynarodowego. Konwencja haska z 1907 r. wymagała, aby podczas prowadzenia walk przedsięwzięto środki niezbędne do oszczędzenia budynków poświęconych m.in. nauce. Szczególnej ochronie miał podlegać także znajdujący się na ich terenie majątek. Prawo haskie pozwalało na dokonywanie rekwizycji jedynie dla potrzeb armii okupacyjnej ${ }^{1}$.

\section{e-MONUMENTA_WUW 2016}


W pierwszych tygodniach okupacji nie wydano na obszarze Generalnego Gubernatorstwa żadnych powszechnie obowiązujących zarządzeń dotyczących polskiego szkolnictwa wyższego. Stąd też władze niektórych uczelni, na podstawie zarządzenia niemieckiego dowództwa wojskowego o obowiązku wszczęcia pracy we wszystkich przedsiębiorstwach i instytucjach, postanowiły rozpocząć nowy rok akademicki. Wiadomości o tych zamiarach wywołały zdecydowaną reakcję okupantów: 31 X 1939 r. miało miejsce spotkanie generalnego gubernatora Hansa Franka z ministrem propagandy Josefem Goebbelsem, który kategorycznie opowiedział się za pozbawieniem Polaków wszelkich możliwości kształcenia. Ta decyzja rozstrzygnęła dalsze losy polskiego szkolnictwa w GG. Nieprzypadkowo 6 XI 1939 r. przeprowadzona została Sonderaktion Krakau. W późniejszym, sporządzonym w 1940 r., sprawozdaniu Deutsches Auslandsinstitut stwierdzano, że „W przyszłości naród polski będzie pozbawiony możliwości rozwijania na wyższym poziomie nauki, literatury, sztuki i muzyki; będzie wykonywał pod kierownictwem narodu niemieckiego proste prace rolnicze i rzemieślnicze" ${ }^{\prime 2}$.

O codziennym położeniu nauki w GG stanowił system okupacyjnego prawa. Już 26 X 1939 r. ogłoszone zostało rozporządzenie o publikacji druków mówiące, że „wydanie, oddanie do druku i rozpowszechnienie utworów drukarskich wszelkiego rodzaju" wymaga zezwolenia (Verordnung/VO über die Herausgabe von Druckerzeugnissen). ${ }_{15} \mathrm{XI}$ wydano rozporządzenie o konfiskacie majątku „byłego” państwa polskiego na obszarze GG (VO über die Beschlagnahme des Vermögens des früheren polnischen Staates innerhalb des Generalgouvernements). Całokształt życia umysłowego w GG regulowało wydane 8 III 1940 r. rozporządzenie o działalności kulturalnej, stanowiące, iż każdy, kto „działa publicznie w dziedzinie piśmiennictwa, podlega nadzorowi Wydziału Oświaty Ludowej i Propagandy" (VO über die kulturelle Betätigung im Generalgouvernement). Jawną aktywność społeczną, uniemożliwioną faktycznie od początku okupacji, wykluczono formalnie rozporządzeniem z 23 VII 1940 r., rozwiązującym stowarzyszenia (VO über das Vereinswesen im Generalgouvernement). Dla działalności uniwersyteckiej kluczowe znaczenie miały również następujące rozporządzenia: o szkolnictwie, przesądzające m.in. likwidację szkół wyższych (VO über das Schulwesen im Generalgouvernement, 31 X 1939 r.), o ustanowieniu urzędu kuratorów szkół wyższych (VO über die Bestellung von Hochschulkuratoren im GG, 29 X 194 o r.), czy też wydane 16 XII 1939 r. rozporządzenie o konfiskacie dzieł sztuki (VO über die Beschlagnahme von Kunstgegenständen im Generalgouvernement). 
W warunkach okupacyjnych pracownicy umysłowi znaleźli się w szczególnie trudnej sytuacji materialnej. „Zamknięcie szkół średnich i wyższych pozbawiło chleba dziesiątki tysięcy rodzin" - 8 II 1940 r. raportował płk Stefan Rowecki ${ }^{3}$. Podobny obraz kreślił raport Delegatury Rządu RP na Kraj z kwietnia 194,2 r.: „Sytuacja inteligencji polskiej pod rządami okupacyjnymi kształtuje się coraz bardziej niepomyślnie i zapowiada głęboko sięgające straty". Wskazywano następujące przyczyny tego stanu rzeczy:

Świadoma polityka okupantów, którzy ustosunkowują się do inteligencji polskiej najbardziej negatywnie, mniejsza odporność środowiska i indywidualna na trudności egzystencyjne, trudności zorganizowania pomocy społecznej, wynikające z wrogiego stosunku okupantów do wszelkich prób organizacyjnych w środowisku polskim.

Do najgroźniejszych skutków tej sytuacji zaliczano:

Wyprzedaże książek, obrazów, sprzętów domowych, papierów wartościowych, z reguły w warunkach najbardziej niekorzystnych, głodowanie, nieopalanie mieszkań, zaniedbywanie zdrowia, brak odzieży, stłoczenie mieszkaniowe, zaniedbywanie nauki dzieci, porzucanie zawodu i zatracanie $\mathrm{w}$ ten sposób tych wartości, które dla dobra ogólnego winny być zachowane na przyszłość ${ }^{4}$.

W przygotowanym na zlecenie warszawskich władz samorządowych opracowaniu pisano, iż w 194,2 r. przydzielono w ramach norm kartkowych zaledwie 1,9\% przedwojennego spożycia tłuszczu, białka - 11,8\%, a węglowodanów - 22,9\%. Wyczerpanie organizmów stwarzało podatny grunt dla chorób i miało poważny wpływ na wzrost umieralności. Gdy przeciętna roczna umieralności ludności chrześcijańskiej w 1938 r. wynosiła ok. $11 \%$, to w 194,0 r. wzrosła do $19 \%$, a w 1941 r. - do $20 \%{ }^{5}$.

Ludzie nauki stracili stosunkowo wysoki, ustabilizowany standard życia, eksponowaną pozycję społeczną. „Bez posady, bez środków do życia, bez możliwości pracy naukowej - żyją z godziny na godzinę czekając, kiedy ich spotka ten sam los, którego doznali ich koledzy krakowscy"6. Niewielkiej tylko części pracowników umysłowych zdołano wypłacić we wrześniu 1939 r. trzymiesięczne pensje. Brak możliwości kontynuowania pracy zmuszał więc do podejmowania zajęć przypadkowych, wyczerpujących, dla przeżycia. Witold Kula znalazł pracę magazyniera w wytwórni butów prowadzonej przez Instytut Spraw 
Społecznych. Dla zdobycia „zbędnej forsy”, przeznaczanej głównie na zakup książek, udzielał korepetycji. Aby uzupełnić kartkowe przydziały, zakupił działkę, na której uprawiał warzywa. Przy tej okazji zaczął się „orientować praktycznie i rozumieć, czym są miary ziemi, wyobrażać sobie, co to jest hektar"

Zdaniem Kazimierza Wyki tym, co uratowało polskiego inteligenta „od śmierci głodowej”, był handel, polegający na „niesamowicie rozwiniętym systemie pośrednictwa. Okupacyjnym pośrednikiem był oficer, który nie poszedł do niewoli; inżynier, któremu się nie opłacało iść do fabryki; żona profesora uniwersytetu, której mąż nie posiadał koniecznych do handlu talentów; wszystkie typy ludzkie, przetasowane w najbardziej fantastyczny sposób". Posiadający „konieczne talenty" profesorowie szkół wyższych utworzyli w al. Niepodległości kawiarnię Ateneum, połączoną z wypożyczalnią książek. Na podobny krok zdecydowała się żona prof. Stanisława Srokowskiego, która prowadziła herbaciarnię. Chiquito Bar przy ul. Wareckiej słynął z dużego wyboru likierów. Trunki te pochodziły z domowej fabryczki profesora chemii, który je produkując zarabiał na życie. Przystanią dla naukowców mniej „utalentowanych" były biura Zarządu m.st. Warszawy9.

Poprawa sytuacji środowisk inteligenckich nadeszła wraz z rozwojem struktur Polskiego Państwa Podziemnego, w których to strukturach zatrudnienie znajdowali w znacznej mierze ludzie z tych kręgów społecznych. Tadeusz Manteuffel oficjalnie zatrudniony był w działającym pod zarządem niemieckim Archiwum Akt Nowych, jednocześnie organizował nauczanie historii na podziemnym Uniwersytecie Warszawskim, był sekretarzem redakcji jednego z organów Armii Krajowej, „Wiadomości Polskich". Stanisław Herbst, poza obowiązkami w strukturach AK, brał udział w konspiracyjnych pracach Towarzystwa Opieki nad Zabytkami Przeszłości, nauczał w Wolnej Wszechnicy Polskiej, pracował jawnie w antykwariacie Czesława Garlińskiego oraz w Bibliotece Uniwersyteckiej, czyli pozostającej pod okupacyjnym zarządem Staatsbibliothek Warschau. Pracę w Biurze Informacji i Propagandy Komendy Głównej AK z działalnością akademicką łączył Ludwik Widerszal ${ }^{10}$.

„Słuchajcie, piszcie, róbcie coś, przecież to jest cudowny czas ta okupacja - czas darowany" - miał powiedzieć w tamtych dniach Karol Irzykowski ${ }^{11}$. Wyzwaniem było zachowanie przedwojennego stylu życia, warsztatów badawczych, spełnianie podstawowego obowiązku twórcy. Jak jednak tworzyć, „gdy tuż obok dzieją się takie okropności; chcę pisać, żeby się uspokoić” - notował Witold Kula 
- „i potrzebuję spokoju, żeby pisać”12. Trwano na różne sposoby, by zachować w szczątkowej bodaj formie obraz życia intelektualnego czasów normalnych. Podtrzymywano tradycję spotkań literackich i naukowych. Spotkania takie odbywały się chociażby w mieszkaniu Stefana Rygla, byłego dyrektora Biblioteki Uniwersyteckiej, najpierw przy ul. Filtrowej, potem przy ul. Niemcewicza, w każdą środę. Zygmunt Klukowski wspominał:

Urlop spędziłem w Warszawie. Odetchnąłem tam w zupełnie innej atmosferze. Zetknąłem się z ludźmi ze świata intelektualnego, których wojna i warunki dzisiejszego dnia nie załamały, którzy pracują umysłowo, oddają się swoim zainteresowaniom. Byłem na zwykłej środzie bibliofilskiej u Rygla. Od Rygla dostałem parę starych rycin z widokami Zamościa i rękopis Aleksandra Brücknera o Krucygierze ze Szczebrzeszyna ${ }^{13}$.

Usiłowały również działać zdelegalizowane stowarzyszenia naukowe. Towarzystwo Naukowe Warszawskie odbyło kilkanaście zebrań z referatami i dyskusjami. Towarzystwo Miłośników Historii od 1940 r. zorganizowało 21 konspiracyjnych odczytów, gromadząc się zwykle w trzeci czwartek miesiąca w mieszkaniu swego prezesa Stanisława Kętrzyńskiego, zaś po jego aresztowaniu w listopadzie 1943 r. w Bibliotece Ordynacji Zamoyskich, pod auspicjami prezesa Polskiego Towarzystwa Historycznego i dyrektora Biblioteki od 1929 r., Ludwika Kolankowskiego. Dyskutowano referaty: Aleksandra Gieysztora Encyklika Sergiusza IV, Marcelego Handelsmana Polityka Adama Czartoryskiego, Stanisława Kętrzyńskiego $O$ zadaniach nauki historycznej $i$ jej organizacji $w$ okresie powojennym, Tadeusza Manteuffla Przyszła organizacja studium historycznego, czy Władysława Tatarkiewicza O poglądach na szczesście ${ }^{14}$. Witold Kula nie porzucał zainteresowań zagadnieniami społeczno-gospodarczymi i w miejscu swego zatrudnienia przeprowadzał ankiety „wśród szewców na temat stosunku ich do pracy zawodowej”, formułował też liczne projekty badawcze, np. Norwida walka o słowo (o sformułowanie myśli) ${ }^{15}$. Maria Ossowska pracowała nad Podstawami nauki o moralności. Stefan Swieżawski w miejscu okupacyjnego pobytu w Nawojowej przygotował maszynopis pracy Commensuratio animae ad hoc corpus u św. Tomasza. Studium to stało się podstawą przewodu habilitacyjnego, który filozof przeprowadził na Uniwersytecie Ziem Zachodnich. Kolokwium habilitacyjne odbyło się w czerwcu 1944 r. w Warszawie, w mieszkaniu Władysława Tatarkiewicza przy ul. Prezydenckiej ${ }^{16}$. Stanisław Lorentz, zaangażowany w różne dziedziny podziemnego życia, prowadził również kwerendy w Archiwum 
Akt Dawnych, w wilanowskim archiwum gospodarczym, uzupełniane wizytami w Bibliotekach Uniwersyteckiej i Narodowej, czego efektem była praca pt. Natolin. „Maszynopis pracy pokazałem profesorowi Batowskiemu, u którego studiowałem na Uniwersytecie Warszawskim i pod którego kierunkiem napisałem w swoim czasie pracę doktorską o Szregerze. Profesor Batowski uznał Natolin za rozprawę odpowiadającą wymogom pracy habilitacyjnej i przeprowadził przewód habilitacyjny na tajnym UW" ${ }^{\prime 1}$. Tadeusz Kotarbiński, aby „uporządkować się wewnętrznie, tłumaczył Novum Organum Franciszka Bacona. Każdy gotowy egzemplarz, dla obrony przed kompletnym zniszczeniem dzieła, znalazł locum w innym mieszkaniu, w innym domu - wszystkie jednak znajdowały się w Warszawie. I wszystkie [cztery] spłonęły"18. Alfred Lauterbach, ukrywający się jako „niearyjczyk” w mieszkaniu na Saskiej Kępie, pracował wraz z Lechem Niemojewskim z Politechniki Warszawskiej nad Włoskq szkoła architektury ${ }^{19}$.

„W popołudniowej porze Warszawa kipi kulturalnym życiem. Dokąd iść? Czy na odczyt profesora Tatarkiewicza o historii filozofii? Czy może na Kotarbińskiego? Lub na wieczór dyskusyjny"20. Optymizm wyrażony w cytowanym fragmencie wydać się może przesadny, nie zmienia to faktu, iż środowiska naukowe starały się realizować właściwą sobie misję, odbudowywać naruszone w czasie okupacji warsztaty naukowe, podtrzymywać aktywność środowisk, wreszcie - prowadzić prace badawcze i tajne nauczanie uniwersyteckie.

\section{Wrzesień 1939 r. i okres tzw. półtolerancji}

W czasie wrześniowych walk, w bezpośrednim sąsiedztwie ówczesnego kampusu, na terenie pałacu Tyszkiewiczów-Potockich mieścił się Zastępczy I Szpital Okręgowy Warszawa, którego komendantem był prof. Edward Loth z Wydziału Lekarskiego UW. W szpitalu, który liczył 2900 łóżek, pracowało 63 lekarzy i 236 sióstr. W jednym z rozkazów, wydanym 15 IX, profesor Loth zakazywał przeprowadzania „rekwizycyj lokali, maszyn do pisania, sprzętu itp. na terenie Uniwersytetu"21. Po zakończeniu walk w miejscu polskiego szpitala polowego ulokowany został szpital niemiecki. 


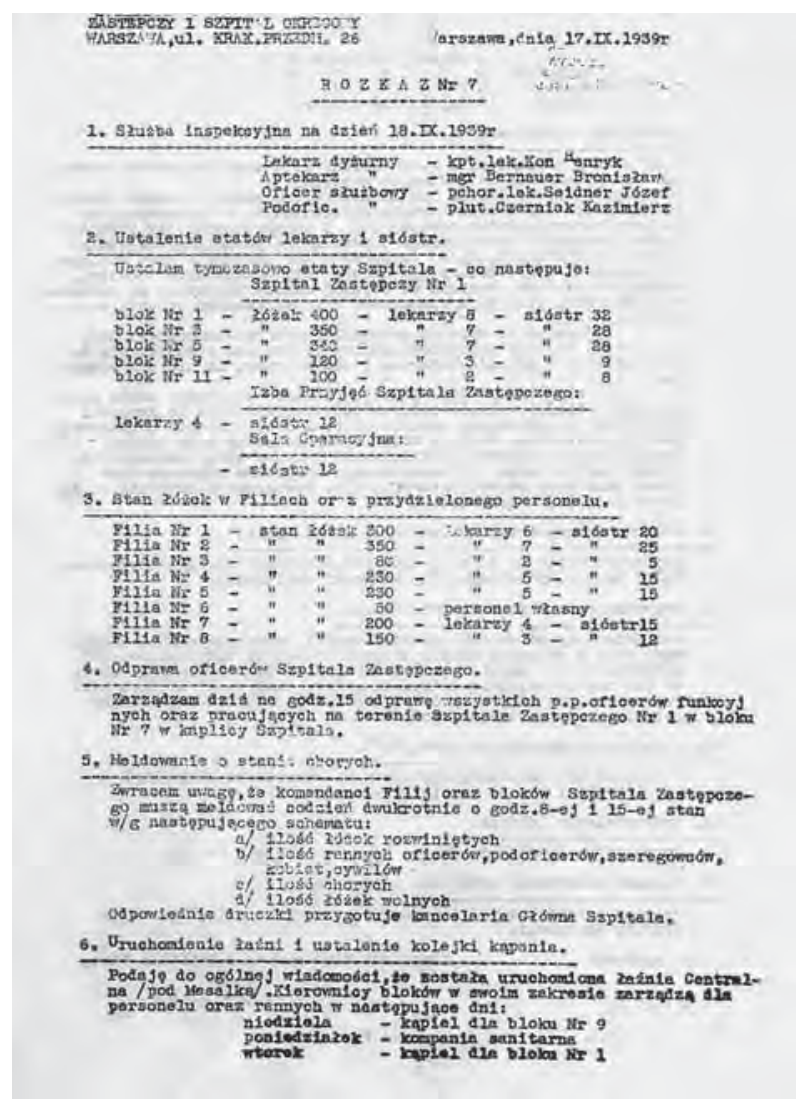

1. Dokument

zastępczego 1 Szpitala

Okręgowego Warszawa w pałacu Tyszkiewiczów-

-Potockich

Teren uniwersytecki stał się ostrzeliwanym celem. Początkowo straty materialne były nieznaczne, a wszystkie pożary gaszono w zarodku. Sytuacja zmieniła się, gdy zabrakło wody. Wówczas teren Uniwersytetu, jak pisał Tadeusz Manteuffel, „przemienił się w ognisko”. Płonął Pałac Kazimierzowski oraz równoległy do Biblioteki Uniwersyteckiej gmach Pokuratorski, mieszczący Archiwum Oświecenia Publicznego. Bomby uszkodziły gmachy Pomuzealny i Medycyny Teoretycznej. Inne budynki straciły szyby, miały podziurawione dachy i uszkodzone ścia$n^{22}$. Tadeusz Manteuffel tak wspominał stan zachowania Archiwum Oświecenia Publicznego: „Znalazłem gmach wypalony do szczętu tak, że nawet po żelaznych schodach i półkach nie pozostało śladu. Ale pracownicy uniwersyteccy usiłujący ugasić pożar wyrzucili przez okna trochę przypadkowo pochwyconych akt. Przejrzenie i pośpieszne posegregowanie w wypożyczalni Biblioteki Uniwersyteckiej tych szczątków nie zabrało mi wiele czasu"23. 
Pracownicy Biblioteki Uniwersyteckiej dyżurowali podczas krytycznych dni obrony Warszawy. Wanda Sokołowska opisuje, że 7 IX na czele dyżurujących stanął dyrektor BUW Adam Lewak. Stałe dyżury podjął też Tadeusz Makowiecki, który podobnie jak Lewak zamieszkał w BUW. Zespół ten, zasilony przez pracowników fizycznych Uniwersytetu oraz bibliotekarki: Małgorzatę Zakrzewską i Henrykę Fokczyńską, uzupełniany od czasu do czasu przez bibliotekarzy docierających do Biblioteki, stanowił - jak twierdzi Sokołowska - jedyną zorganizowaną, utrzymującą porządek grupę na terenie Uniwersytetu. Tadeusz Makowiecki pisał:

Wieniec pożarów naokoło Biblioteki się zacieśnia. Trzykrotnie ogień dostaje się do gmachu: raz na dach, dwa razy trzeba rąbać futryny okien magazynu; wielkie drzwi wejściowe wyrwane przez podmuch, ściana wschodnia pokaleczona odłamkami granatu. Gdy lotnictwo niemieckie zbombardowało większość budynków uniwersyteckich, z płonącego gmachu Pałacu Kazimierzowskiego, w którym znajdował się prowizoryczny szpital, przeniesiono setki ciężko rannych do sieni Biblioteki i na kamienne schody główne - śliskie od krwi - a lżej ranni sami setkami wczołgiwali się do kotłowni i piwnic. Zespół dyżurujący w BUW ratował przed spłonięciem insygnia Uniwersytetu, przenosząc je do budynku Biblioteki ${ }^{24}$.

Nie mniejszym spustoszeniom uległy gmachy uniwersyteckie rozrzucone po mieście. Zniszczone zostały kliniki w szpitalu Św. Ducha, straty poniosły również te, które mieściły się w szpitalu Dzieciątka Jezus, uszkodzony został gmach medycyny sądowej przy ul. Oczki, spłonął na Grochowie gmach kliniki chirurgicznej, uległo zniszczeniu wiele zakładów, mieszczących się w wynajętych lokalach. Spłonął również dom profesorski przy ul. Sewerynów ${ }^{25}$. Wspomniana I Klinika Chorób Wewnętrznych w szpitalu Św. Ducha zajmowała 24, pomieszczenia dla 102 chorych i 10 przeznaczonych na laboratoria, gabinety i salę wykładową. Była wyposażona w najnowsze przyrządy naukowe, posiadała pracownie: analityczną, hematologiczną, przemiany gazowej i podstawowej, elektrokardiograficzną i gabinet elektro-leczniczy; 25 IX szpital został zbombardowany i spalony. Podczas akcji ratowniczej zdołano ewakuować większość chorych, jednak $3^{2}$ mężczyzn, znajdujących się na II piętrze w sali wykładowej, spłonęło żywcem ${ }^{26}$. W jednym z pierwszych powrześniowych raportów stwierdzano, iż podczas działań wojennych pożar zniszczył całkowicie 4 gmachy i część piątego. Spłonęły w nich, oprócz biur, archiwów i sal wykładowych, 23 zakłady z 3 muzeami: mineralogicznym, geologicznym i paleontologicznym. 
Na Wydziale Humanistycznym zniszczeniu uległo 9 zakładów, 13 seminariów zostało poważnie uszkodzonych, 2 biblioteki seminaryjne (językoznawstwa indoeuropejskiego i języka polskiego) zostały wywiezione przez Niemców wkrótce po wkroczeniu do Warszawy. Na Wydziale Matematyczno-Przyrodniczym 6 zakładów (chemii nieorganicznej, organicznej i fizycznej, mineralogii, geologii z paleologią) spłonęło całkowicie, natomiast 4, zakłady (botaniki, zoologii, fizjologii roślin i fizyki doświadczalnej), uszkodzone w czasie bombardowania, zostały ograbione z wyposażenia już po zakończeniu walk - np. wywieziono cenną bibliotekę Instytutu Fizyki Doświadczalnej ${ }^{27}$.

Przez cały czas oblężenia przebywali na terenie Uniwersytetu nowo wybrani - rektor Jerzy Modrakowski i prorektor Stefan Mazurkiewicz.

W pierwszych dniach września 1939 r. dokonano tradycyjnego przekazania władzy przez ustępującego rektora Włodzimierza Antoniewicza nowo wybranemu, wspomnianemu Jerzemu Modrakowskiemu. Przejęli również urzędowanie nowo obrani dziekani wydziałów: Teologii Katolickiej - ks. Zdzisław Obertyński, wykonujący również funkcje duszpasterskie we wspomnianym szpitalu polowym, Teologii Ewangelickiej - ks. Jan Szeruda, Prawa - Roman Rybarski, Lekarskiego - Stanisław Przyłęcki, Humanistycznego - Andrzej Tretiak, Matematyczno-Przyrodniczego Wiktor Lampe, Farmaceutycznego - Witold Witanowski i Weterynaryjnego - Witold Stefański. Senat zdecydował o rozpoczęciu zajęć z początkiem października ${ }^{28}$.

Ministerstwo Wyznań Religijnych i Oświecenia Publicznego, nadzorujące wyższe uczelnie, ewakuowało się z Warszawy 6 IX. Minister Wojciech Świętosławski, opuszczając Warszawę, powierzył obowiązki kierownika resortu Kazimierzowi Szelągowskiemu, który wkrótce po kapitulacji Warszawy 2 X uzyskał od władz okupacyjnych upoważnienie do uruchomienia ministerstwa i urzędów administracji szkolnej. Już dzień wcześniej spotkał się z przedstawicielami organizacji nauczycielskich, m.in. prezesem Towarzystwa Nauczycieli Szkół Średnich i Wyższych Tadeuszem Mikułowskim. Planowano otwarcie uczelni wyższych po usunięciu szkód wojennych. Polskie władze szkolne w układzie organizacyjnym i personalnym zbliżonym do przedwojennego miały możliwość działania tylko w czasie tzw. zarządu wojskowego, w pierwszym okresie okupacji. Na początku grudnia wszelkie kompetencje MWRiOP przejęła tzw. Komisja Likwidacyjna, a sam Szelągowski został aresztowany ${ }^{29}$.

Wspomniana Komisja Likwidacyjna MWRiOP (Abwicklungsstelle für das polnische Kultusministerium) formalnie przejęła kompetencje 


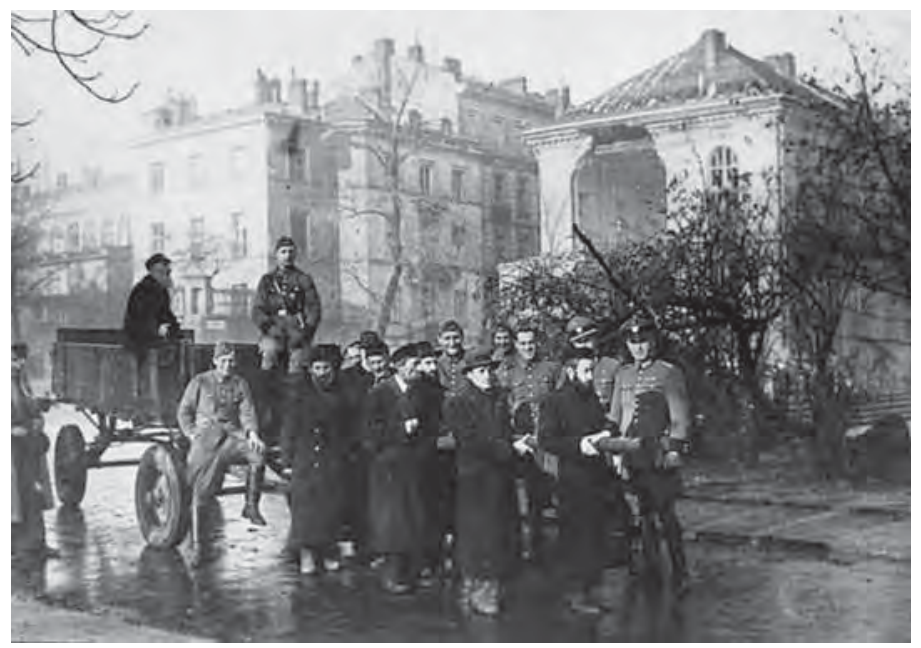

2. Żołnierze niemieccy

i warszawscy Żydzi zmuszani przez nich do prac fizycznych na dziedzińcu UW, jesień $1939 \mathrm{r}$.

resortu 4, XII 1939 r. Proces likwidacji był rozciągnięty w czasie, zezwolono np. na odbycie egzaminów kończących studia lub wieńczących przewody doktorskie na wydziałach: Lekarskim, Farmaceutycznym, Weterynaryjnym i Matematyczno-Przyrodniczym UW, z wyłączeniem jednak osób uznanych za Żydów. Ostatnie takie egzaminy odbyły się w lipcu 1940 r. We wszystkich warszawskich uczelniach wydano w ten sposób ponad goo dyplomów. Komisja Likwidacyjna była z jednej strony wykonawczynią represji spadających na polskie szkolnictwo akademickie, z drugiej jednak owe represje usiłowała wtłoczyć w ramy urzędniczej rutyny. Zabraniała więc, w praktyce nie zawsze konsekwentnie, biurom wyższych uczelni wydawania jakichkolwiek zaświadczeń, ale tolerowała przeprowadzenie wspomnianych egzaminów końcowych. Zakazywała wstępu na teren uczelni osobom nieposiadającym wydanych przez nią imiennych zezwoleń, faktycznie jednak niezajętymi przez okupantów gmachami dysponowali polscy urzędnicy uniwersyteccy i naukowcy. Uruchomione w ten sposób pracownie były w praktyce niezależne od władz okupacyjnych, chociaż ich kierownicy odpowiadali przed Komisją. Komisja umożliwiała wreszcie, bądź zlecała, niezbędne remonty oraz opłacała woźnych i urzędników administrujących gmachami ${ }^{30}$. Komisja Likwidacyjna sama uległa z czasem likwidacji, zaś jej kompetencje z początkiem 19411 r. przejęli kuratorzy szkół wyższych (Universitätskuratoren). Urzędy te podlegały dystryktowym Wydziałom Nauki i Nauczania, zaś ich działalność koncentrowała się na nadzorze nad majątkiem uczelni. 1 II 1941 r. kuratorem warszawskim został Werner Tzschaschel, wcześniej kierujący Komisją Likwidacyjną. Urzędy 


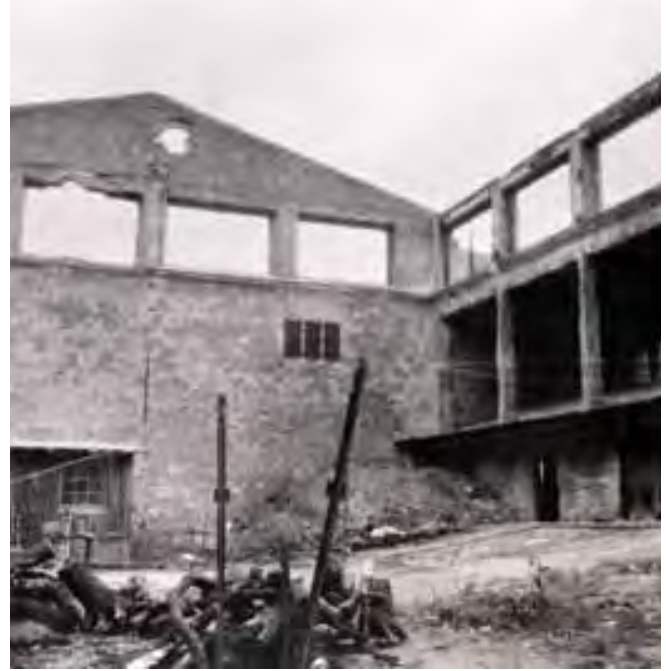

3. Spalona Aula Mickiewicza w Auditorium Maximum, zdjęcie z 1945 r. kuratorów zlikwidowano w grudniu 1943 r. i „byłe polskie szkoły wyższe" podporządkowano bezpośrednio Wydziałom Nauki i Nauczania danego dystryktu ${ }^{31}$.

Wbrew planom polskich władz uniwersyteckich uczelnia nie rozpoczęła działalności dydaktycznej, a 2 X 1939 r. jej teren został zajęty przez batalion Policji Bezpieczeństwa (Sicherheitspolizei). Przybysze rozpoczęli rabowanie mienia uniwersyteckiego, a rzeczy, które nie przedstawiały dla nich wartości, niszczyli. O ich zachowaniu może świadczyć los Wydziału Prawa, którego nowoczesny hall został zamieniony na stajnię z boksami dla koni, zmontowanymi z jesionowych stołów czytelni Biblioteki Uniwersyteckiej. Auditorium Maximum spłonęło w czasie jednej ze świątecznych libacji ${ }^{32}$.

Majątek wyższych uczelni stał się również przedmiotem zorganizowanej akcji rabunkowej, po „spontanicznym” okresie rekwizycji dokonywanych przez Wehrmacht i formacje policyjne. Inicjatywa spenetrowania polskich zbiorów uniwersyteckich pojawiła się we wrześniu 1939 r. w kręgach Forschung- und Lehrgemeinschaft „Das Ahnenerbe” („Dziedzictwo przodków”). Heinrich Himmler powołał 23 IX Kommando, kierowane przez profesora prehistorii Uniwersytetu Berlińskiego SS-Untersturmführera Petera Paulsena; 1 X Kommando Paulsen wyprawione zostało na tereny polskie, by zająć się majątkiem szkół wyższych i instytucji naukowych ${ }^{33}$. Na przełomie października i listopada 1939 r. grupa Paulsena dokonała lustracji w Warszawie, m.in. na Uniwersytecie. Działalność grupy Paulsena i jej podobnych skutkowała wywozem aparatury badawczej oraz księgozbiorów. Ofiarą padły m.in.: Biblioteka Uniwersytecka, Instytut Fonetyczny, Seminaria Językoznawstwa Indoeuropejskiego i Języka Polskiego, Zakłady Archeologii Przedhistorycznej, Fizyki Doświadczalnej, Anatomii Prawidłowej. Proceder ten przerwano wskutek interwencji władz GG, które czuły się suwerenem wobec majątku „byłego państwa polskiego”. W późniejszym okresie Niemcy zlikwidowali uniwersytecki Ogród Botaniczny, który przyłączono do parku Łazienkowskiego, zaś jego zbiory i inwentarz naukowy, podobnie jak w wypadku Zakładu Systematyki Roślin, 
przewieziono częściowo do Zakładu Ogrodownictwa m.st. Warszawy. Znaczna część zbiorów Zakładu Geografii trafiła do krakowskiego Instytutu Niemieckiej Pracy na Wschodzie (Ostinstitut) ${ }^{34}$.

Jak już wspomniano, zarząd nad gmachami uniwersyteckimi formalnie sprawowała Komisja Likwidacyjna, praktycznie jednak zajmował się tym dawny personel uniwersytecki. Ocalałe kliniki Wydziału Lekarskiego pozostawiono pod zarządem profesorów, będących przed wojną ich kierownikami ${ }^{35}$. Administracja uniwersytecka, po zajęciu przez policję gmachów uczelni, przeniosła się do wynajętego lokalu Zakładu Socjologii i Historii Kultury oraz Zakładu Antropogeografii przy Krakowskim Przedmieściu 6 i wznowiła pracę w nieopalanych, ciasnych pomieszczeniach. Personel nie otrzymywał regularnych poborów. Pierwsza okupacyjna zima spowodowała, iż personel zmniejszał się, gdyż niewielu mogło wytrzymać w nieopalanym lokalu, gdzie trzeba było pracować w palcie, czapce i rękawiczkach. Rewizje i odbieranie pieczęci, rabunki mienia, „pożyczki” z funduszu stypendialnego, dokonywane przez żandarmerię, były codziennością. Nieopłacany personel wiosną 1940 r. składał się już tylko z czterech osób: p.o. sekretarza Uniwersytetu Cezarego Kunderewicza, Stefanii Karpowiczowej, Stanisława Sucheckiego oraz woźnego Jana Dudzika. Wobec niemożności opłacania komornego, biuro przeniosło się do lokalu użyczonego przez Księży Misjonarzy przy ul. Traugutta 1. Na wiosnę 1940 r., zgodnie z ludową przepowiednią „im słoneczko wyżej, tym Sikorski bliżej", spodziewano się rychłego zakończenia wojny i klęski Niemiec, więc wysiłek biura poświęcony był remontowi ocalałych gmachów i ratowaniu zbiorów. Jak wcześniej wspomniano, udało się uzyskać wsparcie finansowe Komisji Likwidacyjnej, co pozwoliło na oszklenie ocalałych budynków i na remont gmachów Szkoły Głównej i Medycyny Teoretycznej. Pracownicy sekretariatu przystąpili również do porządkowania akt studenckich. Biuro wydawało także studentom zaświadczenia o stanie ich studiów, wbrew zaleceniom władz okupacyjnych. W styczniu 1941 1 r. jedno z takich zaświadczeń wpadło w ręce władz okupacyjnych. Kunderewicz i Zygmunt Zagórowski zostali wezwani do pałacu Brühla, gdzie oświadczono im, że wystawiając zaświadczenia dopuścili się sabotażu za co grozi postawienie przed Sądem Specjalnym. Ostatecznie skończyło się na zakazaniu Kunderewiczowi jakiejkolwiek działalności na terenie uniwersyteckim. Konsekwencją było też ograniczenie działalności biura uniwersyteckiego do mało znaczących spraw gospodarczych. Na czele biura jako intendent stanął przedwojenny sekretarz Uniwersytetu Kazimierz Libera i pod jego kierownictwem przetrwało ono do powstania, pełniąc rolę punktu kontaktowego służącego pracownikom formalnie nieistniejącej uczelni ${ }^{36}$. 
W spuściźnie archiwalnej Wydziału Lekarskiego zachowały się odpisy zaświadczeń o ukończeniu studiów, wydawanych w pierwszym okresie okupacji studentom, którym pozwolono na zdanie końcowych egzaminów. Zachowane zaświadczenia były podpisywane przez rektora Modrakowskiego. Zachowały się ogółem 193 zaświadczenia (w tym 57 wydanych kobietom) ${ }^{37}$. Z relacji przedwojennego rektora Włodzimierza Antoniewicza wynika, iż posługując się wtórnikiem pieczęci przedwojennej, zachowanej u Kazimierza Libery, Antoniewicz podpisywał, głównie studentom wydziałów Lekarskiego i Prawa, antydatowane na okres przedwojenny zaświadczenia o stanie studiów. Antoniewicz podkreślał również dobrą współpracę ze swoim następcą na stanowisku rektora ${ }^{38}$.

Za symboliczny moment zakończenia okresu, nazwanego przez Tadeusza Manteuffla „okresem półtolerancji”, przyjąć można zarządzenie Komisji Likwidacyjnej z 14 IX 1940 r. stwierdzające, że szkoły wyższe zostały zamknięte z końcem września roku minionego, a posługiwanie się tytułami uniwersyteckimi jest zakazane, zaś kierownicy zakładów uniwersyteckich utracili uprawnienia do zajmowania się tymi placówkami $^{39}$. Wraz z upadkiem Francji oznaczało to kres nadziei na odrodzenie Uniwersytetu.

\section{Uniwersytet w konspiracji}

W połowie 1940 r. w środowiskach inteligenckich dominowało przeświadczenie, że po rozpoczęciu przez Anglię i Francję działań zbrojnych wojna skończy się rychłą klęską Trzeciej Rzeszy. Rozgromienie Francji gwałtownie podcięło tę wiarę. Okupacja zaczęła się zapowiadać na czas dłuższy ${ }^{40}$. Ten stan rzeczy implikował szereg wyzwań, z najważniejszym na czele - zachowaniem w nastrojach społecznych wiary w ostateczny wojenny sukces. Wobec ostatecznego fiaska planów uruchomienia regularnych studiów akademickich przed środowiskiem uniwersyteckim stanął problem podtrzymania zawodowej aktywności i znalezienia środków do życia; przed młodzieżą - znalezienia sposobu na zdobycie wiedzy, którą dziś nazwalibyśmy certyfikowaną.

W kręgach akademickich wytworzyła się w owym czasie atmosfera, w której kwestia tworzenia tajnego szkolnictwa wyższego stała się bez wątpienia zagadnieniem nadrzędnym, realizowanym w poczuciu wypełniania publicznego obowiązku. Jej katalizatorem okazała się presja przedwojennych studentów, młodzieży, która ukończyła przed 
wybuchem wojny szkołę średnią i chciała podjąć studia, oraz tzw. wojennych maturzystów. Te trzy zainteresowane grona najwyraźniej potrzebowały do częściowego bodaj, wewnętrznego ustabilizowania jakiegoś elementu przedwojennego życia. Stały się nim komplety konspiracyjnego Uniwersytetu ${ }^{41}$. Nie sposób jednak nie zauważyć, iż w niektórych kręgach pracowników naukowych wyrażano sceptycyzm wobec możliwości zorganizowania takiego systemu konspiracyjnej nauki, który mógłby zapewnić młodzieży systematyczne, zgodne z programem studia. Kwestionowano możność zachowania dyskrecji przy tak dużej liczbie wtajemniczonych, podnoszono kwestię niewspółmiernych korzyści w stosunku do strat, jakie ponieść można w przypadku dekonspiracji. „Dla kilku niewiadomej wartości młokosów, bo przecież więcej niepodobna w zakonspirowanym uniwersytecie «wykształcić», nie można narażać na pewną śmierć tych nielicznych niedobitków nauki polskiej, których będzie Polska potrzebować po wojnie" - pisano w Krakowie, ale nie był to pogląd wyłącznie dla krakowskich kręgów akademickich właściwy ${ }^{42}$. Z pewnością uczeni, którzy doświadczyli represji, miewali opory przed podejmowaniem działalności dydaktycznej. Przełamanie własnego oporu było aktem odwagi ${ }^{43}$.

Jesienią 1940 r. w Warszawie odbyło się wiele zebrań poświęconych tajnym kompletom uniwersyteckim. Inicjatywa działań praktycznych wyszła z dwóch stron: z kół szkolnictwa średniego (Janina Dembowska, Anna d'Abancourt-Koczwara, Irena Gieysztor, Józef Grabowski, Wanda Karpowicz, Halina Nieniewska, instruktorka MWRiOP), które były zainteresowane losami maturzystów okresu wojennego, oraz ze sfer szkolnictwa wyższego (Witold Cybulski, Alicja Dorabialska, Kazimierz Drewnowski, Marian Gieysztor, Roman Kuntze, Edward Loth, Józef Patkowski, były dyrektor departamentu szkól wyższych MWRiOP, Stefan Pieńkowski, Wacław Roszkowski, Józef Zawadzki). Zaangażowani byli również profesorowie przedwojennego Uniwersytetu Poznańskiego. Administrację objęła zrazu Janina Dembowska, a gdy musiała zrezygnować ze względu na zagrożenie, obowiązki jej przejęła Anna Koczwara jako sekretarka generalna wydziałów: Matematyczno-Przyrodniczego, Lekarskiego, Farmaceutycznego (Uniwersytet), Akademii Stomatologicznej oraz Chemicznego (Politechnika), czyli tzw. grupy nauk ścisłych (por. w dalszej części Wydział Matematyczno-Przyrodniczy). W porozumieniu z sekretarką generalną pozostawały sekretarki grupowe: od początku Wanda Karpowicz, od września 194i1 r. Irena Gieysztor (pseud. Rakowska, Chmielewska). Od września 194,2 r. 
Irena Gieysztor, wskutek rozrostu grup studenckich, dokooptowała do pracy 2 osoby, Marię Moszyńską i Wandę Chmielewską, które miały bezpośredni kontakt z młodzieżą i prowadziły sprawy organizacyjne (wpisy, podział na komplety, dobór lokali). Całość prac związanych z organizacją studiów zainicjował Marian Koczwara, były naczelnik wydziału szkół średnich MWRiOP, pozostając w łączności z Departamentem Oświaty i Kultury (DOiK) Delegatury Rządu. W organizacji tajnych studiów nie przyjęto, ze względów konspiracyjnych, wzorów jawnego szkolnictwa przedwojennego (rektorat, dziekanaty, rady wydziałów). Sprawy dotyczące poszczególnych komórek organizacyjnych (wydziałów, sekcji, klinik) ustalano z osobami bezpośrednio nimi kierującymi. Wykładowcy rekrutowali się spośród naukowców, specjalistów, którym szefowie poszczególnych struktur zlecali zajęcia. Słuchacze rekrutowali się głównie spośród absolwentów warszawskich szkół średnich, zgłaszanych za pośrednictwem nauczycieli ${ }^{44}$.

We wspomnianym Departamencie Oświaty i Kultury sprawy nauki i nauczania podlegały Działowi Szkół Wyższych i Nauki. Kierowali nim kolejno: wspomniany Kazimierz Drewnowski, Bolesław Miklaszewski i Stefan Pieńkowski, także rektor konspiracyjnego Uniwersytetu Warszawskiego. W skład Działu wchodziły komisje: Szkół Akademickich i Nauki, Podręczników Akademickich, Tajnego Nauczania, Opieki nad Pracownikami Nauki. Dział zajmował się nie tylko wspieraniem organizacji tajnego nauczania, ale także opieką socjalną nad pracownikami szkół wyższych i studentami, m.in. poprzez dystrybucję zapomóg i stypendiów otrzymywanych z Departamentu Pracy i Opieki Społecznej Delegatury, który był głównym kanałem przekazywania przez uchodźcze i krajowe władze polskie środków finansowych. Część z nich trafiała do potrzebujących za pośrednictwem działających jawnie: Rady Głównej Opiekuńczej, Polskiego Czerwonego Krzyża, Stołecznego Komitetu Pomocy Społecznej ${ }^{45}$.

Pierwsze okres, od września do końca października 1940 r., poświęcony był organizacji kompletów. Dyrektorzy gimnazjów i liceów warszawskich za pośrednictwem swego delegata Józefa Grabowskiego dokonywali zapisów kandydatów na Uniwersytet i Politechnikę. W mieszkaniu na piątym piętrze przy ul. Śniadeckich 6 m. 12 Wanda Karpowicz prowadziła zapisy na różne wydziały z grupy tzw. nauk ścisłych. Otrzymała instrukcje, że komplet ma liczyć 7-8 osób i musi mieć wyznaczony lokal. W oznaczone dni i godziny młodzież napływała tłumnie; bywało nawet do zo osób. Grupy były organizowane w ten sposób, by słuchacze danego kompletu zamieszkiwali jedną dzielnicę miasta lub dzielnice sąsiadujące. Po rozmowie z kandydatem wpisywała 
go na listę danej grupy. „Na oko”, jak sama wspomina, wybierała przewodniczącego lub przewodniczącą kompletu, czyli tzw. grupowych. Po kilku miesiącach ten sposób organizowania kompletów musiał okazać się niebezpieczny. Lokatorzy kamienicy zaczęli dopytywać się o młodzież zbierającą się na piątym piętrze. W końcu 1941 r. Karpowiczowa musiała na szereg miesięcy przerwać pracę i zmienić lokal. Ostatecznym powodem był wypadek, który opisuje następująco:

W dzień przyjęć zjawił się u mnie student I roku w sprawie ulgi czesnego. W pokoju było prawie ciemno, gdyż oświetlała go tylko mała świeczka, toteż nie mogłam odnaleźć listy z nazwiskami słuchaczy. Nazajutrz zorientowałam się, że atlas geograficzny, w którym miałam ukryte listy słuchaczy z adresami oraz spis lokali dla wykładów, zaginął. Jedno z dwojga, albo chłopak ściągnął atlas lub zależało mu na wykradzeniu list. Po naradzie z Koczwarą postanowiliśmy zawiesić wykłady w kompletach na parę tygodni ${ }^{46}$.

Incydent ten nie pociągnął szczęśliwie za sobą żadnych następstw.

Czynnikiem ułatwiającym podjęcie zorganizowanej działalności dydaktycznej, zarówno w ramach przywołanych wyżej inicjatyw, jak również poza nimi, były kontakty utrzymywane ze studentami, faktycznie od pierwszych dni okupacji. Spotkania ograniczające się początkowo do udzielania byłym studentom porad dotyczących sposobu postępowania w okupacyjnych warunkach, przekształcały się w systematyczne kontakty przybierające formę kształcenia. Zajęcia tego typu odbywały się zazwyczaj w mieszkaniach wykładowców i miały charakter seminariów o ograniczonej liczbie słuchaczy. Były prowadzone jednak przez niewielu wykładowców i nie zostały ujęte w żadną formę organizacyjną. Zaś jak słusznie zauważył Henryk Hiż: „Uniwersytet nie zasługuje na swe miano, gdy student styka się z jednym tylko wykładowcą" ${ }^{\prime 47}$. Organizacja konspiracyjnego Uniwersytetu objęła wszystkie przedwojenne wydziały, wyjąwszy Studium Teologii Prawosławnej48 i Wydział Weterynaryjny, w pełni zasługując na miano szkoły wyższej.

Wydział Teologii Katolickiej. Ze względu na szczególny charakter słuchaczy, Wydział mógł się zorganizować już w lutym 1940 r. Kierownictwo, z powodu wyjazdu ks. dziekana Obertyńskiego, objął ks. prof. Piotr Chojnacki. Pracę wznowiono we wszystkich sekcjach: teologicznej, prawa kanonicznego, filozofii chrześcijańskiej. Przez Wydział przeszło w ciągu całego okresu konspiracyjnego nauczania blisko 100 słuchaczy, przeprowadzono ok. 10 końcowych egzaminów 


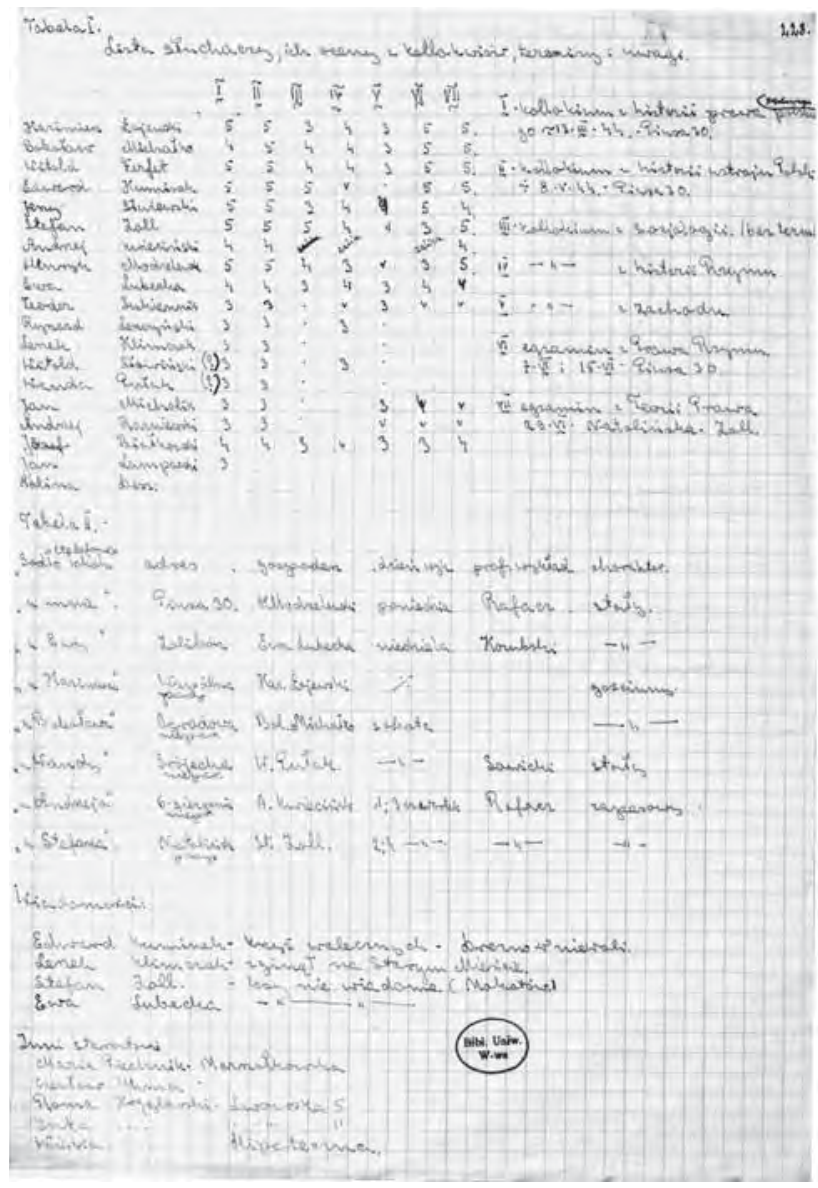

4. Wydział Prawa - lista słuchaczy tajnych kursów, oceny z kolokwiów

i egzaminów

magisterskich i 6 doktorskich. Wykłady odbywały się w mieszkaniach prywatnych wykładowców, na plebaniach, w zakrystiach. Słuchacze, na miarę swych możliwości, uiszczali opłaty ${ }^{49}$.

Wydział Teologii Ewangelickiej. Ze względu na dotkliwe prześladowania, które rozbiły jego przedwojenny skład, Wydział nie podjął zorganizowanej pracy. Księża profesorowie Jan Szeruda i Adolf Suess kontynuowali jednak w latach 1941-1944 pracę dydaktyczną w ramach Wyższej Szkoły Biblijnej, prowadzonej przez Kościół Metodystów, nadto skupiali grono słuchaczy na kompletach w swoich mieszkaniach. Ks. Szeruda wspominał: „Prowadziłem komplet, w którym brało udział 3 studentów bezpłatnie, w biurze (Nowy Świat 14) i w mieszkaniu (Brzozowa 10 m. 5). Ćwiczenia odbywały się dwa razy w tygodniu i były poświęcone egzegezie wybranych rozdziałów Starego Testamentu. Studenci 
składali prace piśmienne na wyznaczone tematy". We wspomnianym dwuletnim kursie biblijnym w Szkole Biblijnej uczestniczyło w 19411 r. 10 studentów, w 194,2 r. - 16, zaś w 1943/1944 - 20. Jan Szeruda wykładał wstęp do ksiąg i teologię Starego Testamentu, księgi: Pierwszą Mojżeszową, Izajasza, Jeremiasza i Daniela. Zagadnienia nowotestamentowe wykładał ks. Suess. Wykłady prowadzone były w domu przy ul. Mokotowskiej 12. Pod koniec roku szkolnego odbywały się egzaminy. Dla studentów zamiejscowych w liczbie $10 \mathrm{ks}$. Szeruda przygotowywał skróty wykładów w formie maszynopisu. Praca w ramach Szkoły Biblijnej została ze względu na niebezpieczeństwo denuncjacji „zalegalizowana" w 1943 r. przez ujawnienie jej jako instytucji kościelnej ${ }^{50}$.

Wydział Prawa został zorganizowany w grudniu 1940 r.; pracami organizacyjnymi podzielili się wówczas profesorowie Roman Rybarski (dziekan) i Józef Rafacz. Pierwszy z nich zajął się uruchomieniem III i IV roku studiów, drugi - I i II. Po aresztowaniu w maju 19411 r. prof. Rybarskiego, funkcję dziekana przejął prof. Rafacz, prodziekana - prof. Zaleski; przeprowadzili oni reorganizację dotychczasowych kompletów, nadając im nową, rozbudowaną formę, która przetrwała do powstania. Stroną organizacyjną rozrastających się kompletów zajmowali się przede wszystkim młodzi prawnicy, na czele z Antonim Symonowiczem, sekretarzem Wydziału, znanym pod pseudonimem „pan Tolek”, oraz Wiesław Kolisko i Andrzej Leśniewski. Niższe lata studiów, a po aresztowaniu Rybarskiego wszystkie, były związane organizacyjnie z UZZ i dopiero z początkiem 1943/1944 r. cały Wydział powrócił do więzi z UW. W roku akademickim 194,1/194,2 pierwszy rok liczył 8 grup, w następnym wzrósł do 11, a w 1943/1944 r. osiągnął 13. Wzrastała równocześnie liczebność grup: w 194:1/194,2 r. składały się z 6 słuchaczy, w 1942/1943 r. wzrosły do 8, a w 1943/1944 do 15-20 osób. W ostatnim roku przed powstaniem Wydział składał się z 35 kompletów, z czego na I rok przypadało wspomnianych 13, na II 11 (ok. 130 słuchaczy), na III - 7, a na IV - 4. Wydział liczył wówczas ok. 6 oo słuchaczy. Kandydatów było nawet więcej, ale nie przyjmowano ich z powodu przeciążenia wykładowców, którzy mieli przeciętnie po 20-30 godzin zajęć tygodniowo. W planie prac uwzględniano wszystkie obowiązujące w normalnym programie studiów przedmioty, rozkładając je tak, aby każda grupa miała przeciętnie 8 godzin zajęć tygodniowo. Obok przedmiotów obowiązkowych zorganizowano wykłady z przedmiotów dodatkowych (filozofia, polityka, chrześcijańskie doktryny społeczne, antropologia społeczno-polityczna, demografia, historia doktryn politycznych, historia dyplomacji), ponadto kilka seminariów (historii prawodawstw słowiańskich, teorii prawa, prawa karnego, 
prawa państwowego i międzynarodowego, prawa handlowego). Niektórzy wykładowcy prowadzili stałe konwersatoria. $\mathrm{Na}$ pierwszym roku wykładali m.in.: Stanisław Borowski, Włodzimierz Kozubski, Maria Petz, Henryk Piętka, Józef Rafacz, Bohdan Sałaciński, Witold Sawicki; na drugim: Cezary Berezowski, Tadeusz Bigo, Stanisław Kasznica, Kazimierz Libera, Jakub Sawicki, Tadeusz Szymański, Stefan Zaleski. Na trzecim: Tadeusz Bigo, Karol Brzoska, Stanisław Kasznica, Henryk Piętka, Roman Rybarski, Stefan Szulc, Tadeusz Szymański, Stanisław Śliwiński. Na czwartym: Jerzy Jodłowski, Władysław Kosieradzki, Włodzimierz Kozubski, Wacław Miszewski, Jan Namitkiewicz. Wielu z nich wykładało także na innych wydziałach UW oraz na UZZ, np. Stefan Zaleski nauczał w ramach Wydziałów Prawa i Teologii Katolickiej UW oraz Wydziału Prawno-Ekonomicznego UZZ. O skali prac Wydziału świadczą końcowe egzaminy magisterskie oraz jeden doktorski; w 1944, r. doktoryzował się Jerzy Osiecki, promotorem był Cezary Berezowski. Jedna z prac magisterskich, Zagadnienia amortyzacji, zachowała się u prof. Zaleskiego; niestety jej autor (mgr Strzeszewski) zginął. Przez cały czas okupacji, co najmniej raz do roku, odbywały się zebrania Rady Wydziału, na których przeprowadzano wybory dziekana i prodziekana, zajmowano się reformą studiów prawniczych, powojenną odbudową gmachów uniwersyteckich ${ }^{51}$.

Wyniki egzaminów były w okresie konspiracyjnego nauczania zasadniczo lepsze niż przed wojną. Na studia w trudnych warunkach decydowali się przeważnie ci, którzy faktycznie chcieli się uczyć, do egzaminu przystępowano zwykle dopiero po dobrym opanowaniu materiału. Kandydaci na studia prawnicze trafiali z rekomendacji dyrektora tajnego gimnazjum, wykładowcy lub innej osoby znanej na Wydziale. Na pierwszym wykładzie Dziekan odbierał ślubowanie, w którym punktem „wojennym” było przyrzeczenie zachowania tajemnicy. Studenci z zasady nie znali mieszkań profesorów; zakonspirowania nazwisk nie można jednak było długo utrzymać, zbyt znanymi osobami byli bowiem wykładowcy. Najdłużej osłonięta tajemnicą pozostawała osoba profesora prawa kościelnego, które wykładał „ks. Paweł”. Niestety, „ks. Paweł” przed jednym z wykładów zapomniał zdjąć obrączkę. Okazało się, że jest to Jakub Sawicki. Chodząc na wykłady, studenci raczej lekceważyli niebezpieczeństwo, tematem zaś dowcipów stawali się „strachliwi" profesorowie. Wiele legend krążyło o jednym z nich, który wciąż widział za sobą szpiega, lecz mimo to nie rezygnował z wykładania. Hasłem bezpieczeństwa jednego z kompletów było zapytanie przy wejściu do mieszkania: „czy można kupić węgiel?”. Przypadek zdarzył, że podano adres mieszkania o piętro niżej. Od rana więc zaczęły budzić 
gospodarza tego lokalu dzwonki, a potem pytania o węgiel; tłumaczył, że węglem nie handluje, na co studenci uśmiechali się, proponując z naciskiem handel. Po paru takich wizytach na drzwiach pojawił się napis: „węgla nie sprzedaje się".

Komplety odbywały się z zasady w prywatnych mieszkaniach, wyjątkowo w lokalach jawnych szkół, pod pozorem innych zajęć, np. wykład mecenasa Sałacińskiego pod przykrywką kursu pisania na maszynie, chociaż wykładowca umiejętność tę opanował słabo. Funkcjonowanie Wydziału zależało od sprawności systemu administracyjnego. Na czele każdego kompletu stał starosta (grupowy) wybierany przez komplet lub mianowany przez sekretarza Wydziału; obowiązkiem starosty było zbieranie czesnego, kontaktowanie się z wykładowcami oraz prowadzenie spraw lokalowych. Nikt niemal nie przeszedł przez Wydział, nie posługując się białą karteczką o treści: „Oddawca niniejszej kartki przychodzi z mojego polecenia. Tolek". Z taką kartką student był przyjmowany na komplet i szedł na egzamin. Administracja zajmowała się przyjmowaniem kandydatów, tworzeniem grup, ustalaniem terminów, miejsc wykładów i egzaminów, przechowywaniem zaświadczeń o wynikach w nauce, które, niestety, w czasie powstania uległy w większości zniszczeniu, a także sprawami finansowymi. Opłaty za naukę wynosiły początkowo $4,0 \mathrm{zl}$, od 194,2 r. $-60 \mathrm{zl}, \mathrm{w} 194,2 / 1943$ r. - $80 \mathrm{zl}$, w ostatnim zaś roku - 150 zł. Udzielano zniżek, tak że niemal co trzeci student uczył się za darmo. Wpływ z czesnego w ostatnim roku studiów wynosił około ćwierć miliona złotych. Wynagrodzenie profesorów za godzinę wykładu wynosiło do 4.0-50 zł. Wydział, w przeciwieństwie do innych, nie otrzymywał dotacji z Departamentu Oświaty i Kultury, natomiast sam pomagał finansowo innym wydziałom. Do osiągnięć Wydziału należało również wydawanie skryptów, np. Prawa karnego prof. Śliwińskiego, nad którym autor pracował od listopada 1939 r., Teorii prawa w opracowaniu dr Piętki, Historii gospodarczej prof. Rutkowskiego. Do nauki prawa administracyjnego używany był podręcznik prof. Kasznicy, napisany w czasie wojny i wydany pod pseudonimem "Kużycki” - Polskie prawo administracyjne. Pojecia i instytucje zasadnicze. $\mathrm{Na}$ Wydziale działało szereg organizacji, wśród nich Koło Prawników, w 194,2/1943 r. mające formę kilkunastoosobowego zespołu, którego kuratorem był prof. Rafacz. W 1943/1944 r. istniał Komitet Samopomocy, który z uzyskiwanych funduszy wypłacał ok. 10 stypendiów po $500 \mathrm{z} 1$ miesięcznie. Wydział dysponował również stypendiami państwowymi, które początkowo wynosiły 150-200 zł miesięcznie, później zaś 300 zł ${ }^{52}$.

Komplety prof. Śliwińskiego obejmowały przeciętnie 12 słuchaczy, frekwencja wahała się od 7 do 10 osób na komplecie. Profesor wykładał 
prawo karne materialne i procesowe, prowadził seminarium z prawa i procesu karnego. $\mathrm{Na}$ seminarium omawiano przykłady praktyczne zaczerpnięte z orzecznictwa Sądu Najwyższego, uczestnicy przygotowywali referaty wraz z rozstrzygnięciem. Z notatek, które częściowo ocalały, wynika, że przeegzaminowanych zostało ok. 100 studentów. Dwukrotnie zdarzyło się, że dom, w którym odbywały się zajęcia, został obstawiony przez żandarmerię. Studenci rozbiegli się po różnych mieszkaniach i uratowali głównie dzięki temu, że rewizje były natury handlowej, nie politycznej. Jednym z ostatnich był komplet XII, który powstał w końcu października 1943 r. Zbierał się w gronie 14 osób na ul. Mokotowskiej w mieszkaniu rodziny L., rodziców jednego z uczestników kompletu. Za kartę wstępu służyło hasło: „od Zbyszka, w sprawie węgla”. Pierwsze zebranie zagaił sekretarz Wydziału, „Pan Tolek”, po czym prof. Rafacz immatrykulował uczestników i zapowiedział swój pierwszy wykład. „Pan Tolek” mianował starostą Halinę Desz. W gronie 19 uczestników kompletu były 3 kobiety. Na początku komplet dysponował dwoma lokalami, poza wspomnianym na ul. Mokotowskiej, którego właściciele dość szybko zaczęli utrudniać naukę, zaś ich syn został przeniesiony na inny komplet, na ul. Piusa. W połowie grudnia jeden ze słuchaczy zorganizował lokal, za który komplet płacił miesięczny czynsz. Godła lokali tworzono od imion ich mieszkańców, najczęściej studentów: np. „u mnie” (H. Modzelewski), „u Ewy” (E. Lubecka), „u Kazimierza” (K. Łojewski), „u Bolesława” (B. Michałko), „u Wandy” (W. Pułak), „u Andrzeja” (A. Kwieciński), „u Stefana” (S. Zoll). Zajęcia odbywały się w czwartki, soboty, niedziele, poniedziałki. Średnia ocen uczestników kompletu wynosiła 3,9. Egzaminy zostały wyznaczone na 10 VIII 1944 r..$^{53}$

Wydział Humanistyczny ze względu na różnorodność jego specjalności nie prowadził pracy jako całość, lecz dzielił się na szereg sekcji, działających autonomicznie. Program studiów magisterskich, obowiązujący od 1926/1927 r., nie przewidywał sztywnej siatki zajęć, wprowadzał kilka obowiązkowych egzaminów, które absolwent musiał złożyć przed przygotowaniem rozprawy magisterskiej. Dopiero 7 V 1944, r. odbyła się pierwsza Rada Wydziału, w której wzięli udział obecni w Warszawie profesorowie; dokonano wyboru dziekana, powołując na to stanowisko Bogdana Nawroczyńskiego. Rada odbyła kilka zebrań, na których zajmowano się problemem zorganizowania studiów w kolejnym roku akademickim, omawiano potrzeby lokalowe Wydziału w okresie powojennym i sprawy personalne. Posiedzenia Rady odbywały się w gabinecie dyrektora Biblioteki Ordynacji Zamojskich Ludwika Kolankowskiego. Przez Wydział przewinęło się w okresie okupacji ok. 2000 studentów $^{54}$. 


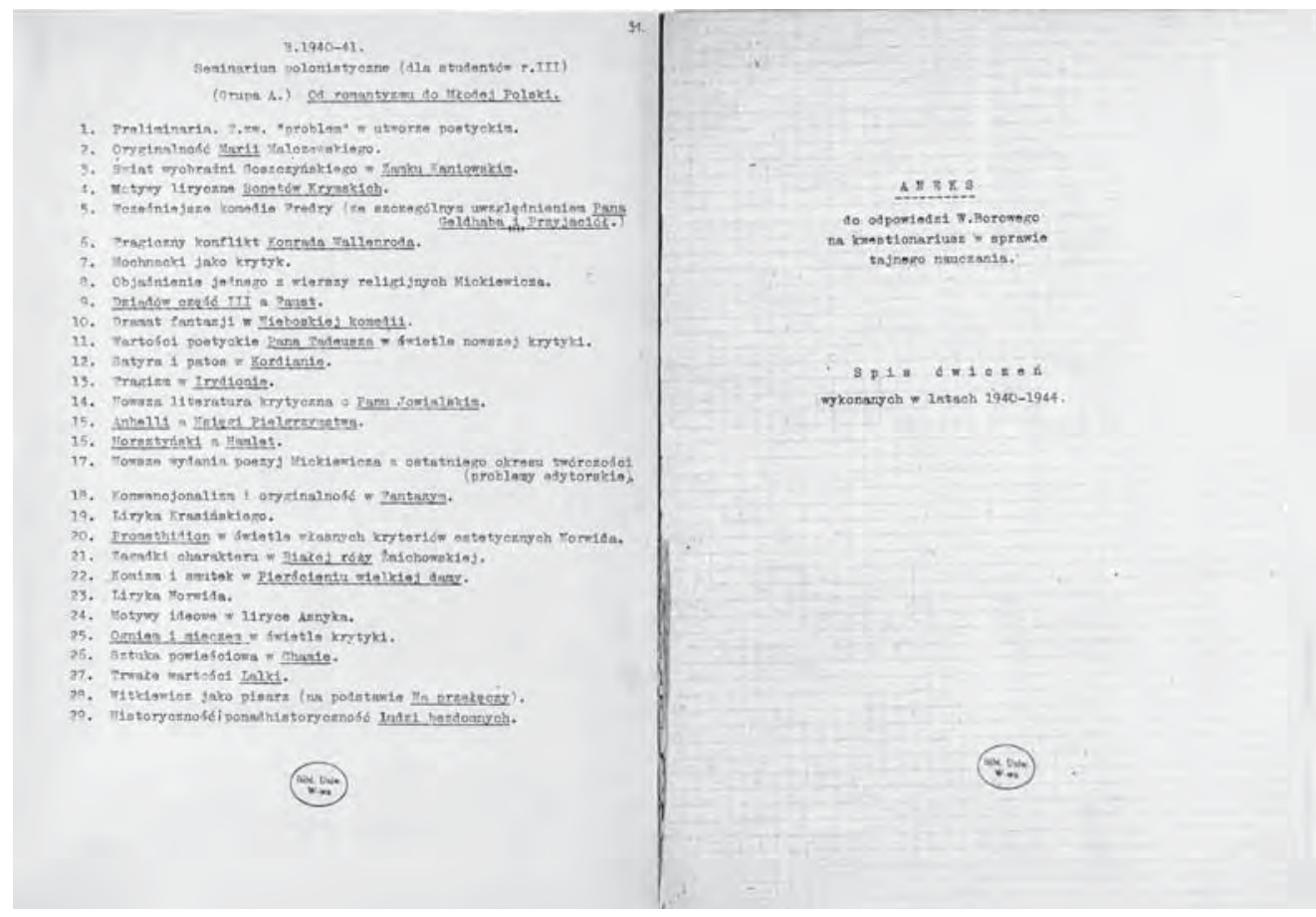

5. Spis ćwiczeń seminaryjnych tajnego seminarium polonistycznego prof. Wacława Borowego

Sekcja polonistyczna rozpoczęła działalność jesienią 1940 r. Inicjatorem jej powstania i kierownikiem był Julian Krzyżanowski, wokół którego skupiła się grupa 14 osób, tworzących komplet I roku ${ }^{55}$. Po latach napisał on:

Wczesnym latem 1940 r. moja żona Irena przyniosła wiadomość, że dyrektorka jej szkoły, Janina Dembowska, pragnęłaby nawiązać kontakt z humanistyką uniwersytecką. W kilka dni później, w mieszkaniu na Żurawiej, koło Placu Trzech Krzyży, Dembowska urządziła spotkanie z przedstawicielem Kuratorium [właśc. Delegatury]; był to bodajże [Czesław] Wycech. Poradziłem mu, by w sprawie historii zwrócił się do doc. Manteuffla, sam zaś obiecałem zająć się zorganizowaniem studium filologicznego. Wyniki były raczej żałosne, o ile chodziło o neofilologię i filologię klasyczną. Przedstawiciel jednej z tych dyscyplin oświadczył, że pomysł jest słuszny, ale że trzeba się nad nim gruntownie zastanowić. No i zastanawiał się do końca wojny. Nie pozostawało nic innego, jak ograniczyć się do polonistyki rozbudowanej możliwie szeroko; literaturę polską wziąłem ja, powszechną Wacław Borowy, filozofię i historię kultury Bogdan Suchodolski, językoznawstwo Witold Doroszewski, nauki pomocnicze Tadeusz Mikulski. 
Jeden z uczestników spotkań u prof. Krzyżanowskiego wspominał z kolei:

Znalazłem się październikowego popołudnia 194,2 r. w mieszkaniu państwa Krzyżanowskich na pierwszym wykładzie historii średniowiecznej literatury polskiej. Wszedł do pokoju prof. Krzyżanowski. Świeżo zwilżone włosy i tabaczkowy szlafrok zamiast marynarki świadczyły, iż przed wykładem odbywał poobiednią sjestę. Przywitał się z wszystkimi szybko, energicznie ściskając dłoń, zasiadł za biurkiem, zapalił «zwijanego» papierosa i zaczął swobodnie opowiadać ${ }^{56}$.

W ciągu kolejnych lat sekcja się rozrastała; w 1941/194,2 r. liczyła, obok jednego kompletu II roku, 4, komplety pierwszego. W 194,2/1943 r. czynne były komplety 3 lat studiów. „Dwa [konspiracyjne] roczniki maturalne" - pisał Krzyżanowski:

[...] dostarczyły kandydatów tak obficie, że liczba ich sięgnęła półtorej setki. Do tego doszło scalenie indywidualnych wysiłków, niezależnie od nas drobny komplecik prowadzili Tadeusz Makowiecki i Stanisław Furmanik. W październiku 19411 r. zaprosiłem do współpracy Zofię Szmydtową, Stanisława Adamczewskiego i Stefana Wierczyńskiego, wykładających literaturę, Stanisława Słońskiego i Henryka Friedricha - językoznawców, Władysława Tatarkiewicza i Jerzego Kreczmara - filozofów, w zakresie nauk pomocniczych doszedł Tadeusz Wiwatowski. Rozmieszczenie stu pięćdziesięciu osób w grupach dziesięcioosobowych dwa razy w tygodniu wymagało trzydziestu lokali. Wyszukanie ich nie było zadaniem łatwym, właściciele mieszkań dzielili się na dwie kategorie: takich, którzy odmawiali wszystkim, i takich, którzy nie odmawiali nikomu ${ }^{57}$.

W roku 1943/1944, sekcja osiągnęła rekordową liczbę ok. 200 słuchaczy. Liczebność kompletów zmieniała się wraz ze zmianą technik pracy konspiracyjnej. Podczas gdy w latach 194,0-1943 zajęcia odbywały się w mieszkaniach prywatnych studentów i profesorów, w 1943/1944, r., dzięki gościnności dyrektora jednej z jawnych szkół Stanisława Tynelskiego przeniesiono zajęcia do budynku szkolnego przy ul. Świętokrzyskiej, gdzie w „normalnych” klasach zbierały się komplety zo-osobowe.

Latem 1943 r. panowała atmosfera, która paraliżowała pracę i stawiała wobec rozpaczliwych pytań: czy można prowadzić robotę i narażać kilkadziesiąt młodych istnień? Morale naszej pracy poczyna się załamywać i to nie u studentów, lecz w gronie uczącym. Wykładowcy nieraz zaniedbują się i nie przychodzą na komplety, których uczestnicy czekają całymi godzinami. Asystent Friedrich oświadczył, że wyjściem z sytuacji byłoby skupienie rozproszonych 
robót w jakiejś szkole i dodał, że szkołę taką potrafi znaleźć. Następnego dnia poznał mnie ze Stanisławem Tynelskim, który prowadził szkołę handlową na Świętokrzyskiej, naprzeciw gmachu PKO. Po południu klasy zostają wolne. $\mathrm{Na}$ zapytanie, co to będzie kosztować, roześmiał się po raz drugi. Nic, muszę tylko porozumieć się z woźnym, któremu wypadnie dyżurować nadobowiązkowo. Rok 1943/4,4 polonistyka podziemna spędziła w lokalu bardzo wygodnym, do którego przychodziło się oficjalnie, bo była to szkoła publiczna. Prof. Doroszewski uczył gramatyki historycznej języka polskiego z podręcznika towaroznawstwa, który przynosił z sobą jako wykładowca kursów handlowych.

Powrót do warunków szkolnych „odmłodził” całe grono, które „odnalazło sztubackie nastroje i podczas pauz dokazywało w najlepsze, goniąc się po korytarzach"58.

Wykłady i ćwiczenia odbywały się według norm przedwojennych. Obowiązkowe minimum wynosiło 8 godzin tygodniowo i obejmowało: na I roku - 2 godziny ćwiczeń proseminaryjnych z przedmiotów pomocniczych historii literatury polskiej, 2 godziny ćwiczeń proseminaryjnych połączonych $\mathrm{z}$ wykładem $\mathrm{z}$ języka polskiego, 2 godziny wykładów z historii literatury polskiej, 2 godziny z filozofii; na II roku - 2 godziny ćwiczeń proseminaryjnych z poetyki, 2 godziny ćwiczeń proseminaryjnych połączonych $\mathrm{z}$ wykładem z gramatyki historycznej, 2 godziny seminarium niższego $\mathrm{z}$ historii literatury polskiej, połączonego z wykładem, 2 godziny wykładów z historii Polski, historii estetyki lub socjologii; na III roku - 2 godziny seminarium wyższego, połączonego $\mathrm{z}$ wykładem $\mathrm{z}$ historii literatury polskiej, 2 godziny seminarium słowotwórczego, połączonego $\mathrm{z}$ wykładem, 2 godziny wykładu i ćwiczeń z literatury obcej oraz 2 godziny wykładu z estetyki. Administrację sekcji prowadziła Zofia Szymanowska, której mieszkanie na Mokotowie było pierwszym etapem, do którego docierał zaopatrzony w polecenie dyrekcji jednego z konspiracyjnych gimnazjów kandydat na polonistę; sprawowała również funkcję kwestorki i to do niej grupowi poszczególnych kompletów przynosili opłaty. „Pani Szymanowska okazała się niezrównanym ministrem finansów, znakomitym gospodarzem, umiejętnie gromadzącym drobne opłaty studenckie, by przekształcić je w znaczne sumy. Osoba energiczna i szorstka" - wspominał kierownik sekcji. Opłaty wzrastały w ciągu czterech lat od 50 do $150 \mathrm{zl}$, z tym, że słuchacze wyższych roczników opłacali z zasady niższe czesne. Stosowane były nadto zwolnienia i zniżki, wypłacano stypendia, w $1943 \mathrm{r}$. zorganizowano „Bratnią Pomoc”. Wsparcie przychodziło także ze strony zamożniejszych wydziałów. „Kiedyś zjawił się u mnie na Brzozowej sąsiad, Stanisław Borowski" - pisał Julian Krzyżanowski: 
Przyszedł z polecenia prof. Rafacza z pytaniem, czy nie potrzeba mi pieniędzy. Borowski zakomunikował mi, że Rafacz kieruje studium prawniczym, ma pokaźne dochody, wobec czego może pomagać studiom słabszym. Gdy oświadczyłem, że dajemy sobie radę, Borowski zapytał: «A stypendia pan ma?». W rezultacie Borowski zostawił mi pękatą kopertę banknotów i od tej chwili odwiedzał mnie co miesiąc z podobną kopertą. Mogłem podwyższyć pobory grona wykładowców, zwolnić od czesnego sporą ilość studentów, kilkunastu z nich dostało stypendia.

Prof. Krzyżanowski potrafił też różnymi sposobami zgromadzić księgozbiór, który przechowywał w tzw. domu profesorskim na ul. Brzozowej i przy pomocy studentów porządkował. Powstała biblioteka, obsługująca sekcję polonistyczną. W czasie powstania uległa zniszczeniu ${ }^{59}$.

„Spośród wszystkich naszych profesorów” - wspominała jedna ze studentek - „nikt nie był takim pedantem jak prof. Borowy. Trudno było przyjść do Borowego i prosić o przesunięcie terminu kolokwium czy referatu. Gdy przychodziło się z tym do prof. Krzyżanowskiego, wiedzieliśmy, że rozumie podtekst takiej prośby i nie gani go. Borowy nie rozumiał, że mogły być dla nas rzeczy ważniejsze niż nauka". Wacław Borowy mieszkał w Zalesiu, skąd kilka razy w tygodniu dojeżdżał do Warszawy. „Długie godziny w pociągu dojazdowym, piesze wędrówki ze stacyjki na Służewcu, gdy do tramwaju dostać się nie było można, ciężki plecak wyładowany książkami [jak wspominał jeden ze słuchaczy: «Dla kilku zdań wiózł z Zalesia do Warszawy i z powrotem grube tomy»], wszystko to nie zachwiało jego wewnętrznej równowagi” - pisał Julian Krzyżanowski. - „Z uśmiechem zjawiał się na kompletach [przy ul. Racławickiej] i nigdy nie kazał na siebie czekać”. Komplety Wacława Borowego zaczęły się od spotkań organizowanych z inicjatywy jego dawnych studentów. Początkowo gromadziły się raz w tygodniu, potem częściej, głównie „w prywatnych mieszkaniach rodziców studentów, które się co czas pewien zmieniało" - jak wspominał prof. Borowy; łącznie spotykało się do 20 osób. Z czasem liczba studentów wzrastała - przez komplety przewinęło się łącznie ok. 55 osób. Spotykali się na zajęciach w lokalu jawnej Szkoły Handlowej inż. Gracjana Pyrka na ul. Świętokrzyskiej. Jednym z głównych tematów seminariów była analiza utworów Szekspira. Na zajęciach seminaryjnych powstawały artykuły i rozprawki, np. Wiesława Pyrka o Pierścieniu wielkiej damy Norwida. Dwie prace seminaryjne Jerzego Pelca złożyły się na rozprawę magisterską Ze studiów nad Krasickim i Mickiewiczem. Pedantyczny Borowy prowadził szczegółowy kalendarz spotkań z listą tematów prac seminaryjnych, „z okienkami na imiona”. 
Stopniowo „amarantowy ołówek” wypełniał okienka, a zielony „przy każdym temacie postawił datę" - do lutego 1944 r. Każdy z uczestników zajęć musiał wybrać temat referatu lub koreferatu, którego „czytelny” tekst na dwa tygodnie przed terminem zebrania referent i koreferent wręczali profesorowi. Borowy egzaminował studentów „komisyjnie” wspólnie z prof. Krzyżanowskim i w wypadku pozytywnych wyników informował ich, że „spełnili warunki potrzebne do uzyskania magisterium". Spośród uczestników zajęć prof. Borowego warunki te spełnili: Wiesław Pyrek (rozprawa: Karol Brzozowski, życie i twórczość), Karolina Pojawska (O „Akropolis"Wyspiańskiego), Anna Gajzler (Literacka zawartość „Monitora" 1765-1784), Zofia Tworkowska (Elementy artystyczne $w$ prozie ideologicznej Stanisława Brzozowskiego). Osobną grupą byli studenci, którzy napisali prace magisterskie i zdali część egzaminów w okresie konspiracji, egzaminy zaś ostateczne dopiero po wojnie: Maria Straszewska (Norwid jako czytelnik literatur obcych) i Jerzy Pelc. Praca magisterska Jerzego Pelca zaginęła w powstaniu, zdążył ją jednak wcześniej przeczytać i zaakceptować prof. Borowy. „Drogi Panie Jerzy” - pisał po wojnie do swego magistranta - „myli się Pan, twierdząc, że «scripta non manent». «Manent» w duchu tych, co je czytali" ${ }^{\prime 60}$.

Estetykę, historię estetyki, fllozofię XIX w. oraz filozofię współczesną wykładał Władysław Tatarkiewicz, na kilku zresztą sekcjach Wydziału Humanistycznego oraz na Uniwersytecie Ziem Zachodnich; dodatkowo na Wydziale Architektury Politechniki Warszawskiej zaangażowany był w przeprowadzanie przewodów doktorskich i habilitacyjnych. W roku 1942/1943 zajęcia Tatarkiewicza odbywały się w mieszkaniach słuchaczy, na ul. Hożej oraz na ul. Jasnej. W roku następnym - przeważnie w szkole wspomnianego dyrektora Tynelskiego, gdy zaś tam stało się mniej bezpiecznie, wykłady zostały przeniesione do mieszkania rodziny Stachurskich na ul. Wspólnej, Niewiadomskich przy ul. Marszałkowskiej 73 i Tallen-Wilczewskich na ul. Jasnej 6. Po ukończeniu pełnego kursu odbywały się egzaminy. Przez kurs przewinęło się łącznie ok. 8o-10o osób, wśród nich Stanisław Dygat i Czesław Miłosz. Z uczniów prof. Tatarkiewicza 6 otrzymało stopień magisterski. Wykłady z filozofii prowadził również Tadeusz Kotarbiński w mieszkaniu rodziny Morysińskich na ul. Smolnej. „Będę dziś mówił o tym, co to znaczy «wyrażać bezpośrednio», «pośrednio», «wypowiadać», «wypowiadać myśl» - zaczął bez zbędnych słów jeden ze swych pierwszych wykładów"61.

Wykłady prof. Tatarkiewicza uchodziły za szczególnie popularne, zwłaszcza w okresie, kiedy odbywały się w szkole Tynelskiego. Ta popularność mogła być też przyczyną przeniesienia ich do innych lokali. 
Nie obowiązek, lecz zainteresowanie przyciągało zawsze tłum ludzi i to także spoza polonistyki, po prostu z miasta - bo oto na sali spotykało się obok słuchaczy podziemnego uniwersytetu również ich znajome i znajomych, narzeczone i narzeczonych, siostry i braci. Młodzież na ogół dobrze ubrana, z zamożnych rodzin inteligenckich, może ziemiańskich, po części złota, trochę snobistyczna, niekiedy zapewne traktująca swe uczestnictwo w zajęciach tego typu jako należące do dobrego tonu.

Znaleźli się w tym gronie również ludzie, których zainteresowania wykraczały poza modę, np. Klemens Szaniawski ${ }^{62}$.

Ćwiczenia z nauk pomocniczych historii literatury prowadził Tadeusz Mikulski w mieszkaniu rodziny Wilczewskich przy ul. Jasnej 6:

Z kartonowej okładki, związanej tasiemką na podwójną kokardkę, Mikulski dobywa plik kartek formatu zeszytowego, pokrytych równym, drobnym, nieco pochylonym w lewo pismem. To skrypt na dzisiejsze zajęcia. Prowadzone przezeń ćwiczenia proseminaryjne zaliczam do najwyższej klasy zajęć tego typu. Zarówno ich program - historia książki dawnej, technika pracy umysłowej i przegląd bibliografii, słowników i encyklopedii - jak realizacja tego programu, oparta na niezwykle starannym przygotowaniu każdego szczegółu i na zasadzie, że wszystko, o czym się mówi, trzeba dać słuchaczowi do ręki - są wzorem do naśladowania ${ }^{63}$.

Proseminarium z nauk pomocniczych, obejmujące podstawowe lektury dla pierwszego roku studiów, czyli ok. 50 pozycji z różnych epok, prowadził Tadeusz Wiwatowski:

Powołany na asystenta dopiero w czasie wojny, prowadził swoje pierwsze w życiu wykłady i ćwiczenia. Ostrością wobec nas starał się dodać sobie powagi. Każdy wykład musiał mieć spisany na karteczce, do której zerkał od czasu do czasu i ucinał szybko wszelkie dyskusje. Na kolokwium maglował niemiłosiernie, zdawałam u niego przez półtorej godziny, podczas gdy na przykład kolokwium u prof. Krzyżanowskiego trwało pół godziny.

Mimo surowości egzaminatora, słuchaczka otrzymała oceną bardzo dobrą ${ }^{64}$.

Seminarium historyczne poświęcone przeglądowi najważniejszych kierunków myśli europejskiej od Arystotelesa po Maritaina prowadził Bogdan Suchodolski.

System jego seminarium polegał na tym, że każdy z nas miał jeden czy dwa referaty na podstawie jednej z książek danego myśliciela czy filozofa, uznanej 
przez profesora za najbardziej reprezentatywną. W rezultacie sprowadzało się to do opisowego referowania dzieł i równie oderwanego, encyklopedycznego przeglądu. Nigdy nie udało się nam sprowokować go do zajęcia własnego stanowiska wobec omawianych prądów czy postaci. A jednak było to seminarium cenne. Dawało bowiem pewną sumę wiedzy o sprawach dla humanisty koniecznych, podstawy wiadomości, bez których nie można w ogóle mówić o myślowych relacjach ${ }^{65}$.

Szczególnie w pamięć uczestników zapadło seminarium z językoznawstwa prowadzone przez Witolda Doroszewskiego. Nie tylko ze względu na autorytet wykładowcy, ale także jego zainteresowania i zwyczaje. Doroszewski gromadził mianowicie nowe słownictwo okupacyjne, spisywał słowa i wyrażenia, które były w obiegu na warszawskiej ulicy. Wiele z nich dostarczali sami studenci. Doroszewski mieszkał w Laskach pod Warszawą i na seminaria przyjeżdżał rowerem. Przez rok seminaria odbywały się w mieszkaniu na ul. Chmielnej, w oficynie na czwartym piętrze. Zaczynał zwykle seminarium od skromnego posiłku, następnie wypijał szklaneczkę bimbru, który produkowała właścicielka mieszkania ${ }^{66}$.

Nauczanie na podziemnych studiach polonistycznych zazębiało się z konspiracyjnym życiem literackim, w które zaangażowani byli młodzi poloniści (m.in. czasopisma literackie „Sztuka i Naród”, „Droga”). W czasie zajęć studenci niejednokrotnie „urywali” kilkanaście minut, żeby wspólnie z wykładowcą przeczytać krążące w odpisach utwory podziemnej literatury. Jeden z wieczorów poetyckich odbył się w mieszkaniu rodziny Rybarskich przy ul. Marszałkowskiej, komplet został po skończeniu normalnych zajęć, przybyli koledzy z innych grup. Symboliczną postacią tego czasu był poeta Wacław Bojarski, student polonistyki, który zginął w 1943 r. podczas manifestacji pod pomnikiem Mikołaja Kopernika przed Pałacem Staszica. Przenikanie środowisk i koleżeńska atmosfera nie sprzyjały konspiracji, wiele osób znało się prywatnie, z nazwiska i z adresu, a zarazem z pseudonimu. Po zajęciach u prof. Krzyżanowskiego na ul. Brzozowej wychodzili „cicho i pojedynczo, ale zaraz na rogu Brzozowej czy na Rynku Staromiejskim czekaliśmy na siebie i szliśmy dalej całą gromadą". Po zdaniu wszystkich kolokwiów ci sami studenci zostali „zaproszeni do państwa Krzyżanowskich na coś w rodzaju uroczystego zakończenia roku. Byli też inni profesorowie i cały nasz rocznik". Jak większość konspiracyjnych zajęć, także te prowadzone na polonistyce, stały się szczególnym azylem wobec okupacyjnej rzeczywistości. Jeden ze studentów, zarazem członków konspiracji wojskowej, bezpośrednio po nieudanym zamachu na 
Arbeitsamt na ul. Kredytowej, w którym brał udział (prawdopodobnie 14. VII 1944, r.), przybiegł do mieszkania Mieczysława Wionczka na Powiśle, gdzie odbywało się spotkanie z prof. Kotarbińskim, którego tematem były Rozważania o przemocy Sorela. „Początkowo z trudem mogłem opanować podniecenie, ale w miarę rozwoju dyskusji zacząłem otrząsać się z przeżytego szoku i pod koniec zebrania najistotniejszą sprawą stały się już dla mnie granice stosowania rewolucyjnej przemocy"67.

Sekcja pedagogiczna powstała jesienią 1940 r. Oprócz słuchaczy początkujących zgłaszało się wielu zaawansowanych, przedwojennych studentów. Starano się realizować program przedwojenny, aczkolwiek nie bez trudności. Problematyczne było np. zorganizowanie ćwiczeń z psychologii. Kwestię tę rozwiązano w taki sposób, że prowadzący ćwiczenia nielegalnie wypożyczali aparaturę należącą do Zakładu Psychologii Wychowawczej, „zabezpieczoną” przez okupantów. Zajęcia z historii wychowania prowadziła Hanna Pohoska, psychologii ogólnej i wychowawczej - Stefan Baley z asystentami: Ludwikiem Goryńskim, Joanną Kunicką i Ewą Rybicką (wszyscy zginęli wskutek okupacyjnych represji), zajęcia z socjologii - prof. Bystroń, pedagogiki i organizacji szkolnictwa - profesorowie Nawroczyński i Suchodolski. Wykłady odbywały się przeważnie w mieszkaniach wykładowców. Podobnie jak na innych kierunkach, były odpłatne, bezpośrednio przed powstaniem opłaty wynosiły $100 \mathrm{zł}$ od osoby; przyznawano stypendia i ulgi ${ }^{68}$.

Bogdan Suchodolski wspominał, iż prowadzone przezeń zajęcia poświęcone były zagadnieniom kultury współczesnej, odbywały się w lokalach uczestników, gromadząc co tydzień 10-15 osób, w tym także studentów sekcji polonistycznej. Wynikiem prac prowadzącego i studentów było przetłumaczenie i wydanie na powielaczu książki Emmanuela Mouniera Manifeste au service on personnalisme. Przez ćwiczenia prof. Suchodolskiego przeszło ogółem ok. 100 osób, niestety, notatki dotyczące zarówno nich, jak również samych zajęć, zaginęły. O systemie zabezpieczeń lokali konspiracyjnych prof. Suchodolski pisał: „Nie mieliśmy żadnej ochrony, prócz zaufania do lokalu i wiary w łut szczęścia". Wykłady z socjologii ogólnej i teorii kultury prowadził również Stanisław Ossowski. Przez jego zajęcia przewinęło się ponad yo słuchaczy. Profesor wykładał także w sekcji historycznej UW, socjologicznej UZZ, ekonomicznej Wolnej Wszechnicy Polskiej. Zabezpieczeniem były: zmiana lokali, „hasła naiwnie stosowane”69.

Jedna ze słuchaczek sekcji wspominała:

Dzięki staraniom prof. Ossowskiej trafiłam na komplety psychologii wychowawczej do konspiracyjnego zakładu prof. Stefana Baleya. Okupacyjne studia 
psychologii zaczęłam od kompletu prowadzonego przez dr Ewę Rybicką, uczęszczając jednocześnie na wykłady dr Goryńskiego. Prowadząca ćwiczenia stała się szybko lubianą jakby starszą koleżanką. Bardziej od Rybickiej «uroczysty» w kontaktach był Goryński. W zawsze starannie przygotowanych, nieco za trudnych dla nas wykładach, uwidaczniało się gruntowne wykształcenie Goryńskiego. Zorganizowane były przez zakład również wykłady i ćwiczenia z anatomii i fizjologii. Komplety dr Kunickiej, rozpoczęte jesienią 194,2 r., odbywały się raz w tygodniu w trzech odległych punktach Warszawy: w mieszkaniu doktor Kunickiej, niedaleko placu Narutowicza, u Stefanowskiej na Kopernika i u mnie na Żoliborzu. Spotkanie trwało czasem cztery, pięć i więcej godzin.

Ta sama słuchaczka brała również udział w kompletach przygotowujących do egzaminu z logiki, prowadzonych pod patronatem prof. Kotarbińskiego przez niedawnego uczestnika kompletu prof. Ossowskiej, logika Henryka Hiża. Wspominał on:

W maju 1940 r. zwrócił się do mnie prof. Kotarbiński z poleceniem poprowadzenia wykładów z filozofii dla grupy polonistów. Sytuacja moja była kłopotliwa; miałem wówczas za sobą tylko dwa lata przedwojennego uniwersytetu, daleko mi jeszcze było do magisterium. Moim zadaniem było przygotowanie studentów do egzaminu. Egzaminy przeprowadzał prof. Kotarbiński.

Komplety w zakładzie prof. Baleya wspomniana słuchaczka zakończyła egzaminem z psychologii wychowawczej i pedagogiki eksperymentalnej. „Zdawałam go w oryginalnych okolicznościach, bo w czasie wspólnego z profesorem [Baleyem] jedzenia obiadu. Nie było mowy o żadnej okupacyjnej ulgowej taryfie. Był maj lub czerwiec 1944"

Sekcja historyczna ${ }^{71}$ działała pod kierunkiem Tadeusza Manteuffla. Spośród późniejszych wykładowców tej sekcji jedynym, który w roku 1939/1940 jako pierwszy skupił wokół siebie kilku dawnych słuchaczy i odbywał z nimi zebrania, był Stanisław Kętrzyński. Decydującą rolę przy zorganizowaniu tajnego nauczania odegrało grono dyrektorów szkół średnich z Janiną Dembowską na czele. To ona zwróciła się do przedwojennego dyrektora Instytutu Historycznego UW, prof. Handelsmana, z propozycją zorganizowania konspiracyjnych zajęć. Handelsman, nie mogąc z powodu ukrywania się przed okupantem podjąć się tego zadania, zaproponował je Tadeuszowi Manteufflowi. „Kontaktem” z Departamentem Oświaty i Kultury Delegatury Rządu była Halina Stypułkowska, która nawiązała współpracę z Manteufflem w roku 1940/19411. Za jej też pośrednictwem wykładowcy sekcji otrzymali pierwsze zasiłki pieniężne. Halina Stypułkowska pełniła następnie 


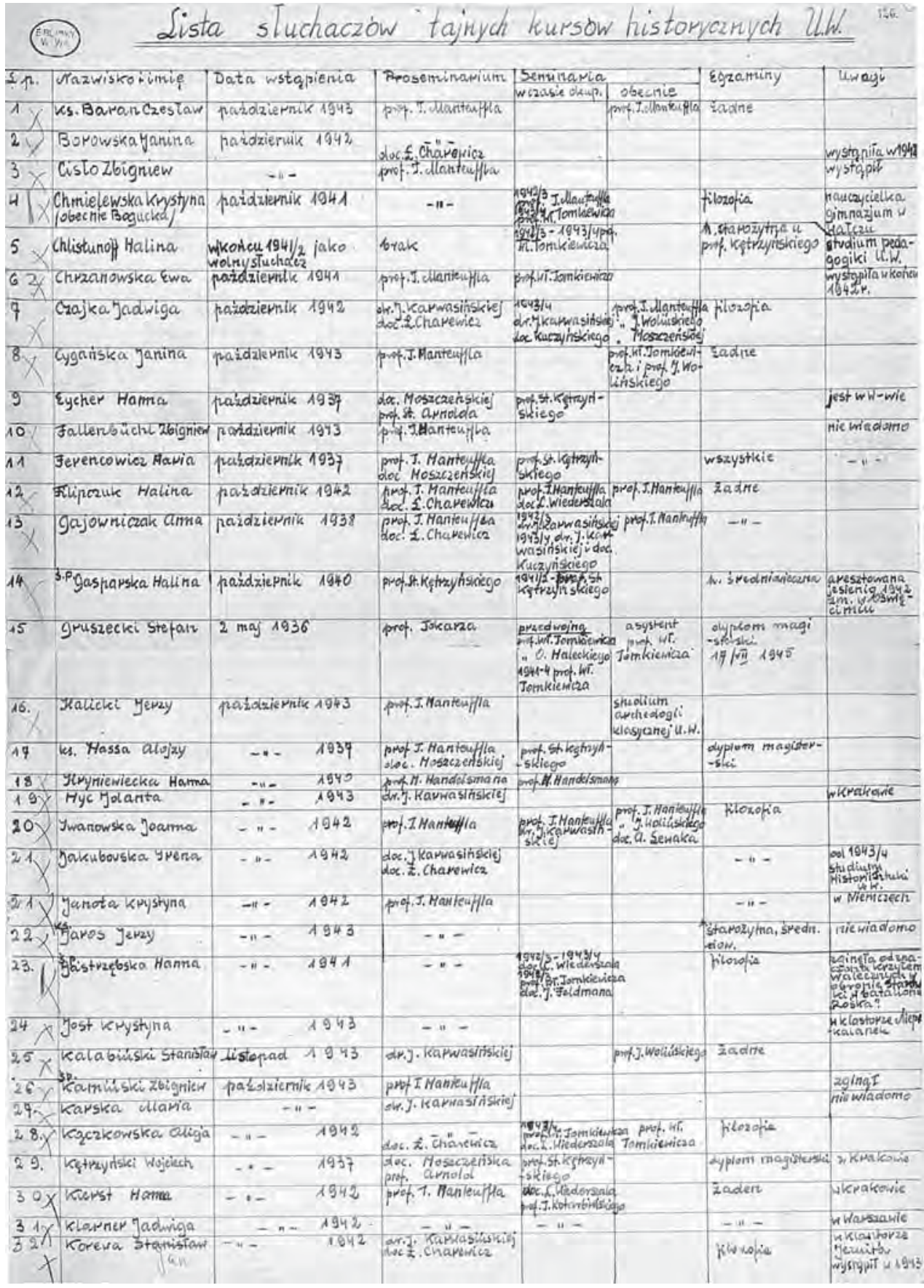

6. Lista słuchaczy tajnych kursów historycznych UW 
funkcję sekretarki sekcji, odpowiadając również za rekrutację studentów. Tadeusz Manteuffel wspominał:

Utrzymywała kontakt z dyrektorami tajnych szkół średnich i kierowała młodzież do mnie. Byłem zatrudniony w Archiwum Akt Nowych przy ul. Rakowieckiej 6. Na parterze miałem oddzielny pokoik, co ułatwiało mi przyjmowanie interesantów. Z tego punktu kontaktowego dane mi było korzystać do lata 1944 r. Odbywałem rozmowy z kandydatami, informując o programie zajęć, miejscu spotkania kompletu i haśle rozpoznawczym uczestników. Nie wymagałem zaprzysiężenia, stosowanego w niektórych sekcjach, wychodząc z założenia, że stanowi ono słabe zabezpieczenie ${ }^{72}$.

Taką „rozmowę kwalifikacyjną” zapamiętał Krzysztof Dunin-Wąsowicz:

Po ukończeniu konspiracyjnego gimnazjum odczuwałem niedosyt wykształcenia. Z wielką radością w lecie 19411 r. powitałem informację Krystyny Rajgrodzkiej, znajomej rodziców, iż istnieje tajny uniwersytet. Poleciła mi zgłosić się do jej koleżanki Hanny Eychhorn (obecnie Szwankowskiej) w Archiwum Miejskim w Arsenale na ul. Długiej 52. Przy drugiej wizycie dowiedziałem się adresu organizatora tajnych studiów, prof. Manteuffla w Archiwum Akt Nowych. Był październik 19411 r. Zadał kilka pytań: w jakim gimnazjum otrzymałem maturę, czy dam sobie radę z łaciną, jakie znam języki obce, czy mam specjalne zainteresowania historyczne. Przypuszczam, że miał już informacje o mojej osobie. Od razu uznał mnie za przyjętego na studia i polecił zgłosić się na proseminarium z nauk pomocniczych historii średniowiecznej oraz na wykłady z historii Polski i z historii powszechnej średniowiecznej, które odbywały się w gmachu sióstr przy ul. Kazimierzowskiej 59. Miałem stawić się wieczorem, bodajże o szóstej godzinie. Czesne miałem wpłacić na ręce sekretarki sekcji, Haliny Stypułkowskiej. Tak się odbyła moja immatrykulacja ${ }^{73}$.

Sekcja rozpoczęła działalność jesienią 1940 r. „Zgłosiło się kilkoro chętnych na jesieni 1940 r.” - wspominał Tadeusz Manteuffel - „powołując się na osobę p. Dembowskiej. Nie wiedziałem, co będę z nimi robić, dostęp do bibliotek naukowych był oficjalnie zamknięty. Zdecydowałem się przerabiać z tą grupą ćwiczenia z historii powszechnej średniowiecznej zgodnie z programem proseminarium, które przed wojną prowadziłem na uniwersytecie. Moja biblioteka mogła stanowić pomoc, ćwiczenia prowadziłem u siebie w mieszkaniu". W ciągu lat okupacji Manteuffel prowadził ćwiczenia proseminaryjne dla I roku, wykład historii powszechnej średniowiecznej oraz seminarium średniowieczne. 


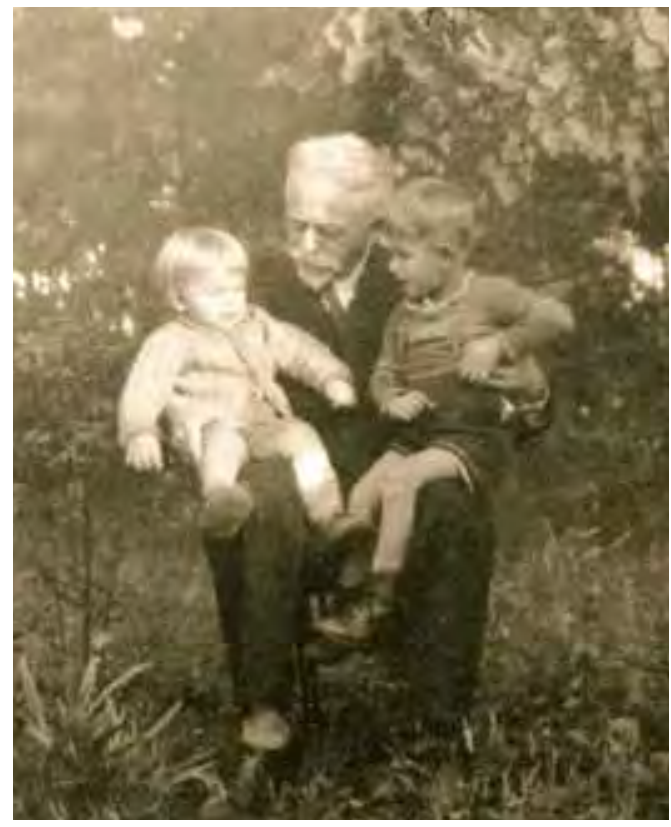

7. Profesor Marceli Handelsman z wnukami podczas okupacji
Na seminariach, poświęconych w jednym roku historii społeczno-gospodarczej Śląska w XIII w., a w drugim historii wpływów polskich na Pomorzu Zachodnim w XII w., wykonano pod jego kierunkiem szereg prac seminaryjnych, np.: Obraz fizjograficzny doliny górnej Oławy na przełomie XII $i X I I I w$. Z czasem powstała tez, uzupełniana z własnych dochodów sekcji, podręczna biblioteka ${ }^{74}$.

Prace były prowadzone w 15-osobowych kompletach, każdy zbierał się na co najmniej cztery dwugodzinne posiedzenia tygodniowo. Program I roku studiów przewidywał proseminarium średniowieczne, mające zapoznać słuchaczy z elementami nauk pomocniczych historii na podstawie obranych przez wykładowcę tekstów. $\mathrm{Z}$ trzech posiedzeń przeznaczonych na wykłady jedno było poświęcone propedeutyce filozofii (teoria poznania, elementy logiki, metodologia nauk humanistycznych), dwa zagadnieniom historycznym lub prehistorycznym, ujętym w formę wykładu kursowego. Na II roku studiów kandydaci interesujący się średniowieczem uczęszczali na seminaria średniowieczne, nowożytnicy przechodzili przez proseminarium nowożytne, po ukończeniu którego mogli brać udział w seminarium, które zapoznawało ich z typami źródeł nowożytnych oraz metodą ich opracowywania. Lata III i IV, drugi okres studiów, pozostawiono pod znakiem specjalizacji i swobody wyboru zajęć. Słuchacz mógł obrać dowolną gałąź historii z możliwością studiowania przedmiotów wykładanych na innych sekcjach, a nawet na innych wydziałach. Program przewidywał więc wykłady z socjologii, historii kultury, historii sztuki i prehistorii. Powyższy program nauczania, wypracowany według koncepcji Tadeusza Manteuffla w czasie okupacji, stosowano również po wojnie ${ }^{75}$.

W roku 194.0/19411 sekcja liczyła 3 wykładowców: Marceli Handelsman, Łucja Charewiczowa i Tadeusz Manteuffel. W roku 194,1/194,2 obok wyżej wymienionych wykładali: Jadwiga Karwasińska, Stanisław Kętrzyński, Maria Ossowska, Władysław Tomkiewicz, Stanisław Więckowski. W roku 194,2/1943 ubył z tego grona dr Więckowski, 
aresztowany w czerwcu 194,2 r., dołączyli natomiast: Tadeusz Kotarbiński, Michał Walicki, Ludwik Widerszal. W roku 1943/1944 ubyła aresztowana Łucja Charewiczowa oraz Michał Walicki, który przeszedł do sekcji historii sztuki, dołączyli natomiast: Włodzimierz Antoniewicz, Józef Feldman, Stefan Kuczyński, Stanisław Ossowski, Janusz Woliński oraz Jerzy Kreczmar. Wielu wykładowców było zaangażowanych w prace konspiracyjne w innych sekcjach, wydziałach, uczelniach. 4. III 1943 r. aresztowano sekretarkę sekcji, która po pobycie w obozach na Majdanku, w Auschwitz i Ravensbrück doczekała oswobodzenia. Znała wszystkich wykładowców, słuchaczy i lokale. Szczęśliwie udało się zabezpieczyć przechowywaną w mieszkaniu Stypułkowskiej listę słuchaczy w formie listy zastrzyków przeciwtyfusowych. Po aresztowaniu Stypułkowskiej, nie chcąc wprowadzać w jej obowiązki nowej osoby, Manteuffel prowadził administrację sekcji osobiście, posługując się pomocą grupowych, czyli wyznaczonych dla każdego kompletu studentów, którzy zajmowali się sprawami administracyjnymi, ściąganiem opłat. Grupowi odwiedzali Manteuffla w Archiwum Akt Nowych, raz na miesiąc, przynosząc zebrane czesne i sprawozdania z pracy. Aresztowanie Stypułkowskiej nie miało związku z jej działalnością w sekcji. Podobnie było w innych przypadkach represji: zimą 1942/1943 r. aresztowano Halinę Gasparską, która znalazła się przypadkowo w punkcie rozdziału poczty konspiracyjnej. W obawie o komplet, w którym uczestniczyła, wstrzymano na pewien czas wszystkie zajęcia i zrezygnowano z korzystania ze znanych aresztowanej lokali. Gasparska nie zdradziła w śledztwie żadnych szczegółów tajnego nauczania - zginęła, zesłana do Auschwitz. Jesienią 1943 r. została zatrzymana jako kurierka Aniela Załęska, wiosną 1944, r. aresztowano Krzysztofa Dunin-Wąsowicza.

Zajęcia odbywały się w mieszkaniach prywatnych bądź w jawnych szkołach. Starano się, aby w jednym lokalu miał miejsce tylko jeden wykład w tygodniu. Sekcja uzyskała też pomoc Zgromadzenia Sióstr Niepokalanek, które przez kilka lat gościły komplety w domu zakonnym przy ul. Kazimierzowskiej 59, dzięki wstawiennictwu absolwentki Uniwersytetu Marii Rytlówny (siostry Ancilli). O jednym z tych zajęć pisze Krzysztof Dunin-Wąsowicz:

Po podaniu przy furcie hasła czy nazwiska, skierowany zostałem do właściwej sali. Kilkanaście osób. Po przedstawieniu się [sic] zająłem miejsce przy stole. Po kilku minutach wszedł prof. Manteuffel. Przywitał się ze wszystkimi i rozdał fotokopie łacińskiego dokumentu. Był zdania, że słuchaczy należy rzucać od razu na głęboką wodę ${ }^{76}$. 
Z pomocą przyszła również dyrektor Maria Bratkowska, współorganizatorka szkolnictwa podziemnego, dyrektorka I Miejskiej Szkoły Zawodowej Żeńskiej w Warszawie, która oddała do dyspozycji sekcji niezbędną liczbę pomieszczeń w szkołach dysponujących wolnymi godzinami popołudniu. Opłaty wzrastały z roku na rok i w 1943/1944, r. wynosiły $150 \mathrm{zl}$ miesięcznie dla I roku, a $120 \mathrm{zl}$ i $100 \mathrm{zl}$ dla wyższych roczników. Ulgi lub zwolnienia z opłat przyznawano z reguły wszystkim, którzy o to prosili. Sekcja dysponowała środkami na stypendia; w roku 1943/1944, wypłacano 4, stypendia, z których żadne nie było niższe niż 500 zł miesięcznie. „Początkowo nie pobieraliśmy od uczestników kompletów opłat i nie płaciliśmy honorariów" - wspominał Tadeusz Manteuffel. „Zmiana nastąpiła w ciągu 19411 r. Wprowadziliśmy wówczas, jak w innych sekcjach, czesne i zaczęliśmy wynagradzać wykładowców. Na jesieni 1943 r. prof. Rafacz [z Wydziału Prawa] zaczął przekazywać na moje ręce za pośrednictwem doc. Stanisława Borowskiego kwoty przeznaczone na stypendia" 77 .

Sekcja liczyła w roku 1940/1941 - 6 słuchaczy, w ostatnim zaś roku, 1943/1944, liczba ta wzrosła do 90-120 (2/3 stanowiły kobiety). Podawana przez prof. Antoniewicza liczba 300 osób wydaje się wygórowana. Frekwencja sięgała przeciętnie $75^{-80} \%$ i spadła znacznie dopiero w 1944, r. Tadeusz Manteuffel szacował, iż z grona studentów sekcji, 10 zaczęło studia przed rokiem 1939, przerwało studia - 8, zdało wszystkie egzaminy - 7 , nie zdało żadnego egzaminu - 12, 1 przeniósł się na inny kierunek UW, 5 przeniosło się z UZZ, 11 poniosło śmierć w czasie okupacji, z tego w powstaniu - 7 (wśród nich: Hanna Jastrzębska, Janina Rostańska, Andrzej Stankiewicz, Krystyna Wańkowicz). W sekcji studiowali m.in.: Jerzy Michalski, Krystyna Sroczyńska, Krzysztof Wąsowicz, Zbigniew Wójcik, Andrzej Wyczański, Andrzej Zahorski. Liczba okupacyjnych magisteriów sięgnęła kilkunastu, nadano też 3 doktoraty (Aleksander Gieysztor, Halina Kapper, Eugeniusz Szwankowski). Jak wspominała Jadwiga Karwasińka:

Organizacja sekcji była luźna. Ogólną tematykę zajęć, skład i liczebność grup, miejsca i terminy omawiało się tylko z doc. Manteufflem na rzadkich spotkaniach w AAN na ul. Rakowieckiej. Z innymi wykładowcami widywałam się na miesięcznych zebraniach Polskiego Towarzystwa Historycznego, np. w mieszkaniu prof. Kętrzyńskiego na Tamce. Nigdy nie omawialiśmy spraw wydziału, najwyżej wymieniali nazwiska i spostrzeżenia co do niektórych słuchaczy ${ }^{78}$.

Wielką troską organizatorów sekcji było zachowanie akademickiego poziomu nauczania i wymagań, w szczególności na etapie weryfikacji 
wiedzy, czyli podsumowującego każdy kurs egzaminu. Krzysztof Dunin-Wąsowicz, przypominając własne doświadczenia egzaminacyjne, pisał:

Postanowiłem najpierw zdawać z historii średniowiecznej. Jesienią 1943 r. miałem więcej czasu po ukończeniu Szkoły Podchorążych Łączności Piechoty AK. W sprawie egzaminu poszedłem do prof. Manteuffla, aby dowiedzieć się o jego wymaganiach. Dostałem porządną porcję lektury. Z historii powszechnej obowiązywała lektura Wielkiej Historii Powszechnej wydanej przez firmę Trzaska, Evert, Michalski. Miałem szczegółowe notatki z wykładów profesora z historii powszechnej średniowiecza z pierwszego roku studiów. Z historii Polski obowiązkowa była lektura Dziejów Polski średniowiecznej, pracy zbiorowej profesorów Grodeckiego, Zachorowskiego i Dąbrowskiego oraz lektura Historii ustroju Polski Kutrzeby. Należało przeczytać przynajmniej jedną monografię w języku obcym i kilka monografii w języku polskim. Przeczytałem książkę Brehiera Les Croisades, Szkice historyczne XI wieku Tadeusza Wojciechowskiego, Bolesław Chrobry - Wielki Stanisława Zakrzewskiego. Poszedłem na egzamin w lutym 1944, r. Dostałem czwórkę. Trudniej niż utrzymanie wysokiego poziomu nauczania przychodziło przestrzeganie reguł konspiracyjnych. Tadeusz Manteuffel wielokrotnie prosił, aby nie przynosić na wykłady prasy konspiracyjnej. Bezskutecznie.

Z czasem wymiana prasy podziemnej bezpośrednio po wykładach stała się niemal zwyczajem. Jadwiga Karwasińska wspominała, iż kiedyś przyszła do niej do Archiwum matka jednej ze słuchaczek z pretensją, że „organizacja werbunku jest lekkomyślna, że wszystkie adresy są w powszechnym obiegu, że są to mieszkania wykładowców, że córce na te komplety uczęszczać nie pozwoli i ostrzeże innych rodziców. Córka uczęszczała jednak nadal na zajęcia, tym niemniej problem był istotny"79.

Tragicznym wydarzeniem, które szczególnie dotknęło sekcję, było skrytobójcze zamordowanie 13 VI 1944, r. Ludwika Widerszala. Jego proseminaria odbywały się w mieszkaniu na ul. Asfaltowej na Mokotowie, gdzie został zastrzelony. Widerszal interesował się historią dyplomacji, szczególnie polityką zagraniczną mocarstw zachodnich na Wschodzie w XIX w. Prowadził także wykład z historii nowożytnej powszechnej XIX w. Jak wspominał jeden z jego studentów, „był na drugim roku studiów tym wykładowcą, któremu najwięcej mieliśmy do zawdzięczenia”. Wobec zagrożenia całego środowiska, działającego na styku sekcji historycznej oraz BIP KG AK, Tadeusz Manteuffel wyznaczył swego następcę na stanowisku kierownika sekcji na wypadek śmierci lub konieczności opuszczenia Warszawy. Został nim Janusz 
Woliński, zaakceptowany przez Radę Wydziału, znany wśród uczestników tajnego nauczania ze stoickiego spokoju. „Prof. Woliński miał wykład monograficzny na temat historii stosunków polsko-pruskich od XVI do XIX w." - wspominał Krzysztof Dunin-Wąsowicz. Podczas jednego z wykładów, odbywających się w szkole Tynelskiego, przed sąsiedni dom zajechała policja niemiecka. „Prof. Woliński podszedł do okna, wyjrzał na ulicę, chwilę się zastanawiał, a potem wrócił do stolika: będziemy kontynuowali wykład"so.

Działające w ramach sekcji Seminarium Archeologiczne, prowadzone przez Włodzimierza Antoniewicza, rozpoczęło swoją działalność 7 XII 1940 r. Raz w miesiącu, w niedzielę, dwunastu archeologów odbywało trzygodzinne spotkanie w mieszkaniu prof. Antoniewicza przy ul. Brzozowej 12. Ostatnie odbyło się w czerwcu 1944, r. Seminaria polegały na referowaniu rozdziałów prac magisterskich i doktorskich, wśród nich: Bohdana Guerquin Topografia i dzieje grodu i zamku $w$ Jazłowcu, szkicu pracy habilitacyjnej dr Krystyny Musianowicz Osadnictwo mazowieckie na Podlasiu w świetle archeologii. Profesor na rzecz seminarium zakupił ok. zoo tomów publikacji w celu uzupełnienia biblioteki Zakładu Archeologii Przedhistorycznej UW; niestety, spłonęły w czasie powstania. Antoniewicz równocześnie prowadził wykłady z ćwiczeniami z prehistorii Polski i Europy w dwu kompletach sekcji historycznej oraz wykładał prehistorię Polski i starożytności słowiańskie w Studium Slawistycznym. Ćwiczenia z prehistorii obejmowały zagadnienia: techniki i rekonstrukcji narzędzi pracy, opisu zabytków ruchomych i nieruchomych, analizy typologicznej zabytków oraz oznaczania chronologii zabytków. Brak praktyk muzealnych i wykopaliskowych sprawił, że prof. Antoniewicz nie dopuścił żadnego studenta do egzaminów magisterskich, co zostało dopełnione po wojnie. Po 2 latach nauczania w prywatnych mieszkaniach, Antoniewicz przeniósł wykłady do szkoły przy ul. Moniuszki oraz do szkoły kilimkarskiej na III piętrze oficyny Pałacu Staszica ${ }^{81}$.

Ćwiczenia z nauk pomocniczych historii oraz proseminarium i seminarium z historii Polski średniowiecznej prowadziła Jadwiga Karwasińska. Jak wspominała:

Początek zajęciom dała inicjatywa [grupy] moich dawnych słuchaczy z r. 1938/39, którą zebrał ks. Alojzy Hassa. Sam chodził na seminarium do prof. Kętrzyńskiego, cały czas dosyłając kogoś, udzielał nam opieki, nawet materialnej. Do grupki, studiującej nauki pomocnicze historii, składającej się z niego, ks. Józefa Wiekiery, Czesława Czerwińskiego i Jana Strzałki, przybyły z początkiem listopada 19411 r. Halina Gasparska i Wanda Osińska. One, zwłaszcza Gasparska, 
wciągnięte w wykłady tajnego uniwersytetu, zarejestrowały mnie u Haliny Stypułkowskiej, sekretarki sekcji. W ciągu paru tygodni dowiedziałam się, że jestem na liście płac, włączona w program wykładów.

Lokalem było mieszkanie Zofii Wladich (Stare Miasto 31, Kamienica Książąt Mazowieckich, IV piętro). Jak wspomina Karwasińska: „Pani Wladich, nauczycielka-przyrodniczka, udostępniła swoje mieszkanie, przesuwając nas z jednego pokoju do drugiego, zależnie od czasu, w którym zbierał się jej własny komplet". Spotkania odbywały się także w mieszkaniu p. Stachowskiej (ul. Filtrowa 68), p. Seńko (ul. Mickiewicza 27), w mieszkaniu prof. Turczynowicza w al. Niepodległości, p. Kocięckiej (prawdopodobnie pseudonim) przy ul. Złotej 4, czy wreszcie w szkole dyr. Tynelskiego. Korzystano także z pomieszczeń i zbiorów AGAD przy ul. Długiej 24, w którym Karwasińska pracowała. Tam np. odbywały się kolokwia. Zajęcia w mieszkaniu p. Wladich odbywały się w godz. 16-19, więc noszenie naręczy książek, także ze zbiorów AGAD, jesienią i zimą, po ciemku, nie zwracało uwagi. Karwasińska korzystała też z książek wypożyczanych z Biblioteki Uniwersyteckiej. W roku 194,2, dzięki uprzejmości Zofii Budkowej, udało się wypożyczyć z Krakowa ze zbiorów Polskiej Akademii Umiejętności kilka tek „Album Palaeographicum”. Zajęcia (dwugodzinne, każda grupa raz w tygodniu) były połączeniem wykładów z ćwiczeniami. Przedmiotem wykładów była metodologia historii i propedeutyka nauk pomocniczych. Na seminarium krótki wykład obejmował historię Polski w XIV w., po czym następował „rozbiór” źródeł. Karwasińska wspomina o niepotwierdzonym przez innych uczestników tajnego nauczania fakcie, jakim było finansowe nagradzanie najlepszych prac seminaryjnych (po 500 zł), z dochodów sekcji. Przez zajęcia Karwasińskiej przewinęło się ok. 50 osób. Z zachowanych przez prowadzącą zajęcia danych wynika, iż w seminarium z historii Polski średniowiecznej w roku 194,2/1943 brało udział 5 osób (w tym 4 kobiety), w roku 1943/1944 - 6 osób (6 kobiet); w ćwiczeniach z nauk pomocniczych w roku 1941/194,2, w semestrze zimowym - 6 osób (2 kobiety), w semestrze letnim - 8 osób (5 kobiet); w proseminarium w roku 1943/1944, w grupie I, w semestrze zimowym - 13 osób (11 kobiet), w semestrze letnim - 10 lub 11 osób (9 kobiet), w grupie II, w semestrze zimowym i letnim - 8 lub 9 osób (3 lub 4 kobiety); w proseminarium w roku 194.2/1943, w semestrze zimowym - 12 osób (9 kobiet), w semestrze letnim - 9 osób (7 kobiet). Jak wspominała Karwasińska, warunki prowadzenia zajęć dalekie były od komfortowych: 
Jedynie pokój na ul. Złotej 4 był oświetlony i ogrzany. Na Żoliborzu i w al. Niepodległości nie było prawie nigdy światła elektrycznego; czasem była karbidówka, czasem gaz ze ściany. Ćwiczenia z paleografii dopiero z wiosną można było prowadzić normalnie przy świetle dziennym. Na Starym Mieście czasem była elektryczność, przeważnie trzeba było poprzestać na świecach, znoszonych przeze mnie i przez słuchaczy. Pamiętam, że były i świece z kościoła, jako że „Panu Bogu nie ubędzie”. Ćwiczenia odbywały się w pokoju zastawionym jak skład mebli i nieopalanym. Trzeba było na środku wstawić piecyk z rurą, w którym podpalało się na pół godziny przed zajęciami. Drzewo opałowe pochodziło z daru Karola Konopackiego (mego krewnego, który zginął w powstaniu). Złożone było w piwnicy Archiwum Głównego. Tam rąbał je woźny Archiwum, Wojciech Zaremba, a ja przynosiłam w plecaku na Stare Miasto. Raz poszedł za mną policjant granatowy, przypuszczając, że niosę w plecaku słoninę. Czasem bardziej się obawiałam pożaru lub uduszenia dymem wypychanym przez wiatr z piecyka, niż niemożności wyłożenia słuchaczom jakiegoś zagadnienia z powodu braków w pomocach naukowych ${ }^{82}$.

Tadeusz Manteuffel pisał po wojnie:

Myślałem z niepokojem o magisteriach, które należałoby nadawać tym słuchaczom, którzy przesłuchali cztery lata i złożyli egzaminy. Zdawałem sobie sprawę, że przy najlepszych chęciach grona wykładowców słuchacze ci będą mieli niemałe luki w wykształceniu, a ich rozprawy dyplomowe dalekie będą od doskonałości. Bieg wypadków wojennych uczynił te obawy bezprzedmiotowymi ${ }^{83}$.

W roku akademickim 1943/1944, z sekcji historycznej wyodrębniła się sekcja historii sztuki, której kierownictwo sprawował Michał Walicki, sekretariat prowadziła zaś Maria Bartczak. Sekcja liczyła ok. 30 słuchaczy ${ }^{84}$.

W 1943/1944 r. zorganizowana została sekcja filozoficzna, działająca pod kierunkiem Marii Ossowskiej, a kontynuująca indywidualne kontakty profesorów i studentów, sięgające pierwszych miesięcy wojny. Sekcja obejmowała wykłady Tadeusza Kotarbińskiego (prakseologia i filozofia kultury), Władysława Tatarkiewicza (historia filozofii), Eugeniusza Geblewicza (psychologia ogólna), Henryka Hiża (logika) oraz Marii Ossowskiej (nauka o moralności). Na komplety, zwłaszcza na historię filozofii, logikę i psychologię, uczęszczali także słuchacze innych sekcji Wydziału Humanistycznego. Opłata wynosiła 4o zł od kompletu, tj. od 2 godzin wykładowych tygodniowo. Autorka relacji zwracała się 
do młodzieży z informacją o możliwości stosowania ulg, z czego miała skorzystać tylko jedna osoba, która odtąd płaciła 15 zł za komplet. Według Marii Ossowskiej, trzon sekcji stanowiło ok. 12 studentów, którzy „dotrwali do końca”. Ogółem jednak przez sekcję przewinęło się ok. 30 osób ${ }^{85}$.

Komplet poświęcony zagadnieniom nauki o moralności Maria Ossowska zorganizowała jeszcze w grudniu 1939 r. Frekwencja wahała się od 5-8 osób. Jak wspominała: „Byli to zdolni wolontariusze różnych specjalności (filozofia, psychologia, biologia, socjologia), można było z nimi utrzymać poziom poważnego seminarium". Ossowska brała té̇ udział w kompletach sekcji polonistycznej i historycznej, prowadząc wstęp do filozofii aż do wybuchu powstania. Na podstawie szczęśliwie zachowanych notatek z egzaminów z tzw. głównych zasad nauk filozoficznych wiadomo, iż 69 studentów zakończyło je z sukcesem, wśród nich 23 studentów historii, m.in.: Krzysztof Dunin-Wąsowicz, Jerzy Michalski, Zbigniew Wójcik, Andrzej Wyczański, Andrzej Zahorski ${ }^{86}$.

Podobną drogą konspiracyjnej dydaktyki szedł Tadeusz Kotarbiński, począwszy od „kompletów indywidualnych: dorywczych, tygodniowych, dwutygodniowych”. Na niektóre odczyty przychodziło nawet „po kilkadziesiąt[!] osób". Jak sam wspominał, pobierał opłaty, a zważywszy na frekwencję, „wykłady były dobrze płatne”. Można zakładać, iż nie wszystkie z tych wykładów mieściły się w ramach nauczania uniwersyteckiego. W jego ramach Kotarbiński związany był, poza sekcją filozoficzną, z sekcjami: pedagogiczną i historyczną. Prowadził w szczególności komplety logiki bezpośrednio lub nadzorując zajęcia prowadzone przez Henryka Hiża. Komplety logiki prowadziła także Dina Sztejnbarg, późniejsza małżonka Kotarbińskiego, aresztowana w 1943 r. Profesor przeprowadził także „szereg egzaminów” z teorii poznania, logiki i metodologii oraz kilka egzaminów magisterskich ${ }^{87}$. Nie inaczej wyglądało zaangażowanie w konspiracyjną dydaktykę Władysława Tatarkiewicza, który już w listopadzie 1939 r. organizował zebrania dla studentów filozofii, którzy „byli w niej zaawansowani”. Odbywały się one raz na tydzień i trwały ok. 3 godzin, z udziałem 8-12 osób, łącząc zwykle referat z dyskusją nad nim. Spotkań takich, według prof. Tatarkiewicza, odbyło się przez cały okres okupacji przeszło 150, w mieszkaniach wykładowców lub słuchaczy (np.: L. Kasiński(?) - ul. Krucza 4,2; D. Krzeszewska - ul. Wspólna 75; A. Szetel(?) - ul. B. Prusa 11b). Zespół uczestników ulegał w ciągu lat okupacji niewielkim zmianom: „paru zabrała śmierć, na miejsce ich przyłączyło się paru dawnych wychowanków uniwersytetu, którzy podczas wojny osiedli 
w Warszawie". W roku 1943/1944 prof. Tatarkiewicz zorganizował dodatkowo wykłady z estetyki dla grupy 6-8 słuchaczy; odbywały się przy ul. Prezydenckiej, w domach - jego lub Bohdana Pniewskiego ${ }^{88}$.

Sekcja filologii klasycznej wyłoniła się z seminariów prowadzonych przez Kazimierza Kumanieckiego niemal od początku okupacji. Pierwsze spotkanie, na którym profesor objaśniał poematy Oppiana, a w którym brało udział ok. 10 osób, odbyło się 15 XII 1939 r. Obok wspomnianego seminarium greckiego Kumaniecki prowadził seminarium łacińskie, na którym zajmował się interpretacją elegii Propercjusza. Odbywało się dwa razy w tygodniu, częściowo u wykładającego, częściowo w mieszkaniach uczestników; w późniejszym okresie zajęcia często odbywały się w klasztorze nazaretanek przy ul. Czerniakowskiej. W roku 194,0/19411 liczba uczestników wzrosła o kilka osób. Obok ćwiczeń seminaryjnych Kumaniecki zaczął wykładać historyczną gramatykę łacińską i grecką w wymiarze 2 godzin tygodniowo oraz prowadzić ćwiczenia stylistyczne z języka łacińskiego. W 1941/194,2 r. nie prowadził już seminarium, odbywały się natomiast wykłady z gramatyki historycznej łacińskiej i greckiej, poświęcone objaśnianiu Pieśni Horacego, a także wykłady z literatury greckiej, w trakcie których objaśniano IX i X pieśni Iliady i Filipiki Demostenesa. W roku 1942/1943 zjawiło się kilku młodszych studentów, którzy przed wojną nie uczęszczali na Uniwersytet. Kumaniecki prowadził dla nich interpretację Listów Horacego i ćwiczenia ze stylistyki łacińskiej. Dla wszystkich studentów przeznaczony był wykład „Starożytności państwowe rzymskie” oraz objaśnianie pieśni Katullusa. W roku 1943/1944, dla młodszych studentów były ćwiczenia ze stylistyki łacińskiej, dla starszych zaś - objaśnianie Teokryta i Herodota. Dla wszystkich studentów przeznaczony był wykład „Historia kultury greckiej” i monograficzny wykład o Salustiuszu. Studenci uczęszczali również na wykłady z filozofii i archeologii klasycznej, prowadzone przez Marię Bernhard. Profesor Kumaniecki przeprowadził kilkadziesiąt egzaminów, wydając studentom tymczasowe zaświadczenia. Złożono profesorowi także pracę magisterską i doktorską, które spłonęły podczas powstania. Liczba studentów sekcji osiągnęła przed powstaniem 30 osób $^{89}$.

W lutym 1943 r. została zorganizowana sekcja filologii romańskiej. Jedyną jej wykładowczynią była Zdana Matuszewicz, która z kompletem liczącym ok. 12 osób realizowała program przewidziany dla I roku studium romanistycznego: 2 godziny wykładów i ćwiczeń z gramatyki historycznej języka francuskiego, 2 godziny wykładu z historii literatury francuskiej, wreszcie 2 godziny ćwiczeń językowych. Egzaminy ze słuchaczami odbywał Stanisław Wędkiewicz ${ }^{90}$. 
W łączności z Wydziałem Humanistycznym pozostawało studium slawistyczne, powołane do życia jesienią 19422 r. Inicjatorami jego powołania była grupka studentów, inspirowanych m.in. przez Jerzego Bąbałę i Włodzimierza Pietrzaka, motywowanych również ideologicznie. Faktycznym organizatorem studium, jako zalążka instytutu naukowego w ramach powojennego UW, był Julian Krzyżanowski. Studium składało się z cykli wykładów obejmujących następujące zagadnienia: lektoraty języka czeskiego i serbsko-chorwackiego, zasady słowianoznawstwa, geografia świata słowiańskiego, literatura serbsko-chorwacka, prelekcje paryskie Mickiewicza, językoznawstwo polskie, słowianoznawstwo polskie, stosunki literackie polsko-czeskie w średniowieczu, historia Rosji, dzieje stosunków polsko-ukraińskich, rosyjska epika ludowa. Nie udało się znaleźć nikogo do prowadzenia wykładów z literatury rosyjskiej, prehistorii słowiańskiej, lektoratu języka rosyjskiego. Wykłady odbywały się na Żoliborzu i w Śródmieściu (na ul. Bednarskiej), w mieszkaniach uczestników. Liczba studentów wahała się między 12 a 20. Pierwszy z inicjatorów studium zmarł w obozie koncentracyjnym na Majdanku, drugi poległ podczas powstania warszawskiego ${ }^{91}$.

Wydział Matematyczno-Przyrodniczy do 1943 r. wchodził w skład wspomnianej wcześniej tzw. grupy nauk ścisłych, obejmującej poza nim wydziały Lekarski i Farmaceutyczny, Akademię Stomatologiczną oraz niektóre wydziały Politechniki. W 1943 r. poszczególne struktury grupy ulegały autonomizacji. Kierownictwo grupy spoczywało w rękach dra Mariana Koczwary.

Po wcześniej opisanym incydencie, zagrażającym bezpieczeństwu kompletów na wczesnym etapie organizacji konspiracyjnych studiów, od jesieni 1942 r. Wanda Karpowicz rozpoczęła pracę na nowo jako „Teresa Krzemińska”. Od Józefa Grabowskiego, poprzez Koczwarę, otrzymywała spisy kandydatów na poszczególne wydziały. Dzieliła młodzież na grupy według miejsca zamieszkania (po 7-8 osób), wyznaczała grupowego, zamieszkującego z zasady w dzielnicy, w której zbierał się komplet. Przed rozpoczęciem roku akademickiego odwiedzała wszystkich grupowych, przedstawiając się z imienia i nazwiska jako wysłanniczka Uniwersytetu, powierzała im spisy uczestników kompletu, rozkłady zajęć otrzymane bezpośrednio od dr Koczwary, polecała znalezienie lokali na wykłady, przekazywała także informację o miejscu i godzinach przyjęć. Rozwój struktur konspiracyjnego nauczania spowodował, iż niezbędne stało się zaangażowanie łączniczek, które pośredniczyły między grupowymi a „Krzemińską” (m.in. Wacława Palczewska - sekcja chemiczna, Anna Daniecka i Anna Szlenk - Akademia Stomatologiczna). 
Zorganizowanych zostało w ten sposób ok. zo kompletów. Przez lokale, w których Karpowicz przyjmowała młodzież, przewijało się nawet do 20 osób w dniu przyjęć; było to mieszkanie użyczane przez rodziców jednej ze słuchaczek, Januszewiczów (ul. Śniadeckich 11), inne przez rodzinę kierownika szkoły powszechnej Teofila Miklaszewskiego (ul. Żurawia 28), czy też - przy ul. Hożej 20 m. 2, należące do „pań Słupińskich". Sprawy, które wymagały bieżącego wyjaśniania, wynikały z samej istoty konspiracyjnego nauczania, np. niezjawienie się wykładowcy. „Był zwyczaj” - wspominała Wanda Karpowicz - „że się nie wymieniało nazwisk profesorów, przychodzili incognito, niektórzy podawali nazwiska fikcyjne. Jednak młodzież dowiadywała się o nazwiskach wykładowców i ich adresach". W sytuacji zagrożenia grupowi musieli znaleźć nowy lokal, ona zaś - zawiadomić Koczwarę, aby mógł jak najszybciej uprzedzić o zmianie wykładowcę. W zwykłym trybie grupowi zbierali się na początku każdego miesiąca, by przekazać zebrane czesne, omówić sprawy ulg lub stypendiów, podręczników i skryptów. Organizację egzaminów Karpowicz wspominała następująco: „Wykładowcy najczęściej sami wyznaczali słuchaczom termin egzaminu czy kolloquium. Kandydaci zapisywali się u mnie i otrzymywali karteczki, na których stopnie oraz podpis dopisywał wykładowca. Karteczki te doręczałam następnie dr Koczwarze, który miał spis egzaminów oraz relacje o nich od profesorów"92.

Według zapisków Mariana Koczwary, struktura zajęć na Wydziale przedstawiała się następująco - 1940/19411 r.: 1 komplet biologii, 1 komplet fizyki; 194,1/194,2 r.: I rok (1 komplet biologii, 1 komplet fizyki), II rok (1 komplet fizyki); 1942/1943 r.: I rok (1 komplet biologii, 2 komplety fizyki, 1 komplet geografii, 1 komplet matematyki), II rok (1 komplet biologii, I komplet fizyki), III rok (1 komplet fizyki); 1943/1944, r.: I rok (1 komplet biologii, 2 komplety fizyki, 1 komplet geografii, 1 komplet matematyki), II rok (1 komplet biologii, 2 komplety fizyki, I komplet geografii, I komplet matematyki), III rok (1 komplet fizyki), IV rok (1 komplet fizyki) ${ }^{93}$. Szczegółowe dane liczbowe odnieść można jedynie do roku akademickiego 1943/1944, kiedy to zapisało się na studia łącznie 288 studentów, z których w ciągu roku ubyło 54 (w tym: 1 rozstrzelany, 2 aresztowanych w łapankach, 4 aresztowanych, 1 postrzelony w ulicznych zajściach); pozostało 66 mężczyzn (28\%) i 168 kobiet (72\%), łącznie 234 osoby (także studenci Wydziału Farmaceutycznego i Akademii Stomatologicznej). Skład poszczególnych grup przedstawiał się następująco: 2 fizyczne (7 mężczyzn, 8 kobiet); 7 chemicznych (29 mężczyzn, 35 kobiet); 2 matematyczne (9 mężczyzn, 5 kobiet); 1 biologiczna (1 mężczyzna, 7 kobiet); 2 geograficzne 
(2 mężczyźni, 10 kobiet) oraz 4, stomatologiczne (1 mężczyzna, 49 kobiet) i 8 farmaceutycznych (17 mężczyzn, 66 kobiet). Opłaty miesięczne wynosiły 200 zł. Na 234, słuchaczy z ulg korzystało 85 (30\%), w tym 65 osób ze zniżki 50\%, 19 osób ze zniżki 75\%, bezpłatnie studiowała 1 osoba; najwięcej zniżek przypadało na sekcje: matematyczną i geograficzną ${ }^{94}$.

Kierowana przez Stefana Pieńkowskiego, zarazem rektora konspiracyjnego Uniwersytetu, zaangażowanego w prace Departamentu Oświaty i Kultury Delegatury Rządu, sekcja fizyczna ${ }^{95}$ rozpoczęła działalność jesienią $1940 \mathrm{r}$. Wykłady odbywały się w mieszkaniach prywatnych i w tych warunkach były ograniczone do teorii. Nawiązano jednak kontakt z jawnie działającą na terenie Politechniki Warszawskiej Państwową Wyższą Szkołą Techniczną i przy pomocy Włodzimierza Ścisłowskiego zorganizowano ćwiczenia, które słuchacze sekcji „odrabiali" w latach akademickich 194,2/1943-1943/1944. W roku 1943/1944, Ścisłowski zorganizował pod kierunkiem Pieńkowskiego pracownię fizyczną Uniwersytetu, przeznaczoną dla słuchaczy III i IV roku. Wyposażenie do pracowni wzięto z Zakładu Fizycznego I Politechniki oraz z Zakładu Fizyki Doświadczalnej UW. W roku 1943/1944 sekcja obejmowała sześć kompletów i ok. 6o słuchaczy ${ }^{96}$.

Instytucjami, bez których trudno byłoby sobie wyobrazić konspiracyjne nauczanie fizyki, były: Zakład Fizyki Doświadczalnej (ul. Hoża 69), kierowany przez Stefana Pieńkowskiego, oraz Zakład Fizyki Teoretycznej (w budynku Wydziału Farmaceutycznego przy ul. Oczki 3), kierowany przez Czesława Białobrzeskiego. Jak już wspomniano, w pierwszych miesiącach okupacji oba zakłady dotknięte zostały okupacyjnymi rekwizycjami: wywieziono część aparatury i zbiorów bibliotecznych. Jak wspominał Jerzy Pniewski:

W końcu października 1939 roku fizyk niemiecki - profesor Kurt Diebner, złożył, jakby się mogło wydawać, kurtuazyjną wizytę Pieńkowskiemu, wyrażając życzenie odwiedzenia Zakładu. Pieńkowski, podobnie jak przed wojną, osobiście pokazywał przybyłemu wszystkie pracownie i cały sprzęt naukowy Zakładu. Dwa tygodnie później ten sam Diebner podjechał ciężarówkami wojskowymi i doskonale zorientowany, gdzie się co znajduje, zaczął kolejno wywozić cały cenniejszy sprzęt, w tym oczywiście akcelerator zbudowany przez Sołtana, wiele innych, jedynych w swoim rodzaju przyrządów, nawet przetwornice zasilające sieć elektryczną Zakładu w różnego rodzaju prądy, a również cały księgozbiór wraz z kompletem wszystkich roczników czasopism ${ }^{97}$.

Aby przetrwać, zakłady przemianowane zostały na tzw. zakłady badawcze, działające pod nadzorem polskich władz samorządowych „dla 
potrzeb zdrowotnych i gospodarczych miasta"; ZFD stał się Zakładem Pomiarów Fizycznych, zaś ZFT - Zakładem Badawczym Fizyki Technicznej. Oficjalnie placówki te obowiązywał zakaz prowadzenia działalności naukowo-dydaktycznej. Zakładowi Badawczemu Fizyki Technicznej, prowadzącemu prace na rzecz szpitali, Dyrekcji Wodociągów i Kanalizacji czy innych instytucji miejskich, udało się uchronić wyposażenie przed dalszymi rekwizycjami, czego nie uniknął Zakład Pomiarów Fizycznych, który został ogołocony z aparatury naukowej, a pomieszczenia przerobiono na pokoje biurowe. W 1943 r. okupanci stopniowo zajęli cały budynek. Zanim to nastąpiło, prof. Pieńkowski organizował komplety tajnego nauczania; studenci odbywali ćwiczenia w sąsiedztwie pomieszczeń zajmowanych przez Niemców. Równocześnie odbywały się cotygodniowe, organizowane najczęściej w mieszkaniu profesora, konwersatoria, na których referowano prace naukowe. W spotkaniach tych brali udział także nauczyciele gimnazjalni, np. Aniela Wolska, która w latach 1939/194,0-1940/19411 uczyła fizyki w tajnych klasach gimnazjalnych przy szkole powszechnej Anny Goldman (ul. Mianowskiego 15), zaś w roku szkolnym 1941/1942 w kompletach licealnych przy gimnazjum im. Stanisława Staszica.

Zakład przy ul. Oczki dotrwał do 1 IX 194,2 r., kiedy to radziecka bomba zburzyła większą część gmachu. Ocalała głęboka suterena, w której kontynuowano prace aż do powstania, zawdzięczając to energii Ignacego Adamczewskiego. Adamczewski został zaangażowany przez prof. Białobrzeskiego już w $193^{2}$ r., brał udział w kampanii wrześniowej, w 1940 r. przez ponad 3 miesiące więziony był w Auschwitz. Jak wspominał: „Po odzyskaniu sił przystąpiłem ponownie do pracy w pracowni profesora Białobrzeskiego, która wykonywała prace dla potrzeb szpitali warszawskich, Dyrekcji Wodociągów i Kanalizacji oraz fabryki kabli w Ożarowie" ${ }^{998}$. W okresie okupacji przygotował m.in. podręcznik Fizyka dla medyków. W mieszkaniu prof. Białobrzeskiego odbywały się zebrania fizyków i filozofów, na których prowadzono dyskusje tyczące podstaw filozoficznych fizyki, na wykłady i konsultacje uczęszczali studenci. Ignacy Adamczewski wspominał:

Przy końcu 194,2 roku profesor Pieńkowski zaproponował mi wykłady na tajnych kompletach Uniwersytetu, właśnie z fizyki dla medyków. To się bardzo dobrze kojarzyło z pisanym przeze mnie podręcznikiem. Tak jak wszystkie wykłady na tajnych kompletach, moje wykłady odbywały się w latach 194,21944, w mieszkaniach prywatnych. Pisałem wtedy teksty wykładów na maszynie i rozdawałem studentom. W ten sposób powstał pierwszy skrypt Fizyki dla medyków $w^{99}$. 
W okresie tym prof. Białobrzeski przygotował do druku dwa tomy trzytomowego dzieła Podstawy poznawcze fizyki. Uległy one spaleniu podczas powstania, jednak po wojnie autor odtworzył je i wyda ${ }^{100}$.

Sekcja chemiczna, która łączyła uniwersyteckie i politechniczne nauczanie tej dyscypliny, rozpoczęła pracę w 194,0 r. z udziałem 6 słuchaczy. Latem 1944, r. było ich niemal 150. Kierownictwo sekcji spoczywało w rękach Józefa Zawadzkiego i Alicji Dorabialskiej. Większość słuchaczy na drugim roku studiów obierała kierunek politechniczny. Wykłady odbywały się w mieszkaniach prywatnych, chemię analityczną oraz preparatykę organiczną odrabiano w Prywatnym Liceum Chemicznym II stopnia p. Szymonikowej (ul. Górskiego 3); w 194,0/19411 r. ćwiczenia te odrabiano również w Państwowym Liceum Chemiczno-Ceramicznym II st. (ul. Hoża 78). Ćwiczenia z fizyki odbywały się w laboratorium wspomnianej Państwowej Wyższej Szkoły Technicznej; z pomocy PWST korzystano również przy odrabianiu ćwiczeń z analizy technicznej i technologii przez kilku najstarszych studentów. Ćwiczenia z technologii specjalnej oraz praktyki odbywały się w fabrykach ${ }^{101}$.

Sekcja biologiczna została uruchomiona w 1940 r. W roku 1944 liczyła 3 komplety, na które uczęszczało ponad 20 studentów. Kierownikiem sekcji był Wacław Roszkowski. Wykłady prowadzono w mieszkaniach wykładowców, ćwiczenia zaś w laboratoriach szpitalnych oraz w Państwowym Muzeum Zoologicznym ${ }^{102}$.

Sekcja matematyczna rozpoczęła działalność w 19422 r. W roku 1944 liczyła 2 komplety, obejmujące łącznie 14 studentów. Kierował nią Karol Borsuk. Kiedy prof. Borsuk był przez kilka miesięcy więziony na Pawiaku, zastępował go Wacław Sierpiński ${ }^{103}$.

Sekcja geograficzna powstała w 194,2 r. W roku 1944, liczyła 2 komplety i 12 słuchaczy. Kierownictwo sekcji spoczywało w rękach Stanisława Lencewicza. Jeden z jej studentów wspominał:

Zostałem studentem we wrześniu 1943 r. W naszej grupie było 9 osób: pięć dziewcząt i czterech chłopców. Wśród nich były osoby później powszechnie znane, np. Halina Tagowska-Klatkowa, profesor Uniwersytetu Łódzkiego, czy Wacław Czyszek, założyciel i kierownik stacji geofizycznej na Helu. Spotykaliśmy się w prywatnych mieszkaniach popołudniami i wieczorami. Opłaty były symboliczne. Część osób była z nich zwolniona, a ktoś otrzymał stypendium z funduszy Delegatury Rządu. Prof. Stanisław Lencewicz był wymagający, potrafił być wręcz nieprzyjemny. Ale wykładał i nauczał doskonale. W maju 1944, r., po czyimś aresztowaniu, trzeba było wykłady odwołać. Profesor nie mógł wytrzymać obciążenia psychicznego i poprosił o kilkutygodniową przerwę w nauce. Mieliśmy to nadrobić na jesieni, ale wybuchło powstanie, a Lencewicz został 


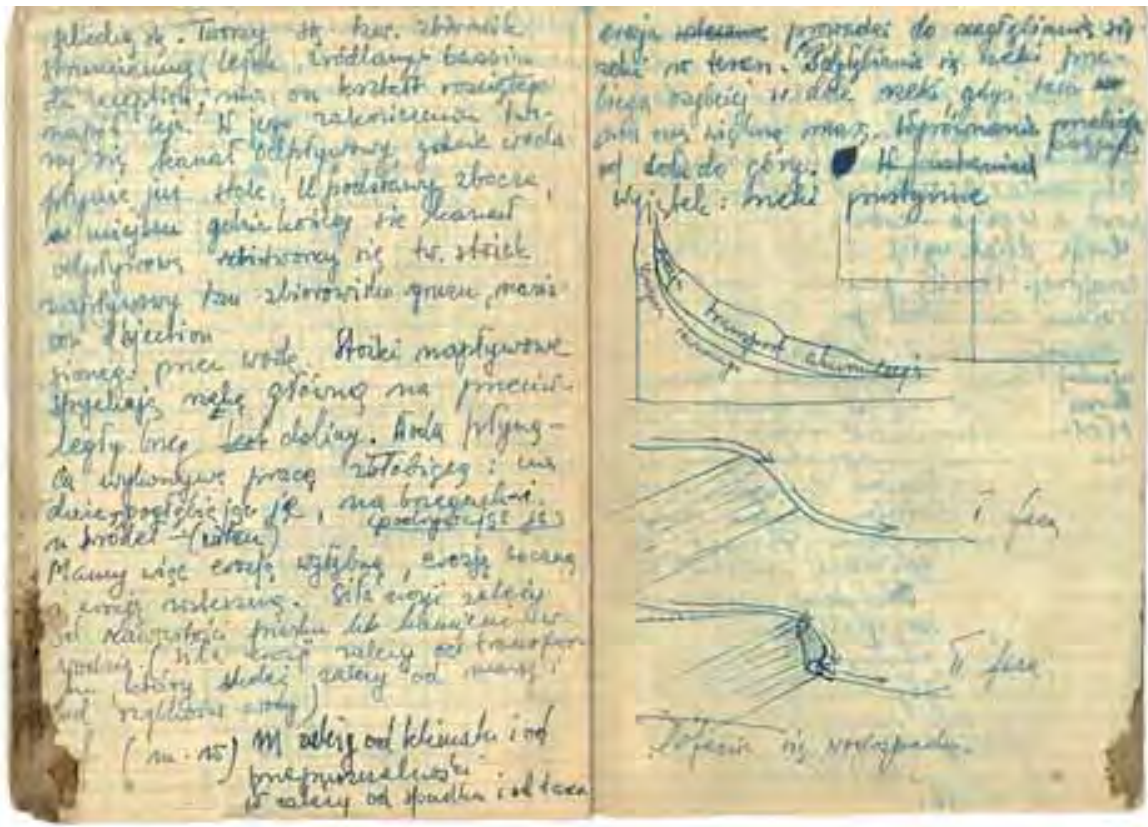

8. Notatki Janusza Paszyńskiego z tajnego nauczania

zamordowany po upadku Starego Miasta. Innym profesorem był Jan Samsonowicz. Wykładał geologię dynamiczną i historyczną. Meteorologię wykładał dr Romuald Gumiński. Zawsze szalenie pogodny. Pamiętam ćwiczenia z doc. Stanisławem Pietkiewiczem. Uczył kartografii i zlecał żmudne zadania domowe. Pracowałem w wojskowym instytucie kartograficznym «Kriegskarten- und Vermessungsamt», mieszczącym się w gmachu Wojskowego Instytutu Geograficznego. Pracę podjąłem za zgodą mojego dowódcy z AK. Pracując w instytucie, dostałem przepustkę do BUW. Byłem tam kilkanaście razy. Kilkakrotnie wypożyczałem książki dla prof. Lencewicza na potrzeby tajnego studiowania. Aresztowano mnie 11 listopada $1943 \mathrm{r}$. przez przypadek. Znaleziono u mnie zeszyt z notatkami z wykładów geografii i mapy wyniesione z instytutu. Zabrano mnie w al. Szucha, a stamtąd na Pawiak. Gestapowcy byli przekonani, że są to notatki z konspiracyjnej podchorążówki i chcieli wymusić, bym wydał nazwiska. Na przesłuchaniach dotkliwie mnie pobili. Do niczego się nie przyznałem. Zostałem zwolniony po kilku miesiącach. Kazano mi chwilowo zerwać kontakty z moim oddziałem AK, a na komplety geografii zacząłem chodzić dopiero po kilku tygodniach ${ }^{104}$.

W 1942 r. dzięki staraniom Edwarda Lotha i Witolda Cybulskiego zostały wznowione studia na Akademii Stomatologicznej, związane 
z tzw. grupą nauk ścisłych, a tym samym z Wydziałem Matematyczno-Przyrodniczym. Wykłady prowadzili m.in. Zygmunt Pękała, Bolesław Wojciechowski, Zbigniew Wojciechowski. Studenci, po wysłuchaniu wykładów i odrobieniu ćwiczeń prosektoryjnych, składali egzaminy, m.in. u prof. Lotha. Na 4,2 studentów, w samym tylko Zakładzie Anatomii Prawidłowej, egzamin zdali wszyscy, $75 \%$ z wynikiem dobrym lub bardzo dobrym. Ogólna liczba studentów Akademii sięgała 200 osób ${ }^{105}$.

Wydział Lekarski organizowany był w oparciu o istniejącą sieć uniwersyteckich klinik i szpitali oraz szkolnictwo zawodowe, dopuszczone przez okupanta do prowadzenia jawnej działalności, czyli tzw. Szkołę Zaorskiego. Przypomnijmy też, że w tzw. okresie półtolerancji władze okupacyjne dopuszczały możliwość ukończenia zapoczątkowanych przed wybuchem wojny studiów. Podziemne studia medyczne zaczęto w sposób zorganizowany uruchamiać od jesieni 19411 r. w obrębie tzw. grupy nauk ścisłych. Według nie zawsze jednolitych relacji, głównymi ich organizatorami mieli być Marian Koczwara i Edward Loth. We wrześniu 1943 r. nastąpiło wyodrębnienie Wydziału, którego kierownikiem został Witold Gądzikiewicz (prowadził ponadto ćwiczenia z higieny w pracowniach przy aptekach i w laboratorium Kliniki Dermatologicznej). Znaczącą rolę odgrywał także Marian Grzybowski, który brał udział w opracowywaniu reformy studiów lekarskich na UW, był także przez pewien okres kierownikiem Wydziału, współdziałając z Koczwarą i Gądzikiewiczem. Powołano sekretariat, w którym pracowały Maria Moszyńska oraz Wanda Chmielewska, zastąpiona w kwietniu 1944 r. przez Wandę Hłasko. O działalności Wydziału mogą świadczyć dane z 1943/1944, r.: na I rok zapisało się 200 słuchaczy, ukończyło go 145; na II rok - 120, ukończyło - 100; na III rok - 75, ukończyło - 30; na IV rok - 5o, ukończyło - 20. Powyższe dane nie obejmują uczniów tzw. Szkoły Zaorskiego, dla których dane są przytaczane w dalszej części artykułu. Listy studentów sporządzone przez Mariana Grzybowskiego, datowane na 15 IX 1944, r., z informacją o zdanych egzaminach i uzyskanych ocenach wskazują na stosunkowo wysoki poziom nauczania (ok. 4,0\% ocen dostatecznych, reszta dobre, bardzo dobre i celujące). Wniosek ten potwierdza lektura listy egzaminów z interny, sporządzonej przez Witolda Orłowskiego 12 VII 1945 r.

Studenci wnosili opłaty, udzielano jednak zniżek $25 \%$ i $50 \%$ oraz zwalniano od opłat młodzież niezamożną i wykazującą postępy w nauce, począwszy od II roku studiów. Obok Wydziału Lekarskiego UW działał również analogiczny wydział na Uniwersytecie Ziem Zachodnich, korzystający często z usług tych samych wykładowców oraz szpitali i klinik, np. kierownik Zakładu Anatomii Patologicznej Ludwik 


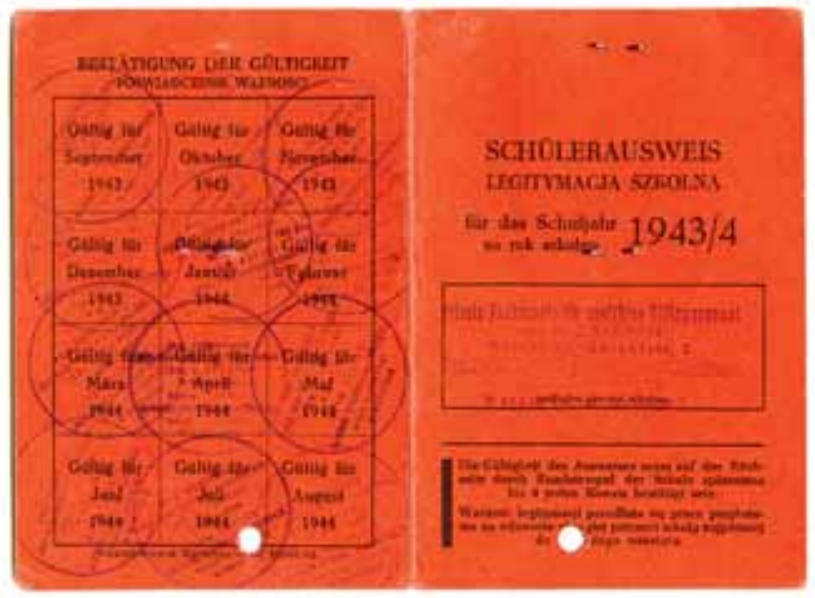

9. Legitymacja

uczniowska Prywatnej

Szkoły Zawodowej dla

Pomocniczego Personelu

Sanitarnego doc. Jana

Zaorskiego

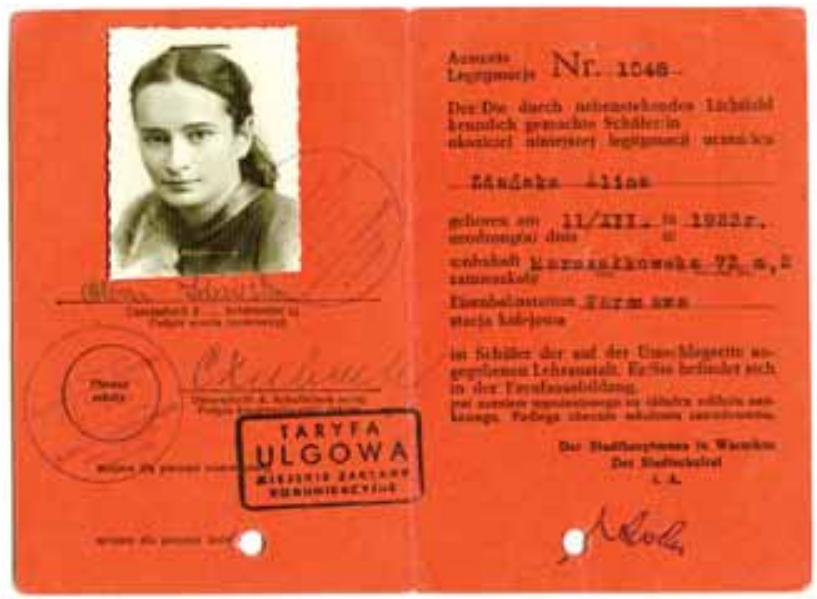

Paszkiewicz sprawował nadzór nad jej nauczaniem na kompletach UZZ i UW, wykładał także anatomię patologiczną w tzw. Szkole Zaorskiego. Podobnie kierownik Zakładu Anatomii Prawidłowej prof. Loth wykładał na UW i UZZ, poza tym egzaminował słuchaczy obu uniwersytetów. Ogólna liczba słuchaczy, którzy odbyli wykłady, ćwiczenia prosektoryjne i złożyli egzaminy u prof. Lotha, wyniosła przeszło 600 osób. Program studiów medycznych obejmował: na I roku - biologię, chemię nieorganiczną i organiczną, ćwiczenia z chemii nieorganicznej, fizykę, anatomię prawidłową (ćwiczenia w prosektorium); na II roku chemię fizjologiczną, fizjologię, histologię szczegółową, parazytologię, anatomie prawidłową; na III roku - anatomię patologiczną (szpitale: Wolski, św. Stanisława, Przemienienia Pańskiego), patologię ogólną,

\section{e-MONUMENTA_WUW 2016}


anatomię topograficzną, bakteriologię; na IV roku - farmakologię, higienę, diagnostykę (szpitale: św. Rocha, Przemienienia Pańskiego, Wolski, Św. Ducha, św. Łazarza). Nadto studenci uczęszczali do klinik: chorób wewnętrznych, dermatologicznej, chirurgicznej, położniczej, laryngologicznej, okulistycznej i psychiatrycznej ${ }^{106}$.

Pomysł wsparcia konspiracyjnych studiów medycznych przez wykorzystanie możliwości, które stwarzało funkcjonowanie jawnych szkół zawodowych, wynikał z oczywistego problemu, jakim było prowadzenie studiów medycznych w wymiarze praktycznym w warunkach nauczania rozproszonego w formie kompletów. Franciszek Czubalski miał zaproponować zorganizowanie pełnych konspiracyjnych studiów medycznych spełniających kryteria akademickie. Zapleczem organizacyjnym była założona przez Jana Zaorskiego Szkoła Masażu Leczniczego. Wydział Zdrowia Zarządu m.st. Warszawy wyraził zgodę na założenie Prywatnej Szkoły Zawodowej dla Pomocniczego Personelu Sanitarnego (Private Fachschule fur Sanitäres Hilfspersonal), zwanej potocznie „Szkołą Zaorskiego". Szkoła rozpoczęła działalność 13 III 19411 r. Aby zapewnić właściwy poziom nauczania, kierownictwo naukowe powierzono Stefanowi Kopciowi. W przeddzień otwarcia został on jednak aresztowany, a następnie rozstrzelany. Ostatecznie dyrektorem naukowym szkoły został wspomniany Franciszek Czubalski, w rękach Zaorskiego pozostało zaś kierownictwo administracyjne. Jako wykładowcy angażowani byli profesorowie Wydziałów Lekarskich UW i UZZ. Szkoła mieściła się początkowo w gmachu Zakładu Medycyny Teoretycznej przy ul. Krakowskie Przedmieście 26/28 i korzystała z pomocy naukowych Zakładów Fizjologii i Chemii Fizjologicznej. Po szeregu interwencji władz okupacyjnych, z powodu zbyt wysokiego poziomu nauki, w lutym 1943 r. Szkoła została usunięta z tego gmachu, a jej inwentarz i pomoce naukowe uległy konfiskacie. Do końca swego istnienia mieściła się w wynajętej części gmachu gimnazjum im. Wojciecha Górskiego. W początkowym okresie działalności władze niemieckie nie ingerowały w jej pracę. Niestety, jak relacjonuje Jan Zaorski, młodzież „upojona możliwością studiowania” zbyt szeroko o tym informowała. $\mathrm{Z}$ tego powodu władze wzywały właściciela szkoły do składania wyjaśnień. Dzięki wsparciu polskich urzędników samorządowych, zwykle udawało się wszystko wyjaśnić „nieporozumieniem”. Niestety, jak wspomina Zaorski, w czasie jednej z kontroli doszło do wpadki. Niemieccy kontrolerzy byli obecni podczas egzaminu z anatomii, w czasie którego uczniom i profesorowi wyrywały się łacińskie terminy, na studiach personelu pomocniczego nieoczywiste; uczestniczyli również w egzaminie z chemii, podczas którego uczniowie pytani przez nich, czym 
chcą być w przyszłości, odpowiadali, że pediatrą, chirurgiem itd. Tylko podczas egzaminu z fizyki uczennice połapały się i odpowiedziały, że chcą być, zgodnie z oficjalnym programem Szkoły, higienistkami i pielęgniarkami. Opuszczając szkołę, kontrolerzy nie mieli wątpliwości, iż jej uczniowie są przekonani, że studiują medycynę. Kontrola skończyła się wydaniem nakazu stosowania programu, który nie będzie wykraczał poza standard szkolnictwa zawodowego.

Nawet jednak i po tym incydencie formalnie działająca szkoła zawodowa realizowała faktycznie program uniwersytecki; anatomia pozostała nauką o budowie ciała ludzkiego, fizjologia nauką o czynnościach narządów ustroju, histologia nauką o budowie tkanek itd. Aby nie dopuszczać nieprzygotowanych osób, wprowadzono egzaminy wstępne. Podczas pierwszego roku nauki w Szkole realizowany był program 2 pierwszych lat studiów medycznych. W drugim roku uczniowie kierowani byli do szpitali i laboratoriów, gdzie odbywali praktyki, np. z notatki dr Bartoszka, ordynatora I Oddziału Wewnętrznego Szpitala Przemienienia Pańskiego, z 3 I 1944 r. wynika, iż na oddziale tym praktykowało 15 studentów. W ten sposób realizowano program trzeciego i czwartego roku medycyny. Kandydatów kończących Szkołę kierowano oficjalnie, przy udziale Wydziału Zdrowia Zarządu m.st. Warszawy, na tzw. praktyki szpitalne w klinikach bądź na oddziałach szpitalnych. Nad poziomem nauczania w Szkole czuwał jej dyrektor naukowy; wyznaczał praktyki w szpitalach, terminy egzaminów, prowadził protokoły postępów uczniów, które miały służyć za podstawę zaliczania studiów po wojnie. Dyrektor administracyjny organizował zapisy uczniów, udzielał zniżek w opłatach, dostarczał pomocy naukowych: chemikaliów, zwierząt doświadczalnych, preparatów anatomicznych, prowadził gospodarkę finansową Szkoły; ponadto wykładał chirurgię oraz opracowywał podręcznik jej nauczania. Po wojnie Jan Zaorski został kierownikiem Zakładu Chirurgii Operacyjnej UW. Warto wspomnieć, iż nauka w Szkole dawała młodzieży dość skuteczną ochronę przed wywozem na roboty, ponieważ kształciła „personel pomocniczy", niezbędny na miejscu.

Przyjmowano do Szkoły młodzież powyżej 18 lat, która skończyła tajne licea i uzyskała „duże” matury. Wywoływało to interwencje ze strony polskich urzędników samorządowych, a nieraz nawet samych Niemców, o stawianie kandydatom zbyt wysokich wymagań. Reagując na tego rodzaju zastrzeżenia przyjęto jednorazowo podwójną liczbę uczniów, wśród nich kilkudziesięciu, którzy mieli tylko „małą maturę"; duża część z nich, nie mogąc podołać wymogom, odpadła. Wobec dużego napływu kandydatów, także spoza Warszawy, organizowano 
dwukrotne zapisy w ciągu roku, przyjmując każdorazowo przeciętnie po 150-250 uczniów. Przez cały okres działania Szkoły przyjęto do niej 1927 osób. Zachowana księga egzaminacyjna dostarcza interesujących informacji na temat poziomu kształcenia (stosunkowo duża liczna ocen niedostatecznych), a także proporcji płci. Na I roku uczyło się 208 osób (w tym 45 kobiet), liczba ocen niedostatecznych z konkretnych przedmiotów wynosiła ok. 130; na roku II: 156 osób (29 kobiet), niedostatecznych 121; na roku III: 153 osoby (37 kobiet); na roku IV: 136 osób (411 kobiet). Zachowana lista studentów, którzy przed 1 VIII 1944 r. „przesłuchali wykłady, zaliczyli pracownie i złożyli egzaminy przejściowe z I na II i z II na III rok", sporządzona 16 VIII 1944, r., obejmuje 22 osoby. Około 100 uczniów uzyskało w 1945 r. absolutorium, niektórzy z nich dyplom lekarski. Wydziały lekarskie UW i innych szkół wyższych z zasady zaliczały lata studiów odbytych w Szkole Zaorskiego ${ }^{107}$.

Zamykając rozważania nad okupacyjną działalnością Wydziału Lekarskiego UW, przyjrzyjmy się aktywności wspomnianych klinik uniwersyteckich, które poza działalnością naukową i dydaktyczną, wspierającą konspiracyjne szkolnictwo akademickie, wykonywały swoje podstawowe zadanie. Kierowana przez Zdzisława Goreckiego I Klinika Chorób Wewnętrznych w szpitalu Św. Ducha zaangażowana była w działalność dydaktyczną obu podziemnych uniwersytetów. Jej kierownik prowadził egzaminy z diagnostyki i chorób wewnętrznych, organizował również seminaria naukowe dla lekarzy i studentów, opracowywał podręcznik chorób płuc. W działalność tę zaangażowani byli również inni pracownicy kliniki, w szczególności Edmund Bratkowski, Stanisław Mańczarski i Zdzisław Michalski ${ }^{108}$.

W II Klinice Chorób Wewnętrznych, kierowanej przez wspomnianego już Witolda Orłowskiego, zorganizowano tajne nauczanie w zakresie chorób wewnętrznych, w ramach którego każdy student musiał przechodzić ćwiczenia i praktyki przez 8 miesięcy, codziennie od godz. 8 do 13. Nauczanie odbywało się grupami w obu Klinikach Chorób Wewnętrznych oraz na oddziałach chorób wewnętrznych szpitala Wolskiego (doc. Roguski, dr Misiewicz), szpitala Św. Ducha (prof. Filiński, dr Grott, Wąsowicz), szpitala św. Łazarza (prof. Semerau-Siemianowski) oraz szpitala Przemienienia Pańskiego (doc. Michalski, dr Bartoszek). Po 2 miesiącach odbywało się kolokwium, po zdaniu którego zaliczano diagnostykę lekarską (program III roku studiów), po pięciu miesiącach internę (IV rok), a po ośmiu miesiącach całość kursu interny. Następnie student mógł przystąpić do egzaminu z chorób wewnętrznych u profesorów Orłowskiego lub Goreckiego. Studia odbywali studenci grupami po 30-35 osób. Nauczanie polegało na codziennej pracy od 
godz. 8 do 13 przy łóżkach chorych, w pracowniach i poradniach Kliniki, oraz na sporządzaniu historii chorób pod kierunkiem lekarzy, z których każdy miał przydzielonych po kilku studentów. Ponadto studenci uczęszczali na obowiązkowy kurs ogólnej diagnostyki lekarskiej, prowadzony przez dr Bolechowskiego oraz brali udział w konferencjach dyrektora Kliniki z lekarzami, raz w tygodniu, na których omawiano poszczególne przypadki. Dla wyróżniających się studentów zorganizowano dodatkowe kursy: leczenia za pomocą krótkich fal, rentgenologii, kurs przeciwgruźliczy. Do końca lipca 1944 r. przez klinikę przeszło 24,4 studentów, końcowy egzamin zdało 138, kurs interny bez egzaminu przeszło 23, kurs diagnostyki lekarskiej 10. Warto podkreślić, iż przyznane przez władze okupacyjnej środki na etaty były ograniczone, dlatego też wielu lekarzy pracowało bezinteresownie, znajdując źródła utrzymania w praktyce prywatnej lub w nauczaniu konspiracyjnym. Lekarze zatrudnieni w klinice prowadzili również prace naukowe: prof. Orłowski przygotował do druku 7 tomów Patologii i terapii chorób wewnętrznych, Andrzej Biernacki Walke z gruźlica na terenie Stołecznego Komitetu Samopomocy Społecznej w r. 1939, 1940 i 1941, a Wacław Markert $O$ zapadaniu na tężec żołnierzy polskich $w$ czasie działań wojennych we wrześniu 1939 r. w zależności od stosowania zapobiegawczego antytoksyny tężcowej. W okresie okupacji pracowano nad 57 zagadnieniami naukowymi, z czego 41 z nich przygotowano do druku ${ }^{109}$.

Tajne nauczanie okulistyki odbywało się w Klinice Okulistycznej pod kierunkiem Janusza Sobańskiego w latach akademickich 1942/19431943/1944. Słuchacze byli podzieleni na grupy po 12-15 osób i odbywali miesięczną praktykę. Wykłady (1-1,5 godz.) odbywały się codziennie. W pozostałych godzinach studenci byli przydzieleni do lekarzy Kliniki, odbywając zajęcia: badanie chorych, prowadzenie kart choroby, wykonywanie niektórych zabiegów. Kształciło się łącznie ok. 220 studentów, jednak dokładna ich lista zaginęła w powstaniu. Większość z nich rekrutowała się z UW, UZZ i Szkoły Zaorskiego ${ }^{110}$.

W latach 1939-1940 w Klinice Otolaryngologii, z przyzwolenia władz okupacyjnych, zdawali egzamin przedwojenni absolwenci i studenci V roku medycyny, łącznie ok. 200 osób. W następnym okresie, do stycznia 194,2 r., odbywali praktykę w Klinice studenci medycyny przydzieleni przez Wydział Szpitalnictwa Zarządu m.st. Warszawy, jako pielęgniarze lub laboranci. Od stycznia 194,2 r. zaczęli zgłaszać się studenci, którzy ukończyli 3 lata studiów lekarskich, głównie na studiach przedwojennych lub w Szkole Zaorskiego. Aż do wybuchu powstania prowadzono z nimi zajęcia polegające na badaniu, rozpoznawaniu i leczeniu chorych, dopuszczając do przypatrywania się operacjom. Odbywały 
się również wykłady z otolaryngologii, wygłaszane przez prof. Dobrzańskiego lub asystentów: Eugeniusza Błeszyńskiego, Jana Szymańskiego, Aleksandra Zakrzewskiego. Tajne nauczanie było przerywane na kilka dni, ilekroć przychodziła wiadomość, że władze niemieckie mają przeprowadzić inspekcję Szpitala Dzieciątka Jezus, w którym mieściła się Klinika. Okres pracy studenta w Klinice w ciągu 6 tygodni zaliczany był jako wykłady i zajęcia praktyczne, obowiązujące studenta medycyny. Zaliczenie uzyskało w ten sposób ok. 150 studentów, a 75 z nich zdało egzamin. W Klinice odbywały się również seminaria naukowe, na których wygłaszano referaty na podstawie prowadzonych prac naukowych, np. Agrafka jako ciało obce w nosie u dziecka, czy Choroby gardła, nosa, krtani i uszu ${ }^{111}$.

Nauczanie tajne odbywało się również w Klinice Psychiatrycznej, gdzie okupanci zredukowali etaty asystenckie do 2 na 14,0 chorych. Odbyło się 8 sześciotygodniowych kursów, w okresie od ${ }_{15}$ I 1943 do 15 VII 1944, r., obejmujących całość wiedzy psychiatrycznej niezbędnej dla lekarza niespecjalisty. Kurs ukończyło go słuchaczy, którzy następnie zdawali egzamin z psychiatrii i otrzymywali zaświadczenia. W prowadzeniu kursów brali udział pracownicy naukowi i lekarze: Helena Dreszer, Ryszard Dreszer, Mieczysław Kaczyński i Jan Mazurkiewicz. Helena Dreszer, która była długoletnią starszą asystentką Kliniki, mimo że została pozbawiona etatu, pracowała bezpłatnie przez cały okres okupacji. W czasie okupacji przygotowywano również prace naukowe. Prof. Mazurkiewicz napisał 2 monografie: Ewolucja aktywności korowo-psychicznej i Dyssolucja aktywności korowo-psychicznej; obie udało się ocalić. Praca dr Kaczyńskiego O paradoksalnych zmianach charakterologicznych po przebytej schizofrenii spłonęła, niestety, $\mathrm{w}$ jego mieszkaniu podczas powstania ${ }^{112}$.

W 1940 r., po utworzeniu dzielnicy żydowskiej, chcąc umożliwić zamkniętej za murem młodzieży udział $\mathrm{w}$ studiach medycznych, Juliusz Zweibaum przystąpił do organizacji kursu odpowiadającego programowi pierwszych 2 lat studiów medycznych i farmaceutycznych. Nosił on oficjalną nazwę „Kurs przysposobienia sanitarnego do walki z epidemiami" i formalnie nie był związany ze strukturami konspiracyjnego nauczania uniwersyteckiego. W skład jego Rady weszli: profesorowie Centnerszwer, Hirszfeld i Lachs oraz kierownik kursu, doc. Zweibaum. Kurs obejmował wykłady z fizyki, chemii nieorganicznej i organicznej, biologii i parazytologii oraz ćwiczenia praktyczne i pokazy w pracowniach; dla drugiego roku - anatomię opisową z prosektorium, 
histologię i embriologię oraz fizjologię człowieka i chemię lekarską. Ludwik Hirszfeld wspominał:

Profesorowie Centnerszwer i Lachs wykładali chemię, doc. Zweibaum histologię, ja bakteriologię. Kursy były płatne i samowystarczalne. Prezes Czerniaków bardzo je popierał, dzięki czemu uzyskaliśmy lokal. Odbywały się pomiędzy piątą a ósmą, gdyż młodzież przed obiadem musiała pracować zarobkowo. Często nie było elektryczności, wykłady odbywały się przy świetle świec lub karbidówek. Od czasu do czasu słyszało się odgłos wystrzałów - to na dole wacha zabijała jakiegoś Żyda. Formalnie treść wykładów stanowiła bakteriologia i nauka o odporności. Właściwy cel należało ukryć, wszystko to się czyniło pod pretekstem walki z epidemią. Należało pomyśleć o studentach starszych, których było ok. trzydziestu. Pracowali na ogół w szpitalach i wciągali się w praktykę w jej najgorszej postaci. [Skierowane zostaje] podanie do władz niemieckich o pozwolenie na kurs dokształcający ze względu na epidemię. Opracowuję program, zwołuję ordynatorów szpitala, przyciągam niektórych kolegów z miasta i organizuję czwarty i piąty roku studiów. Prezes Czerniaków zatwierdza preliminarz budżetowy. Szpital otrzymał nowy gmach na Stawkach. Otrzymałem na pracownię pięć pokoi, przy pracowni urządziliśmy salę wykładową. Tworzymy też pracownię badania głodu pod kierownictwem doktorów Fliederbauma i Apfelbauma. Gdy wchodziło się do pracowni, widziało się głowy pochylone nad mikroskopami, na ścianach tablice, w oknach rośliny. Wszystko błyszczało czystością. Tuż obok sala wykładowa i emblematy szkoły: pulpit i tablica wykładowa. Ludzie wchodzili zdumieni i zdawało im się, że są znowu w Europie.

Kurs trwał do 1942 r., następnie odbyły się egzaminy. Ponieważ w lipcu 194,2 r. rozpoczęła się likwidacja getta, egzaminy złożyło jedynie 4,0 słuchaczy na ok. 500; większość z nich zginęła w powstaniu w $1943 \mathrm{r}$.

W 1942 r., po opuszczeniu dzielnicy żydowskiej, zmuszony do życia w ukryciu, Juliusz Zweibaum rozpoczął pracę nad podręcznikiem histologii dla studentów medycyny i weterynarii, który ukończył w 1944 r. Natomiast efektem prac wspomnianej przez Ludwika Hirszfelda „pracowni badania głodu" było wstrząsające opracowanie, przekazane przez jednego z jego autorów, Emila Apfelbauma, na przechowanie Witoldowi Orłowskiemu, przezeń uratowane i opublikowane po wojnie ${ }^{113}$.

Wydział Farmaceutyczny rozpoczął działalność z początkiem roku akademickiego 1941/1942. Powołana została Rada Wydziału, dziekanem został Bronisław Koskowski. Posiedzenia Rady odbywały się raz na miesiąc, omawiano na nich program nauczania, oparty na przedwojennych wzorach, czy sposób zachowania konspiracji. Wykłady odbywały się w mieszkaniach wykładowców, zaś ćwiczenia w pracowniach 
prywatnych, laboratoriach aptek i wytwórniach farmaceutycznych. Nauka odbywała się w kompletach liczących 12-14 osób. Frekwencja wynosiła zwykle ok. 8o\%, w wypadku utrudnień, np. łapanki, na wykład przychodziła delegacja 2-3 osób, przekazująca następnie notatki nieobecnym koleżankom i kolegom. Miesięczne opłaty za studia wynosiły na początku okupacji $50 \mathrm{zł}$, zaś przed powstaniem - $200 \mathrm{zł}$. Udzielano jednak zwolnień, a nawet wypłacano 2 stypendia po $300 \mathrm{zl}$. W czasie okupacyjnego nauczania przez Wydział przewinęło się ok. 150-200 osób, z których 39 zdało egzamin magisterski. Według relacji Mariana Koczwary działała równoległa struktura Wydziału Farmaceutycznego, związana z tzw. grupą nauk ścisłych (por. Wydział Matematyczno-Przyrodniczy). Działał równiė̇ osobny Wydział Farmaceutyczny na Uniwersytecie Ziem Zachodnich ${ }^{114}$.

Z Wydziałem Farmaceutycznym współpracowali również niektórzy wykładowcy przedwojennego Wydziału Weterynaryjnego, np. Ernest Sym, pracujący jawnie jako kierownik działu chemii w Państwowym Zakładzie Higieny, tajnie zaś zaangażowany od grudnia 1940 r. w ZWZ. W maju 1944 r. z jego oraz Witolda Stefańskiego inicjatywy podjęta została próba zorganizowania tajnych studiów weterynaryjnych. Wybuch powstania uczynił tę próbę bezprzedmiotową ${ }^{115}$.

Praca na konspiracyjnym uniwersytecie, jak równiė̇ studiowanie na nim wiązało się z szeroko rozumianym pojęciem „mecenatu”. Studiowanie zależało od możliwości zamieszkiwania w Warszawie, posiadania pieniędzy na utrzymanie i opłaty, studia bowiem były płatne, co odróżniało je np. od studiów na Uniwersytecie Jagiellońskim, wreszcie - pracy chroniącej przed wywozem na roboty. Wprawdzie wielu niezamożnych studentów korzystało z ulg lub było zwolnionych z opłat, jednak większość musiała je wnosić. Studenci starszych lat uzyskiwali także dochody z udzielania korepetycji i nauczania w tajnym szkolnictwie średnim. Powstawały również struktury studenckiej samopomocy. Młodzież akademicka mogła korzystać też z tanich posiłków w miejskich stołówkach opieki społecznej; pomocy studentom udzielały ponadto szpitale, umożliwiając młodzieży korzystanie z bezpłatnego wyżywienia i zakwaterowania. Studenci medycyny szczególnie wiele zawdzięczali Aleksandrowi Ivance, dyrektorowi Wydziału Finansowego Zarządu Miejskiego m.st. Warszawy. Dzięki niemu znaczne kwoty z kasy miejskiej płynęły do warszawskich szpitali na cele związane z tajnym kształceniem; pod pretekstem subwencjonowania działających jawnie szkół zawodowych wspomagano równiė̇ młodziė̇ studiującą w nich 
tajnie. Studenci jawnych szkół zawodowych mieli też prawo do zniżek przy korzystaniu z komunikacji miejskiej ${ }^{116}$.

Znacznie bardziej skomplikowany był problem mecenatu nad środowiskami naukowymi. Przedwojenny rektor Włodzimierz Antoniewicz zaangażował się jako palacz centralnego ogrzewania w warszawskich szkołach powszechnych na okres od grudnia 1939 r. do kwietnia 194, 0 r. za 150 zł miesięcznie. Jak już wspomniano we wstępnej części opracowania, sytuacja Antoniewicza i innych naukowców zwróciła uwagę polskich władz samorządowych Warszawy na konieczność zajęcia się losem całego środowiska. Od maja 1940 r. ok. 30 osób zostało zaangażowanych w miejskich strukturach samorządowych, np. Włodzimierz Antoniewicz otrzymał pracę w Wydziale Ewidencji Ludności jako kierownik referatu. Wiele osób znalazło również zatrudnienie w Wydziale Ogrodnictwa, uzyskując zaświadczenie pracy zabezpieczające od przymusowej wysyłki na roboty ${ }^{117}$.

Przez cały okres okupacji, także po rozpoczęciu działalności przez uniwersytet konspiracyjny, co zasadniczo zmieniło sytuację środowiska naukowego, instytucje miejskie nie wyrzekły się roli mecenasa, dając naukowcom możność zarobkowania w ich dziedzinie. Wspomniany wcześniej Zakład Pomiarów Fizycznych, kierowany przez Stefana Pieńkowskiego, prowadził badania nad fotometrią szklarń czy świetlnością lamp gazowych, zlecane przez instytucje samorządowe: Gazownię Miejską, Elektrownię Miejską, Dyrekcję Wodociągów i Kanalizacji, Muzeum Narodowe w Warszawie (np. w sierpniu 1941 r. wykonał fotografie podczerwieni do celów konserwatorskich i przeprowadził badanie fluorescencji werniksu mastyksowego produkcji Muzeum) ${ }^{118}$.

W okresie, kiedy raczkowały jeszcze instytucje Polskiego Państwa Podziemnego, w tym także podziemne uniwersytety, godny podkreślenia był również mecenat osób i instytucji prywatnych. Pomocą służył Janusz Radziwiłł, który sfinansował fundusz w wysokości ok. 100 tys. zł. Dzięki zaangażowaniu polskich bankowców, zwłaszcza Feliksa Młynarskiego, prezesa Banku Emisyjnego w Polsce, pieniądze te mogły spoczywać na kontach w bankach działających jawnie. Przez cały okres okupacji banki, z inspiracji podziemia, przychodziły z pomocą, udzielając pożyczek na dogodnych warunkach ${ }^{119}$.

Uczestnicy tajnego nauczania otrzymywali, poza dochodami z czesnego, także dotacje podziemia, czyli faktycznie wynagrodzenie, które w 1943/1944 r. wynosiło 300 zł za jeden komplet na okres 2 miesięcy. Przykładowy miesięczny preliminarz budżetowy Działu Nauki i Szkolnictwa Wyższego DOiK, zachowany w formie pisanej odręcznie notatki na kartce wyrwanej z notesu, obejmował następujące kategorie 
wydatków: „personel” nauczający w liczbie ok. 450 osób; wydatki na konserwacje i naprawy we wszystkich szkołach akademickich; wydatki rzeczowe, inwentaryzacyjne, zakupy wykonywane na rzecz tych szkół; administracja szkolna; pomoc młodzieży: wspieranie pracy 150 studentów, 100 magistrantów, ponadto 50 doktorantów, 25 habilitantów; opiekę społeczną, która dotyczyła 630 profesorów, 4,0o docentów, 500 asystentów. Wsparcie finansowe tyczyło również „podtrzymywania potencjału naukowego" (zbieranie materiału bibliograficznego, liczbowego, graficznego do wykładów lub wydawnictw, opracowywanie zbiorów, projektów nowych urządzeń, organizację pracowni, zakup literatury naukowej) oraz opieki nad resztkami pracowni i zbiorów, w tym ich konserwowanie. Obejmowało te $\dot{z}$ „prace związane z przygotowaniem jutra" (archiwizacja dokumentów uniwersyteckich, list studentów, zaliczonych egzaminów, uzupełnianie kartotek, spisów przyrządów niezbędnych do zakupu ${ }^{120}$. Władze podziemne przeznaczały na prace DOiK znaczne kwoty, np. w 1943 r. ponad goo tys. dolarów (21\% budżetu Delegatury), rok później $2 \mathrm{mln}$ dolarów (16,5\%). Obok wydatków na Departament Pracy i Opieki Społecznej były to najpoważniejsze pozycje w budżecie, chociaż znaczącą ich część pochłaniały wydatki na organizację tajnego nauczania na szczeblu podstawowym i średnim ${ }^{121}$.

Również za pomocą udzielaną przez jawnie działające instytucje charytatywne (Rada Główna Opiekuńcza, Stołeczny Komitet Samopomocy Społecznej, Polski Czerwony Krzyż) stał nierzadko mecenat władz podziemnych i uchodźczych. Te ostatnie zorganizowały tzw. pomoc paczkową, której głównym organizatorem od września 1940 r. był Fundusz Kultury Narodowej. Akcja ta objęła w latach 194,0-194,2 ok. 1600 osób ${ }^{122}$.

Formą mecenatu umożliwiającą nie tylko przeżycie, ale także kontynuowanie pracy twórczej, było zawieranie przez wydawców umów wydawniczych, gwarantujących publikację w okresie powojennym, skutkujących jednak wypłatami zaliczek lub honorariów już w czasie okupacji. Największe bodaj osiągnięcia w tej dziedzinie w Warszawie miał Zbigniew Mitzner, którego „portfel wydawniczy” obejmował 216 pozycji. Autorami kontraktowanych dzieł byli m.in.: Marceli Handelsman, Julian Krzyżanowski, Alfred Lauterbach, Władysław Tatarkiewicz, Kazimierz Wyka. Podobną opiekę nad autorami sprawowały tė̇ znane instytucje wydawnicze, m.in.: M. Arct; Gebethner i Wolff; Trzaska, Evert i Michalski; J. Mortkowicz; E. Kuthan. Próbie podtrzymania zagrożonych warsztatów badawczych posłużyła tė̇ inicjatywa Kasy im. J. Mianowskiego, która, z obawy przed konfiskatą posiadanych w magazynach nakładów, umożliwiła uczonym warszawskim nabycie „na weksle”, 
a w praktyce za darmo, licznych cennych dzieł naukowych. Wiele prac powstało też z inicjatywy i dzięki wsparciu DOiK; dla szkół wszystkich stopni przygotowano ok. 200 podręczników i kilkaset monografii ${ }^{123}$.

Dla funkcjonowania tak skomplikowanej struktury, jaką stało się podziemne nauczanie, istotne było przestrzeganie zasad konspiracji. Instrukcje Departamentu Oświaty i Kultury Delegatury Rządu RP na Kraj zalecały dobór mieszkań u ludzi „pewnych”, okresową zmianę miejsca odbywania się danego kompletu, unikanie mieszkań narażonych na obserwację, mieszkań wykładowców, zabezpieczanie lokali konspiracyjnych, np. poprzez wystawianie czujek, aby w razie niebezpieczeństwa mieć możność ich opuszczenia. Prowadzących zajęcia przestrzegano, aby nie nosili przy sobie spisu uczniów; by ewidencji ocen nie prowadzić w miejscach odbywania się kompletów; zalecano przygotowywanie fikcyjnego tematu rozmowy lub rodzaju kamuflażu („imieniny”) na wypadek wkroczenia Niemców; posiadanie łączników (grupowych) z poszczególnymi grupami, aby ograniczać bezpośrednie kontakty (z zasady w każdej grupie wybierano starostę, grupowego, który, będąc łącznikiem między studentami a wykładowcą i sekretariatem danego wydziału, był odpowiedzialny za sprawy organizacyjne, koordynował plan zajęć, powiadamiał wykładowców i studentów o zmianach, zbierał opłaty); zalecano unikanie wystawiania studentom zaświadczeń o przebiegu studiów w czasie ich trwania, lecz dopiero po ich ukończeniu (formy zaświadczeń zależały od inwencji profesury, np. Bronisław Koskowski, dziekan Wydziału Farmaceutycznego, wydawał świadectwa ukończenia studiów w postaci prywatnych listów podpisywanych „Kazimierz Broniowski"). Studentom konspiracyjnych studiów zalecano: noszenie ze sobą jedynie niezbędnych książek, unikanie chodzenia grupami, przestrzeganie tajemnicy i nierozpowszechnianie wiedzy o tajnym nauczaniu, nieprzynoszenie na zajęcia konspiracyjnych czasopism, troskę o posiadanie „legendy”, uzasadniającej np. udział w ćwiczeniach prowadzonych w szpitalach (np. posiadanie zaświadczenia wystawionego przez Wydział Szpitalnictwa Zarządu m.st. Warszawy, kierującego do wykonywania prac pomocniczych w szpitalach). Istotne były również procedury i kryteria selekcji młodzieży przed przyjęciem na studia: rekomendacje wystawiane były przez znanych kierownictwu studiów pracowników naukowych, działaczy społecznych, członków konspiracji czy nauczycieli konspiracyjnych szkół średnich. Wstępnie zakwalifikowanych kierowano na rozmowę z pracownikami naukowymi, odpowiedzialnymi za przebieg naboru, którzy podejmowali ostateczne decyzje o przyjęciu na studia. Niekiedy odwoływano się do aktów symbolicznych: zaprzysiężenia studentów czy aktów ślubowania pracowników 
naukowych. Bezpieczeństwu konspiracyjnego uniwersytetu sprzyjała również decentralizacja jego struktur oraz ich daleko idąca autonomia ${ }^{124}$.

Trudną do przecenienia rolę w zakonspirowaniu nauczania uniwersyteckiego odgrywały jawne szkoły zawodowe, w szczególności w wypadku studiów medycznych, ale nie wyłącznie. Szkoły stały się faktyczną przykrywką dla wyższych studiów, stwarzając im ramy działalności i upodabniając warunki nauczania w konspiracji do realiów pokojowych. Ten system nauczania pozwalał korzystać z pracowni i uczestniczyć w ćwiczeniach praktycznych, co było niemożliwe do zrealizowania w prywatnych mieszkaniach ${ }^{125}$.

Z przywoływanych wcześniej realiów konspiracyjnego kształcenia na poszczególnych wydziałach czy sekcjach wynika wniosek, iż wiele zaleceń konspiracyjnych władz nie było ściśle przestrzeganych, czy to ze względu na postępującą z czasem rutynę, czy ze względu na tzw. trudności obiektywne. Wiele kłopotów wynikało z kłopotów lokalowych, które pogłębiały się wraz ze wzrostem liczby kompletów. Ocenia się, iż w Warszawie było ok. zoo lokali w mieszkaniach prywatnych (w załączonym do niniejszego opracowania aneksie nr 2, dalece niepełnym, uwzględnionych zostało ok. 100 adresów lokali konspiracyjnych). Niestety, znaczna ich część, jeśli nie większość, była wykorzystywana na rzecz różnych organizacji podziemnych. Część mieszkań należała do wykładowców, osób publicznych. Znaczna część słuchaczy i wykładowców była powiązana z organizacjami konspiracyjnymi, np. w Wydziale Informacji BIP pracowali: Aleksander Gieysztor, Marceli Handelsman, Stanisław Herbst, Witold Kula, Tadeusz Manteuffel, Michał Walicki, Ludwik Widerszal. Ze sporządzonego do celów niniejszego opracowania spisu (Aneks nr 1) wynika, iż co najmniej czwarta część kadry nauczającej związana była z więcej niż jedną uczelnią, nie wspominając już o typowym łączeniu zajęć w sekcjach tego samego wydziału czy na wydziałach tej samej uczelni ${ }^{126}$.

W zarysowanym wyżej kontekście zasadne jest pytanie: co na temat konspiracyjnego nauczania uniwersyteckiego wiedzieli okupanci? Wydaje się, iż stosunkowo bezpieczne, w porównaniu z innymi sferami działalności konspiracyjnej, funkcjonowanie podziemnego szkolnictwa wyższego wynikało zarówno z niedoceniania przez władze okupacyjne znaczenia i zasięgu tej działalności, jak również z przekonania, iż tajne kształcenie było mniej groźne od innych form oporu. W raporcie z 4. VIII 194,2 r., opracowanym w Głównym Wydziale Nauki i Nauczania Rządu GG, informowano o funkcjonowaniu polskiego szkolnictwa akademickiego w tajnych formach. W analogicznym raporcie opracowanym w wyżej wymienionym Wydziale, datowanym na 21 IV 1943 r., 
wyrażano zaniepokojenie faktyczną rolą spełnianą przez polskie jawne szkoły zawodowe. Władze niemieckie wiedziały o organizacji tajnego nauczania (zwłaszcza w tych szkołach) na podstawie sprawozdań wizytatorów, donosów oraz przypadkowo przechwyconych materiałów konspiracyjnych. Sądzić można, iż działanie struktur konspiracyjnych okupanci kojarzyli przede wszystkim z wykorzystywaniem jawnie działających szkół zawodowych, mniej rozpoznając pozostałą sferę konspiracyjnego nauczania. Nie docenili również faktu, że tajne nauczanie nie było dla znacznej części jego uczestników alternatywą dla zbrojnej konspiracji, lecz raczej jej dopełnieniem. Zgodzić się więc wypada z opinią Tadeusza Manteuffla, iż tajne nauczanie było niebezpieczne w przypadku zaangażowania studentów także w inne formy działalności podziemnej, bądź „obciążenia” podobną „różnorodnością” lokali konspiracyjnych. „Ta robota” - pisał Manteuffel - „może była najmniej niebezpieczna". Nie znaczy to jednak, że była pozbawiona ryzyka ${ }^{127}$.

W dyskusji o podziemnym nauczaniu uniwersyteckim zasadne wydaje się pytanie o skuteczność nauczania konspiracyjnego. W ocenie tego zagadnienia szczególnie problematyczne są próby ujęć statystycznych skazane, wobec szczątkowego zachowania danych źródłowych, na walor daleko idącego przybliżenia. W roku akademickim 1938/1939 na obszarze państwa polskiego do 28 szkół wyższych uczęszczało ok. 50 tys. studentów. W roku 1936/1937 dyplomy magisterskie otrzymało 6114 osób, doktorskie - 233. U schyłku II RP pracowało na wyższych uczelniach ponad 800 profesorów i docentów, prawie 2000 asystentów i lektorów. W Warszawie czynnych było w roku 1938/1939 11 szkół akademickich, z ogólną liczbą 20300 słuchaczy. Profesorowie i studenci uczelni warszawskich stanowili ok. 40\% ogólnej ich liczby, zaś w naukach technicznych nawet 50\%. Na samym Uniwersytecie Warszawskim w roku 1937/1938 zatrudnieni byli nauczyciele akademiccy w następujących kategoriach zawodowych i liczbach: profesorowie - 127 (w tym zwyczajni - 83), zastępcy profesorów - 6, prowadzący ćwiczenia i wykłady - 205 (w tym lektorzy - 23), pomocnicze siły naukowe - 300 (w tym asystenci - 137), łącznie - 638 osób. W tym samym roku na UW studiowało ogółem 8388 osób, w tym 3474, kobiety (4,1,4\%). Pochodzenie studentów klasyfikowane wg środowiska społecznego ojca przedstawiało się następująco: rolnictwo $16,3 \%$, służba publiczna i wolne zawody $4,1,3 \%$; 79,1\% studentów pochodziło z miast, których ludność w $193^{1}$ r. stanowiła 27,2\% ogółu ludności Polski. W tajnym nauczaniu, według publikowanych danych oraz uzupełnień dokonanych na podstawie kwerend źródłowych, a zestawionych w Aneksie nr 1, uczestniczyły 394, osoby, czyli ponad połowa stanu liczbowego kadry nauczającej sprzed wojny ${ }^{128}$. 
Jeśli chodzi o liczbę studentów konspiracyjnego Uniwersytetu, szacunki wydają się jeszcze trudniejsze. W całej Warszawie, jako największym ośrodku tajnego nauczania akademickiego, kształciło się ok. 4500-6500 studentów, czyli niewiele ponad 10\% ich ogólnej liczby z 1938 r. Tadeusz Manteuffel szacował liczbę studentów konspiracyjnego UW wiosną 1944, r., czyli w szczytowym okresie jego rozwoju, na blisko 2000 osób. Przyjmuje się, że szacowany sumarycznie efekt pracy konspiracyjnego szkolnictwa wyższego stanowi, licząc dyplomy magisterskie i zawodowe, niewiele ponad 10\%, a doktoraty - $16 \%$, w stosunku do r. 1937. Odnosząc się do struktury społecznej studiującej młodzieży, można zaryzykować stwierdzenie, iż nie zmieniła się ona znacząco w porównaniu z czasami przedwojennymi ${ }^{129}$.

Podsumowując doświadczenie konspiracyjnego nauczania, jeden z jego uczestników, Henryk Hiż, wspominał:

Podjęto eksperyment systematycznej pracy oświatowej i badawczej w warunkach niesprzyjających. Olbrzymia większość tych, co zaczęli chodzić na wykłady, kontynuowała naukę do powstania. Udał się ten eksperyment, bo skutecznie ustanowił w państwie podziemnym niezależność nauki. Swoboda wykładowcy była większa niż w warunkach przedwojennych.

\section{Z drugiej strony jednak:}

Zasięg społeczny uniwersytetu ograniczał się do wąskiej warstwy społecznej. Była to impreza towarzyska warszawskiej inteligencji. Jakość nauczania i jakość pracy studenta pozostawiały dużo do życzenia. Braliśmy iloczyn jakości kompletów i trudności zewnętrznych za jakość naszej pracy. Nie posypały się bezpośrednio po wojnie rewelacyjne prace, które tylko czekały na ogłoszenie drukiem. Tym, co dojrzewali w warunkach podziemia, potrzeba było jeszcze kilku lat, by dojrzeć do warunków bardziej zwykłych ${ }^{130}$.

Obawy o obniżenie poziomu nauczania, spowodowane warunkami okupacyjnymi, nie były obce zarówno organizatorom podziemnego Uniwersytetu, jak również studiującym. Wanda Leopold wspominała:

Dzięki profesorom Krzyżanowskiemu i Borowemu byliśmy w stosunkowo dobrej sytuacji, jeśli chodzi o książki potrzebne do studiów. Referent zwykle otrzymywał potrzebną lekturę. Pozostali uczestnicy seminarium już nie zawsze zdołali ją poznać. Bardzo często jeden egzemplarz nie zdążył „obejść” kompletu. Czasem książka była tylko w oryginale, a nie znaliśmy zbyt dobrze języków obcych. Powodowało to, mimo pomocy profesorów i naszych starań, niebezpodstawny kompleks niedokształcenia. 
$\mathrm{Z}$ jednej strony średnia liczba godzin zajęć na wszystkich kierunkach studiów była proporcjonalnie mniejsza w porównaniu do okresu międzywojennego. $\mathrm{Z}$ drugiej jednak zajęcia prowadzono zasadniczo według przedwojennych norm, obejmujących minimum 8 (do 12) godzin obowiązkowych tygodniowo dla studentów i 20-zo godzin dla wykładowców; na niektórych kompletach studenci przygotowywali w ciągu roku do 12 referatów, podczas gdy w latach międzywojennych wykonywano ich ok. 3; egzaminy prowadzili z zasady samodzielni pracownicy naukowi, podobnie wykłady, adiunkci i asystenci prowadzili ćwiczenia, lektoraty, praktyki i kolokwia. Szczególnie troszczono się o zachowanie przedwojennych rygorów przeprowadzania egzaminów, np. w zakresie kolegialności organów egzaminujących (komisji czy rad wydziału). Przeprowadzano egzaminy na niższy stopień naukowy (magistra, inżyniera), ale zdając sobie sprawę z odmienności sytuacji wojennej, nadawanie tytułu zachowując na okres powojenny. Jeśli chodzi o procedury nadawania wyższych stopni (doktorat, habilitacja), dopuszczano ocenę i przyjęcie pracy, rzadko przeprowadzając egzaminy, publiczne obrony czy wykłady, odsuwając to również na czas powojenny ${ }^{131}$.

Do wyjątków należał więc obroniony w 1942 r. doktorat Aleksandra Gieysztora na podstawie rozprawy: Ze studiów nad genezq wypraw krzyżowych. Encyklika Sergiusza IV (1009-1012):

Zostałem powiadomiony, że Stanisław Wędkiewicz, dziekan przedwojennego Wydziału Humanistycznego, gotów jest mój doktorski egzamin przeprowadzić, załatwiając wszystkie z tym związane formalności na uniwersytecie - wspominał Aleksander Gieysztor. - Najpierw trzeba było zdać egzamin z przedmiotu pobocznego. Wybrałem historię ustroju Polski. Poszedłem do mieszkania prof. Rafacza. Uzyskałem wskazówki co do lektur i zakresu egzaminu. Rozmowa egzaminacyjna odbyła się w rygorach utrzymanych przez prof. Rafacza, w obecności prof. Wędkiewicza. Stanisław Kętrzyński, promotor pracy, w swoim mieszkaniu na Tamce zebrał komisję egzaminacyjną, której przewodniczył prof. Wędkiewicz, uczestniczyli zaś w niej prof. Rafacz oraz recenzent pracy prof. Handelsman. Prof. Kętrzyński na zakończenie aktu egzaminacyjnego polecił komuś z domowników przynieść butelkę francuskiego wina, którą przechowywał sprzed wojny. Jakiś łagodny sauternes uczcił doktorat. Prof. Wędkiewicz wystawił mi zaświadczenie o złożeniu egzaminu z datacją - wrzesień 1939 r. ${ }^{132}$

Dane z powojennego UW (194,8 r.) potwierdzają tezę, iż pierwsze lata po zakończeniu wojny były w pewnym sensie dopełnieniem kształcenia konspiracyjnego. I tak w latach 1944-1946 wydano 6256 dyplomów ukończenia studiów. Bilans półtorarocznej działalności Wydziału Lekarskiego wyglądał następująco: 15 habilitacji, $7 \mathrm{w}$ toku, 
12 doktoratów, 6 w toku, ok. 600 egzaminów, 1500 studentów w trakcie kształcenia. Podobnie pierwsze powojenne posiedzenia Rady Wydziału Matematyczno-Przyrodniczego poświęcone były sprawom zaliczania egzaminów i nadawania stopni magisterskich studentom czasu wojny. Takimi studentami byli m.in. Jacek Prentki i Jan Rzewuski, późniejsi profesorowie fizyki teoretycznej ${ }^{133}$.

Dziedzictwem konspiracyjnego kształcenia były również efekty badawcze. Witold Orłowski opracowywał dalszy ciąg podręcznika chorób wewnętrznych. Janusz Woliński we wstępie do Epilogu elekcji ${ }_{1} 674$ r. pisał, że praca ta, gotowa do druku, spłonęła we wrześniu 1939 r., jednak uratowane materiały umożliwiły podczas okupacji rekonstrukcję książki. Spalenie mieszkania po powstaniu nie oszczędziło i drugiej redakcji. Dwukrotnie zniszczona praca nie została całkowicie odtworzona, opublikowana jednak została po wojnie w serii „Rozprawy PAU, Wydział Historyczno-Filozoficzny". Wacław Miszewski przygotował podręcznik Proces cywilny, którego maszynopis spłonął podczas powstania. Praca ukazała się jednak po wojnie. Po ukończeniu książki O szczéściu (w czasie okupacji przybył m.in. rozdział o nieszczęściu), Władysław Tatarkiewicz zajął się trzecim tomem Historii filozofii. Rękopis leżał na biurku, gdy wybuchło powstanie. „12 sierpnia - wspominał Tatarkiewicz - przyszły wojska niemieckie, otoczyły nasz dom, opróżniły i spaliły. Tom spłonął wraz z domem. Rozdziały te potem z pamięci pisałem na nowo w Krakowie"134.

Jeśli mierzyć aktywność badawczą polskich środowisk naukowych w okresie okupacji przygotowanymi publikacjami, to widać wyraźnie, że była ona znacząca, chociaż nie ma sensu zestawianie jej ilościowych efektów z twórczością czasów pokoju. Autorzy ze wszystkich ośrodków uniwersyteckich opracowali ok. 470 podręczników i monografii, z tego 188 z zakresu humanistyki, 146 nauk przyrodniczych, 52 technicznych, 27 rolniczych, 23 medycznych, 17 prawnych, 15 innych; 282 (68\%) przygotowano w Warszawie, ocalało z nich tylko 5\%. Skalę strat poniesionych w powstaniu potwierdzają powojenne badania Państwowego Instytut Historii Sztuki i Inwentaryzacji Zabytków (obecnie Instytut Sztuki PAN), który przygotował ankietę o tematach badawczych, podejmowanych przez historyków sztuki w czasie okupacji. Badacze warszawscy przekazali informacje o 199 ukończonych pracach, z których 112 zaginęło w czasie powstania ${ }^{135}$.

Prace związane z przygotowaniem jutra, zwane téz ,pracami przyszłościowymi", były również częścią dziedzictwa konspiracyjnego Uniwersytetu. W 1941 r. została powołana, związana z Departamentem Oświaty i Kultury Delegatury Rządu, Główna Komisja Planowania, 
w skład której weszli m.in. profesorowie UW Stanisław Ossowski i Bogdan Suchodolski. Zadaniem komisji było opracowanie projektów aktów prawnych z zakresu szkolnictwa wyższego na okres powojenny. W konspiracyjnych strukturach UW powołano własną Komisję reformy studiów akademickich. W komisji zasiedli profesorowie: Wędkiewicz (przewodniczący), Antoniewicz, Bassalik, Bystroń, Kotarbiński, Krzyżanowski, Pieńkowski, Rafacz i Suchodolski. Efektem prac Komisji były liczne projekty reformy studiów oraz zmian organizacyjnych i inwestycji, obejmujące wszystkie wydziały uniwersyteckie. Wśród zachowanych opracowań można znaleźć nietracący na aktualności projekt stworzenia instytutów naukowo-badawczych w przemyśle czy też szczególnie interesujący dla studentów konspiracyjnych studiów projekt zarządzenia „Do rad wydziałowych szkół wyższych w sprawie zaliczenia studiów i egzaminów odbytych na tajnych kompletach w czasie wojny"136.

Czas okupacji był bez wątpienia w dziejach Uniwersytetu Warszawskiego okresem szczególnym wobec skali wyzwań, przed jakimi stanęło środowisko akademickie. Wydaje się również, iż był to jeden ze znakomitszych okresów w dziejach uniwersyteckich. Podjęcie wysiłku organizacji podziemnego Uniwersytetu, bez poczucia pewności dnia dzisiejszego i gwarancji jutra, zaliczyć należy do kategorii aktów heroicznych. Przypomnijmy, że sformułowana wiele lat po wojnie przez Leszka Kołakowskiego koncepcja uniwersytetu wskazywała, iż instytucja ta winna zapewniać wykształcenie zawodowe na szczeblu wyższym, służyć przekazywaniu dziedzictwa kultury, wzbogacać wiedzę o świecie, która to wiedza jest zdefiniowana nie tylko przez samą jej treść, ale przez procedury uzasadniające jej prawdziwość, upowszechniać wartości, które znajdują zastosowanie nie tylko w nauce, ale we wszystkich sferach życia społecznego (bezstronność w wydawaniu sądów, tolerancję, krytycyzm, przestrzeganie reguł logicznych) ${ }^{137}$. Czymś jeszcze, co można zaliczyć do powinności instytucji akademickich, a co wydaje się być najcenniejszą częścią dziedzictwa uniwersytetu czasu wojny, było wytworzenie szczególnych relacji środowiskowych, relacji między studentem a jego mistrzem.

Jak wspominał Tadeusz Kotarbiński, podziemny Uniwersytet powstał z potrzeby wewnętrznego uporządkowania, aby pracować na przekór wszystkiemu, co odbierało chęć do pracy i uważne skupienie, aby umieć izolować się wewnętrznie na określoną godzinę nie tylko od własnego, lecz także od cudzego cierpienia i niepokoju, aby całą uwagę skupić na robocie, którą podjęliśmy, a którą chcemy wykonywać dobrze dla 
własnego samopoczucia i dla osiągnięcia tego, czemu ma ona służyć w dziedzinie cudzych potrzeb. Tajne nauczanie, według słów Tadeusza Manteuffla, posiadało urok, który pociągał zarówno wykładowców, jak młodzież. Pierwszym dawało ono zapomnienie o rzeczywistości, drugich zachęcało atmosferą wolności, jaką dawało zetknięcie się z pracą naukową. Dawało też możliwość odprężenia psychicznego tym, którzy brali udział w czynnej walce z okupantem ${ }^{138}$.

Uczestnicy konspiracyjnych zajęć podkreślali „pełne bezpośredniości kontakty osobiste studentów z profesorami i pracownikami naukowymi”. Świadomość, jak się narażają, „czyniła nas stokroć bardziej odpowiedzialnymi za wyniki naszej nauki". Głównym walorem kompletów był fakt, iz „,W wyjałowionym z podniet intelektualnych życiu dawały możność zdobycia pokaźnej sumy wiadomości, budziły zainteresowania naukowe, uczyły myśleć i dyskutować”. Cenna była możność utrzymywania kontaktów z „ludźmi tajnego nauczania”, którzy „w najgorszych chwilach, jakie przeżywaliśmy wszyscy, uczyli nas nie tylko filozofii, logiki czy psychologii, ale również, jak żyć, jak radzić sobie z tym, co nas spotkało, jak przetrwać zło, nie tracąc wiary w dobro". Nigdy nie było tak bliskiego kontaktu między profesorem a studentem, jak wówczas, gdy „mógł nas i profesora spotkać ten sam los z rąk okupanta”139.

Jedną z cech życia środowiska naukowego i młodzieży studiującej było łączenie różnych sfer aktywności, nauki z przygotowaniem do walki zbrojnej czy pracą zarobkową, wzajemne przenikanie się różnych konspiracyjnych struktur poprzez udział w nich tych samych osób i grup. Marceli Handelsman, znający się z Jerzym Makowieckim z przedwojennego Klubu Demokratycznego, zarekomendował do BIP KG ZWZ-AK Tadeusza Manteuffla, a ów sukcesywnie wprowadzał w tę strukturę innych historyków, m.in. Aleksandra Gieysztora, Stefana Kieniewicza, Witolda Kulę, Ludwika Widerszala. Kiedy więc Aleksander Gieysztor odwiedzał Handelsmana w Milanówku, czynił to zarówno w roli doktoranta, jak i przedstawiciela BIP. Tajne nauczanie oznaczało przenikanie środowisk o różnych tradycjach ideowych, Uniwersytetu Warszawskiego z bardziej „narodowym” Uniwersytetem Ziem Zachodnich, czy Wolną Wszechnicą Polską. Uczelnie skupiały ludzi z różnych środowisk, a ludzie ci nie ograniczali swej aktywności do jednego miejsca ${ }^{140}$.

Ludzie podziemnego Uniwersytetu w przytłaczającej większości nie ulegli zachętom do współpracy ze strony władz okupacyjnych, a oferty takie otrzymywali rektorzy: Antoniewicz, Modrakowski, Pieńkowski; działająca po wojnie komisja dyscyplinarna w czerwcu 1948 r. uniewinniła Włodzimierza Antoniewicza z zarzutu o niedozwoloną współpracę z krakowskim Ostinstitut. Na marginesie, lektura opracowanej przez 
Kierownictwo Walki Cywilnej (odpowiedzialne za zwalczanie postaw kolaboracyjnych w społeczeństwie) Instrukcji ramowej dla pracowników naukowych $i$ kulturalnych, pozostawia wiele interpretacyjnych wątpliwości ${ }^{141}$. Pracownicy naukowi i kulturalni mieli w warunkach okupacyjnych „kontynuować w miarę możliwości prace naukowe i kulturalne”, podstawowym zaś ich obowiązkiem było utrzymanie „warsztatów pracy". Współpraca z Niemcami dozwolona była tylko w wypadkach, gdy mogło to prowadzić „do zachowania i uratowania polskich placówek lub zbiorów naukowych, artystycznych i kulturalnych - za uprzednią zgodą miarodajnych czynników polskich". Sekretarz generalny Polskiej Akademii Umiejętności, prof. Tadeusz Kowalski pisał po wojnie:

W czasach tak nienormalnych jak minione lata okupacji niemieckiej, kiedy całe życie narodowe przeniosło się do podziemia konspiracji i nie wszystkie pobudki czynów mogły być ujawnione, gwarancję nieskazitelności stanowiła aprobata tych osobistości, które w opinii ogółu uchodziły za bezsporne autorytety w sprawach narodowych.

Takimi autorytetami byli uniwersyteccy wykładowcy, organizatorzy konspiracyjnych studiów ${ }^{142}$.

Podsumowując swoje wojenne doświadczenia, typowe zresztą dla przeżyć całej akademickiej generacji, Tadeusz Kotarbiński wskazywał, że do uniwersyteckiego programu nauczania ,nikt się nie wtrącał, profesor brał na siebie odpowiedzialność za przedmiot; obce było uczestnikom nielegalnej uczelni jakiekolwiek ideologiczne cenzurowanie lub kierownictwo. O paradoksie!” - wspominał - „Nigdy nie brałem udziału w nauczaniu tak absolutnie liberalnym, jak... w dobie najcięższej niewoli"143. Również wielu studentów, którzy doświadczyli uczestnictwa w konspiracyjnym kształceniu, a którzy po wojnie w różnych miejscach i na różnych uczelniach szukali warunków ukończenia studiów, podkreślało, że „tylko tajny Uniwersytet Warszawski uznają za swój uniwersytet macierzysty"144.

\section{Biblioteka Uniwersytecka ${ }^{145}$}

Biblioteka Uniwersytecka dysponowała przed wybuchem II wojny światowej najliczniejszym księgozbiorem w kraju. W 1939 r. jej dyrektorem został Adam Lewak. Również poszczególne zakłady, seminaria, 
instytuty, gabinety i kliniki Uniwersytetu posiadały własne księgozbiory, na ogół nieduże. Łącznie zbiory Uniwersytetu w 1939 r. liczyły $133^{1}$ o87 woluminów ${ }^{146}$.

Jak wspomniano, po zakończeniu działań wojennych we wrześniu 1939 r. teren uniwersytecki został zamknięty, a 2 X zajął go batalion Policji Bezpieczeństwa. W gmachu BUW kwaterował sztab batalionu, umieszczono tam także rozmaite punkty usługowe - warsztaty szewskie i krawieckie, zbrojownię. Biblioteczne szafy, regały, pulpity przeniesiono do innych budynków uniwersyteckich. Bibliotekarze mogli przebywać jedynie w magazynie. Zezwolenie na wstęp na teren Uniwersytetu, a więc i BUW, otrzymało tylko 5 bibliotekarzy (od początku 1940 r. 10 osób) zatrudnionych nieodpłatnie. Przez kilka miesięcy prowadzili oni prace porządkowe, polegające przede wszystkim na zwożeniu książek z tych zakładów uniwersyteckich, które mieściły się w zniszczonych budynkach. Do połowy 1940 r. przetransportowano do gmachu głównego ok. 100 tys. woluminów. Trafiły tam m.in. księgozbiory wydziałów: Teologii Katolickiej (Seminarium Filozofii Chrześcijańskiej, Studium Filozoficzno-Religijne), Teologii Ewangelickiej, Lekarskiego, Prawa (seminaria - Prawa Cywilnego, Prawa Handlowego i Wekslowego, Prawa Procesowego Cywilnego), Humanistycznego (seminaria - Filozoficzne I Władysława Tatarkiewicza, Filozoficzne II Tadeusza Kotarbińskiego, Slawistyczne, Filologii Ukraińskiej, Anglistyczne, Historii Gospodarczo-Społecznej i Geografii Historycznej, Historii Wychowania, zakłady - Archeologii Klasycznej, Historii Sztuki, Archeologii Przedhistorycznej, Etnografii Polski), Matematyczno-Przyrodniczego (seminaria - Filozofii Matematyki, Logiki Matematycznej, Zakład Fizjologii Roślin). Uniwersyteccy bibliotekarze przejmowali też w różnych okresach okupacji księgozbiory prywatne, m.in. Stefana Czarnowskiego, Marcelego Handelsmana, Mieczysława Tretera. Starano się również uzupełniać straty poniesione we wrześniu 1939 r. i nabywać książki naukowe ukazujące się współcześnie. Nabywanie książek było o tyle łatwe, że właściciele bibliotek prywatnych, znalazłszy się w trudnej sytuacji materialnej, wyprzedawali swoje zbiory, była to więc również swoista forma mecenatu. Od kwietnia 1942 r. do czerwca 1944, r. Biblioteka, nabywając 4929 dzieł w 11262 woluminach, wydała łącznie 137465 zł, notabene, ze środków przyznanych przez władze okupacyjne ${ }^{147}$.

Jak wyglądała sytuacja Biblioteki wobec władz niemieckich? Kompetencje wspomnianej Komisji Likwidacyjnej obejmowały także BUW, jednak możliwość jej interwencji była tu bardziej ograniczona niż w innych warszawskich bibliotekach, ponieważ teren uniwersytecki został 
zamknięty po wejściu Schutzpolizei. Odtąd policja, jak już wspomniano, reglamentowała wejście do Biblioteki. Konieczne było również pozwolenie Komisji, jako że wstęp do wszystkich pomieszczeń uczelni warszawskich mógł się odbywać tylko za jej zgodą. Oficjalnym zadaniem bibliotekarzy objętych zezwoleniem były więc prace porządkowe, nieoficjalnym - konspiracyjne udostępnianie książek zamawianych przez pracowników naukowych Uniwersytetu. Po zakończeniu działalności Komisji Likwidacyjnej, biblioteki naukowe w GG zostały podporządkowane Głównemu Zarządowi Bibliotek (Hauptverwaltung der Bibliotheken), na czele którego stał Gustav Abb, dyrektor biblioteki uniwersyteckiej w Berlinie. Zarząd nadzorował bezpośrednio cztery biblioteki państwowe, m.in. w Warszawie (Staatsbibliothek Warschau). W skład tej biblioteki weszły: Oddział I (BUW), Oddział II (Biblioteka Narodowa), Oddział III (Biblioteka Ordynacji Krasińskich).

Praca Biblioteki opierała się na przedwojennym polskim personelu. Polscy pracownicy szczebla kierowniczego zobowiązani zostali do złożenia w lipcu 19411 r. oświadczenia, że swoje obowiązki będą spełniać „wiernie" i że nie czują się związani „żadnym zobowiązaniem wobec dawnego państwa polskiego"148. Praktyka pokazała, iż oświadczenia te, złożone bez możliwości swobodnego podejmowania decyzji, de facto pozostały formalnością. Wanda Sokołowska wspominała:

Już w r. 1939 jako jedno z najpilniejszych wysuwało się zagadnienie umożliwienia dostępu do zbiorów Biblioteki nie tylko uczonym, ale i szerokim kołom społeczeństwa. Wobec trudności, jakie sprawiało wchodzenie na teren Uniwersytetu, zorganizowano wypożyczanie książek za pośrednictwem sekretariatu Uniwersytetu. Otrzymanie tą drogą książek z Biblioteki z reguły trwało długo, gdyż tylko wyjątkowo można było złożone w sekretariacie zamówienie tego samego dnia załatwić. Pewne ułatwienie w sposobie wypożyczania nastąpiło po stworzeniu „Staatsbibliothek".

Zanim powstała Staatsbibliothek, która wprowadziła pewne reguły wypożyczania książek, na podkreślenie zasługuje rola jednego z pracowników uniwersyteckiego sekretariatu, Stanisława Sucheckiego, który udostępniał księgozbiory zakładów i pośredniczył w kontaktach z BUW ${ }^{149}$. Użytkownikami bibliotek państwowych mieli być Niemcy oraz osoby pracujące na rzecz instytucji niemieckich. Jak pisał Ksawery Świerkowski: „Karty wstępu wydawano tylko za zezwoleniem [Wilhelma] Wittego", komisarycznego kierownika Staatsbibliothek Warschau, „który specjalnych trudności nie stawiał Polakom, gdyż zależało mu na liczbach statystycznych". Jak wspominał Adam Lewak: 
Przez kilka miesięcy przychodził w asyście policjanta niemieckiego niemal co dnia prof. [Majer] Bałaban. Z twarzą o cerze papierowej, zupełnie siwy i wynędzniały, połowę chleba i czereśni, którymi go częstowali koledzy polscy, chował dla równie głodnej żony. Polacy otrzymywali pozwolenie na korzystanie z biblioteki na podstawie fałszywych dowodów pracy, często korzystali z nieobecności Wittego w bibliotece między godz. 12 a 15; wtedy zbierali się w czytelni profesorowie i studenci tajnego uniwersytetu i nawet redakcje tajnych gazetek.

Do stałych czytelników BUW należeli: Wacław Borowy, Marceli Handelsman, Julian Krzyżanowski, Stefan Pieńkowski ${ }^{150}$.

Jak wspominał jeden ze studentów konspiracyjnego Uniwersytetu:

Zaopatrzony w listy polecające profesora Krzyżanowskiego i profesora Tatarkiewicza udałem się do [przedwojennego] dyrektora Biblioteki Adama Lewaka. Minąłem bunkier stojący u bramy uniwersytetu, okazałem kennkartę i arbeitskartę wartownikowi z Wehrmachtu i następnie zostałem odesłany na „wachę”, która mieściła się na parterze gmachu porektorskiego, na prawo od biblioteki. Tam jeszcze raz przejrzano moje dokumenty, zabrano mi je i pozwolono iść do budynku biblioteki. Dyrektor Lewak pouczył mnie, iż mam złożyć podanie do Komisarza „Staatsbibliothek Warschau”, Niemca, doktora Wittego. W podaniu tym mam napisać, z jakiego zakresu książki będę czytał. Oczywiście nie z zakresu historii literatury i filozofii, bo tego by Witte nie zaakceptował. - Tu się najczęściej pisze - powiedział z naciskiem dyrektor Lewak - że z zakresu materiałów budowlanych. Do ceremoniału należało stawienie się przed oblicze komisarza doktora Witte. Also Baumaterialen. Ja? Gut. - i podpisał moje podanie. Dopuszczony do Biblioteki Uniwersyteckiej stałem się jej codziennym gościem. Bibliotekarze w czytelni, doktor Krampera z Uniwersytetu Poznańskiego i doktor Herbst znosili mi coraz to nowe „budowlane” dzieła, których wypożyczenie doktor Witte akceptował własnoręcznym podpisem na każdym rewersie ${ }^{151}$.

W lipcu 1943 r. Witte opracował nowy wzór legitymacji, anulując tym samym poprzednio wydane pozwolenia na korzystanie ze zbiorów. Wszystkie książki powinny zostać zwrócone, a ponownie udostępnione mogły być dopiero po uzyskaniu nowej legitymacji. Tak ostre zarządzenie było skierowane przeciw wypożyczaniu tajnemu. Witte zdawał sobie sprawę ze skali tego zjawiska i słusznie podejrzewał, że pracownicy, którzy na swoje rewersy mieli możliwość wypożyczenia 5 woluminów książek lub czasopism, dopuszczali się „przekroczeń”. W rozmowie z Konradem Jażdżewskim, kierującym wówczas Państwowym Muzeum Archeologicznym, miał powiedzieć: „Czy myśli Pan, że ja nie wiem, do 
czego to może być Panu potrzebne?" Książki wypożyczano wielu pracownikom naukowym i studentom. Lektury te były przydatne przede wszystkim do zajęć na tajnych uniwersytetach - Warszawskim i Ziem Zachodnich. Tajne wypożyczanie książek podlegało określonym procedurom, prowadzono dwie kartoteki wypożyczeń: oficjalną i nielegalną. Wypożyczano albo oficjalnie, na zatwierdzone przez Wittego rewersy, albo nieoficjalnie, ukrywane przez kierownika magazynu Józefa Chudka, bądź na osobiste konta bibliotekarzy. Zdarzały się jednak wpadki, gdy w mieszkaniach aresztowanych osób znajdowały się książki z BUW, które w oficjalnej kartotece nie figurowały. Kiedy aresztowana została Łucja Charewiczowa, Stanisława Sawicka w pośpiechu usuwała rewersy ze swego konta. Czytelnikom BUW wypożyczono w ten sposób ok. 35 tys. woluminów ${ }^{152}$.

\section{Ostatnie miesiące - powstanie i akcja pruszkowska $^{153}$}

W chwili wybuchu powstania w Bibliotece Uniwersyteckiej znajdowali się 3 bibliotekarze: Bohdan Korzeniewski, Marian Toporowski i Józef Krampera, oraz magazynier Stanisław Włodarski i jeszcze 4 przypadkowe osoby. Załodze BUW przypadła w udziale wyjątkowo trudna służba. Biblioteka, jak cały teren uczelni, leżała w centrum walk i okupujący ją żołnierze niemieccy zatrudniali bibliotekarzy do różnorakich czynności - noszenia amunicji, transportu rannych, grzebania zwłok. Podczas tych czynności 5 IX śmiertelnie ranny został Józef Krampera, którego dwa dni później pogrzebano w prowizorycznej mogile przed wejściem do Biblioteki.

W sierpniu i wrześniu 1944 r. powstańcy usiłowali odbić kampus uczelni z rąk niemieckich. l VIII nastąpił pierwszy szturm. Niemcy w liczbie ok. 200 pilnowali terenu uczelni. W Gmachu Pomuzealnym składowano 4500 karabinów, a w Auditorium Maximum same skrzynie z granatami wypełniały 2 sale. Żołnierzom 2. Kompanii, dowodzonej przez por. Bicza (Marian Mokrzycki) z VIII zgrupowania AK pod dowództwem Krybara (Cyprian Odorkiewicz), wydano przed szturmem 3 peemy i 7 pistoletów, a także parę nożyc do cięcia drutu. Powstańcy musieli przechodzić obok bramy głównej Uniwersytetu, przy której 


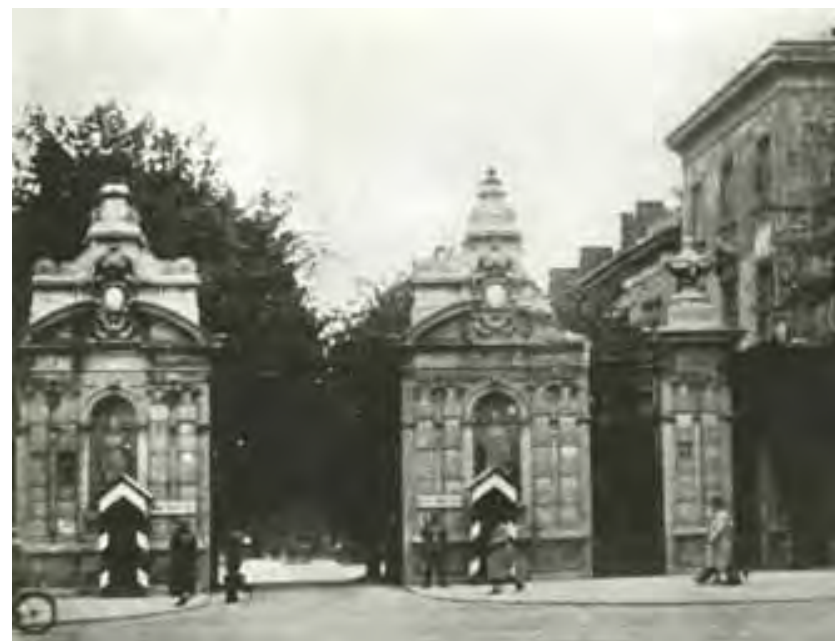

10. Brama Główna UW na kilka miesięcy przed wybuchem powstania warszawskiego

Niemcy parę miesięcy przed powstaniem wybudowali bunkier. Mimo początkowych sukcesów i zajęcia Auditorium Maximum oraz ruin Gmachu Pokuratorskiego, powstańcy musieli się wycofać. Drugi szturm nastąpił dopiero 23 VIII. Plan ataku zakładał uderzenie od Krakowskiego Przedmieścia na Bramę Główną, wspomagane uderzeniem na ul. Oboźnej. Jednocześnie z ul. Browarnej żołnierze AK mieli pozorować atak od strony skarpy, by w końcowej fazie walki faktycznie przejść do natarcia. Dwa stanowiska niemieckiego oporu przy bramie unieszkodliwiono za pomocą granatów i miotaczy ognia, nie powiódł się jednakże szturm z ul. Oboźnej. Po odparciu ataku Niemcy brutalnie potraktowali Polaków przebywających na terenie Uniwersytetu - wszystkich postawiono pod ścianą, czyniąc przygotowania do egzekucji. Po godzinnym czekaniu okupanci zreflektowali się, że polscy mieszkańcy będą im bardziej potrzebni żywi; wysłali ich do reperowania bramy i ustawiania zasieków. Trzeci i ostatni szturm nastąpił 2 IX. Dogorywało Stare Miasto i obrońcy Powiśla mogli lada dzień spodziewać się wzmożonych ataków. Aby je uprzedzić, dowództwo powstania wydało Krybarowi rozkaz szturmu na uczelnię. Grupą atakującą z budynku przy ul. Oboźnej 5 dowodził por. Zaremba (Stanisław Andrzejewski). Jego żołnierze mieli wysadzić bramę uniwersytecką, znajdującą się obok ówczesnego Wydziału Matematyczno-Przyrodniczego (dziś w tym miejscu znajduje się stołówka pracownicza), a potem, korzystając z osłony wozu bojowego „Szary Wilk”, wedrzeć się na teren uczelni. Lewym skrzydłem dowodził por. Dowgird (Władysław Szela), a celem szturmu miała być boczna brama, znajdująca się wtedy niemal na wprost dzisiejszej ulicy Karasia. 


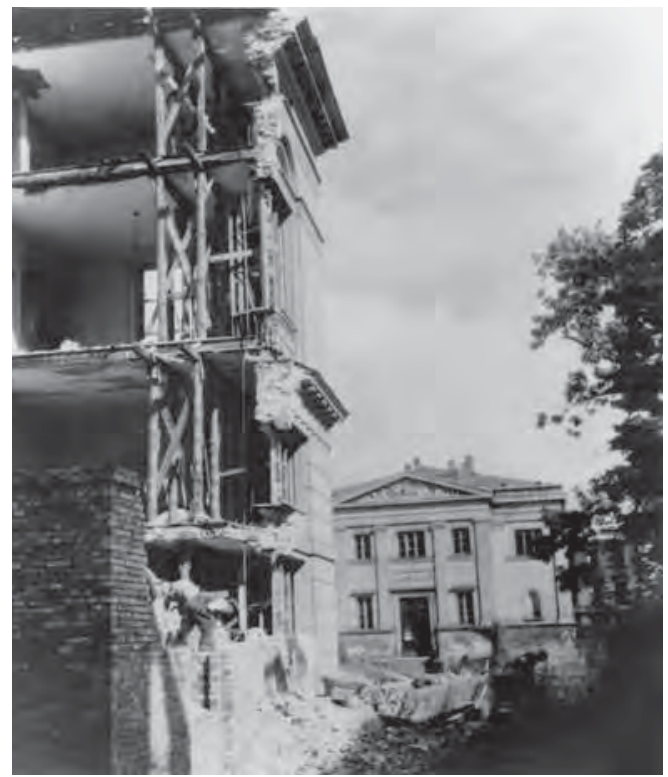

11. Szkoła Główna (obecnie Instytut Archeologii) oraz Gmach Pomuzealny, 1945 r.
Od strony zachodniej zaś, przez ruiny kamienicy przy Krakowskim Przedmieściu 18, powstańcy mieli przedostać się na teren uczelni. Także i ten atak został odparty. Następnie załogę Uniwersytetu poważnie wzmocniono i stąd m.in. wyszło decydujące natarcie na powstańcze Powiśle, które 6 IX upadło ${ }^{154}$.

W budynku Biblioteki umieszczono na początku września kompanię przestępców, którzy, przebywając tu przez kilkanaście dni, zdewastowali wnętrza. „Stoły były porozbijane, papiery z szuflad wyrzucone na podłogę. Stosy książek przygotowane w biurach do katalogowania poszły na barykady okienne, którymi cały gmach zaczęto opatrywać. Inne książki kryminaliści rozkładali i paskudzili na nie. W tym ostatnim celu wyciągali też sztychy z szaf na parterze i wielkie wydawnictwa atlasowe". Ostatnią załogą zapamiętaną przez bibliotekarzy był oddział artylerii. Jego dowódca zapowiedział wysadzenie Biblioteki i wręczył nielicznej załodze BUW nakaz opuszczenia gmachu 18 IX, do którego bibliotekarze się zastosowali ${ }^{155}$.

Układ o zaprzestaniu działań wojennych $w$ Warszawie, zawarty 2 X 1944 r., przewidywał umożliwienie przez stronę niemiecką ewakuacji „przedmiotów posiadających wartość artystyczną, kulturalną i kościelną". Jeszcze w czasie trwania walk powstańczych przygotowano w strukturach Delegatury Rządu 16 drużyn ratowniczych; 4 X powołano „komisję ochrony zagrożonego mienia kulturalnego". Wobec początkowych trudności w uzgodnieniu z Niemcami interpretacji wspomnianego Układu, podjęto akcję ewakuacyjną bez ich przyzwolenia. Tzw. akcja pruszkowska, przeprowadzona w uzgodnieniu z władzami okupacyjnymi, rozpoczęła się z początkiem listopada 1944, r., ale nie ustała też ewakuacja nieformalna. Niemcy zgodzili się na ewakuację, zastrzegając sobie prawo jej przerwania w każdej chwili, ustalili dwutygodniowy termin jej przeprowadzenia, liczbę ewakuowanych książek na 100 tys. woluminów, punkty przechowywania zbiorów na terenie Rzeszy, zagwarantowali środki transportu, zdecydowali o każdorazowym dowożeniu 
z Pruszkowa do Warszawy polskiego personelu. Akcja została zalegalizowana przez władze podziemne, które pokrywały, często za pośrednictwem Rady Głównej Opiekuńczej, związane z nią wydatki. Bilans przedsięwzięcia przekroczył założone limity, ewakuowano ok. 300 tys. woluminów, w tym ok. 85 tys. z Biblioteki Uniwersyteckiej ${ }^{156}$.

Czynności przygotowawcze do ewakuacji przeprowadzali kierownicy tzw. grup materiałowych: muzealnej, archiwalnej i bibliotecznej. Dowodzącemu całą akcją Stanisławowi Lorentzowi, który był jednocześnie kierownikiem grupy muzealnej, podlegali kierownicy pozostałych grup. Grupa biblioteczna, na której czele stał Józef Grycz, dzieliła się na 3 zespoły: Biblioteki Narodowej, Biblioteki Uniwersyteckiej z Tadeuszem Makowieckim na czele, i powstały z końcem listopada zespół Biblioteki Publicznej. Wszystkim grupom przydzielono niemieckich komisarzy. Przed przystąpieniem do akcji przygotowano spis instytucji podlegających ewakuacji, z przewidywaną liczbą środków transportu, szczęśliwie zachowany w spuściźnie uczestnika przedsięwzięcia, Jana Zachwatowicza. Na ewakuację zbiorów BUW przewidywano przeznaczenie 35 wagonów ${ }^{157}$.

Wiele było jednak w czasie tych działań niedoskonałości organizacyjnych, nie tylko po stronie niemieckiej. „Praca w niej [Bibliotece Uniwersyteckiej] posuwa się bardzo ospale, z wielką stratą czasu i grosza publicznego". Niewydajnemu tempu pracy zaradzono dopiero w styczniu, wprowadzając system pracy akordowej: „każdej dwójce wyznaczono 50 worków do zapakowania. Pomysł okazuje się doskonały: wszyscy pracują w ostrym tempie, milcząc". Na posterunku nieustająco trwali: kierownik grupy Tadeusz Makowiecki i jego zastępca Wacław Borowy oraz Stanisław Herbst i Bohdan Korzeniewski. Przystąpieniem ich do akcji pruszkowskiej kierował przede wszystkim etos polskiego inteligenta, nierzadko pracownika konspiracyjnego Uniwersytetu. Działalność ekip miała znaczący wpływ na przetrwanie budynków Biblioteki. Kilkakrotnie wkraczały do nich oddziały Brandkommando, ale wycofywały się, gdy bibliotekarze okazywali upoważnienia do prac ewakuacyjnych ${ }^{158}$.

Inicjatorem ryzykownego, obliczonego na czas powojenny przedsięwzięcia był Tadeusz Makowiecki, mianowicie - przeprowadzenia akcji zamurowania w podziemiach budynku BUW zbioru liczącego około 70 tys. woluminów, takich wydawnictw jak encyklopedie, słowniki, atlasy, teksty literackie czy historyczne. Stosując nadzwyczajne środki ostrożności, przedsięwzięcie 23 XII doprowadzono do końca. Wskutek braku rozwagi redakcji „Biuletynu Informacyjnego” akcja ta została zdemaskowana. Przypadkowi zawdzięczać należy brak reakcji ze strony 
Niemców, bowiem na łamach wspomnianego pisma opublikowano informację, iz „w piwnicy Biblioteki Uniwersyteckiej zabezpieczono około 50\% zawartości biblioteki: gros księgozbioru czytelni i wydawnictw polskich towarzystw naukowych i kolekcję podręczników uniwersyteckich"159. Z perspektywy czasu można oceniać, iż akcja pruszkowska dała efekty w postaci ocalenia na tyle znaczących fragmentów polskiego zasobu kulturalnego i naukowego, by mogły stać się podstawą jego powojennej odbudowy.

Sytuacja popowstaniowa wymagała wzmożenia wszelkich form konspiracyjnego i jawnego mecenatu oraz związanej z nim pomocy społecznej. Wyrzuceni z Warszawy ludzie zwracali się zwykle o pomoc do RGO. We współpracy z Radą, przy zaangażowaniu Włodzimierza Antoniewicza, udało się doprowadzić do utworzenia w Milanówku, gdzie przeniosło się życie Polski Podziemnej, Sekcji Pomocy dla Profesorów Wyższych Uczelni z Warszawy. Sprawozdanie z działalności Sekcji za okres od września do końca listopada 1944 r. określa całkowity poziom wydatków na kwotę 296870 zł, pochodzących m.in. z datków profesorów krakowskich oraz wpłat firm prywatnych. Zapomogi udzielone rodzinom profesorskim wyniosły 99375 zł, liczba rodzin profesorskich pozostających pod opieką Sekcji wynosiła 220 (477 osób), z czego na UW przypadały 84 , rodziny ${ }^{160}$. Po upadku powstania grona wykładowców tajnych uczelni warszawskich współorganizowały tajne komplety poza Warszawą, na podziemnym Uniwersytecie Jagiellońskim, ponadto w regionalnych oddziałach UZZ w Częstochowie, Kielcach i Jędrzejowie. Kilku profesorów znalazło schronienie w klasztorze jasnogórskim, gdzie sporządzili dokumentację techniczną sanktuarium, inni zaś podejmowali studia nad jego dziejami, np. Władysław Tomkiewicz, autor studium Architektura Jasnej Góry w XVII i XVIII wieku, opublikowanego po wojnie ${ }^{161}$.

Jesienią 1944 r., po zdobyciu Pragi przez Armię Czerwoną i Wojsko Polskie, uruchomiono w praskim szpitalu Przemienienia Pańskiego Wydział Lekarski UW. Szpital Przemienienia Pańskiego znalazł się na froncie walk o Warszawę. Jeden z pocisków zabił 3 lekarzy i 6 sióstr miłosierdzia. Podjęto wówczas decyzję o ewakuacji na Grochów do szkoły przy ul. Boremlowskiej (stąd nazwa studiów medycznych - tzw. Akademia Boremlowska), do 14 IX zajmowanej przez SS-manów. W tych warunkach dopiero w połowie października można było wznowić zorganizowaną pracę. Zaczęli się zgłaszać studenci medycyny z prośbą o zorganizowanie wykładów dla III, IV i V roku. Zdecydowano się uruchomić Wydział Lekarski i nawiązać kontakt z Resortem Zdrowia i Opieki Społecznej Polskiego Komitetu Wyzwolenia Narodowego 
w Lublinie. Resort ten odniósł się do propozycji nieprzychylnie, wskazując na niebezpieczeństwo ostrzału oraz na brak dostatecznej liczby wykwalifikowanych sił naukowych. Mimo to postanowiono rozpocząć 1 XI wykłady. W krótkim czasie liczba słuchaczy osiągnęła 150-zoo osób. Na początku lutego 1945 r. nastąpiło połączenie tymczasowej, praskiej Rady Wydziału z członkami przedpowstaniowej Rady. Duże trudności sprawiało potwierdzenie zaliczonych zajęć, gdyż większość studentów nie mogła przedstawić dowodów, tłumacząc to ich zgubieniem lub zniszczeniem $\mathrm{w}$ powstaniu, $\mathrm{w}$ obozie, $\mathrm{w}$ więzieniu lub tė̇ warunkami nauczania konspiracyjnego. Często nie było można ustalić stanu studiów na podstawie zeznań 2 wiarygodnych świadków, gdyż i tych nie sposób było znaleźć. Trudności ostatecznie zostały pokonane dzięki dostarczeniu przez prof. Orłowskiego notatek, dotyczących biegu studiów tajnego nauczania ${ }^{162}$.

Zasygnalizowany wyżej problem był, wobec zniszczenia Warszawy, jednym z największych wyzwań organizacyjnych, ale również etycznych dla środowiska uniwersyteckiego. Profesor Mazurkiewicz pisał:

Wszystkie moje spisy egzaminacyjne spaliły się wraz z biblioteką i z tą teką, w której były przechowywane. Próba jakiejś rekonstrukcji listy z pamięci byłaby, niestety, tylko jakimś fantazjowaniem z mojej strony i prędzej mógłbym sobie przypomnieć nazwiska, gdybym czytał ich listę, przez kogo innego napisaną ${ }^{163}$.

Nie dało się jednak uniknąć tego typu operacji na doświadczanej boleśnie w ciągu ostatnich miesięcy pamięci. Mieczysław Bogucki w sierpniu 1945 r. zaświadczał, że „p. Krystyna Groszkowska wysłuchała wykładów fizjologii na kompletach uniwersyteckich w Warszawie w 1944, r. Egzaminu z tego przedmiotu nie zdawała"164. W archiwum uniwersyteckim zachowały się następujące, odtworzone po 1945 r., listy: studentów Wydziału Lekarskiego, którzy rozpoczęli studia w 1943 r., mających przesłuchane wykłady i częściowo przerobione ćwiczenia; studentów, którzy zdali egzamin z anatomii w szkole Zaorskiego w lipcu 1944, r.; studentów, którzy zdali egzamin z anatomii u prof. Lotha w 1943/1944, r.; wreszcie - studentów I i II roku Wydziału Lekarskiego, studiujących od jesieni 1944 r. lub kontynuujących studia jesienią tego roku w rejonie podwarszawskim, sporządzone przez asystentkę Zakładu Anatomii Prawidłowej Hannę Szuszkiewicz. Podobne zaświadczenia na Wydziale Prawa wydawano także z uwzględnieniem oświadczeń studentów, organizacji studenckich, wykładowców, starosty kompletu (np. Wiesława Chrzanowskiego, w czasie wojny związanego z UZZ, po wojnie, do czasu aresztowania, asystenta Wydziału Prawa UW) ${ }^{165}$. 


\section{Podsumowanie}

Najważniejszymi raportami, jakie dotarły z kraju na uchodźstwo, a w których próbowano oszacować skutki wojny i okupacji, były przywoływane w niniejszym opracowaniu: Prowizoryczne zestawienie strat wojennych Państwa Polskiego sporzadzone na koniec lutego 1940 oraz Działalność władz okupacyjnych na terytorium Rzeczypospolitej za okres od 1 IX 1939 do 1 XII 1940; Straty kulturalne, pochodzące z marca 1944 r., ilustrujące zaś stan do końca roku 1943. Całość tego ostatniego raportu składała się z rozdziałów problemowych, m.in. poświęconego szkolnictwu wyższemu i nauce. Straty osobowe (bo i takie szacowano, w kategoriach kosztów ich odtworzenia) oceniono na 124,6756 ooo zł, biorąc pod uwagę: straty trwałe z powodu zwiększonej śmiertelności, zniszczenie trwałe kadry, zmniejszenie potencjału naukowego, zniszczenie zakładów, zniszczone prace naukowe, zatamowanie dopływu nowych profesorów i docentów, zmniejszenie liczby pomocniczych sił naukowych, czasową przerwę w pracy, brak dopływu ludzi z wyższym wykształceniem akademickim, wyniszczenie ludzi z wyższym

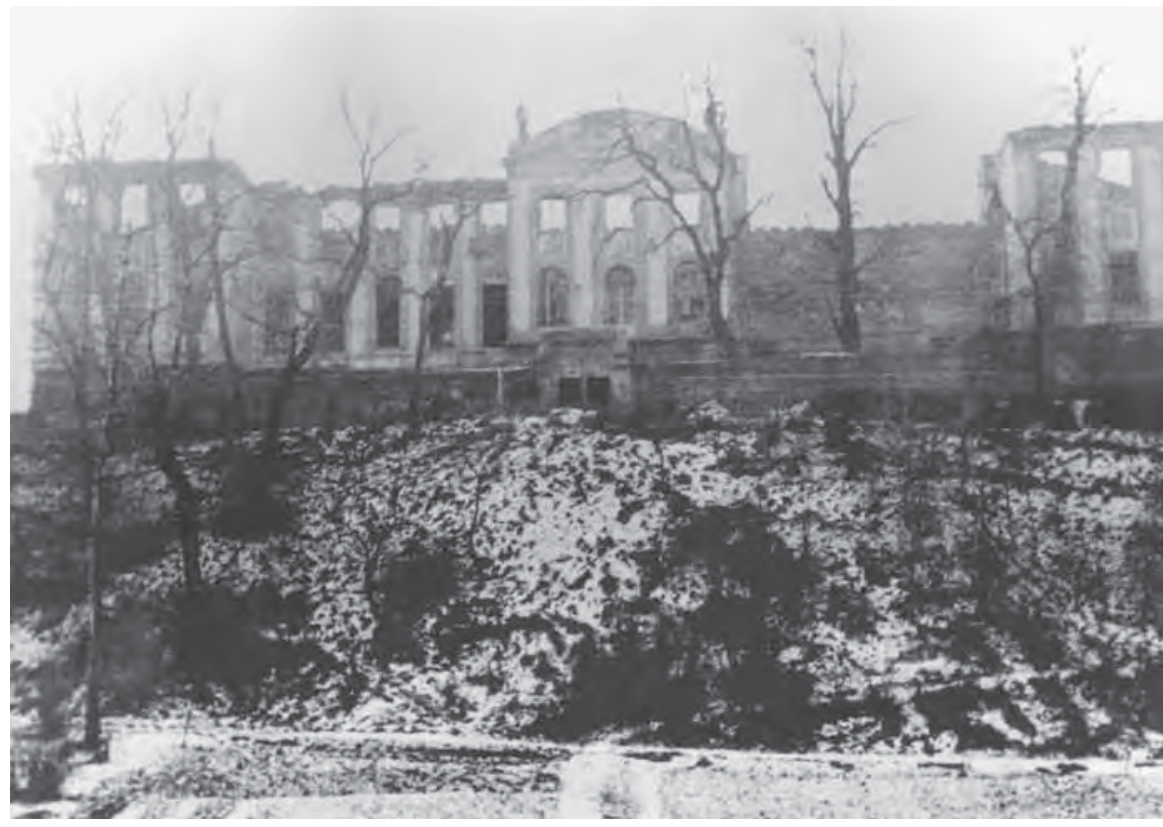

12. Pałac Kazimierzowski, 1945 r. 
wykształceniem. Straty rzeczowe szacowano na 160987 ooo zł, z tego na UW przypadło $40{ }_{16} 67000 \mathrm{z}^{166}$. W opracowaniach Biura Rewindykacji i Odszkodowań z 1947 r. straty szkól wyższych szacowano na $111 \mathrm{mln}$ zl (sprzed 1939 r.) ${ }^{167}$.

Straty materialne UW, szacowane w 194.5 r., były wyższe od szacunków okupacyjnych (wg wartości złotego przedwojennego) i wynosiły 43523579 zł, z tego: budynki (stopień zniszczenia 6o\%) - 13747775 zł, przyrządy naukowe (95\%) - 4, 676 4,12 zł, księgozbiory zakładowe (70\%) - $13880370 \mathrm{zl}$, zbiory (80\%) - $1996900 \mathrm{zl}$, pomoce naukowe (85\%) - $14,874,25 \mathrm{zl}$, niewydane prace naukowe (90\%) - $1047950 \mathrm{zł}$. Straty UW na tle strat całego szkolnictwa wyższego w Polsce wynosiły ponad 25\%. Ogromną stratę poniósł Gabinet Rycin BUW, którego zbiory graficzne były największe w przedwojennej Polsce; ubytki oceniono na $45-62 \%$. Przed wybuchem wojny księgozbiór Instytutu Historycznego UW liczył ok. 12 tys. tomów; wojna pochłonęła połowę zasobu. Spłonęło we wrześniu 1939 r. Archiwum Oświecenia Publicznego, przechowujące źródła do dziejów szkolnictwa i oświaty w Królestwie Kongresowym; uratowano ok. $2 \%$ zbiorów ${ }^{168}$.

Jeszcze we wrześniu 1939 r. spalił się od bomb Pałac Kazimierzowski, Auditorium Maximum, Gmach Pomuzealny został silnie uszkodzony. Pozostałe budynki ocalały, ale były bardzo zdewastowane. Uległo zniszczeniu Theologicum przy ul. Traugutta, Pałac Staszica z oficynami mieszczącymi zakłady uniwersyteckie, Anatomicum przy ul. Chałubińskiego, gmachy przy ul. Oczki, klinika psychiatryczna przy ul. Konwiktorskiej, Obserwatorium Astronomiczne, częściowo gmach Farmacji przy ul. Przemysłowej. Zniszczono domy profesorskie przy ul. Brzozowej 12 i 14, oraz przy ul. Nowy Zjazd $5^{169}$.

Odwołując się do przywoływanych szacunków strat osobowych, przyjąć należy, iż wskutek działań wojennych i okupacji zginęło $37,5 \%$ osób legitymujących się przedwojennym wyższym wykształceniem, podczas gdy dla całej ludności straty wynosiły $22,2 \%$. Zmarło tragicznie, bądź wskutek trudnych warunków życiowych, ok. $38 \%$ profesorów i docentów oraz ok. $32,6 \%$ adiunktów i asystentów. Tak wysokich strat nie poniósł żaden z okupowanych krajów. Straty warszawskiego środowiska akademickiego wynosiły w odniesieniu do strat całkowitych odpowiednio: profesorowie - 224 (UW - 82), docenci - 91 (39), adiunkci - 25 (11), asystenci - 184, (81), wykładowcy - 59 (43), lektorzy, bibliotekarze i inni pomocniczy pracownicy naukowi $-5^{8}(20)^{170}$. Straty osobowe UW oszacowano ogółem na 191 osób: Wydziały Teologiczne - 12, Prawa - 14, Lekarski - 4,2, Humanistyczny - 37, Matematyczno-Przyrodniczy - 32, Farmaceutyczny - 9, Weterynaryjny - 6, BUW - 10, 
administracja - 29. Zginęło również ok. 15\% studentów studiujących na konspiracyjnym Uniwersytecie ${ }^{171}$.

Straty wojenne mają zawsze oblicze konkretnych ludzi; Majer Bałaban, wyczerpany na skutek ciężkich warunków codziennego bytowania, zmarł 1 I 1943 r. w getcie. Łucja Charewiczowa, aresztowana 14/15 VII 1943 r., więziona na Pawiaku, 4, X 1943 r. wywieziona do Auschwitz, zmarła na tyfus plamisty 17 XII tego samego roku. Józef Grzybowski wykładał anatomię topograficzną i chirurgię operacyjną na UW i UZZ, został zastrzelony 5 VIII 1944, r. w Szpitalu Wolskim podczas jego ewakuacji przez Niemców. Marceli Handelsman został 14. VII 1944 r. przez „nieznanych sprawców” zadenuncjowany i po śledztwie wysłany do obozu koncentracyjnego Dora-Nordhausen, gdzie zmarł. Maria Koczwara, w konspiracji od października 1939 r., pełniła funkcję oficera do zadań specjalnych szefa Oddziału Organizacyjnego KG SZP-ZWZ-AK płk Antoniego Sanojcy; wraz z mężem Marianem organizowała tajne nauczanie uniwersyteckie, poległa 9 IX 1944 r. w powstaniu. Zofia Halina Krassowska w 194,2 r. ukończyła szkołę położnych, studiując równiė̇ medycynę na UW lub UZZ, sanitariuszka w grupach szturmowych Szarych Szeregów, od lutego 1944, r. dowódca plutonu kobiet „Oleńka” batalionu „Zośka”, pierwszego dnia powstania ciężko ranna, zmarła w Szpitalu Wolskim 6 VIII 1944, r. Florentyna Danuta Krzeszewska, we wrześniu 1939 r. siostra PCK w szpitalu polowym obok kampusu uniwersyteckiego, uczestniczyła w ratowaniu z pożaru zbiorów BUW, ranna, kontynuowała studia na tajnych kompletach medycznych, w powstaniu siostra PCK w Szpitalu Maltańskim, poległa podczas nalotu 4, IX 1944 r. Mieczysław Milbrandt zginął jako żołnierz AK podczas powstania. Halina Nieniewska, jedna z inicjatorek zorganizowanych jesienią 1940 r. kompletów uniwersyteckich, po raz pierwszy aresztowana 17 VII 194,0 r. z grupą nauczycieli i uczennicami w czasie tajnej matury w Liceum im. Królowej Jadwigi, więziona na Pawiaku, zwolniona, nie zaniechała konspiracji, powtórnie aresztowana 28 IV 194,2 r., zamordowana podczas przesłuchania, prawdopodobnie 22 V. Ewa Pohoska - córka Jana, wiceprezydenta Warszawy, straconego 20/21 VI 1940 r. w Palmirach, i Hanny z Rzepeckich, docent historii UW a zarazem uczestniczki tajnego nauczania - członkini konspiracyjnej grupy skupiającej się wokół pisma „Płomienie”, współzałożycielka pisma "Droga”, łączniczka szefa BIP KG ZWZ-AK, 5 I 1944, r. aresztowana wraz ze słuchaczami tajnego kompletu socjologii oraz rodzicami Hanny Czaki w ich mieszkaniu, gdy przyszła zawiadomić o zatrzymaniu ich córki przez gestapo, osadzona na Pawiaku, rozstrzelana w ruinach getta 11 II 1944, r.; gestapo 
aresztowało wówczas 10 studentów socjologii UZZ wraz z wykładowcą dr Władysławem Okińskim, który zginął 19 I wraz z częścią aresztowanych studentów. Wysiedlony do GG prof. Uniwersytetu Poznańskiego Franciszek Raszeja zamordowany został 2 VII 194,2 r., kiedy za zgodą władz okupacyjnych uczestniczył w konsylium lekarskim u mieszkającego w getcie antykwariusza Abe Gutnajera. Ewa Rybicka-Goryńska 12 XI 1943 r. na skutek donosu została aresztowana w mieszkaniu przy ul. Tynieckiej razem z mężem, z pochodzenia Żydem, ojcem i matką męża Marią Goryńską; wszyscy zostali rozstrzelani w egzekucji publicznej 24 XI lub w grudniu 1943 r. Radomiła Śląska-Piątkowska, żona Wiesława Piątkowskiego (oboje byli studentami historii), który w styczniu 19411 r., w miesiąc po ślubie, został aresztowany i wywieziony do Auschwitz, gdzie zmarł; na początku okupacji pracowała w warszawskim Archiwum Miejskim i kontynuowała studia na UW, prowadziła tajne nauczanie historii w Gimnazjum im. Juliusza Słowackiego, łączniczka w IV Odcinku „Wachlarza”, pisywała również do prasy konspiracyjnej; aresztowana 7/8 X 194,2 r., torturowana, prawdopodobnie zginęła samobójczą śmiercią na Pawiaku. Ludwik Widerszal zginął 13 VI 1944, r.; wykonawcami „wyroku” byli bojówkarze, działający na zlecenie nierozpoznanych do końca kręgów polskiej konspiracji; zostali oni w lipcu 1944 r. ukarani z wyroku sądów podziemnych rozstrzelaniem. Helena Wolff otrzymała dyplom lekarza w 1940 r. na tajnych kompletach, staż odbyła w II Klinice Chorób Wewnętrznych, lekarka Kliniki Położniczej Szpitala Wolskiego i Instytutu Radowego, od 194,2 r. członkini PPR i GL; 30 X 1944, r., w czasie okrążenia grupy partyzantów w Lasach Starachowickich, ciężko ranna, wzięta do niewoli, zmarła $3^{1} \mathrm{X}^{172}$.

Ograniczenie społecznej roli nauki i nauczania akademickiego było jednym z celów niemieckiej polityki w GG. Biorąc pod uwagę skalę poniesionych strat, w znacznym stopniu osiągniętym. Bowiem nawet największe zaangażowanie w działalność konspiracyjną nie było w stanie wyrównać standardów właściwych czasom pokoju. Z drugiej jednak strony aktywność polskich środowisk naukowych w zakresie badań i edukacji pozwoliła na zachowanie na rzecz powojennego odrodzenia struktur uniwersyteckich tego, co dla nauki najważniejsze: elementów warsztatów badawczych, a przede wszystkim - ludzi.

„Odetchnąłem, mijając pusty bunkier przy bramie uniwersytetu” pisał zimą 194.5 r. Tadeusz Manteuffel - „Wszystko wyglądało tak samo jak przed paru dniami, kiedyśmy tu byli pod strażą żandarmów"173. 
W końcu stycznia 1945 r. teren uniwersytecki przy Krakowskim Przedmieściu robił wrażenie niedawno opuszczonego placu boju. Podwórze było poprzecinane rowami strzeleckimi, w których poniewierały się szczątki oporządzenia żołnierskiego i mebli wywleczonych z okolicznych domów. Z wszystkich gmachów uniwersyteckich połowa uległa zniszczeniu już we wrześniu 1939. Pozostała część, pozbawiona szyb i w większym lub mniejszym stopniu uszkodzona, była częściowo zajęta na kwatery oddziałów Armii Czerwonej. Jedynie w podziemiach Biblioteki Uniwersyteckiej przebywała kilkuosobowa ekipa, zabezpieczająca zbiory. Tam więc zgłaszali się przybywający z różnych stron kraju pracownicy uniwersyteccy ${ }^{174}$. 


\section{Aneks 1: Kadra konspiracyjnego UW i jej straty ${ }^{175}$}

Wydziały Teologiczne:

ks. prof. Józef Archutowski († 31 VIII 1944 r.);

ks. prof. A. Borowski;

ks. prof. Piotr Chojnacki, dziekan WTK, także WH, UZZ, KUL;

ks. prof. Jan Czuj;

ks. doc. E. Dąbrowski;

ks. doc. Mieczysław Dybowski, także WL, WH, UZZ;

ks. prof. Ignacy Grabowski, dziekan(?) WTK;

ks. prof. Z. Kozubski;

ks. prof. W. Kwiatkowski;

ks. doc. W. Rosłan;

ks. prof. Jan Stawarczyk († 26 III 1944, r.);

ks. prof. A. Suess, teologia ewangelicka;

ks. prof. Jan Szeruda, dziekan WTE.

Wydział Prawa:

prof. Cezary Berezowski, także WTK, UZZ;

prof. Tadeusz Bigo, także UZZ;

prof. Stanisław Borowski, także UZZ;

dr asystent Karol Brzoska, także UZZ;

mec. Chałaciński;

prof. Józef Czekalski, także Studium Slawistyczne (Stud. Slaw.), $\mathrm{UZZ}$;

mec. Jerzy Jodłowski;

prof. Stanisław Kasznica, także UZZ;

doc. Władysław Kosieradzki, także UZZ († po 4/5 VIII 1944, r.);

prof. Włodzimierz Kozubski, także UZZ;

dr Kazimierz Libera, intendent, kierownik biura uniwersyteckiego (jawnego), także UZZ;

sędzia Wacław Miszewski, także UZZ;

zca prof. Jan Namitkiewicz, także UZZ;

doc. Stanisław Ossowski, także WH, UZZ;

dr Maria Petz;

doc. Henryk Piętka, także UZZ;

prof. Józef Rafacz, dziekan, kurator Koła Prawników, także UZZ

(† 3 VIII 1944, r.);

prof. Roman Rybarski, dziekan, także UZZ († 6 III 194,2 r.); 
mec. Bohdan Sałaciński, także UZZ;

doc. Jakub Teodor Sawicki, także UJ, KUL;

doc. Witold Sawicki, także UZZ;

prof. Stefan Szulc, także UZZ, SGH;

dr Tadeusz Szymański, także UZZ († powstanie);

prof. Stanisław Śliwiński, także UZZ;

st. asyst. Zygmunt Zagórowski, sekretariat uniwersytecki (jawny), także UZZ († powstanie);

prof. Stefan Zaleski, prodziekan, także WTK, UZZ.

Wydział Humanistyczny:

doc. Stanisław Adamczewski, sekcja polonistyczna;

prof. Włodzimierz Antoniewicz, sekcja historyczna, także Stud. Slaw.;

prof. Stefan Baley;

prof. Zygmunt Batowski († 1 IX 194, r.);

dr Jerzy Bąbała, Stud. Slaw. († Majdanek 1943);

dr Maria Bernhard, sekcja filologii klasycznej;

prof. Wacław Borowy, sekcja polonistyczna;

dr Janina Budkiewicz, sekcja pedagogiczna;

prof. Jan Bystroń, sekcje: polonistyczna i pedagogiczna;

doc. Eucja Charewicz, sekcja historyczna († Auschwitz 1943);

prof. Kazimierz Chodynicki, także UZZ († 14, V 1942 r.);

prof. Witold Doroszewski, sekcja polonistyczna;

Witold Dynowski, sekcja polonistyczna;

prof. Józef Feldman (pseud. Sokołowski), sekcja historyczna;

dr Henryk Friedrich, sekcja polonistyczna († 15 IX 1944, r.);

Stanisław Furmanik, sekcja polonistyczna;

dr Eugeniusz Geblewicz, sekcja: pedagogiczna, filozoficzna;

dr Ludwik Goryński, sekcja pedagogiczna († 23 XI lub 2 XII 1943 r.);

dr Tadeusz Stanisław Grabowski, Stud. Slaw., także UJ, UZZ;

prof. Marceli Handelsman, sekcja historyczna († 20 III 1945 r.);

Henryk Hiż, sekcja filozoficzna;

doc. Witold Jabłoński;

Alicja Kadler, sekcja filozoficzna(?);

dr Jadwiga Karwasińska, sekcja historyczna;

prof. Stanisław Kętrzyński, sekcja historyczna;

Apolonia Koperska (siostra Tomea), sekcja pedagogiczna (?) († $3^{1}$ VIII

1944 r.);

prof. Tadeusz Kotarbiński, sekcje: historyczna i filozoficzna;

Jerzy Kram, sekcja polonistyczna;

dr Jerzy Kreczmar, sekcje: polonistyczna, historyczna; 
prof. Adam Krokiewicz, sekcja filozoficzna(?);

prof. Julian Krzyżanowski, kierownik sekcji polonistycznej, także

Stud. Slaw., UJ;

doc. Stefan M. Kuczyński, sekcja historyczna;

prof. Kazimierz Feliks Kumaniecki, sekcja filologii klasycznej, także UJ;

Joanna Kunicka, sekcja pedagogiczna († Auschwitz 1943);

dr Stanisław Lorentz, sekcja historii sztuki;

doc. Tadeusz Makowiecki, sekcja polonistyczna, także BUW;

doc. Tadeusz Manteuffel, kierownik sekcji historycznej;

dr Zdana Matuszewicz, kierownik sekcji filologii romańskiej, także

UZZ;

dr Tadeusz Mikulski, sekcja polonistyczna, także UZZ;

doc. Mieczysław Milbrandt, sekcja filozoficzna(?), także UZZ († 8 lub

9 VIII 1944, r.);

doc. Wanda Moszczeńska (?);

prof. Henryk Mościcki, sekcja polonistyczna;

prof. Bogdan Nawroczyński, sekcja pedagogiczna, dziekan;

doc. Maria Ossowska, kierownik sekcji filozoficznej, sekcje: polonistyczna, historyczna;

dr Włodzimierz Pietrzak, Stud. Slaw. († powstanie);

dr Leon Płoszewski, Stud. Slaw.;

doc. Hanna Pohoska, sekcja pedagogiczna, także UZZ;

prof. Stanisław Poniatowski ( + KZ Flossenburg-Litomierzyce

7 I 1945 r.);

Halina Powiadowska, sekcja filozoficzna; dr Adam Próchnik (?);

Ewa Rybicka-Goryńska, sekcja pedagogiczna († 24 XI 1943 r. lub

w grudniu 1943 r.);

ks. Jan Salamucha, sekcja filozoficzna (?);

doc. Stanisław Sawicki, sekcja polonistyczna († powstanie);

dr Jerzy Sienkiewicz, sekcja historii sztuki;

dr Stanisław Skorupka, sekcja polonistyczna;

prof. Stanisław Słoński, sekcja polonistyczna, także Stud. Slaw.;

prof. Jerzy Słupecki, sekcja filozoficzna(?);

dr Bolesław Sobociński, sekcja filozoficzna (?);

prof. Bogdan Suchodolski, sekcje: polonistyczna, pedagogiczna;

Dina Sztejnbarg (pseud. Janina Kamińska), sekcja filozoficzna;

doc. Zofia Szmydt, sekcja polonistyczna;

prof. Władysław Tatarkiewicz (pseud. Łukowski), sekcja filozoficzna, także WTK, UZZ;

doc. Władysław Tomkiewicz, sekcja: historyczna, historii sztuki, także Stud. Slaw., UZZ; 
dr Maria Twarowska, sekcja historii sztuki;

prof. Kazimierz Tymieniecki (pseud. Zaremba), sekcja historyczna, także WP UZZ;

doc. Michał Walicki, kierownik sekcji historii sztuki, sekcja historyczna; prof. Stanisław Wędkiewicz, sekcja filologii romańskiej, dziekan;

doc. Ludwik Widerszal, sekcja historyczna († 13 VI 1944, r.);

prof. Stefan Wierczyński, Stud. Slaw., także UZZ, UJ;

doc. Stanisław Antoni Więckowski, sekcja historyczna, także WWP (?)

(† Auschwitz 31 XII 1942 r.);

dr Tadeusz Wiwatowski, sekcja polonistyczna († powstanie);

doc. Janusz Woliński, sekcja historyczna, także Stud. Slaw., UZZ;

dr Jan Zachwatowicz, sekcja historii sztuki, także PW;

dr Zawistowicz-Kintopf, sekcja historyczna(?).

Wydział Matematyczno-Przyrodniczy:

dr Ignacy Adamczewski, sekcja fizyczna, także Wydział Lekarski (WL); prof. Osman Achmatowicz, także WL, Wydział Farmaceutyczny

(WFarm.), SGGW, UZZ;

Stanisław Alkiewicz, Akademia Stomatologiczna (Akad. Stomat.);

prof. Kazimierz Bassalik, także WFarm;

prof. Czesław Białobrzeski;

prof. Jan Blaton, także UZZ;

Jan Bogdanowicz, Akad. Stomat., także AWF;

prof. Karol Borsuk, kierownik sekcji matematycznej;

prof. Witold Cybulski, kierownik Akad. Stomat., także WMP;

dr Janina Dąbrowska, Akad. Stomat., także WL, UZZ;

dr Stanisław Dłużewski, Akad. Stomat.;

prof. Alicja Dorabialska, (współ)kierownik sekcji chemicznej;

doc. Marian Józef Gieysztor, także WL, zca szefa Kierownictwa Walki

Cywilnej;

doc. Henryk Gnoiński, Akad. Stomat.;

dr Tadeusz Gorczyński, sekcja biologiczna, także WFarm., SGGW;

dr Romuald Gumiński, sekcja geograficzna;

prof. Józef Heller, Akad. Stomat., także WL(?), WFarm.;

inż. Jezierski, sekcja biologiczna;

dr Roman Kobendza, także WFarm., SGGW, UJ;

doc. Marian Koczwara, organizator studiów na WMP, WFarm., WL;

dr Bronisława Konopacka, Akad. Stomat., także UZZ;

dr Stanisław Kroszczyński, Akad. Stomat.;

dr Piotr Kubikowski, Akad. Stomat., także WL(?), WFarm., UZZ;

dr Kulczycki, sekcja biologiczna; 
dr Kulczyński, sekcja: fizyczna i chemiczna;

prof. Kazimierz Kuratowski, sekcja: fizyczna i matematyczna;

prof. Tadeusz Kurkiewicz, Akad. Stomat., także UZZ;

prof. Wiktor Lampe;

Jadwiga Lemańska, Akad. Stomat.;

prof. Stanisław Lencewicz, kierownik sekcji geograficznej († 1 IX

1944, r.);

dr Jerzy Leśkiewicz, także WL, WFarm. († 12 VIII 1944 r.);

dr Stanisław Lewiński, Akad. Stomat., także WL, UZZ;

doc. Aleksander Ławrynowicz, Akad. Stomat., także UZZ;

prof. Jan Łukasiewicz, sekcja matematyczna;

prof. Roman Małachowski, także WL, WFarm., UZZ († 5 VIII 194.4, r.);

prof. Stefan Mazurkiewicz, sekcje: fizyczna i matematyczna († 19 VI 1945 r.);

dr Mączyński;

dr Halina Milicer-Grużewska, sekcje: chemiczna i matematyczna;

dr Andrzej Mostowicz, sekcja matematyczna;

dr Andrzej Mostowski, sekcja matematyczna;

inż. Niewiadomski, sekcja chemiczna;

dr Edward Otto, sekcja matematyczna;

prof. Leon Julian Józef Padlewski, także UZZ († 8 IX 1943 r.);

prof. Józef Patkowski, sekcja fizyczna, także SGGW († 21 VIII 194,2 r.);

prof. Stefan Pieńkowski, kierownik sekcji fizycznej, rektor, także WL,

WFarm.;

doc. Stanisław Pietkiewicz, sekcja geograficzna;

doc. Stanisław Pleśniewicz, sekcja fizyczna († 12 VII 1943 r.);

doc. Jerzy Pniewski, także UZZ;

T. Pniewski, sekcja biologiczna;

prof. Witold Pogorzelski, także PW, UZZ;

prof. Stanisław Poniatowski, sekcja geograficzna;

dr Aleksander Pruszczyński, Akad. Stomat., także WL, UZZ;

prof. Wacław Aleksander Remigiusz Roszkowski, kierownik sekcji

biologicznej, także WL, WFarm., SGGW († 3 VIII 1944, r.);

prof. Jan Samsonowicz, sekcja geograficzna, także SGGW;

prof. Wacław Sierpiński, kierownik sekcji matematycznej;

dr J. Skowroński;

prof. Franciszek Skupieński, także WFarm., UZZ;

doc. Leonard Sosnowski, sekcja: fizyczna i chemiczna, także UZZ;

prof. Stefan Straszewicz, sekcja chemiczna, także PW;

doc. Zbigniew Sujkowski, sekcja geograficzna;

prof. L. Szperl, sekcja chemiczna; 
ks. dr Józef Szuleta, także WFarm., UZZ;

dr Włodzimierz Ścisłowski, sekcja: fizyczna i chemiczna, także UZZ, PW;

doc. M. Świderek, sekcja chemiczna;

dr Kazimierz Tarwid, także WFarm., UJ;

doc. Zenon Waraszkiewicz, sekcje: fizyczna, chemiczna, biologiczna, także UZZ, PW;

dr Maria Wesołowska, Akad. Stomat., także WL(?);

dr Tadeusz Wiśniewski, sekcja biologiczna, także WFarm., WL († 29 IX 1943 r. lub 2 XII 1943 r.);

Aniela Wolska;

prof. Józef Zawadzki, kierownik sekcji chemicznej;

dr Mirosław Zieliński, sekcja biologiczna († powstanie);

dr Jan Żabiński, Akad. Stomat., także WMP.

Wydział Lekarski:

doc. Jan Adamski, także UZZ;

Maria Afek, Zakład Anatomii Patologicznej;

Aleksandrow, II Klinika Chorób Wewnętrznych;

dr S. Altenberger, Klinika Okulistyczna;

dr Emil Apfelbaum, getto;

Jan Barcikowski, Zakład Anatomii Prawidłowej;

dr Tadeusz Bartoszek, ordynator Kliniki Diagnostycznej w Szpitalu

Przemienienia Pańskiego, także UZZ († 27 IX 1944, r.);

prof. K. Białaszewicz, Zakład Chemii Fizjologicznej;

Andrzej Biernacki, II Klinika Chorób Wewnętrznych;

dr Eugeniusz Błeszyński, Klinika Otolaryngologiczna;

doc. Mieczysław Bogucki;

Bolechowski, II Klinika Chorób Wewnętrznych;

doc. Jan Bowkiewicz;

dr Zofia Bratkowska;

dr Edmund Bratkowski, I Klinika Chorób Wewnętrznych;

doc. Tadeusz Butkiewicz;

prof. Mieczysław Centnerszwer, getto († 27 III 1944, r.);

S. Cepelewicz, Zakład Chemii Fizjologicznej;

dr Stefania Chodkowska-Laskowska, Zakład Anatomii Patologicznej, także UZZ;

dr T. Chrapowicki, Zakład Chemii Fizjologicznej;

Tadeusz Ciombor, Oddział Chirurgiczny Szpitala Dzieciątka Jezus, także UZZ († powstanie);

dr Izabela Cwojdzińska-Gądzikiewicz, także WFarm.;

doc. Czarnocki; 
prof. Franciszek Czubalski, także UZZ, kierownik naukowy tzw. szkoły Zaorskiego;

prof. Adam Czyżewicz, Klinika Położnicza i Ginekologiczna, także UZZ; doc. Antoni Dmochowski, także UZZ;

prof. Antoni Dobrzański, Klinika Chorób Uszu, Nosa i Krtani, także

UZZ;

A. Domaszewicz;

dr Anatol Dorożenko, Klinika Psychiatryczna;

dr Ryszard Dreszer, Klinika Psychiatryczna;

dr Helena Dreszerowa, Klinika Psychiatryczna;

dr Tatiana Dziewanowska, I Klinika Chorób Wewnętrznych;

doc. Aleksander Elkner, także UZZ († Auschwitz 1943/1944, r.);

prof. Włodzimierz Filiński;

dr Arkadiusz Flatau;

dr Fliederbaum, getto;

dr Jerzy Galera(?), także WMP;

prof. Antoni Gałecki, także WFarm., UZZ;

prof. Witold Gądzikiewicz (pseud. Śliwiński, Wiśniewski), dziekan,

także WFarm., UZZ;

płk dr Gilewicz, Zakład Anatomii Prawidłowej;

prof. Glatzl;

prof. Stanisław Glixelli, także WMP, UZZ;

prof. Zdzisław Gorecki, I Klinika Chorób Wewnętrznych († 13 IX 1944 r.);

dr Jan Górski;

Józef Grass, Zakład Anatomii Prawidłowej;

dr Józef Wacław Grott, ordynator Klinika Diagnostycznej w Szpitalu

Św. Ducha, także UZZ;

prof. Józef Grzybowski, także UZZ († 5 VIII 1944, r.);

prof. Marian Grzybowski, II Klinika Chorób Wewnętrznych, dziekan;

prof. Wiktor Grzywo-Dąbrowski, także WTK;

dr W. Guttner, Klinika Okulistyczna;

dr Walenty Hartwig, Klinika Chorób Wewnętrznych, także UZZ;

prof. Ludwik Hirszfeld, kierownik kompletów medycznych w getcie;

Antoni Horst, także UZZ;

doc. Stanisław Hrom, także UZZ († 13 V 1943 r.);

dr Izdebska;

dr Wawrzyniec Jacek, także WFarm., UZZ;

doc. Tadeusz Jaczewski, także WMP, WFarm.;

dr Waleria Janczak, także WFarm., WMP, UZZ;

dr Halina Jankowska, Klinika Psychiatryczna († powstanie); 
doc. Jerzy Jarocki, także WFarm., UZZ;

doc. Edward Józefowicz, także WFarm., UZZ, UZZ;

dr Janina Juraszyńska;

Leopold Jurkiewicz;

F. Justman, Zakład Chemii Fizjologicznej;

dr Mieczysław Kaczyński, Klinika Psychiatryczna;

W. Kaczyński;

Jan Kałuża, Zakład Anatomii Prawidłowej;

doc. Władysław Kapuściński, także UZZ;

dr Leon Klimowicz, także UZZ;

doc. Jan Klukowski, także UZZ († Auschwitz, marzec 194.5 r.);

Stanisław Kmita, Klinika Otolaryngologiczna;

Kodejszko, II Klinika Chorób Wewnętrznych;

prof. Stefan Witysław Kopeć, kierownik naukowy w tzw. szkole

Zaorskiego († 11 III 19411 r.);

dr Konrad Kosieradzki, także UZZ;

dr Zbigniew Kostuch, Klinika Otolaryngologiczna;

dr Franciszek Krajewski, także UZZ;

prof. Alfons Krauze, także WMP, WFarm., UZZ;

doc. Krotowski;

Maria Krzywicka, Zakład Anatomii Patologicznej;

Krzywicki, II Klinika Chorób Wewnętrznych;

dr Adam Kwaskowski;

prof. Hilary Lachs, getto;

Maurycy Landesman, getto $(†)$;

dr Laszkiewicz, II Klinika Chorób Wewnętrznych;

J. Lauber;

prof. Edward Loth, także UZZ († 15 IX 1944, r.);

doc. Aleksander Ławrynowicz, także UZZ († 8 VIII 1944, r.);

dr Mikołaj Łącki;

Wanda Helena Łążyńska († 29 VIII 1944, r.);

Izabela Jadwiga Łopuska, także UZZ, Oddział Chirurgiczny Szpitala

Dzieciątka Jezus († 26 lub zo VII 1944, r.);

dr Łuczyński;

dr Zdzisław Macierewicz;

Jan Majewski, także UZZ;

doc. Stanisław Mańczarski(?), I Klinika Chorób Wewnętrznych;

Zofia Maliszewska, także UZZ;

dr Władysław Marat, także UZZ;

Bolesław Marcinek, także UZZ;

dr Wacław Markert, II Klinika Chorób Wewnętrznych; 
prof. Jan Mazurkiewicz, Klinika Psychiatryczna, także UZZ;

J.W. Meduski, Zakład Chemii Fizjologicznej;

prof. W.H. Melanowski, Klinika Okulistyczna, także UZZ;

doc. Zdzisław Michalski, Klinika Terapeutyczna Chorób Wewnętrznych, także UZZ;

dr Zofia Migdalska, I Klinika Chorób Wewnętrznych;

Maria Wanda Mioduszewska († 5 VIII 194, r.);

dr Janina Misiewicz, ordynator Kliniki Diagnostycznej w Szpitalu Wolskim, także UZZ;

dr Leokadia Młynarczyk, także UZZ;

prof. Jerzy Leopold Modrakowski, także WFarm.(?), UZZ († 14, VI 1945 r.);

Stanisław Morkowski;

doc. J. Mossakowski;

Antoni Motz, Oddział Chirurgiczny Szpitala Dzieciątka Jezus († 1940 r.); dr Stella Niemierko, Zakład Chemii Fizjologicznej;

dr Włodzimierz Niemierko, także WFarm., WMP;

dr Witold Niepołomski, Zakład Anatomii Patologicznej;

prof. Roman Franciszek Henryk Nitsch, także Akad. Stomat. († 29 III 1943 r.);

prof. Opalski;

prof. Kazimierz Opoczyński, także UZZ;

dr Tadeusz Orłowski, także UZZ;

prof. Witold Orłowski, Klinika Terapeutyczna Chorób Wewnętrznych, także UZZ;

prof. W. Ostrowski;

prof. Leon Padlewski, także UZZ;

dr Marian Paleczek;

prof. Ludwik Paszkiewicz, Zakład Anatomii Patologicznej, także UZZ;

doc. Cezary Pawłowski, także WMP;

dr Zygmunt Pękała, Zakład Anatomii Prawidłowej;

dr Józef Maria Piasecki, dyr. Szpitala Wolskiego († 5 VIII 1944, r.);

Pokrzewiński, II Klinika Chorób Wewnętrznych;

dr Jan Pruszczyński, Szpital św. Stanisława;

doc. Feliks Przesmycki, także WFarm., UZZ;

prof. Stanisław Jan Przyłęcki († 5 VIII 1944, r.);

prof. Zygmunt Radliński († 31 XII 19411 r.);

dr Stanisława Raszeja;

doc. Jan Roguski, Klinika Chorób Wewnętrznych, także UZZ;

dr Roliński, I Klinika Chorób Wewnętrznych;

Witold Rudowski, także UZZ; 
doc. Jerzy Rutkowski, kier. Kliniki Chirurgicznej, także UZZ;

Henryk Rybowski, także UZZ;

Rydygier, II Klinika Chorób Wewnętrznych;

prof. Mściwoj Semerau-Siemianowski, Klinika Chorób Wewnętrznych

w Szpitalu św. Łazarza, także UZZ;

dr Serafin;

dr Kazimierz Skibniewski, II Klinika Chorób Wewnętrznych, także UZZ ( $†$ w powstaniu lub 12 II 1943 r.);

doc. Piotr Wacław Słonimski, także UZZ († 2 IX 1944, r.);

dr Apolonia Sluskowska-Demantowa;

doc. Janusz Sobański, kierownik Kliniki Okulistycznej, także UZZ;

doc. Andrzej Sołtan, także WMP, UZZ;

doc. Stankiewicz;

dr M. Stefanowski;

dr Józef Stein, getto $(\dagger)$;

doc. Władysław Sterling, getto († 1943 r.);

Kazimierz Szczepański, także UZZ;

dr Aleksander Szczygieł;

prof. Władysław Szenajch, ordynator Szpitala Dziecięcego im. Karola i Marii;

dr Władysław Szreder, I Klinika Chorób Wewnętrznych;

dr Ludwik Sztabholc, getto;

dr Hanna Szuszkiewicz, Zakład Anatomii Prawidłowej, także $\mathrm{UZZ}$;

dr Jan Szymański, Klinika Otolaryngologiczna;

dr Jan Świderski(?);

Aleksander Świszcz, także UZZ;

doc. Witold Tomassi, także WMP, PW;

dr Maria Trenkner, także WFarm.;

dr Trojanowski, II Klinika Chorób Wewnętrznych;

dr Trzaskowski, II Klinika Chorób Wewnętrznych;

Marian Tulczyński, także UZZ;

Venulet;

dr Teodor Vieweger, także WWP;

dr Stanisław Wąsowicz, ordynator Klinika Diagnostycznej w Szpitalu Św. Ducha, także UZZ;

Andrzej Wejroch, Oddział Chirurgiczny Szpitala Dzieciątka Jezus († 12 XI 1943 r.);

Jan Weremowicz, także UZZ;

dr Piotr Wierzchowski, Zakład Chemii Fizjologicznej;

prof. Jan Wilczyński, także UZZ; 
Edmund Wojciechowski;

dr S. Wojciechowski;

dr Bolesław Wojciechowski, Zakład Anatomii Prawidłowej;

dr Zbigniew Wojciechowski, także UZZ;

prof. Tadeusz Wolski;

Helena Wolff, Klinika Położnicza Szpitala Wolskiego i Instytutu

Radowego († 31 X 1944, r.);

dr Zbigniew Woźniewski;

prof. Wrzosek, także UZZ;

Arkadiusz Wyszomirski, także UZZ;

dr Stefan Wyszyński, II Klinika Chorób Wewnętrznych, także UZZ

(† Warszawa);

dr Witold Zahorski, I Klinika Chorób Wewnętrznych;

dr Aleksander Zakrzewski, Klinika Otolaryngologiczna;

doc. Jan Zaorski, kierownik tzw. szkoły Zaorskiego;

dr Laura Zozulińska, Zakład Anatomii Patologicznej;

doc. Juliusz Zweibaum, getto;

dr Edmund Żera, Szpital św. Rocha;

Zofia Żmichowska, Zakład Chemii Fizjologicznej.

Wydział Farmaceutyczny:

doc. Stanisław Biniecki, także UZZ;

dr Henryk Bukowiecki, także UZZ;

dr J. Chmielewska;

dr Jakub Deryng, także UZZ;

dr Stanisław Gartkiewicz, także UZZ;

Witold Gądzikiewicz, także WL;

doc. Zofia Jerzmanowska-Sienkiewicz, także UZZ;

Tadeusz Kopcewicz, także SGGW;

prof. Bronisław Walery Koskowski, dziekan, także UZZ;

prof. Adam Koss, także UZZ († powstanie);

doc. Aniela Kozłowska, także UJ;

doc. Stanisław Krauze, także UZZ;

doc. Antoni Łaszkiewicz, także WMP, UJ;

Eugeniusz Jan Muszyński, także WMP (sekcja biologiczna), UZZ;

doc. Bolesław Olszewski, także UZZ;

Wanda Polaczek;

Stanisław Sierakowski;

prof. Ernest Sym;

prof. Zygmunt Szymanowski;

dr Ewa Szymańska; 
prof. Stanisław Weil, także UZZ († 25 IX 1944, r.);

prof. Zygmunt Weyberg, także WMP (sekcja biologiczna), UZZ;

prof. Witold Rawita-Witanowski, także UZZ (†);

dr Józef Wize, także UZZ.

Osoby odpowiedzialne za sprawy organizacyjne:

Maria Bartczak, sekcja historyczna;

Wanda Chmielewska, WMP;

Jan Dudzik, woźny, biura uniwersyteckie;

Jan Gacek, WP;

Józef Gierej, woźny, WL;

Irena Gieysztor, WMP;

Wanda Hłasko, WMP;

Stefania Karpowicz, urzędniczka, biura uniwersyteckie;

Wanda Karpowicz (pseud. Teresa Krzemińska), WMP;

Ignacy Kisiel, woźny, WL;

Maria Koczwara, WMP († 9 IX 1944, r.);

Wiesław Kolisko, WP;

Cezary Kunderewicz, p.o. sekretarza UW, biura uniwersyteckie (jawne);

Andrzej Leśniewski, sekcja historyczna, WP;

Antoni Limanowicz, sekcja historyczna;

Michał Ławniczak, woźny, WL;

Aleksander Makarski, woźny, WL;

Maria Moszyńska, sekcja historyczna;

Halina Nieniewska (pseud. Irena Konarska, Iza) († 22 V 1944 r.);

Konstancja Romanowska, WL;

Halina Stypułkowska, sekcja historyczna;

Stanisław Suchecki, urzędnik, biura uniwersyteckie;

Antoni Symonowicz (pseud. Tolek), sekretarz WP;

Zofia Szymanowska, sekcja polonistyczna;

Franciszek Wojdak, woźny, WL;

Zbigniew Wróblewski, WP;

Zaborowski, WP;

Witold Złotnicki, WP. 


\section{Aneks 2: Adresy lokali konspiracyjnych i ich gospodarze (wybór) ${ }^{176}$}

6 sierpnia (A. Kwieciński);

Asfaltowa 17 (L. Widerszal);

Bednarska (Ł. Charewicz);

Bonifraterska 12 (Szpital Jana Bożego);

Brzozowa 10/5 (J. Szeruda);

Brzozowa 12, 14, (dom profesorski);

Chłodna (T. Manteuffel);

Chłodna 10, 39a (T. Makowiecki);

Chmielna (M. Rundo);

Czackiego (H. Hiż);

Czarnieckiego 11 (K. Dunin-Wąsowicz);

Czerniakowska 137 (klasztor nazaretanek);

pl. Dąbrowskiego (Tyszkiewiczowie);

Długa 20 (Nowakowscy);

Długa 24, (AGAD);

Długa $5^{2}$ (Archiwum Miejskie m.st. Warszawy);

Dobra (Miller);

Dziennikarska 3 (K. Wańkowicz);

Elektoralna 2 (Urząd Patentowy);

Elektoralna 12 (Szpital Św. Ducha, I Klinika Chorób Wewnętrznych);

Filtrowa 68 (Stachowska) ${ }^{177}$;

Gdańska 4, (W. Moszczeńska);

Zygmuntowska (Szpital Przemienienia Pańskiego);

Górnośląska (Z. Szmydt);

Górskiego (Krasińscy);

Górskiego 3 (Prywatne Liceum Chemiczne II stopnia);

Graniczna (Hanna Jastrzębska);

Grójecka (W. Pułak);

Hortensji 2 (Gimnazjum im. W. Górskiego);

Hoża (Anusz);

Hoża 20/2 (Słupińscy);

Hoża 78 (Państwowe Liceum Chemiczno-Ceramiczne II stopnia);

Jasna 4. (J. Jeziorański);

Jasna 6 (Tallen-Wilczewscy);

Jazdów 1a (Szpital Ujazdowski);

Al. Jerozolimskie 26 (Janyszkiewicz);

Kazimierzowska 59 (dom zakonny niepokalanek); 
Kopernika (Cierniakowie);

Kopernika (Zielińscy);

Kopernika (Stefanowska);

Kopernika 4,2 (Warszawski Szpital dla Dzieci);

Krakowskie Przedmieście 6 (Zakład Socjologii i Historii Kultury, Zakład Antropogeografii; biura uniwersyteckie);

Krakowskie Przedmieście 24, (Szpital św. Rocha);

Krakowskie Przedmieście 26/28 (Zakład Medycyny Teoretycznej);

Kredytowa (Hiżowie);

Kredytowa 8 (W. Kozubski);

Krochmalna $5^{6}$ (H. Piętka);

Kromera (Grzegorczykowie);

Królewska (Ruff);

Krucza 4,2 (L. Kasiński?);

Książęca (Szpital św. Łazarza);

Langiewicza 13 (J. Krzyżanowski);

Marszałkowska (Rybarscy);

Marszałkowska 46 (Dybczyńscy);

Marszałkowska 73 (Niewiadomscy);

Marszałkowska 81 (szkoła jawna);

Mickiewicza 27 (Seńko; Janina Rostańska);

Mokotowska (Lamparscy);

pl. Narutowicza (J. Kunicka);

Natolińska (S. Zoll);

Nowogrodzka 59 (Szpital Dzieciątka Jezus, Klinika Otolaryngologii, II Klinika Chorób Wewnętrznych);

Nowogrodzka 75 (Dom Księdza Baudouina);

Nowy Świat 14 (Wyższa Szkoła Biblijna Kościoła Metodystów);

Nowy Świat 22 (Pecke);

Nowy Świat 72 (szkoła kilimkarska, oficyna Pałacu Staszica, III p.);

Nowy Zjazd 5 (S. Baley);

Nowy Zjazd 5 (J. Rafacz);

Ogrodowa (Bolesław Michałko);

Piękna 24/26 (Prywatna Żeńska Szkoła im. Cecylii Plater Zyberkówny);

Piusa XI zo (H. Modzelewski);

Płocka (Szpital Wolski);

Prezydencka 4 (W. Tatarkiewicz);

Prezydencka 10 (B. Pniewski);

Prusa 11B (A. Szetelowa?);

Przyrynek 2 (plebania kościoła Nawiedzenia Najświętszej Marii Panny);

Racławicka (W. Leopold); 
Rakowiecka (Rutkowscy);

Rakowiecka 6 (AAN);

Rynek Starego Miasta $3^{1}$ (Kamienica Książąt Mazowieckich, IV p., Z. Wladich);

Senatorska 31/33 (plebania kościoła św. Antoniego Padewskiego);

Sienna 6o (Szpital Dziecięcy Bersohnów i Baumanów);

Sierpecka 6 (Lubeccy; Zdobowie);

Skaryszewska (Tadeusz Borowski);

Smolna (Morysińscy);

Śniadeckich 6/12 (W. Karpowicz);

Śniadeckich 8 (Towarzystwo Naukowe Warszawskie);

Śniadeckich 11 (Januszewiczowie);

Świętokrzyska, róg Jasnej (szkoła Tynelskiego);

Świętokrzyska 17 (szkoła handlowa Gracjana Pyrka);

Tamka (S. Kętrzyński);

Tamka 4a (plebania kościoła św. Teresy od Dzieciątka Jezus);

Traugutta 1 (Gimnazjum św. Stanisława Kostki; seminarium duchowne; biura uniwersyteckie);

Trębacka (J. Kram);

plac Trzech Krzyży 8 (Gimnazjum Filologiczne im. K. Kulwiecia);

Warecka 9 (J. Pelc);

Wilcza 64 (Państwowe Muzeum Zoologiczne);

pl. Wilsona (T. Mikulski);

Wolska 37 (Szpital Zakaźny Miejski św. Stanisława);

Wronia (Anusz);

Wrońskiego (M.R. Karska);

Wspólna (K. Łojewski);

Wspólna (Stachurscy);

Wspólna 75 (F.D. Krzeszewska; Julia Hartwig). 


\section{Przypisy}

1 C. Berezowski, Ochrona prawno-międzynarodowa zabytków i dzieł sztuki $w$ czasie wojny, Warszawa 1948, s. 44-4.9, $54-55,94-95,100-103,108-109,136-137$.

2 C. Madajczyk, Trzecia Rzesza $i$ życie kulturalne na terytoriach przez niq okupowanych, [w:] Inter arma non silent Musae. Wojna i kultura 1939-1945, red. C. Madajczyk, Warszawa 1977, s. 178, 184; C. Łuczak, Losy polskiej nauki i nauczania akademickiego $w$ okresie hitlerowskiej okupacji, Poznań 1981, s. 3, 4, 6; Podstępne uwięzienie profesorów Uniwersytetu Jagiellońskiego i Akademii Górniczej (6 XI 1939). Dokumenty, oprac. J. Buszko, I. Paczyńska, Kraków 1995.

3 Armia Krajowa $w$ dokumentach, t. I: Wrzesień 1939 - czerwiec 1941, Londyn 1970, s. 112-113 (17).

4 Archiwum Akt Nowych (AAN), Delegatura Rządu RP na Kraj, 202/VII-3, Sytuacja inteligencji polskiej pod rzadami okupacyjnymi, k. 47 .

5 W. Lewandowski, Sytuacja aprowizacyjna ludności Warszawy w latach wojny 1939-1942 r., s. 1-8, maszynopis w posiadaniu autora. Władysław Lewandowski, ur. 1905 r., zm. 7 V 1945 r. w Neuenbürg k. Karlsruhe po uwolnieniu z obozu; przed $1939 \mathrm{r}$. pracownik Ministerstwa Skarbu, delegowany do Biura Ekonomicznego Prezydium Rady Ministrów, od 1937/1938 kierownik Sekcji Ekonomicznej Zarządu m.st. Warszawy.

6 Archiwum Zakładu Historii Ruchu Ludowego (dalej jako AZHRL), M 71-25, Z pobytu w Warszawie (od 3 do 13 V 194 o r.). Sytuacja polityczna i ekonomiczna mieszkańców Warszawy, k. 31; M. Walczak, Szkolnictwo wyższe i nauka polska $w$ latach wojny i okupacji 1939-1945, Wrocław 1978, s. 104.

7 T. Szarota, Okupowanej Warszawy dzień powszedni. Studium historyczne, Warszawa 2010, s. 93-95; W. Kula, Dziennik czasu okupacji, oprac. N. Assorodobraj-Kula i M. Kula, Warszawa 1994, s. 13-14 (6 V 1941 r.), 22 (25 V 19411 r.)
8 K. Wyka, Gospodarka wyłaczona, [w:] $\dot{Z}$ ycie na niby. Pamiętnik po klęsce, Kraków 1984, s. 151-153; K.L. Koniński, Uwagi 1940-1942, Poznań 1987, s. 155 (11 XI 19411 r.); Z. Klukowski, Zamojszczyzna, t. I, 1918-1943, Warszawa 2008, s. 248 (3 IX 1941 r.).

9 A. Strzeżek, Od konsumpcji do konspiracji czyli warszawskie lokale gastronomiczne 1939-1944, Warszawa 2012, s. 87, 166.

10 C. Madajczyk, Polityka III Rzeszy w okupowanej Polsce, Warszawa 1970, t. II, s. 26-27; T. Szarota, Okupowanej Warszawy dzień powszedni, s. 94-95, 99-100, 103, 115-119; W. Bartoszewski, Lata wojenne Stanisława Herbsta, [w:] Na drodze do niepodległości, Paryż 1987, s. 106-107; A. Zahorski, O Ludwiku Widerszalu (19o9-1944), „Kronika Warszawy” 1980, nr 2, s. 116-117.

11 S. Kisielewski, Abecadło Kisiela. Testament Kisiela, Warszawa 2011, s. 50-51.

12 W. Kula, Dziennik czasu okupacji, s. 45 (23 VII 194,2 r.).

13 Z. Klukowski, Zamojszczyzna, s. 289 (4. VIII 194,2 r.); J.W. Gomulicki, „Diabet i zboże", [w:] Walka o dobra kultury 19391945. Warszawa 1939-1945, red. S. Lorentz, Warszawa 1970, t. II, s. 71.

14 Kronika Naukowa, [w:] „Kwartalnik Historyczny" 1946, nr 3-4, s. 755-756.

15 W. Kula, Dziennik czasu okupacji, s. 8 (1 XI 1939 r.), 24-25 (30 V 1941 r.), $3^{8}$ (21 VII 194,2 r.).

16 S. Swieżawski, Wielki przełom 19o7-1945, Lublin 1989, s. 388-391.

17 R. Jarocki, Rozmowy z Lorentzem, Warszawa 1981, s. 236-238; S. Lorentz, Zapiski do autobiografii, „Kwartalnik Historii Nauki i Techniki" 1979, nr 4, s. $74,4,-74,5$.

$18 Z$ dziejów podziemnego Uniwersytetu Warszawskiego, Warszawa 1961, s. 16, 18-19 (T. Kotarbiński).

19 A. Lauterbach, Zniszczenie i odbudowa Warszawy zabytkowej, „Kronika Warszawy" 1971, nr 4, s. 47.

20 F. Goetel, Czas wojny, Londyn 1955, s. 5o. 
21 Biblioteka Uniwersytetu Warszawskiego (BUW), Gab. Rękopisów, sygn. 2177, materiały dot. działalności Zastępczego I Szpitala Okręgowego, zorganizowanego przez E. Lotha na terenie UW we wrześniu 1939 , k. 1-8.

22 T. Manteuffel, Uniwersytet Warszawski $w$ latach wojny $i$ okupacji. Kronika 1939/1940 - 1944/1945, Warszawa 1948, s. 255 .

23 T. Manteuffel, Moja praca $w$ Archiwum Akt Nowych podczas okupacji, [w:] Walka o dobra kultury, t. I, s. 571 .

24 T. Makowiecki, Warszawska Biblioteka Uniwersytecka 1939-1944, Frankfurt am Main 1947, s. 3-4.

25 T. Manteuffel, Uniwersytet Warszawski..., s. 256 .

26 Archiwum Uniwersytetu Warszawskiego (AUW), WL-12. Relacje z udziału dydaktyków WL w tajnym nauczaniu i pracach badawczych w okresie okupacji, zbierane przez Dziekanat WL, 1945, t. 2, wykaz i oszacowanie strat spowodowanych wojną z niemcami [sic], 20 VI 1945 r., NN, k. $23-24$.

27 AZHRL, Archiwum Stanisława Kota (ASK), 47, Prowizoryczne zestawienie strat wojennych Państwa Polskiego sporządzone na koniec lutego $1940 \mathrm{r}$. (pierwsze przybliżenie), k. 36-4,2.

28 M. Walczak, Szkolnictwo wyższe i nauka polska, s. 56; T. Manteuffel, Uniwersytet Warszawski..., s. 254-255.

29 Ludzie nauki i nauczyciele polscy podczas II wojny światowej. Ksiegra strat osobowych, Warszawa 1995, s. 19-21.

30 AZHRL, ASK, 71, Działalność władz okupacyjnych na terytorium Rzeczypospolitej w okresie 1 IX 1939 - 1 XI 1940, k. 104-105, opubl.: Działalność władz okupacyjnych na terytorium Rzeczypospolitej $w$ okresie 1 IX 1939 - 1 XI 1940. Raport $z$ archiwum politycznego prof. Stanisława Kota, oprac. J. Gmitruk, J. Mazurek, Warszawa 1999; M. Walczak, Szkolnictwo wyższe i nauka polska, s. 57; C. Łuczak, Losy polskiej nauki, s. 7 .
31 Raporty Ludwiga Fischera, gubernatora dystryktu warszawskiego, 1939-1944, oprac. K. Dunin-Wąsowicz i in., Warszawa 1987 , s. 181-182, raport z 15 IV 1940 za okres 1 III10 IV 1940, s. 279, raport z 10 III 1941 za luty 1941; E.C. Król, Grabież polskich szkót wyższych w okresie okupacji hitlerowskiej, "Przegląd Historyczny" 1979, nr 3, s. 490; C. Madajczyk, Polityka III Rzeszy, t. I, s. 105, 108, 118-119, 124-125, 150, 153, 158-159, 161; S. Piotrowski, Dziennik Hansa Franka, Warszawa 1956, r. II.

32 T. Manteuffel, Uniwersytet Warszawski..., s. $257^{-2} 5^{8}$.

33 A. Mężyński, Kommando Paulsen, październik-grudzień 1939 r., Warszawa 1994 , s. 11.

34 [S. Sawicka], Likwidacja Ogrodu Botanicznego w Warszawie, „Przegląd Spraw Kultury" 1943, nr 1; E.C. Król, Grabież polskich szkół wyższych, s. 479-4,81, $486-489,495$.

35 AZHRL, ASK, M 72-40, $M S W$. Sprawozdanie ze stanu oświaty $i$ kultury na ziemiach polskich za okres od I IV do zo VI 1942, 1943, k. 24-25; BUW, Gab. Rękopisów, sygn. 2294, anonimowa relacja o zniszczeniach dokonanych przez Niemców we wrześniu 1939 r. na terenie UW, [prawdopodobnie 1941], k. 39-40.

36 BUW, Gab. Rękopisów, sygn. 2204, materiały do Kroniki Uniwersytetu Warszawskiego z lat 1939/4,0-194/4/1945 zebrane i przygotowane do druku przez T. Manteuffla, notatka nt. administracyjnej działalności UW w 1939-1941, k. 79-8o; T. Manteuffel, Uniwersytet Warszawski..., s. $259^{-2} 60$.

37 AUW, WL, Dypl. Okupacja, sygn.: 3-3725, 39 940-4,2 912, 9122-30 391, 30 4,12-39 892, $42979-49107$.

38 BUW, Gab. Rękopisów, sygn. 2203, materiały dot. tajnego nauczania w latach 1939-1944, zebrane przez T. Manteuffla, relacja W. Antoniewicza, k. 86; S.K. Kozłowski, Włodzimierz Antoniewicz, profesor z Warszawy, Warszawa 2oog, s. 299-300.

39 T. Manteuffel, Uniwersytet Warszawski..., s. 259 . 
40 B. Gralak, Szkolnictwo wyższe i nauka polska pod okupacja niemiecka i radziecka 1939-1945, Zgierz 2010, s. 46; Z dziejów podziemnego..., s. 140-1411 (W. Leopold), 287 (T. Sołtan).

41 Ludzie nauki..., s. 34; B. Gralak, Szkolnictwo wyższe i nauka polska, s. 4,2; M. Walczak, Szkolnictwo wyższe i nauka polska, s. 72; Z dziejów podziemnego..., s. 39-4, (K. Dąbrowska), 143-14,4 (W. Leopold).

42 M. Walczak, Szkolnictwo wyższe i nauka polska, s. 72; A. Kamiński, Diariusz podręczny 1939-1945, oprac. A. Palarczykowa, J. Stoksik, Warszawa 2001, s. 194-195 (3 XI 194,2 r.)

43 BUW, Gab. Rękopisów, sygn. 2586, nr 6 (numery pakietów/zakładek), materiały S. Pieńkowskiego, papiery nt. nauki, oświaty i kultury w Polsce w 1939-1945, pismo M. Koczwary do T. Manteuffla nt. Kroniki $U W, 28$ V 1948 r.; $Z$ dziejów podziemnego..., s. 143-14.4 (W. Leopold); T. Manteuffel, Uniwersytet Warszawski..., s. 262-264.

44 BUW, Gab. Rękopisów, sygn. 2203, W. Karpowiczówna, Materiały do historii tajnego nauczania. Tajne komplety Uniwersytetu Warszawskiego w r. 1940-1944, k. 6-8; tamże, relacja M. Koczwary, 24, XI 1946, k. 139-14,2; tamże, relacja M. Gieysztora o organizacji, stanie osobowym i działalności UW w latach 194,0-1944, 6 XI 1946, k. 2-5; T. Manteuffel, Uniwersytet Warszawski..., s. 262-264; M. Walczak, Szkolnictwo wyższe i nauka polska, s. 75; J. Pniewski, Wspomnienia autobiograficzne, [w:] Fizycy wspominaja. Zbiór 25 rozmów i wspomnień fizyków polskich opublikowanych pierwotnie w "Postepach Fizyki” i w „Kwartalniku Historii Nauki i Techniki”, wstęp Adam Sobiczewski, przypisy A.K. Wróblewski, red. A.M. Kobos, Kraków 2014, s. 616.

45 S. Salmonowicz, Polskie państwo podziemne. $Z$ dziejów walki cywilnej 1939-1945, Warszawa 1994, s. 164, n.; G. Górski, Administracja Polski Podziemnej w latach 1939-1945. Studium historyczno-prawne, Toruń 1995, s. 150-155.
46 BUW, Gab. Rękopisów, sygn. 2203 , W. Karpowiczówna, Materiały do historii tajnego nauczania. Tajne komplety Uniwersytetu Warszawskiego w r. 19401944, k. 6-8.

47 B. Gralak, Szkolnictwo wyższe i nauka polska, s. 48; T. Manteuffel, Uniwersytet Warszawski..., s. 261-262; Z dziejów podziemnego..., s. 30-31 (H. Hiż).

48 M. Lenczewski, Studium Teologii Prawosławnej na Uniwersytecie Warszawskim w latach 1925-1939, Warszawa 1992.

49 T. Manteuffel, Uniwersytet Warszawski..., s. $265^{-2} 66$.

50 BUW, Gab. Rękopisów, sygn. 2203 , ks. J. Szeruda, odpowiedź na kwestionariusz w sprawie tajnego nauczania, 23 X 1945 r., k. 24; T. Manteuffel, Uniwersytet Warszawski..., s. 266.

51 BUW, Gab. Rękopisów, sygn. 2203, pismo dziekana WP S. Zaleskiego do p.o. rektora UW S. Pieńkowskiego, 31 VII 1945 r., k. 39; tamże, C. Berezowski, odpowiedź na kwestionariusz, 24, X 1945 r., k. 26 ; tamże, S. Zaleski, odpowiedź na kwestionariusz, 29 X 1945 r., k. 40-4,2; T. Manteuffel, Uniwersytet Warszawski..., s. 266-270; Z. Krzemiński, Historia warszawskiej adwokatury, Warszawa 2005, s. 172-177; S.W. Kasznica, Druga wojna światowa. Wspomnienia spisane na podstawie codziennych notatek, wstęp i oprac. Marta Szczesiak-Ślusarek, Warszawa-Poznań 2013, passim.

52 BUW, Gab. Rękopisów, sygn. 2203 , Konspiracyjny okres Wydz. Prawa UW, 1940-44 r. (Sprawozdanie), oprac. Koło Prawników Wydziału Prawa UW, [prawdopodobnie 1946], k. 222-227.

53 BUW, Gab. Rękopisów, sygn. 2203, H. Modzelewski, Historia XII kompletu prawa $U W$, k. 228; tamże, H. Modzelewski, sprawozdanie z działalności Wydziału Prawa - lista słuchaczy, godła i adresy lokali, k. 222-228; tamże, S. Śliwiński, odpowiedź na kwestionariusz, 8 XI 1945 r., k. 34-37.

54 BUW, Gab. Rękopisów, 2203 , W. Antoniewicz, odpowiedź na kwestionariusz, 6 XI 1945 r., k. 82-85; 
T. Manteuffel, Uniwersytet Warszawski..., s. 289 ; tenże, Rola Marcelego Handelsmana $w \dot{z} y c i u$ naukowym Warszawy, "Przegląd Historyczny" 1959, z. 1, s. 8; tenże, Kronika odbudowy Instytutu Historycznego

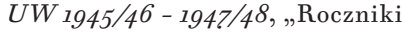
Uniwersytetu Warszawskiego" 1958, s. 114; E. Pawlikowska, W służbie historiografii i bibliotekarstwa - Ryszard Przelaskowski, [w:] Twórcy nowoczesnego bibliotekarstwa polskiego, red. B. Kocowski, Warszawa 1974, s. 286 .

55 T. Manteuffel, Uniwersytet Warszawski..., s. 280-282; J. Krzyżanowski, $Z$ dziejów wojennych polonistyki, „Przegląd Historyczno-Oświatowy" 196o, nr 3 .

56 Z dziejów podziemnego..., s. 6o-61, 63 (J. Pelc), 118-119 (J. Krzyżanowski).

57 Tamże, s. 121, 124-125 (J. Krzyżanowski).

58 Tamże, s. 75-76 (J. Pelc), 129-130 (J. Krzyżanowski).

59 T. Manteuffel, Uniwersytet Warszawski..., s. 297; $Z$ dziejów podziemnego..., s. 118-119, 121-122 (J. Krzyżanowski).

60 BUW, Gab. Rękopisów, sygn. 2203, W. Borowy, odpowiedź na kwestionariusz, 10 XII 1945 r., k. 88-9o; tamże, k. 91-97, spis ćwiczeń prowadzonych przez prof. Borowego; $Z$ dziejów podziemnego..., s. 78-86 (J. Pelc), 119 (J. Krzyżanowski), 173-179 (W. Leopold).

61 BUW, Gab. Rękopisów, sygn. 2203,

W. Tatarkiewicz, odpowiedź na kwestionariusz, 14, XI 1945 r., k. 135; W. Tatarkiewicz, Zapiski do autobiografii, [w:] T. i W. Tatarkiewiczowie, Wspomnienia, Poznań 2011, s. 91, 223, 231; A. Franaszek, Miłosz. Biografia, Kraków 2011, s. 336; $Z$ dziejów podziemnego..., s. 88-92 (J. Pelc).

62 Tamże, s. 76-77, 99-101 (J. Pelc).

63 Tamże, s. 68-71 (J. Pelc).

64 Tamże, s. 169-171 (W. Leopold).

65 Tamże, s. 18o-182 (W. Leopold).

66 Tamżę, s. 166-168 (W. Leopold).

67 Tamże, s. 73, 86-87 (J. Pelc), 149-152, 159-161, 163, 166, 179 (W. Leopold), 307-308 (T. Sołtan).
68 BUW, Gab. Rękopisów, sygn. 2203 , notatka o sekcji pedagogicznej, prawd. B. Nawroczyński, k. 137; T. Manteuffel, Uniwersytet Warszawski..., s. 286-287.

69 BUW, Gab. Rękopisów, sygn. 2203, B. Suchodolski, odpowiedź na kwestionariusz, 3 XI 1945 r., k. 134; tamże, S. Ossowski, odpowiedź na kwestionariusz, 18 X 1945 r., k. 133; patrz też: E. Stawowy, Dylematy $i$ wybory ideowe Bogdana Suchodolskiego, „Annales Universitatis Paedagogicae Cracoviensis. Studia Politologica", folia 129, IX (2013), s. $187-191$.

$70 Z$ dziejów podziemnego..., s. 25-27 (H. Hiż), 4,0-4, $6,5^{0-52}$ (K. Dąbrowska).

71 BUW, Gab. Rękopisów, sygn. 2203, notatka T. Manteuffla, k. 126-127 (czystopis); tamże, T. Manteuffel, odpowiedź na kwestionariusz, 7 X 1945 r., k. 122-125 (brudnopis); T. Manteuffel, Uniwersytet Warszawski..., s. 282-286; $Z$ dziejów podziemnego..., s. 208-211, 214-216, 220-221 (T. Manteuffel).

72 Z dziejów podziemnego..., s. 213-214 (T. Manteuffel).

73 Tamże, s. 24,1, 24:3-24,5

(K. Dunin-Wąsowicz).

74 BUW, Gab. Rękopisów, sygn. 2203, T. Manteuffel, odpowiedź na kwestionariusz, 7 X 1945 r., k. 122-125 (brudnopis); $Z$ dziejów podziemnego..., s. 210 (T. Manteuffel).

75 T. Manteuffel, Kronika odbudowy Instytutu Historycznego $U W 1945 / 46$ - 1947/48, s. 108.

76 Z dziejów podziemnego..., s. 24,5-247

(K. Dunin-Wąsowicz).

77 Tamże, s. 211-212 (T. Manteuffel).

78 BUW, Gab. Rękopisów, 2203,

W. Antoniewicz, odpowiedź na kwestionariusz, 6 XI 1945 r., k. 82-85; Z dziejów podziemnego..., s. 233 (J. Karwasińska).

79 Tamże, s. 232-233 (J. Karwasińska), 250251, 267-268, 2 70 (K. Dunin-Wąsowicz).

80 Tamże, s. 255-257 (K. Dunin-Wąsowicz).

81 BUW, Gab. Rękopisów, 2203,

W. Antoniewicz, odpowiedź na kwestionariusz, 6 XI 1945 r., k. 82-85; 
W. Antoniewicz, Studia

$w$ zakresie archeologii przedhistorycznej $i$ wczesnodziejowej $w$ tajnym Uniwersytecie Warszawskim podczas okupacji niemieckiej, "Biuletyn Historii Sztuki i Kultury” 1946, nr 1/2, s. 119-122; S.K. Kozłowski, Włodzimierz Antoniewicz, s. 155-157, 161-163, 172, 176; $Z$ dziejów podziemnego..., s. 219 (T. Manteuffel).

82 BUW, Gab. Rękopisów, sygn. 2203 ,

J. Karwasińska, odpowiedź na kwestionariusz, k. 98-112; $Z$ dziejów podziemnego..., s. 226-232 (J. Karwasińska).

83 Tamże, s. 221-223 (T. Manteuffel).

84 T. Manteuffel, Uniwersytet Warszawski..., s. $286-287$.

85 BUW, Gab. Rękopisów, sygn. 2203, M. Ossowska, odpowiedź na kwestionariusz, 17 X 1945 r., k. 130-132; T. Manteuffel, Uniwersytet Warszawski..., s. 287-288.

86 BUW, Gab. Rękopisów, sygn. 2203 , M. Ossowska, odpowiedź na kwestionariusz, 17 X 1945 r., k. 130-132.

87 BUW, Gab. Rękopisów, sygn. 2203 , T. Kotarbiński, odpowiedź na kwestionariusz, 8 X 1945 r., k. 115; $Z$ dziejów podziemnego..., s. 20 (T. Kotarbiński).

88 BUW, Gab. Rękopisów, sygn. 2203, W. Tatarkiewicz, odpowiedź na kwestionariusz, 14, XI 1945 r., k. 135.

89 BUW, Gab. Rękopisów, sygn. 2203 , K. Kumaniecki, relacja nt. sekcji filologii klasycznej, k. 119-120; T. Manteuffel, Uniwersytet Warszawski..., s. 287-288.

90 Tamże, s. 288-289.

91 BUW, Gab. Rękopisów, sygn. 2203,

J. Krzyżanowski, Studium Slawistyczne $U W$ czasu wojny, 1 X 1946 r., k. 118; T. Manteuffel, Uniwersytet Warszawski..., s. 288-289.

92 BUW, Gab. Rękopisów, sygn. 2586, nr 18, materiały S. Pieńkowskiego, zaświadczenie S. Pieńkowskiego dla M. Koczwary, 15 XII 1947 r.; T. Manteuffel, Uniwersytet Warszawski..., s. 290-293; tamże, sygn. 2203, W. Karpowiczówna, Materiały do historii tajnego nauczania. Tajne komplety Uniwersytetu Warszawskiego wr. 1940-1944, k. 6-8.
93 BUW, Gab. Rękopisów, sygn. 2203, relacja M. Koczwary, 24, XI 1946 r., k. 139-14,2.

94 BUW, Gab. Rękopisów, sygn. 2203, relacja $\mathrm{M}$. Gieysztora o organizacji, stanie osobowym i działalności UW w 194,0-44, 6 XI 194,6 r., k. 2-5.

95 Za wskazówki bibliograficzne i cenne uzupełnienia dziękuję Panu prof. Andrzejowi Kajetanowi Wróblewskiemu.

96 T. Manteuffel, Uniwersytet Warszawski..., s. 291-293; J. Pniewski, Wspomnienia autobiograficzne, „Kwartalnik Historii Nauki i Techniki" 1988, nr 33, s. 273-276.

97 J. Pniewski, Wspomnienia autobiograficzne, [w:] Fizycy wspominaja, s. 614.

98 Rozmowa z Ignacym Adamczewskim, [w:] Fizycy wspominaja, s. 16.

99 Tamże, s. 16.

100 Z. Ziółkowska, Fizyka teoretyczna w Polsce do 1939 r.: geneza i rozwój, „Kwartalnik Historii Nauki i Techniki" 1987, nr 2, s. 313-3411; A.K. Wróblewski, 75 lat fizyki na Hożej, "Wiedza i Życie” 1996, nr 1, s. 2, 4-5; W. Kapuściński, Stefan Pieńkowski 28 VII 1883 - 20 XI 1953, "Postępy Fizyki” 1963 , z. 6, s. 623 ; W.M. Ścisłowski, Czesław Białobrzeski (1878-1953), „Postępy Fizyki” 1954, z. 4, s. 418-4,19; K. Kozłowski, Powojenni nestorzy gdańskiej fizyki. Ignacy Adamczewski (1907-2000), „Pismo Politechniki Gdańskiej” 2004, nr 4, s. 16; AUW, WL-12, t. 2, relacja

A. Wolskiej, 11 VI 1945 r., k. 41.

101 T. Manteuffel, Uniwersytet Warszawski..., s. $293-294$.

102 Tamże, s. 294-295.

103 BUW, Gab. Rękopisów, sygn. 2204, list W. Sierpińskiego do T. Manteuffla z zo VI 1948 r., k. 77; T. Manteuffel, Uniwersytet Warszawski..., s. 293-294.

104 Tamże, s. 294-295; Chowałem się za plecami Kopernika. $Z$ prof. Januszem Paszyńskim rozmawia dr Robert Gawkowski, „Uniwersytet Warszawski” nr 2 (46), marzec 2010, s. 38-39.

105 AUW, WL-12, t. 2, dane dot. tajnego nauczania studentów Akademii Stomatologicznej w Zakładzie Anatomii 
Prawidłowej UW, przygotowane przez Z. Pękałę i B. Wojciechowskiego, k. 39; BUW, Gab. Rękopisów, sygn. 2203, relacja M. Koczwary, 24, XI 1946 r., k. 139-14,2; T. Manteuffel, Uniwersytet Warszawski..., s. 295 .

106 AUW, WL-11, k. 17-69, 75-79, 84-88; tamże, WL-12, t. 2, relacja L. Paszkiewicza nt. udziału pracowników Zakładu Anatomii Patologicznej WL w tajnym nauczaniu medycyny podczas okupacji niemieckiej, 1 VI 1945 r., k. 1-2; tamże, udział M. Grzybowskiego w nauczaniu tajnym, 13 VI 1945 r., k. 26; tamże, Zakład Anatomii Prawidłowej UW, dane przygotowane przez B. Wojciechowskiego, Z. Pękałę, Z. Wojciechowskiego, 16 VI 1945 r., k. 38; tamże, notatka W. Gądzikiewicza, k. 46; BUW, Gab. Rękopisów, sygn. 2586, nr 6, materiały S. Pieńkowskiego, pismo M. Koczwary do T. Manteuffla dot. Kroniki $U W$, 28 V 1948 r.; T. Manteuffel, Uniwersytet Warszawski..., s. 270-279.

107 AUW, WL-12, t. 2, sprawozdanie z działalności Rady WL z czasów okupacji do czasu uruchomienia UW w 1945 r., k. 48-51; tamże, relacja J. Zaorskiego, 12 VI 1945 r., k. 4.5; tamże, WL-13, Tajne nauczanie - Prywatna Szkoła Zawodowa dla Pomocniczego Personelu Sanitarnego J. Zaorskiego, t. 3, k. 110, 129, 130; BUW, Gab. Rękopisów, sygn. 2203, wywiad z J. Zaorskim, k. 77 - 78; tamże, sygn. 2203, notatka w materiałach J. Zaorskiego, k. 79-8o; BUW, Gab. Rękopisów, sygn. 2203, list J. Zaorskiego do T. Manteuffla z 22 IV 194,8 r., k. 76; T. Manteuffel, Uniwersytet Warszawski..., s. $270-276$.

108 AUW, WL-12, t. 2, dane dot. tajnego nauczania i pracy naukowej I Kliniki Chorób Wewnętrznych, 5 VI 1945 r., NN, k. 20-22.

109 AUW, WL-12, t. 2, II Klinika Chorób Wewnętrznych UW przy Szpitalu Dzieciątka Jezus, sprawozdanie W. Orłowskiego z 4 VI 1945 r., k. 7-9; tamże, sprawozdanie W. Orłowskiego z prac naukowych z 5 VI 1945 r., k. 11-15; BUW, Gab. Rękopisów, sygn. 2203, sprawozdanie W. Orłowskiego, k. 71-72; W. Orłowski, Tajne nauczanie chorób wewnętrznych na Wydziale Lekarskim Uniwersytetu Warszawskiego, w szczególności w II Klinice Chorób Wewnętrznych w latach 1939-1945, „Polski Tygodnik Lekarski" 1946, nr 25, s. 804,805; J. Roguski, Tajne nauczanie studentów medycyny w latach 1939-1944 w Oddziale Chorób Wewnętrznych Szpitala Wolskiego $w$ Warszawie, „Polski Tygodnik Lekarski” 1946, nr 5; J. Rutkowski, Tajne nauczanie studentów medycyny podczas okupacji niemieckiej (1939-1944) w I i II Oddziale Chirurgicznym Szpitala Dzieciatka Jezus $w$ Warszawie, „Polski Tygodnik Lekarski” $1946, \mathrm{nr} 48$.

110 AUW, WL-12, t. 2, relacja S. Altenbergera nt. nauczania studentów medycyny w Klinice Okulistycznej UW, 3 IX 1945 r., k. 3-4.

111 AUW, WL-12, t. 2, sprawozdanie A. Dobrzańskiego z tajnego nauczania i pracy naukowej Kliniki otolaryngologicznej UW, k. 5-6; A. Dobrzański, Tajne nauczanie i praca naukowa w Klinice Otolaryngologicznej Uniwersytetu Warszawskiego $w$ czasie okupacji niemieckiej, "Otolaryngologia Polska" 1947, nr 1.

112 AUW, WL-12, t. 2, nauczanie tajne i praca naukowa w Klinice Psychiatrycznej UW, oprac. przez J. Mazurkiewicza, 8 VI 1945 r., k. 28-29.

113 AUW, WL-12, t. 2, relacja J. Zweibauma, 9 VI 1945 r., k. 47; Ludzie nauki..., s. 32; T. Manteuffel, Uniwersytet Warszawski.., s. 277-279; L. Hirszfeld, Historia jednego życia, Kraków 2011, s. 317-325; T. Szarota, Okupowanej Warszawy dzień powszedni, s. 98 .

114 BUW, Gab. Rękopisów, sygn. 2586, nr 6, materiały S. Pieńkowskiego, pismo M. Koczwary do T. Manteuffla dot. Kroniki $U W, 28$ V 1948 r.; tamże, sygn. 2203, list M. Koczwary, kierownika Zakładu Farmakologii UJ, do T. Manteuffla z 24, XI 194,6 r., k. 143; tamże, sygn. 2203, A. Koss, odpowiedź na kwestionariusz, k. 175; T. Manteuffel, Uniwersytet Warszawski..., s. 295-296. 
115 K. Millak, Uczelnia Weterynaryjna $w$ Warszawie $1840-1965$, Warszawa 1965 , s. 143-14,8; J. Tropiło, biogram Ernesta Syma, „Polski Słownik Biograficzny” 2009, t. 46/2, z. 189 , s. 225; E. Mikulaszek, Ernest Sym (1893-1950). Wspomnienie pośmiertne, "Rocznik Towarzystwa Naukowego Warszawskiego" 1950, t. 43, s. 216-219.

116 B. Gralak, Szkolnictwo wyższe i nauka polska, s. 162-163, 326, 336-339, 350; M. Małecki, Tajny uniwersytet (Tajne nauczanie na Uniwersytecie Jagiellońskim $w$ czasie okupacji niemieckiej), [w:] Ne cedat Academia. Kartki z dziejów tajnego nauczania na Uniwersytecie Jagiellońskim 1939-1945, oprac. M. i A. Zarębowie, Kraków 1975, s. 523 .

117 BUW, Gab. Rękopisów, sygn. 2586, nr 18, materiały S. Pieńkowskiego, zaświadczenie S. Pieńkowskiego dot. działalności S. Wóycickiego, zastępcy kierownika Wydziału Ogrodownictwa m.st. Warszawy, 21 IX 1946 r.(?); S.K. Kozłowski, Włodzimierz Antoniewicz, s. 155-157, 161-163, 172, 176, 299-30о.

118 BUW, Gab. Rękopisów, sygn. 2578, materiały S. Pieńkowskiego, Instytut Fizyki Doświadczalnej UW, sprawozdania z prac wykonanych w Zakładzie Pomiarów Fizycznych w 1940-1942 (materiały wyłącznie z paginacją wytwórcy).

119 S. Wachowiak, Czasy, które przeżyłem, Warszawa 1991, s. 195, 290; M. Walczak, Walka ekonomiczna narodu polskiego 1939-1945, Warszawa 1983, s. 217-218, 225; T. Szarota, Okupowanej Warszawy dzień powszedni, s. 130-133.

120 BUW, Gab. Rękopisów, sygn. 2586, nr 11, materiały S. Pieńkowskiego; T. Szarota, Okupowanej Warszawy dzień powszedni, s. 94-95, 99-100, 115-119.

121 G. Górski, Administracja Polski Podziemnej, s. 155-163; W. Grabowski, Delegatura Rzadu RP na Kraj 1940-1945, Warszawa 1995, s. 106; M. Walczak, Szkolnictwo wyższe i nauka polska, s. 78, 107, 124; Rzeczpospolita Polska czasu wojny. Dziennik Ustaw RP i Monitor Polski 1939-1945, red. A.K. Kunert, Warszawa 1995 (skorowidz).
122 AZHRL, ASK, M 72-37, Położenie inteligencji polskiej w czasie okupacji, b.d., k. 1-2, opubl.: W kraju i na emigracji. Materiały $z$ londyńskiego archiwum ministra prof. Stanisława Kota, oprac. J. Gmitruk, Z. Hemmerling, J. Sałkowski, Warszawa 1989, s. 204-206 (tu sygn. 38); BUW, Gab. Rękopisów, sygn. 2586, nr 11, materiały S. Pieńkowskiego; Ministerstwo Kultury i Sztuki w dokumentach 19181998, Warszawa 1998, s. 198-202 (74), Sprawozdanie z działalności Funduszu Kultury Narodowej w roku 1942, s. 202-205 (75), Sprawozdanie Ministerstwa Spraw Wewnętrznych, Wydział dla spraw kulturalnych.

123 P. Mitzner, Mój Ojciec - konspirator, „Zeszyty Historyczne” 1998, nr 125 , s. 17-66; M. Walczak, Szkolnictwo wyższe i nauka polska, s. 132; R. Jarocki, Uparty wysiłek [Stefan Kieniewicz], [w:] tegoż: Widzieć jasno bez zachwytu, Warszawa 1982, s. 109; R. Jarocki, Zrozumieć innych [Aleksander Gieysztor], [w:] tegoż, Widzieć jasno bez zachwytu, s. 28.

124 AAN, Delegatura Rządu RP na Kraj, Departament Oświaty i Kultury (DOiK), sygn. 202/VII, t. 1, k. 2; BUW, Gab. Rękopisów, sygn. 2586, materiały S. Pieńkowskiego, nr 2; M. Walczak, Szkolnictwo wyższe i nauka polska, s. 76, 91-92, 94; B. Gralak, Szkolnictwo wyższe i nauka polska, s. 16o, 168, 176, 343-345, $347,349,35^{2}, 35^{6}, 3^{61-369}$; Ludzie nauki..., s. 33; $Z$ dziejów podziemnego..., s. 143-144 (W. Leopold); J. Ślaski, Polska walczaca, Warszawa 199o, s. 300.

125 B. Gralak, Szkolnictwo wyższe i nauka polska, s. 347-34,8; $Z$ dziejów podziemnego..., s. 14,2-14,3 (W. Leopold).

126 A. Symonowicz, Wspomnienia z tajnego Wydziału Prawa Uniwersytetu Warszawskiego w okresie okupacji, "Palestra" 1958, nr 3/4, s. 31; G. Mazur, Biuro Informacji i Propagandy SZPZWZ-AK 1939-1945, Warszawa 1987 , s. 30-33, 56-57, 91, 124-129; A. Gieysztor, „Chrobot”, [w:] Stanisław Herbst. Historyk i regionalista, red. J. Kazimierski, Warszawa 1996, s. 91-95; M. Walczak, Szkolnictwo wyższe i nauka polska, s. 83 . 
127 M. Walczak, Szkolnictwo wyższe i nauka polska, s. 94-95; B. Gralak, Szkolnictwo wyższe i nauka polska, s. 465-466; A. Birkenmajer, Co władze okupacyjne wiedzialy o polskim tajnym nauczaniu w tzw. Generalnej Guberni?, „Przegląd Historyczno-Oświatowy" 1947, nr 1, s. 151; T. Manteuffel, Uniwersytet Warszawski..., s. $267-268$.

128 M. Walczak, Szkolnictwo wyższe i nauka polska, s. 50, 52, 83, 308-310; Maty rocznik statystyczny Polski. Wrzesień 1939-czerwiec 1941, Londyn 1941, s. 137-139 (tabl. 1, 3), 14.2 (13), 145 (19), 147 (25), 149 (33), 156 (5).

129 T. Manteuffel, Uniwersytet Warszawski..., s. 298-299; B. Gralak, Szkolnictwo wyższe i nauka polska, s. $162 ; Z$ dziejów podziemnego..., s. 286 (T. Sołtan).

130 Tamże, s. 34-36 (H. Hiż).

131 BUW, Gab. Rękopisów, sygn. 2586, materiały S. Pieńkowskiego, nr 2; M. Walczak, Szkolnictwo wyższe i nauka polska, s. 91-92, za: AAN, Delegatura Rządu RP na Kraj, DOiK, sygn. 202/VII, t. 1, k. 2; B. Gralak, Szkolnictwo wyższe i nauka polska, s. 43, 167-168, 171, 173, 176 , 182, 183; Ludzie nauki..., s. 34; $Z$ dziejów podziemnego..., s. $19^{2}$ (W. Leopold).

132 R. Jarocki, Opowieść o Aleksandrze Gieysztorze, s. 88, 103; tenże, Sztuka i krew 1939-1945. Opowieść o ludziach i zdarzeniach, Warszawa 2012, s. 70-73.

133 AUW, WL-12, t. 2, sprawozdanie z działalności Rady WL z czasów okupacji do czasu uruchomienia UW w 1945 , k. 48-51; M. Walczak, Szkolnictwo wyższe i nauka polska, s. 84, 88, 98-101; Z. Ziółkowska, Fizyka teoretyczna $w$ Uniwersytecie Warszawskim $w$ latach 1939-1951, 1990, s. 1-5.

134 W. Tatarkiewicz, Zapiski do autobiografii, [w:] T. i W. Tatarkiewiczowie, Wspomnienia, s. 222, 224-225, 226.

135 S. Pieńkowski, Nauka polska w czasie okupacji, „Przegląd Historyczno-Oświatowy" 1947, nr 1, s. 119; M. Walczak, Nauka i szkolnictwo wyższe, s. 78, 107, 124, 125; Z. Klukowski, Zamojszczyzna, s. 380 (1o X 1943); K. Piwocki, Prace polskich historyków sztuki w czasie wojny, "Biuletyn Historii Sztuki i Kultury” 1946, nr 3-4, s. 135-153, np.: Zygmunt Batowski (pałac Potockich w Warszawie, Marceli Bacciarelli, Tadeusz Kuntze), Gerard Ciołek (historia ogrodownictwa w Polsce), Tadeusz Dobrowolski (Śląsk, muzealnictwo), Wacław Husarski (polska sztuka nowoczesna, Kazimierz Dolny i jego zabytki), Alfred Lauterbach (pałac Brühla), Stanisław Lorentz (pałac Prymasowski w Warszawie, Natolin), Tadeusz Makowiecki (pałac Łazienkowski), Bohdan Marconi (materiały do falsyfikatów obrazów od XVIII w.), Zygmunt Miechowski (pałac w Kozienicach), Zygmunt Mocarski (polska sztuka fotograficzna), Jan Morawiński (galeria wilanowska), Ksawery Piwocki (rodzima twórczość w historii sztuki), Tadeusz Przypkowski (psychologia kolekcjonerstwa i bibliofilstwa), Bohdan Guerquin (słownik zamków polskich), Jerzy Remer (zabytkoznawstwo, studia konserwatorskie), Tymoteusz Sawicki (Marcin Zaleski), Juliusz Starzyński (upowszechnianie sztuki), Jerzy Szablowski (vademecum inwentaryzatora), Adolf Szyszko-Bohusz (mury obronne Krakowa), Władysław Tatarkiewicz (estetyka, architektura klasycystyczna), Władysław Tomkiewicz (grobowce barokowe i rokokowe w Polsce), Mieczysław Treter (malarstwo polskie XIX w.), Michał Walicki (plastyka gotycka na Mazowszu), Antoni Wieczorkiewicz (ogrody w Polsce), Jan Zachwatowicz (rotunda gnieźnieńska); patrz też: Wykaz prac z działu nauk matematyczno-przyrodniczych wykonanych $w$ Polsce $w$ okresie okupacji niemieckiej 1939-1945, Kraków 1947, s. 145-146.

136 BUW, Gab. Rękopisów, sygn. 2586, nr 14-16, materiały S. Pieńkowskiego; tamże, sygn. 2203, W. Antoniewicz, odpowiedź na kwestionariusz, 6 XI 1945 r., k. 82-85, cyt. [w:] S.K. Kozłowski, Włodzimierz Antoniewicz, s. 159-16o; G. Górski, Administracja Polski Podziemnej, s. 155-163.

137 L. Kołakowski, Neutralność i wartości akademickie, [w:] tegoż, Moje słuszne poglądy na wszystko, Kraków 2011, s. 124-125. 
$138 Z$ dziejów podziemnego..., s. 18-20 (T. Kotarbiński); T. Manteuffel, Uniwersytet Warszawski..., s. 262-264.

$139 Z$ dziejów podziemnego..., s. 34-36 (H. Hiż), 43, 49, 54, 55 (K. Dąbrowska), 182 (W. Leopold), 282 (K. Dunin-Wąsowicz).

140 Tamże, s. 33-34 (H. Hiż), 284, 285 (T. Sołtan); R. Jarocki, Opowieść o Aleksandrze Gieysztorze, Warszawa 2001, s. 85; T. Manteuffel, Rola Marcelego Handelsmana $w$ życiu naukowym Warszawy, "Przegląd Historyczny” 1959, z. 1, s. 11; Ludzie nauki..., s. 32; W. Chrzanowski, Pół wieku polityki. Rozmowa, Warszawa 1997, s. 108-120 (podrozdział: Uniwersytet).

141 P. Majewski, Z frontu walki cywilnej. Przyczynek do dziejów Kierownictwa Walki Cywilnej i Kierownictwa Walki Podziemnej na obszarze Generalnego Gubernatorstwa w latach 1939-1945, "Kwartalnik Historyczny" 2012, nr 4 , s. 693-749; tenże, Kolaboracja, której nie było... Problem postaw społeczeństwa polskiego w warunkach okupacji niemieckiej 1939-1945, „Dzieje Najnowsze” 2004, nr 4.

142 Instrukcje Walki Cywilnej, oprac. P. Majewski, „Dokumenty i Materiały Archiwum Polski Podziemnej 1939-1956" nr 3, 1995, s. 89-109; A. Rybicka, Instytut Niemieckiej Pracy Wschodniej. Institut für Deutsche Ostarbeit. Kraków 1940-1945, Warszawa 2002, s. 153; R. Gawkowski, Jerzy Modrakowski. Rektor bez Uniwersytetu. Poczet rektorów Uniwersytetu Warszawskiego, „Uniwersytet Warszawski” 2012, nr 2, s. 54; W. Kapuściński, Stefan Pieńkowski 28 VII 1883 - 20 XI 1953, s. 623; S.K. Kozłowski, Włodzimierz Antoniewicz, s. 155-157, 161-163, 172, 176, 287-303; por.: K. Jażdżewski, Pamiętniki. Wspomnienia polskiego archeologa $w$ XX wieku, Łódź 1995.

$143 Z$ dziejów podziemnego..., s. 20 (T. Kotarbiński), 126 (J. Krzyżanowski).

144 BUW, Gab. Rękopisów, sygn. 2203, W. Borowy, odpowiedź na kwestionariusz, 10 XII 194.5 r., k. 88-9o.

145 Podrozdział przygotowany na podstawie: A. Mężyński, Biblioteki Warszawy w latach 1939-1945, Warszawa 2010.
146 A. Romańska, Kształtowanie zbiorów Biblioteki, [w:] Biblioteka Uniwersytecka $w$ Warszawie w latach 1945-198o, red. nauk. A. Mężyński, współprac. A. Bednarz, Warszawa 1998, s. 81-83.

147 W. Sokołowska, Dzieje Biblioteki Uniwersytetu Warszawskiego 1939-1945, Warszawa 196o, s. 106-107.

148 Biblioteki naukowe w Generalnym Gubernatorstwie w latach 1939-1945. Wybór dokumentów źródłowych, wybór i oprac. A. Mężyński, współpraca H. Łaskarzewska, Warszawa 2003, s. 76 (27), 215-216 (94), 237, 241 (1).

149 W. Sokołowska, W Bibliotece Uniwersyteckiej 1939-1944, [w:] Walka o dobra kultury, t. I, s. 305; T. Manteuffel, Uniwersytet Warszawski..., s. 296-297.

150 K. Świerkowski, Biblioteki warszawskie w latach 1939-1945, [w:] Warszawa lat wojny i okupacji 1939-1944, 1972, z. 2, s. $3^{28}$; Biblioteki naukowe $w$ Generalnym Gubernatorstwie w latach 1939-1945, s. $377,381(16)$.

151 Z dziejów podziemnego..., s. 64-66 (J. Pelc).

152 A. Romańska, Kształtowanie zbiorów biblioteki, s. 88; K. Jażdżewski, Pamiętniki..., s. 158 .

153 Podrozdział opracowany na podstawie: P. Majewski, Akcja pruszkowska. Ochrona zbiorów kulturalnych $w$ powstaniu warszawskim i po jego upadku, „Rocznik Warszawski" 2004, s. 201-235; A. Mężyński, Biblioteki Warszawy w latach 1939-1945.

154 R. Gawkowski, Kampus uniwersytecki w czasach II wojny światowej, [w:] Kultura artystyczna Uniwersytetu Warszawskiego. Ars et educatio, oprac. J. Miziołek, Warszawa 2003, s. 325-336, z wykorzystaniem wypowiedzi por. rez. Władysława Mroczkowskiego.

155 W. Borowy, Okres Powstania 1944 r. $w$ Bibliotece Uniwersyteckiej $w$ Warszawie. Relacja Bohdana Korzeniewskiego spisana przez Wacława Borowego, Warszawa 1965 , s. $17,20,26-31$.

156 A. Mężyński, Biblioteki naukowe $w$ Generalnym Gubernatorstwie, s. 116-117. 
157 Archiwum Zamku Królewskiego w Warszawie (AZK), Archiwum Jana Zachwatowicza (AJZ), teczka Archiwum akcji zabezpieczania po Powstaniu Warszawskim; M. Łodyński, Pruszkowska akcja zabezpieczania warszawskich zbiorów bibliotecznych (1944-1945). Wspomnienia uczestnika akcji, [w:] Walka o dobra kultury, t. II, s. 269-27o.

158 W. Borowy, Z zapisek Borowego (19441945), oprac. Z. Stefanowska, [w:] Walka o dobra kultury, t. II, s. 198, 204-206, 210.

159 „Biuletyn Informacyjny”, nr 105 z 18 XII 1944, r.; W. Borowy, $Z$ zapisek Borowego (1944-1945), oprac. Z. Stefanowska, [w:] Walka o dobra kultury, t. II, s. 211.

160 BUW, Gab. Rękopisów, sygn. 2586, nr 11, materiały S. Pieńkowskiego; S.K. Kozłowski, Włodzimierz Antoniewicz, s. $155^{-157}, 161-163,17^{2}, 176,287-303$.

161 Ludzie nauki..., s. 33; Z. Ziółkowska, Fizyka teoretyczna $w$ Uniwersytecie Warszawskim w latach 1939-1951, 1990, s. 1-5; J. Zbudniewek, Jasna Góra w latach okupacji, s. 192-193, 198.

162 AUW, Akta ogólne RP/WL, sygn. RP/ WL 35, Akademia Boremlowska, lista płac za listopad 1944; tamże, WL-12, t. 2, II Klinika Chorób Wewnętrznych UW przy Szpitalu Dzieciątka Jezus, sprawozdanie W. Orłowskiego z 4, VI 1945 r., k. 10; BUW, Gab. Rękopisów, sygn. 2204, NN, Krótkie dane historyczne o działalności Wydziału Lekarskiego $U W w$ roku akademickim 1944/45, k. 22-27.

163 AUW, WL-11, t. 1, list J. Mazurkiewicza do W. Orłowskiego z 1(?) XII 194,4, r., k. 1.

164 AUW, WL-11, zaświadczenie, k. 2; tamże, fragment zbiorczego zaświadczenia, k. 6 .

165 AUW, WL-11, k. 13-15; AUW, WP-TUW $1-37$.

166 AAN, Delegatura Rządu RP na Kraj, 202/ I-51, Straty kulturalne, k. 39-51 (Rozdz. IV. Szkoty wyższe i nauka), 73, 76 (Rozdz. VI. Biblioteki), 174-178 (Rozdz. XX. Koszta odbudowy nauki i szkolnictwa wyższego $w$ dziale osobowym).

167 AAN, Biuro Odszkodowań Wojennych (BOW), 11, Zestawienie strat i szkód wojennych Polski w latach 1939-1945 (1947), k. $35,36,41,56-59,65,68$; C. Łuczak, Losy polskiej nauki, s. 9; Ludzie nauki..., s. $55^{-5} 5,798 \mathrm{n}$. (analiza strat osobowych).

168 AAN, Delegatura Rządu RP na Kraj, 202/I-51, Straty kulturalne (Rozdz. V. Archiwa), k. 66; T. Manteuffel, Uniwersytet Warszawski..., s. 300-zol; S. Sawicka, Gabinet Rycin Biblioteki Uniwersyteckiej w Warszawie w latach 1939-1949, „Biuletyn Historii Sztuki” 1949, nr 3-4, s. 392-397; W. Suchodolski, Straty archiwów warszawskich w czasie wojny i okupacji, „Kwartalnik Historyczny” 1946, nr 3-4, s. 701-704; A. Stebelski, Losy archiwów polskich $w$ latach wojny 1939-1945, „Rocznik Warszawski” 1963, s. 178; T. Manteuffel, Archiwum Oświecenia Publicznego $w$ Warszawie, [w:] Straty archiwów i bibliotek warszawskich $w$ zakresie rękopiśmiennych źródeł historycznych, t. II: Archiwa porozbiorowe i najnowsze, Warszawa 1956, s. 211-234; por. szacunki strat Wydziałów Lekarskiego i Farmaceutycznego: AUW, WL-zo, analizy poszczególnych jednostek organizacyjnych dot. strat wojennych, 1945-1949 (m.in. sprawozdanie ze stanu Wydziału Lekarskiego UW, k. 35-36); tamże, WFarm.-15, analizy poszczególnych zakładów dot. strat wojennych, 1945-1946.

169 T. Manteuffel, Uniwersytet Warszawski..., s. 299-300; T.S. Jaroszewski, Architektura Uniwersytetu Warszawskiego, Warszawa 1991, s. 85-87, 89, 92, 100, 101;

J. Gadomski, Losy obserwatorium astronomicznego Uniwersytetu Warszawskiego podczas wojny polsko-niemieckiej i okupacji niemieckiej (19391944), „Urania. Czasopismo Astronomiczne Popularno-Naukowe" 1946, nr 1-2.

170 Por. przypis do Aneksu 1.

171 T. Manteuffel, Uniwersytet Warszawski..., s. 298-299.

172 Słownik uczestniczek walk o niepodległość Polski 1939-1945. Poległe i zmarłe w okresie okupacji niemieckiej, Warszawa 1988 (biogramy); C. Łuczak, Losy polskiej nauki, s. 11; L. Hirszfeld, Historia jednego życia, s. 4,10; R. Jarocki, Opowieść o Aleksandrze Gieysztorze, s. 93, 104-105; K. Moczarski, Zapiski, wstęp, wybór tekstów i oprac. 
A.K. Kunert, Warszawa 1990, relacja o przebiegu dochodzenia po zamordowaniu J. Makowieckiego i L. Widerszala, s. $169-178$.

173 B. Korzeniewski, Książi i ludzie, 1993, s. 136, cyt. za: J. Miziołek, Zarys dziejów Uniwersytetu Warszawskiego, [w:] Kultura artystyczna Uniwersytetu Warszawskiego, s. 68 .

174 T. Manteuffel, Kronika odbudowy Instytutu

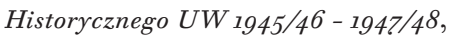
s. $105-107,114$.

175 AUW, WL-12, t. 2, spis osób zaangażowanych w działalność konspiracyjną, k. 33; BUW, Gab. Rękopisów, sygn. 2203, spuścizna W. Sokołowskiej, spis osobowy podziemnego UW, k. 229-234, 237; tamże, relacja M. Koczwary, 24, XI 1946 r., k. 13914,2; Akta Mariana Gieysztora, „Biuletyn Archiwum Polskiej Akademii Nauk" 1977, nr 20; A.K. Kunert, Słownik biograficzny konspiracji warszawskiej, t. 1,Warszawa 1987, s. 70-71; T. Manteuffel, Uniwersytet Warszawski..., s. 268-269, 277-283, 286289, 291-296; Słownik uczestniczek walk o niepodległość, s. 59, 160, 190-191, 197, $247,249-25^{\circ}, 276-277,289-290,347,362$, 433-434; T.W. Świątek, R. Chwiszczuk, Od Sawy do Kamy, czyli kobiecy ruch społecznikowski, Warszawa 2011, s. 28; M. Walczak, Nauka i szkolnictwo wyższe, s. 134-17o; Wspomnienie o Henryku Hizu, "Studia Semiotyczne" 2007 ,

t. XXVI, s. 13-32.

Wskazówki bibliograficzne dotyczące strat osobowych, obejmujące nie tylko uczestników tajnego nauczania: AAN, BOW, 11, Zestawienie strat (1947), k. 40; tamże, Delegatura Rządu RP na Kraj, Straty kulturalne, k. 39-61 (Rozdz. IV. Szkoly wyżse i nauka, Lista strat profesorów, docentów i asystentów podczas wojny i okupacji 1939-1944); AUW, WL-12, t. 2, Zakład Anatomii Prawidłowej UW, relacja B. Wojciechowskiego, Z. Pękały, Z. Wojciechowskiego, 16 VI 1945 r., k. 38; tamże, Nauczanie tajne i praca naukowa $w$ Klinice Psychiatrycznej $U W$, oprac. J. Mazurkiewicz, 8 VI 1945 r., k. 28-29; BUW, Gab. Rękopisów, sygn. 2203, Konspiracyjny okres Wydz. Prawa UW, 1940-44 r., oprac. Koło
Prawników WP UW, 1946(?), k. 222-227; tamże, H. Modzelewski, sprawozdanie z działalności Wydziału Prawa, lista słuchaczy, godła i adresy lokali, k. 222228; A. Bolewski, H. Pierzchała, Losy polskich pracowników nauki, s. 116-158; L. Hirszfeld, Historia jednego życia, s. $3^{26}$, 424; Katyń Uniwersytetu, wystawa, 3-9 IV 1995 r., Muzeum Uniwersytetu Warszawskiego, oprac. R. Gawkowski, b.d.m.w.; Ludzie nauki..., s. 83-158;

C. Łuczak, Losy polskiej nauki, s. 12;

C. Madajczyk, Polityka III Rzeszy, aneks 2, s. 398-4,03, 410-4,11; T. Manteuffel, Uniwersytet Warszawski..., s. 256, 257, 298-299, 302-315; Ofiary wojny (twórcy kultury), „Biuletyn Historii Sztuki i Kultury" 1946, nr 1-2, s. 1; B. Olszewicz, Lista strat kultury polskiej (1 IX 1939 1 III 1946), Warszawa 1947; Pamięci tych co odeszli, „Archeion” 1948, nr XVII, s. 8-19; Straty kultury polskiej 1939-1944, red. A. Ordęga, T. Terlecki, Glasgow 1945; T. Szarota, Okupowanej Warszawy dzień powszedni, s. 51; M. Walczak, Nauka i szkolnictwo wyższe, s. 206-285; M. Walicki, Po wojnie, „BHSiK” 1946, nr 1-2, s. 4-5; Wspomnienia o pracownikach naukowych i czlonkach PTH zmarlych w latach 1939-1945, „Kwartalnik Historyczny" 1946, nr 3-4, s. 405-659 (Uzupełnienie nekrologii wojennej, „KH" 1947, s. 58-72); Wstęp, [w:] Straty archiwów i bibliotek warszawskich, t. II, s. 13. Autor zwraca się z prośbą do PT. Czytelników o uzupełnianie listy kadry nauczającej i nekrologii wojennej poprzez przekazywanie danych do Muzeum Uniwersytetu Warszawskiego.

176 M.in. na podstawie: BUW, Gab. Rękopisów, sygn. 2203, relacja W. Sokołowskiej, spis punktów tajnego nauczania, k. 235-236; tamże, H. Modzelewski, Sprawozdanie z działalności Wydziału Prawa (lista słuchaczy, godła i adresy lokali), k. $222-228$.

177 Pod tym adresem zamieszkiwała także polonistka Natalia Nekrasz, zaangażowana m.in. w organizację tajnego nauczania, za: J. W. Woś, Ze wspomnień ucznia Liceum Ogólnokształcącego $\mathrm{nr} 21$ im. Hugona Kolłąaja $w$ Warszawie (1954-1958), Warszawa 2011, s. 26-33. 


\section{Bibliografia}

\section{Materiały archiwalne}

Archiwum Akt Nowych w Warszawie

Archiwum Polskiej Akademii Nauk

w Warszawie

Archiwum Spółdzielni Mieszkaniowej

Profesorów Uniwersytetu Warszawskiego

Archiwum Uniwersytetu Warszawskiego

Archiwum Zakładu Polskiego Ruchu

Ludowego

Archiwum Zamku Królewskiego w Warszawie

Centralna Biblioteka Wojskowa w Warszawie

Gabinet Dokumentów Życia Społecznego

Biblioteki Uniwersytetu Warszawskiego

Gabinet Rękopisów Biblioteki Uniwersytetu Warszawskiego

\section{Prasa}

"Akademicki Przegląd Sportowy"

„Akademik” (dodatek do „Buntu Młodych”)

„Akademik” (organ Młodzieży Wszechpolskiej)

„Akademik” (organ Związku Młodzieży

Polskiej)

"Akademik Polski”

„Alma Mater”

"Awangarda"

„Biuletyn” (organ Centrali Bratnich Pomocy)
„Bunt Młodych”

„Dzień Akademicki”

„Echo Akademickie”

„Głos Akademicki”

„Kurier Warszawski”

„Nasz Przegląd”

„Ruch Akademicki”

„Wiadomości Akademickie"

„Życie Akademickie”

\section{Wydawnictwa \\ uniwersyteckie}

Manteuffel T., Uniwersytet Warszawski w latach 1915/16-1934/35. Kronika, Warszawa $193^{6 .}$

Manteuffel T., Uniwersytet Warszawski w latach wojny i okupacji. Kronika 1939/1940 1944/1945, Warszawa 1948.

Przepisy dla studentów Uniwersytetu Warszawskiego, [Warszawa 1915].

Przepisy dla studentów Uniwersytetu Warszawskiego, [Warszawa 1916].

Przepisy dla studentów Uniwersytetu Warszawskiego, [Warszawa 1917].

Przepisy dodatkowe dla studentów Wydziału Teologicznego [Uniwersytetu Warszawskiego], [Warszawa 1918]. 
Przepisy ogólne o egzaminach

farmaceutycznych na Wydziale Lekarskim

Uniwersytetu Warszawskiego,

[Warszawa 1918].

Przepisy ogólne o egzaminach na Wydziale

Lekarskim Uniwersytetu Warszawskiego,

[Warszawa 1918].

Regulamin egzaminu prawno-historycznego na Wydziale prawa i nauk politycznych

Uniwersytetu Warszawskiego,

[Warszawa 1918].

Regulamin końcowego egzaminu państwowego na Wydziale prawa i nauk politycznych

Uniwersytetu Warszawskiego dla absolwentów nauk prawnych innych uniwersytetów,

[Warszawa 1918].

Skład Uniwersytetu na rok akademicki 1937/1938, Warszawa 1937.

Spis wykładów i wykładajacych $w$ semestrze zimowym 1918/1919 r., Warszawa 1918.

Spis wykładów na rok akademicki 1936 -1937, Warszawa 1936.

Spis wykładów na rok akademicki 1937-1938, Warszawa 1937.

Spis wykładów w semestrze zimowym 1915/1916 $r$. $i$ w semestrze letnim 1916 r., Warszawa 1916 .

Sprawozdanie z działalności Uniwersytetu Warszawskiego za rok akademicki 1922/23, Warszawa 1925 (w tekście jako: SUW 1922/1923).

Sprawozdanie z działalności Uniwersytetu Warszawskiego za rok akademicki 1923/24, Warszawa 1925 (w tekście jako:

SUW 1923/1924).

Sprawozdanie z działalności Uniwersytetu Warszawskiego za rok akademicki 1924/25, Warszawa 1926 (w tekście jako: SUW 1924/1925).

Sprawozdanie z działalności Uniwersytetu Warszawskiego za rok akademicki 1925/26, Warszawa 1927 (w tekście jako: SUW 1925/1926).

Sprawozdanie z działalności Uniwersytetu Warszawskiego za rok akademicki 1927/28, Warszawa 1929 (w tekście jako: SUW 1927/1928).
Sprawozdanie z działalności Uniwersytetu Warszawskiego za rok akademicki 1928/29, Warszawa 1929 (w tekście jako: SUW 1928/1929).

Sprawozdanie z działalności Uniwersytetu Warszawskiego za rok akademicki 1929/30, Warszawa 1930 (w tekście jako: SUW 1929/1930).

Sprawozdanie z działalności Uniwersytetu Warszawskiego za rok akademicki 1930/31, Warszawa 1935 (w tekście jako: SUW 1930/1931).

Sprawozdanie z działalności Uniwersytetu Warszawskiego za rok akademicki 1931/32, Warszawa 1933 (w tekście jako:

SUW 1931/1932).

Sprawozdanie z działalności Uniwersytetu Warszawskiego za rok akademicki 1932/33, Warszawa 1935 (w tekście jako:

SUW 1932/1933).

Sprawozdanie z działalności Uniwersytetu Warszawskiego za rok akademicki 1933/34, Warszawa 1935 (w tekście jako:

SUW 1933/1934).

Sprawozdania z działalności Uniwersytetu Józefa Piłsudskiego $w$ Warszawie za rok akademicki 1934/35 i za rok akademicki 1935-36, Warszawa $193^{6}$ (w tekście jako: SUW 1934/1935 - 1935/1936).

Sprawozdanie z działalności Uniwersytetu Józefa Piłsudskiego za rok akademicki 1936/37, Warszawa 1938 (w tekście jako:

SUW 1936/1937).

Sprawozdanie z działalności Uniwersytetu Józefa Piłsudskiego za rok akademicki 1937/38, Warszawa 1939 (w tekście jako: SUW 1937/1938).

Sprawozdanie z działalności Wydziału Humanistycznego Uniwersytetu Warszawskiego $w$ roku akademickim 1927/1928, Warszawa 1928 (w tekście jako: SWHUM 1927/1928).

Sprawozdanie z działalności Wydziału Humanistycznego Uniwersytetu Warszawskiego w roku akademickim 1933/1934, Warszawa 1935 (w tekście jako: SWHUM 1933/1934).

Sprawozdanie z działalności Wydziału Lekarskiego Uniwersytetu Warszawskiego $w$ roku akademickim 1928/1929, Warszawa 1929 (w tekście jako: SWL 1928/1929). 
Sprawozdanie z działalności Wydziału Lekarskiego Uniwersytetu Warszawskiego w roku akademickim 1929/1930, Warszawa $193^{\circ}$ (w tekście jako: SWL 1929/1930).

Sprawozdanie z działalności Wydziału Lekarskiego Uniwersytetu Warszawskiego w roku akademickim 1930/1931, Warszawa $193^{1}$ (w tekście jako: SWL 1930/1931).

Sprawozdanie z działalności Wydziału Lekarskiego Uniwersytetu Warszawskiego $w$ roku akademickim 1931/1932, Warszawa $193^{2}$ (w tekście jako: SWL 1931/1932).

Sprawozdanie z działalności Wydziału Lekarskiego Uniwersytetu Warszawskiego w roku akademickim 1932/1933, Warszawa 1933 (w tekście jako: SWL 1932/1933).

Sprawozdanie z działalności Wydziału Lekarskiego Uniwersytetu Warszawskiego w roku akademickim 1933/1934, Warszawa 1935 (w tekście jako: SWL 1933/1934).

Sprawozdanie z działalności Wydziału Lekarskiego Uniwersytetu Warszawskiego $w$ roku akademickim 1934/1935, Warszawa 1936 (w tekście jako: SWL 1934/1935).

Sprawozdanie z działalności Wydziału Lekarskiego Uniwersytetu Józefa Piłsudskiego $w$ Warszawie $w$ roku akademickim 1935/1936, Warszawa 1937 (w tekście jako: SWL 1935/1936).

Sprawozdanie z działalności Wydziału Lekarskiego Uniwersytetu Józefa Piłsudskiego $w$ Warszawie $w$ roku akademickim 1936/1937, Warszawa 1938 (w tekście jako: SWL 1936/1937).

Sprawozdanie z działalności Wydziału Lekarskiego Uniwersytetu Józefa Piłsudskiego $w$ Warszawie $w$ roku akademickim 1937/1938, Warszawa 1939 (w tekście jako: SWL 1937/1938).

Sprawozdanie z działalności Wydziału Prawa Uniwersytetu Warszawskiego za rok akademicki 1927/1928, Warszawa 1929 (w tekście jako: SWP 1927/1928).

Statut tymczasowy Uniwersytetu Warszawskiego, Warszawa 1917.

Statut tymczasowy Uniwersytetu Warszawskiego i ustawy tymczasowe wydziałów, Warszawa 1915.
Statut Uniwersytetu Warszawskiego i ustawy wydziałów, Warszawa 1916 .

Ustawa tymczasowa wydziału teologicznego Uniwersytetu Warszawskiego,

[Warszawa] 1918.

Vorschriften für die Studierenden an der Universität zu Warschau, [Warschau 1916].

Wskazówki dotyczace studiów na wydziale prawa i nauk państwowych, [Warszawa 1917].

\section{Inne publikacje z epoki}

Bartel K., Przemówienie w Senacie przy budżecie Ministerstwa Wyznań Religijnych i Oświecenia Publicznego $w$ dniu 13 marca 1939 r., Warszawa 1939.

[Beseler von H.], Mowa jenerat-gubernatora..., Warszawa, Zamek, dnia 15 grudnia $1916 \mathrm{r}$. Stenogram urzędowy. Przekład urzędowo uwierzytelniony, [Warszawa 1916].

Brudziński J., Otwarcie Uniwersytetu Warszawskiego. Dnia 15 listopada 1915 roku. Mowa Rektora doktora medycyny..., [Warszawa] 1916.

Brudziński J., W sprawie organizacji ogólnej Uniwersytetu, a Wydziału Lekarskiego w szczególności, Warszawa 1915 .

Brudziński J., Wykłady propedeutyki lekarskiej $w$ Uniwersytecie Warszawskim $w$ przeszłości $i$ zadanie ich w chwili obecnej. Wykład wstepny $z$ propedeutyki lekarskiej $w$ dn. 1 kwietnia 1916 r., Warszawa 1916.

Handelsman M., Polska katedra historii powszechnej $w$ Warszawie, b.m. i r.w.

Handelsman M., $Z$ papierów rektora Brudzińskiego, [Warszawa 1928].

Handelsman M., Założenie Uniwersytetu $w$ Warszawie. W setna rocznice jego inauguracji. Odczyt wygłoszony 14 maja 1918 roku w Pałacu Kazimierzowskim, Zamość 1919.

Jasiński S., Kilka uwag o gruźlicy $i$ jej zwalczaniu wśród młodzieży akademickiej w Polsce, [w:] XX lat pracy Koła Medyków S.S.S.M.U.J.P. $w$ Warszawie 1915-1935, red. M. Pertkiewicz, Warszawa 2011. 
Katelbach T., Strajk akademicki $w$ Warszawie 1917, Warszawa 1938.

Kądziałkiewicz E., Praca samopomocowa, [w:] XX lat pracy Koła Medyków S.S.S.M.U.J.P. $w$ Warszawie 1915-1935, red. M. Pertkiewicz, Warszawa 2011.

Kronika Naukowa, „Kwartalnik Historyczny” 3-4/1946.

Kurcyusz J., Sprawozdanie za rok 1931/1932. Towarzystwo „Bratnia Pomoc" Studentów Uniwersytetu Warszawskiego, Warszawa $193^{2}$.

Kutrzeba T., Uniwersytety Warszawskie. Odczyt wygłoszony na uroczystym zebraniu prof[esorów] Uniw[ersytetu] Jagiell[ońskiego $w$ auli Coll[egium] Nowi 15 listopada 1915 r. jako $w$ dn[iu] ponownego otwarcia Uniwersytetu $w$ Warszawie, Kraków 1915 .

Mały rocznik statystyczny 1939, Warszawa 1939.

Obertyński Z., Wskrzeszenie Warszawskiego Wydziału Teologicznego. (Na podstawie kroniki Uniwersytetu i materiałów archiwalnych), Warszawa 1938.

Ogólne przepisy dla stowarzyszeń studenckich na Uniwersytecie i Politechnice $w$ Warszawie, Warszawa 1916 .

Ogólne przepisy dla stowarzyszeń studenckich na Uniwersytecie Warszawskim,

[Warszawa 1917].

Organizacja życia akademickiego. Informator. Rok akademicki 1932/33, red. J. Paprocki, Warszawa 1933 .

Organizacja życia akademickiego. Przewodnik, Warszawa 1927.

Orłowski S., W sprawie Instytutów Wydziału Lekarskiego Uniwersytetu Warszawskiego. Uwagi i dezyderaty, Warszawa-Lublin-Łódź 1915 .

Otwarcie Uniwersytetu i Politechniki $w$ Warszawie 1915, [Warszawa-Warschau 1915].

Pertkiewicz M., Od Sekcji W.F. do Referatu Obozów $i$ W.F., [w:] XX lat pracy Koła Medyków S.S.S.M.U.J.P. w Warszawie 19151935, red. M. Pertkiewicz, Warszawa 2011.

Poray J., Kilka uwag w sprawie Wydziału Teologicznego na Uniwersytecie Warszawskim, Warszawa 1915 .
Prauss K., W sprawie realizacji powszechnego nauczania $w$ Królestwie Polskim, WarszawaLublin-Łódź-Poznań [1917].

Projekt statutu dla Uniwersytetu Warszawskiego. Opracowany przez Komisje ministerialna w r [oku] 1918, [Warszawa] 1918.

Prószyński M., Sprawozdanie z działalności T-wa Bratnia Pomoc Studentów Uniwersytetu Warszawskiego. Złożył za okres 25 II 1929 1 II 1930 Mieczysław Prószyński, Warszawa 1930.

Rabski J., Na drodze walki o dusze młodego pokolenia. Stenogram odczytu uzupetniony aneksem z dokumentami, Warszawa 1936.

Regulamin dla członków Studenckiej Kasy chorych Uniwersytetu Warszawskiego, [Warszawa 1916].

Regulamin dla lekarzy Studenckiej Kasy chorych Uniwersytetu Warszawskiego, [Warszawa 1918].

Rocznik Polityczny i Gospodarczy 1939, Warszawa 1939 .

Rozporzaddzenie wykonawcze co do przyjmowania słuchaczów nadzwyczajnych do Uniwersytetu Warszawskiego, jako uzupetnienie paragr[afu] ${ }_{3} 6$ Statutu Tymczasowego Uniwersytetu Warszawskiego, [Warszawa 1918].

Sas-Wisłocki J., Akademicki kodeks honorowy, Warszawa 1934 .

Skokowska-Rudolfowa M., Odpowiedzialność i partnerstwo, [w:] XX lat pracy Koła Medyków S.S.S.M.U.J.P. $w$ Warszawie 1915-1935, red. M. Pertkiewicz, Warszawa 2011.

Statut tymczasowy Studenckiej Kasy chorych Uniwersytetu Warszawskiego, [Warszawa 1916].

Stołyhwo K., I. Muzeum Antropologiczne $w$ Warszawie. II. Sprawozdanie ze stanu Gabinetu Archeologicznego Uniwersytetu Warszawskiego w r. 1915, Warszawa 1917.

Szczuciński W., Członkowie Koła Medyków w ubiegtym dwudziestoleciu, [w:] XX lat pracy Koła Medyków S.S.S.M.U.J.P. w Warszawie 1915-1935, red. M. Pertkiewicz, Warszawa 2011.

Szenajch W., Rektor Józef Brudziński ${ }_{15}$ XI 1915. Wszechnicy Warszawskiej Księga pamiatkowa. Zbiór prac z dziedziny patologii dziecięcej wspólpracowników dr. med. Józefa Brudzińskiego, Warszawa 1916. 
Szlagowski A., Mowa wypowiedziana podczas uroczystego nabożenstwa w Królewskiej Katedrze Metropolitalnej z powodu otwarcia Uniwersytetu i Politechniki Warszawskiej dnia 15 listopada 1915 r., Warszawa 1915.

Tatarkiewicz W., $Z$ dziejów filozofii na Wszechnicy warszawskiej (Pierwszy wykład na Uniwersytecie warszawskim 18 listopada 1915 roku), Warszawa 1916.

Wesołowski S., Życie towarzyskie na medycynie, [w:] XX lat pracy Koła Medyków S.S.S.M.U.J.P. $w$ Warszawie 1915-1935, red. M. Pertkiewicz, Warszawa 2011.

Wiechecki S., Czaszka w rondlu, czyli opowiadania sqdowe, Kraków 2007.

Wittlinowa H., Atlas szkolnictwa wyższego, Warszawa 1937.

Wykaz imienny docentów według stanu z dnia 31 grudnia 1937 r., Warszawa 1938.

Wykaz prac z działu nauk matematyczno-przyrodniczych wykonanych $w$ Polsce $w$ okresie okupacji niemieckiej 1939-1945, Kraków 1947.

\section{Dzienniki, pamiętniki, wspomnienia}

Antoniewicz W., Studia $w$ zakresie archeologii przedhistorycznej $i$ wczesnodziejowej $w$ tajnym Uniwersytecie Warszawskim podczas okupacji niemieckiej, „Biuletyn Historii Sztuki

i Kultury" 1-2/1946.

Barański J., Lata młodości i walki, London [1983]

Bielecki T., W szkole Dmowskiego, Gdańsk 2000.

Bobrowski Cz., Wspomnienia ze stulecia, Lublin 1985 .

Borowy W., Okres Powstania $1944 r$. $w$ Bibliotece Uniwersyteckiej $w$ Warszawie. Relacja Bohdana Korzeniewskiego spisana przez Waclawa Borowego, Warszawa 1965.

Borowy W., Z zapisek Borowego (1944-1945), oprac. Z. Stefanowska, [w:] Walka o dobra kultury 1939-1945. Warszawa 1939-1945, red. S. Lorentz, t. II, Warszawa 1970.
Brandys K., Miesiace 1978-1981, Warszawa 1997.

Chowałem sie za plecami Kopernika. $Z$ prof. Januszem Paszyńskim rozmawia dr Robert Gawkowski, „Uniwersytet Warszawski" 2/2010.

Dobrzański A., Tajne nauczanie i praca naukowa w Klinice Otolaryngologicznej Uniwersytetu Warszawskiego w czasie okupacji niemieckiej, „Otolaryngologia Polska” 1/1947.

Fizycy wspominają. Zbiór 25 rozmów i wspomnień fizyków polskich opublikowanych pierwotnie w "Postepach Fizyki"

i $w$ „Kwartalniku Historii Nauki i Techniki”, red. A.M. Kobos, Kraków 2014.

Garliński J., Świat mojej pamięci, Warszawa 1998.

Giedroyc J., Autobiografia na cztery rece, Warszawa 1999 .

Gieysztor A., Środowisko historyczne Warszawy $w$ okresie miedzywojennym, [w:] Nauka i szkolnictwo wyższe w Warszawie, red. J. Kazimierski i in., Warszawa 1987 .

Goetel F., Czas wojny, Londyn 1955.

Gombrowicz W., Kronos, Kraków 2013.

Gombrowicz W., Wspomnienia polskie. Wędrówki po Argentynie, Kraków 1996

Gomulicki J. W., „Diabeł i zboże”, [w:] Walka o dobra kultury 1939-1945. Warszawa 19391945, red. S. Lorentz, t. II, Warszawa 1970.

Grupińska A., 12 opowieści żydowskich, Wołowiec 2013.

Hertz A., Wyznania starego człowieka, Warszawa 1991.

Hirszfeld L., Historia jednego życia, Kraków 2011.

Hutten-Czapski B., Sześćdziesiąt lat życia politycznego $i$ towarzyskiego, Warszawa 1936.

Jabłoński T., Młodość mego pokolenia, Warszawa 1977.

Jarocki R., Rozmowy z Lorentzem, Warszawa 1981.

Jarra E., Wspomnienia o Uniwersytecie Warszawskim 1915-1939, Londyn 1972. 
Jażdżewski K., Pamiętniki. Wspomnienia polskiego archeologa $w X X$ wieku, Łódź 1995.

Jędrzejewicz W., Wspomnienia, oprac. J. Cisek, Wrocław 1993 .

Kamieńska M., Ścieżkami wspomnień, Warszawa 1960.

Kamiński A., Diariusz podręczny 1939-1945, oprac. A. Palarczykowa, J. Stoksik, Warszawa 2001.

Kasznica S.W., Druga wojna światowa. Wspomnienia spisane na podstawie codziennych notatek, wstęp i opracowanie M. Szczesiak-

-Ślusarek, Warszawa-Poznań 2013.

Katelbach T., Spowiedź pokolenia, Gdańsk 2001.

Klukowski Z., Zamojszczyzna, t. I, 1918-1943, Warszawa 2008.

Koniński K.L., Uwagi 1940-1942, Poznań 1987.

Koprowska I., O moim życiu i medycynie. Wspomnienia, Poznań 1998.

Kossmann O., Es begann in Polen. Erinnerungen eines Diplomaten und Ostforschers, Marburg 1995.

Krzywicka I., Wyznania gorszycielki, Warszawa 1995 .

Krzywicki L., Wspomnienia, t. III, Warszawa 1959 .

Kula W., Dziennik czasu okupacji, oprac. N. Assorodobraj-Kula i M. Kula, Warszawa 1994.

Kuratowski K., Notatki do autobiografii, Warszawa 1981.

Kutrzeba S., Królestwo i Galicya. Uwagi z czasów wojny, Warszawa-Kraków 1917.

Leszek Raabe we wspomnieniach przyjaciót, Warszawa 1963 .

Lorentz S., Zapiski do autobiografii, „Kwartalnik Historii Nauki i Techniki” 4/1979.

Łazowski E.S., Prywatna wojna. Wspomnienia lekarza-żołnierza 1933-1944, Warszawa 1993.
Łodyński M., Pruszkowska akcja zabezpieczania warszawskich zbiorów bibliotecznych (1944-1945). Wspomnienia uczestnika akcji, [w:] Walka o dobra kultury 1939-1945. Warszawa 1939-1945, red. S. Lorentz, t. I, Warszawa 1970.

Eowicki Judym. Pamiętniki doktora Stanisława Rotstada oraz wspomnienia przyjaciót, red. H. Dusińska i J. Kapuścik, Warszawa 1998.

Manteuffel T., Moja praca $w$ Archiwum Akt Nowych podczas okupacji, [w:] Walka o dobra kultury 1939-1945. Warszawa 1939-1945, red. S. Lorentz, t. I, Warszawa 1970.

Matuszewski R., Chmury na pogodnym niebie, Warszawa 1998.

Michalski Z.A., Przez okopy, alkowy... do medycyny. Pamiętniki, t. I-II, Warszawa $199^{2}$.

Michałowski K., Wspomnienia, Warszawa 1986.

Moczarski K., Zapiski, wstęp, wybór tekstów i oprac. A.K. Kunert, Warszawa 1990.

[Moszczeńska I.], Przyczynek do dziejów odrodzenia Uniwersytetu Warszawskiego w latach 1915-1918 (odbicie w listach ...), oprac. J. Rzepecki, „Roczniki Uniwersytetu Warszawskiego", t. VIII (1968-1969).

Orłowski W., Tajne nauczanie chorób wewnętrznych na Wydziale Lekarskim Uniwersytetu Warszawskiego, w szczególności w II Klinice Chorób Wewnętrznych w latach 1939-1945, „Polski Tygodnik Lekarski” $25 / 1946$.

Pajewski J., Przeszłość z bliska. Wspomnienia, Warszawa 1983 .

Pieńkowski S., Nauka polska w czasie okupacji, „Przegląd Historyczno-Oświatowy" 1/1947.

Piwocki K., Prace polskich historyków sztuki w czasie wojny, „Biuletyn Historii Sztuki i Kultury" 3-4/1946.

Pniewski J., Wspomnienia autobiograficzne, "Kwartalnik Historii Nauki i Techniki” 33/1988.

Podkowińska Z., Fragmenty pamiętnika, [w:] Dzieje archeologii na Uniwersytecie Warszawskim, red. S.K. Kozłowski, J. Kolendo, Warszawa 1993. 
Przetakiewicz Z., Od ONR-u do PAX-u. (Wspomnienia), Warszawa 1994.

Radożycki J., Aby o nich nie zapomniano. Wspomnienia, Szczecin 2007.

Roguski J., Tajne nauczanie studentów medycyny $w$ latach 1939-1944 w Oddziale Chorób Wewnętrznych Szpitala Wolskiego $w$ Warszawie, „Polski Tygodnik Lekarski” 5/1946.

Rosen-Przeworska J., Moje uniwerki, czyli o archeologii z epoki przedhistorycznej, [w:] Dzieje archeologii na Uniwersytecie Warszawskim, red. S.K. Kozłowski, J. Kolendo, Warszawa 1993.

Rutkowska-Kurcyuszowa M., Kamyki Dawida. Wspomnienia, Katowice 2005.

Rutkowski J., Tajne nauczanie studentów medycyny podczas okupacji niemieckiej (1939-1944) w I i II Oddziale Chirurgicznym Szpitala Dzieciątka Jezus w Warszawie, „Polski Tygodnik Lekarski” 4,8/1946.

Siła-Nowicki W., Wspomnienia i dokumenty, t. 1, Wrocław 2002.

Sobański A., Cywil w Berlinie, Warszawa 2006.

Swieżawski W., Wielki przełom 19o7-1945,

Lublin 1989 .

Śpiewak J., Przyjaźnie i animozje, Warszawa 1965 .

Tatarkiewiczowa T., Tatarkiewicz W., Wspomnienia - Zapiski do autobiografii, Poznań 2011.

Tymiński J., Pisane o zmierzchu. Wspomnienia z lat 1924-1985, Warszawa 1988.

Wasiutyński W., Prawa strone labiryntu, Gdańsk 1996.

Wesołowski S., Od kabaretu do skalpela i lazaretu, Warszawa 2006.

Wydział Prawa $w$ relacjach $i$ wspomnieniach pracowników naukowych $i$ studentów (1918-1950) [= „Studia Iuridica” t. 17], Warszawa 1990.

Wyka K., Gospodarka wyłaczona, [w:] Życie na niby. Pamiętnik po klęsce, Kraków 1984.
Zaściński J., Pieśń o Warze, Warszawa 1999.

Zbyszewski K., Niemcewicz od przodu i tyłu, Warszawa 1999 .

Żongołłowicz B., Dzienniki 1930-1936, Warszawa 2004 .

Żukowska T., Na skraju dwóch światów... Wspomnienia 1939-1953, Warszawa 2000.

\section{Opracowania}

75 lat fizyki na Hożej, red. M. Kicińska-Habior, A.K. Wróblewski, Warszawa 1996.

Bartoszewski W., Lata wojenne Stanisława Herbsta, [w:] Na drodze do niepodległości, Paryż 1987 .

Biblioteka Uniwersytecka $w$ Warszawie w latach 1945-1980, red. A. Mężyński, współprac. A. Bednarz, Warszawa 1998.

Biblioteki naukowe w Generalnym Gubernatorstwie w latach 1939-1945. Wybór dokumentów źródłowych, wybór i oprac. A. Mężyński, współpraca H. Łaskarzewska, Warszawa 2003.

Bines J., The Polish Country Section of the Special Operations Executive 1940-1946: A British Perspective, praca doktorska złożona na University of Stirling, 2004.

Birkenmajer A., Co władze okupacyjne wiedzialy o polskim tajnym nauczaniu $w$ tzw. Generalnej Guberni?, „Przegląd Historyczno-Oświatowy" 1/1947.

Cegielski J., Stosunki mieszkaniowe $w$ Warszawie $w$ latach $1864-1964$, Warszawa 1968 .

Dzieje archeologii na Uniwersytecie Warszawskim, red. S.K. Kozłowski, J. Kolendo, Warszawa 1993 .

Dzieje Uniwersytetu Warszawskiego 1807-1915, red. S. Kieniewicz, Warszawa 1981.

Dzieje Uniwersytetu Warszawskiego 1915-1939, red. A. Garlicki, Warszawa 1982.

Dzieje warszawskiego Wydziału

Farmaceutycznego, red. J. Pachecka,

J. Kowalski, P. Tomaszewski, Warszawa 2001. 
Fuks M., $\dot{Z} y d z i w$ Warszawie. Życie codzienne. Wydarzenia. Ludzie, Poznań-Daszewice 1992.

Gadomski J., Budowa pierwszego w Polsce wysokogórskiego Obserwatorium im. Marszałka J. Piłsudskiego $w$ Czarnohorze, „Urania” 1/1938.

Gadomski J., Losy obserwatorium astronomicznego Uniwersytetu Warszawskiego podczas wojny polsko-niemieckiej i okupacji niemieckiej (1939-1944), „Urania. Czasopismo Astronomiczne Popularno-Naukowe" 1-2/1946.

Gralak B., Szkolnictwo wyższe i nauka polska pod okupacja niemieckq i radziecka 1939-1945, Zgierz 2010.

Grochowska M., Wytraceni z milczenia, Warszawa 2005 .

Heise A., Der VDH Warschau 1926-1939, [w:] Die Vereine Deutscher Hochschüler in Polen 1922-1939, red. T. Bierschenk, Hannover 1988.

Jaczewski B., Nauka i szkolnictwo wyższe 1918 - 1939, [w:] Historia Polski, red. C. Madajczyk, t. IV: 1918-1939, red. T. Jędruszczak, Warszawa 1978.

Jarocki R., Sztuka i krew 1939-1945. Opowieść o ludziach $i$ zdarzeniach, Warszawa 2012.

Jarocki R., Widzieć jasno bez zachwytu, Warszawa 1982 .

Jaroszewski T.S., Architektura Uniwersytetu Warszawskiego, Warszawa 1991.

Kaczorowski B., Lis T., Uniwersytet Warszawski. Przewodnik historyczny, Warszawa 1983 .

Kałwa D., Model kobiety aktywnej zawodowo $w$ Polsce międzywojennej, [w:] Kobieta i praca. Wiek XIX $i$ XX. Zbiór studiów, red. A. Żarnowska, A. Szwarc, Warszawa 2000.

Kapuściński W., Stefan Pieńkowski 28 VII 1883-20 XI 1953, „Postępy Fizyki” $6 / 1963$.

Kolendo H., Kadra naukowa Uniwersytetu Warszawskiego w latach 1915-1939. Praca doktorska napisana pod kierunkiem prof. dr hab. Ireny Pietrzak-Pawłowskiej, Warszawa 1979 .

Kolendo H., Odrodzenie Uniwersytetu Warszawskiego $w$ roku 1915. Pierwszy skład wyktadajacych, „Roczniki Uniwersytetu Warszawskiego" 13/1973.
Kollegen, Kommiltonen, Kämpfer. Europäische Universitäten im Ersten Weltkrieg, red. T. Maurer, München 2006.

Konarski K., Dzieje szkolnictwa $w$ b [ylym] Królestwie Kongresowym 1915-1918, Kraków-Warszawa 1923.

Kozłowski K., Powojenni nestorzy gdańskiej fizyki. Ignacy Adamczewski (1907-2000), "Pismo Politechniki Gdańskiej” 4/2004.

Kozłowski S.K., Włodzimierz Antoniewicz, profesor z Warszawy, Warszawa 2009.

Król E.C., Grabież polskich szkół wyższych w okresie okupacji hitlerowskiej, „Przegląd Historyczny" 3/1979.

Kula M., Autoportret rodziny X. Fragment żdowskiej Warszawy lat międzywojennych, Warszawa 2007.

Kula M., Sprawa docenta Rajchmana, [w:] Rozdział wspólnej historii. Studia z dziejów $\dot{Z} y$ dów $w$ Polsce ofiarowane profesorowi Jerzemu Tomaszewskiemu $w$ siedemdziesiata rocznice urodzin, Warszawa 2001.

Krzemiński Z., Historia warszawskiej adwokatury, Warszawa 2005.

Krzyżanowski J., $Z$ dziejów wojennych polonistyki, "Przegląd Historyczno-Oświatowy” 3/1960.

Kultura artystyczna Uniwersytetu Warszawskiego. Ars et educatio, oprac.

J. Miziołek, Warszawa 2003.

Lenczewski M., Studium Teologii

Prawosławnej na Uniwersytecie Warszawskim w latach 1925-1939, Warszawa 1992.

Lipski J.J., Antysemityzm ONR-Falangi, [Warszawa 1985].

Ludzie nauki i nauczyciele polscy podczas II wojny światowej. Ksiega strat osobowych, Warszawa 1995 .

Łuczak C., Losy polskiej nauki i nauczania akademickiego w okresie hitlerowskiej okupacji, Poznań 1981.

Madajczyk C., Polityka III Rzeszy

$w$ okupowanej Polsce, Warszawa 1970. 
Majewski P., Akcja pruszkowska. Ochrona zbiorów kulturalnych $w$ powstaniu warszawskim i po jego upadku, „Rocznik Warszawski" 2004.

Majewski P., Kolaboracja, której nie było... Problem postaw społeczeństwa polskiego $w$ warunkach okupacji niemieckiej 1939-1945, „Dzieje Najnowsze" 4/2004.

Majewski P., Z frontu walki cywilnej. Przyczynek do dziejów Kierownictwa Walki Cywilnej i Kierownictwa Walki Podziemnej na obszarze Generalnego Gubernatorstwa w latach 1939-1945, "Kwartalnik Historyczny” $4 / 2012$

Makowiecki T., Warszawska Biblioteka Uniwersytecka 1939-1944, Frankfurt am Main 1947.

Manteuffel T., Kronika odbudowy Instytutu Historycznego $U W 1945 / 46-1947 / 48$, „Roczniki Uniwersytetu Warszawskiego” $195^{8}$.

Manteuffel T., Rola Marcelego Handelsmana $w \dot{z} y c i u$ naukowym Warszawy, „Przegląd Historyczny" 1/1959.

Marszalec J., Morderstwo na Makowieckich $i$ Widerszalu. Stara sprawa, nowe pytania, nowe wątpliwości, ,Zagłada Żydów. Studia i Materiały" 2/20o6.

Meller B., U Lourse'a, „Almanach Muzealny” 1/1997.

Mężyński A., Biblioteki Warszawy w latach 1939-1945, Warszawa 2010.

Mężyński A., Kommando Paulsen, październikgrudzień 1939 r., Warszawa 1994.

Mikulaszek E., Ernest Sym (1893-1950).

Wspomnienie pośmiertne, „Rocznik

Towarzystwa Naukowego

Warszawskiego" 43/1950.

Millak K., Uczelnia Weterynaryjna $w$ Warszawie $1840-1965$, Warszawa 1965 .

Miziołek J., Uniwersytet Warszawski. Dzieje i tradycja, Warszawa 2005.

Muszyński W. J., Duch młodych. Organizacja Polska i Obóz Narodowo-Radykalny $w$ latach 1934-1944. Od studenckiej rewolty do konspiracji niepodległościowej, Warszawa 2011.
Mycielska D., Postawy polityczne profesorów wyższych uczelni $w$ dwudziestoleciu międzywojennym, [w:] Inteligencja polska $w X I X i X X$ wieku. Studia, t. IV, red. R. Czepulis-Rastenis, Warszawa 1985.

Natkowska M., Numerus clausus, getto ławkowe, numerus nullus, „paragraf aryjski”. Antysemityzm na Uniwersytecie Warszawskim 1931-1939, Warszawa 1999.

Pilch A., "Rzeczpospolita akademicka”. Studenci i polityka 1918-1933, Kraków 1997.

Pleskaczyńska M., Struktura społeczna młodzieży $U W w$ okresie międzywojennym (na podstawie danych $z$ roku akademickiego 1934/1935), „Roczniki Uniwersytetu Warszawskiego" 2/1971.

Poznańska B., Środowisko lekarskie II Rzeczpospolitej, [w:] Inteligencja polska XIX $i$ XX wieku. Studia, t. VI, red. R. Czepulis-Rastenis, Warszawa 1991.

Rudnicki S., Obóz Narodowo Radykalny. Geneza i działalność, Warszawa 1985.

Sawicka S., Gabinet Rycin Biblioteki Uniwersyteckiej $w$ Warszawie w latach 19391949, „Biuletyn Historii Sztuki” 3-4/1949.

Sokołowska W., Dzieje Biblioteki Uniwersytetu Warszawskiego 1939-1945, Warszawa 1960.

Stanisław Herbst. Historyk i regionalista, red. J. Kazimierski, Warszawa 1996.

Stawowy E., Dylematy i wybory ideowe Bogdana Suchodolskiego, "Annales Universitatis Paedagogicae Cracoviensis. Studia Politologica" 9/2013.

Stebelski A., Losy archiwów polskich w latach wojny 1939-1945, „Rocznik Warszawski” 1963.

Straty archiwów i bibliotek warszawskich $w$ zakresie rękopiśmiennych źródeł historycznych, t. II: Archiwa porozbiorowe $i$ najnowsze, Warszawa $195^{6}$.

Suchodolski W., Straty archiwów warszawskich w czasie wojny i okupacji, „Kwartalnik Historyczny" 3-4/1946.

Symonowicz A., Wspomnienia z tajnego Wydziału Prawa Uniwersytetu Warszawskiego w okresie okupacji, „Palestra” 3-4/1958. 
Szarota T., Okupowanej Warszawy dzień powszedni. Studium historyczne, Warszawa 2010.

Szpakowska M., „Wiadomości Literackie” prawie dla wszystkich, Warszawa 2012.

Ścisłowski W.M., Czesław Białobrzeski (1878-1953), „Postępy Fizyki” 4/1954.

Śródka A., Odrodzony Uniwersytet Warszawski, [w:] Dzieje nauczania medycyny i farmacji $w$ Warszawie (1789-1950), red. M. Łyskanowski, A. Stapiński, A. Śródka, Warszawa 1990.

Tomaszewski P., Polskie korporacje akademickie w latach 1918-1939. Struktura, myśl polityczna, działalność, Toruń 2011.

Tradycje i współczesność. Ksiegga pamiątkowa Instytutu Historycznego Uniwersytetu Warszawskiego 1930-2005,

Warszawa 2005.
Uniwersytet Warszawski 1808-1818-1958. Universitas Varsoviensis 1808-1818-1958, red. A. Gieysztor, M. Strzemieński, Warszawa 1958.

Walczak M., Szkolnictwo wyższe i nauka polska w latach wojny i okupacji 1939-1945, Wrocław 1978 .

Wróblewski A.K., 75 lat fizyki na Hożej, „Wiedza i Życie” 1/1996.

$Z$ dziejów podziemnego Uniwersytetu Warszawskiego, Warszawa 1961.

Zahorski A., O Ludwiku Widerszalu (19o9-1944), „Kronika Warszawy” 2/1980.

Ziółkowska Z., Fizyka teoretyczna $w$ Polsce do 1939 r.: geneza i rozwój, „Kwartalnik Historii Nauki i Techniki” 2/1987.

Żarnowski J., Praca zawodowa kobiet $w$ Polsce międzywojennej, [w:] Kobieta i praca. Wiek $X I X i X X$. Zbiór studiów, red. A. Żarnowska, A. Szwarc, Warszawa 2000. 


\section{Noty o Autorach}

Dr Marek Piotr Deszczyński (ur. 1967), pracuje w Instytucie Historycznym UW. Zainteresowania naukowe: historia najnowsza, szczególnie dzieje II Rzeczypospolitej, historia wojskowa, gospodarcza, dyplomatyczna i kultury. Najważniejsze publikacje: Ostatni egzamin. Wojsko Polskie wobec kryzysu czechosłowackiego 1938-1939, Warszawa 2003; Na krawędzi ryzyka. Eksport polskiego sprzętu wojskowego w okresie międzywojennym, Warszawa 2004 (współautor); Kampania polska 1939. Polityka - społeczeństwo - kultura, t. 1-2, Warszawa 2013-2014 (współautor i współredaktor).

Prof. dr hab. Tomasz Kizwalter (ur. 1955), pracuje w Instytucie Historycznym UW. Zainteresowania naukowe: historia idei i społecznych wyobrażeń w XIX i XX w. Najważniejsze publikacje: O nowoczesności narodu. Przypadek polski, Warszawa 1999; Historia powszechna. Wiek $X I X$, Warszawa 2003.

Dr hab. Piotr Majewski (ur. 1971), dyrektor Narodowego Instytutu Muzealnictwa i Ochrony Zbiorów, redaktor naczelny rocznika „Muzealnictwo", profesor nadzwyczajny na Wydziale Nauk Humanistycznych Uniwersytetu Kardynała Stefana Wyszyńskiego w Warszawie. Autor m.in.: Wojna i kultura. Instytucje kultury polskiej $w$ okupacyjnych realiach Generalnego Gubernatorstwa 1939-1945 (2005), Ideologia i konserwacja. Architektura zabytkowa w Polsce w czasach socrealizmu (20og).

Dr hab. Piotr Maciej Majewski (ur. 1972), pracuje w Instytucie Historycznym UW. Zainteresowania naukowe: historia najnowsza Europy Środkowej, szczególnie zaś stosunki czesko-niemieckie w XIX i XX w. oraz kultura pamięci w Polsce i Czechach po 1945 r. Najważniejsze publikacje: Edvard Beneš i kwestia niemiecka w Czechach, Warszawa 2001; „Niemcy sudeccy" 1848-1948. Historia pewnego nacjonalizmu, Warszawa 2007. 


\section{Indeks nazwisk*}

\author{
Abb Gustav 497 \\ Adamczewski Ignacy 473, 529 \\ Adamczewski Stanisław $45^{1}$ \\ Ajdukiewicz Kazimierz 291, 292, 382 \\ Aleksander I Romanow 337 \\ Altenberger Stanisław 530 \\ Anc Dominik 409 \\ Anders Władysław 234 \\ Andrzejewski Marek 4,15 \\ Andrzejewski Stanisław 500 \\ Angelescu Constantin 391 \\ Antoniewicz Włodzimierz 57, 67, 86, 87, 98, \\ $106,148,220,256,268,270,271,273,292$, \\ $293,296,304,309,316,3^{20-322}, 372,377$, \\ $3^{82}, 3^{85}, 386,388,3^{89}, 39^{2}, 406,4,20,422$, \\ $4.27,437,441,462,463,465,485,493,494$, \\ $503,526-529,53^{2}$
}

Antosiewicz Maciej 47

Apfelbaum Emil 483

Appel Karol 76, $3^{82}$

Apuchtin Aleksander 335

Arnaudies Jacques 130, 306

Arnold Stanisław 66, 271, 382

Arystoteles 455

Askenazy Regina 163, 187, 309

Askenazy Szymon 76, 82-84, 90, 278, 321, 363

Assorodobraj-Kula Nina 525

Asterblum Cywja 269, 320

August Jochen 4,8

Bacciarelli Marceli $53^{2}$

Băcioiu Ilie 130, 306

Bacon Francis 434

Baczyński Krzysztof Kamil 4,29

Baehr Wacław 382
Bahr Ernst 130, 306

Bakuniński Józef $3^{12}$

Balabanović Dimitrije 306

Balcerak Wiesław 4,20

Baley Stefan 78, 91, 271, 302, 4.57, 458

Balicki Zygmunt 218

Balzer Oswald 391

Bałaban Majer 9o, 498, 507

Banachiewicz Tadeusz $39^{1}$

Bandel Przemysław 47

Banko Tadeusz 322

Baraniewski Waldemar 4,14

Barański Jan 266, 267, 281, 320, 322

Bartczak Maria 467

Bartel Kazimierz 122, 124, 147, 236, 237, 305, $307,3^{17}, 353,374,383,419$

Bartołd Robert 49

Bartoszek Tadeusz 479, 4,80

Bartoszewski Władysław 525

Bassalik Kazimierz 319, 382, 493

Batawia Stanisław 199

Batowski Zygmunt 382, 395, 398, 4.23, 434, $53^{2}$

Baudouin de Courtenay Jan 382, 391, 396, 4,23

Baudouin de Courtenay Jędrzejewiczowa Cezaria $93,95,417$

Bayer Witold 316, 317

Bąbała Jerzy $47^{\circ}$

Beaulieux Solange 130, zo6

Beck Józef 175, 273, 274, 389, 390-392, 4.24

Bednarz Anna 533

Begin Menachem 166-168, 309

Berencwajg Dawid 176, 310

Berenson Leon 320

Berezowski Cezary 3oo, 447, 525, 527

Berman Jakub 282, 322

* Indeks nie obejmuje aneksów. 
Bernhard Maria 469

Berthélemy Henri 391

Beseler Georg von $33^{2}$

Beseler Hans von 66, 326, 331, 332, 336, 339, $34,2-34,5,4,13$

Bethmann-Hollweg Theobald von 326

Białaszewicz Kazimierz 382

Białobrzeski Czesław 382, 472-474

Bielecki Tadeusz 226, 252, 316, 323

Biernacki Andrzej 481

Biernacki Henryk 309

Bieżuńska Izabela 271

Bigo Tadeusz 4.47

Bilczewski Józef 390, 391

Bines Jeffrey 306

Birkenmajer Aleksander $53^{2}$

Blüth Rafał 278

Błeszyński Eugeniusz 4,82

Bobrowski Czesław 316

Bobrowski Zygmunt 349

Boczyński Stanisław 321, 323

Bogajewski Mitrofan 409

Bogucki Mieczysław 504

Bojarski Wacław 456

Bojemski Aleksander 403

Bolechowski Feliks 4,81

Bolewski Andrzej 535

Bonfante Pietro $39^{1}$

Borejsza Jerzy 282

Borel Émile 391

Borowski Stanisław 4.47, 4.52, 453, 463

Borowy Wacław 81, 82, 84, 86, 87, 97, 99, 106, $107,241,276,301,303,304,318,319,3^{21}$, $3^{22}, 39^{2}, 39^{8}, 427,45^{\circ}, 453,454,490,498$, $502,528,533,534$

Borsuk Karol 474

Bortnowski Władysław 234

Borys III Koburg 390, 391

Boszko Ryszard 309

Bourgeois Émile $39^{1}$

Brandys Kazimierz 162, 163, 229, 261, 284, 287, $309,3^{15}, 3^{16}, 3^{19}, 3^{22}, 3^{23}$

Brandys Marian 163, 229

Bratkowska Maria 463

Bratkowski Edmund 480

Braun Julius von $33^{1}$

Brehier Louis 464

Broglie Louis de 390,391

Broniewski Władysław 244, 24,6, 258, 264, $3^{18}-3^{20}$

Bronikowski Antoni 310

Browicz Tadeusz $39^{1}$
Brown Scott Jacob 391

Brückner Aleksander 391, 433

Brudnicki Zygmunt 305

Brudziński Józef 296, 328, 333, 334, 336-338, $340,341,344,-346,386,409-4,11$

Bruendel Steffen 47

Brzeski Tadeusz 78, 296, 385

Brzeziński Stanisław 315

Brzoska Karol 313, 315, 447

Budkowa Zofia 4,66

Bukowiecki Henryk 4,26

Bukowiecki Stanisław 4,09

Bursche Edmund 92, 4,21

Bursche Juliusz 91, 391

Buszko Józef 525

Byron George 103

Bystroń Jan Stanisław 81, 414, 457, 493

Capitant Henri 391

Cegielski Jerzy 303, 304

Centnerszwer Mieczysław 4,82, 4,83

Charewiczowa Łucja 461, 462, 499, 507

Charléty Sébastien 391

Chitulescu George 129, 306

Chmielewska Wanda 4,4, $47^{6} 6$

Chodakow Helena 309

Chojnacki Piotr 4,4.4

Chojnowski Andrzej 319, 322

Chojnowski Władysław 309, 310

Chruszczow Nikita 29

Chrzanowski Ignacy $3^{6}$ ?

Chrzanowski Wiesław 504, 533

Chudek Józef 499

Chudobiński Zygmunt 309, 312

Chutkiewicz Henryk 305, 309

Chwiszczuk Rafał 535

Chyliński Konstanty 362

Cieślak Edmund 4,15

Ciołek Gerard $53^{2}$

Cisek Janusz 4,17

Cohn-Bendit Daniel 4,1

Connelly John 47

Cybichowski Zygmunt 83, 104, 105, 304

Cybulski Witold 4,42, 475

Czajka Michał 4,16

Czaki Hanna 507

Czarnocki Wilhelm 8o

Czarnowski Stefan 85, 267, 271, 320, 496

Czepulis-Rastenis Ryszarda 303, 307, 417

Czerniaków Adam 483

Czerny Zygmunt 36 ?

Czerwiński Czesław 4,65 
Czerwiński Sławomir 272, 353, 359, 361, 368, ${ }_{4,1} 6$

Czopowski Henryk 328

Czubalski Franciszek 89, 296, 311, 316, 319, $321,322,422,478$

Czyszek Wacław 474

Czyżewicz (Cyzewicz) Adam 4,26

d'Abancourt-Koczwara Anna 4,2

Dalbor Edmund 390, 391

Daniecka Anna 470

Danielak Fajga 307, 322

Daszyński Ignacy $351,35^{2}$

David-Fox Michael 48

Dąbrowska Krystyna 527, 528, 533

De Boer Harry 49

Dembiński Bronisław 352, $39^{1}$

Dembowska Janina 4.42, 4.50, 4.58, 46o

Demostenes 469

Denjoy Arnaud 391

Desz Halina 449

Deszczyński Marek Piotr 4,19

Dickstein Samuel 382, $39^{1}$

Diebner Kurt $47^{2}$

Divéky Androrján 89, 302

Dmowski Roman 281

Dobrowolski Tadeusz $53^{2}$

Dobrucki Gustaw 353

Dobrzański Antoni 310, 482, 530

Dorabialska Alicja 44,2, 474

Doroszewski Witold 450, 452, $45^{6}$

Dreszer Helena 482

Dreszer Ryszard 482

Drewnowski Kazimierz 4,42, 4,43

Drozdowski Marian Marek 4,09, 4,11, 4112, 4,21, 4,27

Dubanowicz Edward 366

Dubiel Gabriel $35^{2}$

Dudzik Jan 440

Dunin-Wąsowicz Krzysztof 411-413, 46o, 462, $464,465,468,5^{26}, 5^{28}, 533$

Dusińska Halina 314

Dybowski Benedykt 391

Dygat Stanisław 454

Dymecki Zbigniew 321

Dziembowski-Pomian Zygmunt 410

Ehrenkreutz Stefan 367, 4,19

Eiger Marek 174

Eigerówna Maria, zob. Kamińska Maria

Einstein Albert 209

Eksteins Modris 47
Enders Jürgen 49

Engberg Arthur 4,20

Eramo Nella 4,20

Esch Michael 4.8

Estreicher Stanisław 367

Etzdorf Ulrich von 326

Evans Eric 49

Eychhorn Hanna, zob. Szwankowska Hanna

Fabre Jean 88

Feldman Józef 4,62

Ferguson Niall 47

Filiński Włodzimierz 4.80

Fiori Antonio 420

Firstenberg Julian 313

Fitzpatrick Sheila 48

Fliederbaum 4.83

Foch Ferdinand 39o, 391, 4,22

Fokczyńska Henryka 436

Franaszek Andrzej 528

Francastel Pierre 88

Frank Hans 66, 293, $43^{\circ}$

Frejlich Stanisław 4,13

Friedrich Henryk 451

Fryderyk August Wettin 337

Fuks Marian 322

Furmanik Stanisław 451

Gaczeński Stanisław 234

Gadomski Jan 300, 534

Gajzler Anna 454

Galiński Kazimierz 310

Gallin Alice 47

Gansiniec Ryszard $33^{1}$

Garlicki Andrzej 9, 300, 345, 385, 4,21

Garliński Czesław $43^{2}$

Garliński Jan $25^{\circ}$

Garliński Józef 128, 163, 175, 306, 309-312, 317,318

Garofalo Rafaelle 391

Gasparska Halina 462, 465, 4,66

Gawkowski Robert 4,14, 533, 535

Gawlina Józef 392

Gawrońska-Wasilkowska Zofia 93, 302, 313, 323

Gądzikiewicz Witold 476, $53^{\circ}$

Geblewicz Eugeniusz 467

Gellner Ernst 294, 323

Gény François 391

Gerber Rafał 218

Gębarzewski Bronisław 64

Ghosal Hiranmoy 4,20, 4,21 
Giedroyc Jerzy 161, 173, 195, 197, 219, 230, 234, 239, 309, 310, 312, 313, 315-317

Gieysztor Aleksander 216, 279, 302, 314, 315, $3^{20}, 3^{21}, 410,433,463,488,491,494,53^{1}$

Gieysztor Irena 4.42, 4.43

Gieysztor Marian Józef 24,8, 44,2, 527, 529

Ginzberg Izaak 122, 123, 305

Gleason Abbott 48

Glimos-Nadgórska Anna 380, 4,18, 4,19

Głąbiński Stanisław 146, 352, 417

Gmitruk Janusz 526, 531

Godlewski Emil 391

Goebbels Joseph 22, 430

Goetel Ferdynand 525

Goldberg Józef, zob. Różański Jacek

Goldberżanka Irena, zob. Krzywicka Irena

Goldman Anna 473

Gombrowicz Jerzy 256

Gombrowicz Witold 16o, 162-164, 243, 256, 258, 308, 309, 318, 319

Gomulicki Juliusz Witold 525

Gordziałkowski Jan 4,26

Gorecki Zdzisław 480

Goryńska Maria 508

Goryński Ludwik 457, 4.58

Górnicki M. 4,24

Górski Grzegorz 527, 531, $53^{2}$

Grabowski Józef 323, 44,2, 4.43, 470

Grabowski Waldemar 531

Grabski Stanisław 352, 353, 417

Grabski Władysław Jan 102, 279, 352, 353, 4.01, 4, 17

Gralak Bronisław 527, 531, $53^{2}$

Grasberżanka Irena, zob. Koprowska Irena

Grażyński Michał $37^{2}$

Grochowska Magdalena 307

Grodzieńska Wanda 24,1

Grodzki Edward $3^{11}$

Groszkowska Krystyna 504.

Grotowicz Viktor 47

Grotowski Jan 283

Grott Józef Wacław 4,80

Grundmann Karl 230

Grupińska Anka 307, 310, 311, 316, $3^{20}$

Grüttner Michael 47, 48

Grycz Józef 502

Grzybowski Józef 507

Grzybowski Marian 476, 530

Grzywo-Dąbrowski Wiktor 4,24, 4,26

Gubrynowicz Bronisław 382

Guerquin Bohdan 465, 532

Gumiński Romuald 475
Gumowska Maria 114

Gutnajer Abe 508

Gutowska Maria 94

Gutowski Bolesław 94

Haber Fritz 18

Halecki Oskar 86, 106, 218, 376, 382, 4,20

Halsey Albert Henry 47

Hammerstein Notker 47

Handelsman Marceli 65, 66, 78, 81, 85-87, 107 , $217,218,239,263,271,277,279,286,322$, $337,3^{6} 3,382,384,397,410,411,433,45^{8}$, $461,486,488,491,494,496,498,507$

Hanworth of Hanworth lord 391

Hass Alojzy 4,65

Heidegger Martin 22

Heimpel Herman 35

Heise Albert 308, $3_{1} 6$

Hemmerling Zygmunt $53^{1}$

Herbst Stanisław 432, 4.88, 498, 502

Herodot 4,69

Hertz Aleksander 278, 321

Heurich Jan 100

Hewelke Jan 310

Heydel Adam 366

Himmler Heinrich 34, 439

Hirszfeld Ludwik 147, 150, 243, 269, 271, 307, $3^{08}, 3^{18}, 3^{20}, 3^{21}, 482,483,530,534,535$

Hiszpański Stanisław 87

Hitler Adolf 20-25, 34, 282

Hiż Henryk 4.44, 458, 467, 468, 490, 527, $5^{28}$, 532,533

Hlond August 184

Hłasko Wanda $47^{6}$

Hobsbawm Eric John 47

Holewiński Władysław 336, 4,o9

Hoover Herbert 390, 391

Horacy 469

Hóman Bálint 391

Hryniewiecki Bolesław 296, 382, 385

Humboldt Wilhelm von 15, 32

Husarski Wacław $53^{2}$

Hutten-Czapski Bogdan 326, 331, 333, 337-339, $341,391,400,4,10-4,12,4,25$

Irzykowski Karol $43^{2}$

Ivanko Aleksander 4,84

Iwanowska Wanda 290

Jabłczyński Kazimierz 382

Jabłonowski Marek 4,18

Jabłoński Henryk 213, 218, 314 
Jabłoński Tadeusz 300, 317, 319, 322

Jaczewski Bohdan 380, 414 4, 4,25

Jakimowicz Roman 256, 330, $33^{1}$

Jakubów Ryszard 4116, 4,18

Jakubski Antoni 367

Jamontt Władysław 116, 269, 286, 305, 322

Janicki Konstanty 382

Janiszewski Tomasz 4,24

Janiszewski Zygmunt 215

Januszewiczowie 471

Jarausch Konrad 47

Jarocki Robert 525, 531-534

Jaroszewski Tadeusz Stefan 534

Jarosz-Nojszewska Anna 4,11

Jarra Eugeniusz 89, 103, 197-199, 219, 283 , $291,303,3^{15}, 3^{18}, 3^{19}, 3^{23}, 33^{8}, 346,3^{6}$, $37^{6}, 4.09-411,413,418,4,20,4,22$

Jasiński Stefan 312

Jastrzębska Hanna 463

Jaśkiewicz Bronisław 4,16

Jaxa Bykowski Ludwik 366

Jażdżewski Konrad 498, 533

Jezernicki Icko, zob. Szamir Icchak

Jezierski Andrzej 4,09, 4,12

Jeżewski Władysław 4,8

Jędruszczak Tadeusz 380, 4:14

Jędrzejewicz Janusz 257, 353, 36o, 361, 367, 402,417

Jędrzejewicz Wacław 105, 304, 353, 361, 362, $365,367,4,17$

Jodłowski Jerzy 4,47

Joravsky David 48

Judt Tony 49

Juszczak Stanisław 310

Kacperski Stanisław 409

Kaczorowski Bartłomiej 4,26

Kaczyński Mieczysław 4,82

Kadlec Karel 376

Kakowski Aleksander 334, 346, 390, $39^{1}$

Kalecki Michał 381

Kalinowska-Król Julia 47

Kalinowski Romuald 114

Kallenbach Józef 4,10

Kałwa Dobrochna 307

Kamieński Michał 382, 396, 397, 4,23

Kamińska Maria 137, 161, 162, 174, 246, 258, $289,307,309,318,319,323$

Kamiński Adam 527

Kapper Halina 4,63

Kapuścik Janusz $3^{14}$

Kapuściński Władysław 79, 529, 533
Karpowicz Wanda 4,4,2-4,4, 4,70, 47 1, 527, 529

Karpowiczowa Stefania 4,40

Karwas Stefan 310

Karwasińska Jadwiga 461, 463-4,66, 528, 529

Kasiński L. 4,68

Kasprowicz Jan 390, 391

Kasprzycki Tadeusz 224

Kasznica Stanisław 4,47, 4,48, 527

Kaszuba Krzysztof 419

Katelbach Tadeusz 239, 253, 317, 319, 412

Katullus 469

Kazimierski Józef 302, 531

Kądziałkiewicz Eugeniusz $3^{12}$

Keach William 48

Kelasz Wiktor $3^{12}$

Kershaw Ian 47

Kesselring Rudolf 92, 302

Kętrzyński Stanisław 85, 433, 458, 461, 463, 465,491

Kielski Bolesław 414

Kieniewicz Stefan 9, 217, 494, 531

Kisielewski Stefan 525

Kitowski Sławomir 4,15

Kizwalter Tomasz 4,09

Klarner Czesław 173

Kluczycka Flora Wanda 94

Klukowski Zygmunt 433, 525, 532

Klus Karol 129, 130, 306

Kłapkowski Bolesław 4,13

Kobos Andrzej Michał 30o, 527

Koc Adam 389

Kochanowski Jan Karol 252, 296, 333, 351, $382,385,4,10$

Kochanowski Tadeusz 4,10

Kocięcka 4,66

Kocowski Bronisław $5^{28}$

Koczwara Anna, zob. d'Abancourt-Koczwara Anna

Koczwara Maria 507

Koczwara Marian 4.43, 4.4.4, 470, 47 1, 476, 4.84, $527,529,530,535$

Kojder Andrzej 301

Kokeli Tadeusz 4,12

Kolankowski Ludwik 433, 4.49

Kolankowski Zygmunt 300, 304, 305, 314, 315, 323

Kolendo Hanna 75, 300-303, 323

Kolendo Jerzy 302

Kolisko Wiesław 4,46

Kołakowski Leszek 31, 4,8, 493, 532

Kołłątaj-Srzednicki Jan 243, 4,22

Kołodziej Edward 4,15, 4,19 
Konarski Kazimierz 4,10

Koniński Karol Ludwik 525

Konopacki Karol 313, 467

Kopeć Stefan 478

Kopij Marta 47

Koprowska Irena 249, 290, 300, 314, 315, 318, 323

Koprowski Hilary $25^{\circ}$

Korbut Gabriel 4,10

Korduba Miron 91, 106, 230, 302, 304

Korusiewicz Leon 305

Korzeniewski Bohdan 499, 502, 535

Koschembahr-Łyskowski Ignacy 89, 219, 292, $296,344,385,410,4,20,4.25$

Kosieradzki Władysław 4,47

Koskowski Bronisław 227, 4,83, 4,87

Kos-Rabcewicz-Zubkowski Ludwik 300, 317 , 318

Koss Adam $53^{\circ}$

Kossmann Oskar 235, 251, 252, 300, 310, 316318

Kostanecki Antoni 296, 345-347, 385, 4,10

Kot Stanisław 83, 84, 366, $5^{26}$

Kotarbińska Janina 4,68

Kotarbiński Tadeusz 78, 217, 267, 269, 271, 286 , $29^{2}, 320,382,434,454,457,45^{8}, 462,467$, $468,493,495,496,525,529,533$

Kotowicz Stanisław 310

Kotowski Stanisław 305, 310, 316

Kott Jan 177, 235, 236, 263, 311

Kowalczyk Elżbieta $3^{19}$

Kowalczyk Stanisław 312

Kowalski Józef zoo

Kowalski Józef Wierusz 296, 331, 410

Kowalski Tadeusz 495

Kozakiewiczówna Izabela 310

Kozłowski Krystyn 529

Kozłowski Leon 353

Kozłowski Stefan Karol 302, 526, 529, 531-534

Kozubski Włodzimierz 4.47

Kráčala Jan 391

Krampera Józef 498, 499

Krasiński Zygmunt $33^{6}$

Krassowska Zofia Halina 507

Krassowski Jan 396, 4,10

Krasuski Józef 309

Kreczmar Jerzy 451, 462

Krementsov Nikolai 48

Kridl Manfred 275, 321

Kries von Wolfgang 326, 331, 332, 345, 410

Krokiewicz Adam 382

Krompiewski Jan 309, 311, 312
Krośnicki Józef 317, 323

Król Eugeniusz Cezary 526

Król Marcin 47

Krupko Stefan 319

Kryński Adam 333, 382, 391, 409, 410

Kryński Leon 333, 409

Krzemiński Zdzisław 527

Krzeszewska Florentyna Danuta 4,68, 507

Krzyształowicz Franciszek 89, 137, 296, 383, 385

Krzywicka Irena 226, 245, 246, 24, 250, 263 , $3^{16-318,3^{20}}$

Krzywicki Jerzy $25^{\circ}$

Krzywicki Kazimierz 337

Krzywicki Ludwik 76, 258, 267, 279, 319, 320, 322,323

Krzyżanowska-Sendlerowa Irena 141, 251, 307

Krzyżanowski Julian 81, 392, 4.50-456, 470, 4.86, $490,493,498,528,529,533$

Kubiczek Franciszek 409

Kucharzewski Jan 4,13

Kuczyński Stefan 462

Kula Marcin 316, 320, 525

Kula Witold 217, 315, 431-433, 488, 525

Kulesiński Stanisław 414

Kumaniecki Kazimierz 352, 469, 529

Kunderewicz Cezary 311, 313, 315, 322, 440

Kunert Andrzej Krzysztof 531, 535

Kunicka Joanna 4,24, 457, 458

Kunicki Wojciech 47

Kuntze Roman 4,4,2

Kuntze Tadeusz $53^{2}$

Kuratowski Kazimierz 215, 314, 367

Kurcyusz Jerzy 252, 257, 309-312, 316, 317, $3^{22}, 323$

Kutrzeba Stanisław 56, 300, 336, 367, 4, 1, 464

Kwiatkowska Irena 310

Kwiatkowski Eugeniusz 370

Kwieciński Andrzej 449

Lachowicz Antoni 322

Lachs Hilary 4,82, 483

Lamota Anna 307, 310, 311, 316, 320

Lampe Wiktor 382, 437

Landau Zbigniew 4,21

Landsberg Marceli 263

Lange Oskar 289

Laskowski Otton 4,16

Latała Jan 311, $3^{12}$

Lato Stanisław 4,16

Laue Max von 24

Lauterbach Alfred 434, 486, 525, 532

Lehr-Spławiński Tadeusz 34 
Lenard Philipp 23

Lencewicz Stanisław 382, 398, 4112, 474, 475

Lenczewski Mikołaj 527

Lenin Włodzimierz I. 26-28, 30

Leopold Wanda 316, 323, 490, 527, 528, 531-533

Leowski Krzysztof 4,21

Lepieszynska Olga 30

Leszczyńska Cecylia 4,12

Leszczyński Adam 4,8

Leśniakowska Marta 4,26

Leśniewski Andrzej 4.46

Leśniewski Stanisław 382

Letwin Shirley 42, 49

Lewak Adam 398, 436, 495, 497, 498

Lewandowski Jan 409

Lewandowski Władysław 525

Lewiński Jan 333, 382, 410, 4,23

Libera Kazimierz 4.4.0, 4.41, 4.47

Lieberman Herman 364

Limanowski Bolesław 391

Lipiński Wacław 4i11

Lipner Roman $3^{12}$

Lipski Jan Józef 322

Lis Tomasz 4,26

Litwinowicz Aleksander 369

Lorentz Stanisław 433, 502, 525, $53^{2}$

Loth Edward 105, 210, 217, 234, 273-275, 304, $3^{21}, 410,4.34,4.42,475-477,504,526$

Lubecka Ewa 449

Lubicz-Łapiński Czesław 4,14

Lubomirski Zdzisław $3^{26}$

Lutostański Karol 83, 104, 105

Łapiński Wacław 4,21

Łaskarzewska Hanna 533

Łaszowski Alfred 236, 263, 279

Łazowski Eugeniusz 250, 314,-319, 322

Łempicki Zygmunt 213, 214, 4.23

Łodyński Marian 534

Łojewski Kazimierz 449

Łopuszański Tadeusz $35^{2}$

Łoś Jan Nepomucen 391

Łotocki Aleksander 88

Łuczak Czesław 525, 526, 534, 535

Łukasiewicz Jan 257, 264, 268, 296, 352, 363, $385,391,410,413$

Łukaszewicz Witold 312

Łunaczarski Anatolij 26

Łysenko Trofim 29, 30

Maciejewski Józef 312

Mackiewicz Aleksander 309
Madajczyk Czesław 48, 38o, 525, 526, 535

Maj Ireneusz Piotr 4.17, 4,18, 4,20

Majewski Piotr Maciej $5^{1}$

Majewski Piotr 4.29, 533

Makowiecki Jerzy 494, 535

Makowiecki Tadeusz 286, 288, 436, 451, 502, $5^{26}, 53^{2}$

Makowski Henryk 117, 305

Makowski Wacław 89, 197, 199, 252, 293

Małecki Mieczysław 531

Mann Alexander 230

Manteuffel Jerzy 85

Manteuffel Tadeusz 65, 73, 81, 82, 84, 86, 96, $100,101,128,132,135,142,144,148,15^{2}$, $172,193,211,217,239,258,279,300-307$, $310,312-315,319,3^{21}, 347,364,39^{8}, 410-$ $414,417,418,4,21-4,26,432,433,435,441$, $45^{\circ}, 458,460-464,467,488-490,494,508$, $5^{26-530,532-535}$

Mańczarski Stanisław 4,80

Marconi Bohdan $53^{2}$

Marcuse Herbert 40

Maritain Jacques 455

Markert Wacław 4,81

Markiewicz Kazimierz 311

Marks Karol 26

Marszalec Janusz 316, $3^{22}$

Maternowska Irena 93, 291

Matuszewicz Zdana 469

Matuszewski Ryszard 159, 221, 235, 236, 240, $243,244,247,25^{0}, 259,308,310,3^{11}, 3^{13}$, $3^{1} 5^{-318}, 3^{20}$

Mauersberg Stanisław 4,11, 4,16-4,18, 4,21

Mazeaud Henri 89

Mazur Grzegorz $53^{1}$

Mazurek Jerzy $5^{26}$

Mazurkiewicz Jan 296, 303, 313, 385, 386, 4,22, $482,504,530,534,535$

Mazurkiewicz Stefan 215, 296, 382, 4,10, 4,23, 437

Mazurkiewicz Władysław 363

Mączewski Ryszard 4,21

Mehring Reinhard 47

Meinhardt P. 238

Meller Beata 302

Mężyński Andrzej 526, 533

Mianowski Józef 335, 337

Michalski Jerzy 463, 468

Michalski Stanisław 391

Michalski Zdzisław 80, 82, 100, 106, 263, 277, $294,301,303,304,320,323,4,26,480$

Michałko Bolesław 4,49 
Michałowicz Mieczysław 8o, 86, 87, 101, 102, 109, 210, 272, 296, 302, 363, 385, 402

Michałowski Kazimierz 79, 85, 302, 4,20

Michejda Karol 268

Mickiewicz Adam 470

Miechowski Zygmunt $53^{2}$

Miklas Mieczysław 312

Miklaszewski Bolesław 353, 367, 443

Miklaszewski Teofil 471

Miklaszewski Walenty 328, 336, 409

Mikulski Tadeusz 45o, 455

Mikułowski Tadeusz 437

Mikułowski-Pomorski Józef 345, 352, 353, $3^{67}$

Milbrandt Mieczysław 507

Millak Konrad 4,26, $53^{1}$

Miłobędzki Tadeusz 328

Miłosz Czesław 454

Minc Hilary 282

Minkiewicz Adam 4,21

Misiewicz Janina 480

Miszewski Wacław 93, 292, 4.47, $49^{2}$

Mitzner Piotr $53^{1}$

Mitzner Zbigniew 486

Miziołek Jerzy 4,23, 4,26, 533, 535

Młynarski Feliks 485

Mniszech Józefina 215

Mocarski Zygmunt $53^{2}$

Moczarski Kazimierz 305, 534

Modrakowski Jerzy 274, 321, 372, 385, 392, 4.37, 4.4,, 4.94

Modzelewski Henryk 449, 527, 535

Modzelewski Zygmunt 282

Mokrzycki Marian 499

Mołotow Wiaczesław 409

Montel Paul $39^{1}$

Moraczewski Jędrzej $35^{2}$

Morawiński Jan $53^{2}$

Morawski Wojciech 4,11, 4.17

Mosdorf Jan 218, 252

Moszczeńska Izabela 4,12

Moszczeńska Wanda 217

Moszyńska Maria 443, $47^{6}$

Mościcki Henryk 382

Mościcki Ignacy 61, 92, 100, 370, 389, 391, 4,05

Mounier Emmanuel 457

Müller Bruno 34

Musianowicz Krystyna 4,65

Muszyński Wojciech Jerzy 316, 317, 319, $3^{20}$, 322,323

Mycielska Dorota 307, 319, 321, 4,17, 4,18
Namitkiewicz Jan 117, 293, 447

Narutowicz Gabriel 264

Natkowska Monika 302, 308, 316, 317, 320-322

Nawroczyński Bogdan 304, 382, 449, 457, 528

Neave Guy $47-49$

Nekrasz Natalia 535

Newton Isaac 209

Nędzusiak Zygmunt 311, $3^{12}$

Niedźwiecka Maria, zob. Ossowska Maria

Niemojewski Lech 434

Nieniewska Halina 4,4,2, 507

Niklewicz Andrzej 231

Niklewicz Bolesław 231

Nitsch Kazimierz 89

Nowaczyński Adolf 278

Nowak Julian $35^{2}$

Nowogródzki Henryk 310

Nowosilcow Nikołaj 335

Obertyński Zdzisław 4.11, 4.13, 4.37, 4.4.4

Ochimowski Franciszek 409

Odorkiewicz Cyprian 499

Ohnesorg Benno 40

Okiński Władysław 508

Opas Tomasz 4,16

Ordęga Adam 535

Orłowski Hubert 47

Orłowski Stanisław 4,09, 4,26

Orłowski Witold 476, 4,80, 481, 4.83, 4.92, 504, 530, 534

Osiecki Jerzy 447

Osińska Wanda 465

Ossowska Maria 95, 106, 112, 139, 247, 264, $271,291,433,457,458,461,467,468,529$

Ossowski Stanisław 106, 112, 194, 247, 264, $457,462,493,528$

Ostrowska Barbara 47

Ostrowski Jerzy 4,19

Otwinowski Stefan 174

Owsionka Antoni 4,21

Pachecka Jan 300

Paciorkowski Tadeusz $3^{12}$

Paczyńska Irena 525

Paderewski Ignacy Jan 352, 389-391

Pajewski Janusz 80, 87, 90, 24,2, 301, 302, 304, $3^{15}, 3^{18}, 3^{21}, 409,413$

Palarczykowa Anna 527

Palczewska Wacława $47^{\circ}$

Panafieu Hector André de 4,22

Paprocki Jan 305

Parczewski Alfons 333, 409 
Parkinson Cyrille Northcote 395

Paszkiewicz Ludwik 209, 275, 477, 530

Paszkowski Wilhelm 331, 34.4

Paszyński Janusz 475

Patkowski Józef 4,14, 4,42

Paulsen Peter 439

Pawiński Jan 409

Pawlikowska Ewa 528

Pawłow Iwan 26

Pawłowski Stanisław 367

Pelc Jerzy 453, 454, 528, 533

Pertkiewicz Marian 311, 317

Petrażycki Leon 82, 83, 219

Petz Maria 4.47

Peukert Detlev 47

Pękała Zygmunt 476, 530, 535

Piasecki Bolesław 163, 198, 219, 231, 252, 279, 280, 309

Piątkowski Wiesław 508

Pieliński Henryk 320, 323

Pieńkowska Maria 314

Pieńkowski Stefan 79, 92, 119, 120, 209-211, $215^{-217}, 227,271,296,300,302-305,311,320$, $367,382,385,388,390,4,22,442,443,47^{2}$, $473,485,493,494,498,527,5^{2} 9-532,534$

Pieracki Bronisław 90

Pieracki Kazimierz 361

Pierson Paul 49

Pierzchała Henryk 535

Pietkiewicz Stanisław 475

Pietrusiewicz Witold 4,26

Pietrzak Włodzimierz $477^{\circ}$

Pietrzak-Pawłowska Irena 300

Piętka Henryk 4.47, 4,4.8

Pilch Andrzej 307, 319, 322

Piłsudski Józef 83, 104, 321, 326, 347-350, 353 , $3^{60}, 3^{61}, 3^{6} 3,3^{68}, 3^{84}, 3^{88}, 3^{89}, 391,411$, $4,22,4,26$

Piotrowski Stanisław $5^{26}$

Pipes Richard 4.8

Pius XI 103, 390, 391

Piwocki Ksawery $53^{2}$

Planck Max 16, 17

Pleskaczyńska Małgorzata 16o, 308

Pniewski Bohdan 469

Pniewski Jerzy 472, 527, $5^{29}$

Podkowińska Zofia 112, 304, 318, 319, 323

Podolska-Meducka Aldona 4,17

Podzielna Alicja 47

Pohoska Ewa 507

Pohoska Hanna 457

Pohoski Jan 507
Pojawska Karolina 454

Pollak Seweryn 174, 241

Pompeiu Dimitrie $39^{1}$

Poniatowski Stanisław 329

Ponikowski Antoni $35^{2}$

Poray Jan 4,1

Porzeziński Jan 89

Porzeziński Wiktor 296, 382

Powell Enoch 4,2

Poznańska Barbara 303, 314.

Prauss Ksawery $35^{2}$

Prentki Jacek 492

Propercjusz 469

Prószyński Mieczysław 312

Prus Bolesław 185

Pruszkowski Tadeusz 388

Prystor Aleksander 353, 361

Przeborski Antoni 382

Przetakiewicz Zygmunt 322

Przychocki Gustaw 78, 137, 139, 249, 296, 382, 385,402

Przyłęcki Stanisław 437

Przypkowski Tadeusz $53^{2}$

Pułak Wanda 449

Puławski Adam 409

Putek Józef 364

Pyrek Gracjan 453

Pyrek Wiesław 453, 4.54

Rabińska Krystyna 47

Rabski Janusz 234, 4,12

Radożycki Jan 117, 171, 183, 186, 229, 305, $3^{10-312,} 3^{16}$

Radziwiłł Janusz 4,85

Radziwiłł Krzysztof 161, 309

Rafacz Józef 197, 219, 446-44.9, 453, 463, 491, 493

Rajchman Aleksander 270, 278, 320, 321

Rajgrodzka Krystyna 460

Rajman Pesach 245, 246, 263, 308, 320

Rakowski Janusz 306, 316

Raszeja Stanisława 508

Ratti Achille, zob. Pius XI

Rataj Maciej 352, 358, 4,16

Reicug Zbigniew 4,16

Reitan Earl 49

Remer Jerzy $53^{2}$

Ringelblum Emanuel 148, 307

Ringer Fritz 47

Robinson Michaił 48

Roguski Jan 4,80, 530

Romańska Anna 533 
Rosen-Przeworska Janina 220, 245, 251, 302, $3^{15}, 3^{17}, 3^{18}, 3^{2} 3$

Rostańska Janina 4,63

Rostocki Władysław 315, 316

Roszkowski Wacław 382, 4,42, 474

Rowecki Stefan 431

Rozwadowski Jan Michał 391

Rozwadowski Piotr 4,16

Różański Jacek 176, 282, 288

Różycki-Kołodziejczyk Tadeusz $3_{116}$

Rubinraut Józef 114

Rucki Dominik 118, 305

Rudnicki Szymon 305, 321

Rudy Willis 47

Rüegg Walter 37, 43, 4.4, 47, 49

Russell Bertrand 18, 47

Rutkowska-Kurcyuszowa Maria 265, 302

Rutkowski Jan 4.48

Rutkowski Jerzy $53^{\circ}$

Rutkowski Tadeusz Paweł zo1

Rybarski Roman 85, 87, 252, 273, 277, 281, 321, $364,4,20,437,4,46,4,47$

Rybicka Anetta 49, 533

Rybicka-Goryńska Ewa 457, 458, 508

Rychlewska Helena 310

Rygel Stefan 398, 433

Rytlówna Maria (siostra Ancilla) 462

Rzeczyc Artur 171

Rzepecka Hanna, zob. Pohoska Hanna

Rzepecki Jan 4,12

Rzewuski Jan 492

Rzętkowski Kazimierz 263, 4,09

Salmonowicz Stanisław $5^{27}$

Saloni Juliusz Bożydar 311, $3^{23}$

Salustiusz 469

Sałaciński Bohdan 4,4, 4,48

Sałkowski Jan 531

Samsonowicz Jan 305, 382, 475

Sandner Henryk 238, 24,8

Sandner T. 248

Sanojca Antoni 507

Sas-Wisłocki Juliusz 256, 316, 317, $3^{19}$

Sawicka Stanisława 499, 526, 534 .

Sawicka-Krasnodębska H. 238

Sawicki Jakub 4,4

Sawicki Kazimierz 349

Sawicki Ludwik 259, 304, 319

Sawicki Tymoteusz $53^{2}$

Sawicki Witold 447

Schieder Theodor 34

Schiller-Walicka Joanna 409
Schmitt Carl 22

Schoeneich Aleksander $39^{1}$

Schorr Mojżesz 90, 91, $3^{6} 7$

Schulze Winfried 48

Semerau-Siemianowski Mściwoj 480

Sendler Irena, zob. Krzyżanowska-Sendlerowa Irena

Seńko 4,66

Serafin Franciszek 380, 4,18

Servan-Schreiber Jean-Jacques 43

Siciliano Italo 88

Siemieński Józef 410

Siemiradzki Henryk 396, 4,23

Sienkiewicz Witold 4,16

Sierpiński Wacław 215, 256, 382, 4,23, 474, 529

Sikorski Władysław 130, 352, 4116, 440

Siła-Nowicki Władysław 183, 265-267, 309, $3^{11}, 3^{20}$

Simone Mariapina di 4,20

Skarżyński Mirosław 48

Skłodowska-Curie Maria 92

Skokowska-Rudolfowa Maria 311, 312

Skolimowska Maria $3^{10}$

Skulski Leopold $35^{2}$

Skwarówna Irena 263

Sławek Walery 353

Sławoj-Składkowski Felicjan 353, 369, 370

Słomiński Michał 257, 281

Słonimski Antoni 263, $27^{6}$

Słoński Stanisław 382, 451

Słupińskie panie $47^{1}$

Smal-Stocki Roman 88, 90

Smoleński Władysław 328, 333, 4,10

Sobański Antoni 16o, 309

Sobański Janusz 481

Sokołowska Wanda 436, 497, 533, 535

Sokołowski Alfred 409

Sołtan Andrzej $47^{2}$

Sołtan Tadeusz 527, 528, 532, 533

Sołtysik Maria 4,19

Sommer W. 238

Sorel Julian 457

Sosnowski Jan 4,10

Sroczyńska Krystyna 463

Srokowski Stanisław $43^{2}$

Stachowska 4,66

Staff Leopold 390-392

Stalin Józef 25, 28-33

Stanghellini Arturo 88

Stankiewicz Andrzej 463

Stankiewicz Witold 4,17

Stankiewicz Władysław 391 
Stark Johannes 23, 24

Starzyński Juliusz $53^{2}$

Starzyński Stanisław 4i1

Stawarczyk Jan 171

Stawecki Piotr 380, 4,15, 4,20

Stawiński Janusz 48

Stawowy Ewa 528

Stebelski Adam 534

Stefanowska Zofia 458, 534

Stefański Witold 75, 382, 437, 484

Stelmach Adam 321, 323

Stempin Arkadiusz 409-4,12

Stępkowski Stanisław 311

Stoch Jerzy 4,20

Stoksik Janina 527

Stołyhwo Kazimierz 330, 4,10

Stopczyk Wojciech $3^{15}$

Stopczyński Waldemar 316

Strandman Otto 390, $39^{1}$

Straszewska Maria 4.54

Stroński Stanisław 281

Strunsky Rose 48

Strzałka Jan 4,65

Strzelecki Leon 234

Strzemieński Marian 4,10

Strzeszewski Zygmunt 4,24, 4.47

Strzeżek Anna 525

Stummer Wanda 4,10, 4.23

Stypułkowska Halina 458, 46o, 462, 4,66

Stypułkowski Zbigniew 228

Suchecki Stanisław 4.40, 497

Suchodolski Bogdan 4.50, 455, 457, 493, 528, 534

Suchodolski Witold 303

Sudnik Wanda 4,16

Suess Adolf 4.45, 4.46

Sujkowski Antoni 353

Suleja Włodzimierz 4,12

Susłow Michaił 4,09

Swianiewicz Stanisław 4,19

Swieżawski Stefan 433, 525

Sym Ernest 4,84, $53^{1}$

Symonowicz Antoni 4,46, $53^{1}$

Szablowski Jerzy $53^{2}$

Szamir Icchak 149, 150, 308

Szaniawski Jan Kalasanty 335

Szaniawski Klemens 455

Szarota Tomasz 309, 525, 530, 531, 535

Szcześniak Władysław 391

Szczęsny Potocki Stanisław 215

Szczuciński Władysław $3^{17}$

Szekspir William 453

Szela Władysław 500
Szelągowski Kazimierz 4.37

Szeptycki Andrzej 161

Szeptycki Stanisław 343

Szeruda Jan 4.37, 4.45, 4.46, $5^{27}$

Szetelowa A. 4,68

Szkudliński Mieczysław 312

Szlagowski Antoni 22 , 234, 296, 334, 339, 346, $385,393,396,405,410,411,4.23$

Szlenk Anna 470

Szmakfeferówna Irena 290

Szmydtowa Zofia $45^{1}$

Szober Stanisław 382

Szöllösi-Janze Margit 47

Szpakowska Małgorzata 276, 320, 321

Szperl Ludwik 4,10

Szromnik Andrzej 4,19

Sztejnbarg Dina, zob. Kotarbińska Janina

Szulc Stefan 4.47

Szuszkiewicz Hanna 504

Szwankowska Hanna 460

Szwankowski Eugeniusz 4,27, 463

Szwarc Andrzej 307

Szwerdszarf Samuel 308

Szweykowski Tadeusz 305

Szweykowski Zygmunt 81

Szymanowska Zofia $45^{2}$

Szymanowski Zygmunt 267, 272, 320

Szymański Jan 482

Szymański Tadeusz 447

Szymonikowa 474

Szyryński Wiktor 261

Szyszko-Bohusz Adolf $53^{2}$

Szyszkowski Wacław 305, 313, 316, 319, $3^{23}$

Ścisłowski Włodzimierz 4722, 529

Śląska-Piątkowska Radomiła 508

Śliwiński Artur $35^{2}$

Śliwiński Stanisław 447, 448, 527

Ślusarska Maria 417

Śmigły-Rydz Edward 26o, 273, 274, 347, 389$392,4,22,4,26$

Śpiewak Jan 164, 168, 173, 184-186, 231, 239 $3^{0} 9^{-} 3^{11}, 3^{16}, 3^{17}$

Śródka Andrzej 321

Świątek Tadeusz Władysław 535

Świeciński 240

Świerkowski Ksawery 497, 533

Świetlicki Andrzej 287

Świeżyński Józef 347

Świętosławski Wojciech 82, 122, 168, 353, 365, $369,370,373,382,392,4,06,417-4,20,4.27,437$ Świtalski Kazimierz 353 
Tagowska-Klatkowa Halina 474

Tarczyński Stefan 309, 311, 312

Tarkowska Aleksandra 4,15, 4.19

Tarski Alfred 79, 81, 107, 304

Tatarkiewicz Krzysztof 109

Tatarkiewicz Władysław 84, 91, 106, 109, 217, $218,227,234,302,304,382,411,433,434$, $45^{1}, 454,467-469,486,492,496,498,5^{28}$, $529,53^{2}$

Tatarkiewiczowa Teresa 106, 109, 302, 304, $5^{28,532}$

Teleżyński D. $3^{20}$

Teokryt 469

Terlecki Tymon 535

Thatcher Margaret 4,2, 43

Thugutt Stanisław Józef 296, 382, 385, 399, 401, 414

Țițeica Gheorghe 391

Todes Daniel 48

Tokarska B. 320

Tokarz Wacław 213, 218, 256, 363

Tomaszewski Bolesław 310

Tomaszewski Patryk 316, 317, 319

Tomaszewski Piotr 300

Tomaszewski Tadeusz Roman 315

Tomczak Maria 47

Tomkiewicz Władysław 4.22, 461, 503, $53^{2}$

Toporowski Marian 499

Treter Mieczysław 4,96, $53^{2}$

Tretiak Andrzej 81, 103, 303, 382, 437

Trocki Lew 26, 27, 40

Tropiło Jan $53^{1}$

Truszkowski Ryszard 129, 130, 306

Trybuś Jarosław 4,27

Trzcińska-Kamińska Zofia $3^{89}$

Tur Jan 382

Turczynowicz Stanisław 4,66

Turek Olgierd 312

Tuwim Julian 321

Twardowski Kazimierz 391

Tworkowska Zofia 4.54

Tymiński Jerzy 231, 311, 313, 315-317, $3^{23}$

Tynelski Stanisław 451, 452, 454, 465, 466

Tyrowicz Stanisław 47

Tzschaschel Werner $4.3^{8}$

Ujejski Józef 97, 296, 303, 304, 311, 363-365, $382,385,386,4.02,4.22$

Ulrych Juliusz 4,20

Umiastowski Roman 4,24

Venulet Franciszek $27^{2}$

Vischer Eberhard $39^{1}$
Wachowiak Stanisław $53^{1}$

Wacławski Stanisław 283

Walczak Marian 525-527, 531, 532, 535

Waledyński Dionizy 88, 89

Walicki Andrzej 48

Walicki Michał 462, 467, 488, 532, 535

Walker Mark 47

Wałek-Czarnecki Tadeusz 83, 85, 286, 364, 367,382

Wańkowicz Krystyna 463

Warden Irena 401

Wardzyńska Maria 48

Warkałło Witold 310

Wasiutyński Bohdan 87, $25^{2}$

Wasiutyński Wojciech 163, 174, 196, 232, 233, $240,254,263,281,309,310,313,316,317$, $319,3^{22}$

Waszkowski Aleksander 213

Wawrzyński Tadeusz 4,18

Wayda Władysław 96

Weber Alfred 17

Weber Max 17

Weryha Władysław 4,10

Wesołowski Stefan 167, 168, 180, 231, 240-24,2, 309-312, 314-318

Westerheijden Don 49

Wędkiewicz Stanisław 85, 469, 491, 493

Whiteheadowie Alfred i Evelyn 18, 47

Widerszal Ludwik 286, 288, 322, 432, 462, 464 4,88, 494, 508, 535

Wiechecki (Wiech) Stefan 187, 311, $3^{12}$

Wieczorkiewicz Antoni $53^{2}$

Wiekiera Józef 4,65

Wielogórski Zbigniew 4,26

Wierczyński Stefan $45^{1}$

Wierusz-Kowalski Józef 296, 331, 410

Wierzbiański Bolesław 309, 319, 322

Wierzbowski Teodor $33^{\circ}$

Więckowski Stanisław Antoni 461

Wilczyński Jan 36 ?

Wilhelm II Hohenzollern 326, 339

Wilson Thomas Woodrow 39o, 391

Winkler Heinrich August 47, 48

Winnicki Zdzisław Julian 4,12

Wionczek Mieczysław 457

Wiśniewski Tadeusz 238

Witanowski Witold 437

Witkowski Marian 312

Witos Wincenty 352, 353, 357, 417

Witte Wilhelm 4.97-4.99

Wittlinowa Halina $124,156,169,170,301$, 305-309, 312

Wittowa Zofia 215 
Wittram Reinhard 35

Witwicki Władysław 90, 217, 302

Wiwatowski Tadeusz 451, 455

Wladich Zofia 466

Włodarski Stanisław 499

Wojciechowski Bolesław 476, 530, 535

Wojciechowski Stanisław 24,2

Wojciechowski Tadeusz 4,64

Wojciechowski Zbigniew 476, 530, 535

Wolff Helena 508

Wolińska Helena 282, 288

Woliński Janusz 4,62, 465, 492

Wolska Aniela 473, 529

Woś Jan Władysław 535

Wójcik Zbigniew 463, 4,68

Wóycicki Stanisław $53^{1}$

Wóycicki Zygmunt 4,10

Wróblewska Teresa 48

Wróblewski Andrzej Kajetan 49, 301, 315, 4,25, $527,5^{2} 9$

Wróblewski Władysław 351, $35^{2}$

Wrzyszcz Andrzej 4.09

Wycech Czesław 450

Wyczański Andrzej 4.09, 463, 468

Wyka Kazimierz 432, 486, 525

Yu Houo Joei 130, 131, 306

Zabolicki Kazimierz $3^{12}$

Zachwatowicz Jan 502, 532, 534

Zadzierski Edmund 268

Zagórowski Zygmunt 4,14, 4,40

Zahorski Andrzej 463, 468, 525

Zajączkowski Ananiasz 4,20

Zakrzewska Małgorzata 436

Zakrzewski Aleksander 482

Zakrzewski Stanisław 367, 4,64
Zaleski Marcin $53^{2}$

Zaleski Stefan 4.46, 4.47, 527

Załęska Aniela 462

Zamojska Dorota 4,14

Zaniewicki Zbigniew 4,21

Zaorski Jan $47^{6-4} 81,504,530$

Zaremba Wojciech 467

Zarębowie Maria i Alfred 531

Zawadzki Józef 4,4,2, 474

Zawidzki Jan 353

Zbudniewek Janusz 534

Zbyszewski Karol 164, 195, 215, 309, 312, 314

Zdrójkowski Zbigniew 304, 316, 318, 320, 323

Zembrzuski Ludwik 80

Zieliński Aleksander 4,25

Zieliński August 340

Zieliński Jarosław 4,26

Zieliński Tadeusz 78, 382, 391, 4,20

Ziółkowska Zofia 529, 532, 534

Zmidrygier-Konopka Zdzisław 112

Zmierczak Maria 47

Zoll Stefan 4.49

Zweibaum Juliusz 482, 4.83, 530

Zyndram-Kościałkowski Marian 353, 4.27

Żarnowska Anna 307

Żarnowski Janusz 307

Żebrowska Maria 4,24

Żeleński (Boy) Tadeusz 263

Żeromski Stefan 137

Żongołłowicz Bronisław 175, 257, 279, 281, $3^{10-3^{12}}, 3^{19}, 3^{20}, 3^{22}, 3^{61}, 3^{62}, 3^{6} 7,3^{68}$, $4,14,4,17,4,18$

Żółkiewski Stefan 240

Żukowska Teodora 250, 316, 318

Żukowski Przemysław Marcin 4,24

Żurawski Kazimierz 382 


\section{Spis ilustracji}

\section{ROZDZIAE „UNIWERSYTETY EUROPEJSKIE W XX WIEKU”, Tomasz Kizwalter}

1. Max Planck, sygn. 19251130_oo1, PAP

2. Trofim Łysenko, fot. Wikimedia Commons, PD

3. Herbert Marcuse w 1955 r., fot. Wikimedia Commons, GNU 1.2, (C) Marcuse family

4. Demonstracje w Paryżu, maj 1968 r. Pośrodku jeden z przywódców studenckiej rewolty, Daniel Cohn-Bendit, śpiewający Międzynarodówkę, sygn. 19680506_oo1, PAP

5. Uniwersytet Columbia, Butler Library, fot. Andrew Chen, Wikimedia Commons, CC 3.0

\section{ROZDZIAŁ „SPOŁECZNOŚĆ AKADEMICKA 1915-1939”, Piotr M. Majewski}

1. Brama Uniwersytetu od strony Krakowskiego Przedmieścia, ze zbiorów W. Baraniewskiego

2. Gmach Biblioteki Uniwersyteckiej - na pierwszym planie krata oddzielająca główny dziedziniec od tzw. uliczki prowadzącej od strony Krakowskiego Przedmieścia, ze zbiorów W. Baraniewskiego

3. Pożar Budynku Pomuzealnego w październiku 1935 r., sygn. 1-N-3292-5, ze zbiorów Narodowego Archiwum Cyfrowego

4. Nowy gmach audytoryjny, styczeń 1936 r., sygn. 1-N-3276-3, ze zbiorów Narodowego Archiwum Cyfrowego

5. Fragment głównego kampusu w pobliżu Gmachu Porektorskiego, ze zbiorów W. Baraniewskiego

6. Gmach Zakładów Wydziału Matematyczno-Przyrodniczego od strony ul. Oboźnej, ze zbiorów W. Baraniewskiego

7. Gmach Pokuratorski w lutym 1928 r., sygn. 1-N-3279, ze zbiorów Narodowego Archiwum Cyfrowego

8. Pałac Kazimierzowski, wrzesień 1927 r., sygn. 1-N-3272, ze zbiorów Narodowego Archiwum Cyfrowego

9. Luneta Obserwatorium Meteorologiczno-Astronomicznego UW na szczycie Pop Iwan, ok. 1938 r., sygn. 1-N-848-4, ze zbiorów Narodowego Archiwum Cyfrowego

10. Kaktusy w ogrodzie botanicznym UW, 1937 r., sygn. 1-G-6902-8, ze zbiorów Narodowego Archiwum Cyfrowego

11. Budynek Wydziału Weterynaryjnego UW przy ul. Grochowskiej, sygn. 1-N-3281-1, ze zbiorów Narodowego Archiwum Cyfrowego

12. Budynek Wydziału Farmaceutycznego UW przy ul. Przemysłowej w 1928 r., sygn. 1-N-3280, ze zbiorów Narodowego Archiwum Cyfrowego

13. Budynek Zakładu Medycyny Sądowej przy ul. Oczki w latach międzywojennych, sygn. 1-N-3286, ze zbiorów Narodowego Archiwum Cyfrowego 
14. Młodzież akademicka przed kościołem sióstr Wizytek po nabożeństwie z okazji inauguracji roku akademickiego 1932/1933, sygn. 1-N-3320-2, ze zbiorów Narodowego Archiwum Cyfrowego

15. Uczestnicy seminarium historycznego prof. Marcelego Handelsmana (pierwszy od lewej). Pierwszy od prawej doc. Tadeusz Manteuffel, lata 30. XX w., sygn. III.192, nowy dopływ 2014, ze zbiorów Archiwum PAN

16. Profesor Marceli Handelsman i doc. Stanisław Arnold na Krakowskim Przedmieściu w pobliżu Uniwersytetu, wrzesień 1929 r., sygn. III.192, nowy dopływ 2014, ze zbiorów Archiwum PAN

17. Inauguracja roku akademickiego 1938/1939. Senat, władze rektorskie i młodzież w drodze na mszę św. do kościoła sióstr Wizytek. Pośrodku, w pelerynie z gronostajów, rektor Włodzimierz Antoniewicz, sygn. NAC 1-N-3326-1, ze zbiorów Narodowego Archiwum Cyfrowego

18. Operacja konia na Wydziale Weterynaryjnym, luty 1928 r., sygn. 1-N-3283, ze zbiorów Narodowego Archiwum Cyfrowego

19. Senat Uniwersytetu Warszawskiego podczas inauguracji roku akademickiego 1936/1937, sygn. 1-N-3324-1, ze zbiorów Narodowego Archiwum Cyfrowego

20. Profesor Ludwik Krzywicki (po lewej) i prof. Szymon Askenazy (po prawej) jako laureaci Nagrody Miasta Stołecznego Warszawy, 30 V 1934, r., sygn. 1-K-1 2545-3, ze zbiorów Narodowego Archiwum Cyfrowego

21. Jubileusz 5o-lecia pracy naukowej prof. Tadeusza Zielińskiego. W pierwszym rzędzie stoją od prawej: prof. Tadeusz Kotarbiński, jubilat, rektor Tadeusz Brzeski, prof. Gustaw Przychocki, sygn. 1-N-678, ze zbiorów Narodowego Archiwum Cyfrowego

22. Profesor Kazimierz Michałowski podczas oględzin egipskiego sarkofagu, 1937 r., sygn. 1-N-1058, ze zbiorów Narodowego Archiwum Cyfrowego

23. Karykatura prof. Mieczysława Michałowicza z Wydziału Lekarskiego, ze zbiorów P.M. Majewskiego

24. Docent Wacław Borowy odbiera państwową nagrodę literacką z rąk ministra Wojciecha Świętosławskiego, styczeń 1938 r., sygn. 1-K-2046-2, ze zbiorów Narodowego Archiwum Cyfrowego

25. Profesor Leon Petrażycki, 1925 r., sygn. 1-N-446, ze zbiorów Narodowego Archiwum Cyfrowego

26. Wykopaliska w Edfu w Egipcie z udziałem Kazimierza Michałowskiego i Jerzego Manteuffla, 1938 r., sygn. 1-E-2855, ze zbiorów Narodowego Archiwum Cyfrowego

27. Spotkanie rektorów i dziekanów UW w Hotelu Europejskim, 9 VI 1939 r., sygn. muw_oo077_i_ooo_oo1, ze zbiorów Muzeum Uniwersytetu Warszawskiego

28. Komisja Organizacyjna Studium Teologii Prawosławnej, 1924-1925. Siedzą od lewej: prof. Ignacy Koschembahr-Łyskowski, rektor Uniwersytetu Warszawskiego prof. Franciszek Kryształowicz, kościelny kurator Studium Teologii Prawosławnej metropolita Kościoła Prawosławnego w Polsce Dionizy Waledyński, prof. Eugeniusz Jarra. Stoją od lewej: prof. Jan Porzeziński, prof. Wacław Makowski, prof. Franciszek Czubalski, prof. Kazimierz Nitsch, sygn. 1-N-329o, ze zbiorów Narodowego Archiwum Cyfrowego

29. Członkowie Państwowej Rady Oświecenia Publicznego, listopad 1936 r. W pierwszym rzędzie pierwszy od lewej prof. Władysław Tatarkiewicz, pierwszy od prawej prof. Juliusz Bursche, prezes Konsystorza Kościoła Ewangelicko-Augsburskiego, w drugim rzędzie, drugi od prawej, prof. Mojżesz Schorr, sygn. 1-A-2 716-2, ze zbiorów Narodowego Archiwum Cyfrowego

3o. Maria Skłodowska-Curie w towarzystwie prezydenta Ignacego Mościckiego (czwarty od prawej) i prof. Stefana Pieńkowskiego (pierwszy od prawej) podczas zwiedzania Instytutu Radowego w Warszawie, $193^{2}$ r., sygn. 1-N-820, ze zbiorów Narodowego Archiwum Cyfrowego

31. Promocja doktorska Flory Wandy Kluczyckiej (pierwsza z prawej) na Wydziale Farmaceutycznym, 6 II $193^{1}$ r., sygn. 1-N-3335-1, ze zbiorów Narodowego Archiwum Cyfrowego

32. Cezaria Baudouin de Courtenay-Jędrzejewiczowa, jeszcze w todze profesorskiej Uniwersytetu Stefana Batorego. W 1934, r. objęła katedrę etnografii polskiej na Wydziale Humanistycznym UW, sygn. NAC 1-N-4, , ze zbiorów Narodowego Archiwum Cyfrowego

33. Urzędniczki rektoratu, 1931-1939, sygn. muw_00015_i_ooo_oo1, ze zbiorów Muzeum Uniwersytetu Warszawskiego 
34. Prawo jazdy doc. Tadeusza Manteuffla, sygn. III.192, nowy dopływ 2014, ze zbiorów Archiwum PAN

35. Profesor Edward Loth, sygn. 1-N-346, ze zbiorów Narodowego Archiwum Cyfrowego

36. Nieistniejący już dom profesorski przy ul. Nowy Zjazd 5, sygn. 1-U-6796, ze zbiorów Narodowego Archiwum Cyfrowego

37. Studenci UW w drodze na wykłady, listopad $193^{1}$ r., sygn. 1-N-358o-2, ze zbiorów Narodowego Archiwum Cyfrowego

38. Chiński student UW Yu Houo Joei, późniejszy lektor języka chińskiego, na wycieczce w Krakowie, sierpień 1930 r., sygn. 1-N-3745, ze zbiorów Narodowego Archiwum Cyfrowego

39. Teczka osobowa Emanuela Ringelbluma z adnotację „nieprzyjęty z powodu numerus clausus”, ze zbiorów Archiwum Uniwersytetu Warszawskiego

40. Indeks i studencka legitymacja tramwajowa Icko Jezernickiego - późniejszego premiera Izraela Icchaka Szamira, ze zbiorów Archiwum Uniwersytetu Warszawskiego

41. Indeks studenta Wydziału Prawa Witolda Gombrowicza, ze zbiorów Archiwum Uniwersytetu Warszawskiego

42. Minister wyznań religijnych i oświecenia publicznego prof. Wojciech Świętosławski podczas odczytu radiowego „O pomoc społeczną dla młodzieży akademickiej”, 30 I 1936 r., sygn. 1-A-2683-2, ze zbiorów Narodowego Archiwum Cyfrowego

43. Dom Akademicki przy ul. Grójeckiej w dniu oddania do użytku, 1930 r., sygn. 1-N-3537, ze zbiorów Narodowego Archiwum Cyfrowego

44. Dom akademicki dla młodzieży żydowskiej przy ul. Namiestnikowskiej na Pradze, $193^{2}$ r., sygn. 1-N-3551, ze zbiorów Narodowego Archiwum Cyfrowego

45. Walne zebranie Bratniej Pomocy Studentów UW, luty $193^{2}$ r., sygn. 1-N-3562, ze zbiorów Narodowego Archiwum Cyfrowego

46. Pływalnia w Domu Akademickim przy ul. Grójeckiej, $193^{1}$ r., sygn. 1-N-3538-2, ze zbiorów Narodowego Archiwum Cyfrowego

47. Mieszkanki Domu Akademiczek przy ul. Górnośląskiej 14, 1936 r., sygn. 1-3545-7, ze zbiorów Narodowego Archiwum Cyfrowego

48. Studenci w jednym z pokojów w Domu Akademickim przy ul. Grójeckiej, lata 30. XX w., sygn. 1-N-354,1, ze zbiorów Narodowego Archiwum Cyfrowego

49. Studencka legitymacja kolejowa Reginy Askenazy, ze zbiorów Archiwum Uniwersytetu Warszawskiego

50. Sala wykładowa Wydziału Farmaceutycznego, lata zo. XX w., sygn. muw_ooo69_i_ooo_o10, ze zbiorów Muzeum Uniwersytetu Warszawskiego

51. Podanie Bolesława Piaseckiego o przełożenie terminu egzaminów z powodu pobytu w areszcie śledczym i osadzenia w obozie odosobnienia w Berezie Kartuskiej, ze zbiorów Archiwum Uniwersytetu Warszawskiego

52. Profesor Eugeniusz Jarra, 1928 r. sygn. 1-N-237, ze zbiorów Narodowego Archiwum Cyfrowego

53. Profesorowie kliniki chirurgicznej UW, 1919-1936, sygn. muw_0oo22_i_o02_oo1, ze zbiorów Muzeum Uniwersytetu Warszawskiego

54. Studenci w laboratorium Zakładu Chemii Organicznej, lata 30. XX w., sygn. muw_ooo94_i_ ooo_oo1, ze zbiorów Muzeum Uniwersytetu Warszawskiego

55. Sekcja zwłok podczas zajęć prof. Ludwika Paszkiewicza, luty 1928 r., sygn. NAC 1-N-3287-2, ze zbiorów Narodowego Archiwum Cyfrowego

56. Profesor Stefan Pieńkowski w karykaturze, ze zbiorów P.M. Majewskiego

57. Czytelnia Biblioteki Uniwersyteckiej, 1935 r., sygn. 1-2-3298, ze zbiorów Narodowego Archiwum Cyfrowego

58. Indeks studenta Wydziału Humanistycznego Aleksandra Gieysztora; nad zdjęciem widoczny stempel „miejsce w ławkach parzystych”, ze zbiorów Archiwum Uniwersytetu Warszawskiego

59. Studenci w pracowni biologicznej Wydziału Matematyczno-Przyrodniczego w budynku Szkoły Głównej, 1935 r., sygn. muw_oo161_i_ooo_oo1, ze zbiorów Muzeum Uniwersytetu Warszawskiego 
6o. Odręczny życiorys Jerzego Giedroycia z 1924, r. w aktach studenckich, ze zbiorów Archiwum Uniwersytetu Warszawskiego

61. Polscy studenci zwiedzają Budapeszt w ramach praktyk wakacyjnych na Węgrzech, lipiec 1936 r., sygn. 1-N-3727, ze zbiorów Narodowego Archiwum Cyfrowego

62. Centralny obóz wyszkolenia Legii Akademickiej w Lidzbarku, sierpień 1938 r., sygn. 1-W2376-2, ze zbiorów Narodowego Archiwum Cyfrowego

63. Obchody 20. rocznicy powstania Towarzystwa Bratniej Pomocy Studentów Uniwersytetu Warszawskiego, styczeń 1936 r. Przemawia rektor Stefan Pieńkowski, za stołem prezydialnym od prawej profesorowie UW: Władysław Tatarkiewicz, Bronisław Koskowski i ks. Antoni Szlagowski, sygn. 1-N-3564-1, ze zbiorów Narodowego Archiwum Cyfrowego

64. Wieczerza wigilijna w Bratniej Pomocy, 24, XII 1936 r., fot. K. Jankowski, sygn. muw_ooo4,8_i_ ooo_oo1, ze zbiorów Muzeum Uniwersytetu Warszawskiego

65. Doroczny komers korporacji „Aquillonia” w Warszawie, listopad 1938 r. Wśród siedzących trzeci od lewej gen. Władysław Anders, dalej, ku prawej: prof. Edward Loth, ks. prof. Antoni Szlagowski, prezes korporacji G. Gaczeński, gen. Władysław Bortnowski, płk Leon Strzelecki i prof. Władysław Tatarkiewicz, sygn. 1-N-3612-1, ze zbiorów Narodowego Archiwum Cyfrowego

66. Mecz piłki wodnej z udziałem drużyn Akademickiego Związku Sportowego w Warszawie i Klubu Wojskowego Legia, Stadion Wojska Polskiego im. marszałka Józefa Piłsudskiego w Warszawie, 7 VI 1938 r., sygn. 1-S-2619-3, ze zbiorów Narodowego Archiwum Cyfrowego

67. Wycieczka Koła Przyrodników UW do Czarnohory i w Gorgany. Przed schroniskiem pod Doboszanką: T. Wiśniewski, W. Sommer, H. Sawicka-Krasnodębska, H. Sandner, P. Meinhardt, 9 VI 1934, r., sygn. muw_oo166_i_ooo_oo1, ze zbiorów Muzeum Uniwersytetu Warszawskiego

68. Uczestnicy seminarium historycznego prof. Marcelego Handelsmana podczas pobytu wakacyjnego w Zaleszczykach. Po prawej, oparty o stół, doc. Tadeusz Manteuffel, 1929 r., sygn. III.192, nowy dopływ 2014, ze zbiorów Archiwum PAN

69. Irena Krzywicka, lata 20. XX w., sygn. 1-K-1580-1, ze zbiorów Narodowego Archiwum Cyfrowego

7o. Młodzi pracownicy naukowi Wydziału Matematyczno-Przyrodniczego na biwaku na Hali Gąsienicowej w Tatrach. Od lewej: H. Sandner, T. Sandner, M. Gieysztor, lipiec 1937 r., sygn. muw_oo168_i_ooo_oo1, ze zbiorów Muzeum Uniwersytetu Warszawskiego

71. Student Legii Akademickiej z dziewczyną, sierpień $193^{8}$ r., sygn. 1-W-2376-5, ze zbiorów Narodowego Archiwum Cyfrowego

72. Poczty sztandarowe organizacji studenckich w drodze do Grobu Nieznanego Żołnierza podczas obchodów 20 rocznicy powstania Towarzystwa Bratniej Pomocy Studentów Uniwersytetu Warszawskiego, styczeń $193^{6}$ r., sygn. 1-N-3564-4, ze zbiorów Narodowego Archiwum Cyfrowego

73. Studenci rozdający ulotki przed bramą Uniwersytetu, luty $193^{2}$ r., sygn. 1-N-3561, ze zbiorów Narodowego Archiwum Cyfrowego

74. Wiec studencki na terenie Uniwersytetu, marzec $193^{1}$ r., sygn. 1-N-3576-2, ze zbiorów Narodowego Archiwum Cyfrowego

75. Komers korporacji akademickiej „Arkonia” z udziałem marszałka Edwarda Śmigłego-Rydza, będący wyrazem zbliżenia między obozem sanacyjnym a radykalną prawicą, 18 V 1937 r., sygn. 1-N-3614-2, ze zbiorów Narodowego Archiwum Cyfrowego

76. Antysemicka karykatura z gazetki studenckiej „Głos Akademicki”, $193_{1}$ r., ze zbiorów P.M. Majewskiego

77. Zamieszki na terenie Uniwersytetu, październik 1933 r., sygn. 1-N-3584-2, ze zbiorów Narodowego Archiwum Cyfrowego

78. Policja rozpędza zamieszki studenckie na Krakowskim Przedmieściu przy pomocy gazu łzawiącego i wody z motopompy, marzec $193^{1}$ r., sygn. 1-N-3576-3, ze zbiorów Narodowego Archiwum Cyfrowego

79. Studenckie akta osobowe Władysława Jamontta zaangażowanego w działalność radykalnej prawicy, z adnotacjami o prowadzonych przeciw niemu postępowaniach dyscyplinarnych, ze zbiorów Archiwum Uniwersytetu Warszawskiego 
8o. Karykatura wymierzona w rektora Włodzimierza Antoniewicza, rozpowszechniana na Uniwersytecie przez prawicę, sygn. III.144, t. 55, ze zbiorów Archiwum PAN

81. Legitymacja studencka Idess (Izabeli) Bieżuńskiej na rok akademicki 1937/1938 z pieczątką „miejsce w ławkach nieparzystych”, ze zbiorów Archiwum Uniwersytetu Warszawskiego

82. Rektor Mieczysław Michałowicz przemawia podczas pogrzebu ministra wyznań religijnych i oświecenia publicznego Sławomira Czerwińskiego, 7 VIII 1931 r., sygn. 1-A-2651-9, ze zbiorów Narodowego Archiwum Cyfrowego

83. Uroczystość nadania doktoratów honoris causa marsz. Edwardowi Śmigłemu-Rydzowi (po prawej) i ministrowi Józefowi Beckowi podczas inauguracji roku akademickiego 1938/1939, sygn. 1-N-3326-10, ze zbiorów Narodowego Archiwum Cyfrowego

84. Profesor Edward Loth z Wydziału Lekarskiego w karykaturze, ze zbiorów P.M. Majewskiego

85. Karykatura profesora Jerzego Modrakowskiego z Wydziału Lekarskiego, ze zbiorów P.M. Majewskiego

86. Bolesław Piasecki (w tle) przemawia na zebraniu Ruchu Narodowo-Radykalnego „Falanga”, Warszawa 28 XI 1937 r., sygn. 1-P-73A, ze zbiorów Narodowego Archiwum Cyfrowego

87. Studenci UW czytający przy bramie głównej ogłoszenie o zamknięciu uczelni w związku z rozruchami antysemickimi, marzec 1934, r., sygn. 1-N-3586, ze zbiorów Narodowego Archiwum Cyfrowego

88. Grupa studentów UW, aresztowanych tymczasowo za udział w zamieszkach antyżydowskich, opuszcza Urząd Śledczy przy ul. Daniłłowiczowskiej, listopad 1931 r., sygn. 1-N-3579-9, ze zbiorów Narodowego Archiwum Cyfrowego

89. Zamieszki przed Uniwersytetem, listopad 1931 r., sygn. 1-N-3579-6, ze zbiorów Narodowego Archiwum Cyfrowego

9o. Profesor Wacław Makowski jako wicemarszałek Senatu RP w Pałacu Staszica podczas spotkania prawników polskich i niemieckich ${ }_{15}$ XII 1938 r.; drugi z prawej minister sprawiedliwości Rzeszy Hans Frank - już niebawem generalny gubernator okupowanych ziem polskich, sygn. 1-D-1175-3, ze zbiorów Narodowego Archiwum Cyfrowego

\section{ROZDZIAE „UNIWERSYTET WARSZAWSKI W II RZECZYPOSPOLITEJ”, Marek P. Deszczyński}

1. Pałac Kazimierzowski, prawdopodobnie ok. 1914 r., ze zbiorów W. Baraniewskiego

2. Uczestnicy uroczystej inauguracji wznowienia Uniwersytetu w 1915 r., ze zbiorów W. Baraniewskiego

3. Lekarz pediatra, doktor Józef Brudziński, pierwszy rektor UW po reaktywacji uczelni przez niemieckie władze okupacyjne w 1915 r., sygn. 1-N-68, ze zbiorów Narodowego Archiwum Cyfrowego

4. Hrabia Bogdan Hutten-Czapski, podczas I wojny światowej kurator Uniwersytetu Warszawskiego z ramienia niemieckich władz okupacyjnych (zdjęcie późniejsze), sygn. 1-P-2o79, ze zbiorów Narodowego Archiwum Cyfrowego

5. Minister wyznań religijnych i oświecenia publicznego Janusz Jędrzejewicz przemawia do delegacji szkół z okazji imienin marszałka Piłsudskiego, 18 III 1933 r., sygn. 1-A-144-5, ze zbiorów Narodowego Archiwum Cyfrowego

6. Posiedzenie Państwowej Rady Oświecenia Publicznego w Warszawie, 29 XI 1934 r. Od lewej: podsekretarz stanu w Ministerstwie Wyznań Religijnych i Oświecenia Publicznego ks. Bronisław Żongołłowicz, minister Wacław Jędrzejewicz i II podsekretarz stanu Konstanty Chyliński, sygn. 1-A-2 715-1, ze zbiorów Narodowego Archiwum Cyfrowego

7. Studenci UW protestujący przeciwko procesowi brzeskiemu, styczeń 1931 r., sygn. 1-N-35752, ze zbiorów Narodowego Archiwum Cyfrowego

8. Prawnik i ekonomista z UW profesor Roman Rybarski (pośrodku) jako świadek w procesie brzeskim w towarzystwie oskarżonych Józefa Putka (po prawej) i Hermana Liebermana, październik 1931 r., sygn. 1-B-6oo-74, ze zbiorów Narodowego Archiwum Cyfrowego 
9. Trumna umieszczona przez studentów na torach tramwajowych przed Uniwersytetem w ramach protestów przeciw nowej ustawie o szkolnictwie wyższym, marzec 1933 r., sygn. 1-N-3583-1, ze zbiorów Narodowego Archiwum Cyfrowego

10. Uroczystości pogrzebowe ministra wyznań religijnych i oświecenia publicznego dr. Sławomira Czerwińskiego; przemawia podsekretarz stanu w tym resorcie, ks. Bronisław Żongołłowicz, 7 VIII $193_{1}$ r., sygn. 1-A-2651-8, ze zbiorów Narodowego Archiwum Cyfrowego

11. Minister wyznań religijnych i oświecenia publicznego Wojciech Świętosławski podczas podpisywania aktu zaprzysiężenia w obecności prezydenta RP prof. Ignacego Mościckiego, $16 \mathrm{~V}$ 1936 r., sygn. 1-A-19o7-2, ze zbiorów Narodowego Archiwum Cyfrowego

12. Rektorzy szkół wyższych u prezydenta, pierwszy z lewej prof. Jerzy Modrakowski kierujący wówczas Akademią Stomatologiczną w Warszawie, pierwszy z prawej rektor UW prof. Włodzimierz Antoniewicz, październik $193^{8}$ r., sygn. 1-A-1453-1, ze zbiorów Narodowego Archiwum Cyfrowego

13. Profesorowie i docenci Wydziału Filozoficznego podczas ostatniego posiedzenia przed jego podziałem na wydziały Humanistyczny i Matematyczno-Przyrodniczy w $19^{2} 7$ r. W pierwszym rzędzie od lewej siedzą: Stefan Mazurkiewicz, Wacław Sierpiński, Wiktor Porzeziński, Kazimierz Żurawski, Stefan Pieńkowski, Adam Kryński, Jan Baudouin de Courtenay, Samuel Dickstein, Bolesław Hryniewiecki, Jan Karol Kochanowski, Tadeusz Zieliński, Antoni Przeborski, Karol Appel, Kazimierz Jabłczyński, Marceli Handelsman, Gustaw Przychocki; drugi rząd od lewej: Stanisław Słoński, Stanisław Lencewicz, Jan Lewiński, Stanisław Thugutt, Wiktor Lampe, Józef Ujejski, Oskar Halecki, Andrzej Tretiak, Michał Kamieński, Wacław Baehr, Kazimierz Bassalik, Kazimierz Białaszewicz, Bronisław Gubrynowicz, Konstanty Janicki, Jan Tur, Adam Krokiewicz, Tadeusz Kotarbiński, Stanisław Szober; trzeci rząd od lewej: Zygmunt Batowski, Wojciech Świętosławski, Kazimierz Ajdukiewicz, Bogdan Nawroczyński, Czesław Białobrzeski, Władysław Tatarkiewicz, Stanisław Leśniewski, Włodzimierz Antoniewicz, Tadeusz Wałek-Czarnecki, Stanisław Arnold, Wacław Roszkowski, Jan Samsonowicz, Witold Stefański, Henryk Mościcki, sygn. muw_ooog8_i_ooo_oo1, ze zbiorów Muzeum Uniwersytetu Warszawskiego

14. Wręczenie Uniwersytetowi Warszawskiemu insygniów przez marszałka Piłsudskiego, 2 V 1921 r., sygn. muw_0oo63_i_002_001, ze zbiorów Muzeum Uniwersytetu Warszawskiego

15. Archeolog, prof. Włodzimierz Antoniewicz, rektor UW w latach 1936-1939, sygn. 1-N-8, ze zbiorów Narodowego Archiwum Cyfrowego

16. Rektor Antoniewicz i marszałek Śmigły-Rydz dokonują odsłonięcia popiersia marszałka Józefa Piłsudskiego w Pałacu Kazimierzowskim, listopad 1937 r., sygn. 1-N-3325-6, ze zbiorów Narodowego Archiwum Cyfrowego

17. Uroczystość nadania doktoratu honoris causa ks. prof. Louisowi de Brogliemu. Pośrodku rektor Stefan Pieńkowski, 1935 r., sygn. muw_ooo95_i_ooo_oo1, ze zbiorów Muzeum Uniwersytetu Warszawskiego

18. Uroczystość nadania doktoratu honoris causa Leopoldowi Staffowi, 1939 r. Dyplom wręcza prof. Julian Krzyżanowski, pierwszy z lewej prof. Wacław Borowy, sygn. 1-3330, ze zbiorów Narodowego Archiwum Cyfrowego

19. Inauguracja roku akademickiego 1937/1938. Na honorowym miejscu pośrodku marszałek Śmigły-Rydz, pierwszy od prawej biskup polowy Józef Gawlina, w pierwszym rzędzie, trzeci od prawej, minister wyznań religijnych i oświecenia publicznego prof. Wojciech Świętosławski, na lewo od niego minister spraw zagranicznych Józef Beck, sygn. 1-N-3325-4, ze zbiorów Narodowego Archiwum Cyfrowego

20. Badania naukowe w Oddziale Przemiany Materii Wydziału Lekarskiego, ok. 1933 r., sygn. muw_00075_i_ooo_o14, ze zbiorów Muzeum Uniwersytetu Warszawskiego

21. Dyrektor Obserwatorium Astronomicznego UW prof. Michał Kamieński przy teleskopie, czerwiec 1925 r., sygn. 1-N-3311-6, ze zbiorów Narodowego Archiwum Cyfrowego

22. Zawieszenie dzwonu w kościele Św. Krzyża przy Krakowskim Przedmieściu, w tle Pałac Staszica (po rewaloryzacji przywracającej wygląd z początku XIX w.), mieszczący liczne instytucje uniwersyteckie, 1926 r., sygn. 1-U-6999, ze zbiorów Narodowego Archiwum Cyfrowego 
23. Obserwatorium Meteorologiczno-Astronomiczne UW na szczycie Pop Iwana w Czarnohorze, prawdopodobnie 1938 r., sygn. 1-N-848-1, ze zbiorów Narodowego Archiwum Cyfrowego

24. Gmach Zakładów Wydziału Matematyczno-Przyrodniczego, luty 1928 r., sygn. 1-N-3279A, ze zbiorów Narodowego Archiwum Cyfrowego

25. Zabezpieczanie ocalałych zbiorów zoologicznych po pożarze Budynku Pomuzealnego w październiku 1935 r., sygn. 1-N-3293-3, ze zbiorów Narodowego Archiwum Cyfrowego

26. Budowa gmachu Auditorium Maximum, fot. Jan Raczyński, 21 XI 1934 r., sygn. muw_00071_i_001_001, ze zbiorów Muzeum Uniwersytetu Warszawskiego

27. Uroczystość poświęcenia kamienia węgielnego pod budowę gmachu Instytutu Chemii przy ul. Pasteura. Drugi od lewej biskup pomocniczy archidiecezji warszawskiej ks. prof. Antoni Szlagowski, czwarty - prezydent Ignacy Mościcki, wiosna 1938 r., 1-N-3277-31-N-3277-3, ze zbiorów Narodowego Archiwum Cyfrowego

28. Jedno z laboratoriów na Wydziale Lekarskim, ok. 1933 r., sygn. muw_ooo75_i_ooo_o13, ze zbiorów Muzeum Uniwersytetu Warszawskiego

29. Zaproszenie na uroczystość poświęcenie Gmachu Chemii, czerwiec 1939 r., ze zbiorów Biblioteki Uniwersytetu Warszawskiego

\section{ROZDZIAŁ „UNIWERSYTET CZASU WOJNY”, Piotr Majewski}

1. Dokument zastępczego 1 Szpitala Okręgowego Warszawa w pałacu Tyszkiewiczów-Potockich, ze zbiorów Muzeum Uniwersytetu Warszawskiego

2. Żołnierze niemieccy i warszawscy Żydzi zmuszani przez nich do prac fizycznych na dziedzińcu UW, jesień 1939 r., ze zbiorów W. Baraniewskiego

3. Spalona Aula Mickiewicza w Auditorium Maximum, zdjęcie z 1945 r., ze zbiorów Muzeum Uniwersytetu Warszawskiego

4. Wydział Prawa - lista słuchaczy tajnych kursów, oceny z kolokwiów i egzaminów, ze zbiorów Biblioteki Uniwersytetu Warszawskiego

5. Spis ćwiczeń seminaryjnych tajnego seminarium polonistycznego prof. Wacława Borowego, ze zbiorów Biblioteki Uniwersytetu Warszawskiego

6. Lista słuchaczy tajnych kursów historycznych UW, ze zbiorów Biblioteki Uniwersytetu Warszawskiego

7. Profesor Marceli Handelsman z wnukami podczas okupacji, sygn. III.192, nowy dopływ 2014 , ze zbiorów Archiwum PAN

8. Notatki Janusza Paszyńskiego z tajnego nauczania, reprod. za: Chowałem się za plecami Kopernika. Z prof. Januszem Paszyńskim rozmawia dr Robert Gawkowski, „Uniwersytet Warszawski", nr 2 (46), marzec 2010

9. Legitymacja uczniowska Prywatnej Szkoły Zawodowej dla Pomocniczego Personelu Sanitarnego doc. Jana Zaorskiego, ze zbiorów Muzeum Uniwersytetu Warszawskiego

10. Brama Główna UW na kilka miesięcy przed wybuchem powstania warszawskiego, ze zbiorów Muzeum Uniwersytetu Warszawskiego

11. Szkoła Główna (obecnie Instytut Archeologii) oraz Gmach Pomuzealny, 1945 r., ze zbiorów Archiwum Uniwersytetu Warszawskiego

12. Pałac Kazimierzowski, 1945 r., ze zbiorów Muzeum Uniwersytetu Warszawskiego 

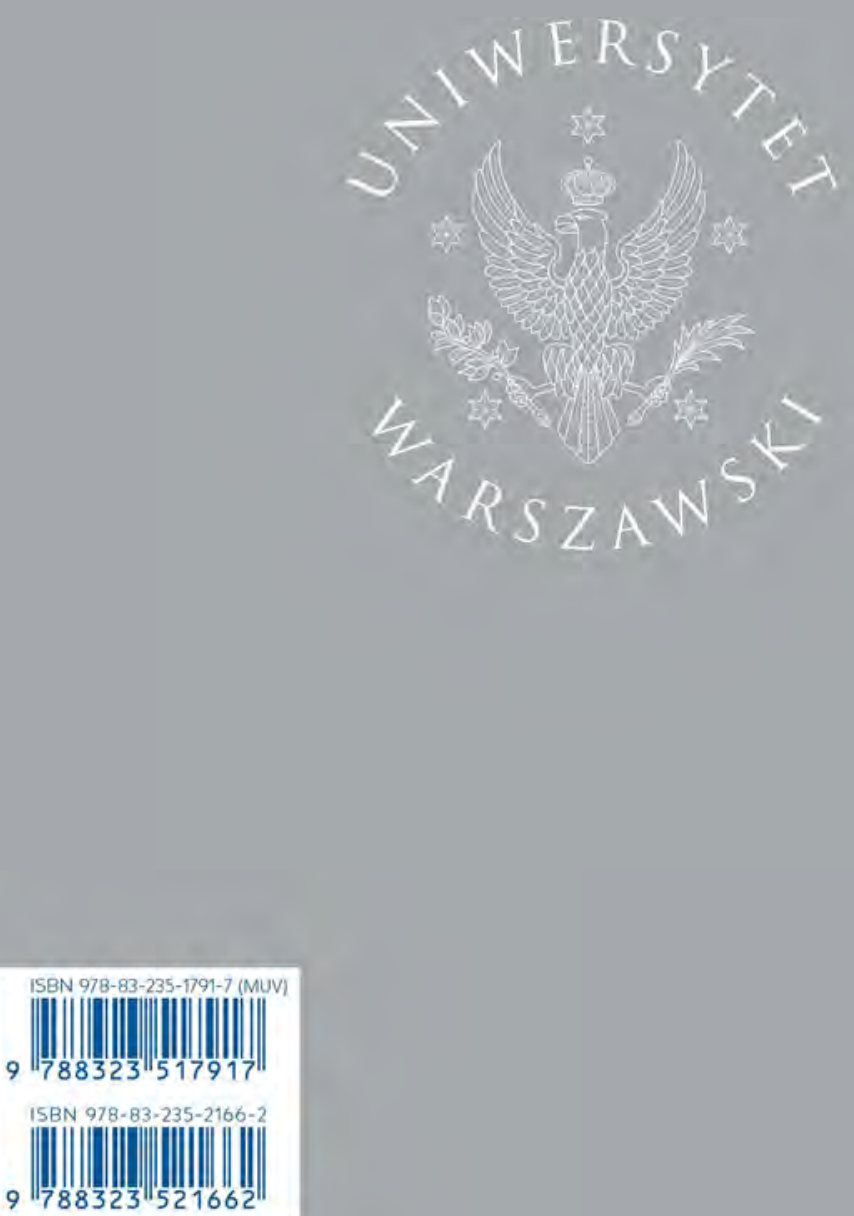

\section{e-MONUMENTA_WUW 2016}

